\title{
DISCLAIMER
}

This document was prepared as an account of work sponsored by the United States Government. While this document is believed to contain correct information, neither the United States Government nor any agency thereof, nor The Regents of the University of Califomia, nor any of their employees, makes any warranty, express or implied, or assumes any legal responsibility for the accuracy, completeness, or usefulness of any information, apparatus, product, or process disclosed, or represents that its use would not infringe privately owned rights. Reference herein to any specific commercial product, process, or service by its trade name, trademark, manufactures, or otherwise, does not necessarily constitute or imply its endorsement, recommendation, or favoring by the United States Government or any agency thereof, or The Regents of the University of California. The views and opinions of authors expressed herein do not necessarily state or reflect those of the United States Government or any agency thereof, or The Regents of the University of California.

Available to DOE and DOE Contractors

from the Office of Scientific and Technical Information

P.O. Box 62, Oak Ridge, TN 37831

Prices available from (615) $576-8401$

Available to the public from the National Technical Information Service

U.S. Department of Commerce

5285 Port Royal Road, Springfield, VA 22161

Emest Orlando Lawrence Berkeley National Laboratory is an equal opportunity employer. 


\title{
$\frac{10}{12}-10-968$ SD
}

LBL-32822 Rev. 4 UC-900

\section{China Energy Databook}

\author{
Ernest Orlando Lawrence Berkeley National Laboratory \\ University of California \\ Berkeley, CA 94720
}

Editor:

Jonathan E. Sinton*

Associate Editors:

David G. Fridley*

Mark D. Levine*

Fuqiang Yang*
Jiang Zhenpingt

Zhuang Xingt

Jiang Kejun ${ }^{\dagger}$

Liu Xiaofengt

Revised September 1996

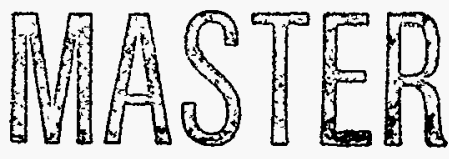

- Energy Analysis Program, Energy and Environment Division, Lawrence Berkeley National Laboratory.

†Energy Research Institute, State Planning Commission of China, Beijing, People's Republic of China.

This work was supported by the Office of International Energy Policy of the U.S. Department of Energy under Contract No. DE-AC03-76SF00098. 


\section{DISCLAIMER}

This report was prepared as an account of work sponsored by an agency of the United States Government. Neither the United States Government nor any agency thereof, nor any of their employees, makes any warranty, express or implied, or assumes any legal liability or responsibility for the accuracy, completeness, or usefulness of any information, apparatus, product, or process disclosed, or represents that its use would not infringe privately owned rights. Reference herein to any specific commercial product; process, or service by trade name, trademark, manufacturer, or otherwise does not necessarily constitute or imply its endorsement, recommendation, or favoring by the United States Government or any agency thereof. The views and opinions of authors expressed herein do not necessarily state or reflect those of the United States Government or any agency thereof. 


\section{DISCLAIMER}

Portions of this document may be illegible in electronic image products. Images are produced from the best available original document. 


\section{Foreword to the 1992 Edition-}

$\mathrm{T}$ The Energy Analysis Program (EAP) at the Lawrence Berkeley Laboratory (LBL) first became involved in Chinese energy issues through a joint China-U.S. symposium on markets and demand for energy held in Nanjing in November of 1988. Discovering common interests, EAP began to collaborate on projects with the Energy Research Institute (ERI) of China's State Planning Commission. In the course of this work it became clear that a major issue in the furtherance of our research was the acquisition of reliable data. In addition to other, more focused activities - evaluating programs of energy conservation undertaken in China and the prospects for making Chinese industries more energy-efficient, preparing historical reviews of energy supply and demand in the People's Republic of China, sponsoring researchers from China to work with experts at LBL on such topics as energy efficiency standards for buildings, adaptation of U.S. energy analysis software to Chinese conditions, and transportation issues - we decided to compile, assess, and organize Chinese energy data. We are hopeful that this volume will not only help us in our work, but help build a broader community of Chinese energy policy studies within the U.S.

In order to select appropriate data from what was available we established several criteria. Our primary interest was to use the data to help understand the historical evolution and likely future of the Chinese energy system. A primary criterion was thus that the data relate to the structure of energy supply and demand in the past and indicate probable developments (e.g., as indicated by patterns of investment). Other standards were accuracy, consistency with other information, and completeness of coverage. This is not to say that all the data presented herein are accurate, consistent, and complete, but where discrepancies and omissions do occur we have tried to note them.

Preparing this volume confronted us with a number of difficult issues. The most frustrating usually involved the different approaches to sectoral divisions taken in China and the U.S. For instance, fuel used by motor vehicles belonging to industrial enterprises is counted as industrial consumption in China; only fuel use by vehicles belonging to enterprises engaged primarily in transportation is counted as transportation use. The estimated adjustment to count all fuel use by vehicles as transportation energy use is quite large, since a large fraction of motor vehicles belong to industrial enterprises. Similarly, Chinese industrial investment figures are skewed compared to those collected in the U.S. because a large portion of enterprises' investment funds is directed towards providing housing and social services for workers and their families.

Notably absent are data on energy prices, key elements in the analysis of energy issues. Although some price information is available, none is very useful from the perspective of the market-oriented analyst. While it may have been tempting to include here some of the sketchy figures that have been published, we felt.that the topic was best excluded until more complete information is made accessible.

Since new energy and other data become available constantly, we plan to issue updates to this volume annually. It is our intention to reissue the entire volume on a bi- or triannual basis. We encourage any comments and corrections users may have, as well as any suggestions for categories of data to be included in future volumes.

MDL and JES

23 July 1992 


\section{Foreword to the}

\section{Edition}

$\mathrm{T}$ The response to the first edition of the China Energy Databook was overwhelmingly positive, and has encouraged us to issue this revised, updated, and expanded edition. It has been a natural counterpart to the Energy Analysis Program's continuing program of collaborative research with the Energy Research Institute. No other current reference volume dedicated to China's energy system contains a similar variety and quality of material. We believe that this edition is even more valuable than the first, since China's State Statistical Bureau ceased publication of its China Energy Statistical Yearbook with the 1991 edition.

Besides incorporating more recent data, we have revised some of the categories and data that appeared in the old volume. The adjustment for energy consumption in the transportation sector, for instance, has been slightly changed to include some fuel use in the commercial sector, which was previously left out. As another example, natural gas consumption statistics in the first edition greatly overstated electric utility use; we have rectified that error. Some tables have changed as statistical collection and reporting practices change in China. Figures on gross output value by sector stop with 1992, and economic output in subsequent years is covered by various measures of value-added, such as national income and gross domestic product.

Greater availability of reliable information in certain categories has allowed us to expand coverage of certain important areas. We have been able to include a new chapter on energy prices - an especially significant addition because recent liberalizations in energy markets (along with other aspects of economic system reforms that provide energy users with the means and incentives to respond to prices) have given energy prices a much greater role in influencing the behavior of energy suppliers and consumers. Additions include quali- ty specifications of coal resources and output, more detailed coverage of oil extraction, refining, and international trade, statistics on China's newly completed nuclear power capacity, performance of major grids, interprovincial coal shipments, investments in energy conservation, motor vehicle output structure and fuel economy, expanded data on the energy intensity of major industrial products, ambient levels of key air pollutants by city, and other categories.

A major disruption in energy statistical collection in China in 1993 has resulted in long delays and $a$ greater than usual range of uncertainty in energy consumption statistics for that year. The State Statistical Bureau has not yet publicly released sectoral energy consumption figures for 1993 (and so they are not included herein), and most experts inside and outside China feel that those data are much less reliable than in previous years. Fortunately, there are indications that the situation for 1994 energy consumption data, which should become available soon, will be much improved.

We hope that readers will continue to give us feedback so that the next edition will better meet their needs. As before, we plan to issue further revised editions of the China Energy Databook at intervals of two to three years, incorporating new data as they become available. We may also publish companion volumes that provide more detail on certain sectors and regions.

JES

30 January 1996 


\section{ACKNOWLEDGMENTS}

Much of the material in the first as well as current editions of the China Energy Databook would not have been available without the close cooperation of the Energy Research Institute (ERI) of China's State Planning Commission (SPC). All of the Chinese and American coeditors directly involved in the project owe a debt of gratitude to ERI Director Zhou Fengqi and Deputy Director Zhou Dadi, and to the members of the China Energy Database team (who helped assemble material for the first edition): Xie Zhijun, Hu Xiulian, Li Jinging, Su Xiaojun, Dong Luying, Wang Jiacheng, and Su Zhengming, and ERI interpreter, Han Yinghua. ERI staff members collected data from published sources that are difficult to obtain outside of China and were invaluable in providing information on definitions and coverage of statistical categories, which often differ significantly from those used in the U.S. and internationally. They were assisted in their efforts by members of the Energy Division of the State Statistical Bureau, the Resources Bureau of the SPC, the China National Energy Investment Corporation, the China National Coal Corporation, the Information Research Institute of Water Resources and Electric Power of the Ministry of Electric Power, and the Research Center of the SPC.

We are especially grateful to Wang Qingyi, vice president of the China Energy Research Society, for advice, criticism, and information that makes this reference work better than it otherwise would have been. Other substantive contributions were made to this or the previous edition by Jessie Audette, W. Bart Davis, Roland Hwang, Kazumasa Imada, Nancy Kiang, Nina Kousnetzoff, Feng Liu, Marc Ross, and Lee Schipper.

Ted Gartner, who laid out this volume in QuarkXpress, displayed great fortitude, flexibility, and good humor in carrying this project through to completion. Brian Pon cheerfully prepared the graphics. It has been a great pleasure to work with both of them. Jon Gimpel, Mark Mandel, and Paul Volk of Mana Graphics designed the layout and typeset the first edition.

Finally, we would like to thank all of those who have shown an interest in this volume, and particularly those who provided us with the feedback that has allowed us to improve it.

Funding for this project was generously supplied by the U.S. Department of Energy. 

Foreword .. $\mathrm{i}$

Acknowledgments ..ii

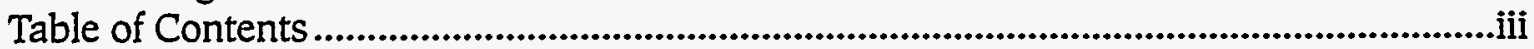

Units and Conversions .....................................................................................................

Chapter I. Resources and Reserves ..............................................................................

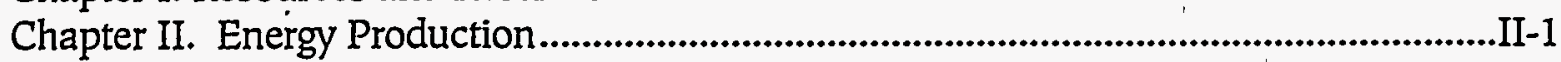

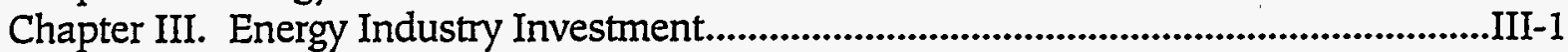

Chapter IV. Energy Consumption ........................................................................................IV-1

Chapter V. Energy-Consuming Equipment and Activities ..............................................V-1

Chapter VI. Imports and Exports of Energy and Energy-Intensive Products ...................VI-1

Chapter VII. Energy and Environment .........................................................................VII-1

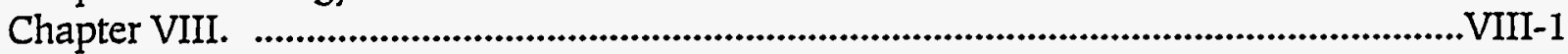

Chapter IX. International Comparisons ..........................................................................

Chapter X. Economic Indicators and Population ...........................................................

Appendices ...............................................................................................................

\section{Table of Tables}

\section{CHAPTER I. RESOURCES AND RESERVES}

1. Energy Resources for Selected Countries ............................................................

2. China's Coal Resources by Type of Coal, End of 1991 ................................................

2. Energy Reserves for Selected Countries...................................................................

\section{CHAPTER II. ENERGY PRODUCTION}

1. Primary Energy Production, 1949-1994 ...........................................................II-7.

2. Commercial Energy Production by Province and Energy Source, 1986-1993 ............II-13

3. Raw Coal Production by Producer, 1950-1994 ........................................................II-26

4. Raw Coal Production by Type of Coal ..................................................................II-31

5. Characteristics of Chinese Steam Coal ............................................................II-32

6. Major Coal Mining Enterprises: Annual Production $>5$ Million Tonnes

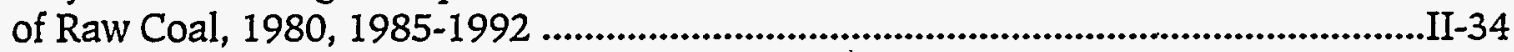

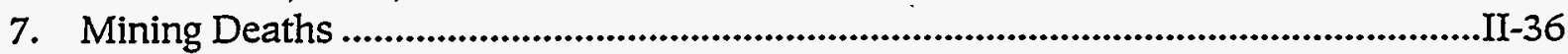

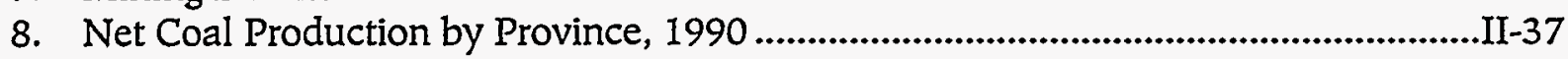

9. Coke Production, 1949-1994 …....................................................................................II-38

10. Coking Coal Used in Coke Production, 1980-1992 .................................................II-40

11. Production of Washed Coal, 1949-1993 ..........................................................II-41

12. Coal Gas Production, 1980-1992 .............................................................................II-43

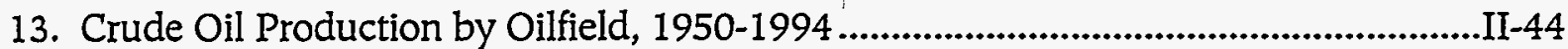

14. Selected Technical Indicators of Crude Oil Production, 1970-1992 ...........................II-54

15. Petroleum Products, 1973-1994 .............................................................................55

16. Natural Gas Production, by Source, 1949-1994...................................................II-58

17. Gross Electricity Generation, 1949-1994 ...............................................................II-60

18. Electricity Generation and Consumption, 1980-1993 .............................................II-63

19. Electricity Generation Capacity and Growth Rates, 1949-1994 ................................II-64

20. Installed Thermal Generation Capacity, by Type of Turbine, 1974-1993 ...................II-68

21. National Average Capacity Factors for Electric Power Generation, 1978-1994 ..........II-66 
22. Installed Capacity and Performance of Large Power Networks, 1991

23. Thermal Power Generation and Capacity by Plant Size, 1978-1993

24. Generation by Self-Producers, 1980-1993

25. Hydropower Generation and Capacity by Plant Size, 1980-1992 ..............................II-74

26. Principal Thermal PowerPlants $>600 \mathrm{MW}, 1991$

27. Capacity Factors for Principal Hydropower Plants, $\geq 250 \mathrm{MW}, 1991$

28. Coverage of Rural Electric Grids, Selected Years

29. Railway and Pipeline Transportation of Coal and Oil,Selected Years

30. Interprovincial Coal Transfers via Railway, 1993

31. Indices of Five Major Pipelines, 1993 $. . I I-83$

32 National Renewable Energy Production Capacities, End of 1992 III-84

\section{CHAPTER III. ENERGY INDUSTRY INVESTMENT}

1. Investment by State: Total and Capital Construction Compared to Energy Industry Investment, 1953-1993

2. Total Investment by Ownership of Enterprise, 1983-1993 ......................................III-12

3. Total Energy Industry Investment by Subsector, 1981-1993 .......................................III-13

4. Energy Industry Capital Construction Investment by Subsector, 1953-1994 .............III-16

5. Energy Industry Capital Construction Investment by Subsector and Purpose, 1953-1992

6. Energy Industry Technical Updating and Transformation Investment by Subsector and Purpose, 1981-1993.

7. Total Technical Updating and Transformation Investment by Investment Category, 1981-1992

8. Energy Supply and Conservation Investments.......................................................III-28

9. Energy Conservation Investments, 1981-1993 ..........................................................III-30

10. Completed Energy Conservation Capital Construction Projects, 1981-1990 ..............III-31

11. Newly Increased Production Capacity of State-Owned Enterprises, 1981-1993 ........III-32

12. Capital Construction Investment by Source of Funds, 1981-1990...............................III-34

\section{CHAPTER IV. ENERGY CONSUMPTION}

\section{OVERALL CONSUMPTION:}

1. Primary Energy Consumption, 1952-1993

2. Primary Energy Consumption: Commercial and Biomass Energy, 1979 and $1987 ; 1990$ and 1992

3. Actual Primary Energy Consumption and Projected Energy Consumption at Frozen 1977 Intensity, 1952-1993

4. Primary Commercial Energy Consumption by Province and Energy Source, 1990...IV-20

5. Per Capita Primary Commercial Energy Consumption by Province and Energy Source, 1990 .

6. Energy Intensity by Province, 1990 Primary Energy Consumption per Unit of National Income.

\section{SECTORAL CONSUMPTION:}

7. End-Use Energy Consumption by Sector, 1980-1992

8. Industrial End-Use Energy Consumption by Energy Type, 1980-1992 
9. Industrial Sector Energy End Use by Subsector and Energy Type, with Gross Output Value by Subsector, 1980-1992

10. Industrial Sector Commercial Energy Consumption

by Province and Energy Source, 1990

IV-53

11. Energy Used as Feedstocks, 1980-1991 ...................................................................IV-58

12. Thermal Electric Utility Fuel Use, 1980-1993 ......................................................59

13. Average Heat Rates of Thermal Power Plants ..........................................................V-62

14. Power Sector Electricity Consumption, Selected Years, 1952-1993 ..........................V-63

15. Transportation Energy Consumption 1980-1992 .......................................................V-64

16. Transportation End-Use Consumption Shares by Mode, 1985 and 1990...................IV-66

17. Agricultural Energy Consumption, 1980-1992 (Commercial Fuels Only) ....................V-68

18. Residential Energy Consumption, 1980-1992 (Commercial Energy Only) ................. IV-70

19. Urban and Rural Residential Energy Consumption (Commercial Energy Only) ........V-73

20. Residential Sector Commercial Energy Consumption

by Province and Energy Source, 1990

21. Rural Energy: Available Energy Sources and Houshold Consumption, $1979,1987,1990$ and 1992

22. Urban Gas Use, 1957-1993

23. Commercial Sector Energy Consumption, 1980-1992

END-USE CONSUMPTION BY SOURCE

24. End-Use Energy Consumption by Source (Commercial Energy Only) .........................81

25. Estimated Energy Consumption by End Use, 1990 .....................................................

26. Coal End Use and Inputs to Conversions, 1980-1993 ..............................................86

27. Coal Gas End-Use and Inputs to Conversions, 1980-1992 .....................................

28. Total Oil Product End Use and Inputs to Conversions, 1980-1992 ............................IV-92

29. Total Oil Product End Use and Inputs to Conversions

by Petroleum Product, 1980-1992

IV-94

30. Crude Oil End Use and Inputs to Conversions .....................................................

31. Diesel Oil End Use and Inputs to Conversions.......................................................IV-98

32. Natural Gas End Use and Inputs to Conversions, 1980-1992 .....................................IV-100

33. Electricity End Use by Sector, 1980-1993

IV-101

\section{CHAPTER V. ENERGY CONSUMING EQUIPMENT AND ACTIVITIES}

1. Freight Movements by Mode, 1949-1993 ...................................................................6

2. Passenger Travel by Mode, 1949-1993 ..................................................................V-8

3. Stock of Civilian Motor Vehicles, 1970-1993 ..............................................................V-10

4. Motor Vehicle Production, 1978-1994 .......................................................................V-12

5. Motor Vehicle Fuel Economy, 1970-1990 ...............................................................V-14

6. Stock of Railway Locomotives, by Engine Type, Various Years, 1952-1993 ..............V-16

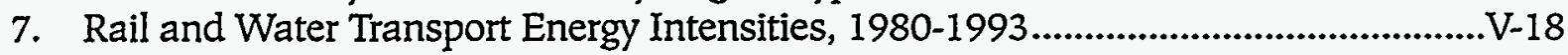

8. Stock and Output of Major Appliances, 1978-1994 ...................................................V-20

9. Urban Household Survey Data, 1981-1993 ............................................................

10. Rural Household Survey Data, Various Years 1978-1993 ...........................................V-24

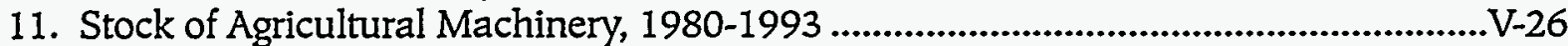

12. Total Stock of Electricity-Consuming Equipment by Subsector, 1986-1993 ..............V-27

13. Energy Efficiencies of Some Major Equipment Types, 1990 .................................V-30 
14. Output of Major Energy-Intensive Industrial Raw Materials, 1980-1990 page

15. Physical Energy Intensity of Selected Industrial Products, 1970-1993`....

CHAPTER VI. ENERGY PRICES

1. Average Minemouth Sales Price of Raw and Washed Coal, Major State-Owned Mines

.VI-4

2. Cost Buildup for Datong Lump Coal Shipped to Shanghai and Guangzhou, March 1992.

3. Average Retail Price of Coal in Various Cities ......................................................

4. Coal Prices, Local Markets

5. Average Retail Prices of Coal and Oil Products in Major Cities, December 1994 .......VI-8

6. Ex-Refinery Oil Products Prices, 1994

VI-9

7. Average Wholesale Electricity Prices by Region

8. Retail Electricity Price by Sector, 1994

9. Electricity Supply Surcharges for Transmission and Distribution, 1993 ......................VI-11

10. Electricity Purchase Price, Tianjin Soda Plant, August 1993 ...................................VI-11

11. Anhui Grid Basic Electricity Rates, Effective 1993

12. Beijing-Tianjin-Tangshan Grid Basic Electricity Rates, Effective 1993

VI-13

13. Fujian Grid Basic Electricity Rates, Effective 1993

VI-14

14. Gansu Grid Basic Electricity Rates, Effective 1993

VI-15

15. Guangxi Grid Basic Electricity Rates, Effective 1993

VI-16

16. Guizhou Grid Basic Electricity Rates, Effective 1993

VI-17

17. Hebei Grid Basic Electricity Rates, Effective 1993

VI-18

18. Henan Grid Basic Electricity Rates, Effective 1993

VI-19

19. Hubei Grid Basic Electricity Rates, Effective 1993

20. Hunan Grid Basic Electricity Rates, Effective 1993

VI-21

21. Inner Mongolia Grid Basic Electricity Rates, Effective 1993

VI-22

22. Jiangsu Grid Basic Electricity Rates, Effective 1993

VI-24

23. Jiangxi Grid Basic Electricity Rates; Effective 1993

VI-25

24. Ningxia Grid Basic Electricity Rates, Effective 1993

VI-26

25. Northeast Grid Basic Electricity Rates, Effective 1993

VI-27

26. Qinghai Grid Basic Electricity Rates, Effective 1993

27. Shaanxi Grid Basic Electricity Rates, Effective 1993

28. Shandong Grid Basic Electricity Rates, Effective 1993

VI-30

29. Shanghai Grid Basic Electricity Rates, Effective 1993

.VI-31

30. Sichuan Grid Basic Electricity Rates, Effective 1993

VI-32

31. Xinjiang Grid Basic Electricity Rates, Effective 1993

VI-33

32. Yunnan Grid Basic Electricity Rates, Effective 1993

VI-34

33. Zhejiang Grid Basic Electricity Rates, Effective 1993

VI-35

\section{CHAPTER VII. IMPORTS AND EXPORTS}

1. Energy Exports and Imports, 1950-1994 ...................................................................VII-4

2. Energy Exports and Imports by Destination and Origin, 1993 ...............................VII-8

3. Gross Energy Exports Earnings and Total Export Earnings,

Selected Years 1953-1970, and 1975-1993.

4. Crude Oil Imports and Exports, 1993 and 1994 ...................................................VII-13

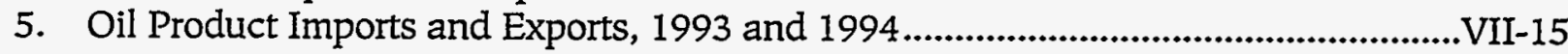


6. page

6. Exports of Energy-Intensive Products, 1981-1993

..VIII-17

7. Imports of Energy-Intensive Products ...........................................................................VIII-18

\section{CHAPTER VIII. ENERGY AND ENVIRONMENT}

A. Ambient Air Pollution Standards ..............................................................................VIII-7

1. Carbon Dioxide Emissions by Source, 1950-1991 ...................................................VIII-8

2. National Total Sulfur Dioxide and Particulate Emissions, 1980 and 1985-1993.......VIII-11

3. Sulfur Dioxide and Particulate Emissions by Region, 1993 .........................................VIII-13

4. Sulfur Dioxide and Particulate Emissions by Industrial Sector, 1991-1993................VIII-14

5. Ambient Air Quality in Chinese Cities, 1980-1993 (Annual Averages) .......................VIII-19

6. Ambient Air Quality in Chinese Cities: Total Suspended Particles, 1986-1993 .........VIII-22

7. Ambient Air Quality in Selected Chinese Cities: Sulfur Dioxide, 1986-1993 ..............VIII-24

8. Ambient Air Quality in Selected Chinese Cities: Nitrogen Oxides, 1986-1993 ...........VIII-26

9. Ambient Air Quality in Selected Chinese Cities: Carbon Monoxide, 1981-1993 ........VIII-28

10. Particulate Deposition Velocity for Selected Cities, 1986-1993 ...................................VIII-29

11. Acidity of Precipitation - Annual Average pH ......................................................VIII-31

12. Indoor Air Pollution in Chinese Residences: Range of Pollutant Levels .....................VIII-32

\section{CHAPTER IX. INTERNATIONAL COMPARISONS}

1. Total Primary Commercial Energy Productionby Energy Source for Selected Countries, 1989-1992.

2. World Primary Commercial Energy Consumption, by Region or Nation, 1989-1992.

3. World Primary Coal Consumption, Selected Years

4. Intensity Trends: Primary Commercial Energy Consumed per Unit GDP, 1970-1993

5. Total Energy Consumption by Sector for Selected Countries, 1992

6. Industrial Energy Consumption by Source, 1992

7. Transportation Energy Consumption by Source, 1992 ....................................................23

8. Residential and Commercial End Use Energy Consumption by Source, 1992 ............XX-25

9. End-Use Energy Consumption Structure by Source....................................................X-27

10. Solid Fuel Consumption by Sector, 1992 .........................................................................X-29

11. Petroleum Products Consumption by Sector, 1992 .................................................XX-31

12. End Use Electricity Consumption by Sector, 1992 .......................................................X-32

13. Crude Steel Production, Selected Countries, 1979-1992 ...............................................X.

14. Cement Production, Selected Countries, 1979-1992 ..................................................X-36

15. Primary Aluminum Production, Selected Countries, 1979-1992 .................................X-37

16. Ethylene Production, Selected Countries, 1979-1992 .................................................

17. Ammonia Production, Selected Countries, 1979-1992 ..................................................X-39

19. Caustic Soda Production, Selected Countries, 1979-1992 …....................................X.

20. Sulphuric Acid Production, Selected Countries, 1979-1992..........................................X.

21. Wood Pulp Production, Selected Countries, 1979-1992 ..............................................X-42

22. Structure of Passenger Travel, Selected Countries, 1992 ...........................................X-43

23. Structure of Freight Transportation, Selected Countries, 1992 ....................................X.

24. Carbon Dioxide Emissions from Fossil Fuel Combustion, Cement Production, and Gas Flaring, 1950-1991 
page

25. GDP Structure for Selected Countries for Selected Years........................................IX-55

26. Population of Selected Countries .......................................................................

\section{CHAPTER $X$. ECONOMIC INDICATORS AND POPULATION}

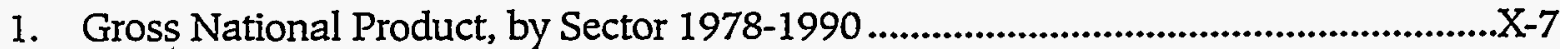

2. Per Capita Gross National Product 1978-1990 .......................................................X-10

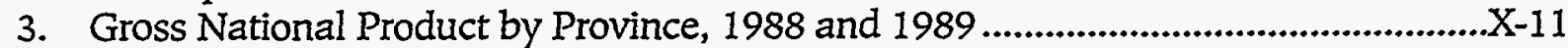

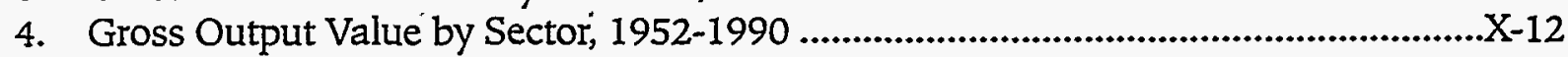

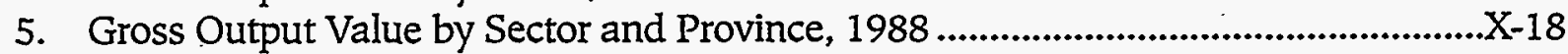

6. Gross Output Value for Agricultural and Industrial Sectors by Province, 1989 .........X-19

7. Gross Output Value by Major Industrial Subsector, 1952-1989 .................................X-20

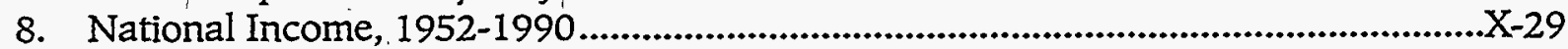

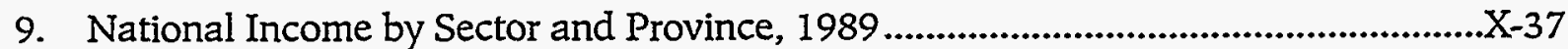

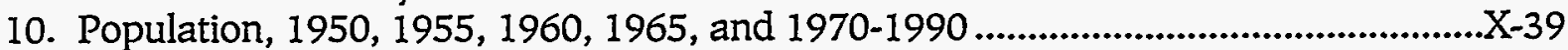

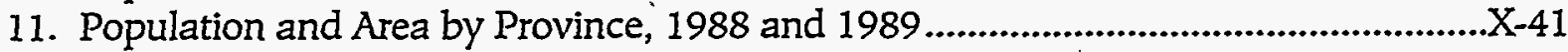

12. Socioeconomic Indicators of Urban Households ................................................. 


\section{Table of Figures}

\section{CHAPTER I. RESOURCES AND RESERVES}

1. Coal Resourcess..............................................................................................................

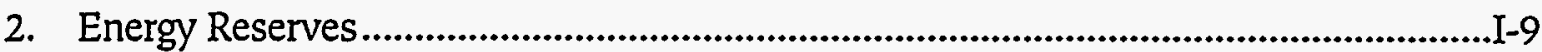

\section{CHAPTER II. ENERGY PRODUCTION}

1. Primary Energy Production by Energy Source in China, 1949-1994 ............................II-9

2. Primary Energy Production by Source, 1950-1990 ......................................................II-9

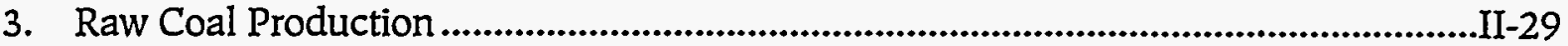

4. Raw Coal Production by Producer....................................................................................

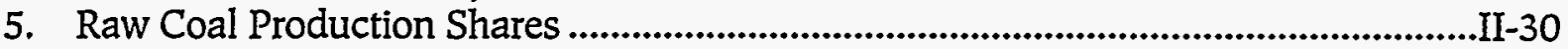

6. Raw Cole Production by Type of Coal ...........................................................................-31

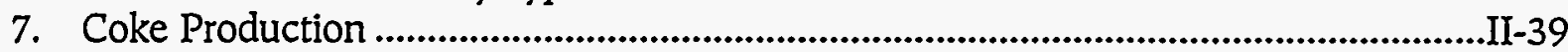

8. Washed Coal Output .................................................................................................

9. Washed Coal and Total Raw Coal Production, 1981-1989 ...........................................II-30

10. Crude Oil Production Growth Rates, Shengli, Daqing, and Total .................................II-52

11. Crude Oil Production Shares by Field .............................................................................

12. Crude Oil Production by Oil Field ......................................................................................II-53

13. Petroleum Refinery Output..........................................................................................II-57

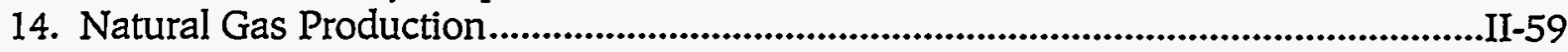

15. Electricity Generation ......................................................................................................-62

16. Electricity Generation Capacity ....................................................................................

17. Railway Transportation of Energy Products ...............................................................II-80

\section{CHAPTER III. ENERGY INDUSTRY INVESTMENT}

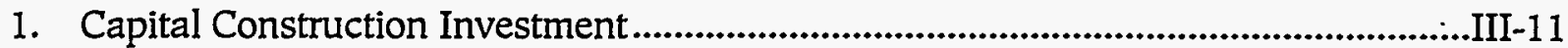

2. Structure of Capital Construction Investment ..............................................................III-11

3. Total Energy Industry Investment by Subsector ...............................................................III-15

4. Shares of Total Energy Industry Investment..................................................................III-15

5. Capital Construction Investment in the Energy Industry by Subsector, ......................III-18

6. Subsectoral Shares of Energy Industry Capital Construction Investment.....................III-18

7. Capital Technical Updating and Transformation Investment

\section{CHAPTER IV. ENERGY CONSUMPTION}

OVERALL CONSUMPTION:

1. Total Primary Energy Consumption, by Fuel Source

2. Shares of Primary Energy Consumption, by Fuel Source

3. Primary Energy Consumption: Commercial and Biomass Energy

4. Energy Intensity of the Chinese Economy

5. Primary Commercial Energy Consumption: Actual Use and Use Predicted by 1977 Energy Intensity 
SECTORAL CONSUMPTION:

6. Commercial Energy End Use by Sector

IV-28

7. Sectoral Shares of Commercial Energy End Use .................................................

8. Industrial Energy End Use by Energy Source ..................................................

9. Subsectoral Shares of Industrial Sector, End-Use Energy Consumption ...................IV-52

10. Fuel Use in Electricity Generation......................................................................61

11. Transportation Sector Energy Consumption.........................................................IV-65

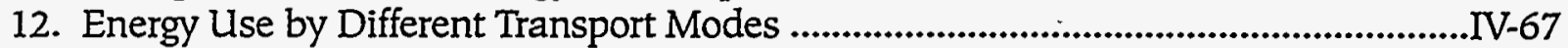

13. Agricultural Energy Consumption........................................................................

14. Residential Energy Consumption (Commercial Energy) .........................................

15. Commercial Sector Energy Consumption by Fuel...................................................IV-79

ENERGY SOURCE CONSUMPTION:

16. End-Use Energy Consumption by Energy Source ..................................................

17. Estimated Energy Consumption, by End Use ....................................................IV-85

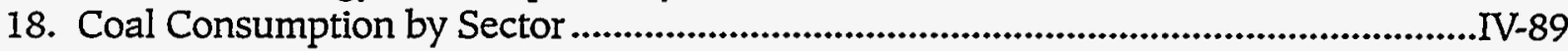

19 Coal Consumption by Sector:Coal Inputs to Electricity Generation

Attributed to Electricity End-Use Sectors .....................................................

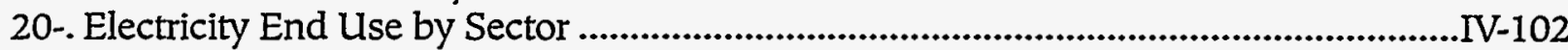

\section{CHAPTER V. EQUIPMENT AND ACTIVITIES}

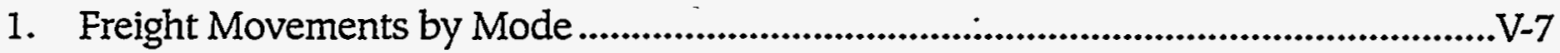

2. Passenger Travel by Mode ..............................................................................

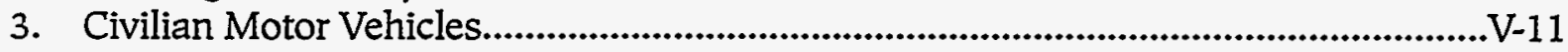

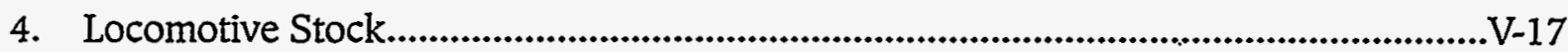

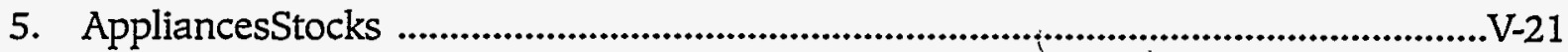

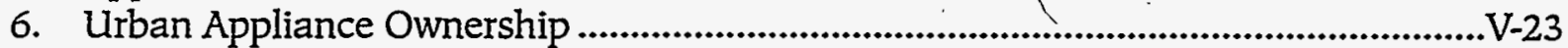

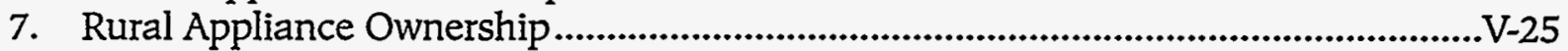

8. Capacity of Electricity-Consuming Equipment...................................................

\section{CHAPTER VII. IMPORTS AND EXPORTS}

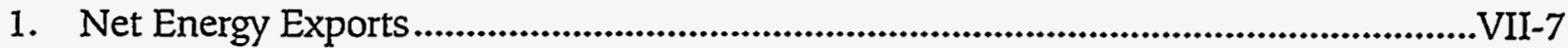

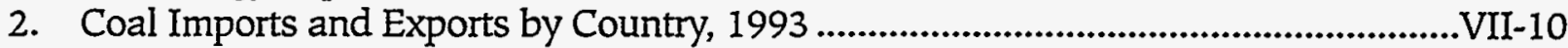

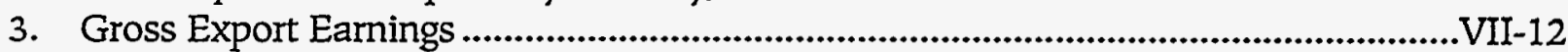

4. Crude Oil Imports and Exports by Country, 1994 .............................................VII-14

5. Oil Product Imports and Exports by Country, 1994 .................................................VII-16

\section{CHAPTER VIII. ENERGY AND ENVIRONMENT}

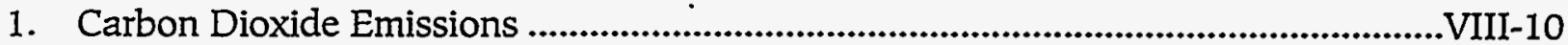

2. Sulfur Dioxide and Particulate Emissions ............................................................VIII-12

3. Pollutant Emissions by Sector .............................................................................VIII-18

4. Ambient Air Pollutant Levels in China's Major Cities (Annual Averages)

Compared to Chinese Class II Air Quality Standards ..VIII-21 


\section{CHAPTER IX INTERNATIONAL COMPARISONS}

1. Shares of Primary Energy Production by Energy Source,

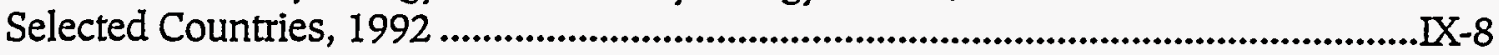

2. Shares of World Primary Energy Source Production by Country, 1992 .......................IX-8

3. Shares of Primary Commercial Energy Consumption by Energy Source, 1992

4. Per Capita Primary Commercial Energy Consumption .................................................IX-12

5. Coal Consumption Shares, Selected Countries ........................................................IX-14

6. Energy Intensity Trends, Selected Countries ...................................................................IX-19

7. Sectoral Shares of Energy End Use, Commercial Energy Only, 1992 .........................IX-21

8. Sectoral Shares of Energy End Use, Commercial and Biomass Energy ........................IX-21

9. Shares of Total Industrial Sector Energy End Use by Energy Source, ..........................X-23

10. Energy Use in Transportation, Selected Countries, 1992 ...............................................X.25

11. Residential and Commercial Energy Use, Selected Countries, 1992 ..........................XX-27

12. Shares of End Use Energy Consumption by Energy Source, Selected Countries, 1992

13. Sectoral Shares of Coal Consumption, 1992 .........................................................XX-31

14. Sectoral Shares of Coal Consumption, 1992: Power Generation Coal Consumption Allocated to End-Use Sectors.

15. Sectoral Shares of Petroleum Consumption, Selected Countries, 1992 ........................X.

16. Sectoral Shares of Electricity Consumption, Selected Countries, 1992 ........................IX-35

17. Passenger Traffic, Selected Countries, 1992 ................................................................

18. Per Capita Passenger Traffic by Mode 1992 ...............................................................X.

19. Freight Traffic, Selected Countries, 1992 ...............................................................X-48

20. Per Capita Freight Traffic by Mode, 1992 ........................................................X.

21. Carbon Dioxide Emissions, USA, USSR, China, India, Japan .....................................X-50

22. Shares of Global CO2 Emissions, USA, USSR, China, India, Japan.............................IX-52

23. Per Capita CO2 Emissions, USA, USSR, China, India, Japan, 1950-1993 ………......XX-54

24. GDProduct Structure, Selected Countries, 1980 ............................................................X.

25. GDProduct Structure, Selected Countries, 1993 ..........................................................X.-56

\section{CHAPTER X. ECONOMIC INDICATORS AND POPULATION}

1. Gross Domestic Product by Sector, 1978-1994 ……........................................................10

2. Sectoral Shares of Gross Domestic Product, 1978-1994 ..................................................10

3. Gross Output Value by Sector, 1952-1990 ...........................................................16

4. Sectoral Shares of Gross Output Value, 1952-1990 ....................................................16

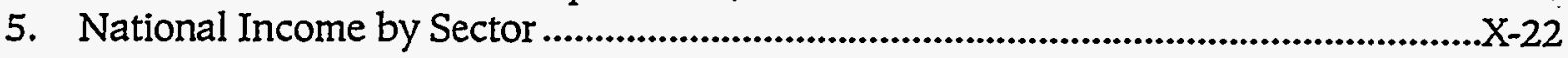

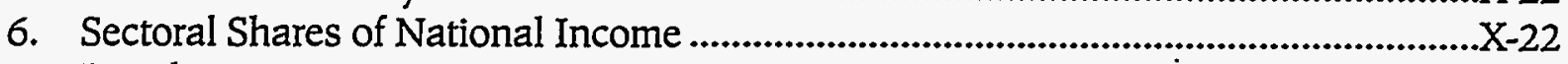

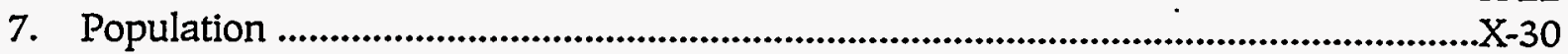

8. Nonagricultural Fraction of Total Population ................................................................30

11. Urban Household Expenditure on Fuels as a Percentage of Total Expenditures........X-33 


\section{CHAPTER I. ENERGY RESOURCES AND RESERVES}

1. Coal-Bearing Sediments

2. China's Principal Hydrocarbon Basins

\section{CHAPTER II. ENERGY PRODUCTION}

1. Energy Production, 1993, (Commercial Energy Sources).......................................II-20

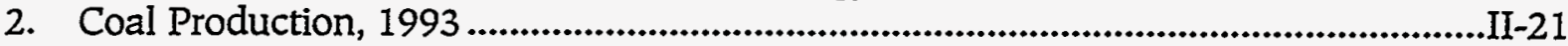

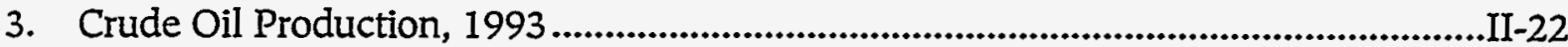

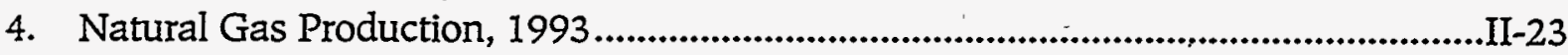

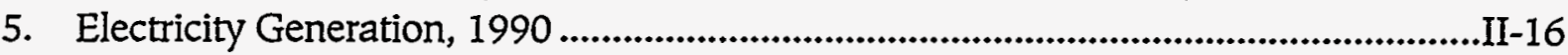

6. Hydroelectricity Generation, 1990.....................................................................17

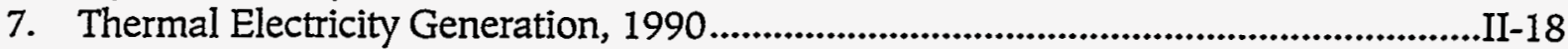

8. Location of Major Coal Mines: Annual Production >5 Million Tonnes

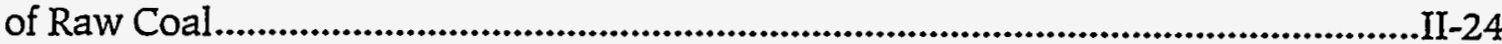

9. Location of Principal Onshore Oil fields..........................................................II-40

\section{CHAPTER III. ENERGY INDUSTRY INVESTMENT}

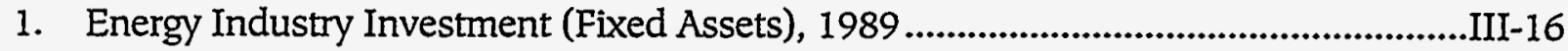

2. Coal Extraction and Processing Investment (Fixed Assets), 1989 ............................III-17

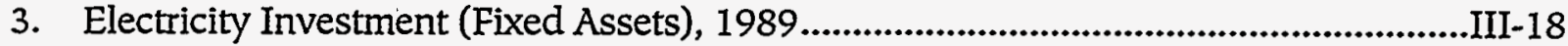

4. Petroleum and Natural Gas Extraction Investment (Fixed Assets), 1989 ..................III-19

\section{CHAPTER IV. ENERGY CONSUMPTION}

OVERALL CONSUMPTION:

1. Per Capita Primary Energy Consumption, 1990 (Commercial Energy Sources) .........IV-22

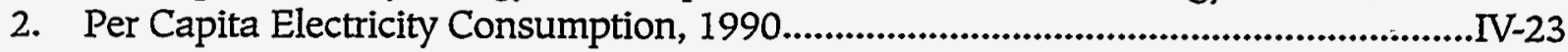

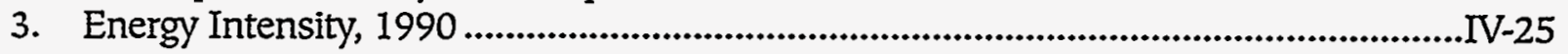

SECTORAL CONSUMPTION:

4. Industrial Sector Energy Consumption, 1990...................................................IV-54

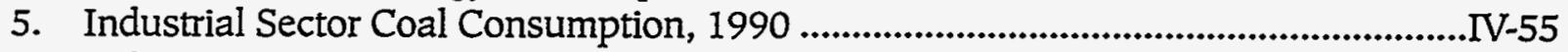

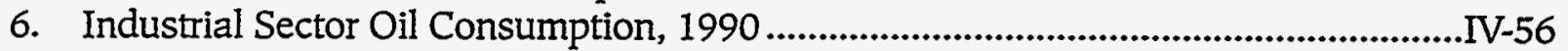

7. Industrial Sector Electricity Consumption, 1990 ..................................................

8. Per Capita Residential Energy Consumption, 1990 (Commercial Energy Sources ....IV-75

\section{CHAPTER VIII. ENERGY AND ENVIRONMENT}

1. Industrial Sulfur Dioxide Emissions Density, 1993 ...........................................VIII-14

2. Industrial Particulate Emissions Density, 1993 ............................................VIII-15

CHAPTER X. ECONOMIC INDICATORS AND POPULATION

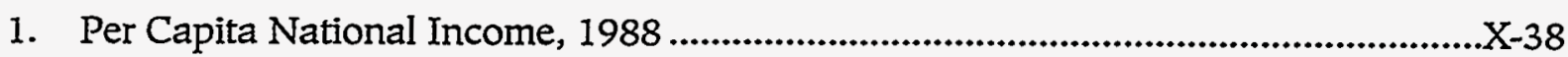

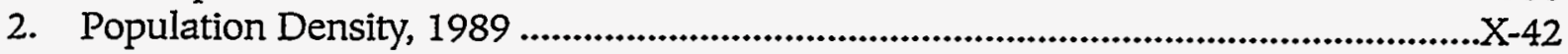




\section{Appendices}

page

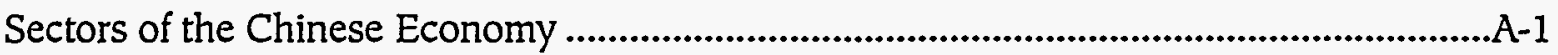

List of Abbreviations .......................................................................................................

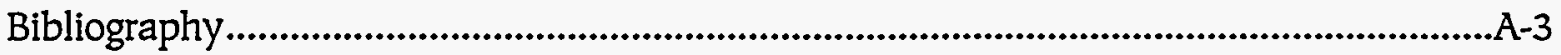




\section{Energy Units and Conversions *}

\begin{tabular}{|c|c|c|c|c|}
\hline Fuel & $\begin{array}{l}\text { Heat Content } \\
\text { (low heat) } \\
\text { (GJ) }\end{array}$ & $\begin{array}{c}\text { Multiplier } \\
\text { (tonnes of } \\
\text { coal equivalent) }\end{array}$ & $\begin{array}{c}\text { Multiplier } \\
\text { (barrels of } \\
\text { oil equivalent) }\end{array}$ & $\begin{array}{c}\text { Multiplier } \\
\text { (million kcal) }\end{array}$ \\
\hline \multicolumn{5}{|l|}{ Coal } \\
\hline Standard coal (metric ton) & 29.310 & 1.000 & 5.147 & 7.00 \\
\hline Chinese average raw coal (metric ton) & 20.934 & 0.714 & 3.676 & 5.00 \\
\hline Chinese average washed coal (metric ton) & 26.377 & 0.900 & 4.632 & 6.30 \\
\hline Bituminous coals (metric ton) & 19.92 to 33.11 & 0.68 to 1.13 & 3.50 to 5.82 & 4.76 to 7.91 \\
\hline Brown coals, lignites (metric ton) $\dagger$ & 7.91 to 19.92 & 0.27 to 0.68 & 1.39 to 3.50 & 1.89 to 4.76 \\
\hline Utility Coal (metric ton) II & 18.729 & 0.639 & . 3.289 & 4.47 \\
\hline Coke (metric ton) & 28.470 & 0.971 & 5.000 & 6.80 \\
\hline Coking Coal Gas (thousand $\mathrm{m}^{3}$ ) & $\begin{array}{l}16.75 \text { to } 18.00 \\
\text { (avg. } 17.24)\end{array}$ & $\begin{array}{l}0.57 \text { to } 0.61 \\
\text { (avg. } 0.59 \text { ) }\end{array}$ & $\begin{array}{r}2.94 \text { to } 3.16 \\
\text { (avg. } 3.03 \text { ) }\end{array}$ & $\begin{array}{l}4.00 \text { to } 4.30 \\
\text { (avg: } 4.12 \text { ) }\end{array}$ \\
\hline \multicolumn{5}{|l|}{ Petroleum } \\
\hline Chinese average crude oil (metric ton) $\S$ & 41.868 & 1.429 & 7.353 & 10.00 \\
\hline Chinese average crude oil (bbl) & 5.694 & 0.199 & 1.000 & 1.36 \\
\hline Fuel Oil (metric ton) & 41.868 & 1.429 & 7.353 & 10.00 \\
\hline Gasoline (metric ton) & 43.124 & 1.471 & 7.574 & 10.30 \\
\hline Kerosene (metric ton) & 43.124 & 1.471 & 7.574 & 10.30 \\
\hline Diesel (metric ton) & 42.705 & 1.457 & 7.500 & 10.20 \\
\hline LPG (metric ton) & 50.241 & 1.714 & 8.823 & 1200 \\
\hline Refinery Gas (metric ton) & 46.055 & 1.571 & 8.088 & 11.00 \\
\hline \multicolumn{5}{|l|}{ Natural Gas } \\
\hline Chinese average natural gas (thousand $\mathrm{m}^{3}$ ) & 38.98 & 1.33 & 6.846 & 9.31 \\
\hline Standard natural gas (thousand $\mathrm{m}^{3}$ ) & 37.68 & 1.29 & 6.617 & 9.00 \\
\hline \multicolumn{5}{|l|}{ Electricity } \\
\hline $\begin{array}{l}\text { Electricity (thousand } \mathrm{kWh} \text { ) } ¥ \\
\mathrm{~kW}=1.341 \mathrm{hp}\end{array}$ & $11.84 \mid$ & 0.404 & 2.080 & 2.83 \\
\hline \multicolumn{5}{|l|}{ Biomass } \\
\hline Fuelwood, air-dried (metric ton) $\dagger$ & 14 to 17 & 0.48 to 0.58 & 0.084 to 0.102 & 3.34 to 4.06 \\
\hline Crop residues, air-dried (metric ton) $\dagger$ & 12 to 16 & 0.41 to 0.55 & 0.072 .to 0.097 & 2.87 to 3.82 \\
\hline Dried dung (metric ton) $\dagger$ & 11 to 14 & 0.38 to 0.48 & 0.067 to 0.084 & 2.63 to 3.34 \\
\hline Peat (metric ton) (b)7.5 to 10.5 & 0.26 to 0.36 & 0.046 to 0.063 & 1.79 to 2.51 & \\
\hline Biogas (thousand $\mathrm{m} 3$ ) ** & 21 to 27 & 0.71 to 0.93 & 3.7 to 4.8 & 5.0 to 6.5 \\
\hline
\end{tabular}

N.B.: THroughout this book tons refers to metric tons (1 metric ton - 1.102 short tons).

* Unless otherwise noted all conversions are from the China Energy Statistical Yearbook, 1989.

$\dagger$ From Smil, 1988.

I Coal used in utility boilers generally has a lower heat content than average coal (Wangi, 1988).

$\S$ This is the same factor used for toe by British Petroleum.

When presenting overall energy production and consumption figures we use a conversion factor of $0.404 \mathrm{kgce} / \mathrm{kWh}$ for electricity. This conversion factor is commonly used by Chinese energy researchers, and agrees well with the heat value for net generation.

** Taylor, 1981 .

Source: Energy Statistical Yearbook of China, various years; Smil, 1988; Wang , 1988; Energy Statistics Handbook, 1987 ; British Petroleum, 1995; Taylor, 1981. 
Chapter I-Resources and Reserves 


\section{Resources and Reserves}

hina is richly endowed with conventional energy resources. In this chapter we present two measures of available energy: energy resources (Table I-1), or the estimated amount in place; and energy reserves (Table I-3), or the amount judged to be recoverable given current economic and technological constraints. ${ }^{1}$ Estimates are for fossil fuels, uranium, and hydroelectricity only.

\section{COAL}

Estimated total coal resources are well behind those of the former Soviet Union and the United States, owing mainly to a lack of exploration. China's own estimates of total resources are considerably higher than international estimates - $960 \mathrm{Gt}$ compared to $590 \mathrm{Gt}$. Of the total coal resource base, $12 \%$ is anthracite, $29 \%$ is coking quality bituminous coal, $46 \%$, various grades of bituminous steam coal, and $13 \%$, lignite (brown coal). Coal bed methane may become an important part of the energy mix in mining areas.

At $115 \mathrm{Gt}$, China's proved reserves of coal are about half the level of the United States and the former Soviet Union. Northern China, especially Shanxi Province, contains most of China's easily accessible high quality coal. Southern coals are generally higher in sulfur and ash, making them unsuitable for many applications. Consequently large amounts of coal are shipped from north to south, putting a great strain on the transportation system, especially railroads.

\section{Crude OIL}

China's oil resources are not large by world standards; the total resource base is estimated at 9.6 $\mathrm{Mt}$, of which up to $3.2 \mathrm{Mt}$ is proved reserves. This ranks China tenth among oil-producing countries, just ahead of Libya. ${ }^{2}$ The easily reached oil fields in the North and Northeast have been in production since the early 1960s. Output at China's largest oil field,
Daqing in Heilongjiang, has peaked at about 55 Mt/yr production, but the water cut in production has risen to over $90 \%$. Most exploration has been near currently producing basins, but development of more remote resources, such as in the Tarim and Junggar Basins in Xinjiang, and offshore fields has accelerated in recent years (often in conjunction with foreign partners) in order to meet long-term demand.

The results of onshore and offshore exploration have been disappointing so far. Although some producing fields have been found, exploration in the harsh and remote deserts of Xinjiang in the Northwest has not yet revealed any sources that will allow China to avoid increasing dependence on large amounts of imported oil. Development of those fields and long-distance transport infrastructure will be key to maintaining domestic output in the long term as yields from older fields decline. In the early 1980 s some experts predicted that offshore production in 1990 would be tens of millions of tons per year, but by 1994 actual production was $6.5 \mathrm{Mt}$ (just over $4 \%$ of total crude oil production). New finds and improvements in drilling techniques mean that the importance of offshore oil will continue to increase, but production is expected to peak in 1997 at 12 Mt/yr. ${ }^{3}$

\section{Natural Gas}

Natural gas resources in China are also small by world standards, less than $1 \%$ of the estimated world totals. With the exceptions of Sichuan Province (where large gas fields are close to demand centers), offshore (where there has been considerable foreign investment), and in the Shaanxi-Gansu-Ningxia basin in the Northwest, natural gas has been relatively neglected both in exploration and development. Analysis of geologic formations has led to expectations that natural gas resources are much greater that current discoveries indicate. Determining the magnitude and location of natural gas resources is one of the most significant issues pertaining to 
China's commercial energy resources.

\section{URANIUM}

With two nuclear power plants already on line and under expansion (the Daya Bay plant near Hong Kong and the Qinshan plant near Shanghai) and several more planned in other locations, uranium resources are likely to play a more important role in China's energy future. China's resources may be enough to meet demand from the 20 to $23 \mathrm{GW}$ of nuclear capacity planned for 2010 and 40 to $50 \mathrm{GW}$ for 2020 , but the ability to supply a large number of conventional reactors solely with domestic resources is uncertain.

\section{HYDROELECTRICITY}

Though China has the largest theoretically achievable capacity of hydroelectricity in the world, it is significantly behind the former Soviet Union in terms of potential annual generation. China's technically exploitable hydropower reserves are nonetheless impressive $-370 \mathrm{GW}$ of potentially usable capacity yielding 1,923 TWh/yr (slightly smaller than the figure found in international references) ${ }^{4}$ and hold the promise of meeting a significant portion of future energy demand. The majority of large sites are in Southwest China, which possesses twothirds of the country's potential generation. Most of the large sites, however, are far from the load centers near the coast, and long-distance transmission lines would have to cross formidable terrain. Small scale ( $<25 \mathrm{MW}$ ) hydropower schemes have supplied otherwise unavailable electricity to many rural communities. Technically exploitable small-scale sites amount to $19 \%$ and $13 \%$ of the capacity and annual generation totals respectively.

\section{Other Renewable Energy SOURCES}

China's biomass, solar, wind, tidal, and other renewable energy resources have not been well characterized. Some attempts have been made to estimate sustainable harvests of fuel wood and crop wastes (see Table IV-21).5 Biogas digesters have been promoted since the 1970s, especially in the
Southwest, with community and industrial digesters operating most successfully. According to some estimates, the potential biogas resource is about 82 Mtce, ${ }^{6}$ or about $6 \%$ of total energy consumption in 1992 (including biomass).

Solar resources are richest (averaging $>200$ $\mathrm{W} / \mathrm{m}^{2}$ ) in the dry, sparsely populated western and northem regions (Xinjiang, Qinghai, Xizang (Tibet), and Inner Mongolia), and relatively abundant ( $>170$ $\mathrm{W} / \mathrm{m}^{2}$ ) in northern and northeastern areas, as well as in Hainan. ${ }^{7}$ Wind resources are also ample in these same areas, but more importantly, the densely populated regions along China's coastline have many sites suitable for wind power development. Coastal areas are also home to many promising high-temperature geothermal sites, as is the Himalayan region. Solar, wind, geothermal, and tidal power have already been exploited on a small scale, but the capitalintensive nature of technologies for hamessing renewable energy sources will probably prevent widespread reliance on these alternatives in the near term.

\section{RELIABILITY OF INTERNATIONAL COMPARISONS}

Most energy resource and reserve figures are based on data provided by the countries surveyed. Since data-collection standards and definitions often vary from country to country, it is best to consider comparisons of country data as rough guides only, accurate to one significant figure at best. This is especially true for mineral resource estimates, which are based not on detailed site surveys but on similarities of the geography of unexplored sites to the features of known mineral-bearing structures.

1 Resources figures generally refer to the sum of the World Energy Conference categories "proved amount in place" and "estimated additional amount in place." Reserves figures refer mainly to the British Petroleum category of "proved reserves."

2 Ranked by proved reserves. British Petroleum, 1995.

${ }^{3}$ For further information on the current state of petroleum and natural gas resource exploration in China, refer to China OGP, 1994.

${ }^{4}$ Currently slightly less than $12 \%$ of harnessable capacity ( 44.6 GW in 1993) has been exploited. Estimates of economically exploitable capacity are significantly less than technical potential, i.e., $290 \mathrm{GW}$ yielding 1,260 TWh/yr (State Economic and Trade Commission, 1994). 
5 See also Smil, 1988.

6 Taylor, 1981.

${ }^{7}$ For a more detailed discussion of renewable energy resources, see State Economic and Trade Commission, 1994. 
I. Physical Units

\begin{tabular}{|c|c|c|c|c|c|c|c|}
\hline \multirow[b]{2}{*}{ Country } & \multicolumn{3}{|c|}{ Coal † (Gt) } & \multirow[b]{2}{*}{$\begin{array}{l}\text { Oilा } \\
\text { (Gt) }\end{array}$} & \multirow[b]{2}{*}{$\begin{array}{c}\text { Natural } \\
\text { GasII } \\
\text { (trillion m3) }\end{array}$} & \multirow[b]{2}{*}{$\begin{array}{l}\text { Hydro- } \\
\text { electricity } \\
\text { (TWh/year) }\end{array}$} & \multirow[b]{2}{*}{$\begin{array}{c}\text { Uranium } \S \\
\text { (kt U) }\end{array}$} \\
\hline & Subtotal & $\begin{array}{l}\text { Proved } \\
\text { Amount } \\
\text { in Place }\end{array}$ & $\begin{array}{c}\text { Estimated } \\
\text { Additional } \\
\text { Amount }\end{array}$ & & & & \\
\hline China & 986.3 & - & - & 9.6 & 10.0 & 5,922 & 51 \\
\hline India & 245.4 & 131.3 & 114.1 & 1.1 & 1.7 & 2,638 & 66 \\
\hline Japan & 8.5 & 8.5 & - & - & - & 718 & 7 \\
\hline USA & $1,570.3$ & 427.8 & 1,1425 & 13.4 & 23.2 & 529 & 2,524 \\
\hline FSU & $5,487.0$ & 287.0 & $5,200.0$ & 24.7 & 104.9 & 3,942 & 686 \\
\hline World & $10,163.3$ & $1,931.4$ & $8,231.9$ & 200.4 & 320.3 & 34,693 & 8,535 \\
\hline
\end{tabular}

\section{Shares of World Totals}

\begin{tabular}{|c|c|c|c|c|c|c|c|}
\hline \multirow[b]{2}{*}{ Country } & \multicolumn{3}{|c|}{ Coal $t$} & \multirow[b]{2}{*}{ Oil T } & \multirow[b]{2}{*}{$\begin{array}{c}\text { Natural II } \\
\text { Gas }\end{array}$} & \multirow[b]{2}{*}{$\begin{array}{l}\text { Hydro- } \\
\text { electricity }\end{array}$} & \multirow[b]{2}{*}{ Uranium $\S$} \\
\hline & Subtotal & $\begin{array}{l}\text { Proved } \\
\text { Amount } \\
\text { in Place }\end{array}$ & $\begin{array}{c}\text { Estimated } \\
\text { Additional } \\
\text { Amount }\end{array}$ & & & & \\
\hline China & $6 \%$ & $15 \%$ & $4 \%$ & $5 \%$ & $3 \%$ & $17 \%$ & $1 \%$ \\
\hline India & $2 \%$ & $7 \%$ & $1 \%$ & $1 \%$ & $1 \%$ & $8 \%$ & $1 \%$ \\
\hline Japan & $0.1 \%$ & $0.4 \%$ & - & - & - & $2 \%$ & $0.1 \%$ \\
\hline USA & $15 \%$ & $22 \%$ & $14 \%$ & $7 \%$ & $7 \%$ & $2 \%$ & $30 \%$ \\
\hline FSU & $54 \%$ & $15 \%$ & $63 \%$ & $12 \%$ & $33 \%$ & $11 \%$ & $8 \%$ \\
\hline World & $100 \%$ & $100 \%$ & $100 \%$ & $100 \%$ & $100 \%$ & $100 \%$ & $100 \%$ \\
\hline
\end{tabular}

* Unless otherwise noted, "resources" here are for end of 1990, and refers to the sum of World Energy Conference category of Proved Amount in Place and Estimated Additional Amount in Place. Proved Amount in Place is defined as "the [amount] that has been carefully measured and has also been assessed as exploitable under present and expected local economic conditions with existing available technology." Estimated Additional Amount in Place "includes estimates of amounts which could exist in unexplored extensions of known deposits or in undiscovered deposits in known fuel-bearing areas as well as amounts inferred through knowledge of favorable geological conditions." All figures are based on data provided by the countries in which the resources are located. Since definitions of resource categories are not uniform among countries, data may not be strictly comparable and comparisons should be made with caution.

$\dagger$ Chinese figure is for end of 1992. Coal resources figure for China is considerably lower than the one that appeared in earlier versions of the China Energy Databook because the definition of resources used by the Chinese government changed to conform more closely with commonly used intemational standards.

1. Figures are sum of identified reserves and an average value for a range of estimates of undiscovered resources. Figures do not include natural gas liquids. Data from Masters, 1991.

\$ 1990. For Japan, and the USA, figures correspond to the sum of the WEC categories of Proved Reserves and Estimated Additional Amounts Recoverable. Proved Reserves refers to "recoverable uranium that occurs in known mineral deposits of such size, grade and configuration that it could be recovered within the stated production cost ranges [under $\$ 130 \mathrm{US} / \mathrm{kg}$ ] with currently proven mining and processing technology." Estimated Additional Amounts Recoverable refers to expected additional deposits, estimated from extensions of already known deposits. For other countries, figures correspond to Other Known Resources, which includes is not strictly comparable to the sum of Proved Reserves and Estimated Additional Amounts Recoverable. For some countries, ultimate resources may be considerably larger than suggested here.

Source: World Energy Conference, 1992; State Economic and Trade Commission, 1994; Masters, 1991; United Nations, 1994. 
Figure I-1. Energy Resources

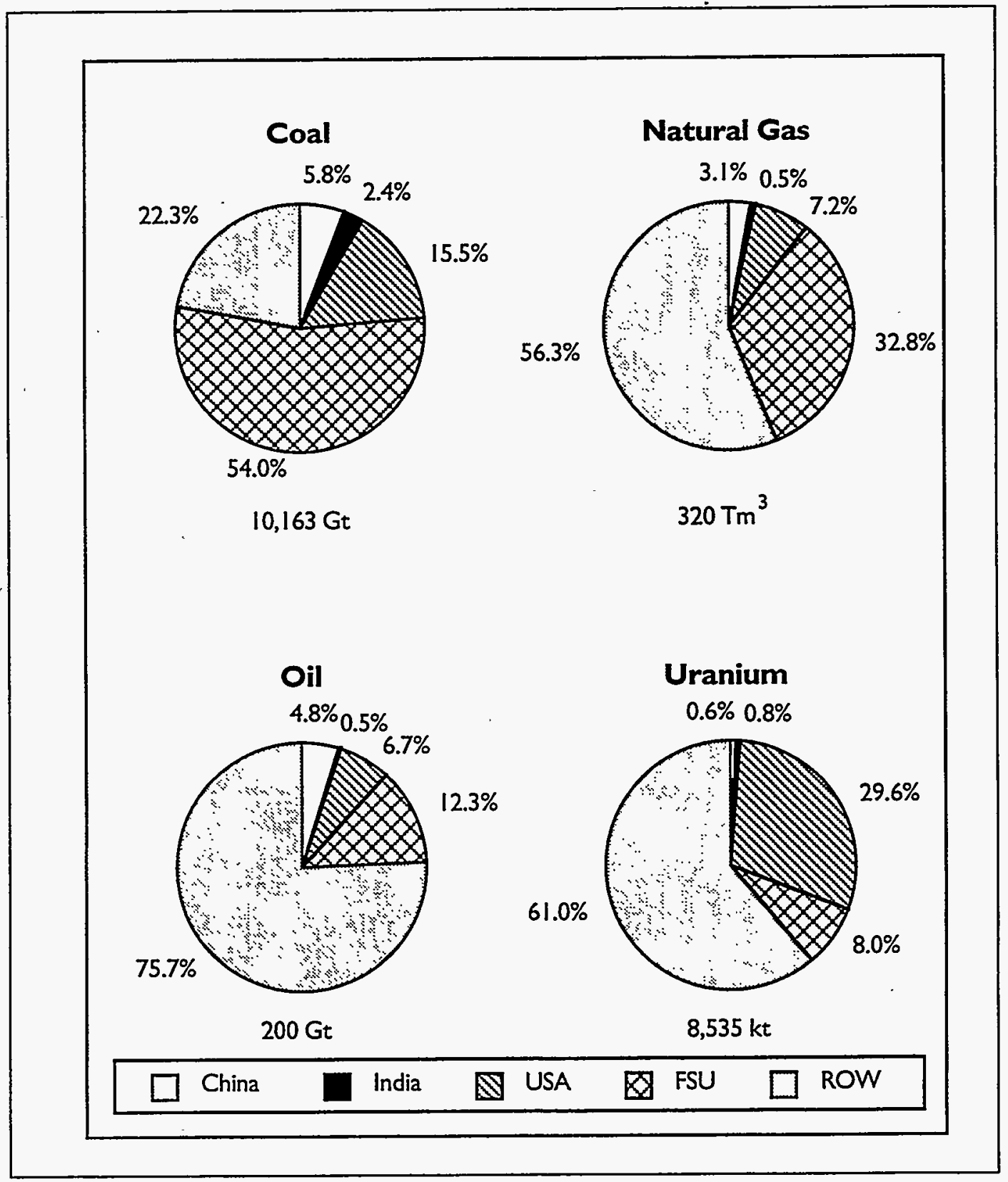


Table I-2. China's Coal Resources * by Type of Coal, End of 1991

\begin{tabular}{|lccc|}
\hline $\begin{array}{l}\text { Coal } \\
\text { Classification }\end{array}$ & $\begin{array}{c}\text { Total } \\
\text { Resource } \\
(\mathbf{G t )}\end{array}$ & $\begin{array}{c}\text { Share of } \\
\text { Steam Coal }\end{array}$ & $\begin{array}{c}\text { Share of } \\
\text { Total Coal }\end{array}$ \\
\hline Steam Coal & & & \\
$\quad$ non-caking coal & 123.7 & $18 \%$ & $13 \%$ \\
long flame coal & 121.0 & $18 \%$ & $13 \%$ \\
weakly caking coal & 16.8 & $2 \%$ & $2 \%$ \\
lean coal & 53.7 & $8 \%$ & $6 \%$ \\
anthracite & 115.4 & $17 \%$ & $12 \%$ \\
brown coal & 123.3 & $18 \%$ & $13 \%$ \\
unclassified & 133.4 & $19 \%$ & $14 \%$ \\
subtotal & 687.4 & $100 \%$ & $71 \%$ \\
Other Coal (Coking) & 276.8 & - & $29 \%$ \\
Total & 964.2 & - & $100 \%$ \\
& & & \\
\hline
\end{tabular}

* This is the Chinese category of "reserves confirmed through exploration." About $30 \%$ of that category corresponds to the WEC category of "proved amount in place," of which a third can be considered economically recoverable reserves.

Source: China Energy Research Society, 1994 
Table I-3. Energy Reserves * for Selected Countries

\begin{tabular}{|c|c|c|c|c|c|c|c|}
\hline \multirow[b]{2}{*}{ Country } & \multicolumn{3}{|c|}{ Coal (Mt) } & \multirow{2}{*}{$\begin{array}{c}\text { Crude } \\
\text { Oil } \\
\text { (Gt) }\end{array}$} & \multirow{2}{*}{$\begin{array}{c}\text { Natural } \\
\text { Gas } \\
\text { (trillion m3) }\end{array}$} & \multirow[b]{2}{*}{$\begin{array}{l}\text { Hydropower } f \\
\text { (TWh/year) }\end{array}$} & \multirow[b]{2}{*}{$\begin{array}{l}\text { Uranium I } \\
(t \in)\end{array}$} \\
\hline & Subtotal & $\begin{array}{c}\text { Bituminous \& } \\
\text { Anthracite }\end{array}$ & $\begin{array}{l}\text { Subbituminous } \\
\text { \& Lignite }\end{array}$ & & & & \\
\hline China & 114,500 & 62,200 & 52,300 & 3.3 & 1.7 & 2,168 & - \\
\hline India & 69,947 & 68,047 & 1,900 & 0.8 & 0.7 & 205 & - \\
\hline Japan & 821 & 804 & 17 & $<0.05$ & $<0.05$ & 135 & 6.6 \\
\hline USA & 240,558 & 106,495 & 134,063 & 3.8 & 4.6 & 376 & 356.1 \\
\hline FSU & 241,000 & 104,000 & 137,000 & 7.8 & 56.0 & $3,83 !$ & 220.6 \\
\hline World & $1,043,864$ & 519,733 & 524,131 & 141.0 & 142.0 & $|4,79|$ & $2,083.7$ \\
\hline
\end{tabular}

\begin{tabular}{|c|c|c|c|c|c|c|c|}
\hline \multirow[b]{2}{*}{ Country } & \multicolumn{3}{|c|}{ Coal } & \multirow[b]{2}{*}{$\begin{array}{c}\text { Crude } \\
\text { Oil }\end{array}$} & \multirow[b]{2}{*}{$\begin{array}{c}\text { Natural } \\
\text { Gas }\end{array}$} & \multirow[b]{2}{*}{ Hydropower $f$} & \multirow[b]{2}{*}{ Uranium q } \\
\hline & Subtotal & $\begin{array}{l}\text { Bituminous \& } \\
\text { Anthracite }\end{array}$ & $\begin{array}{l}\text { Subbituminous } \\
\text { \& Lignite }\end{array}$ & & & & \\
\hline China & $11 \%$ & $12 \%$ & $10 \%$ & $2.3 \%$ & $1.2 \%$ & $15 \%$ & - \\
\hline India & $7 \%$ & $13 \%$ & $0 \%$ & $0.6 \%$ & $0.5 \%$ & $1 \%$ & - \\
\hline Japan & $0 \%$ & $0 \%$ & $0 \%$ & $<0.05 \%$ & $<0.05 \%$ & $1 \%$ & $0 \%$ \\
\hline USA & $23 \%$ & $20 \%$ & $26 \%$ & $2.7 \%$ & $3.2 \%$ & $3 \%$ & $17 \%$ \\
\hline FSU & $23 \%$ & $20 \%$ & $26 \%$ & $5.5 \%$ & $39.4 \%$ & $26 \%$ & $11 \%$ \\
\hline World & $100 \%$ & $100 \%$ & $100 \%$ & $100 \%$ & $100 \%$ & $100 \%$ & $100 \%$ \\
\hline
\end{tabular}

* Unless othenwise noted, "reserves" here refers to the British Petroleum category of Proved Reserves which are defined as"'those quantities which geological and engineering information indicate with reasonable certainty can be recovered in the future from known reservoirs under existing economic and operating conditions." Fossil fuel data are for end of 1994, others for end of 1990.

+ Corresponds to the WEC category of Exploitable Capability, defined as "the amount of Gross Theoretical capability that can be exploited within the limits of current technology and under present and expected local economic conditions." Gross Theoretical Capability is "the annual energy potentially available in the country if all natural flows were turbined down to sea level or to the water level of the border of the country...with 100 percent efficiency from the machinery and driving water-works." Includes output from hydropower stations of all sizes.

I Corresponds to WEC category of Proved Reserves, or the similar UN category of Reasonably Assured Resources. Proved reserves refers to "recoverable uranium that occurs in known mineral deposits of such size, grade and configuration that it could be recovered within the stated production cost ranges with currently proven mining and processing technology. Estimates of tonnage and grade are based on specific sample data and measurements of the deposits together with knowledge of deposit characteristics."

Source: United Nations, 1994; World Energy Council, 1992; British Petroleum, 1994. 
Figure I-2. Energy Reserves

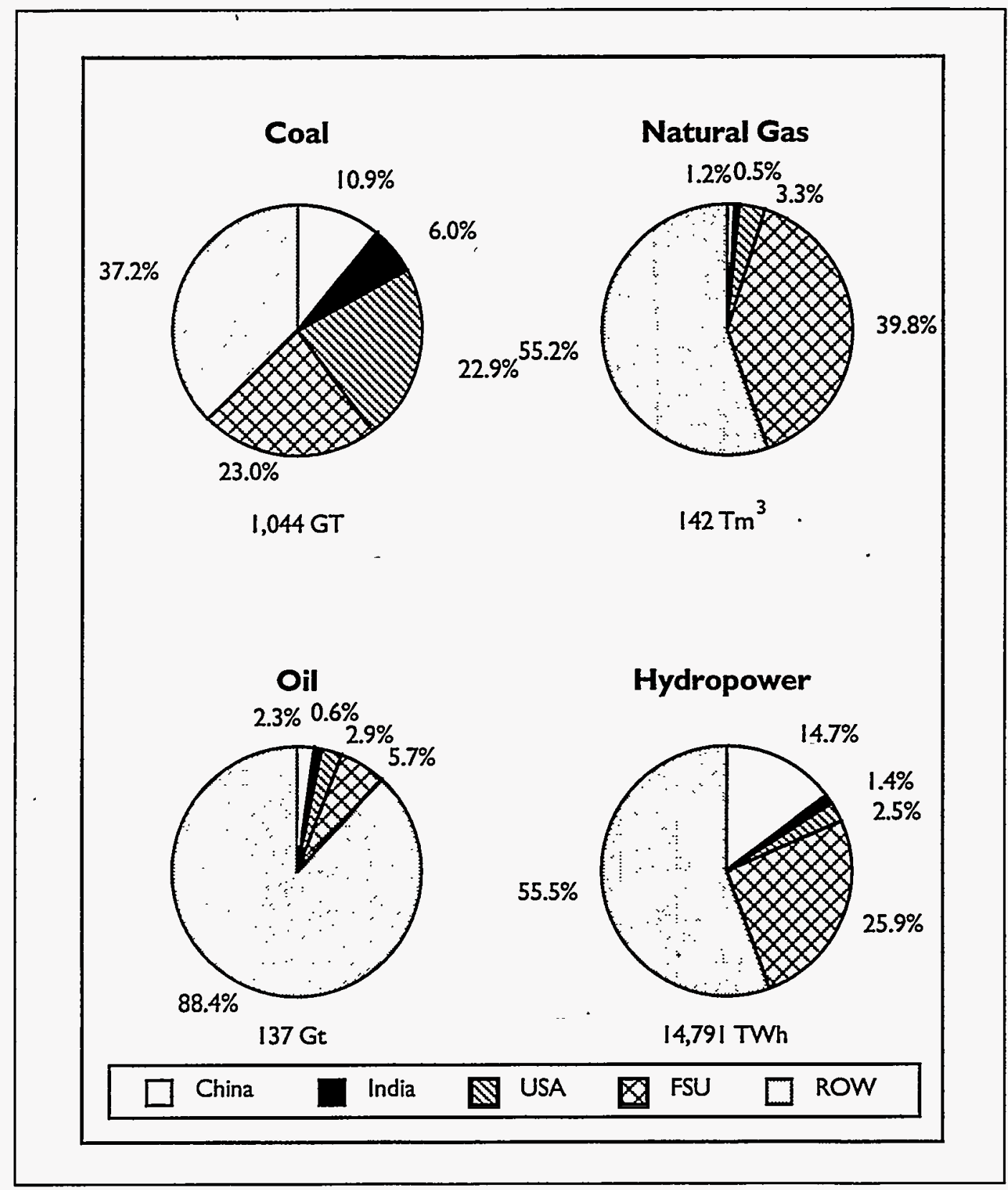


Table I-4. China's Exploitable Hydropower Resources * by Province, 1980

\begin{tabular}{|c|c|c|c|}
\hline Region or Province & $\begin{array}{l}\text { Potential } \\
\text { Installed } \\
\text { Capacity } \\
\text { (GW) }\end{array}$ & $\begin{array}{l}\text { Potential } \\
\text { Annual } \\
\text { Generation } \\
\text { (TWh/yr) }\end{array}$ & $\begin{array}{c}\text { Share of } \\
\text { Total } \\
\text { Potential } \\
\text { Annual } \\
\text { Generation }\end{array}$ \\
\hline North & 6.9 & 23.2 & $1.2 \%$ \\
\hline Hebeit & 1.8 & 4.2 & $0.2 \%$ \\
\hline Shanxi & 26 & 10.7 & $0.6 \%$ \\
\hline Inner Mongolia & 2.4 & 8.4 & $0.4 \%$ \\
\hline Northeast & 12.0 & 38.4 & $2.0 \%$ \\
\hline Liaoning & 1.6 & 5.6 & $0.3 \%$ \\
\hline Jilin & 4.3 & 11.0 & $0.6 \%$ \\
\hline Heilongilang & 6.0 & 21.9 & $1.1 \%$ \\
\hline$\overline{\text { East }}$ & 17.9 & 68.8 & $3.6 \%$ \\
\hline JiangsuT & 0.1 & 0.3 & $0.0 \%$ \\
\hline Zhejiang & 4.7 & 14.6 & $0.8 \%$ \\
\hline Anhui & 0.9 & 2.6 & $0.1 \%$ \\
\hline Fujian & 7.1 & 32.0 & $1.7 \%$ \\
\hline Jiangxi & 5.1 & 19.1 & $1.0 \%$ \\
\hline Shandong & 0.1 & 0.2 & $0.0 \%$ \\
\hline South-Central & 67.4 & 297.4 & $15.5 \%$ \\
\hline Henan & 2.9 & 11.2 & $0.6 \%$ \\
\hline Hubei & 33.1 & 149.4 & $7.8 \%$ \\
\hline Hunan & 10.8 & 48.9 & $25 \%$ \\
\hline Guangdong & 6.4 & 24.0 & $1.2 \%$ \\
\hline Guangxi & 14.2 & 63.9 & $3.3 \%$ \\
\hline Southwest & 232.3 & $1,305.0$ & $67.9 \%$ \\
\hline Sichuan & 91.7 & 515.3 & $26.8 \%$ \\
\hline Guizhou & 12.9 & 65.2 & $3.4 \%$ \\
\hline Yunnan & 71.2 & 394.5 & $20.5 \%$ \\
\hline Xizang & 56.6 & 330.0 & $17.2 \%$ \\
\hline Northwest & 41.9 & 190.5 & $9.9 \%$ \\
\hline Shaanxi & 5.5 & 21.7 & $1.1 \%$ \\
\hline Gansu & 9.1 & 42.4 & $2.2 \%$ \\
\hline Qinghai & 18.0 & 77.2 & $4.0 \%$ \\
\hline Ningxia & 0.8 & 3.2 & $0.2 \%$ \\
\hline Xinjiang & 8.5 & 46.0 & $2.4 \%$ \\
\hline National Totol & 378.5 & $1,923.3$ & $100.0 \%$ \\
\hline
\end{tabular}

- Statistics in this table are calculated on the basis of sites that can accommodate power plants of $\geq 500 \mathrm{~kW}$ of installed capacity. No major revisions have been made to these figures since their publication in the early 1980 s.

$\dagger$ Includes Beijing and Tianjin.

I Includes Shanghai.

Source: Wang, 1988. 


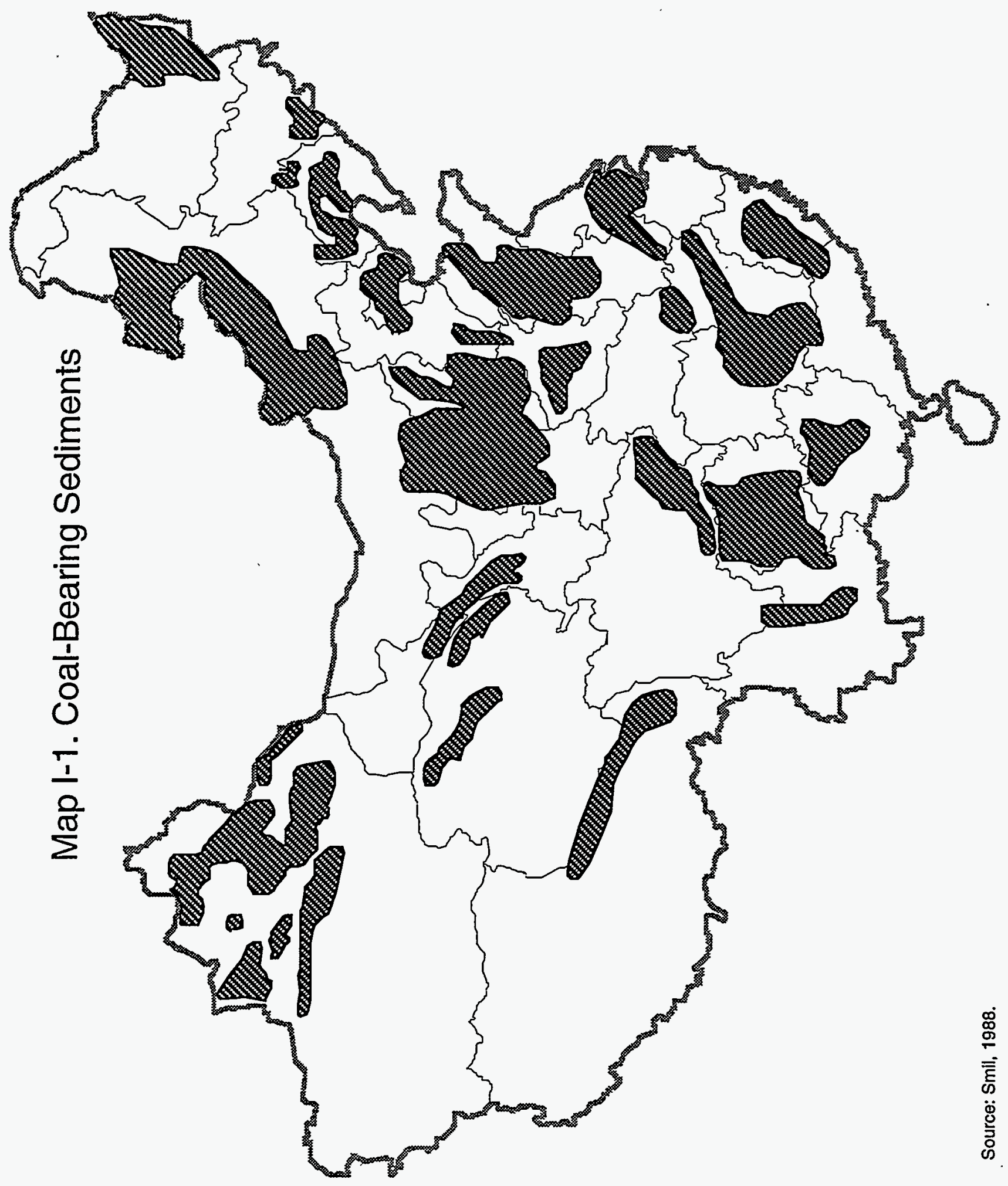




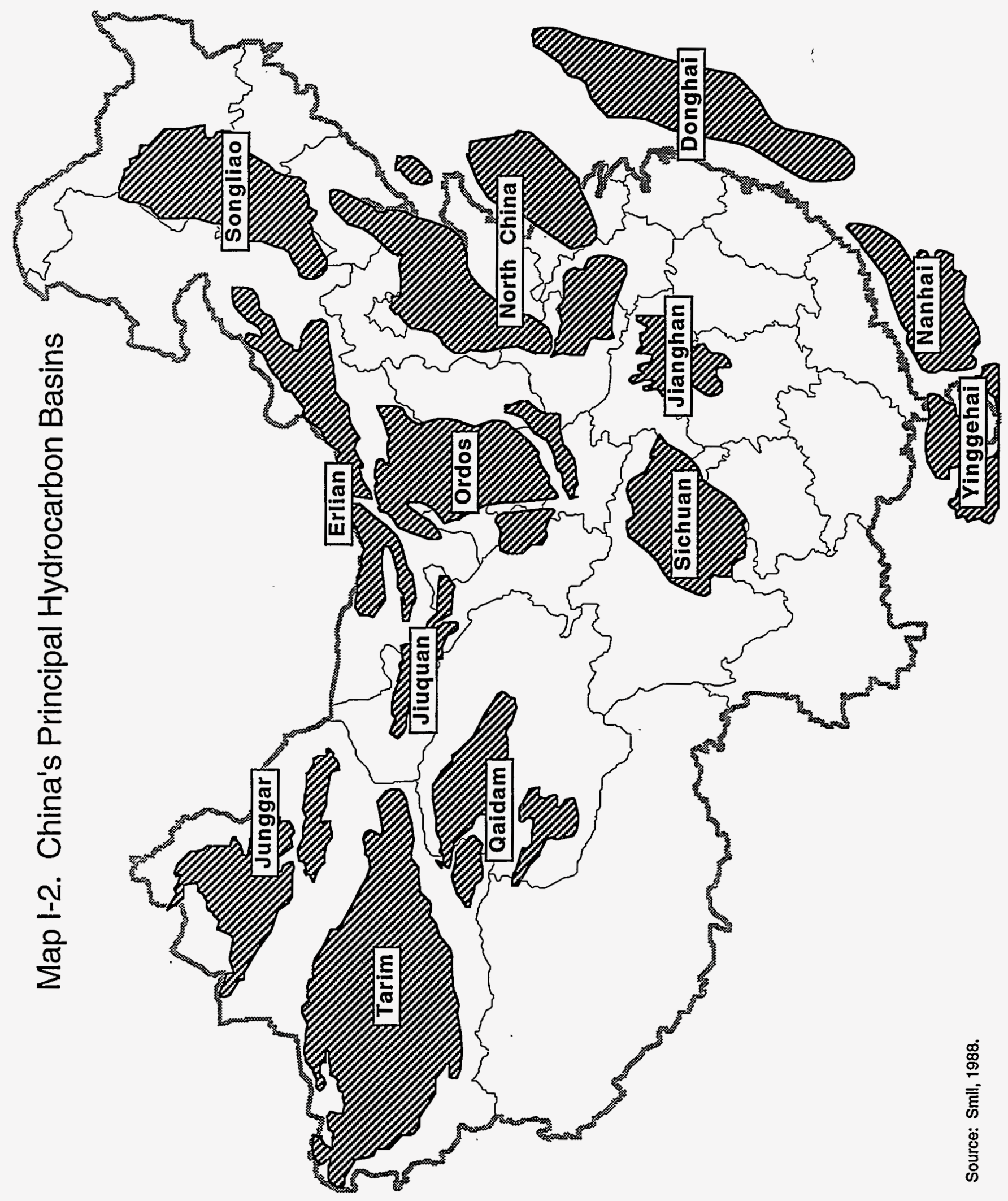


Chapter II-Energy Production 


\section{Energy Production}

$\mathrm{S}$ ince 1949 , growth in energy production has been the rule, with major interruptions only in the 1960s. From 1949-1971 total energy production growth averaged $13 \%$ (Table II-1). This period encompasses both the Great Leap Forward of the late 1950s, when coal production was reported to have tripled in three years, and the subsequent collapse and stagnation of energy production until the late 1960 s. Since then total energy production has fallen only in 1980 and 1981, with annual growth averaging about $6 \%$ between 1971 and 1990, and slowing to under $4 \%$ between 1991 and 1994 .

Although coal clearly is the dominant commercial energy source, petroleum began contributing a significant share in the mid-1960s, peaking at nearly $25 \%$ in 1976 and now accounting for $18 \%$ of total energy production. ${ }^{1}$ There was a spurt of growth in natural gas production in the 1970s, but production fell in the early 1980 s and did not surpass its 1979 peak until 1990. Natural gas now accounts for less than $2 \%$ of primary energy production, down from a high of $3 \%$ in 1979-1980. Hydroelectricity production has grown in all but five years since 1949, and has grown at a faster overall rate since 1971 than any other energy source. Hydroelectricity's share of primary energy production has increased to over $5 \%$.

\section{Coal and Coal Products}

Since the early 1980s the central government has encouraged the development of small, collectively and individually owned coal mines in rural areas to alleviate local shortages. The result has been a remarkable shift in the structure of coal output; between 1980 and 1993, 70\% of the growth in output came from the new rural mines, which now account for over two-fifths of output (Table II-3). Output from state-owned mines has actually declined in the past few years. The development of rural mines may soon slow, however, and issues of mine safety and rational use of coal resources (rural mines tend to waste a large fraction of usable resources) will spur construction of more capital intensive, highly mechanized mines in the near future. Very little coal - about 3\% - comes from open-cast mines. ${ }^{2}$

About three quarters of coal mined is bituminous coal, most of the rest is anthracite, with lignite making up the remaining $4 \%$ (Table II-4). Nearly twothirds of the bituminous coal is classified as coking coal (though only a fraction is actually used in coking; Table II-10). Contrary to many impressions, most of the coal from China's larger mines has a relatively low sulfur content, generally well under $1 \%$ (Table II-5). There are exceptions, of course, with coal from some mines averaging nearly $5 \%$ sulfur. Since relatively little coal is sorted and washed, the ash content of run-of-mine and delivered coal differ little, with a few exceptions ranging between $12 \%$ and $30 \%$. Average heat content of Chinese anthracite 26.5 $\mathrm{MJ} / \mathrm{kg}$, while the averages of various grades of bituminous coal range from 22.3 to $29.6 \mathrm{MJ} / \mathrm{kg}$.

Most coal is mined in North and Northeast China, with one province, Shanxi, accounting for over one-quarter of total output (Table II-2). (The next largest producer, Henan, accounts for only $8 \%$ of national output.) Virtually all of the large stateowned mines are in the North and Northeast (Table II-6). Even in the major coal-producing regions, with the exception of Shanxi, and three or four other provinces, coal consumption outstrips production (Table II-8). As a consequence coal makes up a larger percentage of freight than any other commodity, accounting for $30 \%$ of total metric ton-km of freight in 1993 (Table II-29). Its percentage of total tonnage of freight handled is even higher, indicating that, on average, coal is shipped by rail shorter distances than other commodities. Statistics on interprovincial coal transfers show that, with a few exceptions (Shanxi being the most significant; it supplies coal to all but four of China's 30 provinces) most trade in coal is between neighboring provinces (Table II-30).

The rate of mining deaths in China's coal industry is high by world standards, more than four per $\mathrm{Mt}$ of coal mined, compared to about 0.1 in most devel- 
oped countries in the early 1990 s (Table II-7). ${ }^{3}$ In Poland, a country that relies for its primary energy on a similarly large fraction of coal from underground mines, deaths were fewer than $0.4 / \mathrm{Mt}$ mined. Even India's rate was far lower at about 0.6 deaths per Mt mined. Death rates are somewhat higher in the smaller, rarely mechanized rural mines (5.1 deaths/Mt in 1993 compared to 3.6 at centrally administered mines) because of greater inattention to safety measures.

Trends in coke production have followed closely those of coal production (Table II-8). Two kinds of coke are produced in China, which we have termed "modern" and "old". The former is coke produced on a large scale with modern industrial equipment, while the latter is made with rather backward technology that produces an inferior product, at the same time consuming up to $30 \%$ more coal and emitting several times more pollutants per unit of output. ${ }^{4}$ The spike in production during the Great Leap Forward (1957-1960) was due promotion of local steel production and consequently coke. Thousands of inefficient coke ovens were constructed, and millions of tons of coke were turned out for use in local smelters, the output of which was largely useless. Despite government efforts to curb construction and operation of such ovens, since the early 1980s the output of "old" coke has grown faster than that of "modern" coke, as rural enterprises (especially in Shanxi) compete to supply China's expanding steel mills.

Only $18 \%$ of raw coal output is washed, and nearly all washed coal is used in coking or for locomotives (Table II-11). Since nearly all washeries are at state-owned mines, that means that the washing rate from those mines is much higher, over $45 \%$. The low overall rate of washing means that most of the coal transported contains relatively large amounts of waste material, taxing an already overburdened transportation system and lowering efficiencies in end uses. Prospects for increasing the percentage of coal washed are hampered by the dearth of water in the most productive coal mining regions and the lack of willingness on the part of consumers to pay a premium for coal of better quality. 5

Coal gas production, mainly from coking ovens, has increased steadily, doubling since the mid-1980s (Table II-12). Most coal gas is consumed on-site, but an increasing share is delivered to households for cook- ing as many cities try to improve air quality through switching households from direct burning of coal to gas fuels.

While coal use in the urban residential sector has been declining (see Chapter IV) the manufacture and distribution of coal briquettes - typically 0.75 to $1 \mathrm{~kg}$ cylindrical honeycomb briquettes - for household use has been growing rapidly. Indeed, use of such briquettes, which burn more cleanly and efficiently than the raw coal they replace, is responsible in part for reduced direct use of coal in the household sector. Statistics are not regularly published, but briquette production nationwide reportedly rose from $37 \mathrm{Mt}$ in 1990 to slightly over $50 \mathrm{Mt}$ in 1993.6

\section{Petroleum and Petroleum Products}

Crude oil production increased rapidly in the 1960 s as pumping began at the giant Daqing field in Heilongjiang and the Shengli field in Shandong, then later at the Liaohe field in Liaoning (Table II13). The three provinces in which these fields are located - Heilongjiang, Shandong, and Liaoning together account for $70 \%$ of China's oil output. Growth in crude production was strong throughout the 1970s, but predicted new discoveries failed to materialize and growth leveled off in the 1980s. Both the Daqing and Shengli fields appear to have peaked, and with no fields of comparable size likely to come on line in the near future oil fields will be hard pressed to keep output from falling. Of major fields, Huabei, Dagang, and Zhongyuan have already expe- . rienced declines. Continued development of potentially rich fields in the remote Northwest and offshore will be required if China is to reduce its growing dependence on imported oil. Growth in offshore oil production has been very rapid, now contributing over $4 \%$ of total output compared to $0.2 \%$ a decade ago. While the rate of crude oil loss at oil fields has been relatively steady since the late 1980 s, oil field self-consumption and electricity use per unit of output have been increasing (Table II-14). This in part reflects the greater effort needed to extract oil from older fields and the growing use of secondary recovery techniques, but it may also be due to increased rates of theft and unofficial diversions, which plague 
all segments of the oil industry.

The composition of refined products has shifted significantly since 1980 . In particular, the yield of fuel oil has halved from $42 \mathrm{wt} \%$ in 1980 to 21 $w t \%$ in 1994 owing to continued large investments in refinery upgrading units - particularly fluid catalytic crackers - in the 1980 and 1990s. As a result of this investment program, the total yield of light and middle distillates has risen from $48 w t \%$ in 1980 to $63 \mathrm{wt} \%$ in 1993. Output of transport fuels has risen significantly. Historically the highest priced product in a refinery, gasoline had jumped from $14 \mathrm{wt} \%$ to 22 wt\% of total output by 1994. Diesel yields, however, have barely risen over this period despite rapid growth in demand resulting from low and subsidized ex-refinery prices. Total kerosene production has basically stagnated since 1980 , but the ratio of lamp kerosene to jet fuel has nearly reversed. Currently, jet fuel accounts for about three-fourths of total kerosene output, up from only one-fourth in 1980.

Production of non-fuel products has in general risen as well. Output of coke, wax, and asphalt has grown roughly at the same pace as refinery throughput, while production of chemical feedstocks - primarily middle distillates and naphtha - has tripled since 1980 in response to the dramatic increase in ethylene production capacity, especially since 1987. Output of lubricants, however, has barely risen over this period. The unsuitability of low-quality domestic finished lubricants to modern imported equipment and vehicles has led to a sharp rise in imports, yet raising the quality of domestic lubricants has been hampered by limitations of the paraffinic baseoil feedstock.

Refinery throughput has risen steadily since the reorganization of the refinery sector in 1982, but it fell slightly in 1994 as a result of the surge of crude product imports in the last quarter of 1993 and the resultant sharp increase in inventories. Although utilization of refineries has remained at $80 \%$ and below in recent years, the government's decision to restrict product imports and favor domestic production has resulted in a resumption of crude oil import growth in 1995 and a rise in capacity utilization to around $85 \%$. with demand inexorably rising, China faces the need for significant refinery expansion in the near term, in addition to revamps and upgrades necessary to adapt domestic refiner- ies to an expected increasing volume of Middle East higher-sulfur crude imports.

China currently has more than $8,700 \mathrm{~km}$ of crude and finished oil pipelines, with an annual throughput of $138 \mathrm{Mt}$, most of it canied in five crude oil pipelines in the Northeast and North that together account for $21 \%$ of total pipeline length (Table II-31). Total oil pipeline tumover in 1993 was 59 Gt$\mathrm{km}$, of which $54 \mathrm{Gt}-\mathrm{km}$ was crude oil. Although this figure is not much more than the $50 \mathrm{Gt}-\mathrm{km}$ of oil carried by rail in 1993, the rail volume was composed primarily of finished products. This difference is reflected in average pipeline length; China's 79 crude oil pipelines average $104 \mathrm{~km}$ in length, while product pipelines average only $5 \mathrm{~km}$. Although a number of long-distance product pipelines have been proposed, China will remain dependent on rail for long-distance transport of products for the foreseeable future.

\section{Natural Gas}

Natural gas production grew rapidly from a very low level during the late 1960 s and 1970s, but fell in the 1980s as increased output of associated gas from oil fields was unable to offset production declines at natural gas fields, nearly all of which are in Sichuan (Table II-16). Output from offshore fields near Hainan and from the ShaanGanNing basin in the Northwest will soon boost overall production significantly. Most associated gas comes from a few large oil fields; in 1991 the Daqing, Shengli, Liaohe, Zhongyuan, Xinjiang, and Dagang oil fields produced four-fifths of associated gas. Some gas reportedly is still flared at oil fields because of the expense of transporting it to consumers.

Pipeline transport is limited. Sichuan's provincial pipeline "ring" supplies provincial customers, with pipelines to fertilizer plants in Guizhou, but no other long-distance pipelines are in use. In 1996 a new pipeline from the offshore Hainan gas field to Hong Kong will be inaugurated, and a long-distance pipeline from ShaanGanNing to Beijing is in the design stage.

\section{ELECTRICITY}

Electricity generation has grown faster and more consistently in recent years than production of any other energy source, more than tripling between 
1980 and 1994 to 909 TWh (Table II-17). The share of generation from hydropower plants (two-thirds from plants in south-central and southwestern China) has declined significantly since the mid-1980s, from one-quarter to about $19 \%$ of total generation. Nearly four-fifths of electricity is from fossil fuel-fired plants, reflecting heavier investment in thermal generation over much of China's history since 1949. Thermal power generation is most heavily concentrated in the eastern and south-central regions, which together account for about half. Recently completed nuclear power plants already contribute more than $1 \%$ of China's electricity. Output from geothermal and wind generators is negligible in the national context, but provide otherwise unavailable power to remote communities. Reported in-plant power consumption now accounts for a slightly larger fraction of gross generation than in 1980, but the rate of transmission and distribution losses has declined, so that the ration of delivered electricity to gross generation has remained stable (Table II-18).

Until the mid-1980s, hydropower generation capacity tended to increase at a faster rate than thermal capacity, and in 1984 made up $32 \%$ of total capacity, as opposed to $9 \%$ in 1950 (Table II-19). Since then there has been a spurt of growth in thermal capacity, and fossil plants had a 75\% share of the total $183 \mathrm{GW}$ of generation capacity in 1993 . China's two nuclear power plants now account for $1 \%$ of installed capacity.

Among large fossil generating units (units over $6 \mathrm{MW}$, which made up $89 \%$ of total thermal installed capacity in 1993) the share of large-capacity and more efficient units has been increasing (Table II-20). The share provided by "high-temperature, high-pressure" units increased from $56 \%$ to $84 \%$ between 1974 and 1993. Over the same period the capacity of less efficient units has grown slowly. While the capacity of cogeneration units has risen steadily, their share of total thermal capacity shrank from $14 \%$ to $10 \%$ between 1974 and 1988 , but has since risen again to nearly $12 \%$.

National average capacity factors rose the late 1970s, peaked in 1986-1987 mainly through increased utilization of thermal capacity, and have since fallen back to about 0.52 (Table II-21). Not surprisingly, hydroelectric stations have much lower average capacity factors $(0.37)$ than thermal power plants (0.55). Average capacity factors vary by grid, from well over 0.6 in some coastal areas to under 0.5 in remote inland areas (Table II-22). In general, larger plants, both thermal and hydropower, tend to have larger capacity factors (Tables II-23 and II25). Many of the smallest thermal units (which have declined as a share of total installed capacity) are used for only several weeks out of any given year. Some capacity, especially at smaller plants, is left idle through lack of fuel or water. Self-generators (i.e. nonutility generators like large factories), which account for slightly under $9 \%$ of gross thermal generation, tend to have capacity factors slightly under 0.5 (Table II-24). Small diesel plants have proliferated in the 1980s and 1990s; although they are expensive to operate and have low utilization rates they enabled users to deal with acute power shortages and avoid cutoff blackouts.

The number of large thermal power plants $(\leq 600$ MW) completed or under construction has roughly doubled since the end of the 1980s. The plants are typically composed of $300 \mathrm{MW}$ and smaller units; China's largest plant, Jianbi, is typical, having three $100 \mathrm{MW}$ and four $300 \mathrm{MW}$ units (Table II-26). Several plants, however, already operate or are installing units up to $600 \mathrm{MW}$. Of 82 large plants, only one is entirely oil-fired, and eight others use oil in addition to coal. Out of 41 hydropower plants with capacities of $250 \mathrm{MW}$ or more, 13 have yet to come on line (Table II-27). More than half of those already in place have been completed since 1980, and most are smaller than the ones under construction.

China has been very successful in extending gnids into most rural areas - currently $92 \%$ of villages and $87 \%$ of rural households reportedly have electricity available (Table II-28). In remote areas in the Southwest this has been accomplished mainly through the construction of small hydropower projects. Most options for supplying the over $100 \mathrm{mil}-$ lior people who remain without electricity are beyond local means, so the continued poor state of central government finances probably means that complete electrification is still many years off.

\section{Renewable Energy Resources}

Renewable energy, in the form of biomass, is the primary source of energy for many rural households; wood, crop wastes, and dung are the primary fuels. Estimates on the availability of biomass potential- 
ly usable for fuel vary, and those for "sustainable" fuel wood harvest (i.e., the maximum harvest that would not result in a long-term decrease in harvestable fuel wood) are inevitably lower than actual fuel wood use by a significant margin. About 4.5 million household-scale biogas digesters are currently in use, mainly in the Southwest (Table II-32). These typically produce 1 to 1.5 cubic meters of biogas per day for six to eight months per year. ${ }^{7}$ Some community and factory digesters also are in operation, producing $300,000 \mathrm{~m}^{3}$ of gas per year. Some biomass gasifier projects have been demonstrated. With competition for other uses of biomass strong, it is unlikely that biomass fuels will become more than locally important in China's fuel supply mix.

Small hydropower projects have been a key element of rural development plans, and over 14 GW of hydroelectric capacity (one-third of the total) has been so designated. Wind generators have also been used to provide power to remote communities. Most are less than one $\mathrm{kW}$ capacity $(120,000$ of this type were in use as of 1992), although a few demonstration wind farms with units of several tens of $\mathrm{kW}$ have also been set up. Total capacity of wind farms was $5 \mathrm{MW}$ in 1992, and total capacity of all wind generator systems in China is currently 30 MW (including a $10 \mathrm{MW}$ wind farm in Dabancheng, Xinjiang). ${ }^{8}$ Strong domestic and foreign interest in wind generation foreshadows relatively rapid development of this supply option, with plans calling for $1 \mathrm{GW}$ by 2000 . Early in 1995 Sino-US agreements were signed for 30 to $110 \mathrm{MW}$ of windpower projects.

Geothermal resources, the most promising of which are in Xizang (Tibet), Yunnan, and some coastal areas, have been exploited on a small scale. Most projects are less than $300 \mathrm{~kW}$, but one station near Lhasa has an installed capacity of $25 \mathrm{MW}$. Experimental tidal power stations have been built as well (8.5 MW installed capacity), but the resource base is small and capital costs are higher than for ordinary small hydropower projects. In some areas where temperatures make electricity generation impractical, geothermal sources are used to supply process heat.

Solar energy has long been a focus of China's rural power development, with solar water heaters and large plastic-covered greenhouses (used to extend the growing season) a common feature in rural areas. Passive solar design has been incor- porated into some new housing, and solar cookers have been distributed in some westem areas where fuel is short and sunlight plentiful. China reportedly has the capacity to manufacture several MW of photovoltaic cells per year, but less than $2 \mathrm{MW}$ of PV capacity is currently installed.

1 Because coal is the dominant energy source, all energy sources in this volume, including raw and processed coal, are converted to standard coal equivalent $(29.31 \mathrm{GJ} / \mathrm{metric}$ ton of standard coal) for purposes of comparison. Unless otherwise noted, electricity, including primary electricity, is converted at a nominal average gross heat rate of $404 \mathrm{gce}(11.8 \mathrm{MJ}) / \mathrm{kWh}$, implying an efficiency of $30 \%$.

2 Ministry of Energy, 1990.

3 Ministry of Coal, 1993.

$4 \mathrm{Li}$, Wang, and Qu, 1991.

5 Many boilers, for instance, are designed to handle the raw coal that is most widely available in China.

6 Wang, 1995.

7 Chen, 1991. Chen states that biogas accounts for $0.5 \%$ to $1 \%$ of total primary biomass energy consumption.

8 Wind Energy Weekly, 26 June 1995, p. 4. 
Table II-1. Primary Energy Production, 1949-1994

\begin{tabular}{|c|c|c|c|c|}
\hline \multicolumn{5}{|c|}{ 1. Production in Physical Units } \\
\hline Year & $\begin{array}{c}\text { Raw } \\
\text { Coal * } \\
\text { (Mt) }\end{array}$ & $\begin{array}{l}\text { Crude } \\
\text { Oil } t \\
\text { (Mt) }\end{array}$ & $\begin{array}{l}\text { Natural } \\
\text { Gas } \\
\text { (million } \\
\text { cubic m) }\end{array}$ & $\begin{array}{l}\text { Hydro- } \\
\text { electricity } \\
\text { (TWh) }\end{array}$ \\
\hline 1949 & 32 & 0.12 & 7 & 0.7 \\
\hline 1950 & 43 & 0.20 & 7 & 0.8 \\
\hline 1951 & 53 & 0.31 & 3 & 0.9 \\
\hline 1952 & 66 & 0.44 & 8 & 1.3 \\
\hline 1953 & 70 & 0.62 & 11 & 1.5 \\
\hline 1954 & 84 & 0.79 & 15 & 2.2 \\
\hline 1955 & 98 & 0.97 & 17 & 24 \\
\hline 1956 & 110 & 1.16 & 26 & 3.5 \\
\hline 1957 & $|3|$ & 1.46 & 70 & 4.8 \\
\hline 1958 & 270 & 2.26 & 110 & 4.1 \\
\hline 1959 & 369 & 3.73 & 290 & 4.4 \\
\hline$\overline{1960}$ & 397 & 5.20 & 1,040 & 7.4 \\
\hline 1961 & 278 & 5.31 & 1,470 & 7.4 \\
\hline 1962 & 220 & 5.75 & 1,210 & 9.0 \\
\hline 1963 & 217 & 6.48 & 1,020 & 8.7 \\
\hline 1964 & 215 & 8.48 & 1,060 & 10.6 \\
\hline 1965 & 232 & 11.31 & 1,100 & 10.4 \\
\hline 1966 & 252 & 14.55 & 1,340 & 126 \\
\hline 1967 & 206 & 13.88 & 1.460 & 13.1 \\
\hline 1968 & 220 & 15.99 & 1,400 & 11.5 \\
\hline 1969 & 266 & 21.74 & 1.960 & 16.0 \\
\hline 1970 & 354 & 30.65 & 2,870 & 20.5 \\
\hline 1971 & 392 & 39.41 & 3,740 & 25.1 \\
\hline 1972 & 410 & 45.67 & 4,840 & 28.8 \\
\hline 1973 & 417 & 53.61 & 5,980 & 38.9 \\
\hline 1974 & 413 & 64.85 & 7,530 & 41.4 \\
\hline 1975 & 482 & 77.06 & 8,850 & 47.6 \\
\hline 1976 & 483 & 87.16 & 10,100 & 45.6 \\
\hline 1977 & 550 & 93.64 & 12,120 & 47.6 \\
\hline 1978 & 618 & 104.05 & 13,730 & 44.6 \\
\hline 1979 & 635 & 106.15 & 14.510 & 50.1 \\
\hline 1980 & 620 & 105.95 & 14,270 & 58.2 \\
\hline 1981 & 622 & 101.22 & 12,740 & 65.5 \\
\hline 1982 & 666 & 102.12 & 11,930 & 74.4 \\
\hline 1983 & 715 & 106.07 & 12,210 & 86.4 \\
\hline 1984 & 789 & $\mid 14.61$ & 12,430 & 86.8 \\
\hline 1985 & 872 & 124.89 & 12,930 & 92.4 \\
\hline 1986 & 894 & 130.69 & 13,760 & 94.5 \\
\hline 1987 & 928 & 134.14 & 13,890 & 100.2 \\
\hline 1988 & 980 & 137.05 & 14,260 & 109.2 \\
\hline 1989 & 1.054 & 137.65 & 15,050 & 118.3 \\
\hline 1990 & 1,080 & 138.31 & 15,300 & 126.7 \\
\hline 1991 & 1,087 & 140.99 & 15,490 & 124.7 \\
\hline 1992 & 1,116 & 142.10 & 15,790 & 130.7 \\
\hline 1993 & 1,141 & 144.92 & 16,560 & 146.0 \\
\hline 1994 & 1,212 & 147.65 & 16,972 & 170.4 \\
\hline
\end{tabular}

* Raw coal includes anthracite, bituminous coal, and brown coal, but not slaty coal. Figures for 1986 and later years includes output from private mines.

t Crude oil includes natural crude and shale oil.

Source: China Energy Annual Review, 1994; China Statistical Yearbook, various years; Energy Research Institute. 
Table II-1. Primary Energy Production, 1949-1994 (continued)

\begin{tabular}{|c|c|c|c|c|c|}
\hline \multicolumn{6}{|c|}{ 2. Production in Mtce } \\
\hline Year & $\begin{array}{c}\text { Raw } \\
\text { Coal* } \\
\text { (Mtce) }\end{array}$ & $\begin{array}{l}\text { Crude } \\
\text { Oil } \dagger \\
\text { (Mtce) }\end{array}$ & $\begin{array}{c}\text { Natural } \\
\text { Gas } \\
\text { (Mtce) }\end{array}$ & $\begin{array}{l}\text { Hydro- } \\
\text { electricity I } \\
\text { (Mtce) }\end{array}$ & $\begin{array}{c}\text { Total } \\
\text { (Mtce) }\end{array}$ \\
\hline 1949 & 229 & 0.17 & 0.01 & 0.51 & 23.5 \\
\hline 1950 & 30.7 & 0.29 & 0.01 & 0.58 & 31.5 \\
\hline 1951 & 37.9 & 0.44 & 0.00 & 0.65 & 39.0 \\
\hline 1952 & 47.1 & 0.63 & 0.01 & 0.95 & 48.7 \\
\hline 1953 & 49.8 & 0.89 & 0.01 & 1.04 & 51.7 \\
\hline 1954 & 59.8 & 1.13 & 0.02 & 2.15 & 63.1 \\
\hline 1955 & 70.3 & 1.39 & 0.02 & 1.57 & 73.3 \\
\hline 1956 & 78.8 & 1.66 & 0.03 & 219 & 82.7 \\
\hline 1957 & 93.4 & 2.09 & 0.09 & 290 & 98.5 \\
\hline 1958 & 192.9 & 3.23 & 0.15 & 2.29 & 198.5 \\
\hline 1959 & 263.6 & 5.33 & 0.39 & 2.42 & 271.7 \\
\hline 1960 & 283.6 & 7.43 & 1.38 & 4.09 & 296.5 \\
\hline 1961 & 198.3 & 7.59 & 1.96 & 4.20 & 2120 \\
\hline 1962 & 156.8 & 8.21 & 1.61 & 4.94 & 171.6 \\
\hline 1963 & 155.1 & 9.26 & 1.36 & 4.52 & 170.2 \\
\hline 1964 & 153.3 & 12.11 & 1.41 & 5.27 & 172.1 \\
\hline 1965 & 165.6 & 16.16 & 1.46 & 4.96 & 188.2 \\
\hline 1966 & 180.0 & 20.79 & 1.78 & 5.81 & 208.4 \\
\hline 1967 & 147.1 & 19.83 & 1.94 & 6.07 & 175.0 \\
\hline 1968 & 157.1 & 22.84 & 1.86 & 5.34 & 187.2 \\
\hline 1969 & 190.0 & 31.06 & 2.61 & 7.42 & 231.1 \\
\hline 1970 & 252.9 & 43.79 & 3.82 & 9.49 & 310.0 \\
\hline 1971 & 280.0 & 56.30 & 4.97 & 11.67 & 353.0 \\
\hline 1972 & 2929 & 65.24 & 6.44 & 13.36 & 377.9 \\
\hline 1973 & 297.9 & 76.59 & 7.95 & 17.78 & 400.2 \\
\hline 1974 & 295.0 & 92.64 & 10.01 & 18.63 & 416.3 \\
\hline 1975 & 344.3 & 110.09 & 11.77 & 21.42 & 487.6 \\
\hline 1976 & 345.0 & 124.52 & 13.43 & 20.47 & 503.4 \\
\hline 1977 & 392.9 & 133.77 & 16.12 & 21.23 & 564.0 \\
\hline 1978 & 441.4 & 148.65 & 18.26 & 19.36 & 627.7 \\
\hline 1979 & 453.6 & 151.65 & 19.30 & 21.14 & 645.7 \\
\hline 1980 & 443.0 & 151.36 & 18.98 & 24.04 & 637.3 \\
\hline 1981 & 444.1 & 144.60 & 16.94 & 26.66 & 632.3 \\
\hline 1982 & 476.0 & 145.89 & 15.87 & 30.06 & 667.8 \\
\hline 1983 & 510.4 & 151.53 & 16.24 & 34.56 & 712.7 \\
\hline 1984 & 563.7 & 163.73 & 16.53 & 34.55 & 778.6 \\
\hline 1985 & 623.1 & 178.42 & 17.20 & 36.78 & 855.5 \\
\hline 1986 & 638.6 & 186.70 & 18.30 & 37.61 & 881.2 \\
\hline 1987 & 6629 & 191.63 & 18.47 & 39.88 & 912.9 \\
\hline 1988 & 699.9 & 195.79 & 18.97 & 43.35 & 958.0 \\
\hline 1989 & 753.0 & 196.65 & 20.02 & 46.97 & 1.016 .6 \\
\hline 1990 & 771.4 & 197.58 & 20.35 & 49.67 & $1,039.0$ \\
\hline 1991 & 776.7 & 201.42 & 20.60 & 48.63 & $1,047.4$ \\
\hline 1992 & 797.2 & 203.00 & 21.00 & 50.45 & 1.071 .6 \\
\hline 1993 & 815.0 & 207.03 & 22.02 & 56.06 & $1,100.1$ \\
\hline 1994 & 865.7 & 210.93 & 22.57 & 65.42 & $1,164.7$ \\
\hline
\end{tabular}

* Raw coal includes anthracite, bituminous coal, and brown coal, but not slaty coal. Figures for 1986 and later years includes output from private mines.

$t$ Crude oil includes natural crude and shale oil.

I Converted based on reported average heat rates of gross electricity generation at major Chinese power plants.

Source: China Energy Annual Review, 1994; China Statistical Yearbook, various years; Energy Research Institute. 
Figure II-1. Primary Energy Production by Energy Source in China, Mtce, 1949-1994

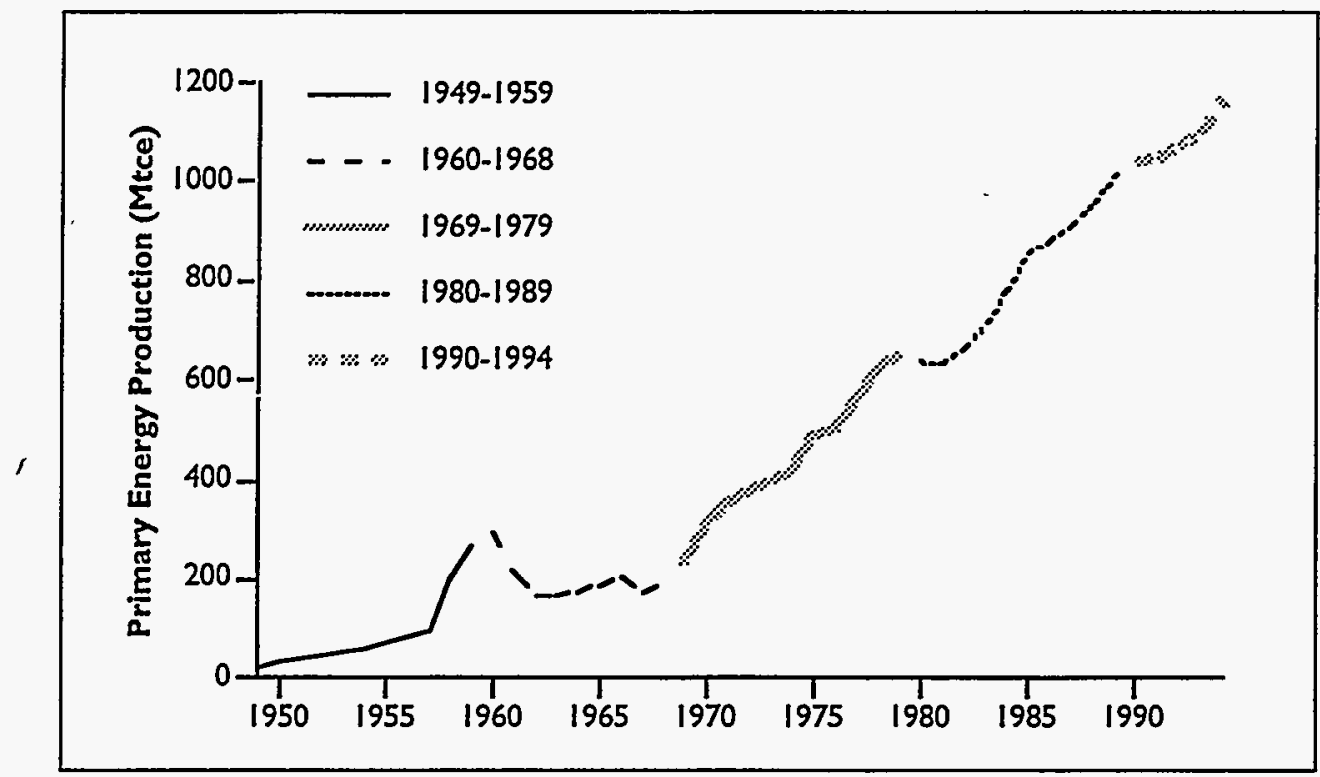

Figure II-2. Primary Energy Production by Source, 1950-1990

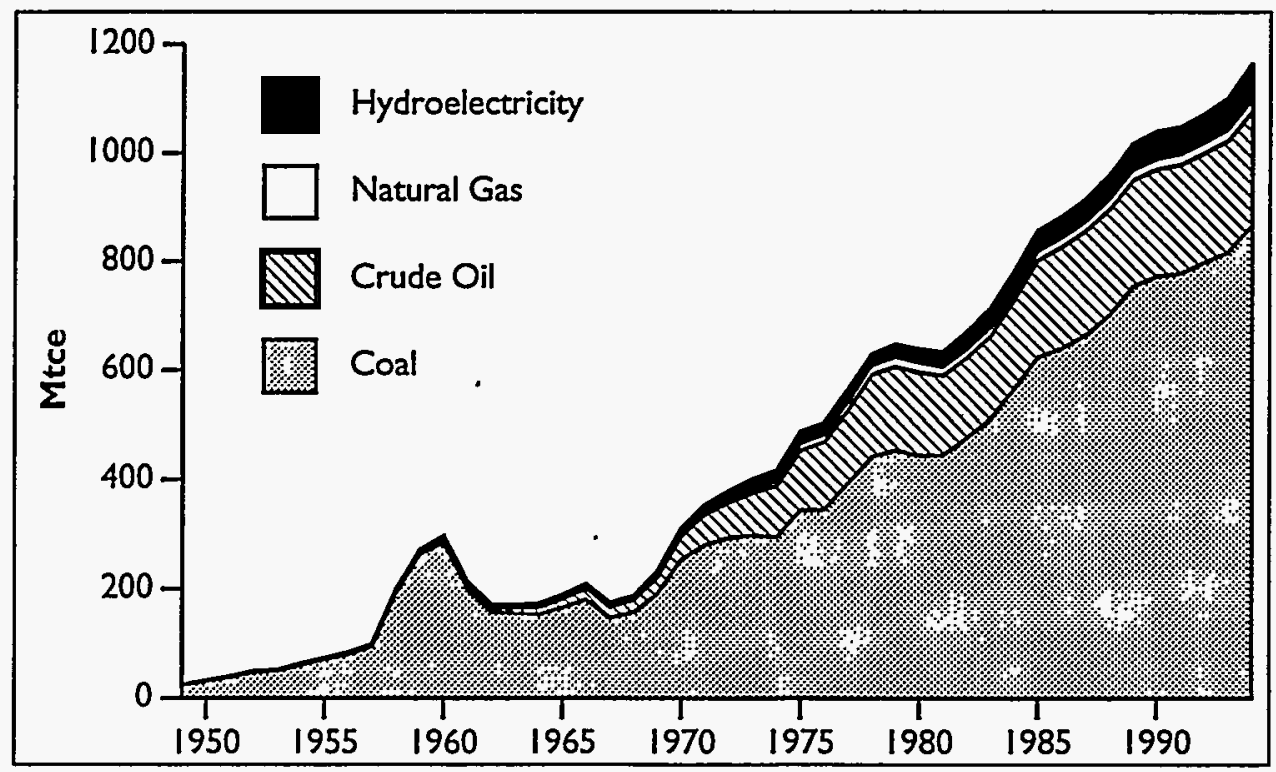


Table II-1. Primary Energy Production, 1949-1994 (continued)

\begin{tabular}{|c|c|c|c|c|}
\hline \multicolumn{5}{|c|}{ 3. Shares of Total } \\
\hline Year & $\begin{array}{l}\text { Raw } \\
\text { Coal }\end{array}$ & $\begin{array}{l}\text { Crude } \\
\text { Oil }\end{array}$ & $\begin{array}{c}\text { Natural } \\
\text { Gas }\end{array}$ & $\begin{array}{l}\text { Hydro- } \\
\text { electricity }\end{array}$ \\
\hline 1949 & $97.1 \%$ & $0.7 \%$ & $0.0 \%$ & $2.2 \%$ \\
\hline 1950 & $97.2 \%$ & $0.9 \%$ & $0.0 \%$ & $1.8 \%$ \\
\hline 1951 & $97.2 \%$ & $1.1 \%$ & $0.0 \%$ & $1.7 \%$ \\
\hline 1952 & $96.7 \%$ & $1.3 \%$ & $0.0 \%$ & $1.9 \%$ \\
\hline 1953 & $96.3 \%$ & $1.7 \%$ & $0.0 \%$ & $2.0 \%$ \\
\hline 1954 & $94.8 \%$ & $1.8 \%$ & $0.0 \%$ & $3.4 \%$ \\
\hline 1955 & $95.9 \%$ & $1.9 \%$ & $0.0 \%$ & $2.1 \%$ \\
\hline 1956 & $95.3 \%$ & $2.0 \%$ & $0.0 \%$ & $26 \%$ \\
\hline 1957 & $94.8 \%$ & $2.1 \%$ & $0.1 \%$ & $2.9 \%$ \\
\hline 1958 & $97.1 \%$ & $1.6 \%$ & $0.1 \%$ & $1.2 \%$ \\
\hline 1959 & $97.0 \%$ & $20 \%$ & $0.1 \%$ & $0.9 \%$ \\
\hline 1960 & $95.6 \%$ & $2.5 \%$ & $0.5 \%$ & $1.4 \%$ \\
\hline 1961 & $93.5 \%$ & $3.6 \%$ & $0.9 \%$ & $2.0 \%$ \\
\hline 1962 & $91.4 \%$ & $4.8 \%$ & $0.9 \%$ & $2.9 \%$ \\
\hline 1963 & $91.1 \%$ & $5.4 \%$ & $0.8 \%$ & $2.7 \%$ \\
\hline 1964 & $89.1 \%$ & $7.0 \%$ & $0.8 \%$ & $3.1 \%$ \\
\hline 1965 & $88.0 \%$ & $8.6 \%$ & $0.8 \%$ & $2.6 \%$ \\
\hline 1966 & $86.4 \%$ & $10.0 \%$ & $0.9 \%$ & $28 \%$ \\
\hline 1967 & $84.1 \%$ & $11.3 \%$ & $1.1 \%$ & $3.5 \%$ \\
\hline 1968 & $84.0 \%$ & $12.2 \%$ & $1.0 \%$ & $29 \%$ \\
\hline 1969 & $82.2 \%$ & $13.4 \%$ & $1.1 \%$ & $3.2 \%$ \\
\hline 1970 & $81.6 \%$ & $14.1 \%$ & $1.2 \%$ & $3.1 \%$ \\
\hline 1971 & $79.3 \%$ & $16.0 \%$ & $1.4 \%$ & $3.3 \%$ \\
\hline 1972 & $77.5 \%$ & $17.3 \%$ & $1.7 \%$ & $3.5 \%$ \\
\hline 1973 & $74.4 \%$ & $19.1 \%$ & $2.0 \%$ & $4.4 \%$ \\
\hline 1974 & $70.9 \%$ & $22.3 \%$ & $2.4 \%$ & $4.5 \%$ \\
\hline 1975 & $70.6 \%$ & $226 \%$ & $2.4 \%$ & $4.4 \%$ \\
\hline 1976 & $68.5 \%$ & $24.7 \%$ & $2.7 \%$ & $4.1 \%$ \\
\hline 1977 & $69.7 \%$ & $23.7 \%$ & $2.9 \%$ & $3.8 \%$ \\
\hline 1978 & $70.3 \%$ & $23.7 \%$ & $2.9 \%$ & $3.1 \%$ \\
\hline 1979 & $70.2 \%$ & $23.5 \%$ & $3.0 \%$ & $3.3 \%$ \\
\hline 1980 & $69.5 \%$ & $23.7 \%$ & $3.0 \%$ & $3.8 \%$ \\
\hline 1981 & $70.2 \%$ & $22.9 \%$ & $2.7 \%$ & $4.2 \%$ \\
\hline 1982 & $71.3 \%$ & $21.8 \%$ & $2.4 \%$ & $4.5 \%$ \\
\hline 1983 & $71.6 \%$ & $21.3 \%$ & $2.3 \%$ & $4.8 \%$ \\
\hline 1984 & $72.4 \%$ & $21.0 \%$ & $2.1 \%$ & $4.4 \%$ \\
\hline 1985 & $72.8 \%$ & $20.9 \%$ & $2.0 \%$ & $4.3 \%$ \\
\hline 1986 & $72.5 \%$ & $21.2 \%$ & $2.1 \%$ & $4.3 \%$ \\
\hline 1987 & $72.6 \%$ & $21.0 \%$ & $2.0 \%$ & $4.4 \%$ \\
\hline 1988 & $73.1 \%$ & $20.4 \%$ & $2.0 \%$ & $4.5 \%$ \\
\hline 1989 & $74.1 \%$ & $19.3 \%$ & $2.0 \%$ & $4.6 \%$ \\
\hline 1990 & $74.2 \%$ & $19.0 \%$ & $2.0 \%$ & $4.8 \%$ \\
\hline 1991 & $74.2 \%$ & $19.2 \%$ & $2.0 \%$ & $4.6 \%$ \\
\hline 1992 & $74.4 \%$ & $18.9 \%$ & $2.0 \%$ & $4.7 \%$ \\
\hline 1993 & $74.1 \%$ & $18.8 \%$ & $2.0 \%$ & $5.1 \%$ \\
\hline 1994 & $74.3 \%$ & $18.1 \%$ & $1.9 \%$ & $5.6 \%$ \\
\hline
\end{tabular}

\begin{tabular}{|c|c|}
\hline \multicolumn{2}{|c|}{ Average Shares of Total: } \\
\hline \multicolumn{2}{|l|}{ Coal } \\
\hline $1949-1990$ & $85 \%$ \\
\hline $1981-1990$ & $72 \%$ \\
\hline $1991-1994$ & $74 \%$ \\
\hline \multicolumn{2}{|l|}{ Petroleum } \\
\hline $1949-1990$ & $13 \%$ \\
\hline $1981-1990$ & $21 \%$ \\
\hline $1991-1994$ & $19 \%$ \\
\hline \multicolumn{2}{|l|}{ Natural Gas } \\
\hline $1949-1990$ & $1.4 \%$ \\
\hline $1981-1990$ & $2.1 \%$ \\
\hline $1991-1994$ & $2.0 \%$ \\
\hline \multicolumn{2}{|c|}{ Hydroelectricity } \\
\hline $1949-1990$ & $3.3 \%$ \\
\hline $1981-1990$ & $4.5 \%$ \\
\hline $1991-1994$ & $5.0 \%$ \\
\hline
\end{tabular}

Source: China Energy Annual Review, 1994; China Statistical Yearbook, various years; Energy Research Institute. 
Table II-1. Primary Energy Production, 1949-1994 (continued).

\begin{tabular}{|c|c|c|c|c|c|}
\hline \multicolumn{6}{|c|}{ 4. Growth Rates (percent over previous year) } \\
\hline Year & $\begin{array}{c}\text { Raw } \\
\text { Coal * }\end{array}$ & $\begin{array}{c}\text { Crude } \\
\text { Oil }+\end{array}$ & $\begin{array}{c}\text { Natural } \\
\text { Gas }\end{array}$ & $\begin{array}{l}\text { Hydro- } \\
\text { electricity }\end{array}$ & Total \\
\hline 1950 & $34.1 \%$ & $66.7 \%$ & $0.0 \%$ & $14.3 \%$ & $33.9 \%$ \\
\hline 1951 & $23.7 \%$ & $55.0 \%$ & $-57.1 \%$ & $12.5 \%$ & $23.7 \%$ \\
\hline 1952 & $24.3 \%$ & $41.9 \%$ & $166.7 \%$ & $44.4 \%$ & $24.9 \%$ \\
\hline 1953 & $5.7 \%$ & $40.9 \%$ & $37.5 \%$ & $10.0 \%$ & $6.2 \%$ \\
\hline 1954 & $20.0 \%$ & $27.4 \%$ & $36.4 \%$ & $107.0 \%$ & $21.9 \%$ \\
\hline 1955 & $17.6 \%$ & $22.8 \%$ & $13.3 \%$ & $-26.9 \%$ & $16.2 \%$ \\
\hline 1956 & $12.2 \%$ & $19.6 \%$ & $529 \%$ & $39.2 \%$ & $12.9 \%$ \\
\hline 1957 & $18.5 \%$ & $25.9 \%$ & $169.2 \%$ & $32.5 \%$ & $19.1 \%$ \\
\hline 1958 & $106.5 \%$ & $54.8 \%$ & $57.1 \%$ & $-20.9 \%$ & $101.6 \%$ \\
\hline 1959 & $36.7 \%$ & $650 \%$ & $163.6 \%$ & $5.8 \%$ & $369 \%$ \\
\hline 1960 & $7.6 \%$ & $39.4 \%$ & $258.6 \%$ & $68.8 \%$ & $9.1 \%$ \\
\hline 1961 & $-30.1 \%$ & $2.1 \%$ & $41.3 \%$ & $2.7 \%$ & $-28.5 \%$ \\
\hline 1962 & $-20.9 \%$ & $8.3 \%$ & $-17.7 \%$ & $17.6 \%$ & $-19.1 \%$ \\
\hline 1963 & $-1.1 \%$ & $127 \%$ & $-15.7 \%$ & $-8.4 \%$ & $-0.8 \%$ \\
\hline 1964 & $-1.2 \%$ & $30.9 \%$ & $3.9 \%$ & $16.5 \%$ & $1.1 \%$ \\
\hline 1965 & $8.0 \%$ & $33.4 \%$ & $3.8 \%$ & $-5.8 \%$ & $9.4 \%$ \\
\hline 1966 & $8.7 \%$ & $28.6 \%$ & $21.8 \%$ & $17.1 \%$ & $10.7 \%$ \\
\hline 1967 & $-18.3 \%$ & $-4.6 \%$ & $9.0 \%$ & $4.4 \%$ & $-16.0 \%$ \\
\hline 1968 & $6.8 \%$ & $15.2 \%$ & $-4.1 \%$ & $-12.0 \%$ & $7.0 \%$ \\
\hline 1969 & $209 \%$ & $360 \%$ & $400 \%$ & $39.1 \%$ & $23.5 \%$ \\
\hline 1970 & $33.1 \%$ & $41.0 \%$ & $46.4 \%$ & $27.8 \%$ & $34.1 \%$ \\
\hline 1971 & $10.7 \%$ & $28.6 \%$ & $30.3 \%$ & $23.0 \%$ & $13.9 \%$ \\
\hline 1972 & $4.6 \%$ & $15.9 \%$ & $29.4 \%$ & $14.5 \%$ & $7.1 \%$ \\
\hline 1973 & $1.7 \%$ & $17.4 \%$ & $23.6 \%$ & $33.0 \%$ & $5.9 \%$ \\
\hline 1974 & $-1.0 \%$ & $21.0 \%$ & $25.9 \%$ & $4.8 \%$ & $4.0 \%$ \\
\hline 1975 & $16.7 \%$ & $18.8 \%$ & $17.5 \%$ & $15.0 \%$ & $17.1 \%$ \\
\hline 1976 & $0.2 \%$ & $13.1 \%$ & $14.1 \%$ & $-4.4 \%$ & $3.3 \%$ \\
\hline 1977 & $13.9 \%$ & $7.4 \%$ & $20.0 \%$ & $3.7 \%$ & $12.0 \%$ \\
\hline 1978 & $12.4 \%$ & $11.1 \%$ & $13.3 \%$ & $-8.8 \%$ & $11.3 \%$ \\
\hline 1979 & $28 \%$ & $20 \%$ & $57 \%$ & $92 \%$ & $29 \%$ \\
\hline 1980 & $-2.3 \%$ & $-0.2 \%$ & $-1.7 \%$ & $13.7 \%$ & $-1.3 \%$ \\
\hline 1981 & $0.2 \%$ & $-4.5 \%$ & $-10.7 \%$ & $10.9 \%$ & $-0.8 \%$ \\
\hline 1982 & $7.2 \%$ & $0.9 \%$ & $-6.4 \%$ & $12.8 \%$ & $5.6 \%$ \\
\hline 1983 & $7.2 \%$ & $3.9 \%$ & $23 \%$ & $15.0 \%$ & $6.7 \%$ \\
\hline 1984 & $10.5 \%$ & $8.1 \%$ & $1.8 \%$ & $0.0 \%$ & $9.2 \%$ \\
\hline 1985 & $10.5 \%$ & $9.0 \%$ & $4.0 \%$ & $6.5 \%$ & $9.9 \%$ \\
\hline 1986 & $2.5 \%$ & $4.6 \%$ & $6.4 \%$ & $23 \%$ & $3.0 \%$ \\
\hline 1987 & $3.8 \%$ & $26 \%$ & $0.9 \%$ & $6.0 \%$ & $3.6 \%$ \\
\hline 1988 & $5.6 \%$ & $2.2 \%$ & $27 \%$ & $8.7 \%$ & $4.9 \%$ \\
\hline 1989 & $76 \%$ & $0.4 \%$ & $55 \%$ & $8.3 \%$ & $6.1 \%$ \\
\hline 1990 & $2.4 \%$ & $0.5 \%$ & $1.7 \%$ & $5.8 \%$ & $2.2 \%$ \\
\hline 1991 & $0.7 \%$ & $1.9 \%$ & $1.2 \%$ & $-2.1 \%$ & $0.8 \%$ \\
\hline 1992 & $2.6 \%$ & $0.8 \%$ & $1.9 \%$ & $3.7 \%$ & $2.3 \%$ \\
\hline 1993 & $2.2 \%$ & $2.0 \%$ & $4.9 \%$ & $11.1 \%$ & $2.7 \%$ \\
\hline 1994 & $6.2 \%$ & $1.9 \%$ & $2.5 \%$ & $16.7 \%$ & $5.9 \%$ \\
\hline
\end{tabular}

\begin{tabular}{|c|c|}
\hline \multicolumn{2}{|c|}{ Average Rates of Growth: } \\
\hline \multicolumn{2}{|l|}{ Coal } \\
\hline $1949-1971$ & $12.1 \%$ \\
\hline $1971-1980$ & $4.7 \%$ \\
\hline $1981-1990$ & $6.3 \%$ \\
\hline $1991-1994$ & $3.7 \%$ \\
\hline \multicolumn{2}{|l|}{ Petroleum } \\
\hline 1949-1971 & $30.1 \%$ \\
\hline $1971-1980$ & $9.8 \%$ \\
\hline $1981-1990$ & $3.5 \%$ \\
\hline $1991-1994$ & $1.6 \%$ \\
\hline \multicolumn{2}{|l|}{ Natural Gas } \\
\hline$|949-197|$ & $33.0 \%$ \\
\hline $1971-1980$ & $12.8 \%$ \\
\hline $1981-1990$ & $2.1 \%$ \\
\hline $1991-1994$ & $3.1 \%$ \\
\hline \multicolumn{2}{|c|}{ Hydroelectricity } \\
\hline $1949-197 \mid$ & $17.7 \%$ \\
\hline $1971-1980$ & $8.1 \%$ \\
\hline $1981-1990$ & $7.6 \%$ \\
\hline $1991-1994$ & $11.0 \%$ \\
\hline \multicolumn{2}{|l|}{ Total } \\
\hline 1949-197| & $13.1 \%$ \\
\hline $1971-1980$ & $6.0 \%$ \\
\hline $1981-1990$ & $5.7 \%$ \\
\hline 1991-1994 & $3.6 \%$ \\
\hline
\end{tabular}

* Raw coal includes anthracite, bituminous coal, and brown coal, but not slaty coal. Figures for 1986 and later years includes output from private mines.

$\uparrow$ Crude oil includes natural crude and shale oil.

Source: China Energy Annual Review, 1994; China Statistical Yearbook, various years; Energy Research Institute. 
Table II-1. Primary Energy Production, 1949-1994 (continued)

\begin{tabular}{|c|c|c|c|c|c|}
\hline \multicolumn{6}{|c|}{ 5. Production in EJ } \\
\hline Year & $\begin{array}{l}\text { Raw } \\
\text { Coal * } \\
\text { (EJ) }\end{array}$ & $\begin{array}{l}\text { Crude } \\
\text { Oil } 1 \\
\text { (EJ) }\end{array}$ & $\begin{array}{l}\text { Natural } \\
\text { Gas } \\
\text { (EJ) }\end{array}$ & $\begin{array}{l}\text { Hydro- } \\
\text { electricity II } \\
\text { (EJ) }\end{array}$ & $\begin{array}{l}\text { Total } \\
\text { (EJ) }\end{array}$ \\
\hline 1949 & 0.67 & 0.01 & 0.00 & 0.01 & 0.69 \\
\hline 1950 & 0.90 & 0.01 & 0.00 & 0.02 & 0.92 \\
\hline 1951 & 1.11 & 0.01 & 0.00 & 0.02 & 1.14 \\
\hline 1952 & 1.38 & 0.02 & 0.00 & 0.03 & 1.43 \\
\hline 1953 & 1.46 & 0.03 & 0.00 & 0.03 & 1.52 \\
\hline 1954 & 1.75 & 0.03 & 0.00 & 0.06 & 1.85 \\
\hline 1955 & 2.06 & 0.04 & 0.00 & 0.05 & 2.15 \\
\hline 1956 & 2.31 & 0.05 & 0.00 & 0.06 & 2.42 \\
\hline 1957 & 2.74 & 0.06 & 0.00 & 0.08 & 289 \\
\hline 1958 & 5.65 & 0.09 & 0.00 & 0.07 & 5.82 \\
\hline 1959 & 7.73 & 0.16 & 0.01 & 0.07 & 7.96 \\
\hline 1960 & 8.31 & 0.22 & 0.04 & 0.12 & 8.69 \\
\hline 1961 & 5.81 & 0.22 & 0.06 & 0.12 & 6.22 \\
\hline 1962 & 4.60 & 0.24 & 0.05 & 0.14 & 5.03 \\
\hline 1963 & 4.54 & 0.27 & 0.04 & 0.13 & 4.99 \\
\hline 1964 & 4.49 & 0.36 & 0.04 & 0.15 & 5.04 \\
\hline 1965 & 4.85 & 0.47 & 0.04 & 0.15 & 5.51 \\
\hline 1966 & 5.28 & 0.61 & 0.05 & 0.17 & 6.11 \\
\hline 1967 & 4.31 & 0.58 & 0.06 & 0.18 & 5.13 \\
\hline 1968 & 4.61 & 0.67 & 0.05 & 0.16 & 5.49 \\
\hline 1969 & 5.57 & 0.91 & 0.08 & 0.22 & 6.77 \\
\hline 1970 & 7.41 & 1.28 & 0.11 & 0.28 & 9.08 \\
\hline 1971 & 8.21 & 1.65 & 0.15 & 0.34 & 10.35 \\
\hline 1972 & 8.58 & 1.91 & 0.19 & 0.39 & 11.08 \\
\hline 1973 & 8.73 & 2.24 & 0.23 & 0.52 & 11.73 \\
\hline 1974 & 8.65 & 2.72 & 0.29 & 0.55 & 12.20 \\
\hline 1975 & 10.09 & 3.23 & 0.34 & 0.63 & 14.29 \\
\hline 1976 & 10.11 & 3.65 & 0.39 & 0.60 & 14.76 \\
\hline 1977 & 11.51 & 3.92 & 0.47 & 0.62 & 16.53 \\
\hline 1978 & 12.94 & 4.36 & 0.54 & 0.57 & 18.40 \\
\hline 1979 & 13.29 & 4.44 & 0.57 & 0.62 & 18.92 \\
\hline 1980 & 12.98 & 4.44 & 0.56 & 0.70 & 18.68 \\
\hline 1981 & 13.02 & 4.24 & 0.50 & 0.78 & 18.53 \\
\hline 1982 & 13.95 & 4.28 & 0.47 & 0.88 & 19.57 \\
\hline 1983 & 14.96 & 4.44 & 0.48 & 1.01 & 20.89 \\
\hline 1984 & 16.52 & 4.80 & 0.48 & 1.01 & 22.82 \\
\hline 1985 & 18.26 & 5.23 & 0.50 & 1.08 & 25.07 \\
\hline 1986 & 18.72 & 5.47 & 0.54 & 1.10 & 25.83 \\
\hline 1987 & 19.43 & 5.62 & 0.54 & 1.17 & 26.76 \\
\hline 1988 & 20.51 & 5.74 & 0.56 & 1.27 & 28.08 \\
\hline 1989 & 22.07 & 5.76 & 0.59 & 1.38 & 29.80 \\
\hline 1990 & 22.61 & 5.79 & 0.60 & 1.46 & 30.45 \\
\hline 1991 & 22.77 & 5.90 & 0.60 & 1.43 & 30.70 \\
\hline 1992 & 23.36 & 5.95 & 0.62 & 1.48 & 31.41 \\
\hline 1993 & 23.89 & 6.07 & 0.65 & 1.64 & 32.25 \\
\hline 1994 & 25.37 & 6.18 & 0.66 & 1.92 & 34.14 \\
\hline
\end{tabular}

* Raw coal includes anthracite, bituminous coal, and brown coal, but not slaty coal. Figures for 1986 and later years includes output from private mines.

$\dagger$ Crude oil includes natural crude and shale oil.

I Converted based on reported average heat rates of gross electricity generation at major Chinese power plants.

Source: China Energy Annual Review, 1994; China Statistical Yearbook, various years; Energy Research Institute. 
Table II-2. Commercial Energy Production by Province and Energy Source, * 1986-1993

\begin{tabular}{|c|c|c|c|c|c|c|c|c|c|}
\hline \multicolumn{10}{|c|}{ I. Coal Production by Province (Mt) } \\
\hline $\begin{array}{c}\text { Planning } \\
\text { Region }\end{array}$ & Province & 1986 & 1987 & 1988 & 1989 & 1990 & 1991 & 1992 & 1993 \\
\hline \multirow[t]{5}{*}{ North } & Beijing & 9 & 9 & 9 & 10 & 10 & 10 & 10 & 11 \\
\hline & Tianjin & - & - & - & - & - & - & - & - \\
\hline & Hebei & 63 & 63 & 64 & 63 & 62 & 61 & 63 & 64 \\
\hline & Shanxi & 222 & 231 & 246 & 275 & 286 & 292 & 297 & 310 \\
\hline & her Mongolia & 33 & 34 & 37 & 44 & 48 & 49 & 50 & 45 \\
\hline \multirow[t]{3}{*}{ Northeost } & Liaoning & 44 & 44 & 46 & 50 & 51 & 52 & 54 & $\overline{56}$ \\
\hline & Jilin & 21 & 21 & 22 & 24 & 26 & 26 & 25 & 24 \\
\hline & Heilongiang & 66 & 68 & 72 & 76 & 83 & 85 & 84 & 73 \\
\hline \multirow[t]{7}{*}{ East } & Shanghai & - & - & - & - & - & - & - & $\overline{-}$ \\
\hline & Jiangsu & 22 & 22 & 23 & 24 & 24 & 25 & 25 & 25 \\
\hline & Zhejiang & 1 & 1 & 1 & 1 & .1 & I & I & 2 \\
\hline & Anhui & 30 & 29 & 31 & 31 & 32 & 31 & 34 & 36 \\
\hline & Fujian & 7 & 8 & 9 & 9 & 9 & 9 & 9 & 10 \\
\hline & Jiangxi & 19 & 20 & 20 & 21 & 20 & 21 & 21 & 21 \\
\hline & Shandong & 51 & 53 & 56 & 57 & 60 & 61 & 64 & 68 \\
\hline \multirow[t]{6}{*}{ South-Centrol } & II Henan & 79 & 81 & 82 & 89 & 91 & 90 & 90 & 93 \\
\hline & Hubei & 8 & 8 & 10 & 10 & 9 & 8 & 9 & 10 \\
\hline & Hunan & 31 & 34 & 36 & 37 & 34 & 33 & 36 & 42 \\
\hline & Guangdong & 9 & 9 & 9 & 10 & 9 & 9 & 10 & 10 \\
\hline & Guangxi & 6 & 8 & 10 & 11 & 10 & 10 & 11 & 12 \\
\hline & Hainan & - & - & - & - & - & - & - & $=$ \\
\hline \multirow[t]{4}{*}{ Southwest } & Sichuan & 57 & 61 & 67 & 71 & 68 & 69 & 71 & $\overline{79}$ \\
\hline & Guizhou & 26 & 31 & 32 & 35 & 37 & 37 & 42 & 45 \\
\hline & Yunnan & 17 & 19 & 21 & 22 & 22 & 22 & 24 & 24 \\
\hline & Xizang & - & - & - & - & - & - & - & - \\
\hline \multirow[t]{5}{*}{ Northwest } & Shaanxi & 29 & 29 & 28 & 31 & 33 & 33 & 34 & $\overline{32}$ \\
\hline & Gansu & 12 & 13 & 14 & 14 & 16 & 15 & 15 & 18 \\
\hline & Qinghai & 3 & 3 & 3 & 3 & 3 & 3 & 3 & 3 \\
\hline & Ningxia & 12 & 13 & 13 & 13 & 14 & 14 & 14 & 14 \\
\hline & Xinjiang & 17 & 16 & 18 & 20 & 21 & 21 & 22 & 24 \\
\hline \multicolumn{2}{|c|}{ National Total } & 894 & 928 & 980 & 1,054 & 1,079 & 1,087 & 1.118 & 1.151 \\
\hline
\end{tabular}

- Some figures for some years are not the same in all editions of Chinese statistical material. In such cases the most recent figures reported are used.

Source: China Energy Statistical Yearbook, various years; China Statistical Yearbook, various years; Energy Research Institute. 
Table II-2. Commercial Energy Production by Province and Energy Source, * 1986-1993 (continued)

\begin{tabular}{|c|c|c|c|c|c|c|c|c|c|}
\hline \multicolumn{10}{|c|}{ 2. Crude Oil Production by Province (Mt) } \\
\hline $\begin{array}{r}\text { Planning } \\
\text { Region }\end{array}$ & Province & 1986 & 1987 & 1988 & 1989 & 1990 & 1991 & 1992 & 1993 \\
\hline \multirow[t]{3}{*}{ North } & Beijing & - & - & - & - & - & - & - & - \\
\hline & Tianjin & 4.133 & 4.530 & 4.628 & 4.704 & 4.695 & 4.749 & 4.918 & 5.170 \\
\hline & Hebei & 10.011 & 7.954 & 6.305 & 5.780 & 5.705 & 5.377 & 4.188 & 5.030 \\
\hline \multirow[b]{2}{*}{ In } & Shanxi & - & - & - & - & - & - & - & - \\
\hline & er Mongolia & - & - & - & - & - & 1.001 & 1.001 & 1.010 \\
\hline \multirow{3}{*}{ Northeast } & Liaoning & 10.210 & 11.461 & 12.673 & 13.450 & 13.687 & 13.742 & 13.878 & 14.200 \\
\hline & Jilin & 2.370 & 2.865 & 3.151 & 3.422 & 3.567 & 3.423 & 3.441 & 3.380 \\
\hline & Heilongilang & 55.552 & 55.553 & 55.703 & 55.556 & 55.622 & 55.623 & 55.658 & 55.900 \\
\hline \multirow[t]{7}{*}{$\overline{\text { East }}$} & Shanghai & - & - & - & - & - & - & - & 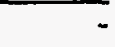 \\
\hline & Jiangsu & 0.601 & 0.658 & 0.750 & 0.833 & 0.880 & 0.925 & 0.916 & 0.950 \\
\hline & Zhejiang & - & - & - & - & - & - & - & - \\
\hline & Anhui & 0.018 & 0.022 & 0.025 & 0.021 & 0.020 & 0.030 & 0.040 & 0.044 \\
\hline & Fujian & - & - & - & - & - & - & - & - \\
\hline & Jiangxi & - & - & - & - & - & - & - & - \\
\hline & Shandong & 29.508 & 31.600 & 33.303 & 33.355 & 33.506 & 33.552 & 33.461 & 32.700 \\
\hline \multirow[t]{6}{*}{ South-Central } & Henan & 8.808 & 9.320 & 9.790 & 9.532 & 8.821 & 8.483 & 8.101 & 7.640 \\
\hline & Hubei & 1.030 & 1.010 & 1.016 & 0.930 & 0.830 & 0.734 & 0.765 & 0.810 \\
\hline & Hunan & - & - & - & - & - & - & - & - \\
\hline & Guangdong & 0.258 & 0.453 & 0.447 & 0.353 & 0.491 & 1.536 & 2.857 & 3.510 \\
\hline & Guangxi & 0.043 & 0.074 & 0.090 & 0.105 & 0.120 & 0.130 & 0.032 & 0.030 \\
\hline & Hainan & - & - & - & - & - & - & - & $=$ \\
\hline \multirow[t]{4}{*}{ Southwest } & Sichuan & 0.119 & 0.119 & 0.120 & 0.126 & 0.162 & 0.138 & 0.140 & 0.170 \\
\hline & Guizhou & - & - & - & - & - & - & - & - \\
\hline & Yunnan & - & - & - & - & - & - & 0.124 & 0.120 \\
\hline & Xizang & - & - & - & - & - & - & - & $=$ \\
\hline \multirow[t]{5}{*}{ Northwest } & Shaanxi & 0.262 & 0.357 & 0.431 & 0.555 & 0.701 & 0.851 & 1.017 & 1.130 \\
\hline & Gansu & 1.563 & 1.528 & 1.483 & 1.469 & 1.461 & 1.618 & 1.981 & 1.480 \\
\hline & Qinghai & 0.350 & 0.575 & 0.640 & 0.725 & 0.810 & 1.020 & 1.055 & 1.080 \\
\hline & Ningxia & 0.348 & 0.308 & 0.321 & 0.287 & 0.258 & 0.230 & 0.208 & 0.210 \\
\hline & Xinjiang & 5.505 & 5.751 & 6.170 & 6.438 & 6.970 & 7.830 & 8.317 & 10.660 \\
\hline \multicolumn{2}{|l|}{ National Total } & 130.689 & 134.140 & 137.046 & 137.641 & 138.306 & 140.992 & 142.097 & 145.224 \\
\hline -. & 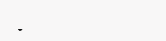 & & & & - & & & & \\
\hline
\end{tabular}

* Some figures for some years are not the same in all editions of Chinese statistical material. In such cases the most recent figures reported are used.

Source: China Energy Statistical Yearbook, various years; China Statistical Yearbook, various years; Energy Research Institute. 

Table II-2. Commercial Energy Production by Province and Energy Source, *
1986-1993 (continued)

3. Natural Gas Production by Province (billion cubic meters)

\begin{tabular}{|c|c|c|c|c|c|c|c|c|c|}
\hline $\begin{array}{c}\text { Planning } \\
\text { Region }\end{array}$ & Province & 1986 & 1987 & 1988 & 1989 & 1990 & 1991 & 1992 & 1993 \\
\hline \multirow[t]{4}{*}{ North } & Beijing & - & - & - & - & - & - & - & - \\
\hline & Tianjin & 0.473 & 0.433 & 0.391 & 0.376 & 0.366 & 0.361 & 0.412 & 0.653 \\
\hline & Hebei & 0.271 & 0.237 & 0.223 & 0.227 & 0.294 & 0.290 & 0.325 & 0.315 \\
\hline & Shanxi & - & - & - & 0.075 & 0.060 & 0.059 & 0.065 & 0.058 \\
\hline \multicolumn{2}{|c|}{ Inner Mongolia } & - & - & - & - & - & - & - & - \\
\hline \multirow[t]{3}{*}{ Northeast } & Liaoning & 1.768 & 1.807 & 1.897 & 1.998 & 2042 & 2055 & 2.110 & 2.078 \\
\hline & Jilin & 0.079 & 0.095 & 0.097 & 0.102 & 0.098 & 0.126 & 0.168 & 0.205 \\
\hline & Heilongiiang & 2301 & 2.205 & 2.226 & 2.249 & 2.247 & 2.273 & 2.287 & 2.228 \\
\hline \multirow[t]{7}{*}{$\overline{\text { East }}$} & Shanghai & - & - & - & - & - & - & - & - \\
\hline & Jiangsu & 0.043 & 0.041 & 0.040 & 0.035 & 0.038 & 0.033 & 0.030 & 0.027 \\
\hline & Zhejiang & - & - & - & - & . & - & - & - \\
\hline & Anhui & - & - & - & - & - & - & - & - \\
\hline & Fujian & - & - & - & - & - & - & - & - \\
\hline & Jiangxi & - & - & - & - & - & - & - & - \\
\hline & Shandong & 1.398 & 1.483 & 1.419 & 1.544 & 1.439 & 1.438 & 1.443 & 1.369 \\
\hline \multirow[t]{6}{*}{ South-Central } & 1 Henan & 0.868 & 1.033 & 1.329 & 1.317 & 1.389 & 1.302 & 1.261 & 1.167 \\
\hline & Hubei & 0.033 & 0.051 & 0.060 & 0.070 & 0.076 & 0.064 & 0.082 & 0.083 \\
\hline & Hunan &. & - & - & - & - & - & - & - \\
\hline & Guangdong & 0.006 & - & - & - & - & - & - & - \\
\hline & Guangxi & - & - & - & - & - & - & - & - \\
\hline & Hainan & - & - & - & - & - & - & - & - \\
\hline \multirow[t]{4}{*}{ Southwest } & Sichuan & 5.891 & 5.989 & 6.034 & 6.458 & 6.621 & 7.310 & 6.710 & 7.287 \\
\hline & Guizhou & 0.024 & 0.024 & 0.020 & 0.022 & 0.028 & 0.034 & 0.044 & 0.112 \\
\hline & Yunnan & - & - & - & - & - & - & 0.044 & 0.112 \\
\hline & Xizang & - & - & - & - & - & - & - & $=$ \\
\hline \multirow[t]{5}{*}{ Northwest } & Shaanxi & 0.006 & 0.003 & 0 & 0.001 & 0.007 & 0.027 & 0.028 & 0.026 \\
\hline & Gansu & 0.018 & 0.017 & 0.027 & 0.028 & 0.033 & 0.068 & 0.043 & 0.027 \\
\hline & Qinghai & 0.004 & 0.029 & 0.033 & 0.038 & 0.051 & 0.075 & 0.052 & 0.046 \\
\hline & Ningxia & 0.010 & 0.008 & 0.008 & 0.008 & 0.007 & 0.004 & 0.009 & 0.014 \\
\hline & Xinjiang & 0.571 & 0.439 & 0.460 & 0.501 & 0.502 & 0.554 & 0.675 & 0.959 \\
\hline \multicolumn{2}{|l|}{ National Total } & 13.764 & 13.894 & 14.264 & 15.049 & 15.298 & 16.073 & 15.788 & 16.766 \\
\hline
\end{tabular}

Some figures for some years are not the same in all editions of Chinese statistical material. In such cases the most recent figures reported are used.

Source: China Energy Statistical Yearbook, various years; China Statistical Yearbook, various years; Energy Research Institute. 


\section{Table II-2. Commercial Energy Production by Province and Energy Source, * 1986-1993 (continued)}

\begin{tabular}{|c|c|c|c|c|c|c|c|c|c|}
\hline $\begin{array}{c}\text { Planning } \\
\text { Region }\end{array}$ & Province & 1986 & 1987 & 1988 & 1989 & 1990 & |99| & 1992 & 1993 \\
\hline \multirow[t]{5}{*}{ North } & Beijing & 0.198 & 0.217 & 0.190 & 0.221 & 0.210 & 0.221 & 0.237 & 0.159 \\
\hline & Tianjin & & 0 & 0 & 0 & 0.018 & 0.020 & 0.019 & 0.017 \\
\hline & Hebei & 0.500 & 0.409 & 0.566 & 0.657 & 0.703 & 0.632 & 0.543 & 0.940 \\
\hline & Shanxi & 0.613 & 0.468 & 0.594 & 0.802 & 0.715 & 0.581 & 0.598 & 0.697 \\
\hline & her Mongolia & 0.064 & 0.073 & 0.058 & 0.050 & 0.070 & 0.124 & 0.111 & 0.113 \\
\hline \multirow[t]{3}{*}{ Northeost } & Liaoning & 4.694 & 4.466 & 2.869 & 1.661 & 3.546 & 4.035 & 3.243 & 2.741 \\
\hline & Jilin & 6.631 & 6.772 & 5.892 & 3.111 & 4.582 & 6.430 & 3.869 & 4.991 \\
\hline & Heilongiiang & 0.615 & 0.553 & 0.510 & 0.420 & 0.592 & 0.582 & 0.625 & 0.552 \\
\hline \multirow[t]{7}{*}{ East } & Shanghai & - & - & - & - & - & - & - & - \\
\hline & Jiangsu & 0.037 & 0.064 & 0.056 & 0.054 & 0.053 & 0.050 & 0.028 & 0.056 \\
\hline & Zhejiang & 3.891 & 4.801 & 5.569 & 6.363 & 5.600 & 5.883 & 5.845 & 6.039 \\
\hline & Anhui & 0.987 & I.I72 & 1.124 & 1.152 & 1.334 & 1.511 & 0.933 & 1.107 \\
\hline & Fujian & 5.055 & 5.278 & 6.724 & 6.838 & 7.814 & 6.272 & 9.469 & 8.975 \\
\hline & jiangxi & 2.060 & 2354 & 3.201. & 3.062 & 2.777 & 3.193 & 3.679 & 4.262 \\
\hline & Shandong & 0.063 & 0.031 & 0.025 & 0.011 & 0.043 & 0.079 & 0.023 & 0.040 \\
\hline \multirow[t]{6}{*}{ South-Central } & Henan & 1.332 & 1.287 & 1.284 & 1.692 & 1.543 & 1.528 & 1.481 & 1.537 \\
\hline & Hubei & 14.713 & 18.208 & 20.909 & 25.370 & 24.188 & 22.548 & 22.703 & 25.571 \\
\hline & Hunan & 7.281 & 8.237 & 9.036 & 9.514 & 10.612 & 10.763 & 10.619 & 12.627 \\
\hline & Guangdong & 7.009 & 7.158 & 6.996 & 7.016 & 7.718 & 5.917 & 9.284 & 10.000 \\
\hline & Guangxi & 6.131 & 6.340 & 6.056 & 5.864 & $\begin{array}{l}-6.890 \\
\text {. }\end{array}$ & 6.372 & 7.398 & 10.083 \\
\hline & Hainan & 0 & 0 & 0.501 & 0.782 & 0.781 & 0.702 & 0.763 & 0.658 \\
\hline \multirow[t]{4}{*}{ Southwest } & Sichuan & 11.199 & 11.602 & 13.200 & 14.684 & 15.136 & 15.506 & 16.830 & 19.586 \\
\hline & Guizhou & 4.264 & 4.426 & 4.949 & 4.115 & 3.750 & 4.431 & 5.207 & 5.425 \\
\hline & Yunnan & 5.023 & 5.013 & 4.811 & 5.913 & 7.546 & 9.312 & 9.126 & 12.509 \\
\hline & Xizang & 0.148 & 0.204 & 0.256 & 0.267 & 0.323 & 0.250 & 0.261 & 0.380 \\
\hline \multirow[t]{5}{*}{ Northwest } & Shaanxi & 0.719 & 0.914 & 1.034 & 1.299 & 1.261 & 1.652 & 3.015 & 4.161 \\
\hline & Gansu & 9.247 & 7.480 & 7.637 & 10.515 & 10.654 & 9.369 & 8.710 & 10.211 \\
\hline & Qinghai & 0.142 & 0.616 & 3.045 & 4.412 & 5.732 & 4.400 & 3.450 & 5.312 \\
\hline & Ningxia & 0.975 & 0.789 & 0.844 & 1.231 & 1.097 & 0.838 & 0.840 & 1.046 \\
\hline & Xinjiang & 0.942 & 1.075 & 1.214 & 1.310 & 1.433 & 1.467 & 1.755 & 2.024 \\
\hline Notional Totol & & 94.533 & 100.007 & 109.150 & 118.386 & $126.72 \mid$ & 124.668 & 130.664 & 151.819 \\
\hline
\end{tabular}

* Some figures for some years are not the same in all editions of Chinese statistical material. In such cases the most recent figures reported are used.

Source: China Energy Statistical Yearbook, various years; China Statistical Yearbook, various years; Energy Research Institute. 

Table II-2. Commercial Energy Production by Province and Energy Source, *
1986-1993 (continued)

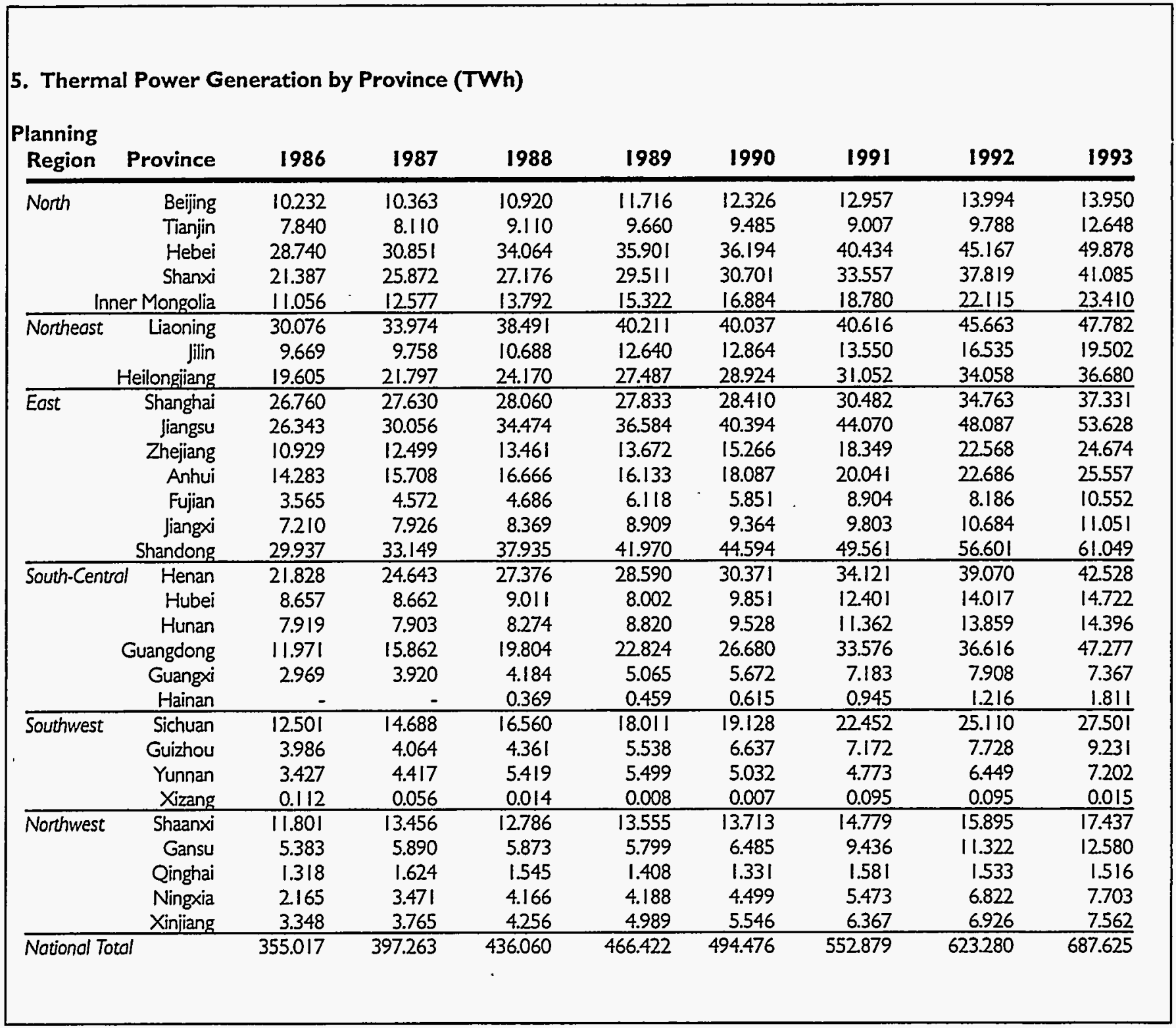

- Some figures for some years are not the same in all editions of Chinese statistical material. In such cases the most recent figures reported are used.

Source: China Energy Statistical Yearbook, various years; China Statistical Yearbook, various years; Energy Research Institute. 
Table II-2. Commercial Energy Production by Province and Energy Source, * 1986-1993 (continued)

\section{Total Power Generation by Province (TWh)}

\begin{tabular}{|c|c|c|c|c|c|c|c|c|c|}
\hline $\begin{array}{c}\text { Planning } \\
\text { Region }\end{array}$ & Province & 1986 & 1987 & 1988 & 1989 & 1990 & 1991 & 1992 & 1993 \\
\hline \multirow[t]{5}{*}{ North } & Beijing & 10.43 & 10.58 & 11.11 & 11.94 & 12.54 & 13.18 & 14.23 & 14.11 \\
\hline & Tianjin & 7.84 & 8.11 & 9.11 & 9.66 & 9.50 & 9.03 & 9.81 & 12.67 \\
\hline & Hebei & 29.24 & 31.26 & 34.63 & 36.56 & 36.90 & 41.07 & 45.71 & 50.82 \\
\hline & Shanxi & 22.00 & 26.34 & 27.77 & 30.31 & 31.42 & 34.14 & 38.42 & 41.78 \\
\hline & Inner Mongolia & 11.12 & 12.65 & 13.85 & 15.37 & 16.95 & 18.90 & 22.23 & 23.52 \\
\hline \multirow[t]{3}{*}{ Northeost } & Liaoning & 34.77 & 38.44 & 41.36 & 41.87 & 43.58 & 44.65 & 48.91 & 50.52 \\
\hline & Jilin & 16.30 & 16.53 & 16.58 & 15.75 & 17.45 & 19.98 & 20.40 & 24.49 \\
\hline & Heilongiang & 20.22 & 22.35 & 24.68 & 27.91 & 29.52 & 31.63 & 34.68 & 37.23 \\
\hline \multirow[t]{7}{*}{ East } & Shanghai & 26.76 & 27.63 & 28.06 & 27.83 & $28.4 !$ & 30.48 & 34.76 & 37.33 \\
\hline & Jiangsu & 26.38 & 30.12 & 34.53 & 36.64 & 40.45 & 44.12 & 48.12 & 53.68 \\
\hline & Zhejiang & 14.82 & 17.30 & 19.03 & 20.04 & 20.87 & 24.23 & 28.41 & 30.71 \\
\hline & Anhui & 15.27 & 16.88 & 17.79 & 17.29 & 19.42 & 21.55 & 23.62 & 26.66 \\
\hline & Fujian & 8.62 & 9.85 & 11.41 & 12.96 & 13.67 & 15.18 & 17.66 & 19.53 \\
\hline & fiangxi & 9.27 & 10.28 & 11.57 & 11.97 & 12.14 & 13.00 & 14.36 & $|5.3|$ \\
\hline & Shandong & 30.00 & 33.18 & 37.96 & 41.98 & 44.64 & 49.64 & 56.62 & 61.09 \\
\hline \multirow[t]{6}{*}{ South-Centrol } & Henan & 23.16 & 25.93 & 28.66 & 30.28 & 31.91 & 35.65 & 40.55 & 44.07 \\
\hline & Hubei & 23.37 & 26.87 & 29.92 & 33.37 & 34.04 & 34.95 & 36.72 & 40.29 \\
\hline & Hunan & 15.20 & 16.14 & 17.31 & 18.33 & 20.14 & 22.13 & 24.48 & 27.02 \\
\hline & Guangdong & 18.98 & 23.02 & 26.80 & 29.84 & 34.40 & 39.49 & 45.90 & 57.28 \\
\hline & Guangxi & 9.10 & 10.26 & 10.24 & 10.93 & 12.56 & 13.56 & 15.31 & 17.45 \\
\hline & Hainan & - & - & 0.87 & 1.24 & 1.40 & 1.65 & 1.98 & 2.47 \\
\hline \multirow[t]{4}{*}{ Southwest } & Sichuan & 23.70 & 26.29 & 29.76 & 32.70 & 34.26 & 37.96 & 41.94 & 47.09 \\
\hline & Guizhou & 8.25 & 8.49 & 9.31 & 9.65 & 10.39 & 11.60 & 12.94 & 14.66 \\
\hline & Yunnan & 8.45 & 9.43 & 10.23 & 11.41 & 12.58 & 14.09 & 15.58 & 19.71 \\
\hline & Xizang & 0.26 & 0.26 & 0.27 & 0.28 & 0.33 & 0.35 & 0.36 & 0.40 \\
\hline \multirow[t]{5}{*}{ Northwest } & Shaanxi & 12.52 & 14.37 & 13.82 & 14.85 & 14.97 & 16.43 & 18.91 & 21.60 \\
\hline & Gansu & 14.63 & 13.37 & 13.51 & 16.31 & 17.14 & 18.81 & 20.03 & 22.79 \\
\hline & Qinghai & 1.46 & 2.24 & 4.59 & 5.82 & 7.06 & 5.98 & .4 .98 & 6.83 \\
\hline & Ningxia & 3.14 & 4.26 & 5.01 & 5.42 & 5.60 & 6.31 & 7.66 & 8.75 \\
\hline & Xinjiang & 4.29 & 4.84 & 5.47 & 6.30 & 6.98 & 7.83 & 8.68 & 9.59 \\
\hline National Total & & 449.55 & 497.27 & 545.21 & 584.81 & 621.20 & 677.55 & 753.94 & $\overline{839.44}$ \\
\hline
\end{tabular}

* Some figures for some years are not the same in all editions of Chinese statistical material. In such cases the most recent figures reported are used Source: China Energy Statistical Yearbook, various years; China Statistical Yearbook, various years; Energy Research Institute. 
Table II-2. Commercial Energy Production by Province and Energy Source, * 1986-1993 (continued)

\begin{tabular}{|c|c|c|c|c|c|c|c|c|c|}
\hline \multicolumn{10}{|c|}{ 7. Primary Commercial Energy † (Mtce) } \\
\hline $\begin{array}{c}\text { Planning } \\
\text { Region }\end{array}$ & Province & 1986 & 1987 & 1988 & 1989 & 1990 & 1991 & 1992 & 1993 \\
\hline \multirow[t]{5}{*}{ North } & Beijing & 6.6 & 6.5 & 6.5 & 7.3 & 7.2 & 7.2 & 7.2 & 7.9 \\
\hline & Tianjin & 6.5 & 7.1 & 7.1 & 7.2 & 7.2 & 7.3 & 7.6 & 8.3 \\
\hline & Hebei & 59.7 & 57.1 & 55.5 & 54.0 & 53.1 & 51.9 & 51.6 & 53.7 \\
\hline & Shanxi & 158.7 & 165.1 & 176.2 & 196.8 & 204.6 & 208.8 & 212.4 & 221.7 \\
\hline & ner Mongolia & 23.5 & 24.4 & 26.7 & 31.3 & 34.3 & 36.5 & 37.2 & 33.6 \\
\hline \multirow{3}{*}{ Northeast } & Liaoning & 50.6 & 51.7 & 54.6 & 58.1 & 60.1 & 61.1 & 62.5 & 64.2 \\
\hline & Jilin & 21.4 & 220 & 229 & 23.7 & 25.6 & 26.2 & 24.6 & 24.3 \\
\hline & Heilongilang & 129.8 & 131.3 & 134.0 & 137.0 & 1420 & 143.5 & 142.9 & 135.2 \\
\hline \multirow[t]{7}{*}{ East } & Shanghai & - & - & & & & - & & \\
\hline & Jiangsu & 16.5 & 17.0 & 17.8 & 18.7 & 18.5 & 19.2 & 19.2 & 19.3 \\
\hline & Zhejiang & 26 & 3.0 & 3.3 & 3.6 & 3.0 & 3.1 & 3.1 & 3.9 \\
\hline & Anhui & 22.0 & 21.1 & 22.3 & 22.7 & 23.4 & 228 & 24.7 & 26.2 \\
\hline & Fujian & 6.9 & 7.8 & 8.9 & 9.5 & 9.6 & 9.0 & 10.3 & 10.8 \\
\hline & jiangxi & 14.1 & 15.0 & 15.9 & 16.0 & 15.4 & 16.3 & 16.5 & 16.7 \\
\hline & Shandong & 80.5 & 85.1 & 89.2 & 90.4 & 92.7 & 93.5 & 95.5 & 97.1 \\
\hline \multirow[t]{6}{*}{ South-Central } & Henan & 71.0 & 728 & 75.2 & 79.3 & 80.1 & 78.7 & 78.1 & 79.5 \\
\hline & Hubei & 13.4 & 14.9 & 17.1 & 19.1 & 17.5 & 16.0 & 16.8 & 18.7 \\
\hline & Hunan & 24.7 & 27.3 & 29.1 & 30.2 & 28.6 & 27.9 & 30.0 & 35.1 \\
\hline & Guangdong & 9.3 & 9.8 & 10.1 & 10.3 & 10.2 & 11.0 & 15.0 & 16.2 \\
\hline & Guangxi & 7.1 & 8.4 & 10.0 & 10.7 & 10.1 & 9.9 & 10.9 & 127 \\
\hline & Hainan & - & - & 0.2 & 0.3 & 0.3 & 0.3 & 0.3 & 0.3 \\
\hline \multirow[t]{4}{*}{ Southwest } & Sichuan & 53.2 & 56.6 & 61.4 & 65.6 & 63.7 & 65.4 & 66.6 & 74.3 \\
\hline & Guizhou & 20.0 & 24.1 & 24.9 & 26.7 & 28.0 & 28.3 & 32.2 & 34.5 \\
\hline & Yunnan & 14.2 & 15.9 & 16.6 & 18.0 & 18.8 & 19.5 & 21.1 & 225 \\
\hline & Xizang & 0.1 & 0.1 & 0.1 & 0.1 & 0.1 & 0.1 & 0.1 & 0.2 \\
\hline \multirow[t]{5}{*}{ Northwest } & Shaanxi & 21.1 & 21.3 & 20.8 & 23.8 & 25.1 & 25.5 & 27.0 & 26.2 \\
\hline & Gansu & 14.9 & 14.4 & 14.9 & 16.5 & 17.9 & 16.9 & 17.1 & 19.1 \\
\hline & Qinghai & 2.5 & 3.1 & 4.1 & 5.0 & 5.7 & 5.5 & 5.1 & 5.8 \\
\hline & Ningxia & 9.7 & 10.0 & 10.3 & 10.5 & 10.8 & 10.7 & 10.6 & 10.7 \\
\hline & Xinjiang & 20.8 & 20.5 & 22.9 & 24.8 & 26.2 & 27.5 & 29.2 & 34.5 \\
\hline \multicolumn{2}{|l|}{ National Total } & 881.7 & 913.3 & 958.7 & 1.017 .3 & $1,039.7$ & $1,049.5$ & $1,075.2$ & $1,113.0$ \\
\hline
\end{tabular}

* Some figures for some years are not the same in all editions of Chinese statistical material. In such cases the most recent figures reported are used

$\dagger$ Primary energy here indicates the sum of coal, oil, natural gas, and hydroelectricity production. Hydroelectricity converted at $0.404 \mathrm{kgce} / \mathrm{kWh}$.

Source: China Energy Statistical Yearbook, various years; China Statistical Yearbook, various years; Energy Research Institute. 


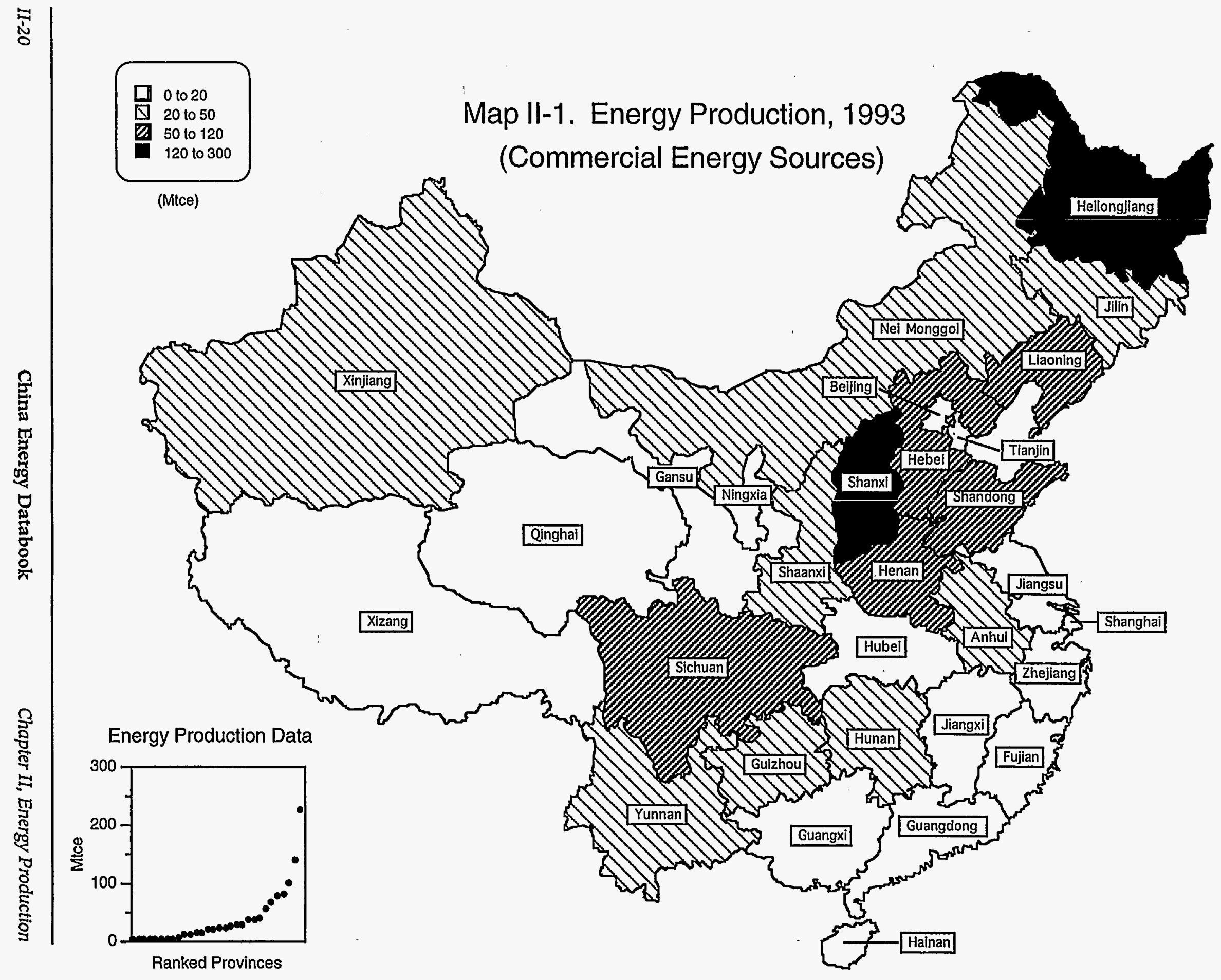




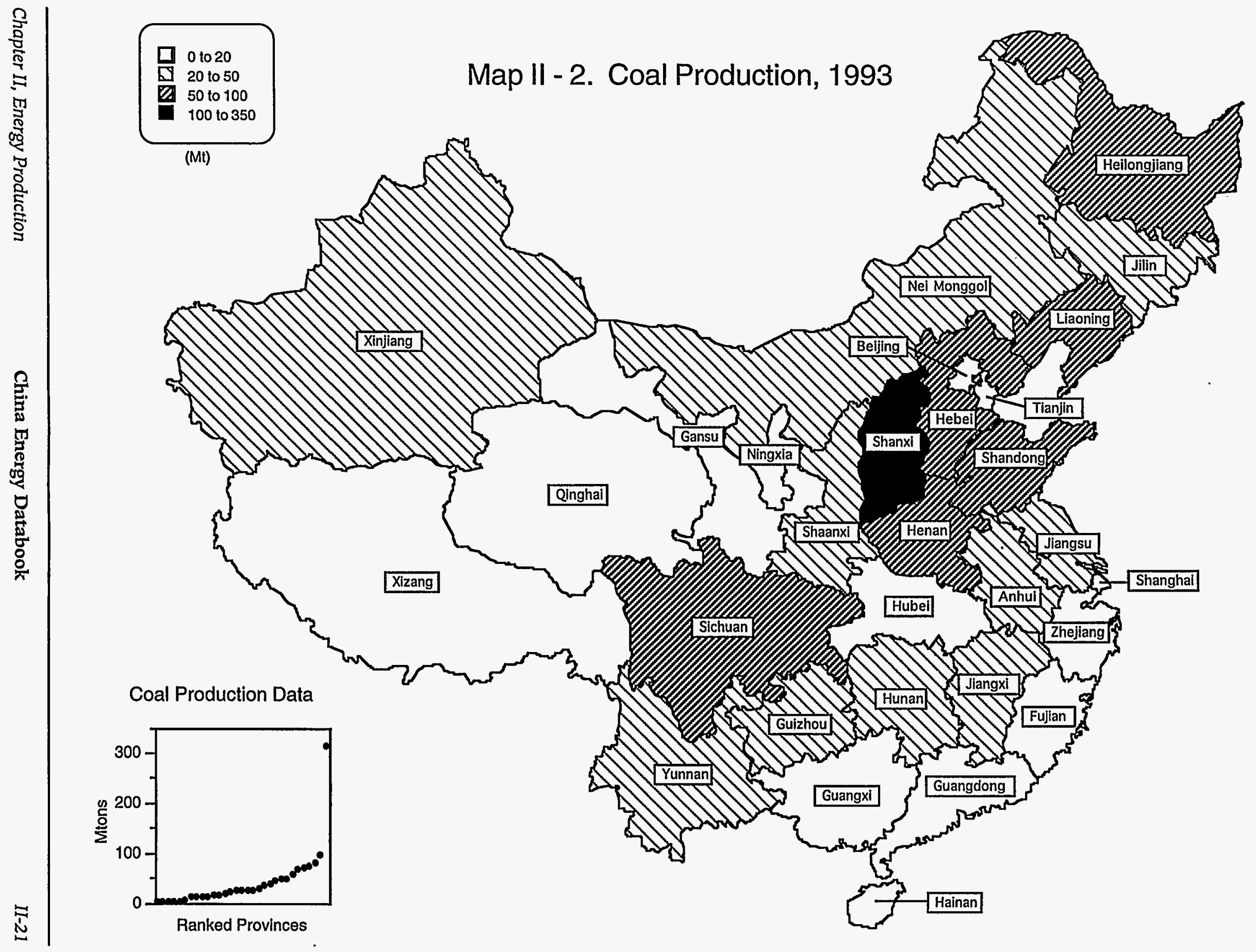




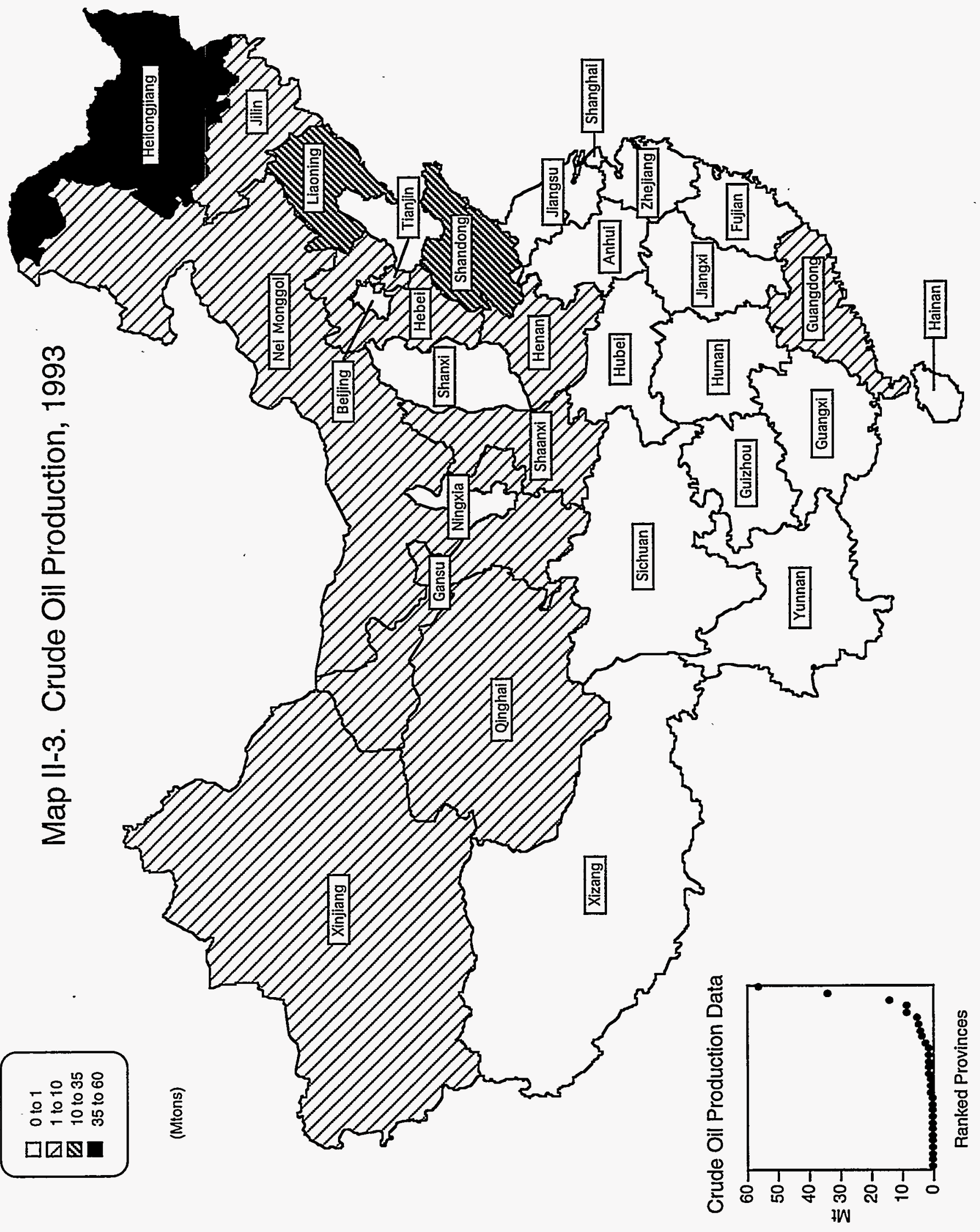




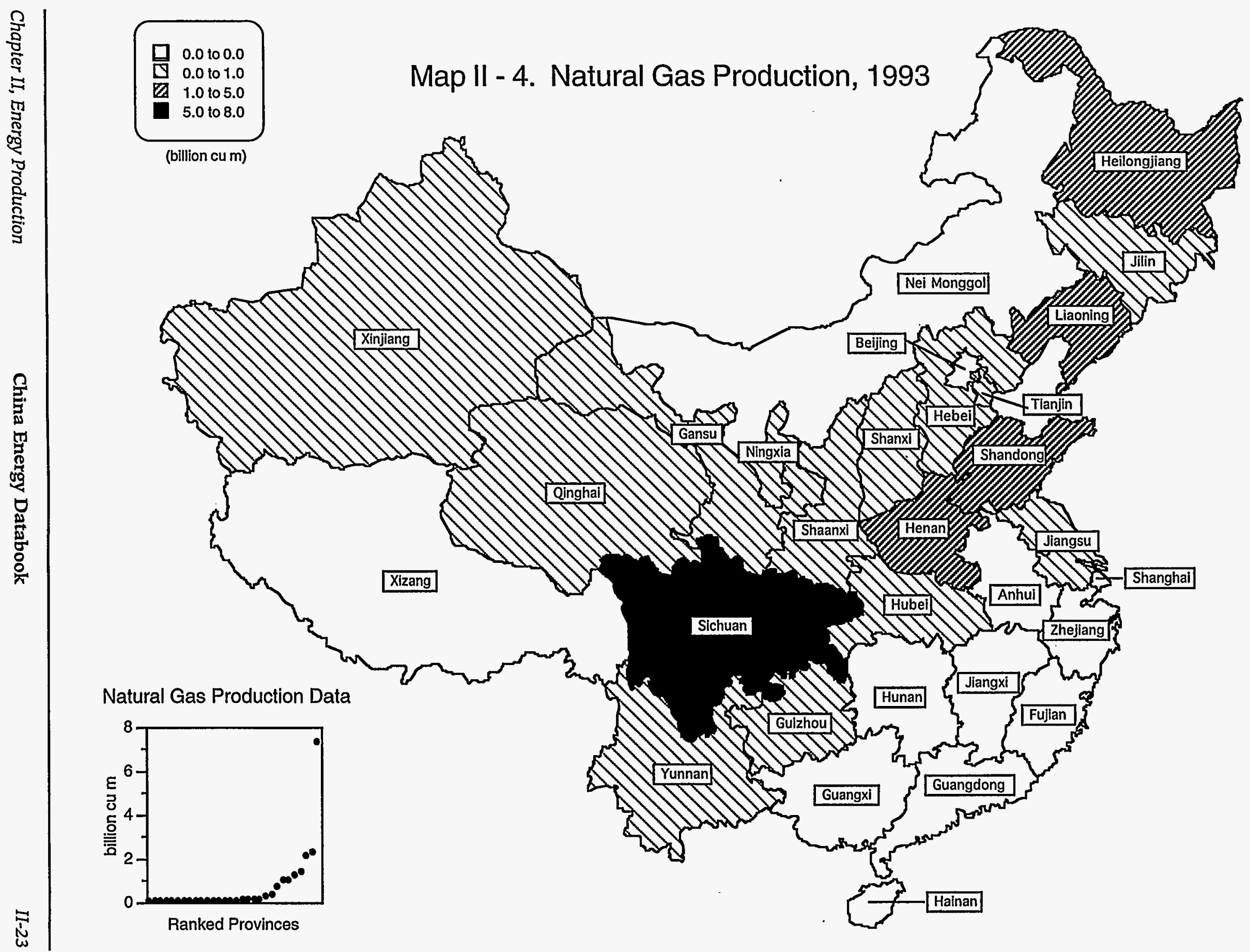




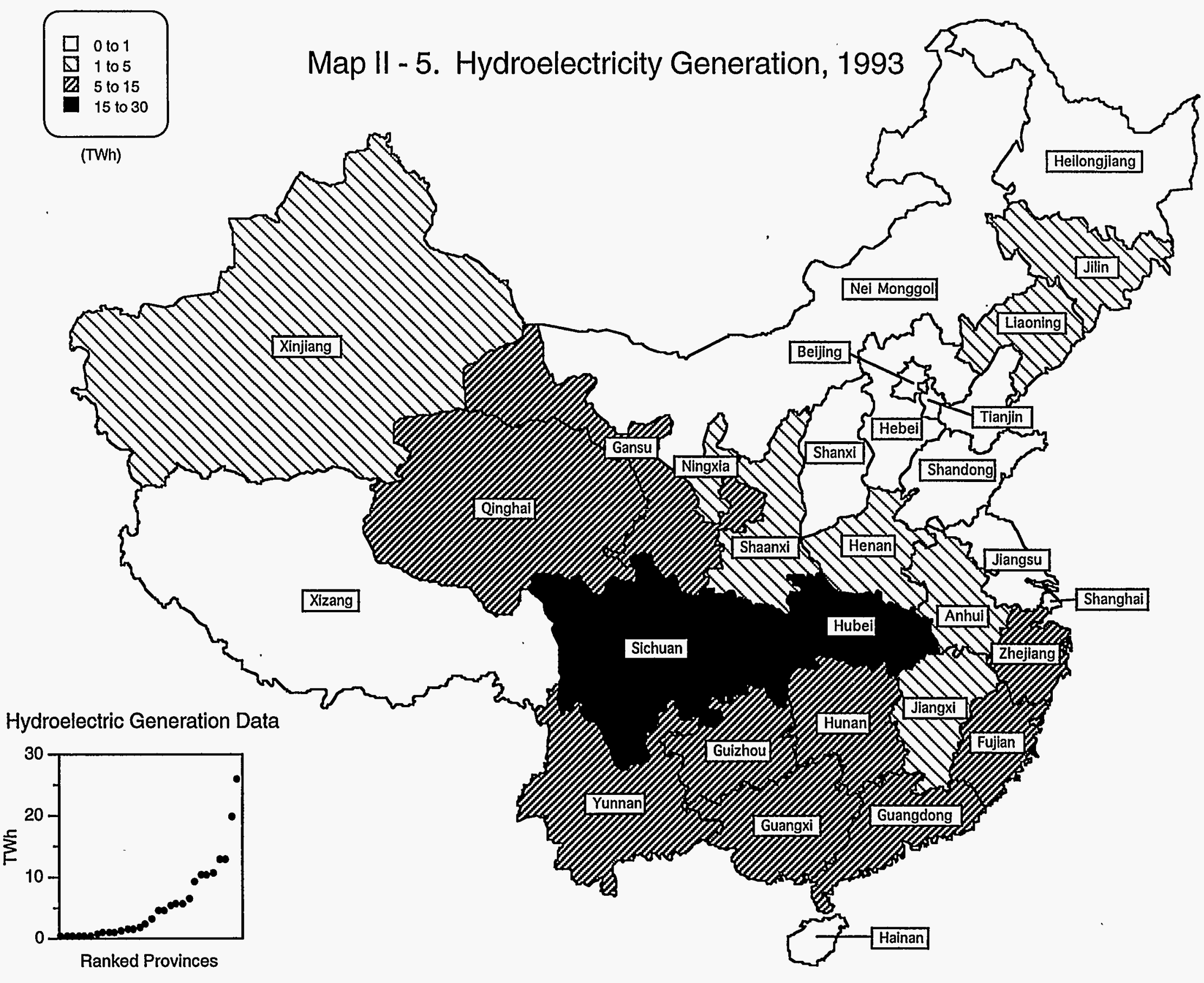




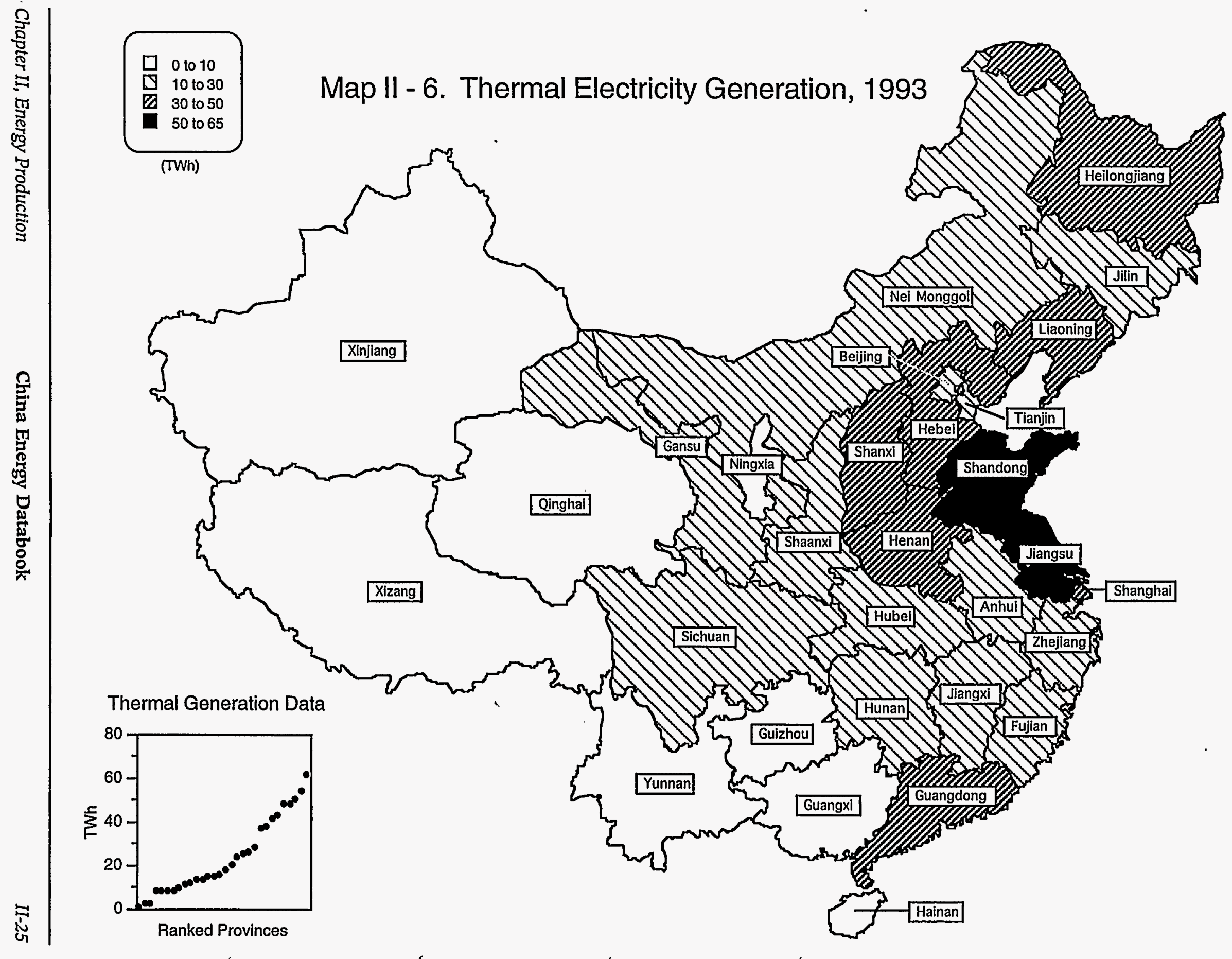


Table II-3. Raw Coal Production by Producer, 1950-1994

\begin{tabular}{|c|c|c|c|c|c|c|c|c|c|}
\hline \multicolumn{10}{|c|}{ 1. Production (Mt) } \\
\hline \multirow[b]{2}{*}{ Year } & \multirow{2}{*}{$\begin{array}{c}\text { Centrally } \\
\text { Administered } \\
\text { State-Owned } \\
\text { Mines }\end{array}$} & \multicolumn{4}{|c|}{ Local State-Owned Mines } & \multirow{2}{*}{$\begin{array}{l}\text { Township \& } \\
\text { Village } \\
\text { Mines }\end{array}$} & \multirow[b]{2}{*}{$\begin{array}{l}\text { Private } \\
\text { Mines * }\end{array}$} & \multirow[b]{2}{*}{$\begin{array}{l}\text { Other } \\
\text { Mines } t\end{array}$} & \multirow[b]{2}{*}{ Total } \\
\hline & & $\begin{array}{l}\text { Provincial } \\
\text { Mines }\end{array}$ & $\begin{array}{c}\text { Prefectural } \\
\text { Mines }\end{array}$ & $\begin{array}{l}\text { County } \\
\text { Mines }\end{array}$ & Subtotal & & & & \\
\hline 1950 & 30.2 & - & - & - & 12.7 & 0.0 & - & - & 42.9 \\
\hline 1951 & 37.1 & - & - & - & 15.9 & 0.0 & - & - & 53.1 \\
\hline 1952 & 48.4 & - & - & - & 18.2 & 0.0 & - & - & 66.6 \\
\hline 1953 & 52.2 & - & - & - & 17.6 & 0.0 & - & - & 69.7 \\
\hline 1954 & 62.3 & - & - & - & 21.4 & 0.0 & - & - & 83.7 \\
\hline 1955 & 73.0 & - & - & - & 25.4 & 0.0 & - & - & 98.4 \\
\hline 1956 & 81.5 & - & - & - & 28.9 & 0.0 & - & - & 110.4 \\
\hline 1957 & 94.3 & - & - & - & 36.5 & 0.0 & - & - & 130.8 \\
\hline 1958 & 157.8 & - & - & - & 78.2 & 34.0 & - & - & 270.0 \\
\hline 1959 & 216.4 & - & - & - & 124.4 & 28.0 & - & - & 368.8 \\
\hline$\overline{1960}$ & 240.4 & - & - & - & 134.9 & 22.0 & - & - & $\overline{397.2}$ \\
\hline 1961 & 175.5 & - & - & - & 102.1 & 0.0 & - & - & 277.6 \\
\hline 1962 & 147.6 & - & - & - & 72.0 & 0.0 & - & - & 219.6 \\
\hline 1963 & 151.3 & - & - & - & 65.8 & 0.0 & - & - & 217.1 \\
\hline 1964 & 150.6 & - & - & - & 64.0 & 0.0 & - & - & 214.6 \\
\hline 1965 & 164.3 & - & - & - & 67.5 & 0.0 & - & - & 231.8 \\
\hline 1966 & 180.7 & - & - & - & 70.8 & 0.0 & - & - & 251.5 \\
\hline 1967 & 135.9 & - & - & - & 61.8 & 8.0 & - & - & 205.7 \\
\hline 1968 & 147.3 & - & - & - & 59.3 & 13.0 & - & - & 219.6 \\
\hline 1969 & 178.6 & - & - & - & 69.4 & 18.0 & - & - & 266.0 \\
\hline 1970 & 226.7 & - & - & - & 96.3 & 31.0 & - & - & 354.0 \\
\hline 1971 & 246.6 & - & - & - & 113.7 & 32.0 & - & - & 392.3 \\
\hline 1972 & 249.2 & - & - & - & 125.3 & 36.0 & - & - & 410.5 \\
\hline 1973 & 247.7 & - & - & - & 127.3 & 42.0 & - & - & 417.0 \\
\hline 1974 & 242.8 & - & - & - & 118.4 & 52.0 & - & - & 413.2 \\
\hline 1975 & 280.0 & - & - & - & 145.3 & 57.0 & - & - & 482.2 \\
\hline 1976 & 273.6 & - & - & - & 144.8 & 65.0 & - & - & 483.5 \\
\hline 1977 & 295.3 & - & - & - & 176.4 & 79.0 & - & - & 550.7 \\
\hline 1978 & 341.8 & - & - & - & 189.0 & 87.0 & - & - & 617.9 \\
\hline 1979 & 357.8 & 69.8 & 45.2 & 56.5 & 171.5 & 106.3 & - & - & 635.5 \\
\hline 1980 & 344.4 & 66.2 & 42.8 & 53.1 & 162.1 & 113.6 & - & - & 620.1 \\
\hline 1981 & 335.1 & 66.9 & 40.4 & 52.7 & 160.0 & 126.6 & - & - & 621.6 \\
\hline 1982 & 349.9 & 70.3 & 42.5 & 57.5 & 170.4 & 146.1 & - & - & 666.3 \\
\hline 1983 & 363.1 & 78.2 & 44.1 & 59.1 & 181.3 & I70.I & - & - & 714.5 \\
\hline 1984 & 394.7 & 67.0 & 46.7 & 64.0 & 177.7 & 216.9 & - & - & 789.2 \\
\hline 1985 & 406.3 & 62.0 & 50.9 & 69.9 & 182.8 & 266.7 & 16.5 & - & 872.3 \\
\hline 1986 & 413.9 & 60.5 & 52.0 & 68.9 & 181.4 & 277.5 & 20.4 & 0.8 & 894.0 \\
\hline 1987 & 420.2 & 63.1 & 49.1 & 68.9 & 181.1 & 296.3 & 28.4 & 2.1 & 928.1 \\
\hline 1988 & 434.5 & 66.4 & 53.4 & 74.1 & 193.9 & 306.7 & 38.0 & 6.8 & 979.9 \\
\hline 1989 & 458.3 & 68.5 & 57.4 & 79.6 & 205.5 & 337.3 & 43.1 & 10.1 & 1.054 .2 \\
\hline 1990 & 480.2 & 66.4 & 58.7 & 80.0 & 205.1 & 346.4 & 43.3 & 4.9 & $1,079.9$ \\
\hline 1991 & 480.6 & 64.6 & 59.3 & 79.7 & 203.6 & 359.1 & 39.9 & 4.3 & $1,087.4$ \\
\hline 1992 & 482.5 & 57.7 & 60.6 & 84.5 & 202.8 & 382.5 & 44.8 & 3.7 & $1,116.4$ \\
\hline 1993 & 458.0 & 55.1 & 62.9 & 86.0 & 204.0 & 429.9 & 529 & 4.9 & $1,149.7$ \\
\hline 1994 & 479.5 & - & - & - & - & - & - & - & 1,2120 \\
\hline
\end{tabular}

- Private mines included in data for collective mines prior to 1985.

$\dagger$ Domestic and foreign joint venture mines.

Source: Yearbook of China's Coal Industry, various years; Energy in China, various years; China Energy Statistical Yearbook various years; Zhongguo Nengyuan [China Energy], no. 2,1995. 
Table II-3. Raw Coal Production by Producer, 1950-1994 (continued)

\section{Growth Over Previous Year}

\begin{tabular}{|c|c|c|c|c|c|c|c|c|c|}
\hline Year & $\begin{array}{l}\text { Centrally } \\
\text { Administered } \\
\text { State-Owned } \\
\text { Mines }\end{array}$ & $\begin{array}{l}\text { Provincial } \\
\text { Mines }\end{array}$ & $\begin{array}{c}\text { Local State-O } \\
\begin{array}{c}\text { Prefectural } \\
\text { Mines }\end{array}\end{array}$ & $\begin{array}{l}d \text { Mines } \\
\text { County } \\
\text { Mines }\end{array}$ & Subtotal & $\begin{array}{l}\text { Township \& } \\
\text { Village } \\
\text { Mines }\end{array}$ & $\begin{array}{l}\text { Private } \\
\text { Mines* }\end{array}$ & $\begin{array}{l}\text { Other } \\
\text { Mines f }\end{array}$ & Total \\
\hline 1950 & - & - & - & - & - & - & - & - & - \\
\hline 1951 & $23.1 \%$ & - & - & - & $25.1 \%$ & - & - & - & $23.7 \%$ \\
\hline 1952 & $30.4 \%$ & - & - & - & $13.9 \%$ & - & - & - & $25.4 \%$ \\
\hline 1953 & $7.7 \%$ & - & - & - & $-3.3 \%$ & - & - & - & $4.7 \%$ \\
\hline 1954 & $19.4 \%$ & - & - & - & $21.8 \%$ & - & - & - & $20.0 \%$ \\
\hline 1955 & $17.2 \%$ & - & - & - & $18.7 \%$ & - & - & - & $17.6 \%$ \\
\hline 1956 & $11.7 \%$ & - & - & - & $13.7 \%$ & - & - & - & $12.2 \%$ \\
\hline 1957 & $15.7 \%$ & - & - & - & $26.3 \%$ & - $\cdot$ & - & - & $18.5 \%$ \\
\hline 1958 & $67.3 \%$ & - & - & - & $114.6 \%$ & - & - & - & $106.5 \%$ \\
\hline 1959 & $37.2 \%$ & - & - & - & $59.0 \%$ & $-17.6 \%$ & - & - & $36.6 \%$ \\
\hline 1960 & $11.1 \%$ & - & - & - & $8.4 \%$ & $-21.4 \%$ & - & - & $7.7 \%$ \\
\hline 1961 & $-27.0 \%$ & - & - & - & $-24.3 \%$ & $-100.0 \%$ & - & - & $-30.1 \%$ \\
\hline 1962 & $-15.9 \%$ & - & - & - & $-29.5 \%$ & - & - & - & $-20.9 \%$ \\
\hline 1963 & $25 \%$ & - & - & - & $-8.6 \%$ & - & - & - & $-1.1 \%$ \\
\hline 1964 & $-0.5 \%$ & - & - & - & $-2.7 \%$ & - & - & - & $-1.2 \%$ \\
\hline 1965 & $9.1 \%$ & - & - & - & $5.5 \%$ & - & .- & - & $8.0 \%$ \\
\hline 1966 & $10.0 \%$ & - & - & - & $4.8 \%$ & - & - & - & $8.5 \%$ \\
\hline 1967 & $-24.8 \%$ & - & - & - & $-12.6 \%$ & - & - & - & $-18.2 \%$ \\
\hline 1968 & $8.4 \%$ & - & - & - & $-4.1 \%$ & $62.5 \%$ & - & - & $6.8 \%$ \\
\hline 1969 & $21.2 \%$ & - & - & - & $17.0 \%$ & $38.5 \%$ & - & - & $21.1 \%$ \\
\hline 1970 & $27.0 \%$ & - & - & - & $38.8 \%$ & $72.2 \%$ & - & - & $33.1 \%$ \\
\hline 1971 & $8.8 \%$ & - & - & - & $18.1 \%$ & $3.2 \%$ & - & - & $10.8 \%$ \\
\hline 1972 & $1.1 \%$ & - & - & - & $10.1 \%$ & $125 \%$ & - & - & $4.6 \%$ \\
\hline 1973 & $-0.6 \%$ & - & - & - & $1.6 \%$ & $16.7 \%$ & - & - & $1.6 \%$ \\
\hline 1974 & $-2.0 \%$ & - & - & - & $-7.0 \%$ & $23.8 \%$ & - & - & $-0.9 \%$ \\
\hline 1975 & $15.3 \%$ & - & - & - & $22.7 \%$ & $9.6 \%$ & - & - & $16.7 \%$ \\
\hline 1976 & $-2.3 \%$ & - & - & - & $-0.3 \%$ & $14.0 \%$ & - & - & $0.3 \%$ \\
\hline 1977 & $7.9 \%$ & - & - & - & $21.8 \%$ & $21.5 \%$ & - & - & $13.9 \%$ \\
\hline 1978 & $15.8 \%$ & - & - & - & $7.1 \%$ & $10.1 \%$ & - & - & $12.2 \%$ \\
\hline 1979 & $4.7 \%$ & - & - & - & $-9.3 \%$ & $222 \%$ & - & - & $2.9 \%$ \\
\hline 1980 & $-3.7 \%$ & $-5.2 \%$ & $-5.2 \%$ & $-6.0 \%$ & $-5.4 \%$ & $6.9 \%$ & - & - & $-2.4 \%$ \\
\hline 1981 & $-2.7 \%$ & $1.1 \%$ & $-5.6 \%$ & $-0.9 \%$ & $-1.3 \%$ & $11.4 \%$ & - & - & $0.2 \%$ \\
\hline 1982 & $4.4 \%$ & $5.1 \%$ & $5.1 \%$ & $9.2 \%$ & $6.5 \%$ & $15.4 \%$ & - & - & $7.2 \%$ \\
\hline 1983 & $3.8 \%$ & $11.2 \%$ & $3.6 \%$ & $27 \%$ & $6.4 \%$ & $16.4 \%$ & - & - & $7.2 \%$ \\
\hline 1984 & $8.7 \%$ & $-14.3 \%$ & $6.0 \%$ & $8.2 \%$ & $-2.0 \%$ & $27.5 \%$ & - & - & $10.5 \%$ \\
\hline 1985 & $2.9 \%$ & $-7.5 \%$ & $9.1 \%$ & $9.3 \%$ & $2.9 \%$ & $23.0 \%$ & - & - & $10.5 \%$ \\
\hline 1986 & $1.9 \%$ & $-24 \%$ & $2.1 \%$ & $-1.4 \%$ & $-0.8 \%$ & $4.0 \%$ & $23.6 \%$ & - & $2.5 \%$ \\
\hline 1987 & $1.5 \%$ & $4.3 \%$ & $-5.5 \%$ & $0.0 \%$ & $-0.1 \%$ & $6.8 \%$ & $38.8 \%$ & $149.4 \%$ & $3.8 \%$ \\
\hline 1988 & $3.4 \%$ & $5.2 \%$ & $8.8 \%$ & $7.5 \%$ & $7.0 \%$ & $3.5 \%$ & $34.1 \%$ & $226.6 \%$ & $5.6 \%$ \\
\hline 1989 & $5.5 \%$ & $3.1 \%$ & $7.5 \%$ & $7.5 \%$ & $6.0 \%$ & $10.0 \%$ & $13.2 \%$ & $48.7 \%$ & $7.6 \%$ \\
\hline 1990 & $4.8 \%$ & $-3.0 \%$ & $2.3 \%$ & $0.4 \%$ & $-0.2 \%$ & $27 \%$ & $0.6 \%$ & $-51.4 \%$ & $24 \%$ \\
\hline 1991 & $0.1 \%$ & $-2.8 \%$ & $1.0 \%$ & $-0.3 \%$ & $-0.7 \%$ & $3.7 \%$ & $-7.8 \%$ & $-127 \%$ & $0.7 \%$ \\
\hline 1992 & $0.4 \%$ & $-10.7 \%$ & $2.2 \%$ & $6.1 \%$ & $-0.4 \%$ & $6.5 \%$ & $121 \%$ & $-129 \%$ & $2.7 \%$ \\
\hline 1993 & $-5.1 \%$ & $-4.6 \%$ & $3.8 \%$ & $1.8 \%$ & $0.6 \%$ & $12.9 \%$ & $18.2 \%$ & $31.0 \%$ & $3.0 \%$ \\
\hline 1994 & $4.7 \%$ & - & - & - & - & - & - & - & $5.4 \%$ \\
\hline
\end{tabular}

- Private mines included in data for collective mines prior to 1985.

$\dagger$ Domestic and foreign joint venture mines.

Source: Yearbook of China's Coal Industry, various years; Energy in China, various years; China Energy Statistical Yearbook various years; Zhongguo Nengyuan (China Energy), 1995 no 2. 
Table II-3. Raw Coal Production by Producer, 1950-1994 (continued)

\begin{tabular}{|c|c|c|c|c|c|c|c|c|c|}
\hline 3. Shar & $\begin{array}{l}\text { Total } \\
\text { Centrally } \\
\text { Administered } \\
\text { State-Owned } \\
\text { Mines }\end{array}$ & $\begin{array}{c}\text { Provincial } \\
\text { Mines }\end{array}$ & $\begin{array}{c}\text { Local State-o } \\
\text { Prefectural } \\
\text { Mines }\end{array}$ & $\begin{array}{l}\text { MinesS } \\
\text { County } \\
\text { Mines }\end{array}$ & Subtotal & $\begin{array}{l}\text { Township \& } \\
\text { Village } \\
\text { Mines }\end{array}$ & $\begin{array}{l}\text { Private } \\
\text { Mines * }\end{array}$ & $\begin{array}{l}\text { Other } \\
\text { Mines } t\end{array}$ & Total \\
\hline 1950 & 30.2 & - & - & - & 12.7 & 0.0 & - & - & $100 \%$ \\
\hline 1950 & $70.3 \%$ & - & - & - & $29.7 \%$ & $0.0 \%$ & - & - & $100 \%$ \\
\hline 1951 & $70.0 \%$ & - & - & - & $30.0 \%$ & $0.0 \%$ & - & - & $100 \%$ \\
\hline 1952 & $72.7 \%$ & - & - & - & $27.3 \%$ & $0.0 \%$ & - & - & $100 \%$ \\
\hline 1953 & $74.8 \%$ & - & - & - & $25.2 \%$ & $0.0 \%$ & - & - & $100 \%$ \\
\hline 1954 & $74.4 \%$ & - & - & - & $25.6 \%$ & $0.0 \%$ & - & - & $100 \%$ \\
\hline 1955 & $74.2 \%$ & - & - & - & $25.8 \%$ & $0.0 \%$ & - & - & $100 \%$ \\
\hline 1956 & $73.9 \%$ & - & - & - & $26.1 \%$ & $0.0 \%$ & - & - & $100 \%$ \\
\hline 1957 & $72.1 \%$ & - & - & - & $27.9 \%$ & $0.0 \%$ & - & - & $100 \%$ \\
\hline 1958 & $58.4 \%$ & - & - & - & $29.0 \%$ & $126 \%$ & - & - & $100 \%$ \\
\hline 1959 & $58.7 \%$ & - & $=$ & - & $33.7 \%$ & $7.6 \%$ & - & - & $100 \%$ \\
\hline 1960 & $60.5 \%$ & - & - & - & $33.9 \%$ & $5.5 \%$ & - & - & $100 \%$ \\
\hline 1961 & $63.2 \%$ & - & - & - & $36.8 \%$ & $0.0 \%$ & - & - & $100 \%$ \\
\hline . 1962 & $67.2 \%$ & - & - & - & $32.8 \%$ & $0.0 \%$ & - & - & $100 \%$ \\
\hline 1963 & $69.7 \%$ & - & - & - & $30.3 \%$ & $0.0 \%$ & - & - & $100 \%$ \\
\hline 1964 & $70.2 \%$ & - & - & - & $29.8 \%$ & $0.0 \%$ & - & - & $100 \%$ \\
\hline 1965 & $70.9 \%$ & - & - & - & $29.1 \%$ & $0.0 \%$ & - & - & $100 \%$ \\
\hline 1966 & $71.9 \%$ & - & - & - & $28.1 \%$ & $0.0 \%$ & - & - & $100 \%$ \\
\hline 1967 & $66.1 \%$ & - & - & - & $30.1 \%$ & $3.9 \%$ & - & - & $100 \%$ \\
\hline 1968 & $67.1 \%$ & - & - & - & $27.0 \%$ & $5.9 \%$ & - & - & $100 \%$ \\
\hline 1969 & $67.1 \%$ & - & - & - & $26.1 \%$ & $6.8 \%$ & - & - & $100 \%$ \\
\hline 1970 & $64.0 \%$ & - & - & - & $27.2 \%$ & $8.8 \%$ & - & - & $100 \%$ \\
\hline 1971 & $62.9 \%$ & - & - & - & $29.0 \%$ & $8.2 \%$ & - & - & $100 \%$ \\
\hline 1972 & $60.7 \%$ & - & - & - & $30.5 \%$ & $8.8 \%$ & - & - & $100 \%$ \\
\hline 1973 & $59.4 \%$ & - & - & - & $30.5 \%$ & $10.1 \%$ & - & - & $100 \%$ \\
\hline 1974 & $58.8 \%$ & - & - & - & $28.7 \%$ & $12.6 \%$ & - & - & $100 \%$ \\
\hline 1975 & $58.1 \%$ & - & - & - & $30.1 \%$ & $11.8 \%$ & - & - & $100 \%$ \\
\hline 1976 & $56.6 \%$ & - & - & - & $30.0 \%$ & $13.4 \%$ & - & - & $100 \%$ \\
\hline 1977 & $53.6 \%$ & - & - & - & $32.0 \%$ & $14.3 \%$ & - & - & $100 \%$ \\
\hline 1978 & $55.3 \%$ & - & - & - & $30.6 \%$ & $14.1 \%$ & - & - & $100 \%$ \\
\hline 1979 & $56.3 \%$ & $11.0 \%$ & $7.1 \%$ & $8.9 \%$ & $27.0 \%$ & $16.7 \%$ & - & - & $100 \%$ \\
\hline$\overline{1980}$ & $55.5 \%$ & $10.7 \%$ & $6.9 \%$ & $8.6 \%$ & $26.1 \%$ & $18.3 \%$ & - & - & $100 \%$ \\
\hline 1981 & $53.9 \%$ & $10.8 \%$ & $6.5 \%$ & $8.5 \%$ & $25.7 \%$ & $20.4 \%$ & - & - & $100 \%$ \\
\hline 1982 & $52.5 \%$ & $10.6 \%$ & $6.4 \%$ & $8.6 \%$ & $25.6 \%$ & $21.9 \%$ & - & - & $100 \%$ \\
\hline 1983 & $50.8 \%$ & $10.9 \%$ & $6.2 \%$ & $8.3 \%$ & $25.4 \%$ & $23.8 \%$ & - & - & $100 \%$ \\
\hline 1984 & $50.0 \%$ & $8.5 \%$ & $5.9 \%$ & $8.1 \%$ & $22.5 \%$ & $27.5 \%$ & - & - & $100 \%$ \\
\hline 1985 & $46.6 \%$ & $7.1 \%$ & $5.8 \%$ & $8.0 \%$ & $21.0 \%$ & $30.6 \%$ & $1.9 \%$ & - & $100 \%$ \\
\hline 1986 & $46.3 \%$ & $6.8 \%$ & $5.8 \%$ & $7.7 \%$ & $20.3 \%$ & $31.0 \%$ & $2.3 \%$ & $0.1 \%$ & $100 \%$ \\
\hline 1987 & $45.3 \%$ & $6.8 \%$ & $5.3 \%$ & $7.4 \%$ & $19.5 \%$ & $31.9 \%$ & $3.1 \%$ & $0.2 \%$ & $100 \%$ \\
\hline 1988 & $44.3 \%$ & $6.8 \%$ & $5.5 \%$ & $7.6 \%$ & $19.8 \%$ & $31.3 \%$ & $3.9 \%$ & $0.7 \%$ & $100 \%$ \\
\hline 1989 & $43.5 \%$ & $6.5 \%$ & $5.4 \%$ & $7.6 \%$ & $19.5 \%$ & $32.0 \%$ & $4.1 \%$ & $1.0 \%$ & $100 \%$ \\
\hline 1990 & $44.5 \%$ & $6.2 \%$ & $5.4 \%$ & $7.4 \%$ & $19.0 \%$ & $32.1 \%$ & $4.0 \%$ & $0.5 \%$ & $100 \%$ \\
\hline 1991 & $44.2 \%$ & $5.9 \%$ & $5.5 \%$ & $7.3 \%$ & $18.7 \%$ & $33.0 \%$ & $3.7 \%$ & $0.4 \%$ & $100 \%$ \\
\hline 1992 & $43.2 \%$ & $5.2 \%$ & $5.4 \%$ & $7.6 \%$ & $18.2 \%$ & $34.3 \%$ & $4.0 \%$ & $0.3 \%$ & $100 \%$ \\
\hline 1993 & $39.8 \%$ & $4.8 \%$ & $5.5 \%$ & $7.5 \%$ & $17.7 \%$ & $37.4 \%$ & $4.6 \%$ & $0.4 \%$ & $100 \%$ \\
\hline 1994 & $39.6 \%$ & - & - & - & - & - & - & - & $100 \%$ \\
\hline
\end{tabular}

* Private mines included in data for collective mines prior to 1985.

$\dagger$ Domestic and foreign joint venture mines

Source: Yearbook of China's Coal Industry, various years; Energy in China, various years; China Energy Statistical Yearbook various years; Zhongguo Nengyuan (China Energy), 1995 no 2. 
Figure II-3. Raw Coal Production

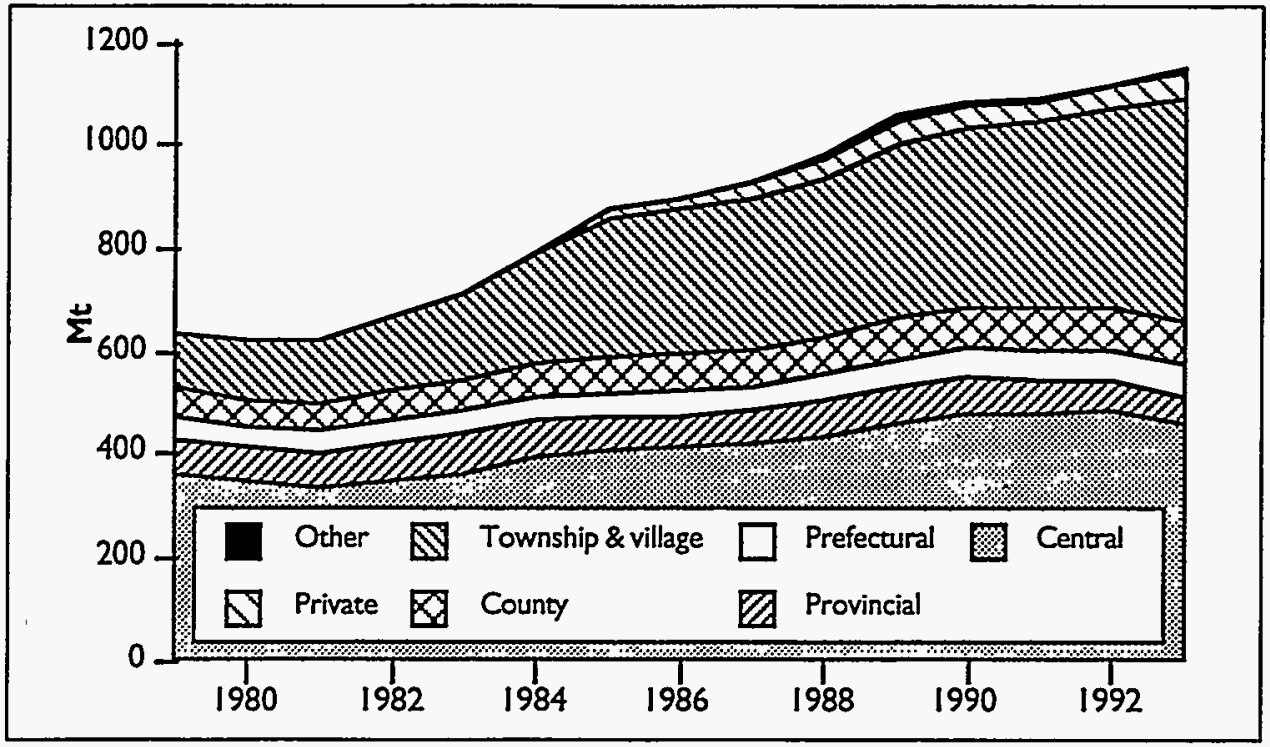

Figure II-4. Raw Coal Production by Producer

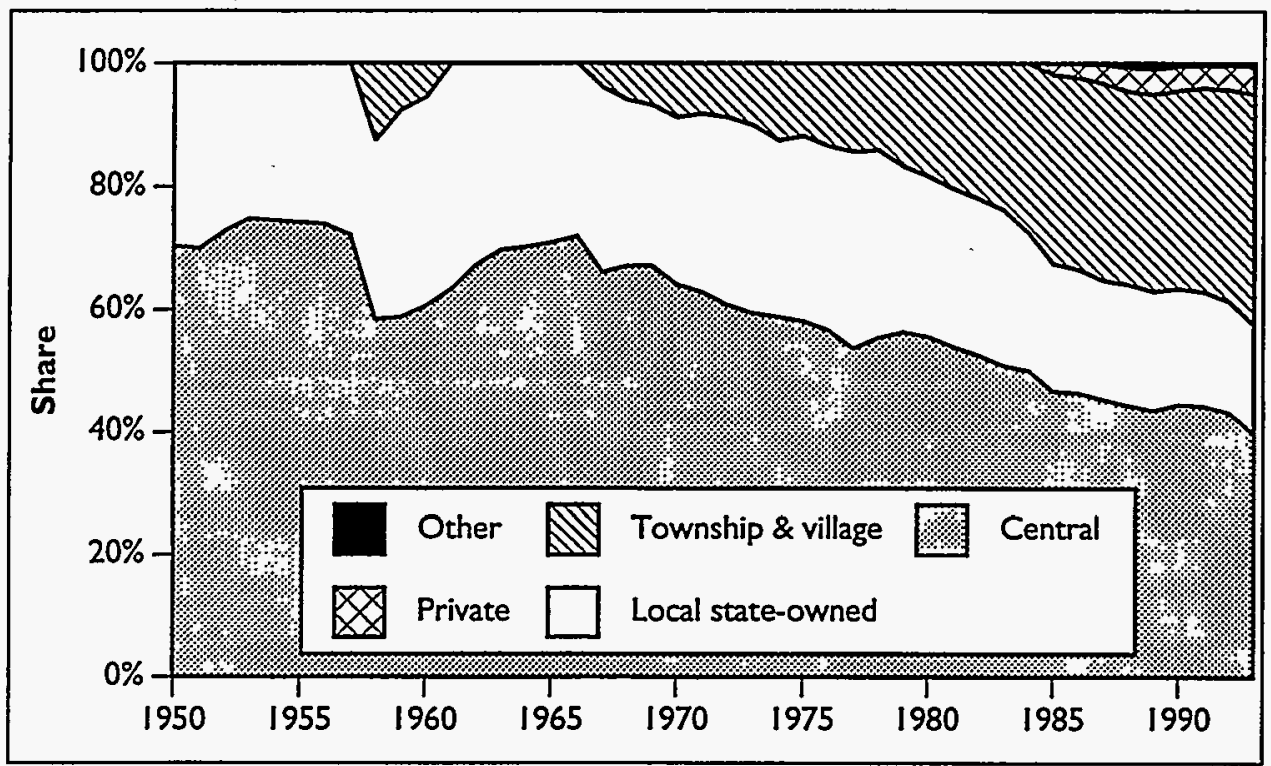


Figure II-5. Annual Growth in Coal Production by Producer

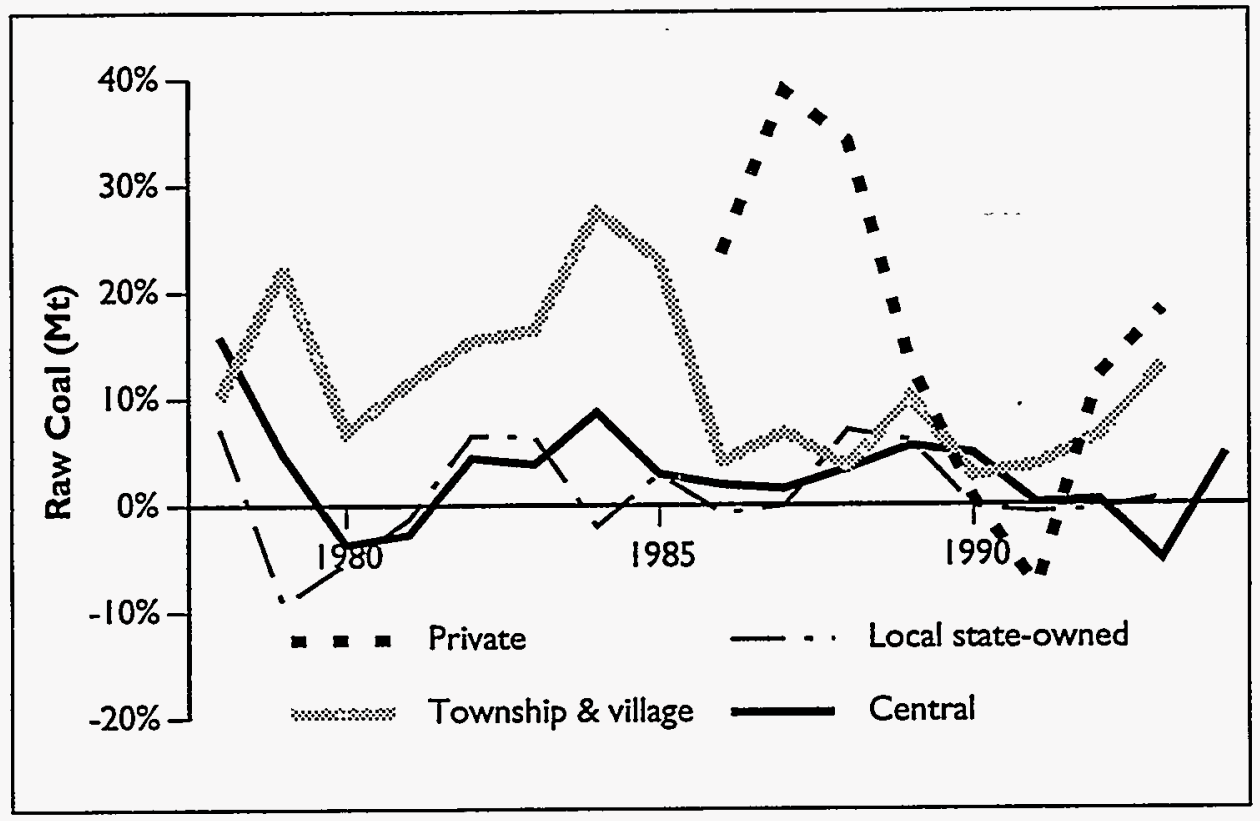

*Included in the local state-owned category for 1990 and 1991. 
Table II-4. Raw Coal Production by Type of Coal (Mt)

\begin{tabular}{|c|c|c|c|c|c|c|c|}
\hline Year & Total & Subtotal & $\frac{\text { Bituminous C }}{\text { Coking Coal }}$ & $\frac{\text { al }}{\text { Other Bitum. }}$ & Anthracite & $\begin{array}{c}\text { All } \\
\text { Hard } \\
\text { Coal }\end{array}$ & $\begin{array}{c}\text { Lignite } \\
\text { and Brown } \\
\text { Coal }\end{array}$ \\
\hline 1952 & 53.96 & 46.16 & 11.36 & 34.80 & 7.72 & 53.88 & 0.08 \\
\hline 1957 & 124.24 & 101.24 & 45.86 & 55.38 & 20.14 & 121.38 & 2.86 \\
\hline 1965 & 231.80 & 183.38 & 106.73 & 76.65 & 39.59 & 222.97 & 8.83 \\
\hline 1979 & 635.54 & 484.45 & 249.49 & 234.96 & 125.84 & 610.29 & 25.25 \\
\hline 1980 & 620.15 & 466.86 & 308.33 & 158.53 & 128.97 & 595.83 & 24.31 \\
\hline 1981 & 621.64 & 467.14 & 303.99 & 163.15 & 131.11 & 598.25 & 23.39 \\
\hline 1982 & 666.33 & 502.31 & 331.14 & 171.17 & 139.05 & 641.36 & 24.97 \\
\hline 1983 & 714.53 & 535.77 & 347.84 & 187.93 & 151.86 & 687.63 & 26.90 \\
\hline 1984 & 789.23 & 589.40 & 373.82 & 215.58 & 169.72 & 759.12 & 30.11 \\
\hline 1985 & 872.28 & 657.78 & 391.09 & 266.69 & 182.28 & 840.06 & 32.22 \\
\hline 1986 & 894.04 & 677.27 & 415.71 & 261.56 & 184.75 & 862.02 & 32.02 \\
\hline 1987 & 927.96 & 70242 & 454.94 & 247.48 & 192.34 & 894.76 & 33.20 \\
\hline 1988 & 979.88 & 740.56 & 46272 & 277.84 & 202.61 & 943.17 & 36.70 \\
\hline 1989 & $1,054.14$ & 793.39 & 499.66 & 293.73 & 217.97 & $1,011.36$ & 42.78 \\
\hline 1990 & $1,079.88$ & 821.53 & 51277 & 308.76 & 212.85 & $1,034.38$ & 45.50 \\
\hline 1991 & $1,084.28$ & 825.12 & 518.26 & 306.86 & 214.37 & $1,039.49$ & 44.79 \\
\hline 1992 & $1,114.55$ & 846.32 & 527.46 & 318.86 & 220.96 & $1,067.28$ & 47.27 \\
\hline 1993* & $1,149.00$ & - & - & - & - & $1,055.00$ & 94.00 \\
\hline
\end{tabular}

* From British Petroleum.

Source: China Energy Statistical Yearbook, 1989; Coal Industry Yearbooks,1982 and 1990; British Petroleum, 1995.

Figure II-6. Raw Coal Production by Type of Coal

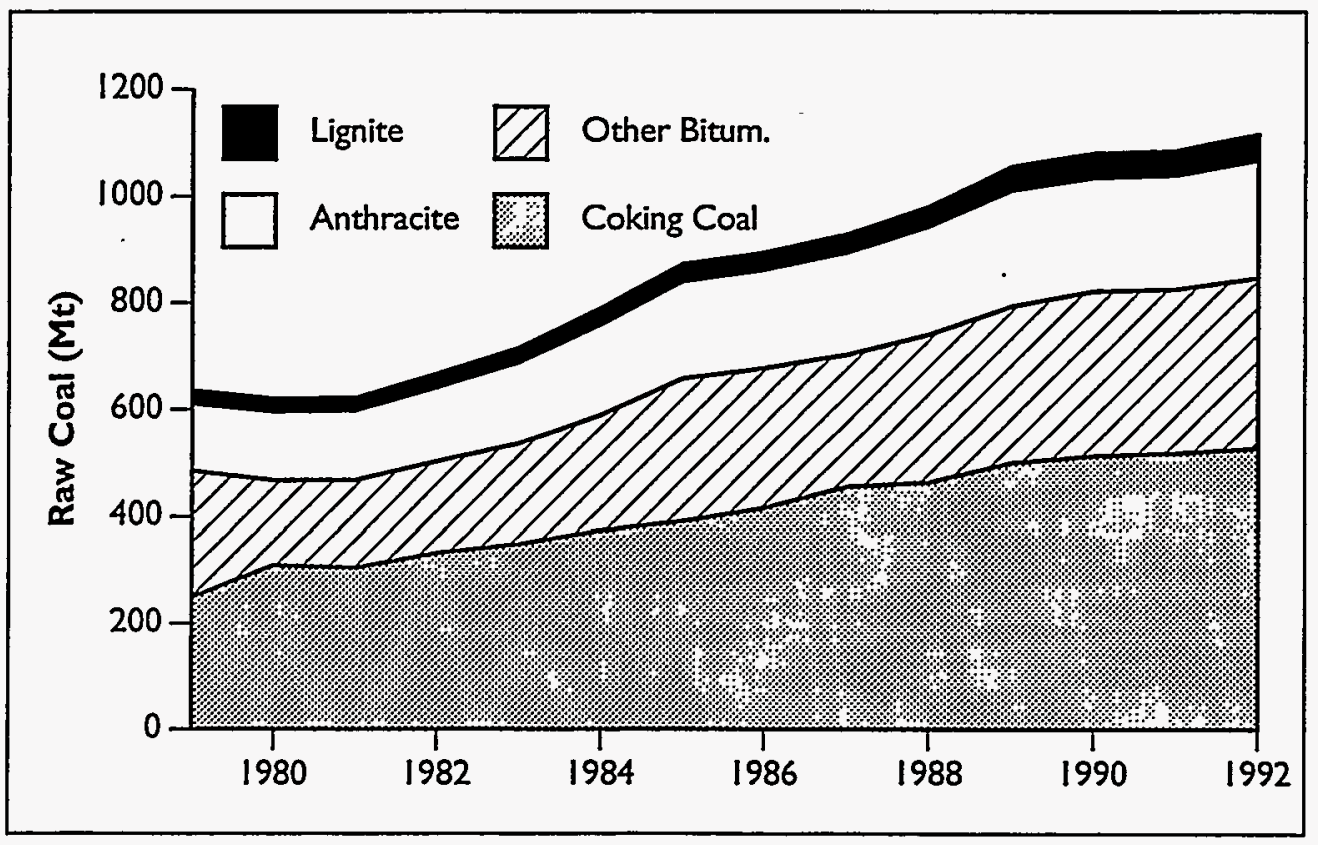


Table II-5. Characteristics of Chinese Steam Coal

1. Steam Coal Output and Characteristics by Mining Authority

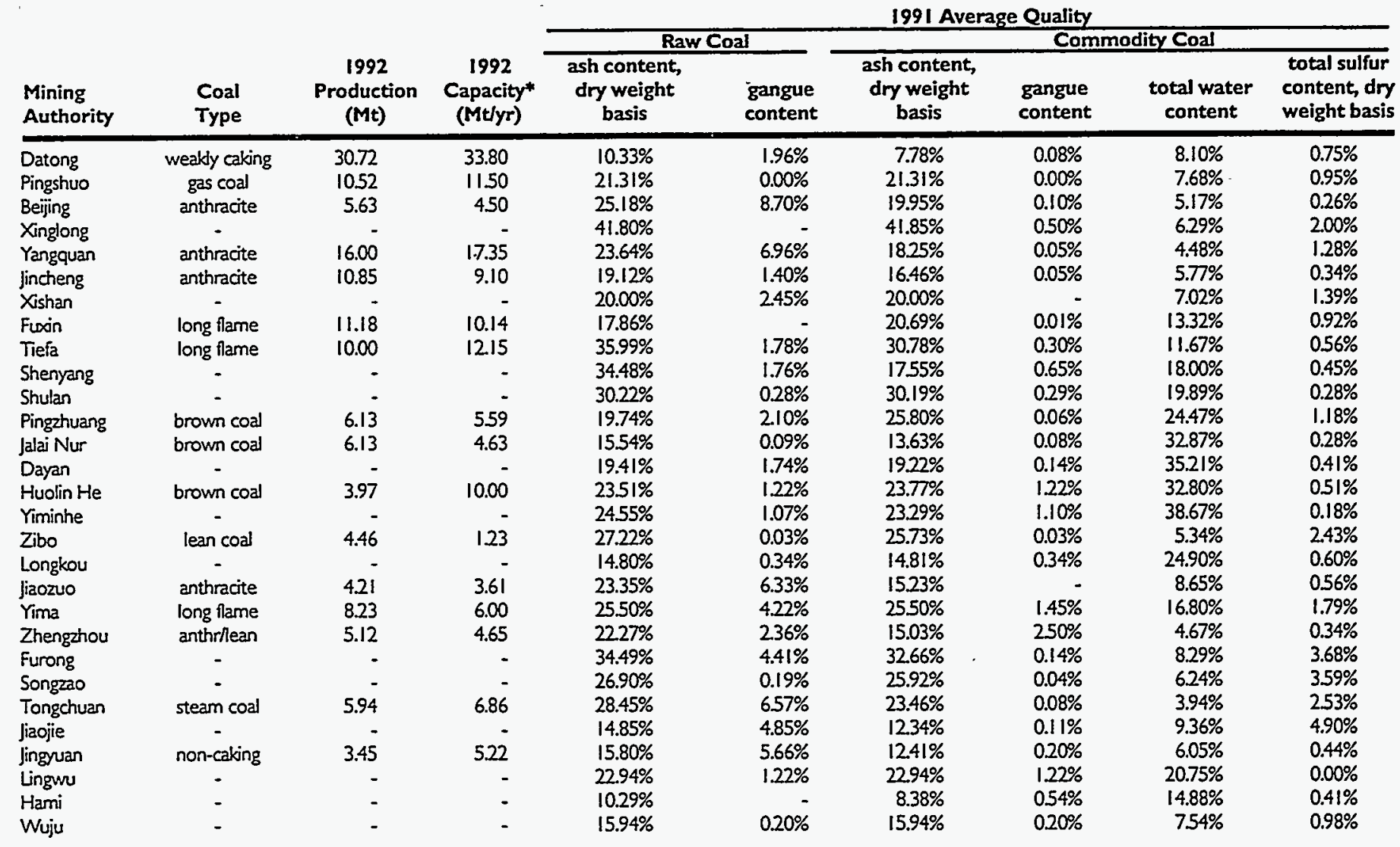

- Note that some mines are producing beyond their design capacities.

Source: China Energy Research Society, 1994 
Table II-5. Characteristics of Chinese Steam Coal (continued)

2. Average Commodity Steam Coal Quality and Output, 1992

\begin{tabular}{|c|c|c|c|c|c|c|c|}
\hline $\begin{array}{c}\text { coal } \\
\text { classification }\end{array}$ & $\begin{array}{c}\text { total } \\
\text { water } \\
\text { content }\end{array}$ & $\begin{array}{l}\text { water } \\
\text { content, } \\
\text { dry air } \\
\text { basis }\end{array}$ & $\begin{array}{c}\text { ash content, } \\
\text { dry weight } \\
\text { basis }\end{array}$ & $\begin{array}{c}\text { volatile } \\
\text { content, } \\
\text { dry, ash-free } \\
\text { basis }\end{array}$ & $\begin{array}{l}\text { total sulfur } \\
\text { content, } \\
\text { dry weight } \\
\text { basis }\end{array}$ & $\begin{array}{c}\text { low heat } \\
\text { content, } \\
\text { as received } \\
(\mathrm{MJ} / \mathrm{kg})\end{array}$ & $\begin{array}{c}1992 \\
\text { output } \\
\text { (Mt) }\end{array}$ \\
\hline brown & $30.80 \%$ & $13.33 \%$ & $28.62 \%$ & $48.08 \%$ & $0.51 \%$ & 16.90 & 47.27 \\
\hline long flame & $13.50 \%$ & $7.02 \%$ & $12.50 \%$ & $42.26 \%$ & $1.18 \%$ & 22.34 & 87.15 \\
\hline non-caking & $11.30 \%$ & $4.74 \%$ & $12.21 \%$ & $32.58 \%$ & $0.67 \%$ & 26.79 & 13.70 \\
\hline weakly caking & $9.00 \%$ & $2.59 \%$ & $9.40 \%$ & $31.32 \%$ & $0.74 \%$ & -29.60 & 76.30 \\
\hline lean & $5.40 \%$ & $1.21 \%$ & $27.83 \%$ & $16.34 \%$ & $2.20 \%$ & 24.39 & 54.19 \\
\hline anthracite & $6.30 \%$ & $2.32 \%$ & $20.55 \%$ & $8.68 \%$ & $1.07 \%$ & 26.48 & 220.96 \\
\hline unclassified & - & - & - & - & - & - & 87.07 \\
\hline $\begin{array}{l}\text { weighted avg/ } \\
\text { total }\end{array}$ & $10.25 \%$ & $4.12 \%$ & $2026 \%$ & $2323 \%$ & $10 \%$ & 2516 & 58664 \\
\hline
\end{tabular}

Source: China Energy Research Society, 1994. 
Table II-6. Major Coal Mining Enterprises:

Annual Production > 5 Million Tonnes of Raw Coal, 1980 and 1985-1992*

\begin{tabular}{|c|c|c|c|c|c|c|c|c|c|c|c|}
\hline \multirow{2}{*}{\multicolumn{2}{|c|}{ Name of Mine }} & \multirow{3}{*}{$\frac{\text { Province }}{\text { Shanxi }}$} & \multirow{3}{*}{$\begin{array}{c}1980 \\
24.520\end{array}$} & \multicolumn{8}{|c|}{ Annual Production (million tonnes of raw coal) } \\
\hline & & & & 1985 & 1986 & 1987 & 1988 & 1989 & 1990 & 1991 & 1992 \\
\hline 1 & Datong & & & 30.805 & 29.184 & 28.738 & 29.229 & 29.990 & 29.931 & 30.010 & 30.720 \\
\hline 2 & Kailuan & Hebei & 19.287 & 16.663 & 18.496 & 18.809 & 17.524 & 17.962 & 17.821 & 17.250 & 17.270 \\
\hline 3 & Pingdingshan & Henan & 13.651 & 15.966 & 16.683 & 17.236 & 17.434 & $17: 613$ & 17.499 & 17.800 & 18.180 \\
\hline 4 & Jixi & Heilongilang & 12700 & 12.997 & 13.486 & 13.440 & 13.322 & 14.607 & 15.707 & 20.060 & 18.060 \\
\hline 5 & Hegang & Heilongjiang & 12732 & 14.298 & 14.477 & 14.586 & $|4.45|$ & 14.750 & 15.708 & 17.520 & 17.400 \\
\hline 6 & Xishan & Shanxi & 9.308 & 11.772 & 12.573 & 13.557 & 13.111 & $|5.70|$ & 15.152 & 15.740 & 15.190 \\
\hline 7 & Yangquan & Shanxi & 12.178 & 13.932 & 14.298 & 14.972 & 15.089 & 15.681 & 16.234 & 15.580 & 16.000 \\
\hline 8 & Huaibei & Anhui & 13.284 & 14.247 & 14.350 & 14.278 & 14.096 & 14.147 & 14.187 & 13.630 & 14.240 \\
\hline 9 & Xuzhou & Jiangsu & 12558 & 12.830 & 12479 & 12639 & 12517 & 12923 & 13.165 & 13.810 & 13.400 \\
\hline 10 & Fuxin & Liaoning & 11.749 & 11.500 & 11.235 & 11.043 & 10.945 & 10.862 & 11.024 & 12.770 & 13.100 \\
\hline$\pi$ & Fengfeng & Hebei & 10.312 & 11.305 & 11.356 & 11.491 & 11.540 & 11.575 & 11.455 & 11.000 & 10.780 \\
\hline 12 & Xinwen & Shandong & 5.631 & 6.667 & 6.696 & 6.828 & 7.519 & 7.721 & 7.359 & 7.440 & 7.230 \\
\hline 13 & Shuangyashan & Heilongilang & 5.272 & 6.741 & 7.389 & 8.035 & 8.290 & 9.678 & 10.597 & 11.260 & 11.470 \\
\hline 14 & Lu'an & Shanxi & 4.517 & 6.840 & 8.026 & 8.805 & 10.001 & 10.104 & 10.102 & 10.180 & 9.120 \\
\hline 15 & Yima & Henan & 6.416 & 8.304 & 8.497 & 8.233 & 8.252 & 10.082 & 10.659 & 10.300 & 9.370 \\
\hline 16 & Jincheng & Shanxi & 4.165 & 6.131 & 6.786 & 8.155 & 10.033 & 10.042 & 10.363 & 10.260 & 10.850 \\
\hline 17 & Yanzhou & Shandong & 2333 & 5.200 & 6.348 & 7.437 & 8.659 & 9.364 & 9.687 & 10.520 & 10.850 \\
\hline 18 & Huainan & Anhui & 9.043 & 9.232 & 9.537 & 7.910 & 8.948 & 9.162 & 10.053 & 9.020 & 10.380 \\
\hline 19 & Qitaine & Heilongjiang & 3.250 & 4.834 & 5.426 & 6.511 & 7.119 & 7.567 & 796.5 & 10.210 & 10.040 \\
\hline 20 & Fushun & Liaoning & 8.079 & 8.213 & 8.150 & 6.904 & 7.053 & 7.357 & 7.584 & 8.780 & 9.120 \\
\hline 21 & Tiefa & Liaoning & 2.173 & 4.555 & 4.929 & 5.630 & 6.709 & 8.030 & 8.57 & 10.260 & 10.190 \\
\hline 22 & Fenxi & Shanxi & 4.502 & 6.185 & 6.731 & 6.668 & 6.924 & 7.083 & 6.929 & 6.820 & 5.690 \\
\hline 23 & Pingzhuang & Liaoning & - & - & - & - & - & 6.330 & - & 6.540 & 6.690 \\
\hline 24 & Shitanjing & Ningxia & 5.379 & 5.780 & 5.806 & 5.905 & 6.216 & 6.319 & 7.19 & 6.600 & 6.170 \\
\hline 25 & Zaozhuang & Shandong & 7.509 & 6.613 & 6.316 & 6.388 & 6.161 & 6.070 & 5.95 & 6.240 & 5.760 \\
\hline 26 & Beijing & & 6.202 & 5.975 & 5.709 & 5.890 & 5.966 & 6.135 & 6.022 & 5.930 & 5.630 \\
\hline 27 & Tongchuan & Shaanxi & 6.684 & 7.059 & 6.997 & 6.515 & 5.857 & 5.855 & 6.146 & 6.200 & 5.940 \\
\hline 28 & Feicheng & Shandong & 3.683 & 3.071 & 3.032 & 3.299 & 3.546 & $3: 831$ & 3.844 & 3.810 & 3.830 \\
\hline 29 & Shenyang & Liaoning & 1.126 & 4.953 & 4.816 & 4.279 & 4.616 & 5.159 & 5.345 & 5.640 & 6.240 \\
\hline 30 & Tonghua & jilin & 4.563 & 4.006 & 3.842 & 4.119 & 4.172 & 4.229 & 4.308 & 5.500 & 4.900 \\
\hline 31 & Zhengzhou & Henan & - & - & - & - & & 5.107 & - & 5.350 & 5.120 \\
\hline 32 & Zibo & Shandong & 5.223 & 4.398 & 4.268 & 3.967 & 4.195 & 4.424 & 4.531 & 3.980 & 4.460 \\
\hline 33 & Hebi & Henan & $4.683^{\circ}$ & 4.854 & 4.917 & 5.135 & 5.181 & 5.009 & 5.048 & 4.800 & 4.420 \\
\hline 34 & Antaibao & Shanxi & 0 & 0 & 0 & 0 & $t$ & $\dagger$ & $t$ & $t$ & $t$ \\
\hline
\end{tabular}

* The listed mines are all key enterprises (large state-run projects).

$\dagger$ The Antaibao mine (in northem Shanxi near Datong) has a capacity of over $15 \mathrm{Mt}$ /yr (steam coal), $12 \mathrm{Mt}$ of which would be washed and $9 \mathrm{Mt}$ of which would be export quality. The mine began production in 1988. Although output data are not available, it is reported that production was about $9 \mathrm{Mt}$ in 1990 and $12 \mathrm{Mt}$ in 1991.

Source: China Energy Statistical Yearbook, various years; Energy in China, various years; Coal Industry Yearbook, 1990; Martin Weil, The China Business Review, 1991; Energy Research Institute. 


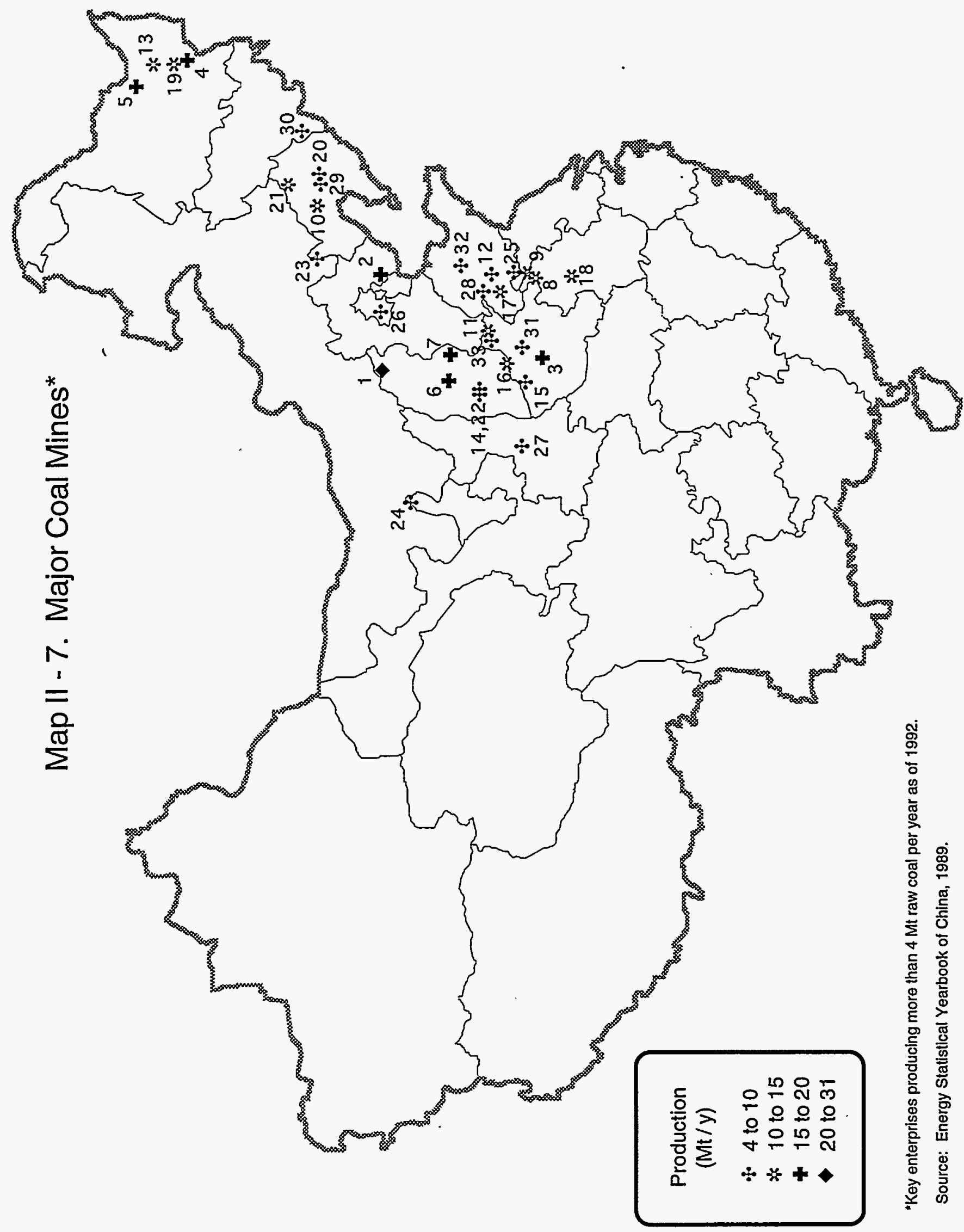


Table II-7. Mining Deaths

\begin{tabular}{|c|c|c|c|c|c|}
\hline Year & $\begin{array}{c}\text { Centrally } \\
\text { Administered } \\
\text { State-Owned } \\
\text { Mines }\end{array}$ & $\begin{array}{c}\text { Locally } \\
\text { Administered } \\
\text { State-Owned } \\
\text { Mines }\end{array}$ & $\begin{array}{l}\text { Rural } \\
\text { Mines }\end{array}$ & $\begin{array}{l}\text { Other } \\
\text { Mines* }\end{array}$ & Total \\
\hline \multicolumn{6}{|c|}{ 1. Deaths from all mining accidents (persons) } \\
\hline 1992 & - & - & - & - & 4,481 \\
\hline 1993 & 1.634 & 926 & 2,476 & - & 5,036 \\
\hline \multicolumn{6}{|c|}{ 2. Production (Mt) } \\
\hline 1992 & 483 & 203 & 427 & 4 & 1,116 \\
\hline 1993 & 458 & 204 & 483 & 5 & 1,150 \\
\hline \multicolumn{6}{|c|}{ 3. Deaths per million tons mined } \\
\hline 1992 & - & - & - & - & 4.01 \\
\hline 1993 & 3.57 & 4.54 & 5.13 & - & 4.38 \\
\hline
\end{tabular}

* Domestic and foreign joint venture mines.

Source: China Energy Statistical Yearbook, various years; Zhongguo Nengyuan [China Energy], no. 2, 1993; China Energy Research Society. 
Table II-8. Net Coal Production by Province, 1990

\begin{tabular}{|c|c|c|c|c|}
\hline $\begin{array}{l}\text { Planning } \\
\text { Region }\end{array}$ & Province & $\begin{array}{l}\text { Raw Coal } \\
\text { Production } \\
\text { (Mt) }\end{array}$ & $\begin{array}{c}\text { Coal } \\
\text { Consumption } \\
(M t)\end{array}$ & $\begin{array}{c}\text { Balance * } \\
\text { (Mt) }\end{array}$ \\
\hline \multirow[t]{4}{*}{ North } & $\begin{array}{l}\text { Beijing } \\
\text { Tianjin }\end{array}$ & $\begin{array}{r}9.06 \\
\dagger\end{array}$ & $\begin{array}{l}23.1 \\
17.3\end{array}$ & $\begin{array}{r}-14.05 \\
\dagger\end{array}$ \\
\hline & Hebei & 64.34 & 77.6 & -13.26 \\
\hline & Shanxi & 246.48 & 72.5 & 174.03 \\
\hline & Inner Mongolia & 37.35 & 34.0 & 3.40 \\
\hline \multirow[t]{3}{*}{ Northeost } & Liaoning & 45.89 & 79.3 & -33.4 \\
\hline & & 22.28 & 36.2 & -13.93 \\
\hline & Heilongilang & 71.72 & 55.9 & 15.81 \\
\hline \multirow[t]{7}{*}{ East } & Shanghai & $t$ & 24.7 & $\dagger$ \\
\hline & Jiangsu & 23.32 & 60.7 & -37.4 \\
\hline & Zhejiang & 1.43 & 23.4 & -21.96 \\
\hline & Anhui & 30.52 & 31.6 & -1.05 \\
\hline & Fujian & 8.46 & 12.1 & -3.64 \\
\hline & Jiangxi & 20.49 & 23.2 & -2.72 \\
\hline & Shandong & 55.59 & 64.7 & -9.13 \\
\hline \multirow[t]{6}{*}{ South-Central } & Henan & 82.45 & 62.7 & 19.71 \\
\hline & Hubei & 10.01 & 33.7 & -23.68 \\
\hline & Hunan & 35.62 & 41.1 & -5.47 \\
\hline & Guangdong & 9.28 & 228 & -13.47 \\
\hline & Guangxi & 10.35 & 15.0 & -4.61 \\
\hline & Hainan & 0.01 & $t$ & I \\
\hline \multirow{4}{*}{ Southwest } & Sichuan & 67.07 & 66.8 & $\overrightarrow{0.26}$ \\
\hline & Guizhou & 32.10 & 23.9 & 8.19 \\
\hline & Yunnan & 20.55 & 21.0 & -0.49 \\
\hline & Xizang & 0.01 & $t$ & $t$ \\
\hline \multirow[t]{5}{*}{ Northwest } & Shaanxi & 27.65 & 25.5 & 2.12 \\
\hline & Gansu & 13.58 & 17.1 & -3.51 \\
\hline & Qinghai & 2.68 & 4.5 & -1.78 \\
\hline & Ningxia & 13.28 & 7.3 & 6.01 \\
\hline & Xinjiang & 18.13 & 16.0 & 2.17 \\
\hline National Total II & & 979.88 & 993.5 & -13.66 \\
\hline Balonce $¥$ & & 0.18 & 0.04 & - \\
\hline
\end{tabular}

- No attempt is made here to account for losses in coal transportation or processing

$\dagger \quad$ Not available. In the cases of Tianjin and Shanghai it can probably be assumed that coal production is negligible compared to consumption.

I The difference between national production and consumption is the result not only of losses in transportation and processing, but also reflects net exports of coal and net additions to or withdrawals from stockpiles.

¥ Because of differences in the coverage of statistics and conversions to standard coal, the sum of local statistics does not equal the national total.

Source: China Energy Statistical Yearbook, 1991. 
Table II-9. Coke Production, 1949-1994-Mt

\begin{tabular}{|c|c|c|c|c|}
\hline Year & Total & "Modern" * & "Antique" $†$ & $\begin{array}{c}\text { "Modern" } \\
\text { Coke as \% } \\
\text { of Total }\end{array}$ \\
\hline 1949 & 0.54 & 0.53. & 0.01 & $98.1 \%$ \\
\hline 1950 & 1.50 & 1.29 & 0.21 & $86.0 \%$ \\
\hline 1951 & 2.03 & 1.69 & 0.34 & $83.3 \%$ \\
\hline 1952 & 2.89 & 222 & 0.67 & $76.8 \%$ \\
\hline 1953 & 3.55 & 2.78 & 0.77 & $78.3 \%$ \\
\hline 1954 & 4.50 & 3.34 & 1.16 & $74.2 \%$ \\
\hline 1955 & 5.48 & 3.90 & 1.58 & $71.2 \%$ \\
\hline 1956 & 6.37 & 4.56 & 1.81 & $71.6 \%$ \\
\hline 1957 & 8.30 & 5.55 & 275 & $66.9 \%$ \\
\hline 1958 & 21.74 & 8.03 & 13.71 & $36.9 \%$ \\
\hline 1959 & 45.04 & 11.24 & 33.80 & $25.0 \%$ \\
\hline 1960. & 56.47 & 16.10 & 40.37 & $28.5 \%$ \\
\hline 1961 & 28.09 & 12.03 & 16.06 & $428 \%$ \\
\hline 1962 & 13.42 & 10.10 & 3.32 & $75.3 \%$ \\
\hline 1963 & 11.06 & 9.55 & 1.51 & $86.3 \%$ \\
\hline 1964 & 11.13 & 9.80 & 1.33 & $88.1 \%$ \\
\hline 1965 & 13.33 & 12.03 & 1.30 & $90.2 \%$ \\
\hline 1966 & 16.34 & 14.19 & 2.15 & $86.8 \%$ \\
\hline 1967 & 11.02 & 10.19 & 0.83 & $925 \%$ \\
\hline 1968 & 10.98 & 10.05 & 0.93 & $91.5 \%$ \\
\hline 1969 & 16.76 & 14.50 & 2.26 & $86.5 \%$ \\
\hline 1970 & 23.30 & 19.16 & 4.14 & $82.2 \%$ \\
\hline 1971 & 30.23 & 23.12 & 7.11 & $76.5 \%$ \\
\hline 1972 & 34.37 & 25.36 & 9.01 & $73.8 \%$ \\
\hline 1973 & 34.51 & 26.51 & 8.00 & $76.8 \%$ \\
\hline 1974 & 31.04 & 23.76 & 7.28 & $76.5 \%$ \\
\hline 1975 & 36.80 & 27.39 & 9.41 & $74.4 \%$ \\
\hline 1976 & 35.70 & 25.86 & 9.84 & $72.4 \%$ \\
\hline 1977 & 39.29 & 26.83 & 12.46 & $68.3 \%$ \\
\hline 1978 & 46.90 & 32.69 & 14.21 & $69.7 \%$ \\
\hline 1979 & 45.83 & 33.54 & 12.29 & $73.2 \%$ \\
\hline 1980 & 43.43 & 34.05 & 9.38 & $78.4 \%$ \\
\hline 1981 & 38.95 & 31.72 & 7.23 & $81.4 \%$ \\
\hline 1982 & 40.19 & 33.11 & 7.08 & $82.4 \%$ \\
\hline 1983 & 42.20 & 34.51 & 7.69 & $81.8 \%$ \\
\hline 1984 & 45.57 & 36.15 & 9.42 & $79.3 \%$ \\
\hline 1985. & 48.02 & 38.36 & 9.66 & $79.9 \%$ \\
\hline 1986 & 52.76 & 40.93 & 11.83 & $77.6 \%$ \\
\hline 1987 & 57.95 & 43.75 & 14.20 & 75.5\% \\
\hline 1988 & 61.08 & 45.42 & 15.66 & $74.4 \%$ \\
\hline 1989 & 66.24 & 46.75 & 19.49 & $70.6 \%$ \\
\hline 1990 & 73.28 & 51.30 & 21.98 & $70.0 \%$ \\
\hline 1991 & 73.52 & 53.96 & 19.56 & $73.4 \%$ \\
\hline 1992 & 79.84 & 56.00 & 23.84 & $70.1 \%$ \\
\hline 1993 & 93.20 & 60.11 & 33.09 & $64.5 \%$ \\
\hline 1994 & & 67.29 & - & \\
\hline
\end{tabular}

* "Modern" coke is coke produced in industrial coke ovens.

$\dagger \quad$ "Antique" coke is coke produced in clay or dirt kilns (usually by rural enterprises), which are much dirtier and more inefficient than industrial coke ovens.

Source: China Energy Statistical Yearbook, various years; China Statistical Yearbook, various years; Zhongguo Nengyuan [China Energy], no. 2, 1995; Energy Research Institute. 
Figure II-7. Coke Production

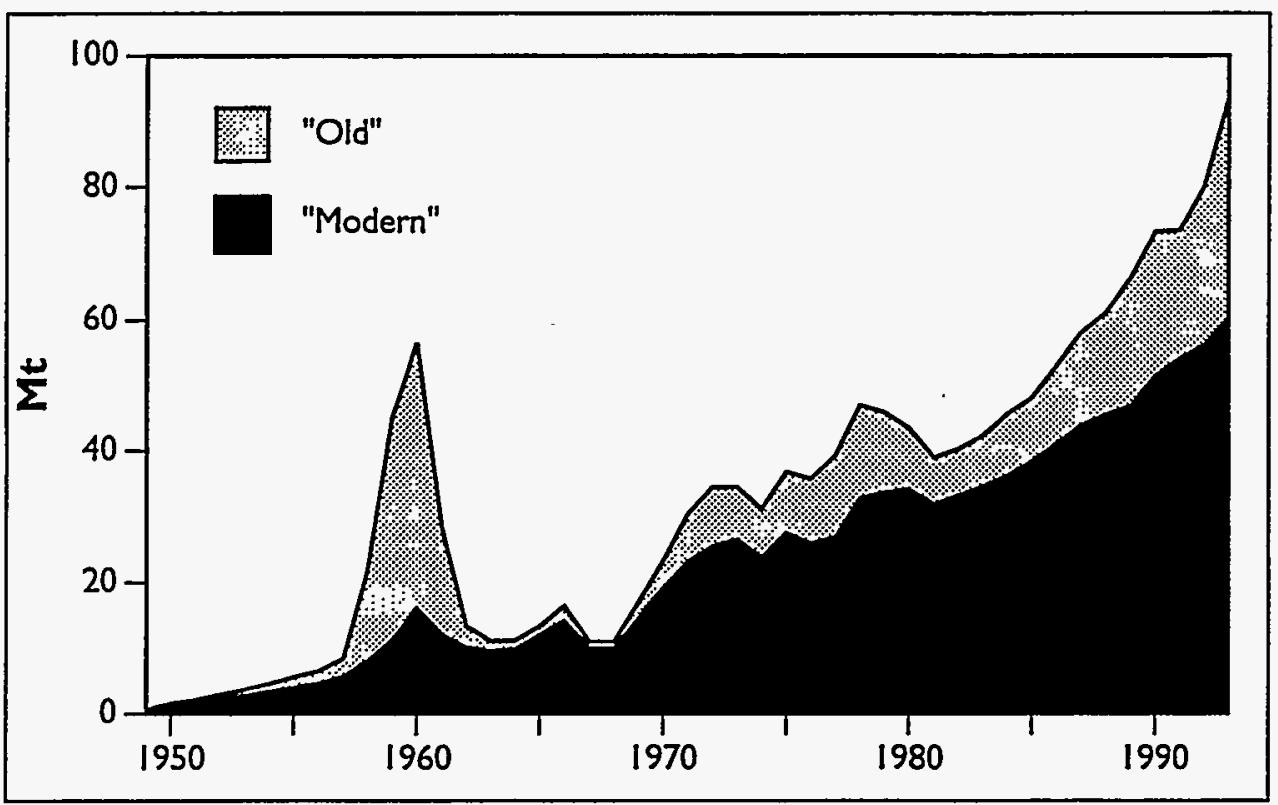


Table II-10. Coking Coal Used in Coke Production, 1980-1992-Mt

\begin{tabular}{|c|c|c|c|c|c|}
\hline Year & $\begin{array}{l}\text { Coking Coal } \\
\text { Production }\end{array}$ & $\begin{array}{l}\text { Used for } \\
\text { Coking }\end{array}$ & $\begin{array}{c}\text { Used for } \\
\text { Other } \\
\text { Purposes }\end{array}$ & $\begin{array}{c}\text { Coke } \\
\text { Production }\end{array}$ & $\begin{array}{l}\% \text { Coking } \\
\text { Coal Used } \\
\text { for Coke }\end{array}$ \\
\hline 1980 & 308.33 & 66.82 & 241.51 & 43.43 & $21.7 \%$ \\
\hline 1981 & 303.99 & 59.09 & 244.90 & 38.95 & $19.4 \%$ \\
\hline 1982 & 331.14 & 60.77 & 270.37 & 40.19 & $18.4 \%$ \\
\hline 1983 & 347.84 & 63.94 & 283.91 & 42.20 & $18.4 \%$ \\
\hline 1984 & 373.82 & 69.63 & 304.19 & 45.57 & $18.6 \%$ \\
\hline 1985 & 391.09 & 73.04 & 318.05 & 48.02 & $18.7 \%$ \\
\hline 1986 & 415.71 & 80.57 & 335.14 & 52.76 & $19.4 \%$ \\
\hline 1987 & 454.94 & 87.66 & 367.28 & 57.95 & $19.3 \%$ \\
\hline 1988 & 46272 & 88.79 & 373.93 & 61.08 & $19.2 \%$ \\
\hline 1989 & 499.66 & 96.31 & 403.35 & 66.24 & $19.3 \%$ \\
\hline 1990 & 512.77 & 106.98 & 405.79 & 73.28 & $20.9 \%$ \\
\hline 1991 & 518.26 & 108.61 & 409.65 & 73.52 & $21.0 \%$ \\
\hline 1992 & 527.46 & 112.82 & 414.64 & 79.84 & $21.4 \%$ \\
\hline
\end{tabular}

Source: China Energy Statistical Yearbook, various years. 
Table II-11. Production of Washed Coal, 1949-1993

\begin{tabular}{|c|c|c|c|c|c|}
\hline \multirow[b]{2}{*}{ Year } & \multirow{2}{*}{$\begin{array}{l}\text { Raw Coal } \\
\text { Input to } \\
\text { Coal } \\
\text { Washing * } \\
\text { (Mt) }\end{array}$} & \multirow{2}{*}{$\begin{array}{l}\text { Percentage } \\
\text { of Total } \\
\text { Production } \\
\text { Washed }\end{array}$} & \multicolumn{3}{|c|}{$\begin{array}{c}\text { Washed Coal Output } \\
\text { (Mt) }\end{array}$} \\
\hline & & & $\begin{array}{l}\text { Washed } \\
\text { Coking } \\
\text { Coal }\end{array}$ & $\begin{array}{c}\text { Other } \\
\text { Washed } \\
\text { Coal }\end{array}$ & $\begin{array}{l}\text { Losses and } \\
\text { Middlings } \dagger \\
\text { (Mt) }\end{array}$ \\
\hline 1949 & - & - & 0.68 & - & - \\
\hline 1950 & - & - & 1.94 & - & $=$ \\
\hline 1951 & - & - & 1.58 & - & - \\
\hline 1952 & - & - & $2 \pi 7$ & - & - \\
\hline 1953 & 5.91 & $8 \%$ & 3.87 & - & 2.04 \\
\hline 1954 & 11.12 & $13 \%$ & 5.19 & - & 5.93 \\
\hline 1955 & 16.40 & $17 \%$ & 7.10 & - & 9.30 \\
\hline 1956 & 18.84 & $17 \%$ & 8.51 & - & 10.33 \\
\hline 1957 & 21.11 & $16 \%$ & 9.16 & - & 11.95 \\
\hline 1958 & 28.52 & $11 \%$ & 14.65 & - & 13.87 \\
\hline 1959 & 44.98 & $-12 \%$ & 26.13 & - & 18.85 \\
\hline 1960 & 53.33 & $13 \%$ & 41.27 & - & 12.06 \\
\hline 1961 & 34.05 & $12 \%$ & 24.03 & - & 10.02 \\
\hline 1962 & 30.94 & $14 \%$ & 15.71 & - & 15.23 \\
\hline 1963 & 29.45 & $14 \%$ & 14.56 & - & 14.89 \\
\hline 1964 & 32.91 & $15 \%$ & 14.71 & - & 18.20 \\
\hline 1965 & 40.56 & $17 \%$ & 18.47 & - & 2209 \\
\hline 1966 & 48.44 & $19 \%$ & 20.41 & - & 28.03 \\
\hline 1967 & 36.31 & $18 \%$ & 16.48 & - & 19.83 \\
\hline 1968 & 24.04 & $11 \%$ & 15.74 & - & 8.30 \\
\hline 1969 & 34.91 & $13 \%$ & 21.47 & - & 13.44 \\
\hline 1970 & 49.31 & $14 \%$ & 29.57 & - & 19.74 \\
\hline 1971 & 78.05 & $20 \%$ & 37.43 & - & 40.62 \\
\hline 1972 & 88.04 & $21 \%$ & 39.81 & - & 48.23 \\
\hline 1973 & 84.23 & $20 \%$ & 40.16 & - & 44.07 \\
\hline 1974 & 79.61 & $19 \%$ & 35.99 & - & 43.62 \\
\hline 1975 & 92.67 & $19 \%$ & 44.38 & - & 48.29 \\
\hline 1976 & 84.00 & $17 \%$ & 40.73 & - & 43.27 \\
\hline 1977 & 89.63 & $16 \%$ & 44.44 & - & 45.19 \\
\hline 1978 & 113.17 & $18 \%$ & 53.97 & - & 59.20 \\
\hline 1979 & 116.12 & $18 \%$ & 54.89 & - & 61.23 \\
\hline 1980 & 114.22 & $18 \%$ & 53.82 & 6.48 & 53.92 \\
\hline 1981 & 11254 & $18 \%$ & 51.59 & 6.73 & 54.22 \\
\hline 1982 & 122.62 & $18 \%$ & 53.01 & 8.20 & 61.41 \\
\hline 1983 & 126.88 & $18 \%$ & 56.29 & 8.28 & 62.31 \\
\hline 1984 & 133.99 & $17 \%$ & 60.17 & 10.81 & 63.01 \\
\hline 1985 & 142.94 & $16 \%$ & 66.77 & 1.60 & 74.57 \\
\hline 1986 & 152.70 & $17 \%$ & 68.54 & 1.33 & 82.83 \\
\hline 1987 & 163.28 & $18 \%$ & 70.25 & 205 & 90.98 \\
\hline 1988 & 171.17 & $17 \%$ & 74.33 & 0.99 & 95.85 \\
\hline 1989 & 181.11 & $17 \%$ & 80.37 & 0.94 & 99.80 \\
\hline 1990 & 191.14 & $18 \%$ & 84.08 & 1.58 & 105.48 \\
\hline 1991 & 196.82 & $18 \%$ & 81.37 & - & 115.45 \\
\hline 1992 & 193.13 & $17 \%$ & 77.42 & - & $115.7 \mid$ \\
\hline 1993 & 209.24 & $18 \%$ & 76.15 & - & 133.09 \\
\hline
\end{tabular}

* Data are for key enterprises only, and so represent the majority of input, but still less than total input.

$\dagger$ Figures are the differences between input and output. Since input is for key enterprises only and output is more nearly a national total, these figures should be considered lower bounds to coal washing losses. Figures for 1953-1979 include "other washed coal". Note that 1991 figure is not comparable to previous years.

Source: China Energy Statistical Yearbook, various years; Yearbook of China's Coal Industry, various years; China Statistical Yearbook, various years; Energy in China, various years; China Energy Annual Review, 1994. 
Figure II-8. Washed Coal Output

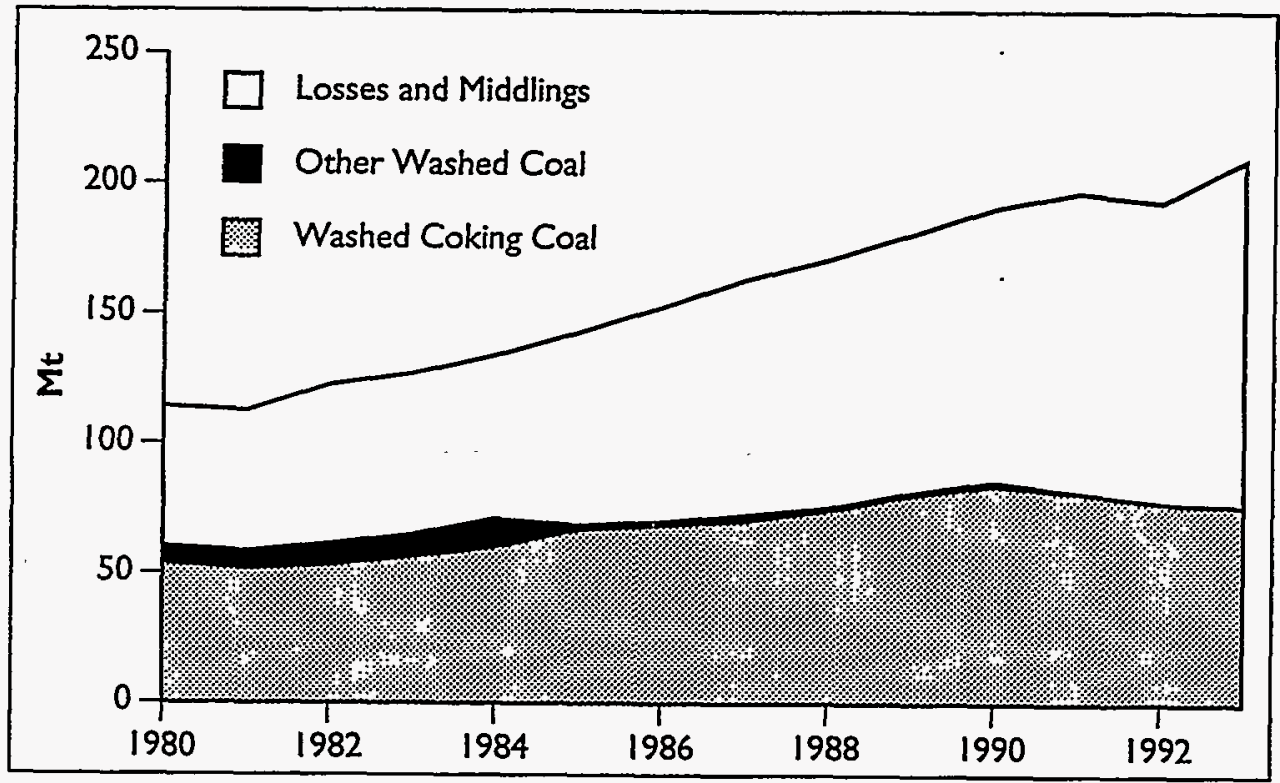

Figure II-9. Washed Coal \& Total Raw Coal Production

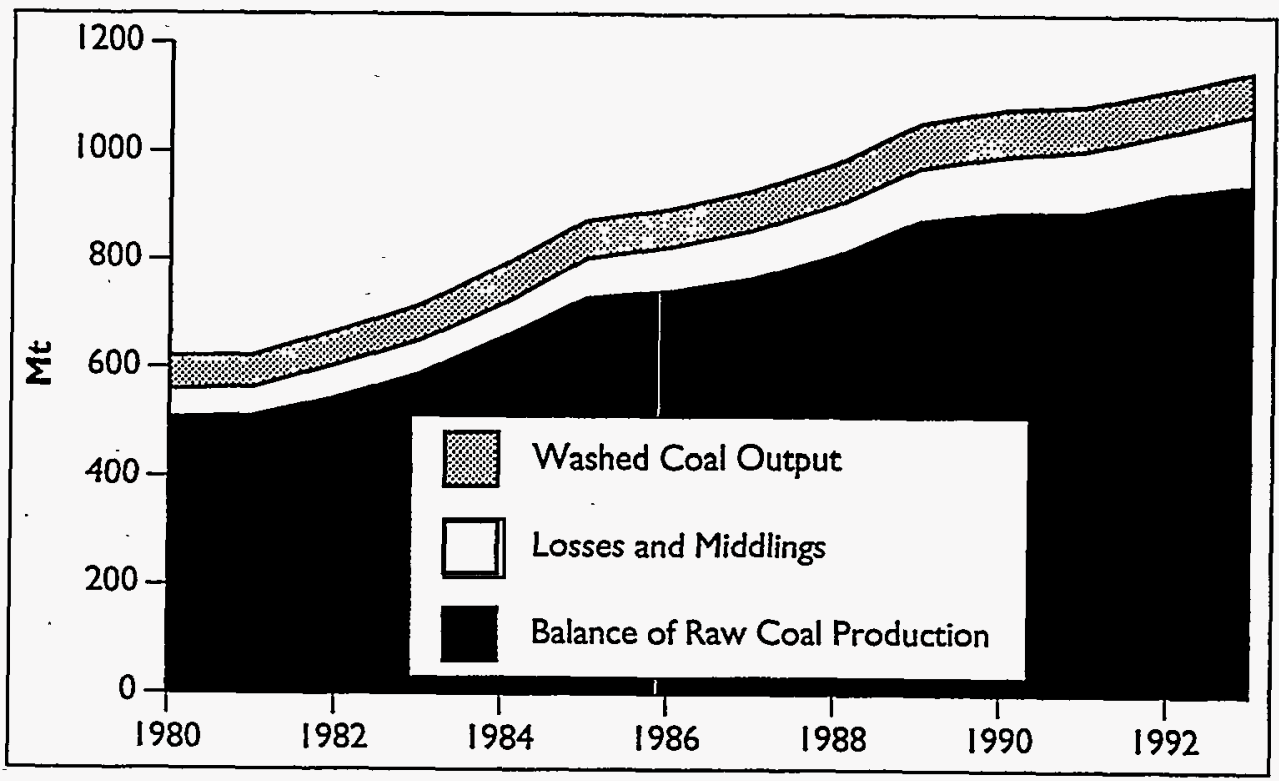


Table II-12. Coal Gas Production, * 1980-1992

\begin{tabular}{|c|c|c|c|c|c|c|c|c|}
\hline \multirow[b]{2}{*}{ Year } & \multirow{2}{*}{$\begin{array}{c}\text { Coal Input } \\
\text { to Coal } \\
\text { Gasification t } \\
\text { (Mt) }\end{array}$} & \multirow{2}{*}{$\begin{array}{l}\text { Coke Input } \\
\text { to Coal } \\
\text { Gasification } \\
\text { (Mt) }\end{array}$} & \multicolumn{3}{|c|}{$\begin{array}{c}\text { Coal Gas } \\
\text { (million cubic meters) }\end{array}$} & \multicolumn{3}{|c|}{$\begin{array}{l}\text { Coal Gas } \\
\text { (Mtce) II }\end{array}$} \\
\hline & & & $\begin{array}{l}\text { From Coking } \\
\text { Ovens }\end{array}$ & Other & Subtotal & $\begin{array}{c}\text { From Coking } \\
\text { Ovens }\end{array}$ & Other & Subtotal \\
\hline 1980 & 1.31 & 0.79 & 10.65 & 1.17 & 11.82 & 6.28 & 0.69 & 6.97 \\
\hline 1981 & 1.37 & 0.80 & 10.74 & 1.30 & 1204 & 6.34 & 0.77 & 7.10 \\
\hline 1982 & 1.40 & 0.82 & 10.69 & 1.72 & 1241 & 6.31 & 1.01 & 7.32 \\
\hline 1983 & 1.48 & 0.89 & 11.89 & 1.52 & 13.41 & 7.02 & 0.90 & 7.91 \\
\hline 1984 & 1.62 & 1.02 & 1205 & 1.56 & 13.61 & 7.11 & 0.92 & 8.03 \\
\hline 1985 & 1.91 & 0.99 & 13.19 & 1.64 & 14.83 & 7.78 & 0.97 & 8.75 \\
\hline 1986 & 2.43 & 0.82 & 16.36 & 3.37 & 19.73 & 9.65 & 1.99 & 11.64 \\
\hline 1987 & 2.24 & 0.19 & 15.53 & 4.21 & 19.74 & 9.16 & 2.48 & 11.65 \\
\hline 1988 & 2.79 & 0.39 & 15.98 & 4.76 & 20.74 & 9.43 & 2.81 & 1224 \\
\hline 1989 & 3.69 & 0.39 & 16.72 & 5.99 & 2271 & 9.86 & 3.53 & 13.40 \\
\hline 1990 & 3.60 & 0.68 & 17.48 & 5.83 & 23.31 & 10.31 & 3.44 & 13.75 \\
\hline 1991 & 3.73 & - & - & - & 24.00 & - & - & 14.16 \\
\hline 1992 & 4.67 & - & - & - & 30.00 & - & - & 17.70 \\
\hline
\end{tabular}

* Figures in italics are estimates.

$\dagger \quad$ Includes raw and washed coal. Sum is uncorrected for the different heat values of raw and washed coal.

I Coking coal gas is assigned a heat value of 0.59 tce/thousand cubic meters, and other coal gas is assigned a value of 0.58 tce/thousand cubic meters. These are central values for a range of figures for different types of coal gas produced in coking ovens and by other processes.

Source: China Energy Statistical Yearbook, various years; Yearbook of China's Coal Industry, various years; China Statistical Yearbook, various years. 
Table II-13. Crude Oil Production by Oilfield, 1950-1994

\begin{tabular}{|c|c|c|c|c|c|c|c|c|c|c|}
\hline \multicolumn{11}{|c|}{ 1. Thousand Barrels per Day* } \\
\hline Year & Daqing & Shengli & Liaohe & Huabei & Zhongyuan & Xinjiang & Dagang & Jilin & Henan & Changqing \\
\hline 1950 & - & - & - & - & - & 2 & - & - & - & - \\
\hline 1951 & - & - & - & - & - & 3 & - & - & - & - \\
\hline 1952 & - & - & - & - & - & 2 & - & - & - & - \\
\hline 1953 & - & - & - & - & - & 2 & - & - & - & - \\
\hline 1954 & - & - & - & - & - & 2 & - & - & - & - \\
\hline 1955 & - & - & - & - & - & 2 & - & - & - & - \\
\hline 1956 & - & - & - & - & - & 2 & - & - & - & - \\
\hline 1957 & - & - & - & - & - & 3 & - & - & - & - \\
\hline 1958 & - & - & - & - & - & 14 & - & - & - & - \\
\hline 1959 & - & - & - & - & - & 27 & - & - & - & - \\
\hline 1960 & 16 & - & - & - & - & 32 & - & - & - & - \\
\hline 1961 & 22 & - & - & - & - & 38 & - & - & - & - \\
\hline 1962 & 40 & 1 & - & - & - & 34 & - & - & - & - \\
\hline 1963 & 53 & 6 & - & - & - & 27 & - & - & - & - \\
\hline 1964 & 68 & 12 & - & - & - & 61 & - & - & - & - \\
\hline 1965 & 85 & 15 & - & - & - & 80 & - & - & - & - \\
\hline 1966 & 108 & 40 & - & - & - & 86 & 2 & - & - & - \\
\hline 1967 & 116 & 53 & - & - & - & 52 & 4 & - & - & - \\
\hline 1968 & 124 & 65 & - & - & - & 43 & 8 & - & - & - \\
\hline 1969 & 257 & 78 & - & - & - & 49 & 10 & - & - & $=$ \\
\hline 1970 & 353 & 90 & 3 & - & - & 29 & 19 & - & - & $=$ \\
\hline 1971 & 443 & 130 & 15 & - & - & 26 & 33 & - & - & - \\
\hline 1972 & 459 & 144 & 31 & - & - & 44 & 38 & - & - & - \\
\hline 1973 & 566 & 176 & 44 & - & - & 39 & 60 & - & - & - \\
\hline 1974 & 680 & 240 & 57 & - & - & 26 & 82 & - & - & - \\
\hline 1975 & 845 & 300 & 81 & - & - & 25 & 87 & - & - & - \\
\hline 1976 & 864 & 331 & 60 & 80 & - & 16 & 82 & - & - & - \\
\hline 1977 & 940 & 364 & 55 & 200 & - & 41 & 75 & - & - & - \\
\hline 1978 & 1,000 & 380 & 77 & 220 & - & 55 & 68 & - & - & - \\
\hline 1979 & 1.010 & 405 & 82 & 240 & - & 68 & 62 & - & - & - \\
\hline 1980 & 1,038 & 401 & 90 & 226 & - & 82 & 55 & - & - & - \\
\hline 1981 & 1,039 & 324 & 100 & 210 & - & 81 & 51 & - & - & - \\
\hline 1982 & 1,039 & 327 & 106 & 227 & 43 & 81 & 58 & - & - & - \\
\hline 1983 & 1,047 & 367 & 122 & 211 & 61 & 85 & 56 & - & - & - \\
\hline 1984 & 1,079 & 463 & 154 & 205 & 98 & 91 & 64 & - & - & - \\
\hline 1985 & 1.106 & 554 & 181 & 207 & 103 & 99 & 64 & - & - & - \\
\hline 1986 & 1,116 & 593 & 201 & 201 & 127 & 110 & 79 & - & - & - \\
\hline 1987 & 1,116 & 635 & 228 & 160 & 137 & 115 & 84 & - & - & - \\
\hline 1988 & 1.119 & 669 & 253 & 123 & 145 & 124 & 85 & - & 52 & - \\
\hline 1989 & 1.116 & 670 & 268 & 110 & 140 & 129 & 82 & 68 & 51 & $\sqrt{29}$ \\
\hline 1990 & 1,118 & 673 & 273 & 107 & 127 & 137 & 77 & 71 & 51 & 29 \\
\hline 1991 & 1.117 & 674 & 275 & 101 & 123 & 141 & 76 & 68 & 48 & 31 \\
\hline 1992 & 1,118 & 672 & 278 & 96 & 116 & 147 & 78 & 69 & 46 & 33 \\
\hline 1993 & 1,123 & 657 & 285 & 92 & 110 & 153 & 81 & 67 & 43 & 36 \\
\hline 1994 & 1.125 & 621 & 302 & 93 & 97 & 159 & 85 & 66 & 41 & 39 \\
\hline
\end{tabular}

* 1 tonne crude oil = 7.33 barrels. Because a different source was used, total production figures for 1950-1985 differ slightly from the figures in Table II-1.

Source: Yearbook of China's Economy, various years; China National Offshore Oil Corporation; China Energy Statistical Yearbook, various years; China, Energy Annual Review, 1994; China National Petroleum Corporation. 
Table II-13. China's Crude Oil Production by Oilfield, 1950-1994 (continued)

\begin{tabular}{|c|c|c|c|c|c|c|c|c|c|c|c|}
\hline \multicolumn{12}{|c|}{ 1. Thousand Barrels per Day * (continued) } \\
\hline Qinghai & Yumen & $\begin{array}{c}\text { Turpan- } \\
\text { Hami }\end{array}$ & Tarim & Jiangsu & Jianghan & Jidong & Sichuan & $\begin{array}{l}\text { Qing- } \\
\text { gian-gui }\end{array}$ & Offshore† & Others & Total \\
\hline - & - & - & - & - & - & - & - & - & - & 2 & 4 \\
\hline - & - & - & - & - & - & - & - & - & - & 3 & 6 \\
\hline - & - & - & - & - & - & - & - & - & - & 7 & 9 \\
\hline - & - & - & - & - & - & - & - & - & - & 11 & 12 \\
\hline - & - & - & - & - & - & - & - & - & - & 14 & 16 \\
\hline - & - & - & - & - & - & - & - & - & - & 18 & 19 \\
\hline - & - & - & - & - & - & - & - & - & - & 21 & 23 \\
\hline - & - & - & - & - & - & - & - & - & - & 26 & 29 \\
\hline$=$ & - & - & - & - & - & - & - & - & - & 31 & 45 \\
\hline- & - & - & - & - & - & - & - & - & - & 47 & 74 \\
\hline - & - & - & - & - & - & - & - & - & - & 52 & 100 \\
\hline - & - & - & - & - & - & - & - & - & - & 50 & 110 \\
\hline - & - & - & - & - & - & - & - & - & - & 45 & 120 \\
\hline - & - & - & - & - & - & - & - & - & - & 43 & 130 \\
\hline - & - & - & - & - & - & - & - & - & - & 40 & 180 \\
\hline - & - & - & - & - & - & - & - & - & - & 51 & 230 \\
\hline - & - & - & - & - & - & - & - & - & - & 54 & 290 \\
\hline - & - & - & - & - & - & - & - & - & - & 56 & 280 \\
\hline$=$ & - & - & - & - & - & - & - & - & - & 61 & 301 \\
\hline- & - & - & - & - & - & - & - & - & - & 87 & 480 \\
\hline - & - & - & - & - & - & - & - & - & - & 105 & 600 \\
\hline - & - & - & - & - & - & - & - & - & - & 133 & 780 \\
\hline - & - & - & - & - & - & - & - & - & - & 186 & 902 \\
\hline - & - & - & - & - & - & - & - & - & - & 205 & 1,090 \\
\hline - & - & - & - & - & - & - & - & - & - & 230 & 1,315 \\
\hline - & - & - & - & - & - & - & - & - & - & 152 & 1,490 \\
\hline - & - & - & - & - & - & - & - & - & - & 241 & 1,675 \\
\hline - & - & - & - & - & - & - & - & - & - & 199 & 1,874 \\
\hline$=$ & - & - & - & - & - & - & - & - & - & 282 & 2.082 \\
\hline. & - & - & - & - & - & - & - & - & - & 255 & 2.122 \\
\hline- & - & - & - & - & - & - & - & - & - & 228 & 2,120 \\
\hline - & - & - & - & - & - & - & - & - & - & 207 & 2,012 \\
\hline- & - & - & - & - & - & - & - & - & - & 164 & 2,045 \\
\hline- & - & - & - & - & - & - & - & - & - & 171 & 2,120 \\
\hline - & - & - & - & - & - & - & - & - & - & 149 & 2,302 \\
\hline- & - & - & - & - & - & - & - & - & 6 & 159 & 2,480 \\
\hline- & - & - & - & - & - & - & - & - & 8 & 191 & 2,625 \\
\hline - & - & - & - & - & - & - & - & - & 14 & 206 & 2,694 \\
\hline- & - & - & - & - & - & - & 2 & - & 15 & 167 & 2,752 \\
\hline$\overline{15}$ & 11 & - & - & 16 & 19 & - & 2 & - & 19 & 20 & 2,764 \\
\hline 16 & 11 & - & - & 17 & 17 & 7 & 3 & 2 & 29 & 14 & 2,778 \\
\hline 20 & 14 & - & - & 17 & 15 & 7 & 3 & 2 & 48 & 51 & 2,831 \\
\hline 21 & 22 & - & 18 & 17 & 15 & 8 & 3 & - & 78 & 12 & 2,848 \\
\hline .22 & 9 & 23 & 32 & 17 & 16 & 9 & 3 & 3 & 93 & 36 & 2,910 \\
\hline 23 & 9 & 28 & 39 & 18 & 17 & 9 & 3 & 2 & 130 & 57 & 2,965 \\
\hline
\end{tabular}

- 1 tonne crude oil $=7.33$ barrels. Because a different source was used, total production figures for 1950-1985 differ slightly from the figures in Table II-1.

$\dagger$ Includes volumes produced from Extended Drill Stem Tests (EDST).

Source: Yearbook of China's Economy, various years; China National Offshore Oil Corporation; China Energy Statistical Yearbook, various years; China, Energy Annual Review, 1994; China National Petroleum Corporation. 
Table II-13. China's Crude Oil Production by Oilfield, 1950-1994 (continued)

\section{Growth over Previous Years}

\begin{tabular}{|c|c|c|c|c|c|c|c|c|c|c|}
\hline Year & Daqing & Shengli & Liaohe & Huabei & Zhongyuan & Xinjiang & Dagang & Jilin & Henan & Changqing \\
\hline 1951 & - & - & - & - & - & $44 \%$ & - & - & - & - \\
\hline 1952 & - & - & - & - & - & $-44 \%$ & - & - & - & - \\
\hline 1953 & - & - & - & - & - & $2 \%$ & - & - & - & - \\
\hline 1954 & - & - & - & - & - & $-4 \%$ & - & - & - & - \\
\hline 1955 & - & - & - & - & - & $-5 \%$ & - & - & - & - \\
\hline 1956 & - & - & - & - & - & $1 \%$ & - & - & - & - \\
\hline 1957 & - & - & - & - & - & $86 \%$ & - & - & - & - \\
\hline 1958 & - & - & - & - & - & $326 \%$ & - & - & - & - \\
\hline 1959 & - & - & $=$ & - & - & $92 \%$ & $=$ & - & - & $=$ \\
\hline 1960 & - & - & - & - & - & $19 \%$ & - & - & - & - \\
\hline 1961 & $36 \%$ & - & - & - & - & $19 \%$ & - & - & - & - \\
\hline 1962 & $85 \%$ & - & - & - & - & $-10 \%$ & - & - & - & - \\
\hline 1963 & $33 \%$ & $597 \%$ & - & - & - & $-20 \%$ & - & - & - & - \\
\hline 1964 & $28 \%$ & $86 \%$ & - & - & - & $123 \%$ & - & - & - & - \\
\hline 1965 & $25 \%$ & $23 \%$ & - & - & - & $31 \%$ & - & - & - & - \\
\hline 1966 & $27 \%$ & $172 \%$ & - & - & - & $8 \%$ & - & - & - & - \\
\hline 1967 & $7 \%$ & $31 \%$ & - & - & - & $-40 \%$ & $100 \%$ & - & - & - \\
\hline 1968 & $7 \%$ & $24 \%$ & - & - & - & $-17 \%$ & $100 \%$ & - & - & - \\
\hline 1969 & $107 \%$ & $19 \%$ & - & - & - & $14 \%$ & $25 \%$ & - & - & $=$ \\
\hline 1970 & $38 \%$ & $16 \%$ & - & - & - & $-40 \%$ & $92 \%$ & - & - & - \\
\hline 1971 & $25 \%$ & $44 \%$ & $429 \%$ & - & - & $-10 \%$ & $71 \%$ & - & - & - \\
\hline 1972 & $4 \%$ & $11 \%$ & $112 \%$ & - & - & $64 \%$ & $16 \%$ & - & - & - \\
\hline 1973 & $23 \%$ & $22 \%$ & $40 \%$ & - & - & $-10 \%$ & $58 \%$ & - & - & - \\
\hline 1974 & $20 \%$ & $36 \%$ & $29 \%$ & - & - & $-33 \%$ & $37 \%$ & - & - & - \\
\hline 1975 & $24 \%$ & $25 \%$ & $43 \%$ & - & - & $-3 \%$ & $5 \%$ & - & - & - \\
\hline 1976 & $2 \%$ & $10 \%$ & $-26 \%$ & - & - & $-35 \%$ & $-5 \%$ & - & - & - \\
\hline 1977 & $9 \%$ & $10 \%$ & $-9 \%$ & $149 \%$ & - & $150 \%$ & $-8 \%$ & - & - & - \\
\hline 1978 & $6 \%$ & $4 \%$ & $40 \%$ & $10 \%$ & - & $33 \%$ & $-9 \%$ & - & - & - \\
\hline 1979 & $1 \%$ & $7 \%$ & $7 \%$ & $9 \%$ & - & $25 \%$ & $-10 \%$ & - & - & $=$ \\
\hline 1980 & $3 \%$ & $-1 \%$ & $10 \%$ & $-6 \%$ & - & $20 \%$ & $-11 \%$ & - & - & $=$ \\
\hline 1981 & $0 \%$ & $-19 \%$ & $10 \%$ & $-7 \%$ & - & $-1 \%$ & $-7 \%$ & - & - & - \\
\hline 1982 & $0 \%$ & $1 \%$ & $6 \%$ & $8 \%$ & - & $-1 \%$ & $14 \%$ & - & - & - \\
\hline 1983 & $1 \%$ & $12 \%$ & $15 \%$ & $-7 \%$ & $40 \%$ & $6 \%$ & $-4 \%$ & - & - & - \\
\hline 1984 & $3 \%$ & $26 \%$ & $26 \%$ & $-3 \%$ & $61 \%$ & $6 \%$ & $14 \%$ & - & - & - \\
\hline 1985 & $3 \%$ & $20 \%$ & $17 \%^{\circ}$ & $1 \%$ & $6 \%$ & $10 \%$ & $1 \%$ & - & - & - \\
\hline 1986 & $1 \%$ & $7 \%$ & $11 \%$ & $-3 \%$ & $22 \%$ & $11 \%$ & $23 \%$ & - & - & - \\
\hline 1987 & $0 \%$ & $7 \%$ & $13 \%$ & $-20 \%$ & $8 \%$ & $5 \%$ & $7 \%$ & - & - & - \\
\hline 1988 & $0 \%$ & $5 \%$ & $11 \%$ & $-23 \%$ & $6 \%$ & $7 \%$ & $1 \%$ & - & - & - \\
\hline 1989 & $0 \%$ & $0 \%$ & $6 \%$ & $-10 \%$ & $-3 \%$ & $4 \%$ & $-3 \%$ & - & $-1 \%$ & $=$ \\
\hline 1990 & $0 \%$ & $0 \%$ & $2 \%$ & $-2 \%$ & $-10 \%$ & $6 \%$ & $-6 \%$ & $4 \%$ & $-1 \%$ & $2 \%$ \\
\hline 1991 & $0 \%$ & $0 \%$ & $1 \%$ & $-6 \%$ & $-3 \%$ & $3 \%$ & $-1 \%$ & $-4 \%$ & $-5 \%$ & $5 \%$ \\
\hline 1992 & $0 \%$ & $0 \%$ & $1 \%$ & $-4 \%$ & $-5 \%$ & $4 \%$ & $2 \%$ & $0 \%$ & $-3 \%$ & $7 \%$ \\
\hline 1993 & $0 \%$ & $-2 \%$ & $3 \%$ & $-4 \%$ & $-5 \%$ & $4 \%$ & $4 \%$. & $-2 \%$ & $-7 \%$ & $10 \%$ \\
\hline 1994 & $0 \%$ & $-6 \%$ & $6 \%$ & $1 \%$ & $-12 \%$ & $4 \%$ & $5 \%$ & $-1 \%$ & $-4 \%$ & $9 \%$ \\
\hline
\end{tabular}

Source: Yearbook of China's Economy, various years; China National Offshore Oil Corporation; China Energy Statistical Yearbook, various years; China, Energy Annual Review, 1994; China National Petroleum Corporation. 
2. Growth over Previous Years (continued)

\begin{tabular}{|c|c|c|c|c|c|c|c|c|c|c|c|}
\hline Qinghai & Yumen & $\begin{array}{c}\text { Turpan- } \\
\text { Hami }\end{array}$ & Tarim & Jiangsu & Jianghan & Jidong & Sichuan & $\begin{array}{l}\text { Qing- } \\
\text { qian-gui }\end{array}$ & Offshore * & Others & Total \\
\hline - & - & - & - & - & - & - & - & - & - & $64 \%$ & $53 \%$ \\
\hline- & - & - & - & - & - & - & - & - & - & $147 \%$ & $43 \%$ \\
\hline- & - & - & - & - & - & - & - & - & - & $54 \%$ & $43 \%$ \\
\hline- & - & - & - & - & - & - & - & - & - & $32 \%$ & $27 \%$ \\
\hline- & - & - & - & - & - & - & - & - & - & $26 \%$ & $22 \%$ \\
\hline - & - & - & - & - & - & - & - & - & - & $22 \%$ & $20 \%$ \\
\hline - & - & - & - & - & - & - & - & - & - & $20 \%$ & $25 \%$ \\
\hline - & - & - & - & - & - & - & - & - & - & $18 \%$ & $53 \%$ \\
\hline- & - & - & - & - & - & - & - & - & - & $54 \%$ & $66 \%$ \\
\hline$\overline{-}$ & - & - & - & - & - & - & - & - & - & $11 \%$ & $36 \%$ \\
\hline - & - & - & - & - & - & - & - & - & - & $-4 \%$ & $10 \%$ \\
\hline . & - & - & - & - & - & - & - & - & - & $-11 \%$ & $9 \%$ \\
\hline - & - & - & - & - & - & - & - & - & - & $-4 \%$ & $8 \%$ \\
\hline - & - & - & - & - & - & - & - & - & - & $-8 \%$ & $39 \%$ \\
\hline - & - & - & - & - & - & - & - & - & - & $28 \%$ & $27 \%$ \\
\hline- & - & - & - & - & - & - & - & - & - & $7 \%$ & $26 \%$ \\
\hline - & - & - & - & - & - & - & - & - & - & $4 \%$ & $-3 \%$ \\
\hline- & - & - & - & - & - & - & - & - & - & $9 \%$ & $7 \%$ \\
\hline- & - & - & - & - & - & - & - & - & - & $43 \%$ & $60 \%$ \\
\hline$=$ & - & - & - & - & - & - & - & - & - & $21 \%$ & $25 \%$ \\
\hline - & - & - & - & - & - & - & - & - & - & $26 \%$ & $30 \%$ \\
\hline- & - & - & - & - & - & - & - & - & - & $40 \%$ & $16 \%$ \\
\hline - & - & - & - & - & - & - & - & - & - & $10 \%$ & $21 \%$ \\
\hline - & - & - & - & - & - & - & - & - & - & $12 \%$ & $21 \%$ \\
\hline- & - & - & - & - & - & - & - & - & - & $-34 \%$ & $13 \%$ \\
\hline - & - & - & - & - & - & - & - & - & - & $58 \%$ & $12 \%$ \\
\hline - & - & - & - & - & - & - & - & - & - & $-17 \%$ & $12 \%$ \\
\hline - & - & - & - & - & - & - & - & - & - & $42 \%$ & $11 \%$ \\
\hline$=$ & - & - & - & - & - & - & - & - & - & $-10 \%$ & $2 \%$ \\
\hline$=$ & - & - & - & - & - & - & - & - & - & $-11 \%$ & $0 \%$ \\
\hline - & - & - & - & - & - & - & - & - & - & $-9 \%$ & $-5 \%$ \\
\hline - & - & - & - & - & - & - & - & - & - & $-21 \%$ & $2 \%$ \\
\hline - & - & - & - & - & - & - & - & - & - & $4 \%$ & $4 \%$ \\
\hline - & - & - & - & - & - & - & - & - & - & $-13 \%$ & $9 \%$ \\
\hline - & - & - & - & - & - & - & - & - & - & $7 \%$ & $8 \%$ \\
\hline- & - & - & - & - & - & - & - & - & $33 \%$ & $20 \%$ & $6 \%$ \\
\hline - & - & - & - & - & - & - & - & - & $90 \%$ & $8 \%$ & $3 \%$ \\
\hline - & - & - & - & - & - & - & - & - & $5 \%$ & $-19 \%$ & $2 \%$ \\
\hline . & - & - & - & - & $=-$ & - & $4 \%$ & - & $26 \%$ & $-88 \%$ & $0 \%$ \\
\hline $11 \%$ & $2 \%$ & - & - & $7 \%$ & $-11 \%$ & - & $6 \%$ & - & $51 \%$ & $-31 \%$ & $0 \%$ \\
\hline $26 \%$ & $27 \%$ & - & - & $1 \%$ & $-12 \%$ & $6 \%$ & $5 \%$ & $9 \%$ & $67 \%$ & - & $2 \%$ \\
\hline $3 \%$ & $56 \%$ & - & - & $-1 \%$ & $4 \%$ & $4 \%$ & $2 \%$ & - & $62 \%$ & - & $1 \%$ \\
\hline $3 \%$ & $-59 \%$ & - & $80 \%$ & $1 \%$ & $6 \%$ & $11 \%$ & $8 \%$ & - & $20 \%$ & - & $2 \%$ \\
\hline $4 \%$ & $-3 \%$ & - & $22 \%$ & $7 \%$ & $7 \%$ & $8 \%$ & $3 \%$ & - & $40 \%$ & - & $2 \%$ \\
\hline
\end{tabular}

- Includes volumes produced from Extended Drill Stem Tests (EDST).

Source: Yearbook of China's Economy, various years; China National Offshore Oil Corporation; China Energy Statistical Yearbook, various years; China, Energy Annual Review, 1994; China National Petroleum Corporation. 
Table II-13. China's Crude Oil Production by Oilfield, 1950-1994 (continued)

\section{Shares of Total Production}

\begin{tabular}{|c|c|c|c|c|c|c|c|c|c|c|}
\hline Year & Daqing & Shengli & Liaohe & Huabei & Zhongyuan & Xinjiang & Dagang & Jilin & Henan & Changqing \\
\hline 1950 & - & - & - & - & - & $58 \%$ & - & - & - & - \\
\hline 1951 & - & - & - & - & - & $55 \%$ & - & - & - & - \\
\hline 1952 & - & - & - & - & - & $21 \%$ & - & - & - & - \\
\hline 1953 & - & - & - & - & - & $15 \%$ & - & - & - & - \\
\hline 1954 & - & - & - & - & - & $12 \%$ & - & - & - & - \\
\hline 1955 & - & - & - & - & - & $9 \%$ & - & - & - & - \\
\hline 1956 & - & - & - & - & - & $8 \%$ & - & - & - & - \\
\hline 1957 & - & - & - & - & - & $11 \%$ & - & - & - & - \\
\hline 1958 & - & - & - & - & - & $31 \%$ & - & - & - & - \\
\hline 1959 & - & - & - & - & - & $36 \%$ & - & - & - & $=$ \\
\hline 1960 & $16 \%$ & - & - & - & - & $32 \%$ & - & - & - & - \\
\hline 1961 & $20 \%$ & - & - & - & - & $35 \%$ & - & - & - & - \\
\hline 1962 & $33 \%$ & $1 \%$ & - & - & - & $29 \%$ & - & - & - & - \\
\hline 1963 & $41 \%$ & $5 \%$ & - & - & - & $21 \%$ & - & - & - & - \\
\hline 1964 & $38 \%$ & $7 \%$ & - & - & - & $34 \%$ & - & - & - & - \\
\hline 1965 & $37 \%$ & $6 \%$ & - & - & - & $35 \%$ & - & - & - & - \\
\hline 1966 & $37 \%$ & $14 \%$ & - & - & - & $30 \%$ & $1 \%$ & - & - & - \\
\hline 1967 & $41 \%$ & $19 \%$ & - & - & - & $18 \%$ & $1 \%$ & - & - & - \\
\hline 1968 & $41 \%$ & $22 \%$ & - & - & - & $14 \%$ & $3 \%$ & - & - & - \\
\hline 1969 & $53 \%$ & $16 \%$ & - & - & - & $10 \%$ & $2 \%$ & - & - & $=$ \\
\hline 1970 & $59 \%$ & $15 \%$ & $0 \%$ & - & - & $5 \%$ & $3 \%$ & - & - & - \\
\hline 1971 & $57 \%$ & $17 \%$ & $2 \%$ & - & - & $3 \%$ & $4 \%$ & - & - & - \\
\hline 1972 & $51 \%$ & $16 \%$ & $3 \%$ & - & - & $5 \%$ & $4 \%$ & - & - & - \\
\hline 1973 & $52 \%$ & $16 \%$ & $4 \%$ & - & - & $4 \%$ & $6 \%$ & - & - & - \\
\hline 1974 & $52 \%$ & $18 \%$ & $4 \%$ & - & - & $2 \%$ & $6 \%$ & - & - & - \\
\hline 1975 & $57 \%$ & $20 \%$ & $5 \%$ & - & - & $2 \%$ & $6 \%$ & - & - & - \\
\hline 1976 & $52 \%$ & $20 \%$ & $4 \%$ & $5 \%$ & - & $1 \%$ & $5 \%$ & - & - & - \\
\hline 1977 & $50 \%$ & $19 \%$ & $3 \%$ & $11 \%$ & - & $2 \%$ & $4 \%$ & - & - & - \\
\hline 1978 & $48 \%$ & $18 \%$ & $4 \%$ & $11 \%$ & - & $3 \%$ & $3 \%$ & - & - & - \\
\hline 1979 & $48 \%$ & $19 \%$ & $4 \%$ & $11 \%$ & - & $3 \%$ & $3 \%$ & - & - & - \\
\hline 1980 & $49 \%$ & $19 \%$ & $4 \%$ & $11 \%$ & - & $4 \%$ & $3 \%$ & - & - & - \\
\hline 1981 & $52 \%$ & $16 \%$ & $5 \%$ & $10 \%$ & - & $4 \%$ & $3 \%$ & - & - & - \\
\hline 1982 & $51 \%$ & $16 \%$ & $5 \%$ & $11 \%$ & $2 \%$ & $4 \%$ & $3 \%$ & - & - & - \\
\hline 1983 & $49 \%$ & $17 \%$ & $6 \%$ & $10 \%$ & $3 \%$ & $4 \%$ & $3 \%$ & - & - & - \\
\hline 1984 & $47 \%$ & $20 \%$ & $7 \%$ & $9 \%$ & $4 \%$ & $4 \%$ & $3 \%$ & - & - & - \\
\hline 1985 & $45 \%$ & $22 \%$ & $7 \%$ & $8 \%$ & $4 \%$ & $4 \%$ & $3 \%$ & - & - & - \\
\hline 1986 & $43 \%$ & $23 \%$ & $8 \%$ & $8 \%$ & $5 \%$ & $4 \%$ & $3 \%$ & - & - & - \\
\hline 1987 & $41 \%$ & $24 \%$ & $8 \%$ & $6 \%$ & $5 \%$ & $4 \%$ & $3 \%$ & - & - & - \\
\hline 1988 & $41 \%$ & $24 \%$ & $9 \%$ & $4 \%$ & $5 \%$ & $4 \%$ & $3 \%$ & - & $1.9 \%$ & - \\
\hline 1989 & $40 \%$ & $24 \%$ & $10 \%$ & $4 \%$ & $5 \%$ & $5 \%$ & $3 \%$ & $25 \%$ & $1.9 \%$ & $1.0 \%$ \\
\hline 1990 & $40 \%$ & $24 \%$ & $10 \%$ & $4 \%$ & $-5 \%$ & $5 \%$ & $3 \%$ & $26 \%$ & $1.8 \%$ & $1.1 \%$ \\
\hline 1991 & $39 \%$ & $24 \%$ & $10 \%$ & $4 \%$ & $4 \%$ & $5 \%$ & $3 \%$ & $24 \%$ & $1.7 \%$ & $1.1 \%$ \\
\hline 1992 & $39 \%$ & $24 \%$ & $10 \%$ & $3 \%$ & $4 \%$ & $5 \%$ & $3 \%$ & $24 \%$ & $1.6 \%$ & $1.2 \%$ \\
\hline 1993 & $39 \%$ & $23 \%$ & $10 \%$ & $3 \%$ & $4 \%$ & $5 \%$ & $3 \%$ & $23 \%$ & $1.5 \%$ & $1.2 \%$ \\
\hline 1994 & $38 \%$ & $21 \%$ & $10 \%$ & $3 \%$ & $3 \%$ & $5 \%$ & $3 \%$ & $22 \%$ & $1.4 \%$ & $1.3 \%$ \\
\hline
\end{tabular}

Source: Yearbook of China's Economy, various years; China National Offshore Oil Corporation; China Energy Statistical Yearbook, various years; China, Energy Annual Review, 1994; China National Petroleum Corporation. 
Table II-13. China's Crude Oil Production by Oilfield, 1950-1994 (continued)

\section{Shares of Total Production (continued)}

\begin{tabular}{|c|c|c|c|c|c|c|c|c|c|c|c|}
\hline Qinghai & Yumen & $\begin{array}{c}\text { Turpan- } \\
\text { Hami }\end{array}$ & Tarim & Jiangsu & Jianghan & Jidong & Sichuan & $\begin{array}{l}\text { Qing- } \\
\text { qian-gui }\end{array}$ & Offshore * & Others & Total \\
\hline - & - & - & - & - & - & - & $\therefore$ & - & - & $42 \%$ & $100 \%$ \\
\hline - & - & - & - & - & - & - & - & - & - & $45 \%$ & $100 \%$ \\
\hline - & - & - & - & - & - & - & - & - & - & $79 \%$ & $100 \%$ \\
\hline - & - & - & - & - & - & - & - & - & - & $85 \%$ & $100 \%$ \\
\hline - & - & - & - & - & - & - & - & - & - & $88 \%$ & $100 \%$ \\
\hline- & - & - & - & - & - & - & - & - & - & $91 \%$ & $100 \%$ \\
\hline- & - & - & - & - & - & - & - & - & - & $92 \%$ & $100 \%$ \\
\hline- & - & - & - & - & - & - & - & - & - & $89 \%$ & $100 \%$ \\
\hline- & - & - & - & - & - & - & - & - & - & $69 \%$ & $100 \%$ \\
\hline - & - & - & - & - & - & - & - & - & - & $64 \%$ & $100 \%$ \\
\hline - & - & - & - & - & - & - & - & - & - & $52 \%$ & $100 \%$ \\
\hline - & - & - & - & - & - & - & - & - & - & $46 \%$ & $100 \%$ \\
\hline- & - & - & - & - & - & - & - & - & - & $37 \%$ & $100 \%$ \\
\hline- & - & - & - & - & - & - & - & - & - & $33 \%$ & $100 \%$ \\
\hline - & - & - & - & - & - & - & - & - & - & $22 \%$ & $100 \%$ \\
\hline - & - & - & - & - & - & - & - & - & - & $22 \%$ & $100 \%$ \\
\hline - & - & - & - & - & - & - & - & - & - & $19 \%$ & $100 \%$ \\
\hline- & - & - & - & - & - & - & - & - & - & $20 \%$ & $100 \%$ \\
\hline- & - & - & - & - & - & - & - & - & - & $20 \%$ & $100 \%$ \\
\hline - & - & - & - & - & - & - & - & - & - & $18 \%$ & $100 \%$ \\
\hline - & - & - & - & - & - & - & - & - & - & $18 \%$ & $100 \%$ \\
\hline - & - & - & - & - & - & - & - & - & - & $17 \%$ & $100 \%$ \\
\hline - & - & - & - & - & - & - & - & - & - & $21 \%$ & $100 \%$ \\
\hline- & - & - & - & - & - & - & - & - & - & $19 \%$ & $100 \%$ \\
\hline - & - & - & - & - & - & - & - & - & - & $17 \%$ & $100 \%$ \\
\hline - & - & - & - & - & - & - & - & - & - & $10 \%$ & $100 \%$ \\
\hline- & - & - & - & - & - & - & - & - & - & $14 \%$ & $100 \%$ \\
\hline$=$ & - & - & - & - & - & - & - & - & - & $11 \%$ & $100 \%$ \\
\hline$\overline{-}$ & - & - & - & - & - & - & - & - & - & $14 \%$ & $100 \%$ \\
\hline - & - & - & - & - & - & - & - & - & - & $12 \%$ & $100 \%$ \\
\hline - & - & - & - & - & - & - & - & - & - & $11 \%$ & $100 \%$ \\
\hline - & - & - & - & - & - & - & - & - & - & $10 \%$ & $100 \%$ \\
\hline- & - & - & - & - & - & - & - & - & - & $8 \%$ & $100 \%$ \\
\hline - & - & - & - & - & - & - & - & - & - & $8 \%$ & $100 \%$ \\
\hline - & - & - & - & - & - & - & - & - & - & $6 \%$ & $100 \%$ \\
\hline - & - & - & - & - & - & - & - & - & $0.2 \%$ & $6 \%$ & $100 \%$ \\
\hline - & - & - & - & - & - & - & - & - & $0.3 \%$ & $7 \%$ & $100 \%$ \\
\hline$=$ & - & - & - & - & - & - & - & - & $0.5 \%$ & $8 \%$ & $100 \%$ \\
\hline$\overline{-}$ & - & - & - & - & - & - & $0.1 \%$ & - & $0.5 \%$ & $6 \%$ & $100 \%$ \\
\hline $0.5 \%$ & $0.4 \%$ & - & - & $0.6 \%$ & $0.7 \%$ & - & $0.1 \%$ & - & $0.7 \%$ & $1 \%$ & $100 \%$ \\
\hline $0.6 \%$ & $0.4 \%$ & - & - & $0.6 \%$ & $0.6 \%$ & $0.3 \%$ & $0.1 \%$ & $0.1 \%$ & $1.0 \%$ & $0.5 \%$ & $100 \%$ \\
\hline $0.7 \%$ & $0.5 \%$ & - & - & $0.6 \%$ & $0.5 \%$ & $0.3 \%$ & $0.1 \%$ & $0.1 \%$ & $1.7 \%$ & $2 \%$ & $100 \%$ \\
\hline $0.7 \%$ & $0.8 \%$ & - & $0.6 \%$ & $0.6 \%$ & $0.5 \%$ & $0.3 \%$ & $0.1 \%$ & - & $2.7 \%$ & $0.4 \%$ & $100 \%$ \\
\hline $0.7 \%$ & $0.3 \%$ & $0.8 \%$ & $1.1 \%$ & $0.6 \%$ & $0.6 \%$ & $0.3 \%$ & $0.1 \%$ & $0.1 \%$ & $3.2 \%$ & $1 \%$ & $100 \%$ \\
\hline $0.8 \%$ & $0.3 \%$ & $1.0 \%$ & $1.3 \%$ & $0.6 \%$ & $0.6 \%$ & $0.3 \%$ & $0.1 \%$ & $0.1 \%$ & $4.4 \%$ & $2 \%$ & $100 \%$ \\
\hline
\end{tabular}

* Includes volumes produced from Extended Drill Stem Tests (EDST).

Source: Yearbook of China's Economy, various years; China National Offshore Oil Corporation; China Energy Statistical Yearbook, various years; China, Energy Annual Review, 1994; China National Petroleum Corporation. 
Table II-13. China's Crude Oil Production by Oilfield, 1950-1994 (continued)

\begin{tabular}{|c|c|c|c|c|c|c|c|c|c|c|}
\hline \multicolumn{11}{|c|}{ 4. Million Tonnes* } \\
\hline Year & Daqing & Shengli & Liaohe & Huabei & Zhongyuan & Xinjiang & Dagang & Jilin & Henan & Changqing \\
\hline 1950 & - & - & - & - & - & 0.11 & - & - & - & - \\
\hline 1951 & - & - & - & - & - & 0.17 & - & - & - & - \\
\hline 1952 & - & - & - & - & - & 0.09 & - & - & - & - \\
\hline 1953 & - & - & - & - & - & 0.09 & - & - & - & - \\
\hline 1954 & - & - & - & - & - & 0.09 & - & - & - & - \\
\hline 1955 & - & - & - & - & - & 0.09 & - & - & - & - \\
\hline 1956 & - & - & - & - & - & 0.09 & - & - & - & - \\
\hline 1957 & - & - & - & - & - & 0.16 & - & - & - & - \\
\hline 1958 & - & - & - & - & - & 0.70 & - & - & - & - \\
\hline 1959 & - & - & - & - & - & 1.33 & - & - & - & - \\
\hline 1960 & 0.79 & - & - & - & - & 1.59 & - & - & - & - \\
\hline 1961 & 1.08 & - & - & - & - & 1.89 & - & - & - & - \\
\hline 1962 & 1.99 & 0.05 & - & - & - & 1.70 & - & - & - & - \\
\hline 1963 & 2.65 & 0.32 & - & - & - & 1.36 & - & - & - & - \\
\hline 1964 & 3.39 & 0.59 & - & - & - & 3.04 & - & - & - & - \\
\hline 1965 & 4.23 & 0.73 & - & - & - & 3.97 & - & - & - & - \\
\hline 1966 & 5.38 & 1.99 & - & - & - & 4.29 & 0.10 & - & - & - \\
\hline 1967 & 5.78 & 2.61 & - & - & - & 2.57 & 0.20 & - & - & - \\
\hline 1968 & 6.17 & 3.24 & - & - & - & 2.15 & 0.40 & - & - & - \\
\hline 1969 & 1278 & 3.86 & - & - & - & 244 & 0.50 & - & - & $=$ \\
\hline 1970 & 17.59 & 4.48 & 0.14 & - & - & 1.46 & 0.96 & - & - & $=$ \\
\hline 1971 & 22.05 & 6.47 & 0.74 & - & - & 1.32 & 1.63 & - & - & - \\
\hline 1972 & 22.88 & 7.17 & 1.56 & - & - & 2.17 & 1.89 & - & - & - \\
\hline 1973 & 28.18 & 8.76 & 2.19 & - & - & 1.95 & 2.99 & - & - & - \\
\hline 1974 & 33.86 & 11.95 & 282 & - & - & 1.30 & 4.10 & - & - & - \\
\hline 1975 & 42.08 & 14.94 & 4.03 & - & - & 1.27 & 4.32 & - & - & - \\
\hline 1976 & 43.04 & 16.48 & 2.99 & 3.99 & - & 0.82 & 4.09 & - & - & - \\
\hline 1977 & 46.81 & 18.13 & 2.73 & 9.96 & - & 2.05 & 3.75 & - & - & - \\
\hline 1978 & 49.80 & 18.92 & 3.82 & 10.95 & - & 2.73 & 3.41 & - & - & - \\
\hline 1979 & 50.29 & 20.17 & 4.09 & 11.95 & - & 3.41 & 3.07 & - & - & $=$ \\
\hline 1980 & 51.68 & 19.97 & 4.50 & 11.23 & - & 4.09 & 2.73 & - & - & - \\
\hline 1981 & 51.75 & 16.11 & 4.97 & 10.47 & - & 4.05 & 2.55 & - & - & - \\
\hline 1982 & 51.73 & 16.29 & 5.29 & 11.31 & 2.15 & 4.01 & 2.90 & - & - & - \\
\hline 1983 & 52.14 & 18.29 & 6.08 & 10.51 & 3.02 & 4.25 & 2.78 & - & - & - \\
\hline 1984 & 53.72 & 23.07 & 7.67 & 10.23 & 4.87 & 4.51 & 3.17 & - & - & - \\
\hline 1985 & 55.10 & 27.60 & 9.00 & 10.30 & 5.15 & 4.95 & 3.19 & - & - & - \\
\hline 1986 & 55.55 & 29.51 & 10.01 & 10.00 & 6.30 & 5.50 & 3.91 & - & - & - \\
\hline 1987 & 55.55 & 31.60 & 11.35 & 7.95 & 6.80 & 5.75 & 4.17 & - & - & - \\
\hline 1988 & 55.70 & 33.30 & 12.58 & 6.12 & 7.22 & 6.15 & 4.22 & - & 2.57 & - \\
\hline 1989 & 55.56 & 33.36 & 13.35 & 5.48 & 6.98 & 6.40 & 4.08 & 3.41 & 2.55 & 1.43 \\
\hline 1990 & 55.66 & 33.51 & 13.60 & 5.35 & 6.30 & 6.80 & 3.83 & 3.55 & 2.52 & 1.47 \\
\hline 1991 & 55.62 & 33.55 & 13.70 & 5.01 & 6.10 & 7.02 & 3.81 & 3.41 & 2.38 & 1.54 \\
\hline 1992 & 55.66 & 33.46 & 13.85 & 4.80 & 5.80 & 7.30 & 3.90 & 3.42 & 2.30 & 1.64 \\
\hline 1993 & 55.90 & 32.70 & 14.20 & 4.60 & 5.50 & 7.60 & 4.05 & 3.35 & 2.13 & 1.80 \\
\hline 1994 & 56.01 & 30.90 & 15.02 & 4.64 & 4.83 & 7.90 & 4.25 & 3.30 & 2.05 & 1.96 \\
\hline
\end{tabular}

1 tonne crude oil $=7.33$ barrels. Because a different source was used, total production figures for $1950-1985$ differ slightly from the figures in Table II-1, Primary Production.

Source: Yearbook of China's Economy, various years; China National Offshore Oil Corporation; China Energy Statistical Yearbook, various years; China, Energy Annual Review, 1994; China National Petroleum Corporation. 
Table II-13. China's Crude Oil Production by Oilfield, 1950-1994 (continued)

4. Million Tonnes (continued)

\begin{tabular}{|c|c|c|c|c|c|c|c|c|c|c|c|}
\hline Qinghai & Yumen & $\begin{array}{c}\text { Turpan- } \\
\text { Hami }\end{array}$ & Tarim & Jiangsu & Jianghan & Jidong & Sichuan & $\begin{array}{l}\text { Qing- } \\
\text { qian-gui }\end{array}$ & Offshore* & Others & Total \\
\hline- & - & - & - & - & - & - & - & - & - & 0.08 & 0.20 \\
\hline - & - & - & - & - & - & - & - & - & - & 0.14 & 0.30 \\
\hline - & - & - & - & - & - & - & - & - & - & 0.34 & 0.43 \\
\hline - & - & - & - & - & - & - & - & - & - & 0.52 & 0.62 \\
\hline - & - & - & - & - & - & - & - & - & - & 0.70 & 0.79 \\
\hline - & - & - & - & - & - & - & - & - & - & 0.88 & 0.96 \\
\hline - & - & - & - & - & - & - & - & - & - & 1.07 & 1.16 \\
\hline - & - & - & - & - & - & - & - & - & - & 1.29 & 1.45 \\
\hline - & - & - & - & - & - & - & - & - & - & 1.52 & 2.22 \\
\hline$=$ & - & - & $=$ & - & - & - & - & - & - & 2.35 & 3.68 \\
\hline- & - & - & - & - & - & - & - & - & - & 2.61 & 4.99 \\
\hline - & - & - & - & - & - & - & - & - & - & 2.51 & 5.48 \\
\hline - & - & - & - & - & - & - & - & - & - & 2.23 & 5.98 \\
\hline- & - & - & - & - & - & - & - & - & - & 2.14 & 6.47 \\
\hline - & - & - & - & - & - & - & - & - & - & 1.97 & 8.99 \\
\hline - & - & - & - & - & - & - & - & - & - & 2.52 & 11.45 \\
\hline - & - & - & - & - & - & - & - & - & - & 2.68 & 14.44 \\
\hline - & - & - & - & - & - & - & - & - & - & 2.78 & 13.94 \\
\hline - & - & - & - & - & - & - & - & - & - & 3.02 & 14.98 \\
\hline$=$ & - & - & - & - & - & - & - & - & - & 4.33 & 23.90 \\
\hline- & - & - & - & - & - & - & - & - & - & 5.25 & 29.88 \\
\hline - & - & - & - & - & - & - & - & - & - & 6.63 & 38.84 \\
\hline - & - & - & - & - & - & - & - & - & - & 9.27 & 44.94 \\
\hline - & - & - & - & - & - & - & - & - & - & 10.20 & 54.28 \\
\hline - & - & - & - & - & - & - & - & - & - & 11.44 & 65.48 \\
\hline - & - & - & - & - & - & - & - & - & - & 7.56 & 74.20 \\
\hline - & - & - & - & - & - & - & - & - & - & 11.98 & 83.39 \\
\hline - & - & - & - & - & - & - & - & - & - & 9.90 & 93.32 \\
\hline - & - & - & - & - & - & - & - & - & - & 14.04 & 103.67 \\
\hline$=$ & - & - & - & - & $=$ & $=$ & $=$ & - & - & 12.68 & 105.67 \\
\hline- & - & - & - & - & - & - & - & - & - & 11.35 & 105.56 \\
\hline - & - & - & - & - & - & - & - & - & - & 10.29 & 100.19 \\
\hline - & - & - & - & - & - & - & - & - & - & 8.15 & 101.83 \\
\hline - & - & - & - & - & - & - & - & - & - & 8.50 & 105.57 \\
\hline- & - & - & - & - & - & - & - & - & - & 7.40 & 114.64 \\
\hline - & - & - & - & - & - & - & - & - & 0.28 & 7.93 & 123.49 \\
\hline - & - & - & - & - & - & - & - & - & 0.38 & 9.54 & 130.69 \\
\hline - & - & - & - & - & - & - & - & - & 0.71 & 10.26 & 134.14 \\
\hline- & - & - & - & - & - & - & 0.12 & - & 0.75 & 8.31 & 137.05 \\
\hline 0.73 & 0.54 & - & - & 0.80 & 0.93 & - & 0.12 & - & 0.95 & 0.99 & 137.65 \\
\hline 0.81 & 0.55 & - & - & 0.86 & 0.83 & 0.35 & 0.13 & 0.09 & 1.43 & 0.68 & 138.31 \\
\hline 1.02 & 0.69 & - & - & 0.87 & 0.73 & 0.37 & 0.14 & 0.10 & 2.39 & 2.54 & 140.99 \\
\hline 1.06 & 1.08 & - & 0.89 & 0.86 & 0.77 & 0.39 & 0.14 & - & 3.87 & 0.62 & 141.80 \\
\hline 1.08 & 0.45 & 1.15 & 1.60 & 0.86 & 0.81 & 0.43 & 0.15 & 0.14 & 4.63 & 1.77 & 144.92 \\
\hline 1.13 & 0.43 & 1.41 & 1.95 & 0.92 & 0.87 & 0.46 & 0.16 & 0.12 & 6.48 & 2.85 & 147.65 \\
\hline
\end{tabular}

1 tonne crude oil $=7.33$ barrels. Because a different source was used, total production figures for $1950-1985$ differ slightly from the figures in Table II-1, Primary Production.

Source: Yearbook of China's Economy, various years; China National Offshore Oil Corporation; China Energy Statistical Yearbook, various years; China, Energy Annual Review, 1994; China National Petroleum Corporation. 
Figure II-10. Crude Oil Production Growth Rates, Shengli, Daqing, and Total

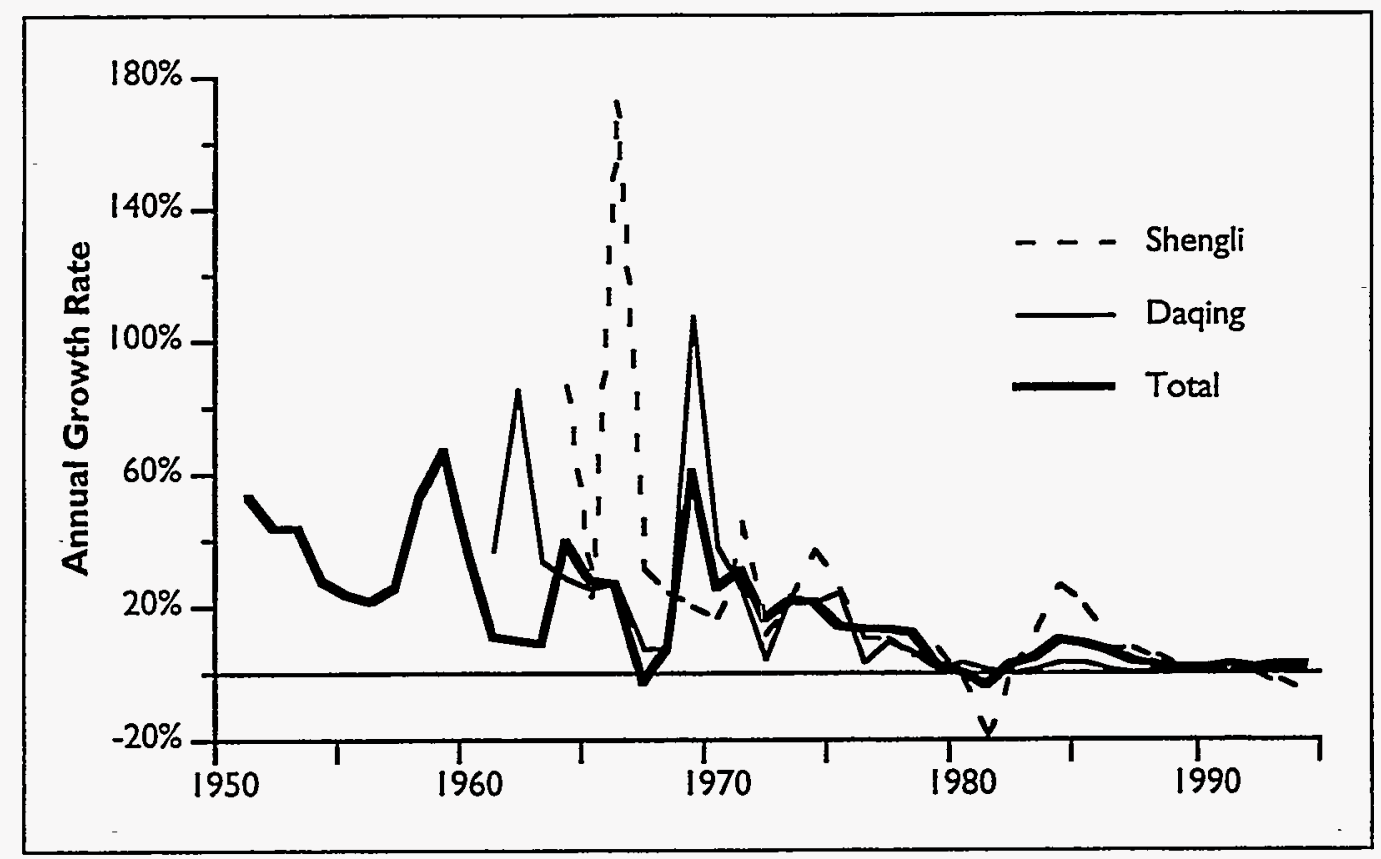

Figure II-11. Crude Oil Production Shares by Field

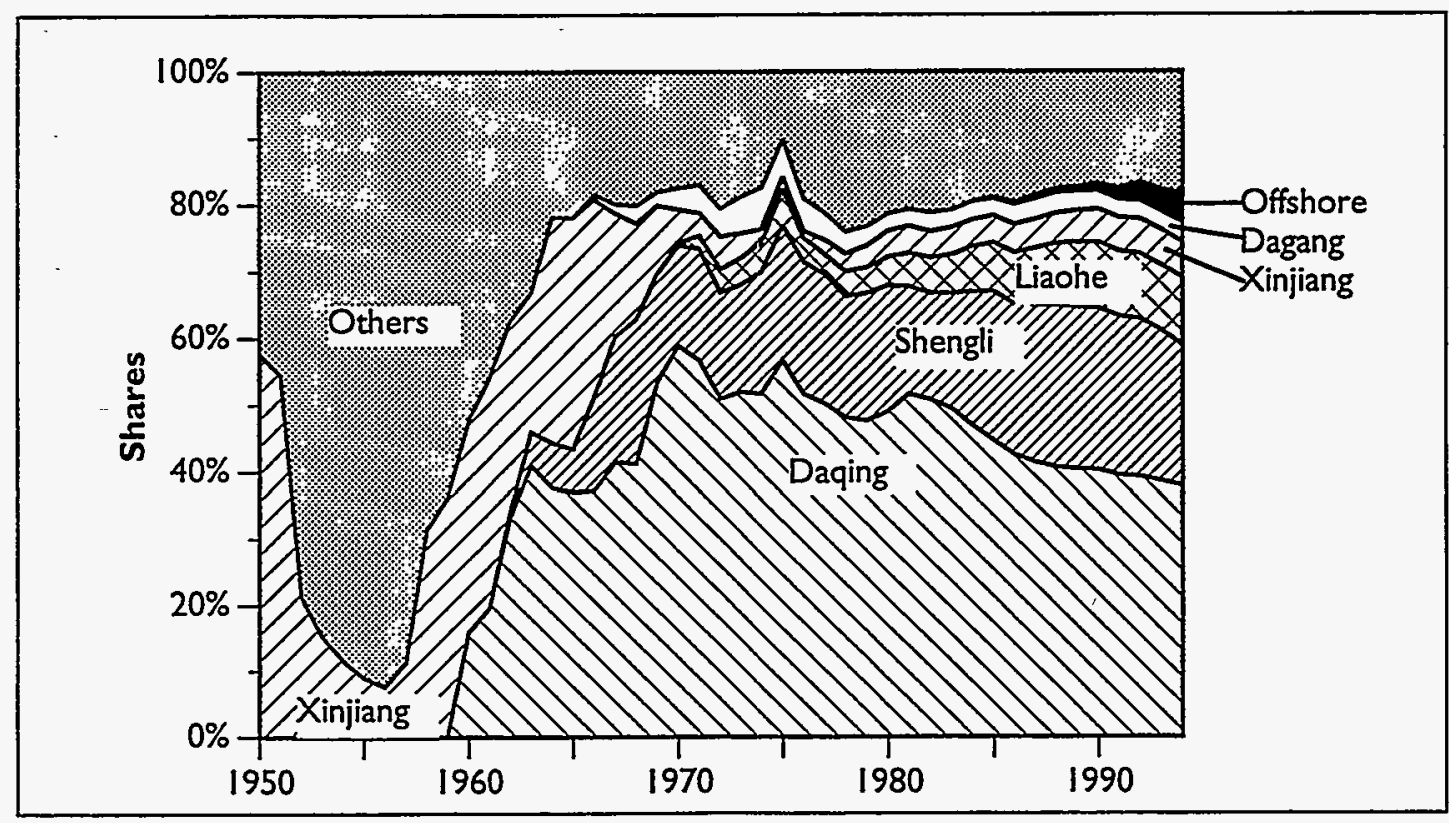


Figure II-12. Crude Oil Production by Field

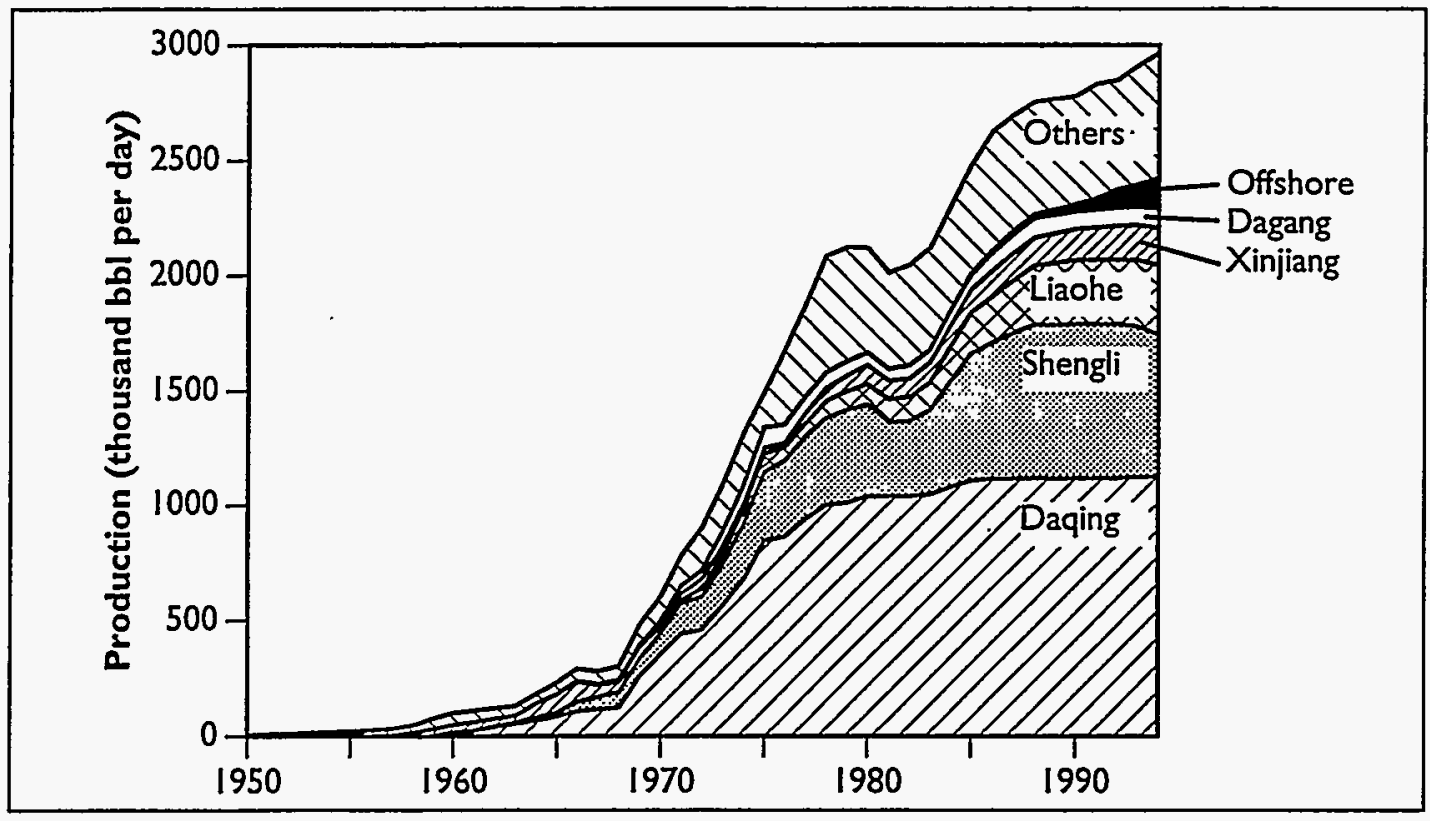


Table II-14. Selected Technical Indicators of Crude Oil Production, 1970-1992

\begin{tabular}{|c|c|c|c|c|c|c|}
\hline Year & $\begin{array}{l}\text { Oilfield } \\
\text { Self-Use * } \\
\text { (\%) }\end{array}$ & $\begin{array}{l}\text { Oilfield } \\
\text { Crude Losses } \\
\text { (\%) }\end{array}$ & $\begin{array}{c}\text { Total } \\
\text { (\%) }\end{array}$ & $\begin{array}{c}\text { Crude } \\
\text { Production } \\
\text { (Mt) }\end{array}$ & $\begin{array}{l}\text { Oilfield } \\
\text { Use \& Loss } \\
\text { (Mt) }\end{array}$ & $\begin{array}{c}\text { Electricity } \\
\text { Consumption } \dagger \\
\text { (kWh/tonne) }\end{array}$ \\
\hline 1970 & $1.34 \%$ & $1.89 \%$ & $3.23 \%$ & 29.88 & 0.97 & - \\
\hline 1971 & $1.01 \%$ & $2.12 \%$ & $3.13 \%$ & 38.84 & 1.22 & - \\
\hline 1972 & $1.22 \%$ & $290 \%$ & $4.12 \%$ & 44.94 & 1.85 & 32.70 \\
\hline 1973 & $1.34 \%$ & $255 \%$ & $3.89 \%$ & 54.28 & 2.11 & 24.60 \\
\hline 1974 & $1.22 \%$ & $264 \%$ & $3.86 \%$ & 65.48 & 2.53 & 24.70 \\
\hline 1975 & $1.25 \%$ & $2.93 \%$ & $4.18 \%$ & 74.20 & 3.10 & 25.73 \\
\hline 1976 & $1.68 \%$ & $258 \%$ & $4.26 \%$ & 83.39 & 3.55 & 28.80 \\
\hline 1977 & $1.56 \%$ & $2.65 \%$ & $4.21 \%$ & 93.32 & 3.93 & 32.55 \\
\hline 1978 & $1.74 \%$ & $237 \%$ & $4.11 \%$ & 103.67 & 4.26 & 35.01 \\
\hline 1979 & $1.84 \%$ & $249 \%$ & $4.33 \%$ & 105.67 & 4.58 & 40.82 \\
\hline 1980 & $1.64 \%$ & $2.27 \%$ & $3.91 \%$ & 105.56 & 4.13 & 38.84 \\
\hline 1981 & $1.54 \%$ & $230 \%$ & $3.84 \%$ & 100.19 & 3.85 & 39.82 \\
\hline 1982 & $1.50 \%$ & $229 \%$ & $3.79 \%$ & 101.83 & 3.86 & 42.96 \\
\hline 1983 & $1.50 \%$ & $230 \%$ & $3.80 \%$ & 105.57 & 4.01 & 45.08 \\
\hline 1984 & $1.46 \%$ & $203 \%$ & $3.49 \%$ & 114.64 & 4.00 & 47.24 \\
\hline 1985 & $1.52 \%$ & $1.65 \%$ & $3.17 \%$ & 123.49 & 3.91 & 51.58 \\
\hline 1986 & $1.55 \%$ & $1.57 \%$ & $3.12 \%$ & 130.69 & 4.08 & 53.39 \\
\hline 1987 & $1.64 \%$ & $1.55 \%$ & $3.19 \%$ & 134.14 & 4.28 & 64.50 \\
\hline 1988 & $1.70 \%$ & $1.90 \%$ & $3.60 \%$ & 137.05 & 4.93 & 73.27 \\
\hline 1989 & $1.82 \%$ & $1.76 \%$ & $3.58 \%$ & 137.65 & 4.93 & 78.75 \\
\hline 1990 & $201 \%$ & $1.80 \%$ & $3.81 \%$ & 138.31 & 5.27 & 87.97 \\
\hline 1991 & $2.10 \%$ & $1.80 \%$ & $3.90 \%$ & 140.99 & 5.50 & 102.62 \\
\hline 1992 & $2.15 \%$ & $1.80 \%$ & $3.95 \%$ & 141.80 & 5.60 & 107.05 \\
\hline
\end{tabular}

* Sometimes referred to as "autoconsumption."

$\dagger \quad$ Electricity consumed per tonne of crude oil produced; does not include refinery consumption.

Source: China Statistical Yearbook, various years; Yearbook of China's Industrial Economy, various years. 
Table II-15. Petroleum Products, 1973-1994-Mt

\begin{tabular}{|c|c|c|c|c|c|c|c|c|c|}
\hline Year & $\begin{array}{l}\text { Crude Oil } \\
\text { Input }\end{array}$ & Gasoline & $\begin{array}{c}\text { Kerosenel } \\
\text { Jet Fuel }\end{array}$ & $\begin{array}{c}\text { Diesel } \\
\text { Oil }\end{array}$ & Fuel Oil * & LPG & $\begin{array}{c}\text { "Refinery } \\
\text { Gas" }\end{array}$ & $\begin{array}{c}\text { Chemical } \\
\text { Feedstock } \dagger\end{array}$ & Lubricants \\
\hline 1973 & - & 5.74 & 2.41 & 10.40 & - & - & - & - & - \\
\hline 1974 & - & 6.63 & 2.61 & 11.79 & - & - & - & - & - \\
\hline 1975 & - & 7.37 & 2.90 & 13.24 & - & - & - & - & - \\
\hline 1976 & - & 8.16 & 2.94 & 14.89 & - & - & - & - & - \\
\hline 1977 & - & 8.67 & 3.17 & 16.16 & - & - & - & - & - \\
\hline 1978 & 70.69 & 9.91 & 3.56 & 18.26 & - & - & - & - & - \\
\hline 1979 & 71.46 & 10.70 & 4.09 & 18.73 & - & - & - & - & - \\
\hline 1980 & 75.38 & 10.79 & 3.99 & 18.28 & 31.42 & 1.23 & - & 2.79 & 1.97 \\
\hline 1981 & 74.76 & 11.12 & 3.67 & 17.78 & 28.18 & 1.11 & 2.02 & 3.43 & 1.50 \\
\hline 1982 & 75.33 & 11.14 & 3.84 & 17.46 & 27.99 & 1.24 & 1.88 & 4.19 & 1.40 \\
\hline 1983 & 80.41 & 12.64 & 4.10 & 19.04 & 28.97 & 1.50 & 1.98 & 4.63 & 1.34 \\
\hline 1984 & 82.51 & 13.50 & 4.08 & 19.47 & 28.57 & 1.54 & 2.18 & 4.88 & 1.47 \\
\hline 1985 & 85.89 & 14.72 & 4.05 & 20.23 & 28.36 & 1.60 & 2.18 & 4.92 & 1.58 \\
\hline 1986 & 92.60 & 16.85 & 4.16 & 22.31 & 29.58 & 2.02 & 2.43 & 4.65 & 1.64 \\
\hline 1987 & 97.75 & 17.37 & 4.18 & 23.66 & 31.31 & 2.15 & 2.53 & 6.69 & 2.02 \\
\hline 1988 & 102.39 & 18.93 & 3.85 & 24.60 & 32.19 & 2.32 & 2.59 & 7.05 & 2.10 \\
\hline 1989 & 106.62 & 20.68 & 3.95 & 25.82 & 32.38 & 2.55 & 2.71 & 7.58 & 2.11 \\
\hline 1990 & 109.61 & 21.57 & 3.93 & 26.09 & 32.68 & 2.62 & 2.81 & 7.85 & 1.97 \\
\hline 1991 & 116.15 & 24.04 & 4.02 & 28.53 & 31.00 & 2.79 & 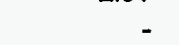 & 8.01 & 2.03 \\
\hline 1992 & 124.00 & 27.26 & 4.06 & 31.71 & 32.32 & 3.08 & - & 8.33 & 2.19 \\
\hline 1993 & 132.57 & 31.60 & 3.93 & 35.43 & 30.47 & 3.69 & - & 8.15 & 2.19 \\
\hline 1994 & .132 .04 & 28.41 & 3.70 & 34.24 & 27.92 & - & - & - & 2.10 \\
\hline
\end{tabular}

* Includes refinery use.

+ . Includes middle distallates and naphtha (currently about $60 \%$ and $40 \%$ respectively)

This is the balance of product subtotal (refinery inputs minus and refinery losses) and reported products.

Source: China Energy Statistical Yearbook, various years; China Statistical Yearbook, various years; Sinopec Yearbook, 1991; China Energy Annual Review, 1994; China OGP, 2/15/94; Energy Research Institute. 
Table II-15. Petroleum Products, 1973-1994-Mt (continued)

\begin{tabular}{|c|c|c|c|c|c|c|c|c|c|}
\hline Year & Asphalt & $\begin{array}{l}\text { Petroleum } \\
\text { Coke }\end{array}$ & Wax & Solvents & Aromatics & $\begin{array}{l}\text { Commercial } \\
\text { Feedstocks }\end{array}$ & $\begin{array}{c}\text { Otherl } \\
\text { Balanceף }\end{array}$ & $\begin{array}{l}\text { Refining } \\
\text { Losses }\end{array}$ & $\begin{array}{l}\text { Product } \\
\text { Subtotal }\end{array}$ \\
\hline 1981 & 1.74 & - & - & - & - & - & $\begin{array}{l}3.52 \\
550\end{array}$ & 0.69 & $\begin{array}{l}74.07 \\
7470\end{array}$ \\
\hline 1983 & 1.77 & 0.87 & 0.47 & 0.34 & 0.71 & 0.81 & $\begin{array}{l}\text { S.59 } \\
0.52\end{array}$ & $\begin{array}{l}0.60 \\
0.73\end{array}$ & $\begin{array}{l}74.73 \\
79.69\end{array}$ \\
\hline 1984 & 2.09 & 0.96 & 0.50 & 0.43 & 0.73 & 0.99 & 0.45 & 0.67 & 81.84 \\
\hline 1985 & 2.38 & 0.92 & 0.56 & 0.43 & 0.90 & 1.41 & 0.51 & 1.13 & 84.76 \\
\hline 1986 & 2.57 & 1.05 & 0.58 & 0.48 & 0.97 & 1.16 & 0.69 & 1.47 & 91.13 \\
\hline 1987 & 2.65 & 1.17 & 0.62 & 0.50 & 0.94 & 1.26 & -1.01 & 1.72 & 96.03 \\
\hline 1988 & 2.18 & 1.22 & 0.67 & 0.47 & 1.20 & 1.76 & -0.54 & 1.81 & 100.58 \\
\hline 1989 & 2.63 & 1.29 & 0.69 & 0.47 & 1.13 & 1.62 & -0.79 & 1.82 & 104.80 \\
\hline 1990 & 2.73 & 1.36 & 0.69 & 0.51 & 1.22 & 1.99 & -1.36 & 2.96 & 106.65 \\
\hline 1991 & 3.12 & 1.58 & 0.67 & 0.50 & - & 2.54 & 4.41 & 2.91 & 113.24 \\
\hline 1992 & 3.43 & 1.65 & 0.69 & 0.55 & - & 2.91 & 0.66 & 5.15 & 118.86 \\
\hline 1993 & 3.27 & 1.88 & 0.72 & 0.48 & - & 3.29 & - & - & 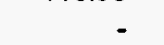 \\
\hline 1994 & - & - & - & - & - & - & - & - & - \\
\hline
\end{tabular}

Includes refinery use.

Includes middle distallates and naphtha (currently about $60 \%$ and $40 \%$ respectively).

This is the balance of product subtotal (refinery inputs minus and refinery losses) and reported products.

Source: China Energy Statistical Yearbook, various years; China Statistical Yearbook, various years; Sinopec Yearbook, 1991; China Energy Annual Review, 1994; China OGP, 2/15/94; Energy Research Institute. 
Figure II-13. Petroleum Refinery Output

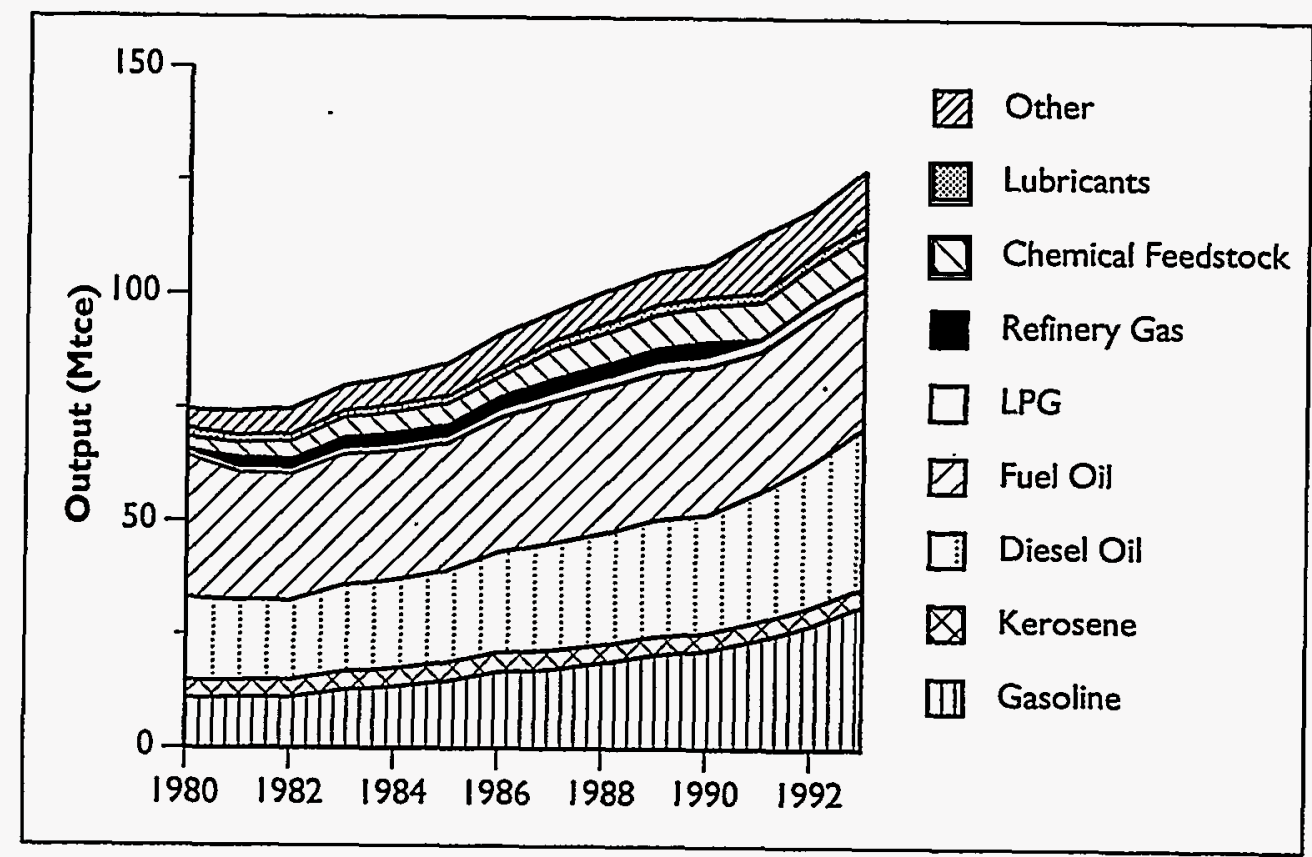


Table II-16. Natural Gas Production by Source, 1949-1994

\begin{tabular}{|c|c|c|c|c|}
\hline \multirow[b]{2}{*}{ Year } & \multicolumn{3}{|c|}{$\begin{array}{l}\text { Natural Gas Production } \\
\text { (billion cubic meters) }\end{array}$} & \multirow{2}{*}{$\begin{array}{c}\text { Natural Gas } \\
\text { from NG } \\
\text { Fields as } \\
\% \text { of Total }\end{array}$} \\
\hline & Total & $\begin{array}{l}\text { Natural Gas } \\
\text { Fields* }\end{array}$ & $\begin{array}{l}\text { Associated } \\
\text { Gas } t\end{array}$ & \\
\hline 1949 & 0.007 & 0.006 & 0.001 & $86 \%$ \\
\hline 1950 & 0.007 & 0.006 & 0.001 & $86 \%$ \\
\hline 1951 & 0.003 & 0.002 & 0.001 & $67 \%$ \\
\hline 1952 & 0.008 & 0.006 & 0.002 & $75 \%$ \\
\hline 1953 & 0.011 & 0.008 & 0.003 & $73 \%$ \\
\hline 1954 & 0.015 & 0.011 & 0.004 & $73 \%$ \\
\hline 1955 & 0.017 & 0.012 & 0.005 & $71 \%$ \\
\hline 1956 & 0.026 & 0.021 & 0.005 & $81 \%$ \\
\hline 1957 & 0.070 & 0.063 & 0.007 & $90 \%$ \\
\hline 1958 & 0.110 & 0.085 & 0.025 & $77 \%$ \\
\hline 1959 & 0.290 & 0.252 & 0.038 & $87 \%$ \\
\hline 1960 & 1.040 & 1.015 & 0.025 & $98 \%$ \\
\hline 1961 & 1.470 & 1.438 & 0.032 & $98 \%$ \\
\hline 1962 & 1.210 & 1.152 & 0.058 & $95 \%$ \\
\hline 1963 & 1.020 & 0.944 & 0.076 & $93 \%$ \\
\hline 1964 & 1.060 & 0.913 & 0.147 & $86 \%$ \\
\hline 1965 & 1.100 & 0.898 & 0.202 & $82 \%$ \\
\hline 1966 & 1.340 & 1.034 & 0.306 & $77 \%$ \\
\hline 1967 & 1.460 & 1.159 & 0.301 & $79 \%$ \\
\hline 1968 & 1.400 & 1.055 & 0.345 & $75 \%$ \\
\hline 1969 & 1.960 & 1.396 & 0.564 & $71 \%$ \\
\hline 1970 & 2870 & 2.028 & 0.842 & $71 \%$ \\
\hline 1971 & 3.740 & 2.594 & 1.146 & $69 \%$ \\
\hline 1972 & 4.840 & 2.977 & 1.863 & $62 \%$ \\
\hline 1973 & 5.980 & 3.446 & 2.534 & $58 \%$ \\
\hline 1974 & 7.530 & 3.975 & 3.555 & $53 \%$ \\
\hline 1975 & 8.850 & 4.767 & 4.083 & $54 \%$ \\
\hline 1976 & 10.100 & 5.558 & 4.542 & $55 \%$ \\
\hline 1977 & 12.120 & 6.746 & 5.374 & $56 \%$ \\
\hline 1978 & 13.730 & 7.770 & 5.960 & $57 \%$ \\
\hline 1979 & 14.510 & 7.980 & 6.530 & $55 \%$ \\
\hline 1980 & 14.270 & 7.050 & 7.220 & $49 \%$ \\
\hline 1981 & 12740 & 6.370 & 6.370 & $50 \%$ \\
\hline 1982 & 11.930 & 5.250 & 6.680 & $44 \%$ \\
\hline 1983 & 12210 & 5.380 & 6.830 & $44 \%$ \\
\hline 1984 & 12.430 & 5.480 & 6.950 & $44 \%$ \\
\hline 1985 & 12.930 & 5.640 & 7.290 & $44 \%$ \\
\hline 1986 & 13.760 & 5.890 & 7.870 & $43 \%$ \\
\hline 1987 & 13.894 & 5.904 & 7.990 & $42 \%$ \\
\hline 1988 & 14.264 & 6.097 & 8.167 & $43 \%$ \\
\hline 1989 & 15.049 & 7.930 & 7.119 & $53 \%$ \\
\hline 1990 & 15.298 & 6.655 & 8.643 & $44 \%$ \\
\hline 1991 & 16.073 & 6.480 & 9.593 & $40 \%$ \\
\hline 1992 & 15.788 & - & - & - \\
\hline 1993 & 16.765 & - & - & - \\
\hline 1994 & 16.972 & 7.067 & 9.906 & $42 \%$ \\
\hline
\end{tabular}

* Virtually all of this is from natural gas fields in Sichuan

$+\quad$ Most other natural gas production comes from six large oil fields. In 1991 the Daqing, Shengli, Liaohe, Zhongyuan, Xinjiang, and Dagang oilfields produced $2.32,1.31,1.75,1.20,0.83$, and 0.40 billion cubic meters respectively, a total of 7.81 billion cubic meters, or four fifths of associated gas production.

Source: China Energy Statistical Yearbook, various years; China Statistical Yearbook, various years; Zhongguo Nengyuan [China Energy], 1995, no.2; China National Petroleum Corporation. 
Figure II-14. Natural Gas Production

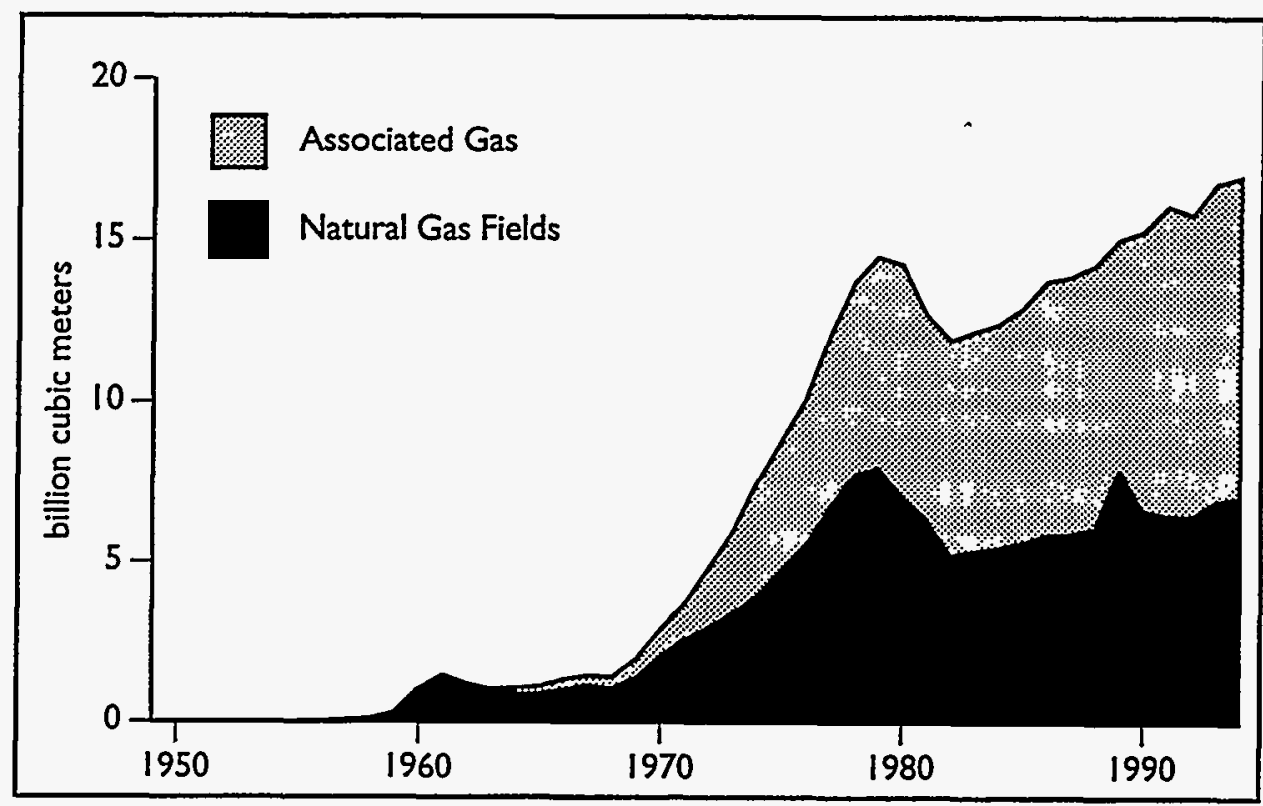

*For 1989 and 1990 only aggregate data were available, so production breakdown was estimated using 1988 production shares. 
Table II-17. Gross Electricity Generation, 1949-1994

\begin{tabular}{|c|c|c|c|c|c|}
\hline \multirow[b]{2}{*}{ Year } & \multicolumn{2}{|c|}{ Total } & \multicolumn{3}{|c|}{ Hydroelectric } \\
\hline & $\begin{array}{c}\text { Generation } \\
\text { (TWh) }\end{array}$ & $\begin{array}{l}\text { Growth Rate } \\
\text { (\% over pre- } \\
\text { vious year) }\end{array}$ & $\begin{array}{c}\text { Generation } \\
\text { (TWh) }\end{array}$ & $\begin{array}{l}\text { Growth Rate } \\
\text { (\% over pre- } \\
\text { vious year) }\end{array}$ & $\begin{array}{r}\text { Percentage } \\
\text { Share } \\
\text { of Total }\end{array}$ \\
\hline 1949 & 4.3 & - & 0.7 & - & $16.3 \%$ \\
\hline 1950 & 4.6 & $7.0 \%$ & 0.8 & $1.4 .3 \%$ & $17.4 \%$ \\
\hline 1951 & 5.7 & $23.9 \%$ & 0.9 & $125 \%$ & $15.8 \%$ \\
\hline 1952 & 7.3 & $28.1 \%$ & 1.3 & $44.4 \%$ & $17.8 \%$ \\
\hline 1953 & 9.2 & $26.0 \%$ & 1.5 & $15.4 \%$ & $16.3 \%$ \\
\hline 1954 & 11.0 & $19.6 \%$ & 2.2 & $46.7 \%$ & $20.0 \%$ \\
\hline 1955 & 12.3 & $11.8 \%$ & 2.4 & $9.1 \%$ & $19.5 \%$ \\
\hline 1956 & 16.6 & $35.0 \%$ & 3.5 & $45.8 \%$ & $21.1 \%$ \\
\hline 1957 & 19.3 & $16.3 \%$ & 4.8 & $37.1 \%$ & $24.9 \%$ \\
\hline 1958 & 27.5 & $42.5 \%$ & 4.1 & $-14.6 \%$ & $14.9 \%$ \\
\hline 1959 & 42.3 & $53.8 \%$ & 4.4 & $7.3 \%$ & $10.4 \%$ \\
\hline 1960 & 59.4 & $40.4 \%$ & 7.4 & $68.2 \%$ & $12.5 \%$ \\
\hline 1961 & 48.0 & $-19.2 \%$ & 7.4 & $0.0 \%$ & $15.4 \%$ \\
\hline 1962 & 45.8 & $-4.6 \%$ & 9.0 & $21.6 \%$ & $19.7 \%$ \\
\hline 1963 & 49.0 & $7.0 \%$ & 8.7 & $-3.3 \%$ & $17.8 \%$ \\
\hline 1964 & 56.0 & $14.3 \%$ & 10.6 & $21.8 \%$ & $18.9 \%$ \\
\hline 1965 & 67.6 & $20.7 \%$ & 10.4 & $-1.9 \%$ & $15.4 \%$ \\
\hline 1966 & 82.5 & $220 \%$ & 12.6 & $21.2 \%$ & $15.3 \%$ \\
\hline 1967 & 77.4 & $-6.2 \%$ & 13.1 & $4.0 \%$ & $16.9 \%$ \\
\hline 1968 & 71.6 & $-7.5 \%$ & 11.5 & $-12.2 \%$ & $16.1 \%$ \\
\hline 1969 & 94.0 & $31.3 \%$ & 16.0 & $39.1 \%$ & $17.0 \%$ \\
\hline 1970 & 115.9 & $23.3 \%$ & 20.5 & $28.1 \%$ & $17.7 \%$ \\
\hline 1971 & 138.4 & $19.4 \%$ & 25.1 & $22.4 \%$ & $18.1 \%$ \\
\hline 1972 & 152.4 & $10.1 \%$ & 28.8 & $14.7 \%$ & $18.9 \%$ \\
\hline 1973 & 166.8 & $9.4 \%$ & 38.9 & $35.1 \%$ & $23.3 \%$ \\
\hline 1974 & 168.8 & $1.2 \%$ & 41.4 & $6.4 \%$ & $24.5 \%$ \\
\hline 1975 & 195.8 & $16.0 \%$ & 47.6 & $1.5 .0 \%$ & $24.3 \%$ \\
\hline 1976 & 203.1 & $3.7 \%$ & 45.6 & $-4.2 \%$ & $22.5 \%$ \\
\hline 1977 & 223.4 & $10.0 \%$ & 47.6 & $4.4 \%$ & $21.3 \%$ \\
\hline 1978 & 256.6 & $14.9 \%$ & 44.6 & $-6.3 \%$ & $17.4 \%$ \\
\hline 1979 & 282.0 & $9.9 \%$ & 50.1 & $12.3 \%$ & $17.8 \%$ \\
\hline 1980 & 300.6 & $6.6 \%$ & 58.2 & $16.2 \%$ & $19.4 \%$ \\
\hline 1981 & 309.3 & $2.9 \%$ & 65.5 & $12.5 \%$ & $21.2 \%$ \\
\hline 1982 & 327.7 & $5.9 \%$ & 74.4 & $13.6 \%$ & $22.7 \%$ \\
\hline 1983 & 351.4 & $7.2 \%$ & 86.4 & $16.1 \%$ & $24.6 \%$ \\
\hline 1984 & 377.0 & $7.3 \%$ & 86.8 & $0.5 \%$ & $23.0 \%$ \\
\hline 1985 & 410.7 & $8.9 \%$ & 92.4 & $6.5 \%$ & $22.5 \%$ \\
\hline 1986 & 449.6 & $9.5 \%$ & 94.5 & $2.3 \%$ & $21.0 \%$ \\
\hline 1987 & 497.3 & $10.6 \%$ & 100.0 & $5.8 \%$ & $20.1 \%$ \\
\hline 1988 & 545.2 & $9.6 \%$ & 109.2 & $9.2 \%$ & $20.0 \%$ \\
\hline 1989 & 584.8 & $7.3 \%$ & 118.3 & $8.3 \%$ & $20.2 \%$ \\
\hline 1990 & 621.2 & $6.2 \%$ & 126.7 & $7.1 \%$ & $20.4 \%$ \\
\hline 1991 & 677.5 & $9.1 \%$ & 124.7 & $-1.6 \%$ & $18.4 \%$ \\
\hline 1992 & 753.9 & $11.3 \%$ & 130.7 & $4.8 \%$ & $17.3 \%$ \\
\hline 1993 & 839.5 & $11.4 \%$ & 151.8 & $16.1 \%$ & $18.1 \%$ \\
\hline 1994 & 909.0 & $8.3 \%$ & 170.4 & $12.2 \%$ & $18.7 \%$ \\
\hline
\end{tabular}

N.B.: The figures for total and fossil gross generation for 1988 and 1989 are each 0.1 TWh higher than in previous versions of the Databood because they were revised to conform with State Statistical Bureau data rather than former Ministry of Energy data.

Source: Energy in China, various years; China Statistical Yearbook, various years; China Energy Annual Review, 1994; China Energy Research Society, 1994; State Statistical Bureau. 
Table II-17. Gross Electricity Generation, 1949-1994 (continued)

\begin{tabular}{|c|c|c|c|c|c|c|}
\hline \multirow[b]{2}{*}{ Year } & \multicolumn{3}{|c|}{ Fossil Fuel } & \multicolumn{3}{|c|}{ Nuclear } \\
\hline & $\begin{array}{c}\text { Generation } \\
\text { (TWh) }\end{array}$ & $\begin{array}{l}\text { Growth Rate } \\
\text { (\% over pre- } \\
\text { vious year) }\end{array}$ & $\begin{array}{l}\text { Percentage } \\
\text { Share } \\
\text { of Total }\end{array}$ & $\begin{array}{c}\text { Generation } \\
\text { (TWh) }\end{array}$ & $\begin{array}{l}\text { Growth Rate } \\
\text { (\% over pre- } \\
\text { vious year) }\end{array}$ & $\begin{array}{c}\text { Percentage } \\
\text { Share } \\
\text { of Total }\end{array}$ \\
\hline 1949 & 3.6 & - & $83.7 \%$ & - & - & $=$ \\
\hline 1950 & 3.8 & $5.6 \%$ & $82.6 \%$ & - & - & - \\
\hline 1951 & 4.8 & $26.3 \%$ & $84.2 \%$ & - & - & - \\
\hline 1952 & 6.0 & $25.0 \%$ & $82.2 \%$ & - & - & - \\
\hline 1953 & 7.7 & $28.3 \%$ & $83.7 \%$ & - & - & - \\
\hline 1954 & 8.8 & $14.3 \%$ & $80.0 \%$ & - & - & - \\
\hline 1955 & 9.9 & $12.5 \%$ & $80.5 \%$ & - & - & - \\
\hline 1956 & 13.1 & $32.3 \%$ & $78.9 \%$ & - & - & - \\
\hline 1957 & 14.5 & $10.7 \%$ & $75.1 \%$ & - & - & - \\
\hline 1958 & 23.4 & $61.4 \%$ & $85.1 \%$ & - & - & - \\
\hline 1959 & 37.9 & $62.0 \%$ & $89.6 \%$ & - & - & - \\
\hline 1960 & 52.0 & $37.2 \%$ & $87.5 \%$ & - & - & - \\
\hline 1962 & 1952 & $40.6 \%$ & $-21.9 \%$ & - & - & - \\
\hline 1962 & 36.8 & $-9.4 \%$ & $80.3 \%$ & - & - & - \\
\hline 1963 & 40.3 & $9.5 \%$ & $82.2 \%$ & - & - & - \\
\hline 1964 & 45.4 & $12.7 \%$ & $81.1 \%$ & - & - & - \\
\hline 1965 & 57.2 & $26.0 \%$ & $84.6 \%$ & - & - & - \\
\hline 1966 & 69.9 & $22.2 \%$ & $84.7 \%$ & - & - & - \\
\hline 1967 & 64.3 & $-8.0 \%$ & $83.1 \%$ & - & - & - \\
\hline 1968 & 60.1 & $-6.5 \%$ & $83.9 \%$ & - & - & - \\
\hline 1969 & 78.0 & $29.8 \%$ & $83.0 \%$ & - & - & $=$ \\
\hline 1970 & 95.4 & $22.3 \%$ & $82.3 \%$ & - & - & - \\
\hline 1971 & 113.3 & $18.8 \%$ & $81.9 \%$ & - & - & - \\
\hline 1972 & 123.6 & $9.1 \%$ & $81.1 \%$ & - & - & - \\
\hline 1973 & 127.9 & $3.5 \%$ & $76.7 \%$ & - & - & - \\
\hline 1974 & 127.4 & $-0.4 \%$ & $75.5 \%$ & - & - & - \\
\hline 1975 & 148.2 & $16.3 \%$ & $75.7 \%$ & - & - & - \\
\hline 1976 & 157.5 & $6.3 \%$ & $77.5 \%$ & - & - & - \\
\hline 1977 & 175.8 & $11.6 \%$ & $78.7 \%$ & - & - & - \\
\hline 1978 & 212.0 & $20.6 \%$ & $82.6 \%$ & - & - & - \\
\hline 1979 & 231.9 & $9.4 \%$ & $82.2 \%$ & - & - & $=$ \\
\hline 1980 & 242.4 & $4.5 \%$ & $80.6 \%$ & - & - & $=$ \\
\hline 1981 & 243.8 & $0.6 \%$ & $78.8 \%$ & - & - & - \\
\hline 1982 & 253.3 & $3.9 \%$ & $77.3 \%$ & - & - & - \\
\hline 1983 & 265.0 & $4.6 \%$ & $75.4 \%$ & - & - & - \\
\hline 1984 & 290.2 & $9.5 \%$ & $77.0 \%$ & - & - & - \\
\hline 1985 & 318.3 & $9.7 \%$ & $77.5 \%$ & - & - & - \\
\hline 1986 & 355.1 & $11.6 \%$ & $79.0 \%$ & - & - & - \\
\hline 1987 & 397.3 & $11.9 \%$ & $79.9 \%$ & - & - & - \\
\hline 1988 & 436.0 & $9.7 \%$ & $80.0 \%$ & - & - & - \\
\hline 1989 & 466.5 & $7.0 \%$ & $79.8 \%$ & - & - & $=$ \\
\hline 1990 & 494.5 & $6.0 \%$ & $79.6 \%$ & - & - & - \\
\hline 1991 & 552.8 & $11.8 \%$ & $81.6 \%$ & - & - & - \\
\hline 1992 & 623.2 & $12.7 \%$ & $82.7 \%$ & - & - & - \\
\hline 1993 & 686.1 & $10.1 \%$ & $81.7 \%$ & 1.6 & - & $0.2 \%$ \\
\hline 1994 & 724.8 & $5.6 \%$ & $79.7 \%$ & 13.9 & $769 \%$ & $1.5 \%$ \\
\hline
\end{tabular}

N.B.: The figures for total and fossil gross generation for 1988 and 1989 are each 0.1 TWh higher than in previous versions of the Databood because they were revised to conform with State Statistical Bureau data rather than former Ministry of Energy data.

Source Energy in China, various years; China Statistical Yearbook, various years; China Energy Annual Review, 1994; China Energy Research Society, 1994; State Statistical Bureau. 
Figure II-15. Electricity Generation

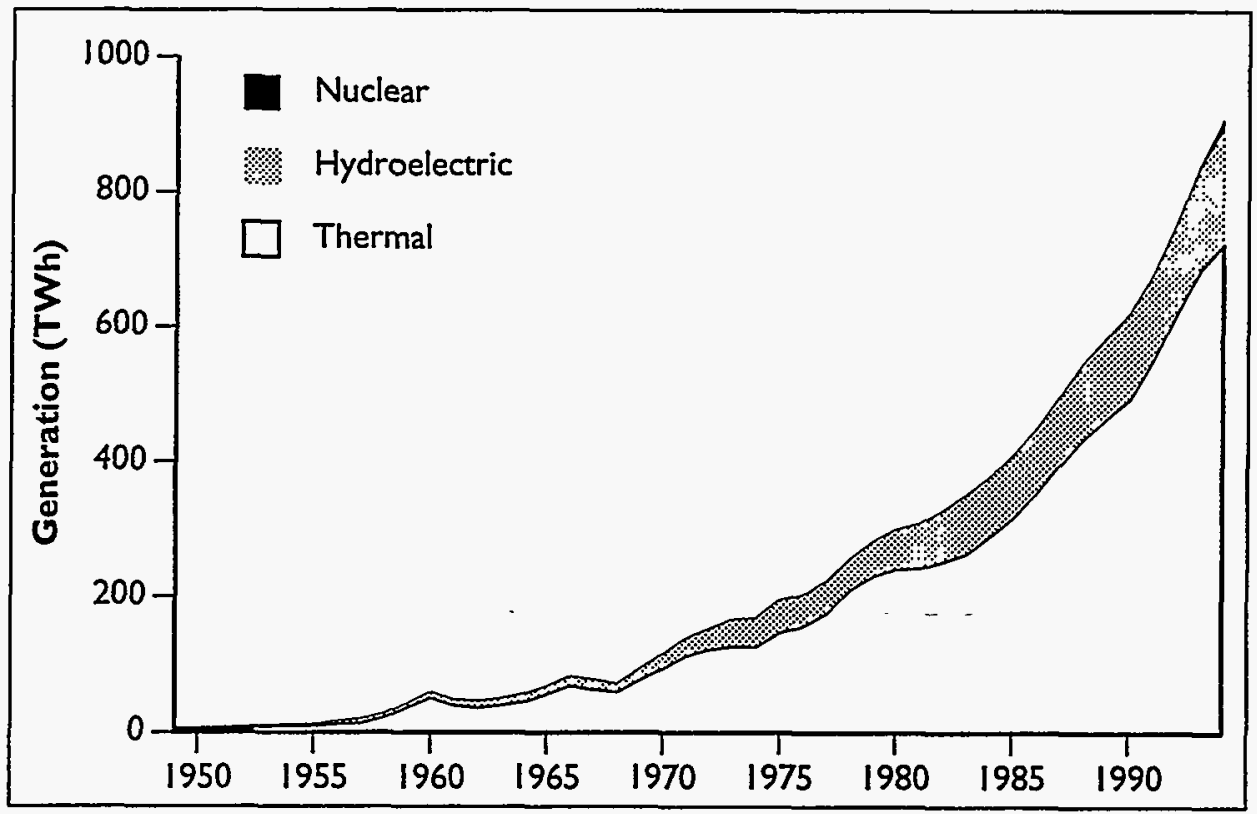




\section{Table II-18. Electricity Generation and Consumption, * 1980-1993 (TWh)}

\begin{tabular}{|ccccccc|}
\hline Year & $\begin{array}{c}\text { Gross } \\
\text { Generation }\end{array}$ & $\begin{array}{c}\text { Power } \\
\text { Sector } \\
\text { Consumptiont }\end{array}$ & $\begin{array}{c}\text { Net } \\
\text { Generation }\end{array}$ & $\begin{array}{c}\text { Net } \\
\text { Imports }\end{array}$ & $\begin{array}{c}\text { T \& D } \\
\text { Losses I }\end{array}$ & $\begin{array}{r}\text { Total } \\
\text { End } \\
\text { Use }\end{array}$ \\
\hline 1980 & 300.6 & 19.4 & 281.2 & 0.00 & 25.1 & 256.1 \\
1981 & 309.3 & 19.8 & 289.5 & 0.30 & 26.0 & 263.8 \\
1982 & 327.7 & 20.7 & 307.0 & 0.33 & 26.5 & 280.8 \\
1983 & 351.4 & 21.8 & 329.6 & 0.43 & 28.1 & 301.9 \\
1984 & 377.0 & 23.7 & 353.3 & 0.80 & 29.3 & 324.9 \\
1985 & 410.7 & 26.4 & 384.3 & 1.07 & 31.4 & 354.0 \\
1986 & 449.5 & 29.4 & 420.1 & 1.17 & 34.2 & 387.0 \\
1987 & 497.3 & 33.1 & 464.2 & 1.25 & 39.4 & 426.1 \\
1988 & 545.2 & 36.5 & 508.7 & 1.47 & 41.6 & 468.6 \\
1989 & 584.7 & 39.8 & 544.9 & 1.72 & 43.7 & 502.9 \\
\hline 1990 & 621.3 & 42.9 & 578.4 & 1.84 & 46.6 & 533.6 \\
1991 & 677.6 & 47.0 & 630.6 & 2.85 & 51.4 & 582.0 \\
1992 & 753.9 & 52.8 & 701.1 & 4.72 & 58.1 & 647.7 \\
1993 & 839.5 & 58.4 & 781.1 & 4.39 & 66.5 & 714.5 \\
& & & & & & \\
\hline
\end{tabular}

- Figures in italics are estimates.

$\dagger$ Power sector consumption, which is composed of in-plant consumption and other power sector use (see Table IV-14, Power Sector Electricity Consumption)

f Transmission and distribution losses; includes only losses from grids that have $>500 \mathrm{~kW}$ of installed generation capacity and does not include losses from end user grids (mainly industry). Inclusion of lineloss from end user distribution lines would approximately double line loss figures (MOE, 1991). A 1988 Ministry of Energy survey of line losses found losses from main transmission lines $(\geq 220 \mathrm{kV})$ to be $2-4 \%, 3-6 \%$ from urban networks $(\leq 110 \mathrm{kV}), 7-10 \%$ from rural grids $(\leq 10 \mathrm{kV})$, and $3-6 \%$ from industrial end user grids. The approximate share of total line losses was found to be: main transmission lines, $24 \%$, urban and rural grids, $26 \%$, heavy industry user grids, $25 \%$, light industry user grids, $8 \%$, rural industry user grids, $5 \%$, rural household and other distribution grids, $12 \%$. Totals are slightly different than in Table IV-33, End Use Electricity Consumption by Sector, due to different methods of calculation. Whereas the totals in Table IV-33 are derived by subtracting power sector use and transmission and distribution losses from gross generation, the totals in this table are the sum of reported sectoral end use minus power sector consumption.

Source: China Energy Statistical Yearbook, various years; Energy in China, various years; National Rural Energy Planning, 1990; Joint Survey Group, MOE, 1991; China Energy Annual Review, 1994. 
Table II-19. Electricity Generation Capacity and Growth Rates, 1949-1994

\begin{tabular}{|c|c|c|c|c|}
\hline \multicolumn{5}{|c|}{ 1. Capacity (GW) } \\
\hline Year & Hydro & Fossil & Nuclear & Total \\
\hline 1949 & 0.16 & 1.69 & - & 1.85 \\
\hline 1950 & 0.17 & 1.70 & - & 1.87 \\
\hline 1951 & 0.18 & 1.70 & - & 1.88 \\
\hline 1952 & 0.19 & 1.77 & - & 1.96 \\
\hline 1953 & 0.33 & 2.02 & - & 2.35 \\
\hline 1954 & 0.41 & 2.19 & - & 2.60 \\
\hline 1955 & 0.50 & 2.50 & - & 3.00 \\
\hline 1956 & 0.90 & 293 & - & 3.83 \\
\hline 1957 & 1.02 & 3.61 & - & 4.63 \\
\hline 1958 & 1.22 & 5.07 & - & 6.29 \\
\hline 1959 & 1.62 & 7.92 & - & 9.54 \\
\hline 1960 & 1.94 & 9.98 & - & 11.92 \\
\hline 1961 & 2.33 & 10.53 & - & 12.86 \\
\hline 1962 & 2.38 & 10.66 & - & 13.04 \\
\hline 1963 & 2.43 & 10.90 & - & 13.33 \\
\hline 1964 & 268 & 11.38 & - & 14.06 \\
\hline 1965 & 3.02 & 12.06 & - & 15.08 \\
\hline 1966 & 3.64 & 13.38 & - & 17.02 \\
\hline 1967 & 3.84 & 14.15 & - & 17.99 \\
\hline 1968 & 4.39 & 14.77 & - & 19.16 \\
\hline 1969 & 5.05 & 15.99 & - & 21.04 \\
\hline 1970 & 6.23 & 17.54 & - & 23.77 \\
\hline 1971 & 7.80 & 18.48 & - & 26.28 \\
\hline 1972 & 8.70 & 20.80 & - & 29.50 \\
\hline 1973 & 10.30 & 23.62 & - & 33.92 \\
\hline 1974 & 11.82 & 26.29 & - & 38.11 \\
\hline 1975 & 13.43 & 29.98 & - & 43.41 \\
\hline 1976 & 14.65 & 32.50 & - & 47.15 \\
\hline 1977 & 15.76 & 35.69 & - & 51.45 \\
\hline 1978 & 17.28 & 39.84 & - & 57.12 \\
\hline 1979 & 19.11 & 43.91 & - & 63.02 \\
\hline 1980 & 20.32 & 45.55 & - & 65.87 \\
\hline 1981 & 21.93 & 47.20 & - & 69.13 \\
\hline 1982 & 2296 & 49.40 & - & 72.36 \\
\hline 1983 & 24.16 & 52.28 & - & 76.44 \\
\hline 1984 & 25.60 & 54.52 & - & 80.12 \\
\hline 1985 & 26.42 & 60.63 & - & 87.05 \\
\hline 1986 & 27.54 & 66.28 & - & 93.82 \\
\hline 1987 & 30.19 & 72.70 & - & 102.90 \\
\hline 1988 & 32.70 & 82.80 & - & 115.50 \\
\hline 1989 & 34.58 & 92.06 & - & 126.64 \\
\hline 1990 & 36.05 & 101.84 & - & 137.89 \\
\hline 1991 & 37.88 & 113.59 & - & 151.47 \\
\hline 1992 & 40.68 & 125.85 & - & 166.53 \\
\hline 1993 & 44.59 & 137.12 & 1.20 & 182.91 \\
\hline 1994 & - & - & 2.10 & 199.00 \\
\hline
\end{tabular}

Source: Energy in China, various years; China Statistical Yearbook, various years; China Energy Research Society, 1994; Ministry of Electric Power Industry. 
Table II-19. Electricity Generation Capacity and Growth Rates, 1949-1994 (continued)

\begin{tabular}{|c|c|c|c|c|}
\hline \multicolumn{5}{|c|}{ 2. Growth Over Previous Year } \\
\hline Year & Hydro & Fossil & Nuclear & Total \\
\hline 1949 & - & - & - & - \\
\hline 1950 & $6.3 \%$ & $0.6 \%$ & - & $\overline{1.1 \%}$ \\
\hline 1951 & $5.9 \%$ & $0.0 \%$ & - & $0.5 \%$ \\
\hline 1952 & $5.6 \%$ & $4.1 \%$ & - & $4.3 \%$ \\
\hline 1953 & $73.7 \%$ & $14.1 \%$ & - & $19.9 \%$ \\
\hline 1954 & $24.2 \%$ & $8.4 \%$ & - & $10.6 \%$ \\
\hline 1955 & $22.0 \%$ & $14.2 \%$ & - & $15.4 \%$ \\
\hline 1956 & $80.0 \%$ & $17.2 \%$ & - & $27.7 \%$ \\
\hline 1957 & $13.3 \%$ & $23.2 \%$ & - & $20.9 \%$ \\
\hline 1958 & $19.6 \%$ & $40.4 \%$ & - & $35.9 \%$ \\
\hline 1959 & $32.8 \%$ & $56.2 \%$ & - & $51.7 \%$ \\
\hline 1960 & $19.8 \%$ & $26.0 \%$ & - & $24.9 \%$ \\
\hline 1961 & $20.1 \%$ & $5.5 \%$ & - & $7.9 \%$ \\
\hline 1962 & $2.1 \%$ & $1.2 \%$ & - & $1.4 \%$ \\
\hline 1963 & $2.1 \%$ & $2.3 \%$ & - & $2.2 \%$ \\
\hline 1964 & $10.3 \%$ & $4.4 \%$ & - & $5.5 \%$ \\
\hline 1965 & $12.7 \%$ & $6.0 \%$ & - & $7.3 \%$ \\
\hline 1966 & $20.5 \%$ & $10.9 \%$ & - & $12.9 \%$ \\
\hline 1967 & $5.5 \%$ & $5.8 \%$ & - & $5.7 \%$ \\
\hline 1968 & $14.3 \%$ & $4.4 \%$ & - & $6.5 \%$ \\
\hline 1969 & $15.0 \%$ & $8.3 \%$ & - & $9.8 \%$ \\
\hline 1970 & $23.4 \%$ & $9.7 \%$ & - & $13.0 \%$ \\
\hline 1971 & $25.2 \%$ & $5.4 \%$ & - & $10.6 \%$ \\
\hline 1972 & $11.5 \%$ & $126 \%$ & - & $12.3 \%$ \\
\hline 1973 & $18.4 \%$ & $13.6 \%$ & - & $15.0 \%$ \\
\hline 1974 & $14.8 \%$ & $11.3 \%$ & - & $12.4 \%$ \\
\hline 1975 & $13.6 \%$ & $14.0 \%$ & - & $13.9 \%$ \\
\hline 1976 & $9.1 \%$ & $8.4 \%$ & - & $8.6 \%$ \\
\hline 1977 & $7.6 \%$ & $9.8 \%$ & - & $9.1 \%$ \\
\hline 1978 & $9.6 \%$ & $11.6 \%$ & - & $11.0 \%$ \\
\hline 1979 & $10.6 \%$ & $10.2 \%$ & - & $10.3 \%$ \\
\hline 1980 & $6.3 \%$ & $3.7 \%$ & - & $4.5 \%$ \\
\hline 1981 & $7.9 \%$ & $3.6 \%$ & - & $4.9 \%$ \\
\hline 1982 & $4.7 \%$ & $4.7 \%$ & - & $4.7 \%$ \\
\hline 1983 & $5.2 \%$ & $5.8 \%$ & - & $5.6 \%$ \\
\hline 1984 & $6.0 \%$ & $4.3 \%$ & - & $4.8 \%$ \\
\hline 1985 & $3.2 \%$ & $11.2 \%$ & - & $8.6 \%$ \\
\hline 1986 & $4.2 \%$ & $9.3 \%$ & - & $7.8 \%$ \\
\hline 1987 & $9.6 \%$ & $9.7 \%$ & - & $9.7 \%$ \\
\hline 1988 & $8.3 \%$ & $13.9 \%$ & - & $12.2 \%$ \\
\hline 1989 & $5.8 \%$ & $11.2 \%$ & - & $9.6 \%$ \\
\hline 1990 & $4.2 \%$ & $10.6 \%$ & - & $\overline{8.9 \%}$ \\
\hline 1991 & $5.1 \%$ & $11.5 \%$ & - & $9.9 \%$ \\
\hline 1992 & $7.4 \%$ & $10.8 \%$ & - & $9.9 \%$ \\
\hline 1993 & $9.6 \%$ & $9.0 \%$ & - & $9.8 \%$ \\
\hline 1994 & - & - & $75.0 \%$ & $8.8 \%$ \\
\hline
\end{tabular}

Source: Energy in China, various years; China Statistical Yearbook, various years; China Energy Research Society, 1994; Ministry of Electric Power Industry. 
Table II-19. Electricity Generation Capacity and Growth Rates, 1949-1994 (continued)

\begin{tabular}{|c|c|c|c|}
\hline \multicolumn{4}{|c|}{ 3. Shares of Total } \\
\hline Year & Hydro & Fossil & Nuclear \\
\hline 1949 & $8.6 \%$ & $91.4 \%$ & - \\
\hline 1950 & $9.1 \%$ & $90.9 \%$ & $=$ \\
\hline 1951 & $9.6 \%$ & $90.4 \%$ & - \\
\hline 1952 & $9.7 \%$ & $90.3 \%$ & - \\
\hline 1953 & $14.0 \%$ & $86.0 \%$ & - \\
\hline 1954 & $15.8 \%$ & $84.2 \%$ & - \\
\hline 1955 & $16.7 \%$ & $83.3 \%$ & - \\
\hline 1956 & $23.5 \%$ & $76.5 \%$ & - \\
\hline 1957 & $22.0 \%$ & $78.0 \%$ & - \\
\hline 1958 & $19.4 \%$ & $80.6 \%$ & - \\
\hline 1959 & $17.0 \%$ & $83.0 \%$ & $=$ \\
\hline 1960 & $16.3 \%$ & $83.7 \%$ & $=$ \\
\hline 1961 & $18.1 \%$ & $81.9 \%$ & - \\
\hline 1962 & $18.3 \%$ & $81.7 \%$ & - \\
\hline 1963 & $18.2 \%$ & $81.8 \%$ & - \\
\hline 1964 & $19.1 \%$ & $80.9 \%$ & - \\
\hline 1965 & $20.0 \%$ & $80.0 \%$ & - \\
\hline 1966 & $21.4 \%$ & $78.6 \%$ & - \\
\hline 1967 & $21.3 \%$ & $78.7 \%$ & - \\
\hline 1968 & $22.9 \%$ & $77.1 \%$ & - \\
\hline 1969 & $24.0 \%$ & $76.0 \%$ & $=$ \\
\hline 1970 & $-26.2 \%$ & $73.8 \%$ & - \\
\hline 1971 & $29.7 \%$ & $70.3 \%$ & - \\
\hline 1972 & $29.5 \%$ & $70.5 \%$ & - \\
\hline 1973 & $30.4 \%$ & $69.6 \%$ & - \\
\hline 1974 & $31.0 \%$ & $69.0 \%$ & - \\
\hline 1975 & $30.9 \%$ & $69.1 \%$ & - \\
\hline 1976 & $31.1 \%$ & $68.9 \%$ & - \\
\hline 1977 & $30.6 \%$ & $69.4 \%$ & - \\
\hline 1978 & $30.3 \%$ & $69.7 \%$ & - \\
\hline 1979 & $30.3 \%$ & $69.7 \%$ & $\therefore$ \\
\hline 1980 & $30.8 \%$ & $69.2 \%$ & $=$ \\
\hline 1981 & $31.7 \%$ & $68.3 \%$ & - \\
\hline 1982 & $31.7 \%$ & $68.3 \%$ & - \\
\hline 1983 & $31.6 \%$ & $68.4 \%$ & - \\
\hline 1984 & $32.0 \%$ & $68.0 \%$ & - \\
\hline 1985 & $30.4 \%$ & $69.6 \%$ & - \\
\hline 1986 & $29.4 \%$ & $70.6 \%$ & - \\
\hline 1987 & $29.3 \%$ & $70.7 \%$ & - \\
\hline 1988 & $28.3 \%$ & $71.7 \%$ & - \\
\hline 1989 & $27.3 \%$ & $72.7 \%$ & $=$ \\
\hline 1990 & $26.1 \%$ & $73.9 \%$ & $=$ \\
\hline 1991 & $25.0 \%$ & $75.0 \%$ & - \\
\hline 1992 & $24.4 \%$ & $75.6 \%$ & - \\
\hline 1993 & $24.4 \%$ & $75.0 \%$ & $0.7 \%$ \\
\hline 1994 & - & - & $1.1 \%$ \\
\hline
\end{tabular}

Source: Energy in China, various years; China Statistical Yearbook, various years; China Energy Research Society, 1994; Ministry of Electric Power Industry. 
Figure II-16. Electricity Generation Capacity

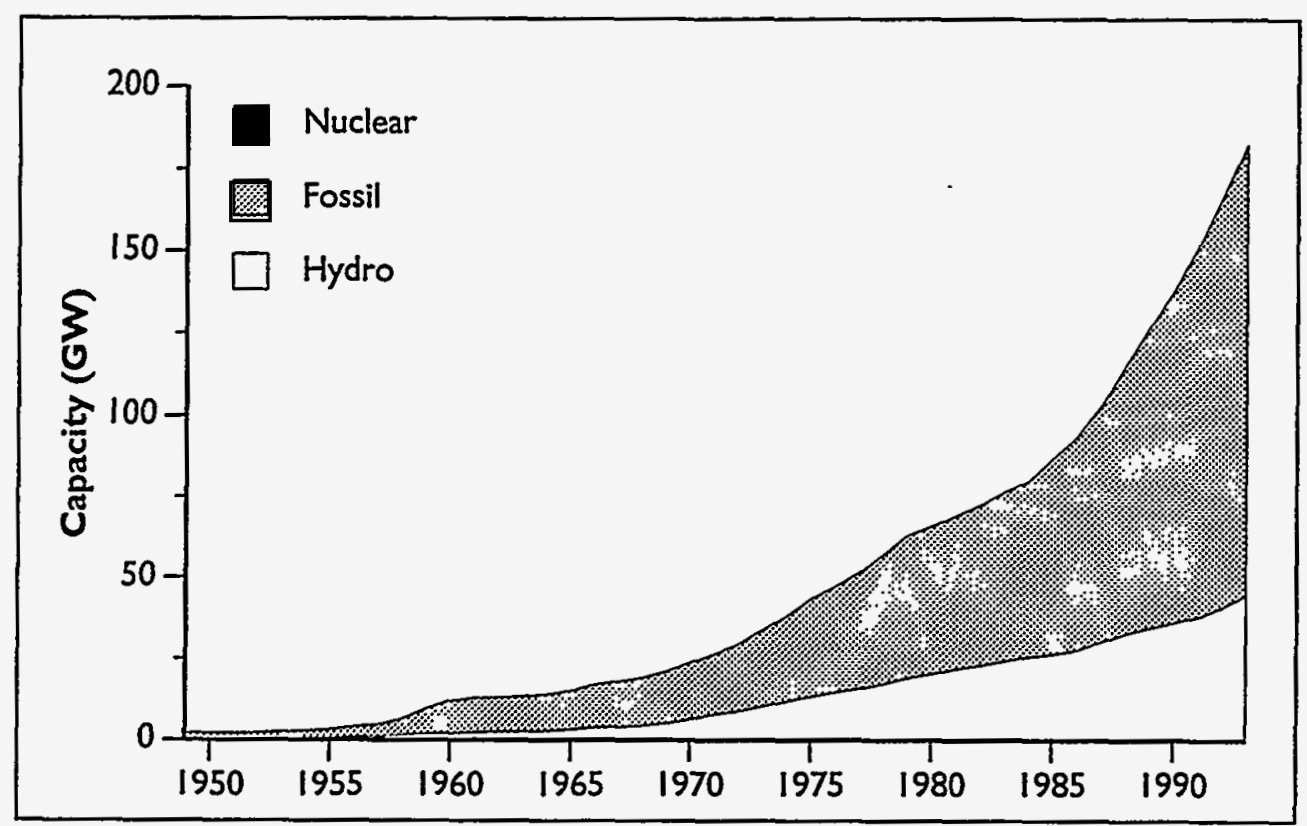


Table II-20. Installed Thermal Generation Capacity, by Type of Turbine, * 1974-1993

\begin{tabular}{|c|c|c|c|c|c|c|c|c|}
\hline \multirow{2}{*}{ Year } & \multirow{2}{*}{$\begin{array}{l}\text { High } \\
\text { Efficiency } \\
\text { Units } t \\
\text { (GW) }\end{array}$} & \multicolumn{3}{|c|}{ Low Efficiency Units I } & \multirow[b]{2}{*}{$\begin{array}{c}\text { Gas } \\
\text { Turbines } \\
\text { (GW) }\end{array}$} & \multirow[b]{2}{*}{$\begin{array}{c}\text { Diesel } ¥ \\
\text { (GW) }\end{array}$} & \multirow[b]{2}{*}{$\begin{array}{l}\text { Total } \\
\text { (GW) }\end{array}$} & \multirow{2}{*}{$\begin{array}{c}\text { of total: } \\
\text { Cogeneration } \\
\S \\
\text { (GW) }\end{array}$} \\
\hline & & $\begin{array}{l}\text { Med. Temp. } / \\
\text { Med. Press. } \\
\text { (GW) }\end{array}$ & $\begin{array}{l}\text { Low Temp.I } \\
\text { Low Press. } \\
\text { (GW) }\end{array}$ & $\begin{array}{c}\text { Subtotal } \\
\text { (GW) }\end{array}$ & & & & \\
\hline 1974 & 12.97 & - & - & - & 0.19 & - & 23.23 & 3.33 \\
\hline 1975 & 15.84 & - & - & - & 0.21 & - & 26.47 & 3.53 \\
\hline 1976 & 17.89 & - & - & - & 0.21 & - & 28.72 & 3.57 \\
\hline 1977 & 20.22 & - & - & - & 0.28 & - & 31.42 & 3.73 \\
\hline 1978 & 23.83 & - & - & - & 0.28 & - & 35.36 & 3.99 \\
\hline 1979 & 26.94 & 11.47 & & 11.47 & 0.29 & - & 38.70 & 4.15 \\
\hline 1980 & 28.48 & 11.45 & 0.27 & 11.72 & 0.30 & - & 40.50 & 4.43 \\
\hline 1981 & 29.62 & 11.60 & 0.26 & 11.86 & 0.30 & - & 41.78 & 4.54 \\
\hline 1982 & 31,41 & 11.74 & 0.26 & 12.00 & 0.30 & - & 43.71 & 4.68 \\
\hline 1983 & 34.49 & 11.88 & 0.22 & 12.10 & 0.29 & - & 46.88 & 4.91 \\
\hline 1984 & 36.75 & 11.92 & 0.22 & 12.14 & 0.27 & - & 49.16 & 5.14 \\
\hline 1985 & 41.99 & 12.16 & 0.21 & 12.37 & 0.47 & - & 54.83 & 5.35 \\
\hline 1986 & 46.41 & 1265 & 0.21 & 12.86 & 0.52 & 0.21 & 60.00 & 5.92 \\
\hline 1987 & 51.64 & 13.13 & 0.21 & 13.34 & 0.62 & 0.21 & 65.81 & 6.23 \\
\hline 1988 & 59.41 & 13.38 & 0.23 & 13.61 & 0.91 & 0.28 & 74.21 & 7.59 \\
\hline 1989 & 66.56 & 14.91 & 0.22 & 15.13 & 0.85 & 0.36 & 82.91 & 8.31 \\
\hline 1990 & 73.79 & 15.78 & 0.22 & 16.00 & 1.25 & 0.53 & 91.57 & 9.99 \\
\hline 1991 & 82.50 & 16.73 & 0.27 & 17.00 & 1.49 & 0.91 & 101.90 & 12.12 \\
\hline 1992 & 93.03 & 17.91 & 0.28 & 18.19 & 1.76 & 1.37 & 114.34 & 13.40 \\
\hline 1993 & 103.22 & 19.16 & 0.29 & 19.45 & 2.03 & 2.18 & 126.88 & 14.65 \\
\hline
\end{tabular}

* Includes only thermal power generation units over $6 \mathrm{MW}$ capacity.

$\dagger$ "High-efficiency" units are those which are designed to operate under high temperature and pressure.

I According to a 1988 source, large, domestically manufactured high-efficiency generating units consume $375-400 \mathrm{~g}$ of coal per $\mathrm{kWh}$ (43-46\% gross generation efficiency), large imported units consume about $335 \mathrm{~g} / \mathrm{kWh}$ ( $51 \%$ efficiency), while low-efficiency units can consume $550 \mathrm{~g} / \mathrm{kWh}$ ( $31 \%$ efficiency) (Wang, 1988).

Before 1985, total does not include diesel generators. Totals for 1974-1978 are greater than sums of categories for which there are figures. These figures differ from those in Table II-19, which include units with less than 6 MW capacity.

§ In 1985 the total installed cogeneration capacity was $6.5 \mathrm{GW}$ (including units with capacities under $6 \mathrm{MW}$ ) and in 1987 the total was $6.68 \mathrm{GW}$.

Source: China Energy Statistical Yearbook, various years; Wang, 1988; Electric Power Industry in China, 1990; Electric Power Industry in China, various years; Energy Research Institute. 
Table II-21. National Average Capacity Factors for Electric Power Generation, * 1978-1994

\begin{tabular}{|c|c|c|c|c|c|c|}
\hline \multirow[b]{2}{*}{ Year } & \multicolumn{3}{|c|}{ Total } & \multicolumn{3}{|c|}{ Hydro } \\
\hline & $\begin{array}{l}\text { Installed } \\
\text { Capacity } \\
\text { (GW) }\end{array}$ & $\begin{array}{c}\text { Gross } \\
\text { Generation } \\
\text { (TWh) }\end{array}$ & $\begin{array}{l}\text { Capacity } \\
\text { Factor }\end{array}$ & $\begin{array}{l}\text { Installed } \\
\text { Capacity } \\
\text { (GW) }\end{array}$ & $\begin{array}{c}\text { Gross } \\
\text { Generation } \\
\text { (TWh) }\end{array}$ & $\begin{array}{c}\text { Capacity } \\
\text { Factor }\end{array}$ \\
\hline $\begin{array}{l}1978 \\
1979\end{array}$ & 57.12 & 256.6 & 0.51 & 17.28 & 44.6 & 0.29 \\
\hline 1980 & 65.87 & 300.6 & 0.52 & 20.32 & $\frac{0.1}{58.2}$ & 0.33 \\
\hline 1981 & 69.00 & 309.3 & 0.51 & 21.93 & 65.5 & 0.34 \\
\hline 1982 & 72.36 & 327.7 & 0.52 & 22.96 & 74.4 & 0.37 \\
\hline 1983 & 76.44 & 351.4 & 0.52 & 24.16 & 86.4 & 0.41 \\
\hline 1984 & 80.12 & 377.0 & 0.54 & 25.60 & 86.8 & 0.39 \\
\hline 1985 & 87.05 & 410.7 & 0.54 & 26.41 & 92.4 & 0.40 \\
\hline 1986 & 93.82 & 449.6 & 0.55 & 27.54 & 94.5 & 0.39 \\
\hline 1987 & 102.90 & 497.3 & 0.55 & 30.19 & 100.2 & 0.38 \\
\hline 1988 & 115.50 & 545.1 & 0.54 & 32.70 & 109.2 & 0.38 \\
\hline 1989 & 126.64 & 584.7 & 0.53 & 34.58 & 118.4 & 0.39 \\
\hline 1990 & 137.89 & 621.2 & 0.51 & 36.05 & 126.7 & 0.40 \\
\hline 1991 & 151.47 & 677.5 & 0.51 & 37.88 & 124.7 & 0.38 \\
\hline 1992 & 166.53 & 753.9 & 0.52 & 40.68 & 130.7 & 0.37 \\
\hline 1993 & 182.91 & 815.9 & 0.51 & 44.59 & 146.0 & 0.37 \\
\hline 1994 & 199.00 & 909.0 & 0.52 & - & 170.4 & - \\
\hline
\end{tabular}

- These figures represent an average for all generation capacity. Capacity factors (CF) for different units may vary substantially from these values.

Source: China Energy Statistical Yearbook, various years; Energy in China, various years; Electric Power Industry in China, various years. 
Table II-21. National Average Capacity Factors for Electric Power Generation, * 1978-1994 (continued)

\begin{tabular}{|c|c|c|c|c|c|c|}
\hline \multirow[b]{2}{*}{ Year } & \multicolumn{3}{|c|}{ Fossil } & \multicolumn{3}{|c|}{ Nuclear } \\
\hline & $\begin{array}{l}\text { Installed } \\
\text { Capacity } \\
\text { (GW) }\end{array}$ & $\begin{array}{c}\text { Gross } \\
\text { Generation } \\
\text { (TWh) }\end{array}$ & $\begin{array}{c}\text { Capacity } \\
\text { Factor }\end{array}$ & $\begin{array}{c}\text { Installed } \\
\text { Capacity } \\
\text { (GW) }\end{array}$ & $\begin{array}{c}\text { Gross } \\
\text { Generation } \\
\text { (TWh) }\end{array}$ & $\begin{array}{c}\text { Capacity } \\
\text { Factor }\end{array}$ \\
\hline $\begin{array}{l}1978 \\
1979\end{array}$ & $\begin{array}{l}39.84 \\
43.91\end{array}$ & $\begin{array}{l}212.0 \\
231.9\end{array}$ & $\begin{array}{l}0.61 \\
0.60\end{array}$ & & - & - \\
\hline 1980 & 45.55 & 242.4 & 0.61 & - & - & - \\
\hline 1981 & 47.07 & 243.8 & 0.59 & - & - & - \\
\hline 1982 & 49.40 & 253.3 & 0.58 & - & - & - \\
\hline 1983 & 5228 & 265.0 & 0.58 & - & - & - \\
\hline 1984 & 54.52 & 290.2 & 0.61 & - & - & - \\
\hline 1985 & 60.64 & 318.3 & 0.60 & - & - & - \\
\hline 1986 & 66.28 & 355.1 & 0.61 & - & - & - \\
\hline 1987 & 72.71 & 397.1 & 0.62 & - & - & - \\
\hline 1988 & 82.80 & 435.9 & 0.60 & - & - & - \\
\hline 1989 & 92.11 & 466.3 & 0.58 & - & - & - \\
\hline 1990 & 101.84 & 494.5 & 0.55 & - & - & - \\
\hline 1991 & 11359 & 552.8 & 0.56 & - & - & - \\
\hline 1992 & 125.85 & 623.2 & 0.56 & - & - & - \\
\hline 1993 & 137.12 & 666.8 & 0.55 & 1.2 & 1.6 & 0.15 \\
\hline 1994 & - & 724.0 & - & 2.1 & 13.9 & 0.76 \\
\hline
\end{tabular}

* These figures represent an average for all generation capacity. Capacity factors (CF) for different units may vary substantially from these values.

Source: China Energy Statistical Yearbook, various years; Energy in China, various years; Electric Power Industry in China, various years. 
Table II-22. Installed Capacity and Performance of Large Power Networks, 1991

\begin{tabular}{|lcccr|}
\hline Network & $\begin{array}{c}\text { Installed } \\
\text { Capacity } \\
\text { (MW) }\end{array}$ & $\begin{array}{c}\text { Average } \\
\text { Utilization } \\
\text { (hours) }\end{array}$ & $\begin{array}{c}\text { Implied } \\
\text { Average } \\
\text { Capacity } \\
\text { Factor }\end{array}$ & $\begin{array}{r}\text { Load } \\
\text { Factor } \\
\text { (\%) }\end{array}$ \\
\hline North China & $18,835.8$ & 5,532 & 0.63 & $90.2 \%$ \\
Northeast China & $23,012.5$ & 4,763 & 0.54 & $85.5 \%$ \\
East China & $23,757.3$ & 5,243 & 0.60 & $90.1 \%$ \\
Central China & $22,003.5$ & 4,905 & .56 & $90.8 \%$ \\
Northwest China & $9,405.6$ & 5,041 & 0.58 & $83.4 \%$ \\
Shandong Province & $9,064.0$ & 5,879 & 0.67 & $87.0 \%$ \\
Fujian Province & $3,238.0$ & 4,253 & 0.49 & $82.6 \%$ \\
Sichuan Province & $7,005.9$ & 4,874 & 0.56 & $85.0 \%$ \\
Guangdong Province & $8,936.9$ & 5,723 & 0.65 & $85.9 \%$ \\
Guangxi Province & $1,746.5$ & 4,513 & 0.52 & $84.4 \%$ \\
Yunnan Province & $2,935.5$ & 4,234 & 0.48 & $81.8 \%$ \\
Guizhou Province & $2,198.3$ & 4,969 & 0.57 & $86.6 \%$ \\
Total/Average & $132,139.8$ & 5,126 & 0.59 & \\
National Total & $151,473.0$ & - & - & - \\
\hline
\end{tabular}

\section{Map II-8.China's Regional Power Networks}

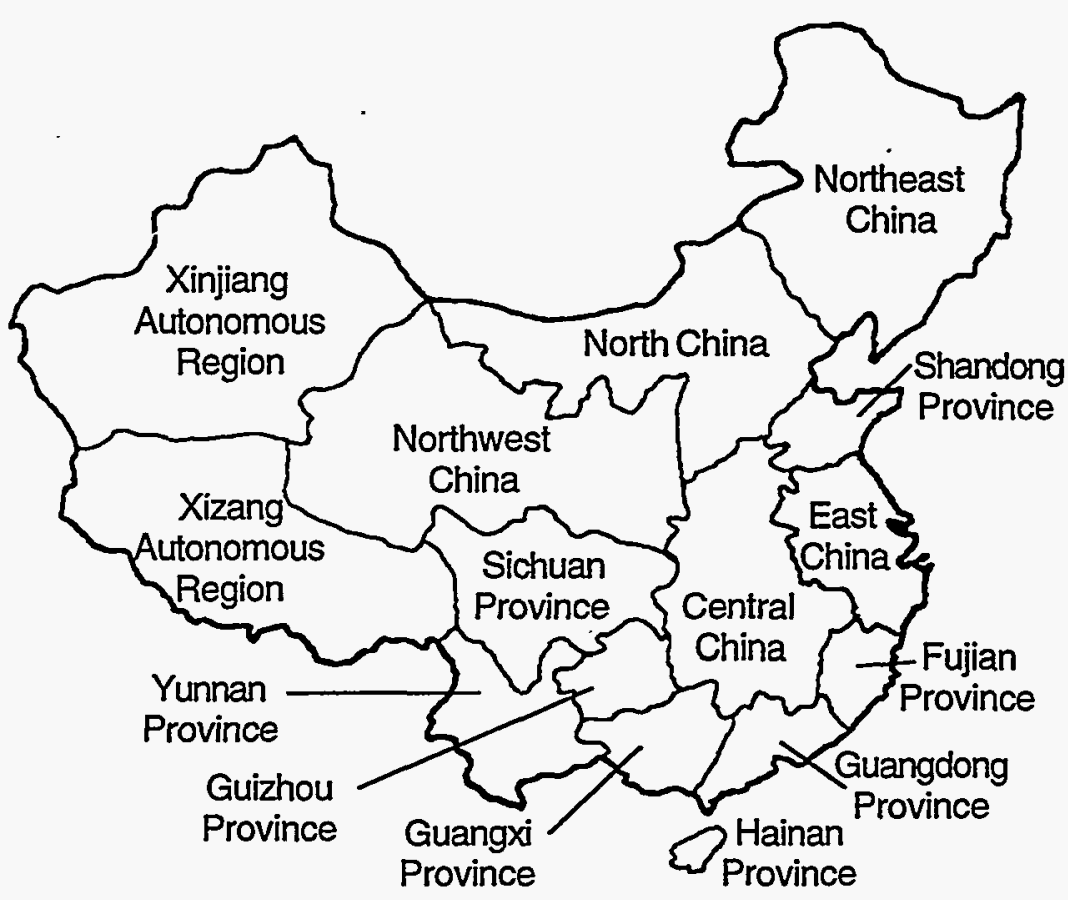

Source: Electric Power Industry in China, 1992. 
Table II-23. Thermal Power Generation and Capacity by Plant Size, 1978-1993

\begin{tabular}{|c|c|c|c|c|c|c|}
\hline \multirow[b]{2}{*}{ Year } & \multicolumn{3}{|c|}{ Power Plants $\geq 6 \mathrm{MW}$} & \multicolumn{3}{|c|}{ Power Plants < $6 \mathrm{MW}$} \\
\hline & $\begin{array}{c}\text { Gross } \\
\text { Generation } \\
\text { (TWh) }\end{array}$ & $\begin{array}{c}\text { Installed } \\
\text { Capacity } \\
\text { (GW) }\end{array}$ & $\begin{array}{c}\text { Capacity } \\
\text { Factor }\end{array}$ & $\begin{array}{c}\text { Gross } \\
\text { Generation } \\
\text { (TWh) }\end{array}$ & $\begin{array}{c}\text { Installed } \\
\text { Capacity } \\
\text { (GW) }\end{array}$ & $\begin{array}{c}\text { Capacity } \\
\text { Factor }\end{array}$ \\
\hline 1978 & - & 35.36 & - & - & 4.48 & - \\
\hline 1979 & 22235 & 38.70 & 0.66 & 9.55 & 5.21 & 0.21 \\
\hline 1980 & 234.29 & 40.50 & 0.66 & 8.11 & 5.05 & 0.18 \\
\hline 1981 & 236.76 & 41.78 & 0.65 & 7.04 & 5.42 & 0.15 \\
\hline 1982 & 246.90 & 43.71 & 0.64 & 6.40 & 5.69 & 0.13 \\
\hline 1983 & 258.88 & 46.88 & 0.63 & 6.12 & 5.40 & 0.13 \\
\hline 1984 & 283.96 & 49.16 & 0.66 & 6.25 & 5.36 & 0.13 \\
\hline 1985 & 310.20 & 54.83 & 0.65 & 8.10 & 5.80 & 0.16 \\
\hline 1986 & 347.82 & 60.01 & 0.66 & 7.27 & 6.27 & 0.13 \\
\hline 1987 & 389.96 & 65.82 & 0.68 & 7.13 & 6.68 & 0.12 \\
\hline 1988 & 427.28 & 73.02 & 0.67 & 8.61 & 9.78 & 0.10 \\
\hline 1989 & 457.50 & 85.11 & 0.61 & 8.70 & 6.95 & 0.14 \\
\hline 1990 & 486.80 & 94.56 & 0.59 & 8.17 & 7.28 & 0.13 \\
\hline 1991 & 544.52 & 105.97 & 0.59 & 8.13 & 7.62 & 0.12 \\
\hline 1992 & 61232 & 117.82 & 0.59 & 10.40 & 8.04 & 0.15 \\
\hline 1993 & - & 122.69 & - & - & 15.32 & - \\
\hline \multicolumn{7}{|c|}{ Power Plants $\geq 500 \mathrm{~kW}$} \\
\hline Year & $\begin{array}{c}\text { Gross } \\
\text { Generation } \\
\text { (TWh) }\end{array}$ & $\begin{array}{c}\text { Installed } \\
\text { Capacity } \\
\text { (GW) }\end{array}$ & $\begin{array}{l}\text { Capacity } \\
\text { Factor }\end{array}$ & $\begin{array}{c}\text { Gross } \\
\text { Generation } \\
\text { (TWh) }\end{array}$ & $\begin{array}{c}\text { Installed } \\
\text { Capacity } \\
\text { (GW) }\end{array}$ & $\begin{array}{c}\text { Capacity } \\
\text { Factor }\end{array}$ \\
\hline 1980 & 241.06 & 43.63 & 0.63 & 1.34 & 1.92 & 0.08 \\
\hline 1981 & 242.12 & 44.95 & 0.61 & 1.69 & 2.25 & 0.09 \\
\hline 1982 & 252.20 & 46.94 & 0.61 & 1.10 & 2.60 & 0.05 \\
\hline 1983 & 264.01 & 50.69 & 0.59 & 0.99 & 1.59 & 0.07 \\
\hline 1984 & 289.14 & 52.34 & 0.63 & 1.06 & 2.18 & 0.06 \\
\hline 1985 & 316.43 & 58.09 & 0.62 & 1.87 & 2.54 & 0.08 \\
\hline 1986 & 352.18 & 63.40 & 0.63 & 2.92 & 2.87 & 0.12 \\
\hline 1987 & 394.70 & 69.57 & 0.65 & 2.40 & 3.14 & 0.09 \\
\hline 1988 & 432.37 & 78.69 & 0.63 & 3.53 & 4.11 & 0.10 \\
\hline 1989 & 462.97 & 87.52 & 0.60 & 3.33 & 4.54 & 0.08 \\
\hline 1990 & 491.92 & 97.08 & 0.58 & 3.05 & 4.76 & 0.07 \\
\hline 1991 & 550.25 & 108.60 & 0.58 & 2.40 & 4.99 & 0.05 \\
\hline 1992 & 619.05 & 120.52 & 0.59 & 3.68 & 5.33 & 0.08 \\
\hline 1993 & 679.38 & 132.91 & 0.58 & 6.43 & 5.10 & 0.14 \\
\hline
\end{tabular}

Source: China Annual Energy Review, 1994; China Energy Statistical Yearbook, various years; China Statistical Yearbook, various years; Electric Power Industry in China, various years; Energy Research Institute. 

Table II-24. Generation by Self-Producers, *
1980-1993

\begin{tabular}{|cccc|}
\hline Year & $\begin{array}{c}\text { Gross } \\
\text { Generation } \\
\text { (TWh) }\end{array}$ & $\begin{array}{c}\text { Installed } \\
\text { Capacity } \\
\text { (GW) }\end{array}$ & $\begin{array}{c}\text { Capacity } \\
\text { Factor }\end{array}$ \\
\hline 1980 & 15.51 & 3.86 & 0.46 \\
1981 & 15.05 & 4.17 & 0.41 \\
1982 & 17.99 & 4.89 & 0.42 \\
1983 & 20.53 & 5.55 & 0.42 \\
1984 & 23.53 & 5.96 & 0.45 \\
1985 & 26.11 & 6.36 & 0.47 \\
1986 & 31.69 & 7.62 & 0.47 \\
1987 & 35.19 & 8.81 & 0.46 \\
1988 & 39.10 & 9.72 & 0.46 \\
1989 & 44.03 & 10.50 & 0.48 \\
1990 & 47.16 & 11.19 & 0.48 \\
1991 & 50.33 & 12.52 & 0.46 \\
1992 & 59.96 & 14.57 & 0.47 \\
1993 & - & 15.50 & - \\
& & & \\
\hline
\end{tabular}

- Thermal generation units operated by non-utility generators, for instance large factories.

Source: China Energy Statistical Yearbook, various years; Electric Power Industry in China, various years. 
Table II-25. Hydropower Generation and Capacity by Plant Size, 1980-1992

\begin{tabular}{|c|c|c|c|c|c|c|c|}
\hline \multicolumn{8}{|c|}{ I. Hydropower Generation for plants with installed capacities $\geq 500 \mathrm{~kW}$ and $<500 \mathrm{~kW}$. } \\
\hline \multirow[b]{2}{*}{ Year } & \multirow{2}{*}{$\begin{array}{c}\text { Total * } \\
\text { Gross } \\
\text { Hydro } \\
\text { Generation } \\
\text { (TWh) }\end{array}$} & \multicolumn{3}{|c|}{ Power Plants $\geq 500 \mathrm{~kW}$} & \multicolumn{3}{|c|}{ Power Plants $<500 \mathrm{~kW}$} \\
\hline & & $\begin{array}{c}\text { Gross } \\
\text { Generation } \\
\text { (TWh) }\end{array}$ & $\begin{array}{c}\text { Installed } \\
\text { Capacity } \\
\text { (GW) }\end{array}$ & $\begin{array}{l}\text { Capacity } \\
\text { Factor }\end{array}$ & $\begin{array}{c}\text { Gross } \\
\text { Generation } \\
\text { (TWh) }\end{array}$ & $\begin{array}{l}\text { Installed } \\
\text { Capacity } \\
\text { (GW) }\end{array}$ & $\begin{array}{c}\text { Capacity } \\
\text { Factor }\end{array}$ \\
\hline 1980 & 58.2 & 53.95 & 16.87 & 0.36 & 4.25 & 3.45 & 0.14 \\
\hline 1981 & 65.5 & 61.36 & 18.41 & 0.38 & 4.14 & 3.52 & 0.13 \\
\hline 1982 & 74.4 & 69.65 & 19.45 & 0.41 & 4.75 & 3.51 & 0.15 \\
\hline 1983 & 86.4 & 81.30 & 20.67 & 0.45 & 5.10 & 3.49 & 0.17 \\
\hline 1984 & 86.8 & 81.87 & 21.93 & 0.43 & 4.93 & 3.67 & 0.15 \\
\hline 1985 & 924 & 86.71 & 22.72 & 0.44 & 5.69 & 3.69 & 0.18 \\
\hline 1986 & 94.5 & 89.13 & 23.93 & 0.42 & 5.37 & 3.61 & 0.17 \\
\hline 1987 & 100.2 & 93.74 & 26.45 & 0.40 & 6.46 & 3.74 & 0.20 \\
\hline 1988 & 109.2 & 102.30 & 28.82 & 0.40 & 6.90 & 3.87 & 0.20 \\
\hline 1989 & 118.4 & 111.09 & 30.42 & 0.42 & 7.31 & 4.17 & 0.20 \\
\hline 1990 & 126.4 & 117.95 & 31.75 & 0.42 & 8.45 & 4.23 & 0.23 \\
\hline 1991 & 124.9 & 117.54 & 33.65 & 0.40 & 7.31 & 4.23 & 0.20 \\
\hline 1992 & 131.5 & 123.51 & 36.69 & 0.38 & 7.96 & 4.22 & 0.22 \\
\hline
\end{tabular}

\begin{tabular}{|c|c|c|c|c|c|c|}
\hline \multicolumn{7}{|c|}{ 2. Hydropower Plant Capacity and Generation by Size, 1983} \\
\hline \multirow[b]{2}{*}{$\begin{array}{l}\text { Plant } \\
\text { Size } \\
\text { (MW) }\end{array}$} & \multirow[b]{2}{*}{ Number } & \multirow[b]{2}{*}{$\begin{array}{c}\text { Installed } \\
\text { Capacity } \\
\text { (GW) }\end{array}$} & \multirow[b]{2}{*}{$\begin{array}{c}\text { Gross } \\
\text { Generation } \\
\text { (TWh) }\end{array}$} & \multirow[b]{2}{*}{$\begin{array}{l}\text { Capacity } \\
\text { Factor }\end{array}$} & \multicolumn{2}{|c|}{ Shares of: } \\
\hline & & & & & $\begin{array}{l}\text { Installed } \\
\text { Capacity } \\
\text { (percent) }\end{array}$ & $\begin{array}{c}\text { Annual } \\
\text { Generation } \\
\text { (percent) }\end{array}$ \\
\hline Total & 4,546 & 33.65 & 117.54 & 0.40 & $100 \%$ & $100 \%$ \\
\hline$>250$ & 25 & 15.93 & 60.84 & 0.44 & $47 \%$ & $52 \%$ \\
\hline $25-250$ & 95 & 7.62 & 25.63 & 0.38 & $23 \%$ & $22 \%$ \\
\hline$<25$ & 4,426 & 10.10 & 31.07 & 0.35 & $30 \%$ & $26 \%$ \\
\hline $12-25 \mathrm{MW}$ & 125 & 1.84 & 6.14 & 0.38 & $5 \%$ & $5 \%$ \\
\hline $0.5-12 \mathrm{MW}$ & 4,095 & 7.53 & 24.81 & 0.38 & $22 \%$ & $21 \%$ \\
\hline
\end{tabular}

* The totals in Table II-23.2 and II-23.3 are different probably because many small hydropower stations were taken out of service in the early 1980 s (e.g., due to poor maintenance or silting of reservoirs). The figures also come from different sources, which may be the cause of the discrepancy.

Source: China Energy Statistical Yearbook, various years; Wang, 1988; Energy in China, various years; Electric Power Industry in China, various years; Water Resources Development in China, various years; Energy Research Institute. 
Table II-25. Hydropower Generation and Capacity by Plant Size, 1980-1992 (continued)

3. Small Hydropower Generation \& Installed Capacity, 1987

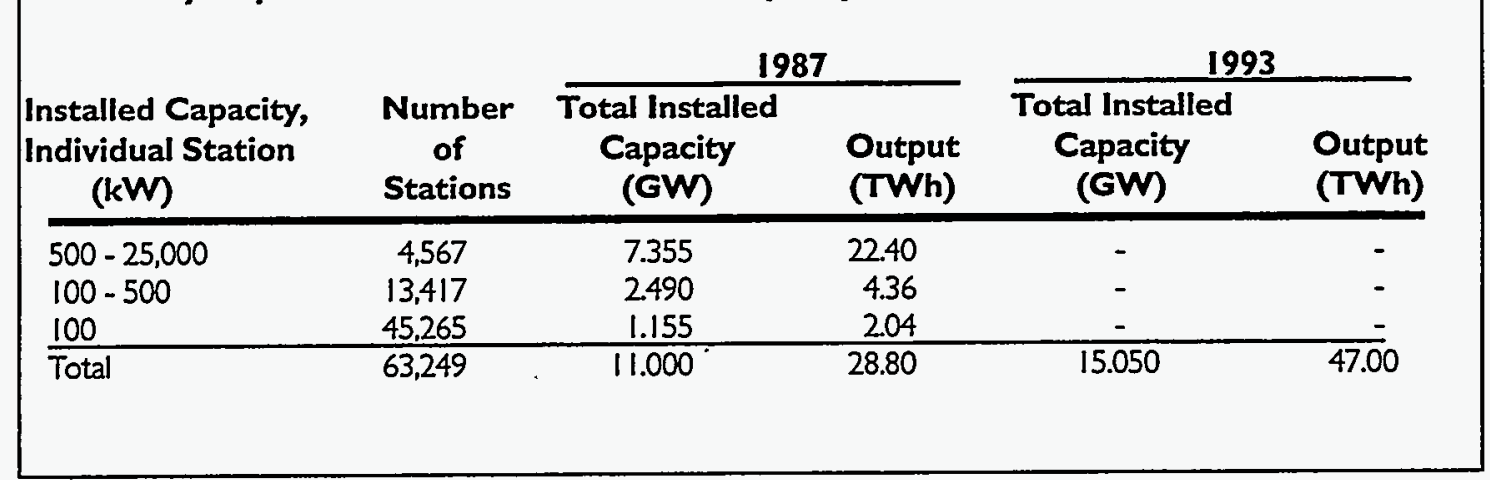

Source: China Energy Statistical Yearbook, various years; Wang, Energy in China, 1988; Energy in China, various years; Electric Power Industry in China, various years; Water Resources Development in China, various years; Energy Research Institute. 
Table II-26. Principal Thermal Power Plants >600.MW, 1991

\begin{tabular}{|c|c|c|c|c|c|}
\hline \multirow[b]{2}{*}{$\begin{array}{l}\text { Name of } \\
\text { Power Plant }\end{array}$} & \multirow[b]{2}{*}{$\begin{array}{l}\text { Location } \\
\text { (Province) }\end{array}$} & \multicolumn{2}{|c|}{ Plant Capacity (MW) } & \multirow[b]{2}{*}{ Configuration * } & \multirow[b]{2}{*}{ Fuel } \\
\hline & & Design & $\begin{array}{l}\text { Existing in } \\
12 / 31 / 91\end{array}$ & & \\
\hline Jianbi & Jiangsu & 1,625 & 1,625 & $3 \times 100,4 \times 300$ & coal \\
\hline Harbin No.3 & Heilongjiang & 1,600 & 400 & $2 \times 200,2 \times 600$ & coal \\
\hline Douhe & Hebei & 1,550 & 1,550 & $2 \times 125,4 \times 200,2 \times 250$ & coal \\
\hline Qinghe & Liaoning & 1,300 & 1,300 & $5 \times 100,4 \times 200$ & coal, oil \\
\hline Shentou & Shanxi & 1,300 & 1,300 & $6 \times 200$ & coal \\
\hline Xuzhou & Jiangsu & 1,300 & 1,300 & $4 \times 125,4 \times 200$ & coal \\
\hline Xingtai & Hebei & 1,290 & 1,290 & $6 \times 200$ & coal \\
\hline Jiaozuo & Henan & 1,224 & 1,024 & $6 \times 200$ & coal \\
\hline Beilungang & Zhejiang & 1,200 & $\cdots \quad t$ & $2 \times 600$ & coal \\
\hline Changshu & liangsu & 1.200 & $t$ & $4 \times 300$ & coal \\
\hline Datong No.2 & Shanxi & 1,200 & 1,200 & $6 \times 200$ & $\overline{c o a l}$ \\
\hline Fularji No. 2 & Heilongjiang & 1,200 & 1,200 & $6 \times 200$ & coal \\
\hline Hanchuan & Hubei & 1,200 & 600 & $4 \times 300$ & coal \\
\hline Hualu & Shandong & 1,200 & 600 & $4 \times 300$ & coal \\
\hline Jinzhou & Liaoning & 1,200 & 1,200 & $6 \times 200$ & coal \\
\hline Pingwei & Anhui & 1,200 & 600 & $2 \times 600$ & coal \\
\hline Shajiao A & Guangdong & 1,200 & 400 & $3 \times 200,2 \times 300$ & coal \\
\hline Shalingzi & Hebei & 1,200 & 300 & $4 \times 300$ & coal \\
\hline Shidongkou & Shanghai & 1,200 & 1,200 & $4 \times 300$ & coal \\
\hline Shidongkou No 2 & Shanghai & 1,200 & $t$ & $2 \times 600$ & coal \\
\hline Tieling & Liaoning & 1,200 & $t$ & $4 \times 300$ & coal \\
\hline Tongliao & Inner Mongolia & 1,200 & 800 & $4 \times 200$ & coal \\
\hline Weihe & Shaanxi & 1,200 & 300 & $4 \times 300$ & coal \\
\hline Xibaipo & Hebei & 1,200 & $t$ & $4 \times 300$ & coal \\
\hline Yaomeng & Henan & 1,200 & 1,200 & $4 \times 300$ & coal \\
\hline Zhouxian & Shandong & 1,200 & 1,200 & $4 \times 300$ & coal \\
\hline Huangpu & Guangdong & 1,100 & 1,100 & $4 \times 125,2 \times 300$ & coal, oil \\
\hline Wangting & Jiangsu & 1,100 & 1,100 & $3 \times 300$ & coal, oil \\
\hline Liaoning & Liaoning & 1,050 & 1,050 & $13 \times 50,2 \times 200$ & coal, oil \\
\hline Qinling & Shaanxi & 1.050 & 1,050 & $2 \times 125,4 \times 200$ & coal \\
\hline Zhenhai & Zhejiang & 1,050 & 1,050 & $2 \times 125,4 \times 200$ & coal, oil \\
\hline Zhangze & Shanxi & 1,040 & 1,040 & $2 \times 100,4 \times 210$ & coal \\
\hline Shentou No.2 & Shanxi & 1,000 & $t$ & $2 \times 500$ & coal \\
\hline Huaibei & Anhui & 950 & 750 & $2 \times 125,3 \times 200$ & coal \\
\hline Wujing & Shanghai & 950 & 750 & $1 \times 100,1 \times 125,2 \times 300$ & coal \\
\hline Huangtai & Shandong & 925 & 925 & $2 \times 100,2 \times 300$ & coal \\
\hline Yuanbaoshan & Inner Mongolia & 900 & 900 & $1 \times 300,1 \times 600$ & coal \\
\hline Jilin & Jitin & 850 & 650 & $2 \times 100,2 \times 200$ & coal, oil \\
\hline Matou & Hebei & 850 & 850 & $2 \times 100,3 \times 200$ & coal \\
\hline Junliancheng & Tianjin & 840 & 640 & $3 \times 200$ & coal, oil \\
\hline
\end{tabular}

* In some cases reported configurations do not match plan capacities because units under $100 \mathrm{MW}$ are not reported, except for Liaoning Power Plant.

$\dagger$ No units commissioned.

I Cogeneration plant.

Source: Electric Power Industry in China, 1992. 
Table II-26. Principal Thermal Power Plants $>600$ MW, 1991 (continued)

\begin{tabular}{|c|c|c|c|c|c|}
\hline \multirow[b]{2}{*}{$\begin{array}{l}\text { Name of } \\
\text { Power Plant }\end{array}$} & \multirow[b]{2}{*}{$\begin{array}{l}\text { Location } \\
\text { (Province) }\end{array}$} & \multicolumn{2}{|c|}{ Plant Capacity (MW) } & \multirow[b]{2}{*}{ Configuration * } & \multirow[b]{2}{*}{ Fuel } \\
\hline & & Design & $\begin{array}{c}\text { Existing in } \\
\mid 2 / 31 / 91\end{array}$ & & \\
\hline Mudanjiang & Heilongilang & 820 & 820 & $4 \times 100,2 \times 210$ & coal \\
\hline Shuangyashan & Heilongijang & 820 & 610 & $2 \times 200,2 \times 210$ & coal \\
\hline Minhang & Shanghai & 818 & 818 & $2 \times 110,4 \times 125$ & coal \\
\hline Jinagyuan & Gansu & 800 & 600 & $4 \times 200$ & coal \\
\hline Taizhou & Zhejiang & 750 & 750 & $6 \times 125$ & coal \\
\hline Shiheng & Shandong & 735 & 735 & $2 \times 300$ & coal \\
\hline \multirow[t]{2}{*}{ Baoshan } & Shanghai & 700 & 700 & $2 \times 350$ & coal, \\
\hline & & & & \multicolumn{2}{|c|}{ blast fumace gas } \\
\hline Dalian & Liaoning & 700 & 700 & - & coal \\
\hline Fuzhou & Fujian & 700 & 700 & $2 \times 350$ & coal \\
\hline Ligang & liangsu & 700 & $t$ & $2 \times 350$ & coal \\
\hline Luohuang & Sichuan & 700 & 700 & $350 \times 2$ & coal \\
\hline Nantong & Jiangsu & 700 & 700 & $2 \times 350$ & coal \\
\hline Shajiao B & Guangdong & 700 & 700 & $2 \times 350$ & coal \\
\hline Shang'an & Hebei & 700 & 700 & $2 \times 350$ & coal \\
\hline Yueyang & Hunan & 700 & 700 & $2 \times 350$ & coal \\
\hline Chongqing & Sichuan & 696 & 696 & $2 \times 200$ & coal \\
\hline Changshan & jilin & 693 & 693 & $2 \times 200$ & coal \\
\hline Qingshan & Hubei & 674 & 674 & $2 \times 100,1 \times 200$ & coal, oil \\
\hline Huangdao & Shandong & 670 & 670 & $2 \times 125,2 \times 210$ & coal \\
\hline liangyou & Sichuan & 660 & 660 & $2 \times 330$ & coal \\
\hline Qingzhen & Guizhou & 658 & 658 & $2 \times 200$ & coal \\
\hline jiujiang & Jiangxi & 650 & 450 & $2 \times 125,2 \times 200$ & coal \\
\hline Dagang No. 1 & Tranjin & 640 & 640 & $2 \times 320$ & oil \\
\hline Dagang No. 2 & Tianjin & 640 & 640 & $2 \times 321$ & coal \\
\hline Shiliquan & Shandong & 625 & 625 & $5 \times 125$ & coal \\
\hline Shaoguan & Guangdong & 624 & 624 & $2 \times 200$ & coal \\
\hline Daba & Ningxia & 600 & 300 & $2 \times 300$ & coal \\
\hline Daqing & Heilongijang & 600 & 200 & $3 \times 200$ & coal \\
\hline Fengzhen & Inner Mongolia & 600 & 400 & $3 \times 200$ & coal \\
\hline Gaojing & Beiling & 600 & 600 & $6 \times 100$ & coal \\
\hline Huainan & Anhui & 600 & 600 & $2 \times 120,2 \times 125$ & coal \\
\hline Jingmen & Hubei & 600 & 600 & $2 \times 100,2 \times 200$ & coal \\
\hline Jinzhushan & Hunan & 600 & 600 & $4 \times 125$ & coal \\
\hline Longkou & Shandong & 600 & 600 & $2 \times 100,2 \times 200$ & coal \\
\hline Luohe & Anhui & 600 & 600 & $2 \times 300$ & coal \\
\hline Naniing & Jiangsu & 600 & $t$ & $2 \times 300$ & coal \\
\hline Shenzhen & Guangdong & 600 & $t$ & $2 \times 300$ & coal \\
\hline Shijingshan $T$ & Beijing & 600 & 600 & $3 \times 200$ & coal \\
\hline Weifang & Shandong & 600 & $t$ & $2 \times 300$ & coal \\
\hline Xindian & Shandong & 600 & 600 & $2 \times 100,2 \times 200$ & oil \\
\hline Yangluo & Hubei & 600 & $t$ & $2 \times 300$ & coal \\
\hline Zhujiang & Guangdong & 600 & $t$ & $2 \times 300$ & coal \\
\hline
\end{tabular}

- In some cases reported configurations do not match plan capacities because units under $100 \mathrm{MW}$ are not reported, except for Liaoning Power Plant.

$\dagger$ No units commissioned.

7 Cogeneration plant.

Source: Electric Power Industry in China, 1992. 
Table II-27. Capacity Factors for Principal Hydropower Plants $\geq 250$ MW, 1991

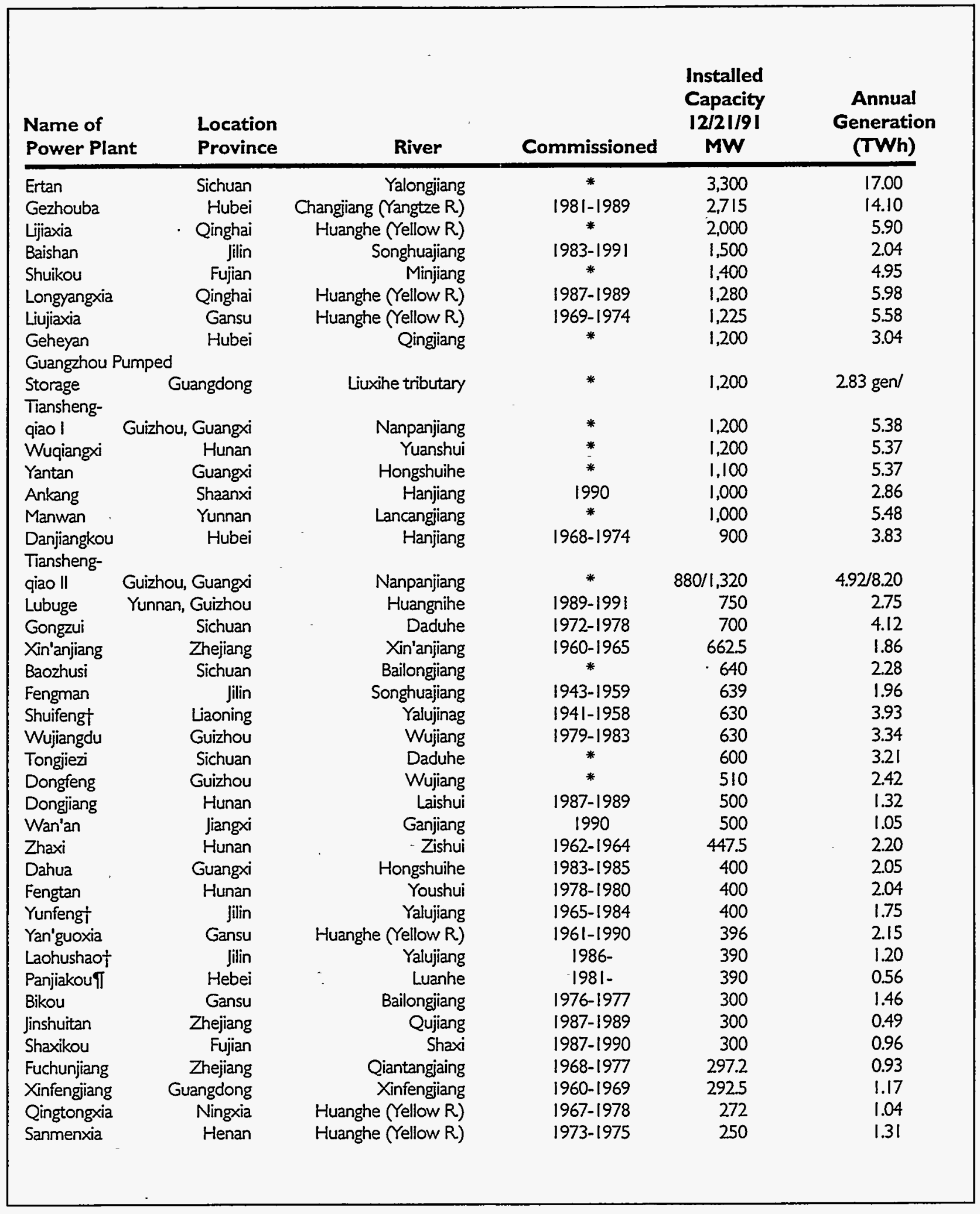

* Under construction.

† The output of hydropower plants on the Yalu River are shared equally by China and North Korea. Their entire capacity and output are included here in calculating the average capacity factor.

I Includes $150 \mathrm{MW}$ conventional and $240 \mathrm{MW}$ pumped storage capacity.

Source: Electric Power Industry in China, 1992. 
Table II-28. Coverage of Rural Electric Grids, * Selected Years

\begin{tabular}{|c|c|c|c|c|c|c|c|}
\hline Northeast & North & Northwest & East & South-Central* & Southwest & Nati & al Average \\
\hline \multicolumn{8}{|c|}{ Percent of Townships with Electricity } \\
\hline 1979 & $98 \%$ & $88 \%$ & $70 \%$ & $90 \%$ & $93 \%$ & $83 \%$ & $87 \%$ \\
\hline 1983 & $98 \%$ & $94 \%$ & $77 \%$ & $95 \%$ & $91 \%$ & $85 \%$ & $90 \%$ \\
\hline 1984 & $99 \%$ & $94 \%$ & $77 \%$ & $95 \%$ & $90 \%$ & $86 \%$ & $90 \%$ \\
\hline 1990 & - & & - & - & - & - & $96 \%$ \\
\hline \multicolumn{8}{|c|}{ Percent of Villages with Electricity } \\
\hline 1979 & $95 \%$ & $78 \%$ & $48 \%$ & $61 \%$ & $64 \%$ & $47 \%$ & $63 \%$ \\
\hline 1983 & $97 \%$ & $87 \%$ & $56 \%$ & $77 \%$ & $71 \%$ & $59 \%$ & $73 \%$ \\
\hline 1984 & $96 \%$ & $86 \%$ & $60 \%$ & $78 \%$ & $74 \%$ & $69 \%$ & $75 \%$ \\
\hline 1990 & - & - & - & - & - & - & $88 \%$ \\
\hline 1993 & - & - & - & - & - & - & $92 \%$ \\
\hline \multicolumn{8}{|c|}{ Percent of Rural Households with Electricity } \\
\hline 1991 & - & - & - & - & - & - & $80 \%$ \\
\hline 1993 & - & - & - & - & - & - & $87 \%$ \\
\hline
\end{tabular}

- The decrease in coverage in some areas may reflect a change in organizational structure in rural areas, e.g., some townships were reclassified as municipalities.

Source: Wang,1988; Jing/l Ribao [Economic Daily], 5 August 1991; Electric Power Industry in China, 1992; Redian Jishu [Cogeneration Technology], 1994, no. 1. 
Table II-29. Railway and Pipeline Transportation of Coal and Oil, * Selected Years

\begin{tabular}{|c|c|c|c|c|c|c|c|}
\hline Year & $\begin{array}{r}\text { Coal } \\
(G t-k m)\end{array}$ & $\begin{array}{r}\text { Coke } \\
(\text { Gt-km) }\end{array}$ & $\begin{array}{r}\text { Oil } \\
\text { (Gt-km) }\end{array}$ & $\begin{array}{r}\text { Subtotal: } \\
\text { Energy } \\
\text { Products } \\
\text { (Gt-km) }\end{array}$ & $\begin{array}{r}\text { Total } \\
\text { Railway } \\
\text { Freight } \\
\text { (Gt-km) }\end{array}$ & $\begin{array}{r}\text { Energy } \\
\text { Products as } \\
\% \text { of Total } \\
\text { Freight }\end{array}$ & $\begin{array}{r}\text { Oil and } \\
\text { Gas } \\
\text { Pipelines } \\
\text { (Gt-km) }\end{array}$ \\
\hline 1965 & 79.29 & 3.17 & 17.16 & 99.62 & 269.64 & $36.9 \%$ & - \\
\hline 1970 & 95.00 & 4.07 & 35.02 & 134.09 & 349.14 & $38.4 \%$ & - \\
\hline 1975 & 110.20 & 4.95 & 41.24 & 156.39 & 424.61 & $36.8 \%$ & 26.2 \\
\hline 1978 & 148.13 & 6.62 & 35.64 & 190.39 & 533.35 & $35.7 \%$ & 43.0 \\
\hline 1979 & 164.68 & 7.28 & 33.07 & 205.03 & 558.87 & $36.7 \%$ & 47.6 \\
\hline 1980 & 176.67 & 6.87 & 30.07 & 213.61 & 570.73 & $37.4 \%$ & 49.1 \\
\hline 1981 & 183.17 & 6.92 & 28.68 & 218.77 & 570.13 & $38.4 \%$ & 49.9 \\
\hline 1982 & 199.76 & 6.49 & 28.85 & 235.10 & 610.90 & $38.5 \%$ & 50.1 \\
\hline 1983 & 213.15 & 7.30 & 29.96 & 250.41 & 663.45 & $37.7 \%$ & 53.4 \\
\hline 1984 & 233.55 & 7.68 & 31.26 & 272.49 & 723.48 & $37.7 \%$ & 57.2 \\
\hline 1985 & 259.59 & 9.59 & 34.07 & 303.25 & 811.16 & $37.4 \%$ & 60.3 \\
\hline 1986 & 277.00 & 10.38 & 37.53 & 324.91 & 875.01 & $37.1 \%$ & 61.2 \\
\hline 1987 & 285.74 & 1261 & 39.69 & 338.04 & 945.57 & $35.7 \%$ & 62.5 \\
\hline 1988 & 299.51 & 15.36 & 39.12 & 353.99 & 986.02 & $35.9 \%$ & 65.0 \\
\hline 1989 & 316.18 & 17.28 & 39.99 & 373.45 & $1,037.30$ & $36.0 \%$ & 62.9 \\
\hline 1990 & 344.64 & 19.46 & 42.00 & 406.10 & $1,060.12$ & $38.3 \%$ & 62.7 \\
\hline 1991 & 341.42 & 18.06 & 43.77 & 403.25 & $1,094.81$ & $36.8 \%$ & 62.1 \\
\hline 1992 & 357.71 & 19.40 & 46.18 & 423.29 & 1.154 .85 & $36.7 \%$ & 61.7 \\
\hline 1993 & 358.86 & 24.65 & 49.90 & 433.41 & $1,192.34$ & $36.3 \%$ & 60.8 \\
\hline
\end{tabular}

* In terms of tonnage handled, coal, coke, and oil accounted for $41.7 \%, 2 \%$, and $4.5 \%$, for a total of $48 \%$ in 1993 .

Source: Statistical Yearbook of China, various years; China Transportation Yearbook various years.

Figure II-17 Railway Transport of Energy Products

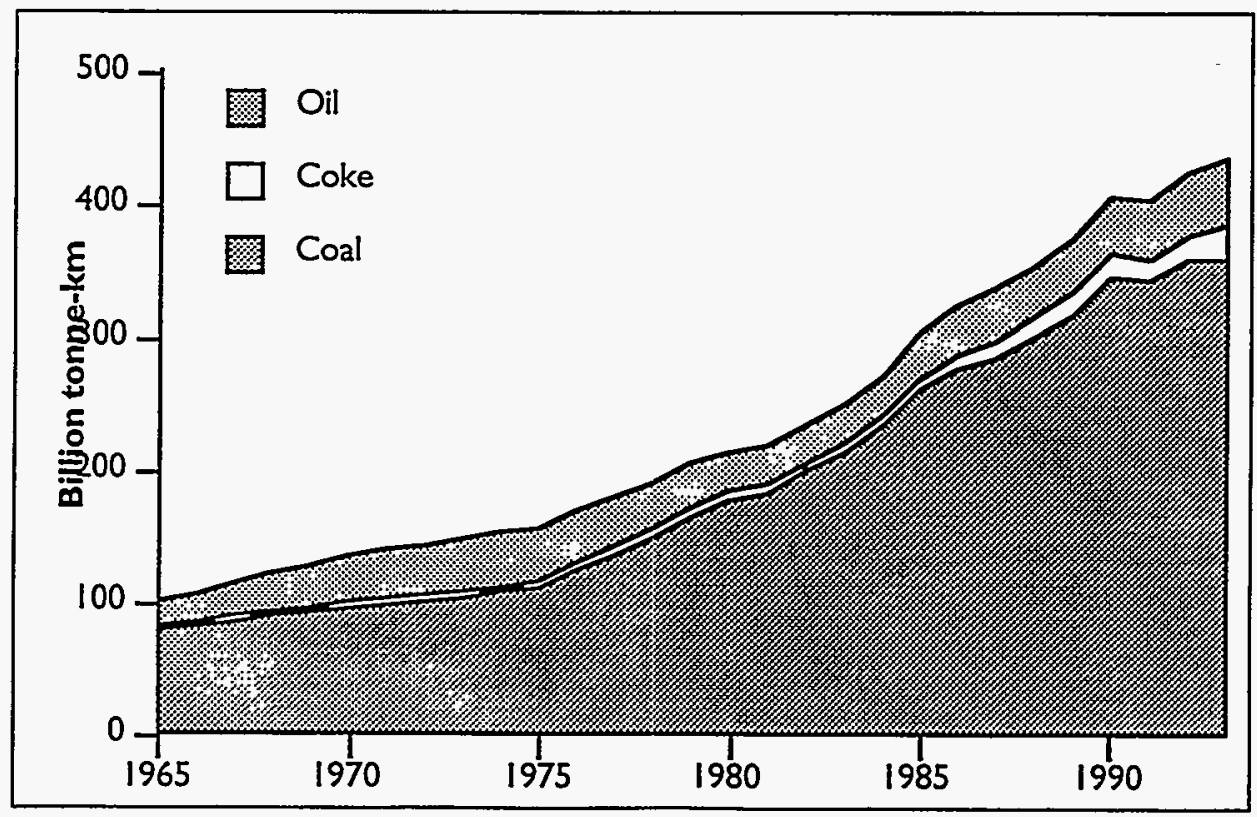


Table II-30. Interprovincial Coal Transfers via Railway, 1993 - Mt

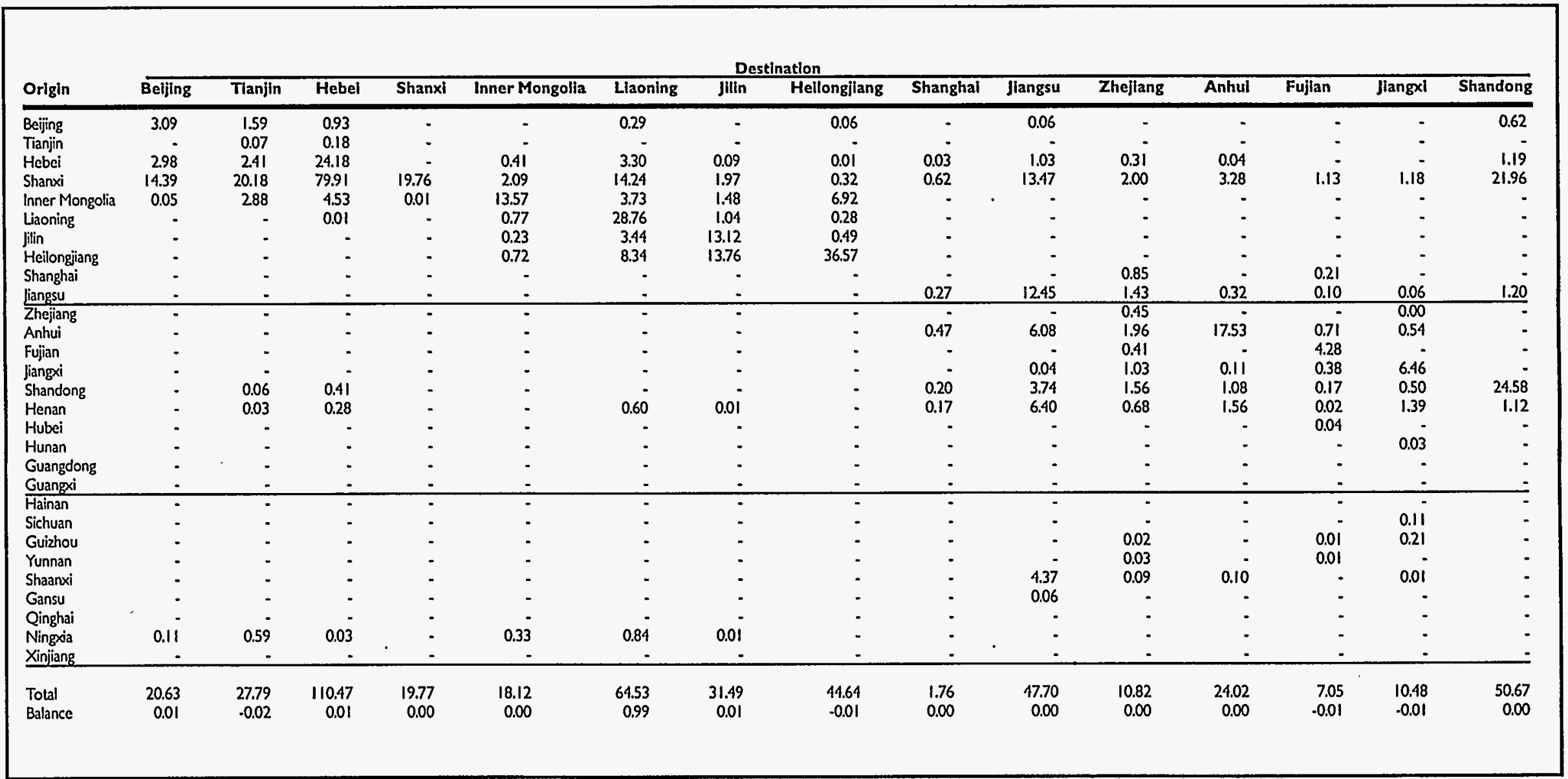

Source: China Transportation Yearbook, 1994. 
Table II-30. Interprovincial Coal Transfers via Railway, 1993 - Mt (continued)

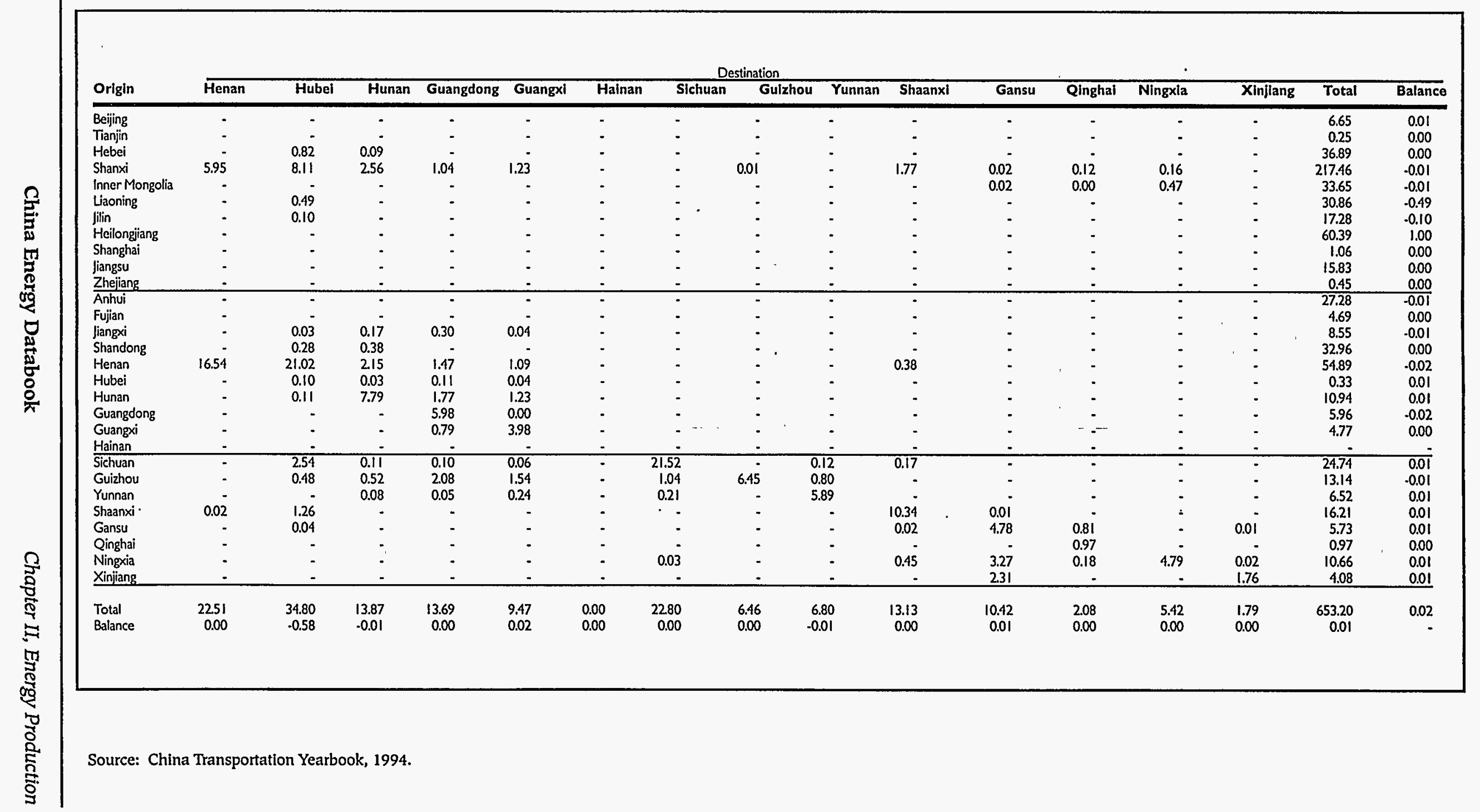




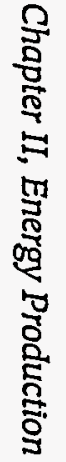

Table II-31. Indices of Five Major Pipelines, 1993

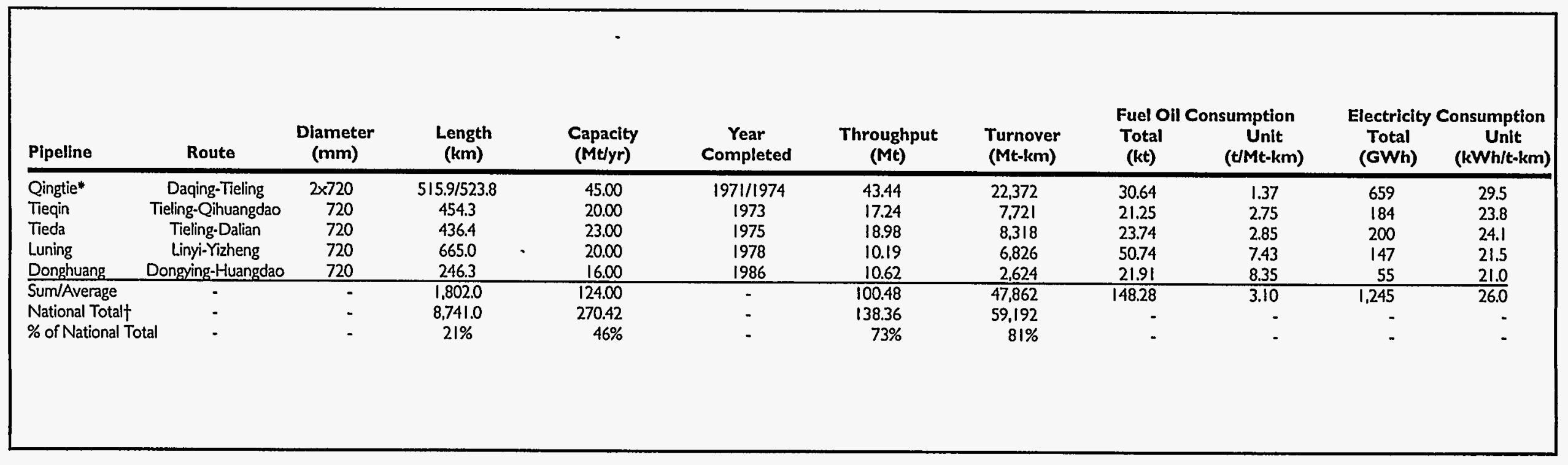

Two parallel plpelines.

Includes 79 crude ofl and 88 finished oil pipelines. Excludes China's 190 natural gas and 21 other gas plpelines (total length 7,510 km and $195 \mathrm{~km}$ respectively).

Source: China Transportation Yearbook, 1994. 
Table II-32. National Renewable Energy Production Capacities, End of 1992

\begin{tabular}{|ll|}
\hline Technology & . Total Capacity \\
\hline & \\
Solar water heaters & 2 million $\mathrm{m}^{2}$ \\
Solar heated houses & 500 thousand $\mathrm{m}^{2}$ \\
Greenhouses (plastic sheeting covered) & 400 thousand ha \\
Solar dryers & 13 thousand $\mathrm{m}^{2}$ \\
Solar cookers & 120 thousand units \\
Photovoltaic cells (operational) & $1.8 \mathrm{MWe}$ \\
Small-scale wind generators & 120 thousand units \\
Wind farms (six farms) & $5 \mathrm{MWe}$ \\
Wind pumps & 1,700 units \\
& \\
Agricultural household biogas digesters $\left(6-10 \mathrm{~m}^{3}\right)$ & 4.5 million units \\
Large-scale biogas digesters & 300 thousand $\mathrm{m}^{3}$ \\
Biomass gasifiers & 300 units \\
Geothermal power stations & $25 \mathrm{MWe}$ \\
Directly used geothermal heat & $89.5 \mathrm{PJ} / \mathrm{yr}$ \\
Tidal power stations & $8.5 \mathrm{MWe}$ \\
Small-scale hydropower stations & $14.41 \mathrm{GW}$ \\
\hline
\end{tabular}

Source: China Energy Development Report, 1994. 
Chapter III-Energy Industry Investment 


\section{Energy Industry Investment}

I nvestment is perhaps the most important indicator of the priorities of Chinese energy policy and planning. Capital in China is scarce and meted out carefully, so for any sector to capture a large share of investment clearly indicates its importance to Chinese planners. The energy sector has been the largest single civilian recipient of industrial capital in China, accounting for nearly $20 \%$ of total investment in state-owned units in 1993 (Table III-1) and $12 \%$ of total investment in units of all types of ownership (state-, collective-, and individual-owned; Table III-2). ${ }^{1}$ This actually represents a steep decline from the peak in 1990, when the respective percentages were $29 \%$ and 19\%; much of the state's resources have been directed to other mining and manufacturing industries, and to other sectors, especially transportation, construction, and utilities (other than electricity). ${ }^{2}$

In the early 1980 s, oil and natural gas extraction and refining accounted for the largest share (between $38 \%$ and $40 \%$ in 1981-1985) of total investment in the state-owned energy sector, with the electricity subsector taking the next largest and the coal subsector the smallest share (Table III-3). ${ }^{3}$ In response to a worsening electricity shortage causing slack industrial capacity (a condition that persists to this day), investment in electricity generation and distribution has taken an increasing share, from $32 \%$ in the early 1980 s to over $50 \%$ in 1993 . Growth in investment has been slowest in the coal subsector, the backbone of China's energy supply.

Chinese investment data are often difficult to interpret because of inconsistencies in coverage, inadequate coverage of rapidly expanding non-state enterprises, inclusion of investments in "nonproductive" facilities like worker housing and services, and the difference between reported and actual investment. As described in the Technical Note at the end of this section, there are some significant problems with the information presented in this section. Awareness of these shortcomings, however, should make the data more useful in gauging past and future trends in energy production and the importance of the energy industry in China's economy.

\section{CoAl}

In the 1980 s the central government adopted a policy of relying on rural collective and private mines to fill growing demand for coal, and they provided most of the increase in production. State coal industry investment consequently leveled off in the late 1980s (Table III-3). Underinvestment, partly due to very low controlled coal prices, contributed to coal shortages that began in the late 1980 s and at the time prevented many power plants and factories from operating at full capacity. Since 1990 investment in state-owned coal mines has picked up again, growing at an average annual rate of $11 \%$ (still much slower than the $17 \%$ for the energy supply industry as a whole). Most of the new funds have been in the form of capital construction investments, i.e., opening up of new mines (Tables III-4). As is the case for other segments of the energy supply sector, the ratio of nonproductive to productive investments has declined overall since the mid-1980s (Table III5). At present stockpiles of coal are quite large, rural coal mines are ubiquitous, and a basically free market for coal exists, so that most customers are able to purchase what they need (although rail transport capacity remains in shortage).

Rural mines are generally very small and poorly equipped, often requiring no more than a few farmers with hand tools, rope, and baskets. Unit investment in such mines is therefore much lower than that for larger ones. In the late 1980s rural mines used 10 to 70 yuan of investment per annual ton of capacity, whereas the large, mechanized state-run mines needed 140 to 240 yuan per annual ton of capacity, and that relationship has probably changed little since. ${ }^{4}$ The inclusion of investment data on rural collective and private mines would certainly increase the investment figures presented here to an uncertain degree, but probably by no more than $20 \% .^{5}$

Investment in coal washing has been consistently 
overlooked, even though the many benefits-including reduced burden on the overloaded transportation system, increased end-use efficiency, and reduced emissions-are well known. Coal products investment is an order of magnitude higher than a decade ago, reflecting the attention focused on improving urban fuel supplies with coal briquettes and town gas.

\section{Oil and Natural Gas}

Rising investment in crude oil extraction has outpaced modest gains in production capacity in recent years (Tables III-3 and III-11). This is in part due to the rising cost of production from older fields in the North and Northeast (resulting in substantial losses for the sector under the pre-May 1994 regime of fixed low prices); to increased use of secondary recovery techniques; and to the higher expense associated with prospecting in remote and offshore areas.

Oil refining (including most oil-based petrochemical investment under the China National Petrochemical Corporation, or Sinopec) accounts for most of the rest of investment in this sector, and its share increased (Tables III-3 and III-5). This trend has reflected the rapid buildup of large ethylene facilities after 1986 as well as a surge of investment in refinery capacity and secondary processing units in order to meet growing demand for light and middle distillates.

Available statistics show the neglect previously accorded natural gas development, with investment actually decreasing in real terms in the late 1980s. Recently, however, new gas fields have been discovered and exploitation begun, most importantly in the offshore fields near Hainan, from which a pipeline to Hong Kong was recently completed (with gas deliveries expected to start in January 1996). Exploration in the Northwest's ShaanGanNing region has also uncovered substantial gas resources, large-scale production from which is expected before the end of the century.

\section{ELECTRICITY}

As mentioned above, the capital-intensive electricity subsector currently accounts for half of total energy industry investment and three fifths of capital construction investment (Table III-3 and III-4).
Funding for thermal capacity has consistently outstripped that for hydropower plants (Table III-5). Thermal power plants can be built more quickly and in a wider variety of locations than hydropower plants, providing planners with more flexibility in meeting urgent demand for supply expansion. Much of the investment has been in plants of smaller capacities (25 MW or less), which are easier for local authorities to build but which offer lower efficiencies and less effective emissions controls. While increments of thermal power generation have been completed fairly consistently over the years, many hydropower stations, begun in the 1980s, began coming on line in the early 1990 s at a rate of five to seven GW per year, compared to less that one GW per year throughout the 1980s (Table III-11). Investment in nuclear power generation has been substantial, with unit investment for currently operating plants reportedly substantially higher than for conventional plants. Investment funding for electricity distribution has been at about the same level as that for hydropower generation.

Unless otherwise noted, the electricity generation and supply subsector includes the production and supply of heat and steam. This is generally a distinction of small significance, e.g., in 1990 just over $1 \%$ of capital construction investment in electric power was for steam and hot water.

\section{ENERgy Conservation}

The Chinese government has paid special attention to investments in energy conservation, establishing a corporation to administer program of grants and lowinterest loans in the early 1980s. From 1981 to 1990 total investment in energy conservation amounted to 30 billion yuan, and another 10 billion yuan was spent between 1991 and 1993 (Table III-8). Overall, about half of the investments have been designated capital construction, and half technical updating (which latter channel is also used for most environmental protection and waste management projects; Tables III-7 to 8). Most funding initially came from the central government in the form of grants, which were later converted to loans. At present, local governments and enterprises account for the largest share of investment funds (Table III-9). 
Targeted technologies included cogeneration, recovery and use of waste heat and gas, overhauling small and inefficient power plants and fertilizer plants, and improvements to steel manufacturing technologies. Conservation investment has been small compared to supply investment, ranging from nearly $12 \%$ of combined energy supply and conservation investment in 1983 to just over 7\% in 1992 (Table III-8), but its impact on China's economy has been significant, probably accounting for more than $10 \%$ of observed reductions in industrial energy intensity (energy consumed per unit of economic output) in the 1980 s. $^{6}$ Efficiency improvements resulting from these programs should include not just the demonstration projects that received funding, but the other facilities that were upgraded by managers who were persuaded through the demonstrations to adopt similar technologies. Analysis of investments suggests that the cost of energy savings was generally below the cost of new energy supply, which in 1990 was over 1,000 yuan per annual ton of delivered coal, including transportation capacity (Tables III-9 and III-10). ${ }^{\text {? }}$

There has been considerable interest in residential energy conservation, particularly the improvement of biomass combustion in rural households through the introduction of improved stoves. ${ }^{8}$ Efforts have also been made to consolidate boilers for apartment buildings, replacing separate boilers for each building with a single larger boiler, and to substitute coal briquettes for raw coal used in cooking and heating. These improvements are intended in large measure to address environmental problems, e.g., biomass stoves should reduce stress on rural ecosystems resulting from overharvesting of fuel wood and other biomass, and consolidation of residential boilers and popularization of briquettes should help improve urban air quality.

\section{SOURCES OF INVESTMENT FUNDS}

Statistics for capital construction investment show that by 1990 direct government investment ${ }^{9}$ in the energy industry decreased slightly in real terms (Table III-12). It decreased substantially as a share of total investment, from well more than half (all segments of the energy supply industry) in the early 1980 s, to less than a fifth in 1990 (petroleum and electricity). This reflects the trend towards encourag- ing local financial responsibility for projects, as the central government's budget has shrunk a portion of GDP.

For the coal industry, bank loans and self-raised funds accounted for an increasing share, and coal substitution funds ${ }^{10}$ also played an important role. Direct investment, however, continued to be the single largest source of capital for state-owned coal mines. The oil and natural gas industry has come to rely to a remarkable degree on foreign capital ${ }^{11}$ (peaking at $52 \%$ of capital construction investment in 1988), replacing direct government investment as the primary source. Direct government investment in the electric power industry dropped precipitously as well, forcing it to rely more on self-raised funds (including bond issues and out-of-plan bank loans), loans, foreign and other sources (e.g., special taxes levied by local governments and utilities). The bulk of oil substitution funds were used by utilities to pay for the conversion of oil-fired boilers to coal.

\section{TECHNICAL NOTE: INVESTMENT Categories}

Official statistics on total investment, referred to as "fixed assets investment" (guding zichan touzi), are the sum of three investment categories, "capital construction" (jiben jianshe), "technical updating and transformation" (gengxin gaizao), and "other fixed assets investment" (qita guding zichan touzi). Capital construction and technical updating and transformation investments are further characterized as "productive" or "nonproductive" (shengchanxing and feishengchanxing). Data on investment are generally available only for state-owned and urban collective enterprises; rural enterprise statistics tend to be less complete and less accurate.

\section{CAPITAL CONSTRUCTION INVESTMENT}

Capital construction generally refers to construction of new facilities as well as purchases and installation of equipment which result in net additions to productive capacity. At present, capital construction funds are administered mainly through the State Planning Commission system, which extends down to the county level. Capital con- 
struction accounts for the majority of investment in state-owned units (currently about $60 \%$; Table III1). Time series data for energy industry capital construction investment are available for a much longer period than for total investment (41 years as opposed to 13 years), so it is a convenient proxy for total energy industry investment. Since the 1980 s the share of energy industry investment from capital construction funds has been similar to the share for all industry from capital construction, providing some support for this.

\section{TECHNICAL UPDATING INVESTMENT}

Investment in this category covers mainly the repair and renovation of existing plant; according to the strict definition, projects are not intended to expand capacity, but often do in practice (especially for projects involving only local government support). Technical updating investments currently are approved and administered through the State Economic and Trade Commission's network, which, like the planning commission system, extends down to the county level. About one-third of investment in state-owned units is for technical updating and transformation, although the share for the energy industry was consistently lower in the 1980s.

\section{OTHER INVESTMENT}

While not a large category compared to the two above, the category of "oil field maintenance and development projects" accounts for more than half of all "other" investment. This is reflected in the larger contribution of "other" investment to energy industry investment compared to all investment. Most of the balance is made up of miscellaneous small purchases of fixed assets (valued at 20,000-50,000 yuan). The energy industry also uses some other funds in this category, but the total must be inferred from other breakdowns of energy industry investment.

\section{"PRODUCTIVE" AND "NONPRODUCTIVE" INVESTMENT}

Because work units in China are responsible for worker welfare, they invest a substantial amount in services not related to production, e.g., housing, education, and health care of work unit personnel and their dependents. To reflect this, investment funds are categorized as either "productive" or "nonproductive". The former category refers to investments in factories, mines, railways, bridges harbors, farmland, and water conservancy facilities, while the latter refers to the construction of schools, hospitals, stores, and living quarters and the purchase of machinery and equipment. The share of "nonproductive" investment in the energy industry has decreased in recent years. ${ }^{12}$

\section{OWNERSHIP: STATE, COLLECTIVE, PRIVATE AND OTHER UNITS}

Until recently, the State Statistical Bureau divided industrial enterprises into four ownership categories: state-owned, collective-owned, private, and other. ${ }^{13}$ State-owned units are those whose means of production and income are owned by any organ or division of the central government or any level of local government. Collective-owned units are those whose means of production and income are owned by collectives in cities (chengshi), counties (xian), and townships (zhen), as well as village (xiang) and rural (cun) enterprises. Individual-owned enterprises are owned by individuals in urban and rural areas, including enterprises belonging to individuals who have pooled capital and management but have received an individual-enterprise license. Other enterprises include: those belonging to joint ventures belonging to state-owned units and collectives, stateowned units and individual investors, or collectives and individual investors; foreign joint ventures; enterprises owned by overseas Chinese; other wholly foreign-owned enterprises; and any other enterprises not fitting into the above categories.

Breakdowns of investment funds by energy industry subsector are generally available only for state-owned units, although urban collective-owned units are sometimes also included (specific coverage is noted in footnotes to the various tables). Some investment data cover village level enterprises and above, excluding rural level and below. The latter category includes rural enterprises, rural joint ventures, and rural individual industry. Investment in stateowned units accounted for between $61 \%$ and $67 \%$ of all investment between 1983 and 1993, while 
urban collectives received between $3 \%$ and $6 \%$ over the same period. The most important category of investment missing is probably investment in rural mines and small hydroelectric plants owned by rural collectives and individuals.

\section{INVESTMENT TARGETS AND ACTUAL INVESTMENT}

Most investment figures are based on budget price at time of project approval. The amount of money ultimately spent on a project may differ significantly from these figures, which are often the only ones available. Most data in this section are for budgeted amounts, although a few tables contain data on actual investment. Given this limitation, as well as those described above, the figures in this section should not be taken as accurate guides to total investment levels, although we believe they provide a reasonable guide to the relative size of investment in different sectors.

1 "Unit" refers to a Chinese "work unit" (danwei), which could be an industrial enterprise, a school, a government agency, etc. Since industrial enterprises are a type of work unit, the terms "enterprise" and "unit" are for all practical purposes interchangeable in the context of this volume.

Hereafter "total investment" will refer only to investment in state-owned enterprises, unless otherwise noted. Stateowned enterprises are those owned by all levels of government down to the county level, and at least nominally subject to central control through ministry and commission branches. Excluded are units under township- and village-level governments, collectives, privately owned enterprises, and domestic and foreign joint ventures. Some sources refer to state-owned units as those "owned by the people" (quanmin suoyouzhi).

2 China Statistical Yearbook, various years.

3 Statistics on capital construction - the largest category of state investment funds, usually used to construct new facilities — show similar patterns (Table III-3). Until 1993, however, a larger share of technical updating funds, generally used for expanding existing facilities, was used in the coal industry than in power generation and distribution (Tables III-3 and III-5; see Technical Note).

4 Lu, 1988; Levine and Liu, 1990.

5 Investment in state-owned and urban collective coal mines was 76 billion yuan (constant 1980 yuan, subsequent figures the same) between 1981 and 1990. Multiplying the net increase in rural mine output over that period (a conservative estimate of capacity increase) by a central estimate of rural mine cost ( 40 yuan/t capacity) gives a total investment in rural mines of 11 bil- lion yuan, or $13 \%$ of the resulting total investment.

6 Sinton and Levine, 1994.

7 Liu et al., 1994.

8 Gu et al., 1991.

9 Direct government investment includes grants from the central government, loans that replace grants, and funds invested by local governments at the direction of the central government.

10 "Coal substitution" (mei dai you) funds are capital construction funds and loans intended to reduce dependence on relatively scarce petroleum. After it became clear that the large oil production increases predicted in the 1970 s were not going to materialize, this fund was established to convert oil-using utility and industrial boilers and other equipment, which had been overbuilt based on those predictions, to coal.

11 Foreign capital includes not only funds from abroad, but equipment, materials, and technology. It does not include foreign equipment and materials purchased with Chinese foreign exchange reserves charged to the import accounts China previously had with Eastern Europe's former centrally planned countries.

12 This is the outcome of declining portions of investment in all segments of the energy supply industry allocated to "nonproductive" investment, and an increase in the share of capital flowing to the electric power industry, which has in the past spent the least on "nonproductive" projects.

13 The statistical categories have changed - through refinement of the "private" and "other" categories - with the publication of the 1994 China Statistical Yearbook. Ownership categories now include: state-owned; collective; private; individual; associated (a mixture of two or more of the preceding), equity participation (registered joint stock companies); foreign-funded (joint and cooperative ventures); Hong Kong, Macao, and Taiwan (joint and cooperative ventures, and wholly owned enterprises); and other. 
Table III-1. Investment by State: Total and Capital Construction Compared to Energy Industry Investment, * 1953-1993

\begin{tabular}{|c|c|c|c|c|c|}
\hline 1. Billi & $\begin{array}{c}\text { Total } \\
\text { Investment }\end{array}$ & $\begin{array}{c}\text { Total } \\
\text { Energy } \\
\text { Industry } \\
\text { Investment } f\end{array}$ & $\begin{array}{c}\text { Total } \\
\text { Capital } \\
\text { Construction } \\
\text { Investment }\end{array}$ & $\begin{array}{c}\text { Industry } \\
\text { Capital } \\
\text { Construction } \\
\text { Investment I }\end{array}$ & $\begin{array}{c}\text { Energy } \\
\text { Industry } \\
\text { Capital } \\
\text { Construction } \\
\text { Investment I }\end{array}$ \\
\hline 1953 & 9.16 & - & 9.04 & 2.83 & 0.70 \\
\hline 1954 & 10.27 & - & 9.91 & 3.84 & 1.02 \\
\hline 1955 & 10.52 & - & 10.04 & 4.30 & 1.36 \\
\hline 1956 & 16.08 & - & 15.53 & 6.82 & 1.97 \\
\hline 1957 & 15.12 & - & 14.33 & 7.24 & 2.25 \\
\hline 1958 & 27.91 & - & 26.90 & 17.30 & 4.13 \\
\hline 1959 & 36.80 & - & 34.97 & 20.89 & 5.78 \\
\hline 1960 & 41.66 & - & 38.87 & 22.96 & 6.34 \\
\hline 1961 & 15.61 & - & 1274 & 7.68 & 275 \\
\hline 1962 & 8.73 & - & 7.13 & 4.01 & 1.57 \\
\hline 1963 & 11.67 & - & 9.82 & 4.92 & 1.65 \\
\hline 1964 & 16.59 & - & 14.41 & 7.21 & 217 \\
\hline 1965 & 21.69 & - & 17.96 & 8.90 & 256 \\
\hline 1966 & 25.48 & - & 20.94 & 9.50 & 270 \\
\hline 1967 & 18.77 & - & 14.02 & 10.20 & 290 \\
\hline 1968 & 15.16 & - & 11.31 & 10.80 & 3.10 \\
\hline 1969 & 24.69 & - & 20.08 & 11.50 & 3.30 \\
\hline 1970 & 36.81 & - & 31.26 & 12.20 & 3.50 \\
\hline 1971 & 41.73 & - & 34.08 & 14.80 & 5.00 \\
\hline 1972 & 41.28 & - & 3280 & 17.40 & 5.70 \\
\hline 1973 & 43.81 & - & 33.81 & 20.00 & 6.40 \\
\hline 1974 & 46.32 & - & 34.77 & 22.60 & 6.80 \\
\hline 1975 & 54.49 & - & 40.93 & 23.10 & 7.15 \\
\hline 1976 & 52.39 & - & 37.64 & 20.87 & 6.99 \\
\hline 1977 & 54.83 & - & 38.24 & 21.74 & 7.87 \\
\hline 1978 & 66.87 & - & 50.10 & 27.32 & 11.47 \\
\hline 1979 & 69.94 & - & 5235 & 25.69 & 11.10 \\
\hline 1980 & 74.59 & - & 55.89 & 27.56 & 11.57 \\
\hline 1981 & 66.75 & 14.19 & 44.29 & 21.60 & 9.46 \\
\hline 1982 & 84.53 & 17.41 & 55.55 & 26.06 & 10.22 \\
\hline 1983 & 95.20 & 21.34 & 59.41 & 28.23 & 12.76 \\
\hline 1984 & 118.52 & 27.90 & 74.32 & 34.16 & 16.60 \\
\hline 1985 & 168.05 & 36.83 & 107.44 & 44.65 & 20.53 \\
\hline 1986 & 197.85 & 44.77 & 117.61 & 53.16 & 26.71 \\
\hline 1987 & 229.80 & 55.00 & 134.31 & 68.28 & 34.01 \\
\hline 1988 & 276.28 & 65.27 & 157.43 & 79.61 & 41.01 \\
\hline 1989 & 253.55 & 70.56 & 155.17 & 82.25 & 44.64 \\
\hline 1990 & 291.86 & 84.67 & 170.38 & 95.26 & 55.83 \\
\hline $199 \mid$ & 362.28 & 95.68 & 211.58 & 114.72 & 64.61 \\
\hline 1992 & 527.36 & $1 \mid 6.41$ & 301.27 & 145.83 & 80.36 \\
\hline 1993 & 765.80 & 149.77 & 461.55 & 200.45 & 109.73 \\
\hline
\end{tabular}

- Figures are for state-owned units unless otherwise noted. State investment was $67 \%$ of all investment in 1983 and $61 \%$ in 1993 . Total investment refers to the State Statistical Bureau's category of "fixed assets investment," which is the sum of "capital construction," "technical updating and transformation, " and "other" investments. Capital construction investments are intended primarily for building new production capacity, while technical updating and transformation funds are for repair and retrofitting of existing capacity. Most of the "other" investment in the energy sector is for further development of existing oilfields. All investment figures include some funds intended for "nonproductive" uses, e.g., worker housing, schools, etc. The magnitude of this "nonproductive" investment can be gauged from its share of capital construction investment, detailed in Table III-5, Energy Industry Capital Construction Investment by Subsector and Purpose. Please refer to general notes at the beginning of this section regarding coverage and significance of these figures.

$\dagger$ Energy industry fixed assets investment figures are for state- and urban collective-owned units, except 1989 and later years, which are for stateowned units only.

I For 1966-1970 and 1971-1974 only total capital construction investment figures are available (54.151 billion current yuan and 74.96 billion current yuan respectively). Here we have approximated the division of investment funds among the years in these two periods by linear extrapolation, using the investment totals as control sums and reported investment in 1965 and 1975 as the endpoints. "Industry capital construction investment" is part of "total capital construction investment," and "energy industry capital construction investment" is part of "industry capital construction investment."

Source: Yearbook of China's Economy, various years; China Energy Statistical Yearbook, various years; China Statistical Yearbook, various years; Energy Research Institute. 
Table III-1. Investment by State: Total and Capital Construction Compared to Energy Industry Investment, * 1953-1993 (continued)

\begin{tabular}{|c|c|c|c|c|c|}
\hline 2. Billi & 1980 Yuan $\S$ & & & & \\
\hline Year & $\begin{array}{c}\text { Total } \\
\text { Investment }\end{array}$ & $\begin{array}{c}\text { Total } \\
\text { Energy } \\
\text { Industry } \\
\text { Investment } \dagger\end{array}$ & $\begin{array}{c}\text { Total } \\
\text { Capital } \\
\text { Construction } \\
\text { Investment }\end{array}$ & $\begin{array}{c}\text { Industry } \\
\text { Capital } \\
\text { Construction } \\
\text { Investment II }\end{array}$ & $\begin{array}{c}\text { Industry } \\
\text { Capital } \\
\text { Construction } \\
\text { Investment I }\end{array}$ \\
\hline 1953 & 7.03 & - & 6.94 & 2.18 & 0.54 \\
\hline 1954 & 8.42 & - & 8.12 & 3.14 & 0.84 \\
\hline 1955 & 8.91 & - & 8.50 & 3.64 & 1.15 \\
\hline 1956 & 14.90 & - & 14.38 & 6.32 & 1.83 \\
\hline 1957 & 1289 & - & 12.22 & 6.17 & 1.92 \\
\hline 1958 & 23.92 & - & 23.06 & 14.83 & 3.54 \\
\hline 1959 & 31.39 & - & 29.83 & 17.81 & 4.93 \\
\hline 1960 & 35.78 & - & -33.38 & 19.72 & 5.45 \\
\hline 1961 & 12.81 & - & 10.46 & 6.30 & 2.25 \\
\hline 1962 & 6.91 & - & 5.64 & 3.17 & 1.24 \\
\hline 1963 & 9.33 & - & 7.85 & 3.93 & 1.32 \\
\hline 1964 & 13.21 & - & 11.48 & 5.74 & 1.73 \\
\hline 1965 & 18.39 & - & 15.23 & 7.54 & 2.17 \\
\hline 1966 & 22.56 & - & 18.54 & 8.41 & 2.39 \\
\hline 1967 & 16.80 & - & 12.55 & 9.13 & 2.60 \\
\hline 1968 & 13.88 & - & 10.35 & 9.89 & 2.84 \\
\hline 1969 & 23.46 & - & 19.08 & 10.93 & 3.14 \\
\hline 1970 & 36.09 & - & 30.64 & 11.96 & 3.43 \\
\hline |97| & 41.10 & - & 33.57 & 14.58 & 4.92 \\
\hline 1972 & 40.99 & - & 32.56 & 17.28 & 5.66 \\
\hline 1973 & 43.67 & - & 33.70 & 19.93 & 6.38 \\
\hline 1974 & 46.18 & - & 34.66 & 2253 & 6.78 \\
\hline 1975 & 55.00 & - & 41.32 & 23.32 & 7.21 \\
\hline 1976 & 53.04 & - & 38.11 & 21.13 & 7.07 \\
\hline 1977 & 55.80 & - & 38.91 & 22.12 & 8.01 \\
\hline 1978 & 67.68 & - & 50.71 & 27.65 & 11.61 \\
\hline 1979 & 69.88 & - & 52.30 & 25.66 & 11.09 \\
\hline 1980 & 74.59 & & 55.89 & 27.56 & 11.57 \\
\hline 1981 & 66.55 & 14.15 & 44.16 & 21.54 & 9.44 \\
\hline 1982 & 84.40 & 17.38 & 55.47 & 26.02 & 10.21 \\
\hline 1983 & 95.22 & 21.35 & 59.43 & 28.24 & 1276 \\
\hline 1984 & 115.64 & 27.23 & 72.51 & 33.33 & 16.19 \\
\hline 1985 & 155.97 & 34.19 & 99.71 & 41.44 & 19.05 \\
\hline 1986 & $\mid 78.21$ & 40.32 & 105.93 & 47.89 & 24.06 \\
\hline 1987 & 196.15 & 46.94 & 114.64 & 58.28 & 29.03 \\
\hline 1988 & 217.86 & 51.47 & 124.15 & 62.78 & 32.34 \\
\hline 1989 & 183.98 & 51.20 & 112.60 & 59.68 & 32.39 \\
\hline 1990 & 210.95 & 61.20 & 123.14 & 68.85 & 40.35 \\
\hline 1991 & 253.45 & 66.93 & 148.02 & 80.26 & 45.20 \\
\hline 1992 & 351.87 & 77.67 & 201.02 & 97.30 & 53.62 \\
\hline 1993 & 474.83 & 92.86 & 286.18 & 124.28 & 68.04 \\
\hline
\end{tabular}

- Figures are for state-owned units unless otherwise noted. State investment was $67 \%$ of all investment in 1983 and $61 \%$ in 1993 . Total investment refers to the State Statistical Bureau's category of "fixed assets investment," which is the sum of "capital construction," "technical updating and transformation," and "other" investments. Capital construction investments are intended primarily for building new production capacity, while technical updating and transformation funds are for repair and retrofitting of existing capacity. Most of the "other" investment in the energy sector is for further development of existing oilfields. All investment figures include some funds intended for "nonproductive" uses, e.g., worker housing, schools, etc. The magnitude of this "nonproductive" investment can be gauged from its share of capital construction investment, detailed in Table III-5, Energy Industry Capital Construction Investment by Subsector and Purpose. Please refer to general notes at the beginning of this section regarding coverage and significance of these figures.

$\dagger$ Energy industry fixed assets investment figures are for state- and urban collective-owned units, except 1989 and later years, which are for stateowned units only.

I For 1966-1970 and 1971-1974 only total capital construction investment figures are available (54.151 billion current yuan and 74.96 billion current yuan respectively). Here we have approximated the division of investment funds among the years in these two periods by linear extrapolation, using the investment totals as control sums and reported investment in 1965 and 1975 as the endpoints. "Industry capital construction investment" is part of "total capital construction investment," and "energy industry capital construction investment" is part of "industry capital construction investment."

$\S$ Investment figures are deflated using the industrial final sector deflators given in Table X-6.

Source: Yearbook of China's Economy, various years; China Energy Statistical Yearbook, various years; China Statistical Yearbook, various years; Energy Research Institute. 
Table III-1. Investment by State: Total and Capital Construction Compared to Energy Industry Investment, * 1953-1993 (continued)

\begin{tabular}{|c|c|c|c|c|c|}
\hline 3. Anr & $\begin{array}{c}\text { Total } \\
\text { Investment }\end{array}$ & $\begin{array}{c}\text { Total } \\
\text { Energy } \\
\text { Industry } \\
\text { Investment } t\end{array}$ & $\begin{array}{c}\text { Total } \\
\text { Capital } \\
\text { Construction } \\
\text { Investment }\end{array}$ & $\begin{array}{c}\text { Industry } \\
\text { Capital } \\
\text { Construction } \\
\text { Investment II }\end{array}$ & $\begin{array}{c}\text { Energy } \\
\text { Industry } \\
\text { Capital } \\
\text { Construction } \\
\text { Investment }\end{array}$ \\
\hline 1953 & - & - & - & - & - \\
\hline 1954 & $20 \%$ & - & $17 \%$ & $45 \%$ & $56 \%$ \\
\hline 1955 & $6 \%$ & - & $5 \%$ & $16 \%$ & $37 \%$ \\
\hline 1956 & $67 \%$ & - & $69 \%$ & $74 \%$ & $59 \%$ \\
\hline 1957 & $-13 \%$ & - & $-15 \%$ & $-2 \%$ & $5 \%$ \\
\hline 1958 & $86 \%$ & - & $89 \%$ & $140 \%$ & $84 \%$ \\
\hline 1959 & $31 \%$ & - & $29 \%$ & $20 \%$ & $39 \%$ \\
\hline 1960 & $14 \%$ & - & $12 \%$ & $11 \%$ & $10 \%$ \\
\hline 1961 & $-64 \%$ & - & $-69 \%$ & $-68 \%$ & $-59 \%$ \\
\hline 1962 & $-46 \%$ & - & $-46 \%$ & $-50 \%$ & $-45 \%$ \\
\hline 1963 & $35 \%$ & - & $39 \%$ & $24 \%$ & $6 \%$ \\
\hline 1964 & $42 \%$ & - & $46 \%$ & $46 \%$ & $31 \%$ \\
\hline 1965 & $39 \%$ & - & $33 \%$ & $31 \%$ & $26 \%$ \\
\hline 1966 & $23 \%$ & - & $22 \%$ & $11 \%$ & $10 \%$ \\
\hline 1967 & $-26 \%$ & - & $-32 \%$ & $9 \%$ & $9 \%$ \\
\hline 1968 & $-17 \%$ & - & $-18 \%$ & $8 \%$ & $9 \%$ \\
\hline 1969 & $69 \%$ & - & $84 \%$ & $11 \%$ & $10 \%$ \\
\hline$\overline{1970}$ & $54 \%$ & - & $61 \%$ & $9 \%$ & $9 \%$ \\
\hline 1971 & $14 \%$ & - & $10 \%$ & $22 \%$ & $44 \%$ \\
\hline 1972 & $0 \%$ & - & $-3 \%$ & $19 \%$ & $15 \%$ \\
\hline 1973 & $7 \%$ & - & $3 \%$ & $15 \%$ & $13 \%$ \\
\hline 1974 & $6 \%$ & - & $3 \%$ & $13 \%$ & $6 \%$ \\
\hline 1975 & $19 \%$ & - & $19 \%$ & $4 \%$ & $6 \%$ \\
\hline 1976 & $-4 \%$ & - & $-8 \%$ & $-9 \%$ & $-2 \%$ \\
\hline 1977 & $5 \%$ & - & $2 \%$ & $5 \%$ & $13 \%$ \\
\hline 1978 & $21 \%$ & - & $30 \%$ & $25 \%$ & $45 \%$ \\
\hline 1979 & $3 \%$ & - & $3 \%$ & $-7 \%$ & $-4 \%$ \\
\hline 1980 & $7 \%$ & - & $7 \%$ & $7 \%$ & $4 \%$ \\
\hline 1981 & $-11 \%$ & - & $-21 \%$ & $-22 \%$ & $-18 \%$ \\
\hline 1982 & $27 \%$ & $23 \%$ & $26 \%$ & $21 \%$ & $8 \%$ \\
\hline 1983 & $13 \%$ & $23 \%$ & $7 \%$ & $9 \%$ & $25 \%$ \\
\hline 1984 & $21 \%$ & $28 \%$ & $22 \%$ & $18 \%$ & $27 \%$ \\
\hline 1985 & $35 \%$ & $26 \%$ & $38 \%$ & $24 \%$ & $18 \%$ \\
\hline 1986 & $14 \%$ & $18 \%$ & $6 \%$ & $16 \%$ & $26 \%$ \\
\hline 1987 & $10 \%$ & $16 \%$ & $8 \%$ & $22 \%$ & $21 \%$ \\
\hline 1988 & $11 \%$ & $10 \%$ & $8 \%$ & $8 \%$ & $11 \%$ \\
\hline 1989 & $-16 \%$ & $-1 \%$ & $-9 \%$ & $-5 \%$ & $0 \%$ \\
\hline 1990 & $15 \%$ & $20 \%$ & $9 \%$ & $15 \%$ & $25 \%$ \\
\hline 1991 & $20 \%$ & $9 \%$ & $20 \%$ & $17 \%$ & $12 \%$ \\
\hline 1992 & $39 \%$ & $16 \%$ & $36 \%$ & $21 \%$ & $19 \%$ \\
\hline 1993 & $35 \%$ & $20 \%$ & $42 \%$ & $28 \%$ & $27 \%$ \\
\hline
\end{tabular}

- Figures are for state-owned units unless otherwise noted. State investment was $67 \%$ of all investment in 1983 and $61 \%$ in 1993 . Total investment refers to the State Statistical Bureau's category of "fixed assets investment," which is the sum of "capital construction," "technical updating and transformation," and "other" investments. Capital construction investments are intended primarily for building new production capacity, while technical updating and transformation funds are for repair and retrofitting of existing capacity. Most of the "other" investment in the energy sector is for further development of existing oilfields. All investment figures include some funds intended for "nonproductive" uses, e.g., worker housing, schools, etc. The magnitude of this "nonproductive" investment can be gauged from its share of capital construction investment, detailed in Table III-5, Energy Industry Capital Construction Investment by Subsector and Purpose. Please refer to general notes at the beginning of this section regarding coverage and significance of these figures.

$\dagger$ Energy industry fixed assets investment figures are for state- and urban collective-owned units, except 1989 and later years, which are for stateowned units only.

I For 1966-1970 and 1971-1974 only total capital construction investment figures are available (54.151 billion current yuan and 74.96 billion current yuan respectively). Here we have approximated the division of investment funds among the years in these two periods by linear extrapolation, using the investment totals as control sums and reported investment in 1965 and 1975 as the endpoints. "Industry capital construction investment" is part of "total capital construction investment," and "energy industry capital construction investment" is part of "industry capital construction investment."

Source: Yearbook of China's Economy, various years; China Energy Statistical Yearbook, various years; China Statistical Yearbook, various years; Energy Research Institute. 
Table III-1. Investment by State: Total and Capital Construction Compared to Energy Industry Investment, * 1953-1993 (continued)

\begin{tabular}{|c|c|c|c|c|c|}
\hline \multicolumn{6}{|c|}{ 4. Shares, Billion Current Yuan } \\
\hline Year & $\begin{array}{c}\text { Total } \\
\text { Investment }\end{array}$ & $\begin{array}{c}\text { Total } \\
\text { Energy } \\
\text { Industry } \\
\text { Investment } \Phi\end{array}$ & $\begin{array}{c}\text { Total } \\
\text { Capital } \\
\text { Construction } \\
\text { Investment }\end{array}$ & $\begin{array}{c}\text { Industry } \\
\text { Capital } \\
\text { Construction } \\
\text { Investment II }\end{array}$ & $\begin{array}{c}\text { Energy } \\
\text { Industry } \\
\text { Capital } \\
\text { Construction } \\
\text { Investment II }\end{array}$ \\
\hline 1953 & $100 \%$ & - & $99 \%$ & $31 \%$ & $8 \%$ \\
\hline 1954 & $100 \%$ & - & $96 \%$ & $37 \%$ & $10 \%$ \\
\hline 1955 & $100 \%$ & - & $95 \%$ & $41 \%$ & $13 \%$ \\
\hline 1956 & $100 \%$ & - & $97 \%$ & $42 \%$ & $12 \%$ \\
\hline 1957 & $100 \%$ & - & $95 \%$ & $48 \%$ & $15 \%$ \\
\hline 1958 & $100 \%$ & - & $96 \%$ & $62 \%$ & $15 \%$ \\
\hline 1959 & $100 \%$ & - & $95 \%$ & $57 \%$ & $16 \%$ \\
\hline 1960 & $100 \%$ & - & $93 \%$ & $55 \%$ & $15 \%$ \\
\hline 1961 & $100 \%$ & - & $82 \%$ & $49 \%$ & $18 \%$ \\
\hline 1962 & $100 \%$ & - & $82 \%$ & $46 \%$ & $18 \%$ \\
\hline 1963 & $100 \%$ & - & $84 \%$ & $42 \%$ & $14 \%$ \\
\hline 1964 & $100 \%$ & - & $87 \%$ & $43 \%$ & $13 \%$ \\
\hline 1965 & $100 \%$ & - & $83 \%$ & $41 \%$ & $12 \%$ \\
\hline 1966 & $100 \%$ & - & $82 \%$ & $37 \%$ & $11 \%$ \\
\hline 1967 & $100 \%$ & - & $75 \%$ & $54 \%$ & $15 \%$ \\
\hline 1968 & $100 \%$ & - & $75 \%$ & $71 \%$ & $20 \%$ \\
\hline 1969 & $100 \%$ & - & $81 \%$ & $47 \%$ & $13 \%$ \\
\hline 1970 & $100 \%$ & - & $85 \%$ & $33 \%$ & $10 \%$ \\
\hline 1971 & $100 \%$ & - & $82 \%$ & $35 \%$ & $12 \%$ \\
\hline 1972 & $100 \%$ & - & $79 \%$ & $42 \%$ & $14 \%$ \\
\hline 1973 & $100 \%$ & - & $77 \%$ & $46 \%$ & $15 \%$ \\
\hline 1974 & $100 \%$ & - & $75 \%$ & $49 \%$ & $15 \%$ \\
\hline 1975 & $100 \%$ & - & $75 \%$ & $42 \%$ & $13 \%$ \\
\hline 1976 & $100 \%$ & - & $72 \%$ & $40 \%$ & $13 \%$ \\
\hline 1977 & $100 \%$ & - & $70 \%$ & $40 \%$ & $14 \%$ \\
\hline 1978 & $100 \%$ & - & $75 \%$ & $41 \%$ & $17 \%$ \\
\hline 1979 & $100 \%$ & - & $75 \%$ & $37 \%$ & $16 \%$ \\
\hline 1980 & $100 \%$ & & $75 \%$ & $37 \%$ & $16 \%$ \\
\hline 1981 & $100 \%$ & $21 \%$ & $66 \%$ & $32 \%$ & $14 \%$ \\
\hline 1982 & $100 \%$ & $21 \%$ & $66 \%$ & $31 \%$ & $12 \%$ \\
\hline 1983 & $100 \%$ & $22 \%$ & $62 \%$ & $30 \%$ & $13 \%$ \\
\hline 1984 & $100 \%$ & $24 \%$ & $63 \%$ & $29 \%$ & $14 \%$ \\
\hline 1985 & $100 \%$ & $22 \%$ & $64 \%$ & $27 \%$ & $12 \%$ \\
\hline 1986 & $100 \%$ & $23 \%$ & $59 \%$ & $27 \%$ & $13 \%$ \\
\hline 1987 & $100 \%$ & $24 \%$ & $58 \%$ & $30 \%$ & $15 \%$ \\
\hline 1988 & $100 \%$ & $24 \%$ & $57 \%$ & $29 \%$ & $15 \%$ \\
\hline 1989 & $100 \%$ & $28 \%$ & $61 \%$ & $32 \%$ & $18 \%$ \\
\hline 1990 & $100 \%$ & $29 \%$ & $58 \%$ & $33 \%$ & $19 \%$ \\
\hline 1991 & $100 \%$ & $26 \%$ & $58 \%$ & $32 \%$ & $18 \%$ \\
\hline 1992 & $100 \%$ & $22 \%$ & $57 \%$ & $28 \%$ & $15 \%$ \\
\hline 1993 & $100 \%$ & $20 \%$ & $60 \%$ & $26 \%$ & $14 \%$ \\
\hline
\end{tabular}

** Figures are for state-owned units unless otherwise noted. State investment was $67 \%$ of all investment in 1983 and $61 \%$ in 1993 . Total investment refers to the State Statistical Bureau's category of "fixed assets investment," which is the sum of "capital construction," "technical updating and transformation," and "other" investments. Capital construction investments are intended primarily for building new production capacity, while technical updating and transformation funds are for repair and retrofitting of existing capacity. Most of the "other" investment in the energy sector is for further development of existing oilfields. All investment figures include some funds intended for "nonproductive" uses, e.g., worker housing, schools, etc. The magnitude of this "nonproductive" investment can be gauged from its share of capital construction investment, detailed in Table III-5, Energy Industry Capital Construction Investment by Subsector and Purpose. Please refer to general notes at the beginning of this section regarding coverage and significance of these figures.

t Energy industry fixed assets investment figures are for state- and urban collective-owned units, except 1989 and later years, which are for stateowned units only.

I For 1966-1970 and 1971-1974 only total capital construction investment figures are available (54.151 billion current yuan and 74.96 billion current yuan respectively). Here we have approximated the division of investment funds among the years in these two periods by linear extrapolation, using the investment totals as control sums and reported investment in 1965 and 1975 as the endpoints. "Industry capital construction investment" is part of "total capital construction investment," and "energy industry capital construction investment" is part of "industry capital construction investment."

Source: Yearbook of China's Economy, various years; China Energy Statistical Yearbook, various years; China Statistical Yearbook, various years; Energy Research Institute. 
Figure III-1. Capital Construction Investment

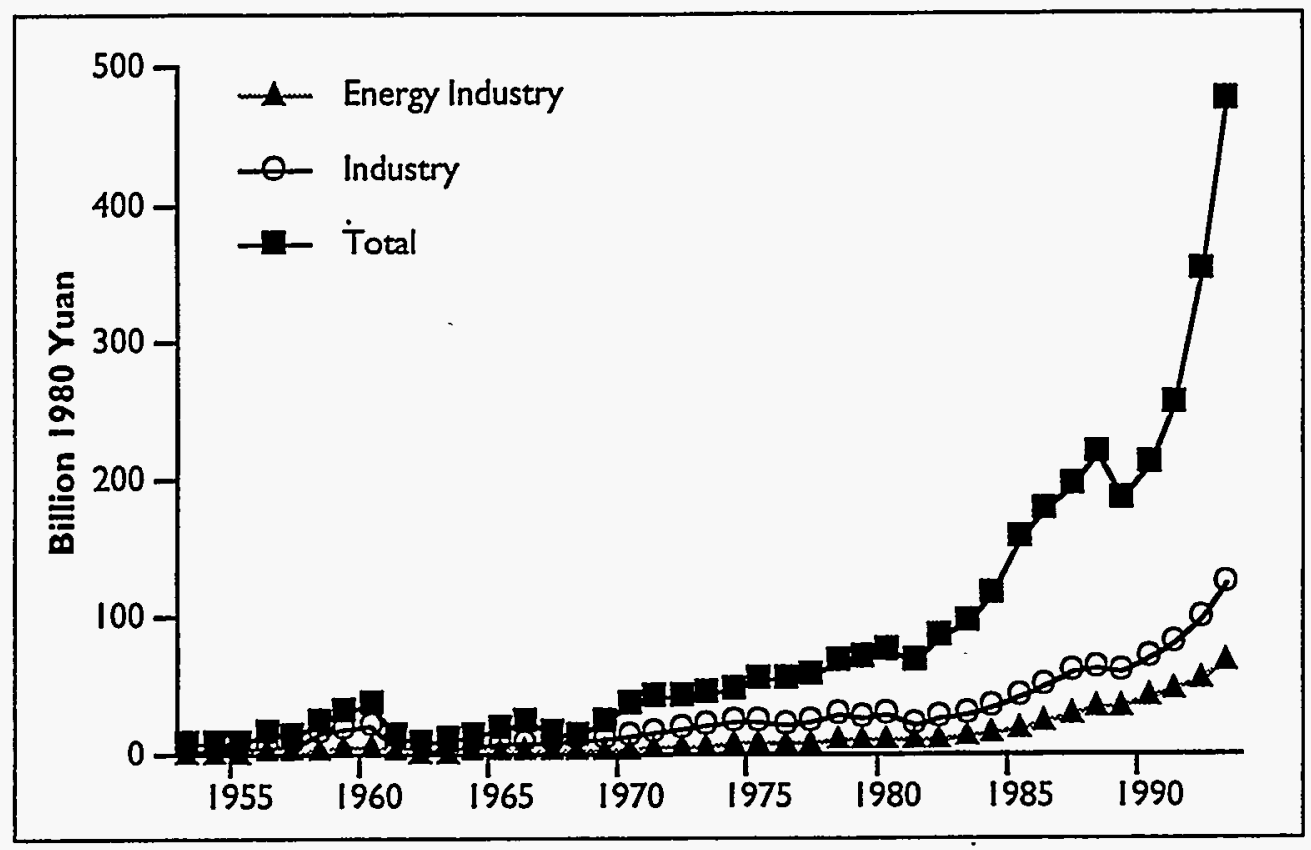

Figure III-2. Structure of Capital Construction Investment

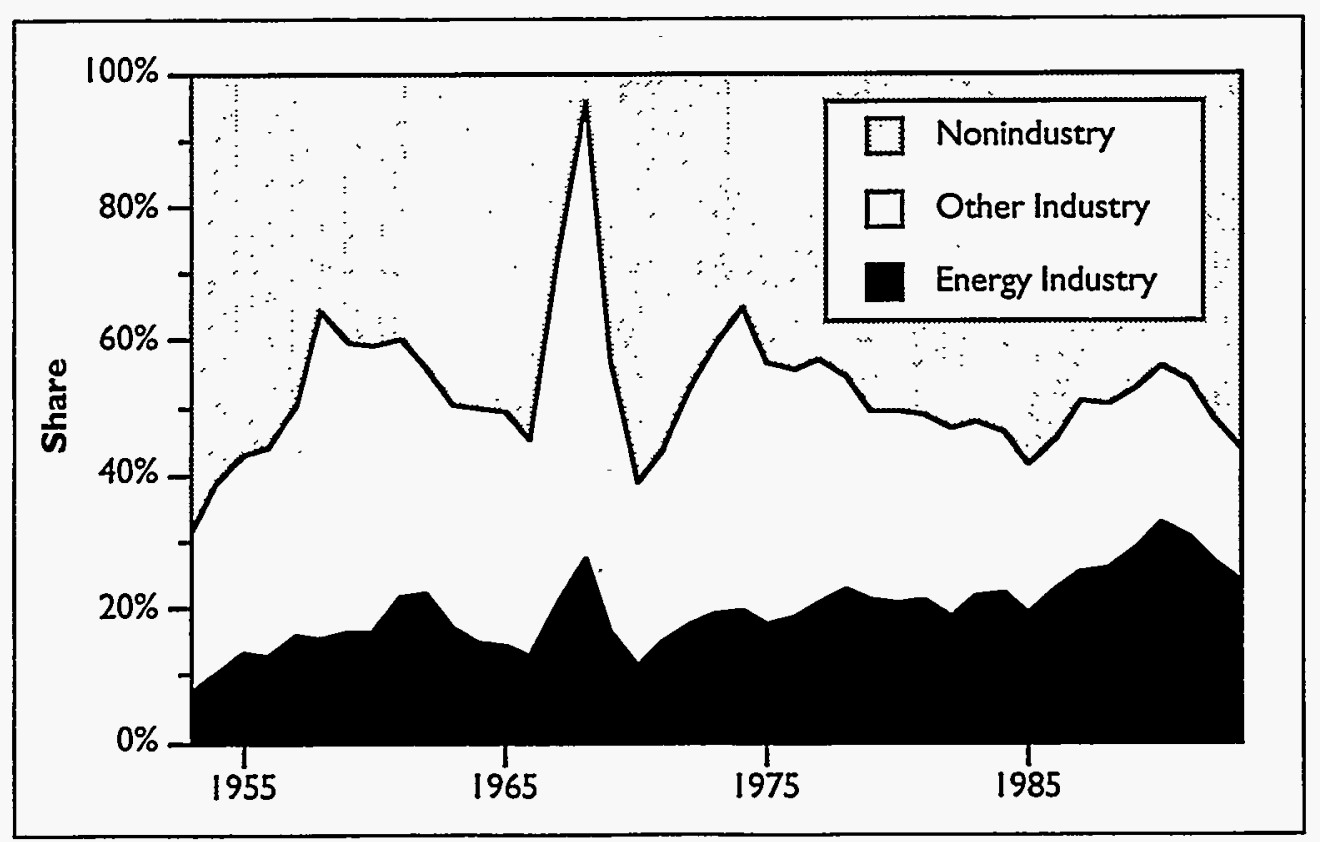


Table III-2. Total Investment by Ownership of Enterprise, * 1983-1993

\begin{tabular}{|c|c|c|c|c|c|c|c|c|c|c|}
\hline \multicolumn{5}{|c|}{ I. Billion Current Yuan } & & & & \multirow{3}{*}{$\begin{array}{l}\text { Joint } \\
\text { Venture } \\
\text { \& Other }\end{array}$} & \multirow{3}{*}{\multicolumn{2}{|c|}{$\begin{array}{r}\text { Total Energy } \\
\text { Industry } \\
\text { Total Investment }\end{array}$}} \\
\hline \multicolumn{2}{|c|}{ State-Owned } & \multicolumn{3}{|c|}{ Collective-Owned Units } & \multicolumn{3}{|c|}{ Individual Investment } & & & \\
\hline Year & Units & Urban & Rural & Subtotal & Urban & Rural & Subtotal & & & \\
\hline 1983 & 95.196 & 4.565 & 11.068 & 15.633 & 1.672 & 30.505 & 32.177 & - & 143.006 & 21.34 \\
\hline 1984 & 118.518 & 6.386 & 17.483 & 23.869 & 2.989 & 37.911 & 40.900 & - & | 83.287 & 27.90 \\
\hline 1985 & 168.051 & 12.823 & 19.923 & 32.746 & 5.679 & 47.843 & 53.522 & - & 254.319 & 36.83 \\
\hline 1986 & 197.850 & 14.639 & 24.535 & 39.174 & 7.456 & 57.482 & 64.938 & - & 301.962 & 44.77 \\
\hline 1987 & 229.799 & 18.130 & 36.571 & 54.701 & 10.051 & 69.535 & 79.586 & - & 364.086 & 55.00 \\
\hline 1988 & 276.276 & 25.497 & 45.674 & 71.171 & 15.685 & 86.523 & 102.208 & - & 449.655 & 65.27 \\
\hline 1989 & 253.548 & 18.563 & 38.436 & 56.999 & 14.023 & 89.203 & 103.226 & - & 413.773 & 70.56 \\
\hline 1990 & 291.864 & 16.338 & 36.610 & 52.948 & 12.470 & 87.647 & 100.117 & - & 444.929 & 84.67 \\
\hline 1991 & 362.811 & 20.383 & 49.398 & 69.781 & 14.032 & 104.256 & 118.288 & - & 550.880 & 95.68 \\
\hline 1992 & 527.364 & 36.449 & 99.486 & 135.935 & 21.647 & 100.552 & 122.199 & - & 785.498 & 116.41 \\
\hline 1993 & 765.797 & 60.015 & 163.119 & 223.134 & 33.850 & 113.773 & 147.623 & 109.232 & 1245.786 & 149.77 \\
\hline
\end{tabular}

\begin{tabular}{|c|c|c|c|c|c|c|c|c|c|c|}
\hline \multirow{2}{*}{\multicolumn{2}{|c|}{$\begin{array}{l}\text { 2. Shares of Total } \\
\text { State-Owned } \\
\text { Year Units }\end{array}$}} & \multicolumn{3}{|c|}{ Collective-Owned Units } & \multicolumn{3}{|c|}{ Individual Investment } & \multirow{2}{*}{$\begin{array}{l}\text { Joint } \\
\text { Venture } \\
\text { \& Other }\end{array}$} & \multirow{2}{*}{\multicolumn{2}{|c|}{$\begin{array}{r}\text { Total Energy } \\
\text { Industry } \\
\text { Total Investment } \dagger\end{array}$}} \\
\hline & & Urban & Rural & Subtotal & Urban & Rural & Subtotal & & & \\
\hline 1983 & $66.6 \%$ & $3.2 \%$ & $7.7 \%$ & $10.9 \%$ & $1.2 \%$ & $21.3 \%$ & $22.5 \%$ & - & $100.0 \%$ & $14.9 \%$ \\
\hline 1984 & $64.7 \%$ & $3.5 \%$ & $9.5 \%$ & $13.0 \%$ & $1.6 \%$ & $20.7 \%$ & $22.3 \%$ & - & $100.0 \%$ & $15.2 \%$ \\
\hline 1985 & $66.1 \%$ & $5.0 \%$ & $7.8 \%$ & $12.9 \%$ & $2.2 \%$ & $18.8 \%$ & $21.0 \%$ & - & $100.0 \%$ & $14.5 \%$ \\
\hline 1986 & $65.5 \%$ & $4.8 \%$ & $8.1 \%$ & $13.0 \%$ & $2.5 \%$ & $19.0 \%$ & $21.5 \%$ & - & $100.0 \%$ & $14.8 \%$ \\
\hline 1987 & $63.1 \%$ & $5.0 \%$ & $10.0 \%$ & $15.0 \%$ & $28 \%$ & $19.1 \%$ & $21.9 \%$ & - & $100.0 \%$ & $15.1 \%$ \\
\hline 1988 & $61.4 \%$ & $5.7 \%$ & $10.2 \%$ & $15.8 \%$ & $3.5 \%$ & $19.2 \%$ & $22.7 \%$ & - & $100.0 \%$ & $14.5 \%$ \\
\hline 1989 & $61.3 \%$ & $4.5 \%$ & $9.3 \%$ & $13.8 \%$ & $3.4 \%$ & $21.6 \%$ & $24.9 \%$ & - & $100.0 \%$ & $17.1 \%$ \\
\hline 1990 & $65.6 \%$ & $3.7 \%$ & $8.2 \%$ & $11.9 \%$ & $2.8 \%$ & $19.7 \%$ & $22.5 \%$ & - & $100.0 \%$ & $19.0 \%$ \\
\hline 1991 & $65.9 \%$ & $3.7 \%$ & $9.0 \%$ & $127 \%$ & $2.5 \%$ & $18.9 \%$ & $21.5 \%$ & - & $100.0 \%$ & $17.4 \%$ \\
\hline 1992 & $67.1 \%$ & $4.6 \%$ & $127 \%$ & $17.3 \%$ & $2.8 \%$ & $12.8 \%$ & $15.6 \%$ & - & $100.0 \%$ & $14.8 \%$ \\
\hline 1993 & $61.5 \%$ & $4.8 \%$ & $13.1 \%$ & $17.9 \%$ & $2.7 \%$ & $9.1 \%$ & $11.8 \%$ & $8.8 \%$ & $100.0 \%$ & $12.0 \%$ \\
\hline
\end{tabular}

* Unlike most of the tables in this chapter, which only refer to investment in state-owned units, this table has data on collective and individual investment as well. Breakdowns of investment in units owned by collectives and individuals are not available. The most important investment category not well-characterized by available data is probably investment in collective- and individually-owned rural coal mines.

$\dagger$ For state- and urban collective-owned units.

Source: China Statistical yearbook, various years. 
Table III-3. Total Energy Industry Investment by Subsector, * 1981-1993

\begin{tabular}{|c|c|c|c|c|c|c|c|}
\hline \multicolumn{8}{|c|}{ 1. Billion Current Yuan } \\
\hline Year & $\begin{array}{c}\text { Coal } \\
\text { Extraction }\end{array}$ & $\begin{array}{l}\text { Coking, Coal } \\
\text { Gas and } \\
\text { Coal Products }\end{array}$ & $\begin{array}{l}\text { Oil and } \\
\text { Natural Gas } \\
\text { Extraction }\end{array}$ & $\begin{array}{c}\text { Oil } \\
\text { Refining }\end{array}$ & $\begin{array}{l}\text { Electricity } \\
\text { Generation } \\
\text { and Supply }\end{array}$ & $\begin{array}{c}\text { Energy } \\
\text { Industry } \\
\text { Subtotal ף }\end{array}$ & $\begin{array}{c}\text { Total } \\
\text { Industry } \\
\text { Investment ๆ }\end{array}$ \\
\hline 1981 & 3.633 & 0.359 & 4.686 & 0.737 & 4.755 & 14.170 & 38.043 \\
\hline 1982 & 4.865 & 0.114 & 6.199 & 0.700 & 5.515 & 17.393 & 46.743 \\
\hline 1983 & 6.208 & 0.145 & 7.424 & 0.649 & 6.888 & 21.314 & 54.662 \\
\hline 1984 & 8.188 & 0.374 & 9.460 & 0.987 & 8.841 & 27.850 & 65.352 \\
\hline 1985 & 8.799 & 1.072 & 13.029 & 1.209 & 12.166 & 36.275 & 91.365 \\
\hline 1986 & 9.310 & 1.632 & 13.782 & 1.627 & 17.795 & 44.146 & 115.982 \\
\hline 1987 & 9.938 & 1.720 & 16.623 & 2.635 & 23.113 & 54.029 & 140.715 \\
\hline 1988 & 10.796 & 1.996 & 19.690 & 4.211 & 27.311 & 64.004 & 170.909 \\
\hline 1989 & 12.230 & 1.993 & 23.294 & 3.474 & 29.572 & 70.563 & 159.701 \\
\hline 1990 & 14.633 & 3.284 & 24.926 & 4.243 & 36.604 & 83.690 & 180.988 \\
\hline 1991 & 16.869 & 3.577 & 27.469 & 6.030 & 41.018 & 94.963 & 211.320 \\
\hline 1992 & 18.495 & 3.994 & 32.687 & 6.699 & 53.621 & 115.496 & 275.947 \\
\hline 1993 & 21.864 & 4.507 & 35.930 & 12.603 & 74.863 & 149.767 & 357.157 \\
\hline
\end{tabular}

\begin{tabular}{|c|c|c|c|c|c|c|c|}
\hline \multicolumn{8}{|c|}{ 2. Billion 1980 Yuan $f$} \\
\hline Year & $\begin{array}{c}\text { Coal } \\
\text { Extraction }\end{array}$ & $\begin{array}{l}\text { Coking, Coal } \\
\text { Gas and } \\
\text { Coal Products }\end{array}$ & $\begin{array}{c}\text { Oil and } \\
\text { Natural Gas } \\
\text { Extraction }\end{array}$ & $\begin{array}{c}\text { Oil } \\
\text { Refining }\end{array}$ & $\begin{array}{l}\text { Electricity } \\
\text { Generation } \\
\text { and Supply }\end{array}$ & $\begin{array}{c}\text { Energy } \\
\text { Industry } \\
\text { Subtotal } \pi\end{array}$ & $\begin{array}{c}\text { Total } \\
\text { Industry } \\
\text { Investment II }\end{array}$ \\
\hline 1981 & 3.622 & 0.358 & 4.672 & 0.735 & 4.741 & 14.128 & 37.931 \\
\hline 1982 & 4.858 & 0.114 & 6.190 & 0.699 & 5.507 & 17.367 & 46.673 \\
\hline 1983 & 6.210 & 0.145 & 7.426 & 0.649 & 6.890 & 21.319 & 54.676 \\
\hline 1984 & 7.989 & 0.365 & 9.230 & 0.963 & 8.626 & 27.173 & 63.763 \\
\hline 1985 & 8.166 & 0.995 & 12092 & 1.122 & 11.291 & 33.667 & 84.796 \\
\hline 1986 & 8.386 & 1.470 & 12.414 & 1.465 & 16.028 & 39.763 & 104.468 \\
\hline 1987 & 8.483 & 1.468 & 14.189 & 2249 & 19.729 & 46.118 & 120.111 \\
\hline 1988 & 8.513 & 1.574 & 15.527 & 3.321 & 21.537 & 50.472 & 134.774 \\
\hline 1989 & 8.875 & 1.446 & 16.903 & 2521 & 21.458 & 51.203 & 115.885 \\
\hline 1990 & 10.576 & 2.374 & 18.015 & 3.067 & 26.456 & 60.487 & 130.810 \\
\hline 1991 & 11.801 & 2.502 & 19.217 & 4.219 & 28.696 & 66.435 & 147.838 \\
\hline 1992 & 12341 & 2.665 & 21.810 & 4.470 & 35.778 & 77.063 & 184.122 \\
\hline 1993 & 13.557 & 2795 & 22.278 & 7.814 & $46.418^{\circ}$ & 92862 & 221.453 \\
\hline
\end{tabular}

- Estimates in italics. Figures before 1989 include investment in state- and urban collective-owned units only. 1989 and later figures are for state-owned units only. Sum of sectoral figures is slightly less than total figure because only one item in the "Other Investment" category (oilfield maintenance and development projects, amounting to about13.5 billion yuan per year) was available. Investment includes capital construction, technical updating and transformation, and other investment, the former representing the majority of investment. Please see notes at the beginning of this section.

$\dagger$ ' Deflated using the implicit deflators for the industrial sector in Table X-6.

I All years include investment in state-owned units only.

Source: China Statistical Yearbook, various years; China Energy Statistical Yearbook, various years; Statistical Yearbook of China's Industrial Economy, various years; Energy Research Institute. 


\section{Table III-3. Total Energy Industry Investment by Subsector, * 1981-1993 (continued)}

\begin{tabular}{|c|c|c|c|c|c|c|c|}
\hline \multicolumn{8}{|c|}{ 3. Shares of Energy Industry Investment } \\
\hline Year & $\begin{array}{c}\text { Coal } \\
\text { Extraction }\end{array}$ & $\begin{array}{l}\text { Coking Coal } \\
\text { Gas and } \\
\text { Coal Products }\end{array}$ & $\begin{array}{c}\text { Oil and } \\
\text { Natural Gas } \\
\text { Extraction }\end{array}$ & $\begin{array}{c}\text { Oil } \\
\text { Refining }\end{array}$ & $\begin{array}{l}\text { Electricity } \\
\text { Generation } \\
\text { and Supply }\end{array}$ & $\begin{array}{c}\text { Energy } \\
\text { Industry } \\
\text { Subtotal II }\end{array}$ & $\begin{array}{c}\text { Energy } \\
\text { Industry as } \\
\text { Percent of Total } \\
\text { Industry }\end{array}$ \\
\hline 1981 & $26 \%$ & $3 \%$ & $33 \%$ & $5 \%$ & $34 \%$ & $100 \%$ & $37 \%$ \\
\hline 1982 & $28 \%$ & $1 \%$ & $36 \%$ & $4 \%$ & $32 \%$ & $100 \%$ & $37 \%$ \\
\hline 1983 & $29 \%$ & $1 \%$ & $35 \%$ & $3 \%$ & $32 \%$ & $100 \%$ & $39 \%$ \\
\hline 1984 & $29 \%$ & $1 \%$ & $34 \%$ & $4 \%$ & $32 \%$ & $100 \%$ & $43 \%$ \\
\hline 1985 & $24 \%$ & $3 \%$ & $36 \%$ & $3 \%$ & $34 \%$ & $100 \%$ & $40 \%$ \\
\hline 1986 & $21 \%$ & $4 \%$ & $31 \%$ & $4 \%$ & $40 \%$ & $100 \%$ & $38 \%$ \\
\hline 1987 & $18 \%$ & $3 \%$ & $31 \%$ & $5 \%$ & $43 \%$ & $100 \%$ & $38 \%$ \\
\hline 1988 & $17 \%$ & $3 \%$ & $31 \%$ & $7 \%$ & $43 \%$ & $100 \%$ & $37 \%$ \\
\hline 1989 & $17 \%$ & $3 \%$ & $33 \%$ & $5 \%$ & $42 \%$ & $100 \%$ & $44 \%$ \\
\hline 1990 & $17 \%$ & $4 \%$ & $30 \%$ & $5 \%$ & $44 \%$ & $100 \%$ & $46 \%$ \\
\hline 1991 & $18 \%$ & $4 \%$ & $29 \%$ & $6 \%$ & $43 \%$ & $100 \%$ & $45 \%$ \\
\hline 1992 & $16 \%$ & $3 \%$ & $28 \%$ & $6 \%$ & $46 \%$ & $100 \%$ & $42 \%$ \\
\hline 1993 & $15 \%$ & $3 \%$ & $24 \%$ & $8 \%$ & $50 \%$ & $100 \%$ & $42 \%$ \\
\hline
\end{tabular}

* Estimates in italics. Figures before 1989 include investment in state- and urban collective-owned units only. 1989 and later figures are for state-owned units only. Sum of sectoral figures is slightly less than total figure because only one item in the "Other Investment" category (oilfield maintenance and development projects, amounting to about13.5 billion yuan per year) was available. Investment includes capital construction, technical updating and transformation, and other investment, the former representing the majority of investment. Please see notes at the beginning of this section.

Source: China Statistical Yearbook, various years; China Energy Statistical Yearbook, various years; Statistical Yearbook of China's Industrial Economy, various years; Energy Research Institute. 
Figure III-3. Total Energy Industry Investment by Subsector

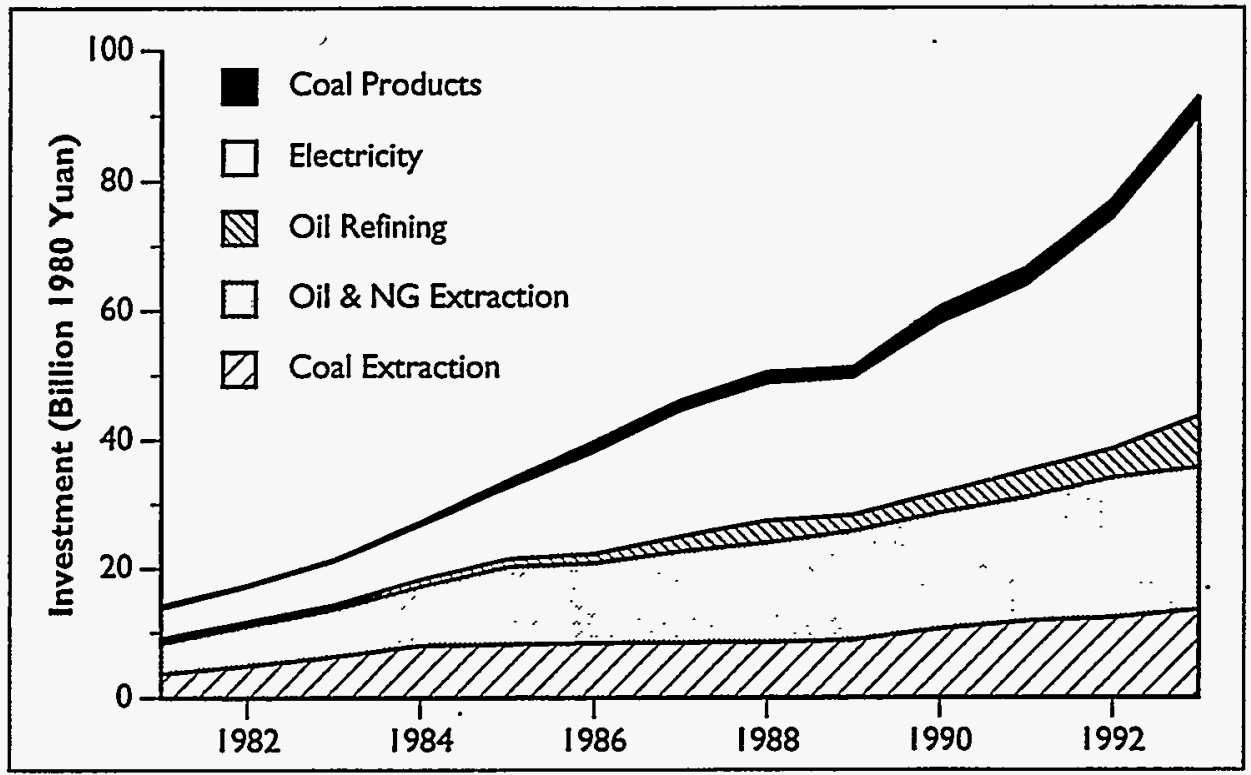

Figure III-4. Shares of Total Energy Industry Investment

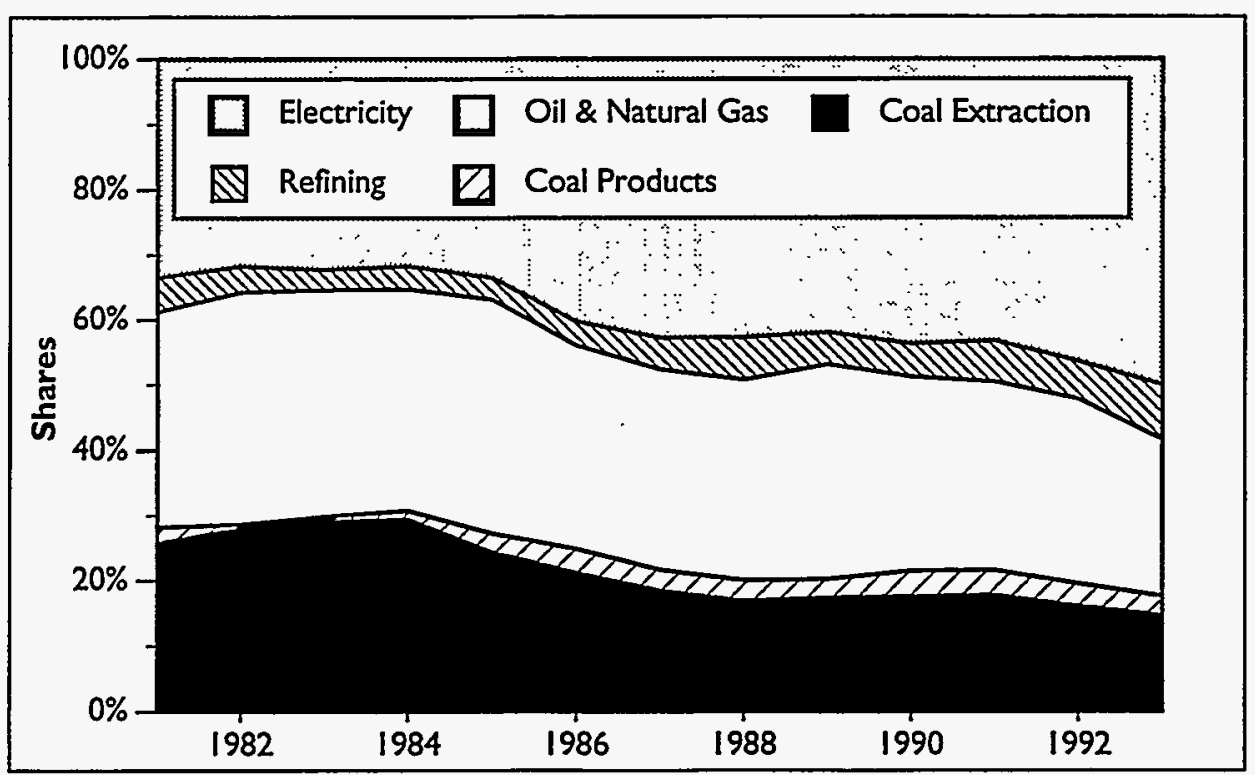




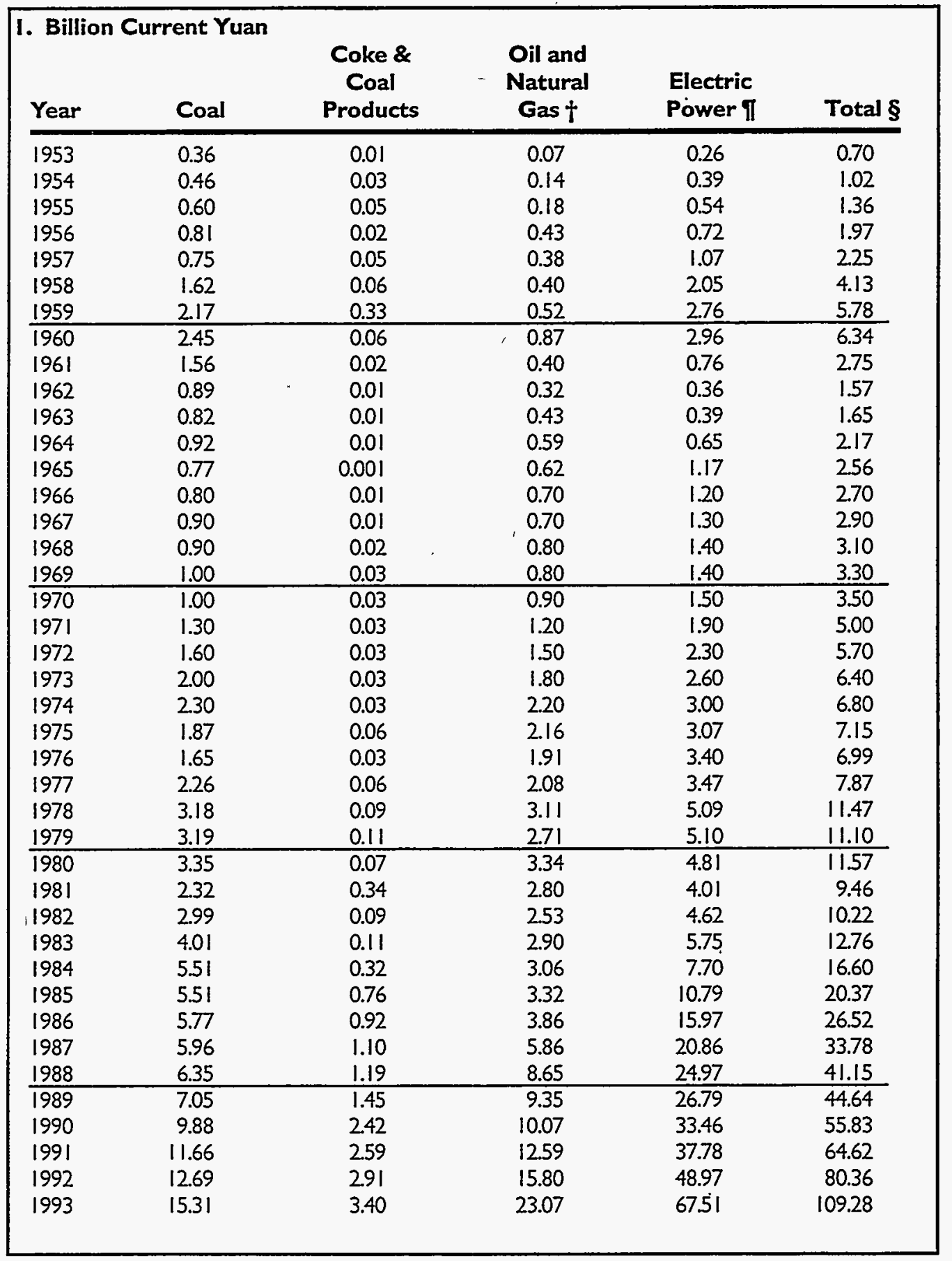

* For state-owned units only. Official statistics for energy investment for 1966-1970 and 1971-1974 are not available for individual years. Here we have approximated the division of investment funds among the years in these two periods by linear extrapolation, using the investment totals for each period as control sums and reported investment in 1965 and 1975 as the endpoints. Investment figures are deflated using the implicit deflators for the industrial sector in Table X-6.

$\dagger$ Includes investments in refining.

Does not include investment in steam and hot water supply for years before 1988.

$\S$ Totals for 1985-1990 differ from official data because, for consistency with previous years, we exclude electricity sector investment in steam and hot water supply (which in 1989 amounted to 322 million yuan).

Source: China Energy Statistical Yearbook, various years; China Statistical Yearbook, various years; Energy Research Institute. 
Table III-4. Energy Industry Capital Construction Investment by Subsector,*

1953-1994 (continued)

\begin{tabular}{|c|c|c|c|c|c|}
\hline \multicolumn{6}{|c|}{ 2. Constant 1980 Yuan } \\
\hline Year & Coal & $\begin{array}{c}\text { Coke \& } \\
\text { Coal } \\
\text { Products }\end{array}$ & $\begin{array}{c}\text { Oil and } \\
\text { Natural } \\
\text { Gas } \dagger\end{array}$ & $\begin{array}{l}\text { Electric } \\
\text { Power \ }\end{array}$ & Total $\S$ \\
\hline 1953 & 0.27 & 0.01 & 0.05 & 0.20 & 0.54 \\
\hline 1954 & 0.37 & 0.02 & 0.12 & 0.32 & 0.84 \\
\hline 1955 & 0.50 & 0.04 & 0.15 & 0.45 & 1.15 \\
\hline 1956 & 0.75 & 0.02 & 0.39 & 0.67 & 1.83 \\
\hline 1957 & 0.64 & 0.04 & 0.33 & 0.91 & 1.92 \\
\hline 1958 & 1.39 & 0.05 & 0.34 & 1.76 & 3.54 \\
\hline 1959 & 1.85 & 0.28 & 0.44 & 235 & 4.93 \\
\hline 1960 & 2.11 & 0.05 & 0.75 & 2.55 & 5.45 \\
\hline 1961 & 1.28 & 0.01 & 0.33 & 0.63 & 2.25 \\
\hline 1962 & 0.70 & 0.01 & 0.25 & 0.28 & 1.24 \\
\hline 1963 & 0.66 & 0.01 & 0.34 & 0.31 & 1.32 \\
\hline 1964. & 0.73 & 0.00 & 0.47 & 0.52 & 1.73 \\
\hline 1965 & 0.65 & 0.00 & 0.53 & 0.99 & 2.17 \\
\hline 1966 & 0.71 & 0.01 & 0.62 & 1.06 & 2.40 \\
\hline 1967 & 0.81 & 0.01 & 0.63 & 1.16 & 261 \\
\hline 1968 & 0.82 & 0.02 & 0.73 & 1.28 & 2.86 \\
\hline 1969 & 0.95 & 0.02 & 0.76 & 1.33 & 3.06 \\
\hline 1970 & 0.98 & 0.03 & 0.88 & 1.47 & 3.36 \\
\hline 1971 & 1.28 & 0.03 & 1.18 & 1.87 & 4.36 \\
\hline 1972 & 1.59 & 0.03 & 1.49 & 2.28 & 5.39 \\
\hline 1973 & 1.99 & 0.03 & 1.79 & 259 & 6.41 \\
\hline 1974 & 2.29 & 0.03 & 2.19 & 2.99 & 7.51 \\
\hline 1975 & 1.88 & 0.06 & 2.18 & 3.09 & 7.21 \\
\hline 1976 & 1.67 & 0.03 & 1.93 & 3.44 & 7.07 \\
\hline 1977 & 2.30 & 0.06 & 2.11 & 3.53 & 8.01 \\
\hline 1978 & 3.22 & 0.09 & 3.15 & 5.15 & 11.61 \\
\hline 1979 & 3.18 & 0.11 & 270 & 5.09 & 11.09 \\
\hline 1980 & 3.35 & 0.07 & 3.34 & $4.8 I$ & 11.57 \\
\hline 1981 & 2.31 & 0.34 & 2.79 & 4.00 & 9.44 \\
\hline 1982 & 2.98 & 0.08 & 2.53 & 4.62 & 10.21 \\
\hline 1983 & 4.01 & 0.11 & 2.90 & 5.75 & 12.76 \\
\hline 1984 & 5.38 & 0.31 & 2.99 & 7.51 & 16.19 \\
\hline 1985 & 5.11 & 0.70 & 3.08 & 10.01 & 18.91 \\
\hline 1986 & 5.20 & 0.83 & 3.48 & 14.39 & 23.89 \\
\hline 1987 & 5.09 & 0.94 & 5.00 & 17.81 & 28.84 \\
\hline 1988 & 5.01 & 0.93 & 6.82 & 19.69 & 32.45 \\
\hline 1989 & 5.12 & 1.05 & 6.79 & 19.44 & 32.39 \\
\hline 1990 & 7.14 & 1.75 & 7.28 & 24.18 & 40.35 \\
\hline 1991 & 8.16 & 1.81 & 8.81 & 26.43 & 45.20 \\
\hline 1992 & 8.46 & 1.94 & 10.54 & 3267 & 53.62 \\
\hline 1993 & 9.49 & 2.11 & 14.30 & 41.86 & 67.76 \\
\hline
\end{tabular}

* For state-owned units only. Official statistics for energy investment for 1966-1970 and 1971-1974 are not available for individual years. Here we have approximated the division of investment funds among the years in these two periods by linear extrapolation, using the investment totals for each period as control sums and reported investment in 1965 and 1975 as the endpoints. Investment figures are deflated using the implicit deflators for the industrial sector in Table X-6.

+ Includes investments in refining.

I Does not include investment in steam and hot water supply for years before 1988.

\$ Totals for 1985-1990 differ from official data because, for consistency with previous years, we exclude electricity sector investment in steam and hot water supply (which in 1989 amounted to 322 million yuan).

Source: China Energy Statistical Yearbook, various years; China Statistical Yearbook, various years; Energy Research Institute. 
Figure III-5. Capital Construction Investment in the Energy Industry by Subsector

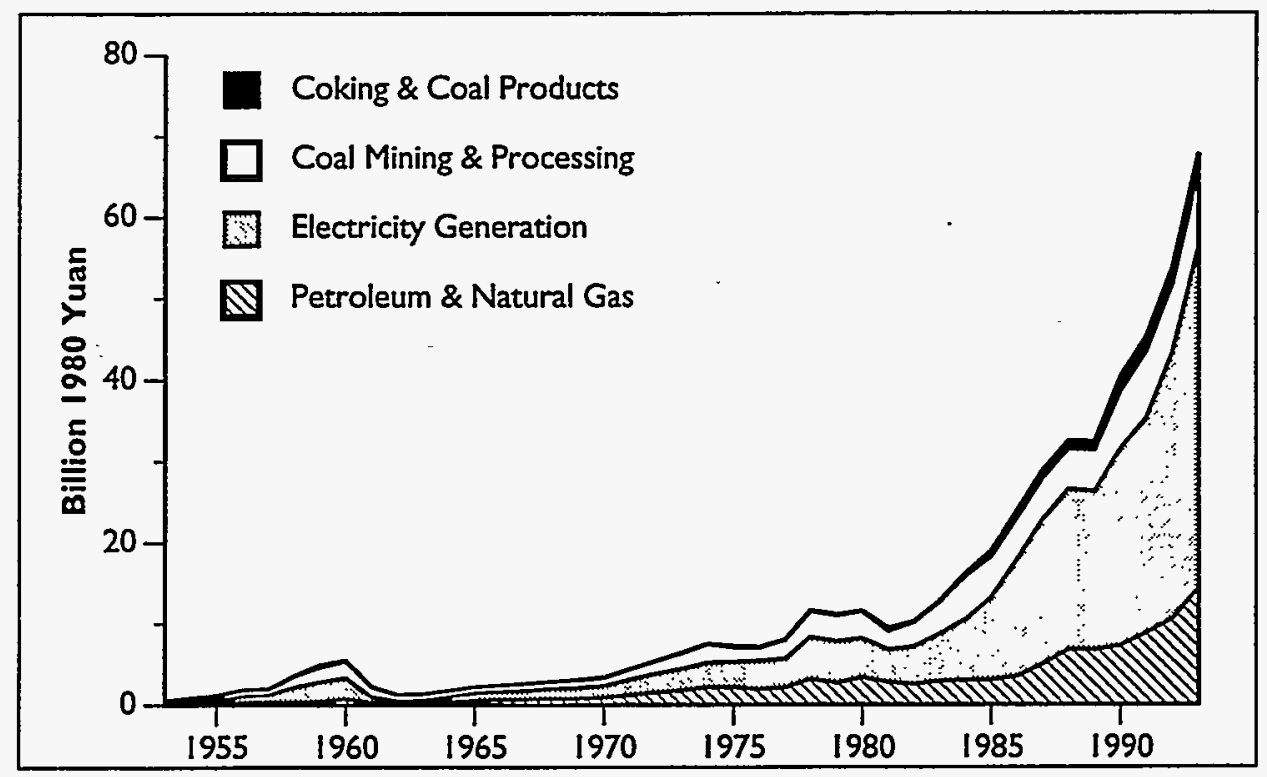

Figure III-6. Subsectoral Shares of Energy Industry Capital Construction Investment

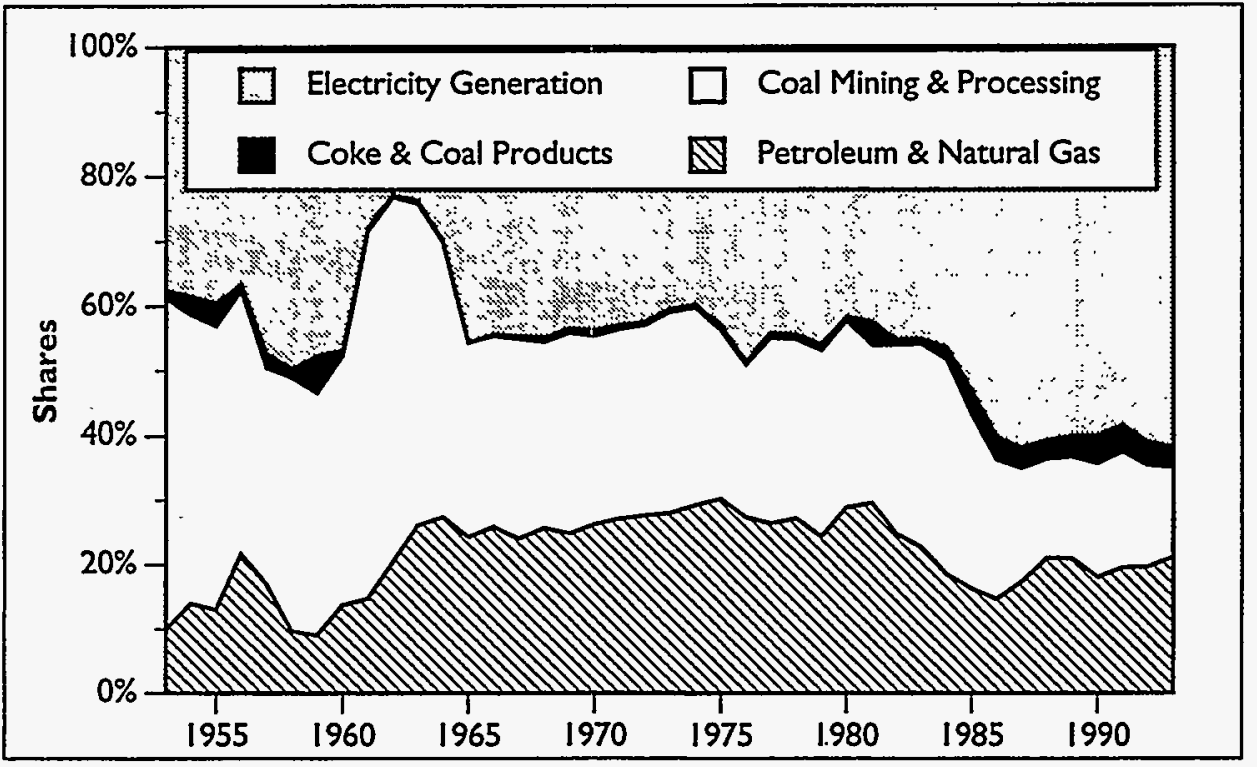




\section{Table III-5. Energy Industry Capital Construction Investment by Subsector and Purpose, * 1985-1992}

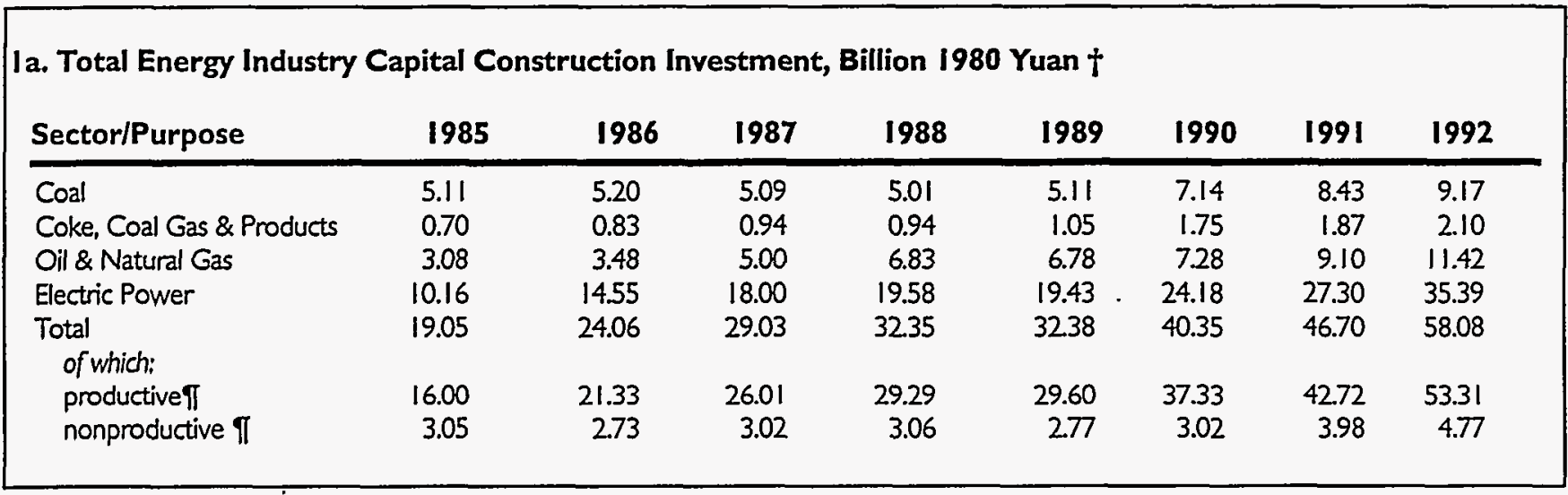

\begin{tabular}{|c|c|c|c|c|c|c|c|c|}
\hline Sector/Purpose & 1985 & 1986 & 1987 & 1988 & 1989 & 1990 & 1991 & 1992 \\
\hline $\begin{array}{l}\text { Coal } \\
\text { Coke, Coal Gas \& Products } \\
\text { Oil \& Natural Gas } \\
\text { Electric Power } \\
\text { Total } \\
\text { of which: } \\
\text { productive } \pi \\
\text { nonproductive } 9\end{array}$ & $\begin{array}{r}27 \% \\
4 \% \\
16 \% \\
53 \% \\
100 \%\end{array}$ & $\begin{array}{r}22 \% \\
3 \% \\
14 \% \\
61 \% \\
100 \%\end{array}$ & $\begin{array}{r}18 \% \\
3 \% \\
17 \% \\
62 \% \\
100 \%\end{array}$ & $\begin{array}{r}15 \% \\
3 \% \\
21 \% \\
61 \% \\
100 \%\end{array}$ & $\begin{array}{r}16 \% \\
3 \% \\
21 \% \\
60 \% \\
100 \%\end{array}$ & $\begin{array}{r}18 \% \\
4 \% \\
18 \% \\
60 \% \\
100 \%\end{array}$ & $\begin{array}{r}18 \% \\
4 \% \\
19 \% \\
58 \% \\
100 \%\end{array}$ & $\begin{array}{r}16 \% \\
4 \% \\
20 \% \\
61 \% \\
100 \%\end{array}$ \\
\hline
\end{tabular}

- Figures refer to investment in capital construction of state-and urban collective-owned units only, and consequently differ slightly from those in the previous table, which are for state-owned units only.

$\dagger$ Deflated using the implicit deflators for industry sector national income presented in Table X- 6 .

9 Productive investment is for the purpose of increasing or maintaining production capacity. Nonproductive investment refers to construction of schools, hospitals, housing and other workforce social welfare facilities.

Source: China Energy Statistical Yearbook, various years; China Statistical Yearbook, various years. 


\section{Table III-5. Energy Industry Capital Construction Investment by Subsector and Purpose, * 1985-1992 (continued)}

2a. Coal Industry Capital Construction Investment, Billion 1980 Yuan $\dagger$

\begin{tabular}{lcccccccc} 
Sector/Purpose & 1985 & 1986 & 1987 & 1988 & 1989 & 1990 & 1991 & 1992 \\
\hline Extraction & 5.02 & 5.10 & 4.87 & 4.88 & 5.02 & - & - & - \\
Preparation & 0.10 & 0.10 & 0.22 & 0.13 & 0.09 & - & - & - \\
Total & 5.11 & 5.20 & 5.09 & 5.01 & 5.11 & 7.14 & 8.43 & 9.17 \\
$\quad$ of which: & & & & & & & & \\
$\quad$ productive II & 3.90 & 4.17 & 4.15 & 4.16 & 4.32 & 6.08 & 7.10 & 7.59 \\
$\quad$ nonproductive I & 1.21 & 1.03 & 0.94 & 0.85 & 0.80 & 1.07 & 1.33 & 1.58
\end{tabular}

\begin{tabular}{|c|c|c|c|c|c|c|c|c|}
\hline Sector/Purpose & 1985 & 1986 & 1987 & 1988 & 1989 & 1990 & 1991 & 1992 \\
\hline $\begin{array}{l}\text { Extraction } \\
\text { Preparation }\end{array}$ & $\begin{array}{r}98.1 \% \\
1.9 \%\end{array}$ & $\begin{array}{r}98.1 \% \\
1.9 \%\end{array}$ & $\begin{array}{r}95.8 \% \\
4.2 \%\end{array}$ & $\begin{array}{r}97.5 \% \\
25 \%\end{array}$ & $\begin{array}{r}98.2 \% \\
1.8 \%\end{array}$ & - & - & - \\
\hline $\begin{array}{l}\text { Total } \\
\text { of which: }\end{array}$ & $100.0 \%$ & $100.0 \%$ & $100.0 \%$ & $100.0 \%$ & $100.0 \%$ & $100.0 \%$ & $100.0 \%$ & $100.0 \%$ \\
\hline $\begin{array}{l}\text { productive } \\
\text { nonproductive } \mathbb{T}\end{array}$ & $\begin{array}{l}76.3 \% \\
23.7 \%\end{array}$ & $\begin{array}{l}80.2 \% \\
19.8 \%\end{array}$ & $\begin{array}{l}81.5 \% \\
18.5 \%\end{array}$ & $\begin{array}{l}83.1 \% \\
16.9 \%\end{array}$ & $\begin{array}{l}84.4 \% \\
15.6 \%\end{array}$ & $\begin{array}{l}85.1 \% \\
14.9 \%\end{array}$ & $\begin{array}{l}84.2 \% \\
15.8 \%\end{array}$ & $\begin{array}{l}82.7 \% \\
17.3 \%\end{array}$ \\
\hline
\end{tabular}

* Figures refer to investment in capital construction of state-and urban collective-owned units only, and consequently differ slightly from those in the previous table, which are for state-owned units only.

$\dagger$ Deflated using the implicit deflators for industry sector national income presented in Table X-6.

I Productive investment is for the purpose of increasing or maintaining production capacity. Nonproductive investment refers to construction of schools, hospitals, housing and other workforce social welfare facilities.

Source: China Energy Statistical Yearbook, various years; China Statistical Yearbook, various years. 


\section{Table III-5. Energy Industry Capital Construction Investment by Subsector and Purpose, * 1985-1992 (continued)}

3a. Coke, Coal Gas, and Coal Products Industry Capital Construction Investment, Billion 1980 Yuan $†$

\begin{tabular}{lllllllll} 
Sector/Purpose & 1985 & 1986 & 1987 & 1988 & 1989 & 1990 & $\mathbf{1 9 9 1}$ & 1992 \\
\hline Coke production & 0.08 & 0.22 & 0.25 & 0.24 & 0.34 & - & - & - \\
Coal gas production & 0.46 & 0.35 & 0.43 & 0.40 & 0.47 & - & - & - \\
Coal gas supply & 0.15 & 0.24 & 0.25 & 0.28 & 0.23 & - & - & - \\
Coal products production & 0.01 & 0.01 & 0.01 & 0.01 & 0.02 & - & - & - \\
Total & 0.70 & 0.83 & 0.94 & 0.94 & 1.05 & 1.75 & 1.87 & 2.10 \\
$\quad$ of which: & & & & & & & & \\
$\quad$ productivef & 0.54 & 0.66 & 0.78 & 0.81 & 0.95 & 1.60 & 1.70 & 1.80 \\
$\quad$ nonproductive II & 0.16 & 0.17 & 0.16 & 0.13 & 0.10 & 0.15 & 0.17 & 0.30
\end{tabular}

3b. Shares of Coke, Coal Gas, and Coal Products Industry Capital Construction Investment

\begin{tabular}{|c|c|c|c|c|c|c|c|c|}
\hline Sector/Purpose & 1985 & 1986 & 1987 & 1988 & 1989 & 1990 & 1991 & 1992 \\
\hline $\begin{array}{l}\text { Coke production } \\
\text { Coal gas production }\end{array}$ & $\begin{array}{l}11.9 \% \\
64.9 \%\end{array}$ & $\begin{array}{l}27.1 \% \\
42.2 \%\end{array}$ & $\begin{array}{l}26.5 \% \\
45.7 \%\end{array}$ & $\begin{array}{l}25.5 \% \\
43.0 \%\end{array}$ & $\begin{array}{l}32.1 \% \\
44.8 \%\end{array}$ & - & - & - \\
\hline $\begin{array}{l}\text { Coal gas production } \\
\text { Coal gas supply }\end{array}$ & $\begin{array}{l}64.9 \% \\
21.8 \%\end{array}$ & $\begin{array}{l}42.2 \% \\
29.3 \%\end{array}$ & $26.4 \%$ & $30.3 \%$ & $21.7 \%$ & - & - & - \\
\hline Coal products production & $1.3 \%$ & $1.4 \%$ & $1.4 \%$ & $1.2 \%$ & $1.4 \%$ & - & - & - \\
\hline Total & $100.0 \%$ & $100.0 \%$ & $100.0 \%$ & $100.0 \%$ & $100.0 \%$ & $100.0 \%$ & $100.0 \%$ & $100.0 \%$ \\
\hline of which: & & & & & & & & \\
\hline productivel & $77.4 \%$ & $80.0 \%$ & $\begin{array}{l}83.2 \% \\
16.8 \%\end{array}$ & $\begin{array}{l}86.3 \% \\
137 \%\end{array}$ & $\begin{array}{r}90.6 \% \\
9.4 \%\end{array}$ & $\begin{array}{r}91.5 \% \\
85 \%\end{array}$ & $\begin{array}{r}90.9 \% \\
91 \%\end{array}$ & $\begin{array}{l}85.8 \% \\
147 \%\end{array}$ \\
\hline nonproductive $\mathbb{I}$ & $226 \%$ & $20.0 \%$ & $16.8 \%$ & & $9.4 \%$ & & $9.1 \%$ & $14.2 \%$ \\
\hline
\end{tabular}

- Figures refer to investment in capital construction of state-and urban collective-owned units only, and consequently differ slightly from those in the previous table, which are for state-owned units only.

$\dagger$ Deflated using the implicit deflators for industry sector national income presented in Table X-6.

I Productive investment is for the purpose of increasing or maintaining production capacity. Nonproductive investment refers to construction of schools, hospitals, housing and other workforce social welfare facilities.

Source: China Energy Statistical Yearbook, various years; China Statistical Yearbook, various years. 


\section{Table III-5. Energy Industry Capital Construction Investment by Subsector and Purpose, * 1985-1992 (continued)}

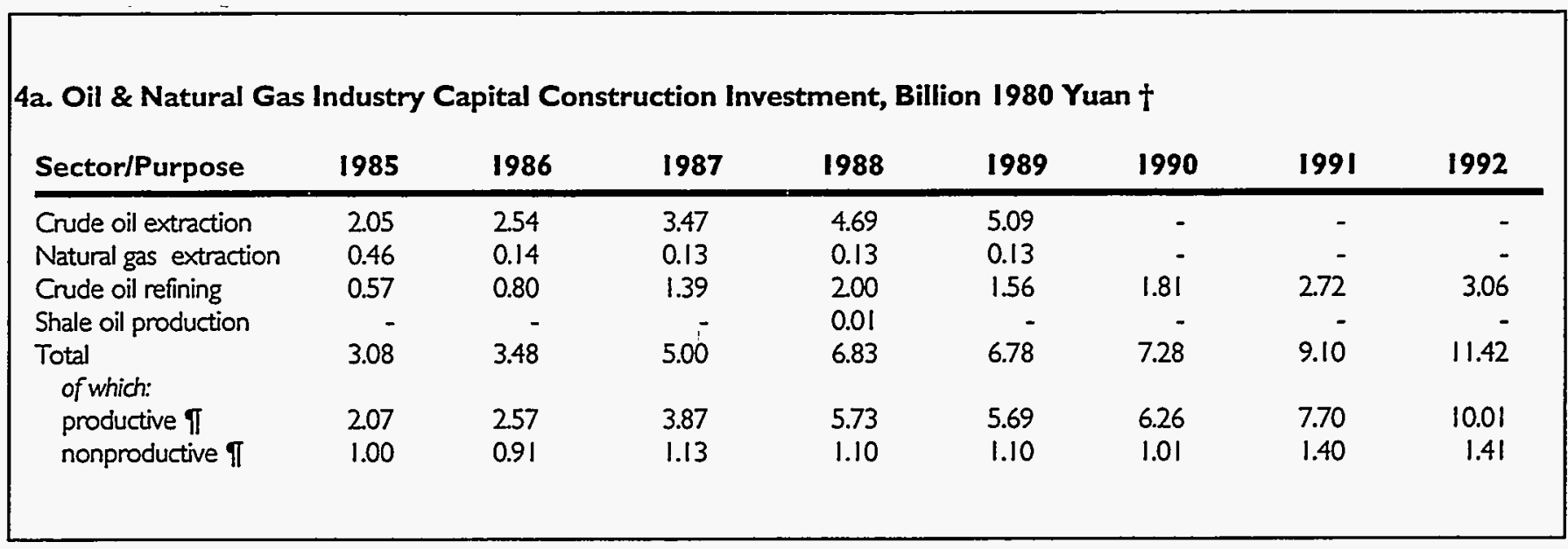

\section{4b. Oil \& Natural Gas Industry Capital Construction Investment, Shares}

\begin{tabular}{lcccccccc} 
Sector/Purpose & 1985 & 1986 & 1987 & 1988 & 1989 & 1990 & 199 I & 1992 \\
\hline Crude oil extraction & $66.6 \%$ & $73.0 \%$ & $69.4 \%$ & $68.7 \%$ & $75.1 \%$ & - & - & - \\
Natural gas extraction & $15.0 \%$ & $4.1 \%$ & $2.7 \%$ & $1.9 \%$ & $1.9 \%$ & - & - & - \\
Crude oil refining & $18.4 \%$ & $22.9 \%$ & $27.9 \%$ & $29.3 \%$ & $23.0 \%$ & $24.9 \%$ & $29.8 \%$ & $26.8 \%$ \\
Shale oil production & - & - & - & $0.2 \%$ & - & - & - & - \\
Total & $100.0 \%$ & $100.0 \%$ & $100.0 \%$ & $100.0 \%$ & $100.0 \%$ & $100.0 \%$ & $100.0 \%$ & $100.0 \%$ \\
$\quad$ of which: & & & & & & & & \\
productive $\mathbb{T}$ & $67.4 \%$ & $73.9 \%$ & $77.5 \%$ & $83.9 \%$ & $83.8 \%$ & $86.1 \%$ & $84.6 \%$ & $87.7 \%$ \\
nonproductive II & $32.6 \%$ & $26.1 \%$ & $22.5 \%$ & $16.1 \%$ & $16.2 \%$ & $13.9 \%$ & $15.4 \%$ & $12.3 \%$ \\
& & & & & & & & \\
\hline
\end{tabular}

- Figures refer to investment in capital construction of state-and urban collective-owned units only, and consequently differ slightly from those in the previous table, which are for state-owned units only.

$\dagger$ Deflated using the implicit deflators for industry sector national income presented in Table X- 6 .

I Productive investment is for the purpose of increasing or maintaining production capacity. Nonproductive investment refers to construction of schools, hospitals, housing and other workforce social welfare facilities.

Source: China Energy Statistical Yearbook, various years; China Statistical Yearbook, various years. 


\section{Table III-5. Energy Industry Capital Construction Investment by Subsector and Purpose, * 1985-1992 (continued)}

\begin{tabular}{|c|c|c|c|c|c|c|c|c|}
\hline Sector/Purpose & 1985 & 1986 & 1987 & 1988 & 1989 & $1990 \S$ & 1991 & 1992 \\
\hline Extraction & 5.02 & 5.10 & 4.87 & 4.88 & 5.02 & - & - & - \\
\hline Thermal Power Generation & 4.64 & 7.68 & 9.10 & 11.53 & 11.10 & - & - & - \\
\hline Hydropower Generation & 2.89 & 3.30 & 3.66 & 3.91 & 3.91 & - & - & - \\
\hline Nuclear Power Generation & 0.14 & 0.16 & 0.79 & - & 0.71 & - & - & - \\
\hline Other Power Generation $\S$ & 0.05 & 0.06 & 0.17 & 0.06 & 0.05 & 20.30 & - & - \\
\hline Power Distribution & 2.29 & 3.19 & 4.09 & 3.77 & 3.44 & 3.56 & - & - \\
\hline Steam and Hot Water & - & - & - & - & - & - & - & - \\
\hline Production and Supply & 0.15 & 0.17 & 0.19 & 0.31 & 0.23 & 0.32 & - & - \\
\hline Total & 10.16 & 14.55 & 18.00 & 19.58 & 19.43 & 24.18 & 27.30 & 35.39 \\
\hline of which: & & & & & & 2339 & 2622 & \\
\hline $\begin{array}{l}\text { productive } \pi \\
\text { nonproductive I }\end{array}$ & $\begin{array}{l}9.48 \\
0.68\end{array}$ & $\begin{array}{r}13.93 \\
0.63\end{array}$ & $\begin{array}{r}17.21 \\
0.79\end{array}$ & $\begin{array}{r}18.59 \\
0.99\end{array}$ & $\begin{array}{r}18.65 \\
0.78\end{array}$ & $\begin{array}{r}23.39 \\
0.79\end{array}$ & $\begin{array}{r}26.22 \\
1.08\end{array}$ & 1.48 \\
\hline
\end{tabular}

\section{5b. Shares of Power Industry Capital Construction Investment}

\begin{tabular}{|c|c|c|c|c|c|c|c|c|}
\hline Sector/Purpose & 1985 & 1986 & 1987 & 1988 & 1989 & $1990 \S$ & 1991 & 1992 \\
\hline Thermal Power Generation & $45.7 \%$ & $528 \%$ & $50.6 \%$ & $58.9 \%$ & $57.1 \%$ & - & - & - \\
\hline Hydropower Generation & $28.4 \%$ & $226 \%$ & $20.3 \%$ & $19.9 \%$ & $20.1 \%$ & - & - & - \\
\hline Nuclear Power Generation & $1.4 \%$ & $1.1 \%$ & $4.4 \%$ & - & $3.6 \%$ & - & - & - \\
\hline Other Power Generation § & $0.5 \%$ & $0.4 \%$ & $1.0 \%$ & $0.3 \%$ & $0.2 \%$ & $84.0 \%$ & - & - \\
\hline Power Distribution & $22.5 \%$ & $21.9 \%$ & $22.7 \%$ & $19.3 \%$ & $17.7 \%$ & $14.7 \%$ & - & - \\
\hline Steam and Hot Water & - & - & - & - & - & - & - & \\
\hline Production and Supply & $1.5 \%$ & $1.1 \%$ & $1.1 \%$ & $1.6 \%$ & $1.2 \%$ & $1.3 \%$ & - & - \\
\hline $\begin{array}{l}\text { Total } \\
\text { of which: }\end{array}$ & $100.0 \%$ & $100.0 \%$ & $100.0 \%$ & $100.0 \%$ & $100.0 \%$ & $100.0 \%$ & $100.0 \%$ & $100.0 \%$ \\
\hline productive ๆ & $93.3 \%$ & $95.7 \%$ & $95.6 \%$ & $95.0 \%$ & $96.0 \%$ & $96.7 \%$ & $96.0 \%$ & $95.8 \%$ \\
\hline nonproductive $\pi$ & $6.7 \%$ & $4.3 \%$ & $4.4 \%$ & $5.0 \%$ & $4.0 \%$ & $3.3 \%$ & $4.0 \%$ & $4.2 \%$ \\
\hline
\end{tabular}

- Figures refer to investment in capital construction of state-and urban collective-owned units only, and consequently differ slightly from those in the previous table, which are for state-owned units only.

$\dagger$ Deflated using the implicit deflators for industry sector national income presented in Table X-6.

I Productive investment is for the purpose of increasing or maintaining production capacity. Nonproductive investment refers to construction of schools, hospitals, housing and other workforce social welfare facilities.

$\S$ For 1990 "other power generation" includes all generation.

Source: China Energy Statistical Yearbook, various years; China Statistical Yearbook, various years. 
Table III-6. Energy Industry Technical Updating and Transformation Investment by Subsector and Purpose, * 1981-1993

\begin{tabular}{|c|c|c|c|c|c|c|c|c|c|c|c|c|c|}
\hline Sector/Purpose & 1981 & 1982 & 1983 & 1984 & 1985 & 1986 & 1987 & 1988 & 1989 & 1990 & 1991 & 1992 & 1993 \\
\hline Coal subtotal & 1.29 & 1.35 & 1.60 & 1.74 & 2.43 & 275 & 3.02 & 3.47 & 4.31 & 4.75 & 5.21 & 5.81 & 6.56 \\
\hline extraction & 1.28 & 1.34 & 1.58 & 1.72 & 2.42 & 2.73 & 3.00 & 3.45 & 4.27 & - & - & 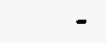 & - \\
\hline processing & 0.01 & 0.01 & 0.01 & 0.02 & 0.01 & 0.02 & 0.02 & 0.02 & 0.04 & - & & - & - \\
\hline \multicolumn{14}{|l|}{ Coke, Coal } \\
\hline $\begin{array}{l}\text { Gas \& Products } \\
\text { Oil \& Natural }\end{array}$ & 0.02 & 0.03 & 0.04 & 0.05 & 0.30 & 0.63 & 0.52 & 0.71 & 0.54 & 0.86 & 0.99 & 1.09 & 1.11 \\
\hline Gas subtotal & 261 & 1.95 & 2.86 & 1.28 & 1.49 & 1.71 & 2.15 & 4.28 & 3.92 & 3.71 & 4.22 & 3.31 & 8.44 \\
\hline extraction & 2.37 & 1.64 & 2.52 & 0.79 & 0.92 & 1.03 & 1.18 & 2.76 & 260 & 1.97 & 1.95 & 0.84 & 4.82 \\
\hline refining & 0.24 & 0.31 & 0.34 & 0.48 & 0.58 & 0.68 & 0.96 & 1.52 & 1.32 & 1.73 & 2.27 & 2.46 & 3.62 \\
\hline \multicolumn{14}{|l|}{ Electric } \\
\hline Power subtotal & 0.74 & 0.89 & 1.14 & 1.14 & 1.38 & 1.82 & 2.25 & 288 & 279 & 3.19 & 3.24 & 4.65 & 7.35 \\
\hline .generation & 0.35 & 0.44 & 0.53 & 0.53 & 0.67 & 0.89 & 1.04 & 1.41 & 1.43 & 1.85 & - & - & - \\
\hline distribution & 0.39 & 0.45 & 0.62 & 0.61 & 0.68 & 0.89 & 1.13 & 1.38 & 1.30 & 1.28 & - & - & - \\
\hline steam \& hot water & & & & & 0.03 & 0.04 & 0.09 & 0.09 & 0.06 & 0.06 & - & - & \\
\hline Total $\pi$ & 4.66 & 4.22 & 5.63 & 4.21 & 5.59 & 6.91 & 7.93 & 11.34 & 11.56 & 12.51 & 13.66 & 14.86 & 23.45 \\
\hline
\end{tabular}

2. Total Energy Industry Technical Updating \& Transformation Investment, Billion I980 Yuan †

\begin{tabular}{|c|c|c|c|c|c|c|c|c|c|c|c|c|c|}
\hline Sector/Purpose & 1981 & 1982 & 1983 & 1984 & 1985 & 1986 & 1987 & 1988 & 1989 & 1990 & 1991 & 1992 & 1993 \\
\hline \multirow{3}{*}{$\begin{array}{l}\text { Coal subtotal } \\
\text { extraction } \\
\text { processing }\end{array}$} & 1.29 & 1.34 & 1.60 & 1.70 & 225 & 2.47 & 2.57 & 2.74 & 3.13 & 3.43 & 3.65 & 3.88 & 4.07 \\
\hline & 1.27 & 1.33 & 1.58 & 1.68 & 2.25 & 246 & 2.56 & 2.72 & 3.10 & - & - & - & - \\
\hline & 0.01 & 0.01 & 0.01 & 0.02 & 0.00 & 0.01 & 0.02 & 0.02 & 0.03 & - & - & - & - \\
\hline \multicolumn{14}{|l|}{ Coke, Coal } \\
\hline \multicolumn{14}{|l|}{$\begin{array}{l}\text { Gas \& Products } \\
\text { Oil \& Natural }\end{array}$} \\
\hline \multirow{3}{*}{$\begin{array}{l}\text { Gas subtotal } \\
\text { extraction } \\
\text { refining }\end{array}$} & 2.60 & 1.95 & 286 & 1.24 & 1.38 & 1.54 & 1.83 & 3.38 & 284 & 2.68 & 2.95 & 2.21 & 5.23 \\
\hline & 2.36 & 1.64 & 2.52 & 0.77 & 0.85 & 0.93 & 1.01 & 2.18 & 1.88 & 1.43 & 1.36 & 0.56 & 2.99 \\
\hline & 0.24 & 0.31 & 0.34 & 0.47 & 0.53 & 0.61 & 0.82 & 1.20 & 0.96 & 1.25 & 1.59 & 1.64 & 2.24 \\
\hline \multicolumn{14}{|l|}{ Electric } \\
\hline Power subtotal & 0.74 & 0.89 & 1.14 & 1.11 & 1.28 & 1.64 & 1.92 & 2.27 & 202 & 2.31 & 2.27 & 3.10 & 4.56 \\
\hline generation & 0.35 & 0.44 & 0.53 & 0.52 & 0.62 & 0.80 & 0.89 & 1.11 & 1.04 & 1.34 & - & - & - \\
\hline distribution & 0.39 & 0.45 & 0.62 & 0.60 & 0.63 & 0.80 & 0.96 & 1.09 & 0.94 & 0.93 & - & - & - \\
\hline steam \& hot water & & & & & 0.03 & 0.04 & 0.07 & 0.07 & 0.04 & 0.04 & 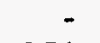 & 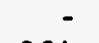 & - \\
\hline Total $\pi$ & 4.65 & 4.21 & 5.64 & 4.11 & 5.19 & 6.22 & 6.77 & 8.94 & 8.39 & 9.04 & 9.56 & 9.91 & 14.54 \\
\hline
\end{tabular}

* Figures refer to investment in state-and urban collective-owned units only.

$\dagger$ Deflated using the implicit deflators for industrial sector national income presented in Table X-6.

I From 1984 onward about $85 \%$ of technical updating and transformation investment was for "productive" purposes, i.e. directly related to production. The balance went for "nonproductive" purposes, such as construction of schools, hospitals, housing and other workforce social welfare facilities.

Source: China Energy Statistical Yearbook,various years; China Statistical Yearbook, various years; Energy Research Institute. 


\section{Table III-6. Energy Industry Technical Updating and Transformation Investment by Subsector and Purpose * 1981-1993 (continued)}

\section{Total Energy Industry Technical Updating \& Transformation Investment, Shares}

\begin{tabular}{lcccccccccccccc} 
Sector/Purpose & 1981 & 1982 & 1983 & 1984 & 1985 & 1986 & 1987 & 1988 & 1989 & 1990 & 1991 & 1992 & 1993 \\
\hline Coal subtotal & $28 \%$ & $32 \%$ & $28 \%$ & $41 \%$ & $43 \%$ & $40 \%$ & $38 \%$ & $31 \%$ & $37 \%$ & $38 \%$ & $38 \%$ & $39 \%$ & $28 \%$ \\
$\quad$ extraction & $27 \%$ & $32 \%$ & $28 \%$ & $41 \%$ & $43 \%$ & $40 \%$ & $38 \%$ & $30 \%$ & $37 \%$ & - & - & - & - \\
$\begin{array}{l}\text { processing } \\
\text { Coke, Coal }\end{array}$ & $0.3 \%$ & $0.2 \%$ & $0.2 \%$ & $0.5 \%$ & $0.1 \%$ & $0.2 \%$ & $0.2 \%$ & $0.2 \%$ & $0.3 \%$ & - & - & - & - \\
Gas \& Products & $0.4 \%$ & $0.7 \%$ & $0.7 \%$ & $1.3 \%$ & $5.3 \%$ & $9.1 \%$ & $6.6 \%$ & $6.2 \%$ & $4.7 \%$ & $6.9 \%$ & $7.2 \%$ & $7.3 \%$ & $4.7 \%$ \\
Oil \& Natural & & & & & & & & & & & & & \\
Gas subtotal & $56 \%$ & $46 \%$ & $51 \%$ & $30 \%$ & $27 \%$ & $25 \%$ & $27 \%$ & $38 \%$ & $34 \%$ & $30 \%$ & $31 \%$ & $22 \%$ & $36 \%$ \\
$\quad$ extraction & $51 \%$ & $39 \%$ & $45 \%$ & $19 \%$ & $16 \%$ & $15 \%$ & $15 \%$ & $24 \%$ & $22 \%$ & $16 \%$ & $14 \%$ & $6 \%$ & $21 \%$ \\
$\quad$ refining & $5 \%$ & $7 \%$ & $6 \%$ & $11 \%$ & $10 \%$ & $10 \%$ & $12 \%$ & $13 \%$ & $11 \%$ & $14 \%$ & $17 \%$ & $17 \%$ & $15 \%$ \\
Electric & $16 \%$ & $21 \%$ & $20 \%$ & $27 \%$ & $25 \%$ & $26 \%$ & $28 \%$ & $25 \%$ & $24 \%$ & $26 \%$ & $24 \%$ & $31 \%$ & $31 \%$ \\
Power subtotal & $16 \%$ & $10 \%$ & $9 \%$ & $13 \%$ & $12 \%$ & $13 \%$ & $13 \%$ & $12 \%$ & $12 \%$ & $15 \%$ & - & - & - \\
$\quad \begin{array}{l}\text { generation } \\
\text { distribution }\end{array}$ & $8 \%$ & $11 \%$ & $11 \%$ & $15 \%$ & $12 \%$ & $13 \%$ & $14 \%$ & $12 \%$ & $11 \%$ & $10 \%$ & - & - & - \\
steam \& hot water & - & - & - & - & $0.5 \%$ & $0.6 \%$ & $1.1 \%$ & $0.8 \%$ & $0.5 \%$ & $0.5 \%$ & - & - & - \\
Total $\dagger$ & $100 \%$ & $100 \%$ & $100 \%$ & $100 \%$ & $100 \%$ & $100 \%$ & $100 \%$ & $100 \%$ & $100 \%$ & $100 \%$ & $100 \%$ & $100 \%$ & $100 \%$ \\
& & & & & & & & & & & & &
\end{tabular}

- Figures refer to investment in state-and urban collective-owned units only.

+ From 1984 onward about $85 \%$ of technical updating and transformation investment was for "productive" purposes, i.e. directly related to production. The balance went for "nonproductive" purposes, such as construction of schools, hospitals, housing and other workforce social welfare facilities.

Source: China Energy Statistical Yearbook,various years; China Statistical Yearbook, various years; Energy Research Institute. 
Figure III-7. Capital Technical Updating and Transformation Investment in Energy Industries

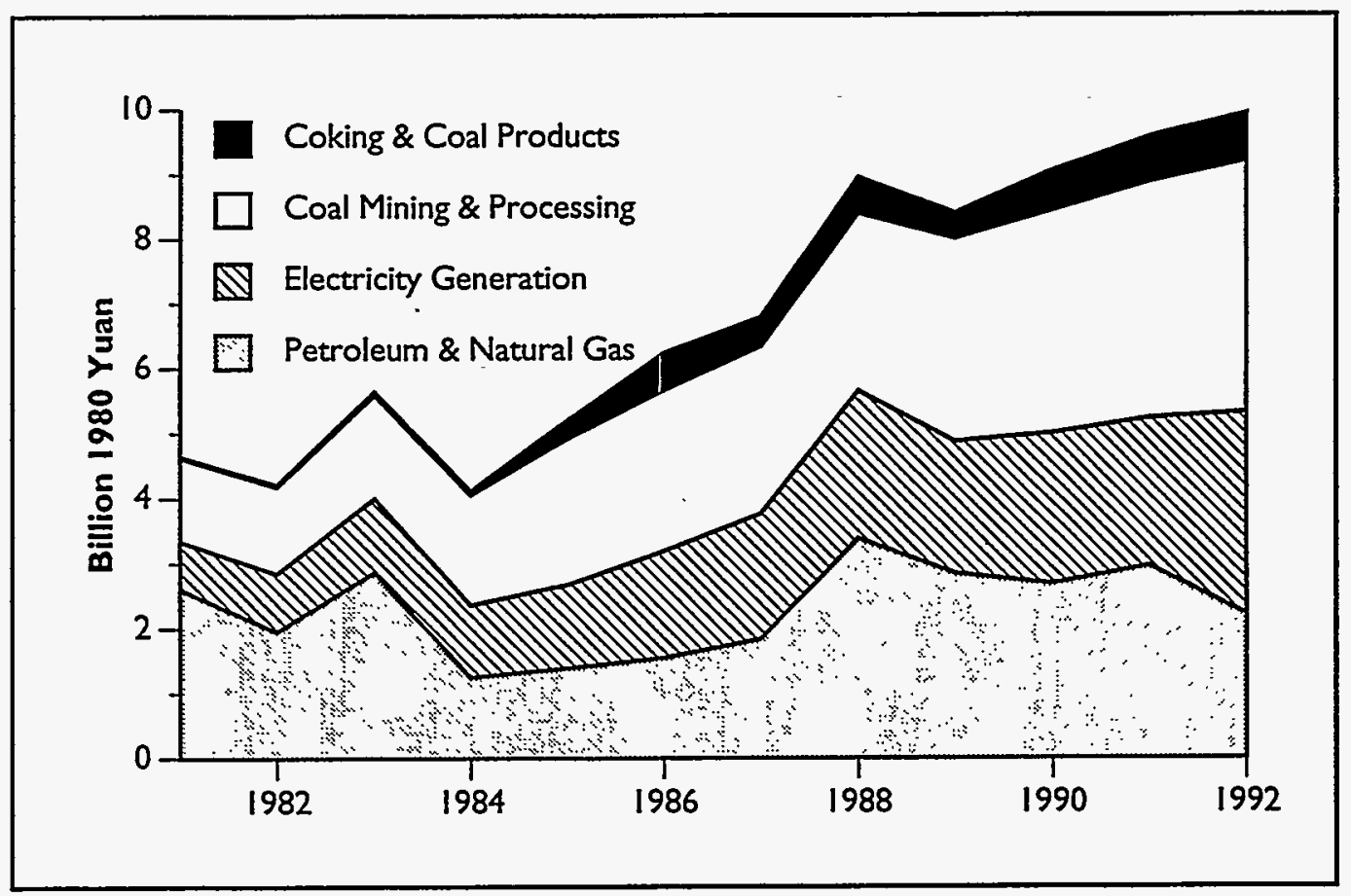




\section{Table III-7. Total Technical Updating and Transformation Investment by Investment Category, * 1981-1992-Billion 1980 Yuan}

\begin{tabular}{|c|c|c|c|c|c|c|c|}
\hline \multirow[b]{2}{*}{ Year } & \multicolumn{6}{|c|}{ Technical Updating and Transformation Investment } & \multirow[b]{2}{*}{$\begin{array}{c}\text { Total } \\
\text { Investment }\end{array}$} \\
\hline & $\begin{array}{c}\text { Energy } \\
\text { Conservation }\end{array}$ & $\begin{array}{c}\text { Waste } \\
\text { Management } \dagger\end{array}$ & $\begin{array}{l}\text { Environmental } \\
\text { Protection }\end{array}$ & $\begin{array}{c}\text { Residential } \\
\text { Energy } \\
\text { Conservation }\end{array}$ & Other & Subtotal & \\
\hline 1981 & 0.895 & 0.336 & 0.135 & - & 18.106 & 19.472 & 66.553 \\
\hline 1982 & 1.196 & 0.411 & 0.225 & -. & 23.167 & 24.999 & 84.403 \\
\hline 1983 & 1.327 & 0.437 & 0.144 & - & 27.212 & 29.120 & 95.224 \\
\hline 1984 & 1.693 & 0.596 & 0.205 & 0.081 & 27.601 & 30.176 & 115.636 \\
\hline 1985 & 1.612 & 0.843 & - & 0.094 & 39.136 & 41.685 & 155.969 \\
\hline 1986 & 2.049 & 1.061 & - & - & 53.564 & 56.674 & 178.208 \\
\hline 1987 & 2.211 & 1.223 & - & - & 61.317 & 64.751 & 196.151 \\
\hline 1988 & 2.409 & 1.324 & - & - & 73.508 & 77.241 & 217.864 \\
\hline 1989 & 1.832 & 1.088 & - & - & 54.317 & 57.237 & 183.983 \\
\hline 1990 & 1.972 & 1.067 & - & - & 56.964 & 60.002 & 210.946 \\
\hline 1991 & 2343 & 1.368 & - & - & 67.873 & 71.584 & 253.449 \\
\hline 1992 & 2761 & 1.557 & - & - & 93.172 & 97.490 & 351.873 \\
\hline
\end{tabular}

* Includes only funds actually invested in state-owned units, not investment targets. Includes investment in all sectors. About half of investment in this category goes for expansion or replacement of existing production capacity, and most of the rest is devoted to product development (increasing variety and improving quality) and "nonproductive" construction (e.g. housing, schools, and hospitals). Technical updating and transformation figures (including subcategory figures) are deflated using the industrial sector national income deflators (see Table X-6).

+ Referred to in Chinese sources as "zhili sanfei," or management of the "three wastes," i.e., waste water, waste gases, including soot, "industrial dust" and and sulfur dioxide; and waste residue (presumably solid waste).

Source: Rational Resource Utilization Handbook, 1991; China Statistical Yearbook, various years; Energy Research Institute. 
Table III-8. Energy Supply and Conservation Investments, 1981-1992*

\begin{tabular}{|c|c|c|c|c|}
\hline \multicolumn{5}{|c|}{ I. Investment in Billion Current Yuan } \\
\hline Year & $\begin{array}{c}\text { Energy } \\
\text { Supply } \\
\text { Investment }\end{array}$ & $\begin{array}{c}\text { Energy } \\
\text { Conservation } \\
\text { Capital Construction } \\
\text { Investment } \dagger\end{array}$ & $\begin{array}{c}\text { Energy } \\
\text { Conservation } \\
\text { Technical Updating } \\
\text { Investment }\end{array}$ & $\begin{array}{c}\text { Total } \\
\text { Energy } \\
\text { Conservation } \\
\text { Investment }\end{array}$ \\
\hline 1981 & 14.170 & 0.593 & 0.898 & 1.491 \\
\hline 1982 & 17.393 & 0.889 & 1.198 & 2.087 \\
\hline 1983 & 21.314 & 1.481 & 1.327 & 2.808 \\
\hline 1984 & 27.850 & 1.481 & 1.735 & 3.216 \\
\hline 1985 & 36.275 & 1.481 & 1.737 & 3.218 \\
\hline 1986 & 44.146 & 1.652 & 2.275 & 3.927 \\
\hline 1987 & 54.029 & 2.088 & 2590 & 4.678 \\
\hline 1988 & 64.004 & 2.439 & 3.055 & 5.494 \\
\hline 1989 & 70.563 & 2461 & 2.525 & 4.986 \\
\hline 1990 & 83.690 & 2669 & 2.728 & 5.397 \\
\hline 1991 & 94.963 & 4.922 & 3.349 & 8.271 \\
\hline 1992 & 115.496 & 4.922 & 4.138 & 9.060 \\
\hline
\end{tabular}

\begin{tabular}{|c|c|c|c|c|}
\hline \multicolumn{5}{|c|}{ 2. Investment in Billion Constant 1980 Yuan } \\
\hline Year & $\begin{array}{l}\text { Energy } \\
\text { Supply } \\
\text { Investment }\end{array}$ & $\begin{array}{c}\text { Energy } \\
\text { Conservation } \\
\text { Capital Construction } \\
\text { Investment } \uparrow\end{array}$ & $\begin{array}{c}\text { Energy } \\
\text { Conservation } \\
\text { Technical Updating } \\
\text { Investment }\end{array}$ & $\begin{array}{c}\text { Total } \\
\text { Energy } \\
\text { Conservation } \\
\text { Investment }\end{array}$ \\
\hline 1981 & 14.128 & 0.591 & 0.895 & 1.486 \\
\hline 1982 & 17.367 & 0.887 & 1.196 & 2.084 \\
\hline 1983 & 21.319 & $1.482^{-}$ & 1.327 & 2.809 \\
\hline 1984 & 27.173 & 1.445 & 1.693 & 3.138 \\
\hline 1985 & 33.667 & 1.375 & 1.612 & 2.987 \\
\hline 1986 & 39.763 & 1.488 & 2.049 & 3.537 \\
\hline 1987 & 46.118 & 1.782 & 2.211 & 3.993 \\
\hline 1988 & 50.472 & 1.923 & 2.409 & 4.332 \\
\hline 1989 & 51.203 & 1.786 & 1.832 & 3.618 \\
\hline 1990 & 60.492 & 1.929 & 1.972 & 3.901 \\
\hline 1991 & 66.440 & 3.443 & 2.343 & 5.786 \\
\hline 1992 & 77.068 & 3.284 & 2.761 & 6.045 \\
\hline
\end{tabular}

Estimates in italics.

$\dagger \quad$ For 1983-1985 and 1991-1992 only the sums of investment were available. For those periods totals were divided equally among the three years.

Source: China Statistical Yearbook, various years; Rational Resource Utilization Handbook, 1991 ; State Energy Conservation Investment Corporation; Energy Research Institute. 
Table III-8. Energy Supply and Conservation Investments, 1981-1992* (continued)

\begin{tabular}{|ccccc|}
\hline 3. Shares of Total Energy & Investment & & \\
Year & $\begin{array}{c}\text { Energy } \\
\text { Energy } \\
\text { Supply } \\
\text { Investment }\end{array}$ & $\begin{array}{c}\text { Conservation } \\
\text { Capital Construction } \\
\text { Investment }\end{array}$ & $\begin{array}{c}\text { Energy } \\
\text { Conservation } \\
\text { Technical Updating } \\
\text { Investment }\end{array}$ & $\begin{array}{c}\text { Total } \\
\text { Energy } \\
\text { Conservation } \\
\text { Investment }\end{array}$ \\
\hline 1981 & $90.48 \%$ & $3.78 \%$ & $5.73 \%$ & $9.52 \%$ \\
1982 & $89.29 \%$ & $4.56 \%$ & $6.15 \%$ & $10.71 \%$ \\
1983 & $88.36 \%$ & $6.14 \%$ & $5.50 \%$ & $11.64 \%$ \\
1984 & $89.65 \%$ & $4.77 \%$ & $4.58 \%$ & $10.35 \%$ \\
1985 & $91.85 \%$ & $3.75 \%$ & $4.73 \%$ & $8.15 \%$ \\
1986 & $91.83 \%$ & $3.44 \%$ & $4.41 \%$ & $8.17 \%$ \\
1987 & $92.03 \%$ & $3.56 \%$ & $4.40 \%$ & $7.97 \%$ \\
1988 & $92.09 \%$ & $3.51 \%$ & $3.34 \%$ & $6.60 \%$ \\
1989 & $93.40 \%$ & $3.26 \%$ & $3.06 \%$ & $6.06 \%$ \\
1990 & $93.94 \%$ & $3.00 \%$ & $3.24 \%$ & $8.01 \%$ \\
1991 & $91.99 \%$ & $4.77 \%$ & $3.32 \%$ & $7.27 \%$ \\
1992 & $9273 \%$ & $3.95 \%$ & & \\
\hline
\end{tabular}

- Estimates in italics.

$\dagger \quad$ For 1983-1985 and 1991-1992 only the sums of investment were available. For those periods totals were divided equally among the three years.

Source: China Statistical Yearbook, various years; Rational Resource Utilization Handbook, 1991; State Energy Conservation Investment Corporation; Energy Research Institute. 
Table III-9. Energy Conservation Investments, 1981-1993

\begin{tabular}{|lccc|}
\hline & & & \\
& unit & $1981-1990$ & $\mathbf{1 9 9 1 - 1 9 9 3}$ \\
\hline Capital Construction Projects & & & \\
Total Investment & billion yuan & 17.235 & 14 \\
$\quad$ national allocations and loans* & billion yuan & 9.753 & 6 \\
local and enterprise funds & billion yuan & 7.482 & 8 \\
Energy savings capacity, Mtcelyr. & Mtce/yr & 25.04 & 20 \\
Unit investment, yuan/(tce/yr) & yuan/(tce/yr) & 688 & 700 \\
Technical Updating and Transformotion Projects & & & 3 \\
Total Investment & billion yuan & 9.953 & 1.6 \\
$\quad$ national allocations and loans* & billion yuan & 5.219 & 1.4 \\
local and enterprise funds & billion yuan & 4.734 & 10 \\
Energy savings capacity & Mtce/yr & 30.79 & 300 \\
Unit investment & yuan/(tce/yr) & 324 & \\
& & & \\
& & & \\
\hline
\end{tabular}

* Between 1980 and 1990 national conservation technical updating investment comprised 1.397 billion in allocations and 3.822 billion in loans. In 1987 all allocations were converted to low interest loans.

Source: Wang, et al., 1995. 
Table III-10. Completed Energy Conservation Capital Construction Projects, 1981-1990

\begin{tabular}{|lcccc|}
\hline Project & $\begin{array}{c}\text { Total } \\
\text { Capacity }\end{array}$ & $\begin{array}{c}\text { Investment, } \\
\text { (billion yuan) }\end{array}$ & $\begin{array}{c}\text { Energy } \\
\text { Savings } \\
\text { (Mtcelyr) }\end{array}$ & $\begin{array}{c}\text { Unit } \\
\text { Cost } \\
\text { (yuan/(tce/yr) }\end{array}$ \\
\hline Cogeneration & $5,230 \mathrm{MW}$ & 9.95 & 7.83 & 1.270 \\
Recovery of Waste Gases & $9.32 \mathrm{Mm} 3 / \mathrm{day}$ & 1.74 & 3.57 & 487 \\
District Heating & $39.8 \mathrm{Mm} 2$ & - & - & - \\
Replacement of Small Thermal & $1,5590 \mathrm{MW}$ & 0.67 & 0.93 & 720 \\
Power Sets with Large & $1.29 \mathrm{Mt} / \mathrm{yr}$ & 0.67 & 1.8 & 372 \\
$\begin{array}{l}\text { Renovation of small } \\
\text { Ammonia Plants }\end{array}$ & $53.69 \mathrm{Mt} / \mathrm{yr}$ & 0.52 & 2.75 & 189 \\
Coal Washing and Matching & $3.29 \mathrm{Mt} / \mathrm{yr}$ & 0.38 & 0.21 & 476 \\
Continuous Casting & $1.88 \mathrm{Mt} / \mathrm{yr}$ & 0.19 & 1.61 & 354 \\
Scrap Steel Processing & $12.26 \mathrm{Mt} / \mathrm{yr}$ & 0.3 & 2.3 & 130 \\
Coal Briquette Production & $150 \mathrm{MW}$ & 0.14 & 0.34 & 412 \\
Waste Heat Power Generation & $70 \mathrm{kt} / \mathrm{yr}$ & 0.33 & 0.12 & 2.750 \\
Steel Conservation & -1.58 & 1.69 & 935 \\
Other & & 17.24 & 25.04 & 688 \\
Total & & & & \\
\hline
\end{tabular}

Source: Rational Resources Utilization Handbook, 1991. 
Table III-1 1. Newly Increased Production Capacity of State-Owned Enterprises, 1981-1993

\begin{tabular}{|c|c|c|c|c|c|c|c|c|c|c|}
\hline \multicolumn{11}{|c|}{ I. Increments from Capital Construction Investment } \\
\hline \multirow[b]{2}{*}{ Year } & \multirow[b]{2}{*}{$\begin{array}{l}\text { Coal } \\
\text { Mining } \\
\text { (Mt/yr) }\end{array}$} & \multirow[b]{2}{*}{$\begin{array}{c}\text { Coal } \\
\text { Washing } \\
\text { (Mt/yr) }\end{array}$} & \multirow[b]{2}{*}{$\begin{array}{l}\text { Coking } \\
\text { (Mt/yr) }\end{array}$} & \multirow[b]{2}{*}{$\begin{array}{c}\text { Petroleum } \\
\text { Extraction } \\
\text { (Mt/yr) }\end{array}$} & \multicolumn{2}{|c|}{ Refinery Capacity } & \multirow[b]{2}{*}{$\begin{array}{c}\text { Natural Gas } \\
\text { Extraction } \\
\text { (bcm/yr) }\end{array}$} & \multicolumn{3}{|c|}{ Generating Capacity } \\
\hline & & & & & $\begin{array}{c}\text { Refinery } \\
\text { Distillation } \\
(\mathrm{M} t / \mathrm{yr})\end{array}$ & 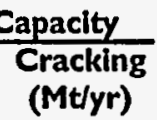 & & $\begin{array}{c}\text { Thermal } \\
\text { (MW) }\end{array}$ & $\begin{array}{l}\text { Hydro } \\
\text { \& Other } \\
\text { (MW) }\end{array}$ & $\begin{array}{l}\text { Total } \\
\text { (MW) }\end{array}$ \\
\hline 1981 & 13.73 & 2.25 & - & 5.189 & - & - & 0.622 & $1,523.4$ & $1,116.7$ & $2,640.1$ \\
\hline 1982 & 8.20 & 2.55 & - & 6.365 & - & - & 0.627 & $2,053.0$ & 889.5 & $2,942.5$ \\
\hline 1983 & 18.52 & 7.75 & - & 8.108 & - & - & 0.475 & $3,416.9$ & $1,074.2$ & $4,491.1$ \\
\hline 1984 & 24.35 & 5.00 & - & 13.970 & - & - & 0.547 & $2,687.9$ & $1,091.3$ & $3,779.2$ \\
\hline 1985 & 16.47 & 6.66 & - & 17.372 & - & - & 1.080 & $5,870.7$ & 505.7 & $6,376.4$ \\
\hline 1986 & 21.05 & 13.30 & - & 15.485 & - & - & 0.537 & $5,409.9$ & $1,228.1$ & $6,638.0$ \\
\hline 198.7 & 21.06 & 11.70 & - & 16.400 & - & - & 0.440 & $6,070.5$ & $2,673.5$ & $8,744.0$ \\
\hline 1988 & 33.02 & 4.45 & - & 15.810 & - & - & 1.350 & $2,337.8$ & $8,832.4$ & $11,170.2$ \\
\hline 1989 & 28.45 & 19.60 & - & 16.499 & - & - & 0.531 & 8.961 .0 & $1,648.1$ & $10,609.1$ \\
\hline 1990 & 23.36 & 11.81 & - & 13.244 & - & - & 0.707 & $7,725.6$ & $1,429.9$ & $9,155.5$ \\
\hline 1991 & 33.40 & - & - & 13.087 & - & - & 0.72 & - & - & $11,373.0$ \\
\hline 1992 & 27.92 & - & - & 14.521 & - & - & 1.07 & - & - & $13,789.0$ \\
\hline 1993 & - & - & - & - & - & - & - & - & - & - \\
\hline
\end{tabular}

Source: China Energy Statistical Yearbook, various years; China Statistical Yearbook, various years; Energy Research Institute. 

(continued)

2. Increments from Technical Updating and Transformation Investment

\begin{tabular}{|c|c|c|c|c|c|c|c|c|c|c|c|}
\hline \multirow[b]{3}{*}{ Year } & \multirow{3}{*}{$\begin{array}{c}\text { Coal } \\
\text { Mining } \\
\text { (Mt/yr) }\end{array}$} & \multirow{3}{*}{$\begin{array}{c}\text { Coal } \\
\text { Washing } \\
\text { (Mt/yr) }\end{array}$} & \multirow[b]{3}{*}{$\begin{array}{l}\text { Coking } \\
\text { (Mt/yr) }\end{array}$} & \multirow{3}{*}{$\begin{array}{c}\text { Petroleum } \\
\text { Extraction * } \\
\text { (Mt/yr) }\end{array}$} & \multirow{2}{*}{\multicolumn{2}{|c|}{ Refinery Capacity }} & \multirow{3}{*}{$\begin{array}{c}\text { Natural Gas } \\
\text { Extraction } \\
\text { (bcm/yr) }\end{array}$} & \multicolumn{4}{|c|}{ Generating Capacity } \\
\hline & & & & & & & & & Hydro & Co-generatic & \\
\hline & & & & & $\begin{array}{l}\text { Distillation } \\
\text { (Mt/yr) }\end{array}$ & $\begin{array}{l}\text { Cracking } \\
\text { (Mt/yr) }\end{array}$ & & $\begin{array}{c}\text { Thermal } \\
\text { (MW) }\end{array}$ & $\begin{array}{l}\text { \& Other } \\
\text { (MW) }\end{array}$ & $\begin{array}{l}\text { \& Other } \\
\text { (MW) }\end{array}$ & $\begin{array}{l}\text { Total } \dagger \\
\text { (MW) }\end{array}$ \\
\hline 1981 & 3.32 & 1.01 & - & 3.580 & 0.308 & 0.053 & - & 185.7 & 78.0 & 81.8 & 345.5 \\
\hline 1982 & 4.28 & 3.37 & -. & 3.195 & 0.153 & 0.144 & - & 39.2 & 80.1 & 52.2 & 171.5 \\
\hline 1983 & 4.48 & 0.90 & - & 2.690 & 0.550 & 0.000 & - & 70.1 & 86.9 & 53.2 & 210.2 \\
\hline 1984 & 5.31 & 0.60 & - & 0.160 & 0.850 & 0.401 & - & 121.8 & 37.8 & 63.5 & 223.1 \\
\hline 1985 & 4.16 & 1.12 & 0.263 & 0.099 & 0.900 & 0.313 & - & 78.9 & 41.9 & 44.5 & 165.3 \\
\hline 1986 & 4.10 & 1.93 & 0.332 & 0.045 & 0.784 & 0.241 & - & 368.7 & 46.1 & 71.9 & 486.7 \\
\hline 1987 & 3.45 & 1.21 & 1.018 & 0.857 & 1.060 & 0.480 & $\cdots$ & 329.8 & 53.2 & 51.5 & 570.0 \\
\hline 1988 & 2.74 & 0.27 & 1.132 & 1.637 & 0.850 & 0.961 & - & 420.0 & 61.0 & 113.0 & 622.0 \\
\hline 1989 & 2.95 & 3.56 & 0.804 & 0.610 & 1.153 & 1.048 & - & 265.6 & 50.4 & 107.5 & 444.5 \\
\hline 1990 & 3.41 & 1.43 & $\cdot 1.141$ & 0.911 & 3.334 & 2.135 & - & 760.8 & 152.5 & 139.1 & $1,094.7$ \\
\hline 1991 & 1.64 & - & 0.742 & 0.039 & - & - & - & 166.1 & 512.8 & 137.5 & 823.9 \\
\hline 1992 & 2.73 & - & - & - & - & - & - & 87.3 & 679.9 & 100.4 & 867.6 \\
\hline 1993 & 3.61 & - & - & 1.231 & - & - & - & 260.1 & 701.8 & 45.3 & $1,007.2$ \\
\hline
\end{tabular}

* For 1987-1991 there is an unexplained discrepancy between total new generating capacity and the sum of the categories.

$\dagger$ Includes increased capacity from oilfield conservation and development funds.

Source: China Energy Statistical Yearbook, various years; China Statistical Yearbook, various years; Energy Research Institute. 
Table III-12. Capital Construction Investment by Source of Funds, * 1981-1990

\begin{tabular}{|c|c|c|c|c|c|c|c|}
\hline \multicolumn{8}{|c|}{ 1a. Former Ministry of Coal, Billion 1980 Yuan $t$} \\
\hline Year & $\begin{array}{c}\text { Direct } \\
\text { Government } \\
\text { Expenditures } \pi\end{array}$ & $\begin{array}{c}\text { Domestic } \\
\text { Bank } \\
\text { Loans }\end{array}$ & $\begin{array}{c}\text { Foreign } \\
\text { Investment }\end{array}$ & $\begin{array}{c}\text { Coal } \\
\text { Substitution }\end{array}$ & $\begin{array}{c}\text { Self- } \\
\text { Raised } \\
\text { Funds § }\end{array}$ & $\begin{array}{l}\text { Other } \\
\text { Sources § }\end{array}$ & Total \\
\hline 1981 & 1.66 & 0.08 & 0.43 & - & 0.32 & - & 2.50 \\
\hline 1982 & 1.95 & 0.09 & 0.67 & - & 0.51 & - & 3.23 \\
\hline 1983 & 3.07 & 0.06 & 0.60 & 0.31 & 0.31 & 0.002 & 4.35 \\
\hline 1984 & 4.14 & 0.21 & 0.35 & 0.46 & 0.51 & 0.04 & 5.72 \\
\hline 1985 & 3.38 & 0.85 & 0.03 & 0.58 & 0.59 & 0.06 & 5.50 \\
\hline 1986 & 3.68 & 0.71 & 0.03 & 0.56 & 0.52 & 0.07 & 5.58 \\
\hline 1987 & 3.35 & 1.00 & 0.07 & 0.46 & 0.40 & 0.17 & 5.45 \\
\hline 1988 & 2.89 & 0.88 & 0.11 & 0.38 & 0.51 & 0.08 & 4.86 \\
\hline 1989 & 2.61 & 1.24 & 0.31 & 0.44 & 1.02 & 0.55 & 6.17 \\
\hline 1990 & 3.27 & 2.46 & 0.62 & 0.92 & 1.44 & 0.18 & 8.89 \\
\hline \multicolumn{8}{|c|}{ Ib. Former Ministry of Coal, Shares } \\
\hline Year & $\begin{array}{c}\text { Direct } \\
\text { Government } \\
\text { Expenditures } \mathbb{I}\end{array}$ & $\begin{array}{c}\text { Domestic } \\
\text { Bank } \\
\text { Loans }\end{array}$ & $\begin{array}{c}\text { Foreign } \\
\text { Investment }\end{array}$ & $\begin{array}{c}\text { Coal } \\
\text { Substitution }\end{array}$ & $\begin{array}{c}\text { Self- } \\
\text { Raised } \\
\text { Funds § }\end{array}$ & $\begin{array}{l}\text { Other } \\
\text { Sources § }\end{array}$ & Total \\
\hline 1981 & $66.6 \%$ & $3.0 \%$ & $17.4 \%$ & - & $13.0 \%$ & - & $100.0 \%$ \\
\hline 1982 & $60.5 \%$ & $2.9 \%$ & $20.9 \%$ & - & $15.8 \%$ & - & $100.0 \%$ \\
\hline 1983 & $70.5 \%$ & $1.3 \%$ & $13.8 \%$ & $7.2 \%$ & $7.2 \%$ & $0.04 \%$ & $100.0 \%$ \\
\hline 1984 & $72.4 \%$ & $3.7 \%$ & $6.2 \%$ & $8.1 \%$ & $8.9 \%$ & $0.7 \%$ & $100.0 \%$ \\
\hline 1985 & $61.6 \%$ & $15.5 \%$ & $0.6 \%$ & $10.6 \%$ & $10.7 \%$ & $1.0 \%$ & $100.0 \%$ \\
\hline 1986 & $66.0 \%$ & $12.7 \%$ & $0.6 \%$ & $10.1 \%$ & $9.3 \%$ & $1.2 \%$ & $100.0 \%$ \\
\hline 1987 & $61.6 \%$ & $18.3 \%$ & $1.2 \%$ & $8.5 \%$ & $7.4 \%$ & $3.1 \%$ & $100.0 \%$ \\
\hline 1988 & $59.5 \%$ & $18.0 \%$ & $2.3 \%$ & $7.9 \%$ & $10.6 \%$ & $1.7 \%$ & $100.0 \%$ \\
\hline 1989 & $42.3 \%$ & $20.1 \%$ & $5.0 \%$ & $7.1 \%$ & $16.6 \%$ & $9.0 \%$ & $100.0 \%$ \\
\hline 1990 & $36.8 \%$ & $27.6 \%$ & $6.9 \%$ & $10.3 \%$ & $16.2 \%$ & $2.1 \%$ & $100.0 \%$ \\
\hline
\end{tabular}

* Data up to 1988 include only funds administered by the former Ministries of Coal, Electric Power and Water Resources, and Petroleum (which were consolidated in 1988 into the former Ministry of Energy, which was subsequently disbanded in 1993), so some totals are lower than in other tables. Data for 1989 and 1990 are for all state-owned units.

$\dagger$ Deflated with the national income deflators for the industrial sector in Table X-6.

1988 and later figures for direct government investment include loans which were originally allocated as direct government investment.

- § 1981 and 1982 figures for self-raised funds include "other" investment.

Source: China Energy Statistical Yearbook, various years; China Statistical Yearbook, various years. 
Table III-12. Capital Construction Investment by Source of Funds, * 1981-1990 (continued)

2a. Former Ministry of Petroleum, Billion 1980 Yuan $t$

\begin{tabular}{cccccccc} 
Year & $\begin{array}{c}\text { Direct } \\
\text { Government } \\
\text { Expenditures I }\end{array}$ & $\begin{array}{c}\text { Domestic } \\
\text { Bank } \\
\text { Loans }\end{array}$ & $\begin{array}{c}\text { Foreign } \\
\text { Investment }\end{array}$ & $\begin{array}{c}\text { Coal } \\
\text { Substitution }\end{array}$ & $\begin{array}{c}\text { Self- } \\
\text { Raised } \\
\text { Funds } \S\end{array}$ & $\begin{array}{c}\text { Other } \\
\text { Sources } \S\end{array}$ & Total \\
\hline 1981 & 2.30 & 0.11 & 0.10 & - & 0.38 & - & 2.89 \\
1982 & 2.25 & 0.03 & 0.35 & - & 0.32 & - & 2.95 \\
1983 & 2.50 & 0.04 & 0.05 & - & 0.39 & 0.00 & 2.98 \\
1984 & 2.19 & 0.06 & 0.14 & - & 0.36 & 0.00 & 2.76 \\
1985 & 2.11 & 0.03 & 0.61 & 0.001 & 0.45 & 0.00 & 3.20 \\
1986 & 2.11 & 0.01 & 1.19 & 0.003 & 0.46 & 0.00 & 3.77 \\
1987 & 2.13 & 0.05 & 1.10 & 0.001 & 0.50 & 0.03 & 3.81 \\
1988 & 1.46 & 0.60 & 2.50 & 0.004 & 0.20 & 0.05 & 4.81 \\
1989 & 0.66 & 1.81 & 2.93 & 0.113 & 0.70 & 0.57 & 6.79 \\
1990 & 0.94 & 2.79 & 2.08 & 0.111 & 0.86 & 0.50 & 7.28
\end{tabular}

2b. Former Ministry of Petroleum, Shares

\begin{tabular}{cccccccc} 
Year & $\begin{array}{c}\text { Direct } \\
\text { Government } \\
\text { Expenditures I }\end{array}$ & $\begin{array}{c}\text { Domestic } \\
\text { Bank } \\
\text { Loans }\end{array}$ & $\begin{array}{c}\text { Foreign } \\
\text { Investment }\end{array}$ & $\begin{array}{c}\text { Coal } \\
\text { Substitution }\end{array}$ & $\begin{array}{c}\text { Self- } \\
\text { Raised } \\
\text { Funds } \S\end{array}$ & $\begin{array}{c}\text { Other } \\
\text { Sources }\end{array}$ & Total \\
\hline 1981 & $79.6 \%$ & $3.6 \%$ & $3.6 \%$ & - & $13.2 \%$ & - & $100.0 \%$ \\
1982 & $76.2 \%$ & $0.9 \%$ & $11.9 \%$ & - & $10.9 \%$ & - & $100.0 \%$ \\
1983 & $83.9 \%$ & $1.3 \%$ & $1.7 \%$ & - & $13.0 \%$ & $0.002 \%$ & $100.0 \%$ \\
1984 & $79.4 \%$ & $2.3 \%$ & $5.1 \%$ & - & $13.1 \%$ & $0.1 \%$ & $100.0 \%$ \\
1985 & $66.0 \%$ & $0.9 \%$ & $19.0 \%$ & $0.0 \%$ & $14.1 \%$ & $0.01 \%$ & $100.0 \%$ \\
1986 & $55.9 \%$ & $0.2 \%$ & $31.6 \%$ & $0.1 \%$ & $12.1 \%$ & $0.1 \%$ & $100.0 \%$ \\
1987 & $56.0 \%$ & $1.3 \%$ & $28.8 \%$ & $0.02 \%$ & $13.1 \%$ & $0.7 \%$ & $100.0 \%$ \\
1988 & $30.3 \%$ & $12.4 \%$ & $52.0 \%$ & $0.1 \%$ & $4.2 \%$ & $1.0 \%$ & $100.0 \%$ \\
1989 & $9.7 \%$ & $26.7 \%$ & $43.2 \%$ & $1.7 \%$ & $10.3 \%$ & $8.4 \%$ & $100.0 \%$ \\
1990 & $12.9 \%$ & $38.3 \%$ & $28.6 \%$ & $1.5 \%$ & $11.8 \%$ & $6.8 \%$ & $100.0 \%$ \\
\hline
\end{tabular}

- Data up to 1988 include only funds administered by the former Ministries of Coal, Electric Power and Water Resources, and Petroleum (which were consolidated in 1988 into the former Ministry of Energy, which was subsequently disbanded in 1993), so some totals are lower than in other tables. Data for 1989 and 1990 are for all state-owned units.

$\dagger$ Deflated with the national income deflators for the industrial sector in Table X-6.

I 1988 and later figures for direct government investment include loans which were originally allocated as direct government investment.

$\S \quad 1981$ and 1982 figures for self-raised funds include "other" investment.

Source: China Energy Statistical Yearbook, various years; China Statistical Yearbook, various years. 
Table III-12. Capital Construction Investment by Source of Funds, * 1981-1990 (continued)

\begin{tabular}{|c|c|c|c|c|c|c|c|}
\hline \multicolumn{8}{|c|}{ 3.a. Former Ministry of Electric Power, Billion I 980 Yuan $\dagger$} \\
\hline Year & $\begin{array}{c}\text { Direct } \\
\text { Government } \\
\text { Expenditures } \mathbb{I}\end{array}$ & $\begin{array}{l}\text { Domestic } \\
\text { Bank } \\
\text { Loans }\end{array}$ & $\begin{array}{c}\text { Foreign } \\
\text { Investment }\end{array}$ & $\begin{array}{c}\text { Coal } \\
\text { Substitution }\end{array}$ & $\begin{array}{l}\text { Self- } \\
\text { Raised } \\
\text { Funds § }\end{array}$ & $\begin{array}{l}\text { Other } \\
\text { Sources § }\end{array}$ & Total \\
\hline $\begin{array}{l}1981 \\
1982 \\
1983 \\
1984 \\
1985 \\
1986 \\
1987 \\
1988 \\
1989 \\
1990\end{array}$ & $\begin{array}{l}2.05 \\
1.83 \\
2.89 \\
3.95 \\
4.00 \\
4.94 \\
3.88 \\
275 \\
2.03 \\
2.63\end{array}$ & $\begin{array}{l}1.12 \\
1.80 \\
1.68 \\
1.48 \\
2.72 \\
3.18 \\
4.03 \\
4.12 \\
4.48 \\
6.14\end{array}$ & $\begin{array}{l}0.12 \\
0.08 \\
0.25 \\
0.55 \\
0.64 \\
1.56 \\
0.86 \\
0.57 \\
2.23 \\
3.14\end{array}$ & $\begin{array}{l}- \\
- \\
0.50 \\
0.61 \\
0.81 \\
1.31 \\
1.31 \\
1.74 \\
1.50 \\
1.83\end{array}$ & $\begin{array}{l}0.47 \\
0.82 \\
0.41 \\
0.74 \\
1.65 \\
1.77 \\
3.20 \\
4.44 \\
5.86 \\
6.13\end{array}$ & $\begin{array}{l}- \\
0.02 \\
0.10 \\
0.15 \\
0.66 \\
2.19 \\
2.81 \\
3.34 \\
4.30\end{array}$ & $\begin{array}{r}3.75 \\
4.53 \\
5.75 \\
7.43 \\
9.95 \\
13.43 \\
15.48 \\
16.43 \\
19.44 \\
24.18\end{array}$ \\
\hline \multicolumn{8}{|c|}{ 3.b. Former Ministry of Electric Power Shares } \\
\hline Year & $\begin{array}{c}\text { Direct } \\
\text { Government } \\
\text { Expenditures } \mathbb{I}\end{array}$ & $\begin{array}{l}\text { Domestic } \\
\text { Bank } \\
\text { Loans }\end{array}$ & $\begin{array}{c}\text { Foreign } \\
\text { Investment }\end{array}$ & $\begin{array}{c}\text { Coal } \\
\text { Substitution }\end{array}$ & $\begin{array}{c}\text { Self- } \\
\text { Raised } \\
\text { Funds § }\end{array}$ & $\begin{array}{l}\text { Other } \\
\text { Sources } \S\end{array}$ & Total \\
\hline 1981 & $54.6 \%$ & $29.8 \%$ & $3.2 \%$ & - & $12.4 \%$ & - & $100.0 \%$ \\
\hline 1982 & $40.4 \%$ & $39.7 \%$ & $1.7 \%$ & - & $18.1 \%$ & - & $100.0 \%$ \\
\hline 1983 & $50.3 \%$ & $29.2 \%$ & $4.3 \%$ & $8.7 \%$ & $7.1 \%$ & $0.4 \%$ & $100.0 \%$ \\
\hline 1984 & $53.1 \%$ & $19.9 \%$ & $7.4 \%$ & $8.2 \%$ & $10.0 \%$ & $1.3 \%$ & $100.0 \%$ \\
\hline 1985 & $40.2 \%$ & $27.3 \%$ & $6.4 \%$ & $8.1 \%$ & $16.5 \%$ & $1.5 \%$ & $100.0 \%$ \\
\hline 1986 & $36.8 \%$ & $23.7 \%$ & $11.6 \%$ & $9.8 \%$ & $13.2 \%$ & $5.0 \%$ & $100.0 \%$ \\
\hline 1987 & $25.1 \%$ & $26.0 \%$ & $5.6 \%$ & $8.4 \%$ & $20.7 \%$ & $14.2 \%$ & $100.0 \%$ \\
\hline 1988 & $16.7 \%$ & $25.1 \%$ & $3.5 \%$ & $10.6 \%$ & $27.0 \%$ & $17.1 \%$ & $100.0 \%$ \\
\hline 1989 & $10.4 \%$ & $23.0 \%$ & $11.5 \%$ & $7.7 \%$ & $30.2 \%$ & $17.2 \%$ & $100.0 \%$ \\
\hline 1990 & $10.9 \%$ & $25.4 \%$ & $13.0 \%$ & $7.6 \%$ & $25.3 \%$ & $17.8 \%$ & $100.0 \%$ \\
\hline
\end{tabular}

* Data up to 1988 include only funds administered by the former Ministries of Coal, Electric Power and Water Resources, and Petroleum (which were consolidated in 1988 into the former Ministry of Energy, which was subsequently disbanded in 1993), so some totals are lower than in other tables. Data for 1989 and 1990 are for all state-owned units.

$\dagger$ Deflated with the national income deflators for the industrial sector in Table X-6.

I 1988 and later figures for direct government investment include loans which were originally allocated as direct government investment.

$\S 1981$ and 1982 figures for self-raised funds include "other" investment.

Source: China Energy Statistical Yearbook, various years; China Statistical Yearbook, various years. 
Chapter IV-Energy Consumption 


\section{Energy Consumption}

C hina's energy consumption patterns have recently undergone some changes that may foreshadow larger alterations in the future. Coal still dominates both the primary and end use consumption mixes. Its share is declining, however, as oil imports grow to meet demand that stagnant domestic oil production cannot, and as an increasing fraction of coal goes for thermal power generation. Use of electricity is rising faster than for any other energy source, and only lack of supply is preventing it from growing faster. Natural gas use has leveled off, primarily because supplies are limited, but recent large finds both offshore and onshore promise to raise consumption significantly in the near term.

The dominance of industry in the sectoral end use mix remains unchanged, and has in fact strengthened. Direct coal use in industry has been giving way to indirect coal use, as the share of electricity rises. Remarkably, household energy use has dropped in recent years, since the decline in coal use (due to increased efficiency of coal use and fuel switching) has more than offset accelerating growth in electricity use. Commercial sector energy use is rising fastest, and now consumes more than China's huge agricultural sector. Transportation energy use is going up nearly as quickly, as vehicle fleets swell; the sector now uses nearly as much oil as industry.

\section{Primary Energy}

\section{PRIMARY ENERGY CONSUMPTION}

China recently became the world's second largest consumer of energy, surpassing in 1994 the Russian Federation. Primary modern energy use in 1993 was about 1,113 Mtce (Table IV-1), more than two-thirds higher than a decade previously. Coal dominates the primary mix, followed by oil, primary electricity, and natural gas. Biomass fuel consumption in 1992 is estimated to have been about 250 Mtce (with wood and crop wastes each account- ing for half of the total, aside from a small fraction of dung), marking a slight decline from levels of several years ago (Table IV-2).

Coal is still by far the dominant fuel in the primary consumption mix, accounting for $73 \%$. Total coal use, however, actually declined slightly in 1993, and was the main factor in slow overall growth in energy use. Oil contributes one-fifth of the primary consumption mix. It been the fastest growing primary energy source recently, accounting for $40 \%$ of the increase in total primary consumption between 1990 and 1993. Nearly all this increase represents use of imported oil, since domestic production has remained flat. Primary electricity and natural gas together account for $7 \%$ of primary consumption, as has been the case since the mid-1970s. Growth of both these energy sources has been uneven, since energy sector investment has emphasized thermal power plants and oil. Energy consumption in China generally has followed production closely. The shares that each primary energy source contribute to consumption are almost identical to the production shares. The exception to this is oil, of which there were substantial net exports in the 1970 s and 1980s, and of which China is now a net importer.

Per capita energy consumption has climbed steadily at a rate not quite half that of economic expansion, from 612 kgce per person in 1980 to 939 kgce per person in 1993. Over a period in which the population more than doubled (1952-1993), commercial energy consumption increased by a factor of 24. Growth in per capita primary energy use has slowed considerably in recent years, increasing by just over $2 \%$ in 1993 compared with an average rate of nearly $6 \%$ in the 1980 s. Because the population continues to expand, per capita energy use is now growing more slowly than total energy use; total consumption grew at an average annual rate of $4 \%$ between 1990 and 1993, but per capita use rose by $3 \%$ per year.

Most of the large energy-consuming provinces are found along the coast and in the Northeast, although Sichuan and inland provinces in the South 
Central region with large populations are also large consumers (Table IV-4). The highest per capita rates of energy use (for all forms) are found in China's three directly administered cities, Beijing, Tianjin, and Shanghai (Table IV-5). At 2.0 to $2.5 \mathrm{tce} / \mathrm{per}-$ son-yr, per capita rates of energy use are more than twice the national average of under 0.9 tce/personyr. Most other areas with high per capita rates of energy use are in the northern half of the country, mainly due to coal use for winter space heating.

\section{PRIMARY ENERGY INTENSITY}

One of post-Mao China's most remarkable phenomena has been the sustained economic and industrial expansion characterized by slower growth in energy use than in output. The energy intensity (energy consumption per unit of economic output) of the Chinese economy has decreased steadily since 1977 , falling by nearly half since then, a trend unparalleled in any other large developing country (Table IV-3). If the energy intensity of China's economy were the same now as in the late 1970s, the country would need to consume twice as much energy as it does currently. As a group, the sparsely populated northwestern provinces have the highest energy intensities, as do the centers of heavy industry and energy production in the North and Northeast (Table IV-6). In the South, two of the poorest provinces (Guangxi and Guizhou) and one of the richest (Guangdong) also exhibit high intensities.

Analysis has shown that structural change, i.e., shifts in the relative output shares among the major sectors, have contributed very little to this decline. ${ }^{1}$ The driving forces behind this trend are to be found within sectors, primarily improvements in technical efficiency (specific energy consumption) and shifts towards more expensive products. ${ }^{2}$ Govermmentsponsored programs and organizations for energy conservation investments, technical assistance, and energy management have probably played a significant role in achieving this overall improvement in the energy efficiency of the nation's economy. ${ }^{3}$

\section{END-USE ENERGY CONSUMPTION BY SECTOR}

Energy end-use in 1992 was over 990 Mtce (Table IV-7). ${ }^{4}$ Despite significant changes in patterns of use among individual energy sources, the overall sectoral structure of energy consumption changed relatively little between 1980 and 1992. All sectors saw monotonic increases in levels of energy use, excepting the agriculture and residential sectors, both of which experienced declines in 1992.

Industry's share of total end-use, which has fluctuated near $65.5 \%$ for years, rose to $67 \%$ in 1992 , but this may be just a short-term rise. Transportation accounts for only a marginally larger share than a decade ago, as coal use falls and oil use rises. Shares of the agricultural and residential sectors have been dropping slowly and steadily since the early 1980s. For agriculture this is the result of declining shares in use of all energy forms, but for the residential sector this is the result of switching from solid fuels to electricity for many tasks.

Average growth in energy end use ( $4.9 \%$ between 1980 and 1992) has been dominated by industry, the largest consumer. The average was dragged down mainly by slower growth in households, the second largest energy-consuming sector. This trend contradicts the prevailing impression that increasing energy use in the residential sector is a driving force behind China's rising energy demand (see below). Growth was fastest in what was until recently the smallest consumer, the commercial sector, followed by the transportation sector. While important, the magnitude of demand increases in these two sectors is dwarfed by that in industry.

\section{INDUSTRY}

Industrial sector ${ }^{5}$ end uses-664 Mitce in 1992, excluding utility use-continue to be dominated by solid fuels (Table IV-8). Coal and coke together have consistently accounted for over half of end use since 1980 , although that share has declined gradually since the mid-1980s. The shares of electricity and delivered heat have grown most rapidly, while those for oil and natural gas has fallen off, the latter particularly rapidly so that it now accounts for less than $3 \%$ of industrial end use.

Despite years of exhortations from policy makers to emphasize development of light industry in order to reduce industrial energy intensity, heavy indus- 
try ${ }^{6}$ has consistently taken four-fifths of total industrial end-use. In 1992 chemicals and ferrous metals manufacturing each accounted for $15.8 \%$ of total end use, and building materials manufacturing for a further $14.4 \%$. While the shares of some energyintensive sectors, e.g., building materials ${ }^{7}$ and machine building, have fallen, those of others, e.g., ferrous and nonferrous metals, have risen. Structural change in industry has meant shifts among energy-intensive sectors more than shifts between heavy and light sectors.

Heavy industry's share of coal use is significantly smaller than its share of total industrial end use. Known underreporting of coal use in rural industry means that reported total coal use and heavy industry's share of coal use are lower than actual. ${ }^{8}$ The largest coal-consuming sector by far is the building materials manufacturing industry, with over $27 \%$ of coal end use in 1992 . Heavy industry's share has declined slightly relative to light industry since 1985 . The sources of this shift seem to be increases in consumption of certain chemical industries classified as "light," pharmaceuticals, textiles, and declines in building materials and metals. Heavy industry accounts for most oil and nearly all coke consumption in the industrial sector.

Fuel oil dominates industrial oil use, but despite years of work, nearly $4 \mathrm{Mt} / \mathrm{yr}$ of crude oil were still burned directly in 1992, half at oil fields and refineries. Natural gas use is concentrated in oil fields and chemical plants. The chemicals industry is by far the largest consumer of both delivered heat and electricity. Light industry approaches half the consumption levels of heavy industry only for coal, kerosene, and delivered heat; for all other energy sources light industry consumes a much smaller portion.

Industrial sector electricity use nearly doubled between 1985 and 1992. Heavy industry's share of electricity use was about $77 \%$ in 1992, down one percentage point from 1985 with little fluctuation in the intervening period. The chemicals industry was the largest single electricity consumer in 1992, using $15.4 \%$, followed by ferrous metals manufacturing with $12.4 \%$ of the total.

Despite growing demand for fertilizers and petrochemical products, feedstock uses of energy have grown more slowly that overall energy use, falling from $8 \%$ of primary energy use to under $7 \%$ in the early 1990s (Table IV-11). Recent rapid construction of petrochemical processing facilities is reversing this trend.

Industrial energy use is concentrated in China's north and east, dominated by Liaoning, Hebei (including Beijing and Tianjin), Shandong, and Jiangsu, all of which used over 40 Mtce in 1990 (Table IV-10). The only inland province in that category, Sichuan, has a population of over 110 million.

\section{ELECTRIC UTILITIES}

Electricity generation is taking an increasingly large share of primary energy. From a low of $16.5 \%$ in 1985, utility fuel inputs have risen to $22.3 \%$ of primary energy consumption (1993), doubling in quantity over that time (Table IV-12). Coal's dominance of the fuel mix has strengthened; 231 of the 249 Mtce burned in 1993 came from coal. Policies to convert oil-fired utility boilers to coal, and to eliminate firing of utility boilers with crude oil succeeded in reversing the increase in oil use by the end of the 1980s. Reported utility oil use was $12 \mathrm{Mt}$ in 1983, compared to over 20 in 1980. Unreported oil burning, particularly of smuggled diesel in small generators in coastal provinces, is probably on the rise, and actual oil use for generation is larger than official reports suggest. 9 Natural gas use appears to have fallen off after peaking in 1990 or 1991.

The efficiency of delivering electricity has begun to improve again, after leveling off in the late 1980 s (Table IV-13). In 1993 heat rates for gross and net generation stood at 384 gce and 417 gce per $\mathrm{kWh}$ respectively (corresponding to gross and net generation efficiencies of $27.5 \%$ and just over $25 \%$, respectively). Rising average size of power plants and improvements in transmission and distribution lie behind this trend, although power shortages induce utilities and self-generators to keep inefficient units in service. Bureaucratic barriers and difficulties in raising investment for larger plants have created an environment in which continued construction of smaller scale (e.g., $10 \mathrm{MW}$ ) and therefore relatively inefficient power plants is attractive to many local authorities. (See, for example, Wirthshafter and Shih, 1990.) Also, efficiencies on China's many small rural grids can be quite low, as line loss rates tend to be quite high, sometimes well over $20 \%$ 
(Sathaye, 1992). In-plant electricity consumption has been rising slowly as a percentage of gross generation (Table IV-14).

\section{TRANSPORTATION}

Not surprisingly, most of the transportation sector's energy comes from petroleum products $-76 \%$ in $1992 .{ }^{10}$ In the early 1980 s steam locomotives still dominated railways, and coal's share of sectoral energy uses exceeded one-third. With the phasing out of steam locomotives in favor of diesel and electric ones, and with the increasing dependence on road transport, coal's share has fallen to less than half of its previous levels. Transportation end use doubled between 1980 and 1992 to 79 Mtce, due almost entirely to increased gasoline and diesel use. The quintupling of electricity use (and doubling of its share of end use) reflects the influence of railway electrification projects.

Studies of energy use by mode for the 1980 s show that in the latter half of the decade railroad energy use dropped from nearly one-half of the total to about one third, whereas road vehicle energy use rose from about one third to nearly half (Table IV16). Locomotive coal use dropped more slowly than oil and electricity use rose, but the net effect was a gradual decline in total end use, implying significant efficiency gains. Aircraft fuel use kept pace with overall growth. ${ }^{13}$

\section{AGRICULTURE}

Between 1980 and 1992 agricultural sector energy consumption grew more slowly than in any other sector - at an annual rate of $3.1 \%$ compared to the average of $5.2 \%$ (Table IV-17). The main change in the agicultural energy end use mix has been the replacement of electricity for coal and oil products. Whereas electricity use has risen quickly, as in other sectors, diesel consumption has been slow to rise, and coal use has fallen off quickly after reaching a high in 1988.

\section{HOUSEHOLDS}

In few sectors are changes in energy end use mix more profound than in the household sector. After growing faster than any other sector until the late 1980s, total energy use actually dropped in 1992 (Table IV-18). Like agriculture, total coal use in the sector peaked in 1988. As a share of total end use, coal has fallen from $90 \%$ to $72 \%$ of end use in a dozen years. These drops are due in part to penetration of coal briquettes and more efficient stoves, to the spread of electrical heating and cooking appliances, and increasing availability of gas.

Trends in electricity use have been exactly the opposite, with total use growing from 10.5 TWh in 1980 to $64.0 \mathrm{TWh}$ in 1992 and the share rising from $5 \%$ to $18 \%$. While the household sector may not have a large impact on overall consumption growth rates, it has become very important in terms of the electricity supply.

Urban households still account for more than half of energy use in the sector, but the share consumed by rural households has risen slowly since coal use has dropped off earlier and more quickly in urban areas (Table IV-19). Earlier appliance penetration in urban households resulted in a widening of the gap between total urban and rural electricity use in the 1980s. That gap has begun to narrow in recent years, however, as rural appliance use rises as well. Location is the main variable affecting energy use; households in China's heating zone (the northern regions where space heating is permitted) use considerably more coal than those in other parts of the country, and per capital electricity use is highest in wealthier coastal areas, around Beijing, and in the Northeast (Table IV-20).

Biomass fuels are still the major sources of energy for China's large rural population. Estimated biomass use in rural homes ${ }^{12}$ in 1990 was over 260 Mtce, nearly $60 \%$ greater than consumption of commercial energy in all households (Table IV-21). Official estimates for years after 1990 show declines in biomass use. While estimates of biomass consumption are subject to significant uncertainty, such a trend would be in line with evidence that many rural households are switching from biomass to coal (as a result of wider availability of coal from nural mines) and with the widespread penetration of more efficient biomass stoves. 
Gas fuels for cooking (about half being LPG) have become a much more substantial presence in Chinese homes, with nearly $60 \%$ residents of cities now having access (Table IV-22). Gas fuel consumption has been rising at a rate about as fast as electricity, as cities nationwide push to improve the efficiency and cleanliness of household cooking fuel use. LPG demand growth, concentrated in the coastal area south of the Yangtze River, has made China a net importer. Such fuels are still virtually unavailable in rural areas, however, and less than 100 million people of a population of 1.2 billion now use gas. Muchpublicized district heating schemes have resulted in a large increase in delivered heat, but this source still accounts for less than $3 \%$ of total end use.

\section{COMMERCIAL SECTOR}

End use in this sector is dominated by buildings. Coal still makes up close to half of end use in the commercial sector, but coal use is already falling off after reaching a peak in 1991, possibly as a result of improvements in space heating systems (Table IV23). Electricity, which now accounts for one-third of end use, is rapidly edging coal out as lighting, air conditioning, and other uses expand. Oil product and other energy use has fluctuated in both absolute and percentage terms.

\section{CONSUMPTION BY TYPE OF ENERGY: END USE AND CONVERSIONS}

In 1992 the fraction of end use from directly burned coal and coke dropped to $51 \%$, its lowest level since such figures have been reported (Table IV24). ${ }^{13}$ Direct coal use has grown at half the rate of electricity use, as slightly more than half of marginal coal use since 1980 has gone to utilities rather than end users. Use of electricity and delivered heat have risen faster than for other energy sources; at $7 \%$ to $8 \%$ per year they have kept pace with long-term economic growth rates. The share of oil in the end use mix is approaching levels last seen in the 1970s and early 1980 s, i.e., $16 \%$ and over. This reflects mainly rising transportation sector demand. End use of natural gas appears to have stagnated. Supplies have been slow to expand, and are generally allocated away from domestic use to fertilizer production and electricity generation.

China's estimated stock of 400 thousand industrial boilers use fully one-third of China's coal, about $350 \mathrm{Mt}$ in 1990 (Table IV-25). Utility boilers take another quarter, followed by industrial kilns with $16 \%$ and coke ovens and metallurgical industry furnaces with $10 \%$. Of the remainder, the largest share is used in household stoves (about $90 \mathrm{Mt}$ ), and the rest for town gas manufacture, steam locomotives, and other uses.

An industrial sector category, kilns, also take the largest single share of oil end-use- over $22 \%$, slightly more than that used in motor vehicles. ${ }^{14}$ Utility and industrial boilers take a further $15 \%$, and the remaining significant oil-using sectors are mainly various means of transport. Aggregated miscellaneous uses account for one-fifth of end use.

Electricity end uses are dominated by pumps, fans, and compressors, responsible for $21 \%, 10 \%$, and $9 \%$ respectively. Building and appliance uses (lighting, refrigeration, and air conditioning) combined take at least $13 \%$, not counting household electronics, electric rice cookers, fans, and other equipment. Various industrial uses-furnaces, cement mills, gas separators, and arc welders-account for most of the rest, aside from slightly over $2 \%$ for inigation pumps and less than $1 \%$ for electrified railways.

\section{COAL AND COAL PRODUCTS}

Direct coal end use dropped slightly from 606 Mt to $603 \mathrm{Mt}$ between 1991 and 1992 as a result of declining coal consumption in non-industrial sectors, though total use continued to rise because of increasing transformation inputs (Table IV-26). End use of coal in industry resumed its climb after the general slowdown of economic activity in 1989 and 1990. Industry's share of direct coal use, at slightly over one-third, has exhibited a weak downward trend in the 1990s. Transportation coal end use is falling as steam locomotives are gradually retired in favor of diesel and electric locomotives. Probably the most important factor behind the drop in residential coal use since 1988 is the spread of cleaner burning and more efficient briquettes (which replace raw coal and homemade coal bricks) to most urban and some suburban areas. Other factors include increas- 
ing availability of LPG and town gas, and widespread use of electric cooking appliances, especially rice cookers.

Coal inputs to thermal power generation have been growing by over $20 \mathrm{Mt}$ per year (i.e., by more than total coal use in the transportation or agricultural sectors) since the late 1980 s. In the same period, the rate of addition to thermal power generation capacity has been in excess of $10 \mathrm{GW}$ per year. While total coal use did not quite double between 1980 and 1992, the amount burned in power plants tripled.

When coal inputs to thermal electric utilities are attributed to end use sectors, industry's share of total coal use rises to over half, since industry is also the largest user of electricity. Its share is, in fact, several percentage points higher than a decade ago. Coal use, whether directly burned or used indirectly through electricity demand, continues to be dominated by industrial uses.

Coal gas use has risen considerably, more than doubling over the past decade (Table IV-27). By far the greatest part is used in-industry, though household use has been growing at a faster rate recently. Most of the increased use represents utilization of previously exhausted gas, e.g., from coke ovens.

\section{OIL}

Most oil is consumed in end use sectors (109 Mt in 1992), accounting for $84 \%$ of total use, up five percentage points from 1980 (Table IV-28). Total end use has nearly doubled over the same period. Oil inputs at power plants, on the other hand, have remained about the same, and its share of total use consequently has been halved. While anecdotal evidence suggests that diesel is increasingly being consumed for power generation, the available statistics show large fluctuations, possibly indicating sensitivity to the unstable price and import environments (Table IV-31).15 Direct burning of crude oil in end uses continues, with no clear long-term trend in total use (Table IV-30)

Among end use sectors, increasing consumption is most evident in transportation. Transportation now accounts for almost one-third of oil use, up about 10 percentage points from a decade ago. Its share of diesel use, however, has fallen slightly from its high in 1987. Industrial end uses are still predominant at $40 \%$ of total oil consumption, but the share is slowly falling. The share of diesel use has remained steady at about one-quarter in recent years. Agricultural consumption of oil products (almost all diesel) has leveled off at $7 \mathrm{Mt}$ per year. This may reflect rural oil shortages as much as stagnating demand. Residential sector oil use, while rising quickly, still represents only a small fraction of total use. The commercial sector only uses about $3 \%$ of all oil products, but now accounts for $11 \%$ of diesel consumption. Whether this reflects growth in diesel vehicle use or diesel generators attributed to this sector is unknown.

While inputs to conversions have fallen off from $25 \%$ to $17 \%$ of total oil use since 1980 , the actual quantity has changed little, with only small and temporary shifts in the fuel mix (Table IV-29). End uses are increasingly dominated by gasoline and diesel, with fuel oil use rising slowly and direct use of crude oil falling. Kerosene consumption has remained flat, as lighting use declines and jet fuel consumption climbs. Fuel oil consumption continues to increase, but at a somewhat slower pace than overall oil use.

\section{NATURAL GAS .}

Natural gas consumption is small by the standards of developed countries-not quite 16 billion cubic meters in 1992-and has grown rather slowly (IV-32). Consumption will increase substantially in the near future as new pipelines make output from newly developed offshore fields available. End use data on natural gas are incomplete, with sectoral divisions often hiding different end uses. Some available data indicate that currently up to twothirds of natural gas is used to generate electricity, but this is certainly erroneous; a more realistic figure is in the neighborhood of $5 \%$. Residential deliveries account for another $11 \%$ to $14 \%$. The balance goes mainly for fertilizer production (about onethird) and self-use at oil and natural gas fields.

\section{ELECTRICITY}

Consumption of electricity use has grown faster 
than that of any other energy source, rising from 234 TWh in 1980 to 637 TWh in 1993 (Table IV-33). As with other energy sources, industry takes the lion's share-over $71 \%$ in 1993. Still, industry's share has been declining steadily (as has that of agriculture, though relatively more quickly) as consumption in other sectors has ballooned. Residential electricity use has shot up dramatically, from 11 TWh in 1980 to 73 TWh in 1993. Rapid penetration of previously unavailable electrical appliances and electronic devices, particularly in urban areas, lies behind this trend (see Chapter V). Commercial sector electricity use, now over $6 \%$ of the total, has also risen quickly because of construction of new hotels and office buildings, as well as upgrading of older buildings.

Although consumption is growing at a higher rate than any other form of energy, electricity use would have grown faster were it not for chronic supply shortages, which some Chinese sources estimate at $20 \%$ of demand. Official Chinese plans call for meeting this large reservoir of latent demand through massive investment in power generation and supply networks in the coming years.

1 Even within manufacturing, the shares of energy-intensive industries have changed only slowly (Sinton and Levine, 1994).

2 Anecdotal evidence suggests that overreporting of output and changes in price regimes accompanying the economic system reforms are also important contributors, but would not fundamentally change the conclusions.

3 Levine and Liu, 1991; Liu et al., 1994.

${ }^{4}$ Electricity converted at the nominal gross heat rate of delivered electricity of $404 \mathrm{gce} / \mathrm{kWh}$. All the following aggregate statistics are treated this way also, and exclude utility sector energy use (except for Tables IV-9 and IV-10). Note that due to rounding and slight differences in accounting, totals in Table IV-7 and in the breakout by energy sources (Table IV-24) are slightly different.

5 Chinese energy accounts include the utility sector among industrial energy statistics. Utility sector figures here include only energy used for plant operation, not inputs to power and heat generation, which are distributed among end use sectors by using the nominal gross heat rate of power generation to convert electricity to standard coal.

6 Including utility sector energy use, i.e., that energy used for running plants and auxiliary activities, not inputs to generation.

7 The case for a decline in building materials industry energy consumption is not entirely without problems, since some uncertainty remains regarding rural enterprise energy use. While official statistics show energy consumption in the building mate- rials sector of not quite $110 \mathrm{Mtce}$ in 1991 , actual consumption was probably between 140 and $150 \mathrm{Mtce}$, and 1993 consumption was about $170 \mathrm{Mtce}$. Much of this unreported consumption is of coal from rural mines that probably also is not covered in national statistics (Wang, 1995).

8 In addition to the large amount of unreported coal use in the building materials industry, rural coking plants, mainly in Shanxi, use on the order of $50 \mathrm{Mt} / \mathrm{yr}$ of coal for inputs, much of which goes unreported (Wang, 1995).

9 In 1994, for instance, an estimated 2 to $3 \mathrm{Mt}$ ( 40 to $60 \mathrm{kbd}$ ) of diesel was smuggled into China, with an unknown percentage of that going for power generation.

10 Official Chinese statistics cover only dedicated transportation enterprises, excluding fuel use by the majority of road vehicles, which are owned by industrial and agricultural sector enterprises. Sectoral statistics in this volume are adjusted to include estimated unreported transportation energy use, resulting in figures somewhat greater than officially reported data.

II Exclusion from earlier data of significant coal and electricity use by pipelines and ships prevent comparisons for those modes.

12 Biomass use in rural industry and in agriculture is negligible by comparison. Most fossil fuel and electricity use in rural areas is for agriculture and industry.

13 Converting electricity at its heat value $(3.6 \mathrm{MJ} / \mathrm{kWh})$ the corresponding percentage would be $62 \%$.

14 At present motor vehicles are probably the largest oil-consuming segment of the economy.

15 Statistics on diesel use for power generation are incomplete, especially for the high demand areas along the eastern and southeastern coast, introducing significant uncertainty to these national total. 


\section{Overall Consumption}


Table IV-1. Primary Energy Consumption, 1952-1993

\begin{tabular}{|c|c|c|c|c|}
\hline \multicolumn{5}{|c|}{ 1. Consumption in Physical Units } \\
\hline Year & $\begin{array}{l}\text { Raw } \\
\text { Coal * } \\
\text { (Mt) }\end{array}$ & $\begin{array}{l}\text { Crude } \\
\text { Oil * } \\
\text { (Mt) }\end{array}$ & $\begin{array}{c}\text { Natural } \\
\text { Gas } \dagger \\
\text { (million } \\
\text { cubic m) }\end{array}$ & $\begin{array}{l}\text { Hydroelec- } \\
\text { tricity I } \\
\text { (TWh) }\end{array}$ \\
\hline 1952 & 62.47 & 1.10 & 8 & 1.3 \\
\hline 1953 & 71.49 & 1.44 & 8 & 1.5 \\
\hline 1954 & 81.59 & 1.89 & 9 & 2.2 \\
\hline 1955 & 90.70 & 2.39 & 15 & 2.4 \\
\hline 1956 & 114.28 & 2.97 & 20 & 3.5 \\
\hline 1957 & 124.69 & 3.10 & 60 & 4.8 \\
\hline 1958 & 233.23 & 4.82 & 75 & 4.1 \\
\hline 1959 & 317.26 & 6.78 & 250 & 4.4 \\
\hline 1960 & 397.01 & 8.68 & 1,023 & 7.4 \\
\hline 1961 & 260.76 & 7.80 & 1,444 & 7.4 \\
\hline 1962 & 206.69 & 7.65 & 1,158 & 9.0 \\
\hline 1963 & 193.89 & 7.84 & 947 & 8.7 \\
\hline 1964 & 205.00 & 9.35 & 910 & 10.6 \\
\hline 1965 & 228.84 & 13.57 & 895 & 10.4 \\
\hline 1966 & 244.80 & 14.42 & 1,023 & 12.6 \\
\hline 1967 & 217.60 & 13.96 & 1,158 & 13.1 \\
\hline 1968 & 215.98 & 15.56 & 1,053 & 11.5 \\
\hline 1969 & 260.81 & 21.87 & 1,398 & 16.0 \\
\hline 1970 & 331.84 & 30.05 & 2,023 & 20.5 \\
\hline 1971 & 382.61 & 38.60 & 3,737 & 25.1 \\
\hline 1972 & 404.63 & 44.75 & 4,850 & 28.8 \\
\hline 1973 & 409.93 & 50.81 & 5,970 & 38.8 \\
\hline 1974 & 405.60 & 58.12 & 7,511 & 41.3 \\
\hline 1975 & 457.13 & 66.93 & 8,573 & 47.5 \\
\hline 1976 & 468.30 & 76.93 & 10,105 & 45.5 \\
\hline 1977 & 515.14 & 82.78 & 12.121 & 47.5 \\
\hline 1978 & 565.64 & 90.83 & 13,752 & 44.5 \\
\hline 1979 & 585.16 & 89.28 & 14,534 & 50.0 \\
\hline 1980 & 610.10 & 87.57 & $.14,060$ & 58.1 \\
\hline 1981 & 605.84 & 83.06 & 12,450 & 65.4 \\
\hline 1982 & 641.26 & 82.10 & 11,900 & 74.2 \\
\hline 1983 & 687.13 & 83.83 & 12,130 & 86.2 \\
\hline 1984 & 749.68 & 86.55 & 12,620 & 86.6 \\
\hline 1985 & 816.03 & 91.69 & 12,930 & 92.1 \\
\hline 1986 & 860.15 & 97.28 & 13,760 & 94.2 \\
\hline 1987 & 927.99 & 103.12 & 13,890 & 99.7 \\
\hline 1988 & 993.54 & 110.93 & 14,360 & 108.8 \\
\hline 1989 & $1,034.27$ & 115.84 & 15.030 & 117.9 \\
\hline 1990 & $1,052.94$ & 114.69 & 15,585 & 126.3 \\
\hline 1991 & $1,105.68$ & 124.23 & 15,606 & 124.3 \\
\hline 1992 & I,I56.96 & 133.73 & 15,596 & 130.2 \\
\hline 1993 & $1,139.12$ & 153.34 & 16,807 & 151.2 \\
\hline
\end{tabular}

* Consumption figures for 1952 and for 1990 and later years are not available in physical units and are derived from percentage share data; other figures are reported directly.

$\dagger$ 1952-1979 consumption figures for natural gas are not available in physical units and are derived from percentage share data; other figures are reported directly.

I Figures are for net hydro generation (gross generation minus in-plant use). In-plant use for 1953-1956 and 1958-1964 is calculated at the reported 1952 in-plant consumption rate of $0.22 \%$ (see Table IV-14), which is high but may be more realistic than the historically low $0.14 \%$ reported in 1957. Reported in-plant consumption rates are for key plants only and are probably lower than the national averages, which are unavailable. Direct reports of primary electricity consumption are not available.

Source: China Energy Statistical Yearbook, various years; China Statistical Yearbook, various years. China Energy Annual Review, 1994. 


\begin{tabular}{|c|c|c|c|c|c|}
\hline \multicolumn{6}{|c|}{ 2. Consumption in Mtce } \\
\hline Year & $\begin{array}{l}\text { Raw } \\
\text { Coal * } \\
\text { (Mtce) }\end{array}$ & $\begin{array}{l}\text { Crude } \\
\text { Oil * } \\
\text { (Mtce) }\end{array}$ & $\begin{array}{c}\text { Natural } \\
\text { Gas } \\
\text { (Mtce) } \dagger\end{array}$ & $\begin{array}{l}\text { Hydro- } \\
\text { electricity } \\
\text { (Mtce) } T\end{array}$ & $\begin{array}{c}\text { Total } \\
\text { (Mtce) }\end{array}$ \\
\hline 1952 & 44.62 & 1.58 & 0.01 & 0.52 & 46.73 \\
\hline 1953 & 51.07 & 2.06 & 0.01 & 0.60 & 53.74 \\
\hline 1954 & 58.28 & 270 & 0.01 & 0.89 & 61.88 \\
\hline 1955 & 64.79 & 3.41 & 0.02 & 0.97 & 69.19 \\
\hline 1956 & 81.63 & 4.24 & 0.03 & 1.41 & 87.31 \\
\hline 1957 & 89.07 & 4.43 & 0.08 & 1.94 & 95.51 \\
\hline 1958 & 166.60 & 6.89 & 0.10 & 1.65 & 175.23 \\
\hline 1959 & 226.62 & 9.69 & 0.33 & 1.77 & 238.41 \\
\hline 1960 & 283.58 & 1240 & 1.36 & 298 & 300.33 \\
\hline 1961 & 186.26 & 11.14 & 1.92 & 2.98 & 202.31 \\
\hline 1962 & 147.64 & 10.93 & 1.54 & 3.63 & 163.74 \\
\hline 1963 & 138.50 & 11.20 & 1.26 & 3.51 & 154.46 \\
\hline 1964 & 146.43 & 13.36 & 1.21 & 4.27 & 165.27 \\
\hline 1965 & 163.46 & 19.39 & 1.19 & 4.19 & 188.23 \\
\hline 1966 & 174.86 & 20.60 & 1.36 & 5.08 & 201.90 \\
\hline 1967 & 155.43 & 19.94 & 1.54 & 5.28 & 182.20 \\
\hline 1968 & 154.27 & 22.23 & 1.40 & 4.64 & 182.54 \\
\hline 1969 & 186.30 & 31.24 & 1.86 & 6.45 & 225.85 \\
\hline 1970 & 237.03 & 42.93 & 2.69 & 8.27 & 290.92 \\
\hline 1971 & 273.30 & 55.14 & 4.97 & 10.12 & 343.54 \\
\hline 1972 & 289.03 & 63.93 & 6.45 & 11.62 & 371.02 \\
\hline 1973 & 292.81 & 72.59 & 7.94 & 15.69 & 389.03 \\
\hline 1974 & 289.72 & 83.03 & 9.99 & 16.70 & 399.44 \\
\hline 1975 & 326.53 & 95.62 & 11.40 & 19.20 & 45275 \\
\hline 1976 & 334.51 & 109.90 & 13.44 & 18.39 & 476.24 \\
\hline 1977 & 367.96 & 118.26 & 16.12 & 19.19 & 521.54 \\
\hline 1978 & 404.04 & 129.76 & 18.29 & 17.98 & 570.07 \\
\hline 1979 & 417.98 & 127.55 & 19.33 & 20.20 & 585.06 \\
\hline 1980 & 435.79 & 125.10 & 18.70 & 23.99 & 603.59 \\
\hline 1981 & 432.75 & 118.66 & 16.56 & 26.61 & 594.57 \\
\hline 1982 & 458.05 & 117.29 & 15.83 & 29.99 & 621.16 \\
\hline 1983 & 490.82 & 119.76 & 16.13 & 34.48 & 661.19 \\
\hline 1984 & 535.50 & 123.65 & 16.78 & 34.46 & 710.39 \\
\hline 1985 & 582.89 & 130.99 & 17.20 & 36.67 & 767.75 \\
\hline 1986 & 614.41 & 138.97 & 18.30 & 37.51 & 809.19 \\
\hline 1987 & 662.86 & 147.32 & 18.47 & 39.68 & 868.33 \\
\hline 1988 & 709.69 & 158.47 & 19.10 & 43.21 & 930.46 \\
\hline 1989 & 738.78 & 165.49 & 19.99 & 46.82 & 971.08 \\
\hline 1990 & 75212 & 163.85 & 20.73 & 49.52 & 986.21 \\
\hline 1991 & 789.79 & 177.47 & 20.76 & 48.48 & $1,036.49$ \\
\hline 1992 & 826.42 & 191.05 & 20.74 & 50.26 & $1,088.47$ \\
\hline 1993 & 813.67 & 219.07 & 22.35 & 58.05 & $1,113.14$ \\
\hline
\end{tabular}

- Consumption figures for 1952 and for 1990 and later years are not available in physical units and are derived from percentage share data; other figures are reported directly.

$\dagger$ 1952-1979 consumption figures for natural gas are not available in physical units and are derived from percentage share data; other figures are reported directly.

1 Figures are for net hydro generation (gross generation minus in-plant use). In-plant use for 1953-1956 and 1958-1964 is calculated at the reported 1952 in-plant consumption rate of $0.22 \%$ (see Table IV-14), which is high but may be more realistic than the historically low $0.14 \%$ reported in 1957. Reported in-plant consumption rates are for key plants only and are probably lower than the national averages, which are unavailable. Direct reports of primary electricity consumption are not available.

Source: China Energy Statistical Yearbook, various years; China Statistical Yearbook, various years. China Energy Annual Review, 1994. 
Figure IV-1. Total Primary Energy Consumption, by Fuel Source

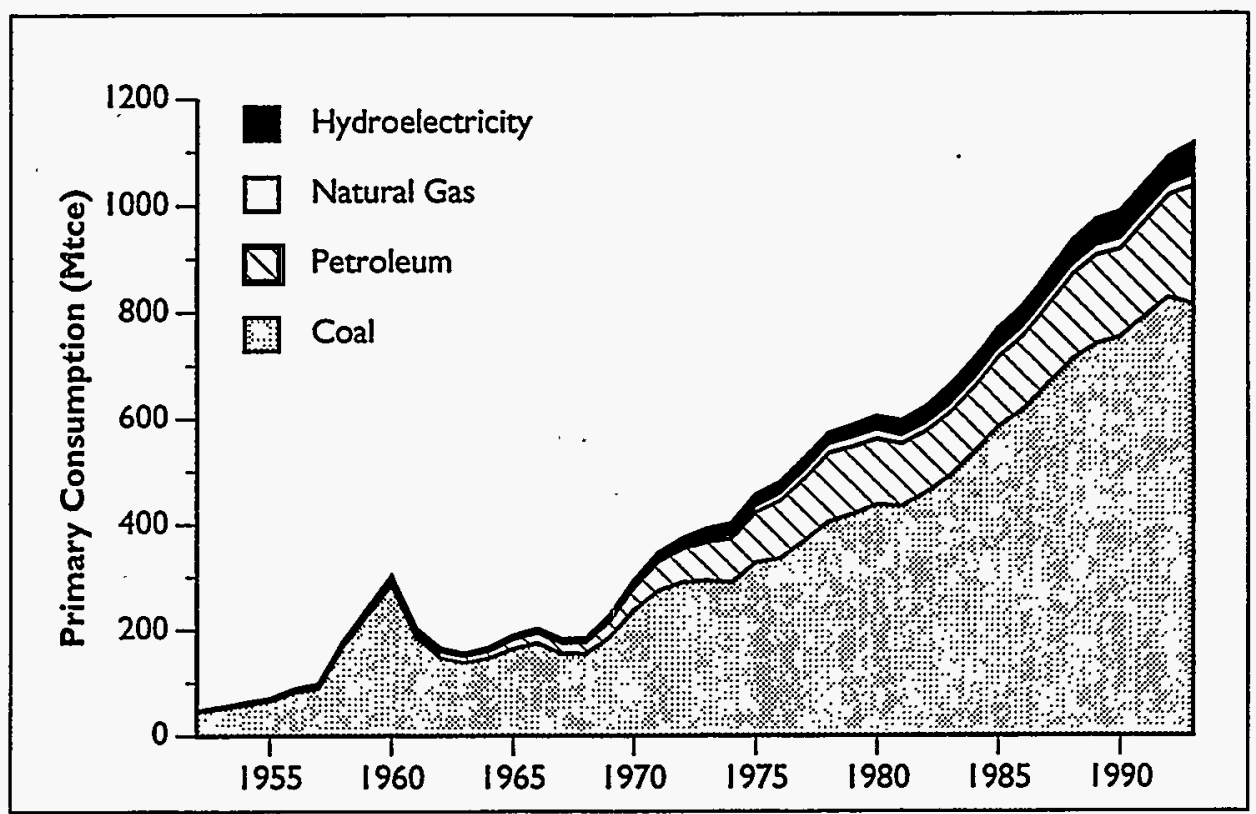

Figure IV-2. Shares of Primary Energy Consumption, by Fuel Source

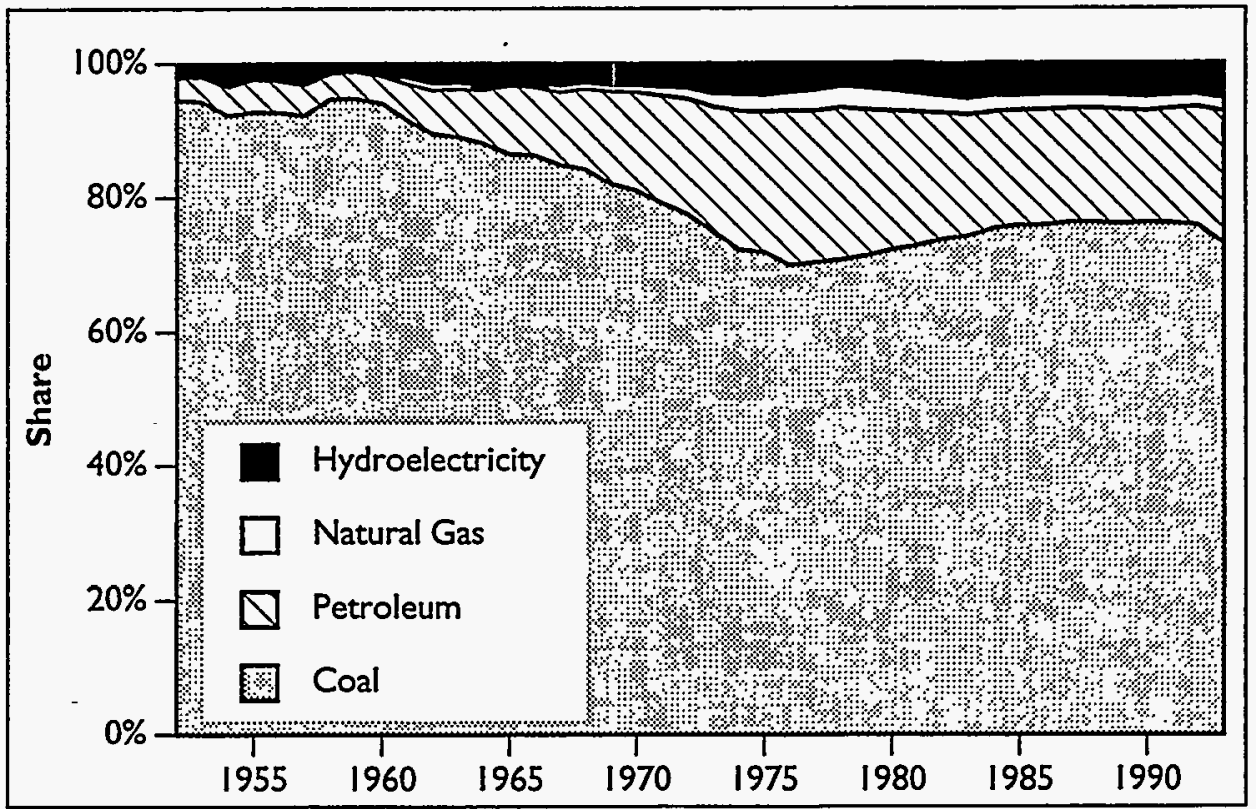




\section{Table IV-1. Primary Energy Consumption, 1952-1993 (continued)}

\begin{tabular}{|c|c|c|c|c|}
\hline \multicolumn{5}{|c|}{ 3. Shares of Total } \\
\hline Year & $\begin{array}{c}\text { Raw } \\
\text { Coal * } \\
(\%)\end{array}$ & $\begin{array}{c}\text { Crude } \\
\text { Oil } \dagger \\
(\%)\end{array}$ & $\begin{array}{c}\text { Natural } \\
\text { Gas II } \\
\text { (\%) }\end{array}$ & $\begin{array}{l}\text { Hydro- } \\
\text { electricity } \\
\text { (\%) }\end{array}$ \\
\hline 1952 & $95.5 \%$ & $3.4 \%$ & $0.02 \%$ & $1.1 \%$ \\
\hline 1953 & $95.0 \%$ & $3.8 \%$ & $0.02 \%$ & $1.1 \%$ \\
\hline 1954 & $94.2 \%$ & $4.4 \%$ & $0.02 \%$ & $1.4 \%$ \\
\hline 1955 & $93.6 \%$ & $4.9 \%$ & $0.03 \%$ & $1.4 \%$ \\
\hline 1956 & $93.5 \%$ & $4.9 \%$ & $0.03 \%$ & $1.6 \%$ \\
\hline 1957 & $93.3 \%$ & $4.6 \%$ & $0.08 \%$ & $20 \%$ \\
\hline 1958 & $95.1 \%$ & $3.9 \%$ & $0.06 \%$ & $0.9 \%$ \\
\hline 1959 & $95.1 \%$ & $4.1 \%$ & $0.14 \%$ & $0.7 \%$ \\
\hline 1960 & $94.4 \%$ & $4.1 \%$ & $0.45 \%$ & $1.0 \%$ \\
\hline 1961 & $92.1 \%$ & $5.5 \%$ & $0.9 \%$ & $1.5 \%$ \\
\hline 1962 & $90.2 \%$ & $6.7 \%$ & $0.9 \%$ & $22 \%$ \\
\hline 1963 & $89.7 \%$ & $7.3 \%$ & $0.8 \%$ & $23 \%$ \\
\hline 1964 & $88.6 \%$ & $8.1 \%$ & $0.7 \%$ & $26 \%$ \\
\hline 1965 & $86.8 \%$ & $10.3 \%$ & $0.6 \%$ & $2.2 \%$ \\
\hline 1966 & $86.6 \%$ & $10.2 \%$ & $0.7 \%$ & $2.5 \%$ \\
\hline 1967 & $85.3 \%$ & $10.9 \%$ & $0.8 \%$ & $29 \%$ \\
\hline 1968 & $84.5 \%$ & $12.2 \%$ & $0.8 \%$ & $25 \%$ \\
\hline 1969 & $825 \%$ & $13.8 \%$ & $0.8 \%$ & $29 \%$ \\
\hline 1970 & $81.5 \%$ & $14.8 \%$ & $0.9 \%$ & $28 \%$ \\
\hline 1971 & $79.6 \%$ & $16.1 \%$ & $1.4 \%$ & $2.9 \%$ \\
\hline 1972 & $77.9 \%$ & $17.2 \%$ & $1.7 \%$ & $3.1 \%$ \\
\hline 1973 & $75.3 \%$ & $18.7 \%$ & $20 \%$ & $4.0 \%$ \\
\hline 1974 & $72.5 \%$ & $20.8 \%$ & $25 \%$ & $4.2 \%$ \\
\hline 1975 & $72.1 \%$ & $21.1 \%$ & $25 \%$ & $4.2 \%$ \\
\hline 1976 & $70.2 \%$ & $23.1 \%$ & $28 \%$ & $3.9 \%$ \\
\hline 1977 & $70.6 \%$ & $227 \%$ & $3.1 \%$ & $3.7 \%$ \\
\hline 1978 & $70.9 \%$ & $22.8 \%$ & $3.2 \%$ & $3.2 \%$ \\
\hline 1979 & $71.4 \%$ & $21.8 \%$ & $3.3 \%$ & $3.5 \%$ \\
\hline 1980 & $722 \%$ & $20.7 \%$ & $3.1 \%$ & $4.0 \%$ \\
\hline $198 \mid$ & $72.8 \%$ & $20.0 \%$ & $28 \%$ & $4.5 \%$ \\
\hline 1982 & $73.7 \%$ & $18.9 \%$ & $25 \%$ & $4.8 \%$ \\
\hline 1983 & $74.2 \%$ & $18.1 \%$ & $24 \%$ & $5.2 \%$ \\
\hline 1984 & $75.4 \%$ & $17.4 \%$ & $2.4 \%$ & $4.9 \%$ \\
\hline 1985 & $75.9 \%$ & $17.1 \%$ & $22 \%$ & $4.8 \%$ \\
\hline 1986 & $75.9 \%$ & $17.2 \%$ & $23 \%$ & $4.6 \%$ \\
\hline 1987 & $76.3 \%$ & $17.0 \%$ & $2.1 \%$ & $4.6 \%$ \\
\hline 1988 & $76.3 \%$ & $17.0 \%$ & $21 \%$ & $4.6 \%$ \\
\hline 1989 & $76.1 \%$ & $17.0 \%$ & $2.1 \%$ & $4.8 \%$ \\
\hline 1990 & $76.3 \%$ & $16.6 \%$ & $21 \%$ & $5.0 \%$ \\
\hline 1991 & $76.2 \%$ & $17.1 \%$ & $20 \%$ & $4.7 \%$ \\
\hline 1992 & $75.9 \%$ & $17.6 \%$ & $1.9 \%$ & $4.6 \%$ \\
\hline 1993 & $73.1 \%$ & $19.7 \%$ & $20 \%$ & $5.2 \%$ \\
\hline
\end{tabular}

- Consumption figures for 1952 and for 1990 and later years are not available in physical units and are derived from percentage share data; other figures are reported directly.

$\dagger$ 1952-1979 consumption figures for natural gas are not available in physical units and are derived from percentage share data; other figures are reported directly.

I Figures are for net hydro generation (gross generation minus in-plant use). In-plant use for 1953-1956 and 1958-1964 is calculated at the reported 1952 in-plant consumption rate of $0.22 \%$ (see Table IV-14), which is high but may be more realistic than the historically low $0.14 \%$ reported in 1957. Reported in-plant consumption rates are for key plants only and are probably lower than the national averages, which are unavailable. Direct reports of primary electricity consumption are not available.

Source: China Energy Statistical Yearbook, various years; China Statistical Yearbook, various years. China Energy Annual Review, 1994. 
Table IV-1. Primary Energy Consumption, 1952-1993 (continued)

\section{Growth Rates (percent increase over previous year)}

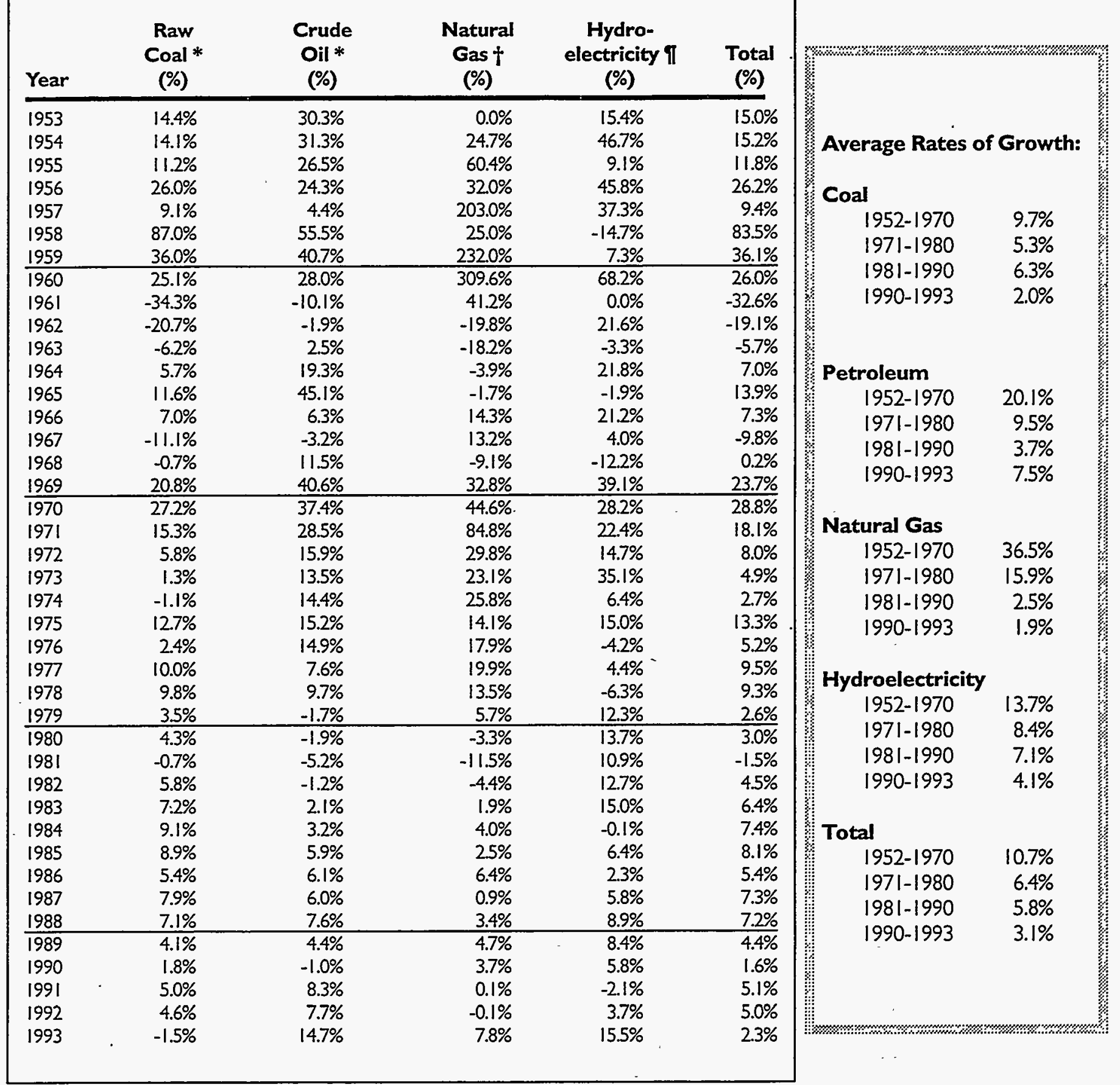

* Consumption figures for 1952 and for 1990 and later years are not available in physical units and are derived from percentage share data); other figures are reported directly.

$\dagger \quad$ 1952-1979 consumption figures for natural gas are not available in physical units and are derived from percentage share data; other figures are reported directly.

I Figures are for net hydro generation (gross generation minus in-plant use). In-plant use for 1953-1956 and 1958-1964 is calculated at the reported 1952 in-plant consumption rate of $0.22 \%$ (see Table IV-14), which is high but may be more realistic than the historically low $0.14 \%$ reported in 1957 . Reported in-plant consumption rates are for key plants only and are probably lower than the national averages, which are unavailable. Direct reports of primary electricity consumption are not available.

Source: China Energy Statistical Yearbook, various years; China Statistical Yearbook, various years. China Energy Annual Review, 1994. 


\section{Table IV-1. Primary Energy Consumption, 1952-1993 (continued)}

\section{Per Capita Consumption in Physical Units}

\begin{tabular}{|c|c|c|c|c|c|c|}
\hline Year & $\begin{array}{c}\text { Population } \\
\text { (millions) }\end{array}$ & $\begin{array}{c}\text { Raw } \\
\text { Coal * } \\
\text { (kg/cap) }\end{array}$ & $\begin{array}{c}\text { Crude } \\
\text { Oil * } \\
\text { (kg/cap) }\end{array}$ & $\begin{array}{c}\text { Natural } \\
\text { Gas } \uparrow \\
\text { (cubic m/cap) }\end{array}$ & $\begin{array}{c}\text { Hydro- } \\
\text { electricity } I \\
\text { (kWh/cap) }\end{array}$ & $\begin{array}{c}\text { Total } \\
\text { (kgce/cap) }\end{array}$ \\
\hline 1952 & 574.82 & 109 & 1.9 & 0.01 & 2.3 & 81 \\
\hline 1953 & 587.96 & 122 & 24 & 0.01 & 2.5 & 91 \\
\hline 1954 & 602.66 & 135 & 3.1 & 0.02 & 3.6 & 103 \\
\hline 1955 & 614.65 & 148 & 3.9 & 0.02 & 3.9 & 113 \\
\hline 1956 & 628.28 & 182 & 4.7 & 0.03 & 5.6 & 139 \\
\hline 1957 & 646.53 & 193 & 4.8 & 0.09 & 7.4 & 148 \\
\hline 1958 & 659.94 & 353 & 7.3 & 0.11 & 6.2 & 266 \\
\hline 1959 & 672.07 & 472 & 10 & 0.37 & 6.5 & 355 \\
\hline 1960 & 662.07 & 600 & 13 & 1.5 & 11 & 454 \\
\hline 1961 & 658.59 & 396 & 12 & 22 & 11 & 307 \\
\hline 1962 & 672.95 & 307 & 11 & 1.7 & 13 & 243 \\
\hline 1963 & 691.72 & 280 & 11 & 1.4 & 13 & 223 \\
\hline 1964 & 704.99 & 291 & 13 & 1.3 & 15 & 234 \\
\hline 1965 & 725.38 & 315 & 19 & 1.2 & 14 & 259 \\
\hline 1966 & 745.42 & 328 & 19 & 1.4 & 17 & $27 I$ \\
\hline 1967 & 763.68 & 285 & 18 & 1.5 & 17 & 239 \\
\hline 1968 & 785.34 & 275 & 20 & 1.3 & 15 & 232 \\
\hline 1969 & 806.71 & 323 & 27 & 1.7 & 20 & 280 \\
\hline 1970 & 829.92 & 400 & 36 & 24 & 25 & $\overline{351}$ \\
\hline 1971 & 852.29 & 449 & 45 & 4.4 & 29 & 403 \\
\hline 1972 & 871.77 & 464 & 51 & 5.6 & 33 & 426 \\
\hline 1973 & 892.11 & 460 & 57 & 6.7 & 44 & 436 \\
\hline 1974 & 908.59 & 446 & 64 & 8.3 & 45 & 440 \\
\hline 1975 & 924.20 & 495 & 72 & 9.3 & 51 & 490 \\
\hline 1976 & 937.17 & 500 & 82 & 10.8 & 49 & 508 \\
\hline 1977 & 949.74 & 542 & 87 & 12.8 & 50 & 549 \\
\hline 1978 & 962.59 & 588 & 94 & 14.3 & 46 & 592 \\
\hline 1979 & 975.42 & 600 & 92 & 14.9 & 51 & 600 \\
\hline 1980 & 987.05 & 618 & 89 & 14.2 & 59 & 612 \\
\hline 1981 & $1,000.72$ & 605 & 83 & 12.4 & 65 & 594 \\
\hline 1982 & $1,016.54$ & 631 & 81 & 11.7 & 73 & 611 \\
\hline 1983 & $1,030.08$ & 667 & 81 & 11.8 & 84 & 642 \\
\hline 1984 & $1,043.57$ & 718 & 83 & 12.1 & 83 & 681 \\
\hline 1985 & $1,058.51$ & 771 & 87 & 122 & 87 & 725 \\
\hline 1986 & $1,075.07$ & 800 & 90 & 128 & 88 & 753 \\
\hline 1987 & $1,093.00$ & 849 & 94 & 127 & 91 & 794. \\
\hline 1988 & 1.110 .26 & 895 & 100 & 12.9 & .98 & 838 \\
\hline 1989 & $1,127.04$ & 918 & 103 & 13.3 & 105 & 862 \\
\hline 1990 & $1,143.33$ & 921 & 100 & 13.6 & 110 & $86 \dot{3}$ \\
\hline 1991 & $1,158.23$ & 955 & 107 & 13.5 & 107 & 895 \\
\hline 1992 & $1,171.71$ & 987 & 114 & 13.3 & 111 & 929 \\
\hline 1993 & $1,185.17$ & 961 & 129 & 14.2 & 128 & 939 \\
\hline
\end{tabular}

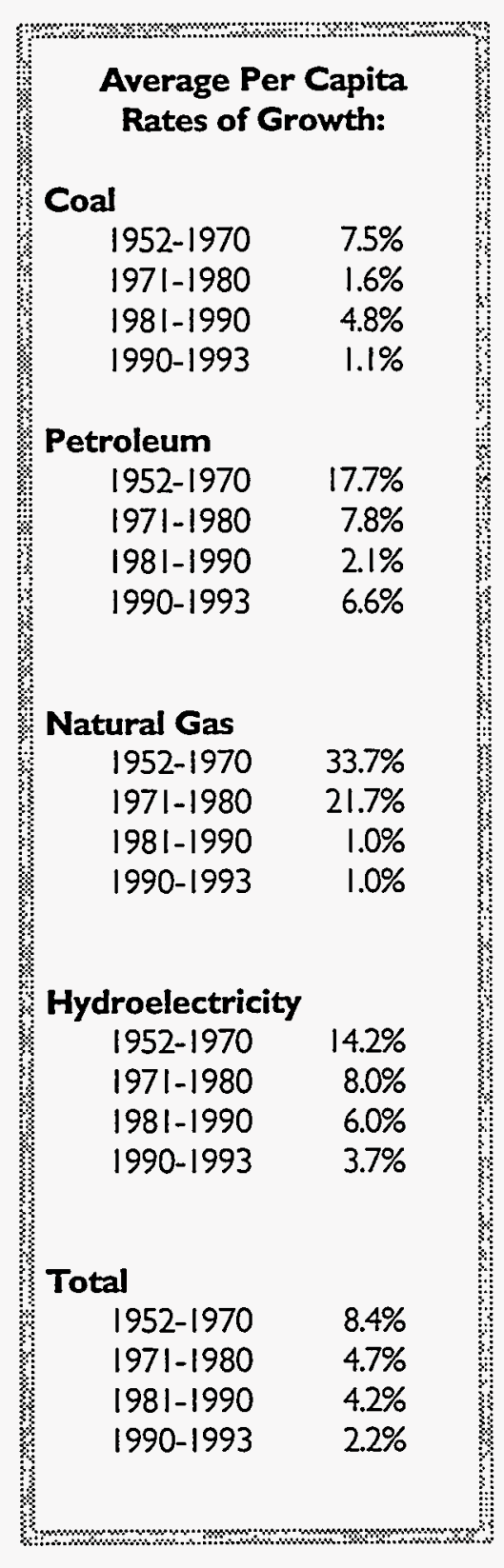

* Consumption figures for 1952 and for 1990 and later years are not available in physical units and are derived from percentage share data; other figures are reported directly.

$+1952-1979$ consumption figures for natural gas are not available in physical units and are derived from percentage share data; other figures are reported directly.

Figures are for net hydro generation (gross generation minus in-plant use). In-plant use for 1953-1956 and 1958-1964 is calculated at the reported 1952 in-plant consumption rate of $0.22 \%$ (see Table IV-14), which is high but may be more realistic than the historically low $0.14 \%$ reported in 1957. Reported in-plant consumption rates are for key plants only and are probably lower than the national averages, which are unavailable. Direct reports of primary electricity consumption are not available.

Source: China Energy Statistical Yearbook, various years; China Statistical Yearbook, various years. China Energy Annual Review, 1994. 
Table IV-2. Primary Energy Consumption: Commercial and Biomass Energy, 1979 and 1987; 1990 and 1992

\begin{tabular}{|c|c|c|c|c|c|c|c|c|c|c|}
\hline & \multicolumn{5}{|c|}{ Fossil Fuels * } & \multicolumn{5}{|c|}{ Biomass Fuels † } \\
\hline & Coal & Oil & $\begin{array}{c}\text { Natural } \\
\text { Gas }\end{array}$ & $\begin{array}{l}\text { Hydro- } \\
\text { electricity }\end{array}$ & Subtotal & $\begin{array}{l}\text { Crop } \\
\text { Stalk }\end{array}$ & $\begin{array}{l}\text { Dung } \\
\text { Cake }\end{array}$ & Firewood & Subtotal & Total \\
\hline \multicolumn{11}{|c|}{ Energy Consumption (Mtce) } \\
\hline 1979 & 418 & 128 & 19 & 20 & 585 & 114 & 6 & 104 & 224 & 809 \\
\hline 1987 & 663 & 147 & 18 & 40 & 869 & 130 & 3 & 133 & 266 & 1,135 \\
\hline 1990 & 752 & 164 & 21 & 50 & 987 & 132 & - & 131 & 263 & 1,250 \\
\hline 1992 & 826 & 191 & 21 & 50 & 1,092 & 136 & - & 110 & 246 & 1,338 \\
\hline \multicolumn{6}{|c|}{ Percent of Commercial Energy Consumption } & \multicolumn{4}{|c|}{ Percent of Biomass Energy Consumption } & \\
\hline 1979 & $71 \%$ & $22 \%$ & $3 \%$ & $3 \%$ & $100 \%$ & $51 \%$ & $3 \%$ & $46 \%$ & $100 \%$ & $100 \%$ \\
\hline 1987 & $76 \%$ & $17 \%$ & $2 \%$ & $5 \%$ & $100 \%$ & $49 \%$ & $1 \%$ & $50 \%$ & $100 \%$ & $100 \%$ \\
\hline 1990 & $76 \%$ & $.17 \%$ & $2 \%$ & $5 \%$ & $100 \%$ & $50 \%$ & - & $50 \%$ & $100 \%$ & $100 \%$ \\
\hline 1992 & $76 \%$ & $17 \%$ & $2 \%$ & $5 \%$ & $100 \%$ & $55 \%$ & - & $45 \%$ & $100 \%$ & $100 \%$ \\
\hline \multicolumn{6}{|c|}{ Percent of Totol Energy Consumption } & & & & & \\
\hline 1979 & $52 \%$ & $16 \%$ & $2 \%$ & $2 \%$ & $72 \%$ & $14 \%$ & $1 \%$ & $13 \%$ & $28 \%$ & $100 \%$ \\
\hline 1987 & $58 \%$ & $13 \%$ & $2 \%$ & $4 \%$ & $77 \%$ & $11 \%$ & $0 \%$ & $12 \%$ & $23 \%$ & $100 \%$ \\
\hline 1990 & $60 \%$ & $13 \%$ & $2 \%$ & $4 \%$ & $79 \%$ & $11 \%$ & $0 \%$ & $11 \%$ & $21 \%$ & $100 \%$ \\
\hline 1992 & $62 \%$ & $14 \%$ & $2 \%$ & $4 \%$ & $82 \%$ & $10 \%$ & $0 \%$ & $8 \%$ & $18 \%$ & $100 \%$ \\
\hline
\end{tabular}

* Fossil fuels are counted in their primary forms. Hydropower is converted as I $\mathrm{kWh}=0.404 \mathrm{kgce}$.

$\dagger$ Biomass figures are for rural household consumption. Since sources vary, official estimates of biomass use for various years may not be comparable.

Sources: China Energy Statistical Yearbook, various years; National Rural Energy Planning, 1990; China Energy Annual Review, 1994 ; Energy in China, 1992 
Figure IV-3. Primary Energy Consumption:

Commercial and Biomass Energy

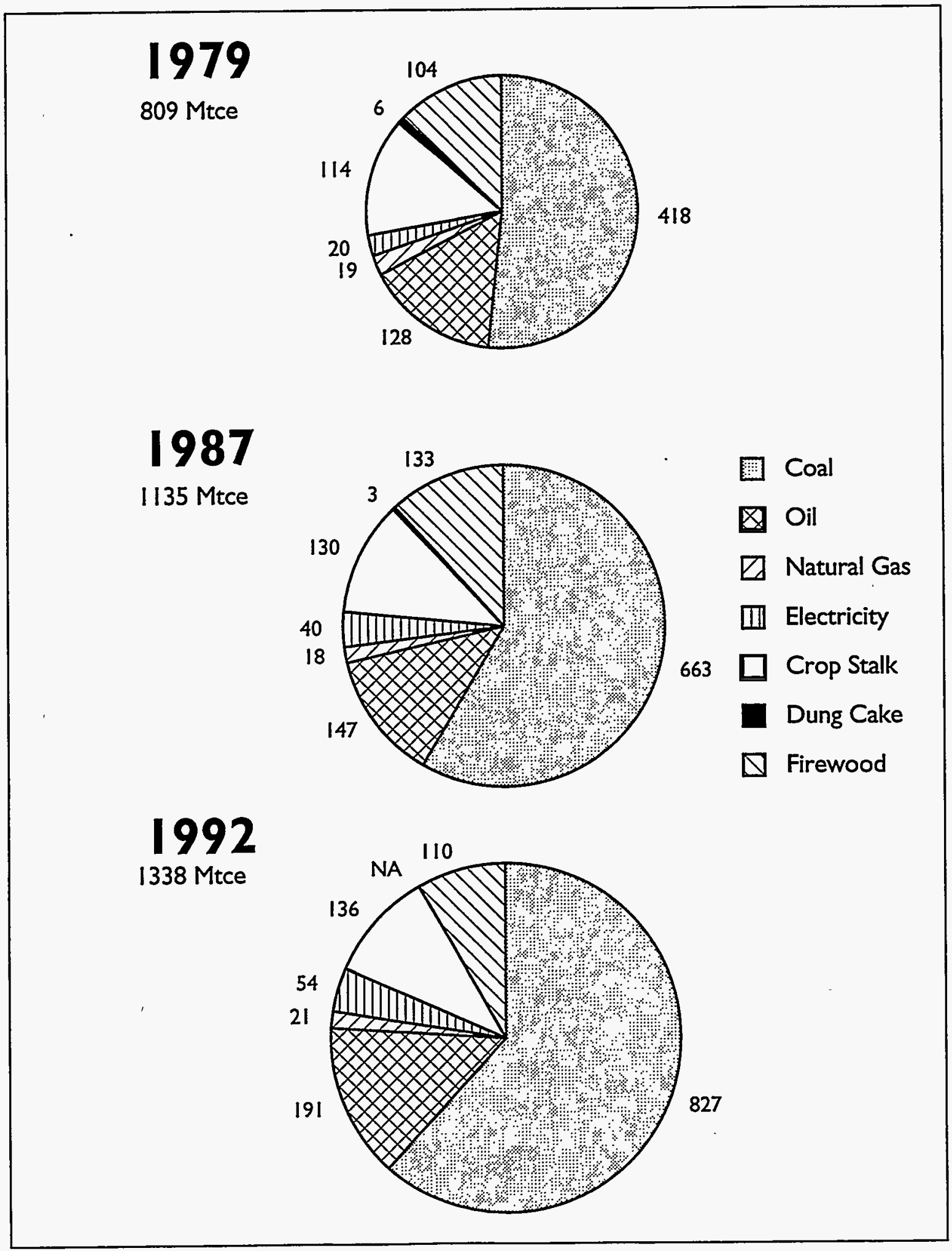


Table IV-3. Actual Primary Energy Consumption and Projected Energy Consumption at Frozen 1977 Intensity, 1952-1993 *

\begin{tabular}{|c|c|c|c|c|c|}
\hline Year & $\begin{array}{l}\text { National } \\
\text { Income } \\
\text { (billion } \\
1980 \text { yuan) }\end{array}$ & $\begin{array}{c}\text { Energy } \\
\text { Consumption } \\
\text { (Mtce) }\end{array}$ & $\begin{array}{c}\text { Energy } \\
\text { Intensity } \\
\text { (Mtce/billion } \\
1980 \text { yuan NI) }\end{array}$ & $\begin{array}{c}\text { Consumption } \\
\text { at } 1977 \\
\text { Intensity }\end{array}$ & Difference \\
\hline 1952 & 100 & 47 & 0.47 & - & - \\
\hline 1953 & 108 & 54 & 0.50 & - & - \\
\hline 1954 & 112 & 63 & 0.56 & - & - \\
\hline 1955 & 120 & 70 & 0.58 & - & - \\
\hline 1956 & 133 & 88 & 0.66 & - & - \\
\hline 1957 & 138 & 96 & 0.70 & - & - \\
\hline 1958 & 156 & 176 & 1.13 & - & - \\
\hline 1959 & 155 & 239 & 1.55 & - & $=$ \\
\hline 1960 & 145 & 301 & 2.08 & - & - \\
\hline 1961 & 113 & 204 & 1.80 & - & - \\
\hline 1962 & 111 & 165 & 1.49 & - & - \\
\hline 1963 & 123 & 155 & 1.26 & - & - \\
\hline 1964 & 142 & 166 & 1.17 & - & - \\
\hline 1965 & 162 & 189 & 1.17 & - & - \\
\hline 1966 & 184 & 203 & 1.10 & - & - \\
\hline 1967 & 176 & 183 & 1.04 & - & - \\
\hline 1968 & 167 & 183 & 1.10 & - & - \\
\hline 1969 & 188 & 227 & 1.21 & - & $=$ \\
\hline 1970 & 221 & 292 & 1.32 & - & - \\
\hline 1971 & 235 & 345 & 1.47 & - & - \\
\hline 1972 & 240 & 373 & 1.55 & - & - \\
\hline 1973 & 260 & 391 & 1.51 & - & - \\
\hline 1974 & 264 & 401 & 1.52 & - & - \\
\hline 1975 & 284 & 455 & 1.60 & - & - \\
\hline 1976 & 277 & 478 & 1.73 & - & - \\
\hline 1977 & 294 & 524 & 1.78 & 524 & 0 \\
\hline 1978 & 326 & 571 & 1.75 & 581 & 9 \\
\hline 1979 & 349 & 586 & 1.68 & 620 & 35 \\
\hline 1980 & 369 & 604 & 1.64 & 656 & 53 \\
\hline 1981 & 387 & 595 & 1.54 & 688 & 94 \\
\hline 1982 & 418 & 621 & 1.48 & 745 & 124 \\
\hline 1983 & 460 & 661 & 1.44 & 819 & 158 \\
\hline 1984 & 523 & 710 & 1.36 & 931 & 220 \\
\hline 1985 & 593 & 768 & 1.29 & 1,056 & 288 \\
\hline 1986 & 639 & 809 & 1.27 & 1,138 & 328 \\
\hline 1987 & 704 & 868 & 1.23 & 1,254 & 385. \\
\hline 1988 & 784 & 930 & 1.19 & 1,395 & 465 \\
\hline 1989 & 812 & 971 & 1.20 & 1,446 & 475 \\
\hline 1990 & 854 & 986 & 1.15 & 1,520 & 534 \\
\hline 1991 & 928 & 1,036 & 1.12 & 1,652 & 616 \\
\hline 1992 & 1,075 & 1,088 & 1.01 & 1,914 & 825 \\
\hline 1993 & 1,242 & 1,113 & 0.90 & 2,211 & 1,098 \\
\hline
\end{tabular}

* Energy intensity is here defined as total primary energy consumption (in Mtce) per unit of GDP. Projections of primary energy consumption at 1977 intensity for 1978-1989 are obtained by multiplying actual GDP for those years by 1977 intensity.

Source: China Statistical Yearbook, various years; China Energy Annual Review, 1994. 
Figure IV-4. Energy Intensity of the Chinese Economy

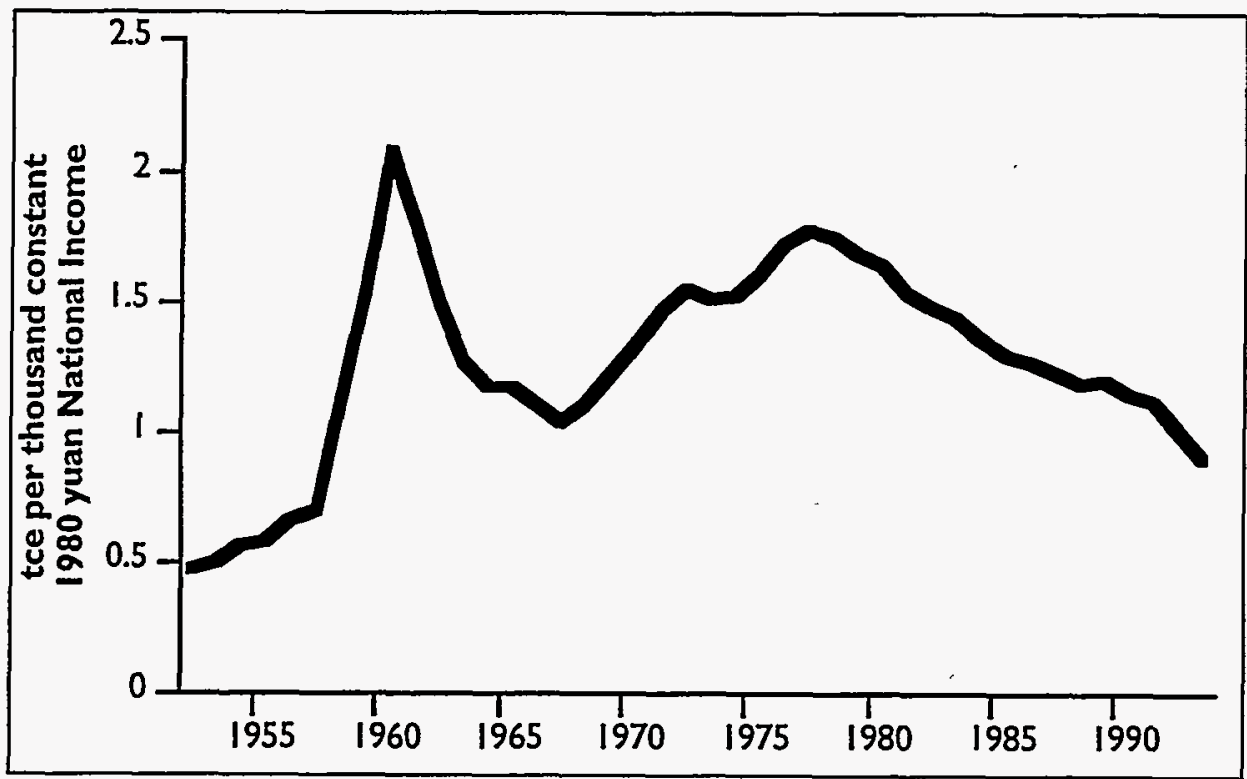

Figure IV-5. Primary Commercial Energy Consumption: Actual Use and Use Predicted by 1977 Energy Intensity

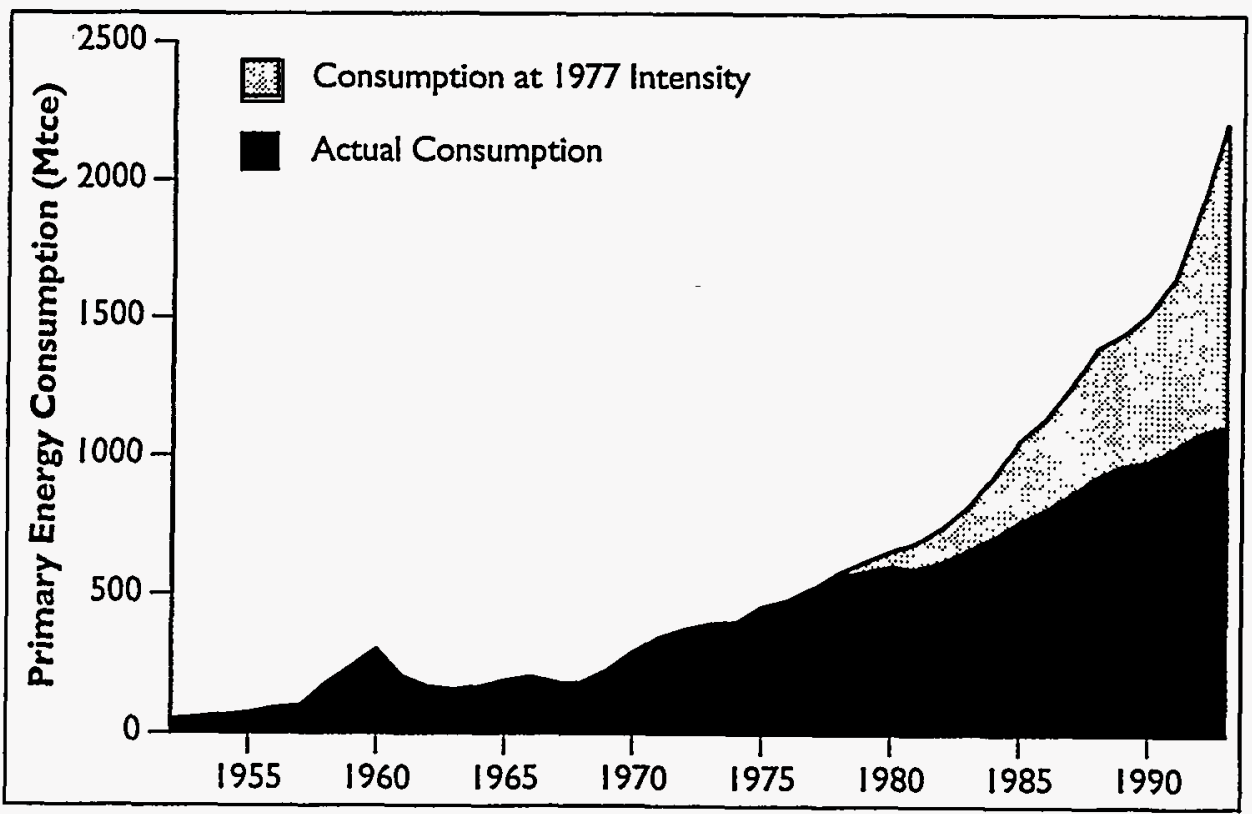


Table IV-4. Primary Commercial Energy Consumption by Province and Energy Source, 1990

\begin{tabular}{|c|c|c|c|c|c|}
\hline $\begin{array}{c}\text { Planning } \\
\text { Region }\end{array}$ & Province & $\begin{array}{c}\text { Total } \\
\text { Primary } \\
\text { Energy } \\
\text { Consumption * } \\
\text { (Mtce) }\end{array}$ & $\begin{array}{c}\text { Coal } \\
\text { Consumption } \\
\text { (Mtons) }\end{array}$ & $\begin{array}{c}\text { Oil } \\
\text { Consumption } \dagger \\
\text { (Mtons) }\end{array}$ & $\begin{array}{c}\text { Electricity } \\
\text { Consumption } ¥ \\
\text { (TWh) }\end{array}$ \\
\hline \multirow[t]{5}{*}{ North } & Beijing & 27.1 & 24.1 & 5.5 & 17.4 \\
\hline & Tianjin & 20.7 & 17.9 & 4.4 & 12.4 \\
\hline & Hebei & 61.2 & 78.8 & 3.8 & 35.4 \\
\hline & Shanxi & 47.1 & 76.6 & 1.4 & 25.5 \\
\hline & Iner Mongolia & 24.2 & 39.5 & 1.0 & 12.2 \\
\hline \multirow[t]{3}{*}{ Northeost } & Liaoning & 78.6 & 82.5 & 12.2 & 46.2 \\
\hline & jilin & 35.2 & 40.1 & 3.7 & 19.1 \\
\hline & Heilongilang & 52.9 & 65.2 & 7.5 & 29.6 \\
\hline \multirow[t]{7}{*}{$\overline{\text { Eost }}$} & Shanghai & 31.8 & 27.4 & 8.0 & 26.5 \\
\hline & liangsu & 55.1 & 62.2 & 7.0 & 41.2 \\
\hline & Zhejiang & 25.8 & 24.9 & 3.2 & 23.0 \\
\hline & Anhui & 27.6 & 34.3 & 2.3 & 18.6 \\
\hline & Fujian & 14.5 & 13.1 & 1.2 & 13.7 \\
\hline & Jiangxi & 17.3 & 22.7 & 1.3 & 12.8 \\
\hline & Shandong & 68.3 & 72.6 & 10.4 & 44.9 \\
\hline \multirow{6}{*}{ South-Centrol } & Henan & 52.1 & 61.0 & 3.3 & 33.8 \\
\hline & Hubei & 40.0 & 33.4 & 5.4 & 28.1 \\
\hline & Hunan & 38.2 & 39.6 & 2.7 & 22.6 \\
\hline & Guangdong & 40.7 & 29.9 & 10.5 & 35.9 \\
\hline & Guangxi & 13.1 & 15.6 & 1.0 & 126 \\
\hline & Hainan & 1.2 & 0.7 & 0.2 & 1.4 \\
\hline \multirow[t]{4}{*}{ Southwest } & Sichuan & 63.5 & 66.5 & 1.8 & 35.0 \\
\hline & Guizhou & 21.3 & 27.1 & 0.8 & 10.3 \\
\hline & Yunnan & 19.6 & 21.9 & 1.0 & 12.5 \\
\hline & Xizang & - & - & - & \\
\hline \multirow{5}{*}{ Northwest } & Shaanxi & 22.4 & 27.3 & 1.3 & 17.0 \\
\hline & Gansu & 21.8 & 18.6 & 2.5 & 17.8 \\
\hline & Qinghai & 5.1 & 4.7 & 0.5 & 4.2 \\
\hline & Ningxia & 7.1 & 8.9 & 0.5 & 5.5 \\
\hline & Xinjiang & 20.7 & 18.4 & 3.4 & 7.0 \\
\hline National Total & & 987.0 & $1,055.2$ & 114.9 & 623.0 \\
\hline Balance $\pi$ & & 32.9 & -0.3 & 7.1 & 0.8 \\
\hline
\end{tabular}

* Includes coal, oil, natural gas, and hydroelectricity.

$\dagger$ Includes crude oil and petroleum products.

Includes electricity from both hydro and thermal generation

Because of differences in the coverage of statistics and conversions to standard coal, the sum of local statistics does not equal the national total

Source: China Energy Statistical Yearbook, 1991. 


\section{Table IV-5. Per Capita Primary Commercial Energy Consumption by Province and Energy Source, 1990}

\begin{tabular}{|c|c|c|c|c|c|c|}
\hline $\begin{array}{l}\text { Planning } \\
\text { Region }\end{array}$ & Province & $\begin{array}{c}1990 \\
\text { Population } \\
\text { (millions) }\end{array}$ & $\begin{array}{c}\text { Per Capita } \\
\text { Primary } \\
\text { Energy } \\
\text { Consumption * } \\
\text { (tce/yr) }\end{array}$ & $\begin{array}{c}\text { Per Capita } \\
\text { Coal } \\
\text { Consumption } \\
(t / y r)\end{array}$ & $\begin{array}{c}\text { Per Capita } \\
\text { Oil } \\
\text { Consumption } \\
(t / y r)\end{array}$ & $\begin{array}{c}\text { Per Capita } \\
\text { Electricity } \\
\text { Consumption I } \\
\text { (MWh/yr) }\end{array}$ \\
\hline \multirow{5}{*}{ North } & Beijing & 10.86 & 250 & 2.22 & 0.50 & 1.60 \\
\hline & Tianjin & 8.84 & 2.35 & 2.02 & 0.49 & 1.40 \\
\hline & Hebei & 61.59 & 0.99 & 1.28 & 0.06 & 0.57 \\
\hline & Shanxi & 28.99 & 1.63 & 2.64 & 0.05 & 0.88 \\
\hline & Inner Mongolia & 21.63 & 1.12 & 1.83 & 0.04 & 0.56 \\
\hline \multirow[t]{3}{*}{ Northeost } & Liaoning & 39.67 & 1.98 & 2.08 & 0.31 & 1.16 \\
\hline & jilin & 24.83 & 1.42 & 1.61 & 0.15 & 0.77 \\
\hline & Heilongilang & 35.43 & 1.49 & 1.84 & 0.21 & 0.84 \\
\hline \multirow[t]{7}{*}{ Eost } & Shanghai & 13.37 & 238 & 2.05 & 0.60 & 1.98 \\
\hline & Jiangsu & 67.67 & 0.81 & 0.92 & 0.10 & 0.61 \\
\hline & Zhejiang & 41.68 & 0.62 & 0.60 & 0.08 & 0.55 \\
\hline & Anhui & 56.75 & 0.49 & 0.60 & 0.04 & 0.33 \\
\hline & Fujian & 30.37 & 0.48 & 0.43 & 0.04 & 0.45 \\
\hline & jiangxi & 38.10 & 0.45 & 0.60 & 0.03 & 0.34 \\
\hline & Shandong & 84.93 & 0.80 & 0.85 & 0.12 & 0.53 \\
\hline \multirow[t]{6}{*}{ South-Centrol } & Henan & 86.49 & 0.60 & 0.71 & 0.04 & 0.39 \\
\hline & Hubei & 54.39 & 0.74 & 0.61 & 0.10 & 0.52 \\
\hline & Hunan & 61.28 & 0.62 & 0.65 & 0.04 & 0.37 \\
\hline & Guangdong & 63.46 & 0.64 & 0.47 & 0.17 & 0.57 \\
\hline & Guangxi & 4261 & 0.31 & 0.37 & 0.02 & 0.30 \\
\hline & Hainan & 6.63 & 0.18 & 0.11 & 0.04 & 0.21 \\
\hline \multirow[t]{4}{*}{ Southwest } & Sichuan & 108.04 & 0.59 & 0.62 & 0.02 & 0.32 \\
\hline & Guizhou & 32.68 & 0.65 & 0.83 & 0.03 & 0.32 \\
\hline & Yunnan & 37.31 & 0.53 & 0.59 & 0.03 & 0.34 \\
\hline & Xizang & 222 & - & - & - & - \\
\hline \multirow[t]{5}{*}{ Northwest } & Shaanxi & 33.16 & 0.68 & 0.82 & 0.04 & $\overline{0.51}$ \\
\hline & Gansu & 22.55 & 0.96 & 0.82 & 0.11 & 0.79 \\
\hline & Qinghai & 4.48 & 1.14 & 1.05 & 0.11 & 0.94 \\
\hline & Ningxia & 4.70 & 1.50 & 1.89 & 0.10 & 1.17 \\
\hline & Xinijang & 15.29 & 1.35 & 1.20 & 0.22 & 0.46 \\
\hline Notional Total & & $1,143.33$ & 0.86 & 0.92 & 0.10 & 0.54 \\
\hline
\end{tabular}

- Includes coal, oil, natural gas, and hydroelectricity.

$\dagger$ Includes crude oil and petroleum products.

Includes electricity from both hydro and thermal generation.

Source: China Energy Statistical Yearbook, 1991; China Statistical Yearbook, 1991. 

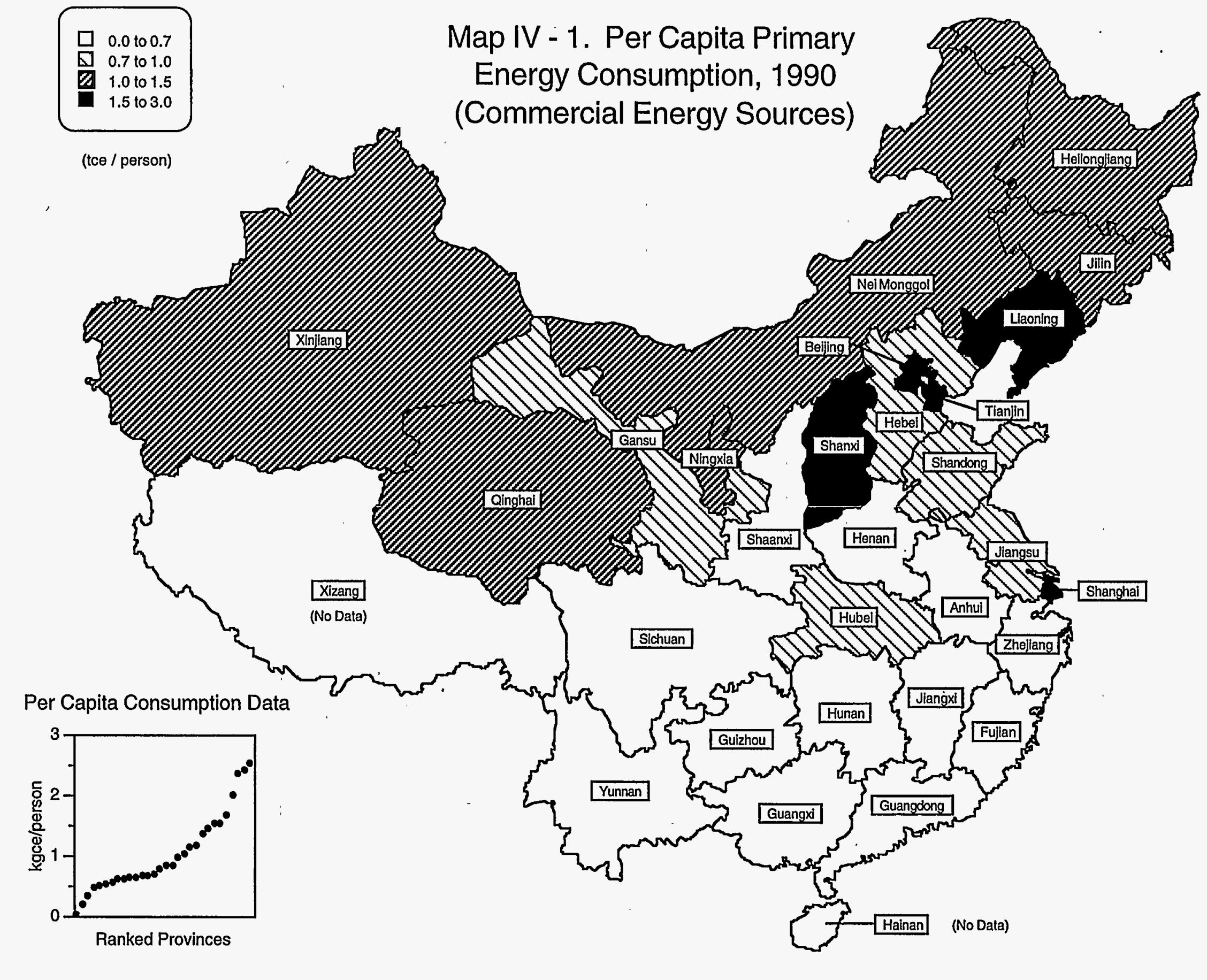

Map IV - 1. Per Capita Primary Energy Consumption, 1990

(Commercial Energy Sources) 


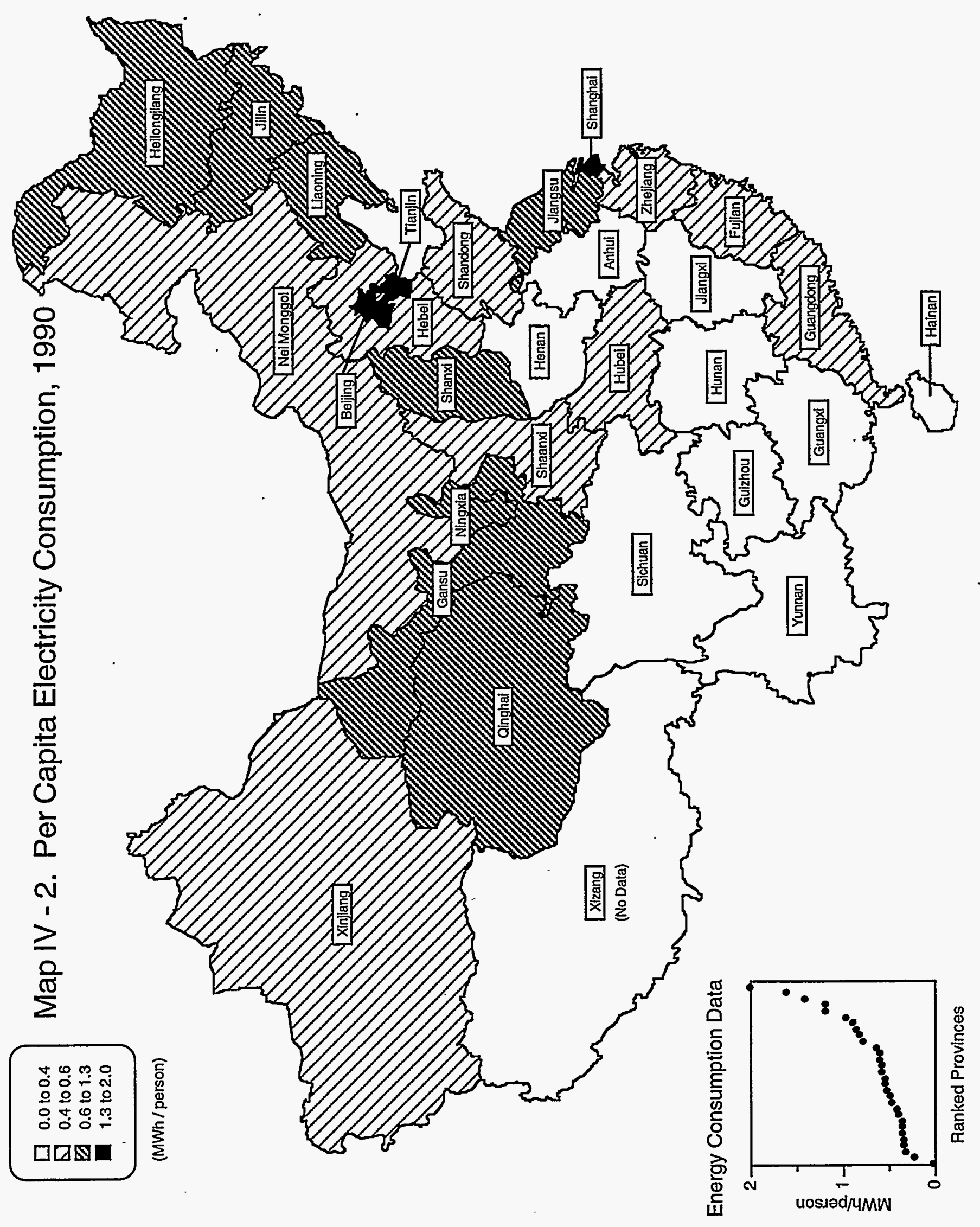


Table IV-6. Energy Intensity by Province, 1990 Primary Energy Consumption per Unit of National Income

\begin{tabular}{|c|c|c|c|c|}
\hline $\begin{array}{l}\text { Planning } \\
\text { Region }\end{array}$ & Province & $\begin{array}{c}\text { Primary } \\
\text { Energy } \\
\text { Consumption } \\
\text { (Mtce) }\end{array}$ & $\begin{array}{l}\text { National } \\
\text { Income } \\
\text { (billion } \\
\text { current yuan) }\end{array}$ & $\begin{array}{c}\text { NI Energy } \\
\text { Intensity } \\
\text { (kgce/thousand } \\
\text { current yuan) }\end{array}$ \\
\hline \multirow[t]{5}{*}{ North } & Beijing & 27.1 & 36.7 & 0.74 \\
\hline & Tranjin & 20.7 & 25.6 & 0.81 \\
\hline & Hebei & 61.2 & 70.2 & 0.87 \\
\hline & . Shanxi & 47.1 & 31.6 & 1.49 \\
\hline & Inner Mongolia & 24.2 & 23.3 & 1.04 \\
\hline \multirow[t]{3}{*}{ Northeast } & Liaoning & 78.6 & 78.4 & 1.00 \\
\hline & Jilin & 35.2 & 33.7 & 1.04 \\
\hline & Heilongilang & 52.9 & 56.4 & 0.94 \\
\hline \multirow[t]{7}{*}{$\overline{\text { East }}$} & Shanghai & 31.8 & 61.7 & 0.52 \\
\hline & Jiangsu & 55.1 & 113.8 & 0.48 \\
\hline & Zhejiang & 25.8 & 72.7 & 0.36 \\
\hline & Anhui & 27.6 & 51.9 & 0.53 \\
\hline & Fujian & 14.5 & 38.9 & 0.37 \\
\hline & Jianxi & 17.3 & 35.4 & 0.49 \\
\hline & Shandong & 68.3 & II 4.4 & 0.60 \\
\hline \multirow[t]{6}{*}{ South-Central } & Henan & 52.1 & 75.4 & 0.79 \\
\hline & Hubei & 40.0 & 66.1 & 0.68 \\
\hline & Hunan & 38.2 & 59.1 & 0.34 \\
\hline & Guangdong & 40.7 & 113.2 & 1.21 \\
\hline & Guangxi & 13.1 & 33.6 & 1.70 \\
\hline & Hainan & 1.2 & 7.7 & 0.16 \\
\hline \multirow[t]{4}{*}{ Southwest } & Sichuan & 63.5 & 79.9 & 0.79 \\
\hline & Guizhou & 21.3 & 17.9 & 1.19 \\
\hline & Yunnan & 19.6 & 24.0 & 0.82 \\
\hline & Xizang & - & 1.6 & $=$ \\
\hline \multirow{5}{*}{ Northwest } & Shaanxi & 22.4 & 24.0 & 0.94 \\
\hline & Gansu & 21.8 & 16.4 & 1.33 \\
\hline & Qinghai & 5.1 & 4.2 & 1.23 \\
\hline & Ningxia & 7.1 & 3.7 & 1.90 \\
\hline & Xinjiang & 20.7 & 15.4 & 1.34 \\
\hline \multicolumn{5}{|l|}{ National } \\
\hline Total/Averoge & & 987.0 & $1,438.4$ & 0.69 \\
\hline Balance * & & 32.9 & 51.5 & 0.64 \\
\hline
\end{tabular}

- Because of differences in the coverage of statistics and conversions to standard coal, the sum of local statistics does not equal the national total. Per capita figures in the balance row are calculated from the sums of provincial figures (i.e. national totals minus their respective balances).

Source: Chana Energy Statistical Yearbook, 1991; China Statistical Yearbook, 1992. 


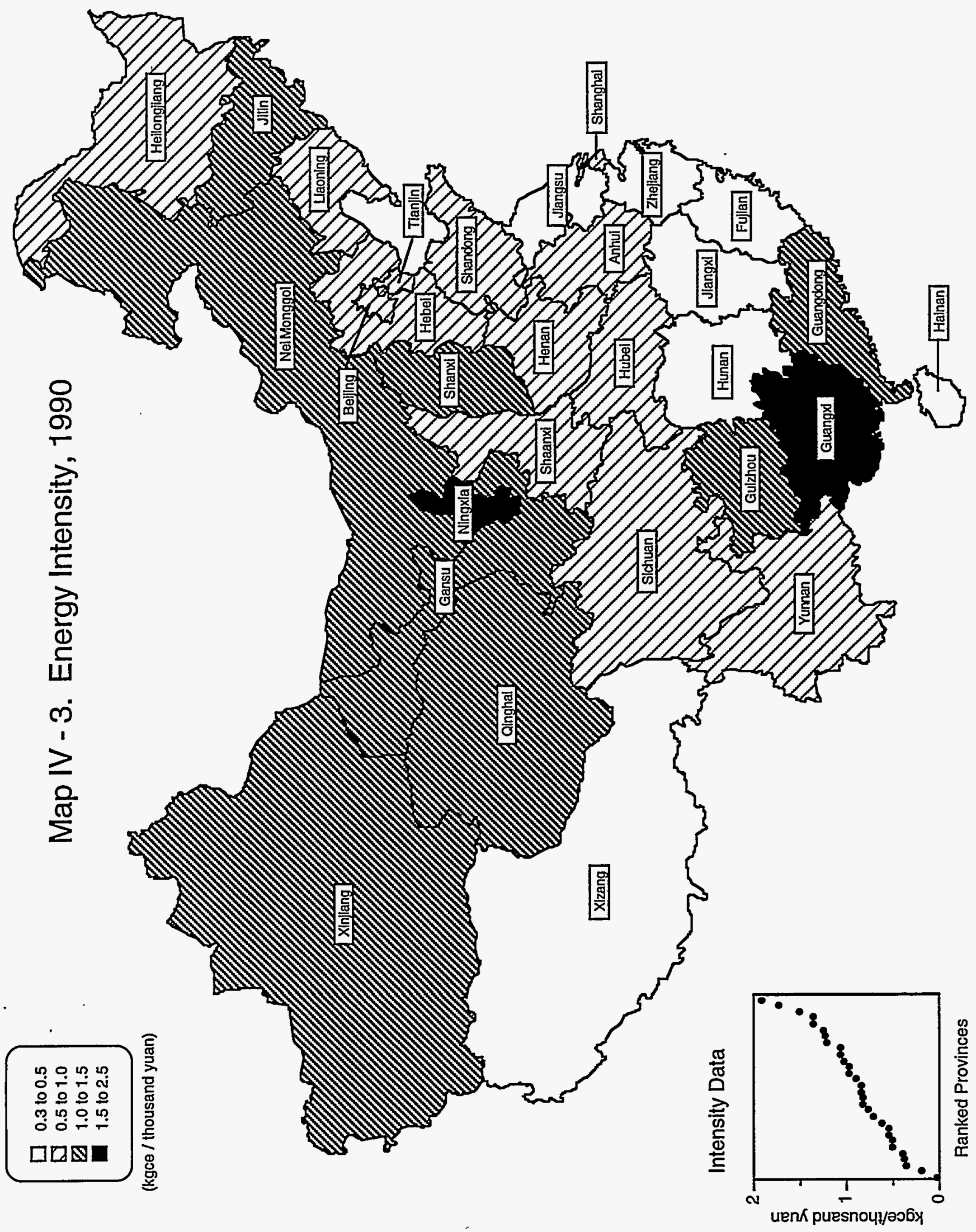


Sectoral Consumption 
Table IV-7. End-Use Energy Consumption by Sector, * 1980-1994

\begin{tabular}{|c|c|c|c|c|c|c|c|c|}
\hline \multicolumn{9}{|l|}{ I. Mtce } \\
\hline Year & Industrial † & Agricultural & Transportation & Residential & Commercial & Sum & Total & Balance \\
\hline 1980 & 378.59 & 31.0 & 39.6 & 91.8 & 19.6 & 560.6 & 566.7 & 6.1 \\
\hline 1981 & 366.58 & 31.1 & 39.7 & 96.4 & 20 & 553.8 & 559.9 & 6.1 \\
\hline 1982 & 385.56 & 31.7 & 41.7 & 99.2 & 21 & 579.2 & 585 & 5.8 \\
\hline 1983 & 412.52 & 326 & 44.1 & 104.5 & 23 & 616.7 & 623.2 & 6.5 \\
\hline 1984 & 442.65 & 34.6 & 47.5 & 112.9 & 25.1 & 6627 & 669.3 & 6.6 \\
\hline 1985 & 471.57 & 36.3 & 52.4 & $127.3^{\circ}$ & 27.6 & 715.1 & 722.9 & 7.8 \\
\hline 1986 & 500.17 & 37.8 & 56.6 & 130.9 & 28.8 & 754.3 & 760.4 & 6.1 \\
\hline 1987 & 539.44 & 40 & 59.8 & 138.1 & 31.1 & 808.3 & 814.6 & 6.2 \\
\hline 1988 & 576.01 & 41.9 & 63.9 & 148.8 & 35.3 & 866 & 874 & 8.1 \\
\hline 1989 & 605.13 & 42.4 & 66.6 & 149 & 37.3 & 900.5 & 908.9 & 8.4 \\
\hline 1990 & 612.14 & 43.2 & 67.4 & 150.3 & 40.4 & 913.4 & 921.7 & 8.3 \\
\hline 1991 & 641.43 & 45.4 & 73.2 & 152.3 & 43.5 & 955.8 & 963.9 & 8.1 \\
\hline 1992 & 685.86 & 44.7 & 79.2 & 146.7 & 46.7 & $1,003.2$ & $1,013.1$ & 9.9 \\
\hline 1993 & - & - & - & - & - & - & - & - \\
\hline 1994 & 777.0 & 46.3 & 83.4 & 150.8 & 61.7 & $1,119.1$ & $1,131.7$ & 12.6 \\
\hline
\end{tabular}

2. Shares of Total

\begin{tabular}{ccccccccc} 
Year & Industrial & Agricultural & Transportation & Residential & Commercial & Sum & Total & Balance \\
\hline 1980 & $66.8 \%$ & $5.5 \%$ & $7.0 \%$ & $16.2 \%$ & $3.5 \%$ & $98.9 \%$ & $100.0 \%$ & $1.1 \%$ \\
1981 & $65.5 \%$ & $5.6 \%$ & $7.1 \%$ & $17.2 \%$ & $3.6 \%$ & $98.9 \%$ & $100.0 \%$ & $1.1 \%$ \\
1982 & $65.9 \%$ & $5.4 \%$ & $7.1 \%$ & $17.0 \%$ & $3.6 \%$ & $99.0 \%$ & $100.0 \%$ & $1.0 \%$ \\
1983 & $66.2 \%$ & $5.2 \%$ & $7.1 \%$ & $16.8 \%$ & $3.7 \%$ & $99.0 \%$ & $100.0 \%$ & $1.0 \%$ \\
1984 & $66.1 \%$ & $5.2 \%$ & $7.1 \%$ & $16.9 \%$ & $3.7 \%$ & $99.0 \%$ & $100.0 \%$ & $1.0 \%$ \\
1985 & $65.2 \%$ & $5.0 \%$ & $7.3 \%$ & $17.6 \%$ & $3.8 \%$ & $98.9 \%$ & $100.0 \%$ & $1.1 \%$ \\
1986 & $65.8 \%$ & $5.0 \%$ & $7.4 \%$ & $17.2 \%$ & $3.8 \%$ & $99.2 \%$ & $100.0 \%$ & $0.8 \%$ \\
1987 & $66.2 \%$ & $4.9 \%$ & $7.3 \%$ & $17.0 \%$ & $3.8 \%$ & $99.2 \%$ & $100.0 \%$ & $0.8 \%$ \\
1988 & $65.9 \%$ & $4.8 \%$ & $7.3 \%$ & $17.0 \%$ & $4.0 \%$ & $99.1 \%$ & $100.0 \%$ & $0.9 \%$ \\
1989 & $66.6 \%$ & $4.7 \%$ & $7.3 \%$ & $16.4 \%$ & $4.1 \%$ & $99.1 \%$ & $100.0 \%$ & $0.9 \%$ \\
\hline 1990 & $66.4 \%$ & $4.7 \%$ & $7.3 \%$ & $16.3 \%$ & $4.4 \%$ & $99.1 \%$ & $100.0 \%$ & $0.9 \%$ \\
1991 & $66.5 \%$ & $4.7 \%$ & $7.6 \%$ & $15.8 \%$ & $4.5 \%$ & $99.2 \%$ & $100.0 \%$ & $0.8 \%$ \\
1992 & $67.7 \%$ & $4.4 \%$ & $7.8 \%$ & $14.5 \%$ & $4.6 \%$ & $99.0 \%$ & $100.0 \%$ & $1.0 \%$ \\
1993 & - & - & - & - & - & - & - & - \\
1994 & $68.7 \%$ & $4.1 \%$ & $7.4 \%$ & $13.3 \%$ & $5.5 \%$ & $98.9 \%$ & $100.0 \%$ & $1.1 \%$
\end{tabular}

* Figures given here differ from official data. We obtained these figures by summing sectoral consumption of individual energy sources using as presented in other tables. Adjustments, conversions, and rounding have led to discrepancies between sectoral sums and total end use data.

$\dagger$ Industrial sector includes construction, excludes utility sector energy use.

I Energy use for transportation is adjusted from official Chinese data (see transportation sector consumption table) Energy use in other sectors is adjusted accordingly.

Source: China Energy Statistical Yearbook, various years; China Statistical Yearbook, various years. 
Figure IV-6. Commercial Energy End Use by Sector

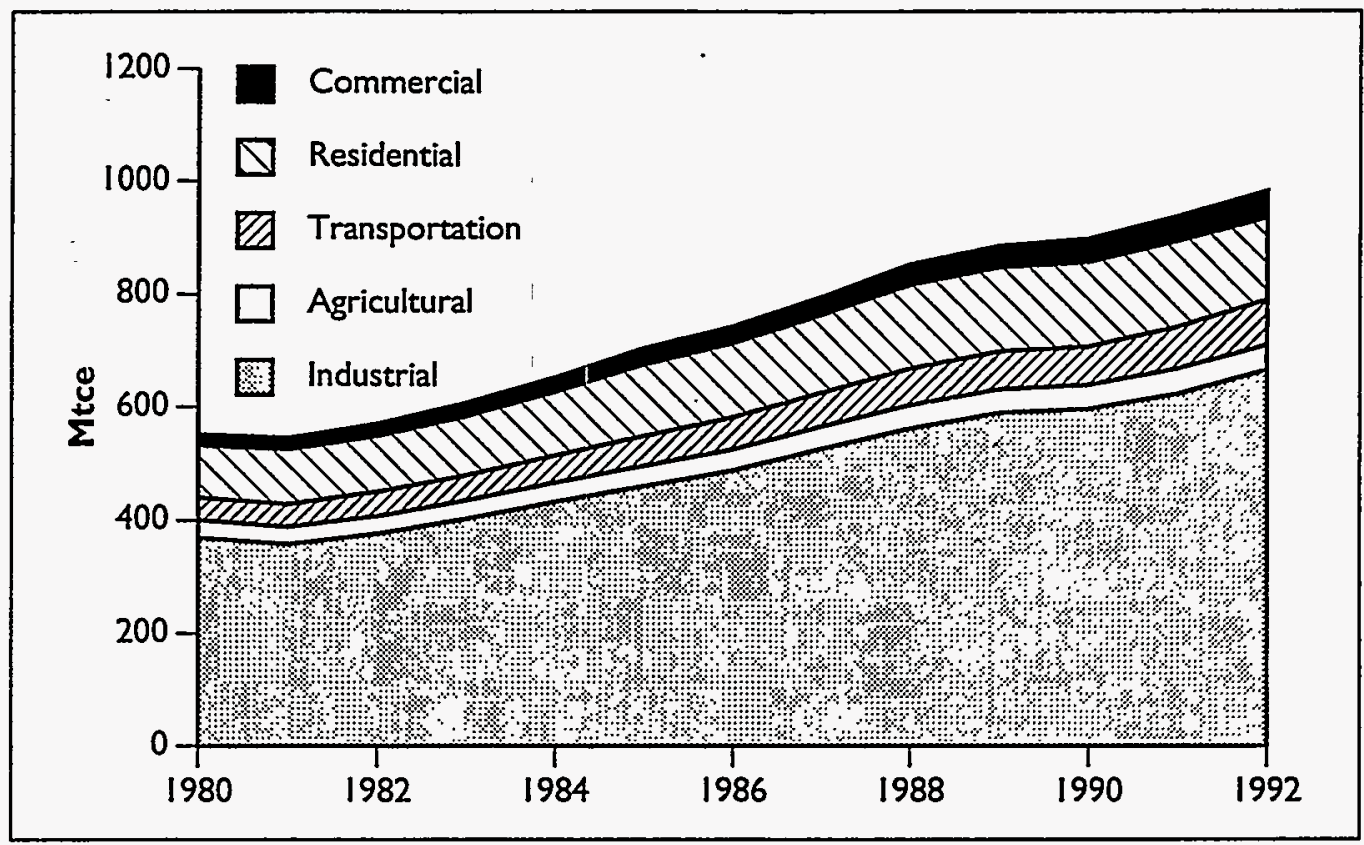

Figure IV-7. Sectoral Shares of Commercial Energy End Use

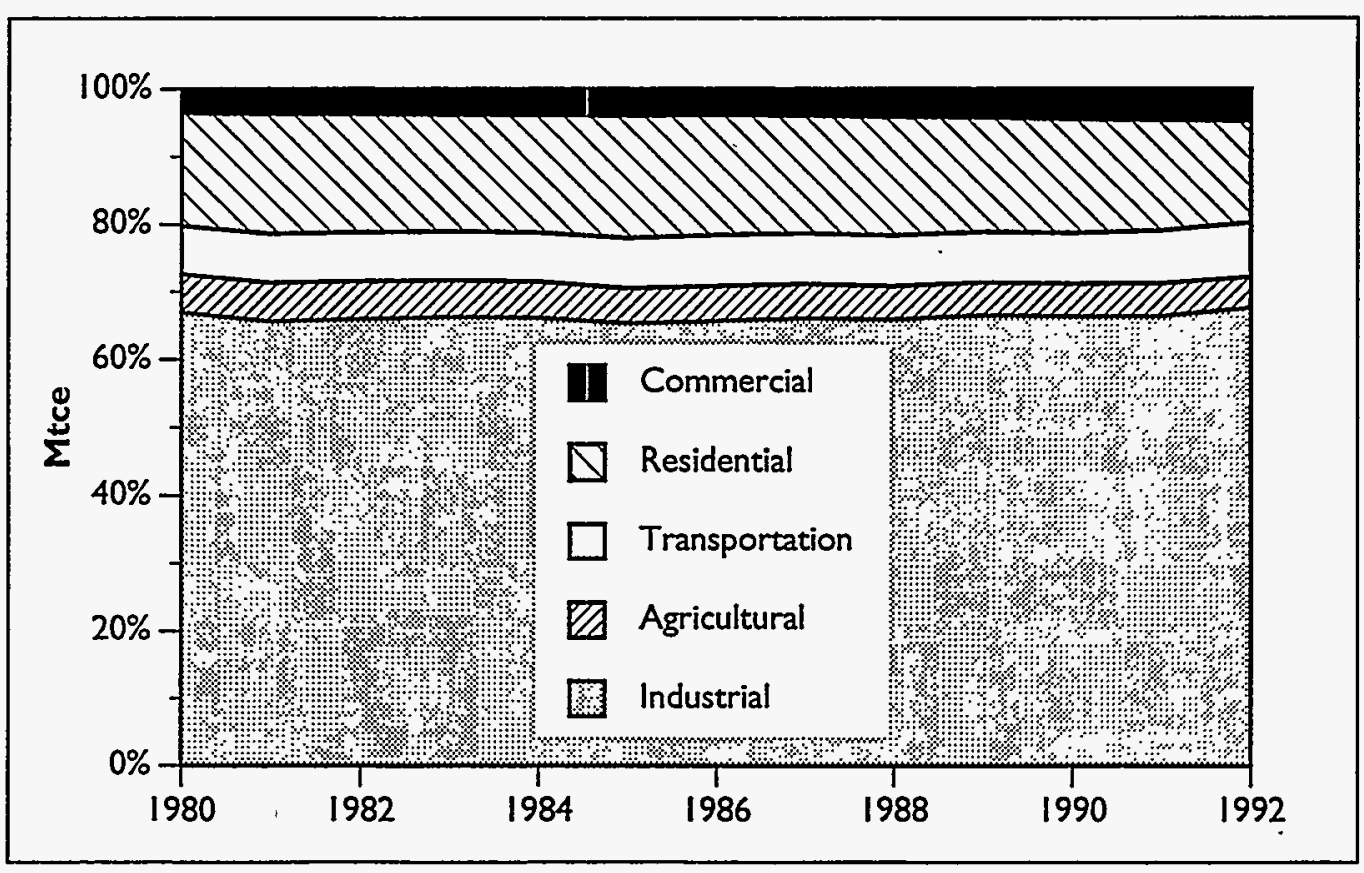


Table IV-8. Industrial End-Use Energy Consumption by Fuel * 1980-1992

\begin{tabular}{|c|c|c|c|c|c|c|c|c|}
\hline \multicolumn{9}{|l|}{ I. Mtce } \\
\hline Year & Coal $\uparrow$ & Coke & Electricity & Liquids I & $\begin{array}{c}\text { Natural } \\
\text { Gas }\end{array}$ & $\begin{array}{l}\text { Coal } \\
\text { Gas }\end{array}$ & $\begin{array}{c}\text { Delivered } \\
\text { Heat \& } \\
\text { Other } ¥\end{array}$ & Total \\
\hline 1980 & 158.08 & 43.72 & 84.13 & 51.95 & 18.27 & 5.58 & 16.86 & 378.59 \\
\hline 1981 & $|55.3|$ & 39.89 & 85.69 & 48.29 & 16.09 & 5.72 & 15.59 & 366.58 \\
\hline 1982 & 167.90 & 40.63 & 91.79 & 48.75 & 15.43 & 5.72 & 15.34 & 385.56 \\
\hline 1983 & 184.08 & 41.10 & 99.10 & 49.03 & 15.80 & 6.39 & 17.02 & 412.52 \\
\hline 1984 & 201.62 & 44.96 & 106.22 & 51.13 & 15.99 & 6.42 & 16.31 & 442.65 \\
\hline 1985 & 215.38 & 47.29 & 112.58 & 55.26 & 15.77 & 7.20 & 18.09 & 471.57 \\
\hline 1986 & 225.14 & 51.95 & 124.28 & 58.68 & 16.45 & 9.38 & 14.30 & 500.17 \\
\hline 1987 & 244.06 & 56.31 & 136.22 & 62.66 & 16.80 & 8.34 & 15.04 & 539.44 \\
\hline 1988 & 259.50 & 59.32 & 148.80 & 66.11 & 16.93 & 9.68 & 15.66 & 576.01 \\
\hline 1989 & 266.88 & 62.78 & 157.57 & 70.42 & 16.82 & 10.72 & 19.93 & 605.13 \\
\hline 1990 & 256.59 & 68.09 & 164.63 & 68.81 & 17.14 & 10.90 & 25.98 & 612.14 \\
\hline 1991 & 264.19 & 71.17 & 176.82 & 73.53 & 18.43 & - & 37.28 & 641.43 \\
\hline 1992 & 277.80 & 77.02 & 195.50 & 75.75 & 17.99 & - & 41.80 & 685.86 \\
\hline
\end{tabular}

\begin{tabular}{|c|c|c|c|c|c|c|c|c|}
\hline \multicolumn{9}{|c|}{ 2. Shares } \\
\hline Year & Coal t & Coke & Electricity & Liquids II & $\begin{array}{c}\text { Natural } \\
\text { Gas }\end{array}$ & $\begin{array}{l}\text { Coal } \\
\text { Gas }\end{array}$ & $\begin{array}{c}\text { Delivered } \\
\text { Heat \& } \\
\text { Other } ¥\end{array}$ & Total \\
\hline 1980 & $41.8 \%$ & $11.5 \%$ & $222 \%$ & $13.7 \%$ & $4.8 \%$ & $1.5 \%$ & $4.5 \%$ & $100.0 \%$ \\
\hline 1981 & $42.4 \%$ & $10.9 \%$ & $23.4 \%$ & $13.2 \%$ & $4.4 \%$ & $1.6 \%$ & $4.3 \%$ & $100.0 \%$ \\
\hline 1982 & $43.5 \%$ & $10.5 \%$ & $23.8 \%$ & $126 \%$ & $4.0 \%$ & $1.5 \%$ & $4.0 \%$ & $100.0 \%$ \\
\hline 1983 & $44.6 \%$ & $10.0 \%$ & $24.0 \%$ & $11.9 \%$ & $3.8 \%$ & $1.5 \%$ & $4.1 \%$ & $100.0 \%$ \\
\hline 1984 & $45.5 \%$ & $10.2 \%$ & $24.0 \%$ & $11.6 \%$ & $3.6 \%$ & $1.5 \%$ & $3.7 \%$ & $100.0 \%$ \\
\hline 1985 & $45.7 \%$ & $10.0 \%$ & $23.9 \%$ & $11.7 \%$ & $3.3 \%$ & $1.5 \%$ & $3.8 \%$ & $100.0 \%$ \\
\hline 1986 & $45.0 \%$ & $10.4 \%$ & $24.8 \%$ & $11.7 \%$ & $3.3 \%$ & $1.9 \%$ & $2.9 \%$ & $100.0 \%$ \\
\hline 1987 & $45.2 \%$ & $10.4 \%$ & $25.3 \%$ & $11.6 \%$ & $3.1 \%$ & $1.5 \%$ & $2.8 \%$ & $100.0 \%$ \\
\hline 1988 & $45.1 \%$ & $10.3 \%$ & $25.8 \%$ & $11.5 \%$ & $2.9 \%$ & $1.7 \%$ & $2.7 \%$ & $100.0 \%$ \\
\hline 1989 & $44.1 \%$ & $10.4 \%$ & $26.0 \%$ & $11.6 \%$ & $28 \%$ & $1.8 \%$ & $3.3 \%$ & $100.0 \%$ \\
\hline 1990 & $41.9 \%$ & $11.1 \%$ & $26.9 \%$ & $11.2 \%$ & $28 \%$ & $1.8 \%$ & $4.2 \%$ & $100.0 \%$ \\
\hline 1991 & $41.2 \%$ & $11.1 \%$ & $27.6 \%$ & $11.5 \%$ & $29 \%$ & - & $5.8 \%$ & $100.0 \%$ \\
\hline 1992 & $40.5 \%$ & $11.2 \%$ & $28.5 \%$ & $11.0 \%$ & $26 \%$ & - & $6.1 \%$ & $100.0 \%$ \\
\hline
\end{tabular}

- Includes construction, which is broken out as a separate sector in Chinese statistics. Excludes utility sector energy use.

$\dagger$ Coal includes uncorrected total of raw coal, washed coal, and middlings (conversion factor: $0.714 \mathrm{kgce} / \mathrm{kg}$ ).

Liquids include crude oil, fuel oil, kerosene, diesel, and LPG. Diesel use is adjusted to exclude estimated transportation use by industrial enterprises (see transportation energy consumption table for details).

* This category includes heat produced by cogeneration and dedicated heat plants and sold to the industrial, commercial, and residential sectors. Other products include refinery gas, LPG, coal gas (for years not covered in the coal gas column), and others.

Source: China Energy Statistical Yearbook, various years; China Statistical Yearbook, various years. 
Figure IV-8. Industrial Energy End Use by Energy Source

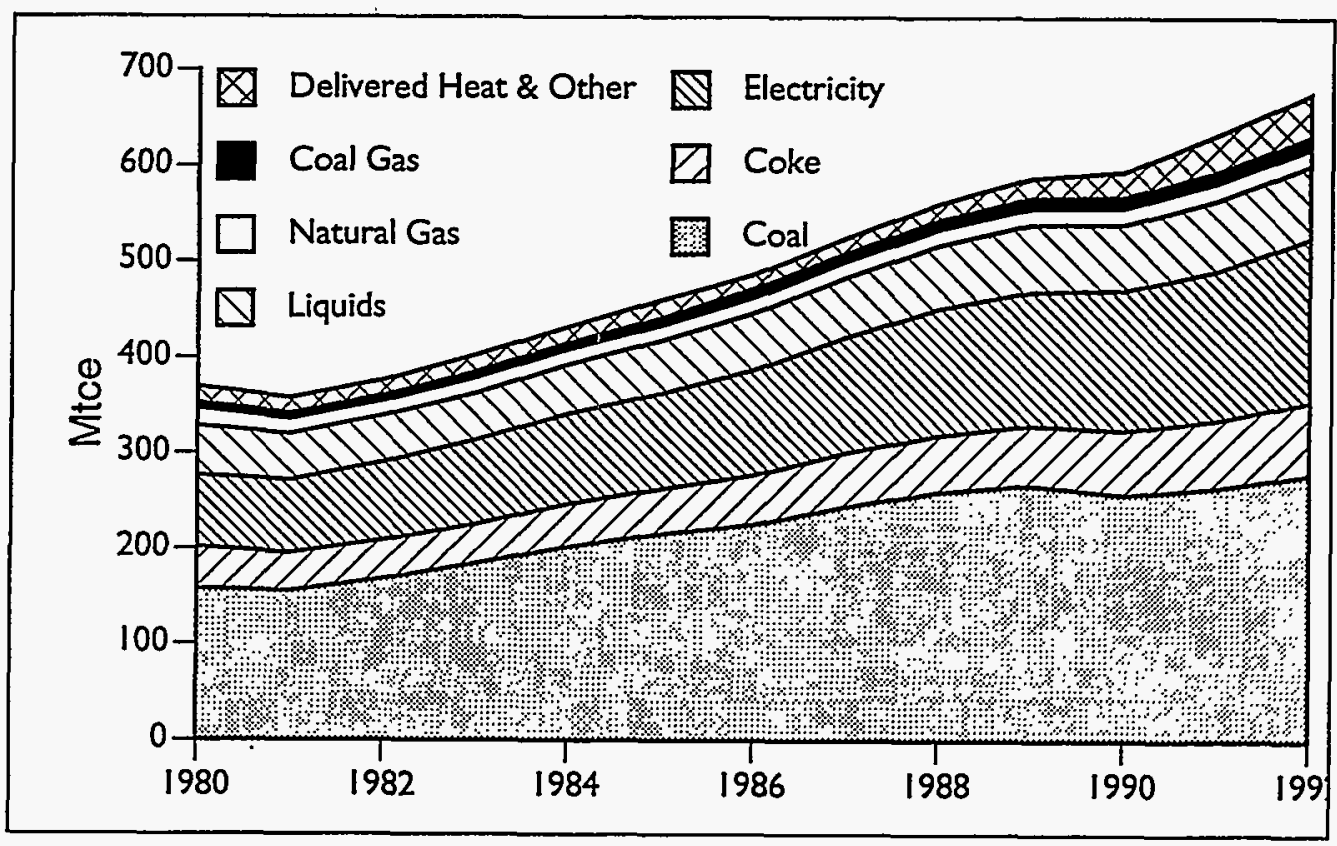


Table IV-9. Industrial Sector Energy End Use by Subsector and Energy Type, with Gross Output Value by Subsector, 1980-1992

\section{Industrial Sector Energy Consumption*}

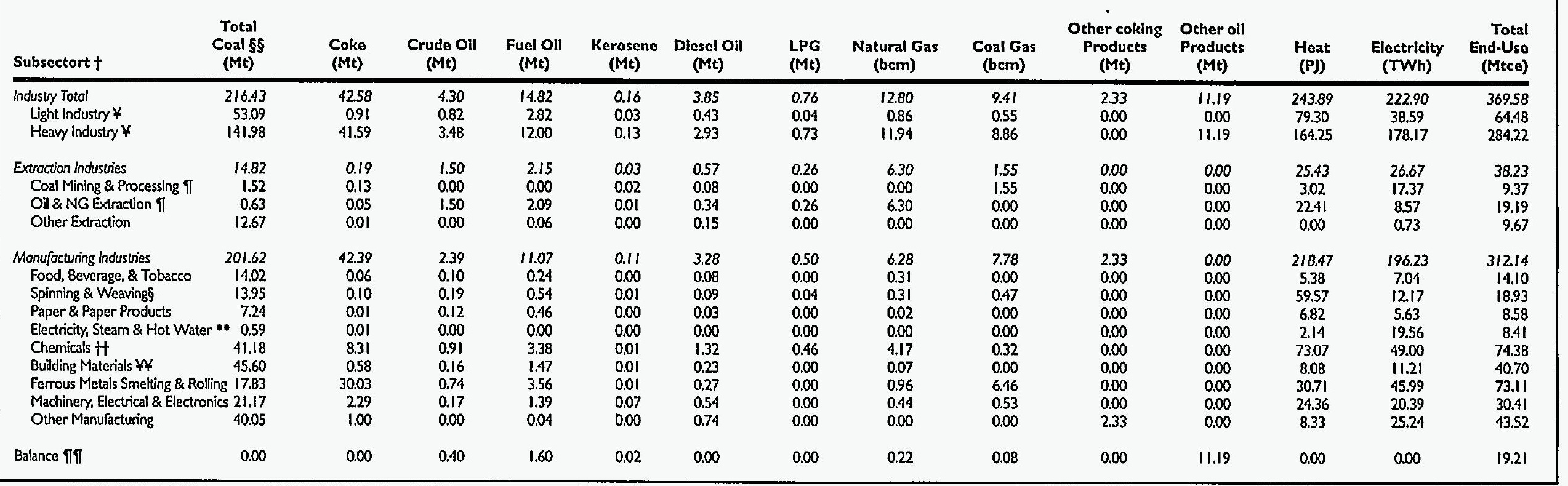

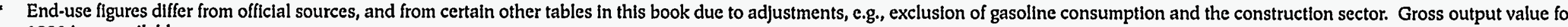
1980 is unavallable.

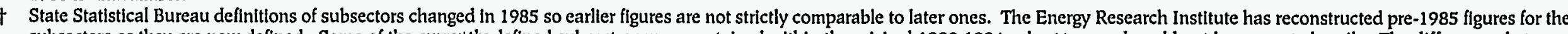

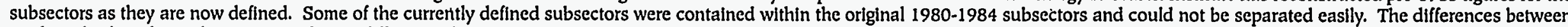

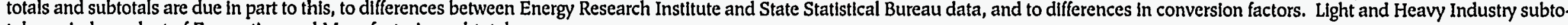
tals are independent of Excavation and Manufacturing subtotals.

Light and heavy industry subtotals are independent of subsectoral divisions.

1 The coal and oil \& natural gas subsectors may include the coal products and refining subsectors, which are listed separately for 1985-1988.

$\S$ The textiles subsector probably includes the chemical fibers subsector, which is listed separately for 1985-1988.

* Figures for the utilities sector (normally not counted as an industrial sector in energy accounts of other countries) do not include power generation inputs.

it Gross output value for the chemicals industry includes rubber products.

Gross output for the building materials industry includes raw materials mining.

II Total minus extraction and manufacturing subtotals.

$\S \S$ Unadjusted sum of raw and washed coal.

Source: Energy Research Instltute; China Energy Statistical Yearbook, various years; China Statistical Yearbook, various years. 
Table IV-9. Industrial Sector Energy End Use by Subsector and Energy Type, with Gross Output Value by Subsector, 1980-1992 (continued)

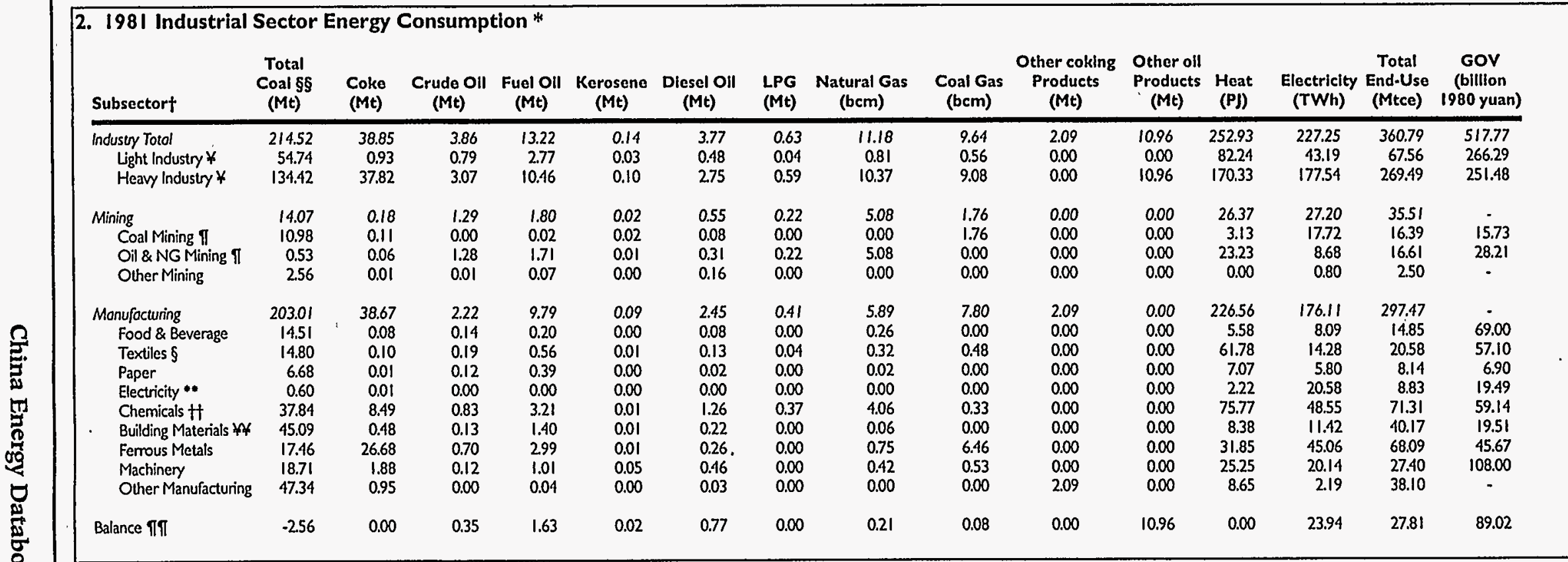

* End-use figures differ from official sources, and from certain other tables in this book due to adjustments, e.g., exclusion of gasoline consumption and the construction sector.

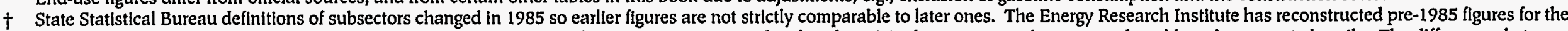

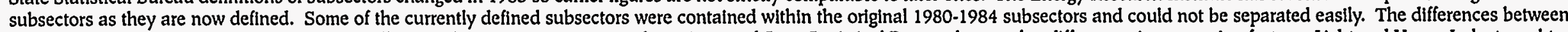

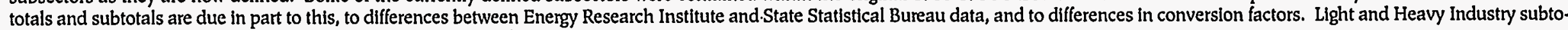
tals are independent of Excavation and Manufacturing subtotals.

Light and heavy industry subtotals are independent of subsectoral divisions.

I The coal and oil \& natural gas subsectors may include the coal products and refining subsectors, which are listed separately for $1985-1988$.

$\S$ The textiles subsector probably includes the chemical fibers subsector, which is listed separately for 1985-1988.

** Figures for the utilities sector (normally not counted as an industrfal sector in energy accounts of other countries) do not include power generation inputs.

H Gross output value for the chemicals industry includes rubber products.

Gross output for the building materials industry includes raw materials mining.

IT Total minus extraction and manufacturing subtotals.

$\S \S$ Unadjusted sum of raw and washed coal.

Source: Energy Research Institutè; China Energy Statistical Yearbook, various years; China Statistical Yearbook, various years. 


\section{1982 Industrial Sector Energy Consumption *}

\begin{tabular}{|c|c|c|c|c|c|c|c|c|c|c|c|c|c|c|c|}
\hline Subsector $\uparrow$ & $\begin{array}{l}\text { Total } \\
\text { Coal \$̧ } \\
\text { (Mt) }\end{array}$ & $\begin{array}{l}\text { Coke } \\
(M t)\end{array}$ & $\begin{array}{l}\text { Crude Oil } \\
\text { (Mt) }\end{array}$ & $\begin{array}{c}\text { Fuel Oll } \\
\text { (Mt) }\end{array}$ & $\begin{array}{c}\text { Kerosene } \\
(M t)\end{array}$ & $\begin{array}{l}\text { Diesel Oll } \\
\text { (Mt) }\end{array}$ & $\begin{array}{l}\text { LPG } \\
\text { (Mt) }\end{array}$ & $\begin{array}{c}\text { Natural Gas } \\
\text { (bcm) }\end{array}$ & $\begin{array}{c}\text { Coal Gas } \\
\text { (bcm) }\end{array}$ & $\begin{array}{c}\text { Other cok } \\
\text { Product } \\
\text { (Mt) }\end{array}$ & $\begin{array}{l}\text { gother oil } \\
\text { Products } \\
\text { (Mt) }\end{array}$ & $\begin{array}{c}\text { Heat } \\
\text { (PJ) }\end{array}$ & $\begin{array}{c}\text { Electriclty } \\
\text { (TWh) }\end{array}$ & $\begin{array}{c}\text { Total } \\
\text { End-Use } \\
\text { (Mtce) }\end{array}$ & $\begin{array}{c}\text { GOV } \\
\text { (billion } \\
1980 \text { yuan) }\end{array}$ \\
\hline $\begin{array}{l}\text { Industy Totol } \\
\text { Light Industry } \\
\text { Heavy Industry } *\end{array}$ & $\begin{array}{r}231.47 \\
58.39 \\
146.44\end{array}$ & $\begin{array}{r}39.55 \\
1.05 \\
38.39\end{array}$ & $\begin{array}{l}3.63 \\
0.73 \\
2.90\end{array}$ & $\begin{array}{r}12.97 \\
2.70 \\
10.26\end{array}$ & $\begin{array}{l}0.15 \\
0.04 \\
0.12\end{array}$ & $\begin{array}{l}3.70 \\
0.51 \\
2.91\end{array}$ & $\begin{array}{l}0.71 \\
0.05 \\
0.66\end{array}$ & $\begin{array}{r}11.44 \\
0.79 \\
9.90\end{array}$ & $\begin{array}{l}9.65 \\
0.50 \\
9.15\end{array}$ & $\begin{array}{l}2.16 \\
0.00 \\
0.00\end{array}$ & $\begin{array}{r}11.42 \\
0.00 \\
11.42\end{array}$ & $\begin{array}{r}257.83 \\
83.83 \\
173.64\end{array}$ & $\begin{array}{r}242.91 \\
46.50 \\
187.53\end{array}$ & $\begin{array}{r}380.50 \\
71.50 \\
282.71\end{array}$ & $\begin{array}{l}557.75 \\
281.49 \\
276.26\end{array}$ \\
\hline $\begin{array}{l}\text { Extroction Industries } \\
\text { Coal Mining \& Processing II } \\
\text { Oil \& NG Extraction I } \\
\text { Other Extraction }\end{array}$ & $\begin{array}{r}14.54 \\
11.49 \\
0.66 \\
2.39\end{array}$ & $\begin{array}{l}0.21 \\
0.13 \\
0.07 \\
0.01\end{array}$ & $\begin{array}{l}1.22 \\
0.00 \\
1.21 \\
0.00\end{array}$ & $\begin{array}{l}1.65 \\
0.01 \\
1.64 \\
0.01\end{array}$ & $\begin{array}{l}0.03 \\
0.02 \\
0.01 \\
0.00\end{array}$ & $\begin{array}{l}0.51 \\
0.08 \\
0.27 \\
0.16\end{array}$ & $\begin{array}{l}0.24 \\
0.00 \\
0.24 \\
0.00\end{array}$ & $\begin{array}{l}4.87 \\
0.00 \\
4.87 \\
0.00\end{array}$ & $\begin{array}{l}1.56 \\
1.56 \\
0.00 \\
0.00\end{array}$ & $\begin{array}{l}0.00 \\
0.00 \\
0.00 \\
0.00\end{array}$ & $\begin{array}{l}0.00 \\
0.00 \\
0.00 \\
0.00\end{array}$ & $\begin{array}{r}26.88 \\
3.19 \\
23.69 \\
0.00\end{array}$ & $\begin{array}{r}28.68 \\
18.77 \\
9.10 \\
0.81\end{array}$ & $\begin{array}{r}35.77 \\
17.09 \\
16.39 \\
2.29\end{array}$ & $\begin{array}{l}16.63 \\
28.80 \\
-\end{array}$ \\
\hline $\begin{array}{l}\text { Manufocturing Industries } \\
\text { Food, Beverage, \& Tobacco } \\
\text { Spinning \& Weaving § } \\
\text { Paper \& Paper Products } \\
\text { Electricity, Steam \& Hot Water *• } \\
\text { Chemicals Ht } \\
\text { Building Materials } ¥ \% \\
\text { Ferrous Metals Smelting \& Rolling } \\
\text { Machinery, Electrical \& Electronics } \\
\text { Other Manufacturing }\end{array}$ & $\begin{array}{r}216.93 \\
15.76 \\
15.45 \\
7.29 \\
0.63 \\
40.52 \\
51.78 \\
17.73 \\
20.36 \\
47.41\end{array}$ & $\begin{array}{r}39.34 \\
0.09 \\
0.12 \\
0.01 \\
0.03 \\
8.38 \\
0.53 \\
27.11 \\
2.01 \\
1.06\end{array}$ & $\begin{array}{l}2.41 \\
0.08 \\
0.21 \\
0.06 \\
0.00 \\
0.71 \\
0.10 \\
0.78 \\
0.10 \\
0.39\end{array}$ & $\begin{array}{r}11.32 \\
0.19 \\
0.54 \\
0.35 \\
0.00 \\
3.17 \\
1.45 \\
2.92 \\
1.02 \\
1.67\end{array}$ & $\begin{array}{l}0.13 \\
0.00 \\
0.01 \\
0.00 \\
0.00 \\
0.01 \\
0.01 \\
0.01 \\
0.07 \\
0.03\end{array}$ & $\begin{array}{l}2.92 \\
0.11 \\
0.09 \\
0.02 \\
0.00 \\
1.41 \\
0.28 \\
0.26 \\
0.45 \\
0.30\end{array}$ & $\begin{array}{l}0.47 \\
0.00 \\
0.05 \\
0.00 \\
0.00 \\
0.42 \\
0.00 \\
0.00 \\
0.00 \\
0.00\end{array}$ & $\begin{array}{l}6.57 \\
0.22 \\
0.29 \\
0.07 \\
0.00 \\
3.83 \\
0.06 \\
0.69 \\
0.45 \\
0.96\end{array}$ & $\begin{array}{l}8.09 \\
0.00 \\
0.45 \\
0.00 \\
0.00 \\
0.21 \\
0.00 \\
6.72 \\
0.66 \\
0.05\end{array}$ & $\begin{array}{l}2.16 \\
0.00 \\
0.00 \\
0.00 \\
0.00 \\
0.00 \\
0.00 \\
0.00 \\
0.00 \\
216\end{array}$ & $\begin{array}{l}0.00 \\
0.00 \\
0.00 \\
0.00 \\
0.00 \\
0.00 \\
0.00 \\
0.00 \\
0.00 \\
0.00\end{array}$ & $\begin{array}{r}230.95 \\
5.69 \\
62.97 \\
7.21 \\
2.27 \\
.77 .24 \\
8.55 \\
32.47 \\
25.74 \\
8.81\end{array}$ & $\begin{array}{r}205.35 \\
8.70 \\
15.52 \\
6.20 \\
21.38 \\
51.27 \\
13.31 \\
46.84 \\
21.25 \\
20.88\end{array}$ & $\begin{array}{r}324.43 \\
15.89 \\
21.51 \\
8.67 \\
9.19 \\
73.97 \\
45.88 \\
69.54 \\
29.30 \\
50.50\end{array}$ & $\begin{array}{r}75.60 \\
55.27 \\
7.40 \\
20.71 \\
65.90 \\
22.26 \\
48.52 \\
122.50 \\
-\end{array}$ \\
\hline Balance $\Pi \pi$ & 0.00 & 0.00 & 0.00 & 0.00 & 0.00 & 0.27 & 0.00 & 0.00 & 0.00 & 0.00 & 11.42 & 0.00 & 8.88 & 20.30 & 94.16 \\
\hline
\end{tabular}

* End-use ftgures differ from official sources, and from certain other tables in this book due to adjustments, e.g., exclusion of gasoline consumption and the construction sector.

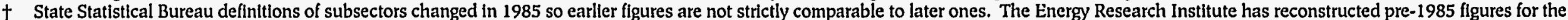

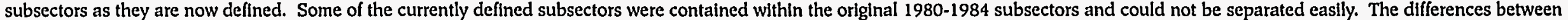

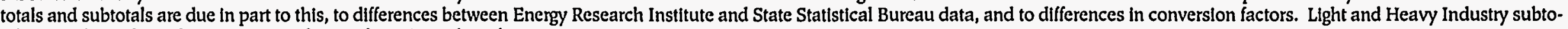
tals are independent of Excavatlon and Manufacturing subtotals.

* Light and heavy Industry subtotals are independent of subsectoral divisions.

The coal and oil \& natural gas subsectors may include the coal products and refining subsectors, which are listed separately for 1985-1988.

\$ The textiles subsector probably includes the chemical fibers subsector, which is listed separately for 1985-1988.

*t Figures for the utilities sector (normally not counted as an industrial sector in energy accounts of other countries) do not include power generation inputs.

H Gross output value for the chemicals industry includes rubber products.

Gross output for the building materlals industry includes raw materials mining.

IT Total minus extraction and manufacturing subtotals.

$\S \S$ Unadjusted sum of raw and washed coal.

Source: Energy Research Institute; China Energy Statistical Yearbook, various years; China Statistical Yearbook, various years. 

1980-1992 (continued)

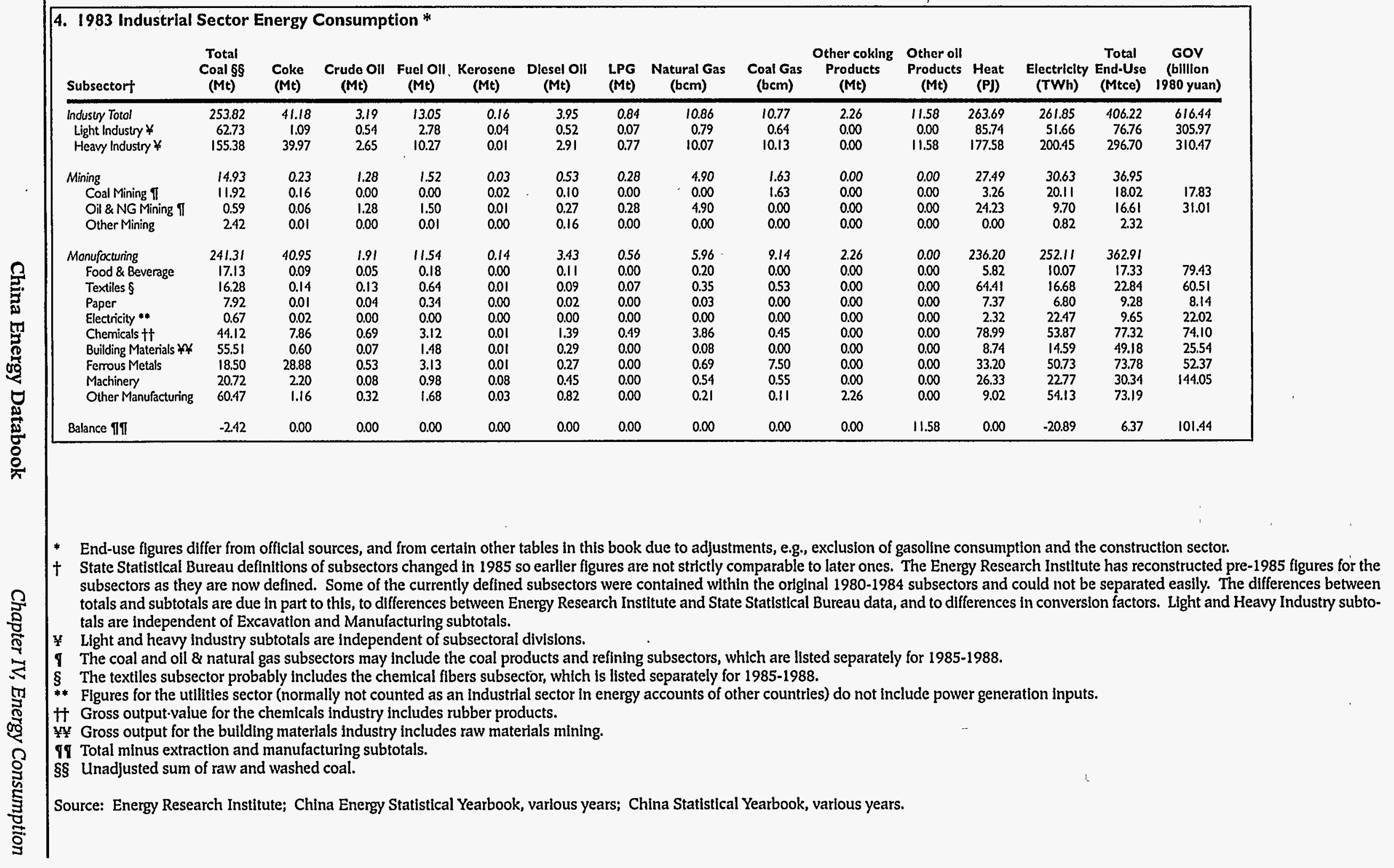




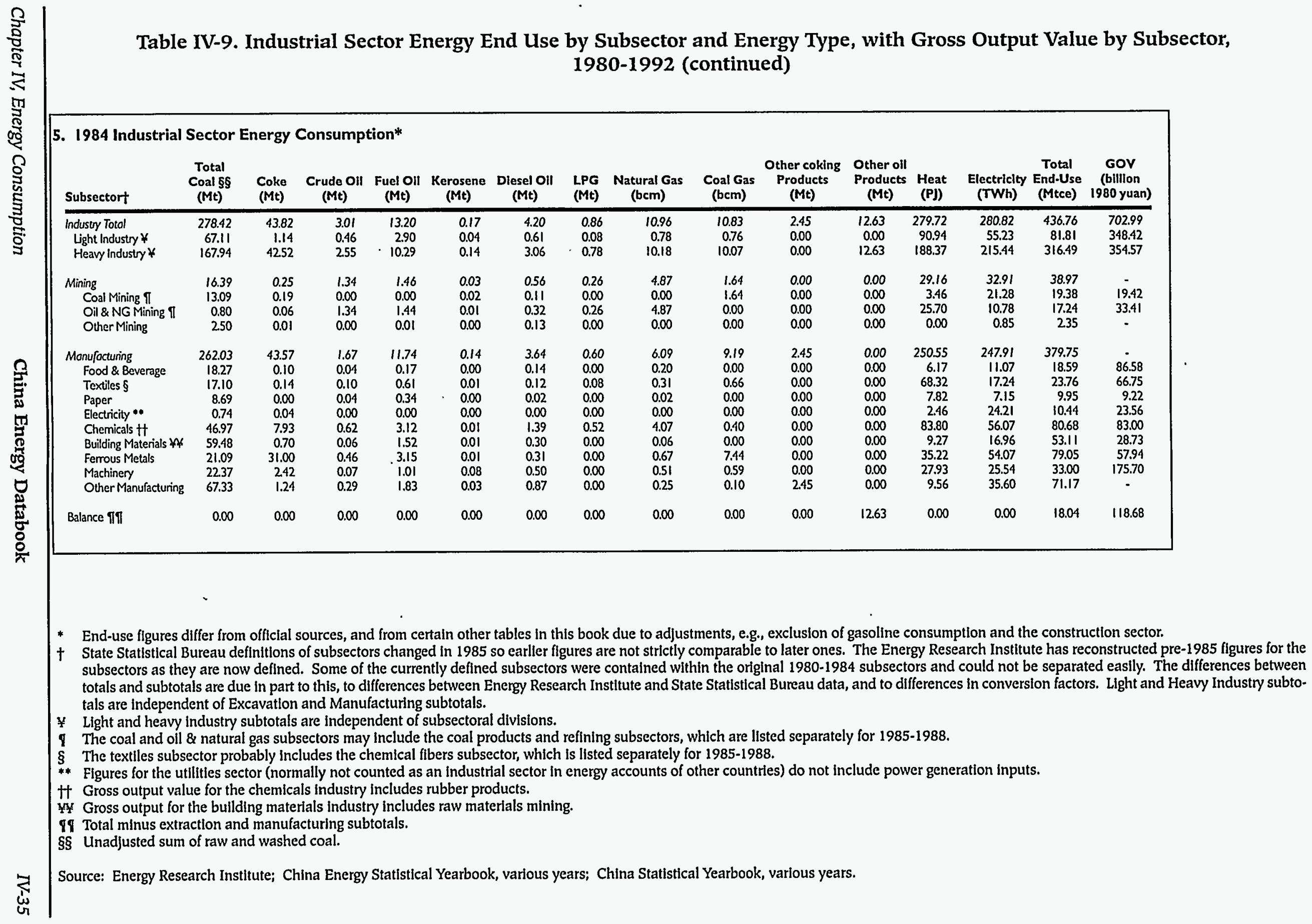


Table IV-9. Industrial Sector Energy Enduse by Subsector and Energy Type, with Gross Output Value by Subsector, 1980-1992 (continued)

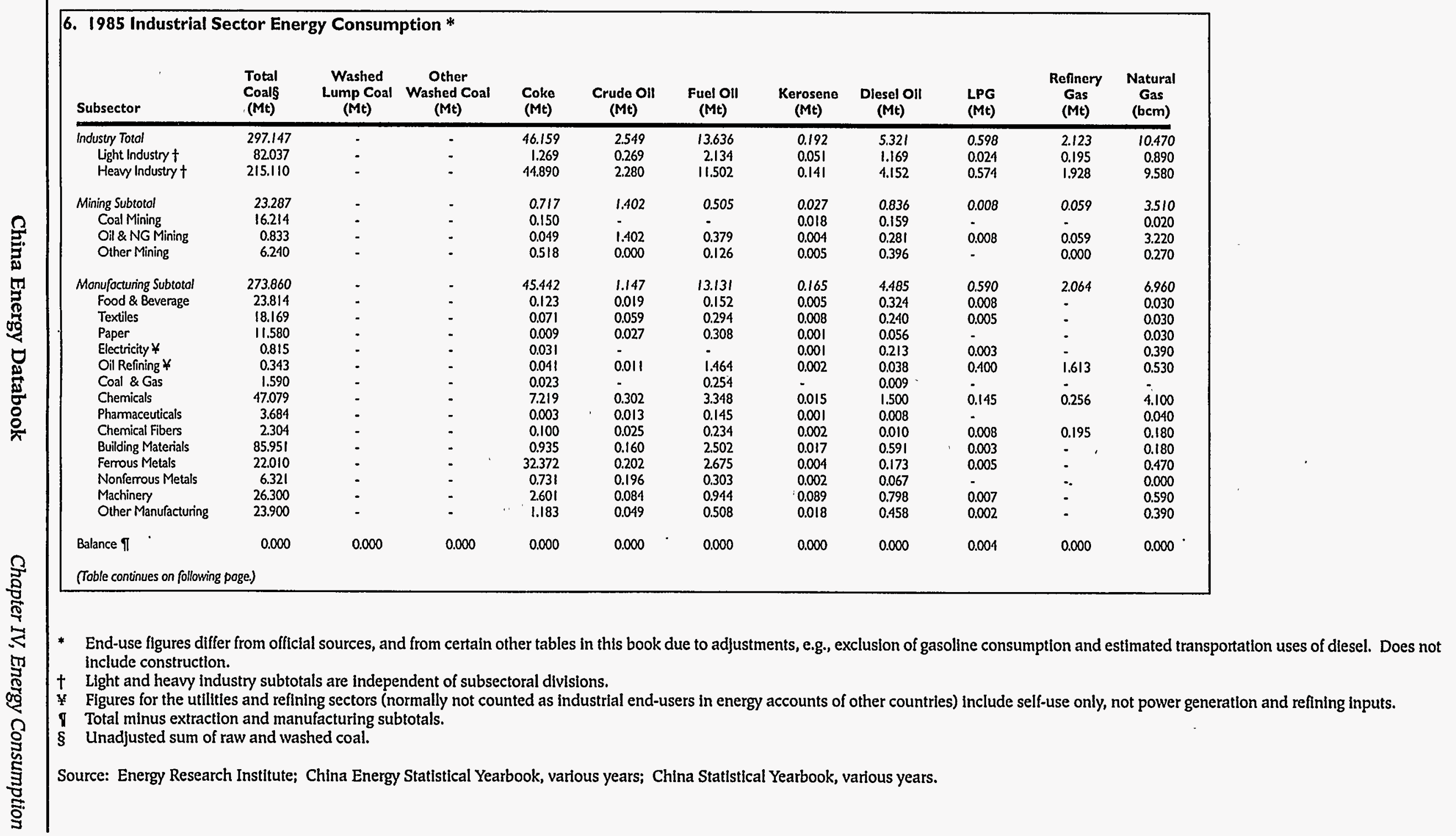


6. 1985 Industrial Sector Energy Consumption * (continued)

\begin{tabular}{|c|c|c|c|c|c|c|c|c|c|c|c|}
\hline Subsector & $\begin{array}{c}\text { Coke } \\
\text { Oven Gas } \\
\text { (bcm) }\end{array}$ & $\begin{array}{l}\text { Other } \\
\text { Coal Gas } \\
\text { (bcm) }\end{array}$ & $\begin{array}{l}\text { Other Coking } \\
\text { Products } \\
\text { (Mt) }\end{array}$ & $\begin{array}{l}\text { Other Oll } \\
\text { Products } \\
\text { (Mt) }\end{array}$ & $\begin{array}{l}\text { Heat } \\
\text { (PJ) }\end{array}$ & $\begin{array}{c}\text { Electricity } \\
\text { (TWh) }\end{array}$ & $\begin{array}{c}\text { Total } \\
\text { End Use } \\
\text { (Mtce) }\end{array}$ & $\begin{array}{l}\text { Conversion } \\
\text { Losses } \\
\text { (Mtce) }\end{array}$ & $\begin{array}{l}\text { Other } \\
\text { Losses } \\
\text { (Mtce) }\end{array}$ & $\begin{array}{c}\text { Total } \\
\text { Energy Use } \\
\text { (Mtce) }\end{array}$ & $\begin{array}{c}\text { Gross } \\
\text { Output Value } \\
\text { e (billion } \\
\text { (1980 yuan) }\end{array}$ \\
\hline $\begin{array}{l}\text { Industry Totol } \\
\text { Light Industryt } \\
\text { Heavy Industryt }\end{array}$ & $\begin{array}{r}10.900 \\
0.120 \\
10.780\end{array}$ & $\begin{array}{l}1.240 \\
0.230 \\
1.010\end{array}$ & $\begin{array}{l}2.825 \\
2.825\end{array}$ & $\begin{array}{l}15.738 \\
- \\
15.738\end{array}$ & $\begin{array}{r}316.649 \\
97.478 \\
219.171\end{array}$ & $\begin{array}{r}297.910 \\
65.570 \\
232.340\end{array}$ & $\begin{array}{r}468.662 \\
96.126 \\
372.535\end{array}$ & $\begin{array}{r}14.910 \\
0.018 \\
14.892\end{array}$ & $\begin{array}{l}15.562 \\
- \\
15.562\end{array}$ & $\begin{array}{r}499.134 \\
96.144 \\
402.989\end{array}$ & $\begin{array}{l}895.723 \\
439.537 \\
456.186\end{array}$ \\
\hline $\begin{array}{l}\text { Mining Subtotol } \\
\text { Coal Mining } \\
\text { Oil \& NG Mining } \\
\text { Other Mining }\end{array}$ & $\begin{array}{l}0.130 \\
- \\
- \\
-\end{array}$ & : & $:$ & $\begin{array}{l}\dot{0} \\
\dot{0} \\
-\end{array}$ & $\begin{array}{r}4.910 \\
21.500 \\
4.136 \\
0.259\end{array}$ & $\begin{array}{r}43.290 \\
20.790 \\
8.520 \\
13.270\end{array}$ & $\begin{array}{r}43.797 \\
8.408 \\
11.555 \\
11.453\end{array}$ & $\begin{array}{l}8.441 \\
- \\
0.033 \\
-\end{array}$ & $\begin{array}{r}3.235 \\
29.198 \\
3.235 \\
-\end{array}$ & $\begin{array}{l}55.473 \\
21.815 \\
14.823 \\
11.453\end{array}$ & $\begin{array}{l}37.947 \\
- \\
16.132 \\
-\end{array}$ \\
\hline $\begin{array}{l}\text { Monufocturing Subtotal } \\
\text { Food \& Beverage } \\
\text { Textiles } \\
\text { Paper }\end{array}$ & $\begin{array}{r}10.770 \\
0.000 \\
0.110\end{array}$ & $\begin{array}{l}1.240 \\
0.010 \\
0.090 \\
0.010\end{array}$ & : & $:$ & $\begin{array}{r}311.739 \\
11.814 \\
35.991 \\
8.594\end{array}$ & $\begin{array}{r}254.620 \\
10.860 \\
18.570 \\
8.090\end{array}$ & $\begin{array}{r}399.556 \\
22.647 \\
22.636 \\
12.408\end{array}$ & $\begin{array}{l}6.469 \\
- \\
-\end{array}$ & $\begin{array}{l}12.327 \\
- \\
-\end{array}$ & $\begin{array}{r}418.352 \\
22.647 \\
22.636 \\
12408\end{array}$ & $\begin{array}{r}689.665 \\
99.469 \\
121.506 \\
16468\end{array}$ \\
\hline $\begin{array}{l}\text { Paper } \\
\text { Electricity } *\end{array}$ & - & 0.010 & : & 2.650 & $\begin{array}{r}8.594 \\
28.380\end{array}$ & $\begin{array}{r}8.090 \\
12.991\end{array}$ & 12.408 & 12.116 & 25.107 & $\begin{array}{l}12.408 \\
27.364\end{array}$ & 16.468 \\
\hline Oil Refining $*$ & - & - & - & - & 23.584 & 4.020 & 8.691 & 0.919 & 0.211 & 9.821 & 21.132 \\
\hline Coal \& Gas & 1.500 & 0.270 & - & - & 3.232 & 0.860 & 3.022 & 3.263 & - & 6.285 & 2.416 \\
\hline Chemicals & 0.520 & 0.050 & - & - & 89.669 & 51.350 & 77.878 & 0.228 & - & 78.106 & 56.507 \\
\hline Pharmaceuticals & $\cdot$ & - & - & - & 10.402 & 2.320 & 4.169 & $\cdot$ & - & 4.169 & 14.271 \\
\hline Chemical Fibers & - & - & - & - & 26.041 & 3.340 & 4.803 & 0.026 & - & 4.829 & 10.330 \\
\hline Building Materials & 0.110 & 0.100 & . & - & 9.820 & 22.160 & 76.600 & - & - & 76.600 & 49.308 \\
\hline Ferrous Metals & 8.010 & 0.040 & - & - & 45.258 & 36.320 & 72.942 & 2029 & - & 74.971 & 43.891 \\
\hline Nonferrous Metals & 0.070 & 0.030 & - & - & 9.758 & 17.390 & 13.409 & 0.000 & - & 13.109 & 19.160 \\
\hline Machinery & 0.320 & 0.550 & - & - & 29.980 & 32030 & 39.199 & 0.004 & - & 39.203 & 207.843- \\
\hline Other Manufacturing & 0.130 & 0.090 & - & - & 4.946 & 18.930 & 28.155 & $\cdot \cdot$ & - & 28.155 & - \\
\hline Balance I & 0.000 & 0.000 & 2.825 & 15.738 & 0.000 & 0.000 & 25.315 & 0.000 & 0.000 & 25.315 & 168.111 \\
\hline
\end{tabular}

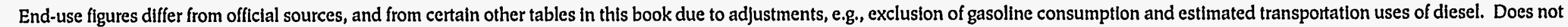
Include construction.

$\dagger$ Light and heavy industry subtotals are independent of subsectoral divisions.

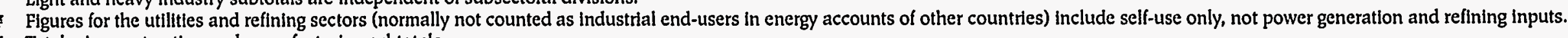

I Total minus extraction and manufacturing subtotals.

$\S$ Unadjusted sum of raw and washed coal.

Source: Energy Research Institute; China Energy Statistical Yearbook, various years; China Statistical Yearbook, various years. 
Table IV-9. Industrial Sector Energy End Use by Subsector and Energy Type, with Gross Output Value by Subsector, 1980-1992(continued)

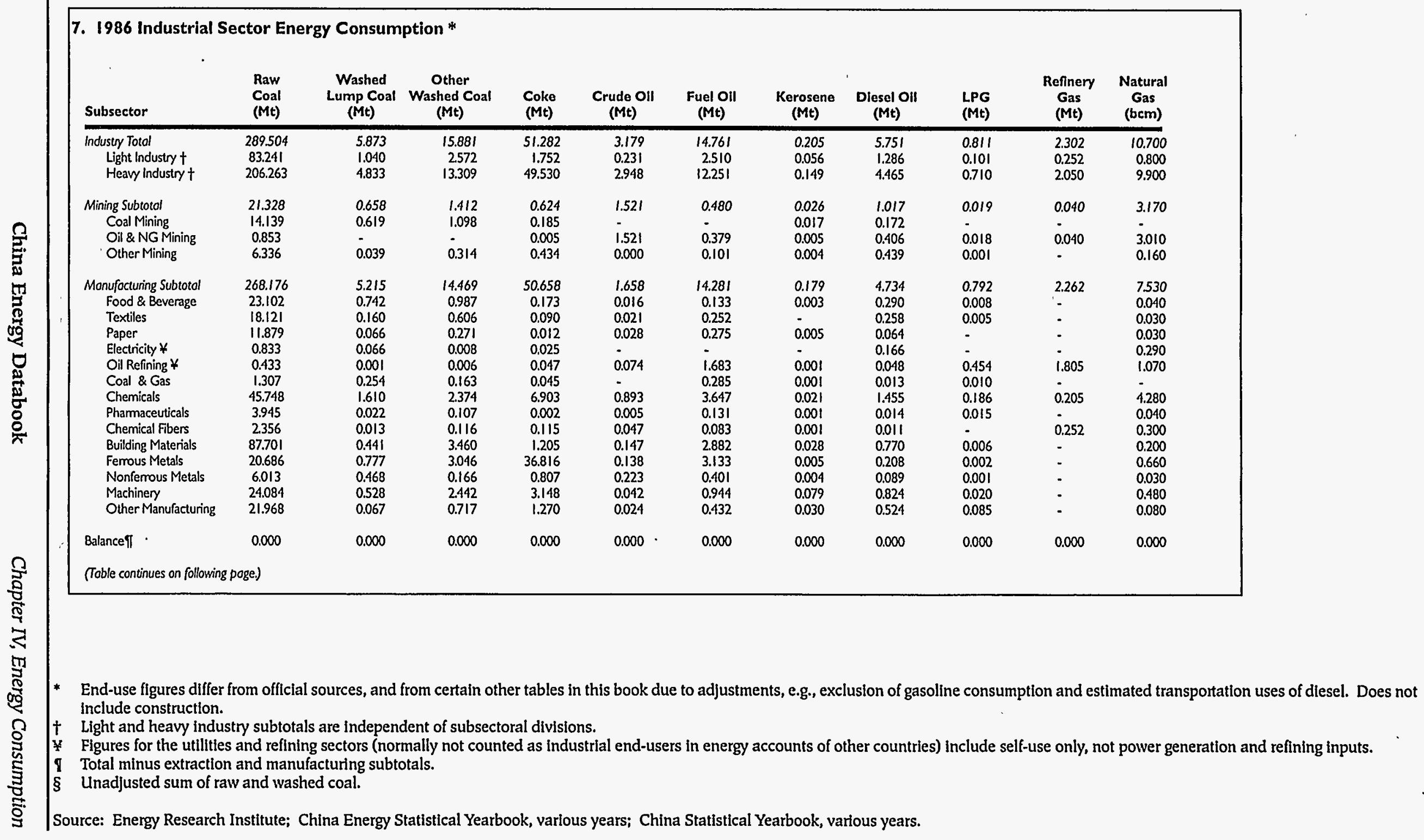


Table IV-9. Industrial Sector Energy End Use by Subsector and Energy Type, with Gross Output Value by Subsector, 1980-1992 (continued)

\section{1986 Industrial Sector Energy Consumption * (continued)}

\begin{tabular}{|c|c|c|c|c|c|c|c|c|c|c|c|}
\hline Subsector & $\begin{array}{l}\text { Coke } \\
\text { Oven Gas } \\
\text { (bcm) }\end{array}$ & $\begin{array}{l}\text { Other } \\
\text { Coal Gas } \\
\text { (bcm) }\end{array}$ & $\begin{array}{l}\text { Other Coking } \\
\text { Products } \\
\text { (Mt) }\end{array}$ & $\begin{array}{l}\text { Other Oll } \\
\text { Products } \\
\text { (Mt) }\end{array}$ & $\begin{array}{l}\text { Heat } \\
\text { (PJ) }\end{array}$ & $\begin{array}{c}\text { Electricity } \\
\text { (TWh) }\end{array}$ & $\begin{array}{c}\text { Total } \\
\text { End Use } \\
\text { (Mtce) }\end{array}$ & $\begin{array}{c}\text { Conversion } \\
\text { Losses } \\
\text { (Mtce) }\end{array}$ & $\begin{array}{l}\text { Other } \\
\text { Losses } \\
\text { (Mtce) }\end{array}$ & $\begin{array}{c}\text { Total } \\
\text { Energy Use } \\
\text { (Mtce) }\end{array}$ & $\begin{array}{c}\text { Gross } \\
\text { Output Value } \\
\text { (billion } \\
\text { I980 yuan) }\end{array}$ \\
\hline $\begin{array}{l}\text { Industy Totol } \\
\text { Light Industry } \dagger \\
\text { Heavy Industry } \dagger\end{array}$ & $\begin{array}{r}13.050 \\
0.110 \\
12.940\end{array}$ & $\begin{array}{l}2.760 \\
0.280 \\
2.480\end{array}$ & $\begin{array}{l}2.131 \\
- \\
2.131\end{array}$ & $\begin{array}{l}11.720 \\
- \\
11.720\end{array}$ & $\begin{array}{l}337.102 \\
111.226 \\
225.877\end{array}$ & $\begin{array}{r}331.670 \\
72380 \\
259.290\end{array}$ & $\begin{array}{l}501.823 \\
104.646 \\
397.177\end{array}$ & $\begin{array}{r}16.877 \\
0.031 \\
16.846\end{array}$ & $\begin{array}{l}16.642 \\
- \\
16.642\end{array}$ & $\begin{array}{l}535.342 \\
104.677 \\
430.665\end{array}$ & $\begin{array}{l}986.696 \\
490.348 \\
496.348\end{array}$ \\
\hline $\begin{array}{l}\text { Mining Subtotol } \\
\text { Coal Mining } \\
\text { Oil \& NG Mining } \\
\text { Other Mining }\end{array}$ & $\begin{array}{l}- \\
-\end{array}$ & $\begin{array}{l}0.020 \\
0.020 \\
:\end{array}$ & $:$ & $\begin{array}{l}- \\
\vdots\end{array}$ & $\begin{array}{l}5.249 \\
1.093 \\
4.136 \\
0.020\end{array}$ & $\begin{array}{r}49.910 \\
23.800 \\
9.840 \\
16.270\end{array}$ & $\begin{array}{l}46.723 \\
21.759 \\
12.121 \\
12.843\end{array}$ & $\begin{array}{l}9.531 \\
9.486 \\
0.045 \\
-\end{array}$ & $\begin{array}{l}3.366 \\
- \\
3.366 \\
-\end{array}$ & $\begin{array}{l}59.620 \\
31.245 \\
15.532 \\
12.843\end{array}$ & $\begin{array}{l}39.676 \\
22.523 \\
17.153 \\
-\end{array}$ \\
\hline $\begin{array}{l}\text { Monufocturing Subtotol } \\
\text { Food \& Beverage } \\
\text { Textiles } \\
\text { Paper } \\
\text { Electricity } ¥ \\
\text { Oil Refining } ¥ \\
\text { Coal \& Gas } \\
\text { Chemicals } \\
\text { Pharmaceuticals } \\
\text { Chemical Fibers } \\
\text { Building Materials } \\
\text { Ferrous Metals } \\
\text { Nonferrous Metals } \\
\text { Machinery } \\
\text { Other Manufacturing }\end{array}$ & $\begin{array}{l}13.050 \\
-.020 \\
\cdot \\
\cdot \\
i .560 \\
0.580 \\
\cdot \\
\dot{0} \\
0.090 \\
10.490 \\
0.050 \\
0.230 \\
0.030\end{array}$ & $\begin{array}{l}2.740 \\
0.010 \\
0.080 \\
0.010 \\
: \\
- \\
0.040 \\
0.080 \\
: \\
- \\
0.090 \\
1.040 \\
0.020 \\
1.330 \\
0.040\end{array}$ & $\begin{array}{l}- \\
- \\
: \\
: \\
: \\
: \\
- \\
- \\
- \\
-\end{array}$ & $\begin{array}{l}: \\
: \\
: \\
: \\
: \\
: \\
: \\
: \\
:\end{array}$ & \begin{tabular}{r|}
331.853 \\
7.187 \\
51.475 \\
9.883 \\
8.912 \\
27.067 \\
4.215 \\
96.098 \\
10.478 \\
26.518 \\
6.149 \\
35.991 \\
9.615 \\
35.146 \\
3.119
\end{tabular} & $\begin{array}{r}281.760 \\
14.190 \\
19.930 \\
9.010 \\
30.800 \\
4.900 \\
1.200 \\
55.490 \\
2.540 \\
4.290 \\
25.680 \\
39.240 \\
19.060 \\
34.460 \\
20.970\end{array}$ & $\begin{array}{r}436.226 \\
24.882 \\
24.154 \\
13.309 \\
14.018 \\
10.753 \\
3.354 \\
83.564 \\
4.564 \\
5.419 \\
83.753 \\
83.575 \\
14.742 \\
42.192 \\
27.947\end{array}$ & $\begin{array}{l}7.346 \\
: \\
- \\
- \\
1.061 \\
3.942 \\
0.276 \\
- \\
0.031 \\
- \\
2.013 \\
- \\
0.023 \\
-\end{array}$ & $\begin{array}{c}13.276 \\
- \\
- \\
13.218 \\
0.058 \\
- \\
- \\
- \\
- \\
= \\
-\end{array}$ & $\begin{array}{r}456.848 \\
24.882 \\
24.154 \\
13.309 \\
27.236 \\
11.872 \\
7.296 \\
83.840 \\
4.564 \\
5.450 \\
83.753 \\
85.588 \\
14.742 \\
42.215 \\
27.947\end{array}$ & $\begin{array}{r}758.399 \\
109.049 \\
131.377 \\
18.877 \\
29.311 \\
23.368 \\
2.600 \\
62.007 \\
17.035 \\
12.059 \\
58.279 \\
50.326 \\
21.465 \\
222.646 \\
-\end{array}$ \\
\hline Balance $\mathbb{T}$ & 0.000 & 0.000 & 2.131 & 11.720 & 0.000 & 0.000 & 18.874 & 0.000 & 0.000 & 18.874 & $|88.62|$ \\
\hline
\end{tabular}

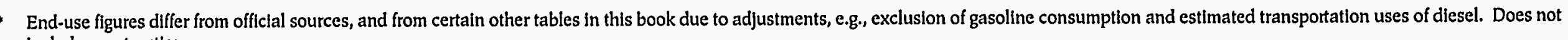
include construction.

Light and heavy industry subtotals are Independent of subsectoral divisions.

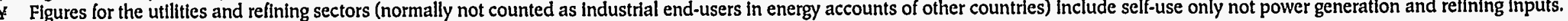

Total minus extraction and manufacturing subtotals.

$\S$ Unadjusted sum of raw and washed coal.

Source: Energy Research Institute; China Energy Statistical Yearbook, various years; China Statistical Yearbook, various years. 
Table IV-9. Industrial Sector Energy End Use by Subsector and Energy Type, with Gross Output Value by Subsector, 1980-1992(continued)

\section{1987 Industrial Sector Energy Consumption *}

\begin{tabular}{|c|c|c|c|c|c|c|c|c|c|c|c|}
\hline Subsector & $\begin{array}{l}\text { Raw } \\
\text { Coaļ } \\
\text { (Mt) }\end{array}$ & $\begin{array}{l}\text { Washed } \\
\text { Lump Coal } \\
\text { (Mt) }\end{array}$ & $\begin{array}{c}\text { Other } \\
\text { Washed Coal } \\
\text { (Mt) }\end{array}$ & $\begin{array}{l}\text { Coke } \\
\text { (Mt) }\end{array}$ & $\begin{array}{l}\text { Crude Oil } \\
\text { (Mt) }\end{array}$ & $\begin{array}{l}\text { Fuel Oil } \\
\text { (Mt) }\end{array}$ & $\begin{array}{c}\text { Kerosene } \\
\text { (Mt) }\end{array}$ & $\begin{array}{l}\text { Diesel Oll } \\
\text { (Mt) }\end{array}$ & $\begin{array}{l}\text { LPG } \\
\text { (Mt) }\end{array}$ & $\begin{array}{c}\text { Refinery } \\
\text { Gas } \\
\text { (Mt) }\end{array}$ & $\begin{array}{c}\text { Natural } \\
\text { Gas } \\
\text { (bcm) }\end{array}$ \\
\hline $\begin{array}{l}\text { Industy Totol } \\
\text { Light Industry } \dagger \\
\text { Heavy Industry } \dagger \\
\text { Mining Subtotol } \\
\text { Coal Mining } \\
\text { Oil \& NG Mining } \\
\text { Other Mining }\end{array}$ & $\begin{array}{r}310.688 \\
96.111 \\
214.577 \\
22.581 \\
15.088 \\
0.761 \\
6.732\end{array}$ & $\begin{array}{l}7.998 \\
1.212 \\
6.786 \\
1.063 \\
0.939 \\
0.124\end{array}$ & $\begin{array}{r}19.800 \\
2.719 \\
17.081 \\
1.871 \\
1.390 \\
0.008 \\
0.473\end{array}$ & $\begin{array}{r}55.835 \\
1.882 \\
53.953 \\
0.644 \\
0.242 \\
0.003 \\
0.399\end{array}$ & $\begin{array}{l}2.751 \\
0.242 \\
2.509 \\
1.139 \\
- \\
1.135 \\
0.004\end{array}$ & $\begin{array}{r}15.747 \\
3.175 \\
12.572 \\
0.757 \\
- \\
0.705 \\
0.052\end{array}$ & $\begin{array}{l}0.229 \\
0.068 \\
0.161 \\
0.036 \\
0.022 \\
0.010 \\
0.001\end{array}$ & $\begin{array}{l}5.840 \\
1.251 \\
4.589 \\
1.026 \\
0.182 \\
0.412 \\
0.432\end{array}$ & $\begin{array}{l}0.811 \\
0.173 \\
0.638 \\
0.020 \\
- \\
0.020 \\
-\end{array}$ & $\begin{array}{l}2.411 \\
0.145 \\
2.266 \\
0.075 \\
- \\
0.075 \\
-\end{array}$ & $\begin{array}{r}11.050 \\
0.530 \\
10.520 \\
3.430 \\
0.050 \\
3.240 \\
0.140\end{array}$ \\
\hline $\begin{array}{l}\text { Monufocturing Subtotol } \\
\text { Food \& Beverage } \\
\text { Textiles } \\
\text { Paper } \\
\text { Electricity } ¥ \\
\text { Oil Refining } * \\
\text { Coal \& Gas } \\
\text { Chemicals } \\
\text { Phamaceuticals } \\
\text { Chemical Fibers } \\
\text { Building Materials } \\
\text { Ferrous Metals } \\
\text { Nonferrous Metals } \\
\text { Machiner } \\
\text { Other Manufacturing }\end{array}$ & $\begin{array}{r}288.107 \\
25.465 \\
19.659 \\
12.432 \\
0.997 \\
0.543 \\
1.378 \\
52.320 \\
4.789 \\
2.546 \\
93.535 \\
20.089 \\
6.041 \\
24.656 \\
23.657\end{array}$ & $\begin{array}{l}6.935 \\
0.822 \\
0.194 \\
0.097 \\
0.001 \\
- \\
0.266 \\
2.597 \\
0.015 \\
0.026 \\
0.658 \\
1.253 \\
0.178 \\
0.571 \\
0.257\end{array}$ & $\begin{array}{r}17.929 \\
1.469 \\
0.521 \\
0.294 \\
0.161 \\
0.004 \\
0.030 \\
3.371 \\
0.098 \\
0.048 \\
4.493 \\
3.781 \\
0.159 \\
2.994 \\
0.506\end{array}$ & $\begin{array}{r}55.191 \\
0.226 \\
0.078 \\
0.014 \\
0.024 \\
0.047 \\
0.114 \\
7.653 \\
0.017 \\
0.146 \\
1.298 \\
39.828 \\
0.852 \\
3.248 \\
1.646\end{array}$ & $\begin{array}{l}1.612 \\
0.020 \\
0.011 \\
0.014 \\
- \\
0.065 \\
- \\
0.893 \\
0.008 \\
0.060 \\
0.153 \\
0.108 \\
0.221 \\
0.043 \\
0.016\end{array}$ & $\begin{array}{r}14.990 \\
0.132 \\
0.234 \\
0.206 \\
- \\
2.045 \\
0.349 \\
3.679 \\
0.153 \\
0.103 \\
2.913 \\
3.157 \\
0.432 \\
0.950 \\
0.637\end{array}$ & $\begin{array}{l}0.193 \\
0.004 \\
0.008 \\
0.003 \\
0.002 \\
0.002 \\
0.001 \\
0.023 \\
0.002 \\
0.001 \\
0.028 \\
0.004 \\
0.003 \\
0.081 \\
0.031\end{array}$ & $\begin{array}{l}4.814 \\
0.284 \\
0.224 \\
0.061 \\
0.245 \\
0.060 \\
0.015 \\
1.528 \\
0.017 \\
0.018 \\
0.751 \\
0.218 \\
0.090 \\
0.761 \\
0.542\end{array}$ & $\begin{array}{l}0.791 \\
- \\
0.004 \\
- \\
- \\
0.397 \\
0.004 \\
0.169 \\
0.049 \\
0.106 \\
0.040 \\
0.001 \\
0.001 \\
0.005 \\
0.015\end{array}$ & $\begin{array}{l}2.336 \\
- \\
- \\
- \\
- \\
1.981 \\
- \\
0.206 \\
- \\
0.145 \\
0.004 \\
- \\
- \\
-\end{array}$ & $\begin{array}{l}.7 .620 \\
0.040 \\
0.030 \\
0.020 \\
0.070 \\
1.110 \\
0.060 \\
4.430 \\
0.040 \\
0.390 \\
0.210 \\
0.720 \\
0.030 \\
0.420 \\
0.050\end{array}$ \\
\hline Balance Tा & 0.000 & 0.000 & 0.000 & 0.000 & 0.000 & 0.000 & 0.000 & 0.000 & 0.000 & 0.000 & 0.000 \\
\hline
\end{tabular}

(Toble continues on following page.)

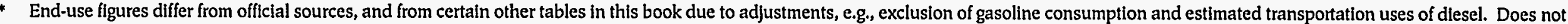
include construction.

$\dagger$ Light and heavy industry subtotals are independent of subsectoral divisions.

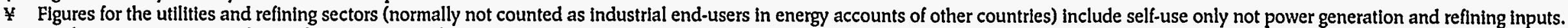

T Total minus extraction and manufacturing subtotals.

$\S$ Unadjusted sum of raw and washed coal.

Source: Energy Research Institute; China Energy Statistical Yearbook, various years; China Statistical Yearbook, various years. 


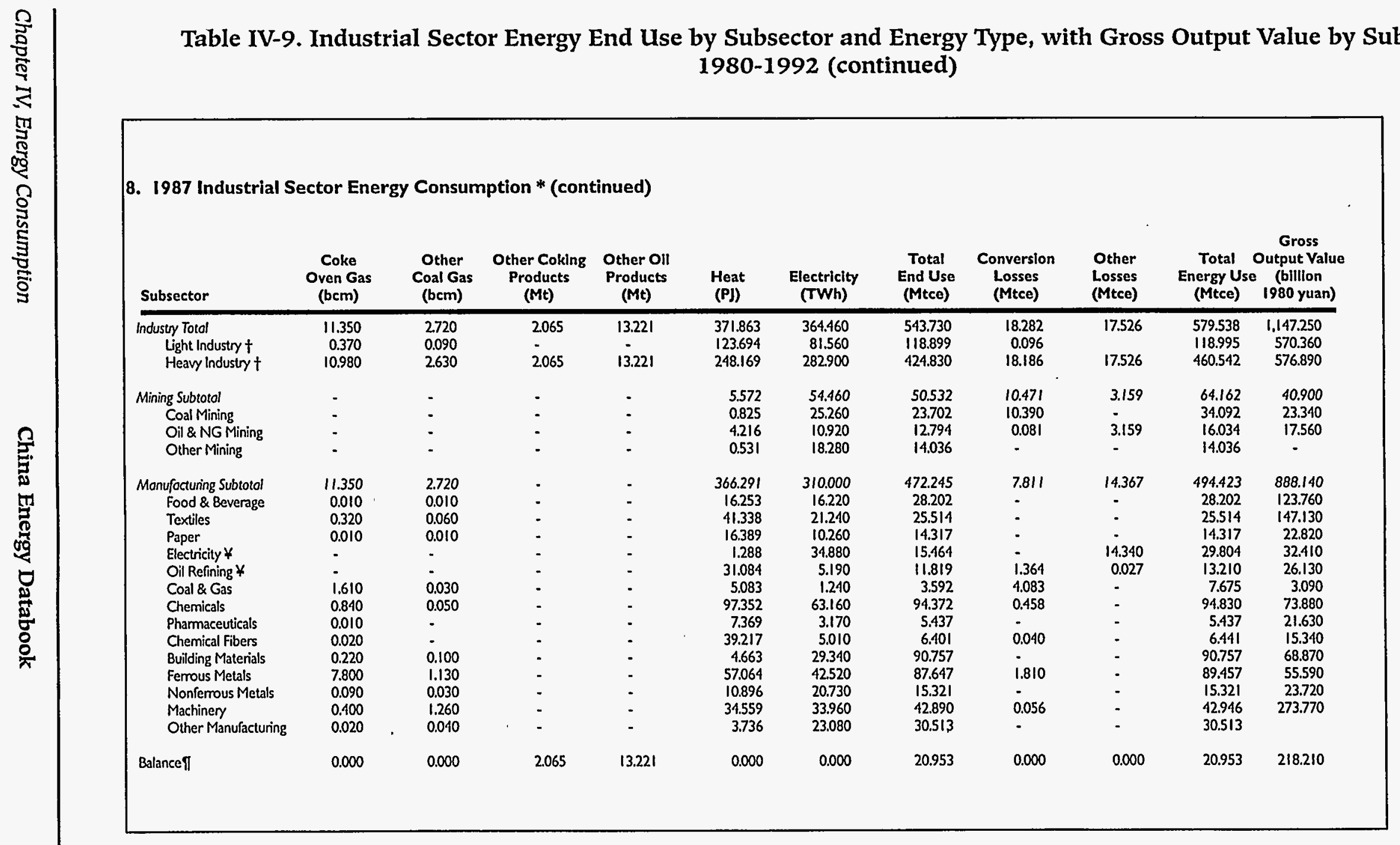

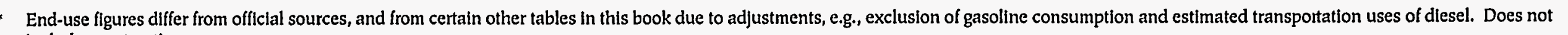
Include constructlon.

$\dagger$ Light and heavy industry subtotals are independent of subsectoral divisions.

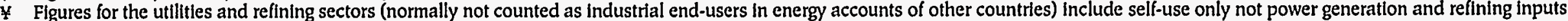

I Total minus extraction and manufacturing subtotals.

$\S$ Unadjusted sum of raw and washed coal.

Source: Energy Research Institute; China Energy Statistical Yearbook, various years; China Statistical Yearbook, various years. 
Table IV-9. Industrial Sector Energy End Use by Subsector and Energy Type, with Gross Output Value by Subsector, 1980-1992 (continued)

\begin{tabular}{|c|c|c|c|c|c|c|c|c|c|c|c|}
\hline \multicolumn{12}{|c|}{ 9. 1988 Industrial Sector Energy Consumption * } \\
\hline Subsector & $\begin{array}{l}\text { Raw } \\
\text { Coalg } \\
(\mathrm{Mt})\end{array}$ & $\begin{array}{l}\text { Washed } \\
\text { Lump Coal } \\
\text { (Mt) }\end{array}$ & $\begin{array}{c}\text { Other } \\
\text { Washed Coal } \\
\text { (Mt) }\end{array}$ & $\begin{array}{l}\text { Coke } \\
(M t)\end{array}$ & $\begin{array}{c}\text { Crude Oll } \\
\text { (Mt) }\end{array}$ & $\begin{array}{l}\text { Fuel Oll } \\
\text { (Mt) }\end{array}$ & $\begin{array}{c}\text { Kerosene } \\
\text { (Mt) }\end{array}$ & $\begin{array}{l}\text { Dlesel Oil } \\
\text { (Mt) }\end{array}$ & $\begin{array}{l}\text { LPG } \\
\text { (Mt) }\end{array}$ & $\begin{array}{c}\text { Refinery } \\
\text { Gas } \\
\text { (Mt) }\end{array}$ & $\begin{array}{c}\text { Natural } \\
\text { Gas } \\
\text { (bcm) }\end{array}$ \\
\hline $\begin{array}{l}\text { Industry Totol } \\
\text { Light Industry } t \\
\text { Heavy industry } \dagger\end{array}$ & $\begin{array}{l}330.437 \\
101.453 \\
228.984\end{array}$ & $\begin{array}{l}8.328 \\
1.510 \\
6.818\end{array}$ & $\begin{array}{r}22.154 \\
2.417 \\
19.737\end{array}$ & $\begin{array}{r}58.790 \\
1.838 \\
56.952\end{array}$ & $\begin{array}{l}3.658 \\
0.285 \\
3.373\end{array}$ & $\begin{array}{r}16.306 \\
2.789 \\
13.517\end{array}$ & $\begin{array}{l}0.227 \\
0.076 \\
0.151\end{array}$ & $\begin{array}{l}5.634 \\
1.435 \\
4.199\end{array}$ & $\begin{array}{l}0.902 \\
0.105 \\
0.797\end{array}$ & $\begin{array}{l}2.398 \\
0.166 \\
2.232\end{array}$ & $\begin{array}{r}11.110 \\
0.830 \\
10.280\end{array}$ \\
\hline $\begin{array}{l}\text { Mining Subtotol } \\
\text { Coal Mining } \\
\text { Oil \& NG Mining } \\
\text { Other Mining }\end{array}$ & $\begin{array}{c}23.100 \\
14.306 \\
0.928 \\
7.866\end{array}$ & $\begin{array}{l}1.084 \\
1.003 \\
- \\
0.081\end{array}$ & $\begin{array}{l}4.229 \\
3.897 \\
0.004 \\
0.328\end{array}$ & $\begin{array}{l}0.830 \\
0.341 \\
0.004 \\
0.485\end{array}$ & $\begin{array}{l}1.370 \\
0.001 \\
1.369\end{array}$ & $\begin{array}{l}0.753 \\
0.001 \\
0.674 \\
0.078\end{array}$ & $\begin{array}{l}0.027 \\
0.018 \\
0.003 \\
0.006\end{array}$ & $\begin{array}{l}1.147 \\
0.229 \\
0.488 \\
0.430\end{array}$ & $\begin{array}{l}0.024 \\
- \\
0.024 \\
0.000\end{array}$ & $\begin{array}{l}0.056 \\
- \\
0.056 \\
0.000\end{array}$ & $\begin{array}{l}3.620 \\
0.060 \\
3.400 \\
0.160\end{array}$ \\
\hline $\begin{array}{l}\text { Monufocturing Subtotol } \\
\text { Food \& Beverage } \\
\text { Textiles } \\
\text { Paper } \\
\text { Electricity } * \\
\text { Oil Refining * } \\
\text { Coal \& Gas } \\
\text { Chemicals } \\
\text { Pharmaceuticals } \\
\text { Chemical Fibers } \\
\text { Building Materials } \\
\text { Ferrous Metals } \\
\text { Nonferrous Metals } \\
\text { Machinery } \\
\text { Other Manufacturing }\end{array}$ & $\begin{array}{c}307.337 \\
27.496 \\
21.117 \\
13.091 \\
1.700 \\
0.639 \\
1.697 \\
56.060 \\
4.860 \\
2.561 \\
98.935 \\
21.654 \\
6.746 \\
25.996 \\
24.785\end{array}$ & $\begin{array}{l}7.244 \\
1.028 \\
0.177 \\
0.085 \\
0.026 \\
-0.013 \\
0.013 \\
0.046 \\
0.022 \\
0.614 \\
1.587 \\
0.012 \\
0.385 \\
0.451\end{array}$ & $\begin{array}{r}17.925 \\
1.062 \\
0.605 \\
0.286 \\
0.151 \\
0.008 \\
0.041 \\
3.967 \\
0.105 \\
0.013 \\
5.299 \\
2.814 \\
0.179 \\
2.855 \\
0.540\end{array}$ & $\begin{array}{r}57.960 \\
0.199 \\
0.112 \\
0.030 \\
0.026 \\
0.009 \\
0.113 \\
8.128 \\
0.010 \\
0.152 \\
1.436 \\
41.378 \\
1.045 \\
3.657 \\
1.665\end{array}$ & $\begin{array}{l}2.288 \\
0.010 \\
0.022 \\
0.012 \\
- \\
0.173 \\
- \\
1.367 \\
0.002 \\
0.041 \\
0.284 \\
0.257 \\
0.001 \\
0.102 \\
0.017\end{array}$ & $\begin{array}{l}15.553 \\
0.113 \\
0.175 \\
0.183 \\
0.033 \\
2.108 \\
0.020 \\
3.954 \\
0.211 \\
0.248 \\
3.035 \\
3.397 \\
0.443 \\
0.942 \\
0.691\end{array}$ & $\begin{array}{l}0.200 \\
0.009 \\
0.012 \\
0.003 \\
0.001 \\
0.001 \\
- \\
0.025 \\
0.002 \\
0.002 \\
0.025 \\
0.005 \\
0.004 \\
0.081 \\
0.030\end{array}$ & $\begin{array}{l}4.487 \\
0.299 \\
0.336 \\
0.070 \\
0.224 \\
0.190 \\
0.014 \\
0.652 \\
0.020 \\
0.023 \\
0.810 \\
0.245 \\
0.088 \\
1.015 \\
0.501\end{array}$ & $\begin{array}{l}0.878 \\
0.001 \\
0.002 \\
- \\
- \\
0.627 \\
0.001 \\
0.139 \\
0 . \\
0.089 \\
0.013 \\
0.001 \\
0.001 \\
0.003 \\
0.001\end{array}$ & $\begin{array}{l}2.342 \\
- \\
- \\
- \\
1.975 \\
0.000 \\
0.219 \\
- \\
0.138 \\
0.008 \\
- \\
0.002\end{array}$ & $\begin{array}{l}7.490 \\
0.040 \\
0.030 \\
0.020 \\
0.140 \\
0.970 \\
0.010 \\
4.560 \\
0.040 \\
0.350 \\
0.220 \\
0.700 \\
0.040 \\
0.350 \\
0.020\end{array}$ \\
\hline $\begin{array}{l}\text { Balance } \\
\text { (Table continues on followin }\end{array}$ & 0.000 & 0.000 & 0.000 & 0.000 & 0.000 & 0.000 & 0.000 & 0.000 & 0.000 & 0.000 & 0.000 \\
\hline
\end{tabular}

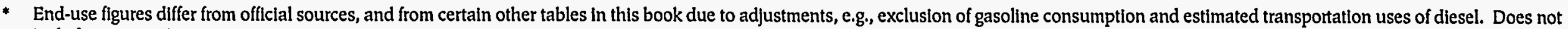
include construction.

$\dagger$ Light and heavy industry subtotals are independent of subsectoral divisions.

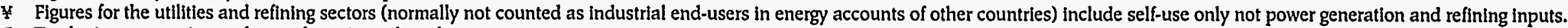

I Total minus extraction and manufacturing subtotals.

$\S$ Unadjusted sum of raw and washed coal.

Source: Energy Research Institute; China Energy Statistical Yearbook, various years; China Statistical Yearbook, various years. 


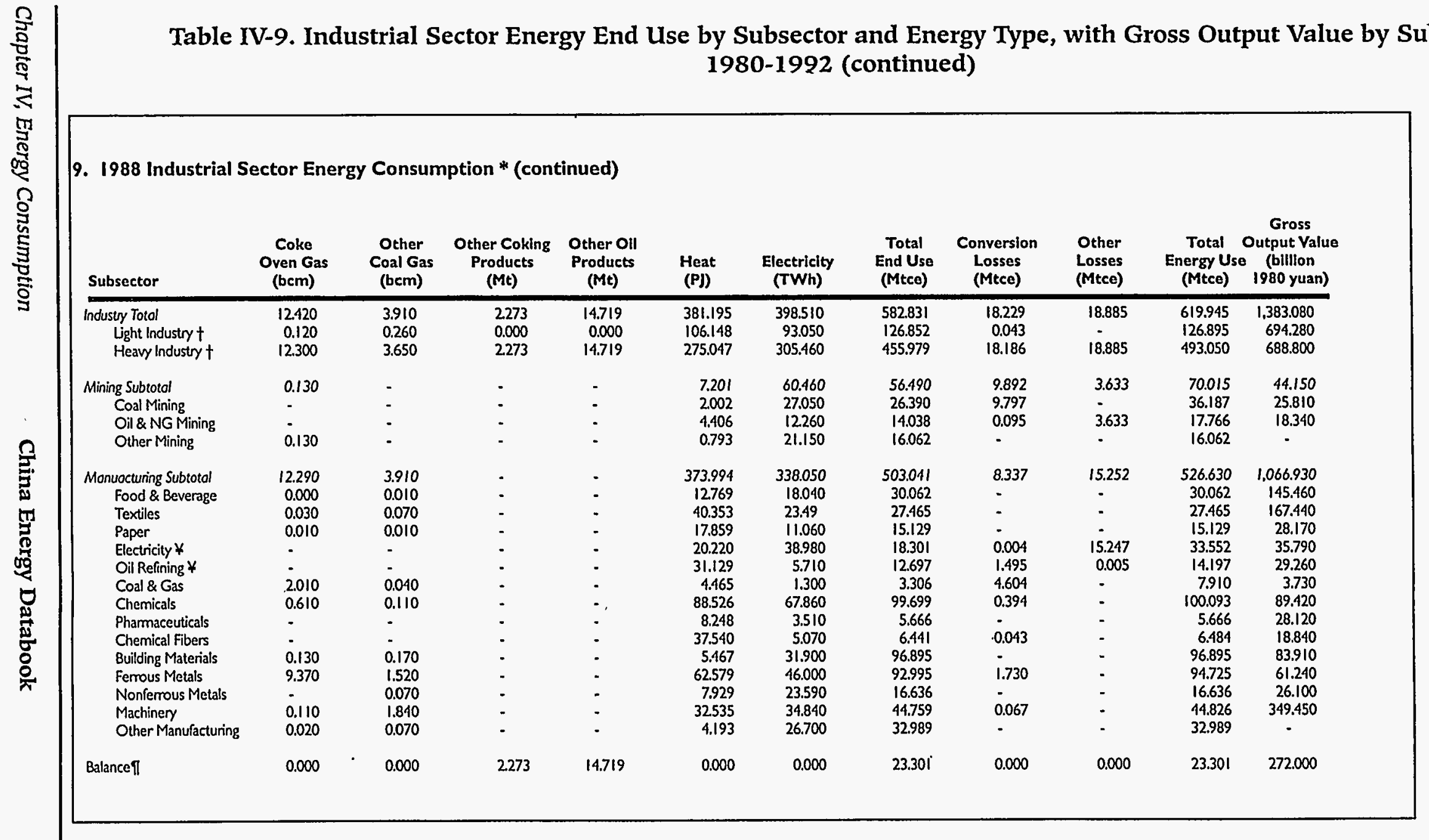

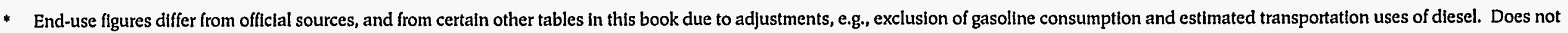
include construction.

$\dagger$ Light and heavy industry subtotals are independent of subsectoral divislons.

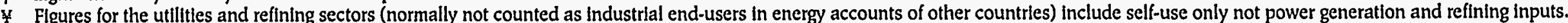

i Total minus extraction and manufacturing subtotals.

$\S$ Unadjusted sum of raw and washed coal

Source: Energy Research Institute; China Energy Statistical Yearbook, various years; China Statistical Yearbook, varlous years. 
Table IV-9. Industrial Sector Energy End Use by Subsector and Energy Type, with Gross Output Value by Subsector, 1980-1990-Mtce (continued)

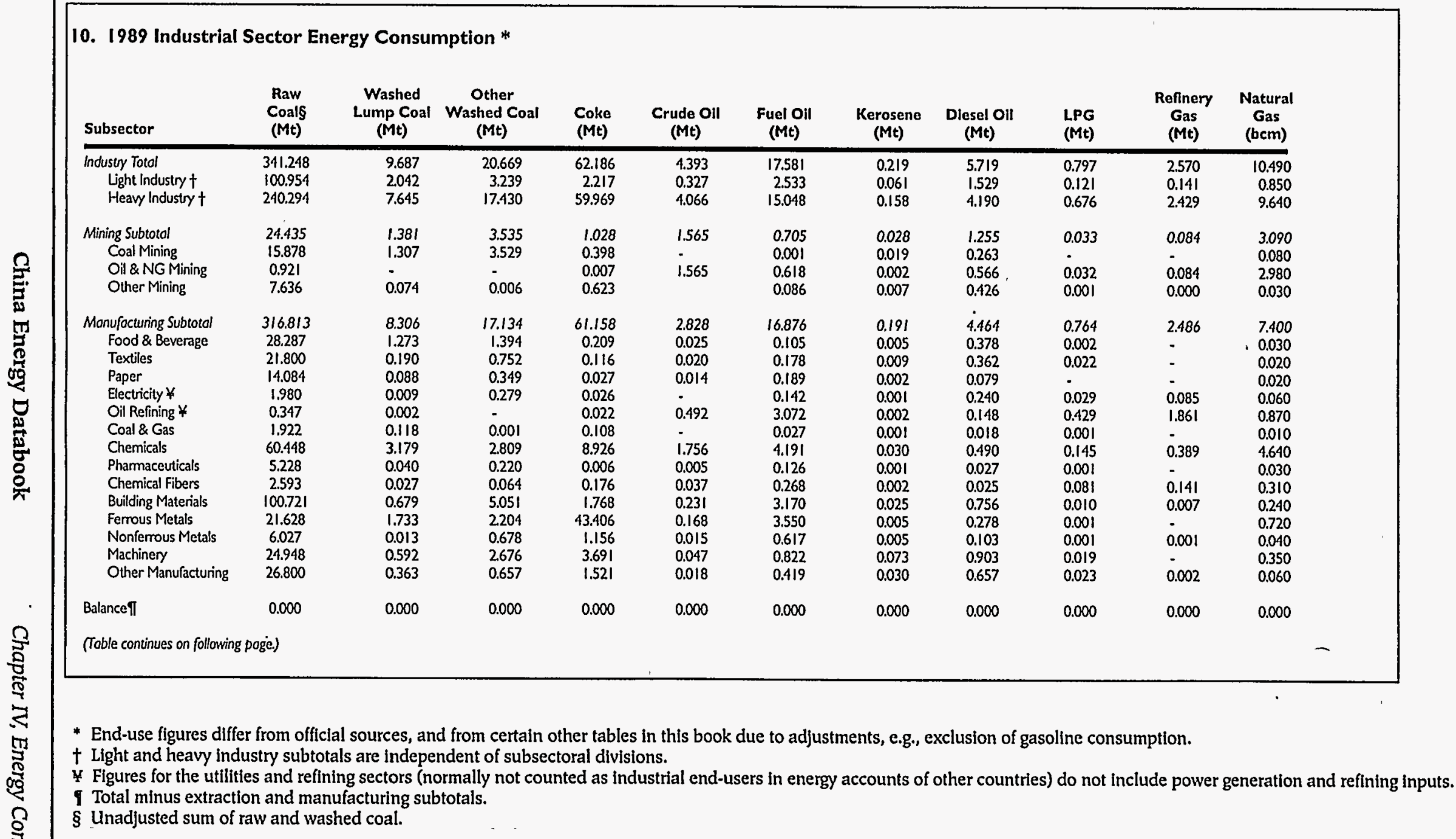

Source: Energy Research Institute; China Energy Statistical Yearbook, various years; China Statistical Yearbook, various years. 


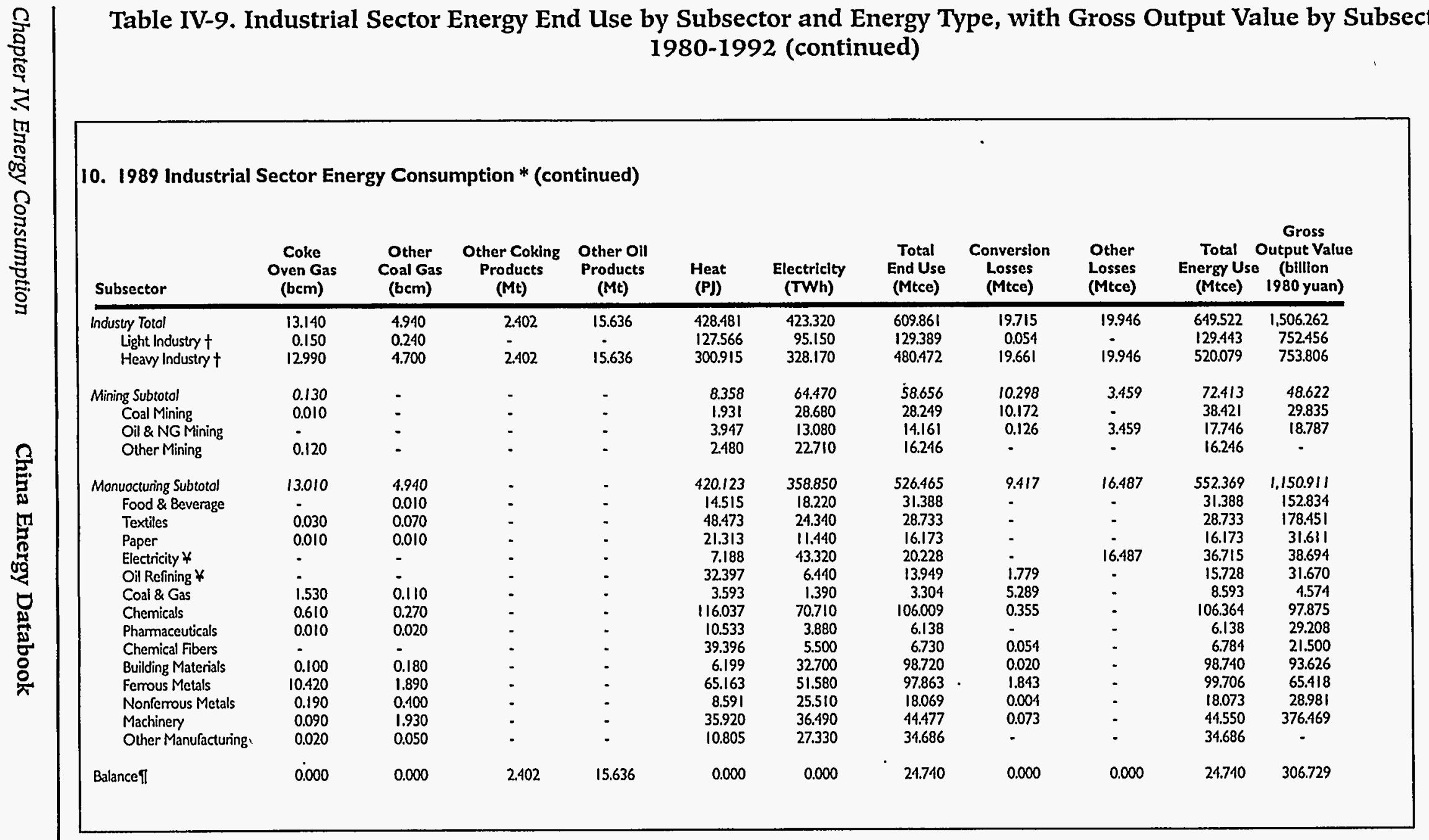

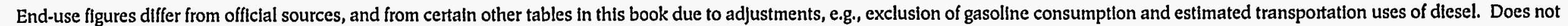
Include construction.

$\dagger$ Light and heavy industry subtotals are independent of subsectoral divisions.

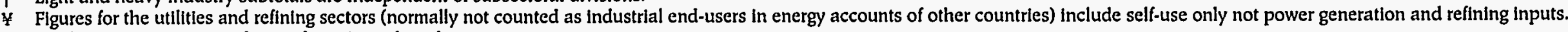

I Total minus extraction and manufacturing subtotals.

$\S$ Unadjusted sum of raw and washed coal.

Source: Energy Research Institute; China Energy Statistical Yearbook, various years; China Statistical Yearbook, varlous years. 
Table IV-9. Industrial Sector Energy End Use by Subsector and Energy Type, with Gross Output Value by Subsector, 1980-1992 (continued)

\begin{tabular}{|c|c|c|c|c|c|c|c|c|c|c|c|}
\hline Subsector & $\begin{array}{l}\text { Raw } \\
\text { Coals } \\
\text { (Mt) }\end{array}$ & $\begin{array}{l}\text { Washed } \\
\text { Lump Coal } \\
\text { (Mt) }\end{array}$ & $\begin{array}{c}\text { Other } \\
\text { Washed Coal } \\
\text { (Mt) }\end{array}$ & $\begin{array}{l}\text { Coke } \\
(M t)\end{array}$ & $\begin{array}{l}\text { Crude Oil } \\
\text { (Mt) }\end{array}$ & $\begin{array}{l}\text { Fuel Oil } \\
\text { (Mt) }\end{array}$ & $\begin{array}{c}\text { Kerosene } \\
(M t)\end{array}$ & $\begin{array}{l}\text { Diesel Oil } \\
\text { (Mt) }\end{array}$ & $\begin{array}{l}\text { LPG } \\
\text { (Mt) }\end{array}$ & $\begin{array}{c}\text { Refinery } \\
\text { Gas } \\
\text { (Mt) }\end{array}$ & $\begin{array}{c}\text { Natural } \\
\text { Gas } \\
\text { (bcm) }\end{array}$ \\
\hline $\begin{array}{l}\text { Industy Total } \\
\text { Light Industry } \dagger \\
\text { Heawy Industry } \dagger\end{array}$ & $\begin{array}{l}331.157 \\
100.149 \\
231.008\end{array}$ & $\begin{array}{l}7.210 \\
0.811 \\
6.399\end{array}$ & $\begin{array}{r}19.371 \\
2.754 \\
16.617\end{array}$ & $\begin{array}{r}67.404 \\
2.049 \\
65.355\end{array}$ & $\begin{array}{l}3.334 \\
0.256 \\
3.078\end{array}$ & $\begin{array}{r}17.665 \\
2.337 \\
15.328\end{array}$ & $\begin{array}{l}0.206 \\
0.057 \\
0.149\end{array}$ & $\begin{array}{l}6.012 \\
1.458 \\
4.554\end{array}$ & $\begin{array}{l}0.779 \\
0.132 \\
0.647\end{array}$ & $\begin{array}{l}2.467 \\
0.190 \\
2.277\end{array}$ & $\begin{array}{r}10.850 \\
0.870 \\
9.980\end{array}$ \\
\hline $\begin{array}{l}\text { Mining Subtotol } \\
\text { Coal Mining } \\
\text { Oil \& NG Mining } \\
\text { Other Mining }\end{array}$ & $\begin{array}{r}23.673 \\
16.281 \\
1.000 \\
6.392\end{array}$ & $\begin{array}{l}1.403 \\
1.341 \\
- \\
0.062\end{array}$ & $\begin{array}{l}3.190 \\
2.925 \\
0.007 \\
0.258\end{array}$ & $\begin{array}{l}1.041 \\
0.379 \\
0.004 \\
0.658\end{array}$ & $\begin{array}{l}1.381 \\
- \\
1.380 \\
0.001\end{array}$ & $\begin{array}{l}0.902 \\
0.001 \\
0.816 \\
0.085\end{array}$ & $\begin{array}{l}0.036 \\
0.027 \\
0.004 \\
0.005\end{array}$ & $\begin{array}{l}1.457 \\
0.277 \\
0.633 \\
0.547\end{array}$ & $\begin{array}{l}0.034 \\
- \\
0.034 \\
0.000\end{array}$ & $\begin{array}{l}0.101 \\
- \\
0.101 \\
0.000\end{array}$ & $\begin{array}{l}3.130 \\
0.070 \\
2.940 \\
0.120\end{array}$ \\
\hline $\begin{array}{l}\text { Monufocturing Subtotol } \\
\text { Food \& Beverage } \\
\text { Textiles } \\
\text { Paper } \\
\text { Electricity } ¥ \\
\text { Oil Refining } ¥ \\
\text { Coal \& Gas } \\
\text { Chemicals } \\
\text { Pharmaceuticals } \\
\text { Chemical Fibers } \\
\text { Building Materials } \\
\text { Ferrous Metals } \\
\text { Nonferrous Metals } \\
\text { Machinery } \\
\text { Other Manufacturing }\end{array}$ & $\begin{array}{c}307.484 \\
28.270 \\
21.535 \\
13.244 \\
2.629 \\
0.488 \\
2.245 \\
59.035 \\
4.812 \\
2.535 \\
93.651 \\
19.424 \\
6.742 \\
24.142 \\
28.732\end{array}$ & $\begin{array}{l}5.807 \\
0.536 \\
0.119 \\
0.041 \\
0.004 \\
- \\
0.181 \\
1.869 \\
0.018 \\
0.002 \\
0.592 \\
1.463 \\
0.091 \\
0.793 \\
0.098\end{array}$ & $\begin{array}{r}16.181 \\
1.632 \\
0.763 \\
0.452 \\
0.089 \\
0.009 \\
0.106 \\
2.027 \\
0.479 \\
0.023 \\
4.785 \\
2.235 \\
0.435 \\
2.158 \\
0.988\end{array}$ & $\begin{array}{r}66.363 \\
0.226 \\
0.107 \\
0.025 \\
0.012 \\
0.011 \\
0.082 \\
9.462 \\
0.031 \\
0.146 \\
1.822 \\
48.097 \\
1.120 \\
3.754 \\
1.468\end{array}$ & $\begin{array}{l}1.953 \\
0.018 \\
0.024 \\
0.012 \\
0.001 \\
0.289 \\
- \\
1.131 \\
0.005 \\
0.054 \\
0.188 \\
0.165 \\
0.001 \\
0.052 \\
0.013\end{array}$ & $\begin{array}{r}16.763 \\
0.112 \\
0.195 \\
0.164 \\
0.041 \\
3.071 \\
0.028 \\
4.208 \\
0.117 \\
0.293 \\
3.114 \\
3.614 \\
0.615 \\
0.772 \\
0.419\end{array}$ & $\begin{array}{l}0.170 \\
0.003 \\
0.007 \\
0.002 \\
0.001 \\
0.001 \\
- \\
0.020 \\
0.002 \\
0.003 \\
0.022 \\
0.004 \\
0.003 \\
0.073 \\
0.029\end{array}$ & $\begin{array}{l}4.555 \\
0.341 \\
0.286 \\
0.080 \\
0.355 \\
0.131 \\
0.031 \\
0.655 \\
0.032 \\
0.023 \\
0.794 \\
0.307 \\
0.099 \\
0.788 \\
0.633\end{array}$ & $\begin{array}{l}0.745 \\
0.001 \\
0.029 \\
- \\
- \\
0.384 \\
0.001 \\
0.181 \\
0.001 \\
0.085 \\
0.010 \\
0.001 \\
0.001 \\
0.025 \\
0.026\end{array}$ & $\begin{array}{l}2.366 \\
- \\
- \\
- \\
- \\
1.817 \\
- \\
0.350 \\
\dot{0} \\
0.189 \\
0.007 \\
- \\
0.001 \\
- \\
0.002\end{array}$ & $\begin{array}{l}7.720 \\
0.030 \\
0.020 \\
0.020 \\
0.020 \\
0.990 \\
0.010 \\
4.850 \\
0.030 \\
0.350 \\
0.260 \\
0.690 \\
0.030 \\
0.370 \\
0.050\end{array}$ \\
\hline Balanceff & 0.000 & 0.000 & 0.000 & 0.000 & 0.000 & 0.000 & 0.000 & 0.000 & 0.000 & 0.000 & 0.000 \\
\hline
\end{tabular}

(Toble continues on following poge.)

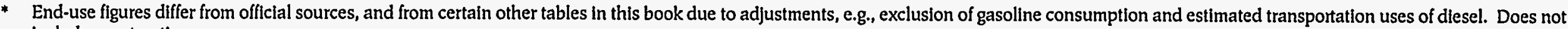
Include construction.

$\dagger$ Light and heavy industry subtotals are independent of subsectoral divisions.

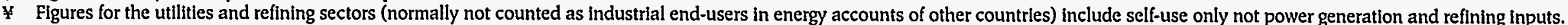

T Total minus extraction and manufacturing subtotals.

\& Unadjusted sum of raw and washed coal.

Source: Energy Research Institute; China Energy Statistical Yearbook, various years; China Statistical Yearbook, various years. 
Table IV-9. Industrial Sector Energy End Use by Subsector and Energy Type, with Gross Output Value by Subsector, 1980-1992 (continued)

11. 1990 Industrial Sector Energy Consumption * (continued)

\begin{tabular}{|c|c|c|c|c|c|c|c|c|c|c|c|}
\hline Subsector & $\begin{array}{c}\text { Coke } \\
\text { Oven Gas } \\
(\mathrm{bcm})\end{array}$ & $\begin{array}{l}\text { Other } \\
\text { Coal Gas } \\
\text { (bcm) }\end{array}$ & $\begin{array}{l}\text { Other Coking } \\
\text { Products } \\
\text { (Mt) }\end{array}$ & $\begin{array}{l}\text { Other Oll } \\
\text { Products } \\
\text { (Mt) }\end{array}$ & $\begin{array}{l}\text { Heat } \\
(\mathrm{PJ})\end{array}$ & $\begin{array}{l}\text { Electricity } \\
\text { (TWh) }\end{array}$ & $\begin{array}{c}\text { Total } \\
\text { End Use } \\
\text { (Mtce) }\end{array}$ & $\begin{array}{l}\text { Conversion } \\
\text { Losses } \\
\text { (Mtce) }\end{array}$ & $\begin{array}{l}\text { Other } \\
\text { Losses } \\
\text { (Mtce) }\end{array}$ & $\begin{array}{c}\text { Total } \\
\text { Energy Use } \\
\text { (Mtce) }\end{array}$ & $\begin{array}{c}\text { Gross } \\
\text { Output Value } \\
\text { (billion } \\
1980 \text { yuan) }\end{array}$ \\
\hline $\begin{array}{l}\text { Industry Totol } \\
\text { Light Industry } \dagger \\
\text { Heavy industry } \dagger\end{array}$ & $\begin{array}{r}13.590 \\
0.200 \\
13.390\end{array}$ & $\begin{array}{l}4.790 \\
0.330 \\
4.460\end{array}$ & $\begin{array}{l}2.678 \\
\dot{2} .678\end{array}$ & $\begin{array}{l}|5.45| \\
- \\
|5.45|\end{array}$ & $\begin{array}{l}514.167 \\
155.304 \\
358.863\end{array}$ & $\begin{array}{r}443.870 \\
99.580 \\
344.290\end{array}$ & $\begin{array}{l}614.630 \\
129.422 \\
485.208\end{array}$ & $\begin{array}{r}22.638 \\
0.044 \\
22.594\end{array}$ & $\begin{array}{c}20.748 \\
- \\
20.748\end{array}$ & $\begin{array}{l}658.016 \\
129.466 \\
528.550\end{array}$ & $\begin{array}{r}1,570.197 \\
795.597 \\
774.600\end{array}$ \\
\hline $\begin{array}{l}\text { Mining Subtotol } \\
\text { Coal Mining } \\
\text { Oil \& NG Mining } \\
\text { Other Mining }\end{array}$ & $\begin{array}{l}0.110 \\
- \\
0.110\end{array}$ & $\begin{array}{l}- \\
- \\
-\end{array}$ & $\dot{-}$ & $\dot{:}$ & $\begin{array}{l}9.086 \\
1.501 \\
3.403 \\
4.182\end{array}$ & $\begin{array}{l}67.510 \\
29.960 \\
14.460 \\
23.090\end{array}$ & $\begin{array}{l}59.477 \\
28.523 \\
14.859 \\
16.096\end{array}$ & $\begin{array}{r}13.605 \\
12.981 \\
0.624 \\
0.000\end{array}$ & $\begin{array}{l}3.290 \\
- \\
3.290 \\
0.000\end{array}$ & $\begin{array}{l}76.372 \\
41.504 \\
18.773 \\
16.096\end{array}$ & $\begin{array}{l}49.940 \\
30.488 \\
19.452 \\
-\end{array}$ \\
\hline $\begin{array}{l}\text { Manuacturing Subtotol } \\
\text { Food \& Beverage } \\
\text { Textiles } \\
\text { Paper } \\
\text { Electricity } ¥ \\
\text { Oil Refining } * \\
\text { Coal \& Gas } \\
\text { Chemicals } \\
\text { Pharmaceuticals } \\
\text { Chemical Fibers } \\
\text { Building Materials } \\
\text { Ferrous Metals } \\
\text { Nonferrous Metals } \\
\text { Machinery } \\
\text { Other Manufacturing }\end{array}$ & $\begin{array}{l}13.480 \\
\dot{0.030} \\
- \\
\cdot \\
\dot{-} .870 \\
0.600 \\
0.010 \\
\dot{0} \\
0.160 \\
10.680 \\
.0 .100 \\
0.030\end{array}$ & $\begin{array}{l}4.790 \\
0.010 \\
0.070 \\
0.010 \\
- \\
- \\
0.470 \\
0.280 \\
- \\
- \\
0.180 \\
1.510 \\
0.420 \\
1.760 \\
0.080\end{array}$ & $\begin{array}{l}: \\
: \\
: \\
: \\
: \\
: \\
: \\
- \\
: \\
:\end{array}$ & $\begin{array}{l}: \\
- \\
: \\
- \\
: \\
- \\
: \\
: \\
- \\
-\end{array}$ & $\begin{array}{r}505.081 \\
22.615 \\
54.157 \\
29.519 \\
13.499 \\
43.704 \\
3.695 \\
144.531 \\
12.396 \\
38.109 \\
4.749 \\
78.061 \\
9.067 \\
38.227 \\
12.752\end{array}$ & $\begin{array}{r}376.360 \\
18.230 \\
24.660 \\
11.980 \\
45.310 \\
7.150 \\
1.590 \\
73.510 \\
4.230 \\
5.920 \\
33.080 \\
55.570 \\
26.990 \\
36.600 \\
31.540\end{array}$ & $\begin{array}{r}530.401 \\
31.126 \\
28.705 \\
16.037 \\
21.279 \\
14.360 \\
4.174 \\
105.241 \\
6.258 \\
6.926 \\
93.487 \\
102.642 \\
18.862 \\
43.502 \\
37.803\end{array}$ & $\begin{array}{l}9.033 \\
- \\
- \\
- \\
2.186 \\
3.755 \\
0.591 \\
- \\
0.031 \\
0.043 \\
2.332 \\
-0.095 \\
-\end{array}$ & $\begin{array}{l}17.458 \\
: \\
: \\
17.396 \\
0.009 \\
0.053 \\
- \\
: \\
: \\
: \\
- \\
-\end{array}$ & $\begin{array}{r}556.892 \\
31.126 \\
28.705 \\
16.037 \\
38.675 \\
16.555 \\
7.982 \\
105.832 \\
6.258 \\
6.957 \\
93.530 \\
104.974 \\
18.862 \\
43.597 \\
37.803\end{array}$ & $\begin{array}{r}1.196 .108 \\
160.635 \\
185.530 \\
32.903 \\
41.581 \\
32.908 \\
5.305 \\
107.062 \\
33.546 \\
25.724 \\
90.536 \\
68.544 \\
29.891 \\
381.943 \\
-\end{array}$ \\
\hline Balance I & 0.000 & 0.000 & 2.678 & $|5.45|$ & 0.000 & 0.000 & 24.751 & 0.000 & 0.000 & 24.751 & 324.849 \\
\hline
\end{tabular}

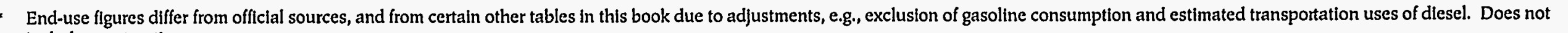
include constructlon.

t Light and heavy industry subtotals are independent of subsectoral divisions.

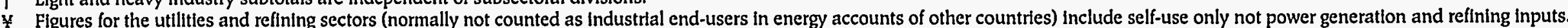

I Total minus extraction and manufacturing subtotals.

$\S$ Unadjusted sum of raw and washed coal.

Source: Energy Research Institute; China Energy Statistical Yearbook, varlous years; China Statistical Yearbook, various years. 
Table IV-9. Industrial Sector Energy End Use by Subsector and Energy Type, with Gross Output Value by Subsector, 1980-1992 (continued)

\section{1991 Industrial Sector Energy Consumption *}

Subsector
Industry Total
Light Industry $\dagger$
Heavy Industry $\dagger$
Mining Subtotol
Coal Mining
Oil \& NG Mining
Other Mining
Manufocturing Subtotol

Textiles

Paper

Electricity $*$

Coal \& Gas

Chemicals

Pharmaceuticals

Chemical Fibers

Building Materials

errous Metals

Nonferrous Metals

Machinery

Other Manufacturing

Balance

\begin{tabular}{lcc}
$\begin{array}{l}\text { Total } \\
\text { Coals } \\
\text { (Mt) }\end{array}$ & $\begin{array}{c}\text { Washed } \\
\text { Lump Coal } \\
\text { (Mt) }\end{array}$ & $\begin{array}{c}\text { Other } \\
\text { Washed Coal } \\
\text { (Mt) }\end{array}$ \\
\hline 376.798 & - & -
\end{tabular}

376.798 - $\quad$ - $\quad 69.711$

108.190
268.608

2.08

$30.859 \quad-\quad \quad \quad-\quad 1.148$

22.708

1.441
6.710

1.148
0.379

0.379
0.005
0.764

$\begin{array}{rrrr}345.938 & - & - & 68.563 \\ 31254 & - & - & 0.262\end{array}$

68.563
.0 .262
0.113

31.254
22.579

$\begin{array}{llll}22.579 & - & - & 0.113 \\ 14.197 & - & - & 0.026 \\ 3.266 & - & - & 0.009\end{array}$

3.266

0.663

2.169
66693

66.693

2.925

102.576

25.062

7.815

7.815
27.248

33.412

0.026
0.009

0.009

0.010
0.076

9.512
0.006

0.006

0.171

1.822
50.071
1.239

50.071
1.239
3.676

3.676

0.000

0.000

(Toble continues on following page.)

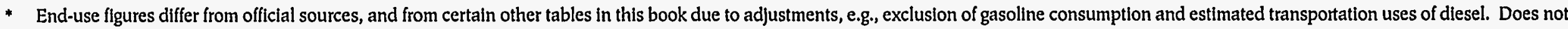
include construction.

$\dagger$ Light and heavy industry subtotals are independent of subsectoral divisions.

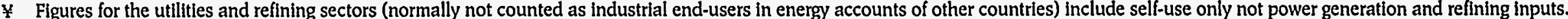

Total minus extraction and manufacturing subtotals.

$\S$ - Unadjusted sum of raw and washed coal.

Source: Energy Research Institute; China Energy Statistical Yearbook, various years; China Statistical Yearbook, various years. 


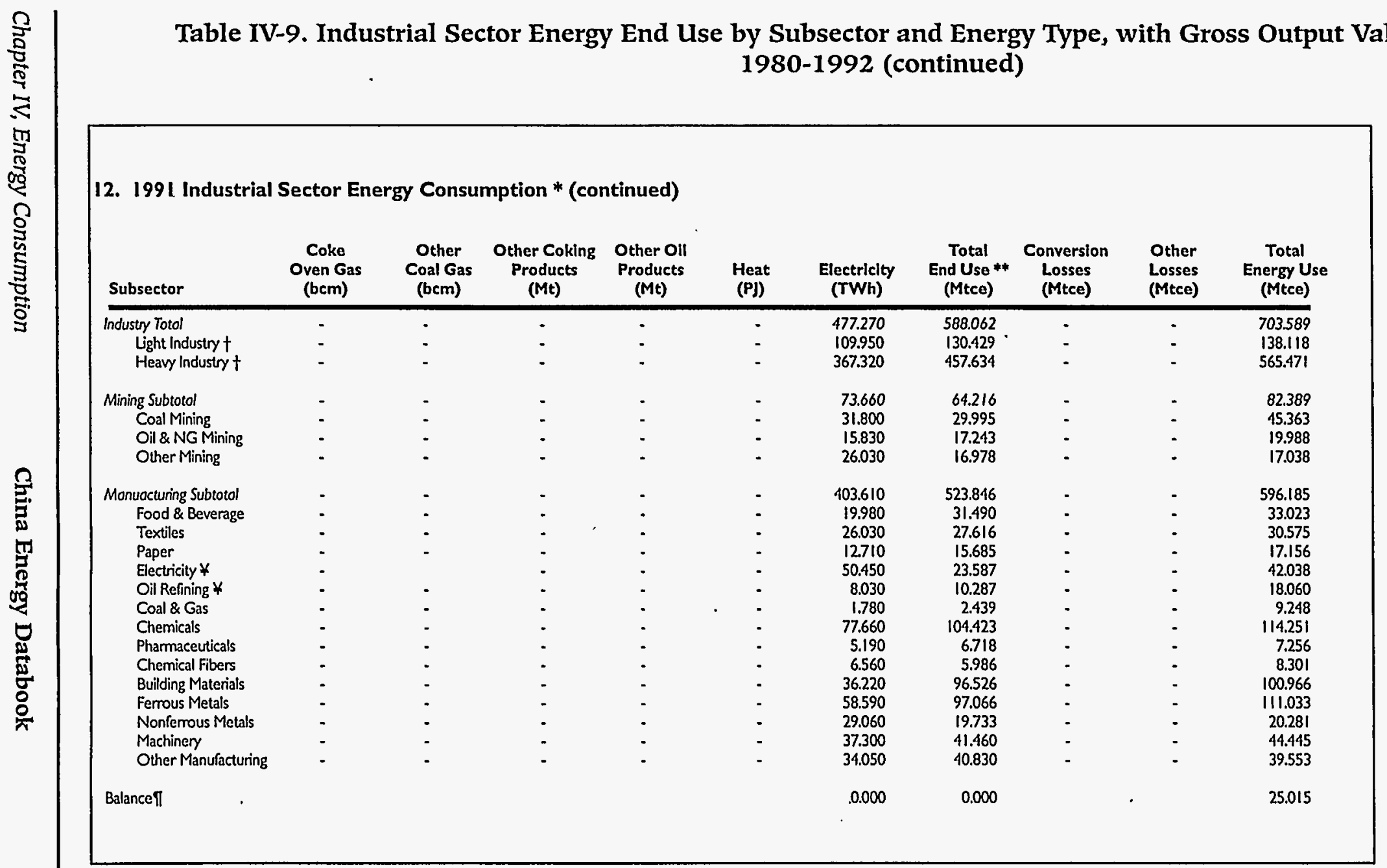

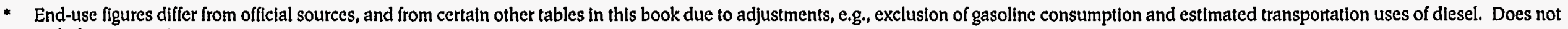
include construction.

$\dagger$ Light and heavy industry subtotals are independent of subsectoral divisions.

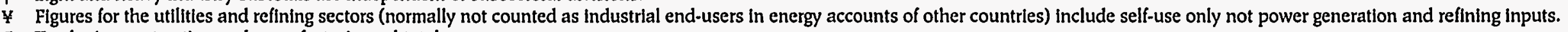

I Total minus extraction and manufacturing subtotals.

$\S$ Unadjusted sum of raw and washed coal.

** Incomplete. Does not include LPG, refinery gaqs, coke oven gas, other coal gas, other coking and oll products, and heat.

Source: Energy Research Institute; China Energy Statistical Yearbook, various years; China Statistical Yearbook, varlous years. 
Table IV-9. Industrial Sector Energy End Use by Subsector and Energy Type, with Gross Output Value by Subsector, 1980-1992 (continued)

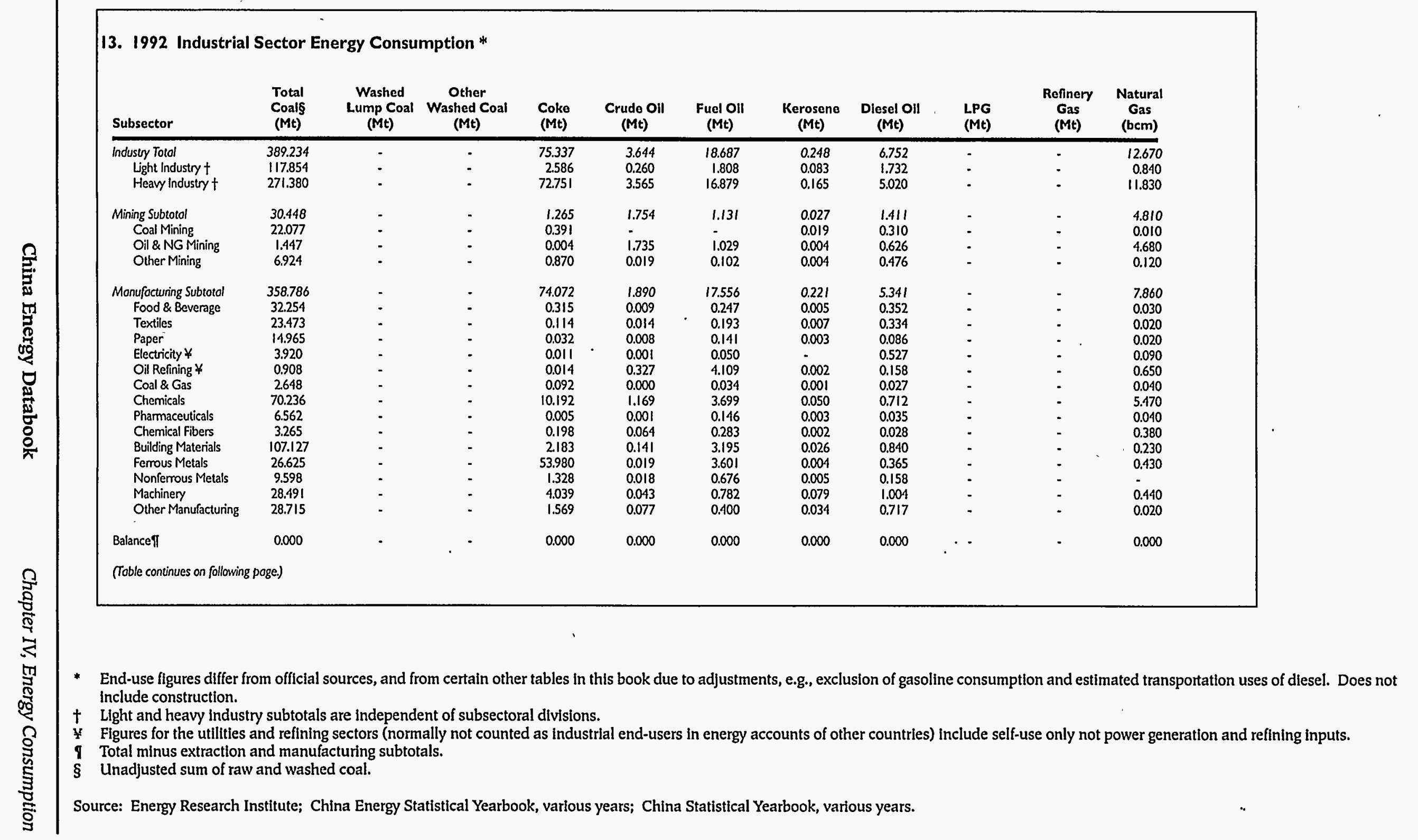


Table IV-9. Industrial Sector Energy End Use by Subsector and Energy Type, with Gross Output Value by Subsector, 1980-1990-Mtce (continued)

\section{1992 Industrial Sector Energy Consumption * (continued)}

\begin{tabular}{|c|c|c|c|c|c|c|c|c|c|c|}
\hline Subsector & $\begin{array}{c}\text { Coke } \\
\text { Oven Gas } \\
\text { (bcm) }\end{array}$ & $\begin{array}{l}\text { Other } \\
\text { Coal Gas } \\
\text { (bcm) }\end{array}$ & $\begin{array}{l}\text { Other Coking } \\
\text { Products } \\
\text { (Mt) }\end{array}$ & $\begin{array}{l}\text { Other Oll } \\
\text { Products } \\
\text { (Mt) }\end{array}$ & $\begin{array}{l}\text { Heat } \\
\text { (PJ) }\end{array}$ & $\begin{array}{l}\text { Electricity } \\
\text { (TWh) }\end{array}$ & $\begin{array}{c}\text { Total } \\
\text { End Use } \\
\text { (Mtce) }\end{array}$ & $\begin{array}{c}\text { Conversion } \\
\text { Losses } \\
\text { (Mtce) }\end{array}$ & $\begin{array}{l}\text { Other } \\
\text { Losses } \\
\text { (Mtce) }\end{array}$ & $\begin{array}{l}\text { Total } \\
\text { Energy Use } \\
\text { (Mtce) }\end{array}$ \\
\hline $\begin{array}{l}\text { Industry Totol } \\
\text { Light Industry } \dagger \\
\text { Heovy Industry } t\end{array}$ & $\dot{-}$ & $\dot{-}$ & $\vdots$ & $\dot{-}$ & $\dot{-}$ & $\begin{array}{l}528.440 \\
120.820 \\
407.620\end{array}$ & $\begin{array}{l}623.658 \\
142.223 \\
481.694\end{array}$ & 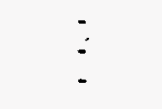 & $\dot{-}$ & $\begin{array}{l}751.628 \\
152.963 \\
598.664\end{array}$ \\
\hline $\begin{array}{l}\text { Mining Subtotol } \\
\text { Coal Mining } \\
\text { Oil \& NG Mining } \\
\text { Other Mining }\end{array}$ & $\begin{array}{l}- \\
- \\
-\end{array}$ & $\begin{array}{l}- \\
-\end{array}$ & $\vdots$ & : & $:$ & $\begin{array}{l}79.960 \\
34.600 \\
17.080 \\
28.280\end{array}$ & $\begin{array}{l}67.895 \\
30.620 \\
19.027 \\
18.248\end{array}$ & $:$ & $\dot{-}$ & $\begin{array}{l}83.237 \\
43.442 \\
21.559 \\
18.236\end{array}$ \\
\hline $\begin{array}{l}\text { Monuocturing Subtotol } \\
\text { Food \& Beverage } \\
\text { Textiles } \\
\text { Paper } \\
\text { Electricity } ¥ \\
\text { Oil Refining } ¥ \\
\text { Coal \& Gas } \\
\text { Chemicals } \\
\text { Pharmaceuticals } \\
\text { Chemical Fibers } \\
\text { Building Materials } \\
\text { Ferrous Metals } \\
\text { Nonferrous Metals } \\
\text { Machinery } \\
\text { Other Manufacturing }\end{array}$ & 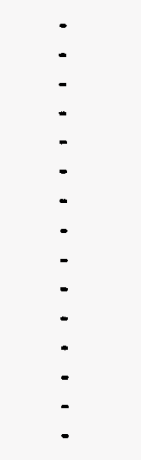 & $\begin{array}{l}: \\
: \\
- \\
: \\
- \\
: \\
: \\
: \\
: \\
: \\
-\end{array}$ & $\begin{array}{l}- \\
: \\
- \\
\cdot \\
- \\
: \\
- \\
- \\
- \\
- \\
-\end{array}$ & $\begin{array}{l}- \\
- \\
- \\
- \\
- \\
: \\
- \\
- \\
: \\
: \\
-\end{array}$ & $\begin{array}{l}: \\
: \\
: \\
: \\
: \\
: \\
- \\
: \\
- \\
- \\
-\end{array}$ & $\begin{array}{r}448.480 \\
21.840 \\
28.010 \\
13.970 \\
59.360 \\
10.320 \\
2.110 \\
81.420 \\
5.690 \\
7.090 \\
41.720 \\
65.740 \\
31.870 \\
41.740 \\
37.600\end{array}$ & $\begin{array}{r}555.762 \\
33.094 \\
29.013 \\
16.734 \\
27.752 \\
12.266 \\
2.975 \\
108.305 \\
7.310 \\
6.433 \\
101.830 \\
104.293 \\
22.251 \\
44.480 \\
39.029\end{array}$ & $\begin{array}{l}- \\
- \\
- \\
- \\
- \\
- \\
- \\
- \\
- \\
- \\
-\end{array}$ & $\begin{array}{l}- \\
: \\
- \\
- \\
- \\
- \\
- \\
- \\
- \\
-\end{array}$ & $\begin{array}{r}641.744 \\
35.010 \\
32609 \\
18.729 \\
49.034 \\
22.045 \\
9.761 \\
119.038 \\
7.884 \\
9.260 \\
108.007 \\
118.687 \\
22.750 \\
48.109 \\
40.823\end{array}$ \\
\hline Balance II & - & - & - & - & - & 0.000 & 0.000 & - & - & 26.647 \\
\hline
\end{tabular}

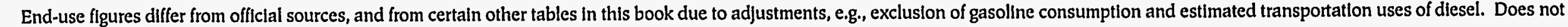
include construction.

$\dagger \quad$ Light and heavy industry subtotals are Independent of subsectoral divisions.

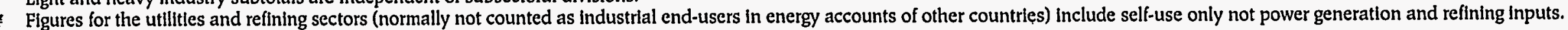

Total minus extraction and manufacturing subtotals.

Unadjusted sum of raw and washed coal.

** Incomplete. Does not include LPG, refinery gaqs, coke oven gas, other coal gas, other coking and oil products, and heat.

Source: Energy Research Institute; ChIna Energy Statistical Yearbook, various years; China Statistical Yearbook, various years. 
Figure IV-9. Subsectoral Shares of Industrial Sector, End-Use Energy Consumption

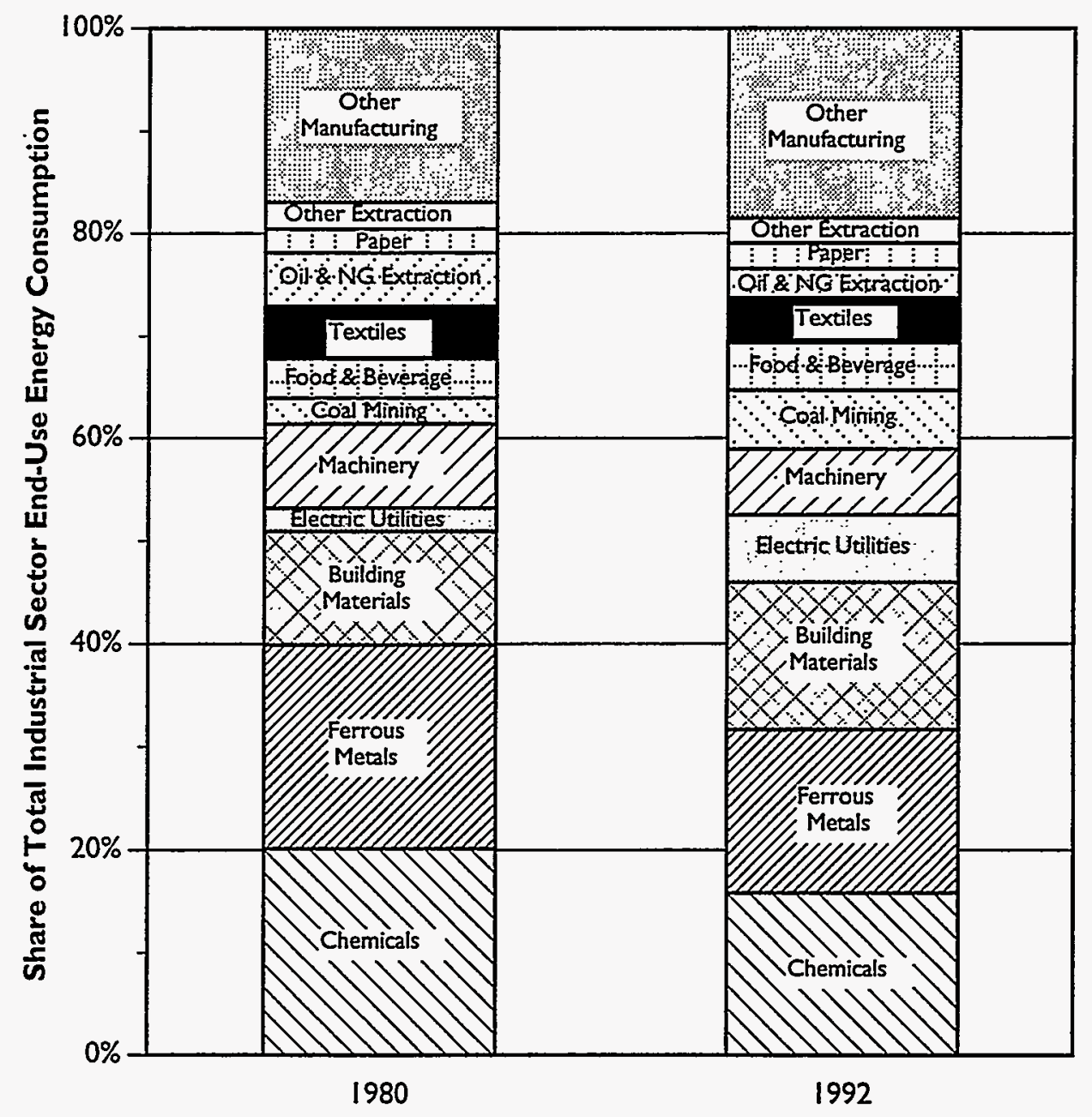




\section{Table IV-10. Industrial Sector * Commercial Energy Consumption by Province and Energy Source, 1990}

\begin{tabular}{|c|c|c|c|c|c|}
\hline $\begin{array}{c}\text { Planning } \\
\text { Region }\end{array}$ & Province & $\begin{array}{c}\text { Coal } \dagger \\
\text { (Mt) }\end{array}$ & $\begin{array}{l}\text { Oil } \\
\text { Products } t \\
\text { (Mt) }\end{array}$ & $\begin{array}{c}\text { Electricity II } \\
\text { (TWh) }\end{array}$ & $\begin{array}{l}\text { Total } \\
\text { Energy } ¥ \\
\text { (Mtce) }\end{array}$ \\
\hline North & $\begin{array}{l}\text { Beijing } \\
\text { Tianjin } \\
\text { Hebei } \\
\text { Shanxi } \\
\text { Inner Mongolia }\end{array}$ & $\begin{array}{l}16.21 \\
12.18 \\
60.35 \\
64.91 \\
29.33\end{array}$ & $\begin{array}{l}4.0460 \\
3.1926 \\
1.8635 \\
0.6057 \\
0.4853\end{array}$ & $\begin{array}{r}12.240 \\
9.778 \\
27.006 \\
21.033 \\
9.528 \\
\end{array}$ & $\begin{array}{l}16.86 \\
13.56 \\
41.70 \\
34.85 \\
15.61\end{array}$ \\
\hline Northeast & $\begin{array}{l}\text { Liaoning } \\
\text { Jilin } \\
\text { Heilongjiang } \\
\end{array}$ & $\begin{array}{l}65.85 \\
28.05 \\
48.60 \\
\end{array}$ & $\begin{array}{l}9.9006 \\
2.8625 \\
5.1699\end{array}$ & $\begin{array}{l}38.556 \\
15.059 \\
21.764 \\
\end{array}$ & $\begin{array}{l}58.78 \\
22.82 \\
31.80 \\
\end{array}$ \\
\hline$\overline{\text { Eost }}$ & $\begin{array}{l}\text { Shanghai } \\
\text { jiangsu } \\
\text { Zhejiang } \\
\text { Anhui } \\
\text { Fujian } \\
\text { Jiangxi } \\
\text { Shandong } \\
\end{array}$ & $\begin{array}{l}24.80 \\
52.86 \\
21.45 \\
28.63 \\
10.36 \\
18.53 \\
57.53 \\
\end{array}$ & $\begin{array}{l}5.6312 \\
4.9279 \\
1.5681 \\
1.4301 \\
0.2845 \\
0.6296 \\
7.1751 \\
\end{array}$ & $\begin{array}{r}22.097 \\
32.017 \\
17.901 \\
14.558 \\
9.771 \\
9.905 \\
35.325 \\
\end{array}$ & $\begin{array}{r}24.45 \\
41.65 \\
18.97 \\
20.70 \\
9.71 \\
12.64 \\
48.54\end{array}$ \\
\hline South-Central & $\begin{array}{l}\text { Henan } \\
\text { Hubei } \\
\text { Hunan } \\
\text { Guangdong } \\
\text { Guangxi } \\
\text { Hainan }\end{array}$ & $\begin{array}{r}43.83 \\
26.63 \\
29.78 \\
25.88 \\
13.87 \\
0.53 \\
\end{array}$ & $\begin{array}{l}1.1595 \\
3.3306 \\
1.5771 \\
6.7096 \\
0.3596 \\
0.0489\end{array}$ & $\begin{array}{r}26.950 \\
22.384 \\
18.055 \\
26.666 \\
9.630 \\
0.818 \\
\end{array}$ & $\begin{array}{r}33.25 \\
29.83 \\
27.52 \\
28.54 \\
10.00 \\
0.52 \\
\end{array}$ \\
\hline Southwest & $\begin{array}{l}\text { Sichuan } \\
\text { Guizhou } \\
\text { Yunnan } \\
\text { Xizang }\end{array}$ & $\begin{array}{c}44.53 \\
17.12 \\
16.36 \\
- \\
\end{array}$ & $\begin{array}{l}0.5523 \\
0.1627 \\
0.2109 \\
-\end{array}$ & $\begin{array}{r}27.382 \\
8.340 \\
9.714 \\
0.035 \\
\end{array}$ & $\begin{array}{r}42.17 \\
12.20 \\
13.46 \\
-\end{array}$ \\
\hline Northwest & $\begin{array}{l}\text { Shaanxi } \\
\text { Gansu } \\
\text { Qinghai } \\
\text { Ningxia } \\
\text { Xinilang } \\
\end{array}$ & $\begin{array}{r}19.85 \\
11.58 \\
3.46 \\
7.04 \\
10.76 \\
\end{array}$ & $\begin{array}{l}0.6895 \\
1.9711 \\
0.3594 \\
0.2997 \\
2.1428 \\
\end{array}$ & $\begin{array}{r}12.607 \\
14.267 \\
3.780 \\
4.608 \\
4.906 \\
\end{array}$ & $\begin{array}{r}14.29 \\
14.41 \\
3.72 \\
5.17 \\
11.54 \\
\end{array}$ \\
\hline $\begin{array}{l}\text { National Total } \\
\text { Bolance ** }\end{array}$ & & $\begin{array}{r}810.91 \\
0.05\end{array}$ & $\begin{array}{r}73.2160 \\
3.8697\end{array}$ & $\begin{array}{r}487.330 \\
0.650\end{array}$ & $\begin{array}{r}675.78 \\
16.52\end{array}$ \\
\hline
\end{tabular}

* Excludes enterprises below the village level. Chinese statistics for the industrial sector include the electric power subsector and the coke, coal gas, and other coal products subsector.

$\dagger$ Includes fossil fuels used in electricity generation, coking, coal gas production, and production.of other coal products.

I Includes electricity from both hydro and thermal generation. Includes electric power subsector and coal products subsector consumption of electricity.

¥ Total energy consumption in industry figures are as reported in the China Energy Statistical Yearbook and the China Statistical Yearbook, and include inputs to secondary conversions (e.g. electricity generation). The total end use cannot be reliably calculated from these totals, nor from the fuel subtotals reported in the Energy Statistical Yearbook because of double counting due to: inclusion of power generation in the coal subtotal; inclusion of consumption of thermal electricity in the electricity consumption subtotal; and exclusion of natural gas consumption.

** Because of differences in the coverage of statistics and conversions to standard coal, the sums of local statistics do not equal the national total.

Source: China Energy Statistical Yearbook, 1991. 


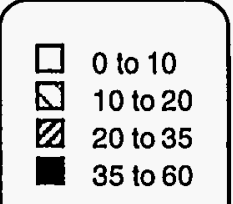

D 10 to 20

20 to 35
35 to 60

(Mtce)

Map IV - 4. Industrial Sector

Energy Consumption, 1990
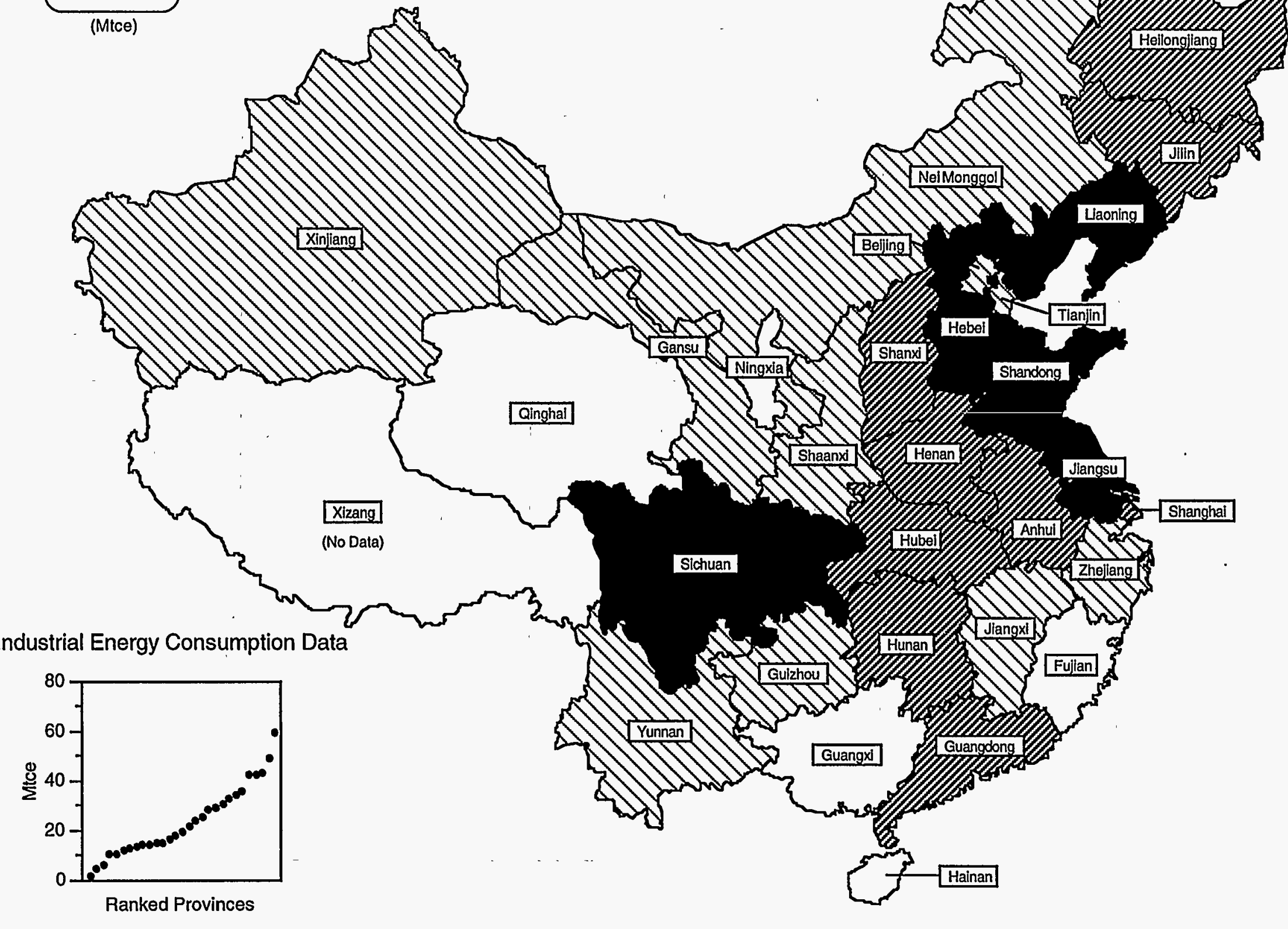

Qinghal

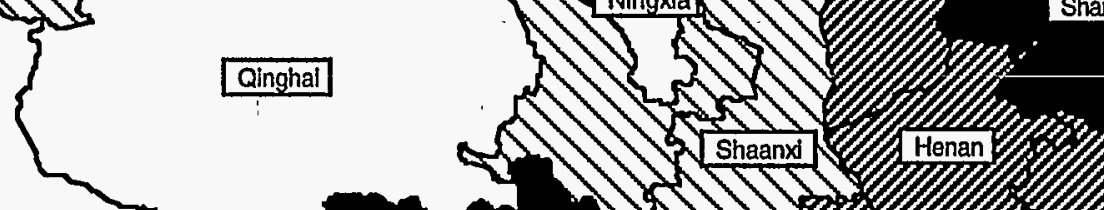

S1 Hangu

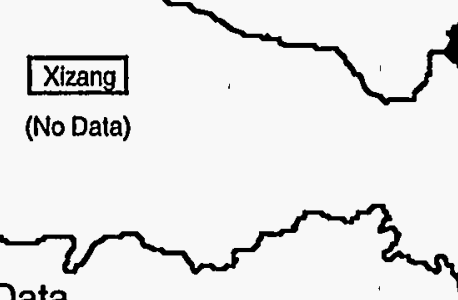

Industrial Energy Consumption Data

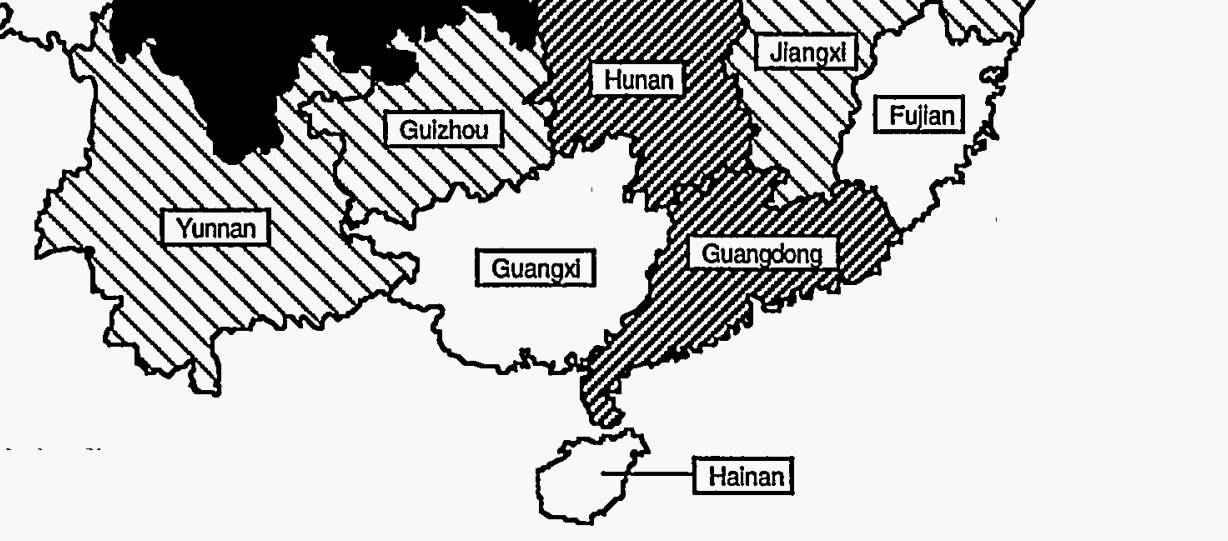


Map IV-5. Industrial Sector

(Mit)

Coal Consumption, 1990

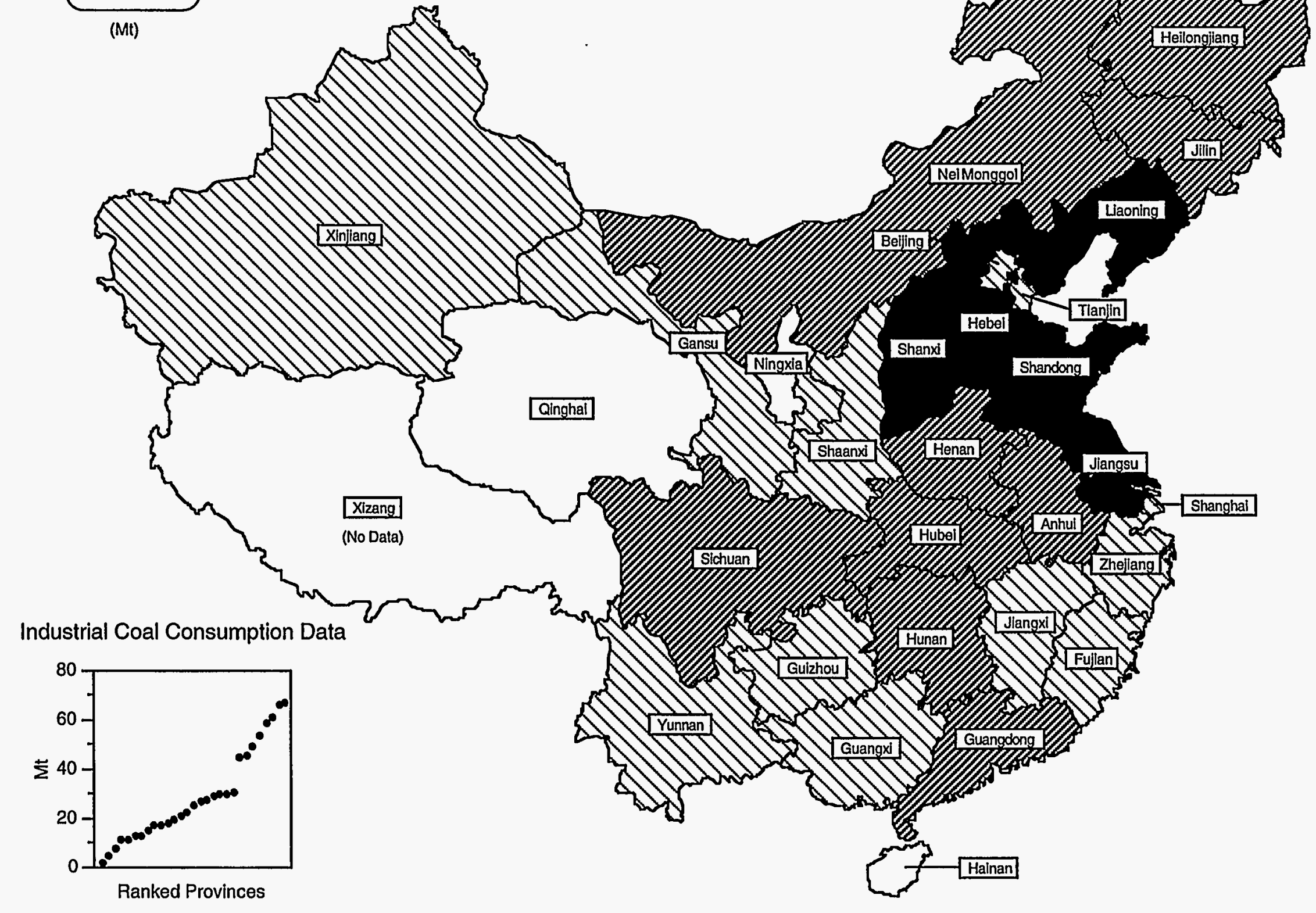




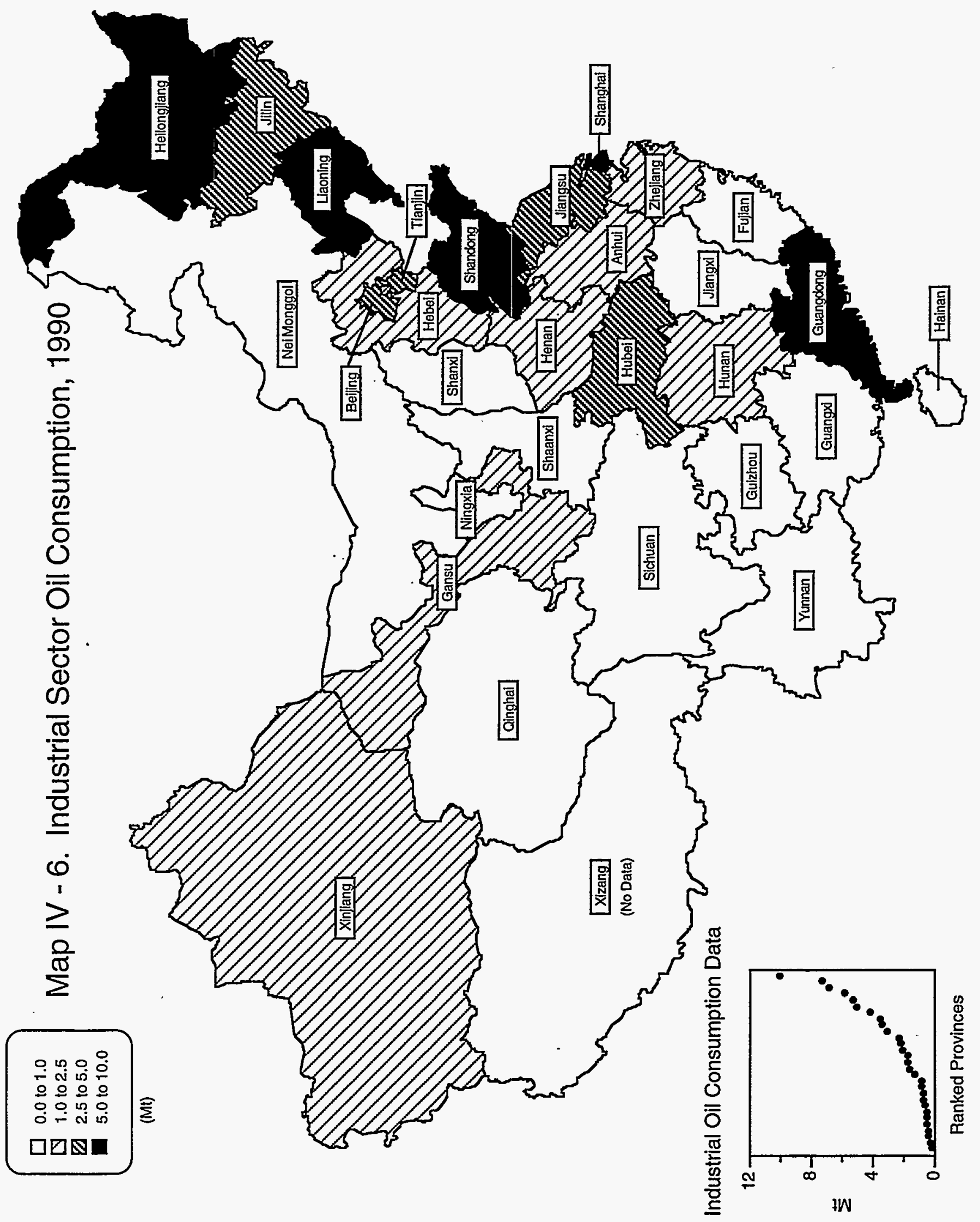


$(\mathrm{TWh})$

Electricity Consumption, 1990

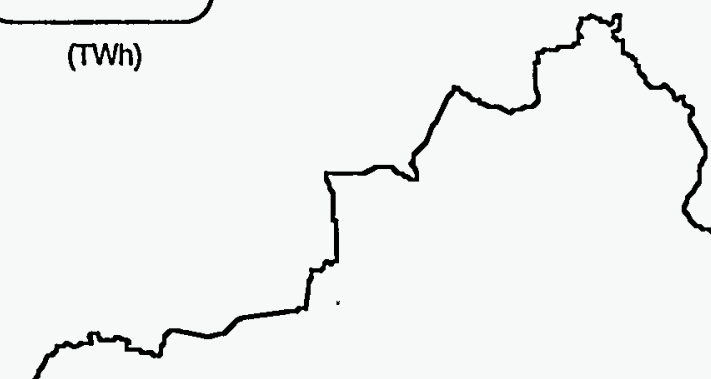

Industrial Electricity Consumption Data
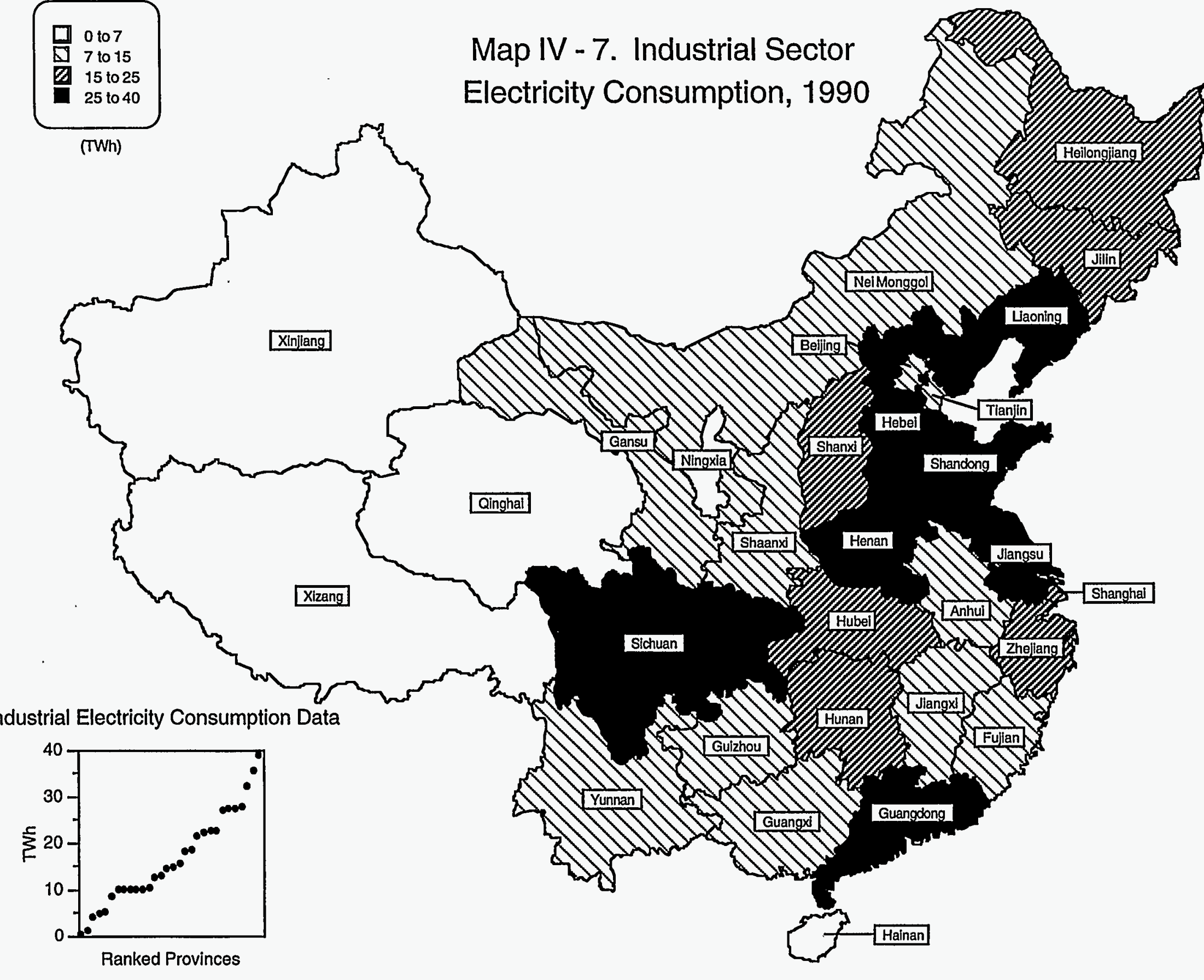

Qinghai

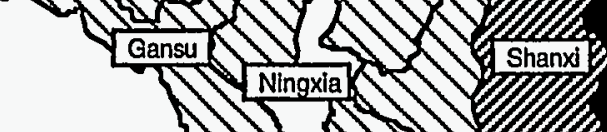

Shandong
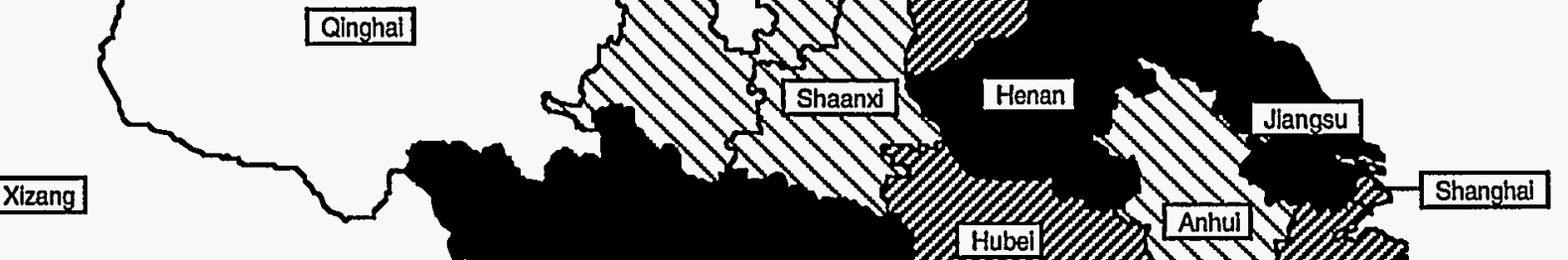

\section{Sichuan}
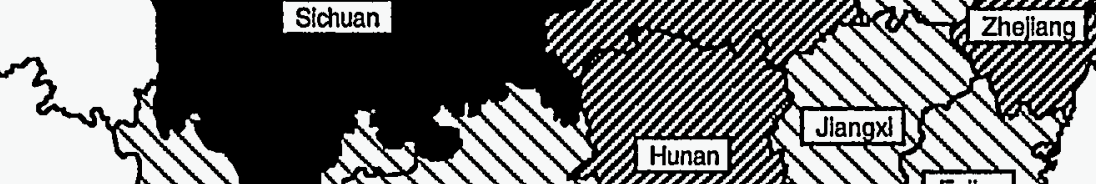

H

Jiangxi 15

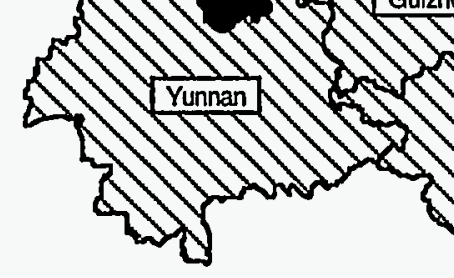

Fuian

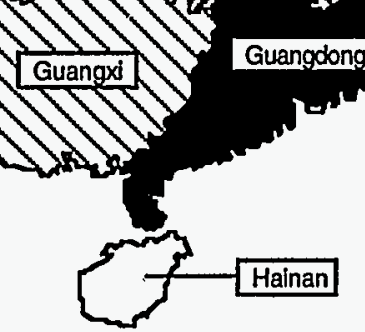


Table IV-11. Energy Used as Feedstocks, 1980-1991-Mtce

\begin{tabular}{|c|c|c|c|c|c|c|c|c|c|}
\hline Year & Coal & Coke & $\begin{array}{l}\text { Crude } \\
\text { Oil * }\end{array}$ & $\begin{array}{c}\text { Heavy } \\
\text { Oil * }\end{array}$ & $\begin{array}{c}\text { Natural } \\
\text { Gas }\end{array}$ & Subtotal & $\begin{array}{c}\text { Other } \\
\text { Coking } \\
\text { Products }+\end{array}$ & $\begin{array}{c}\text { Other } \\
\text { Petroleum } \\
\text { Productst } 7\end{array}$ & $\begin{array}{c}\text { Total } \\
\text { Feedstocks }\end{array}$ \\
\hline 1980 & 17.76 & 6.49 & 0.88 & 1.33 & 4.62 & 31.08 & 2.26 & 16.00 & 49.34 \\
\hline 1981 & 13.82 & 6.85 & 0.70 & 1.38 & 4.80 & 27.55 & 2.03 & 15.68 & 45.25 \\
\hline 1982 & 12.46 & 6.76 & 0.72 & 1.50 & 4.52 & 25.96 & 2.09 & 16.33 & 44.38 \\
\hline 1983 & 15.23 & 6.57 & 0.80 & 1.86 & 4.20 & 28.66 & 2.20 & 16.56 & 47.41 \\
\hline 1984 & 16.17 & 6.22 & 0.56 & 3.64 & 5.45 & 3204 & 2.37 & 18.06 & 52.47 \\
\hline 1985 & 1210 & 5.47 & 0.94 & 1.60 & 7.20 & 27.31 & 2.74 & 22.51 & 52.56 \\
\hline 1986 & - & - & - & - & - & - & 2.07 & 16.76 & - \\
\hline 1987 & - & - & - & - & - & - & 2.00 & 18.91 & - \\
\hline 1988 & - & - & - & - & - & - & 2.20 & 21.05 & - \\
\hline 1989 & 25.40 & 5.38 & 2.45 & 3.52 & 7.12 & 43.87 & 2.33 & 22.36 & 67.39 \\
\hline 1990 & 24.34 & 5.48 & 1.53 & 3.83 & 7.28 & 42.46 & 2.60 & 22.09 & 66.50 \\
\hline 1991 & 22.71 & 5.10 & 1.84 & 3.82 & 7.24 & 40.71 & 3.05 & - & 66.61 \\
\hline
\end{tabular}

- Some crude oil and heavy oil feedstocks are used in ethylene production.

$\dagger$ Industrial sector consumption of unspecified petroleum and coking products, which we here assume is used as feedstocks. Conversion factors for these two are, respectively, 1.43 tce/ton for petroleum products and 0.97 tce/ton for coking products.

I Includes feedstocks used in ethylene production (which are mainly gasoil and about one-third naphtha), naphtha used in fertilizer production, and probably lube oil base stock and other non-energy uses.

Source: China Energy Statistical Yearbook, various years; Energy Research Institute. 


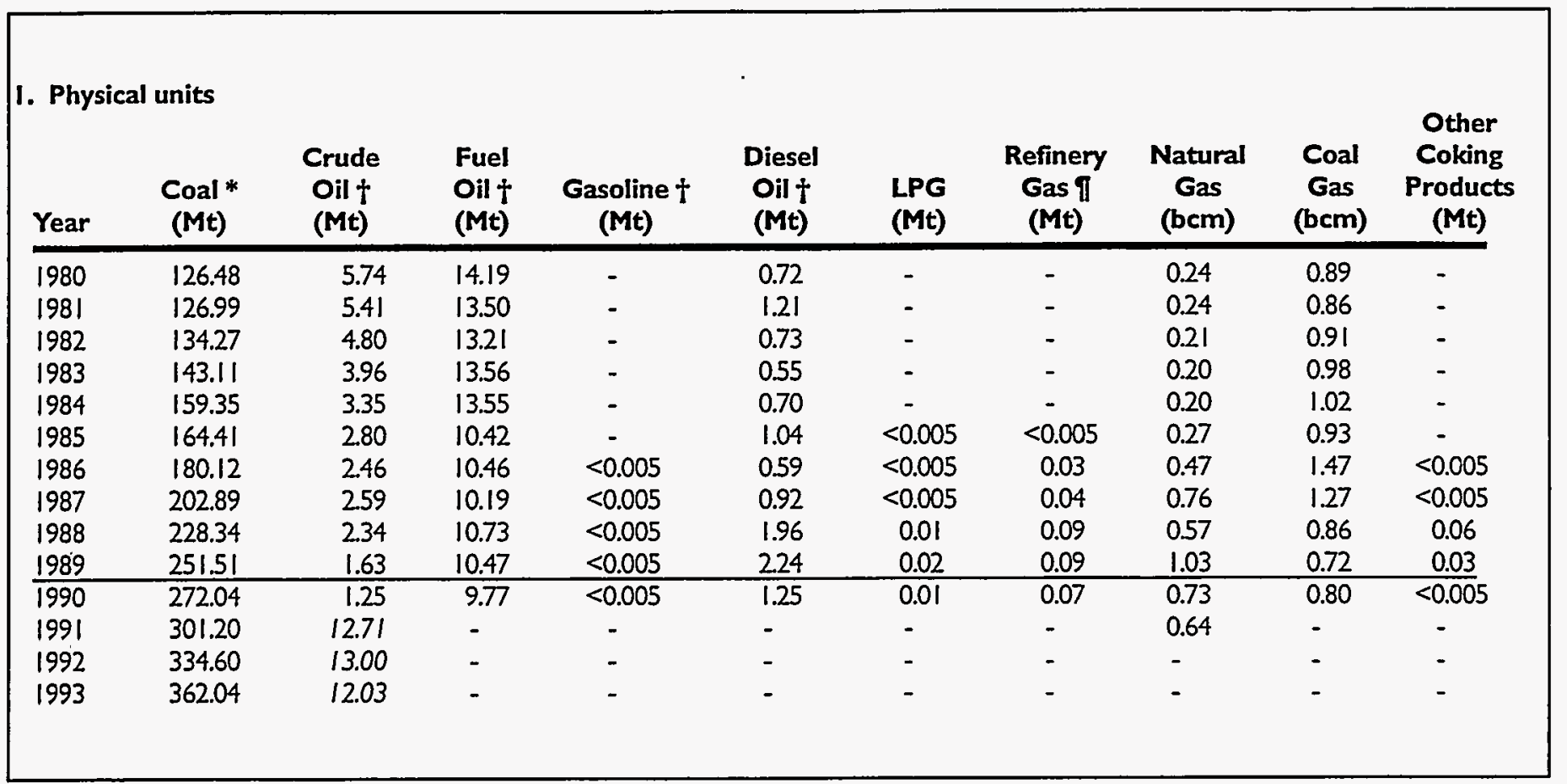

\section{Mtce}

\begin{tabular}{|c|c|c|c|c|c|c|c|c|c|c|c|}
\hline Year & Coal * & $\begin{array}{l}\text { Crude } \\
\text { Oil t }\end{array}$ & $\begin{array}{l}\text { Fuel } \\
\text { Oil } t\end{array}$ & Gasoline $\uparrow$ & $\begin{array}{c}\text { Diesel } \\
\text { Oil } t\end{array}$ & $\begin{array}{l}\text { Liquefied } \\
\text { LPG }\end{array}$ & $\begin{array}{c}\text { Refinery } \\
\text { Gas } 1\end{array}$ & $\begin{array}{c}\text { Natural } \\
\text { Gas }\end{array}$ & $\begin{array}{l}\text { Coal } \\
\text { Gas }\end{array}$ & $\begin{array}{l}\text { Other } \\
\text { Coking } \\
\text { Products }\end{array}$ & Total \\
\hline 1980 & 80.82 & 8.20 & 20.27 & - & 1.06 & - & - & 0.32 & 0.53 & - & 111.21 \\
\hline 1981 & 81.15 & 7.73 & 19.29 & - & 1.77 & - & - & 0.32 . & 0.51 & - & 110.77 \\
\hline 1982 & 85.80 & 6.86 & 18.87 & - & 1.07 & - & - & 0.28 & 0.54 & - & $|13.4|$ \\
\hline 1983 & 91.45 & 5.65 & 19.36 & - & 0.80 & - & - & 0.27 & 0.58 & - & 118.11 \\
\hline 1984 & 101.83 & 4.79 & 19.35 & - & 1.03 & - & - & 0.27 & 0.60 & - & 127.87 \\
\hline 1985 & 105.06 & 3.99 & 14.89 & - & 1.52 & $<0.005$ & $<0.005$ & 0.36 & 0.55 & - & 126.37 \\
\hline 1986 & 115.10 & 3.51 & 14.94 & $<0.005$ & 0.87 & $<0.005$ & 0.05 & 0.63 & 0.87 & $<0.005$ & 135.96 \\
\hline 1987 & 129.65 & 3.70 & 14.55 & $<0.005$ & 1.36 & 0.00 & 0.07 & 1.01 & 0.75 & $<0.005$ & 151.09 \\
\hline 1988 & $|45.9|$ & 3.35 & 15.32 & $<0.005$ & 288 & 0.01 & 0.15 & 0.76 & 0.51 & 0.06 & 168.95 \\
\hline 1989 & 160.71 & 2.33 & 14.96 & 0.00 & 3.29 & 0.04 & 0.14 & 1.37 & 0.43 & 0.03 & 183.31 \\
\hline 1990 & 173.84 & 1.78 & 13.96 & 0.00 & 1.83 & 0.02 & 0.10 & 0.97 & 0.47 & 0.00 & 19298 \\
\hline 1991 & 19247 & 18.15 & - & - & - & - & - & 0.85 & - & - & 211.47 \\
\hline 1992 & 213.81 & 18.57 & - & - & - & - & - & - & - & - & 23238 \\
\hline 1993 & 231.34 & 17.19 & - & - & - & - & - & - & - & - & 248.53 \\
\hline
\end{tabular}

* Figures are uncorrected sums of consumption of raw and washed coal. Coal is converted as utility coal ( 0.639 tce/tonne utility coal). In official statistics, 1980-1984 values for power generation include coal used for heating. The figures above are calculated assuming that the amount of coal used for heating in 1980-1984 was proportional to the average ratio of coal used for heating to coal used for power generation in 1985-1988 (9.2\%).

$\dagger$ In official statistics, 1980-1984 values for power generation consumption of liquid fossil fuels include that used for heating. The figures above are calculated assuming that the amount of fuel used for heating in 1980-1984 was proportional to the average ratio of fuel used for heating to fuel used for power generation in 1985-1988. The average ratios are: crude oil: 1.6\%; fuel oil: 24\%; diesel oil: $1.9 \%$. $1991-1993$ crude oil figures are estimated totals for oil products use.

I Refinery gas (lianchang gangi) is a byproduct of oil refining.

Source: China Energy Statistical Yearbook, various years; China Statistical Yearbook, various years; China Energy Annual Review, 1994. 
Table IV-12. Thermal Electric Utility Fuel Use, 1980-1993-Mtce (continued)

\begin{tabular}{|c|c|c|c|c|c|c|}
\hline \multicolumn{7}{|c|}{ 3. Estimated net heat rates } \\
\hline Year & $\begin{array}{l}\text { Thermal Gross } \\
\text { Generation } \\
\text { (TWh) }\end{array}$ & $\begin{array}{c}\text { kgce per } \\
\text { gross kWh } ¥\end{array}$ & $\begin{array}{c}\text { Rate of } \\
\text { in-plant } \\
\text { electricity } \\
\text { consumption }\end{array}$ & $\begin{array}{l}\text { Net Thermal } \\
\text { Generation } \\
\text { (TWh) }\end{array}$ & $\begin{array}{c}\text { Ratio of } \\
\text { Gross to } \\
\text { Net }\end{array}$ & $\begin{array}{r}\text { kgce per } \\
\text { net kWh } ¥\end{array}$ \\
\hline 1980 & 242.4 & 0.459 & $7.65 \%$ & 223.86 & 1.083 & 0.497 \\
\hline 1981 & 243.8 & 0.454 & $7.76 \%$ & 224.88 & 1.084 & 0.493 \\
\hline 1982 & 253.3 & 0.448 & $7.71 \%$ & 233.77 & 1.084 & 0.485 \\
\hline 1983 & 265.0 & 0.446 & $7.78 \%$ & 244.38 & 1.084 & 0.483 \\
\hline 1984 & 290.2 & 0.441 & $7.70 \%$ & 267.85 & 1.083 & 0.477 \\
\hline 1985 & 318.3 & 0.397 & $7.78 \%$ & 293.54 & 1.084 & 0.431 \\
\hline 1986 & 355.1 & 0.383 & $7.83 \%$ & 327.30 & 1.085 & 0.415 \\
\hline 1987 & 397.1 & 0.380 & $7.88 \%$ & 365.81 & 1.086 & 0.413 \\
\hline 1988 & 435.9 & 0.388 & $7.94 \%$ & 401.29 & 1.086 & 0.421 \\
\hline 1989 & 466.4 & 0.393 & $8.12 \%$ & 428.55 & 1.088 & 0.428 \\
\hline 1990 & 494.5 & 0.390 & $8.22 \%$ & 453.83 & 1.090 & 0.425 \\
\hline 1991 & 552.8 & 0.383 & $8.13 \%$ & 507.86 & 1.088 & 0.416 \\
\hline 1992 & 623.2 & 0.373 & $8.08 \%$ & 572.85 & 1.088 & 0.406 \\
\hline 1993 & 666.8 & 0.373 & $8.08 \%$ & 612.94 & 1.088 & 0.405 \\
\hline
\end{tabular}

$¥$ Calculated from data in this table; differs from official data on heat rates.

Figures in italics are estimates.

Source: China Energy Statistical Yearbook, various years; China Statistical Yearbook, various years; China Energy Annual Review, 1994. 
Figure IV-10. Fuel Use in Electricity Generation

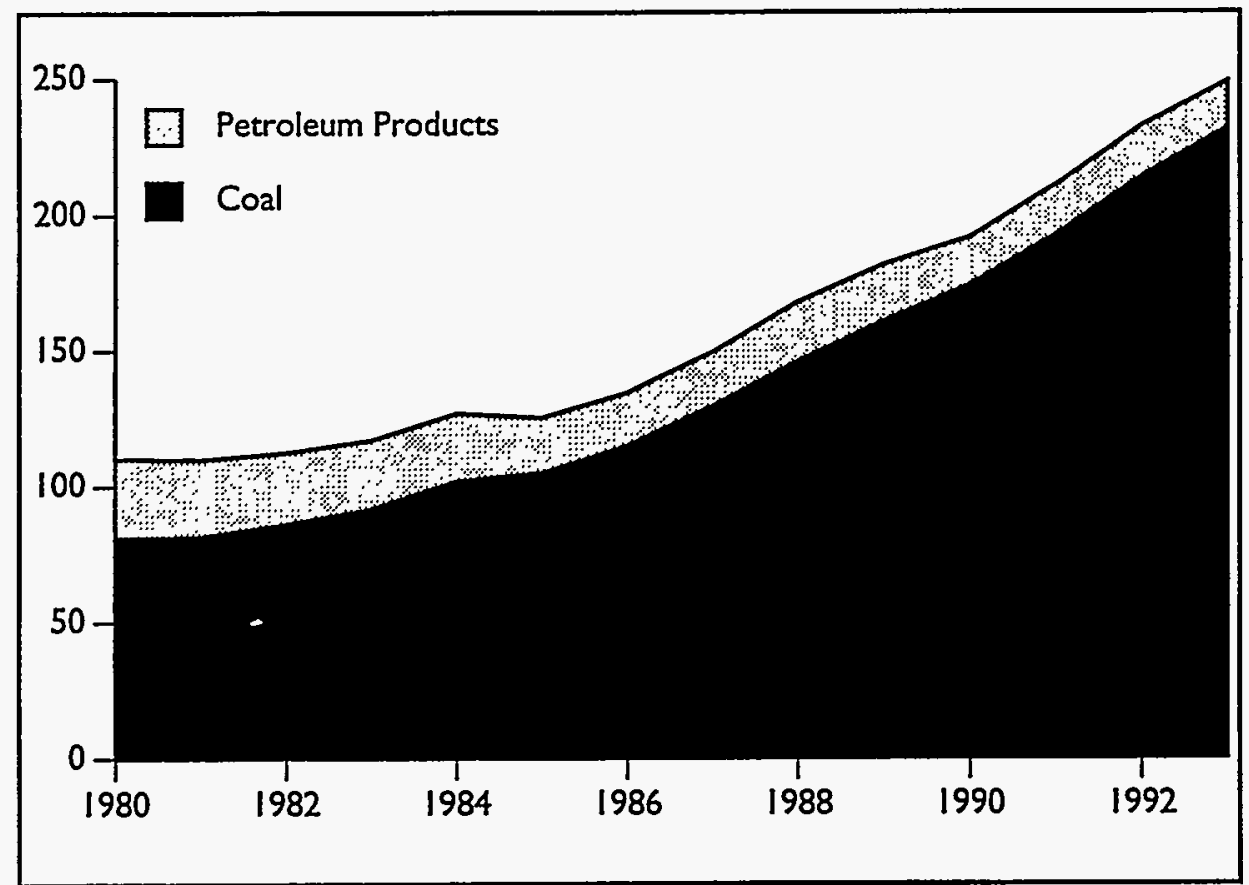


Table IV-13. Average Heat Rates of Thermal Power Plants *

\begin{tabular}{|c|c|c|c|c|}
\hline Year & $\begin{array}{c}\text { Gross } \\
\text { Generation } \\
\text { Efficiency }\end{array}$ & $\begin{array}{c}\text { Net } \\
\text { Generation } \\
\text { Efficiency }\end{array}$ & $\begin{array}{c}\text { Coal } \\
\text { Consumption } \\
\text { of Gross } \\
\text { Generation } \\
\text { (gce/kWh) }\end{array}$ & $\begin{array}{c}\text { Coal } \\
\text { Consumption } \\
\text { of Net } \\
\text { Generation } \\
\text { (gce/kWh) }\end{array}$ \\
\hline 1965 & 0.257 & 0.237 & 477 & 518 \\
\hline 1966 & 0.266 & 0.247 & 461 & 498 \\
\hline 1967 & 0.265 & 0.245 & 463 & 502 \\
\hline 1968 & 0.265 & 0.244 & 464 & 503 \\
\hline 1969 & 0.265 & 0.244 & 464 & 503 \\
\hline 1970 & 0.265 & 0.245 & 463 & 502 \\
\hline 1971 & 0.264 & 0.243 & 465 & 505 \\
\hline 1972 & 0.265 & 0.244 & 464 & 504 \\
\hline 1973 & 0.269 & 0.248 & 457 & 496 \\
\hline 1974 & 0.273 & 0.252 & 450 & 488 \\
\hline 1975 & 0.273 & 0.251 & 450 & 489 \\
\hline 1976 & 0.274 & 0.252 & 449 & 487 \\
\hline 1977 & 0.275 & 0.254 & 446 & 484 \\
\hline 1978 & 0.283 & 0.261 & 434 & $47 I$ \\
\hline 1979 & 0.291 & 0.269 & 422 & 457 \\
\hline 1980 & 0.297 & 0.274 & 413 & 448 \\
\hline 1981 & 0.302 & 0.278 & 407 & 442 \\
\hline 1982 & 0.304 & 0.280 & 404 & 438 \\
\hline 1983 & 0.307 & 0.283 & 400 & 434 \\
\hline 1984 & 0.309 & 0.284 & 398 & 432 \\
\hline 1985 & 0.309 & 0.285 & 398 & 431 \\
\hline 1986 & 0.309 & 0.284 & 398 & 432 \\
\hline 1987 & 0.309 & 0.284 & 398 & 432 \\
\hline 1988 & 0.309 & 0.285 & 397 & 431 \\
\hline 1989 & 0.309 & 0.284 & 397 & 432 \\
\hline 1990 & 0.313 & 0.288 & 392 & 427 \\
\hline 1991 & 0.315 & 0.288 & 390 & 427 \\
\hline 1992 & 0.318 & 0.292 & 386 & 420 \\
\hline 1993 & 0.320 & 0.295 & 384 & 417 \\
\hline
\end{tabular}

* For power plants with $\geq 6 \mathrm{MW}$ of installed capacity, which in the 1980 s accounted for about $89 \%$ of installed capacity and $97 \%$ of gross thermal electricity generation.

Source: China Energy Statistical Yearbook, various years; Energy Research Institute; China Energy Annual Review, 1994. 
Table IV-14. Power Sector Electricity Consumption, Selected Years, 1952-1993

\begin{tabular}{|c|c|c|c|c|c|c|}
\hline \multirow[b]{2}{*}{ Year } & \multicolumn{2}{|c|}{ Overall } & \multicolumn{2}{|c|}{ Hydro } & \multicolumn{2}{|c|}{ Thermal } \\
\hline & $\begin{array}{c}\text { Percent } \\
\text { of Gross } \\
\text { Generation * }\end{array}$ & $\begin{array}{c}\text { Consumption } \\
\text { (TWh) } t\end{array}$ & $\begin{array}{c}\text { Percent } \\
\text { of Gross } \\
\text { Generation * }\end{array}$ & $\begin{array}{c}\text { Consumption } \\
\text { (TWh) } \dagger\end{array}$ & $\begin{array}{c}\text { Percent } \\
\text { of Gross } \\
\text { Generation* }\end{array}$ & $\begin{array}{c}\text { Consumption } \\
\text { (TWh) } t\end{array}$ \\
\hline 1952 & $6.17 \%$ & 0.45 & $0.22 \%$ & 0.003 & $7.42 \%$ & 0.45 \\
\hline 1957 & $5.99 \%$ & 1.16 & $0.14 \%$ & 0.01 & $7.17 \%$ & 1.04 \\
\hline 1965 & $6.98 \%$ & 4.72 & $0.21 \%$ & 0.02 & $7.98 \%$ & 4.56 \\
\hline 1966 & $6.55 \%$ & 5.40 & $0.18 \%$ & 0.02 & $7.50 \%$ & 5.24 \\
\hline 1967 & $6.70 \%$ & 5.19 & $0.18 \%$ & 0.02 & $7.72 \%$ & 4.96 \\
\hline 1968 & $6.75 \%$ & 4.83 & $0.22 \%$ & 0.03 & $7.71 \%$ & 4.63 \\
\hline 1969 & $6.65 \%$ & 6.25 & $0.21 \%$ & 0.03 & $7.80 \%$ & 6.08 \\
\hline 1970 & $6.54 \%$ & 7.58 & $0.17 \%$ & 0.03 & $7.78 \%$ & 7.42 \\
\hline 1971 & $6.68 \%$ & 9.25 & $0.17 \%$ & 0.04 & $7.89 \%$ & 8.94 \\
\hline 1972 & $6.68 \%$ & 10.18 & $0.17 \%$ & 0.05 & $7.88 \%$ & 9.74 \\
\hline 1973 & $6.26 \%$ & 10.44 & $0.15 \%$ & 0.06 & $7.83 \%$ & 10.01 \\
\hline 1974 & $6.19 \%$ & 10.45 & $0.16 \%$ & 0.07 & $7.87 \%$ & 10.03 \\
\hline 1975 & $6.23 \%$ & 1220 & $0.15 \%$ & 0.07 & $7.91 \%$ & 11.72 \\
\hline 1976 & $6.34 \%$ & 1288 & $0.17 \%$ & 0.08 & $7.88 \%$ & 12.41 \\
\hline 1977 & $6.41 \%$ & 14.32 & $0.19 \%$ & 0.09 & $7.83 \%$ & 13.77 \\
\hline 1978 & $6.61 \%$ & 16.96 & $0.21 \%$ & 0.09 & $7.71 \%$ & 16.35 \\
\hline 1979 & $6.54 \%$ & 18.44 & $0.20 \%$ & 0.10 & $7.63 \%$ & 17.69 \\
\hline 1980 & $6.44 \%$ & 19.36 & $0.19 \%$ & 0.11 & $7.65 \%$ & 18.54 \\
\hline 1981 & $6.40 \%$ & 19.80 & $0.20 \%$ & 0.13 & $7.76 \%$ & 18.92 \\
\hline 1982 & $6.32 \%$ & 20.71 & $0.21 \%$ & 0.16 & $7.71 \%$ & 19.53 \\
\hline 1983 & $6.21 \%$ & 21.82 & $0.23 \%$ & 0.20 & $7.78 \%$ & 20.62 \\
\hline 1984 & $6.28 \%$ & 23.68 & $0.25 \%$ & 0.22 & $7.70 \%$ & 22.35 \\
\hline 1985 & $6.42 \%$ & 26.37 & $0.28 \%$ & 0.26 & $7.78 \%$ & 24.76 \\
\hline 1986 & $6.54 \%$ & 29.40 & $0.28 \%$ & 0.26 & $7.83 \%$ & 27.80 \\
\hline 1987 & $6.66 \%$ & 33.12 & $0.31 \%$ & 0.31 & $7.88 \%$ & 31.29 \\
\hline 1988 & $6.69 \%$ & 36.47 & $0.34 \%$ & 0.37 & $7.94 \%$ & 34.61 \\
\hline 1989 & $6.81 \%$ & 39.82 & $0.30 \%$ & 0.36 & $8.12 \%$ & 37.86 \\
\hline 1990 & $6.90 \%$ & 42.87 & $0.30 \%$ & 0.38 & $8.22 \%$ & 40.68 \\
\hline 1991 & $6.94 \%$ & 47.03 & $0.32 \%$ & 0.40 & $8.13 \%$ & 44.92 \\
\hline 1992 & $7.00 \%$ & 5277 & $0.37 \%$ & 0.49 & $8.08 \%$ & 50.22 \\
\hline 1993 & $6.96 \%$ & 58.43 & $0.41 \%$ & 0.62 & $8.08 \%$ & 55.57 \\
\hline
\end{tabular}

- Figures for years before 1971 are for plants with installed capacities $\geq 500 \mathrm{~kW}$, while those for 1971 and later years are for plants with installed capacities $26 \mathrm{MW}$.

$\dagger$ Power plant consumption is calculated as the product of gross generation and rate of power plant electricity consumption. Data for power plant consumption is for plants $6 \mathrm{MW}$ and over. Thermal power plants under $6 \mathrm{MW}$ accounted for about $10 \%$ of installed thermal capacity and less than 5\% of gross thermal generation from the late 1970s through the 1980 s (see Table II-23). In 1983 hydropower plants with installed capacities $<12 \mathrm{MW}$ accounted for about $22 \%$ of installed hydro capacity and $8 \%$ of gross hydro generation. Since the shares of electricity generated by thermal and hydro plants were about $80 \%$ and $20 \%$ respectively through the 1980 , the losses accounted for here apply to more than $90 \%$ of total generation. If loss rates at all of the smaller plants were assumed to be about $10 \%$, then the overall rate of power plant consumption for power plant consumption would increase by less than one percentage point.

Source: China Energy Statistical Yearbook, various years; China Energy Annual Review, 1994. 
Table IV-15. Transportation Energy Consumption, * 1980-1992

\begin{tabular}{|c|c|c|c|c|c|c|}
\hline \multicolumn{7}{|c|}{ 1. Mtce } \\
\hline Year & Coal $t$ & Gasoline II & Diesel $¥$ & Electricity & Other ** & $\begin{array}{c}\text { Total } \\
\text { End-Use }\end{array}$ \\
\hline 1980 & 13.81 & 14.68 & 7.59 & 1.07 & 2.42 & 39.57 \\
\hline 1981 & 14.89 & 13.82 & 7.26 & 1.18 & 2.55 & 39.70 \\
\hline 1982 & 15.52 & 14.60 & 7.53 & 1.21 & 287 & 41.72 \\
\hline 1983 & 15.65 & 16.10 & 8.12 & 1.45 & 2.82 & 44.14 \\
\hline 1984 & 16.28 & 17.64 & 8.64 & 1.67 & 3.24 & 47.46 \\
\hline 1985 & 16.47 & 20.53 & 9.58 & 256 & 3.28 & 52.42 \\
\hline 1986 & 16.39 & 22.05 & 11.63 & 2.70 & 3.85 & 56.62 \\
\hline 1987 & 16.00 & 23.88 & 12.87 & 3.10 & 3.91 & 59.76 \\
\hline 1988 & 16.13 & 26.31 & 13.71 & 3.62 & 4.09 & 63.86 \\
\hline 1989 & 16.31 & 27.25 & 14.44 & 3.99 & 4.65 & 66.63 \\
\hline 1990 & 15.43 & 27.92 & 14.46 & 4.28 & 5.35 & 67.44 \\
\hline 1991 & 14.46 & 32.48 & 15.49 & 4.73 & 6.04 & 73.21 \\
\hline 1992 & 13.39 & 36.89 & 16.79 & 5.50 & 6.63 & 79.20 \\
\hline
\end{tabular}

\begin{tabular}{|lccccc|}
\hline 2. Shares & & & & & \\
Year & Coal † & Gasoline I & Diesel $¥$ & Electricity & $\begin{array}{c}\text { Other } \\
\text { Fuels }\end{array}$ \\
\hline 1980 & $35 \%$ & $37 \%$ & $19 \%$ & $3 \%$ & $6 \%$ \\
1981 & $38 \%$ & $35 \%$ & $18 \%$ & $3 \%$ & $6 \%$ \\
1982 & $37 \%$ & $35 \%$ & $18 \%$ & $3 \%$ & $7 \%$ \\
1983 & $35 \%$ & $36 \%$ & $18 \%$ & $3 \%$ & $6 \%$ \\
1984 & $34 \%$ & $37 \%$ & $18 \%$ & $4 \%$ & $7 \%$ \\
1985 & $31 \%$ & $39 \%$ & $18 \%$ & $5 \%$ & $6 \%$ \\
1986 & $29 \%$ & $39 \%$ & $21 \%$ & $5 \%$ & $7 \%$ \\
1987 & $27 \%$ & $40 \%$ & $22 \%$ & $5 \%$ & $7 \%$ \\
1988 & $25 \%$ & $41 \%$ & $21 \%$ & $6 \%$ & $6 \%$ \\
1989 & $24 \%$ & $41 \%$ & $22 \%$ & $6 \%$ & $7 \%$ \\
\hline 1990 & $23 \%$ & $41 \%$ & $21 \%$ & $6 \%$ & $8 \%$ \\
1991 & $20 \%$ & $44 \%$ & $21 \%$ & $6 \%$ & $8 \%$ \\
1992 & $17 \%$ & $47 \%$ & $21 \%$ & $7 \%$ & $8 \%$ \\
. & & & & & \\
\hline
\end{tabular}

* The figures presented here differ from official data. Units in non-transportation sectors, especially industry, operate significant numbers of motor vehicles, the fuel consumption of which is reported in the official data for those sectors, not as transportation fuel use. Energy use in post and communication services is reported in the transportation category.

$\dagger$ Coal includes raw and washed coal and small amounts of coke and middlings.

Gasoline includes rational total use; ron-transportation consumption of gasoline is considered insignificant, so all gasoline consumption is treated as transportation.

Y Transportation sector consumption of diesel oil includes reported transportation use plus $20 \%$ of agricultural use, $10 \%$ of industrial use, and $12 \%$ of commercial and other use. Data in the Statistical Yearbook of China indicates that trucks and transportation tractors accounted for $20 \%$ to $30 \%$ of total agricultural sector machine power in the 1980 s. For the time period covered in this table we believe that taking $20 \%$ of reported agricultural diesel use as transportation sector use is a reasonable adjustment. We estimate that $10 \%$ of the national truck fleet (with payload over 4 tons) is diesel fueled, and that $90 \%$ of the diesel truck fleet is owned by industrial work units. China Statistical Yearbooks show that less than $10 \%$ of China's truck fleet is owned by transportation companies. Using an average diesel use per vehicle-km of 35 liters/100 vehicle-km (from the Energy Statistical Yearbook of China; probably an average for 8-ton trucks, the most common size in China) and an estimated average vehicle travel of $10,000 \mathrm{~km} / y$ ear, we estimate that $10 \%$ of reported industrial diesel use was for transportation in 1988 . This percentage was applied to data for other years as well.

Other fuels include kerosene, crude oil, fuel oil, and natural gas.

** Other fuels include kerosene, crude oil, fuel oil, and natural gas.

Source: China Energy Statistical Yearbook, various years; China Statistical Yearbook, various years. 
Figure IV-11. Transportation Sector Energy Consumption

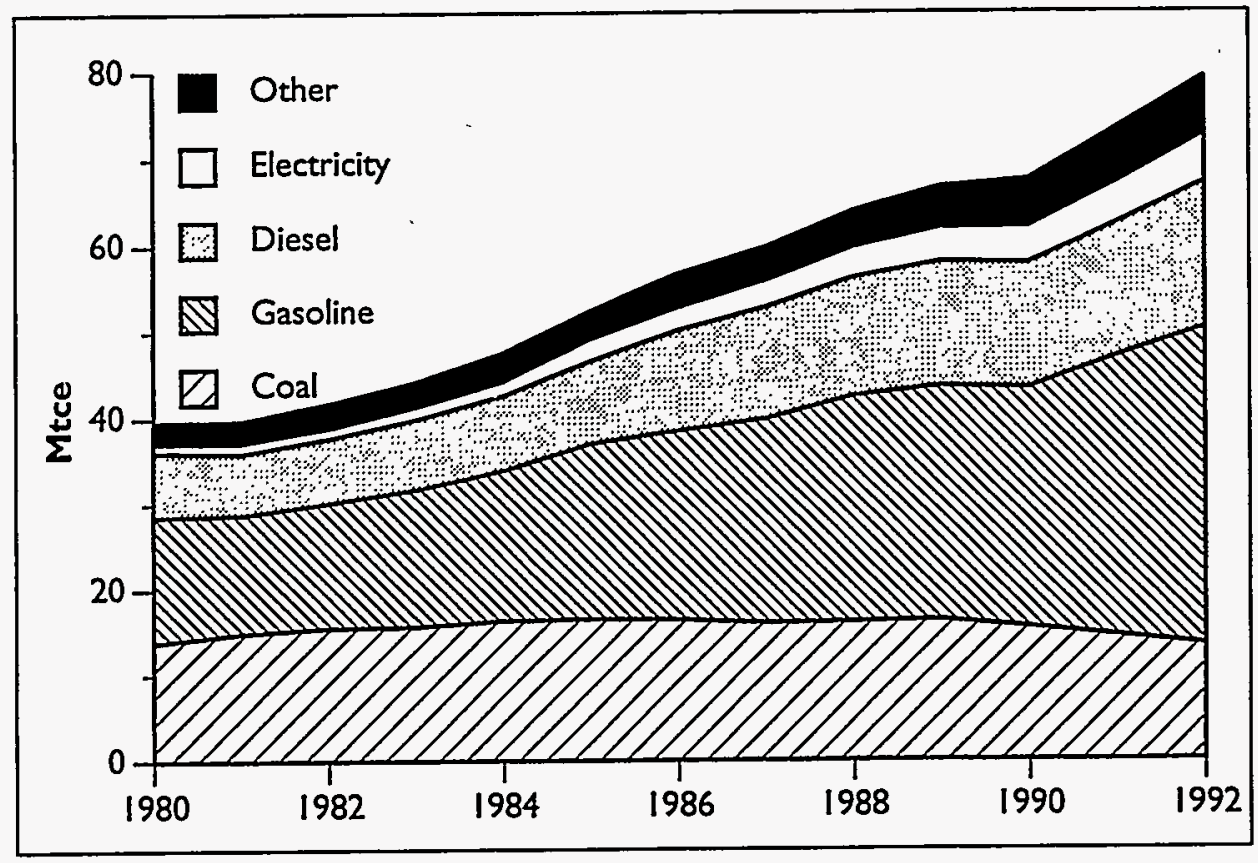


Table IV-16. Transportation End-Use Consumption Shares by Mode, 1985 and 1990 *

\begin{tabular}{|c|c|c|c|c|c|}
\hline \multirow{2}{*}{$\begin{array}{l}\text { 1. } 1985 \\
\text { Sector }\end{array}$} & \multicolumn{4}{|c|}{ Consumption } & \multirow{2}{*}{$\begin{array}{c}\text { Percent } \\
\text { of Total } \\
\text { Consumption }\end{array}$} \\
\hline & $\begin{array}{l}\text { Coal } \\
\text { (Mt) }\end{array}$ & $\begin{array}{l}\text { Oil } \\
\text { (Mt) }\end{array}$ & $\begin{array}{c}\text { Electricity } \\
\text { (billion kWh) }\end{array}$ & $\begin{array}{l}\text { Total } \\
\text { (Mtce) }\end{array}$ & \\
\hline $\begin{array}{l}\text { Rail } \\
\text { of which: }\end{array}$ & - & - & - & 23.3 & $47.6 \%$ \\
\hline Steam Locomotives & 26.0 & - & - & 18.6 & $38.0 \%$ \\
\hline Diesel Locomotives & - & 2.1 & - & 3.0 & $6.2 \%$ \\
\hline Electric Locomotives & - & - & 4.2 & 1.7 & $3.5 \%$ \\
\hline Road II & - & 120 & - & 17.5 & $35.8 \%$ \\
\hline Water $¥$ & - & 4.3 & - & 6.2 & $128 \%$ \\
\hline Air $\S$ & - & 0.7 & - & 1.0 & $2.0 \%$ \\
\hline Pipeline ** & - & 0.6 & - & 0.9 & $1.8 \%$ \\
\hline Total & 26.0 & 19.6 & 4.2 & 48.9 & $100.0 \%$ \\
\hline
\end{tabular}

\begin{tabular}{|c|c|c|c|c|c|}
\hline \multirow{2}{*}{$\begin{array}{l}\text { 2. } 1989 * * * \\
\text { Sector }\end{array}$} & \multicolumn{4}{|c|}{ Consumption } & \multirow{2}{*}{$\begin{array}{c}\text { Percent } \\
\text { of Total } \\
\text { Consumption }\end{array}$} \\
\hline & $\begin{array}{l}\text { Coal } \\
\text { (Mt) }\end{array}$ & $\begin{array}{l}\text { Oil } \\
(M t)\end{array}$ & $\begin{array}{c}\text { Electricity } \\
\text { (billion kWh) }\end{array}$ & $\begin{array}{l}\text { Total } \\
\text { (Mtce) }\end{array}$ & \\
\hline $\begin{array}{l}\text { Rail } \\
\text { of which: }\end{array}$ & - & - & - & 21.7 & $30.0 \%$ \\
\hline Steam Locomotives † & 20.63 & - & - & 14.7 & $20.4 \%$ \\
\hline Diesel Locomotives- & - & 2.87 & - & 4.2 & $5.8 \%$ \\
\hline Electric Locomotives & - & - & 6.82 & 28 & $3.8 \%$ \\
\hline $\operatorname{Road} \pi$ & 2.58 & 21.87 & 1.60 & 34.4 & $47.6 \%$ \\
\hline Water $¥$ & 4.70 & 5.89 & 2.96 & 13.2 & $18.2 \%$ \\
\hline Air $\S$ & 0.01 & 1.00 & 0.01 & 1.5 & $2.0 \%$ \\
\hline Pipeline ** & 0.25 & 0.41 & 2.16 & 1.6 & $2.3 \%$ \\
\hline Total & 28.2 & 320 & 13.6 & 72.4 & $100.0 \%$ \\
\hline
\end{tabular}

* Figures in this table are slightly different than in other tables because sources are different. Figures include both passenger and freight transportation by vehicles and vessels of all types of ownership, not just dedicated transportation units.

$\dagger$ Coal is converted as standard coal, although the real value is probably higher since high-quality lump coal is used by steam locomotives.

I Includes fuel consumption for national stock of trucks and passenger vehicles (estimated at 3.21 million in 1985 by the source below). Figure is for total gasoline and diesel use; we use the conversion factor for diesel here.

¥ Includes diesel oil and residual oil; converted as diesel oil.

$\S$ Kerosene and gasoline.

** Assumed to be crude oil.

Source: Yang, 1988; Yang, 1991. 
Figure IV-12. Energy Use by Different Transport Modes

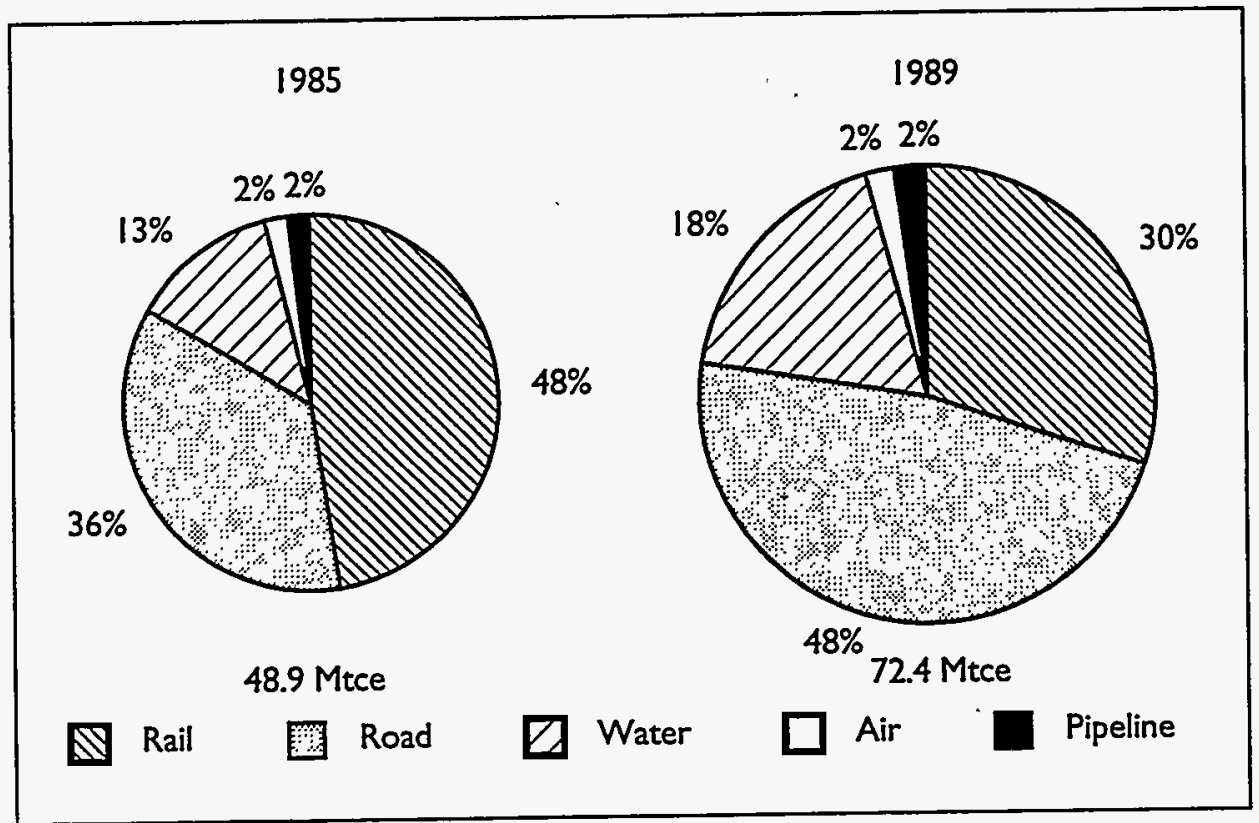


Table IV-17. Agricultural Energy Consumption * 1980-1992 (Commercial Fuels Only)

\begin{tabular}{|lllccc|}
\hline I. Mtce & & & & & \\
Year & Coal $\dagger$ & Electicity & Diesel II & Other Fuels $¥$ & Total \\
\hline 1980 & 11.17 & 10.91 & 8.75 & 0.18 & 31.01 \\
1981 & 11.30 & 11.38 & 8.23 & 0.19 & 31.10 \\
1982 & 12.33 & 11.57 & 7.64 & 0.16 & 31.70 \\
1983 & 13.18 & 11.57 & 7.77 & 0.06 & 32.58 \\
1984 & 14.64 & 11.65 & 8.23 & 0.08 & 34.60 \\
1985 & 15.97 & 12.82 & 7.35 & 0.11 & 36.25 \\
1986 & 16.88 & 13.01 & 7.84 & 0.06 & 37.79 \\
1987 & 16.79 & 14.53 & 8.52 & 0.11 & 39.95 \\
1988 & 17.55 & 15.31 & 8.96 & 0.12 & 41.94 \\
1989 & 16.10 & 16.58 & 9.63 & 0.13 & 42.44 \\
\hline 1990 & 15.55 & 17.24 & 10.28 & 0.09 & 43.16 \\
1991 & 15.51 & 19.38 & 10.41 & 0.09 & 45.40 \\
1992 & 13.14 & 21.10 & 10.32 & 0.12 & 44.68 \\
\hline
\end{tabular}

\begin{tabular}{|lcccc|}
\hline 2. Shares & & & & \\
& & & & \\
Year & Coal $\dagger$ & Electicity & Diesel & Ot \\
\hline 1980 & $36 \%$ & $35 \%$ & $28 \%$ & $0.6 \%$ \\
1981 & $36 \%$ & $37 \%$ & $26 \%$ & $0.6 \%$ \\
1982 & $39 \%$ & $36 \%$ & $24 \%$ & $0.5 \%$ \\
1983 & $40 \%$ & $36 \%$ & $24 \%$ & $0.2 \%$ \\
1984 & $42 \%$ & $34 \%$ & $24 \%$ & $0.2 \%$ \\
1985 & $44 \%$ & $35 \%$ & $20 \%$ & $0.3 \%$ \\
1986 & $45 \%$ & $34 \%$ & $21 \%$ & $0.2 \%$ \\
1987 & $42 \%$ & $36 \%$ & $21 \%$ & $0.3 \%$ \\
1988 & $42 \%$ & $37 \%$ & $21 \%$ & $0.3 \%$ \\
1989 & $38 \%$ & $39 \%$ & $23 \%$ & $0.3 \%$ \\
\hline 1990 & $36 \%$ & $40 \%$ & $24 \%$ & $0.2 \%$ \\
1991 & $34 \%$ & $43 \%$ & $23 \%$ & $0.2 \%$ \\
1992 & $29 \%$ & $47 \%$ & $23 \%$ & $0.3 \%$ \\
\hline
\end{tabular}

* Agricultural sector energy use statistics may include a small amount of "sideline" industry consumption. Industrial sector consumption figures, however, generally include all known rural industry consumption at the village level and above, so the correction probably would be small.

$\dagger$ Coal includes raw coal plus small amounts of coke and middlings. Coal is used for processes such as curing tobacco and drying other agricultural products.

I Diesel use is adjusted to exclude estimated transportation use (see Table IV-15).

Other fuels include crude oil, fuel oil, and kerosene.

Source: China Energy Statistical Yearbook, various years; China Statistical Yearbook, various years. 
Figure IV-13. Agricultural Energy Consumption

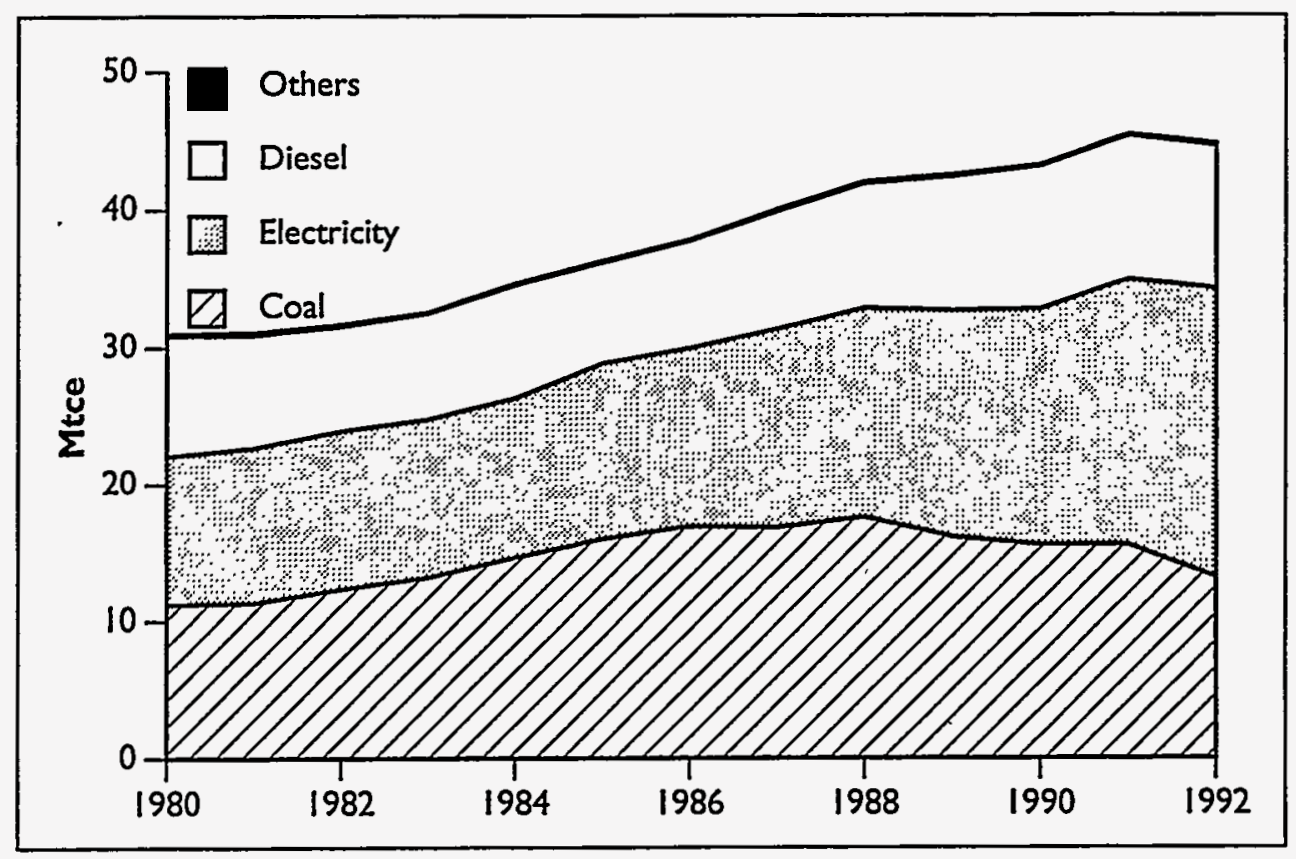


Table IV-18. Residential Energy Consumption, 1980-1992 (Commercial Energy Only)

\begin{tabular}{|c|c|c|c|c|c|c|c|}
\hline \multicolumn{8}{|c|}{ 1. Physical Units } \\
\hline Year & $\begin{array}{c}\text { Coal * } \\
(\mathbf{M t})\end{array}$ & $\begin{array}{c}\text { Electricity } \dagger \\
\text { (TWh) }\end{array}$ & $\begin{array}{l}\text { District } \\
\text { Heating I } \\
\text { (TJ) }\end{array}$ & $\begin{array}{c}\text { Kerosene } \\
\text { (Mt) }\end{array}$ & $\begin{array}{l}\text { LPG } \\
\text { (Mt) }\end{array}$ & $\begin{array}{l}\text { Natural } \\
\text { Gas } \\
\text { (billion } \mathrm{m} 3 \text { ) }\end{array}$ & $\begin{array}{c}\text { Town } \\
\text { Gas } ¥ \\
\text { (billion } \mathrm{m} 3 \text { ) }\end{array}$ \\
\hline 1980 & 115.7 & 10.5 & 46 & 1.0 & 0.4 & 0.2 & 1.4 \\
\hline 1981 & 120.9 & 11.8 & 47 & 1.2 & 0.5 & 0.2 & 1.4 \\
\hline 1982 & 124.6 & 12.5 & 48 & 1.0 & 0.5 & 0.2 & 1.5 \\
\hline 1983 & 130.6 & 13.7 & 49 & 1.2 & 0.6 & 0.1 & 1.5 \\
\hline 1984 & 139.8 & 15.9 & 52 & 1.5 & 0.6 & 0.5 & 1.6 \\
\hline 1985 & 156.2 & 22.3 & 57 & 1.2 & 0.9 & 0.4 & 1.3 \\
\hline 1986 & 158.2 & 24.8 & 66 & 1.3 & 1.1 & 0.7 & 1.4 \\
\hline 1987 & 164.9 & 28.7 & 78 & 1.3 & 1.2 & 0.8 & 1.7 \\
\hline 1988 & 175.3 & 34.3 & 77 & 1.2 & 1.3 & 1.5 & 1.7 \\
\hline 1989 & 170.4 & 39.5 & 84 & 1.3 & 1.5 & 1.7 & 27 \\
\hline 1990 & 167.0 & 48.1 & 90 & 1.0 & 1.6 & 1.9 & 2.9 \\
\hline $199 \mid$ & 164.5 & 54.4 & 98 & 0.9 & 2.0 & 1.8 & 3.6 \\
\hline 1992 & 147.8 & 64.0 & 114 & 0.9 & 2.4 & 22 & 5.2 \\
\hline
\end{tabular}

\begin{tabular}{|c|c|c|c|c|c|c|c|c|}
\hline \multicolumn{9}{|c|}{ 2. Mtce } \\
\hline \multicolumn{9}{|c|}{$\begin{array}{l}\text { District } \\
\text { Heating I }\end{array}$} \\
\hline 1980 & 82.7 & 4.3 & 1.6 & 1.5 & 0.7 & 0.3 & 0.8 & 91.8 \\
\hline 1981 & 86.4 & 4.8 & 1.6 & 1.7 & 0.8 & 0.3 & 0.9 & 96.4 \\
\hline 1982 & 89.0 & 5.1 & 1.6 & 1.5 & 0.8 & 0.3 & 0.9 & 99.2 \\
\hline 1983 & 93.3 & 5.5 & 1.7 & 1.8 & 1.0 & 0.2 & 0.9 & 104.5 \\
\hline 1984 & 99.9 & 6.4 & 1.8 & 22 & 1.0 & 0.6 & 1.0 & 112.9 \\
\hline 1985 & 111.6 & 9.0 & 1.9 & 1.8 & 1.6 & 0.6 & 0.8 & 127.3 \\
\hline 1986 & 113.0 & 10.0 & 23 & 20 & 2.0 & 0.9 & 0.9 & 130.9 \\
\hline 1987 & 117.8 & 11.6 & 27 & 1.9 & 2.1 & 1.0 & 1.0 & 138.1 \\
\hline 1988 & 125.2 & 13.9 & 26 & 1.8 & 2.3 & 2.0 & 1.1 & 148.8 \\
\hline 1989 & 121.7 & 16.0 & 2.9 & 1.9 & 26 & 2.2 & 1.7 & 149.0 \\
\hline 1990 & 119.3 & 19.4 & 3.1 & 1.5 & 27 & 2.5 & 1.8 & 150.3 \\
\hline 1991 & 117.5 & 22.0 & 3.3 & 1.4 & 3.5 & 2.4 & 2.2 & 152.3 \\
\hline 1992 & 105.6 & 25.9 & 3.9 & 1.3 & 4.1 & 2.9 & 3.2 & 146.7 \\
\hline
\end{tabular}

- Unadjusted total of raw, washed, and screened coal, and small amounts of coke and middlings. This includes only direct use of coal in households and in small boilers. Coal used in large boilers (with capacities of several tens of tons of steam per hour) for district heating systems, in cogeneration systems which supply residences, and in generation of residential electricity is not included in this category. The electricity and district heating categories are composed mainly of coal used to generate the electricity and steam consumed in residences.

$\dagger$ Assuming a conversion efficiency in thermal power plants of $0.404 \mathrm{kgce} / \mathrm{kWh}$. Figures for $1980-1984$ include only electricity generated by plants with installed capacity of $\geq 500 \mathrm{~kW}$.

I Calculated as the amount of coal used in boilers, not heat delivered. This may result in double counting if heat is from cogeneration systems,but the correction is probably small because cogeneration accounts for less than $10 \%$ of installed electricity generation capacity nationally.

* Composed mainly of coke-oven gas and other coal gas ( 0.614 tce/1000 m3). Also includes a very small amount of refinery gas (1.571 tce/tonne) for 1985-1988.

Source: China Energy Statistical Yearbook, various years; China Statistical Yearbook, various years. 
Table IV-18. Residential Energy Consumption, 1980-1992 (Commercial Energy Only) (continued)

\begin{tabular}{|c|c|c|c|c|c|c|c|c|}
\hline Year & Coal * & Electricity & $\begin{array}{l}\text { District } \\
\text { Heating I }\end{array}$ & Kerosene & LPG & $\begin{array}{c}\text { Natural } \\
\text { Gas }\end{array}$ & $\begin{array}{l}\text { Town } \\
\text { Gas } ¥\end{array}$ & Total \\
\hline 1980 & $90.1 \%$ & $4.6 \%$ & $1.7 \%$ & $1.6 \%$ & $0.8 \%$ & $0.3 \%$ & $0.9 \%$ & $100 \%$ \\
\hline 1981 & $89.6 \%$ & $4.9 \%$ & $1.7 \%$ & $1.8 \%$ & $0.8 \%$ & $0.3 \%$ & $0.9 \%$ & $100 \%$ \\
\hline 1982 & $89.7 \%$ & $5.1 \%$ & $1.7 \%$ & $1.5 \%$ & $0.8 \%$ & $0.3 \%$ & $0.9 \%$ & $100 \%$ \\
\hline 1983 & $89.3 \%$ & $5.3 \%$ & $1.6 \%$ & $1.8 \%$ & $1.0 \%$ & $0.2 \%$ & $0.9 \%$ & $100 \%$ \\
\hline 1984 & $88.5 \%$ & $5.7 \%$ & $1.6 \%$ & $1.9 \%$ & $0.9 \%$ & $0.5 \%$ & $0.9 \%$ & $100 \%$ \\
\hline 1985 & $87.7 \%$ & $7.1 \%$ & $1.5 \%$ & $1.4 \%$ & $1.2 \%$ & $0.4 \%$ & $0.6 \%$ & $100 \%$ \\
\hline 1986 & $86.3 \%$ & $7.6 \%$ & $1.7 \%$ & $1.5 \%$ & $1.5 \%$ & $0.7 \%$ & $0.7 \%$ & $100 \%$ \\
\hline 1987 & $85.3 \%$ & $8.4 \%$ & $1.9 \%$ & $1.4 \%$ & $1.5 \%$ & $0.7 \%$ & $0.8 \%$ & $100 \%$ \\
\hline 1988 & $84.1 \%$ & $9.3 \%$ & $1.8 \%$ & $1.2 \%$ & $1.5 \%$ & $1.4 \%$ & $0.7 \%$ & $100 \%$ \\
\hline 1989 & $81.7 \%$ & $10.7 \%$ & $1.9 \%$ & $1.3 \%$ & $1.8 \%$ & $1.5 \%$ & $1.1 \%$ & $100 \%$ \\
\hline 1990 & $79.4 \%$ & $12.9 \%$ & $20 \%$ & $1.0 \%$ & $1.8 \%$ & $1.6 \%$ & $1.2 \%$ & $100 \%$ \\
\hline 1991 & $77.2 \%$ & $14.4 \%$ & $2.2 \%$ & $0.9 \%$ & $23 \%$ & $1.6 \%$ & $1.5 \%$ & $100 \%$ \\
\hline 1992 & $72.0 \%$ & $17.6 \%$ & $27 \%$ & $0.9 \%$ & $2.8 \%$ & $1.9 \%$ & $22 \%$ & $100 \%$ \\
\hline
\end{tabular}

- Unadjusted total of raw, washed, and screened coal, and small amounts of coke and middlings. This includes only direct use of coal in households and in small boilers. Coal used in large boilers (with capacities of several tens of tons of steam per hour) for district heating systems, in cogeneration systems which supply residences, and in generation of residential electricity is not included in this category. The electricity and district heating categories are composed mainly of coal used to generate the electricity and steam consumed in residences.

$\dagger$ Assuming a conversion efficiency in thermal power plants of $0.404 \mathrm{kgce} / \mathrm{kWh}$. Figures for $1980-1984$ include only electricity generated by plants with installed capacity of $\geq 500 \mathrm{~kW}$.

I Calculated as the amount of coal used in boilers, not heat delivered. This may result in double counting if heat is from cogeneration systems,but the correction is probably small because cogeneration accounts for less than $10 \%$ of installed electricity generation capacity nationally.

* Composed mainly of coke-oven gas and other coal gas $(0.614 \mathrm{tce} / 1000 \mathrm{~m} 3)$. Aso includes a very small amount of refinery gas (1.571 tce/tonne) for 1985-1988.

Source: China Energy Statistical Yearbook, various years; China Statistical Yearbook, various years. 
Figure IV-14. Residential Energy Consumption (Commercial Energy)

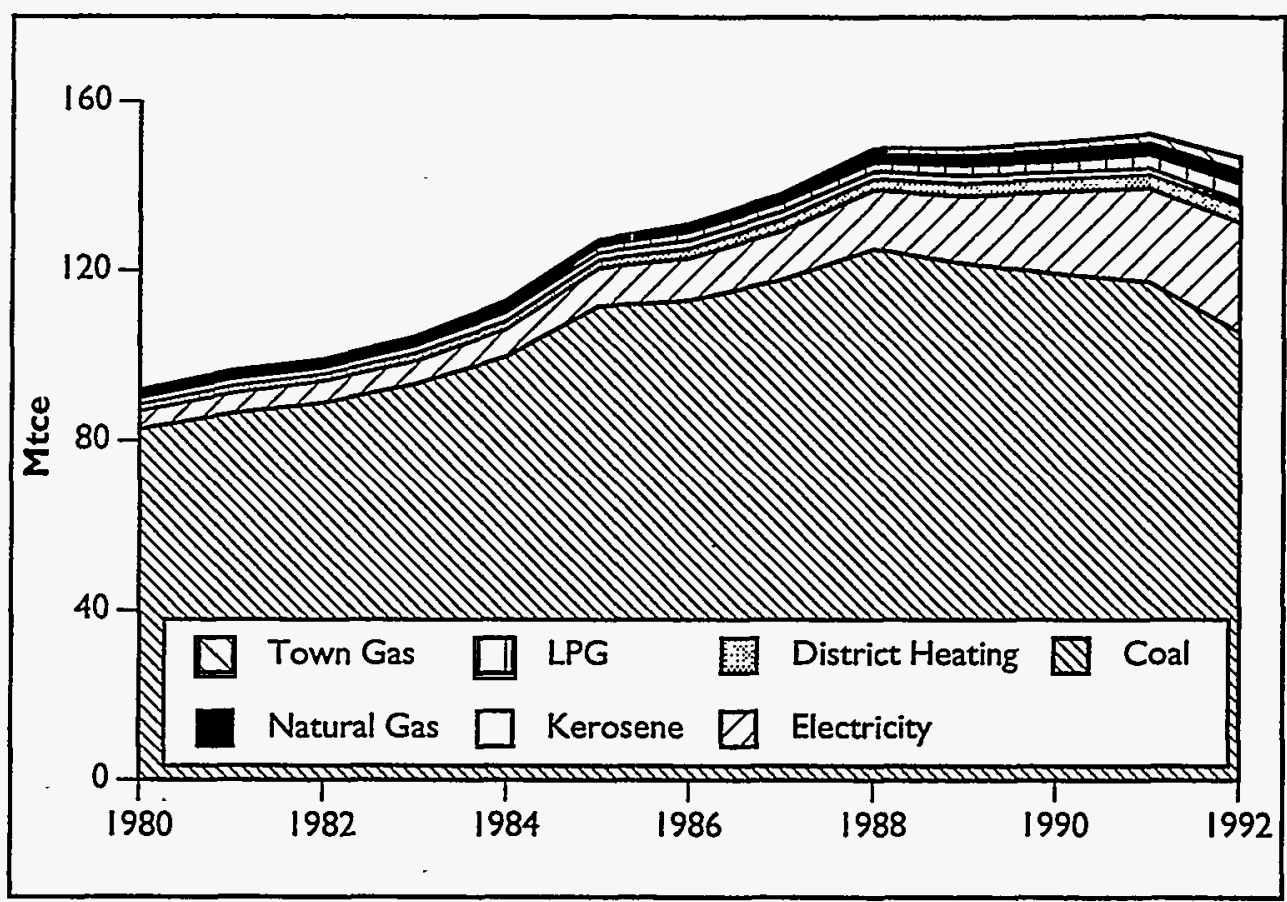


Table IV-19. Urban and Rural Residential Energy Consumption (Commercial Energy Only)

\begin{tabular}{|c|c|c|c|c|c|}
\hline \multicolumn{6}{|c|}{ 1. Coal Consumption * } \\
\hline \multirow[b]{2}{*}{ Year } & \multicolumn{3}{|c|}{ Mt } & \multicolumn{2}{|c|}{ Shares } \\
\hline & Urban & Rural & Total & Urban & Rural \\
\hline 1985 & 87.45 & 68.80 & 156.24 & $56 \%$ & $44 \%$ \\
\hline 1986 & 87.18 & 67.64 & 154.82 & $56 \%$ & $44 \%$ \\
\hline 1987 & 88.45 & 72.98 & 161.43 & $55 \%$ & $45 \%$ \\
\hline 1988 & 90.82 & 79.55 & 170.37 & $53 \%$ & $47 \%$ \\
\hline 1989 & 89.88 & 80.55 & 170.43 & $53 \%$ & $47 \%$ \\
\hline 1990 & 88.94 & 78.06 & 167.00 & $53 \%$ & $47 \%$ \\
\hline 1991 & 85.66 & 78.87 & 164.52 & $52 \%$ & $48 \%$ \\
\hline 1992 & 72.48 & 75.33 & 147.81 & $49 \%$ & $51 \%$ \\
\hline \multicolumn{6}{|c|}{ 2. Electricity Consumption } \\
\hline & & TWh & & \multicolumn{2}{|c|}{ Shares } \\
\hline Year & Urban & Rural & Total & $\overline{\text { Urban }}$ & Rural \\
\hline 1985 & 12.25 & 10.00 & 22.25 & $55 \%$ & $45 \%$ \\
\hline 1986 & 14.43 & 10.36 & 24.79 & $58 \%$ & $42 \%$ \\
\hline 1987 & 16.23 & 12.42 & 28.65 & $57 \%$ & $43 \%$ \\
\hline 1988 & 19.44 & 14.89 & 34.33 & $57 \%$ & $43 \%$ \\
\hline 1989 & 22.51 & 17.01 & 39.52 & $57 \%$ & $43 \%$ \\
\hline 1990 & 27.22 & 20.86 & 48.08 & $57 \%$ & $43 \%$ \\
\hline $199 \mid$ & 31.97 & 22.39 & 54.36 & $59 \%$ & $41 \%$ \\
\hline 1992 & 35.98 & 28.02 & 64.00 & $56 \%$ & $44 \%$ \\
\hline \multicolumn{6}{|c|}{ 3. Total Energy Consumption $t$} \\
\hline & & Mtce & & \multicolumn{2}{|c|}{ Shares } \\
\hline Year & Urban & Rural & $\overline{\text { Total }}$ & Urban & Rural \\
\hline 1985 & 75.49 & 57.70 & 133.18 & $57 \%$ & $43 \%$ \\
\hline 1986 & 78.56 & 57.27 & 135.83 & $58 \%$ & $42 \%$ \\
\hline 1987 & 81.17 & 62.06 & i 43.23 & $57 \%$ & $43 \%$ \\
\hline 1988 & 86.48 & 68.86 & I55.34 & $56 \%$ & $44 \%$ \\
\hline 1989 & 86.37 & 69.47 & 155.83 & $55 \%$ & $45 \%$ \\
\hline 1990 & 88.95 & 69.04 & 158.00 & $56 \%$ & $44 \%$ \\
\hline 1991 & 89.64 & 70.29 & I59.93 & $56 \%$ & $44 \%$ \\
\hline 1992 & 84.50 & 71.86 & 156.36 & $54 \%$ & $46 \%$ \\
\hline
\end{tabular}

- Unadjusted sum of raw and washed coal.

$\dagger$ Figures are unadjusted and so differ from those in the previous table.

Source: China Energy Statistical Yearbook, various years; China Statistical Yearbook, various years. 


\section{Table IV-20. Residential Sector Commercial Energy Consumption by Province and Energy Source, 1990}

\begin{tabular}{|c|c|c|c|c|c|c|c|c|}
\hline \multirow[b]{2}{*}{$\begin{array}{c}\text { Planning } \\
\text { Region }\end{array}$} & \multirow[b]{2}{*}{ Province } & \multicolumn{4}{|c|}{ Total } & \multicolumn{3}{|c|}{ Per Capita } \\
\hline & & $\begin{array}{l}\text { End-of-Year } \\
\text { Population } \\
\text { (millions) }\end{array}$ & $\begin{array}{l}\text { Coal } \\
\text { (Mt) }\end{array}$ & $\begin{array}{l}\text { Electricity } \\
\text { (TWh) }\end{array}$ & $\begin{array}{l}\text { Total } \\
\text { Energy } \\
\text { (Mtce) }\end{array}$ & $\begin{array}{l}\text { Coal } \\
\text { (kg) }\end{array}$ & $\begin{array}{c}\text { Electricity } \\
\text { (kWh) }\end{array}$ & $\begin{array}{c}\text { Total } \\
\text { Energy } \\
\text { (kgce) }\end{array}$ \\
\hline \multirow[t]{5}{*}{ North } & Beijing & 10.86 & 4.003 & 0.950 & 3.687 & 369 & 87 & 339 \\
\hline & Tlanjin & 8.84 & 2.123 & 0.803 & 2.123 & 240 & 91 & 240 \\
\hline & Hebei & 61.59 & 15.305 & 2.239 & $12.248^{\circ}$ & 249 & 36 & 199 \\
\hline & Shanxi & 28.99 & 8.407 & 1.226 & 6.930 & 290 & 42 & 239 \\
\hline & Inner Mongolia & 21.63 & 5.858 & 0.879 & 4.372 & 271 & 41 & 202 \\
\hline \multirow[t]{3}{*}{ Northeast } & Liaoning & 39.67 & 9.007 & 3.303 & 9.541 & 227 & 83 & 241 \\
\hline & Jilin & 24.83 & 6.330 & 1.788 & 6.085 & 255 & 72 & 245 \\
\hline & Heilongilang & 35.43 & 10.787 & 3.347 & 11.048 & 304 & 94 & 312 \\
\hline \multirow[t]{7}{*}{ East } & Shanghai & 13.37 & 2.145 & 1.444 & 2493 & 160 & 108 & 186 \\
\hline & Jiangsu & 67.67 & 5.871 & 2.610 & 5.612 & 87 & 39 & 83 \\
\hline & Zhejiang & 41.68 & 2.028 & 2.572 & 2.594 & 49 & 62 & 62 \\
\hline & Anhui & 56.75 & 3.511 & 1.538 & 3.293 & 62 & 27 & 58 \\
\hline & Fujian & 30.37 & 1.960 & 1.848 & 2183 & 65 & 61 & 72 \\
\hline & jiangxi & 38.10 & 3.039 & 0.847 & 2.240 & 80 & 22 & 59 \\
\hline & Shandong & 84.93 & 6.754 & 3.755 & 7.258 & 80 & 44 & 85 \\
\hline \multirow[t]{6}{*}{ South-Central } & Henan & 86.49 & 14.395 & 2.045 & 11.659 & 166 & 24 & 135 \\
\hline & Hubei & 54.39 & 4.517 & 1.560 & 4.012 & 83 & 29 & 74 \\
\hline & Hunan & 61.28 & 6.604 & 1.468 & 5.452 & 108 & 24 & 89 \\
\hline & Guangdong & 63.46 & 3.480 & 3.917 & 4.526 & 55 & 62 & 71 \\
\hline & Guangxi & 42.61 & 0.603 & 1.745 & 1.068 & 14 & 41 & 25 \\
\hline & Hainan & 6.63 & 0.042 & 0.080 & 0.092 & 6 & 12 & 14 \\
\hline \multirow{4}{*}{ Southwest } & Sichuan & 108.04 & 20.210 & 3.785 & 16.646 & 187 & 35 & 154 \\
\hline & Guizhou & 32.68 & 6.967 & 0.728 & 5.401 & 213 & 22 & 165 \\
\hline & Yunnan & 37.31 & 4.815 & 1.012 & 3.716 & 129 & 27 & 100 \\
\hline & Xizang & 2.22 & & 0.080 & & 0 & 36 & 0 \\
\hline \multirow[t]{5}{*}{ Northwest } & Shaanxi & 33.16 & 6.014 & 0.832 & 4.765 . & 181 & 25 & 144 \\
\hline & Gansu & 22.55 & 4.238 & 0.920 & 3.530 . & 188 & 41 & 157 \\
\hline & Qinghai & 4.48 & 1.242 & 0.120 & $0.992^{\circ}$ & 277 & 27 & 221 \\
\hline & Ningxia & 4.70 & 1.059 & 0.216 & 0.855 & 225 & 46 & 182 \\
\hline & Xiniiang & 15.29 & 5.684 & 0.422 & 4.933 & 372 & 28 & 323 \\
\hline National Total & & $1,143.33$ & 166.997 & 48.080 & 157.995 & 146 & 42 & 138 \\
\hline Bolance * & & 3.33 & 0.000 & 0.001 & 8.641 & - & - & - \\
\hline
\end{tabular}

* Because of differences in the coverage of provincial and national statistics and conversions to standard coal, the sums of provincial statistics do not equal national totals.

Source: China Energy Statistical Yearbook, 1991; China Statistical Yearbook, 1991. 


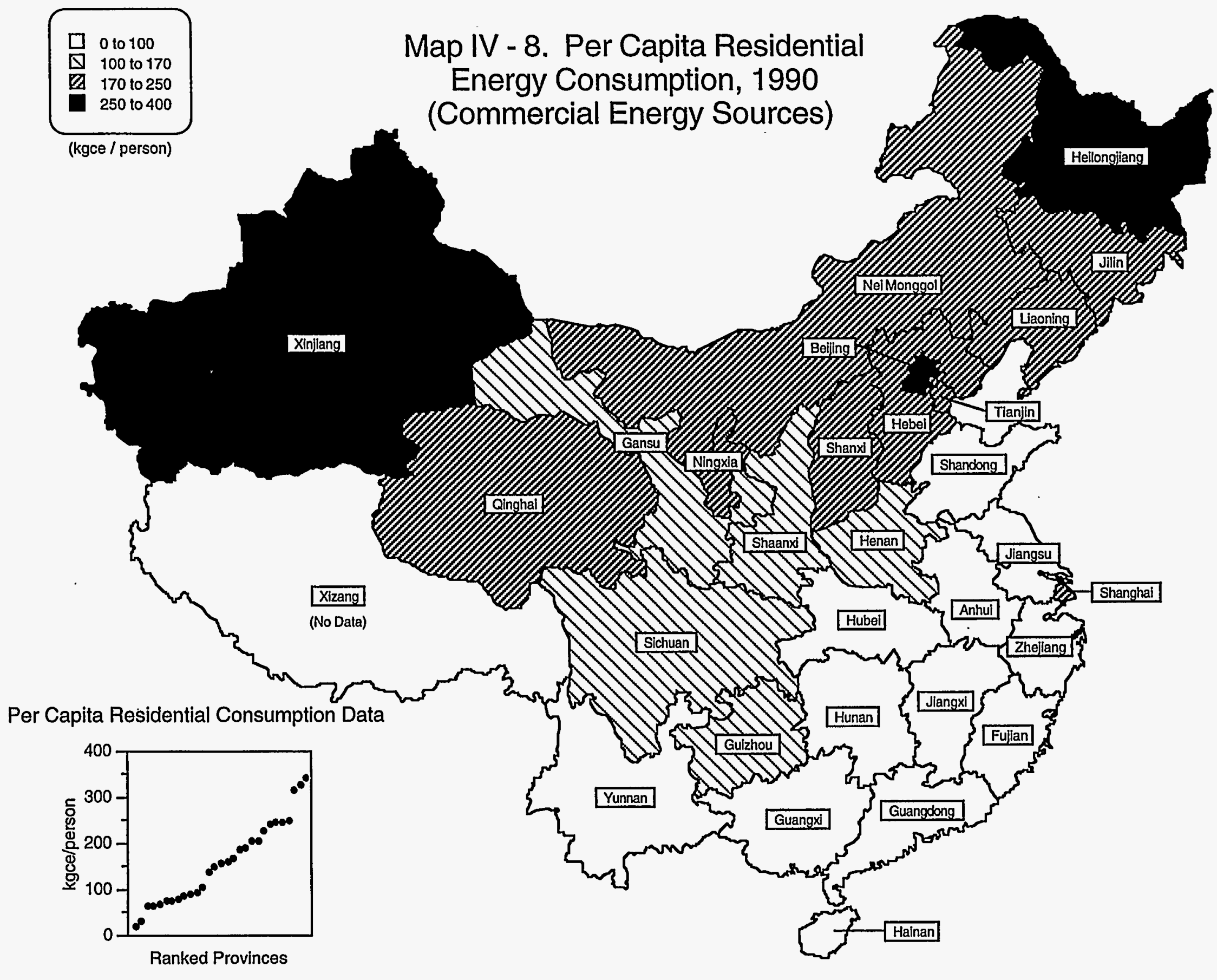


Table IV-21. Rural Energy: Available Energy Sources and Houshold Consumption, $1979,1987,1990$ and $1992-$ Mtce

\begin{tabular}{|c|c|c|c|c|c|c|}
\hline \multirow[b]{2}{*}{ Energy Source } & \multicolumn{3}{|c|}{1979} & \multicolumn{3}{|c|}{1987} \\
\hline & $\begin{array}{l}\text { Avallable } \\
\text { Energy * }\end{array}$ & $\begin{array}{c}\text { Household } \\
\text { Consumption }\end{array}$ & Balance & $\begin{array}{l}\text { Avallable } \\
\text { Energy* }\end{array}$ & $\begin{array}{l}\text { Household } \\
\text { Consumption }\end{array}$ & Balance \\
\hline $\begin{array}{l}\text { Crop Stalk } \\
\text { Dung Cake } \\
\text { Firewood } \\
\text { Biomass Subtotal }\end{array}$ & $\begin{array}{r}183.60 \\
129.43 \\
66.79 \\
379.82\end{array}$ & $\begin{array}{r}113.69 \\
6.32 \\
103.77 \\
223.78\end{array}$ & $\begin{array}{r}69.91 \\
123.11 \\
-36.98 \\
156.04\end{array}$ & $\begin{array}{r}268.31 \\
91.05 \\
76.93 \\
436.29\end{array}$ & $\begin{array}{r}130.32 \\
3.24 \\
132.63 \\
266.19\end{array}$ & $\begin{array}{r}137.99 \\
87.81 \\
-55.70 \\
170.10\end{array}$ \\
\hline Commercial Subtotal & 76.49 & 37.19 & 40.81 & 223.61 & 66.45 & 159.05 \\
\hline \multirow[b]{2}{*}{ Energy Source } & 456.31 & 260.97 & 195.34 & 659.90 & 332.64 & 327.26 \\
\hline & $\begin{array}{l}\text { Economic Activity } \\
\text { Consumption }\end{array}$ & $\begin{array}{c}1990 \\
\text { Household } \\
\text { Consumption }\end{array}$ & $\begin{array}{l}\text { Total Energy } \\
\text { Consumption }\end{array}$ & $\begin{array}{l}\text { Economic Activity } † \\
\text { Consumption }\end{array}$ & $\begin{array}{c}1992 \\
\text { Household } \\
\text { Consumption }\end{array}$ & $\begin{array}{l}\text { Total Energy } \\
\text { Consumption }\end{array}$ \\
\hline $\begin{array}{l}\text { Electricity } \\
\text { Coal } \\
\text { Oil Products } ¥\end{array}$ & $\begin{array}{r}31.66 \\
149.81 \\
26.49\end{array}$ & $\begin{array}{r}2.12 \\
64.29 \\
1.22\end{array}$ & $\begin{array}{r}33.78 \\
214.10 \\
27.71\end{array}$ & $\begin{array}{r}42.00 \\
159.56 \\
30.98\end{array}$ & $\begin{array}{r}11.20 \\
78.89 \\
1.41\end{array}$ & $\begin{array}{r}53.20 \\
238.45 \\
32.39\end{array}$ \\
\hline Commercial Subtotal & 207.96 & 67.63 & 275.59 & 232.54 & 91.50 & 324.04 \\
\hline Total & 207.96 & 330.66 & 538.62 & 249.36 & 320.47 & 569.83 \\
\hline
\end{tabular}

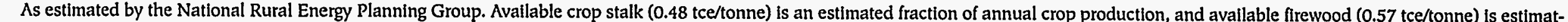
ed sustainable output. Available electricity is all generation from small hydropower stations (rural grids), and available coal is the output of rural mines.

Agriculture, transportation, rural industry, and services.

$\dagger$ Agriculture, transportation, rural industry, and services.

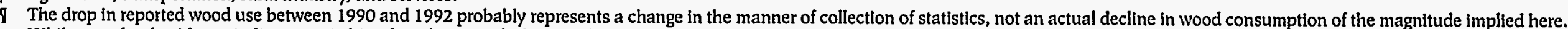

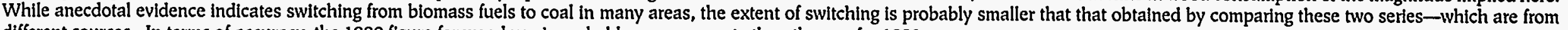
different sources. In terms of accuracy, the 1990 figure for wood use is probably more accurate than the one for 1992.

$¥$ Household oll use is kerosene and LPG. In practice, penetration of LPG into rural areas is very low.

Source: National Rural Energy Planning, 1990; Energy in China, 1992; China Energy Annual Review, 1994; Energy Research Institute. 
Table IV-22. Urban Gas Use, 1957-1993

\begin{tabular}{|c|c|c|c|c|c|c|c|c|c|c|}
\hline \multirow[b]{2}{*}{ Year } & \multirow{2}{*}{$\begin{array}{l}\text { Total } \\
\text { Number } \\
\text { of Cities }\end{array}$} & \multirow{2}{*}{$\begin{array}{l}\text { Number of } \\
\text { Cities in } \\
\text { which Gas } \\
\text { Available }\end{array}$} & \multicolumn{3}{|c|}{$\begin{array}{l}\text { Population Using Gas } \\
\text { (Million Persons) }\end{array}$} & \multirow[b]{2}{*}{ Total } & \multirow{2}{*}{$\begin{array}{l}\text { Households } \\
\text { Using Gas } \\
\text { (Million } \\
\text { Households) } \pi\end{array}$} & \multirow{2}{*}{$\begin{array}{l}\text { Total Urban } \\
\text { Population } \\
\text { (millions) }\end{array}$} & \multirow{2}{*}{$\begin{array}{l}\text { Percentage of } \\
\text { Total Urban } \\
\text { Population } \\
\text { Using Gas } †\end{array}$} & \multirow{2}{*}{$\begin{array}{c}\text { Percentage of } \\
\text { Nonagricultural } \\
\text { Urban } \\
\text { Population } \\
\text { Using Gas } ¥\end{array}$} \\
\hline & & & $\overline{\text { LPG }}$ & gas & gas & & & & & \\
\hline 1957 & - & - & - & - & - & - & - & - & - & $1.5 \%$ \\
\hline 1965 & - & - & - & - & - & - & - & - & - & $3.0 \%$ \\
\hline 1978 & - & - & . & - & - & - & - & - & - & $13.9 \%$ \\
\hline 1980 & 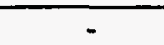 & - & - & - & - & & - & - & - & $16.8 \%$ \\
\hline 1981 & 225 & 64 & - & - & - & 16.72 & - & - & $8.3 \%$ & - \\
\hline 1984 & - & - & - & - & - & - & - & - & - & $21.1 \%$ \\
\hline 1985 & 324 & 133 & 15.34 & 9.11 & 2.81 & 27.26 & - & 212.28 & $12.8 \%$ & $22.4 \%$ \\
\hline 1986 & - & - & - & - & - & - & - & 233.15 & & $28.5 \%$ \\
\hline 1987 & 371 & & 23.99 & 11.77 & 6.34 & 42.09 & - & 262.31 & $16.0 \%$ & $32.6 \%$ \\
\hline 1988 & 424 & 247 & 27.64 & 13.57 & 7.48 & 48.70 & - & 298.22 & $16.3 \%$ & $34.9 \%$ \\
\hline 1989 & 441 & 259 & 31.56 & 14.98 & 8.96 & 55.50 & - & 317.66 & $17.5 \%$ & $37.9 \%$ \\
\hline 1990 & 467 & & - & & - & - & 20.27 & 335.43 & - & $42.2 \%$ \\
\hline 1991 & 479 & 416 & - & - & - & - & 20.95 & 346.02 & - & $47.1 \%$ \\
\hline 1992 & 517 & - & 47.96 & 21.81 & 11.19 & 80.97 & 21.81 & 383.91 & $21.1 \%$ & $52.4 \%$ \\
\hline 1993 & 570 & - & - & - & - & - & 22.84 & - & - & $57.0 \%$ \\
\hline
\end{tabular}

* Plped coal and natural gas, and LPG. The percentages here are calculated from statistics on population and household statistics and some differ from officially reported percentages Total population registered as living in urban areas, excluding population in outlying countles. Calculated, except 1981 figure.

Nonagricultural population in urban areas, excluding population in outlying counties. Reported.

Average urban household size has been declining, from 3.89 in 1985 to 3.31 in 1993.

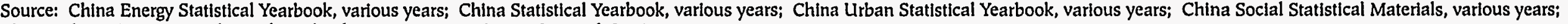
China Urban Economic and Social Yearbook, various years; Energy Research Institute. 
Table IV-23. Commercial Sector Energy Consumption, * 1980-1992

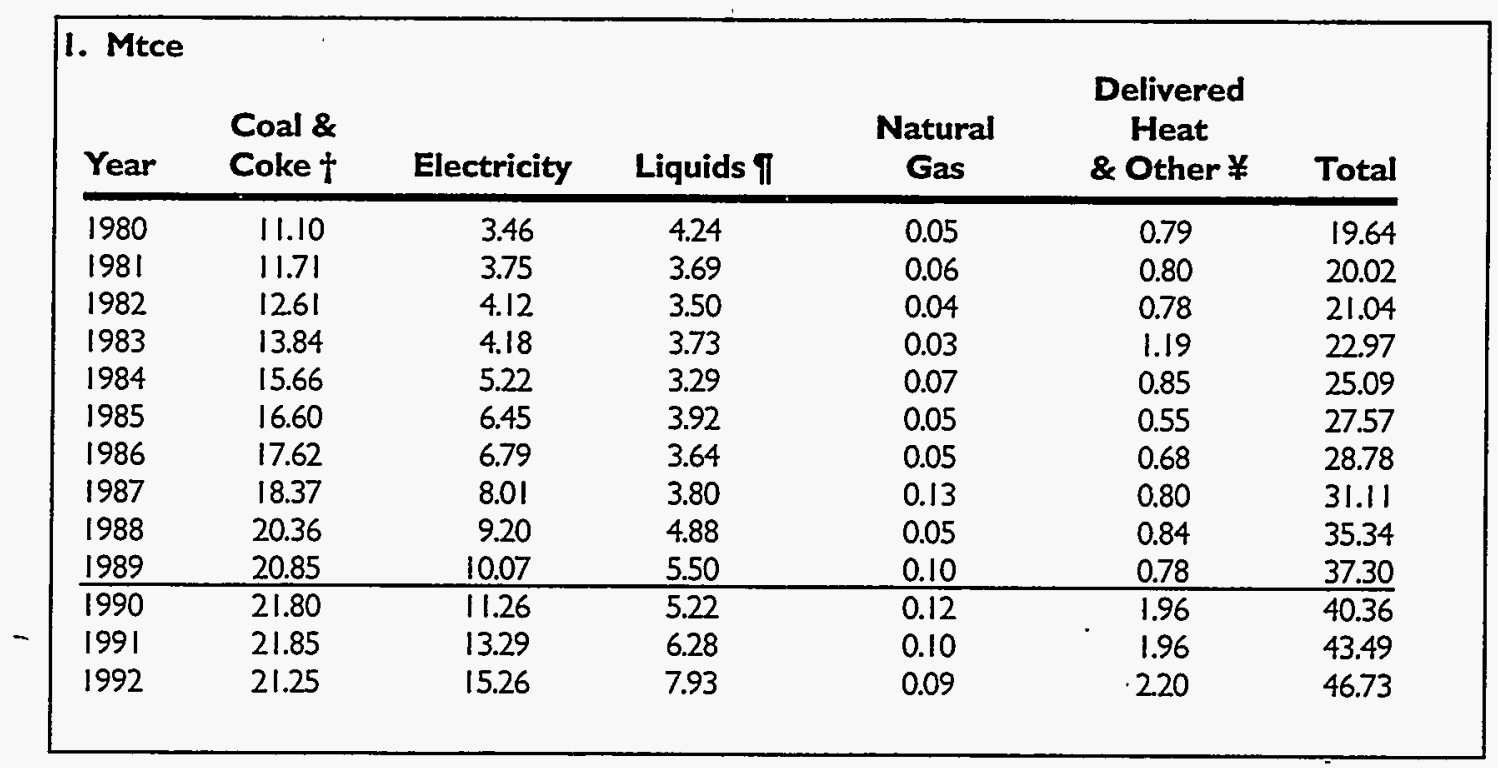

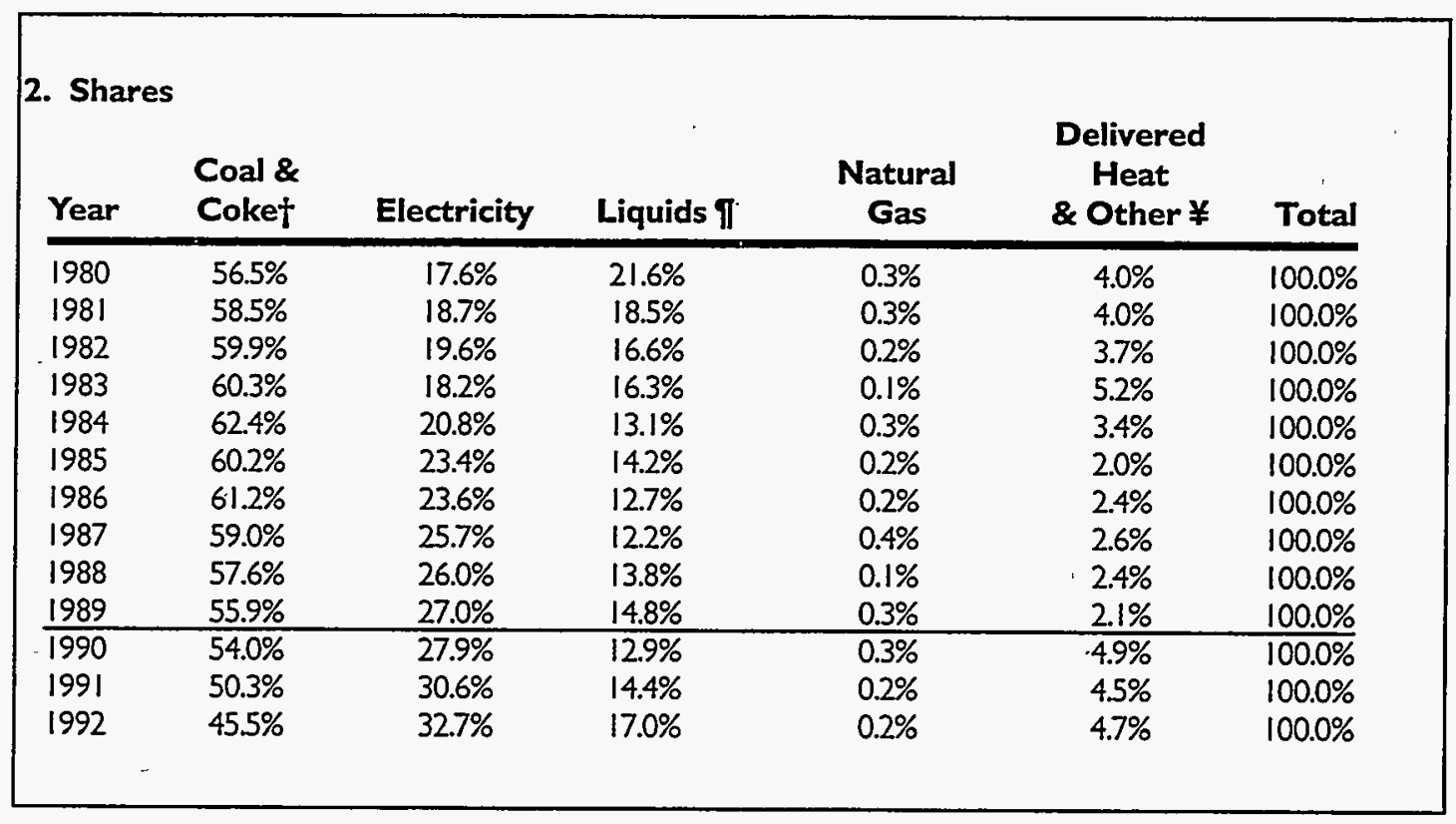

* This table covers energy use in both the "commerce" and "non-productive" sectors, as defined by the Chinese State Statistical Bureau.

$\dagger$ Includes raw and processed coal and small amounts of coke and middlings.

Includes kerosene, diesel, fuel oil, and crude oil.

This category includes heat produced by cogeneration and dedicated heat plants and sold to the industrial, commercial, and residential sectors. Also includes various fuels such as LPG, refinery gas, and coal gas.

Source: China Energy Statistical Yearbook, various years; China Statistical Yearbook, various years. 
Figure IV-15. Commercial Sector Energy Consumption by Fuel

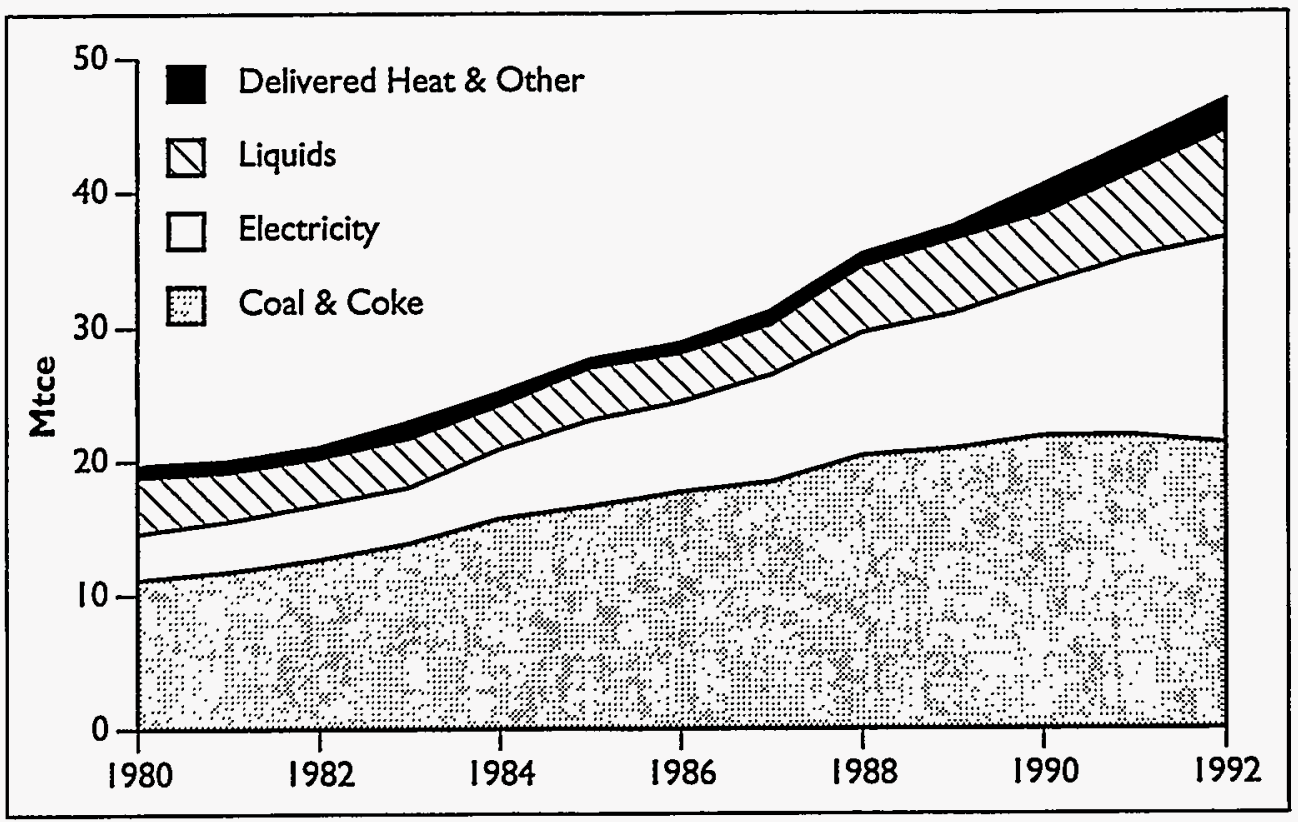




\section{Energy Source Consumption}


Table IV-24. End-Use Energy Consumption by Source (Commercial Energy Only)

\begin{tabular}{|c|c|c|c|c|c|c|c|c|}
\hline Year & $\begin{array}{l}\text { Coal \& } \\
\text { Coke * }\end{array}$ & $\begin{array}{l}\text { Petroleum } \\
\text { Products * }\end{array}$ & $\begin{array}{c}\text { Natural } \\
\text { Gas * }\end{array}$ & $\begin{array}{l}\text { Coal } \\
\text { Gast }\end{array}$ & Electricity $\pi$ & $\begin{array}{c}\text { Delivered } \\
\text { Heat } \S\end{array}$ & Other $¥$ & $\begin{array}{l}\text { Total Energy } \\
\text { End-Use }\end{array}$ \\
\hline 1980 & 319.1 & 91.9 & 18.7 & 6.4 & 103.8 & 10.5 & 16.2 & 566.7 \\
\hline 1981 & 318.1 & 86.4 & 16.6 & 6.6 & 106.8 & 10.9 & 14.6 & 559.9 \\
\hline 1982 & 336.6 & 87.3 & 15.8 & 6.6 & 113.7 & 11.1 & 13.9 & 585.0 \\
\hline 1983 & 360.8 & 90.4 & 16.1 & 7.3 & 121.8 & 11.4 & 15.4 & 623.20 \\
\hline 1984 & 391.4 & 95.4 & 16.8 & 7.4 & 131.2 & 121 & 15.1 & 669.30 \\
\hline 1985 & 421.9 & 102.5 & 16.2 & 8.2 & 143.4 & 13.0 & 17.7 & 7229 \\
\hline 1986 & 440.1 & 111.0 & 17.5 & 10.4 & 156.8 & 14.1 & 10.5 & 760.4 \\
\hline 1987 & 468.4 & 118.8 & 18.3 & 9.6 & 173.4 & 15.8 & 10.3 & 814.6 \\
\hline 1988 & 496.5 & 127.1 & 18.7 & 11.0 & 190.8 & 16.1 & 13.9 & 874.0 \\
\hline 1989 & 502.7 & 134.3 & 19.8 & 126 & 204.2 & 17.9 & 17.3 & 908.9 \\
\hline 1990 & 494.4 & 134.6 & 20.2 & 129 & 216.8 & 21.1 & 21.7 & 921.7 \\
\hline 1991 & 501.2 & 147.1 & 20.8 & 13.0 & 236.2 & - & 45.6 & 963.9 \\
\hline 1992 & 505.2 & 157.4 & 20.9 & 13.0 & 263.2 & - & 53.4 & 1.013 .1 \\
\hline 1993 & & & & - & & - & - & - \\
\hline $1994 * *$ & 548.8 & 177.2 & 21.5 & 23.7 & 288.3 & 37.4 & 34.7 & $1,131.7$ \\
\hline
\end{tabular}

\begin{tabular}{|c|c|c|c|c|c|c|c|c|}
\hline $\begin{array}{l}\text { 2a. Shares } \\
\text { Year }\end{array}$ & $\begin{array}{l}\text { Coal \& } \\
\text { Coke * }\end{array}$ & $\begin{array}{l}\text { Petroleum } \\
\text { Products * }\end{array}$ & $\begin{array}{c}\text { Natural } \\
\text { Gas * }\end{array}$ & $\begin{array}{l}\text { Coal } \\
\text { Gas }+\end{array}$ & Electricity II & $\begin{array}{c}\text { Delivered } \\
\text { Heat } \S\end{array}$ & Other $¥$ & $\begin{array}{l}\text { Total Energy } \\
\text { End-Use }\end{array}$ \\
\hline 1980 & $56.3 \%$ & $16.2 \%$ & $3.3 \%$ & $1.1 \%$ & $18.3 \%$ & $1.9 \%$ & $29 \%$ & $100.0 \%$ \\
\hline 1981 & $56.8 \%$ & $15.4 \%$ & $3.0 \%$ & $1.2 \%$ & $19.1 \%$ & $20 \%$ & $26 \%$ & $100.0 \%$ \\
\hline 1982 & $57.5 \%$ & $14.9 \%$ & $2.7 \%$ & $1.1 \%$ & $19.4 \%$ & $1.9 \%$ & $24 \%$ & $100.0 \%$ \\
\hline 1983 & $57.9 \%$ & $14.5 \%$ & $2.6 \%$ & $1.2 \%$ & $19.6 \%$ & $1.8 \%$ & $2.5 \%$ & $100.0 \%$ \\
\hline 1984 & $58.5 \%$ & $14.2 \%$ & $2.5 \%$ & $1.1 \%$ & $19.6 \%$ & $1.8 \%$ & $23 \%$ & $100.0 \%$ \\
\hline 1985 & $58.4 \%$ & $14.2 \%$ & $2.2 \%$ & $1.1 \%$ & $19.8 \%$ & $1.8 \%$ & $2.4 \%$ & $100.0 \%$ \\
\hline 1986 & $57.9 \%$ & $14.6 \%$ & $2.3 \%$ & $1.4 \%$ & $20.6 \%$ & $1.9 \%$ & $1.4 \%$ & $100.0 \%$ \\
\hline 1987 & $57.5 \%$ & $14.6 \%$ & $2.2 \%$ & $1.2 \%$ & $21.3 \%$ & $1.9 \%$ & $1.3 \%$ & $100.0 \%$ \\
\hline 1988 & $56.8 \%$ & $14.5 \%$ & $2.1 \%$ & $1.3 \%$ & $21.8 \%$ & $1.8 \%$ & $1.6 \%$ & $100.0 \%$ \\
\hline 1989 & $55.3 \%$ & $14.8 \%$ & $2.2 \%$ & $1.4 \%$ & $22.5 \%$ & $2.0 \%$ & $1.9 \%$ & $100.0 \%$ \\
\hline 1990 & $53.6 \%$ & $14.6 \%$ & $2.2 \%$ & $1.4 \%$ & $23.5 \%$ & $2.3 \%$ & $24 \%$ & $100.0 \%$ \\
\hline 1991 & $52.0 \%$ & $15.3 \%$ & $2.2 \%$ & $1.3 \%$ & $24.5 \%$ & - & $4.7 \%$ & $100.0 \%$ \\
\hline 1992 & $49.9 \%$ & $15.5 \%$ & $2.1 \%$ & $1.3 \%$ & $26.0 \%$ & - & $5.3 \%$ & $100.0 \%$ \\
\hline 1993 & & & & & & - & - & \\
\hline 1994*** & $48.5 \%$ & $15.7 \%$ & $1.9 \%$ & $2.1 \%$ & $25.5 \%$ & $3.3 \%$ & $3.1 \%$ & $100.0 \%$ \\
\hline
\end{tabular}

N.B. Figures given here differ from official data. Utility sector consumption is excluded.Figures in italics are estimates. Excludes over 250 Mtce annual.

- Includes feedstocks.

** 1994 figures are preliminary and subject to revision.

$\dagger 1991$ and 1992 figures are lower bounds.

1 Converted at $0.404 \mathrm{kgce} / \mathrm{kWh}$.

$\S$ This category includes heat produced by cogeneration and dedicated heat plants and sold to the industrial, commercial, and residential sectors.

$¥$ Includes refinery gas, LPG, various petroleum and coking products, and delivered heat for years in which the last is not reported.

Source: China Energy Statistical Yearbook, various years; China Statistical Yearbook, various years. 


\begin{tabular}{|c|c|c|c|c|c|c|c|c|}
\hline \multicolumn{9}{|c|}{ 3. Mtce (electricity converted at heat value) } \\
\hline Year & $\begin{array}{l}\text { Coal \& } \\
\text { Coke * }\end{array}$ & $\begin{array}{l}\text { Petroleum } \\
\text { Products * }\end{array}$ & $\begin{array}{c}\text { Natural } \\
\text { Gas * }\end{array}$ & $\begin{array}{l}\text { Coal } \\
\text { Gas } t\end{array}$ & Electricity I & $\begin{array}{c}\text { Delivered } \\
\text { Heat § }\end{array}$ & Other $¥$ & $\begin{array}{l}\text { Total Energy } \\
\text { End-Use }\end{array}$ \\
\hline 1980 & 319.1 & 91.9 & 18.7 & 6.4 & 31.6 & 10.5 & 16.2 & 494.5 \\
\hline 1981 & 318.1 & 86.4 & 16.6 & $6.6^{\circ}$ & 32.5 & 10.9 & 14.6 & 485.7 \\
\hline 1982 & 336.6 & 87.3 & 15.8 & 6.6 & 34.6 & 11.1 & 13.9 & 505.9 \\
\hline 1983 & 360.8 & 90.4 & 16.1 & 7.3 & 37.1 & 11.4 & 15.4 & 538.5 \\
\hline 1984 & 391.4 & 95.4 & 16.8 & 7.4 & 39.9 & 12.1 & 15.1 & 578.1 \\
\hline 1985 & 421.9 & 102.5 & 16.2 & 8.2 & 43.7 & 13.0 & 17.7 & 623.1 \\
\hline 1986 & 440.1 & 111.0 & 17.5 & 10.4 & 47.7 & 14.1 & 10.5 & 651.4 \\
\hline 1987 & 468.4 & 118.8 & 18.3 & 9.6 & 52.8 & 15.8 & 10.3 & 694.0 \\
\hline 1988 & 496.5 & 127.1 & 18.7 & 11.0 & 58.1 & 16.1 & 13.9 & 741.3 \\
\hline 1989 & 502.7 & 134.3 & 19.8 & 12.6 & 622 & 17.9 & 17.3 & 766.9 \\
\hline 1990 & 494.4 & 134.6 & 20.2 & 12.9 & 66.0 & 21.1 & 21.7 & 770.9 \\
\hline 1991 & 501.2 & 147.1 & 20.8 & 13.0 & 71.9 & - & 45.6 & 799.6 \\
\hline 1992 & 505.2 & 157.4 & 20.9 & 13.0 & 80.1 & - & 53.4 & 830.0 \\
\hline 1993 & & - & - & - & - & - & - & - \\
\hline 1994 & 548.8 & 177.2 & 21.5 & 23.7 & 98.7 & 37.4 & 34.7 & 942.2 \\
\hline
\end{tabular}

\begin{tabular}{|c|c|c|c|c|c|c|c|c|}
\hline \multicolumn{9}{|c|}{ 4. Shares } \\
\hline Year & $\begin{array}{l}\text { Coal \& } \\
\text { Coke * }\end{array}$ & $\begin{array}{l}\text { Petroleum } \\
\text { Products * }\end{array}$ & $\begin{array}{c}\text { Natural } \\
\text { Gas* }\end{array}$ & $\begin{array}{l}\text { Coal } \\
\text { Gas } t\end{array}$ & Electricity ๆ & $\begin{array}{c}\text { Delivered } \\
\text { Heat } \S\end{array}$ & Other $¥$ & $\begin{array}{l}\text { Total Energy } \\
\text { End-Use }\end{array}$ \\
\hline 1980 & $64.5 \%$ & $18.6 \%$ & $3.8 \%$ & $1.3 \%$ & $6.4 \%$ & $2.1 \%$ & $3.3 \%$ & $100.0 \%$ \\
\hline 1981 & $65.5 \%$ & $17.8 \%$ & $3.4 \%$ & $1.4 \%$ & $6.7 \%$ & $2.3 \%$ & $3.0 \%$ & $100.0 \%$ \\
\hline 1982 & $66.5 \%$ & $17.2 \%$ & $3.1 \%$ & $1.3 \%$ & $6.8 \%$ & $2.2 \%$ & $27 \%$ & $100.0 \%$ \\
\hline 1983 & $67.0 \%$ & $16.8 \%$ & $3.0 \%$ & $1.3 \%$ & $6.9 \%$ & $2.1 \%$ & $2.9 \%$ & $100.0 \%$ \\
\hline 1984 & $67.7 \%$ & $16.5 \%$ & $2.9 \%$ & $1.3 \%$ & $6.9 \%$ & $2.1 \%$ & $26 \%$ & $100.0 \%$ \\
\hline 1985 & $67.7 \%$ & $16.5 \%$ & $2.6 \%$ & $1.3 \%$ & $7.0 \%$ & $2.1 \%$ & $28 \%$ & $100.0 \%$ \\
\hline 1986 & $67.6 \%$ & $17.0 \%$ & $2.7 \%$ & $1.6 \%$ & $7.3 \%$ & $2.2 \%$ & $1.6 \%$ & $100.0 \%$ \\
\hline 1987 & $67.5 \%$ & $17.1 \%$ & $2.6 \%$ & $1.4 \%$ & $7.6 \%$ & $2.3 \%$ & $1.5 \%$ & $100.0 \%$ \\
\hline 1988 & $67.0 \%$ & $17.1 \%$ & $2.5 \%$ & $1.5 \%$ & $7.8 \%$ & $2.2 \%$ & $1.9 \%$ & $100.0 \%$ \\
\hline 1989 & $65.6 \%$ & $17.5 \%$ & $2.6 \%$ & $1.6 \%$ & $8.1 \%$ & $2.3 \%$ & $2.3 \%$ & $100.0 \%$ \\
\hline 1990 & $64.1 \%$ & $17.5 \%$ & $26 \%$ & $1.7 \%$ & $8.6 \%$ & $2.7 \%$ & $2.8 \%$ & $100.0 \%$ \\
\hline 1991 & $62.7 \%$ & $18.4 \%$ & $2.6 \%$ & $1.6 \%$ & $9.0 \%$ & - & $5.7 \%$ & $100.0 \%$ \\
\hline 1992 & $60.9 \%$ & $19.0 \%$ & $2.5 \%$ & $1.6 \%$ & $9.7 \%$ & - & $6.4 \%$ & $100.0 \%$ \\
\hline 1993 & & & & - & - & - & - & - \\
\hline 1994 & $58.3 \%$ & $18.8 \%$ & $2.3 \%$ & $2.5 \%$ & $10.5 \%$ & - & $3.7 \%$ & $100.0 \%$ \\
\hline
\end{tabular}

N.B. Figures given here differ from official data. Figures in italics are estimates.

* Includes feedstocks.

$\dagger 1991$ and 1992 figures are lower bounds.

I Converted at $0.123 \mathrm{kgce} / \mathrm{kWh}$.

$\S$ This category includes heat produced by cogeneration and dedicated heat plants and sold to the industrial, commercial, and residential sectors.

$¥$ Includes refinery gas, LPG, various petroleum and coking products, and delivered heat for years in which the latter is not reported.

Source: China Energy Statistical Yearbook, various years; China Statistical Yearbook, various years. 
Figure IV-16. End-Use Energy Consumption by Energy Source

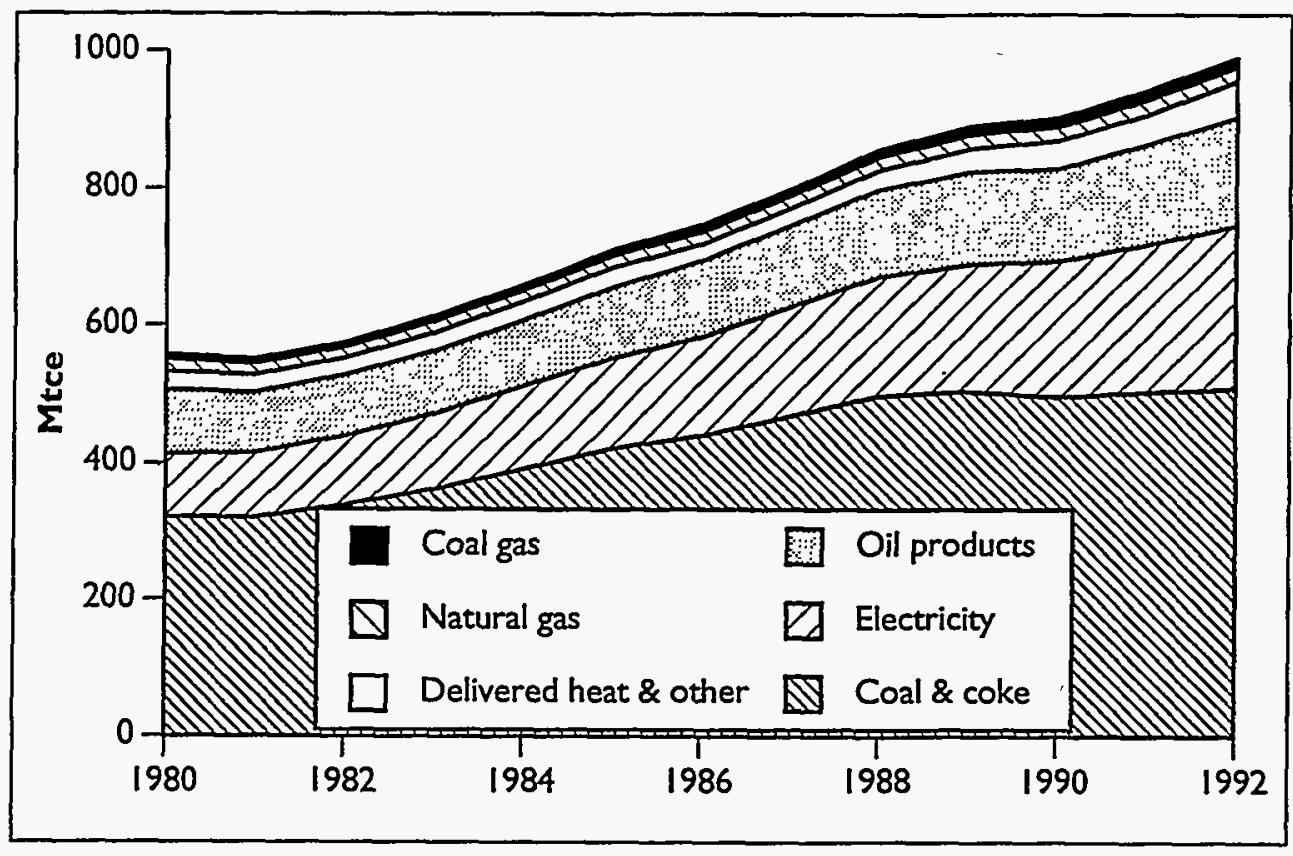


Table IV-25 Estimated Energy Consumption by End Use, 1990

\begin{tabular}{|lrr|}
\hline 1. Coal & Mt & Share \\
\hline Utility boilers & -272.0 & $25.8 \%$ \\
Industrial boilers & 350.0 & $33.2 \%$ \\
Producer and coal gas ovens & 45.0 & $4.3 \%$ \\
Coke ovens and metallurgical fumaces & 107.0 & $10.1 \%$ \\
Industrial kilns & 164.2 & $15.6 \%$ \\
Household stoves & 90.0 & $8.5 \%$ \\
Steam locomotives & 14.0 & $1.3 \%$ \\
Other & 13.0 & $1.2 \%$ \\
Total * & $1,055.2$ & $100.0 \%$ \\
& & - \\
\hline
\end{tabular}

\begin{tabular}{|lrr|}
\hline 2. Oil & Mt & Share \\
\hline Utility boilers & 12.34 & $12.1 \%$ \\
Industrial boilers & 3.56 & $3.5 \%$ \\
Kilns & 23.00 & $22.6 \%$ \\
Producer ovens & 0.40 & $0.4 \%$ \\
Motor vehicles & 22.30 & $21.9 \%$ \\
Water vessels & 9.27 & $9.1 \%$ \\
Locomotives & 2.51 & $2.5 \%$ \\
Tractors & 3.80 & $3.7 \%$ \\
Airplanes & 0.41 & $0.4 \%$ \\
Other diesel engines & 3.00 & $3.0 \%$ \\
Other gasoline generator sets & 0.90 & $0.9 \%$ \\
Other & 20.18 & $19.8 \%$ \\
Total * & 101.67 & $9.6 \%$ \\
\hline
\end{tabular}

\begin{tabular}{|lrr|}
\hline 3. Electricity & & \\
& TWh & Share \\
\hline Medium and small motors & 32.50 & $5.2 \%$ \\
Fans & 65.00 & $10.4 \%$ \\
Pumps & 130.00 & $20.9 \%$ \\
Compressors & 58.50 & $9.4 \%$ \\
Industrial electrical fumaces & 32.50 & $5.2 \%$ \\
Arc welders & 3.25 & $0.5 \%$ \\
Gas separators & 18.69 & $3.0 \%$ \\
Refrigeration and air conditioning & 34.27 & $5.5 \%$ \\
Caustic soda electric fumaces & 9.35 & $1.5 \%$ \\
Ferrous metals electric are fumaces & 15.58 & $2.5 \%$ \\
Electric locomotives & 3.80 & $0.6 \%$ \\
Agricultural irrigation equipment & 14.33 & $2.3 \%$ \\
Lighting and household appliances & 47.97 & $7.7 \%$ \\
Cement mills & 22.90 & $3.7 \%$ \\
Transmission and distribution losses & 43.46 & $7.0 \%$ \\
Other & 90.94 & $14.6 \%$ \\
\hline Total * & 623.04 & $100.0 \%$ \\
\hline
\end{tabular}

* These totals differ from those in other tables because of differences in sources and adjustments. The electricity total, for instance, includes line losses and nearly 89 TWh consumed by electric utilities.

Source: Energy Research Institute. 
Figure IV-17. Estimated Energy Consumption by End Use, 1990

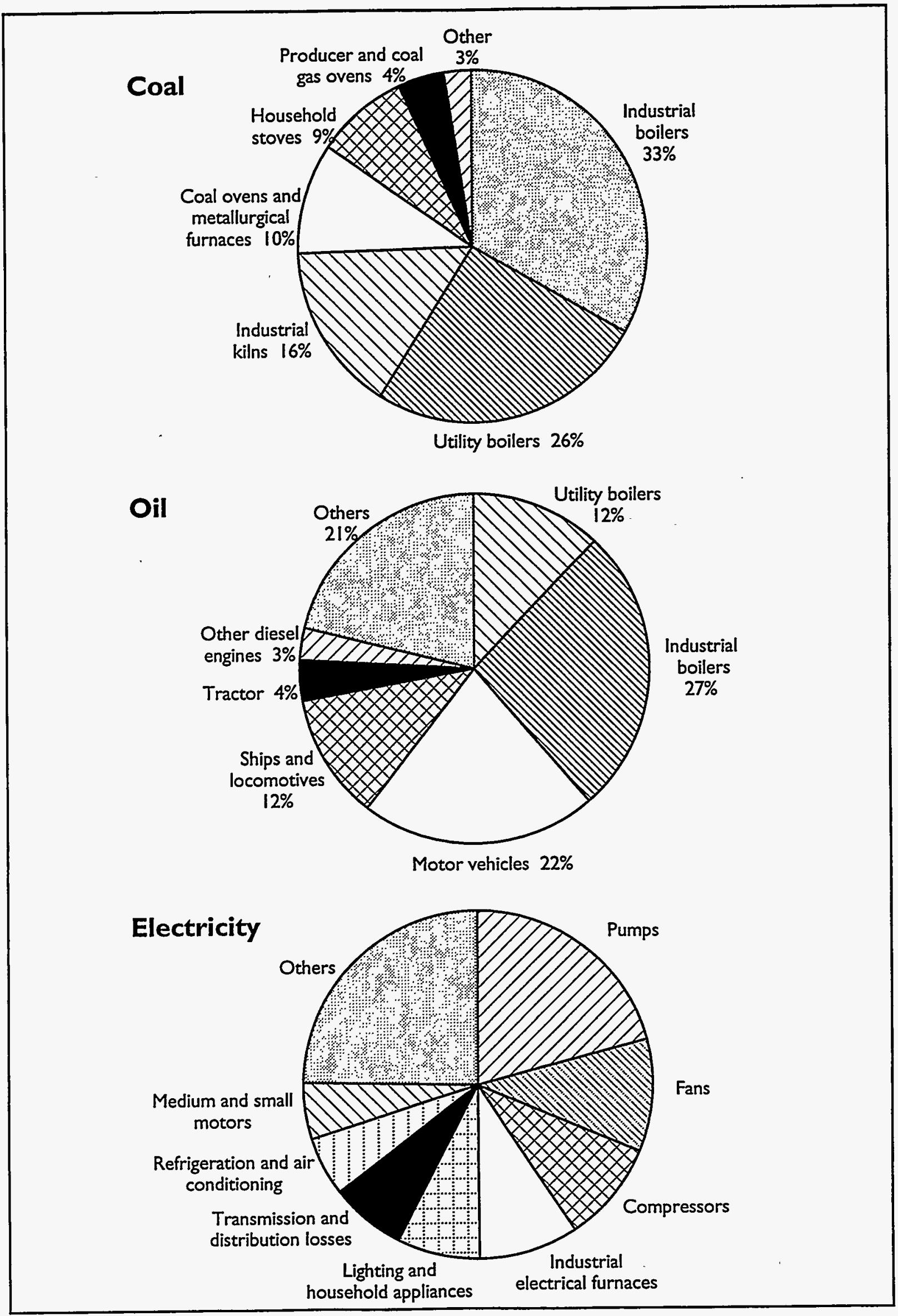


Table IV-26. Coal End Use and Inputs to Conversions, 1980-1993

\begin{tabular}{|c|c|c|c|c|c|c|c|c|c|c|c|c|c|c|}
\hline \multicolumn{15}{|l|}{ 1. Mt Raw Coal * } \\
\hline & 1980 & 1981 & 1982 & 1983 & 1984 & 1985 & 1986 & 1987 & 1988 & 1989 & 1990 & 1991 & 1992 & 1993 \\
\hline \multicolumn{15}{|l|}{ End Use Sectors } \\
\hline Industry & 221.4 & 217.5 & 235.2 & 257.8 & 282.4 & 301.7 & 315.3 & 341.8 & 363.4 & 373.8 & 359.4 & 370.0 & 389.1 & - \\
\hline Agriculture & 15.5 & 15.7 & 17.1 & 18.4 & 20.2 & 22.1 & 23.0 & 22.9 & 23.8 & 21.8 & 21.0 & 21.2 & 17.7 & - \\
\hline Transportation & 19.3 & 20.9 & 21.7 & 21.9 & 22.8 & 23.1 & 23.0 & 22.4 & 22.6 & 22.8 & 21.6 & 20.2 & 18.8 & - \\
\hline Commercial & 4.6 & 5.2 & 5.7 & 6.4 & 7.3 & 7.4 & 7.8 & 8.3 & 9.3 & 10.2 & 10.6 & 10.0 & 9.6 & - \\
\hline Other $\uparrow$ & 10.9 & 11.1 & 11.9 & 13.0 & 14.5 & 15.8 & 16.7 & 17.3 & 19.1 & 18.8 & 19.8 & 20.4 & 19.8 & - \\
\hline Residential & 115.7 & 120.9 & 124.6 & 130.6 & 139.8 & 156.2 & 158.2 & 164.9 & 175.3 & 170.4 & 167.0 & 164.5 & 147.8 & - \\
\hline Subtotal: & 387.4 & 391.3 & 416.2 & 448.1 & 487.1 & 526.2 & 544.0 & 577.5 & 613.5 & 617.9 & 599.3 & 606.4 & 602.7 & - \\
\hline \multicolumn{15}{|l|}{ Inputs to Conversions } \\
\hline$\overline{\text { Power Generation }}$ & 127.1 & 127.6 & 134.9 & 143.8 & 160.1 & 165.2 & 181.1 & 204.1 & 230.3 & 253.9 & 274.8 & 304.5 & 338.5 & 362.0 \\
\hline Heat $¥$ & - & - & - & - & - & 14.6 & 16.2 & 18.9 & 21.2 & 23.9 & 30.0 & 34.4 & 38.5 & 41.9 \\
\hline Coking § & 66.8 & 59.1 & 60.8 & 63.9 & 69.6 & 73.0 & 80.6 & 87.7 & 88.8 & 96.3 & 107.0 & 108.6 & 112.8 & - \\
\hline Coal Gas & 1.3 & 1.4 & 1.4 & 1.5 & 1.6 & 1.9 & 2.4 & 2.2 & 2.8 & 3.7 & 3.6 & 3.7 & 4.7 & - \\
\hline Coal Washing Losses & 27.4 & 26.5 & 28.0 & 29.9 & 31.3 & 35.0 & 35.9 & 37.5 & 37.1 & 38.7 & 40.6 & 46.7 & 43.6 & - \\
\hline Subtotal: & 222.6 & 214.5 & 225.1 & 239.1 & 262.6 & 289.8 & 316.2 & 350.5 & 380.1 & 416.4 & 455.9 & 497.9 & 538.1 & - \\
\hline Total & 610.1 & 605.8 & 641.3 & 687.1 & 749.7 & 816.0 & 860.2 & 928.0 & 993.5 & $1,034.3$ & $1,055.2$ & $1,104.3$ & $1,140,8$ & - \\
\hline
\end{tabular}

* Figures are uncorrected sums of consumption of raw and washed coal.

$\dagger$ Figures include feedstocks. Industry category includes industry and construction, but excludes power generation, heating, coking and coal gas production, and differs from official statistics. Probably understates actual consumption due to underreporting of rural industry coal use.

I This is reported in official data as "nomproductive" sector use of coal, e.g., govemment, education, financial services, etc. See Appendix for sector definitions.

* This category includes heat produced by cogeneration and dedicated heat plants and sold to the industrial, commercial, and residential sectors. $1980-1984$ heating use of coal was included in electricity generation use of coal.

§ Coking inputs may be underreported by as much as $50 \%$ due to incomplete statistics from rural coking plants.

Source: China Energy Statistical Yearbook, various years; China Statistical Yearbook, varlous years. 
Table IV-26. Coal End Use and Inputs to Conversions, 1980-1993 (continued)

\begin{tabular}{|c|c|c|c|c|c|c|c|c|c|c|c|c|c|c|}
\hline \multicolumn{10}{|l|}{ 2. Mtce * } & \multicolumn{5}{|c|}{$\cdot$} \\
\hline & 1980 & $\mid 981$ & 1982 & 1983 & 1984 & 1985 & 1986 & 1987 & 1988 & 1989 & 1990 & 1991 & 1992 & 1993 \\
\hline \multicolumn{15}{|l|}{ End Use Sectors } \\
\hline Industry $\dagger$ & 158.1 & 155.3 & 167.9 & 184.1 & 201.6 & 215.4 & 225.1 & 244.1 & 259.5 & 266.9 & 256.6 & 264.2 & 277.8 & - \\
\hline Agriculture & 11.1 & 11.2 & 12.2 & 13.1 & 14.4 & 15.8 & 16.4 & 16.3 & 17.0 & 15.6 & 15.0 & 15.2 & 12.6 & - \\
\hline Transportation & 13.8 & 14.9 & 15.5 & 15.6 & 16.3 & 16.5 & 16.4 & 16.0 & 16.1 & 16.3 & 15.4 & 14.5 & 13.4 & - \\
\hline Commercial & 3.3 & 3.7 & 4.0 & 4.5 & 5.2 & 5.3 & 5.6 & 5.9 & 6.7 & 7.3 & 7.6 & 7.1 & 6.8 & - \\
\hline Other $\pi$ & 7.8 & 7.9 & 8.5 & 9.3 & 10.4 & 11.3 & 11.9 & 12.4 & 13.6 & 13.4 & 14.1 & 14.6 & 14.2 & - \\
\hline Residential & 82.6 & 86.3 & 88.9 & 93.3 & 99.8 & 111.6 & 113.0 & 117.7 & 125.1 & 121.7 & 119.2 & 117.5 & 105.5 & - \\
\hline Subtotal: & 276.6 & 279.4 & 297.2 & 319.9 & 347.8 & 375.7 & 388.4 & 412.4 & 438.0 & 441.2 & 427.9 & 433.0 & 430.4 & - \\
\hline \multicolumn{15}{|l|}{ Inputs to Conversions } \\
\hline Power Generation & 90.7 & 91.1 & 96.3 & 102.7 & 114.3 & 118.0 & 129.3 & 145.7 & 164.4 & 181.2 & 196.2 & 217.4 & 241.7 & 258.5 \\
\hline Heat $\S$ & - & - & - & - & - & 10.4 & 11.6 & 13.5 & 15.1 & 17.0 & 21.4 & 24.6 & 27.5 & 29.9 \\
\hline Coking $¥$ & 47.7 & 42.2 & 43.4 & 45.6 & 49.7 & 52.1 & 57.5 & 62.6 & 63.4 & 68.8 & 76.4 & 77.5 & 80.6 & - \\
\hline Coal Gas & 0.9 & 1.0 & 1.0 & 1.1 & 1.2 & 1.4 & 1.7 & 1.6 & 2.0 & 2.6 & 2.6 & 2.7 & 3.3 & - \\
\hline Coal Washing Losses & 19.6 & 18.9 & 20.0 & 21.3 & 22.3 & 25.0 & 25.6 & 26.8 & 26.5 & 27.6 & 29.0 & 33.4 & 31.1 & - \\
\hline Subtotal: & 159.0 & 153.2 & 160.7 & 170.7 & 187.5 & 206.9 & 225.8 & 250.2 & 271.4 & 297.3 & 325.5 & 355.5 & 384.2 & - \\
\hline Total & 435.6 & 432.6 & 457.9 & 490.6 & 535.3 & 582.6 & 614.1 & 662.6 & 709.4 & 738.5 & 753.4 & 788.5 & 814.6 & - \\
\hline
\end{tabular}

* Figures are uncorrected sums of consumption of raw and washed coal. Converted at 0.714 tce/t coal.

$\dagger$ Figures include feedstocks. Industry category includes industry and construction, but excludes power generation, heating, coking and coal gas production, and differs from official statistcs. Probably understates actual consumption due to underreporting of rural industry coal use.

9 This is reported in official data as "nonproductive" sector use of coal, e.g., government, education, financial services, etc. See Appendix for sector definitions.

\$ This category includes heat produced by cogeneration and dedicated heat plants and sold to the industrial, commercial, and residential sectors. $1980-1984$ heating use of coal was included in electricity generation use of coal.

¥ Coking inputs may be underreported by as much as $50 \%$ due to incomplete statistics from rural coking plants.

Source: China Energy Statistical Yearbook, various years; China Statistical Yearbook, various years. 
Table IV-26. Coal End Use and Inputs to Conversions, 1980-1993 (continued)

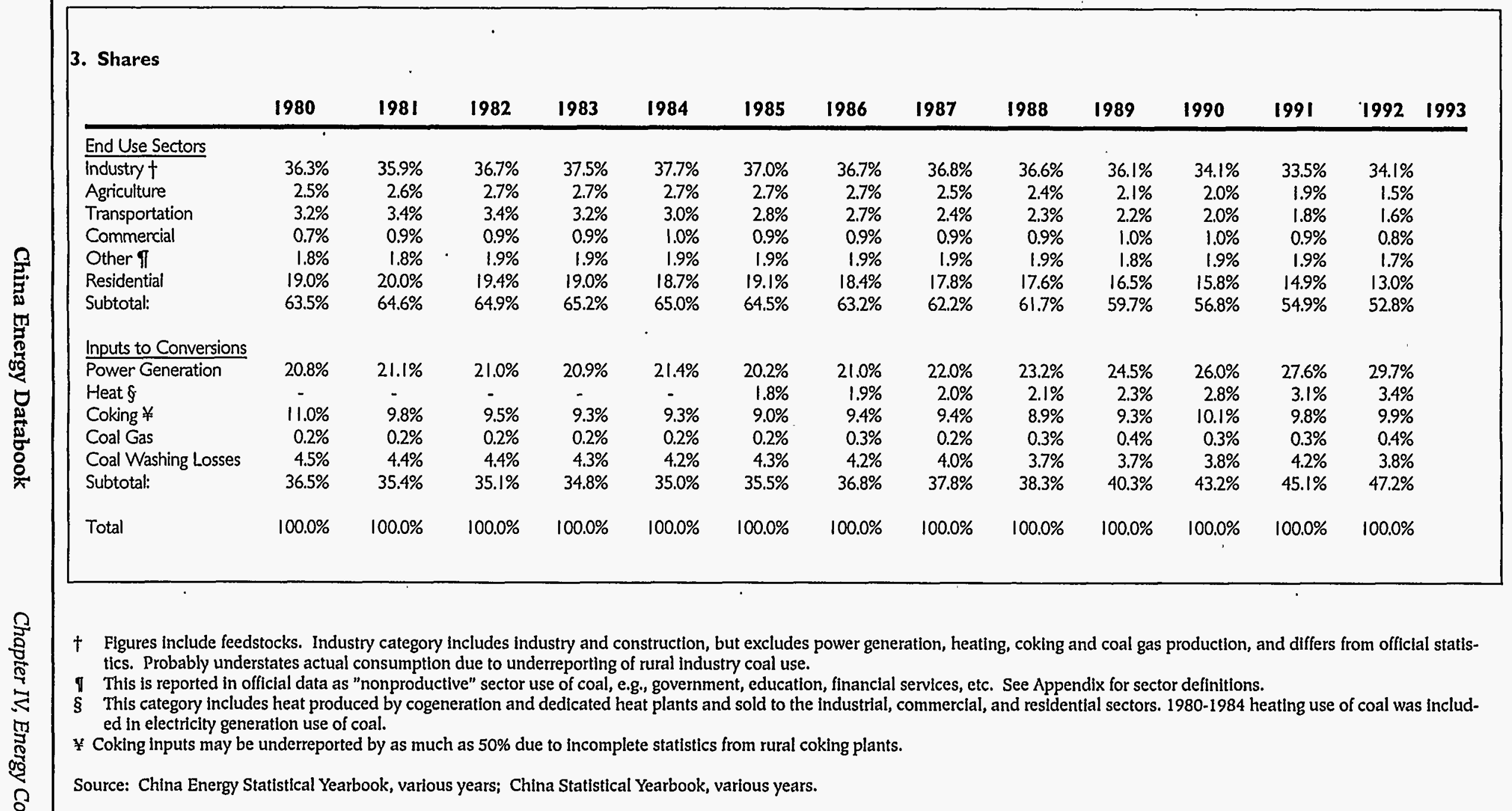


Figure IV-18. Coal Consumption by Sector

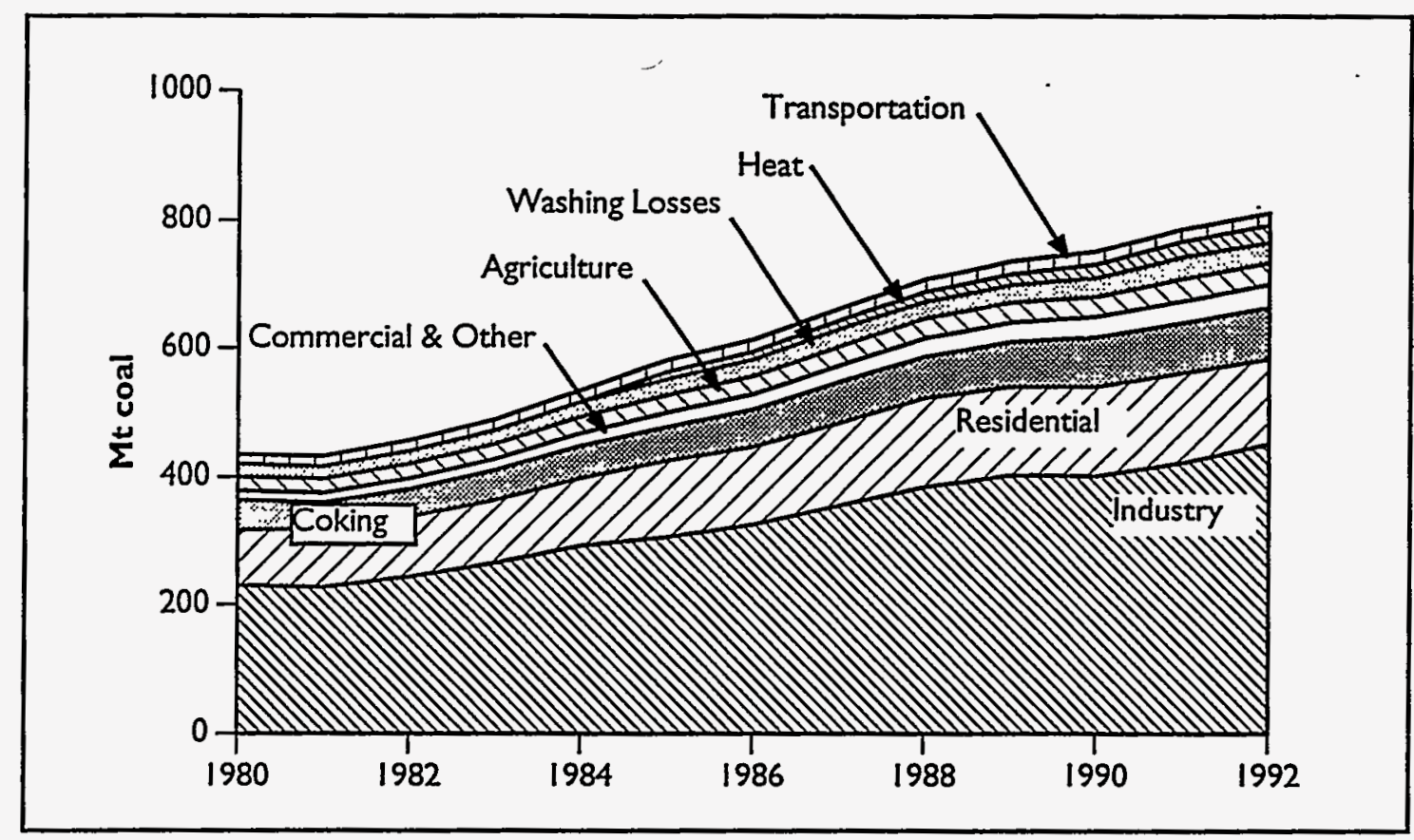

Figure IV-19. Coal Consumption by Sector:

Coal Inputs to Electricity Generation Attributed to Electricity End-Use Sectors *

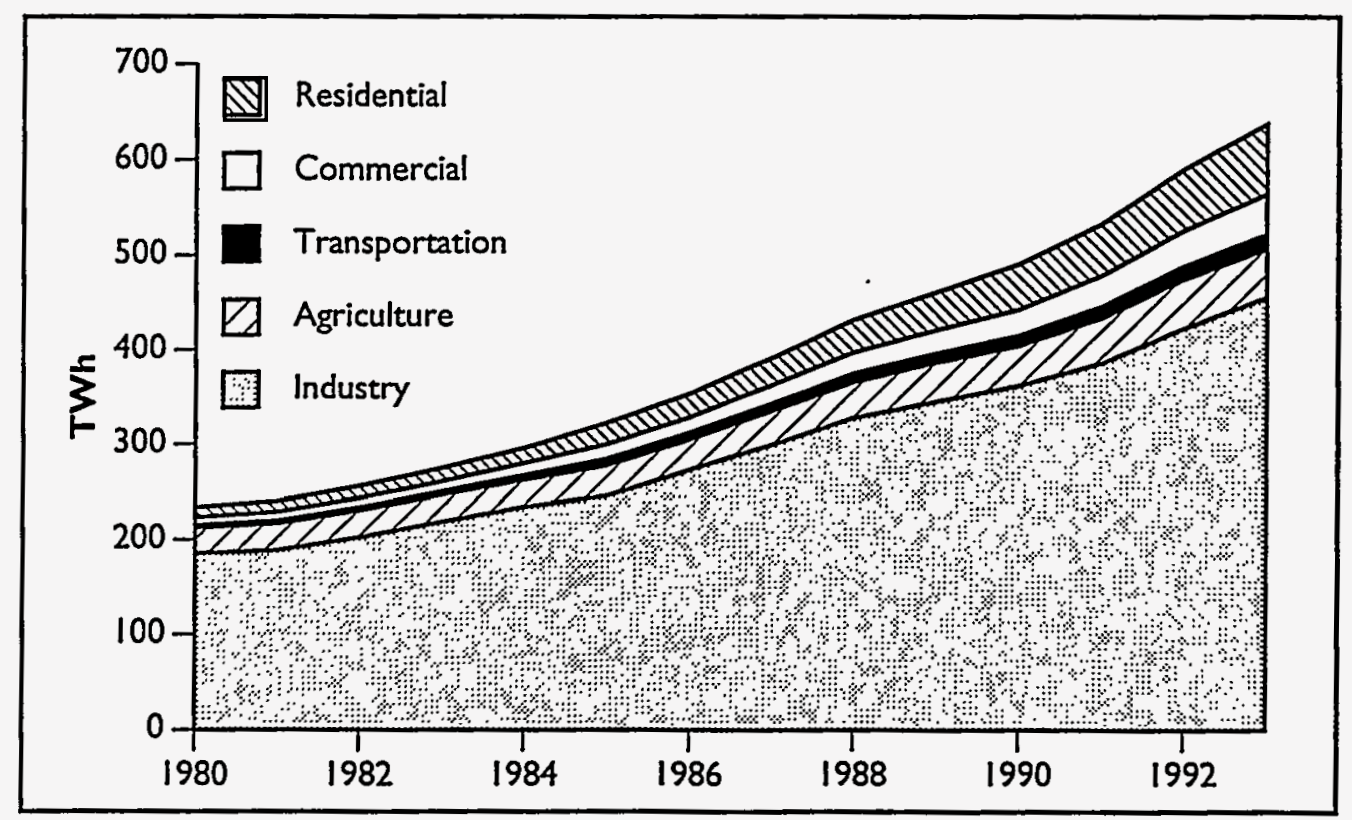

- Shares of coal used in electricity generation have been assigned according to sectoral shares of end-use electricity consumption (Table IV-34). 
Table IV-27. Coal Gas End Use and Inputs to Conversions, 1980-1992

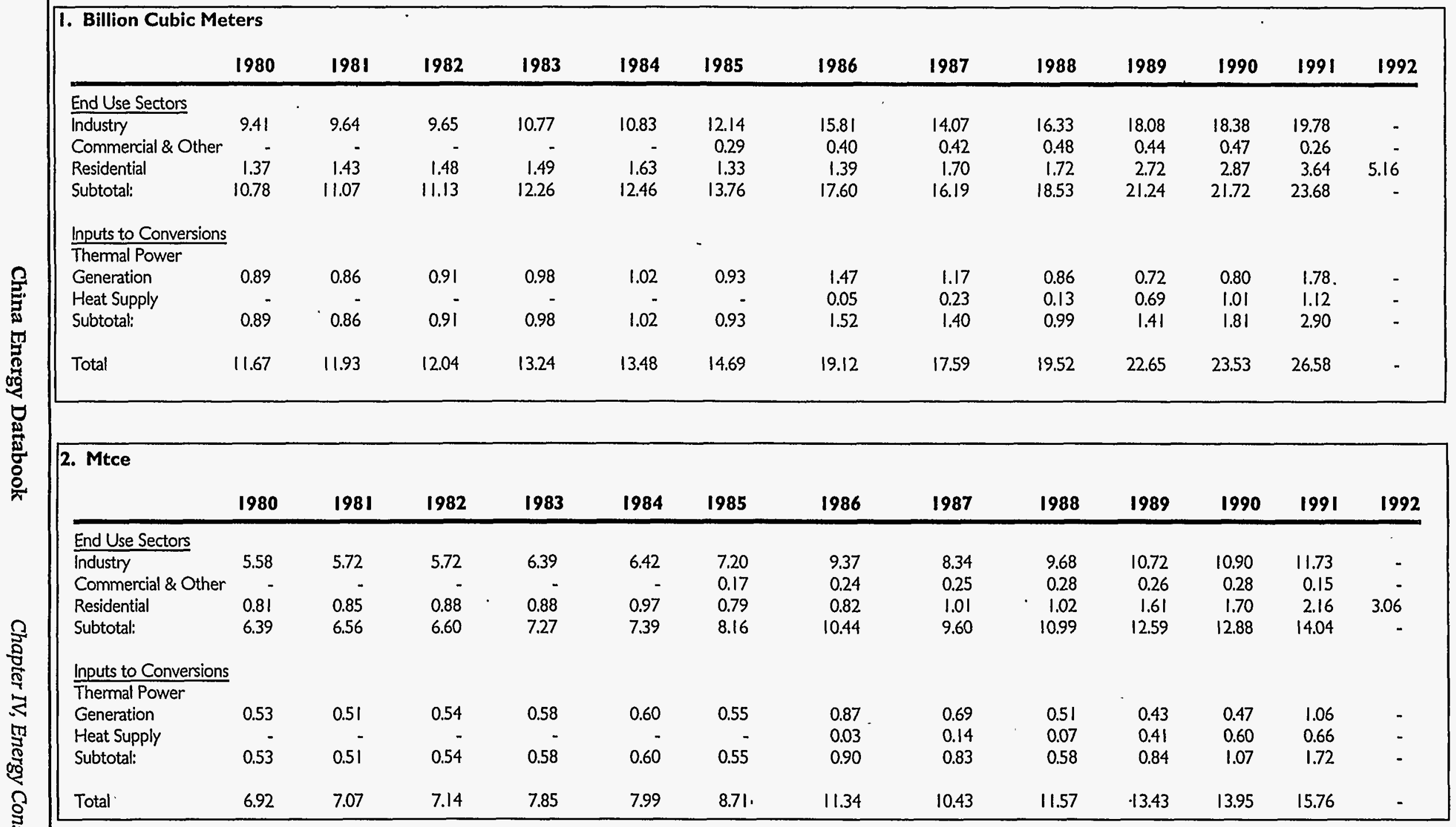

Source: China Energy Statistical Yearbook, various years; China Urban Statistical Yearbook, various years; Energy Research Institute. 


\begin{tabular}{|c|c|c|c|c|c|c|c|c|c|c|c|c|c|}
\hline & able & 27. Co & Gas C & sumpt & by En & Use a & puts t & nvers & 1980 & 992( & Itinue & & \\
\hline \multicolumn{14}{|l|}{ 3. Shares } \\
\hline & 1980 & 1981 & 1982 & 1983 & 1984 & 1985 & 1986 & 1987 & 1988 & 1989 & 1990 & 1991 & 1992 \\
\hline \multicolumn{14}{|l|}{ End Use Sectors } \\
\hline Industry & $81 \%$ & $81 \%$ & $80 \%$ & $81 \%$ & $80 \%$ & $83 \%$ & $83 \%$ & $80 \%$ & $84 \%$ & $80 \%$ & $78 \%$ & $74 \%$ & - \\
\hline Commencial \& Other & - & & - & - & - & $2 \%$ & $2 \%$ & $2 \%$ & $2 \%$ & $2 \%$ & $2 \%$ & $1 \%$ & - \\
\hline Residential & $12 \%$ & $12 \%$ & $12 \%$ & $11 \%$ & $12 \%$ & $9 \%$ & $7 \%$ & $10 \%$ & $9 \%$ & $12 \%$ & $12 \%$ & $14 \%$ & - \\
\hline Subtotal: & $92 \%$ & $93 \%$ & $92 \%$ & $93 \%$ & $92 \%$ & $94 \%$ & $92 \%$ & $92 \%$ & $95 \%$ & $94 \%$ & $92 \%$ & $89 \%$ & - \\
\hline Inputs to Conversions: & & & & & & & & & & & & & \\
\hline $\begin{array}{l}\text { Themal Power } \\
\text { Generation }\end{array}$ & $8 \%$ & $7 \%$ & $8 \%$ & $7 \%$ & $8 \%$ & $6 \%$ & $8 \%$ & $7 \%$ & $4 \%$ & $3 \%$ & $3 \%$ & $7 \%$ & - \\
\hline $\begin{array}{l}\text { Generation } \\
\text { Heat Supply }\end{array}$ & . & $7 \%$ & $8 \%$ & 780 & $\%$ & $6 \%$ & $\begin{array}{l}8 \% \\
0 \%\end{array}$ & $1 \%$ & $\begin{array}{l}4 \% \\
1 \%\end{array}$ & $\begin{array}{l}3 \% \\
3 \%\end{array}$ & $\begin{array}{l}3 \% \\
4 \%\end{array}$ & $4 \%$ & - \\
\hline Subtotal: & $8 \%$ & $7 \%$ & $8 \%$ & $7 \%$ & $8 \%$ & $6 \%$ & $8 \%$ & $8 \%$ & $5 \%$ & $6 \%$ & $8 \%$ & $11 \%$ & - \\
\hline
\end{tabular}

Source: China Energy Statistical Yearbook, varlous years; China Urban Statistical Yearbook, various years; Energy Research Institute. 
Table IV-28. Total Oil Product End Use and Inputs to Conversions, ${ }^{*} 1980-1992$

\begin{tabular}{|c|c|c|c|c|c|c|c|c|c|c|c|c|c|}
\hline \multicolumn{14}{|l|}{ I. $M t$} \\
\hline & 1980 & 1981 & 1982 & 1983 & 1984 & 1985 & 1986 & 1987 & 1988 & 1989 & 1990 & 1991 & 1992 \\
\hline \multicolumn{14}{|l|}{ End Use Sectors } \\
\hline Industry $\dagger$ & 35.67 & 33.18 & 33.49 & 33.65 & 35.11 & 37.59 & 39.92 & 42.59 & 44.97 & 47.70 & 46.95 & 50.32 & 51.75 \\
\hline Agriculture & 6.12 & 5.78 & 5.34 & 5.37 & 5.69 & 5.11 & 5.41 & 5.91 & 6.22 & 6.70 & 7.11 & 7.21 & 7.17 \\
\hline Transportation & 16.78 & 16.06 & 17.01 & 18.38 & 20.08 & 22.63 & 25.46 & 27.61 & 29.78 & 31.02 & 31.02 & 36.78 & 41.09 \\
\hline Commercal \& Other $\pi$ & T 2.89 & 2.52 & 2.38 & 2.55 & 2.24 & 2.71 & 2.53 & 2.60 & 3.40 & 3.85 & 3.70 & 4.41 & 5.51 \\
\hline $\begin{array}{l}\text { Residential } \\
\text { of which: }\end{array}$ & 1.42 & 1.61 & 1.49 & 1.85 & 2.09 & 2.12 & 2.49 & 2.52 & 2.52 & 2.82 & 2.63 & 3.00 & 3.33 \\
\hline urban residential & - & - & - & - & - & 0.98 & 1.27 & 1.36 & 1.45 & 1.64 & 1.74 & - & - \\
\hline rural residential & - & - & - & - & - & 1.15 & 1.24 & 1.19 & 1.10 & 1.19 & 0.93 & - & - \\
\hline End-Use Subtotal & 62.88 & 59.15 & 59.72 & 61.80 & 65.22 & 70.16 & 75.81 & 81.24 & 86.89 & 92.08 & 91.41 & 101.72 & 108.85 \\
\hline \multicolumn{14}{|l|}{ Inputs to Conversions } \\
\hline \multicolumn{14}{|l|}{ Thermal Power } \\
\hline Generation & 16.26 & 15.79 & 15.20 & 14.52 & 13.82 & 13.67 & 13.66 & 13.66 & 14.57 & 17.60 & 15.84 & 15.48 & 14.09 \\
\hline Heat § & $¥$ & $¥$ & $\not$ & $¥$ & $\not$ & 2.86 & 3.22 & 2.84 & 3.23 & 3.39 & 3.56 & 3.37 & 2.72 \\
\hline Refinery Losses & 0.82 & 0.69 & 0.60 & 0.73 & 0.67 & 1.13 & 1.47 & 1.72 & 1.81 & 1.82 & 2.96 & 2.91 & 5.15 \\
\hline Gasification & 0.37 & 0.37 & 0.38 & 0.38 & 0.40 & 0.35 & 0.38 & 0.37 & 0.38 & 0.42 & 0.40 & 0.45 & 0.48 \\
\hline $\begin{array}{l}\text { Conversion Inputs Subto } \\
22.44\end{array}$ & total & 17.44 & 16.85 & 16.18 & 15.62 & 14.89 & 18.00 & 18.73 & 18.59 & 19.98 & 23.23 & 22.76 & 22.21 \\
\hline Total Use & 80.32 & 76.00 & 75.91 & 77.42 & 80.11 & 88.15 & 94.55 & 99.83 & 106.87 & 115.31 & 114.17 & 123.93 & 131.29 \\
\hline
\end{tabular}

* Sectoral use of diesel oil has been adjusted so the above figures differ from those reported officially. Transportation sector use of diesel fuel has been estimated as reported transportation sector use plus $20 \%$ of reported agricultural use, $10 \%$ of reported industrial use, and $12 \%$ of commercial and other use. Figures for those sectors have been adjusted accordingly.

$\dagger$ Includes construction sector, which is listed separately in official Chinese statistics. Excludes electric utilities.

I According to Sinopec, kerosene production is approximately $75 \%$ jet fuel and $25 \%$ lamp kerosene. Given the small reported use in the transportation sector (less than $10 \%$ in 1980 to nearly $20 \%$ in 1988), most of the consumption in the "other" category (2.169 Mt (3.188 Mtce) in 1980, declining to 1.425 Mt (2.095 Mtce) in 1988) is probably for military aircraft.

$\S$ This category includes heat produced by cogeneration and dedicated heat plants and sold to the industrial, commercial, and residential sectors.

* Crude, fuel, and diesel oll used for heating is included in the total for electricity generation for 1980-1984.

Source: China Energy Statistical Yearbook, various years; Statistical Yearbook of China'a Industrial Economy, various years. 


\begin{tabular}{|c|c|c|c|c|c|c|c|c|c|c|c|c|c|}
\hline & 1980 & 1981 & 1982 & 1983 & 1984 & 1985 & 1986 & 1987 & 1988 & 1989 & 1990 & 1991 & 1992 \\
\hline \multicolumn{14}{|l|}{ End Use Sectors } \\
\hline Industry & $45 \%$ & $44 \%$ & $44 \%$ & $44 \%$ & $44 \%$ & $43 \%$ & $43 \%$ & $43 \%$ & $42 \%$ & $42 \%$ & $41 \%$ & $41 \%$ & $40 \%$ \\
\hline Agriculture & $8 \%$ & $8 \%$ & $7 \%$ & $7 \%$ & $7 \%$ & $6 \%$ & $6 \%$ & $6 \%$ & $6 \%$ & $6 \%$ & $6 \%$ & $6 \%$ & $6 \%$ \\
\hline Transportation & $21 \%$ & $21 \%$ & $23 \%$ & $24 \%$ & $25 \%$ & $26 \%$ & $27 \%$ & $28 \%$ & $28 \%$ & $27 \%$ & $28 \%$ & $30 \%$ & $31 \%$ \\
\hline Commercal \& Other $\mathbb{T}$ & $4 \%$ & $3 \%$ & $3 \%$ & $3 \%$ & $3 \%$ & $3 \%$ & $3 \%$ & $3 \%$ & $3 \%$ & $3 \%$ & $3 \%$ & $4 \%$ & $5 \%$ \\
\hline Residential & $2 \%$ & $2 \%$ & $2 \%$ & $3 \%$ & $3 \%$ & $3 \%$ & $3 \%$ & $3 \%$ & $3 \%$ & $3 \%$ & $3 \%$ & $3 \%$ & $3 \%$ \\
\hline \multicolumn{6}{|l|}{$\begin{array}{l}\text { of which: } \\
\text { urban residential }\end{array}$} & $1 \%$ & $2 \%$ & & $2 \%$ & & & & \\
\hline rural residential & - & - & - & - & - & $1 \%$ & $1 \%$ & $1 \%$ & $1 \%$ & $1 \%$ & $1 \%$ & - & - \\
\hline End-Use Subtotal & $79 \%$ & $79 \%$ & $79 \%$ & $81 \%$ & $82 \%$ & $80 \%$ & $81 \%$ & $82 \%$ & $82 \%$ & $81 \%$ & $81 \%$ & $83 \%$ & $84 \%$ \\
\hline \multicolumn{14}{|l|}{ Inputs to Conversions } \\
\hline Thermal Power Generation & $20 \%$ & $20 \%$ & $19 \%$ & $18 \%$ & $17 \%$ & $15 \%$ & $14 \%$ & $13 \%$ & $13 \%$ & $14 \%$ & $13 \%$ & $12 \%$ & $10 \%$ \\
\hline Heat $\S$ & $¥$ & * & \# & \# & \# & $3 \%$ & $3 \%$ & $3 \%$ & $3 \%$ & $3 \%$ & $3 \%$ & $3 \%$ & $2 \%$ \\
\hline Refinery Losses & $1 \%$ & $1 \%$ & $1 \%$ & $1 \%$ & $1 \%$ & $1 \%$ & $2 \%$ & $2 \%$ & $2 \%$ & $2 \%$ & $3 \%$ & $2 \%$ & $4 \%$ \\
\hline Gasification & $0.5 \%$ & $0.5 \%$ & $0.5 \%$ & $0.5 \%$ & $0.5 \%$ & $0.4 \%$ & $0.4 \%$ & $0.4 \%$ & $0.3 \%$ & $0.4 \%$ & $0.3 \%$ & $0.4 \%$ & $0.4 \%$ \\
\hline Conversion Inputs Subtotal & $21 \%$ & $21 \%$ & $21 \%$ & $19 \%$ & $18 \%$ & $20 \%$ & $19 \%$ & $18 \%$ & $18 \%$ & $19 \%$ & $19 \%$ & $17 \%$ & $16 \%$ \\
\hline Total Use & $100 \%$ & $100 \%$ & $100 \%$ & $100 \%$ & $100 \%$ & $100 \%$ & $100 \%$ & $100 \%$ & $100 \%$ & $100 \%$ & $100 \%$ & $100 \%$ & $100 \%$ \\
\hline
\end{tabular}

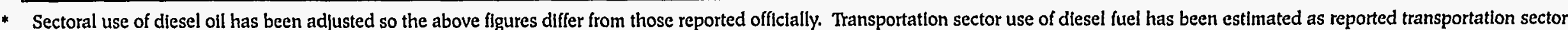
use plus $20 \%$ of reported agricultural use, $10 \%$ of reported industrial use, and $12 \%$ of commercial and other use. Figures for those sectors have been adjusted accordingly.

$\dagger$ Includes construction sector, which is listed separately in official Chinese statistics. Excludes electric utilities.

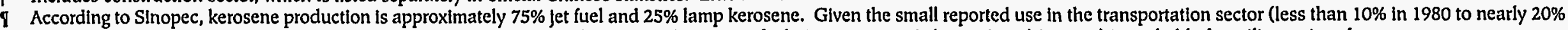
in 1988), most of the consumption in the"'"other" category (2.169 Mt (3.188 Mtce) in 1980, declining to $1.425 \mathrm{Mt}$ (2.095 Mtce) in 1988$)$ is probably for military aircraft.

\$ This category includes heat produced by cogeneration and dedicated heat plants and sold to the industrial, commercial, and residential sectors.

$¥$ Crude, fuel, and diesel oll used for heating is included in the total for electricity generation for 1980-1984. 
Table IV-29. Total Oil Product End Use and Inputs to Conversions by Petroleum Product, 1980-1992

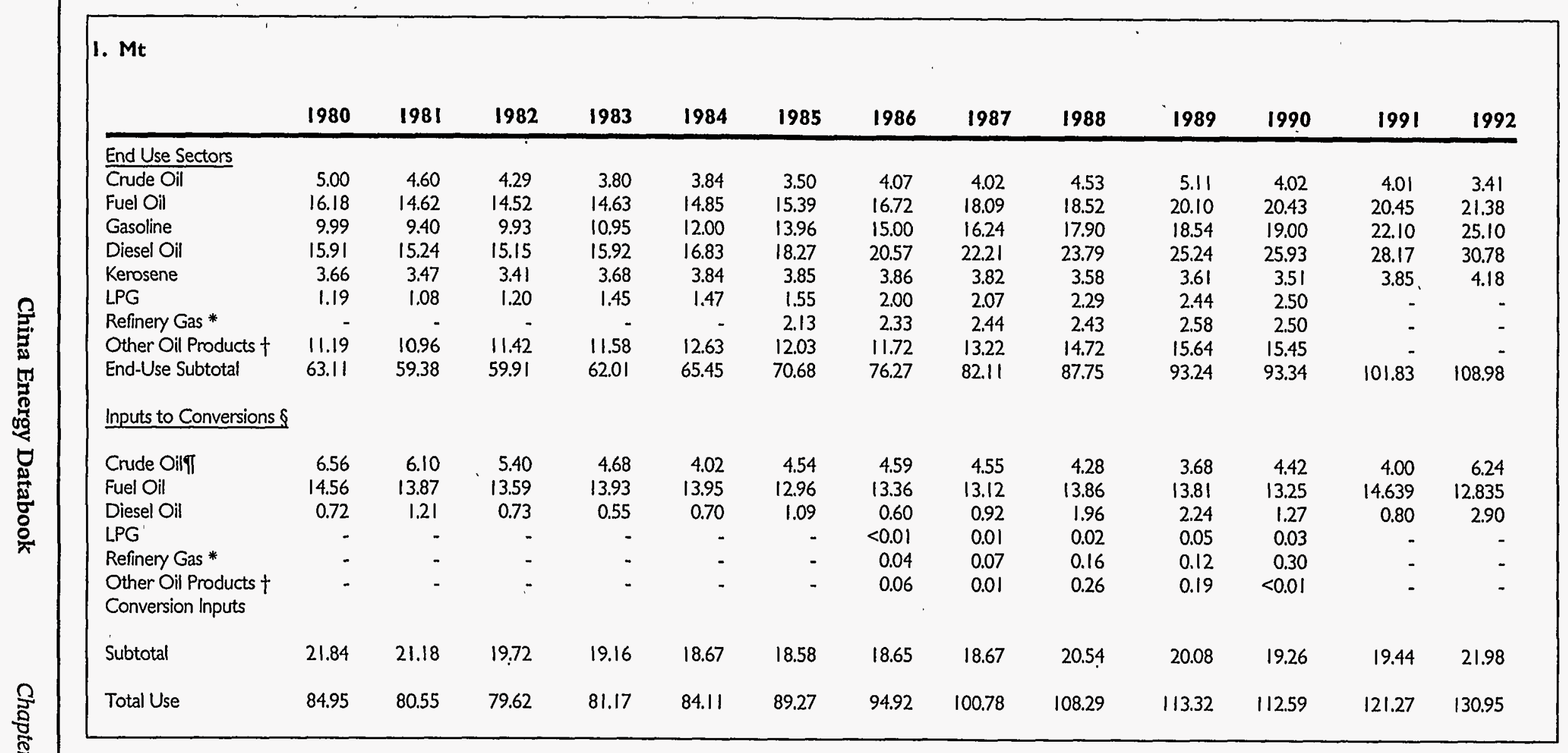

* Refinery gas (llanchang ganql) is a byproduct of oll refining composed primarily of $\mathrm{C} 1$ and $\mathrm{C} 2$ fractions. Most is consumed within refineries as refinery fuel.

$\dagger$ Lubricants, asphalt, coke, paraffin wax, solvents, aromatics, and petrochemical feedstocks account for all but about 2 Mt of products in this category. The balance may be intermediate unfinished products.

1 Includes refinery losses of crude oil.

§ Primarily thermal power generation.

Source: China Energy Statistical Yearbook, various years; Statistical Yearbook of China'a Industrial Economy, various years; China Statistical Yearbook, various years. 


\begin{tabular}{|c|c|c|c|c|c|c|c|c|c|c|c|c|c|}
\hline & & & able II & $\begin{array}{l}\text { 29. Tot } \\
\text { by } \mathrm{Pe}\end{array}$ & $\begin{array}{l}\text { Oil P } \\
\text { leum }\end{array}$ & $\begin{array}{l}\text { duct } \mathrm{E} \\
\text { roduct }\end{array}$ & $\begin{array}{l}\text { d Use } \\
1980-1\end{array}$ & $\begin{array}{l}\text { and Inp } \\
92 \text { (co }\end{array}$ & $\begin{array}{l}s \text { to } C o \\
\text { inued) }\end{array}$ & ersion & & & \\
\hline 2. Shares & 1980 & 1981 & 1982 & 1983 & 1984 & 1985 & 1986 & 1987 & 1988 & 1989 & 1990 & 1991 & 1992 \\
\hline \multicolumn{14}{|l|}{ End Use Sectors } \\
\hline Crude Oil & $5.9 \%$ & $5.7 \%$ & $5.4 \%$ & $4.7 \%$ & $4.6 \%$ & $3.9 \%$ & $4.3 \%$ & $4.0 \%$ & $4.2 \%$ & $4.5 \%$ & $3.6 \%$ & $3.3 \%$ & $2.6 \%$ \\
\hline Fuel Oil & $19.0 \%$ & $18.2 \%$ & $18.2 \%$ & $18.0 \%$ & $17.6 \%$ & $17.2 \%$ & $17.6 \%$ & $18.0 \%$ & $17.1 \%$ & $17.7 \%$ & $18.1 \%$ & $16.9 \%$ & $16.3 \%$ \\
\hline Gasoline & $11.8 \%$ & $11.7 \%$ & $12.5 \%$ & $13.5 \%$ & $14.3 \%$ & $15.6 \%$ & $15.8 \%$ & $16.1 \%$ & $16.5 \%$ & $16.4 \%$ & $16.9 \%$ & $18.2 \%$ & $19.2 \%$ \\
\hline Diesel Oil & $18.7 \%$ & $18.9 \%$ & $19.0 \%$ & $19.6 \%$ & $20.0 \%$ & $20.5 \%$ & $21.7 \%$ & $22.0 \%$ & $22.0 \%$ & $22.3 \%$ & $23.0 \%$ & $23.2 \%$ & $23.5 \%$ \\
\hline Kerosene & $4.3 \%$ & $4.3 \%$ & $4.3 \%$ & $4.5 \%$ & $4.6 \%$ & $4.3 \%$ & $4.1 \%$ & $3.8 \%$ & $3.3 \%$ & $3.2 \%$ & $3.1 \%$ & $3.2 \%$ & $3.2 \%$ \\
\hline LPG & $1.4 \%$ & $1.3 \%$ & $1.5 \%$ & $1.8 \%$ & $1.7 \%$ & $1.7 \%$ & $2.1 \%$ & $2.1 \%$ & $2.1 \%$ & $2.2 \%$ & $2.2 \%$ & - & - \\
\hline Refinery Gas* & - & - & & & & $2.4 \%$ & $2.4 \%$ & $2.4 \%$ & $2.2 \%$ & $2.3 \%$ & $2.2 \%$ & - & - \\
\hline Other Oil Productst & $13.2 \%$ & $13.6 \%$ & $14.3 \%$ & $14.3 \%$ & $15.0 \%$ & $13.5 \%$ & $12.3 \%$ & $13.1 \%$ & $13.6 \%$ & $13.8 \%$ & $13.7 \%$ & - & - \\
\hline End-Use Subtotal & $74.3 \%$ & $73.7 \%$ & $75.2 \%$ & $76.4 \%$ & $77.8 \%$ & $79.2 \%$ & $80.3 \%$ & $81.5 \%$ & $81.0 \%$ & $82.3 \%$ & $82.9 \%$ & $84.0 \%$ & $83.2 \%$ \\
\hline \multicolumn{14}{|l|}{ Inputs to Conversions $\S$} \\
\hline Crude OilT & $7.7 \%$ & $7.6 \%$ & $6.8 \%$ & $5.8 \%$ & $4.8 \%$ & $5.1 \%$ & $4.8 \%$ & $4.5 \%$ & $4.0 \%$ & $3.2 \%$ & $3.9 \%$ & $3.3 \%$ & $4.8 \%$ \\
\hline Fuel Oil & $17.1 \%$ & $17.2 \%$ & $17.1 \%$ & $17.2 \%$ & $16.6 \%$ & $14.5 \%$ & $14.1 \%$ & $13.0 \%$ & $12.8 \%$ & $12.2 \%$ & $11.8 \%$ & $12.1 \%$ & $9.8 \%$ \\
\hline Diesel Oil & $0.9 \%$ & $1.5 \%$ & $0.9 \%$ & $0.7 \%$ & $0.8 \%$ & $1.2 \%$ & $0.6 \%$ & $0.9 \%$ & $1.8 \%$ & $2.0 \%$ & $1.1 \%$ & $0.7 \%$ & $2.2 \%$ \\
\hline LPG & - & & & & - & - & & $0.0 \%$ & $0.0 \%$ & $0.0 \%$ & $0.0 \%$ & - & - \\
\hline Refinery Gas* & - & - & - & - & - & - & $0.0 \%$ & $0.1 \%$ & $0.1 \%$ & $0.1 \%$ & $0.3 \%$ & - & - \\
\hline Other Oil Products $†$ & - & - & - & - & - & - & $0.1 \%$ & $0.0 \%$ & $0.2 \%$ & $0.2 \%$ & - & - & - \\
\hline $\begin{array}{l}\text { Conversion Inputs } \\
\text { Subtotal }\end{array}$ & $25.7 \%$ & $26.3 \%$ & $24.8 \%$ & $23.6 \%$ & $22.2 \%$ & $20.8 \%$ & $19.7 \%$ & $18.5 \%$ & $19.0 \%$ & $17.7 \%$ & $17.1 \%$ & $16.0 \%$ & $16.8 \%$ \\
\hline Total Use & $100.0 \%$ & $100.0 \%$ & $100.0 \%$ & $100.0 \%$ & $100.0 \%$ & $100.0 \%$ & $100.0 \%$ & $100.0 \%$ & $100.0 \%$ & $100.0 \%$ & $100.0 \%$ & $100.0 \%$ & $100.0 \%$ \\
\hline
\end{tabular}

- Refinery gas (lianchang ganql) is a byproduct of oll refining composed primarily of $\mathrm{Cl}$ and $\mathrm{C2}$ fractions. Most is consumed within refineries as refinery fuel.

+ Lubricants, asphalt, coke, paraffin wax, solvents, aromatics, and petrochemical feedstocks account for all but about 2 Mt of products in this category. The balance may be intermediate unfinished products.
Includes refinery losses of crude oil

$\S$ Primarily thermal power generation. 
Table IV-30. Crude Oil End Use and Inputs to Conversions, * 1980-1992

\begin{tabular}{|c|c|c|c|c|c|c|c|c|c|c|c|c|c|}
\hline \multirow{2}{*}{ I. $\mathrm{Mt}$} & \multirow[b]{2}{*}{1980} & \multirow[b]{2}{*}{1981} & \multirow[b]{2}{*}{1982} & \multirow[b]{2}{*}{1983} & \multirow[b]{2}{*}{1984} & \multirow[b]{2}{*}{1985} & \multirow[b]{2}{*}{1986} & \multirow[b]{2}{*}{1987} & \multirow[b]{2}{*}{1988} & \multirow[b]{2}{*}{1989} & \multirow[b]{2}{*}{1990} & \multirow[b]{2}{*}{$1991^{\circ}$} & \multirow[b]{2}{*}{1992} \\
\hline & & & & & & & & & & & & & \\
\hline \multicolumn{14}{|l|}{ End Use Sectors } \\
\hline Industry & 4.59 & 4.18 & 3.96 & 3.61 & 3.51 & 3.29 & 3.74 & 3.74 & 4.30 & 4.90 & 3.89 & 3.52 & 2.84 \\
\hline Agriculture & 0.08 & 0.07 & 0.05 & 0.00 & 0.00 & 0.01 & 0.01 & 0.01 & 0.01 & 0.01 & 0.00 & 0.00 & 0.00 \\
\hline Transportation & 0.27 & 0.29 & 0.27 & 0.19 & 0.32 & 0.20 & 0.32 & 0.23 & 0.22 & 0.18 & 0.12 & 0.49 & 0.56 \\
\hline Commercial \& Other & 0.06 & 0.06 & 0.01 & 0.01 & 0.00 & 0.01 & 0.00 & 0.04 & 0.00 & 0.02 & 0.01 & 0.00 & 0.00 \\
\hline Subtotal: & 5.00 & 4.60 & 4.29 & 3.80 & 3.84 & 3.50 & 4.07 & 4.02 & 4.53 & 5.11 & 4.02 & 4.01 & 3.41 \\
\hline \multicolumn{14}{|l|}{ Inputs to Conversions } \\
\hline \multicolumn{14}{|l|}{ Thermal Power } \\
\hline Generation & 5.74 & 5.41 & 4.80 & 3.96 & 3.35 & 2.80 & 2.46 & 2.59 & 2.34 & 1.63 & 1.25 & 1.09 & 1.09 \\
\hline Heat Supply & $t$ & $t$ & $t$ & $t$ & $\dagger$ & 0.61 & 0.65 & 0.24 & 0.13 & 0.23 & 0.21 & $t$ & t \\
\hline Refinery Losses & 0.82 & 0.69 & 0.60 & 0.73 & 0.67 & 1.13 & 1.47 & 1.72 & 1.81 & 1.82 & 2.96 & 2.99 & 5.15 \\
\hline Subtotal: & 6.56 & 6.10 & 5.40 & 4.68 & 4.02 & 4.54 & 4.59 & 4.55 & 4.28 & 3.68 & 4.42 & 4.00 & 6.24 \\
\hline Total & 11.55 & 10.70 & $\cdot 9.69$ & 8.48 & 7.86 & 8.04 & 8.66 & 8.57 & 8.81 & 8.79 & 8.44 & 8.01 & 9.65 \\
\hline
\end{tabular}

- Figures are based on end-use data in comprehensive energy balance tables in the Energy Statistical Yearbook of China and in some cases differ from data in other official tables of petroleum use.

$\dagger$ Crude oil used for heat is Included in the total for electricity generation.

Source: China Energy Statistical Yearbook of China, varlous years; China Statistical Yearbook, various years; Guofl Shlyou Jing/l (International OIl Economy), no. 2, 1994; 
Table IV-30. Crude Oil End Use and Inputs to Conversions, * 1988-1992 (continued)

\begin{tabular}{|c|c|c|c|c|c|c|c|c|c|c|c|c|c|}
\hline 2. Shares & 1980 & 1981 & 1982 & 1983 & 1984 & 1985 & 1986 & 1987 & 1988 & 1989 & 1990 & 1991 & 1992 \\
\hline \multicolumn{14}{|l|}{ End Use Secotrs } \\
\hline$\overline{\text { Industry }}$ & $39.7 \%$ & $39.1 \%$ & $40.8 \%$ & $42.5 \%$ & $44.7 \%$ & $40.9 \%$ & $43.2 \%$ & $43.7 \%$ & $.48 .8 \%$ & $55.8 \%$ & $46.1 \%$ & $43.9 \%$ & $29.5 \%$ \\
\hline Agriculture & $0.7 \%$ & $0.6 \%$ & $0.5 \%$ & $0.0 \%$ & $0.0 \%$ & $0.1 \%$ & $0.1 \%$ & $0.1 \%$ & $0.1 \%$ & $0.1 \%$ & $0.0 \%$ & $0.0 \%$ & $0.0 \%$ \\
\hline Transportation & $2.3 \%$ & $2.7 \%$ & $2.8 \%$ & $2.2 \%$ & $4.1 \%$ & $2.5 \%$ & $3.7 \%$ & $2.7 \%$ & $2.5 \%$ & $2.1 \%$ & $1.5 \%$ & $6.1 \%$ & $5.8 \%$ \\
\hline Commercial \& Other & $0.5 \%$ & $0.5 \%$ & $0.1 \%$ & $0.1 \%$ & $0.0 \%$ & $0.1 \%$ & $0.0 \%$ & $0.4 \%$ & $0.0 \%$ & $0.2 \%$ & $0.1 \%$ & $0.0 \%$ & $0.0 \%$ \\
\hline Subtotal: & $43.3 \%$ & $43.0 \%$ & $44.2 \%$ & $44.8 \%$ & $48.8 \%$ & $43.6 \%$ & $47.0 \%$ & $46.9 \%$ & $51.4 \%$ & $58.1 \%$ & $47.7 \%$ & $50.1 \%$ & $35.3 \%$ \\
\hline \multicolumn{14}{|l|}{ Inputs to Conversions } \\
\hline \multicolumn{14}{|l|}{ Thermal Power } \\
\hline Generation & $49.7 \%$ & $50.6 \%$ & $49.6 \%$ & $46.7 \%$ & $42.7 \%$ & $34.8 \%$ & $28.4 \%$ & $30.2 \%$ & $26.6 \%$ & $18.5 \%$ & $14.8 \%$ & $13.6 \%$ & $11.3 \%$ \\
\hline Heat Supply & $t$ & $t$ & $t$ & $t$ & $t$ & $7.6 \%$ & $7.6 \%$ & $2.8 \%$ & $1.4 \%$ & $2.6 \%$ & $2.5 \%$ & $t$ & \\
\hline Refinery Losses & $7.1 \%$ & $6.5 \%$ & $6.2 \%$ & $8.6 \%$ & $8.5 \%$ & $14.0 \%$ & $17.0 \%$ & $20.1 \%$ & $20.5 \%$ & $20.7 \%$ & $35.1 \%$ & $36.3 \%$ & $53.4 \%$ \\
\hline Subtotal: & $56.7 \%$ & $57.0 \%$ & $55.8 \%$ & $55.2 \%$ & $51.2 \%$ & $56.4 \%$ & $53.0 \%$ & $53.1 \%$ & $48.6 \%$ & $41.9 \%$ & $52.3 \%$ & $49.9 \%$ & $64.7 \%$ \\
\hline Total & $100.0 \%$ & $100.0 \%$ & $100.0 \%$ & $100.0 \%$ & $100.0 \%$ & $100.0 \%$ & $100.0 \%$ & $100.0 \%$ & $100.0 \%$ & $100.0 \%$ & $100.0 \%$ & $100.0 \%$ & $100.0 \%$ \\
\hline
\end{tabular}

* Figures are based on end-use data in comprehensive energy balance tables in the Energy Statistical Yearbook of China and in some cases differ from data in other official tables of petroleum use.

+ Crude oll used for heat is included in the total for electricity generation.

Source: China Energy Statistical Yearbook of China, various years; China Statistical Yearbook, various years; Guo/l Shlyou Jing/I (International OIl Economy), no. 2, 1994; 
Table IV-31. Diesel Oil End Use and Inputs to Conversions, * 1980-1992

\begin{tabular}{|c|c|c|c|c|c|c|c|c|c|c|c|c|c|}
\hline \multicolumn{14}{|l|}{ 1. $M t$} \\
\hline & 1980 & 1981 & 1982 & 1983 & 1984 & 1985 & 1986 & 1987 & 1988 & 1989 & 1990 & 1991 & 1992 \\
\hline \multicolumn{14}{|l|}{ End Use Sectors } \\
\hline Industry & 4.15 & 4.05 & 4.29 & 4.41 & 4.74 & 5.91 & 6.53 & 6.65 & 6.35 & 6.47 & 6.87 & 7.61 & 8.28 \\
\hline Agriculture & 5.99 & 5.64 & 5.23 & 5.32 & 5.64 & 5.03 & 5.37 & 5.84 & 6.14 & 6.61 & 7.05 & 7.15 & 7.08 \\
\hline Transportation & 5.20 & 4.97 & 5.16 & 5.56 & 5.92 & 6.56 & 7.97 & 8.82 & 9.39 & 9.89 & 9.91 & 10.61 & 11.50 \\
\hline Commercal \& Other & 0.56 & 0.59 & 0.47 & 0.63 & 0.53 & 0.75 & 0.68 & 0.88 & 1.85 & 2.26 & 2.11 & 2.80 & 3.90 \\
\hline $\begin{array}{l}\text { Residential } \\
\text { of which: }\end{array}$ & - & - & - & - & - & 0.02 & 0.02 & 0.03 & 0.06 & 0.01 & 0.00 & 0.00 & 0.02 \\
\hline urban residential & - & - & - & - & - & $<0.01$ & 0.02 & 0.01 & 0.03 & $<0.01$ & $<0.01$ & $<0.01$ & 0.01 \\
\hline rural residential & - & - & - & - & - & 0.01 & - & 0.02 & 0.03 & 0.01 & $<0.01$ & $<0.01$ & 0.01 \\
\hline Subtotal & 15.91 & 15.24 & 15.15 & 15.92 & 16.83 & 18.27 & 20.57 & 22.21 & 23.79 & 25.24 & 25.93 & 28.17 & 30.78 \\
\hline \multicolumn{14}{|l|}{ Inputs to Conversions } \\
\hline \multicolumn{14}{|l|}{ Thermal Power } \\
\hline Generation & 0.72 & 1.21 & 0.73 & 0.55 & 0.70 & 1.04 & 0.59 & 0.92 & 1.96 & 2.24 & 1.25 & 0.80 & 2.90 \\
\hline Heat Supply & $t$ & $t$ & $t$ & $t$ & $\dagger$ & 0.05 & 0.01 & $<0.01$ & $<0.01$ & $<0.01$ & 0.02 & - & - \\
\hline Subtotal & 0.72 & 1.21 & 0.73 & 0.55 & 0.70 & 1.09 & 0.60 & 0.92 & 1.96 & 2.24 & 1.27 & 0.80 & 2.90 \\
\hline Total & 16.63 & 16.45 & 15.87 & 16.47 & 17.53 & 19.36 & 21.17 & 23.14 & 25.75 & 27.48 & 27.20 & 28.97 & 33.68 \\
\hline
\end{tabular}

* Sectoral use has been adjusted and the above figures differ from those reported officially. Transportation sector use of diesel fuel has been estimated as reported transportation sector use plus $20 \%$ of reported agricultural use, $10 \%$ of reported industrial use, and $12 \%$ of commercial use. Flgures for agricultural and industrial sector consumption have been adjusted accordingly. Figures are based on end-use data in comprehensive energy balance tables and differ from data in other official tables of petroleum use. Figures in italics are estimates.

$\dagger$ Diesel oil used for heating is included in the totals for electricity generation.

Source: China Energy Statistical Yearbook, various years; China Statistical Yearbook, various years. 


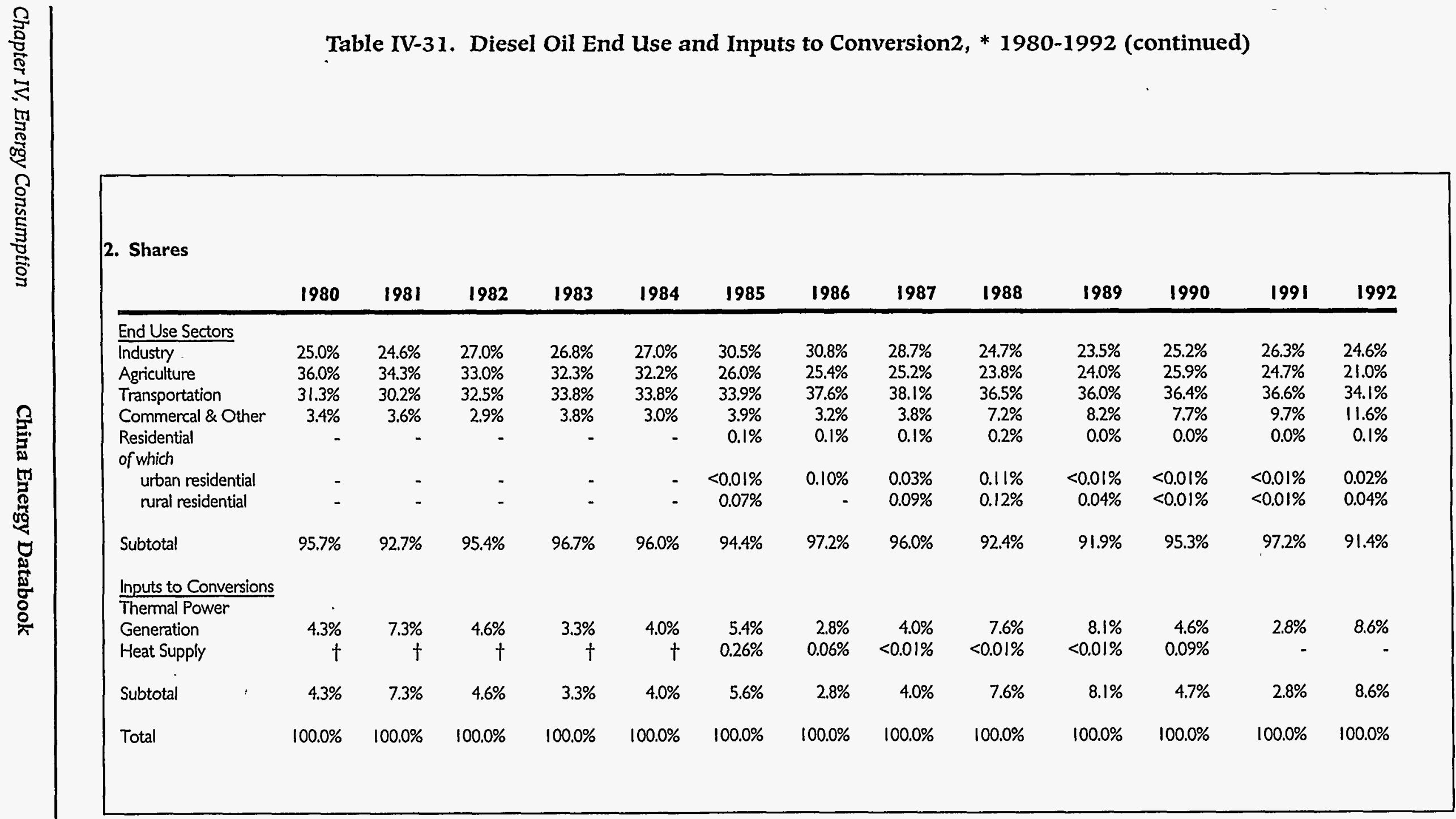

* Sectoral use has been adjusted and the above figures differ from those reported officially. Transportatlon sector use of diesel fuel has been estimated as reported transportation sector use plus $20 \%$ of reported agricultural use, $10 \%$ of reported industrial use, and $12 \%$ of commercial use. Figures for agricultural and industrial sector consumption have been adjusted accordingly. Figures are based on end-use data in comprehensive energy balance tables and differ from data in other official tables of petroleum use. Figures in italics are estimates.

$\dagger$ Diesel oil used for heating is included in the totals for electricity generation.

Source: China Energy Statistical Yearbook, various years; China Statistical Yearbook, various years. 
Table IV-32. Natural Gas End Use and Inputs to Conversions, 1980-1992

\begin{tabular}{|c|c|c|c|c|c|c|c|c|}
\hline \multicolumn{9}{|l|}{ I. Billion Cubic Meters } \\
\hline End Use Sectors & 1985 & 1986 & 1987 & 1988 & 1989 & 1990 & 1991 & 1992 \\
\hline Oil \& Natural Gas Extraction * & 3.42 & 3.35 & 3.91 & 4.00 & 3.85 & 3.59 & 4.00 & 4.68 \\
\hline Chemical Industry $\dagger$ & 4.14 & 4.28 & 4.43 & 4.56 & 4.73 & 4.85 & 5.55 & 5.47 \\
\hline Transportation & 0.08 & 0.10 & 0.05 & 0.11 & 0.07 & 0.19 & 0.12 & 0.11 \\
\hline Commercial \& Other & 0.05 & 0.05 & 0.13 & 0.06 & 0.10 & 0.12 & 0.10 & 0.09 \\
\hline Residential & 0.43 & 0.65 & 0.77 & 1.53 & 1.68 & 1.86 & 1.81 & 2.15 \\
\hline Other $¥$ & 4.03 & 4.75 & 4.46 & 3.82 & 4.48 & 4.60 & 4.05 & 3.20 \\
\hline Total & 12.54 & 13.47 & 13.82 & 14.22 & 14.97 & 15.23 & 15.76 & 15.79 \\
\hline \multicolumn{9}{|l|}{ Inputs to Conversions } \\
\hline$\overline{\text { Power Generation } \pi}$ & 0.66 & 0.76 & 0.83 & 0.71 & 1.09 & 0.75 & 0.77 & - \\
\hline Heat Supply & 0.02 & 0.03 & 0.03 & 0.01 & 0.03 & 0.26 & 0.03 & - \\
\hline \multicolumn{9}{|l|}{ 2. Mtce } \\
\hline End Use Sectors & 1985 & 1986 & 1987 & 1988 & 1989 & 1990 & 1991 & 1992 \\
\hline Oil \& Natural Gas Extraction* & 4.55 & 4.46 & 5.20 & 5.32 & 5.12 & 4.77 & 5.32 & 6.22 \\
\hline Chemical Industry & 5.51 & 5.69 & 5.89 & 6.06 & 6.29 & 6.45 & 7.38 & 7.28 \\
\hline Transportation & 0.11 & 0.13 & 0.07 & 0.15 & 0.09 & 0.25 & 0.16 & 0.15 \\
\hline Commercial \& Other & 0.07 & 0.07 & 0.17 & 0.08 & 0.13 & 0.16 & 0.13 & 0.12 \\
\hline Residential & 0.57 & 0.86 & 1.02 & 2.03 & 2.23 & 2.47 & 2.41 & 2.86 \\
\hline Other $¥$ & 5.36 & 6.32 & 5.93 & 5.08 & 5.96 & 6.12 & 5.39 & 4.26 \\
\hline Total & 16.68 & 17.92 & 18.38 & 18.91 & 19.91 & 20.26 & 20.96 & 21.00 \\
\hline \multicolumn{9}{|l|}{ Inputs to Conversions } \\
\hline Power Generation IT & 0.88 & 1.01 & 1.10 & 0.94 & 1.45 & 1.00 & 1.02 & - \\
\hline Heat Supply & 0.03 & 0.04 & 0.04 & 0.01 & 0.04 & 0.35 & 0.04 & - \\
\hline \multicolumn{9}{|l|}{ 3. Shares } \\
\hline End Use Sectors & 1985 & 1986 & 1987 & 1988 & 1989 & 1990 & 1991 & 1992 \\
\hline Oil \& Natural Gas Extraction * & $27 \%$ & $25 \%$ & $28 \%$ & $28 \%$ & $26 \%$ & $24 \%$ & $25 \%$ & $30 \%$ \\
\hline Chemical Industry $\dagger$ & $33 \%$ & $32 \%$ & $32 \%$ & $32 \%$ & $32 \%$ & $32 \%$ & $35 \%$ & $35 \%$ \\
\hline Transportation & $1 \%$ & $1 \%$ & $0 \%$ & $1 \%$ & $0 \%$ & $1 \%$ & $1 \%$ & $1 \%$ \\
\hline Commercial \& Other & $0 \%$ & $0 \%$ & $1 \%$ & $0 \%$ & $1 \%$ & $1 \%$ & $1 \%$ & $1 \%$ \\
\hline Residential & $3 \%$ & $5 \%$ & $6 \%$ & $11 \%$ & $11 \%$ & $12 \%$ & $11 \%$ & $14 \%$ \\
\hline Other $r *$ & $32 \%$ & $35 \%$ & $32 \%$ & $27 \%$ & $30 \%$ & $30 \%$ & $26 \%$ & $20 \%$ \\
\hline \multirow{2}{*}{\multicolumn{9}{|c|}{ Inputs to Conversions }} \\
\hline & & & & & & & & \\
\hline Power Generation II & $5 \%$ & $6 \%$ & $6 \%$ & $5 \%$ & $7 \%$ & $5 \%$ & $5 \%$ & - \\
\hline Heat Supply & $0.2 \%$ & $0.2 \%$ & $0.2 \%$ & $0.1 \%$ & $0.2 \%$ & $1.7 \%$ & $0.2 \%$ & - \\
\hline
\end{tabular}

* Oil and natural gas fields are known to use natural gas for multiple uses, including production, fertilizer manufacture, power generation, and residential fuel. At typical fields, actual production use and field losses account for about $6 \%$ of reported consumption. The remainder is marketed directly or as products.

$\dagger$ The largest end use in this category is probably fertilizer feedstock.

¥ This category, representing a wide range of industrial subsectors, probably contains mainly power generation and heat supply (including cogeneration) use of natural gas. Also includes losses, e.g. total reported losses of $0.32 \mathrm{bcm}$ in 1990 , of which $0.14 \mathrm{bcm}$ were reported to be transportation losses.

I Former Ministry of Energy statistics for power generation use of natural gas (found in various editions of Energy of China, for instance, and the China Energy Annual Review, 1994) considerably overstate consumption in this category, often by a factor of ten or more. Includes all utility uses.

Source: Energy Statistical Yearbook of China, various years; China Statistical Yearbook, various years; China Energy Research Society; Energy Research Institute 
Table IV-33. Electricity End Use by Sector, 1980-1993

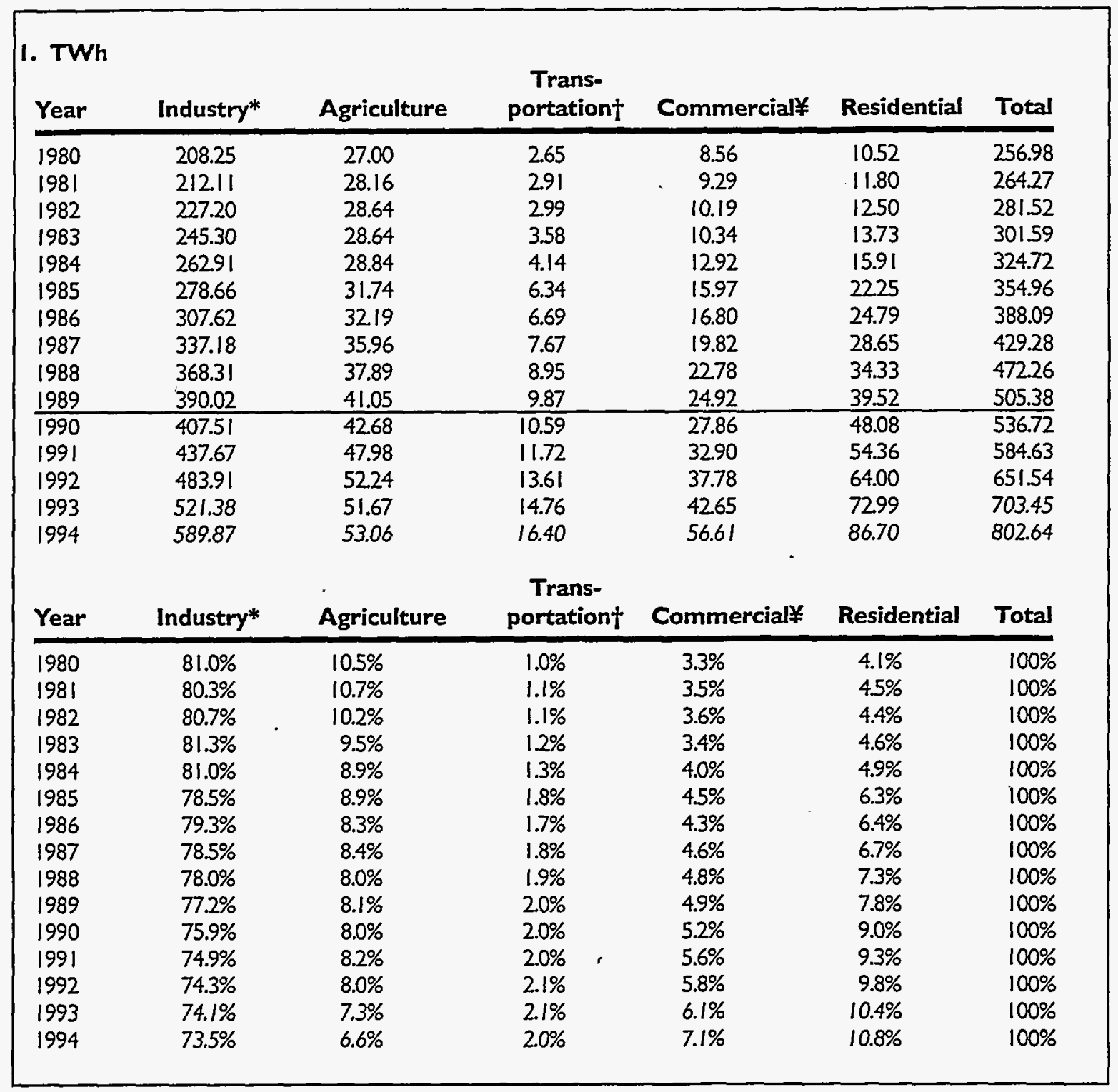

- Includes construction sector and excludes power sector consumption, which is composed of in-plant consumption and other power sector use (see Table IV-14).

t Does not include that used for transportation by units in other sectors.

* Includes electricity consumption for "nonproductive" sectors. Note change in definition of residential electricity consumption in 1985 to include that formerly counted in other sectors, primarily industry.

Figures in italics are estimated.

Source: China Energy Statistical Yearbook, various years; Energy in China, various years; China Statistical Yearbook, various years; Ministry of Coal. 
Figure IV-20. Electricity End Use by Sector

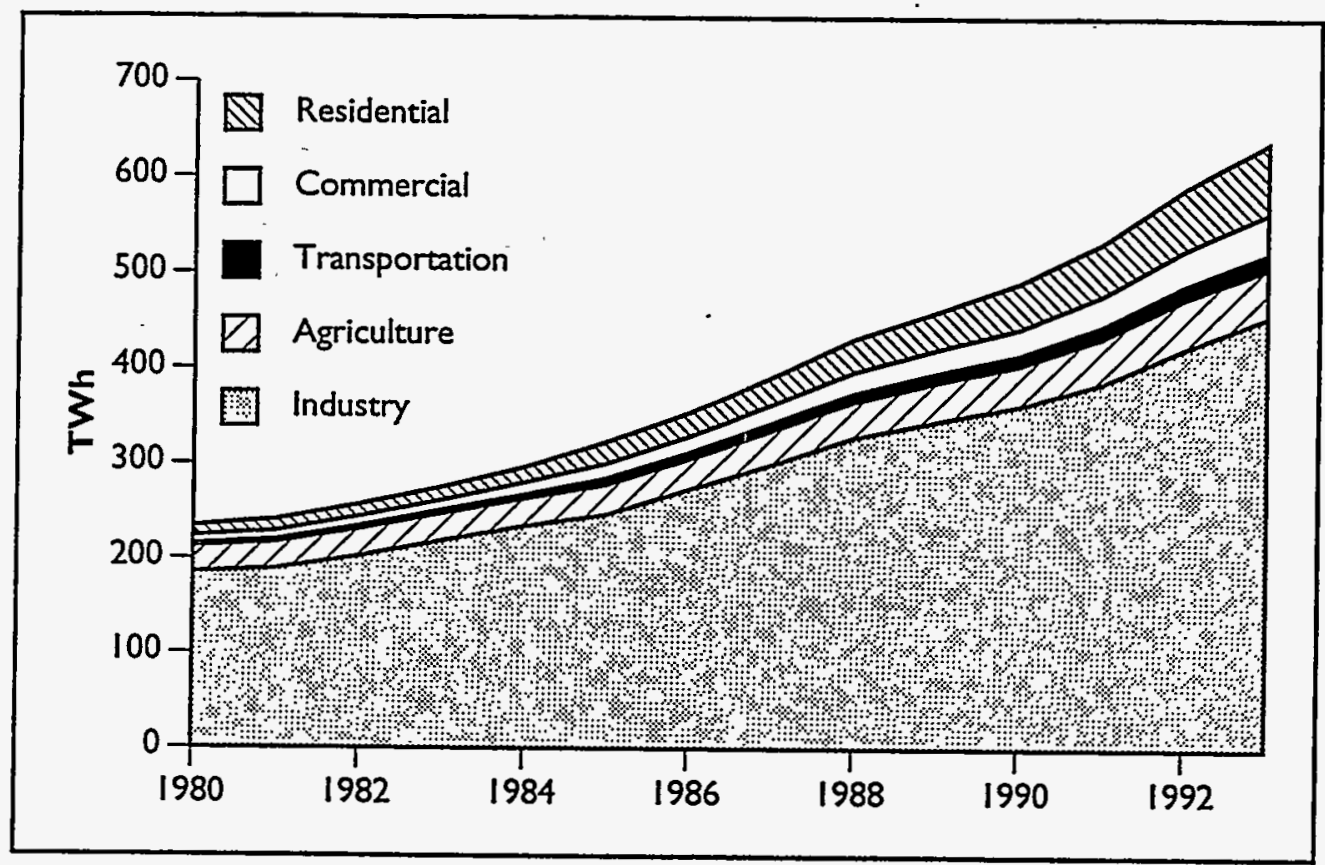




\section{Chapter V-Energy Consuming Equipment and Activities}




\section{Equipment and Activities}

$\mathrm{S}$ tatistics on stocks of energy-using equipment, output of energy-intensive products, and transportation turnover all point towards continued and strong growth in energy demand. Rising outputs of major industrial products, paralleling rates of economic growth, suggest that industry's dominance of energy use will continue. Climbing appliance and motor vehicle stocks indicate that there will be no deceleration of energy demand from the household and transportation sectors. Technical efficiency gains, then, will be key to slowing growth in overall energy use.

Reductions in the energy intensity of China's economy have continued in the 1990s, allowing rapid economic growth to continue. Intensity reductions apparently have not come from any significant shifts in the balance between economic sectors, implying big gains in production efficiency. The picture that emerges from physical energy intensity indicators (energy consumed per unit of physical output), however, does not bear this out completely. Although there have been significant drops for some product categories, e.g., steel and petrochemicals, others show ambiguous or rising tendencies, e.g., aluminum and synthetic ammonia. Careful sectoral and regional analysis is needed to sort out the root causes of past improvements in the overall energy efficiency of China's economy, and to design practical strategies to achieve further efficiency gains.

\section{TRANSPORTATION EQUIPMENT AND MODES}

In the early 1980s, freight carriage was split almost evenly between rail and water, with a very small portion carried by truck and a still more insignificant fraction carried by air (Table V-1). Air freight remains relatively rare, though it has grown a faster rate than any other mode, and water and rail still dominate the mix. Freight carried on roads, however, has grown faster than any other mode save air, and has come to account for over $13 \%$ of China's total freight caniage, or 400 out of three trillion t-km in 1993. Pipeline transport has actually dropped, peaking in 1989.

The increasing importance of motor vehicles is even more apparent in passenger traffic statistics (Table V-2). Whereas in 1980 rail accounted for nearly twice as many passenger-km as road traffic, by 1992 roads had just edged out rail, taking $47 \%$ of the 1993 total of 786 billion passenger-km. Air travel expanded by a factor of ten in those twelve years, and now accounts for $6 \%$ of passenger travel. As for freight, growth in road travel is second only to growth in air travel.

Motor vehicle output has leapt upward since the mid-1980s, when annual production was in the neighborhood of 400,000 units per year (Table V4). By 1993 vehicle output was nearly 1.3 million, with large future increases expected. Passenger vehicle production has been increasing relative to trucks, all-terrain vehicles, and others. From only $2 \%$ a decade ago, output of sedans has grown to $18 \%$ of motor vehicle output. Buses are mainly smaller vehicles, carrying up to about 20 passengers. Most trucks are light- and medium-duty vehicles; less than $5 \%$ are large-capacity diesel vehicles. Tractor production, formerly twice the level of motor vehicle output, (mainly small two-wheeled tractors, often used for transport in rural areas) hit a plateau in the late 1980 s and has begun to decline. Imported kits account for the largest share of domestically assembled sedans, and significant shares of small buses and light trucks are also assembled from imports.

Vehicle stocks reflect changing output patterns, having become more oriented towards passenger caniage (Table V-3). In the early 1980 s the ratio of trucks to passenger vehicles (including buses) was about four to one, but by 1992 it was two to one, with 4.4 million trucks and 2.3 million passenger vehicles. The stock of motorcycles (nearly all privately owned, unlike other motor vehicles) rose more than tenfold in the same period to nearly 6.5 million. Tractor stocks grew very quickly in the late 1980 s, but growth has since leveled off 
Statistics from China's dedicated transportation enterprises ${ }^{1}$ show a steady overall decline in vehicle miles per gallon for both trucks and buses, whether fueled by gasoline or diesel (Table V-5). The statistics on ton-km per gallon, however, indicate improvement for freight vehicles, as average vehicle size grows, while buses seem to be more inefficient than before, perhaps due to lower passenger loadings than in the past. Design values for fuel economy of newer vehicles is significantly improved over older vehicles, though fuel use under actual driving conditions is thought to be $20 \%$ to $30 \%$ higher than design values. ${ }^{2}$

China's steam locomotives are rapidly being phased out, replaced by cleaner and more efficient diesel and electric locomotives (Table V-6). By 1993 the combined capacity of electric locomotives was over $7 \mathrm{GW}$, compared to less than $2 \mathrm{GW}$ in 1986 (Table IV-12) Some of the locomotives discarded by the central railway system end up at local railways. The total number of units has been rising every year as construction of China's overburdened railways continues.

The average efficiency of steam locomotives (energy used per $t-\mathrm{km}$ ) has deteriorated as the fleet ages and resources are put into maintaining diesel and electric locomotives instead (Table V-7). These latter two types of locomotives saw significant improvements in efficiency through the 1980 s, but have leveled off in the 1990 s. Water transport efficiencies have fluctuated, with diesel units tending towards overall improvements.

\section{HOUSEHOLDS APPLIANCES}

Statistics on stocks of household durable goods show waves of penetration of various classes of electrical appliances beginning in the late 1970s (Table V-8). Electric fans (260 million in 1992) were first, followed by television sets ( 228 million), clothes washers (117 million), and refrigerators ( 39 million). Air conditioners are becoming more numerous, but statistics on total stocks are not yet available. Trends in output for air conditioners resemble those for the other appliances (and imports-both official and unofficial-are substantial), suggesting that stocks will be similar to those of the other appliances (i.e. several tens of millions) by the end of the decade. In terms of combined capacity of electrical appliances, between 1986 and 1993, urban and rural stocks grew by $12 \%$ and $14 \%$ annually to $29 \mathrm{GW}$ and $18 \mathrm{GW}$ respectively (Table V-12).

By 1993 most urban households had at least one fan and one TV, most likely a color TV (Table V-9). Most also had clothes washers, two-thirds had electric cooking utensils (typically electric rice cookers), and slightly more than half owned refrigerators. Air conditioners and freezers were still relatively rare, with 2.3 and 1.6 per hundred households respectively. In most urban households appliance operation is limited by the relatively low capacity of residential wiring (generally about $1.5 \mathrm{~kW}$ ), but many utilities will rewire apartments for a fee, allowing ownership of, for instance, multiple air conditioners.

Electrical appliances are much less commonplace in rural households, about $70 \%$ of which had television sets and electric fans in 1993 (Table V10). There were only 14 clothes washers and 3.6 refrigerators per hundred households. Limits on the power rural households can draw are even more severe than for urban households, and a significant minority (about 13\%) of rural dwellers are still without electricity.

\section{Agricultural Machinery}

Agricultural machinery has doubled in terms of power since 1980 (Table V-11). The largest increments among the various categories have been in small, two-wheeled diesel tractors (often used for transportation) and trucks. The former grew by a factor of six and the latter by a factor of four, together accounting for about two-thirds of the increase. Over the same period, however, agricultural sector oil use rose by only one-fifth, possibly indicating worsening rural oil shortages, large amounts of unreported consumption, or both. On the other hand, a "wholesale ex-retail" market in oil products has arisen in recnet years, and consumption is likely not to be counted in the rural sector. Nearly half the 64 GW total capacity of the sector's electrical equipment is in the form of irrigation pumps, and utilization rates are low, under 10\% (Table V-12). 


\section{INDUSTRIAL EQUIPMENT AND PRODUCTS}

Despite continuing improvements, Chinesemade equipment still has a long way to go before reaching the efficiency levels of equipment available internationally. The average Chinese industrial boiler has an efficiency of $65 \%$, at least 15 percentage points less efficient than what is used in developed countries (Table V-13). This is due in part to boiler design, materials, and manufacturing quality, typically small unit size, and in part to the generally poor quality of coal (unsorted, unwashed, and often of thermal quality outside boiler design parameters) used to fire most boilers. Fans and pumps by themselves are about $75 \%$ efficient. While this is about 10 percentage points that what is available elsewhere, system efficiencies (including components other than fans and pumps) are much lower, about half of the $70 \%$ or more of efficient international systems. While the efficiencies of China's larger advanced motors approach international levels, smaller ones (1.1 kW) are significantly less efficient.

Output of representative energy-intensive products has increased across the board since 1980 (Table V-14). Building materials, paper, and petrochemicals have kept pace with or exceeded the economy's $9-10 \%$ average growth rates, while those of iron and steel have been slightly less. Growth in output of other chemicals, especially ammonia for synthetic fertilizers, have grown much more slowly.

The Chinese government began collecting detailed information on physical energy intensity (energy per unit of physical output, or specific energy consumption) at state-owned enterprises in the early 1980s.3 Reductions in energy intensity in certain categories have been marked, whereas in some no consistent pattem is visible, and in others increasing electrification has caused intensity to rise (Table V-15). Prospects for further improvements in technical efficiency are good, since many cost-effective opportunities remain. Furthermore, rising energy prices (particularly electricity rates; see Chapter VI) and the growing sensitivity of enterprises to costs continue to raise awareness of the desirability of raising energy efficiency.

Energy inputs per unit of steel, including both fuel and electricity, have declined significantly, at an average rate of over $2 \%$ per year. This is true for primary producers and scrap metal processors. On the other hand, China still uses considerably more energy than the steel industries in other countries, including Russia and India. Trends for nonferrous metals have not been so clear, fluctuating over the decade. The electricity intensity of aluminum smelting declined overall, for instance, while alumina production required nearly one-fourth more energy per unit of output in 1992 compared to 1980.

Statistics for cement, bricks, and flat glass demonstrate that fuel intensity for building materials manufacture has declined while electricity use has risen. For cement, small rural plants actually use less energy per unit of output (since many state-owned plants use fuel-intensive wet process kilns), but turn out a product of lower quality. Average energy intensities are much greater than in Japan, but comparable to or lower than the US and Russia. Small brick manufacturers use nearly one and one-half times as much energy to produce the same amount of output, although intensity for both rural plants and the sector as a whole have been declining steadily.

Intensities of chemical manufacturing processes have shown mixed trends. Some have dropped significantly, especially those for petrochemicals, as unit size has increased, facilities are modernized, and feedstock mixes shift. Ethylene intensities, for example, fell by $3 \%$ per year in the later 1980 s (although levels are still about twice those of Japan), and polypropylene intensities even more. The energy intensity of ammonia production actually increased overall between 1980 and 1992, while it fell by $1.4 \%$ and $2.8 \%$ per year for medium and small plants respectively, partly as the result of vigorous efforts by the government to improve efficiency in the industry. Calcium carbide and phosphorous intensities declined, while those for carbon black and sulfuric acid rose. Sulfuric acid manufacture is actually an exothermic process which in other countries is used to generate electricity, but in China electricity demand for this process has been rising.

Electricity intensities of light industrial sectors, represented here by paper and cotton spinning, have generally increased, as demand for higher quality products and installation of environmental controls makes manufacturing processes more complex.

Between 1986 and 1993 installed capacity of electricity-using equipment (including utility sector equipment) grew from about $250 \mathrm{GW}$ to $429 \mathrm{GW}$ 
(Table V-12). The fastest growing sector was households, more than doubling from $20 \mathrm{GW}$ to $47 \mathrm{GW}$. The largest increment was in industry, with over $60 \%$ of capacity. Industry also has the highest utilization rate (as implied by electricity consumption statistics), i.e., 0.27, with the highest rates for industries with continuous processes like oil refining, chemicals, and metals. The lowest utilization rate, 0.09 , is in agriculture, in which half of electricity using capacity is devoted to irrigation pumps.

1 These represent only a fraction of China's vehicle stock, as most are owned by entities in other sectors, e.g., factories, commercial enterprises, farms, or individuals.

2 Jiang, 1995.

3 For those industrial sectors dominated by large state-owned enterprises, e.g., ferrous metals and refining, such statistics are reasonably good proxies for industry-wide averages. For other sectors, e.g., building materials, in which half of output or more comes from non-state enterprises, official data may be a poor guide to conditions typical of many enterprises. 
Table V-1. Freight Movements by Mode, 1949-1993-Billion Tonne-km

\begin{tabular}{|c|c|c|c|c|c|c|c|c|c|}
\hline \multirow[b]{2}{*}{ Year } & \multicolumn{3}{|c|}{ Railroad } & \multirow[b]{2}{*}{ Highway* } & \multirow[b]{2}{*}{ River } & \multirow[b]{2}{*}{ Ocean } & \multirow[b]{2}{*}{ Pipeline } & \multirow[b]{2}{*}{ Air } & \multirow[b]{2}{*}{ Total } \\
\hline & Central & Local & Total & & & & & & \\
\hline 1949 & 18.40 & - & 18.40 & 0.81 & 6.31 & - & - & 0.02 & 25.55 \\
\hline 1950 & 39.41 & - & 39.41 & 0.94 & 5.13 & - & - & $<0.005$ & 45.48 \\
\hline 1951 & 51.56 & - & $5 i .56$ & 1.15 & 8.65 & 1.7 & - & $<0.005$ & 63.06 \\
\hline 1952 & 60.16 & - & 60.16 & 1.45 & 11.78 & 2.8 & - & $<0.005$ & 76.19 \\
\hline 1953 & 78.14 & - & 78.14 & 2.33 & 14.46 & 4.1 & - & $<0.005$ & 99.03 \\
\hline 1954 & 93.24 & - & 93.24 & 2.91 & 20.47 & 3.7 & - & 0.01 & 120.33 \\
\hline 1955 & 98.15 & - & 98.15 & 3.41 & 23.40 & 7.0 & - & 0.01 & 131.97 \\
\hline 1956 & 120.35 & - & 120.35 & 4.44 & 27.69 & 6.6 & - & 0.01 & 159.09 \\
\hline 1957 & 134.59 & - & 134.59 & 4.80 & 33.86 & 7.7 & - & 0.01 & 180.96 \\
\hline 1958 & 185.53 & - & 185.53 & 7.75 & 44.22 & 7.5 & - & 0.01 & 245.01 \\
\hline 1959 & 247.63 & - & 247.63 & 10.67 & 59.30 & 9.6 & - & 0.02 & 327.22 \\
\hline 1960 & 276.69 & - & 276.69 & 13.25 & 64.98 & 11.8 & - & 0.03 & 366.75 \\
\hline 1961 & 200.77 & - & 200.77 & 7.61 & 42.58 & 11.7 & - & 0.02 & 262.68 \\
\hline 1962 & 171.91 & 0.20 & 172.11 & 6.21 & 33.96 & 11.3 & 0.0 & 0.02 & 223.60 \\
\hline 1963 & 181.46 & 0.14 & 181.60 & 6.43 & 33.70 & 13.1 & 0.0 & 0.02 & 234.85 \\
\hline 1964 & 212.45 & 0.15 & 21260 & 7.42 & 36.93 & 18.1 & 0.0 & 0.02 & 275.07 \\
\hline 1965 & 269.65 & 0.23 & 269.88 & 9.51 & 43.32 & 23.7 & 0.0 & 0.03 & 346.44 \\
\hline 1966 & 301.63 & 0.27 & 301.89 & 11.64 & 48.60 & 28.0 & 0.0 & 0.03 & 390.16 \\
\hline 1967 & 226.58 & 0.30 & 226.88 & 10.15 & 41.57 & 26.4 & 0.0 & 0.04 & 305.04 \\
\hline 1968 & 223.53 & 0.35 & 223.88 & 8.44 & 43.07 & 35.5 & 0.0 & 0.03 & 310.92 \\
\hline 1969 & 277.93 & 0.40 & 278.33 & 11.03 & 49.53 & 36.5 & 0.0 & 0.03 & 375.42 \\
\hline 1970 & 349.14 & 0.46 & 349.60 & 13.81 & 51.23 & 41.9 & 0.0 & 0.04 & 456.58 \\
\hline 1971 & 375.95 & 0.64 & 376.59 & 15.38 & 56.87 & 70.7 & 0.9 & 0.03 & 520.47 \\
\hline 1972 & 390.51 & 0.81 & 391.32 & 16.43 & 60.88 & 90.1 & 5.7 & 0.03 & 564.46 \\
\hline 1973 & 407.48 & 0.74 & 408.22 & 17.57 & 67.22 & 127.7 & 8.7 & 0.03 & 629.44 \\
\hline 1974 & 380.58 & 0.71 & 381.29 & 17.48 & 69.18 & 147.1 & 16.3 & 0.04 & 631.39 \\
\hline 1975 & 424.62 & 0.95 & 425.57 & 20.27 & 81.77 & 175.7 & 26.2 & 0.06 & 729.57 \\
\hline 1976 & 386.07 & 0.88 & 386.95 & 20.96 & 85.52 & 161.2 & 35.7 & 0.07 & 690.40 \\
\hline 1977 & 455.73 & 1.15 & 456.88 & 25.13 & 102.07 & 174.1 & 38.7 & 0.08 & 796.96 \\
\hline 1978 & 533.35 & 1.17 & 534.52 & 27.41 & 129.22 & 248.7 & 43.0 & 0.10 & 982.95 \\
\hline 1979 & 558.80 & 1.00 & 559.80 & 74.50 & 139.32 & 317.1 & 47.6 & 0.12 & $1,138.44$ \\
\hline 1980 & 570.75 & 0.96 & 571.70 & 76.40 & 152.08 & 353.2 & 49.1 & 0.14 & $1,202.62$ \\
\hline 1981 & 570.13 & 1.07 & 571.20 & 78.00 & 150.69 & 364.3 & 49.9 & 0.17 & $1,214.26$ \\
\hline 1982 & 610.92 & 1.08 & 612.00 & 94.90 & 170.81 & 376.9 & 50.1 & 0.20 & $1,304.91$ \\
\hline 1983 & 663.39 & 1.21 & 664.60 & 108.40 & 181.06 & 397.7 & 52.4 & 0.23 & $1,404.39$ \\
\hline 1984 & 723.51 & 1.29 & 724.80 & 153.60 & 196.10 & 437.4 & 57.2 & 0.31 & $1,569.41$ \\
\hline 1985 & 811.19 & 1.41 & 812.60 & 169.30 & 237.10 & 532.9 & 60.3 & 0.42 & $1,812.62$ \\
\hline 1986 & 875.03 & 1.47 & 876.50 & 211.80 & 270.00 & 594.8 & 61.2 & 0.48 & $2,014.78$ \\
\hline 1987 & 945.62 & 1.58 & 947.20 & 266.00 & 288.90 & 657.6 & 62.5 & 0.65 & $2,222.85$ \\
\hline 1988 & 986.06 & 1.74 & 987.80 & 322.00 & 310.40 & 696.6 & 65.0 & 0.73 & $2,382.53$ \\
\hline 1989 & $1,037.30$ & 2.12 & $1,039.42$ & 337.47 & 349.76 & 768.9 & 62.9 & 0.69 & 2.559 .14 \\
\hline 1990 & 1.060 .12 & 2.12 & $1,062.24$ & 335.81 & $\dagger$ & $1,159.19$ & 62.7 & 0.82 & $2,620.76$ \\
\hline 1991 & $1,094.81$ & 2.39 & $1,097.20$ & 342.80 & 396.54 & 899.0 & 62.1 & 1.01 & $2,798.65$ \\
\hline 1992 & $1,154.85$ & 2.70 & $1,157.56$ & 375.54 & 422222 & 903.4 & 61.7 & 1.34 & $2,921.76$ \\
\hline 1993 & $1,192.34$ & 3.12 & 1.195 .46 & 407.05 & 472.68 & 913.4 & 60.8 & 1.66 & 3.042 .66 \\
\hline
\end{tabular}

- Data on highway transport for 1949-1978 include freight carried by transportation work units only. Subsequent data also include freight carried by vehicles belonging to other types of work units, e.g., industrial and agricultural. Data for 1984 and later years further include freight carried by private motor vehicles.

$\dagger$ River shipping is contained in 1990 figure for ocean shipping.

Source: China Statistical Yearbook, various years. 
Table V-1. Freight Movements by Mode, 1949-1993 (continued)

\begin{tabular}{|ccccccccc|}
\hline \multicolumn{2}{l}{ Average Annual Rates of Growth } \\
& Rail & Highway & River & Ocean & Pipeline & Air & Total \\
\hline $1949-1971$ & $14.3 \%$ & $12.9 \%$ & $10.0 \%$ & $17.4 \%$ & - & $3.0 \%$ & $14.0 \%$ \\
$1971-1980$ & $4.7 \%$ & $19.5 \%$ & $11.5 \%$ & $19.6 \%$ & $55.9 \%$ & $18.7 \%$ & $9.8 \%$ \\
$1981-1990$ & $7.1 \%$ & $17.6 \%$ & $9.6 \%$ & $9.3 \%$ & $2.6 \%$ & $19.1 \%$ & $8.9 \%$ \\
$1990-1993$ & $4.0 \%$ & $6.6 \%$ & $11.1 \%$ & $3.9 \%$ & $-1.0 \%$ & $26.5 \%$ & $5.1 \%$ \\
& & & & & & & \\
\hline
\end{tabular}

Figure V-1. Freight Movements by Mode

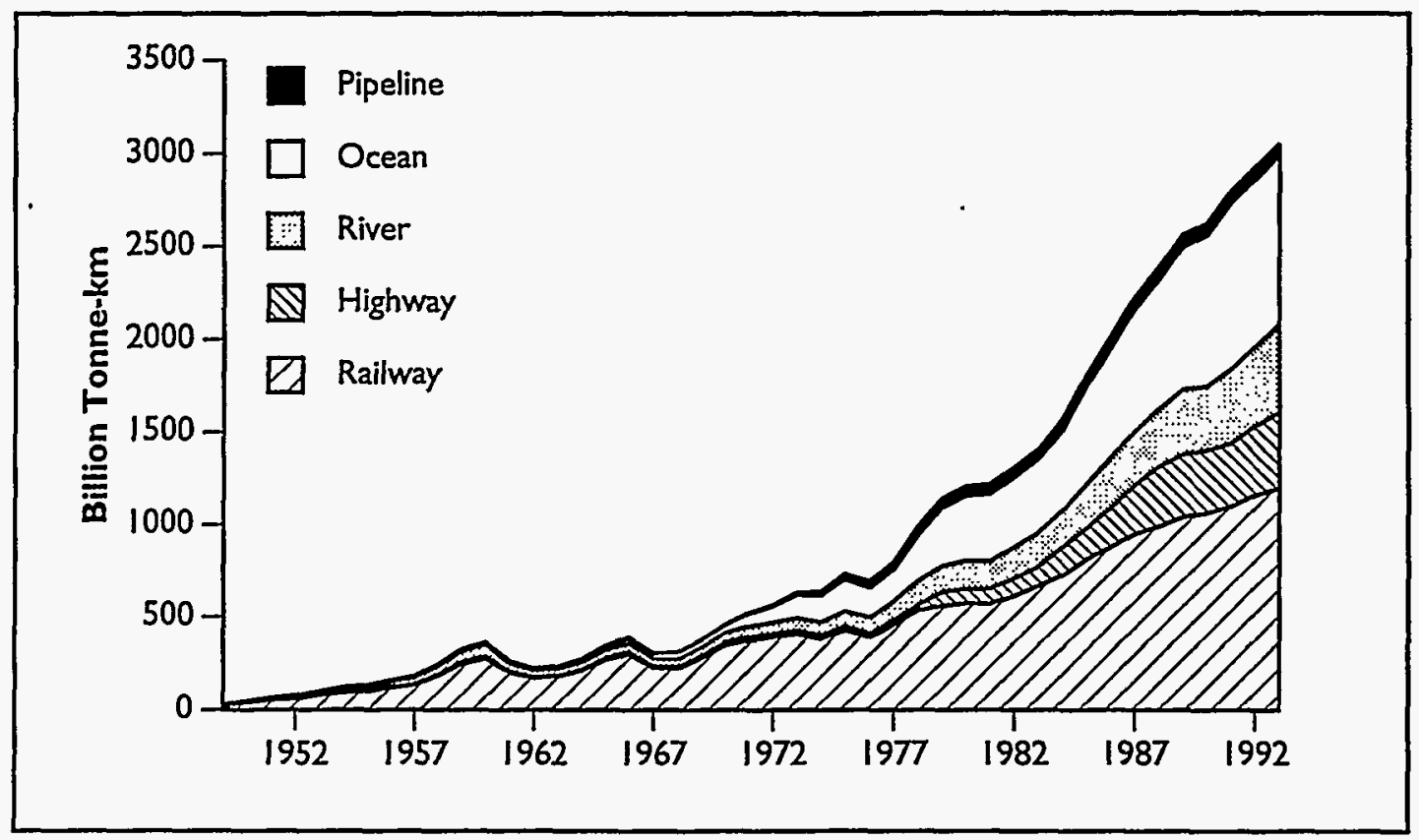

Source: Statistical Yearbook of China, various years. 
Table V-2. Passenger Travel by Mode, 1949-1993-Billion Passenger-km

\begin{tabular}{|c|c|c|c|c|c|c|c|}
\hline \multirow[b]{2}{*}{ Year } & \multicolumn{3}{|c|}{ Railroad } & \multirow[b]{2}{*}{ Highway } & \multirow[b]{2}{*}{ Water } & \multirow[b]{2}{*}{ Air } & \multirow[b]{2}{*}{ Total } \\
\hline & Central & Local & Total & & & & \\
\hline 1949 & 13.00 & - & 13.00 & 0.80 & 1.52 & 0.19 & 15.50 \\
\hline 1950 & 21.24 & - & 21.24 & 1.28 & 1.47 & 0.01 & 24.00 \\
\hline 1951 & 23.05 & - & 23.05 & 1.72 & 2.17 & 0.02 & 26.96 \\
\hline 1952 & 20.06 & - & 20.06 & 2.26 & 2.45 & 0.02 & 24.79 \\
\hline 1953 & 28.17 & - & 28.17 & 3.38 & 3.41 & 0.03 & 34.99 \\
\hline 1954 & 29.47 & - & 29.47 & 4.13 & 3.44 & 0.05 & 37.09 \\
\hline 1955 & 26.74 & - & 26.74 & 5.03 & 3.52 & 0.06 & 35.35 \\
\hline 1956 & 34.38 & - & 34.38 & 7.82 & 4.23 & 0.10 & 46.53 \\
\hline 1957 & 36.13 & - & 36.13 & 8.81 & 4.64 & 0.08 & 49.66 \\
\hline 1958 & 40.92 & - & 40.92 & 11.61 & 4.58 & 0.12 & 57.23 \\
\hline 1959 & 51.72 & - & 51.72 & 13.97 & 5.34 & 0.14 & 71.17 \\
\hline 1960 & 67.40 & - & 67.40 & 14.60 & 6.19 & 0.16 & 88.35 \\
\hline 1961 & 89.56 & - & 89.56 & 12.88 & 7.95 & 0.14 & 110.53 \\
\hline 1962 & 85.73 & 0.17 & 85.90 & 14.15 & 8.39 & 0.12 & 108.56 \\
\hline 1963 & 53.12 & 0.09 & 53.21 & 13.43 & 5.88 & 0.14 & 72.66 \\
\hline 1964 & 48.52 & 0.09 & 48.62 & 14.63 & 5.13 & 0.20 & 68.58 \\
\hline 1965 & 47.78 & 0.12 & 47.90 & 16.82 & 4.47 & 0.25 & 69.44 \\
\hline 1966 & 50.36 & 0.13 & 50.49 & 20.75 & 6.43 & 0.22 & 77.89 \\
\hline 1967 & 59.38 & 0.15 & 59.54 & 20.00 & 6.60 & 0.24 & 86.38 \\
\hline 1968 & 67.88 & 0.17 & 68.06 & 18.58 & 6.78 & 0.21 & 93.63 \\
\hline 1969 & 77.01 & 0.20 & 77.21 & 22.22 & 7.47 & 0.17 & 107.07 \\
\hline 1970 & 71.59 & 0.23 & 71.82 & 24.01 & 7.10 & 0.18 & 103.11 \\
\hline 1971 & 76.01 & 0.24 & 76.25 & 26.81 & 7.34 & 0.30 & 110.70 \\
\hline 1972 & 84.90 & 0.29 & 85.19 & 30.25 & 7.71 & 0.42 & 123.57 \\
\hline 1973 & 89.99 & 0.27 & 90.26 & 33.33 & 8.36 & 0.57 & 132.52 \\
\hline 1974 & 92.28 & 0.27 & 92.55 & 35.49 & 8.69 & 0.93 & 137.66 \\
\hline 1975 & 95.26 & 0.15 & 95.41 & 37.45 & 9.06 & 1.54 & 143.46 \\
\hline 1976 & 95.47 & 0.24 & 95.71 & 40.25 & 9.43 & 1.57 & 146.96 \\
\hline 1977 & 102.02 & 0.26 & 102.27 & 44.81 & 9.75 & 1.83 & I58.67 \\
\hline 1978 & 109.08 & 0.24 & 109.32 & 52.10 & 10.06 & 2.79 & 174.27 \\
\hline 1979 & 121.37 & 0.24 & 121.62 & 60.33 & 11.40 & 3.50 & 196.85 \\
\hline 1980 & 138.04 & 0.26 & 138.30 & 72.95 & 12.91 & 3.96 & 228.11 \\
\hline 1981 & 146.99 & 0.28 & 147.26 & 83.90 & 13.78 & 5.02 & 249.96 \\
\hline 1982 & 157.20 & 0.28 & 157.48 & 96.39 & 14.45 & 5.95 & 274.28 \\
\hline 1983 & 177.34 & 0.31 & 177.65 & 110.56 & 15.39 & 5.90 & 309.50 \\
\hline 1984 & 204.32 & 0.32 & 204.64 & 133.69 & 15.39 & 8.35 & 362.07 \\
\hline 1985 & 241.25 & 0.36 & 241.61 & 172.49 & 17.87 & 11.70 & 443.66 \\
\hline 1986 & 258.31 & 0.36 & 258.67 & 198.17 & $18.21^{-}$ & 14.60 & 489.65 \\
\hline 1987 & 284.00 & 0.31 & 284.31 & 219.04 & 19.59 & 18.20 & 541.14 \\
\hline 1988 & 325.73 & 0.30 & 326.03 & 252.82 & 20.39 & 21.70 & 620.94 \\
\hline 1989 & 303.44 & 0.30 & 303.74 & 266.21 & 18.83 & 18.68 & 607.46 \\
\hline 1990 & 261.01 & 0.25 & 261.26 & 262.03 & 16.49 & 23.05 & 562.83 \\
\hline 1991 & 282.48 & 0.33 & 282.81 & 287.17 & 17.72 & 30.13 & 617.84 \\
\hline 1992 & 314.83 & 0.39 & 315.22 & 319.26 & 19.84 & 40.61 & 694.94 \\
\hline 1993 & 347.94 & 0.39 & 348.33 & 370.07 & 19.65 & 47.76 & 785.81 \\
\hline
\end{tabular}

Source: China Statistical Yearbook, various years. 
Table V-2. Passenger Travel by Mode, 1949-1993 (continued)

\begin{tabular}{|lcccrr|}
\hline \multicolumn{2}{|c|}{ Average Rates of Growth } & & & & \\
& Rail & Highway & Water & Air & Total \\
\hline $1949-1971$ & $8.4 \%$ & $17.3 \%$ & $7.4 \%$ & $2.1 \%$ & $9.3 \%$ \\
$1971-1980$ & $6.8 \%$ & $11.8 \%$ & $6.5 \%$ & $33.4 \%$ & $8.4 \%$ \\
$1981-1990$ & $6.6 \%$ & $13.5 \%$ & $2.0 \%$ & $18.5 \%$ & $9.4 \%$ \\
$1990-1993$ & $10.1 \%$ & $12.2 \%$ & $6.0 \%$ & $27.5 \%$ & $11.8 \%$ \\
& & & & & \\
\hline
\end{tabular}

Figure V-2. Passenger Travel by Mode

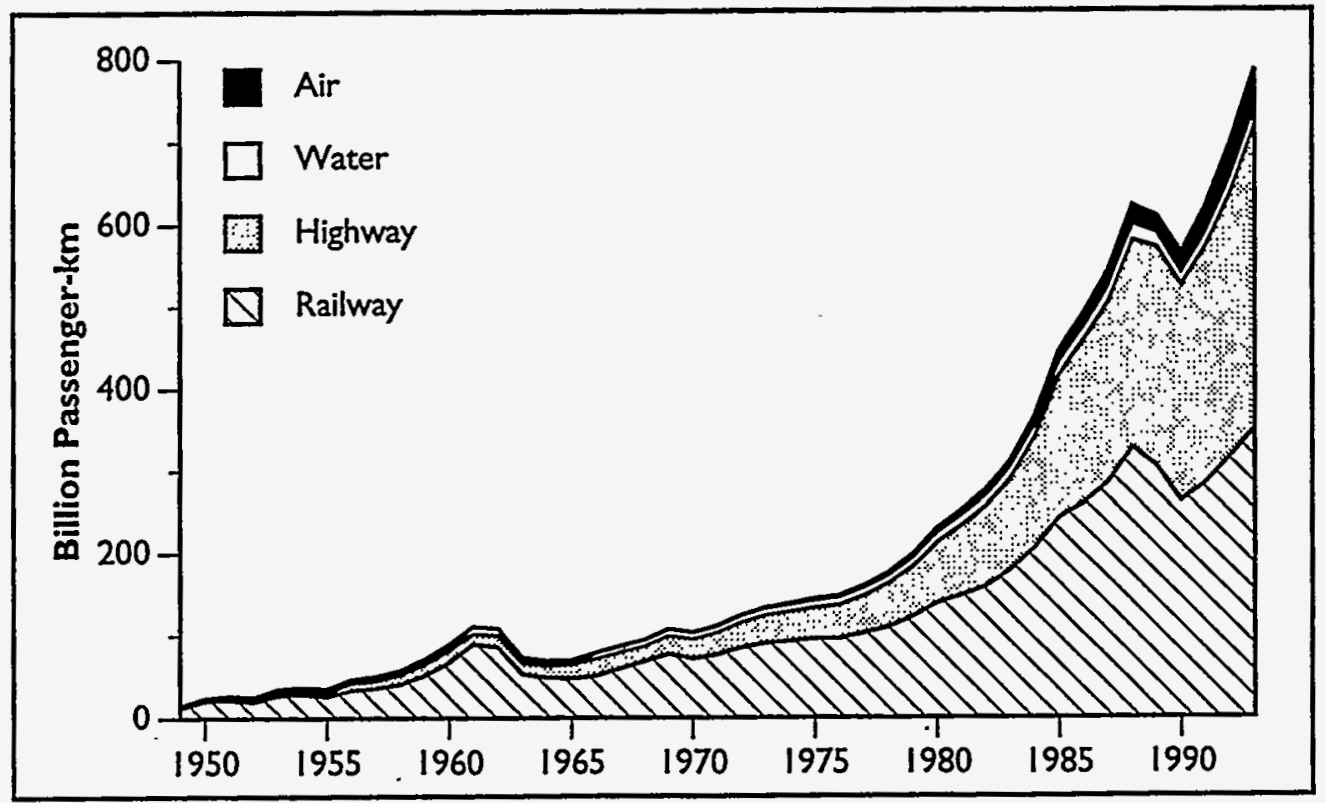




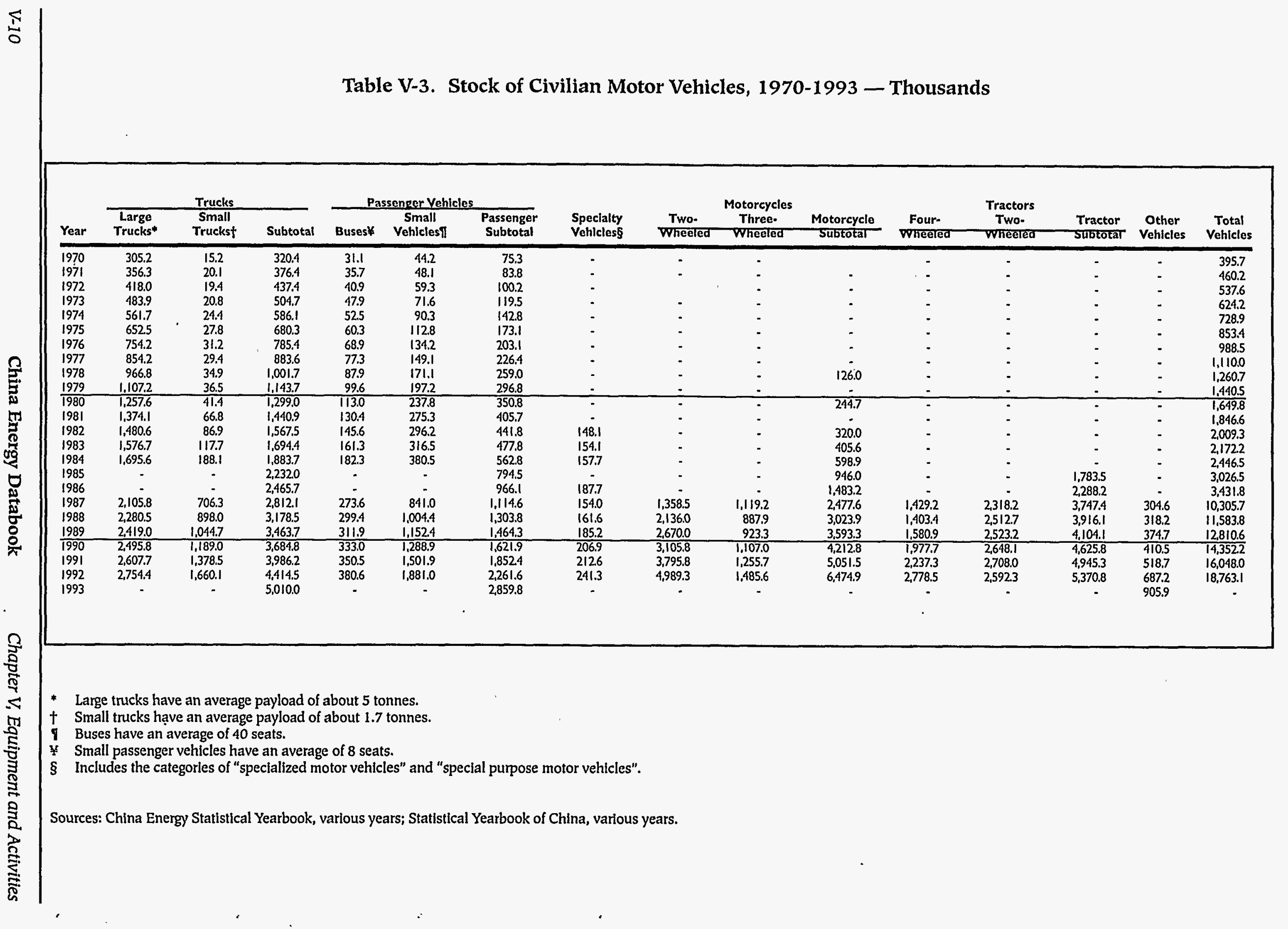


Figure V-3. Civilian Motor Vehicles

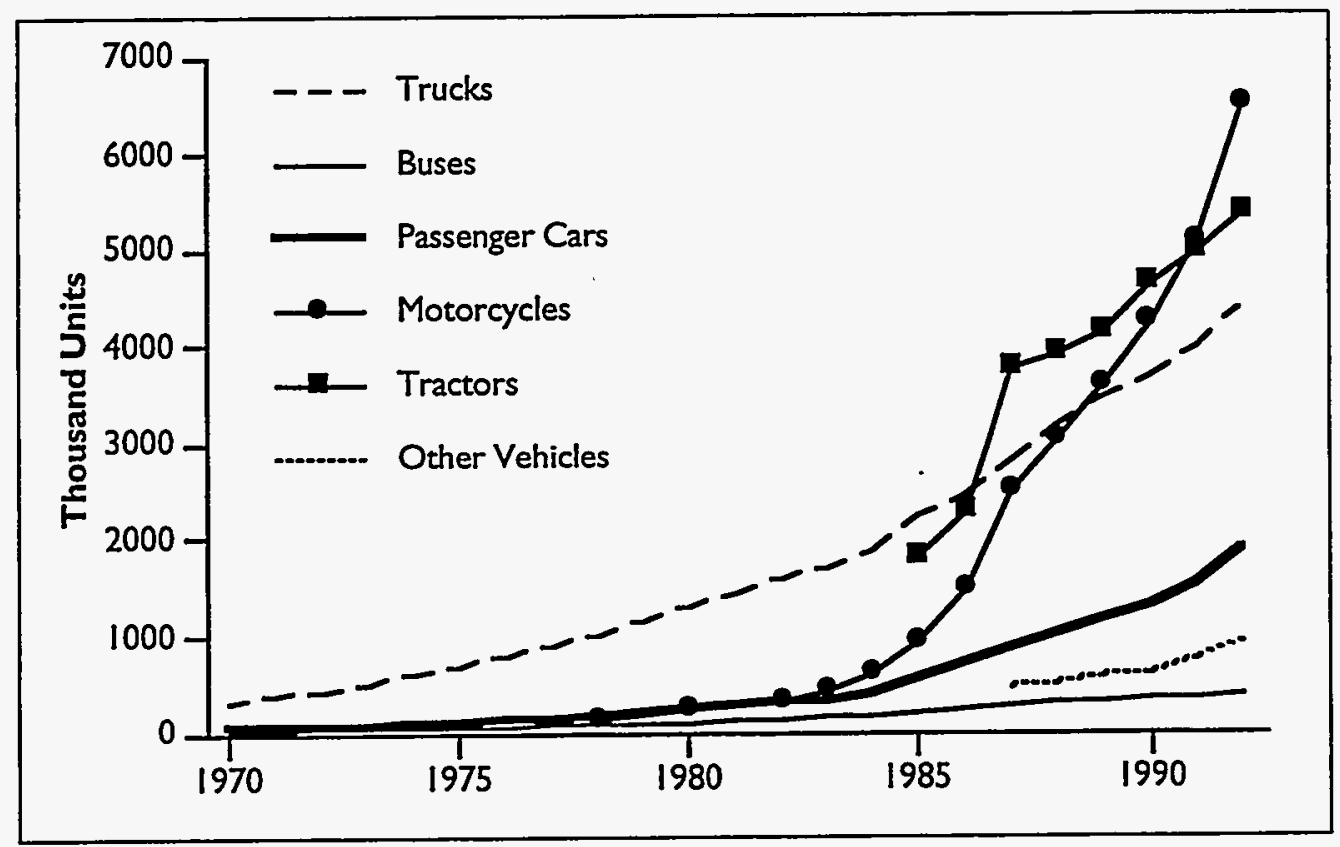


Table V-4. Motor Vehicle Production, 1978-1994

\begin{tabular}{|c|c|c|c|c|c|c|c|c|c|}
\hline \multicolumn{10}{|c|}{ I. Output time series*, Thousands } \\
\hline Year & $\begin{array}{l}\text { Motor } \\
\text { Vehicles }\end{array}$ & $\frac{\text { of which: }}{\text { buses }}$ & sedans & ATVs & trucks $¥$ & other & Motorcycles & $\begin{array}{c}\text { Large \& } \\
\text { Medium } \\
\text { Tractors † }\end{array}$ & $\begin{array}{l}\text { Small } \\
\text { Tractors }\end{array}$ \\
\hline 1978 & 149.1 & - & 26 & 12.9 & 96.1 & - & - & 113.5 & 324.2 \\
\hline 1979 & 185.7 & - & 4.2 & 17.2 & - & - & - & 125.6 & 317.5 \\
\hline 1980 & 222.3 & - & 5.4 & 20.4 & 135.5 & - & - & 97.9 & 217.9 \\
\hline 1981 & 175.6 & - & 3.4 & 15.5 & - & - & - & 52.8 & 198.9 \\
\hline 1982 & 196.3 & - & 4.0 & 15.3 & - & - & - & 40.3 & 298.3 \\
\hline 1983 & 239.8 & 6.2 & 6.0 & 18.2 & 137.1 & 72.2 & - & 37.0 & 497.7 \\
\hline 1984 & 316.4 & 7.0 & 6.0 & 16.6 & 181.8 & 105.0 & - & 39.7 & 688.6 \\
\hline 1985 & 437.2 & 11.9 & 5.2 & -20.7 & 269.0 & 130.3 & - & 45.0 & 822.5 \\
\hline 1986 & 369.8 & 9.2 & 12.3 & 21.9 & 229.1 & 97.3 & - & 28.6 & 774.5 \\
\hline 1987 & 471.8 & 20.5 & 20.9 & 27.4 & 298.4 & 104.7 & - & 37.1 & $1,106.0$ \\
\hline 1988 & 644.7 & 50.9 & 36.8 & 36.0 & 403.3 & 117.7 & - & 47.2 & $1,335.7$ \\
\hline 1989 & 583.5 & 47.6 & 28.8 & 48.3 & 363.4 & 95.3 & - & 39.8 & 1.118 .1 \\
\hline 1990 & 514.0 & 23.1 & 42.4 & 44.3 & 289.7 & 114.4 & - & 39.4 & $1,101.4$ \\
\hline 1991 & 714.2 & 42.8 & 81.1 & 53.4 & 3825 & 154.5 & - & 52.7 & $1,347.8$ \\
\hline 1992 & $1,066.7$ & 84.6 & 162.7 & 61.7 & 476.7 & 281.0 & - & 57.0 & $1,390.7$ \\
\hline 1993 & $1,298.5$ & - & 230.0 & - & 597.9 & - & - & 37.7 & 961.4 \\
\hline 1994 & 1.402 .4 & - & 380.0 & - & - & - & $5,124.8$ & 50.7 & I,287.7 \\
\hline
\end{tabular}

* These are mainly State Statistical Bureau figures, which in general are slightly larger than other statistics, e.g., the China Automotive Industry Corporation. Data in subtable 2.

$\dagger$ Tractors with power $\geq 14.72 \mathrm{~kW}$.

Source: China Statistical Yearbook, various years; China Automotive Industry Yearbook, 1993; China News Service, 6/29/95; State Statistical Bureau. 
Table V-4. Motor Vehicle Production, 1978-1994 (continued)

\begin{tabular}{|c|c|c|c|}
\hline \multicolumn{4}{|c|}{ 2. Output structure, $1992-$ units } \\
\hline Vehicle type & $\begin{array}{l}\text { Domestically } \\
\text { Manufactured }\end{array}$ & $\begin{array}{l}\text { Imported } \\
\text { Kits }\end{array}$ & Total \\
\hline Trucks & 441,107 & 19.167 & 460,274 \\
\hline heavy & 9.747 & 729 & 10,476 \\
\hline medium & 178,728 & 0 & 178,728 \\
\hline light & 194,114 & 18,238 & 212,352 \\
\hline mini & 58,518 & 200 & 58.718 \\
\hline ATVs & 63,373 & 0 & 63,373 \\
\hline heavy & 874 & 0 & 874 \\
\hline medium & 752 & 0 & 752 \\
\hline light & 61,747 & 0 & 61,747 \\
\hline passenger & 55,378 & 0 & 55,378 \\
\hline Dump Trucks & 38,093 & 485 & 38,578 \\
\hline Tow Trucks & 757 & 1 & 758 \\
\hline Buses & 75,986 & 8,565 & 84,551 \\
\hline jointed & 230 & 0 & 230 \\
\hline large & 1,964 & 82 & 2,046 \\
\hline medium & 5,625 & 110 & 5,735 \\
\hline small & 60,848 & 8,373 & 69,221 \\
\hline mini & 7,269 & 0 & 7,269 \\
\hline Sedans & 67,716 & 95,009 & 162,725 \\
\hline mini & 2.716 & 35.608 & 38,324 \\
\hline Passenger Vans & 40,669 & 0 & 40,669 \\
\hline light & 17,389 & 0 & 17,389 \\
\hline mini & 23,280 & 0 & 23,280 \\
\hline Cargo Vans & 11,372 & 0 & 11,372 \\
\hline heavy & 4 & 0 & 4 \\
\hline medium & 209 & 0 & 209 \\
\hline light & 10,108 & 0 & 10,108 \\
\hline $\operatorname{mini}$ & 1.051 & 0 & 1.051 \\
\hline Other Vehicles & 259 & 0 & 259 \\
\hline Automotive Chassis & 199,162 & 0 & 199,162 \\
\hline truck & 105,080 & 0 & 105,080 \\
\hline ATV & 11,428 & 0 & 11,428 \\
\hline passenger & 81,270 & 0 & 81,270 \\
\hline other & 1,384 & 0 & 1,384 \\
\hline Total & 938.494 & 123,227 & $1,061,721$ \\
\hline
\end{tabular}

Source: China Statistical Yearbook, various years; China Automotive Industry Yearbook, 1993; China News Service, 6/29/95. 
Table V-5. Motor Vehicle Fuel Economy, 1970-1990

\begin{tabular}{|c|c|c|c|c|c|c|c|c|}
\hline \multicolumn{9}{|c|}{$\begin{array}{l}\text { I. Truck and Bus Averages* } \\
\text { Trucks }\end{array}$} \\
\hline & $1 / 100 \mathrm{t}-\mathrm{km}$ & t-mpg & liters $/ 100 \mathrm{~km}$ & $\mathbf{m p g}$ & I/100 t-km & t-mpg & liters/100 km & $\mathrm{mpg}$ \\
\hline 1970 & 9.4 & 25 & 324 & 7.31 & 6.3 & 38 & 24.9 & 9.51 \\
\hline 1971 & 9.2 & 26 & 322 & 7.35 & 6.2 & 38 & 25.2 & 9.40 \\
\hline 1972 & 9.1 & 26 & 33.0 & 7.18 & 6.1 & 39 & 26.3 & 9.00 \\
\hline 1973 & 9.1 & 26 & 33.3. & 7.11 & 6.0 & 39 & 26.3 & 9.00 \\
\hline 1974 & 9.3 & 25 & 34.2 & 6.92 & 6.3 & 38 & 26.5 & 8.94 \\
\hline 1975 & 9.3 & 25 & 34.1 & 6.94 & 6.9 & 34 & 27.4 & 8.64 \\
\hline 1976 & 9.0 & 26 & 34.1 & 6.94 & 5.8 & 41 & 28.4 & 8.34 \\
\hline 1977 & 8.6 & 28 & 33.9 & 6.99 & 6.5 & 36 & 22.6 & 10.48 \\
\hline 1978 & 8.5 & 28 & 33.7 & 7.03 & 6.0 & 39 & 26.7 & 8.87 \\
\hline 1979 & 8.7 & 27 & 33.4 & 7.09 & 6.1 & 39 & 27.1 & 8.74 \\
\hline 1980 & 8.7 & 27 & 33.4 & 7.09 & 6.2 & 38 & 27.8 & 8.52 \\
\hline 1981 & 8.5 & 28 & 34.0 & 6.97 & 6.0 & 39 & 28.4 & 8.34 \\
\hline 1982 & 8.2 & 29 & 33.8 & 7.01 & 5.9 & 40 & 28.9 & 8.19 \\
\hline 1983 & 8.0 & 30 & 34.6 & 6.84 & 5.8 & 41 & 29.6 & 8.00 \\
\hline 1984 & 7.9 & 30 & 35.3 & 6.71 & 5.7 & 42 & 31.0 & 7.64 \\
\hline 1985 & 7.7 & 31 & 36.0 & 6.58 & 5.8 & 41 & 32.7 & 7.24 \\
\hline 1986 & 7.6 & 31 & 36.4 & $6.51^{\circ}$ & 5.1 & 46 & 34.0 & 6.97 \\
\hline 1987 & 7.6 & 31 & 37.3 & 6.35 & 5.1 & 46 & 34.8 & 6.81 \\
\hline 1988 & 7.2 & 33 & 37.3 & 6.35 & 4.8 & 49 & 35.4 & 6.69 \\
\hline 1989 & 7.1 & 33 & - & - & 4.7 & 50 & - & - \\
\hline 1990 & 7.1 & 33 & - & - & 4.8 & 49 & - & - \\
\hline
\end{tabular}

Buses

\begin{tabular}{|c|c|c|c|c|c|c|c|c|}
\hline & \multicolumn{4}{|c|}{ Gasoline } & \multicolumn{3}{|c|}{ Diesel } & \multirow[b]{2}{*}{$\mathrm{mpg}$} \\
\hline & //100 t-km & t-mpg & liters $/ 100 \mathrm{~km}$ & $\mathrm{mpg}$ & I/100 t-km & t-mpg & liters/100 km & \\
\hline 1970 & - & - & 28.3 & 8.37 & - & - & 24.6 & 9.63 \\
\hline 1971 & - & - & 28.0 & 8.46 & - & - & 24.7 & 9.59 \\
\hline 1972 & - & - & 28.5 & 8.31 & - & - & 21.0 & 11.28 \\
\hline 1973 & - & - & 28.7 & 8.25 & - & - & 22.5 & 10.53 \\
\hline 1974 & - & - & 29.7 & 7.97 & - & - & 25.0 & 9.47 \\
\hline 1975 & - & - & 29.9 & 7.92 & - & - & 24.8 & 9.55 \\
\hline 1976 & - & - & 30.4 & 7.79 & - & - & 25.8 & 9.18 \\
\hline 1977 & - & - & 29.7 & 7.97 & - & - & 26.7 & 8.87 \\
\hline 1978 & - & - & 28.6 & 8.28 & - & - & 26.8 & 8.84 \\
\hline 1979 & - & - & 28.3 & 8.37 & - & - & 25.1 & 9.43 \\
\hline 1980 & - & - & 28.5 & 8.31 & - & - & 29.1 & 8.14 \\
\hline 1981 & - & - & 23.6 & 10.03 & - & - & 24.4 & 9.71 \\
\hline 1982 & - & - & 29.0 & 8.17 & - & - & 25.7 & 9.21 \\
\hline 1983 & - & - & 29.2 & 8.11 & - & - & 26.6 & 8.90 \\
\hline 1984 & - & - & 29.2 & 8.11 & - & - & 24.7 & 9.59 \\
\hline 1985 & 8.0 & 30 & 30.0 & 7.89 & 6.1 & 39 & 26.9 & 8.80 \\
\hline 1986 & 8.1 & 29 & 29.9 & 7.92 & 6.4 & 37 & 27.4 & 8.64 \\
\hline 1987 & 8.2 & 29 & 30.3 & 7.82 & 6.2 & 38 & 25.0 & 9.47 \\
\hline 1988 & 8.2 & 29 & 30.9 & 7.66 & 6.4 & 37 & 25.2 & 9.40 \\
\hline 1989 & 8.1 & 29 & - & - & 6.5 & 36 & - & - \\
\hline 1990 & 8.7 & 27 & - & - & 7.2 & 33 & - & - \\
\hline
\end{tabular}

- Includes only vehicles belonging to local, state-owned transportation enterprises.

Source: China Energy Yearbook, various years; Energy Conservation in China, 1993; Energy of China, no. 2, 1994. 
Table V-5. Motor Vehicle Fuel Economy, 1970-=1990 (continued)

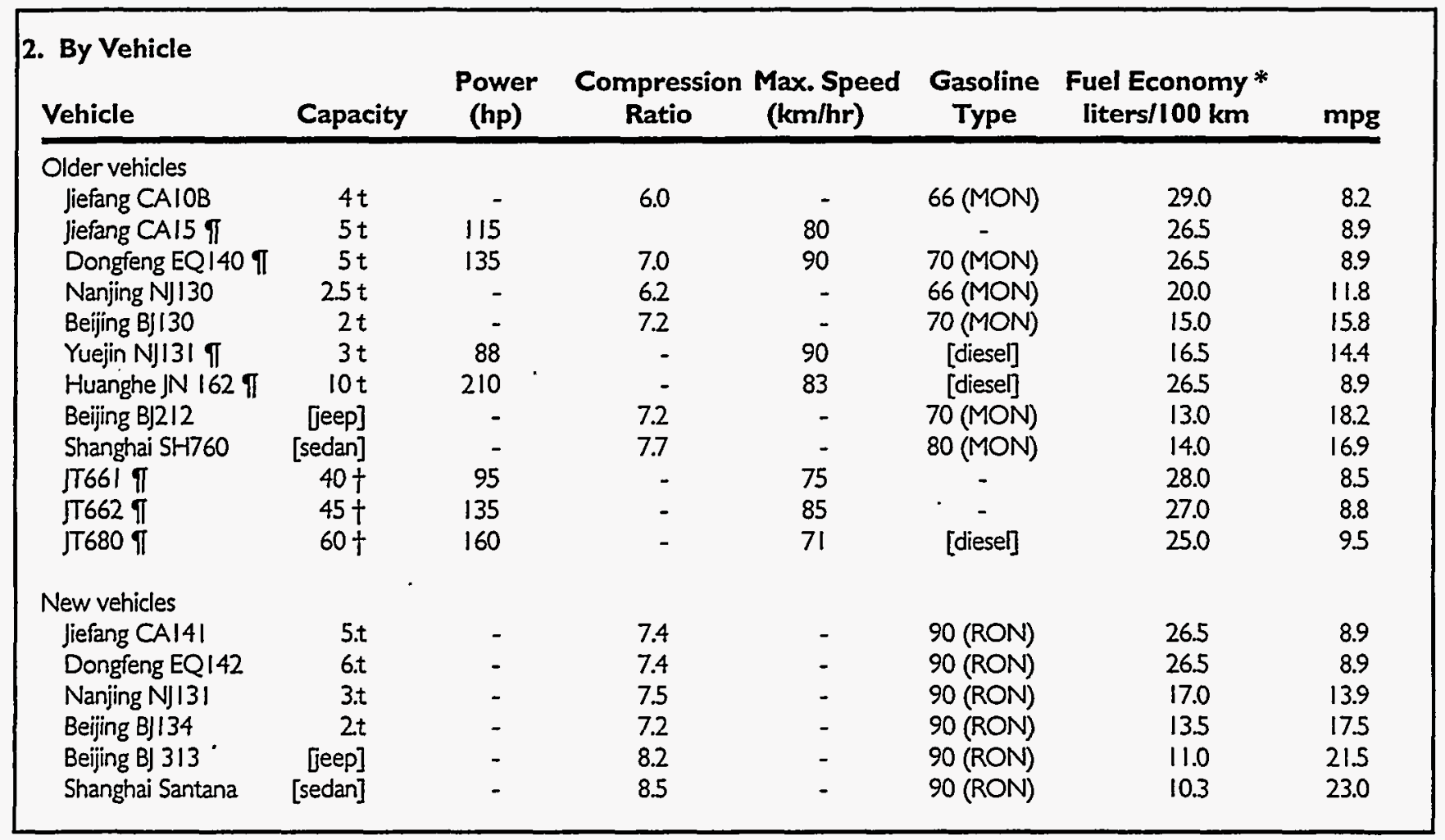

* These are design values for vehicle $\mathrm{km}$. Actual fuel economy tends to be significantly lower, e.g., the Santana uses 12-13 V/100 km in urban driving, rather than the $10.31 / 100 \mathrm{~km}$ intended for urban settings.

$\dagger$ Number of passengers

1985 figures.

Source: China Energy Yearbook, various years; Energy Conservation in China, 1993; Energy of China, no. 2, 1994. 
Table V-6. Stock of Railway Locomotives by Engine Type, Various Years 1952-1993

\begin{tabular}{|c|c|c|c|c|c|c|c|}
\hline \multicolumn{8}{|c|}{ I. Central Railway Locomotives } \\
\hline \multirow[b]{2}{*}{ Year } & \multicolumn{2}{|c|}{ Steam } & \multicolumn{2}{|c|}{ Diesel } & \multicolumn{2}{|c|}{ Electric } & \multirow[b]{2}{*}{$\begin{array}{l}\text { Total } \\
\text { Units }\end{array}$} \\
\hline & $\begin{array}{l}\text { Quantity } \\
\text { (units) }\end{array}$ & $\begin{array}{l}\text { Haulage/Unit } \\
\text { (tonnes) }\end{array}$ & $\begin{array}{l}\text { Quantity } \\
\text { (units) }\end{array}$ & $\begin{array}{c}\text { Haulage/Unit } \\
\text { (tonnes) }\end{array}$ & $\begin{array}{l}\text { Quantity } \\
\text { (units) }\end{array}$ & $\begin{array}{l}\text { Haulage/Unit } \\
\text { (tonnes) }\end{array}$ & \\
\hline 1952 & 4,180 & - & 0 & - & 0 & - & 4,180 \\
\hline 1955 & 4,218 & - & 0 & - & 0 & - & 4,218 \\
\hline 1960 & 6,039 & - & 12 & - & 2 & - & 6,053 \\
\hline 1965 & 6.142 & - & 66 & - & 30 & - & 6.238 \\
\hline 1970 & 6,878 & - & 566 & - & 60 & - & 7,504 \\
\hline 1971 & 7,076 & - & 701 & - & 85 & - & 7,862 \\
\hline 1972 & 7,272 & - & 887 & - & 94 & - & 8,253 \\
\hline 1973 & 7,522 & - & 1,064 & - & 140 & - & 8,726 \\
\hline 1974 & 7.715 & - & 1,253 & - & 170 & - & 9,138 \\
\hline 1975 & 7,824 & - & 1,352 & - & 191 & - & 9,367 \\
\hline 1976 & 7,836 & - & 1,478 & - & 191 & - & 9,505 \\
\hline 1977 & 7,830 & - & 1,617 & - & 199 & - & 9,646 \\
\hline 1978 & 7.828 & - & 1,805 & - & 221 & - & 9,854 \\
\hline 1979 & 7,899 & - & 2,014 & - & 236 & - & 10,149 \\
\hline 1980 & 7,801 & - & 2,190 & - & 287 & - & 10,278 \\
\hline 1981 & 7,718 & - & 2,325 & - & 317 & $=$ & 10,360 \\
\hline 1982 & 7,613 & - & 2,508 & - & 350 & - & 10,471 \\
\hline 1983 & 7,530 & - & 2,734 & - & 407 & - & 10,671 \\
\hline 1984 & 7,551 & 2,156 & 3,102 & 2,018 & 484 & 2,248 & 11.137 \\
\hline 1985 & 7,674 & 2,192 & 3,511 & 2,216 & 587 & 2,378 & 11,772 \\
\hline 1986 & 7,542 & 2,212 & 4,017 & 2,379 & 707 & 2,483 & 12,266 \\
\hline 1987 & 7,381 & 2,207 & 4,400 & 2,460 & 948 & 2,577 & 12,729 \\
\hline 1988 & 7,130 & 2,191 & 4,836 & 2,489 & 1,197 & 2,597 & 13,163 \\
\hline 1989 & 6,686 & - & 5,250 & - & 1,430 & - & 13,366 \\
\hline 1990 & 6,279 & - & 5,680 & - & 1,633 & - & 13,592 \\
\hline 1991 & 5,986 & 2,104 & 6,111 & 2,591 & 1,809 & 2,639 & 13,906 \\
\hline 1992 & 5,498 & 2,102 & 6,582 & 2,603 & 2,003 & 2,693 & 14,083 \\
\hline 1993 & 5,109 & 2,052 & 7,092 & 2,618 & 2,196 & 2,759 & 14,397 \\
\hline
\end{tabular}

\begin{tabular}{|lccc|}
\hline \multicolumn{3}{|c}{ 2. Local Railway Locomotives } \\
Year & $\begin{array}{c}\text { Steam } \\
\text { (units) }\end{array}$ & $\begin{array}{c}\text { Diesel } \\
\text { (tonnes) }\end{array}$ & $\begin{array}{c}\text { Total } \\
\text { Units }\end{array}$ \\
\hline 1978 & 211 & 114 & 325 \\
1979 & - & - & - \\
\hline 1980 & 279 & 126 & 405 \\
1981 & - & - & - \\
1982 & - & - & - \\
1983 & - & - & - \\
1984 & - & - & - \\
1985 & 239 & 129 & 368 \\
1986 & 250 & 124 & 374 \\
1987 & 247 & 122 & 369 \\
1988 & 233 & 128 & 361 \\
1989 & 233 & 122 & 355 \\
\hline 1990 & 253 & 125 & 378 \\
1991 & 264 & 125 & 389 \\
1992 & 259 & 125 & 384 \\
1993 & 261 & 123 & 384 \\
& & & \\
\hline
\end{tabular}

Source: China Energy Statistical Yearbook, various years; China Statistical Yearbook, various years; China Transportation Yearbook, 1994. 
Figure V-4. Locomotive Stock

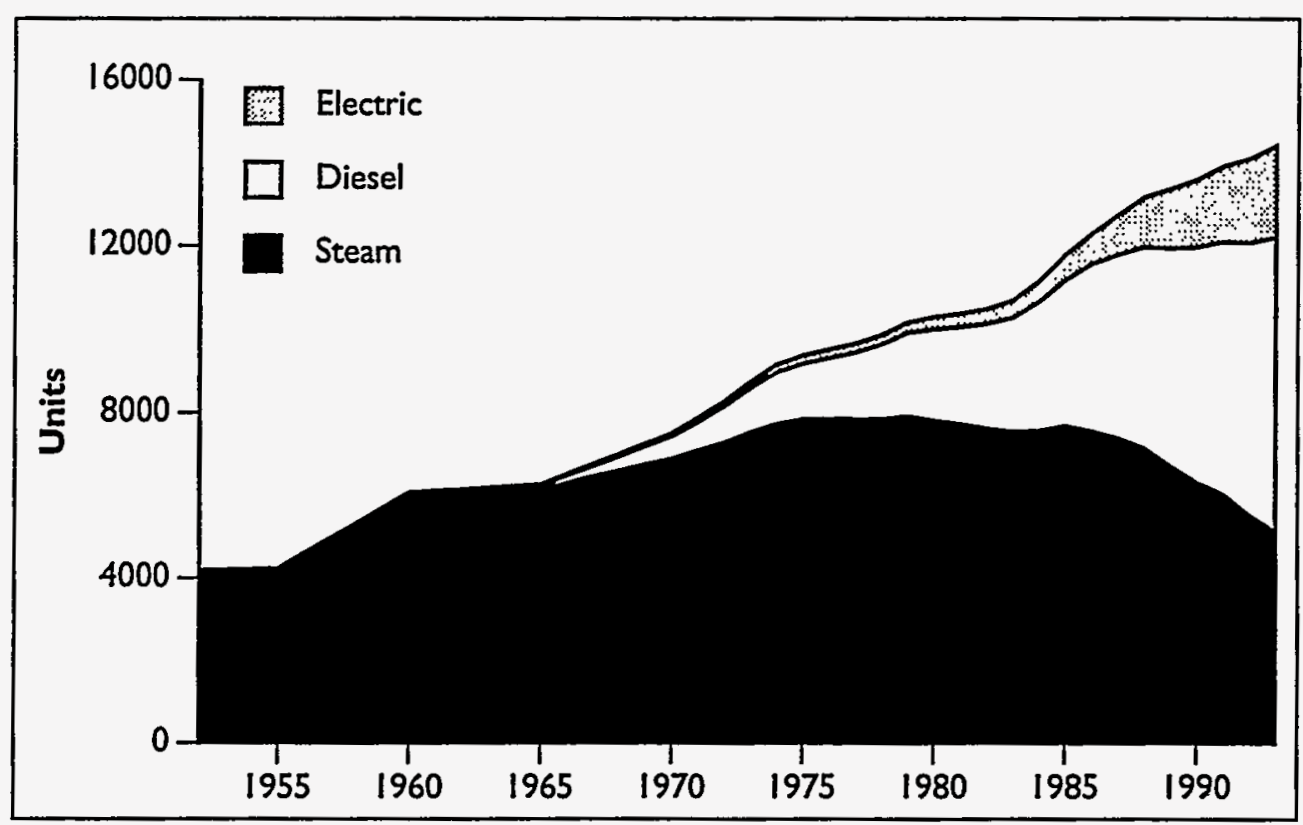


Table V-7. Rail and Water Transport Energy Intensities, * 1980-1993

\begin{tabular}{|c|c|c|c|c|c|c|c|c|c|c|c|c|c|c|}
\hline \multicolumn{15}{|c|}{$\begin{array}{l}\text { 1. Rail Transport } \\
\text { Steam Locomotives (kgce/1000 t-km) }\end{array}$} \\
\hline \multicolumn{15}{|l|}{ Railway } \\
\hline Admin. & 1980 & 1981 & 1982 & 1983 & 1984 & 1985 & 1986 & 1987 & 1988 & 1989 & 1990 & 1991 & 1992 & 1993 \\
\hline Harbin & - & - & - & - & 23.17 & 23.09 & 22.50 & 22.77 & 23.07 & 23.30 & 23.65 & - & - & - \\
\hline Shenyang & - & - & - & - & 17.02 & 17.10 & 17.41 & 17.63 & 17.90 & 19.07 & 21.87 & - & - & - \\
\hline Beijing & - & - & - & - & 14.56 & 14.10 & 15.12 & 16.59 & 17.23 & 17.78 & 18.72 & - & - & - \\
\hline Hohot & - & - & - & - & 18.40 & 18.35 & 18.54 & 18.50 & 19.12 & 19.04 & 19.52 & - & - & - \\
\hline Zhengzhou & - & - & - & - & 14.24 & 13.97 & 13,90 & 13.73 & 14.16 & 15.42 & 14.85 & - & - & - \\
\hline Jinan & - & - & - & - & 13.76 & 15.06 & 15.44 & 14.78 & 14.29 & 15.63 & 16.32 & - & - & - \\
\hline Shanghai & - & - & $\because$ & - & 15.68 & 16.85 & 17.49 & 18.50 & 19.47 & 19.50 & 19.71 & - & - & - \\
\hline Guangzhou & - & - & - & - & 14.13 & 14.11 & 14.14 & 15.78 & 19.98 & 21.68 & 22.43 & - & - & - \\
\hline Yingzhou & - & - & - & - & 14.19 & 13.79 & 13.68 & 13.28 & 12.78 & 13.14 & 13.74 & - & - & - \\
\hline Chengdu & - & - & - & - & 18.94 & 19.78 & 21.54 & 19.78 & 19.50 & 19.30 & 19.15 & - & - & - \\
\hline Lanzhou & - & - & - & - & 26.38 & 26.30 & 26.42 & 26.53 & 27.33 & 28.35 & 28.42 & - & - & - \\
\hline Urumgi & - & - & - & - & 17.50 & 17.44 & 21.07 & - & - & - & - & - & - & - \\
\hline average & - & - & $\overline{-}$ & - & 17.33 & 17.49 & 18.10 & 17.99 & 18.62 & 19.29 & 19,85 & - & - & - \\
\hline key enterprises & 16.38 & 16.66 & 16.71 & 16.56 & 16.56 & 16.77 & 17.12 & 17.54 & 17.99 & 19.03 & 19.79 & 19.98 & 19.66 & 20.06 \\
\hline \multicolumn{15}{|c|}{ Diesel Locomotives (kg dlesel/1000 t-km) } \\
\hline Railway & & & & & & & & & & & & & & \\
\hline Admin. & 1980 & 1981 & 1982 & 1983 & 1984 & 1985 & 1986 & 1987 & 1988 & 1989 & 1990 & 1991 & 1992 & 1993 \\
\hline Harbin & - & - & - & - & 4.01 & 4.14 & 3.84 & 3.61 & 3.24 & 3.09 & 2.98 & - & - & - \\
\hline Shenyang & - & - & - & - & 3.30 & 3.14 & 2.73 & 2.56 & 2.42 & 2.26 & 2.24 & - & - & - \\
\hline Beijing & - & - & - & - & 2.63 & 2.58 & 2.54 & 2.41 & 2.42 & 2.41 & 2.40 & - & - & - \\
\hline Hohot & - & - & - & - & - & - & - & 3.53 & 2.83 & 2.58 & 2.54 & - & - & - \\
\hline Zhengzhou & - & - & - & - & 2.54 & 2.28 & 2.17 & 2.12 & 2.12 & 2.06 & 2.11 & - & - & - \\
\hline Jinan & - & - & - & - & 2.27 & 2.02 & 2.00 & 1.99 & 1.98 & 1.97 & 2.00 & - & - & - \\
\hline Shanghai & - & - & - & - & 2.63 & 2.11 & 1.98 & 1.96 & 1.96 & 1.97 & 2.00 & - & - & - \\
\hline Guangzhou & - & - & - & - & 3.00 & 2.91 & 2.78 & 2.52 & 2.35 & 2.18 & 2.23 & - & - & - \\
\hline Yingzhou & - & - & - & - & 4.55 & 3.94 & 3.83 & 3.73 & 3.74 & 3.32 & 3.05 & - & - & - \\
\hline Chengdu & - & - & - & - & 4.67 & 4.58 & 4.53 & 4.58 & 4.61 & 4.62 & 4.64 & - & - & - \\
\hline Lanzhou & - & - & - & - & 6.61 & 5.59 & 4.57 & 4.35 & 4.32 & 4.28 & 4.15 & - & - & - \\
\hline Urumgi & - & - & - & - & 3.87 & 3.69 & 3.51 & 3.30 & 3.24 & 3.24 & 3.23 & - & - & $=$ \\
\hline average & - & $\cdot$ & - & - & 3.64 & 3.36 & 3.13 & 3.06 & 2.94 & 3.09 & 3.05 & - & & \\
\hline key enterprises & 3.5 & 3.41 & 3.29 & 3.24 & 3.14 & 2.88 & 2.68 & 2.59 & 2.52 & 2.44 & 2.44 & 2.43 & 2.44 & 2.44 \\
\hline
\end{tabular}

Water transport includes only dedicated shipping enterprises, excluding the large number of vessels operated privately and by non-transportation enterprises.

Source: China Energy Statistical Yearbook, various years; China Transportation Yearbook, 1994; Zhongguo Nengyuan [Energy of China], no. 3, 1994. 
Table V-7. Rail and Water Transport Energy Intensities, * 1980-1993 (continued)

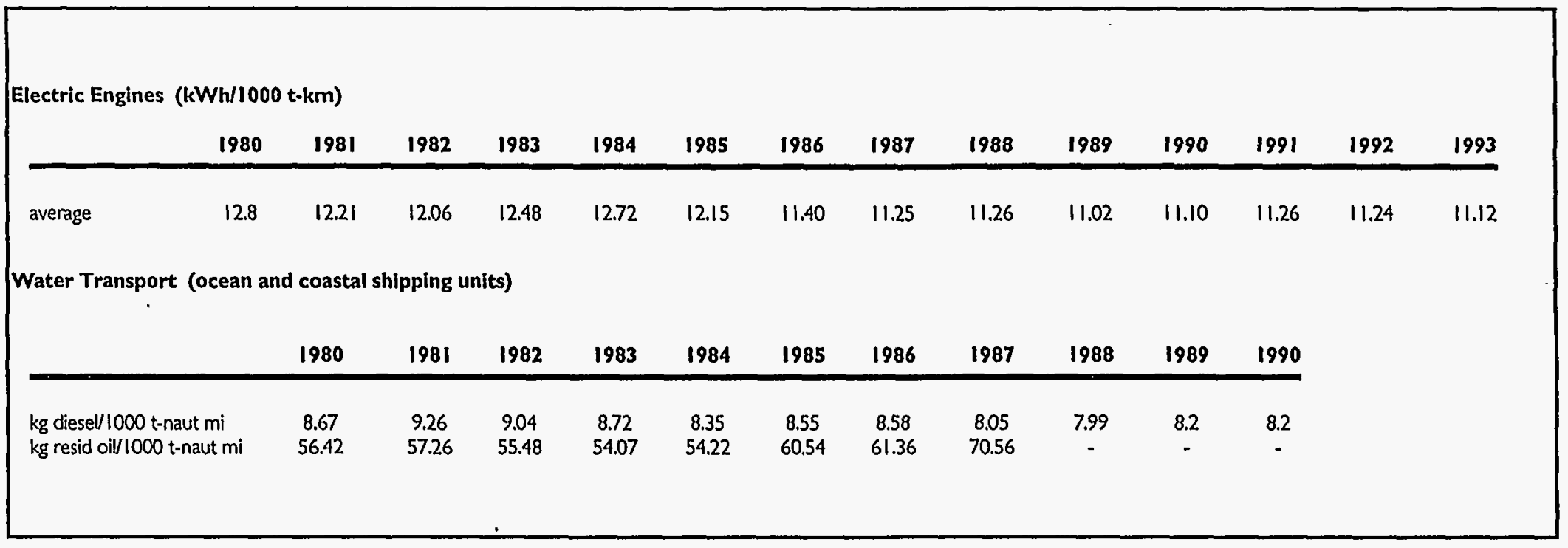

* Water transport includes only dedicated shipping enteprises, excluding the large number of vessels operated privately and by non-transportation enterprises.

Source: China Energy Statistical Yearbook, varlous years; China Transportation Yearbook, 1994; Zhongguo Nengyuan [Energy of China], no. 3, 1994. 
Table V-8. Stock and Output of Major Appliances, 1978-1994

\begin{tabular}{|lcccc|}
\hline 1. Stock, millions & & & \\
Year & $\begin{array}{c}\text { Electric } \\
\text { Fans }\end{array}$ & TV Sets & $\begin{array}{c}\text { Electric } \\
\text { Clothes } \\
\text { Washers }\end{array}$ & Refrigerators \\
\hline 1978 & 9.20 & 3.04 & 0.01 & 0.09 \\
1979 & 10.50 & 4.85 & 0.03 & 0.13 \\
\hline 1980 & 13.65 & 9.02 & 0.26 & 0.19 \\
1981 & 17.92 & 15.62 & 1.50 & 0.25 \\
1982 & 25.91 & 27.61 & 5.90 & 0.44 \\
1983 & 33.57 & 36.11 & 12.52 & 1.05 \\
1984 & 43.40 & 47.63 & 19.28 & 1.82 \\
1985 & 63.60 & 69.65 & 30.30 & 4.10 \\
1986 & 86.05 & 92.14 & 43.33 & 7.27 \\
1987 & 111.88 & 116.01 & 57.62 & 11.81 \\
1988 & 145.46 & 143.44 & 74.64 & 19.27 \\
1989 & 173.33 & 165.93 & 87.01 & 25.54 \\
1990 & 201.27 & 185.46 & 96.28 & 29.96 \\
1991 & 229.89 & 206.71 & 106.15 & 34.66 \\
1992 & 257.74 & 228.43 & 117.09 & 39.41 \\
\hline
\end{tabular}

2. Output, millions

\begin{tabular}{lccccc} 
Year & $\begin{array}{c}\text { Electric } \\
\text { Fans }\end{array}$ & TV Sets & $\begin{array}{c}\text { Washing } \\
\text { Machines }\end{array}$ & $\begin{array}{c}\text { Refrigerators } \\
\text { Ran }\end{array}$ & $\begin{array}{c}\text { Room } \\
\text { Air }\end{array}$ \\
\hline 1978 & 1.4 & 0.5 & $<0.01$ & 0.03 & $<0.01$ \\
1979 & 2.3 & 1.3 & 0.02 & 0.03 & 0.01 \\
\hline 1980 & 7.2 & 2.5 & 0.25 & 0.05 & 0.01 \\
1981 & 10.5 & 24 & 1.28 & 0.06 & 0.01 \\
1982 & 9.2 & 5.9 & 2.53 & 0.10 & 0.02 \\
1983 & 10.5 & 6.8 & 3.66 & 0.19 & 0.03 \\
1984 & 17.7 & 10.0 & 5.78 & 0.55 & 0.06 \\
1985 & 31.8 & 16.7 & 8.87 & 1.45 & 0.12 \\
1986 & 35.3 & 14.6 & 8.93 & 2.25 & 0.10 \\
1987 & 36.6 & 19.3 & 9.90 & 4.01 & 0.13 \\
1988 & 45.0 & 25.1 & 10.47 & 7.58 & 0.26 \\
\hline 1989 & 49.9 & 27.7 & 8.25 & 6.71 & 0.37 \\
1990 & 58.0 & 26.8 & 6.63 & 4.63 & 0.24 \\
1991 & 62.2 & 26.9 & 6.87 & 4.70 & 0.63 \\
1992 & 68.4 & 28.7 & 7.08 & 4.86 & 1.58 \\
1993 & 73.9 & 30.3 & 8.76 & 5.97 & 2.92 \\
$1994 *$ & - & - & 10.10 & 7.30 & 3.60 \\
& & & & & \\
\hline
\end{tabular}

* First 11 months

Source: China Statistical Yearbook, various years; ACEEE. 
Figure V-5. Appliance Output

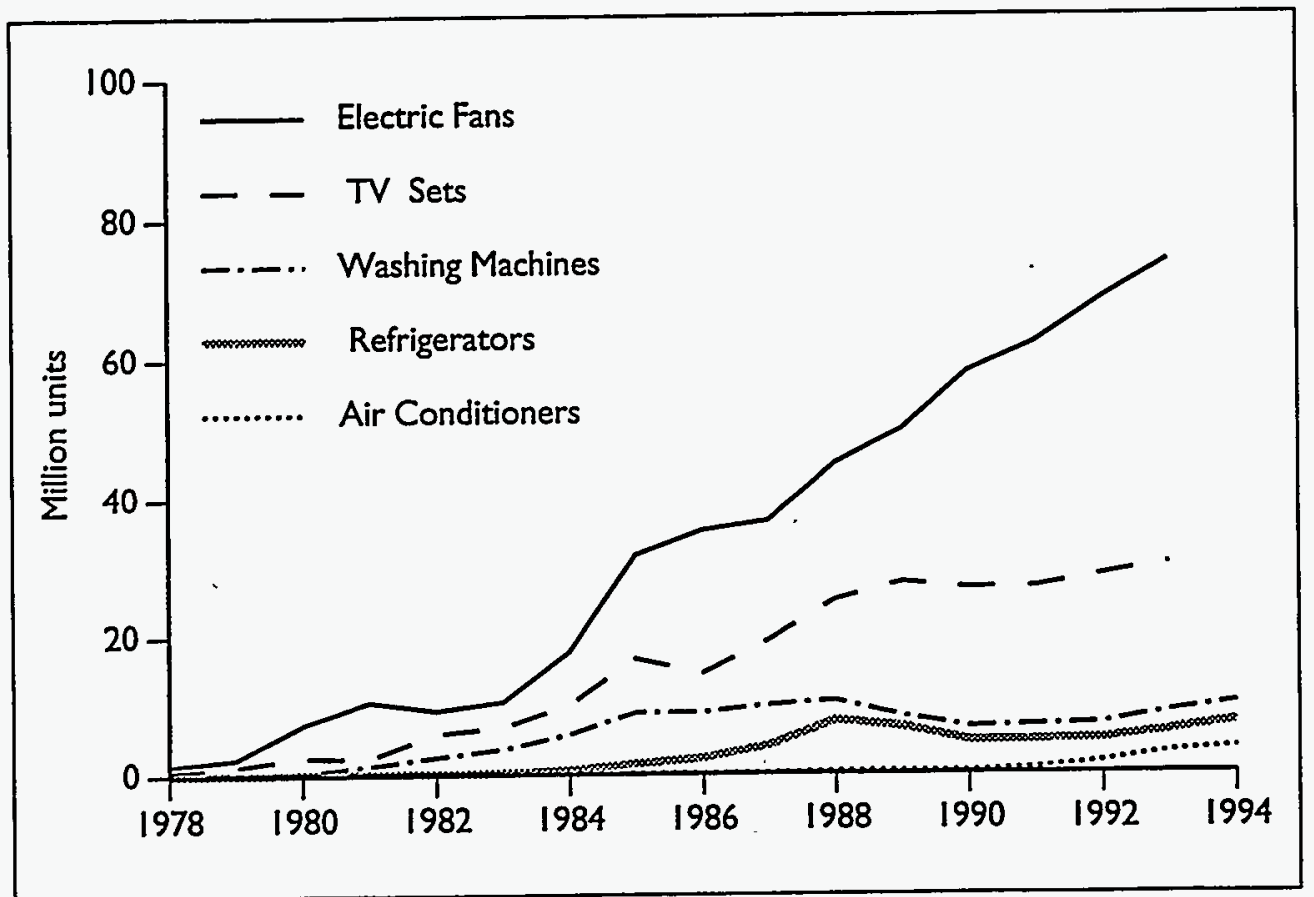


Table V-9. Urban Household Survey Data, * 1981-1993

\begin{tabular}{|c|c|c|c|c|c|c|}
\hline & 1981 & 1982 & 1983 & 1984 & 1985 & 1986 \\
\hline Surveyed Households & 8,715 & 9,020 & 9,060 & 12,500 & 24,338 & 31,126 \\
\hline People per Household & 4.24 & 4.14 & 4.06 & 4.04 & 3.89 & 3.82 \\
\hline Average Annual income (vuan/yr) $\dagger$ & 2,122 & 2,216 & 2,326 & 2,667 & 2,913 & 3,476 \\
\hline Annual Cost of Living (yuan/yr) $\dagger$ & 1,937 & 1,950 & 2,054 & 2,260 & 2,619 & 3,052 \\
\hline of which cost of fuels \& utitites (yuon/yr) & 56 & 57 & 59 & 62 & 71 & 80 \\
\hline Floor Area per Person (m2) & 5.27 & 5.61 & 5.9 & 6.32 & 7.46 & 8.04 \\
\hline $\begin{array}{l}\text { Coal Use per Household }(\mathrm{kg} / \mathrm{yr}) \\
\text { Applionces per } 100 \text { Households: }\end{array}$ & 1,018 & 950 & 931 & 1,029 & 1,053 & 1,022 \\
\hline Fans & 43 & 53 & 64 & 66 & 74 & 90 \\
\hline B \& WTV Sets & 57 & 72 & 81 & 82 & 67 & 65 \\
\hline Color TV Sets & 0.6 & 1 & 3 & 5 & 17 & 27 \\
\hline Cothes Washers $¥$ & 6 & 16 & 29 & 40 & 48 & 60 \\
\hline Refrigerators & 0.2 & 0.7 & 2 & 3 & 7 & 13 \\
\hline Freezers & - & - & - & - & - & - \\
\hline Room Air Conditioners & - & - & - & - & 0.1 & - \\
\hline Electric Cooking Utensils $¥$ & - & - & - & - & 19.0 & - \\
\hline
\end{tabular}

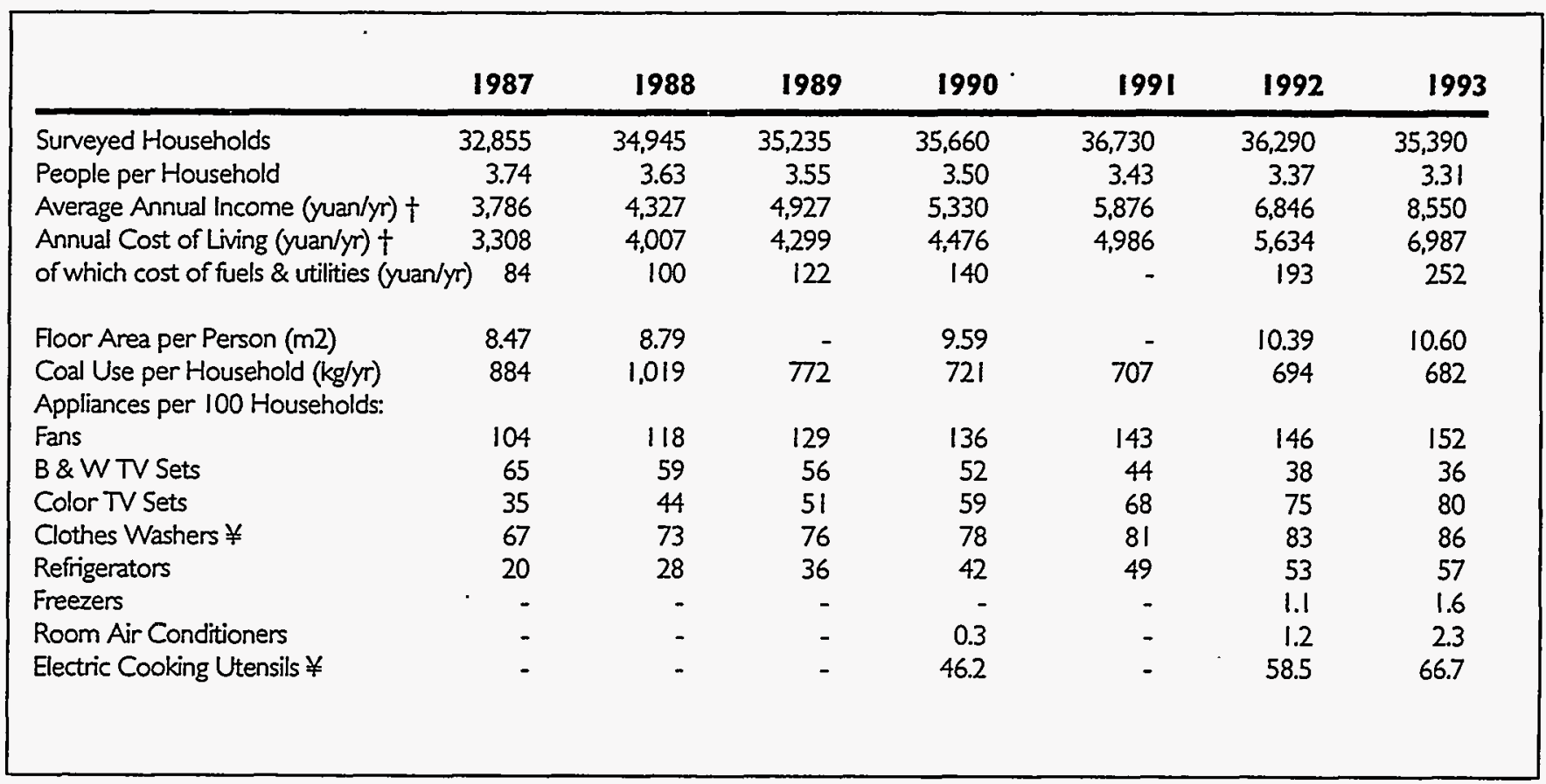

* Surveys were conducted among a large number of cities. Data may not be statistically representative of all urban areas in China $\dagger$ Current yuan per household.

I Chinese clothes washers are mainly small capacity, single- or double-tube, manual and semi-automatic washers.

$¥$ For instance electric rice cookers.

Source: China Statistical Yearbook, various years. 
Figure V-6. Urban Appliance Ownership

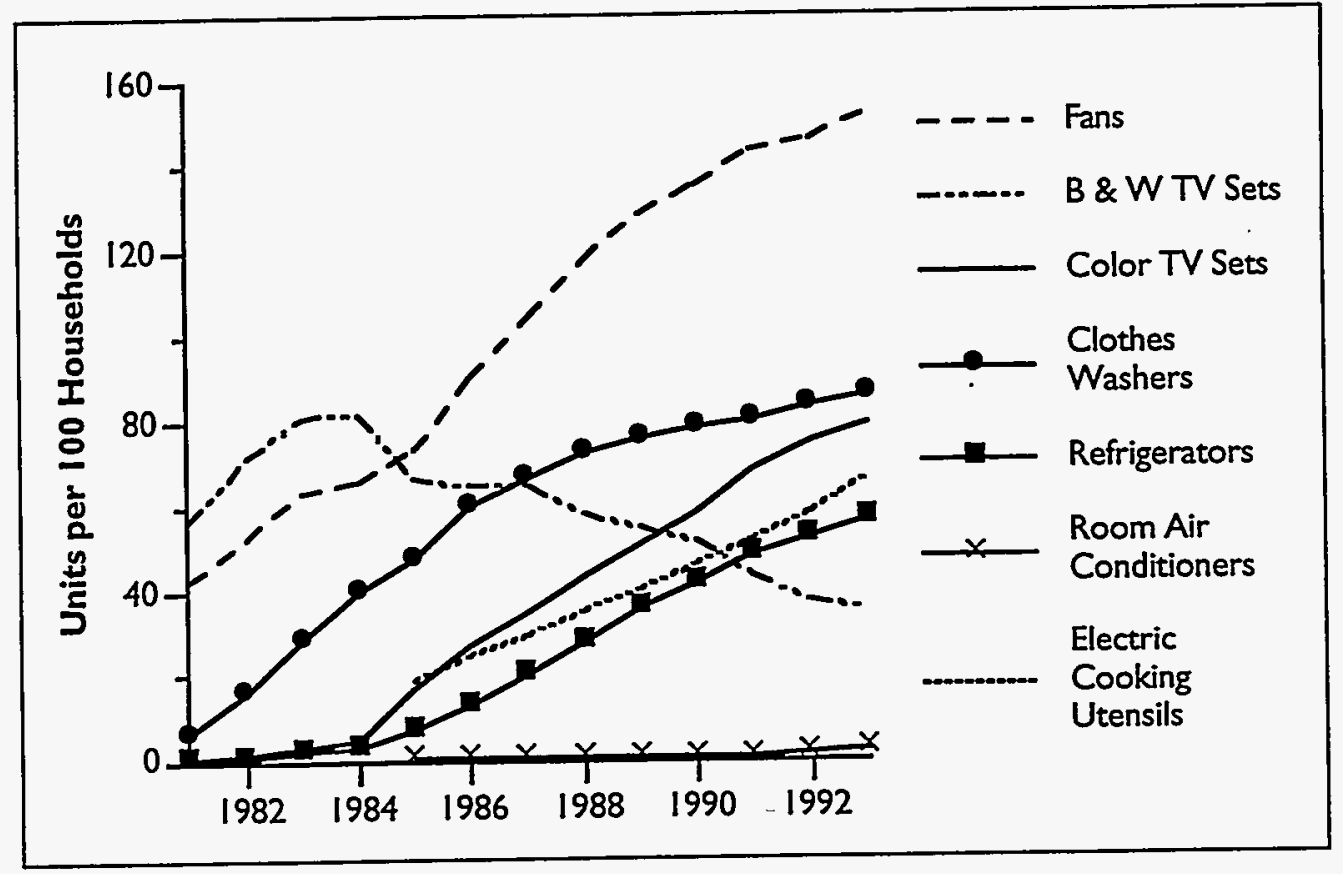


Table V-10. Rural Household Survey Data, * Various Years 1978-1993

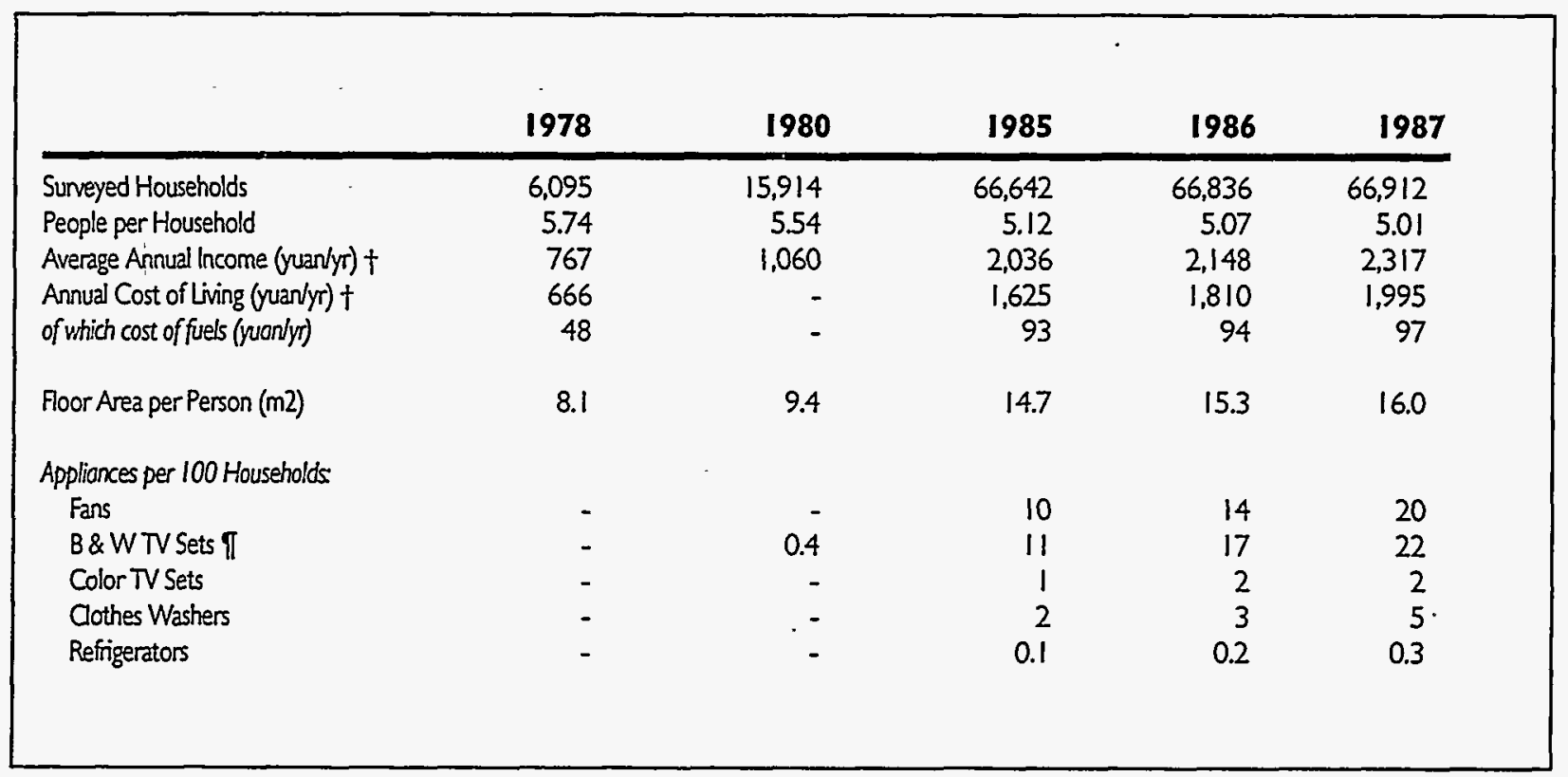

\begin{tabular}{|c|c|c|c|c|c|c|}
\hline & 1988 & 1989 & 1990 & 1991 & 1992 & 1993 \\
\hline Surveyed Households & 67,186 & 66,906 & 66,960 & 67,410 & 67,490 & 67,570 \\
\hline People per Household & 4.94 & 4.86 & 4.84 & $4.7 !$ & 4.67 & 4.59 \\
\hline Average Annual hcome (yuan/yr) † & 2,692 & 2,923 & 3,294 & 3,337 & 3,661 & 4,230 \\
\hline Annual Cost of living (yuan/yr) $\dagger$ & 2,355 & 2,602 & 2,806 & 2,919 & 3,078 & 3,533 \\
\hline of which cost of fuels (yuanlyr) & 107 & 114 & 117 & - & - & - \\
\hline $\begin{array}{l}\text { Floor Area per Person (m2) } \\
\text { Appliances per } 100 \text { Households. }\end{array}$ & 16.1 & 17.2 & 17.8 & - & 18.9 & 20.8 \\
\hline Fans & 28 & 34 & 41 & 53 & 60 & 72 \\
\hline B\&WTV Sets $\pi$ & 29 & 34 & 40 & 48 & 52 & 58 \\
\hline Color TV Sets & 3 & 4 & 5 & 6 & 8 & 11 \\
\hline Cothes Washers & 7 & 8 & 9 & 11 & 12 & 14 \\
\hline Refrigerators & 0.6 & 0.9 & 1.2 & 1.6 & 22 & 3.1 \\
\hline
\end{tabular}

* Surveys were conducted in a wide variety of areas. Data may not be statistically representative of all rural areas in China $\dagger$ Current yuan per household

I 1980 figure is total of color and black and white television sets.

Source: China Statistical Yearbook, various year. 
Figure V-7. Rural Appliance Ownership

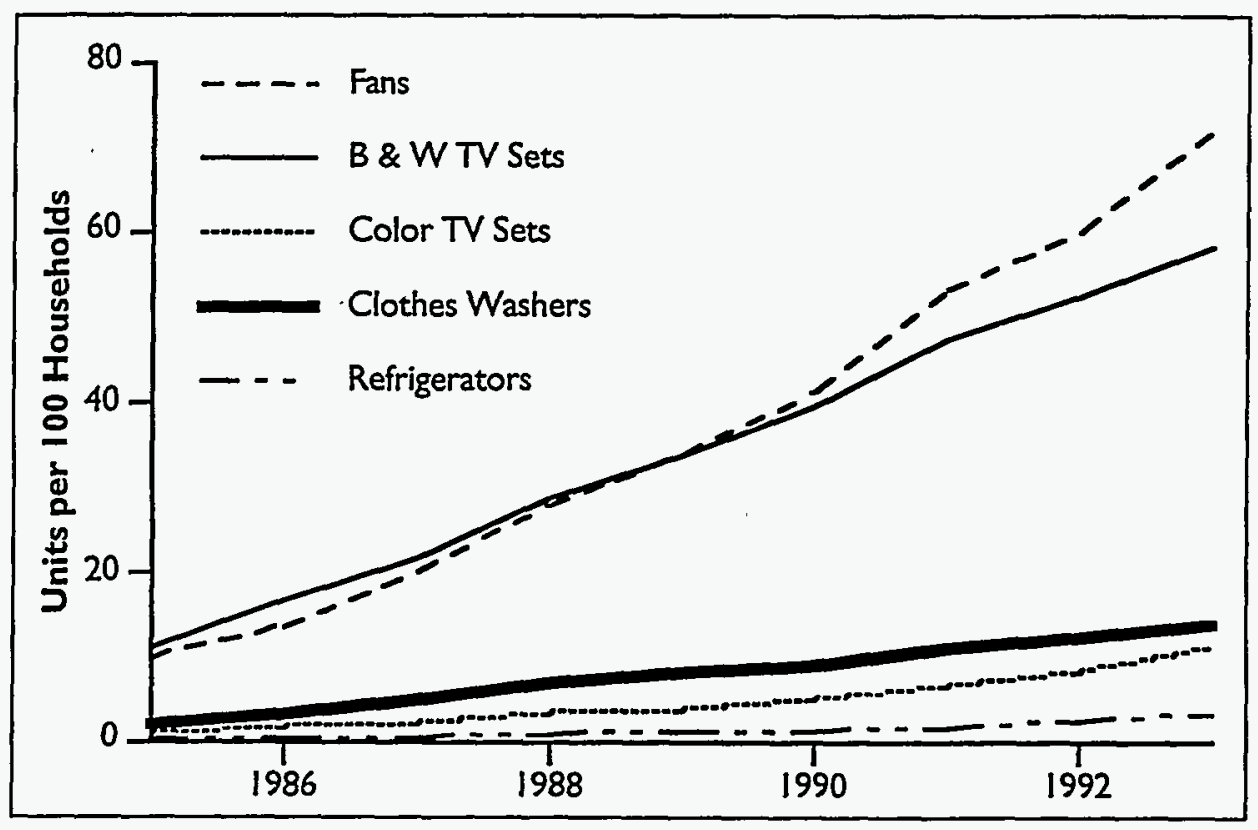


Table V-1 1. Stock of Agricultural Machinery *, 1980-1993-GW

\begin{tabular}{|c|c|c|c|c|c|c|c|c|c|c|c|c|c|}
\hline Year & $\begin{array}{l}\text { Large \& } \\
\text { Medium } \\
\text { Tractors }\end{array}$ & $\begin{array}{l}\text { Small \& } \\
\text { Walking } \\
\text { Tractors Tr }\end{array}$ & $\begin{array}{l}\text { Boat } \\
\text { Iractors } t\end{array}$ & $\begin{array}{c}\text { Rice } \\
\text { Trans- } \\
\text { planters }\end{array}$ & $\begin{array}{l}\text { Draina } \\
\text { diesel }\end{array}$ & $\begin{array}{l}\text { ge and Irr } \\
\text { electric }\end{array}$ & $\begin{array}{l}\text { rigation } 1 \\
\text { other }\end{array}$ & $\begin{array}{l}\text { Motors } \\
\text { subtotal }\end{array}$ & $\begin{array}{c}\text { ' } \\
\text { Trucks }\end{array}$ & $\begin{array}{l}\text { Motorized } \\
\text { Fishing } \\
\text { Boats }\end{array}$ & $\begin{array}{l}\text { Motor- } \\
\text { Driven } \\
\text { Sprayers }\end{array}$ & $\begin{array}{l}\text { Balancel } \\
\text { Other I }\end{array}$ & Total \\
\hline $1980 *$ & 24.02 & 16.38 & 0.58 & 0.21 & 27.57 & 20.35 & 7.74 & 55.66 & 9.09 & 2.62 & 0.54 & 40.40 & 149.50 \\
\hline $1981 *$ & 25.59 & 17.85 & 0.62 & 0.16 & 27.12 & 20.81 & 7.99 & 55.92 & 11.75 & 2.97 & 0.59 & 43.51 & 158.97 \\
\hline $1982 *$ & 26.49 & 20.16 & 0.55 & 0.12 & 26.92 & 29.75 & 0.52 & 57.19 & 14.08 & 3.27 & 0.62 & 45.95 & 168.45 \\
\hline $1983^{*}$ & 27.46 & 24.25 & 0.48 & 0.07 & 27.41 & 30.66 & 0.46 & 58.53 & 19.11 & 3.31 & 0.67 & 48.84 & 182.73 \\
\hline 1984 * & 27.57 & 29.27 & 0.39 & 0.05 & 26.54 & 31.59 & 0.44 & 58.57 & 24.97 & 3.40 & 0.64 & 52.82 & 197.68 \\
\hline $1985 *$ & 27.82 & 34.14 & 0.32 & 0.03 & 26.03 & 31.95 & 0.36 & 58.35 & 31.18 & 3.72 & 0.57 & 55.90 & 212.03 \\
\hline 1986 & 28.07 & 40.03 & 0.30 & 0.03 & 26.90 & 32.91 & 0.63 & 60.44 & $35.8 \mathrm{~F}$ & 4.24 & 0.53 & 60.05 & 229.50 \\
\hline 1987 & 28.76 & 47.13 & 0.28 & 0.03 & 28.18 & 33.97 & 0.43 & 62.58 & 39.66 & 4.86 & 0.53 & 64.53 & 248.36 \\
\hline 1988 & 28.96 & 53.19 & 0.29 & 0.04 & 29.98 & 35.17 & 0.53 & 65.68 & 43.25 & 5.45 & 0.60 & 68.29 & 265.75 \\
\hline 1989 & 28.14 & 58.48 & 0.25 & 0.04 & 32.07 & 36.07 & 0.39 & 68.53 & 46.34 & 6.09 & 0.61 & 72.20 & 280.67 \\
\hline 1990 & 27.46 & 62.31 & 0.26 & 0.05 & 33.49 & 37.49 & 0.32 & 71.29 & 46.21 & 6.96 & 0.75 & 71.79 & 287.08 \\
\hline 1991 & 26.82 & 65.29 & - & - & - & - & - & - & 46.91 & 7.33 & 0.96 & 146.58 & 293.89 \\
\hline 1992 & 26.30 & 67.20 & - & - & - & - & - & - & 48.52 . & 7.86 & 1.09 & 152.12 & 303.08 \\
\hline 1993 & 25.31 & 70.43 & - & - & - & - & - & - & 52.46 & 8.05 & 1.14 & 160.78 & 318.17 \\
\hline
\end{tabular}

* Values in these rows (except for irrigation motor subtotals, boats, and totals, which are given in watts in the China Energy Statistical Yearbook) were calculated using a factor of $I \mathrm{~kW}=1.341 \mathrm{hp}$, derived from figures for an overlapping year given in horsepower in the China Statistical Yearbook and in watts in the Energy Statistical Yearbooks.

$\dagger$ "Boat tractors" are used in rice cultivation.

I "Other" includes pumps, sprinkler machines, combine harvesters, motor-driven harvesters, motor-driven threshers, seed selecting machines, grain drying machines, rice and wheat mills, cotton-ginning mills, oil presses, fodder grinders and forage grass harvesters. This column also includes discrepancies in reported values for categories and totals.

Sources: China Energy Statistical Yearbook, various years; China Statistical Yearbook, various years. 
Table V-12. Total Stock of Electricity-Consuming Equipment

by Subsector, 1986-1993

\begin{tabular}{|c|c|c|c|c|c|c|c|}
\hline \multicolumn{8}{|l|}{ I. Capacity of Electrical Equipment (GW) } \\
\hline & 1986 & 1987 & 1988 & 1989 & 1990 & 1992 & 1993 \\
\hline Agriculture and Associated Sectors & 43.91 & 47.72 & 51.29 & 54.33 & 56.64 & 63.26 & 64.30 \\
\hline imigation & 20.01 & 23.02 & 24.62 & 25.86 & 25.78 & 29.81 & 29.28 \\
\hline agricultural sidelines & - & - & - & - & - & 16.88 & 15.27 \\
\hline Agriculture & 27.65 & 31.48 & 35.51 & 38.44 & 40.23 & 45.03 & 45.52 \\
\hline Forestry & 0.41 & 0.43 & 0.43 & 0.48 & 0.56 & 0.82 & 0.76 \\
\hline Livestock & 0.66 & 0.57 & 0.60 & 0.69 & 0.82 & 0.98 & 1.01 \\
\hline Fisheries & 0.49 & 0.53 & 0.59 & 0.72 & 0.87 & 1.09 & 1.04 \\
\hline Water conservancy & 10.29 & 9.47 & 9.17 & 8.91 & 9.22 & 9.78 & 9.94 \\
\hline Other & 4.41 & 5.23 & 4.97 & 5.08 & 4.95 & 5.56 & 6.03 \\
\hline Total Industry $†$ & 145.67 & 160.48 & 173.47 & 191.88 & 221.31 & 247.83 & 266.54 \\
\hline Light Industry & 42.30 & 45.99 & 49.53 & 55.75 & 57.53 & 65.29 & 69.32 \\
\hline Heavy industry & 98.83 & 109.34 & 118.40 & 130.25 & 157.98 & 175.46 & 188.60 \\
\hline Other ${ }^{\circ}$ & 4.54 & 5.14 & 5.54 & 5.88 & 5.80 & 7.08 & 8.63 \\
\hline nural industry & - & - & - & - & - & 26.34 & 28.83 \\
\hline \multicolumn{8}{|l|}{ Extroction } \\
\hline Coal & 9.43 & 10.75 & 11.50 & 11.63 & 12.27 & 13.25 & 13.66 \\
\hline Petroleum \& NG & 3.89 & 4.10 & 4.51 & 5.40 & 5.62 & 6.73 & 6.95 \\
\hline Ferrous Metals & 1.64 & 1.94 & 1.94 & 2.19 & 2.29 & 2.39 & 258 \\
\hline Nonferrous Metals & 2.36 & 2.54 & 241 & 2.50 & 287 & 3.12 & 3.40 \\
\hline Construction Materials \& Other Nonmetal & 1.55 & 1.56 & 1.85 & 1.85 & 2.08 & 2.37 & 2.51 \\
\hline Salt & 0.33 & 0.33 & 0.35 & 0.34 & 0.38 & 0.46 & 0.48 \\
\hline Other Mineral & 0.08 & 0.12 & 0.11 & 0.11 & 0.12 & 0.12 & 0.19 \\
\hline Timber \& Bamboo & 0.35 & 0.36 & 0.36 & 0.38 & 0.39 & 0.48 & 0.46 \\
\hline Water Supply & 2.20 & 2.30 & 257 & 2.91 & 3.22 & 3.77 & 4.09 \\
\hline Extraction Subtotal & 21.83 & 24.01 & 25.59 & 27.31 & 29.23 & 3269 & 34.32 \\
\hline \multicolumn{8}{|l|}{ Monufocturing } \\
\hline Food, Beverage \& Tobacco & 10.88 & 11.75 & 1201 & 13.38 & 13.15 & 14.57 & 15.26 \\
\hline Spinning \& Weaving & 8.06 & 8.53 & 9.51 & 11.06 & 11.19 & 12.22 & 1267 \\
\hline Paper \& Paper Production & 3.44 & 3.64 & 4.05 & 4.57 & 4.52 & 5.27 & 5.64 \\
\hline Electricity, Steam \& Hot Waterf & 0.42 & 0.96 & 1.23 & 2.67 & 24.67 & 25.82 & 27.62 \\
\hline Petroleum Refining & 1.90 & 211 & 2.35 & 1.97 & 2.21 & 2.79 & 2.74 \\
\hline Coking, Coal Gas \& Coal Products & 0.80 & 0.85 & 0.89 & 1.07 & 1.13 & 1.39 & 1.75 \\
\hline Chemicals & 17.55 & 17.78 & 19.99 & 22.37 & 2252 & 25.92 & 28.33 \\
\hline Pharmaceuticals & 1.17 & 1.27 & 1.44 & 1.67 & 1.93 & 2.25 & 2.46 \\
\hline Synthetic Fibers & 1.44 & 1.48 & 1.90 & 1.86 & 2.49 & 2.31 & 2.42 \\
\hline Rubber \& Plastics & 3.17 & 3.91 & 4.50 & 5.10 & 5.10 & 6.11 & 6.68 \\
\hline \multicolumn{8}{|l|}{ Construction Materials and Nonmetal } \\
\hline Mineral Products & 1283 & 14.52 & 15.22 & 16.89 & 17.63 & 19.93 & 2263 \\
\hline Ferrous Metals Smelting \& Rolling & 1224 & 13.25 & 14.49 & 17.00 & 19.08 & 2218 & 24.00 \\
\hline Nonferrous Metals Smelting \& Rolling & 4.97 & 5.85 & 6.46 & 7.53 & 8.31 & 9.40 & 10.06 \\
\hline Metal Products & 8.37 & 8.62 & 8.87 & 9.18 & 9.03 & 10.06 & 10.49 \\
\hline Machinery & 14.08 & 16.47 & 17.05 & 17.70 & 17.70 & 18.71 & 19.37 \\
\hline Transportation, Electrical \& Electronic Equipment & 7.24 & 8.25 & 8.97 & 9.67 & 10.63 & 11.80 & 12.27 \\
\hline Other Industrial & 10.76 & 12.08 & 13.42 & 15.02 & 14.96 & 17.28 & 19.21 \\
\hline Manufacturing Subtotal $\dagger$ & 119.30 & 131.33 & 142.35 & 158.71 & 186.26 & 208.02 & 223.59 \\
\hline Transportation and telecommunications & 6.12 & 7.20 & 8.34 & 9.11 & 9.78 & 12.11 & 13.88 \\
\hline Transportation & 5.50 & 6.49 & 7.58 & 8.37 & 8.88 & 10.90 & 12.48 \\
\hline pipelines & 0.55 & 0.65 & 0.67 & 0.71 & 0.71 & 0.70 & 0.74 \\
\hline electric railways & 1.93 & 261 & 3.67 & 4.16 & 4.20 & 6.66 & 7.15 \\
\hline Posts and telecommunications & 0.62 & 0.69 & 0.75 & 0.74 & 0.90 & 1.21 & 1.40 \\
\hline Other Production Sectors II & 18.46 & 20.36 & 23.97 & 24.55 & 26.62 & 33.17 & 38.41 \\
\hline Households & 19.96 & 25.21 & 28.90 & 28.73 & 33.06 & 42.21 & 46.70 \\
\hline urban & 1270 & 16.76 & 19.13 & 18.04 & 19.91 & 25.67 & 28.75 \\
\hline nural & 7.26 & 8.44 & 9.76 & 10.69 & 13.15 & 1654 & 17.95 \\
\hline Total of All Sectors $\#$ & 234.11 & 260.95 & 285.96 & 308.59 & 347.41 & 398.58 & 429.83 \\
\hline
\end{tabular}

- Includes SSB categories of Geological Survey and Exploration, and Construction.

$\dagger$ Electricity sector capacity figures before 1990 do not include equipment such as substation transformers. If adjusted to the pre-1990 category definition, 1993 capacity would be $9.67 \mathrm{GW}$. Electricity use is divided almost evenly between in-plant use and line losses.

I Includes commercial food service, public utilities, real estate, public health, sports, education, broadcasting, research, govemment, and other organizations.

* Figures are slightly smaller than those reported by the State Statistical Bureau.

Source: China Energy Statistical Yearbook, various years; Zhongguo Dianlt [China Electric Power], October 1994. 

by Subsector, 1986-1993 (continued)

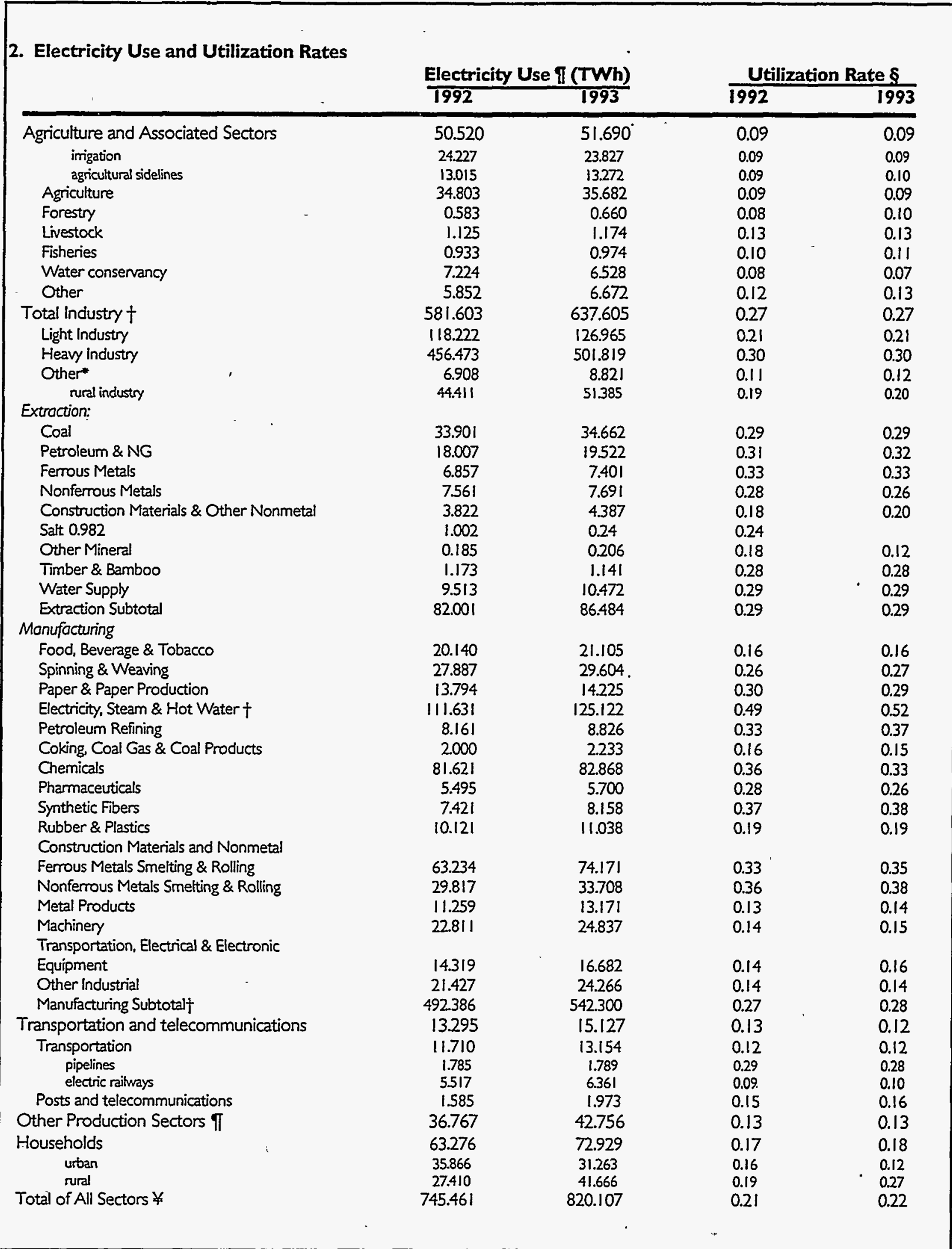

* Includes SSB categories of Geological Survey and Exploration, and Construction.

$\dagger$ Electricity sector capacity figures before 1990 do not include equipment such as substation transformers. If adjusted to the pre-1990 category defini tion, 1993 capacity would be $9.67 \mathrm{GW}$. Electricity use is divided almost evenly between in-plant use and line losses.

Includes commercial food service, public utilities, real estate, public health, sports, education, broadcasting, research, govemment, and other organi zations.

$¥$ Figures are slightly smaller than those reported by the State Statistical Bureau.

Source: China Energy Statistical Yearbook, various years; Zhongguo Dlanli [China Electric Power], October 1994. 


\section{Figure V-8. Capacity of Electricity-Consuming Equipment}

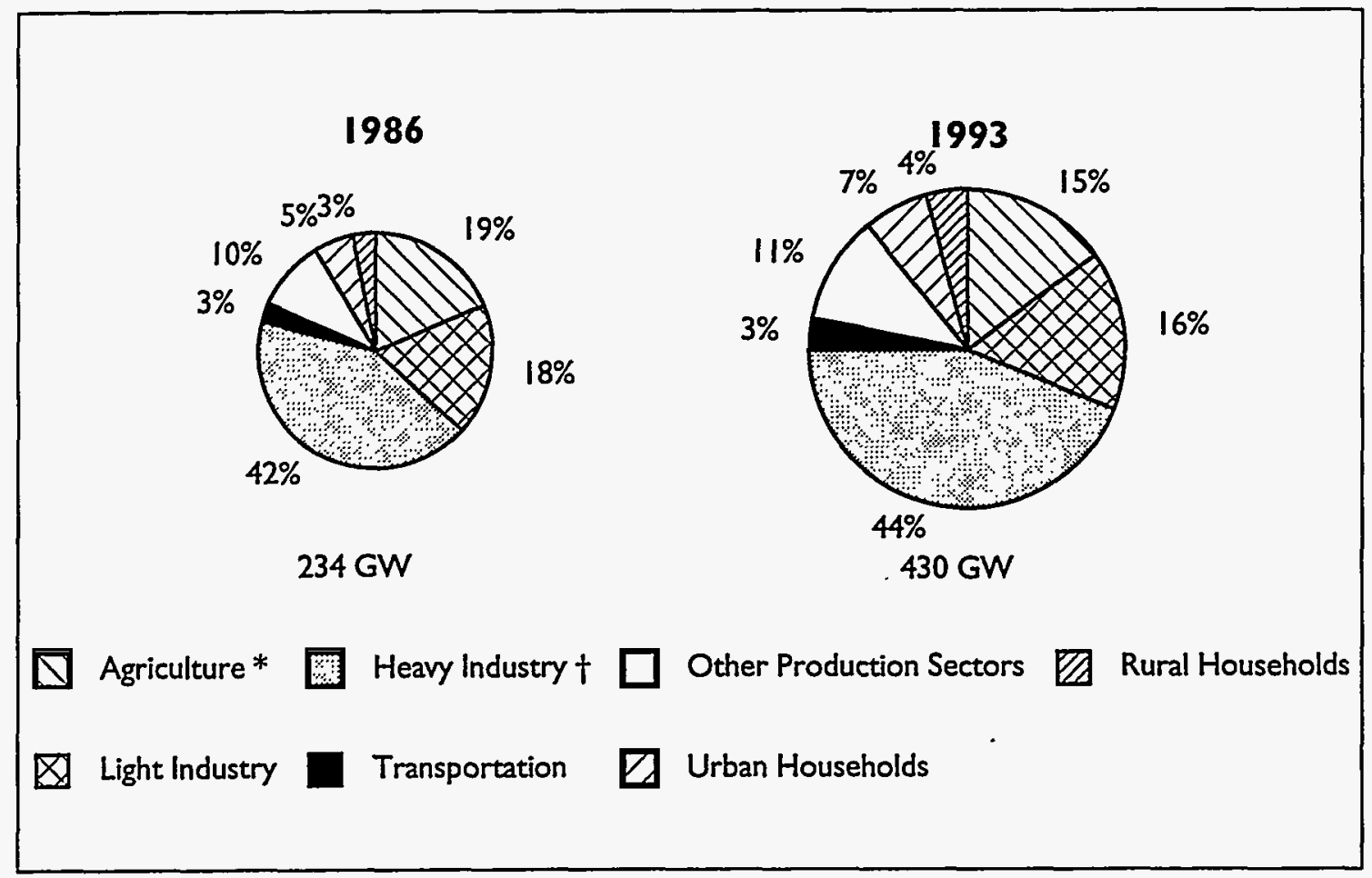

- Includes SSB categories of Agriculture, Forestry, Animal Husbandry, Fishery and Water Conservation.

$\dagger$ Includes SSB categories of Geological Survey and Exploration, and Construction. 
Table V-13. Energy Efficiencies of Some Major Equipment Types, 1990

\begin{tabular}{|c|c|c|c|c|}
\hline Equipment & $\begin{array}{c}\text { Share of Total } \\
\text { Energy Use }\end{array}$ & Remark & $\begin{array}{l}\text { National } \\
\text { Average }\end{array}$ & $\begin{array}{r}\text { Advanced } \\
\text { International }\end{array}$ \\
\hline Industrial Boilers * & $30 \%$ of total coal use & - & $65 \%$ & $>80 \%$ \\
\hline Fans and Pumps & $30 \%$ of total & $\begin{array}{l}\text { equipment } \\
\text { system }\end{array}$ & $\begin{array}{r}75 \% \\
30-40 \%\end{array}$ & $\begin{array}{l}>85 \% \\
>70 \%\end{array}$ \\
\hline Electric Motors † & $\begin{array}{l}60 \% \text { of industrial } \\
\text { sector electricity use }\end{array}$ & $\begin{array}{l}1.1 \mathrm{~kW} \\
22 \mathrm{~kW} \\
75 \mathrm{~kW}\end{array}$ & $\begin{array}{l}75 \% \\
92 \% \\
93 \%\end{array}$ & $\begin{array}{l}86 \% \\
94 \% \\
95 \%\end{array}$ \\
\hline
\end{tabular}

* Industrial boiler figures represent operating efficiencies.

$\dagger$ Motor figures represent rated efficiencies. Chinese motor figures are for Y-series motors, intemational figures are averages for US highefficiency motors.

Source: Wang, 1995. 
Table V-14. Output of Major Energy-Intensive Industrial Raw Materials 1980-1990-Million Tonnes

\begin{tabular}{|c|c|c|c|c|c|c|c|c|c|c|c|}
\hline Year & $\begin{array}{c}\text { Paper \& } \\
\text { Paperboard }\end{array}$ & Pig Iron & $\begin{array}{r}\text { Crude } \\
\text { Steel }\end{array}$ & $\begin{array}{c}\text { Rolled Steel } \\
\text { Products }\end{array}$ & Cement & $\begin{array}{c}\text { Plate Glass } \\
\text { (M cases) }\end{array}$ & $\begin{array}{l}\text { Soda } \\
\text { Ash }\end{array}$ & $\begin{array}{c}\text { Caustic } \\
\text { Soda }\end{array}$ & $\begin{array}{l}\text { Sulfuric } \\
\text { Acid }\end{array}$ & $\begin{array}{l}\text { Synthetic } \\
\text { Ammonia }\end{array}$ & Ethylene \\
\hline 1980 & 5.35 & 38.02 & 37.12 & 27.16 & 79.86 & 24.66 & 1.61 & 1.92 & 7.64 & 14.97 & 0.49 \\
\hline 1981 & 5.40 & 34.17 & 35.60 & 26.70 & 82.90 & 27.01 & 1.65 & 1.92 & 7.81 & 14.83 & 0.51 \\
\hline 1982 & 5.89 & 35.51 & 37.16 & 29.02 & 95.20 & 31.54 & 1.74 & 2.07 & 8.18 & 15.46 & 0.56 \\
\hline 1983 & 6.61 & 37.38 & 40.02 & 30.72 & 108.25 & 36.47 & 1.79 & 2.12 & 8.70 & 16.77 & 0.65 \\
\hline 1984 & 7.56 & 40.01 & 43.47 & 33.72 & 123.02 & 41.90 & 1.88 & 2.22 & 8.17 & 18.37 & 0.65 \\
\hline 1985 & 9.11 & 43.84 & 46.79 & 36.93 & 145.95 & 49.42 & 2.01 & 2.35 & 6.76 & 17.18 & 0.65 \\
\hline 1986 & 9.99 & 50.64 & 52.20 & 40.58 & 166.06 & 52.02 & 2.15 & 2.52 & 7.63 & 16.76 & 0.69 \\
\hline 1987 & 11.41 & 55.03 & 56.28 & 43.86 & 186.25 & 58.03 & 2.36 & 2.74 & 9.83 & 19.41 & 0.94 \\
\hline 1988 & 12.70 & 57.04 & 59.43 & 46.89 & 210.14 & 72.93 & 2.61 & 3.01 & 11.11 & 19.86 & 1.23 \\
\hline 1989 & 13.33 & 58.20 & 61.59 & 48.59 & 210.29 & 84.42 & 3.04 & 3.21 & 11.53 & 20.68 & 1.40 \\
\hline 1990 & 13.72 & 62.38 & 66.35 & 51.53 & 209.71 & 80.67 & 3.80 & 3.35 & 11.97 & 21.29 & 1.57 \\
\hline 1991 & 14.79 & 67.65 & 71.00 & 56.38 & 252.61 & 87.12 & 3.94 & 3.54 & 13.33 & 22.02 & 1.76 \\
\hline 1992 & 17.25 & 75.89 & 80.94 & 66.97 & 308.22 & 93.59 & 4.55 & 3.80 & 14.09 & 22.98 & 2.00 \\
\hline 1993 & 19.14 & 87.39 & 89.56 & 77.16 & 367.88 & 110.86 & 5.35 & 3.95 & 13.37 & 21.93 & 2.03 \\
\hline 1994 & 17.33 & 96.42 & 91.53 & 80.04 & 400.05 & $|15.4|$ & 5.68 & 4.21 & 14.95 & 24.17 & 2.19 \\
\hline \multicolumn{12}{|c|}{ annual average } \\
\hline
\end{tabular}

Source: China Statistical Yearbook, various years; Statistical Yearbook of China'a Industrial Economy, varlous years; State Statistical Bureau; Statistical Information and Consultancy Service Center, 1994. 
Table V-15. Physical Energy Intensity of Selected Industrial Products, * 1980-1993

\begin{tabular}{|c|c|c|c|c|c|c|c|c|c|c|c|c|c|c|c|}
\hline Product & Unit & 1980 & 1981 & 1982 & 1983 & 1984 & 1985 & 1986 & 1987 & 1988 & 1989 & 1990 & 1991 & 1992 & $1993 \#$ \\
\hline $\begin{array}{l}\text { Raw coal production, raw coal use } \dagger \\
\text { Raw coal production, electricity use } t\end{array}$ & $\begin{array}{c}\mathrm{kg} / \mathrm{t} \\
\mathrm{kWWh} / \mathrm{t}\end{array}$ & $\begin{array}{l}39.1 \\
34.3 \\
\end{array}$ & $\begin{array}{l}41.9 \\
35.7 \\
\end{array}$ & $\begin{array}{l}41.2 \\
35.9 \\
\end{array}$ & $\begin{array}{l}41.3 \\
36.4 \\
\end{array}$ & $\begin{array}{c}44.4 \\
36.7 \\
\end{array}$ & $\begin{array}{l}41.1 \\
37.3 \\
\end{array}$ & $\begin{array}{l}39.4 \\
39.1 \\
\end{array}$ & $\begin{array}{l}40.3 \\
39.6 \\
\end{array}$ & $\begin{array}{l}39.5 \\
40.9 \\
\end{array}$ & $\begin{array}{l}41.4 \\
39.0 \\
\end{array}$ & $\begin{array}{l}37.3 \\
40.2 \\
\end{array}$ & 47.0 & $\stackrel{-}{50.5}$ & 53.0 \\
\hline Crude oil production, electricity use & $\mathrm{kWh} / \mathrm{t}$ & 38.8 & 39.8 & 43.0 & 45.1 & 47.2 & 51.6 & 59.4 & 64.5 & 73.3 & 78.8 & 88.0 & 102.6 & 107.5 & 114.6 \\
\hline Crude oil production, total energy use & $\mathrm{kgce} / \mathrm{t}$ & $\therefore$ & - & - & - & - & 143.0 & - & - & 141.5 & 144.9 & 148.9 & 128.9 & 139.6 & 146.4 \\
\hline Oil refining, electricity use & $\mathrm{kWh} / \mathrm{t}$ & 39.4 & 39.8 & 39.5 & 34.6 & 40.7 & 41.9 & 42,3 & 41.7 & 44.3 & 45.6 & 49.3 & 50.3 & 50.7 & 52.4 \\
\hline Oil refining, fuel oil use & $\mathrm{kg} / \mathrm{t}$ & 29.2 & 26.1 & 22.6 & 19.2 & 18.6 & 18.7 & 19.7 & 20.0 & 20.5 & 20.4 & 21.0 & 19.9 & 19.6 & 20.7 \\
\hline Oil refining, total energy use & G/t & - & - & - & - & - & - & - & $\cdot$ & - & - & - & 3.62 & 3.68 & 3.68 \\
\hline Steel, all enterprises, total energy use & $\mathrm{G} / \mathrm{t}$ & 59.8 & 56.7 & 55.9 & 53.8 & 52.3 & 51.2 & 50.0 & 49.1 & 48.3 & 48.0 & 47.2 & 46.9 & 46.1 & - \\
\hline $\begin{array}{l}\text { Steel, key enterprises, total energy use } \\
\text { Steel, local "backbone" enterprises, }\end{array}$ & G//t & - & - & - & $\cdot$ & $\cdot$ & 38.0 & 41.6 & 41.4 & 35.3 & 35.6 & 35.2 & 35.3 & 34.8 & 31.2 \\
\hline total energy use & GJ/t & - & - & $\therefore$ & - & - & 50.4 & 52.2 & 49.2 & 46.0 & 44.2 & 42.1 & 40.7 & 39.4 & - \\
\hline Electric arc fumaces, key enterprises & $\mathrm{kWh} / \mathrm{t}$ & 647 & 651 & 643 & 625 & 619 & 626 & 607 & 590 & 594 & 601 & 595 & 590 & 593 & 597 \\
\hline Aluminum, 8 large plants, total energy use & $\mathrm{G} / \mathrm{t}$ & 336.5 & 336.5 & 331.2 & 323.3 & 307.5 & 303.4 & 315.1 & 304.8 & 332.4 & 340.9 & 337.9 & - & & - \\
\hline Alumina, total energy use & $\mathrm{G} / \mathrm{t}$ & 44.5 & 44.5 & 45.9 & 46.7 & 48.0 & 47.5 & 46.1 & 45.8 & 47.6 & 58.4 & 56.2 & 56.5 & 55.1 & 57.0 \\
\hline Electrolytic aluminum, total energy use & $\mathrm{G} / \mathrm{t}$ & 218.5 & 214.0 & 216.8 & 207.5 & 208.6 & 203.1 & 200.4 & 198.4 & 216.5 & 205.0 & 202.7 & 197.3 & 193.5 & 196.0 \\
\hline Electrolytic aluminum, DC use & $\mathrm{MWh} / \mathrm{t}$ & 15.4 & 15.7 & 16.1 & 15.6 & 15.5 & $\frac{15.0}{500}$ & 15.3 & 15.4 & 15.3 & 15.0 & 14.9 & 14.9 & 14.8 & 14.7 \\
\hline Cement clinker, fuel use & $\mathrm{GJ} / \mathrm{t}$ & 6.05 & 6.08 & 6.09 & 6.04 & 6.03 & 5.89 & 5.81 & 5.67 & 5.60 & 5.52 & 5.43 & 5.38 & 5.23 & - \\
\hline $\begin{array}{l}\text { Cement, electricity use } \\
\text { Cement, large \& med. plants, }\end{array}$ & $\mathrm{kWh} / \mathrm{t}$ & 96.7 & 98.6 & 100.0 & 100.9 & 102.4 & 103.9 & 105.6 & 106.2 & 107.3 & 108.7 & 109.9 & 110.5 & 110.3 & - \\
\hline total energy use & $\mathrm{G} / \mathrm{t}$ & 6.12 & 6.04 & 6.06 & 5.99 & 6.19 & 6.10 & 6.08 & 5.93 & 5.86 & 5.87 & 5.89 & 5.35 & 5.22 & 5.32 \\
\hline Cement, small plants, total energy use & $\mathrm{G} / \mathrm{t}$ & $\therefore$ & - & - & - & - & - & - & 5.87 & 5.73 & 5.62 & 5.64 & - & - & - \\
\hline Cement, rural plants, total energy use & $\mathrm{G} / \mathrm{t}$ & 5.86 & - & $=$ & - & - & 5.42 & 5.13 & 5.22 & 5.13 & 4.84 & 4.84 & - & - & - \\
\hline Bricks, total energy use & GJ/million & 375.8 & - & - & 345.9 & 322.4 & 279.9 & 290.5 & 273.5 & 231.5 & 259.1 & 249.1 & - & $\cdot$ & - \\
\hline Bricks, rural plants, total energy use & G//million & 439.7 & - & - & - & - & 363.4 & 360.5 & 354.7 & 337.1 & 334.1 & 331.2 & - & - & $=$ \\
\hline Flat glass, fuel use (per $50 \mathrm{~kg}$ case) & Gy/case & 0.904 & 0.899 & 0.895 & 0.882 & 0.876 & 0.902 & 0.910 & 0.957 & 0.925 & 0.850 & 0.838 & 0.795 & 0.718 & - \\
\hline Flat glass, electricity use & $\mathrm{kWh} /$ case & 3.63 & 3.80 & 3.71 & 3.49 & 3.65 & 5.29 & 5.43 & 5.26 & 6.97 & 7.06 & 7.39 & - & - & - \\
\hline Flat glass, total energy use & $\mathrm{G} /$ case & 0.952 & 0.943 & 0.940 & 0.924 & 0.935 & 0.964 & 0.969 & 1.036 & 1.011 & 0.921 & 0.924 & 1.016 & 0.925 & 0.936 \\
\hline
\end{tabular}

* Unless otherwise noted, data refer to key state-owned enterprises

\# First nine months, except indicators for aluminum manufacturing.

$\dagger$ Coal production intensity figures include only centrally-run mines; local mines, including provincial mines, are excluded.

I Cotton spinning electricity intensity is much lower than in China than in other countries because production processes are less automated.

§ Average for Eastern Europe and the Former Soviet Union.

** Date unknown

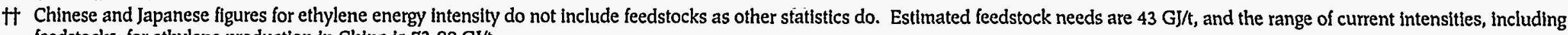
feedstocks, for ethylene production in China is 73-90 GJ/t.

Wate 1980s.

\#\# Generation figures in brackets.

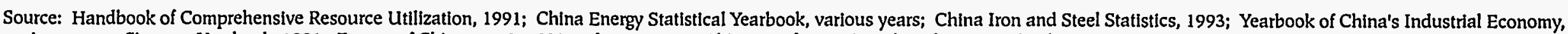

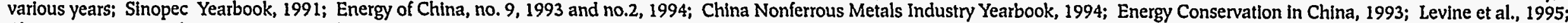

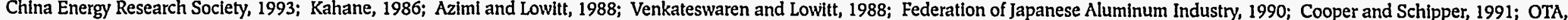
1993; Energy Research Institute. 
Table V-15. Physical Energy Intensities of Selected Industrial Products, $*$ 1980-1993 (continued)

\begin{tabular}{|c|c|c|c|c|c|c|c|c|c|}
\hline Product & $80-92$ & \multicolumn{3}{|c|}{ average annual growth rates } & FSU & India & Japan & USA & OECD \\
\hline Raw coal production, raw coal use & - & - & $-0.5 \%$ & - & - & - & - & - & - \\
\hline Raw coal production, electricity uset & $3.3 \%$ & $3.4 \%$ & $1.6 \%$ & - & $55.5(89)$ & - & $85.9(90)$ & - & - \\
\hline Crude oil production, electricity use & $8.9 \%$ & $10.3 \%$ & $8.5 \%$ & - & - & - & - & - & - \\
\hline Crude oil production, total energy use & - & $-1.5 \%$ & - & - & - & - & - & - & - \\
\hline Oil refining, electricity use & $2.1 \%$ & $2.6 \%$ & $2.3 \%$ & - & - & - & - & - & - \\
\hline Oil refining, fuel oil use & $-3.3 \%$ & $0.8 \%$ & $-3.3 \%$ & - & - & - & - & - & - \\
\hline Oil refining, total energy use & - & - & - & $0.8 \%(91-93)$ & $6.0(90) \$$ & - & $2.1(90)$ & $4.4(90)$ & $2.7-3.5(92)$ \\
\hline Steel, all enterprises, total energy use & $-2.1 \%$ & $-1.2 \%$ & $-2.3 \%$ & - & $23.7(90)$ & $38.7(91)$ & $18.4(90)$ & $22.2(90)$ & $18-21(92)$ \\
\hline Steel, key enterprises, total energy use & - & $-1.0 \%$ & - & - & - & - & - & - & - \\
\hline Steel, local "backbone" enterprises, total en & agy use & - & $-3.0 \%$ & - & - & - & - & - & - \\
\hline Electric are furnaces, key enterprises & $-0.7 \%$ & $-0.8 \%$ & $-0.8 \%$ & - & - & - & $428(84)$ & $590(83)$ & - \\
\hline Aluminum, 8 large plants, total energy use & - & - & $0.04 \%$ & - & - & - & - & - & - \\
\hline Alumina, total energy use & $1.8 \%$ & $2.5 \%$ & $2.4 \%$ & - & - & - & - & $37.5(80)$ & - \\
\hline Electrolytic aluminum, total energy use & $-1.0 \%$ & $-0.4 \%$ & $-0.7 \%$ & - & - & - & - & $187.5(80)$ & - \\
\hline Electrolytic aluminum, DC use & $-0.3 \%$ & $-0.1 \%$ & $-0.3 \%$ & - & - & - & $16.1(86)$ & $13.4-14.7 \approx$ & - \\
\hline Cement clinker, fuel use & $-1.2 \%$ & $-1.3 \%$ & $-1.1 \%$ & - & $6.8(85)$ & - & $2.9(90)$ & $4.7(85)$ & - \\
\hline Cement, electricity use & $1.1 \%$ & $0.9 \%$ & $1.3 \%$ & - & $112(85)$ & - & $102.2(90)$ & $138.2(85)$ & - \\
\hline Cement, large \& med. plants, total energy & se $-1.3 \%$ & $-1.9 \%$ & $-0.4 \%$ & . $\quad-$ & $7.3(90)$ & - & $3.3(90)$ & $5.7(88)$ & - \\
\hline Cement, small plants, total energy use & - & - & - & $-1.3 \%(87-90)$ & - & - & - & - & - \\
\hline Cement, rural plants, total energy use & - & - & $-1.9 \%$ & - & - & - & - & - & $=$ \\
\hline Bricks, total energy use & - & - & $-4.0 \%$ & - & - & $=$ & - & - & - \\
\hline Bricks, rural plants, total energy use & - & - & $-2.8 \%$ & - & - & - & - & - & - \\
\hline Flat glass, fuel use (per $50 \mathrm{~kg}$ case) & $-1.9 \%$ & $-1.8 \%$ & $-0.8 \%$ & - & - & - & 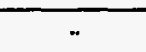 & - & $0.4(90)$ \\
\hline Flat glass, electricity use & - & - & $7.4 \%$ & - & - & - & - & - & - \\
\hline Flat glass, total energy use & $-0.2 \%$ & $0.8 \%$ & $-0.3 \%$ & - & - & - & - & $0.793(85)$ & - \\
\hline
\end{tabular}

- Unless othenwlse noted, data refer to key state-owned enterprlses

\# Coal productlon intensity flgures include only centrally-run mines; local mines, Including provinclal mines, are excluded.

\$ Sinopec plants only.

1 Cotton splnning electrleity intensity is much lower than in China than in other countrles because production processes are less automated

8. Average for Eastern Europe and the Former Soviet Unlon.

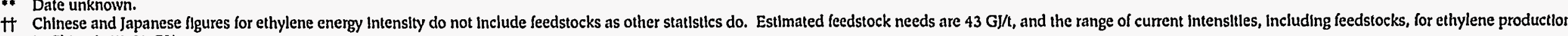

In China is 73-90 GJ/.

Y\% Late 1980s.

\#\#\# Generation figures in brackets.

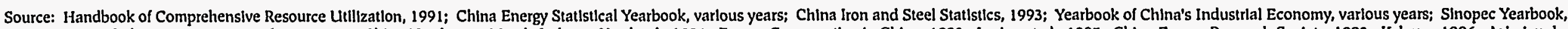

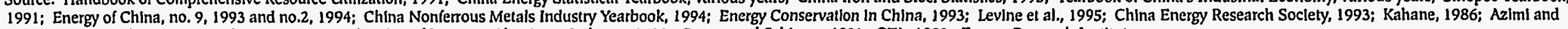




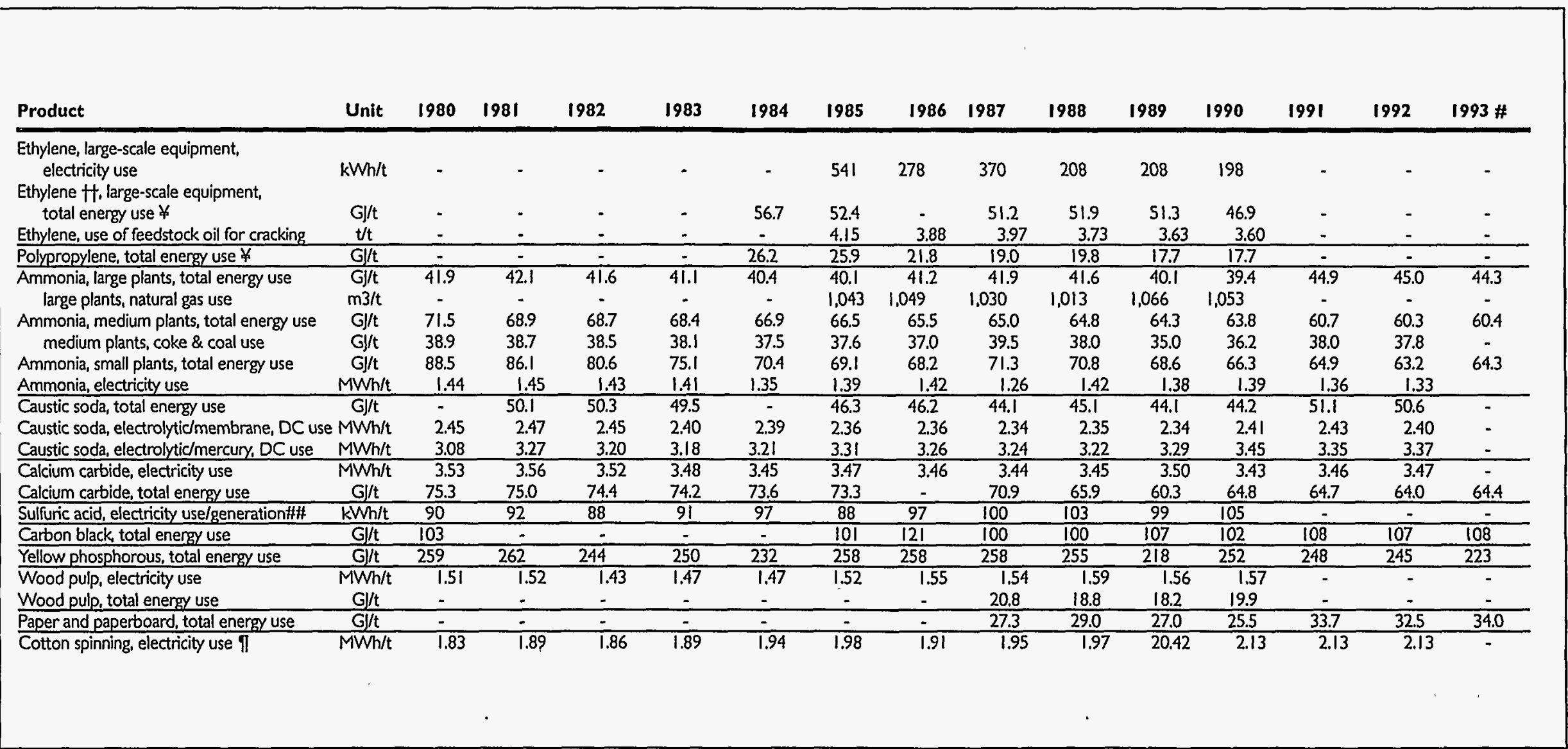

Unless othenwlse noted, data refer to key state-owned enterprises

First nine months, except Indicators for aluminum manufacturlng.

Coal production intensity flgures include only centrally-run mines; local mines, including provinclal mines, are excluded.

Sinopec plants only.

Cotton spinning electriclty intensity is much lower than in China than in other countrles because production processes are less automated

Average for Eastern Europe and the Former Soviet Union.

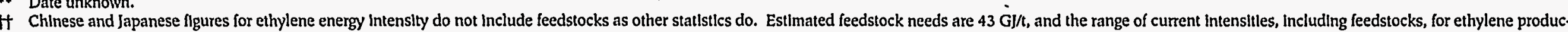
tion In China Is $73-90 \mathrm{G} / \mathrm{l}$.

Late 1980s.

\#\# Generation figures in brackets.

Source: Handbook of Comprehensive Resource Utilization, 1991; China Energy Statistlcal Yearbook, varlous years; China Iron and Steel Statistlcs, 1993; Yearbook of China's Industrial Economy, varlous years; Sinopec

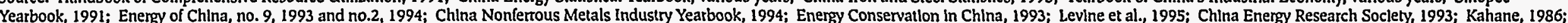
AzIml and Lowitt, 1988; Venkateswaren and Lowitt, 1988; Federatton of Japanese Aluminum Industry, 1990; Cooper and Schipper, 1991; OTA, 1993; Energy Research Instllute. 
Table V-15. Physical Energy Intensities of Selected Industrial Products, *1980-1993 (continued)

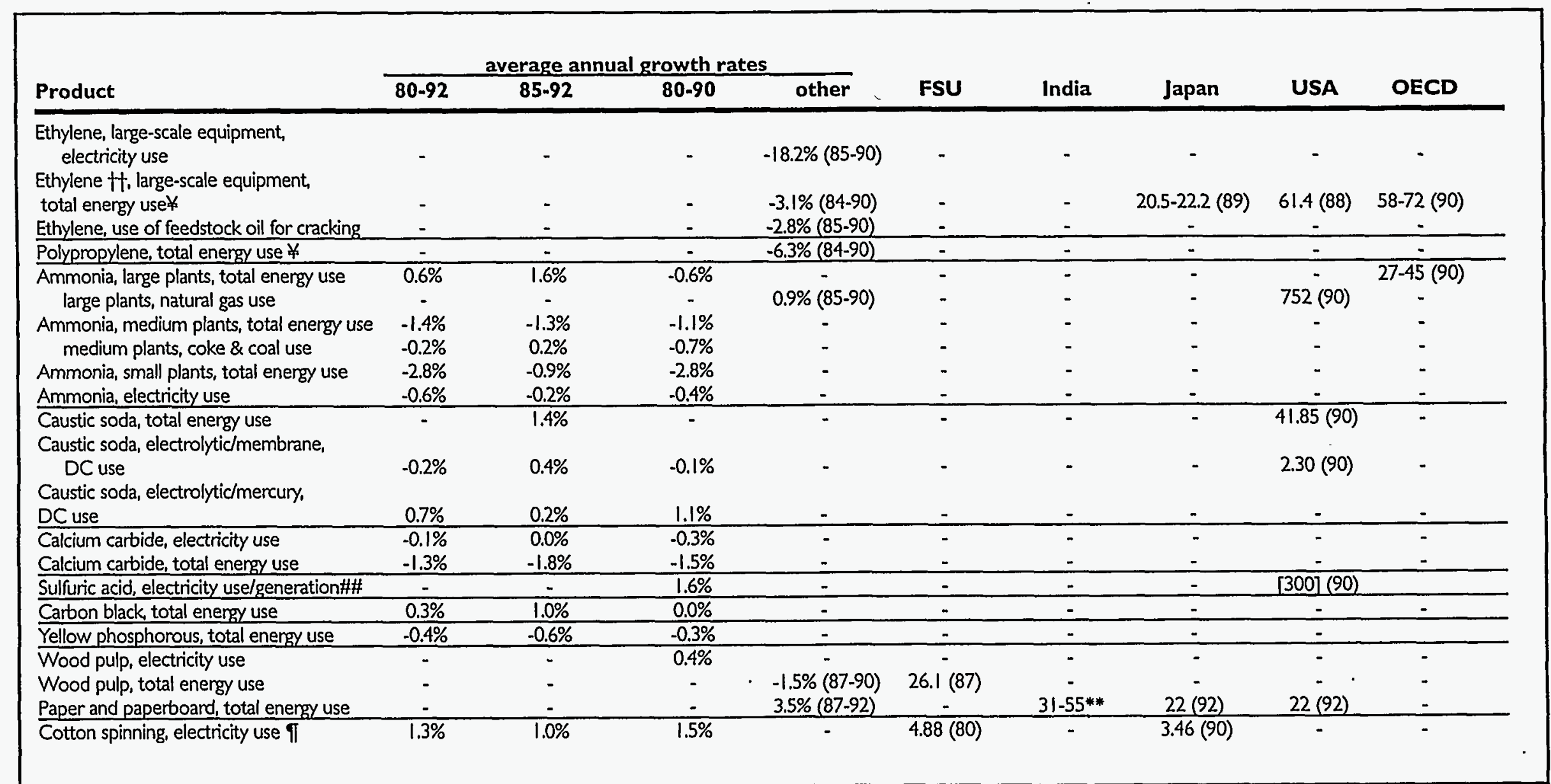

- Unless othenvlse noted, data refer to key state-owned enterprlses

First nine months, except Indicators for aluminum manufacturing.

Coal productlon Intensty

Cotton spinning electrlcly Intensity is much lower than in China than in other countries because production processes are less automated

Average for Eastern Europe and the Former Soviet Union.

* Date unknown.

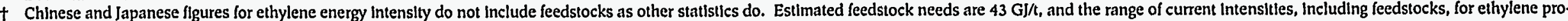
ductlon in China is $73-90 \mathrm{G} / \mathrm{t}$.

4* Late 1980s.

H\# Generation flgures in brackets.

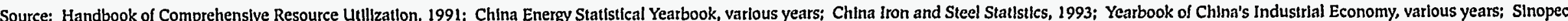

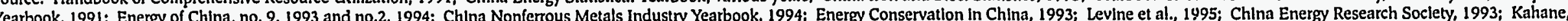
1986; AzImi and Lowitt, 1988; Venkatesivaren and Lowitt, 1988; Federation of Japanese Aluminum Industry, 1990; Cooper and Schipper, 1991; OTA, 1993; Energy Research Institute. 

Chapter VI—Energy Prices 


\section{Energy Prices}

$\mathrm{O}$ ne oft-cited key to stimulating efficient use of energy is freeing of energy prices. Statistics on coal, oil, and electricity prices show that much progress has been made in this area, especially over the past several years. Energy pricing reform began in the 1980s, when a portion of energy products were allowed to be sold at prices higher than the in-plan prices, resulting in a multi-track pricing system. At first the higher prices were constrained to be within a certain range, usually a specified percentage of the in-plan price, and later they were allowed to float freely.

Since 1990 s the commitment of the central government to carrying through pricing reform has appeared to strengthen. Coal prices have basically been freed since 1993; since then they have risen and leveled off, and show significant regional variation. Oil prices, on the other hand, remain relatively tightly controlled, after partial decontrol starting in 1992. Electricity prices have risen several times over in many areas, and are expected to continue increasing. In early 1994 six major grids adopted a scheme whereby electricity from new power plants would be priced to recover costs and a set rate of return. Some municipalities have already instituted peak pricing. ${ }^{1}$

\section{COAL}

Average mine-mouth coal prices from stateowned mines rose only incrementally during the 1980s, but by 1992 were 55 to 60 yuan/t, double the levels prevailing four or five years earlier (Table VI-1). Price reforms since then have allowed coal prices to float even higher.

A 1992 price buildup of coal (sorted bituminous coal) shipped from Datong in Shanxi to Shanghai and Guangzhou shows that, for distant customers, the mine mouth coal price is a fraction of the delivered price (Table VI-2). Starting from a low in-plan mine mouth price of 20 yuan/t, additional costs include 31 yuan for rail shipment to the coastal port of Qinhuangdao, railway fees of 6 yuan, port charges of 56 yuan, ocean shipping charges (to Shanghai) of 7 to 13 yuan, and Shanghai port charges of 24 to 25 yuan, for a final cost of 143 to 151 yuan per ton. All such charges have increased in the past three years, and a value-added tax of $17 \%$ has been applied (since January 1, 1994) as well.

A cross section of average coal prices in various cities from 1992 to 1994 shows the fast rise in coal prices as they were allowed to float, and the equally rapid leveling off as supply met (and even exceeded) demand (Table VI-3). In some cases 1994 prices were lower, even after addition of the new valueadded tax. In general, coal prices are lower near areas of coal supply than in the eastern and southern coastal provinces.

A more detailed look at coal shows prices at northern China's major coastal coal terminal, Qinhuangdao, peaking in the sping of 1994, after which prices came down slightly (Table VI-4). As in other areas of China represented in the table, with the notable exception of Wuhan, anthracite is considerably cheaper than bituminous coal. Areas with no local coal resources, e.g., Shanghai and Guangzhou, exhibited wide swings in bituminous coal prices in 1994 , falling from levels in excess of 300 yuan $(\$ 34) / t$ down to 200 to 230 yuan ( $\$ 23$ to $\$ 26) /$, and then back up over 300 yuan/t again.

A cross-section of December 1994 coal prices shows a very wide range in local markets (Table VI5). Bituminous coal sold for 310 yuan $(\$ 36) / t$ in Guangzhou, but for only 120 yuan (\$14)/t in Xi'an, Shaanxi Province. Anthracite prices were highest in Wuhan, Hubei Province at 320 yuan $(\$ 37) / t$, and lowest in Zhengzhou, in neighboring Henan Province, at 120 yuan $(\$ 14) / t$.

\section{OIL}

Controls over oil product prices have been tightened in China over the past year. Ex-refinery prices (from all refineries) for various grades of leaded gasoline ran from $\$ 273$ to $\$ 314 / t$ in 1994 , and slightly more for unleaded varieties (Table VI-6). Diesel 
was sold for between $\$ 217$ and $\$ 267 / t$ depending on the grade, and jet fuel for between $\$ 241$ and $\$ 254 / \mathrm{t}$. Lighting kerosene was slightly cheaper at $\$ 233 / t$, and the price of centrally allocated LPG for the household sector was set at $\$ 95 / \mathrm{t}$.

Oil product prices are somewhat more uniform across regional markets than coal prices, in part because the former are still much more highly regulated than the latter. Unlike coal, oil products are generally more expensive inland than in the coastal provinces, though with many exceptions (table VI5). December 1994 retail gasoline ( $90 \mathrm{RON})$ prices varied between 2,550 yuan (\$293)/t in Chongqing, Sichuan Province to 3,000 yuan (\$345)/t in Wuhan, Hubei Province. Diesel prices varied even less, from $2,000$ yuan ( $\$ 230) / t$ in Qingdao, Shandong Province to 2,350 yuan ( $\$ 270) / t$ in Changchun, Jilin Province. Retail prices for oil products to rural agricultural customers were significantly higher than in the urban markets, i.e., 2,800 to 3,150 yuan ( $\$ 322$ to $\$ 345$ )/t for various grades of gasoline and 2,500 yuan $(\$ 287) / t$ for diesel. Heavy oil sold for half the price or less of the lighter distillates, from 850 yuan (\$98)/t in Tianjin and Changchun to 1,400 yuan ( $\$ 161) / t$ in Wuhan. Although China instituted central price controls on crude oil and oil products in May 1994, prices in areas that are significantly dependent on imported oil (e.g., Guangdong) are now largely determined by prices in the Singapore market.

\section{ELECTRICITY}

Wholesale electricity prices, like other energy prices, have continued to rise, and are not expected to level off in the near future. In the early $1990 \mathrm{~s}$ price increases began slowly, with the national average rising from 118 to 145 yuan/MWh, and then took off in 1993, jumping to 194 yuan/MWh (Table VI-7). Price variations among the regional grids are significant. The lowest prices are found in the southwestern provinces (Guangxi and Guizhou) where hydropower is plentiful, and the highest in the eastern and southeastern coastal provinces.

Some typical retail electricity prices show the disparity between regions (Jinan, the capital of Shandong Province in the north and Shenzhen, Guangdong Province in the southeast) and between sectors (Table VI-8). In 1994 the price to industrial customers in Jinan was between 0.17 and 0.22 yuan
(2.0 and $2.5 \$) / \mathrm{kWh}$ and in Shanzhen was 0.60 yuan $(6.9 \$) / \mathrm{kWh}$. Rates to commercial customers were highest, at 0.35 yuan (4.0\$)/ $\mathrm{kWh}$ and 0.70 yuan $(8.0 \$) / \mathrm{kWh}$ in Jinan and Shenzhen respectively. According to anecdotal evidence, the highest electricity prices are generally paid by rural users, both household and industrial users, which are charged over 1.00 yuan $(12 \$) / \mathrm{kWh}$ in some areas.

Rates to industrial customers vary by line voltage, with the per unit charge inversely related to line voltage (Table VI-9). In 1993 customers connected to $380 \mathrm{~V}$ and $220 \mathrm{~V}$ distribution lines, for instance, were charged 500 to 550 yuan ( $\$ 57$ to $\$ 63$ )/kVA per month, while those connected to $110 \mathrm{kV}$ lines were charged 150 to 180 yuan ( $\$ 17$ to $\$ 21$ )/kVA per month.

China's largest caustic soda manufacturer, a plant in Tianjin, was paying an average of 0.258 yuan/kWh for its delivered power in August 1993 (Table VI-10). Of that total 0.045 yuan was the electricity cost, and 0.174 the demand charge. The remaining 0.039 yuan was composed of various surcharges, including items for local street lighting, and financing for the Three Gorges Dam project (which is assessed nationally).

A breakdown of 1993 charges to various customers in the Beijing-Tianjin grid shows that residential customers $(0.22$ yuan $/ \mathrm{kWh})$ were being charged less for electricity than commercial and small industrial users $(0.268$ to 0.307 yuan $/ \mathrm{kWh}$; Table VI-11). Large industrial users paid significantly less ( 0.183 yuan $/ \mathrm{kWh})$, with energy intensive industries receiving a further break $(0.173$ yuan $/ \mathrm{kWh}$ ). Agricultural users ( 0.218 yuan $/ \mathrm{kWh}$ ) paid slightly less than residential customers, with the exception of irrigators in designated poor rural counties $(0.06$ yuan $/ \mathrm{kWh})$. The grid had in place a peak pricing scheme for industrial and commercial users. Peak prices were $40 \%$ higher than non-peak prices, while electricity prices in periods of low demand were $35 \%$ lower.

${ }^{1}$ For a further discussion of energy price reform see Wang, 1995. 
Table VI-1. Average Minemouth Sales Price of Raw and Washed Coal, Major State-Owned Mines (yuan/t)

\begin{tabular}{|lcccc|}
\hline & $\begin{array}{c}\text { Average price } \\
\text { of raw and washed coal }\end{array}$ & Datong Bureau & Kailuan Bureau & Huaibei Bureau \\
\hline 1953 & 11.00 & - & - & - \\
1957 & 11.46 & - & - & - \\
1965 & 17.68 & - & - & - \\
1975 & 16.48 & - & - & - \\
1980 & 21.33 & - & - & - \\
1982 & 21.58 & - & - & - \\
1984 & 22.73 & - & - & - \\
1985 & 26.05 & - & - & - \\
1986 & 26.51 & 27.93 & 26.84 & - \\
1987 & 26.28 & 28.32 & - & - \\
1988 & 27.72 & - & - & - \\
1990 & 43.85 & - & - & 55.45 \\
1991 & 47.89 & 49.14 & 53.10 & \\
1992 & 54.73 & 58.04 & 61.65 & \\
& & & & \\
\hline
\end{tabular}

Source: Energy Research Institute. 
Table VI-2. Cost Buildup for Datong Lump Coal Shipped to Shanghai and Guangzhou, March 1992

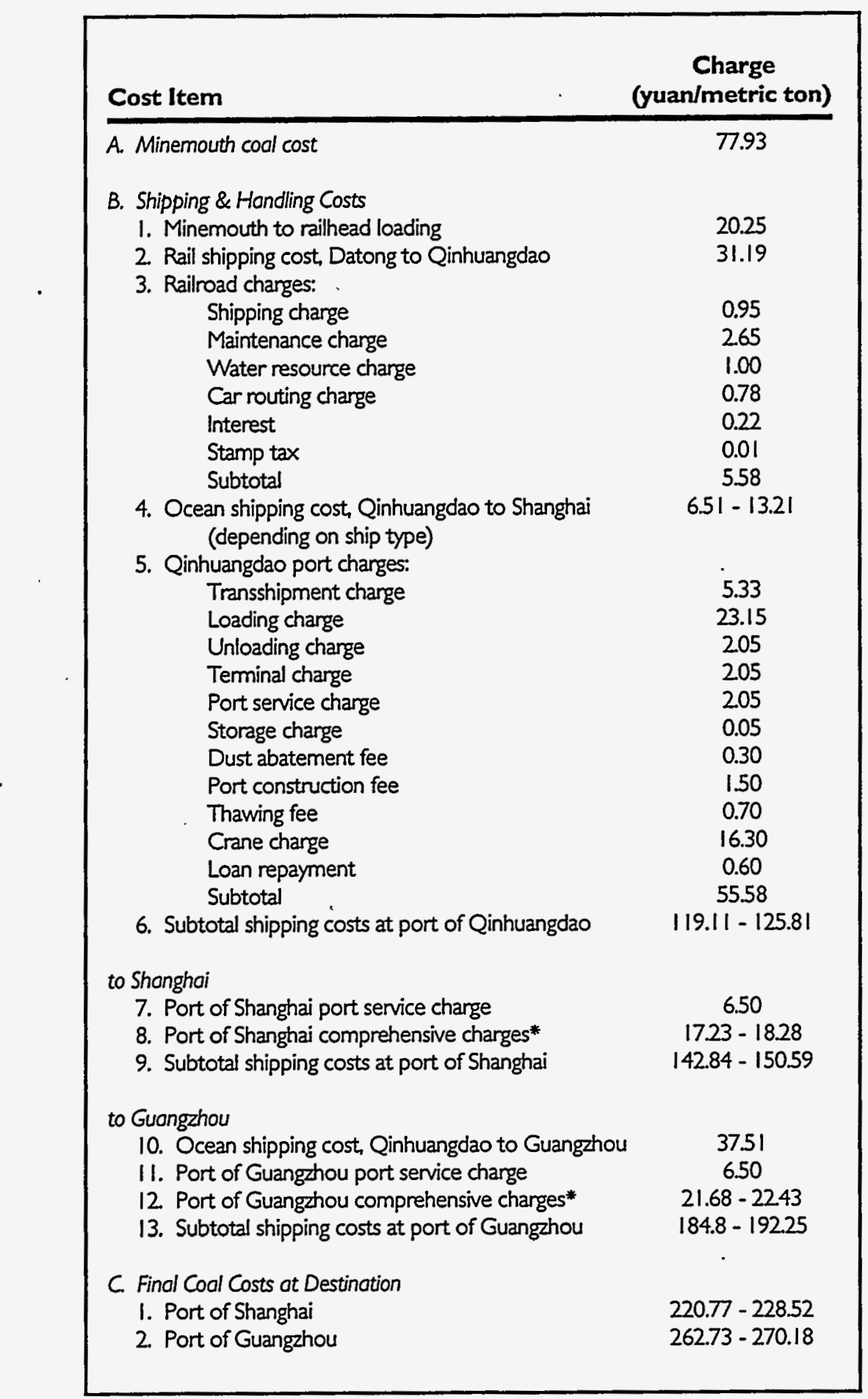

- Comprehensive port charges include bank interest, profit, management fees,and normal depreciation.

Source: Wang, 1995. 
Table V1-3. Average Retail Price of Coal in Various Cities - yuan/t

\begin{tabular}{|lcccc|}
\hline City & Province & November 1992 & August 1993 & June 1994 \\
\hline Datong & Shanxi & 114 & 224 & 236 \\
Dalian & Liaoning & 185 & 250 & 255 \\
Shanghai & & 190 & 230 & 230 \\
Nanjing & Jiangsu & 195 & 230 & 262 \\
Zhangiiagang & Jiangsu & 215 & 285 & 310 \\
Ningbo & Zhejiang & 191 & 251 & 258 \\
Hangzhou & Zhejiang & - & 275 & 285 \\
Wuhan & Hubei & 153 & 163 & 200 \\
Xiamen & Fujian & 235 & 260 & 340 \\
Guangzhou & Guangdong & 228 & 308 & 280 \\
& & & & \\
\hline
\end{tabular}

N.B.:

1. Market prices are posted prices of local Fuels Corporations.

2. Coal types: Dalian price is for Fuxin bituminous coal, Wuhan price is for Luo'an bituminous coal, others are generally for Datong mixed coal.

3. June 1994 coal prices include value-added tax of $17 \%$.

Source: Energy Research Institute; China Energy Research Society, 1995. 


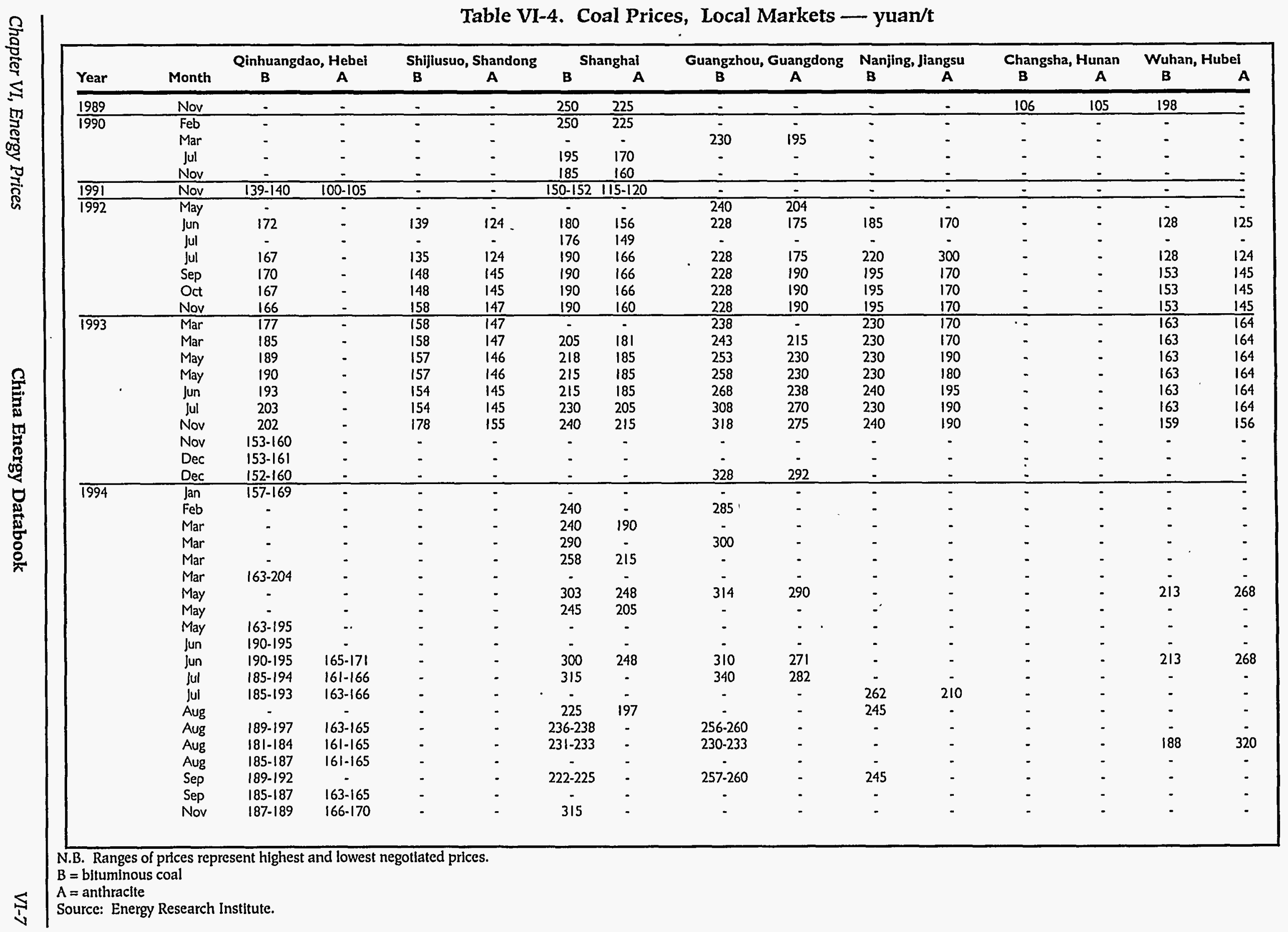




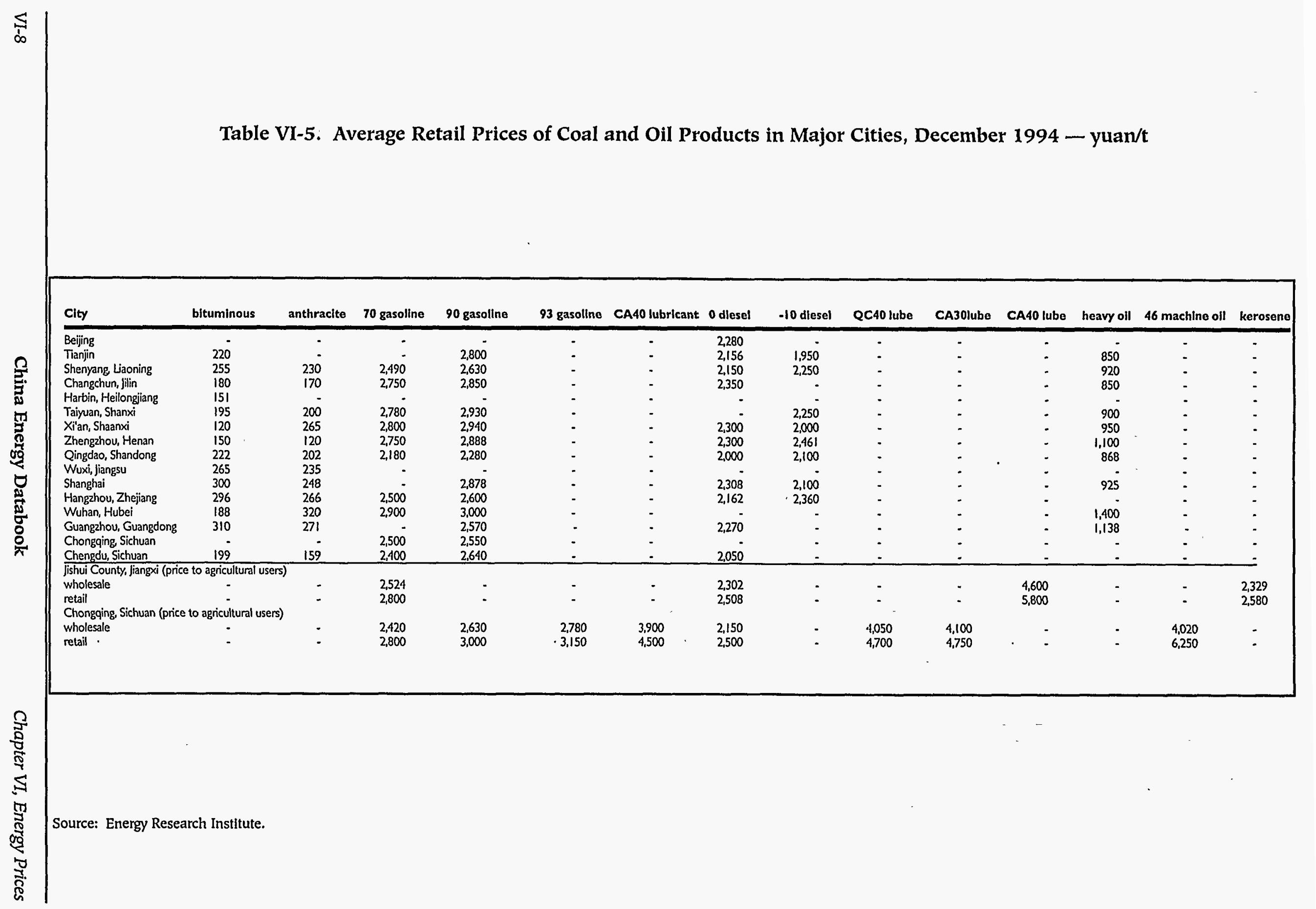


Table VI-6. Ex-Refinery Oil Products Prices, 1994 — \$US/t

\begin{tabular}{|llr|}
\hline Product & Grade & Price \\
\hline Gasoline & $\# 70$ & $\$ 27260$ \\
& $\# 90$ & $\$ 287.50$ \\
& $\# 93$ & $\$ 299.40$ \\
& $\# 97$ & $\$ 314.20$ \\
& $\# 90$ no lead & $\$ 299.40$ \\
& $\# 93$ no lead & $\$ 322.60$ \\
$\# 95$ no lead & $\$ 328.60$ \\
& $\#+10$ & $\$ 217.30$ \\
Diesel & $\#+5$ & $\$ 22200$ \\
& $\# 0$ & $\$ 226.20$ \\
& $\#-10$ & $\$ 241.10$ \\
& $\#-50$ & $\$ 267.30$ \\
\hline Jet fuel & $\# 1$ & $\$ 241.40$ \\
& $\# 2$ & $\$ 246.40$ \\
& $\# 3$ & $\$ 253.60$ \\
& $\# 4$ & $\$ 24290$ \\
\hline Kerosene (lighting) & & $\$ 232.70$ \\
LPG & & $\$ 95.20$ \\
\hline
\end{tabular}

Source: Energy Research Institute. 


\begin{tabular}{|lcccc|}
\hline & & & & \\
Regional Grid & 1990 & $\mathbf{1 9 9 1}$ & $\mathbf{1 9 9 2}$ & $\mathbf{1 9 9 3}$ \\
\hline East China & 135.53 & 146.37 & 172.02 & 233.54 \\
North China & 116.65 & 131.38 & 147.34 & 217.40 \\
North-East China & 106.40 & 132.63 & 140.44 & 202.14 \\
Middle China & 115.93 & 125.18 & 143.74 & 188.09 \\
North-west China & 96.88 & 107.81 & 119.92 & 154.52 \\
\hline Shandong & 104.30 & 115.03 & 122.51 & 183.14 \\
Sichuan & 110.43 & 119.38 & 135.19 & 154.84 \\
Yunnan & 108.14 & 116.49 & 121.81 & 165.72 \\
Guizhou & 106.17 & 125.49 & 133.76 & 147.34 \\
Guangxi & 151.75 & 172.26 & 177.34 & 118.31 \\
Fujian & 127.05 & 129.59 & 149.49 & 217.68 \\
Guangdong & 136.66 & 138.79 & 146.55 & \\
\hline National Average & 118.08 & 132.32 & 145.43 & 194.32 \\
& & & & \\
\hline
\end{tabular}

N.B. This table represents sales price to the grid by generators.

Source: Energy Research Institute.

Table VI-8. Retail Electricity Price by Sector, 1994 - yuan/kwh

\begin{tabular}{lcc}
$\begin{array}{l}\text { Customer } \\
\text { Type }\end{array}$ & Shenzhen, Guangdong & Jinan, Shandong \\
\hline Industry & 0.60 & $0.17-0.22$ \\
Agriculture & - & 0.22 \\
Commercial & 0.70 & 0.35 \\
Residential & 0.50 & 0.22
\end{tabular}

Source: Energy Research Institute. 
Table VI-9. Electricity Supply Surcharges for Transmission and Distribution, ${ }^{*} 1993$

\begin{tabular}{|cc|}
\hline Customer Line Voltage & $\begin{array}{c}\text { Electricity } \\
\text { Supply Surcharge } \\
\text { (yuan/kVA) }\end{array}$ \\
\hline $380 \mathrm{~V} \& 220 \mathrm{~V}$ & $500-550$ \\
$10 \mathrm{KV}$ & $440-450$ \\
$35 \mathrm{kV}$ & $300-330$ \\
$63 \mathrm{kV}$ & $200-220$ \\
$110 \mathrm{kV}$ & $150-180$ \\
\hline
\end{tabular}

- Charged to customers and used for transmission and distribution network ( $\leqslant 110 \mathrm{kV}$ ) construction projects.

Source: China Energy Research Society, 1995.

Table VI-10. Electricity Purchase Price, Tianjin Soda Plant, August 1993

\begin{tabular}{|lc|}
\hline Cost Item & yuan/kWh \\
\hline Basic electricity cost & 0.045 \\
Demand charge & 0.174 \\
Surcharge & 0.009 \\
Street lighting charge & 0.002 \\
Electric power construction fund & 0.020 \\
Three Gorges Project fund & 0.003 \\
Coal purchase fee* & 0.005 \\
& \\
Total & 0.258 \\
\end{tabular}

N.B. Tianjin Soda Plant is China's largest manufacturer of caustic soda, with output in 1992 of $610 \mathrm{kt}$, or nearly $54 \%$ of the national total. It supplies $44 \%$ of its own electricity needs with a $20 \mathrm{MW}$ power plant, at a cost of generation of 75.6 yuan/MWh.

* In order to fulfill generation targets some utilities need to buy additional coal at higher prices, and pass the extra expense through to customers.

Source: China Energy Research Society, 1995. 
Table VI-11. Anhui Grid Basic Electricity Rates, Effective 1993

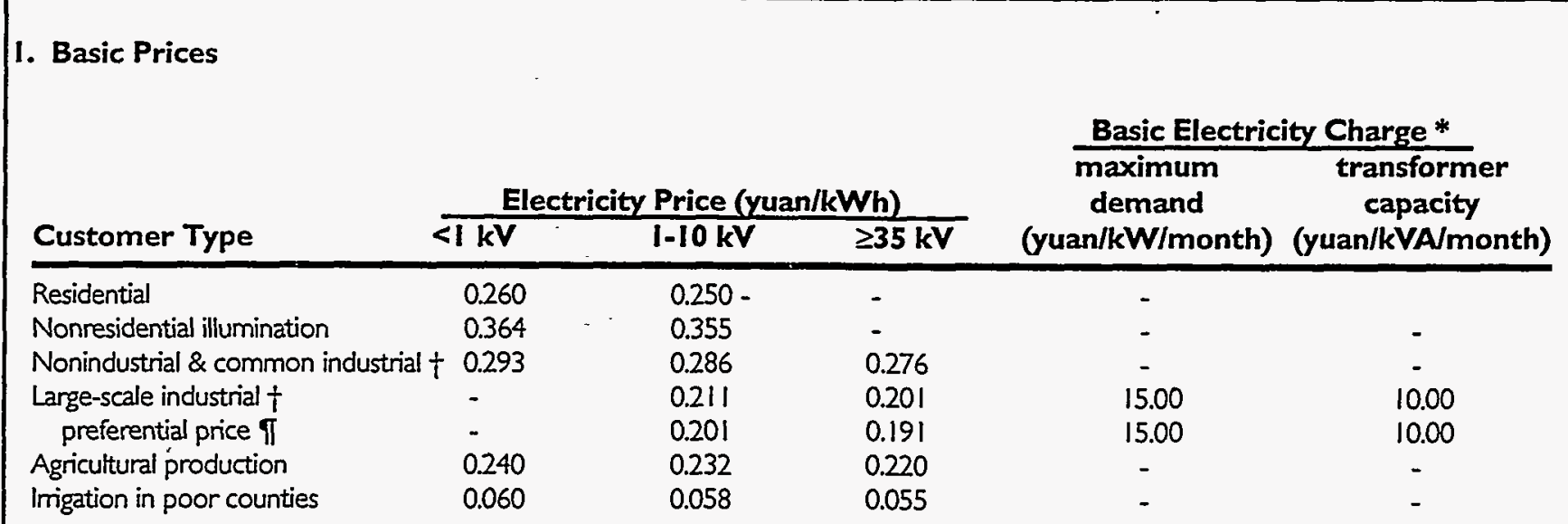

\begin{tabular}{|c|c|c|c|c|}
\hline \multirow[b]{2}{*}{ Customer Type } & \multicolumn{2}{|c|}{ County-level wholesale prices } & \multicolumn{2}{|c|}{ Below County-level wholesale prices } \\
\hline & $1-10 \mathrm{~kW}$ & $\geq 35 \mathrm{~kW}$ & $1.10 \mathrm{~kW}$ & $\geq 35 \mathrm{~kW}$ \\
\hline Residential & 0.187 & - & 0.205 & - \\
\hline Nonresidential illumination & 0.281 & - & 0.299 & - \\
\hline Industrial \& nonindustrial & 0.215 & 0.207 & 0.223 & 0.215 \\
\hline Agricultural production & 0.194 & 0.181 & 0.194 & 0.181 \\
\hline Irrigation in poor counties & 0.035 & 0.030 & 0.035 & 0.030 \\
\hline
\end{tabular}

N.B. Electricity rates are subject to a wide variety of taxes, surcharges, and additional tanifs depending on location and customer type. This rate schedule excludes surcharges to all customers nationally of 0.02 yuan/kWh for a utility construction fund and 0.003 yuan $/ \mathrm{kWh}$ for the Three Gorges Project fund. Retail rates paid by customers may be significantly higher and vary among cities and counties in the same province. All rates went into effect on 1 April, except residential rates, which went into effect on 1 July.

- Either maximum demand or transformer capacity is selected as the method of calculating base charges for each customer

$\dagger$ Fertilizer manufacturers are subject to preferential rates: $87 \%$ of ordinary industry list rates for small and medium plants, and $82 \%$ of large-scale industrial list rates for large fertilizer manufacturers.

For manufacturers of calcium carbide, electrolytic process caustic soda, yellow phosphorous, and synthetic ammonia.

Source: Editorial Board of the China Price Yearbook, 1994. 
Table VI-12. Beijing-Tianjin-Tangshan Grid Basic Electricity Rates, Effective 1993

\section{Basic Prices}

\begin{tabular}{|c|c|c|c|c|c|}
\hline \multirow[b]{3}{*}{ Customer Type } & \multirow{2}{*}{\multicolumn{3}{|c|}{ Electricity Price (yuan/kWh) }} & \multicolumn{2}{|c|}{ Basic Electricity Charge * } \\
\hline & & & & \multirow{2}{*}{$\begin{array}{c}\text { maximum } \\
\text { demand } \\
\text { (yuan/kW/month) }\end{array}$} & \multirow{2}{*}{$\begin{array}{c}\text { transformer } \\
\text { capacity } \\
\text { (yuan/kVA/month) }\end{array}$} \\
\hline & $<\mathbf{k V}$ & $1-10 \mathrm{kV}$ & $\geq 35 \mathrm{kV}$ & & \\
\hline Residential & 0.220 & 0.210 & 0.210 & - & - \\
\hline Nonresidential illumination & 0.307 & 0.297 & 0.297 & - & - \\
\hline Nonindustrial \& common industrial $\dagger$ & +0.268 & 0.261 & 0.252 & - & - \\
\hline Large-scale industrial $\dagger$ & - & 0.183 & 0.174 & 15.00 & 10.00 \\
\hline preferential price $\uparrow$ & - & 0.173 & 0.164 & 15.00 & 10.00 \\
\hline Agricultural & 0.218 & 0.211 & 0.200 & - & - \\
\hline Imigation in poor rural counties & 0.060 & 0.058 & 0.055 & - & - \\
\hline
\end{tabular}

\begin{tabular}{|c|c|c|c|c|c|c|}
\hline \multicolumn{7}{|c|}{ 2. Wholesale Prices (yuan/kWh) $¥$} \\
\hline \multirow[b]{2}{*}{ Customer Type } & \multicolumn{2}{|c|}{ Wholesale Schedule ! } & \multicolumn{2}{|c|}{ Wholesale Schedule 2} & \multicolumn{2}{|c|}{ Wholesale Schedule 3} \\
\hline & $1-10 \mathrm{~kW}$ & $\geq 35 \mathrm{~kW}$ & $1.10 \mathrm{~kW}$ & $\geq 35 \mathrm{~kW}$ & $1-10 \mathrm{~kW}$ & $\geq 35 \mathrm{~kW}$ \\
\hline Residential Use & 0.161 & 0.161 & 0.158 & 0.158 & 0.180 & 0.180 \\
\hline Nonresidential illumination & 0.242 & 0.242 & 0.236 & 0.236 & 0.235 & 0.265 \\
\hline Industrial \& nonindustrial & 0.202 & 0.195 & 0.196 & 0.196 & 0.215 & - \\
\hline Agricultural production & 0.181 & 0.168 & 0.174 & 0.174 & 0.195 & - \\
\hline Irrigation in poor counties & 0.035 & 0.130 & 0.035 & 0.035 & - & - \\
\hline
\end{tabular}

3. Peak Pricing Schedule (yuan/kWh)

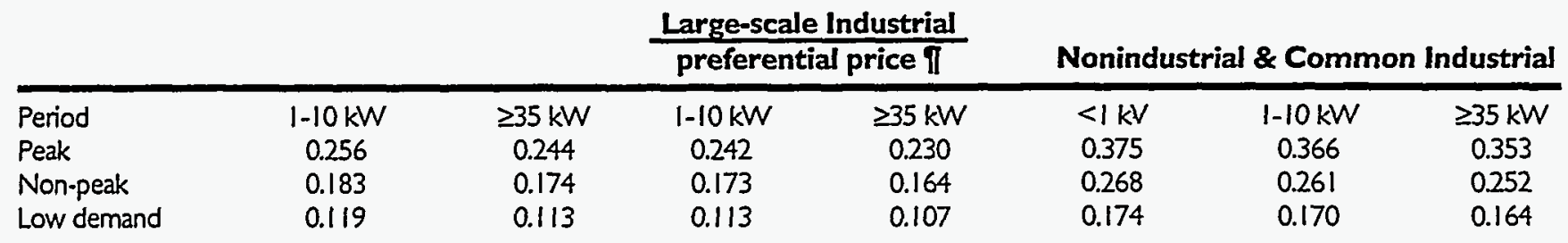

N.B. Electricity rates are subject to a wide variety of taxes, surcharges, and additional tarifs depending on location and customer type. This rate schedule excludes surcharges to all customers nationally of 0.02 yuan $/ \mathrm{kW}$ for a utility construction fund and 0.003 yuan $/ \mathrm{kWh}$ for the Three Gorges Project fund. Retail rates paid by customers may be significantly higher and vary among cities and counties in the same province. All rates went into effect on 1 April, except residential rates, which went into effect I July.

* Either maximum demand or transformer capacity is selected as the method of calculating base charges for each customer.

$\dagger$ Manufacturers of fertilizers are temporarily subject to preferential rates: $88 \%$ of ordinary industry list rates for small and medium plants, and $84 \%$ of large-scale industrial list rates for large plants.

I Preferential price is for manufacturers of caustic soda (electrolytic process), yellow phosphorous (electrolytic process), synthetic ammonia, and calcium carbide.

$¥$ The three wholesale schedules apply respectively to (1) counties with line losses $<6 \%$, (2) counties with line losses $\geq 6 \%$, and (3) suburban counties.

Source: Editorial Board of the China Price Yearbook, 1994; Wang et al., 1995. 
Table VI-13. Fujian Grid Basic Electricity Rates, Effective 1993

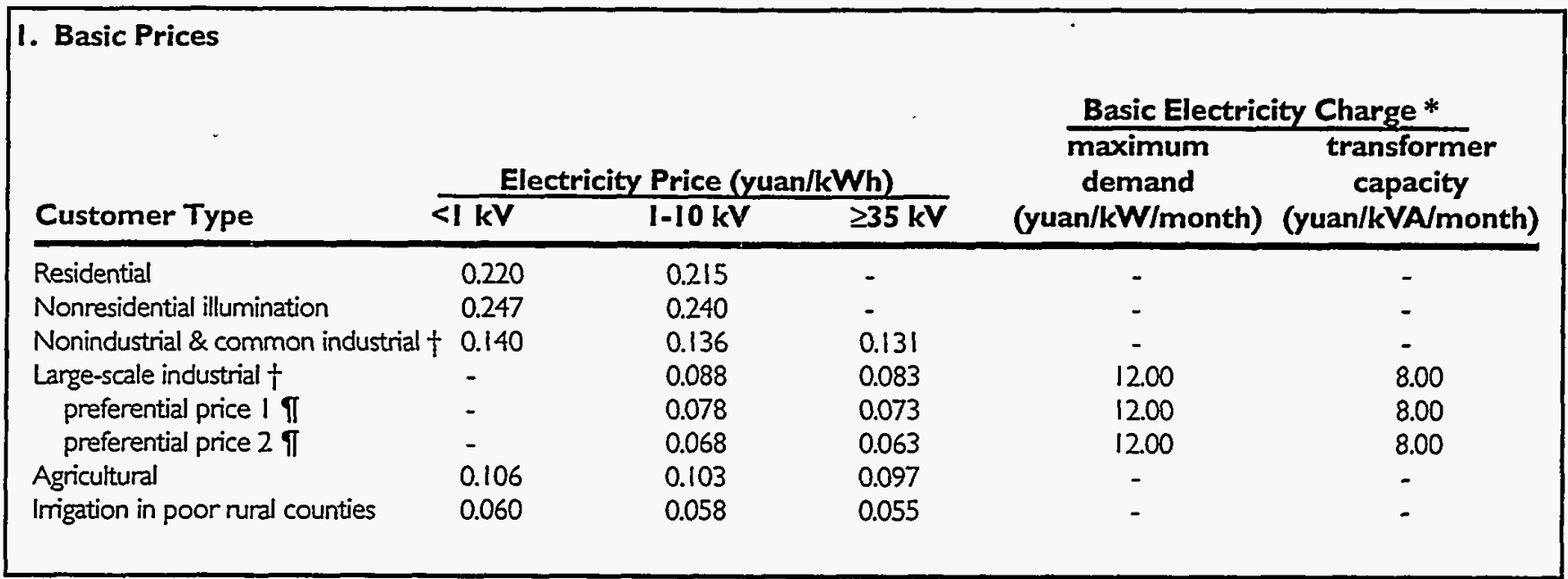

2. Wholesale Prices (yuan/kWh)

\begin{tabular}{|c|c|c|c|c|}
\hline \multirow[b]{2}{*}{ Customer Type } & \multicolumn{2}{|c|}{ County-level wholesale prices } & \multicolumn{2}{|c|}{ Below County-level wholesale prices } \\
\hline & $1-10 \mathrm{~kW}$ & $\geq 35 \mathrm{~kW}$ & $1.10 \mathrm{~kW}$ & $\geq 35 \mathrm{~kW}$ \\
\hline Residential & 0.153 & - & 0.169 & - \\
\hline Nonresidential illumination & 0.174 & 0.174 & 0.193 & 0.193 \\
\hline Industrial & 0.095 & 0.092 & 0.103 & 0.100 \\
\hline Agricultural production & 0.072 & 0.065 & 0.072 & 0.065 \\
\hline Irigation in poor counties & 0.035 & 0.030 & 0.035 & 0.030 \\
\hline
\end{tabular}

N.B. Electricity rates are subject to a wide variety of taxes, surcharges, and additional tarrifs depending on location and customer type. This rate schedule excludes surcharges to all customers nationally of 0.02 yuan $/ \mathrm{kWh}$ for a utility construction fund and 0.003 yuankWh for the Three Gorges Project fund. Retail rates paid by customers may be significantly higher and vary among cities and counties in the same province. All rates went into effect on 1 October.

* Either maximum demand or transformer capacity is selected as the method of calculating base charges for each customer.

$\dagger$ Manufacturers of fertilizers are temporarily subject to preferential rates: large-scale industry list rates for small and medium plants, and $54 \%$ of large-scale industrial list rates for large plants.

I Preferential price 1 is for manufacturers of caustic soda (electrolytic process), ferrous alloys (electric fumace), yellow phosphorous (electrolytic process), synthetic ammonia, and calcium, phosphorus, and magnesium fertilizers (electric fumace). Preferential price 2 is for manufacturers of calcium carbide. In addition, certain pesticide, calcium carbide, and aluminum manufacturers were allowed to continue paying the low rates that they were subject to before implementation of the new schedule.

Source: Editorial Board of the China Price Yearbook, 1994. 
Table VI-14. Gansu Grid Basic Electricity Rates, Effective 1993

\begin{tabular}{|c|c|c|c|c|c|}
\hline \multicolumn{6}{|l|}{ I. Basic Prices } \\
\hline \multirow[b]{3}{*}{ Customer Type } & \multirow{2}{*}{\multicolumn{3}{|c|}{ Electricity Price (yuan/kWh) }} & \multicolumn{2}{|c|}{ Basic Electricity Charge * } \\
\hline & & & & demand & capacity \\
\hline & $<\mathrm{kV}$ & $1-10 \mathrm{kV}$ & $\geq 35 \mathrm{kV}$ & (yuan/kW/month) & (yuan/kVA/month) \\
\hline Residential & 0.220 & 0.210 & 0.210 & - & - \\
\hline Nonresidential illumination & 0.294 & 0.287 & 0.287 & - & - \\
\hline Nonindustrial \& common industrial & +0.232 & 0.228 & 0.222 & - & - \\
\hline Lange-scale industrial $f$ & - & 0.164 & 0.160 & 13.50 & 9.00 \\
\hline preferential price I I] & - & 0.125 & 0.120 & 13.50 & 9.00 \\
\hline preferential price $2 \pi$ & - & 0.115 & 0.110 & 13.50 & 9.00 \\
\hline Agricultural & 0.157 & 0.152 & 0.144 & - & - \\
\hline Irrigation in poor rural counties & 0.060 & 0.058 & 0.055 & - & - \\
\hline
\end{tabular}

2. Wholesale Prices (yuan/kWh)

\begin{tabular}{lccccc} 
& \multicolumn{2}{c}{ County-level wholesale prices } & & \multicolumn{2}{c}{ Below County-level wholesale prices } \\
\cline { 2 - 3 } \cline { 5 - 6 } Customer Type & $\mathbf{1 - 1 0} \mathbf{~ k W}$ & $\mathbf{3 5} \mathbf{~ k W}$ & & $\mathbf{1 0} \mathbf{~ k W}$ & $\mathbf{3 5} \mathbf{k W}$ \\
\hline Residential & 0.157 & 0.157 & 0.176 & 0.176 \\
Nonresidential illumination & 0.206 & 0.206 & 0.225 & 0.225 \\
Industrial & 0.153 & 0.150 & 0.164 & 0.161 \\
Agricultural production & 0.107 & 0.099 & 0.107 & 0.099 \\
Inigation in poor counties & 0.035 & 0.030 & & 0.035 & 0.030 \\
\hline
\end{tabular}

N.B. Electricity rates are subject to a wide variety of taxes, surcharges, and additional tariffs depending on location and customer type. This rate schedule excludes surcharges to all customers nationally of 0.02 yuan $/ \mathrm{kWh}$ for a utility construction fund and 0.003 yuan/ $\mathrm{kWh}$ for the Three Gorges Project fund. Retail rates paid by customers may be significantly higher and vary among cities and counties in the same province. All rates went into effect on 1 April, except residential rates, which went into effect on 1 July.

- Either maximum demand or transformer capacity is selected as the method of calculating base charges for each customer.

$\dagger$ Manufacturers of fertilizers are temporarily subject to preferential rates: $87 \%$ of ordinary industry list rates for small and medium plants, and $82 \%$ of large-scale industrial list rates for large plants.

I Preferential price 1 is for manufacturers of caustic soda (electrolytic process), ferrous alloys (electric furnace), yellow phosphorous (electrolytic process), synthetic ammonia, and calcium, phosphons, and magnesium fertilizers (electric fumace). Preferential price 2 is for manufacturers of calcium carbide.

Source: Editorial Board of the China Price Yearbook, 1994. 
Table VI-15. Guangxi Grid Basic Electricity Rates, Effective 1993

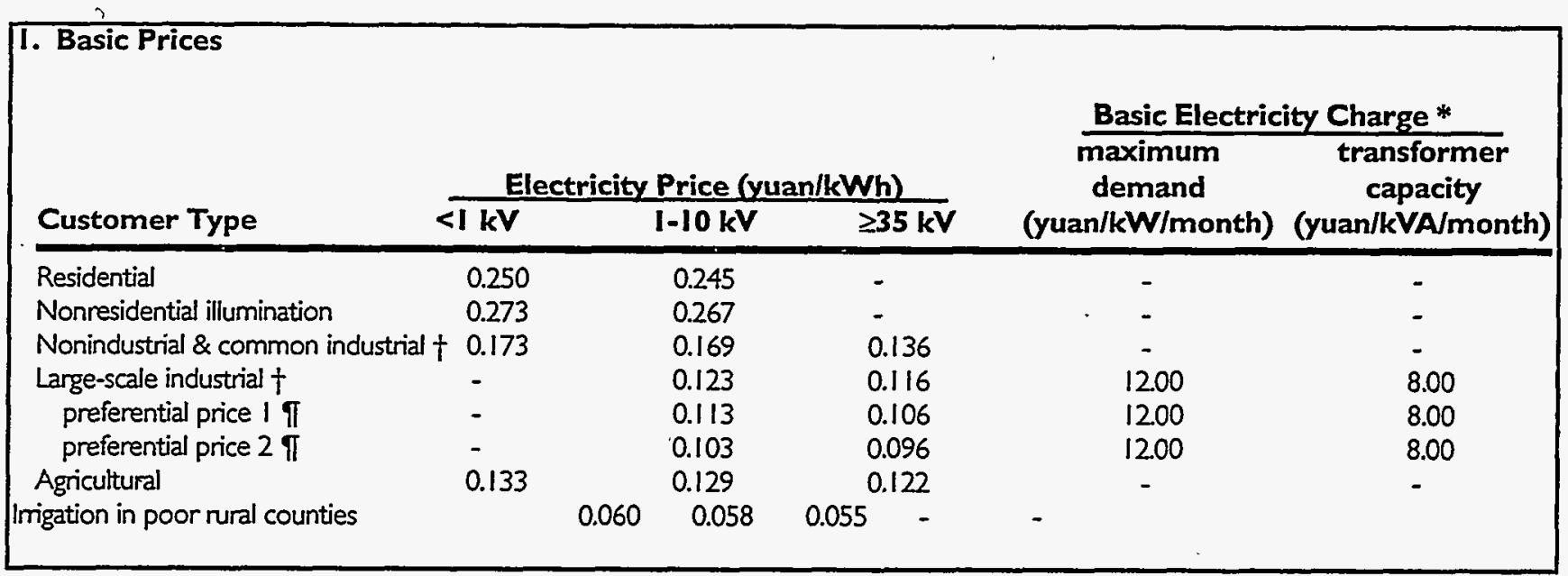

2. Wholesale Prices (yuan/kWh)

\begin{tabular}{lccccc} 
& \multicolumn{2}{c}{ County-level wholesale prices } & & \multicolumn{2}{c}{ Below County-level wholesale prices } \\
\cline { 2 - 3 } Customer Type & $\mathbf{1 - 1 0} \mathbf{~ k W}$ & $\mathbf{3 5 \mathbf { k W }}$ & & $\mathbf{1 - 1 0} \mathbf{k W}$ & $\mathbf{3 5} \mathbf{k W}$ \\
\hline Residential & 0.175 & 0.175 & & 0.194 & 0.194 \\
Nonresidential illumination & 0.201 & 0.201 & & 0.220 & 0.220 \\
Industrial & 0.124 & 0.120 & & 0.132 & 0.128 \\
Agricultural production & 0.102 & 0.093 & & 0.102 & 0.093 \\
Irrigation in poor counties & 0.035 & 0.030 & & 0.035 & 0.030
\end{tabular}

N.B. Electricity rates are subject to a wide variety of taxes, surcharges, and additional tarrifs depending on location and customer type. This rate schedule excludes surcharges to all customers nationally of 0.02 yuankWh for a utility construction fund and 0.003 yuan/kWh for the Three Gorges Project fund. Retail rates paid by customers may be significantly higher and vary among cities and counties in the same province. All rates went into effect on 1 October.

* Either maximum demand or transformer capacity is selected as the method of calculating base charges for each customer.

$\dagger$ Manufacturers of fertilizers are temporarily subject to unspecified preferential rates.

I. Preferential price 1 is for manufacturers of caustic soda (electrolytic process), ferrous alloys (electric furnace), yellow phosphorous (electrolytic process), synthetic ammonia, and calcium, phosphorus, and magnesium fertilizers (electric fumace). Preferential price 2 is for manufacturers of calcium carbide.

Source: Editorial Board of the China Price Yearbook, 1994. 
Table V1-16. Guizhou Grid Basic Electricity Rates, Effective 1993

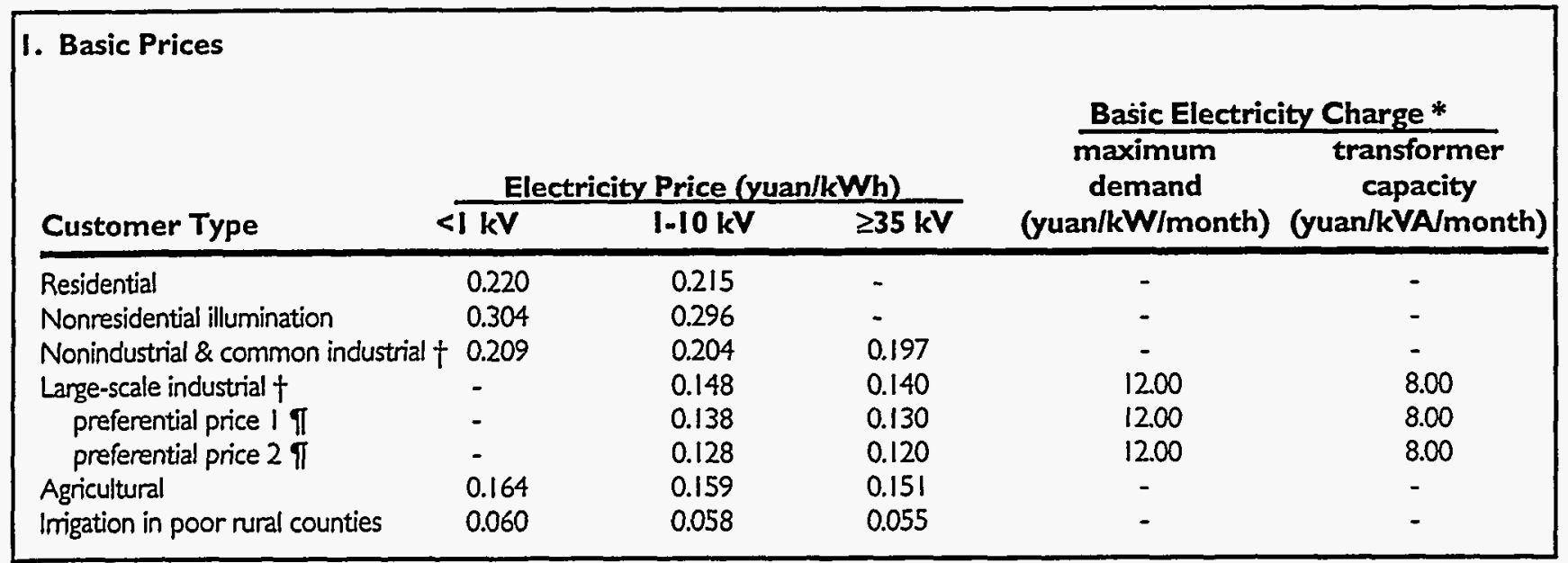

\section{Wholesale Prices (yuan/kWh)}

\begin{tabular}{|c|c|c|c|c|}
\hline \multirow[b]{2}{*}{ Customer Type } & \multicolumn{2}{|c|}{ County-level wholesale prices } & \multicolumn{2}{|c|}{ Below County-level wholesale prices } \\
\hline & $1-10 \mathrm{~kW}$ & $\geq 35 \mathrm{~kW}$ & $1.10 \mathrm{~kW}$ & $\geq 35 \mathrm{~kW}$ \\
\hline Residential & 0.154 & - & 0.173 & - \\
\hline Nonresidential illumination & 0.224 & 0.244 & 0.243 & 0.243 \\
\hline Industrial & 0.148 & 0.142 & 0.156 & 0.150 \\
\hline Agricultural production & 0.125 & 0.116 & 0.125 & 0.116 \\
\hline Irrigation in poor counties & 0.035 & 0.030 & 0.035 & 0.030 \\
\hline
\end{tabular}

N.B. Electricity rates are subject to a wide variety of taxes, surcharges, and additional tariffs depending on location and customer type. This rate schedule excludes surcharges to all customers nationally of 0.02 yuan/kWh for a utility construction fund and 0.003 yuan/kWh for the Three Gorges Project fund. Retail rates paid by customers may be significantly higher and vary among cities and counties in the same province. All rates went into effect on 1 July, except residential rates, which went into effect on 1 December.

* Either maximum demand or transformer capacity is selected as the method of calculating base charges for each customer.

+ Fertilizer manufacturers are subject to preferential rates: $72 \%$ of ordinary industry list rates for small and medium plants, and $60 \%$ of large-scale industrial list rates for large plants.

1 Preferential price 1 is for manufacturers of caustic soda (electrolytic process), ferrous alloys (electric fumace), yellow phosphorous (electrolytic process), synthetic ammonia, and calcium, phosphons, and magnesium fertilizers (electric fumace).

Source: Editorial Board of the China Price Yearbook, 1994. 
Table VI-17. Hebei Grid Basic Electricity Rates, Effective 1993

\begin{tabular}{|c|c|c|c|c|c|}
\hline 1. Basic Prices & & & & Basic Electric & ity Charge * \\
\hline \multirow[b]{2}{*}{ Customer Type } & \multicolumn{3}{|c|}{ Electricity Price (yuan/kWh) } & $\begin{array}{l}\text { maximum } \\
\text { demand }\end{array}$ & $\begin{array}{c}\text { transformer } \\
\text { capacity }\end{array}$ \\
\hline & <I kV & $\mathrm{I}-10 \mathrm{kV}$ & $\geq 35 \mathrm{kV}$ & (yuan/kW/month) & (yuan/kVA/month) \\
\hline Residential & 0.220 & 0.210 & 0.210 & - & - \\
\hline Nonresidential illumination & 0.335 & 0.324 & 0.324 & - & - \\
\hline Nonindustrial \& common industrial t & $\dagger 0.305$ & 0.297 & 0.587 & - & - \\
\hline Large-scale industrial $\dagger$ & - & 0.222 & 0.211 & 15.00 & 10.00 \\
\hline preferential price $\mathbb{\pi}$ & - & 0.212 & 0.201 & 15.00 & 10.00 \\
\hline Agricultural & 0.245 & 0.237 & 0.225 & - & - \\
\hline Irrigation in poor rural counties & 0.060 & 0.058 & 0.055 & - & - \\
\hline
\end{tabular}

2. Wholesale Prices (yuan/kWh)

\begin{tabular}{lccccc} 
& \multicolumn{2}{c}{ County-level wholesale prices } & & \multicolumn{2}{c}{ Below County-level wholesale prices } \\
\cline { 2 - 3 } Customer Type & $\mathbf{1 - 1 0} \mathbf{~ k W}$ & $\mathbf{3 5 \mathbf { k W }}$ & & $\mathbf{1 0} \mathbf{~ k W}$ & $\mathbf{3 5 \mathbf { k W }}$ \\
\hline Residential & 0.164 & 0.164 & & 0.179 & 0.179 \\
Nonresidential illumination & 0.262 & 0.262 & & 0.276 & 0.276 \\
Industrial & 0.226 & 0.215 & & 0.231 & 0.223 \\
Agricultural production & 0.201 & 0.188 & & 0.201 & 0.188 \\
Imigation in poor rural counties & 0.035 & 0.030 & & 0.035 & 0.030
\end{tabular}

N.B. Electricity rates are subject to a wide variety of taxes, surcharges, and additional tariffs depending on location and customer type. This rate schedule excludes surcharges to all customers nationally of 0.02 yuan/kWh for a utility construction fund and 0.003 yuan $/ \mathrm{kWh}$ for the Three Gorges Project fund. Retail rates paid by customers may be significantly higher and vary among cities and counties in the same province. All rates went into effect on 1 April, except residential rates, which went into effect on 1 July.

* Either maximum demand or transformer capacity is selected as the method of calculating base charges for each customer

$\dagger$ Manufacturers of fertilizers are temporarily subject to preferential rates: $80 \%$ of ordinary industry list rates for small and medium plants, and $73 \%$ of large-scale industrial list rates for large plants.

I Preferential price is for manufacturers of caustic soda (electrolytic process), yellow phosphorous (electrolytic process), synthetic ammonia, and calcium carbide.

Source: Editorial Board of the China Price Yearbook, 1994. 
Table VI-18. Henan Grid Basic Electricity Rates, Effective 1993

1. Basic Prices

\begin{tabular}{|c|c|c|c|c|c|}
\hline \multirow[b]{3}{*}{ Customer Type } & \multirow{2}{*}{\multicolumn{3}{|c|}{ Electricity Price (yuan $/ k W h$ ) }} & \multicolumn{2}{|c|}{ Basic Electricity Charge * } \\
\hline & & & & \multirow{2}{*}{$\begin{array}{c}\text { maximum } \\
\text { demand } \\
\text { (yuan/kW/month) }\end{array}$} & \multirow{2}{*}{$\begin{array}{c}\text { transformer } \\
\text { capacity } \\
\text { (yuan/kVA/month) }\end{array}$} \\
\hline & $<1 \mathrm{kV}$ & $1-10 \mathrm{kV}$ & $\geq 35 \mathrm{kV}$ & & \\
\hline Residential & 0.220 & 0.215 & - & - & - \\
\hline Nonresidential illumination & 0.299 & 0.292 & - & - & - \\
\hline Nonindustrial \& common industrial $†$ & +0.204 & 0.199 & $0: 192$ & - & - \\
\hline Large-scale industrial t & - & 0.139 & 0.132 & 13.50 & 9.00 \\
\hline preferential price i $/ \pi$ & - & 0.129 & 0.122 & 13.50 & 9.00 \\
\hline preferential price $2 \pi$ & - & 0.119 & 0.112 & 13.50 & 9.00 \\
\hline Agricultural & 0.159 & 0.153 & 0.145 & - & - \\
\hline Inigation in poor rural counties & 0.060 & 0.058 & 0.055 & - & - \\
\hline
\end{tabular}

2. Wholesale Prices (yuan/kWh)

\begin{tabular}{|c|c|c|c|c|}
\hline \multirow[b]{2}{*}{ Customer Type } & \multicolumn{2}{|c|}{ County-level wholesale prices } & \multicolumn{2}{|c|}{ Below County-level wholesale prices. } \\
\hline & $1.10 \mathrm{~kW}$ & $\geq 35 \mathrm{~kW}$ & $1-10 \mathrm{~kW}$ & $\geq 35 \mathrm{~kW}$ \\
\hline Residential & 0.157 & - & 0.176 & - \\
\hline Nonresidential illumination & 0.223 & 0.223 & 0.242 & 0.242 \\
\hline Industrial & 0.146 & 0.141 & 0.154 & 0.149 \\
\hline Agricultural production & 0.122 & 0.113 & 0.122 & 0.113 \\
\hline Imigation in poor counties & 0.035 & 0.030 & 0.035 & 0.030 \\
\hline
\end{tabular}

N.B. Electricity rates are subject to a wide variety of taxes, surcharges, and additional tariffs depending on location and customer type. This rate schedule excludes surcharges to all customers nationally of 0.02 yuan $/ \mathrm{kWh}$ for a utility construction fund and 0.003 yuan $/ \mathrm{kWh}$ for the Three Gorges Project fund. Retail rates paid by customers may be significantly higher and vary among cities and counties in the same province. All rates went into effect on 1 October.

* Either maximum demand or transformer capacity is selected as the method of calculating base charges for each customer.

$\dagger$ Manufacturers of fertilizers are temporarily subject to preferential rates: $95 \%$ of ordinary industry list rates for small and medium plants, and $93 \%$ of large-scale industrial list rates for large plants.

1 Preferential price 1 is for manufacturers of caustic soda (electrolytic process), ferrous alloys (electric furnace), yellow phosphorous (electrolytic process), synthetic ammonia, and calcium, phosphorus, and magnesium fertilizers (electric fumace). Preferential price 2 is for manufacturers of calcium carbide.

Source: Editorial Board of the China Price Yearbook, 1994. 
Table VI-19. Hubei Grid Basic Electricity Rates, Effective 1993

I. Basic Prices

\begin{tabular}{|c|c|c|c|c|c|}
\hline \multirow[b]{3}{*}{ Customer Type } & \multirow{2}{*}{\multicolumn{3}{|c|}{ Electricity Price (yuan/kWh) }} & \multicolumn{2}{|c|}{ Basic Electricity Charge* } \\
\hline & & & & $\begin{array}{l}\text { maximum } \\
\text { demand }\end{array}$ & $\begin{array}{c}\text { transformer } \\
\text { capacity }\end{array}$ \\
\hline & $<I \mathrm{kV}$ & $1-10 \mathrm{kV}$ & $\geq 35 \mathrm{kV}$ & (yuan/kW/month) & (yuan/kVA/month) \\
\hline Residential & 0.250 & 0.245 & 0.254 & - & - \\
\hline Nonresidential illumination & 0.341 & 0.332 & 0.332 & - & - \\
\hline Nonindustrial \& common industrial $\dagger$ & +0.252 & 0.246 & 0.238 & - & - \\
\hline Large-scale industrial $\dagger$ & - & 0.173 & 0.164 & 15.00 & 10.00 \\
\hline preferential price I $\pi$ & - & 0.163 & 0.154 & 15.00 & 10.00 \\
\hline preferential price $2 \pi$ & - & 0.153 & 0.144 & 15.00 & 10.00 \\
\hline Agricultural & 0.204 & 0.197 & 0.187 & - & - \\
\hline Irrigation in poor rural counties & 0.060 & 0.058 & 0.055 & - & - \\
\hline
\end{tabular}

\section{Wholesale Prices (yuan/kWh)}

\begin{tabular}{|c|c|c|c|c|}
\hline \multirow[b]{2}{*}{ Customer Type } & \multicolumn{2}{|c|}{ County-level wholesale prices } & \multicolumn{2}{|c|}{ Below County-level wholesale prices } \\
\hline & $\overline{I-10 \mathrm{~kW}}$ & $\geq 35 \mathrm{~kW}$ & $1.10 \mathrm{~kW}$ & $\geq 35 \mathrm{~kW}$ \\
\hline Residential & 0.176 & 0.176 & .0 .195 & 0.195 \\
\hline Nonresidential illumination & 0.257 & 0.257 & 0.276 & 0.276 \\
\hline Industrial & 0.179 & 0.172 & 0.187 & 0.180 \\
\hline Agricultural production & 0.157 & 0.145 & 0.157 & 0.145 \\
\hline Irrigation in poor counties & 0.035 & 0.030 & 0.035 & 0.030 \\
\hline
\end{tabular}

N.B. Electricity rates are subject to a wide variety of taxes, surcharges, and additional tariffs depending on location and customer type. This rate schedule excludes surcharges to all customers nationally of 0.02 yuan/kWh for a utility construction fund and 0.003 yuan/kWh for the Three Gorges Project fund. Retail rates paid by customers may be significantly higher and vary among cities and counties in the same province. All rates went into effect on 1 April, except residential rates, which went into effect on 1 July.

* Either maximum demand or transformer capacity is selected as the method of calculating base charges for each customer.

$\dagger$ Manufacturers of fertilizers are temporarily subject to preferential rates: $74 \%$ of ordinary industry list rates for small and medium plants, and $62 \%$ of large-scale industrial list rates for large plants.

I Preferential price 1 is for manufacturers of caustic soda (electrolytic process), ferrous alloys (electric fumace), yellow phosphorous (electrolytic process), synthetic ammonia, and calcium, phosphorus, and magnesium fertilizers (electric fumace). Preferential price 2 is for manufacturers of calcium carbide.

Source: Editorial Board of the China Price Yearbook, 1994. 
Table VI-20. Hunan Grid Basic Electricity Rates, Effective 1993

I. Basic Prices

\begin{tabular}{|c|c|c|c|c|c|}
\hline \multirow[b]{3}{*}{ Customer Type } & \multirow{2}{*}{\multicolumn{3}{|c|}{ Electricity Price (yuan $/ \mathrm{kWh}$ ) }} & \multicolumn{2}{|c|}{ Basic Electricity Charge* } \\
\hline & & & & \multirow{2}{*}{$\begin{array}{c}\text { maximum } \\
\text { demand } \\
\text { (yuan/kW/month) }\end{array}$} & \multirow{2}{*}{$\begin{array}{c}\text { transformer } \\
\text { capacity } \\
\text { (yuan/kVA/month) }\end{array}$} \\
\hline & $<1 \mathrm{kV}$ & $1-10 \mathrm{kV}$ & $\geqslant 35 \mathrm{kV}$ & & \\
\hline Residential & 0.250 & 0.245 & - & - & - \\
\hline Nonresidential illumination & 0.356 & 0.347 & - & - & - \\
\hline Nonindustrial \& common industrial $\dagger$ & $\dagger 0.269$ & 0.263 & 0.253 & - & - \\
\hline Large-scale industrial $t$ & - & 0.191 & 0.181 & 15.00 & 10.00 \\
\hline preferential price I $\pi$ & - & 0.181 & 0.171 & 15.00 & 10.00 \\
\hline preferential price $2 \pi$ & - & 0.171 & 0.161 & 15.00 & 10.00 \\
\hline Agricultural & 0.147 & 0.139 & 0.129 & - & - \\
\hline Imigation in poor rural counties & 0.110 & 0.108 & 0.105 & - & - \\
\hline
\end{tabular}

2. Wholesale Prices (yuan/kWh)

\begin{tabular}{|c|c|c|c|c|}
\hline \multirow[b]{2}{*}{ Customer Type } & \multicolumn{2}{|c|}{ County-level wholesale prices } & \multicolumn{2}{|c|}{ Below County-level wholesale prices } \\
\hline & $1-10 \mathrm{~kW}$ & $\geq 35 \mathrm{~kW}$ & $1-10 \mathrm{~kW}$ & $\geq 35 \mathrm{~kW}$ \\
\hline Residential & 0.187 & - & - & - \\
\hline Nonresidential illumination & 0.267 & - & - & - \\
\hline Industrial \& nonindustrial & 0.189 & 0.182 & - & - \\
\hline Agricultural production & 0.105 & 0.093 & - & - \\
\hline Irigation in poor counties & 0.078 & 0.073 & - & - \\
\hline
\end{tabular}

N.B. Electricity rates are subject to a wide variety of taxes, surcharges, and additional tariffs depending on location and customer type. This rate schedule excludes surcharges to all customers nationally of 0.02 yuan $/ \mathrm{kWh}$ for a utility construction fund and 0.003 yuan $/ \mathrm{kWh}$ for the Three Gorges Project fund. Retail rates paid by customers may be significantly higher and vary among cities and counties in the same province. All rates went into effect on 1 January, except residential rates, which went into effect 1 April.

- Either maximum demand or transformer capacity is selected as the method of calculating base charges for each customer.

$\dagger$ Ammonium bicarbonate, phosphorus fertilizer, and ammonium chloride manufacturers are temporarily subject to preferential rates: 93.2\% of ordinary industry list rates for small and medium plants, and $90.5 \%$ of large-scale industrial list rates for large fertilizer manufacturers.

I Preferential price 1 is for manufacturers of caustic soda (electrolytic process), ferrous alloys (electric furnace), yellow phosphorous (electrolytic process), synthetic ammonia, and calcium, phosphorus, and magnesium fertilizers (electric furnace). Preferential price 2 is for manufacturers of calcium carbide. 


\section{Basic Prices, Western Mongolia Grid}

\begin{tabular}{|c|c|c|c|c|c|}
\hline \multirow[b]{3}{*}{ Customer Type } & \multirow{2}{*}{\multicolumn{3}{|c|}{ Electricity Price (yuan/kWh) }} & \multicolumn{2}{|c|}{ Basic Electricity Charge * } \\
\hline & & & & \multirow{2}{*}{$\begin{array}{c}\text { maximum } \\
\text { demand } \\
\text { (yuan/kW/month) }\end{array}$} & \multirow{2}{*}{$\begin{array}{c}\text { transformer } \\
\text { capacity } \\
\text { (yuan/kVA/month) }\end{array}$} \\
\hline & <ा kV & $1.10 \mathrm{kV}$ & $\geq 35 \mathrm{kV}$ & & \\
\hline Residential & 0.220 & 0.210 & 0.210 & - & - \\
\hline Nonresidential illumination & 0.268 & 0.260 & 0.260 & - & - \\
\hline Nonindustrial \& common industrial & 0.200 & 0.196 & 0.188 & - & - \\
\hline Large-scale industrial & - & 0.140 & 0.133 & 13.50 & 9.00 \\
\hline preferential price $1+$ & - & 0.130 & 0.123 & 13.50 & 9.00 \\
\hline preferential price $2 \nmid$ & - & 0.120 & 0.123 & 13.50 & 9.00 \\
\hline Agricultural & 0.158 & 0.153 & 0.145 & - & - \\
\hline Irrigation in poor rural counties & 0.094 & 0.092 & 0.089 & - & - \\
\hline
\end{tabular}

\section{Basic Prices, Eastern Mongolia Grid}

\begin{tabular}{|c|c|c|c|c|c|}
\hline \multirow[b]{3}{*}{ Customer Type } & \multirow{2}{*}{\multicolumn{3}{|c|}{ Electricity Price (yuan/kWh) }} & \multicolumn{2}{|c|}{ Basic Electricity Charge * } \\
\hline & & & & maximum & transformer \\
\hline & $\langle\overline{k V}$ & $1-10 \mathrm{kV}$ & $\geq 35 \mathrm{kV}$ & (yuan/kW/month) & (yuan/kVA/month) \\
\hline Residential & 0.220 & 0.210 & 0.210 & - & - \\
\hline Ṅonresidential illumination & 0.335 & 0.327 & 0.327 & - & - \\
\hline Nonindustrial \& common industrial & 0.277 & 0.272 & 0.266 & - & - \\
\hline Large-scale industrial & - & 0.172 & 0.168 & 15.00 & 10.00 \\
\hline Agricultural & 0.193 & 0.187 & 0.177 & - & - \\
\hline Irrigation in poor rural counties & 0.086 & 0.084 & 0.081 & - & - \\
\hline
\end{tabular}

N.B. Electricity rates are subject to a wide variety of taxes, surcharges, and additional tariffs depending on location and customer type. This rate schedule excludes surcharges to all customers nationally of 0.02 yuan $/ \mathrm{kWh}$ for a utility construction fund and 0.003 yuan/kWh for the Three Gorges Project fund. Retail rates paid by customers may be significantly higher and vary among cities and counties in the same province. All rates went into effect on 1 July.

* Either maximum demand or transformer capacity is selected as the method of calculating base charges for each customer.

$\dagger$ Preferential price 1 is for manufacturers of caustic soda (electrolytic process), ferrous alloys (electric furnace), yellow phosphorous (electrolytic process), synthetic ammonia, and calcium, phosphonus, and magnesium fertilizers (electric fumace). Preferential price 2 is for manufacturers of calcium carbide.

Source: Editorial Board of the China Price Yearbook, 1994. 
Table VI-21. Inner Mongolia Grid Basic Electricity Rates, Effective 1993 (continued)

3. Wholesale Prices, Western Mongolia Grid (yuan/kWh)

\begin{tabular}{|c|c|c|c|c|}
\hline \multirow[b]{2}{*}{ Customer Type } & \multicolumn{2}{|c|}{ County-level wholesale prices } & \multicolumn{2}{|c|}{ Below County-level wholesale prices } \\
\hline & $1.10 \mathrm{~kW}$ & $\geq 35 \mathrm{~kW}$ & $1-10 \mathrm{~kW}$ & $\geq 35 \mathrm{~kW}$ \\
\hline Residential & 0.156 & 0.156 & 0.172 & 0.172 \\
\hline Nonresidential illumination & 0.201 & 0.201 & 0.217 & 0.217 \\
\hline Industrial & 0.144 & 0.139 & 0.152 & 0.147 \\
\hline Agricultural production & 0.122 & 0.112 & 0.122 & 0.112 \\
\hline Irigation in poor counties & 0.069 & 0.064 & 0.069 & 0.064 \\
\hline
\end{tabular}

4. Wholesale Prices, Eastern Mongolia Grid (yuan/kWh)

\begin{tabular}{|c|c|c|c|c|}
\hline \multirow[b]{2}{*}{ Customer Type } & \multicolumn{2}{|c|}{ County-level wholesale prices } & \multicolumn{2}{|c|}{ Below County-level wholesale prices } \\
\hline & $1.10 \mathrm{~kW}$ & $\geq 35 \mathrm{~kW}$ & $1-10 \mathrm{~kW}$ & $\geq 35 \mathrm{~kW}$ \\
\hline Residential & 0.150 & 0.155 & 0.169 & 0.169 \\
\hline Nonresidential illumination & 0.255 & 0.255 & 0.274 & 0.274 \\
\hline Industrial & 0.201 & 0.196 & 0.212 & 0.207 \\
\hline Agricultural production & 0.160 & 0.148 & 0.060 & 0.148 \\
\hline Irrigation in poor counties & 0.058 & 0.053 & 0.058 & 0.053 \\
\hline
\end{tabular}


Table VI-22. Jiangsu Grid Basic Electricity Rates, Effective 1993

1. Basic Prices

\begin{tabular}{|c|c|c|c|c|c|}
\hline \multirow[b]{3}{*}{ Customer Type } & \multirow{2}{*}{\multicolumn{3}{|c|}{ Electricity Price (yuan/kWh) }} & \multicolumn{2}{|c|}{ Basic Electricity Charge * } \\
\hline & & & & \multirow{2}{*}{$\begin{array}{c}\text { maximum } \\
\text { demand } \\
\text { (yuan/kW/month) }\end{array}$} & \multirow{2}{*}{$\begin{array}{c}\text { transformer } \\
\text { capacity } \\
\text { (yuan/kVA/month) }\end{array}$} \\
\hline & $<\mathrm{lkV}$ & $\mathrm{I}-10 \mathrm{kV}$ & $\geq 35 \mathrm{kV}$ & & \\
\hline Residential & 0.260 & 0.250 & - & - & - \\
\hline Nonresidential illumination & 0.379 & 0.369 & - & - & - \\
\hline Nonindustrial \& common industrial $\dagger$ & $\dagger 0.302$ & 0.295 & 0.284 & - & - \\
\hline Large-scale industrial $\dagger$ & - & 0.213 & 0.202 & 15.00 & 10.00 \\
\hline preferential price $\mathbb{T}$ & - & 0.203 & 0.192 & 15.00 & 10.00 \\
\hline Agricultural production & 0.250 & 0.242 & 0.229 & - & - \\
\hline Irrigation in poor counties & 0.060 & 0.058 & 0.055 & - & - \\
\hline
\end{tabular}

2. Wholesale Prices (yuan/kWh)

\begin{tabular}{|c|c|c|c|c|}
\hline \multirow[b]{2}{*}{ Customer Type } & \multicolumn{2}{|c|}{ County-level wholesale prices } & \multicolumn{2}{|c|}{ Below County-level wholesale prices } \\
\hline & $1-10 \mathrm{~kW}$ & $\geq 35 \mathrm{~kW}$ & $1.10 \mathrm{~kW}$ & $\geq 35 \mathrm{~kW}$ \\
\hline Residential & 0.185 & - & 0.203 & - \\
\hline Nonresidential illumination & 0.290 & - & 0.308 & - \\
\hline Industrial \& nonindustrial & 0.224 & 0.216 & 0.232 & 0.224 \\
\hline Agricultural production & 0.204 & 0.190 & 0.204 & 0.190 \\
\hline Imigation in poor counties & 0.035 & 0.030 & 0.035 & 0.030 \\
\hline
\end{tabular}

N.B. Electricity rates are subject to a wide variety of taxes, surcharges, and additional tariffs depending on location and customer type. This rate schedule excludes surcharges to all customers nationally of 0.02 yuan/ $\mathrm{kWh}$ for a utility construction fund and 0.003 yuan $\mathrm{kWh}$ for the Three Gorges Project fund. Retail rates paid by customers may be significantly higher and vary among cities and counties in the same province. All rates went into effect on 1 April, except residential rates, which went into effect on 1 July.

* Either maximum demand or transformer capacity is selected as the method of calculating base charges for each customer.

† Fertilizer manufacturers are subject to preferential rates: $89 \%$ of ordinary industry list rates for small and medium plants, and $85 \%$ of largescale industrial list rates for large-scale fertilizer manufacturers.

I For manufacturers of calcium carbide, electrolytic process caustic soda, yellow phosphorous, and synthetic ammonia.

Source: Editorial Board of the China Price Yearbook, 1994. 
Table VI-23. Jiangxi Grid Basic Electricity Rates, Effective 1993

I. Basic Prices

\begin{tabular}{|c|c|c|c|c|c|}
\hline \multirow[b]{3}{*}{ Customer Type } & \multirow{2}{*}{\multicolumn{3}{|c|}{ Electricity Price (yuan/kWh) }} & \multicolumn{2}{|c|}{ Basic Electricity Charge * } \\
\hline & & & & \multirow{2}{*}{$\begin{array}{c}\text { maximum } \\
\text { demand } \\
\text { (yuan/kW/month) }\end{array}$} & \multirow{2}{*}{$\begin{array}{c}\text { transformer } \\
\text { capacity } \\
\text { (yuan/kVA/month) }\end{array}$} \\
\hline & <l kV & $1.10 \mathrm{kV}$ & $\geq 35 \mathrm{kV}$ & & \\
\hline Residential & 0.220 & 0.215 & - & - & - \\
\hline Nonresidential illumination & 0.324 & 0.316 & - & - & - \\
\hline Nonindustrial \& common industrial $\dagger$ & +0.233 & 0.228 & 0.220 & - & - \\
\hline Large-scale industrial $\dagger$ & - & 0.159 & 0.150 & 15.00 & 10.00 \\
\hline preferential price i f] & - & 0.149 & 0.140 & 15.00 & 10.00 \\
\hline preferential price $2 \pi$ & - & 0.139 & 0.130 & 15.00 & 10.00 \\
\hline Agricultural & 0.188 & 0.182 & 0.172 & - & - \\
\hline Irigation in poor rural counties & 0.060 & 0.058 & 0.055 & - & - \\
\hline
\end{tabular}

2. Wholesale Prices (yuan/kWh)

\begin{tabular}{|c|c|c|c|c|}
\hline \multirow[b]{2}{*}{ Customer Type } & \multicolumn{2}{|c|}{ County-level wholesale prices } & \multicolumn{2}{|c|}{ Below County-level wholesale prices } \\
\hline & $1-10 \mathrm{~kW}$ & $\geq 35 \mathrm{~kW}$ & $1-10 \mathrm{~kW}$ & $\geq 35 \mathrm{~kW}$ \\
\hline Residential & 0.176 & - & - & - \\
\hline Nonresidential illumination & 0.235 & 0.235 & - & - \\
\hline Industrial & 0.162 & 0.156 & - & - \\
\hline Agricultural production & 0.137 & 0.127 & - & - \\
\hline Ingation in poor counties & 0.035 & 0.030 & - & - \\
\hline
\end{tabular}

N.B. Electricity rates are subject to a wide variety of taxes, surcharges, and additional tariffs depending on location and customer type. This rate schedule excludes surcharges to all customers nationally of 0.02 yuan $/ \mathrm{kWh}$ for a utility construction fund and 0.003 yuan/kWh for the Three Gorges Project fund. Retail rates paid by customers may be significantly higher and vary among cities and counties in the same province. All rates went into effect on 1 October.

- Either maximum demand or transformer capacity is selected as the method of calculating base charges for each customer.

$\dagger$ Manufacturers of fertilizers are temporarily subject to preferential rates: $91 \%$ of ordinary industry list rates for small and medium plants, and $87 \%$ of large-scale industrial list rates for large plants.

I Preferential price 1 is for manufacturers of caustic soda (electrolytic process), ferrous alloys (electric fumace), yellow phosphorous (electrolytic process), synthetic ammonia, and calcium, phosphorus, and magnesium fertilizers (electric furnace). Preferential price 2 is for manufacturers of calcium carbide.

Source: Editorial Board of the China Price Yearbook, 1994. 
Table VI-24. Ningxia Grid Basic Electricity Rates, Effective 1993

\begin{tabular}{|c|c|c|c|c|c|}
\hline \multirow{3}{*}{$\begin{array}{l}\text { I. Basic Prices } \\
\text { Customer Type }\end{array}$} & \multirow{2}{*}{\multicolumn{3}{|c|}{ Electricity Price (yuan/kWh) }} & \multicolumn{2}{|c|}{ Basic Electricity Charge * } \\
\hline & & & & \multirow{2}{*}{$\begin{array}{c}\text { Basic Electric } \\
\text { maximum } \\
\text { demand } \\
\text { (yuan/kW/month) }\end{array}$} & \multirow{2}{*}{$\begin{array}{c}\text { transformer } \\
\text { capacity } \\
\text { (yuan/kVA/month) }\end{array}$} \\
\hline & $<1 \mathrm{kV}$ & $1.10 \mathrm{kV}$ & $\geq 35 \mathrm{kV}$ & & \\
\hline Residential & 0.220 & 0.210 & - & - & - \\
\hline Nonresidential illumination & 0.325 & 0.317 & 0.317 & - & - \\
\hline Nonindustrial \& common industrial & +0.234 & 0.229 & 0.221 & - & - \\
\hline Large-scale industrial $\dagger$ & - & 0.173 & 0.164 & 13.50 & 9.00 \\
\hline preferential price I IT & - & 0.163 & 0.154 & 13.50 & 9.00 \\
\hline preferential price $2 \pi$ & - & 0.153 & 0.144 & 13.50 & 9.00 \\
\hline Agricultural & 0.188 & 0.182 & 0.172 & - & - \\
\hline Irrigation in poor rural counties & 0.060 & 0.058 & 0.055 & - & - \\
\hline
\end{tabular}

2. Wholesale Prices (yuan/kWh)

\begin{tabular}{|c|c|c|c|c|}
\hline \multirow[b]{2}{*}{ Customer Type } & \multicolumn{2}{|c|}{ County-level wholesale prices } & \multicolumn{2}{|c|}{ Below County-level wholesale prices } \\
\hline & $1.10 \mathrm{~kW}$ & $\geq 35 \mathrm{~kW}$ & $1.10 \mathrm{~kW}$ & $\geq 35 \mathrm{~kW}$ \\
\hline Residential & 0.152 & & 0.171 & - \\
\hline Nonresidential illumination & 0.244 & 0.244 & 0.263 & 0.263 \\
\hline Industrial & 0.168 & 0.162 & 0.176 & 0.170 \\
\hline Agricultural production & 0.144 & 0.133 & 0.144 & 0.133 \\
\hline Imigation in poor counties & 0.035 & 0.030 & 0.035 & 0.030 \\
\hline
\end{tabular}

N.B. Electricity rates are subject to a wide variety of taxes, surcharges, and additional tariffs depending on location and customer type. This rate schedule excludes surcharges to all customers nationally of 0.02 yuam $/ \mathrm{kWh}$ for a utility construction fund and 0.003 yuan $/ \mathrm{kWh}$ for the Three Gorges Project fund. Retail rates paid by customers may be significantly higher and vary among cities and counties in the same province. All rates went into effect on 1 April, except residential rates, which went into effect on I September.

* Either maximum demand or transformer capacity is selected as the method of calculating base charges for each customer.

$\dagger$ Manufacturers of fertilizers are temporarily subject to preferential rates: $89 \%$ of ordinary industry list rates for small and medium plants, and $86 \%$ of large-scale industrial list rates for large plants.

8 Preferential price 1 is for manufacturers of caustic soda (electrolytic process), ferrous alloys (electric furnace), yellow phosphorous (electrolytic process), synthetic ammonia, and calcium, phosphorus, and magnesium fertilizers (electric fumace). Preferential price 2 is for manufacturers of calcium carbide.

Source: Editorial Board of the China Price Yearbook, 1994. 
1. Basic Prices

Basic Electricity Charge t maximum transformer demand capacity

\begin{tabular}{|c|c|c|c|c|c|}
\hline Customer Type & $<\overline{\mathbf{k V}}$ & $1-10 \mathrm{kV}$ & $235 \mathrm{kV}$ & (yuan/kW/month) & (yuan/kVA/month) \\
\hline Residential & 0.220 & 0.210 & 0.210 & - & - \\
\hline Nonresidential illumination & 0.312 & 0.306 & 0.306 & - & - \\
\hline Nonindustrial \& common industrial & \ $0.28 \mathrm{I}$ & 0.274 & 0.264 & - & - \\
\hline Large-scale industrial $\pi$ & - & 0.198 & 0.187 & 15.00 & 10.00 \\
\hline preferential price $\S$ & - & 0.188 & 0.177 & 15.00 & 10.00 \\
\hline Agricultural & 0.227 & 0.220 & 0.208 & - & - \\
\hline
\end{tabular}

Agricultural

0.227

$\cdot$

\section{Wholesale Prices (yuan/kWh)}

\begin{tabular}{|c|c|c|c|c|}
\hline \multirow[b]{2}{*}{ Customer Type } & \multicolumn{2}{|c|}{ County-level wholesale prices } & \multicolumn{2}{|c|}{ Below County-level wholesale } \\
\hline & $1-10 \mathrm{~kW}$ & $\geq 35 \mathrm{~kW}$ & $1-10 \mathrm{~kW}$ & $\geq 35 \mathrm{~kW}$ \\
\hline idential & 0.160 & 0.160 & 0.174 & 0.174 \\
\hline Nonresidential illumination & 0.235 & 0.235 & 0.249 & 0.249 \\
\hline Industrial \& nonindustrial & 0.195 & 0.188 & 0.222 & 0.214 \\
\hline Agricultural production & 0.172 & 0.162 & 0.172 & 0.162 \\
\hline
\end{tabular}

N.B. Electricity rates are subject to a wide variety of taxes, surcharges, and additional tariffs depending on location and customer type. This rate schedule excludes surcharges to all customers nationally of 0.02 yuan $/ \mathrm{kWh}$ for a utility construction fund and 0.003 yuan $\mathrm{kWh}$ for the Three Gorges Project fund. Retail rates paid by customers may be significantly higher and vary among cities and counties in the same province. All rates went into effect on 1 April, except residential rates, which went into effect on 1 July.

- This region includes Liaoning, Jilin, and Heilongilang Provinces.

$\dagger$ Either maximum demand or transformer capacity is selected as the method of calculating base charges for each customer.

7 Manufacturers of fertilizers are temporarily subject to preferential rates: $86 \%$ of ordinary industry list rates for small and medium plants, and $80 \%$ of large-scale industrial list rates for large plants.

$\S$ Preferential price is for manufacturers of caustic soda (electrolytic process), yellow phosphorous (electrolytic process), synthetic ammonia, and calcium carbide.

Source: Editorial Board of the China Price Yearbook, 1994. 
Table VI-26. Qinghai Grid Basic Electricity Rates, Effective 1993

1. Basic Prices

\begin{tabular}{|c|c|c|c|c|c|}
\hline \multirow[b]{3}{*}{ Customer Type } & \multirow{2}{*}{\multicolumn{3}{|c|}{ Electricity Price (yuan/kWh) }} & \multicolumn{2}{|c|}{ Basic Electricity Charge* } \\
\hline & & & & \multirow{2}{*}{$\begin{array}{c}\text { maximum } \\
\text { demand } \\
\text { (yuan/kW/month) }\end{array}$} & \multirow{2}{*}{$\begin{array}{c}\text { transformer } \\
\text { capacity } \\
\text { (yuan/kVA/month) }\end{array}$} \\
\hline & $<\overline{\mathbf{k V}}$ & $1-10 \mathrm{kV}$ & $\geq 35 \mathrm{kV}$ & & \\
\hline Residential & 0.210 & 0.205 & - & - & - \\
\hline Nonresidential illumination & 0.229 & 0.224 & - & - & - \\
\hline Nonindustrial \& common industrial & 0.120 & 0.117 & 0.113 & - & - \\
\hline Large-scale industrial & - & 0.075 & 0.071 & 12.00 & 8.00 \\
\hline preferential price $1 \dagger$ & - & 0.065 & 0.061 & 12.00 & 8.00 \\
\hline preferential price $2 \dagger$ & - & 0.055 & 0.051 & 12.00 & 8.00 \\
\hline Agricultural & 0.090 & 0.087 & 0.083 & - & - \\
\hline Imigation in poor rural counties & 0.060 & 0.058 & 0.055 & - & - \\
\hline
\end{tabular}

\section{Wholesale Prices (yuan/kWh)}

\begin{tabular}{|c|c|c|c|c|}
\hline \multirow[b]{2}{*}{ Customer Type } & \multicolumn{2}{|c|}{ County-level wholesale prices } & \multicolumn{2}{|c|}{ Below County-level wholesale p } \\
\hline & $I-10 \mathrm{~kW}$ & $\geq 35 \mathrm{~kW}$ & $1-10 \mathrm{~kW}$ & $\geq 35 \mathrm{~kW}$ \\
\hline Residential & 0.147 & - & 0.166 & - \\
\hline Nonresidential iliumination & 0.164 & - & 0.183 & - \\
\hline Industrial & 0.083 & 0.080 & 0.091 & 0.088 \\
\hline Agricultural production & 0.061 & 0.054 & 0.061 & 0.054 \\
\hline Imigation in poor counties & 0.035 & 0.030 & 0.035 & 0.030 \\
\hline
\end{tabular}

N.B. Electricity rates are subject to a wide variety of taxes, surcharges, and additional tariffs depending on location and customer type. This rate schedule excludes surcharges to all customers nationally of 0.02 yuan/kWh for a utility construction fund and 0.003 yuan/kWh for the Three Gorges Project fund. Retail rates paid by customers may be significantly higher and vary among cities and counties in the same province. All rates went into effect on 1 January, except residential rates, which went into effect 1 April.

* Either maximum demand or transformer capacity is selected as the method of calculating base charges for each customer.

$\dagger$ Preferential price 1 is for manufacturers of caustic soda (electrolytic process), ferrous alloys (electric furnace), yellow phosphorous (electrolytic process), synthetic ammonia, and calcium, phosphorus, and magnesium fertilizers (electric fumace). Preferential price 2 is for manufacturers of calcium carbide.

Source: Editorial Board of the China Price Yearbook, 1994. 
1. Basic Prices

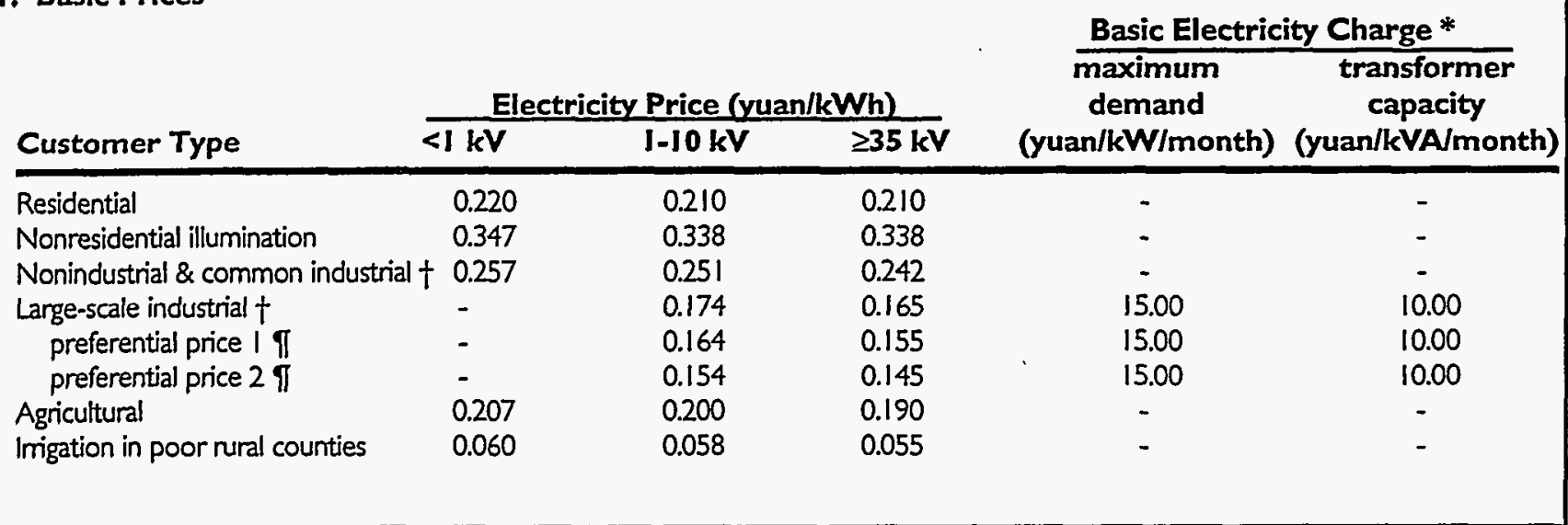

\section{Wholesale Prices (yuan/kWh)}

\begin{tabular}{|c|c|c|c|c|}
\hline \multirow[b]{2}{*}{ Customer Type } & \multicolumn{2}{|c|}{ County-level wholesale prices } & \multicolumn{2}{|c|}{ Below County-level wholesale prices } \\
\hline & $1-10 \mathrm{~kW}$ & $\geq 35 \mathrm{~kW}$ & $1-10 \mathrm{~kW}$ & $\geq 35 \mathrm{~kW}$ \\
\hline Residential & 0.157 & 0.157 & 0.177 & 0.177 \\
\hline Nonresidential illumination & 0.263 & 0.263 & 0.282 & 0.282 \\
\hline Industrial & 0.187 & 0.180 & 0.195 & 0.188 \\
\hline Agricultural production & 0.166 & 0.154 & 0.166 & 0.154 \\
\hline Imigation in poor counties & 0.035 & 0.030 & 0.035 & 0.030 \\
\hline
\end{tabular}

N.B. Electricity rates are subject to a wide variety of taxes, surcharges, and additional tariffs depending on location and customer type. This rate schedule excludes surcharges to all customers nationally of 0.02 yuan $/ \mathrm{kWh}$ for a utility construction fund and 0.003 yuar $/ \mathrm{kWh}$ for the Three Gorges Project fund. Retail rates paid by customers may be significantly higher and vary among cities and counties in the same province. All rates went into effect on 1 April, except residential rates, which went into effect on 1 July.

- Either maximum demand or transformer capacity is selected as the method of calculating base charges for each customer.

$\dagger$ Manufacturers of fertilizers are temporarily subject to preferential rates: $49 \%$ of ordinary industry list rates for small and medium plants, and $26 \%$ of large-scale industrial list rates for large plants.

1 Preferential price 1 is for manufacturers of caustic soda (electrolytic process), ferrous alloys (electric furnace), yellow phosphorous (electrolytic process), synthetic ammonia, and calcium, phosphorus, and magnesium fertilizers (electric fumace). Preferential price 2 is for manufacturers of calcium carbide.

Source: Editorial Board of the China Price Yearbook, 1994. 
Table VI-28. Shandong Grid Basic Electricity Rates, Effective 1993

1. Basic Prices

\begin{tabular}{|c|c|c|c|c|c|}
\hline \multirow[b]{3}{*}{ Customer Type } & \multirow{2}{*}{\multicolumn{3}{|c|}{ Electricity Price (yuan/kWh) }} & \multicolumn{2}{|c|}{ Basic Electricity Charge * } \\
\hline & & & & \multirow{2}{*}{$\begin{array}{c}\text { maximum } \\
\text { demand } \\
\text { (yuan/kW/month) }\end{array}$} & \multirow{2}{*}{$\begin{array}{c}\text { transformer } \\
\text { capacity } \\
\text { (yuan/kVA/month) }\end{array}$} \\
\hline & $<\mathbf{l ~ k V}$ & $1.10 \mathrm{kV}$ & $\geq 35 \mathrm{kV}$ & & \\
\hline Residential . ..... & 0.220 & 0.210 & 0.210 & - & - \\
\hline Nonresidential illuminatión & 0.287 & 0.280 & 0.280 & - & - \\
\hline Nonindustrial \& common industrial $\uparrow$ & +0.210 & 0.206 & 0.201 & - & - \\
\hline Large-scale industrial $\dagger$ & - & 0.148 & 0.142 & 13.50 & 9.00 \\
\hline preferential price $\mathbb{\pi}$ & - & 0.138 & 0.132 & 13.50 & 9.00 \\
\hline Agricultural & 0.149 & 0.144 & 0.137 & - & - \\
\hline
\end{tabular}

2. Wholesale Prices (yuan/kWh)

\begin{tabular}{llc} 
& \multicolumn{2}{c}{ County-level wholesale prices } \\
\cline { 2 - 3 } Customer Type & $\mathbf{1 - 1 0 \mathrm { kW }}$ & $\mathbf{3 5 \mathrm { kW }}$ \\
\hline Residential & 0.150 & 0.150 \\
Nonresidential illumination & 0.211 & 0.211 \\
Industrial \& nonindustrial & 0.152 & 0.152 \\
Agricultural production & 0.112 & 0.103
\end{tabular}

N.B. Electricity rates are subject to a wide variety of taxes, surcharges, and additional tariffs depending on location and customer type. This rate schedule excludes surcharges to all customers nationally of 0.02 yuan/kWh for a utility construction fund and 0.003 yuan $/ \mathrm{kWh}$ for the Three Gorges Project fund. Retail rates paid by customers may be significantly higher and vary among cities and counties in the same province. All rates went into effect on 1 July.

* Either maximum demand or transformer capacity is selected as the method of calculating base charges for each customer.

t Manufacturers of fertilizers are temporarily subject to preferential rates: $90 \%$ of ordinary industry list rates for small and medium plants, and $92 \%$ of large-scale industrial list rates for large plants.

I Preferential price is for manufacturers of caustic soda (electrolytic process), yellow phosphorous (electrolyticprocess), synthetic ammonia, and calcium carbide.

Source: Editorial Board of the China Price Yearbook, 1994. 


\section{Table VI-29. Shanghai Grid Basic Electricity Rates, Effective 1993}

\section{Basic Prices}

\begin{tabular}{|c|c|c|c|c|c|}
\hline \multirow[b]{3}{*}{ Customer Type } & \multirow{2}{*}{\multicolumn{3}{|c|}{ Electricity Price (yuan/kWh) }} & \multicolumn{2}{|c|}{ Basic Electricity Charge * } \\
\hline & & & & \multirow{2}{*}{$\begin{array}{c}\text { maximum } \\
\text { demand } \\
\text { (yuan/kW/month) }\end{array}$} & \multirow{2}{*}{$\begin{array}{c}\text { transformer } \\
\text { capacity } \\
\text { (yuan/kVA/month) }\end{array}$} \\
\hline & $\langle\overline{\mathbf{k V}}$ & $1-10 \mathrm{kV}$ & $\geq 35 \mathrm{kV}$ & & \\
\hline Residential & 0.270 & 0.260 & 0.260 & - & - \\
\hline Nonresidential illumination & 0.387 & 0.377 & 0.377 & - & - \\
\hline Nonindustrial \& common industrial $\dagger$ & +0.305 & 0.298 & 0.287 & - & - \\
\hline Large-scale industrial $\dagger$ & - & 0.214 & 0.203 & 15.00 & 10.00 \\
\hline preferential price $\pi$ & - & 0.204 & 0.193 & 15.00 & 10.00 \\
\hline Agricultural production & 0.246 & 0.238 & 0.225 & - & - \\
\hline
\end{tabular}

N.B. Electricity rates are subject to a wide variety of taxes, surcharges, and additional tariffs depending on location and customer type. This rate schedule excludes surcharges to all customers nationally of 0.02 yuan/kWh for a utility construction fund and 0.003 yuankWh for the Three Gorges Project fund. Retail rates paid by customers may be significantly higher and vary among cities and counties in the same province. All rates went into effect on 1 April, except residential rates, which went into effect on 1 July.

- Either maximum demand or transformer capacity is selected as the method of calculating base charges for each customer.

$\dagger$ Fertilizer manufacturers are subject to preferential rates: $83 \%$ of ordinary industry list rates for small- and medium-scale plants, and $76 \%$ of large-scale industrial list rates for large-scale fertilizer manufacturers.

I For manufacturers of calcium carbide, electrolytic process caustic soda, yellow phosphorous, and synthetic ammonia.

Source: Editorial Board of the China Price Yearbook, 1994. 
Table VI-30. Sichuan Grid Basic Electricity Rates, Effective 1993

\begin{tabular}{|c|c|c|c|c|c|}
\hline \multirow{3}{*}{$\begin{array}{l}\text { I. Basic Prices } \\
\text { Customer Type }\end{array}$} & \multirow{2}{*}{\multicolumn{3}{|c|}{ Electricity Price (yuan $/ \mathbf{k W} \mathbf{h})$}} & \multicolumn{2}{|c|}{ Basic Electricity Charge * } \\
\hline & & & & \multirow{2}{*}{$\begin{array}{l}\text { Basic Electric } \\
\text { maximum } \\
\text { demand } \\
\text { (yuan/kW/month) }\end{array}$} & \multirow{2}{*}{$\begin{array}{c}\text { transformer } \\
\text { capacity } \\
\text { (yuan/kVA/month) }\end{array}$} \\
\hline & $<\mathrm{l} \mathrm{kV}$ & $1.10 \mathrm{kV}$ & $\geq 35 \mathrm{kV}$ & & \\
\hline Residential & 0.220 & 0.210 & - & - & - \\
\hline Nonresidential illumination & 0.288 & 0.281 & - & - & - \\
\hline Nonindustrial \& common industrial $\dagger$ & $\dagger 0.189$ & 0.185 & 0.178 & - & - \\
\hline Large-scale industrial $t$ & - & 0.124 & 0.118 & 13.50 & 9.00 \\
\hline preferential price I $\pi$ & - & 0.114 & 0.108 & 13.50 & 9.00 \\
\hline preferential price $2 \pi$ & - & 0.104 & 0.098 & 13.50 & 9.00 \\
\hline Agricultural & 0.148 & 0.143 & 0.136 & - & - \\
\hline Irrigation in poor rural counties & 0.060 & 0.058 & 0.055 & - & - \\
\hline
\end{tabular}

\section{Wholesale Prices (yuan/kWh)}

\begin{tabular}{lccccc} 
& \multicolumn{2}{c}{ County-level wholesale prices } & \multicolumn{2}{c}{ Below County-level wholesale prices } \\
\cline { 2 - 3 } \cline { 5 - 6 } Customer Type & $\mathbf{1 - 1 0 ~ k W}$ & $\mathbf{3 5} \mathbf{~ k W}$ & & $1-10 \mathbf{k W}$ & $\mathbf{3 5} \mathbf{k W}$ \\
\hline Residential & 0.152 & - & 0.171 & - \\
Nonresidential illumination & 0.211 & 0.126 & 0.230 & - \\
Industrial \& nonindustrial & 0.134 & 0.101 & 0.142 & 0.137 \\
Agricultural production & 0.110 & 0.030 & 0.110 & 0.101 \\
Irigation in poor counties & 0.035 & 0.035 & 0.030
\end{tabular}

N.B. Electricity rates are subject to a wide variety of taxes, surcharges, and additional tariffs depending on location and customer type. This rate schedule excludes surcharges to all customers nationally of 0.02 yuan $/ \mathrm{kWh}$ for a utility construction fund and 0.003 yuan/kWh for the Three Gorges Project fund, and a surcharge to Sichuan customers of 0.0013 yuan $\mathrm{kWh}$ for small hydropower project development. Retail rates paid by customers may be significantly higher and vary among cities and counties in the same province. All rates went into effect on 1 Appril.

* Either maximum demand or transformer capacity is selected as the method of calculating base charges for each customer.

$\dagger$ Manufacturers of ammonia, phosphorus, potassium, calcium, and blended fertilizers are temporarily subject to preferential rates: $66 \%$ of ordinary industry list rates for small and medium plants, and $49 \%$ of large-scale industrial list rates for large plants.

I Preferential price 1 is for manufacturers of caustic soda (electrolytic process), ferrous alloys (electric furmace), yellow phosphorous (electrolytic process), synthetic ammonia, and calcium, phosphorus, and magnesium fertilizers (electric furnace). Preferential price 2 is for manufacturers of calcium carbide.

Source: Editorial Board of the China Price Yearbook, 1994. 
Table VI-31. Xinjiang Grid Basic Electricity Rates, Effective 1993

\section{Basic Prices}

\begin{tabular}{|c|c|c|c|c|c|}
\hline \multirow[b]{3}{*}{ Customer Type } & \multirow{2}{*}{\multicolumn{3}{|c|}{ Electricity Price (yuan/kWh) }} & \multicolumn{2}{|c|}{ Basic Electricity Charge * } \\
\hline & & & & \multirow{2}{*}{$\begin{array}{c}\text { maximum } \\
\text { demand } \\
\text { (yuan/kW/month) }\end{array}$} & \multirow{2}{*}{$\begin{array}{c}\text { transformer } \\
\text { capacity } \\
\text { (yuan/kVA/month) }\end{array}$} \\
\hline & $<\mathrm{l} \mathrm{kV}$ & $\mathrm{I}-10 \mathrm{kV}$ & $\geq 35 \mathrm{kV}$ & & \\
\hline Residential & 0.220 & 0.215 & - & - & - \\
\hline Nonresidential illumination & 0.317 & 0.309 & - & - & - \\
\hline Nonindustrial \& common industrial $\dagger$ & $\dagger 0.222$ & 0.217 & 0.209 & - & - \\
\hline Large-scale industrial $\dagger$ & - & 0.156 & 0.148 & 12.00 & 8.00 \\
\hline preferential price I $\pi$ & - & 0.146 & 0.138 & 12.00 & 8.00 \\
\hline preferential price $2 \pi$ & - & 0.136 & 0.128 & 12.00 & 8.00 \\
\hline Agricultural & 0.180 & 0.175 & 0.166 & - & - \\
\hline Irrigation in poor rural counties & 0.060 & 0.058 & 0.055 & - & - \\
\hline
\end{tabular}

\section{Wholesale Prices (yuan/kWh)}

\begin{tabular}{|c|c|c|c|c|}
\hline \multirow[b]{2}{*}{ Customer Type } & \multicolumn{2}{|c|}{ County-level wholesale prices } & \multicolumn{2}{|c|}{ Below County-level wholesale price } \\
\hline & $1-10 \mathrm{~kW}$ & $\geq 35 \mathrm{~kW}$ & $1-10 \mathrm{~kW}$ & $\geq 35 \mathrm{~kW}$ \\
\hline Residential & 0.157 & 0.157 & 0.177 & 0.177 \\
\hline Nonresidential illumination & 0.239 & 0.239 & 0.258 & 0.258 \\
\hline Industrial & 0.160 & 0.098 & 0.168 & 0.098 \\
\hline Agricultural production & 0.137 & 0.127 & 0.137 & 0.127 \\
\hline Imigation in poor counties & 0.035 & 0.030 & 0.035 & 0.030 \\
\hline
\end{tabular}

N.B. Electricity rates are subject to a wide variety of taxes, surcharges, and additional tariffs depending on location and customer type. This rate schedule excludes surcharges to all customers nationally of 0.02 yuan/kWh for a utility construction fund and 0.003 yuan/kWh for the Three Gorges Project fund. Retail rates paid by customers may be significantly higher and vary among cities and counties in the same province. All rates went into effect on 1 December.

* Either maximum demand or transformer capacity is selected as the method of calculating base charges for each customer.

$\dagger$ Fertilizer manufacturers are subject to preferential rates: $91 \%$ of ordinary industry list rates for small and medium plants, and $87.2 \%$ of large-scale industrial list rates for large plants.

1 Preferential price 1 is for manufacturers of caustic soda (electrolytic process), ferrous alloys (electric furnace), yellow phosphorous (electrolytic process), synthetic ammonia, and calcium, phosphorus, and magnesium fertilizers (electric furnace).

Source: Editorial Board of the China Price Yearbook, 1994. 
Table VI-32. Yunnan Grid Basic Electricity Rates, Effective 1993

\section{Basic Prices}

\begin{tabular}{|c|c|c|c|c|c|}
\hline \multirow[b]{3}{*}{ Customer Type } & \multirow{2}{*}{\multicolumn{3}{|c|}{ Electricity Price (yuan/kWh) }} & \multicolumn{2}{|c|}{ Basic Electricity Charge * } \\
\hline & & & & \multirow{2}{*}{$\begin{array}{c}\text { maximum } \\
\text { demand } \\
\text { (yuan/kW/month) }\end{array}$} & \multirow{2}{*}{$\begin{array}{c}\text { transformer } \\
\text { capacity } \\
\text { (yuan/kVA/month) }\end{array}$} \\
\hline & $<\overline{l ~ k V}$ & $1.10 \mathrm{kV}$ & $\geq 35 \mathrm{kV}$ & & \\
\hline Residential & 0.220 & 0.215 & - & - & - \\
\hline Nonresidential illumination & 0.311 & 0.303 & - & - & - \\
\hline Nonindustrial \& common industrial $\uparrow$ & +0.232 & 0.226 & 0.218 & - & - \\
\hline Large-scale industrial $\dagger$ & - & 0.166 & 0.158 & 12.00 & 8.00 \\
\hline preferential price I I & - & 0.156 & 0.148 & 12.00 & 8.00 \\
\hline preferential price 2 I & - & 0.146 & 0.138 & 12.00 & 8.00 \\
\hline Agricultural & 0.188 & 0.182 & 0.173 & - & - \\
\hline Irrigation in poor rural counties & 0.060 & 0.058 & 0.055 & - & - \\
\hline
\end{tabular}

2. Wholesale Prices (yuan/kWh)

\begin{tabular}{|c|c|c|c|c|}
\hline \multirow[b]{2}{*}{ Customer Type } & \multicolumn{2}{|c|}{ County-level wholesale prices } & Below County & 1olesale p \\
\hline & $1-10 \mathrm{~kW}$ & $\geq 35 \mathrm{~kW}$ & $1-10 \mathrm{~kW}$ & $\geq 35 \mathrm{~kW}$ \\
\hline Residential & 0.157 & - & 0.177 & - \\
\hline Nonresidential illumination & 0.235 & 0.235 & 0.254 & 0.254 \\
\hline Industrial & 0.163 & 0.157 & 0.171 & 0.165 \\
\hline Agricultural production & 0.141 & 0.131 & 0.141 & 0.131 \\
\hline Irrigation in poor counties & 0.035 & 0.030 & 0.035 & 0.030 \\
\hline
\end{tabular}

N.B. Electricity rates are subject to a wide variety of taxes, surcharges, and additional tariffs depending on location and customer type. This rate schedule excludes surcharges to all customers nationally of 0.02 yuan $/ \mathrm{kWh}$ for a utility construction fund and 0.003 yuan $\mathrm{kWh}$ for the Three Gorges Project fund. Retail rates paid by customers may be significantly higher and vary among cities and counties in the same province. All rates went into effect on 1 October.

* Either maximum demand or transformer capacity is selected as the method of calculating base charges for each customer.

$\dagger$ Fertilizer manufacturers are subject to preferential rates: $65 \%$ of ordinary industry list rates for small and medium plants, and $52 \%$ of large-scale industrial list rates for large plants.

I Preferential price 1 is for manufacturers of caustic soda (electrolytic process), ferrous alloys (electric fumace), yellow phosphorous (electrolytic process), synthetic ammonia, and calcium, phosphorus, and magnesium fertilizers (electric fumace).

Source: Editorial Board of the China Price Yearbook, 1994. 


\section{Table VI-33. Zhejiang Grid Basic Electricity Rates, Effective 1993}

\section{Basic Prices}

\begin{tabular}{|c|c|c|c|c|c|}
\hline \multirow[b]{3}{*}{ Customer Type } & \multirow{2}{*}{\multicolumn{3}{|c|}{ Electricity Price (yuan/kWh) }} & \multicolumn{2}{|c|}{ Basic Electricity Charge* } \\
\hline & & & & \multirow{2}{*}{$\begin{array}{c}\text { maximum } \\
\text { demand } \\
\text { (yuan/kW/month) }\end{array}$} & \multirow{2}{*}{$\begin{array}{c}\text { transformer } \\
\text { capacity } \\
\text { (yuan/kVA/month) }\end{array}$} \\
\hline & $<\mathrm{l} \mathrm{kV}$ & $1.10 \mathrm{kV}$ & $\geq 35 \mathrm{kV}$ & & \\
\hline Residential & 0.250 & 0.245 & - & - & - \\
\hline Nonresidential illumination & 0.344 & 0.332 & - & - & - \\
\hline Nonindustrial \& common industrial & $\dagger 0.311$ & 0.304 & 0.293 & - & - \\
\hline Large-scale industrial $\dagger$ & - & 0.217 & 0.205 & 15.00 & 10.00 \\
\hline preferential price $\tilde{ள}$ & - & 0.207 & 0.195 & 15.00 & 10.00 \\
\hline Agricultural production & 0.254 & 0.246 & 0.233 & - & - \\
\hline Inigation in poor counties & 0.060 & 0.058 & 0.055 & - & - \\
\hline
\end{tabular}

\section{Wholesale Prices (yuan/kWh)}

\begin{tabular}{lccccc} 
& \multicolumn{2}{c}{ County-level wholesale prices } & & \multicolumn{2}{c}{ Below County-level wholesale prices } \\
\cline { 2 - 3 } Customer Type & $\mathbf{1 - 1 0 ~ k W}$ & $\mathbf{3 5} \mathbf{~ k W}$ & & $\mathbf{1 - 1 0} \mathbf{k W}$ & $\mathbf{3 5} \mathbf{~ k W}$ \\
\hline Residential & 0.192 & - & - & 0.206 & - \\
Nonresidential illumination & 0.247 & 0.228 & 0.288 & - \\
Industrial \& nonindustrial & 0.237 & 0.202 & 0.245 & 0.236 \\
Agricultural production & 0.217 & 0.030 & 0.217 & 0.202 \\
Imigation in poor counties & 0.035 & & 0.035 & 0.030
\end{tabular}

N.B. Electricity rates are subject to a wide variety of taxes, surcharges, and additional tariffs depending on location and customer type. This rate schedule excludes surcharges to all customers nationally of 0.02 yuan/kWh for a utility construction fund and 0.003 yuankWh for the Three Gorges Project fund. Retail rates paid by customers may be significantly higher and vary among cities and counties in the same province. All rates went into effect on 1 April, except residential rates, which went into effect on 1 July.

- Either maximum demand or transformer capacity is selected as the method of calculating base charges for each customer.

$\dagger$ Fertilizer manufacturers are subject to preferential rates: $86 \%$ of ordinary industry list rates for small and medium plants, and $80 \%$ of large-scale industrial list rates for Jarge fertilizer manufacturers.

1 For manufacturers of calcium carbide, electrolytic process caustic soda, yellow phosphorous, and synthetic ammonia.

Source: Editorial Board of the China Price Yearbook, 1994. 


\section{Chapter VII-Imports and Exports}




\section{Imports and Exports}

$\mathrm{F}$ or much of its histPeople's Republic of China has been very much self-reliant for its needs, including energy and energy-intensive industrial products like metals and chemicals. In the 1980 s, however, the country began to participate in world markets for these products on a large scale. At one point many believed that China would become one of the world's major petroleum suppliers. That situation has reversed, and while China is exporting more coal than ever before, it is poised to become one of Asia's largest oil importers. Flows in and out of China of energy-intensive products have varied a great deal, and it is not clear that increased international trade in such products has had a significant impact on overall energy consumption and intensity.

\section{ENERGY}

China has exported petroleum - mainly crude oil - since the mid-1960s (Table VII-1). Petroleum exports have accounted for a substantial share of domestic production (between $16 \%$ and $30 \%$ over the past decade), but are not large by world standards (about $1.3 \%$ of the volume of petroleum traded internationally in 1994). ${ }^{1}$ Imports of petroleum were generally less than 1 Mt until the late 1980s, and by 1993 imports of crude oil and petroleum distillates (mainly diesel oil) shot up to $15.7 \mathrm{Mt}$ and $17.3 \mathrm{Mt}$ respectively, making China a net petroleum importer for the first time since 1970, which was itself an atypical year. Imports dropped in 1994, to a total of $25 \mathrm{Mt}$, but the future is likely to see steady increases in imports, and little growth in exports; by 2010 China may need to import as much as $150 \mathrm{Mt} / \mathrm{yr}$, or the equivalent of total current domestic production.

In general, China shifted its trade policy in oil significantly after the oil price collapse of 1986. Crude exports have seen a continuous decline as a greater proportion is diverted to domestic refiner- ies, while imports have grown significantly (to $14 \%$ of total refinery runs in 1994). Similarly, restrictions on product imports were eased in 1986, resulting in a rapid increase in product (primarily diesel) imports, while product exports have declined in most years since then.

Earnings from petroleum exports have been substantial, but have declined in importance relative to other exports since 1985 , when $26 \%$ of gross export earnings came from energy products, nearly all oil (Table VII-2). By 1993 energy products accounted for only $4 \%$ of export earnings. While earnings from oil have declined overall from levels of the 1980s, those from coal have risen steadily.

China trades in petroleum products with over 90 countries. China trades in petroleum byproducts, e.g., waxes, with most of these countries, imports distillates from a smaller number, imports crude oil from fewer still, and exports oil in significant amounts (over $1 \mathrm{kt} / \mathrm{yr}$ ) to slightly more than a dozen (Table VII-3). ${ }^{2}$ In 1994 about two-thirds of China's exported crude went to Japan, as did $8 \%$ of exported distillates and half of other petroleum products (Tables VII-4 and VII-5) The next largest buyers of Chinese crude are the United States, the two Koreas, and Singapore. Singapore also buys half of China's petroleum product exports, with Hong Kong, Japan, and Thailand the other largest customers. For its crude imports China is highly dependent on Indonesia's lowsulfur oil, with most of the rest coming from Oman and Yemen. All but a tenth of distillate imports come from Singapore, South Korea, the former Soviet Union, the United States, and Japan.

China has been an exporter of coal since 1950 (Table VII-1). While coal imports have remained between $1 \mathrm{Mt}$ and $2.5 \mathrm{Mt}$ per year since the $1960 \mathrm{~s}$, exports quadrupled between 1980 and 1993 as newly built coal washing, rail, and port facilities made more of China's high quality coal available for export. Japan is by far the most important buyer 
of Chinese coal, followed by South Korea, Taiwan, Hong Kong, and North Korea (Table VII-3). Many of the loans Japan has extended to China have been for improvement of railroads and ports important for the overseas transport of Shanxi coal. ${ }^{3}$ About half of China's coal imports come from Vietnam, with most of the rest from North Korea; Australia, and New Zealand.

A small amount of electricity ( $0.5 \%$ of China's total supply in 1993) comes from Hong Kong and the former Soviet Union (Table VII-3). China itself sells an even smaller amount to Macau. China has built several hydroelectric projects jointly with North Korea along their mutual border, and purchases by the Chinese of part of North Korea's share of generation could be considered imports, but the magnitude of this trade is small and unreported.

\section{Energy-Intensive Products}

China's exports of energy-intensive industrial products have varied greatly from year to year, with no clear pattern emerging across all categories (Table VII6). Exports of building materials (cement and flat glass) peaked in the early 1990s, falling as domestic demand has grown and international market prices weakened. Crude and finished steel exports show a similar trend, as domestic demand continues to rise. Exports of petroleum byproducts and nonferrous metals show overall growth that continues to the present. Expressed as a percentage of domestic output, exports are most significant for paraffin, petroleum coke, and flat glass $(36 \%, 23 \%$, and $23 \%$ respectively in 1993).
Imports of most products increased in the first half of the 1980s, only to decrease in the latter half (Table VII-7). This trend led some analysts to emphasize the role of imports of embedded energy in reducing the overall energy intensity of China's economy. More recently net imports of some energy-intensive commodities (e.g., metals and petrochemicals) have risen, while those of others have fallen off (e.g., inorganic chemicals and paper) or fluctuated (e.g., some nonferrous metals and fertilizers).

The impact of international trade in such products on China's energy intensity and total energy consumption deserves reexamination. Although net imports currently are significant with respect to domestic production mainly for nonferrous metals and petrochemicals, the future may be rather different. Domestic petrochemicals manufacturing capacity is expanding rapidly, so it is likely that imports of intermediate chemicals will soon be replaced by oil imports. Fertilizer imports, which have fallen recently, may increase in the near future; demands on China's shrinking and increasingly less fertile farmland are becoming heavier, while investment in fertilizer plant capacity has stagnated because of the low controlled price of domestic product. China's steelmaking capacity also may not be able to keep pace with the rapid rate of building and infrastructure construction.

1 British Petroleum, 1995.

2 Distillates include gasoline, naphtha, kerosene, diesel, fuel oil, lube oil, and other distillates. Byproducts include waxes, LPG, asphalt, petroleum coke, etc.

3 OECF, 1991. 
Table VII-1. Energy Exports and Imports, 1950-1994

\begin{tabular}{|c|c|c|c|c|c|c|c|c|c|}
\hline \multicolumn{10}{|c|}{ I. Physical Units } \\
\hline \multirow[b]{2}{*}{ Year } & \multicolumn{5}{|c|}{ Exports } & \multicolumn{4}{|c|}{ Imports } \\
\hline & $\begin{array}{l}\text { Coal } \\
(M t)\end{array}$ & $\begin{array}{l}\text { Coke } \\
\text { (Mt) }\end{array}$ & $\begin{array}{c}\text { Crude } \\
\text { Oil } \\
\text { (Mt) }\end{array}$ & $\begin{array}{l}\text { Petroleum } \\
\text { Products * } \\
\text { (Mt) }\end{array}$ & $\begin{array}{c}\text { Electricity } \\
\text { (GWh) }\end{array}$ & $\begin{array}{l}\text { Coal } \\
\text { (Mt) }\end{array}$ & $\begin{array}{c}\text { Crude } \\
\text { Oil } \\
\text { (Mt) }\end{array}$ & $\begin{array}{c}\text { Petroleum } \\
\text { Products } \dagger \\
\text { (Mt) }\end{array}$ & $\begin{array}{l}\text { Electricity } \\
\text { GWh) }\end{array}$ \\
\hline 1950 & 1.96 & 0.00 & - & - & - & 0.04 & 0.04 & - & - \\
\hline 1951 & 0.25 & 0.00 & - & - & - & $<0.01$ & 0.06 & - & - \\
\hline 1952 & 0.29 & 0.00 & - & - & - & $<0.01$ & 0.10 & - & - \\
\hline 1953 & 0.95 & 0.00 & - & - & - & $<0.01$ & 0.11 & - & - \\
\hline 1954 & 1.51 & 0.04 & - & - & - & $<0.01$ & 0.15 & - & - \\
\hline 1955 & 1.63 & 0.00 & - & - & - & 0.02 & 0.38 & - & - \\
\hline 1956 & 203 & 0.11 & - & - & - & 0.24 & 0.40 & - & - \\
\hline 1957 & 1.88 & 0.16 & - & - & - & 0.07 & 0.38 & - & - \\
\hline 1958 & 200 & 0.04 & - & - & - & 0.57 & 0.66 & - & - \\
\hline 1959 & 1.99 & 0.05 & - & - & - & 1.25 & 0.65 & - & $=$ \\
\hline 1960 & 2.12 & 0.05 & - & - & - & 1.24 & 0.59 & - & $=$ \\
\hline 1961 & 2.32 & 0.04 & - & 0.001 & - & 1.42 & 0.06 & - & - \\
\hline 1962 & 260 & 0.05 & 0.06 & 0.03 & - & 1.41 & 0.10 & - & - \\
\hline 1963 & 260 & 0.09 & 0.07 & 0.01 & - & 1.20 & 0.12 & - & - \\
\hline 1964 & 297 & 0.12 & 0.09 & 0.04 & - & 1.30 & 0.12 & - & - \\
\hline 1965 & 3.36 & 0.12 & 0.20 & 0.10 & - & 1.99 & 0.13 & - & - \\
\hline 1966 & 3.97 & 0.11 & 0.20 & 0.20 & - & 1.60 & 0.17 & - & - \\
\hline 1967 & 3.49 & 0.07 & 0.16 & 0.14 & - & 1.13 & 0.06 & - & - \\
\hline 1968 & 2.13 & 0.07 & 0.13 & 0.11 & - & 1.08 & 0.09 & - & - \\
\hline 1969 & 1.46 & 0.06 & 0.11 & 0.14 & - & 0.96 & 0.20 & - & $=$ \\
\hline 1970 & 2.27 & 0.27 & 0.19 & 0.19 & - & 1.23 & 0.47 & - & $=$ \\
\hline 1971 & 287 & 0.39 & 0.26 & 0.37 & - & 1.22 & 0.07 & - & - \\
\hline 1972 & 282 & 0.36 & 0.64 & 0.89 & - & 1.35 & 0.17 & - & - \\
\hline 1973 & 282 & 0.45 & 1.83 & 1.16 & - & 1.56 & 0.18 & - & - \\
\hline 1974 & 287 & 0.44 & 5.07 & 1.48 & - & 1.84 & 0.90 & - & - \\
\hline 1975 & 3.00 & 0.43 & 9.88 & 2.10 & - & 2.59 & 1.76 & - & - \\
\hline 1976 & 2.27 & 0.25 & 8.50 & 1.95 & - & 2.06 & 0.80 & - & - \\
\hline 1977 & 263 & 0.20 & 9.11 & 1.96 & - & 204 & 0.48 & - & - \\
\hline 1978 & 3.12 & 0.30 & 11.31 & 2.07 & - & 2.44 & 0.69 & - & - \\
\hline 1979 & 4.63 & 0.30 & 13.43 & 3.03 & - & 2.15 & 0.26 & - & $=$ \\
\hline 1980 & 6.32 & 0.27 & 13.31 & 4.20 & - & 1.99 & 0.37 & - & - \\
\hline 1981 & 6.57 & 0.25 & 13.86 & 4.67 & - & 1.93 & 0.07 & - & 300 \\
\hline 1982 & 6.44 & 0.47 & 14.68 & 4.91 & - & 2.19 & 0.64 & - & 330 \\
\hline 1983 & 6.56 & 0.35 & 14.82 & 4.91 & - & 2.14 & 0.37 & - & 430 \\
\hline 1984 & 7.04 & 0.35 & 22.01 & 5.70 & 30 & 2.43 & 0.25 & - & 800 \\
\hline 1985 & 7.77 & 0.37 & 30.30 & 6.21 & 40 & 2.31 & 0.72 & 0.07 & 1,100 \\
\hline 1986 & 9.82 & 0.46 & 28.50 & 5.46 & 40 & 2.47 & 1.07 & 1.97 & 1.210 \\
\hline 1987 & 13.53 & 0.61 & 27.23 & 4.94 & 40 & 1.94 & 1.72 & 1.98 & 1,290 \\
\hline 1988 & 15.65 & 1.03 & 26.05 & 4.79 & 40 & 1.69 & 0.86 & 3.07 & 1.510 \\
\hline 1989 & 15.34 & 1.66 & 24.39 & 4.74 & 50 & 2.29 & 3.26 & 5.35 & 1.642 \\
\hline 1990 & 17.29 & 1.30 & 23.99 & 5.26 & 85 & 1.98 & 2.92 & 3.17 & 1,925 \\
\hline 1991 & 20.10 & 1.08 & 22.60 & 4.81 & 260 & 1.37 & 5.97 & 4.61 & 3,110 \\
\hline 1992 & 19.70 & 1.35 & 21.51 & 5.39 & 260 & 1.23 & 11.36 & 7.78 & 4,980 \\
\hline 1993 & 19.81 & 2.61 & 19.43 & 3.72 & 117 & 1.43 & 15.67 & 17.29 & 4,506 \\
\hline 1994 & $24.25 \pi$ & - & 18.49 & 3.79 & - & - & 12.35 & 12.77 & - \\
\hline
\end{tabular}

- Composed mainly of gasoline, gasoil (diesel), fuel oil, naphtha, aviation kerosene, and lubricant base oil. Petroleum products are converted as gasoline or kerosene (1.47 tce/t).

$\dagger$ Diesel is the largest component of product imports. Smuggling of diesel and gasoline has grown in recent years, and official statistics understate actual imports.

I Ministry of Coal, $1 / 10 / 95$

Source: Almanac of China's Foreign Economic Relations and Trade, 1984-1990/91; China Statistical Information and Consultancy Service Center, 1992; China Energy Annual Review, 1994; China Statistical Yearbook, 1994; Chinese customs statistics. Earlier data are from MOFERT, and the following are customs statistics: exports of coal (1984 and later), coke (1984 and later), crude oil (1981 and later), oil products (1981 and later), and electricity (1989 and later); imports of coal (1984 and later), crude oil (1988 and later), oil products (1985 and later), and electricity (1989 and later); and as noted. 
Table VII-1. Energy Exports and Imports, 1950-1994 (continued)

\begin{tabular}{|c|c|c|c|c|c|c|c|c|c|}
\hline \multicolumn{10}{|c|}{ 2. Mtce } \\
\hline Year & Coal * & Coke & $\begin{array}{c}\text { Crude } \\
\text { Oil }\end{array}$ & $\begin{array}{l}\text { Petroleum } \\
\text { Products } \dagger\end{array}$ & Electricity II & Coal * & $\begin{array}{c}\text { Crude } \\
\text { Oil }\end{array}$ & $\begin{array}{l}\text { Petroleum } \\
\text { Products } t\end{array}$ & Electricity I \\
\hline 1950 & 1.96 & 0.00 & - & - & - & 0.04 & 0.06 & - & - \\
\hline 1951 & 0.25 & 0.00 & - & - & - & $<0.01$ & 0.09 & - & - \\
\hline 1952 & 0.29 & 0.00 & - & - & - & $<0.01$ & 0.14 & - & - \\
\hline 1953 & 0.95 & 0.00 & - & - & - & $<0.01$ & 0.16 & - & - \\
\hline 1954 & 1.51 & 0.03 & - & - & - & $<0.01$ & 0.22 & - & - \\
\hline 1955 & 1.63 & 0.00 & - & - & - & 0.02 & 0.54 & - & - \\
\hline 1956 & 2.03 & 0.11 & - & - & - & 0.24 & 0.57 & - & - \\
\hline 1957 & 1.88 & 0.15 & - & - & - & 0.07 & 0.54 & - & - \\
\hline 1958 & 2.00 & 0.03 & - & - & - & 0.57 & 0.95 & - & - \\
\hline 1959 & 1.99 & 0.05 & - & - & - & 1.25 & 0.94 & - & $=$ \\
\hline 1960 & 2.12 & 0.04 & - & - & - & 1.24 & 0.85 & - & - \\
\hline 1961 & 2.32 & 0.04 & - & 0.001 & - & 1.42 & 0.08 & - & - \\
\hline 1962 & 2.60 & 0.05 & 0.09 & 0.04 & - & 1.41 & 0.15 & - & - \\
\hline 1963 & 260 & 0.09 & 0.11 & 0.01 & - & 1.20 & 0.17 & - & - \\
\hline 1964 & 2.97 & 0.12 & 0.13 & 0.05 & - & 1.30 & 0.18 & - & - \\
\hline 1965 & 3.36 & 0.12 & 0.28 & 0.15 & - & 1.99 & 0.18 & - & - \\
\hline 1966 & 3.97 & 0.11 & 0.28 & 0.29 & - & 1.60 & 0.24 & - & - \\
\hline 1967 & 3.49 & 0.07 & 0.23 & 0.20 & - & 1.13 & 0.08 & - & - \\
\hline 1968 & 2.13 & 0.06 & 0.19 & 0.16 & - & 1.08 & 0.13 & - & - \\
\hline 1969 & 1.46 & 0.06 & 0.15 & 0.21 & - & 0.96 & 0.28 & - & - \\
\hline 1970 & 2.27 & 0.26 & 0.27 & 0.28 & - & 1.23 & 0.68 & - & $=$ \\
\hline 1971 & 2.87 & 0.38 & 0.38 & 0.55 & - & 1.22 & 0.11 & - & - \\
\hline 1972 & 2.82 & 0.35 & 0.91 & 1.31 & - & 1.35 & 0.24 & - & - \\
\hline 1973 & 2.82 & 0.44 & 2.62 & 1.71 & - & 1.56 & 0.25 & - & - \\
\hline 1974 & 2.87 & 0.42 & 7.25 & 2.17 & - & 1.84 & 1.28 & - & - \\
\hline 1975 & 3.00 & 0.42 & 14.13 & 3.09 & - & 2.59 & 251 & - & - \\
\hline 1976 & 2.27 & 0.24 & 12.15 & 2.86 & - & 206 & 1.14 & - & - \\
\hline 1977 & 2.63 & 0.20 & 13.02 & 2.89 & - & 204 & 0.68 & - & - \\
\hline 1978 & 3.12 & 0.29 & 16.18 & 3.05 & - & 244 & 0.99 & - & - \\
\hline 1979 & 4.63 & 0.29 & 19.21 & 4.46 & - & 2.15 & 0.37 & - & $=$ \\
\hline 1980 & 6.32 & 0.26 & 19.03 & 6.18 & - & 1.99 & 0.52 & - & $\bar{T}$ \\
\hline $198 \mid$ & 6.57 & 0.24 & 19.82 & 6.86 & - & 1.93 & 0.10 & - & 0.121 \\
\hline 1982 & 6.44 & 0.46 & 20.99 & 7.22 & - & 2.19 & 0.92 & - & 0.133 \\
\hline 1983 & 6.56 & 0.34 & 21.19 & 7.22 & - & 2.14 & 0.53 & - & 0.174 \\
\hline 1984 & 7.04 & 0.34 & 31.47 & 8.38 & 0.012 & 243 & 0.35 & - & 0.323 \\
\hline 1985 & 7.77 & 0.36 & 43.33 & 9.13 & 0.016 & 2.31 & 1.02 & 0.10 & 0.444 \\
\hline 1986 & 9.82 & 0.45 & 40.75 & 8.02 & 0.016 & 247 & 1.54 & 2.87 & 0.489 \\
\hline 1987 & 13.53 & 0.59 & 38.93 & 7.26 & 0.016 & 1.94 & 2.45 & 2.89 & 0.521 \\
\hline 1988 & 15.65 & 1.00 & 37.24 & 7.05 & 0.016 & 1.69 & 1.22 & 4.48 & 0.610 \\
\hline 1989 & 15.34 & 1.61 & 34.87 & 6.96 & 0.020 & 229 & 4.67 & 7.80 & 0.663 \\
\hline 1990 & 17.29 & 1.26 & 34.30 & 7.74 & 0.034 & 1.98 & 4.18 & 4.62 & 0.778 \\
\hline 1991 & 20.10 & 1.05 & 3232 & 7.08 & 0.105 & 1.37 & 8.54 & 6.73 & 1.256 \\
\hline 1992 & 19.70 & 1.31 & 30.76 & 7.92 & 0.105 & 1.23 & 16.24 & 11.36 & 2012 \\
\hline 1993 & 19.81 & 2.53 & 27.79 & 5.46 & 0.047 & 1.43 & 2241 & 25.25 & 1.820 \\
\hline 1994 & $24.25 \S$ & 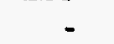 & 26.44 & 5.58 & - & - & 17.65 & 18.64 & - \\
\hline
\end{tabular}

- Exported coal is of high quality and is here assumed to be equivalent to standard coal $(29.3 \mathrm{GJ} / \mathrm{t}$, low heat).

$\dagger$ Composed mainly of gasoline, gasoil (diesel), fuel oil, naphtha, aviation kerosene, and lubricant base oil. Petroleum products are converted as gasoline or kerosene (1.47 tce/t). Diesel is the largest component of product imports. Smuggling of diesel and gasoline has grown in recent years, and official statistics understate actual imports.

I Converted at $0.404 \mathrm{kgce} / \mathrm{kWh}$.

§ Ministry of Coal, $1 / 10 / 95$.

Source: Almanac of China's Foreign Economic Relations and Trade, 1984-1990/91; China Statistical information and Consultancy Service Center, 1992; China Energy Annual Review, 1994; China Statistical Yearbook, 1994; Chinese customs statistics. Earlier data are from MOFERT, and the following are customs statistics: exports of coal (1984 and later), coke (1984 and later), crude oil (1981 and later), oil products (1981 and later), and electricity (1989 and later); imports of coal (1984 and later), crude oil (1988 and later), oil products (1985 and later), and electricity (1989 and later); and as noted. 
Table VII-1. Energy Exports and Imports, 1950-1994 (continued)

\begin{tabular}{|c|c|c|c|c|c|c|c|c|c|c|}
\hline \multicolumn{11}{|c|}{ 3. Net Exports, Mtce } \\
\hline \multirow[b]{2}{*}{ Year } & \multicolumn{3}{|c|}{ Coal and Coke * } & \multicolumn{3}{|c|}{ Petroleum \& Products $\uparrow$} & \multicolumn{3}{|c|}{ Electricity II } & \multirow{2}{*}{$\begin{array}{l}\text { Overall } \\
\text { Net } \\
\text { Exports }\end{array}$} \\
\hline & Exports & Imports & $\begin{array}{c}\text { Net } \\
\text { Exports }\end{array}$ & Exports & Imports & $\begin{array}{c}\text { Net } \\
\text { Exports }\end{array}$ & Exports & Imports & $\begin{array}{c}\text { Net } \\
\text { Exports }\end{array}$ & \\
\hline 1950 & 1.96 & 0.04 & 1.92 & - & 0.06 & -0.06 & - & - & - & 1.86 \\
\hline 1951 & 0.25 & $<0.01$ & 0.25 & - & 0.09 & -0.09 & - & - & - & 0.16 \\
\hline 1952 & 0.29 & $<0.01$ & 0.29 & - & 0.14 & -0.14 & - & - & - & 0.15 \\
\hline 1953 & 0.95 & $<0.01$ & 0.95 & - & 0.16 & -0.16 & - & - & - & 0.79 \\
\hline 1954 & 1.54 & $<0.01$ & 1.54 & - & 0.22 & -0.22 & - & - & - & 1.33 \\
\hline 1955 & 1.63 & 0.02 & $1.6 !$ & - & 0.54 & -0.54 & - & - & - & 1.07 \\
\hline 1956 & 2.14 & 0.24 & 1.90 & - & 0.57 & -0.57 & - & - & - & 1.33 \\
\hline 1957 & 2.03 & 0.07 & 1.96 & - & 0.54 & -0.54 & - & - & - & 1.42 \\
\hline 1958 & 2.03 & 0.57 & 1.47 & - & 0.95 & -0.95 & - & - & - & 0.52 \\
\hline 1959 & 2.04 & 1.25 & 0.79 & - & 0.94 & -0.94 & - & - & - & -0.15 \\
\hline 1960 & 2.16 & 1.24 & 0.92 & - & 0.85 & -0.85 & - & - & - & 0.07 \\
\hline 1961 & 2.36 & 1.42 & 0.93 & 0.001 & 0.08 & -0.08 & - & - & - & 0.85 \\
\hline 1962 & 2.65 & 1.41 & 1.24 & 0.13 & 0.15 & -0.02 & - & - & - & 1.22 \\
\hline 1963 & 2.69 & 1.20 & 1.48 & 0.12 & 0.17 & -0.05 & - & - & - & 1.43 \\
\hline 1964 & 3.09 & 1.30 & 1.79 & 0.18 & 0.18 & 0.00 & - & - & - & 1.80 \\
\hline 1965 & 3.48 & 1.99 & 1.49 & 0.43 & 0.18 & 0.25 & - & - & - & 1.74 \\
\hline 1966 & 4.08 & 1.60 & 2.48 & 0.57 & 0.24 & 0.33 & - & - & - & 2.82 \\
\hline 1967 & 3.56 & 1.13 & 2.43 & 0.43 & 0.08 & 0.35 & - & - & - & 2.78 \\
\hline 1968 & 2.19 & 1.08 & 1.12 & 0.34 & 0.13 & 0.21 & - & - & - & 1.33 \\
\hline 1969 & 1.52 & 0.96 & 0.55 & 0.36 & 0.28 & 0.08 & - & - & - & 0.64 \\
\hline 1970 & 2.53 & 1.23 & 1.30 & 0.56 & 0.68 & -0.12 & - & - & - & 1.18 \\
\hline 1971 & 3.25 & 1.22 & 2.03 & 0.92 & 0.11 & 0.82 & - & - & - & 2.85 \\
\hline 1972 & 3.17 & 1.35 & 1.81 & 2.22 & 0.24 & 1.98 & - & - & - & 3.79 \\
\hline 1973 & 3.26 & 1.56 & 1.69 & 4.33 & 0.25 & 4.08 & - & - & - & 5.77 \\
\hline 1974 & 3.29 & 1.84 & 1.45 & 9.42 & 1.28 & 8.14 & - & - & - & 9.59 \\
\hline 1975 & 3.42 & 2.59 & 0.82 & 17.21 & 2.51 & 14.70 & - & - & - & 15.52 \\
\hline 1976 & 2.51 & 2.06 & 0.45 & 15.01 & 1.14 & 13.87 & - & - & & $|4.3|$ \\
\hline 1977 & 2.83 & 2.04 & 0.78 & 15.91 & 0.68 & 15.23 & - & - & - & 16.01 \\
\hline 1978 & 3.41 & 2.44 & 0.97 & 19.23 & 0.99 & 18.24 & & - & - & 19.21 \\
\hline 1979 & 4.92 & 215 & 2.77 & 23.67 & 0.37 & 23.30 & - & - & - & 26.07 \\
\hline 1980 & 658 & 1.99 & 4.59 & 25.21 & 0.52 & 24.69 & - & - & - & 29.28 \\
\hline 1981 & 0.81 & 1.93 & 4.88 & 26.68 & 0.10 & 26.58 & - & 0.12 & -0.12 & 31.34 \\
\hline 1982 & 0.90 & 2.19 & 4.72 & 28.21 & 0.92 & 27.29 & - & 0.13 & -0.13 & 31.87 \\
\hline 1983 & 0.89 & 2.14 & 4.75 & 28.41 & 0.53 & 27.88 & - & 0.17 & -0.17 & 32.46 \\
\hline 1984 & 7.38 & 2.43 & 4.95 & 39.85 & 0.35 & 39.50 & 0.01 & 0.32 & -0.31 & 44.14 \\
\hline 1985 & 8.13 & 2.31 & 5.82 & 52.46 & 1.02 & 51.44 & 0.02 & 0.44 & -0.43 & 56.83 \\
\hline 1986 & 10.27 & 2.47 & 7.80 & 48.77 & 4.41 & 44.36 & 0.02 & 0.49 & -0.47 & 51.69 \\
\hline 1987 & 14.12 & 1.94 & 12.18 & 46.20 & 5.35 & 40.85 & 0.02 & 0.52 & -0.51 & 52.53 \\
\hline 1988 & 16.65 & 1.69 & 14.96 & 44.29 & 5.70 & 38.59 & 0.02 & 0.61 & -0.59 & 52.96 \\
\hline 1989 & 16.95 & 229 & 14.66 & 41.84 & 1247 & 29.37 & - & 0.66 & -0.64 & 43.38 \\
\hline 1990 & 18.55 & 1.98 & 16.57 & 42.04 & 8.80 & 33.24 & 0.03 & 0.78 & -0.74 & 49.06 \\
\hline 1991 & 21.15 & 1.37 & 19.78 & 39.39 & 15.27 & 24.13 & 0.11 & 1.26 & -1.15 & 42.76 \\
\hline 1992 & 21.01 & 1.23 & 19.78 & 38.68 & 27.60 & 11.08 & 0.11 & 2.01 & -1.91 & 28.95 \\
\hline 1993 & 22.34 & 1.43 & 20.91 & 33.25 & 47.66 & -14.41 & 0.05 & 1.82 & -1.77 & 4.73 \\
\hline 1994 & - & - & - & 32.02 & 36.30 & -4.28 & - & - & - & - \\
\hline
\end{tabular}

* Exported coal is of high quality and is here assumed to be equivalent to standard coal (29.3 GJ/t, low heat).

$\dagger$ Composed mainly of gasoline, gasoil (diesel), fuel oil, naphtha, aviation kerosene, and lubricant base oil. Petroleum products are converted as gasoline or kerosene ( 1.47 tce/t). Diesel is the largest component of product imports. Smuggling of diesel and gasoline has grown in recent years, and official statistics understate actual imports.

I Converted at $0.404 \mathrm{kgce} / \mathrm{kWh}$.

Source: Almanac of China's Foreign Economic Relations and Trade, 1984-1990/91; China Statistical Information and Consultancy Service Center, 1992; China Energy Annual Review, 1994; China Statistical Yearbook, 1994; Chinese customs statistics. Earlier data are from MOFERT, except the following are customs statistics: exports of coal (1984 and later), coke (1984 and later), crude oil (1981 and later), oil products (1981 and later), and electricity (1989 and later); imports of coal (1984 and later), crude oil (1988 and later), oil products (1985 and later), and electricity (1989 and later); and as noted. 
Table VII-1. Net Energy Exports, 1950-1994 (continued)

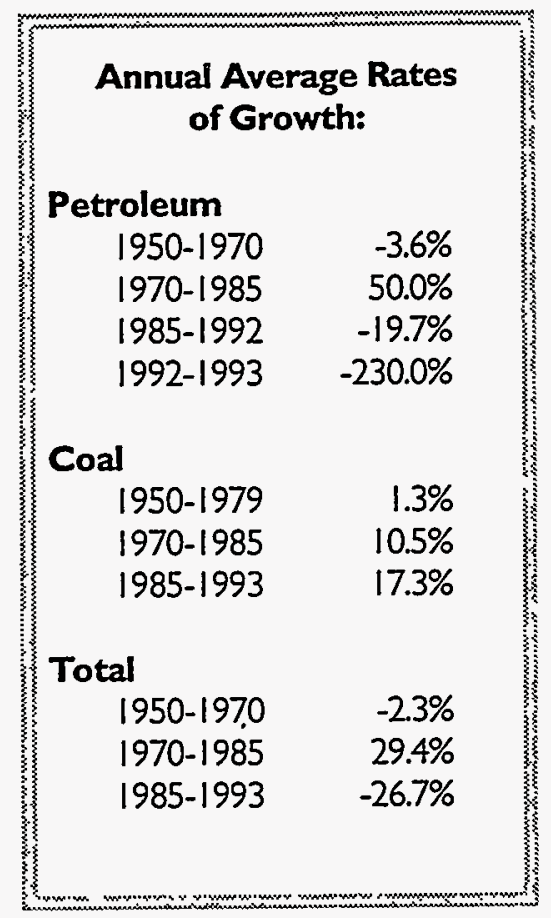

Figure VII-1. Net Energy Exports

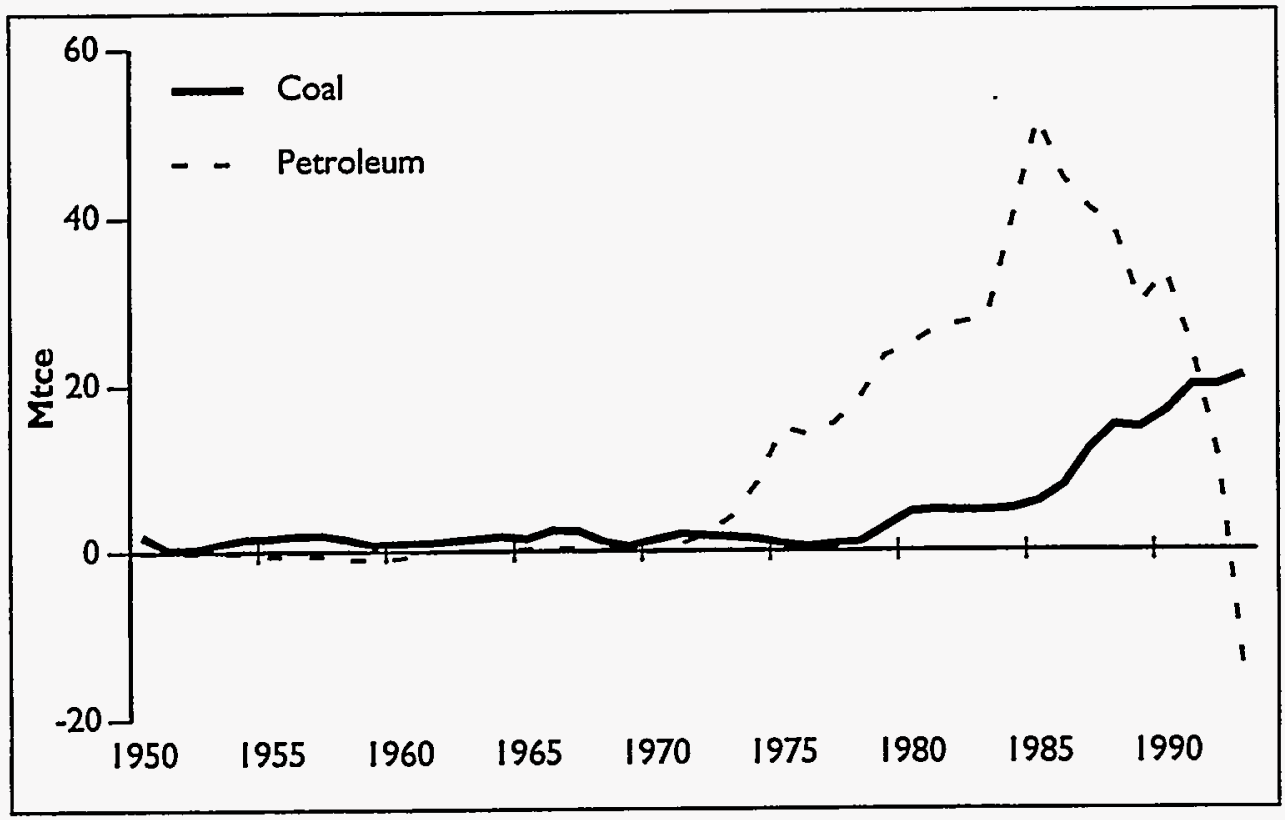


Table VII- 2. Energy Exports and Imports by Destination and Origin, * 1993

\begin{tabular}{|c|c|c|c|c|c|c|c|c|c|c|}
\hline \multirow[b]{2}{*}{ Country } & \multicolumn{2}{|c|}{ Coal \& Coal Products (t) } & \multicolumn{2}{|c|}{ Crude Oll (t) } & \multicolumn{2}{|c|}{$\begin{array}{l}\text { Petroleum } \\
\text { Distillates }+(t)\end{array}$} & \multicolumn{2}{|c|}{$\begin{array}{l}\text { Other Petroleum Products } \\
\text { \& Byproducts } I(t)\end{array}$} & \multicolumn{2}{|c|}{ Electricity (MWh) } \\
\hline & Exports & Imports & $\overline{\text { Exports }}$ & Imports & Exports & Imports & Exports & Imports & Exports & Imports \\
\hline $\begin{array}{l}\text { Angola } \\
\text { Amonting }\end{array}$ & & - & - & $1,224,482$ & - & 23863 & & - & - & - \\
\hline $\begin{array}{l}\text { Agustruma } \\
\text { Austia }\end{array}$ & 11 & 403,742 & . & 402,967 & 90 & 5,351 & 3,309 & 6.018 & . & . \\
\hline Austria & & & 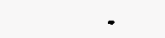 & & & 1 & & & & \\
\hline Bahrain & & - & - & - & 1 & & 101 & - & - & . \\
\hline Bangladesh & 5,513 & - & - & . & 312 & 5,499 & 3,449 & 0 & . & . \\
\hline Belgium & 247,743 & - & - & - & - & 1,434 & 19,802 & 99 & - & . \\
\hline Brazil & 451,797 & - & - & - & - & 2 & & 29 & - & . \\
\hline Bulgaria & 16,000 & & . & - & & 24,554 & & - & $\cdot$ & - \\
\hline Burma (Myanmar) & 133 & 6,370 & - & - & 5,302 & 7 & 32,662 & - & - & - \\
\hline Belanus & 000 & 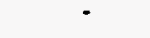 & - & 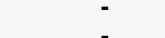 & 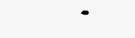 & 1,000 & & 100 & - $>$ o & 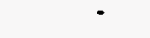 \\
\hline Chile & , & $:$ & : & $:$ & $\therefore$ & 120,508 & & 100 & & \\
\hline Columbia & - & - & . & - & . & . & 9,800 & . & - & : \\
\hline Costa Rica & - & - & - & - & . & . & 263 & - & . & . \\
\hline Cuba & - & - & - & - & - & - & 600 & - & - & . \\
\hline Cyprus & - & - & - & - & - & & 70 & - & - & - \\
\hline Denmark & & & - & & & 62 & 35 & & - & - \\
\hline Ecuador & $\cdot$ & $\cdot$ & - & - & 75 & & 2,359 & - & & - \\
\hline El Salvador & & - & - & - & $\left(\frac{1}{2}\right.$ & & 2,003 & 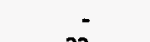 & - & - \\
\hline Egypt & 15,000 & & - & - & - & 1,871 & 27,273 & 32 & - & - \\
\hline Estonia & & - & - & - & - & 4,966 & 333 & - & : & - \\
\hline Finland & & & 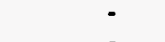 & & & 1265071 & 333 & & - & 33171 \\
\hline FSU & 1,540 & 7,142 & - & 13,923 & 270 & $1,265,021$ & 11,124 & 1,453 & - & 33,171 \\
\hline France & 651,248 & & - & & 42 & 2,226 & 1 & 69 & - & - \\
\hline Gabon & & - & - & 126,740 & - & - & - & & - & - \\
\hline Gambia & & - & - & & & & & & - & - \\
\hline Germany & 464,417 & - & - & 1 & 113 & 2,608 & $\begin{array}{r}7,259 \\
100\end{array}$ & 195 & - & - \\
\hline Ghana & . & $:$ & . & 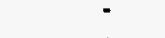 & 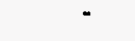 & & 102 & 850 & $:$ & 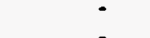 \\
\hline Greece & . & . & . & - & . & 599 & - & - &. & : \\
\hline Greenland & . & & . & 70208 & . & $\because$ & : & 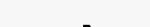 & 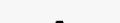 & - \\
\hline $\begin{array}{l}\text { Guinea } \\
\text { Hodurss }\end{array}$ & : & 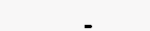 & . & & & & $480^{\circ}$ & - & : & - \\
\hline $\begin{array}{l}\text { Hong Kong } \\
\text { Hon }\end{array}$ & $1,971,312$ & 3 & - & - & 456,754 & 383.866 & 33,279 & 47,373 & . & $4,472,990$ \\
\hline Hungary & & & & & & 4,000 & 8,000 & & & \\
\hline India & 137,327 & • & & & & 68,371 & . 135,232 & 28 & . & \\
\hline Indonesia & 159,426 & 3 & 369,128 & $4,017,944$ & 2,688 & 89,684 & 8,651 & 21,334 & - & \\
\hline Iran & 55,000 & & & 67,860 & 67 & 415 & 10,073 & 64 & - & - \\
\hline Iraq & & - & & & & 23 & & 7 & - & - \\
\hline $\begin{array}{l}\text { Israel } \\
\text { ftaly }\end{array}$ & $\begin{array}{l}60,000 \\
185,714\end{array}$ & : & 111,438 & $:$ & & 72200 & 1756 & 74 & $:$ & $:$ \\
\hline Jamaica & & & & & & & 223 & & 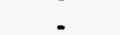 & \\
\hline Japan & $6,730,486$ & 1.351 & $12,695,794$ & - & 413,734 & 932,324 & 546,307 & 102,675 & - & - \\
\hline Jordan & & & & & & & 116 & & & \\
\hline Kazakhstan & 14,229 & & - & - & 3,110 & 3,669 & 40 & & - & - \\
\hline Kenya & & & & & 198 & & 752 & & & \\
\hline Korea (DPPK) & 1.751 .415 & 154,926 & $1,032,954$ & 19,022 & 78,265 & 16,508 & 12,666 & 5,158 & - & - \\
\hline Korea (RK) & $5.424,083$ & 18 & $1,605.140$ & 1,941 & 545,981 & $2,188.273$ & 26,493 & 92,469 & & - \\
\hline Kuwait & & & & & & 5,375 & 41 & 1,636 & - & - \\
\hline
\end{tabular}

- Customs statistlcs Indlcate proxlmate destination only, not final destination. Thus figures for fossil fuels may not reflect the actual balance of trade with some trading, e.g., with Hong Kong, from where many Chinese

goods are transhlpped to other destinations.
Includes gasoline, naphtha, other llght distlllates, kerosene and other middle distlllates, dlesel, fuel oll, lube oll and grease, and other heavy distlllates.

Includes waxes, petroleum Jelly, llquefled petroleum gases, asphalt, bltumen, coke, and other byproducts

Other petroleum product exports are malnly small amounts of paraffin. Other coal and petroleum product imports are mainly from overseas branches of Chinese companles.

Source: China's Customs Statistics Yearbook. 1993. 
Table VII- 2. Energy Exports and Imports by Destination and Origin*, 1993 (continued)

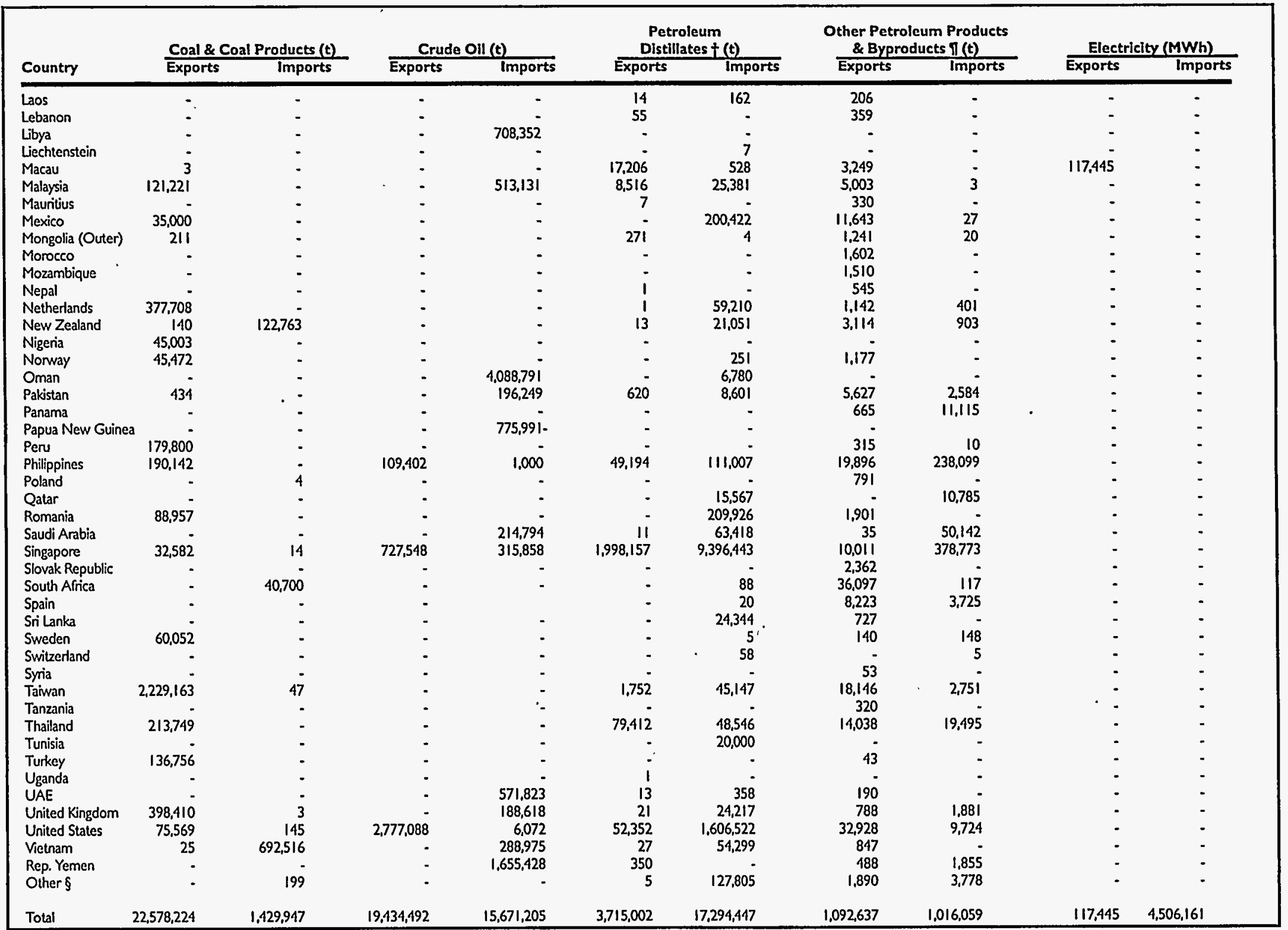

Customs statistics Indicate proximate destination only, not final destination. Thus figures for fossil fuels may not reflect the actual balance of trade with some trading, e.g., with Hong Kong, from where many Chinese goods are transhlpped to other destlnatlons.

Includes gasoline, naphtha, other light distillates, kerosene and other mlddle distillates, dlesel, fuel oil, lube oll and grease, and other heavy distillates.

Includes waxes, petroleum jelly, llquefied petroleum gases, asphalt, bltumen, coke, and other byproducts

Other petroleum product exports are mainly small amounts of parafin. Other coal and petroleum product Imports are malnly from overseas branches of Chinese companles.

Source: China's Customs Statlstics Yearbook, 1993. 
Figure VII-2. Coal Imports and Exports by Country, 1993

I. Coal Imports

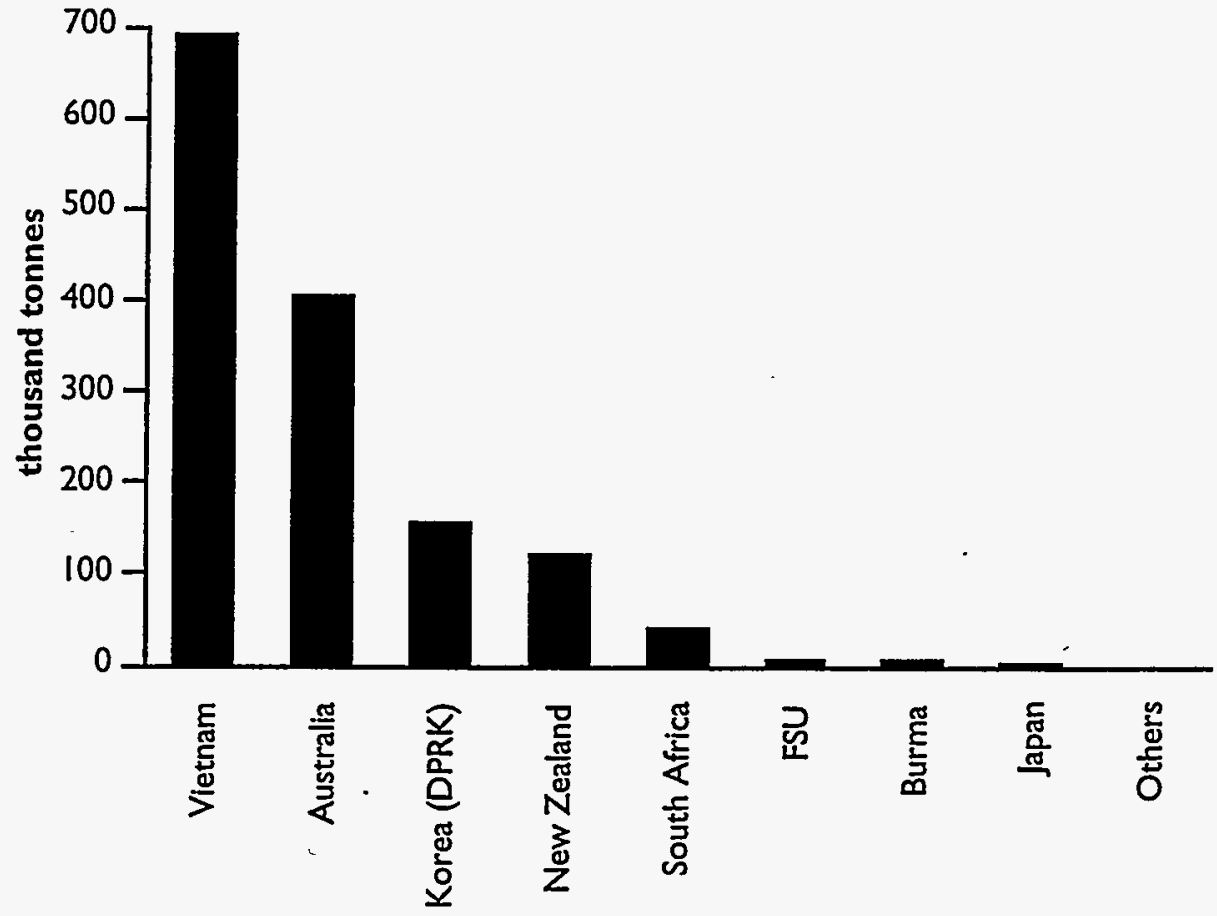

2. Coal Exports

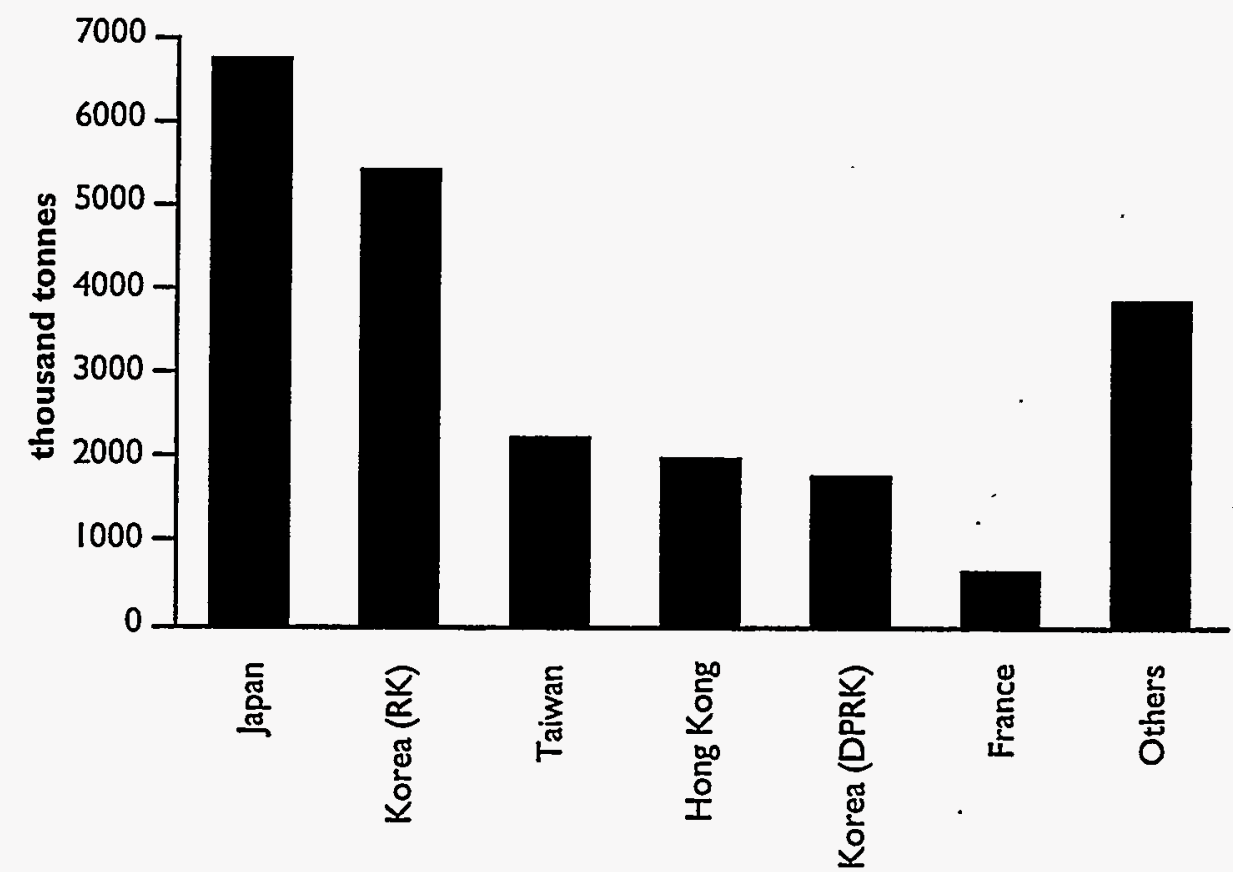


Table VII-3. Gross Energy Exports Earnings and Total Export Earnings Selected Years 1953-1970, and 1975-1993 - Billion Current US Dollars

\begin{tabular}{|c|c|c|c|c|c|}
\hline Year & $\begin{array}{c}\text { Total Gross } \\
\text { Export } \\
\text { Earnings }\end{array}$ & $\begin{array}{c}\text { Coal \& } \\
\text { Coke } \\
\text { Subtotal }\end{array}$ & $\begin{array}{l}\text { Oil \& Oil } \\
\text { Products } \\
\text { Subtotal }\end{array}$ & $\begin{array}{c}\text { Gross } \\
\text { Energy } \\
\text { Export } \\
\text { Earnings* }\end{array}$ & $\begin{array}{c}\text { Percentage of } \\
\text { Total Gross } \\
\text { Export } \\
\text { Earnings } †\end{array}$ \\
\hline 1953 & 1.022 & - & - & 0.008 & $0.8 \%$ \\
\hline 1957 & 1.597 & - & - & 0.018 & $1.1 \%$ \\
\hline 1965 & 2228 & - & - & 0.068 & $3.1 \%$ \\
\hline 1966 & 2.366 & - & - & 0.068 & $29 \%$ \\
\hline 1970 & 2260 & - & - & 0.063 & $28 \%$ \\
\hline 1975 & 7.264 & - & - & 1.093 & $15.0 \%$ \\
\hline 1976 & 6.855 & - & - & 0.942 & $13.7 \%$ \\
\hline 1977 & 7.590 & - & - & $1.068^{\circ}$ & $14.1 \%$ \\
\hline 1978 & 9.745 & - & - & 1.345 & $13.8 \%$ \\
\hline 1979 & 13.660 & - & 2231 & 2.654 & $19.4 \%$ \\
\hline 1980 & 18.270 & - & 4.119 & 4.588 & $25.1 \%$ \\
\hline 1981 & 22015 & - & 4.496 & 5.054 & $23.0 \%$ \\
\hline 1982 & 22.321 & 0.380 & 4.897 & 5.317 & $23.8 \%$ \\
\hline 1983 & 22.226 & 0.327 & 4.475 & 4.666 & $21.0 \%$ \\
\hline 1984 & 26.139 & 0.322 & 5.680 & 6.002 & $23.0 \%$ \\
\hline 1985 & 27.350 & 0.349 & 6.687 & 7.035 & $25.7 \%$ \\
\hline 1986 & 30.942 & 0.455 & 3.150 & 3.605 & $11.7 \%$ \\
\hline 1987 & 39.437 & 0.536 & 3.905 & 4.441 & $11.3 \%$ \\
\hline 1988 & 47.516 & 0.594 & 3.239 & 3.832 & $8.1 \%$ \\
\hline 1989 & 52.380 & 0.680 & 3.456 & 4.136 & $7.9 \%$ \\
\hline 1990 & 62.091 & 0.754 & 4.279 & 5.034 & $8.1 \%$ \\
\hline 1991 & 71.843 & 0.829 & 3.780 & 4.609 & $6.4 \%$ \\
\hline 1992 & 84.940 & 0.840 & 3.640 & 4.479 & $5.3 \%$ \\
\hline 1993 & 91.763 & 0.874 & 3.038 & 3.912 & $4.3 \%$ \\
\hline
\end{tabular}

* 1985-1991 figures include gas and electricity. 1982 and 1983 figures are not equal to the sum of coal and oil subtotals because figures for those years are from different sources. 1991, 1992 figures from China Statistical Yearbook.

$\dagger$ Percentages for 1979-1985 may be in error because of different sources for total exports and energy exports in those years.

Source: Almanac of China's Foreign Economic Relations and Trade, 1984-1990 customs statistics; Far Eastem Economic Review. Earlier data are from MOFERT and the following are from customs statistics: gross export earnings (1979 and later), coal exports (1985 and later), oil exports (1979 and later), and gross energy exports (1985 and later). 
Table VII-3. Export Earnings, 1975-1993 (continued)

\begin{tabular}{|c|c|}
\hline \multicolumn{2}{|c|}{$\begin{array}{c}\text { Annual Average Rates } \\
\text { of Growth }\end{array}$} \\
\hline \multicolumn{2}{|l|}{ Energy } \\
\hline $\begin{array}{l}1975-1985 \\
1985-1993\end{array}$ & $\begin{array}{r}20.5 \% \\
-11.1 \%\end{array}$ \\
\hline \multicolumn{2}{|l|}{ Total } \\
\hline $1975-1985$ & $14.2 \%$ \\
\hline $1985-1993$ & $16 . .3 \%$ \\
\hline
\end{tabular}

Figure VII-3. Gross Export Earnings

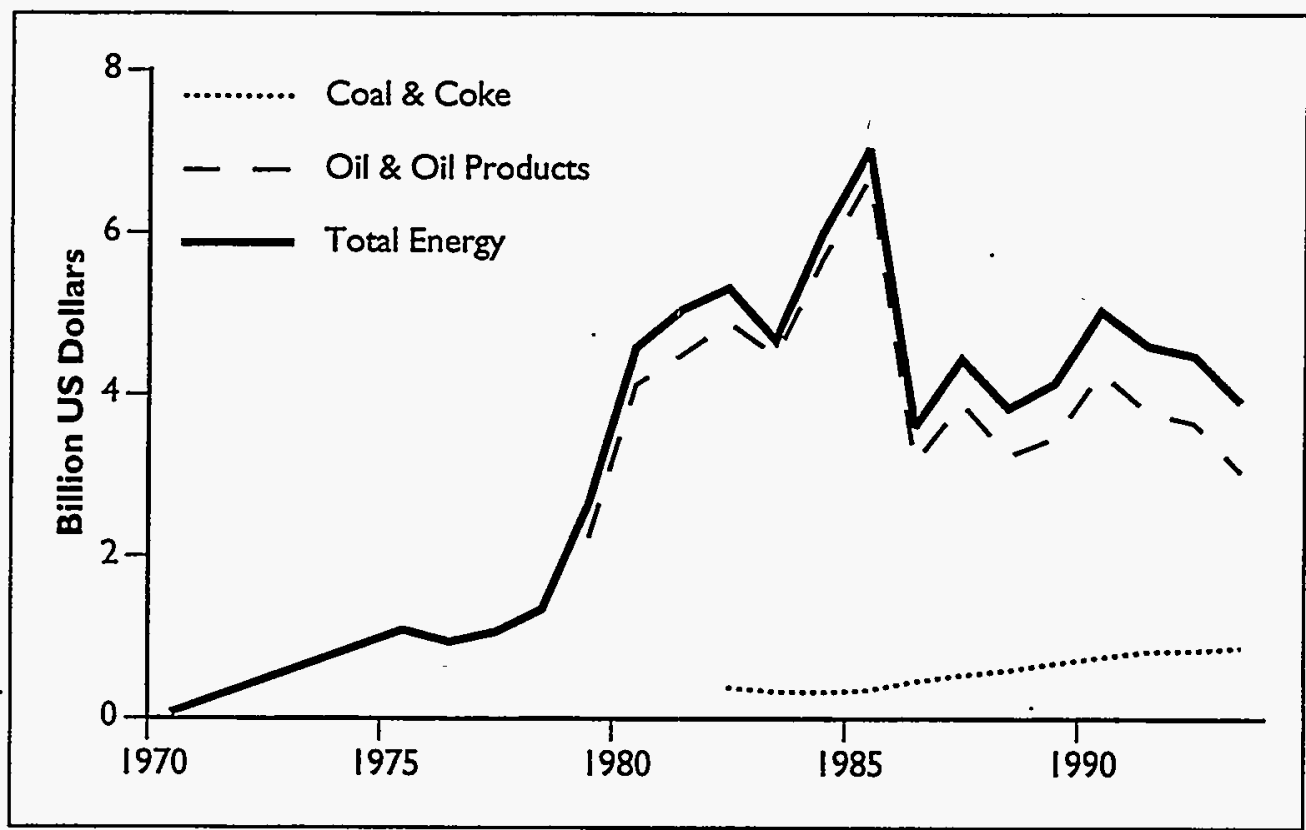


Table VII-4. Crude Oil Imports and Exports, 1993 and 1994

\begin{tabular}{|c|c|c|}
\hline \multicolumn{3}{|c|}{ I. Crude Oil Exports by Destination ( $t$ ) } \\
\hline & 1993 & 1994 \\
\hline Japan & $12,695,794$ & $11,904,814$ \\
\hline United States & $2,777,088$ & $3,059,690$ \\
\hline Korea (RK) & $1,605,140$ & $1,609,796$ \\
\hline Korea (DPRK) & $1,032,954$ & 832,785 \\
\hline Singapore & 727,548 & 618,969 \\
\hline Israel & 117,438 & 412,970 \\
\hline Indonesia & 369,128 & 51,905 \\
\hline Philippines & 109,402 & - \\
\hline Total & 19.434 .492 & 18.490 .929 \\
\hline \multicolumn{3}{|c|}{ 2. Crude Oil Imports by Origin ( $t$ ) } \\
\hline & 1993 & 1994 \\
\hline Indonesia & $4,017,944$ & $4,724,534$ \\
\hline Oman & $4,088,791$ & $3,367,376$ \\
\hline Yemen & $1,655,428$ & $1,258,220$ \\
\hline Papua New Guinea & 775,991 & 801,811 \\
\hline Libya & 708,352 & - \\
\hline Vietnam & 288,975 & 610,418 \\
\hline Angola & $1,224,482$ & 372,145 \\
\hline Malaysia & 513,131 & 286,542 \\
\hline Pakistan & 196,249 & 250,676 \\
\hline Saudi Arabia & 214,794 & 146,449 \\
\hline Argentina & 201,035 & - \\
\hline United Kingdom & 188,618 & - \\
\hline Gabon & 126,740 & 124,032 \\
\hline Iran & 67,860 & 69.119 \\
\hline Australia & 402,967 & 66,980 \\
\hline UAE & 571,823 & 65,528 \\
\hline Singapore & 315,858 & 65,207 \\
\hline Guinea & 70,208 & - \\
\hline Korea (DPRK) & 19,022 & - \\
\hline FSU & 13,923 & 57,072 \\
\hline Canada & - & 34,513 \\
\hline Thailand & - & 26,881 \\
\hline Korea (RK) & 1,941 & 6,986 \\
\hline Algeria & - & 6,462 \\
\hline Hong Kong & - & 2,860 \\
\hline Unites States & 6,072 & 2,069 \\
\hline Philippines & 1,000 & - \\
\hline Others & 1 & 30 \\
\hline Total & $15,671,205$ & 12.345 .910 \\
\hline
\end{tabular}

Source: China Customs Statistics. 
Figure VII-4. Crude Oil Imports and Exports by Country, 1994

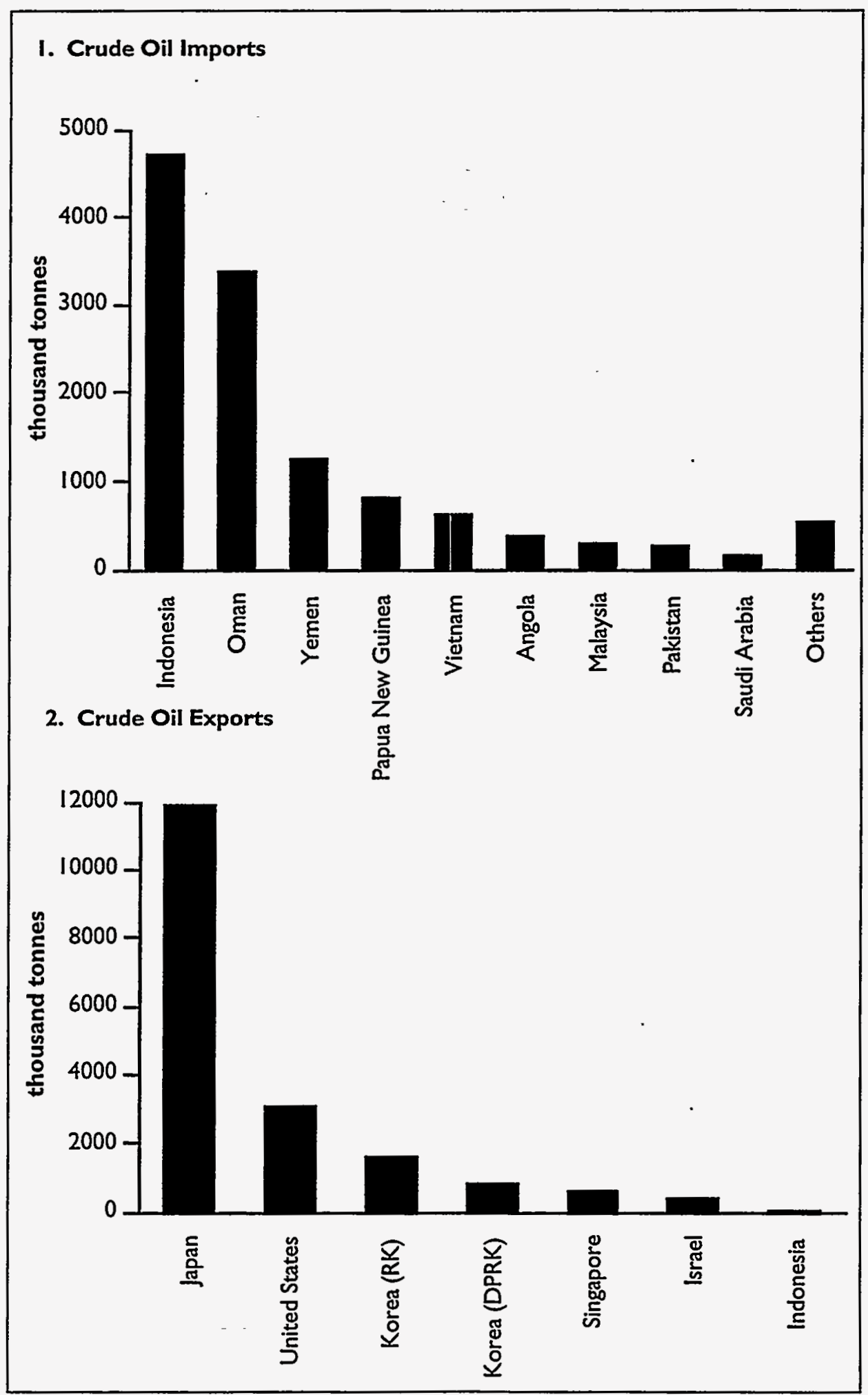


Table VII-5. Oil Product* Imports and Export, 1993 and 1994

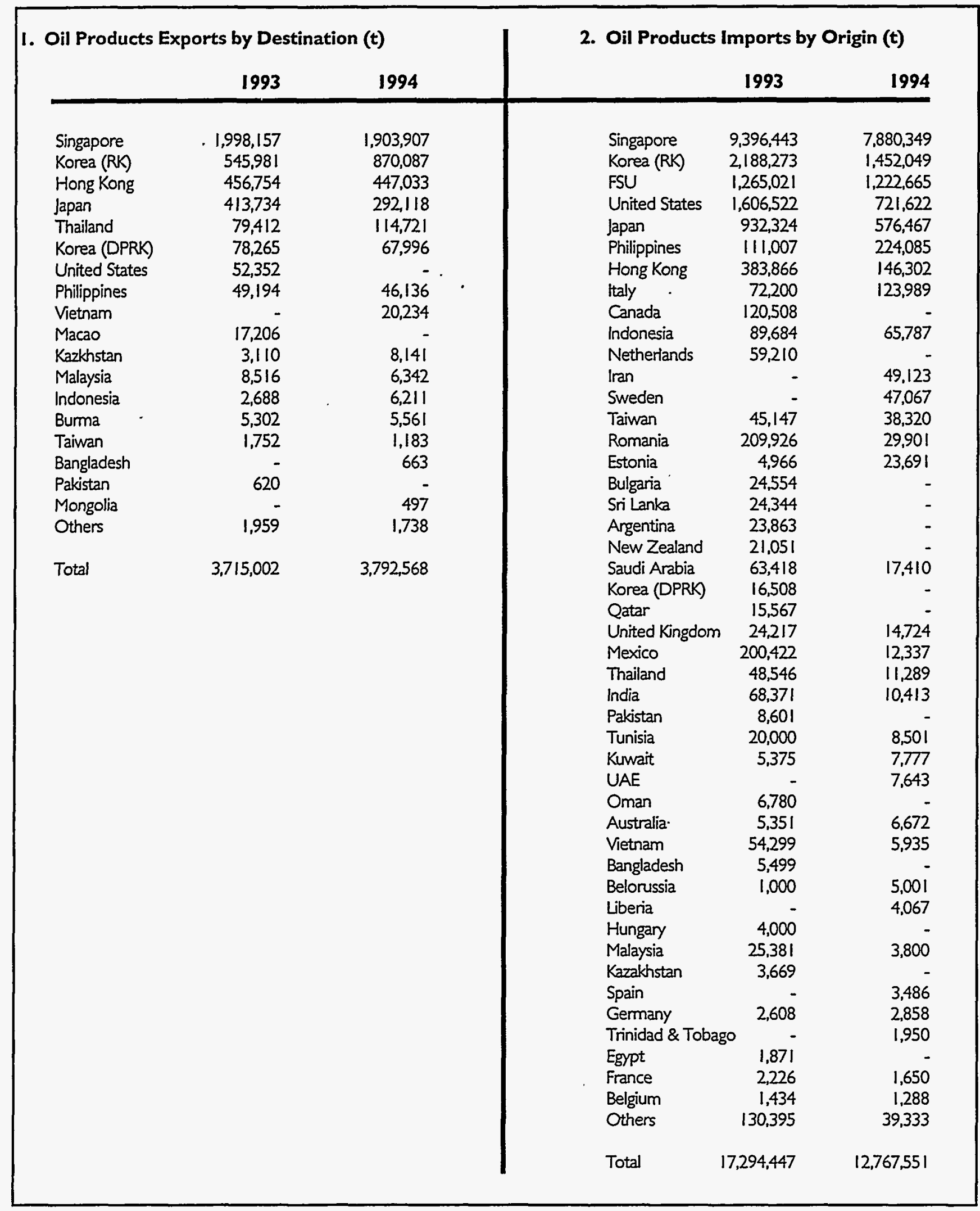

* Includes gasoline, naphtha, other light distillates, kerosene and other middle distillates, diesel, fuel oil, lube oil and grease, and other heavy distillates.

Source: China Customs Statistics. 
Figure VII-5. Oil Product Imports and Exports by Country, 1994

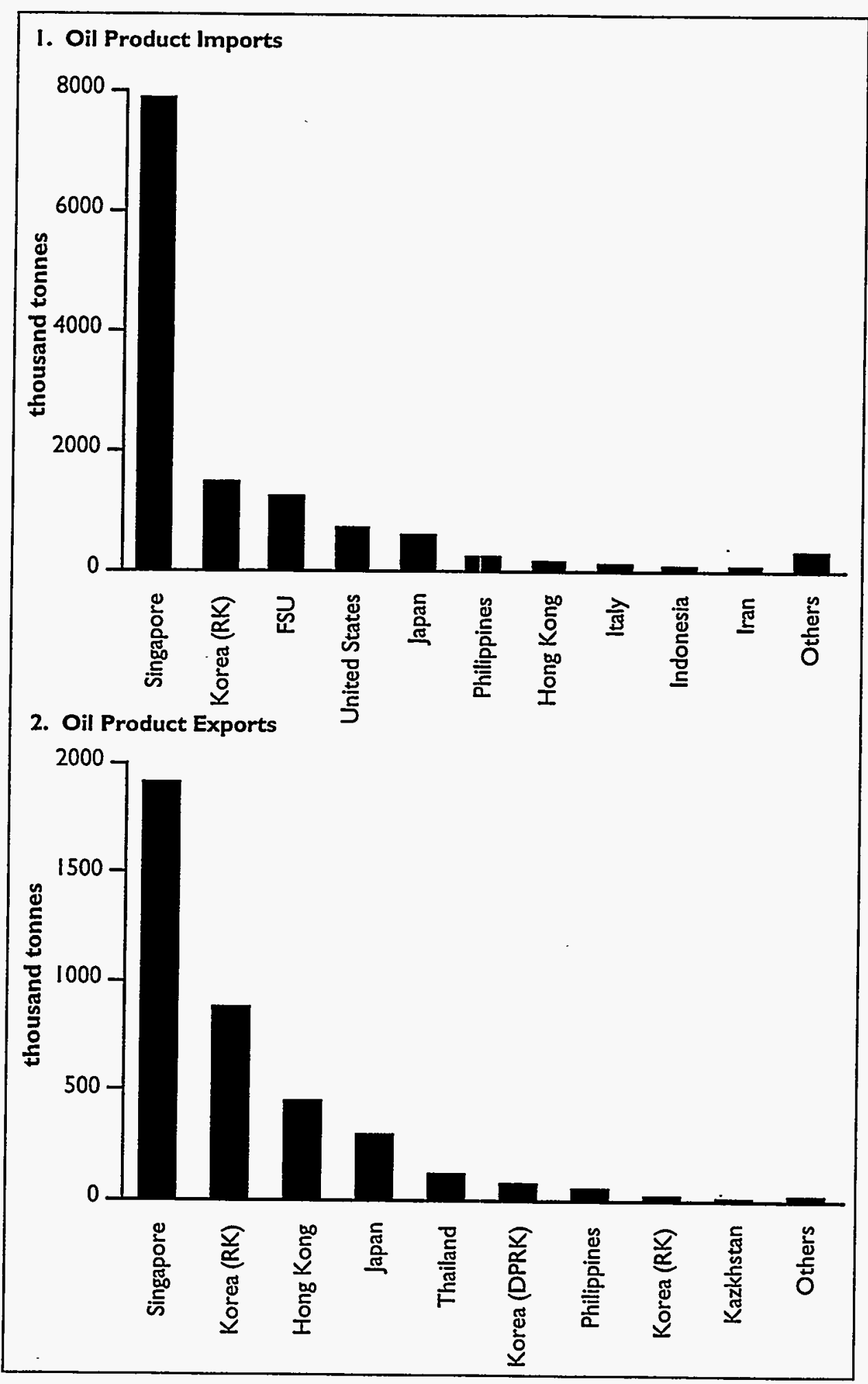




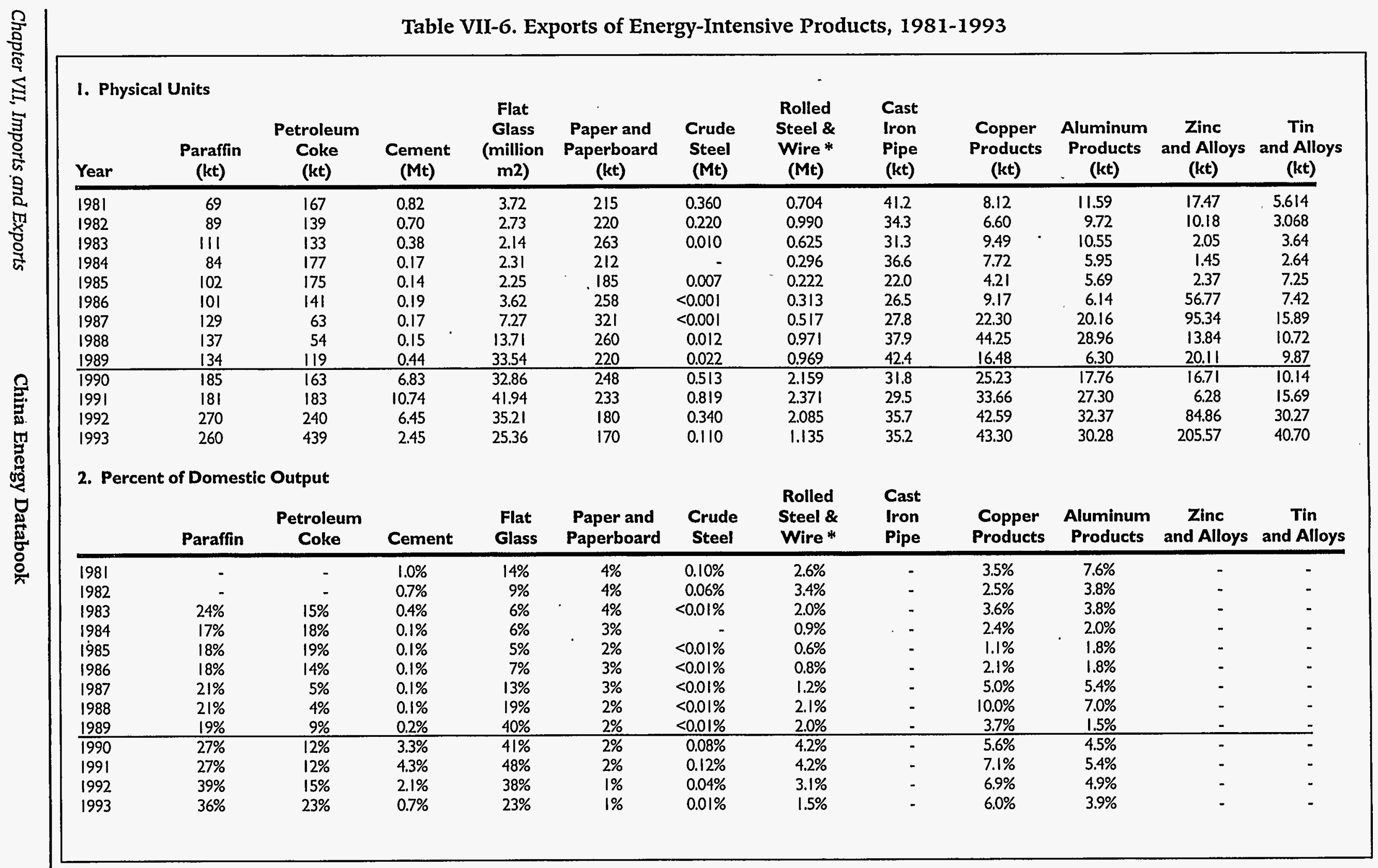

* Includes iron and steel wire.

Source: China Energy Statistical Yearbook, various years; China Statistical Yearbook, various years (customs statlstics); Yearbook of China's Industrial Economy, varlous years; Yearbook of China's Nonferrous Metals Industry, various years; Yearbook of China's Iron and Steel Industry, various years; SInopec Yearbook, 1991; China OGP, 2/15/94. 


\begin{tabular}{|c|c|c|c|c|c|c|c|c|c|c|}
\hline Year & $\begin{array}{c}\text { Rolled Steel } \\
\text { \& Wire * } \\
\text { (kt) }\end{array}$ & $\begin{array}{c}\text { Copper } \\
\text { and Alloys } \\
(k t)\end{array}$ & $\begin{array}{l}\text { Aluminum } \\
\text { and Alloys } \\
\text { (kt) }\end{array}$ & $\begin{array}{c}\text { Zinc } \\
\text { and Alloys } \\
\text { (kt) }\end{array}$ & $\begin{array}{l}\text { Caustic } \\
\text { Soda } \\
\text { (kt) }\end{array}$ & $\begin{array}{l}\text { Soda } \\
\text { Ash } \\
\text { (kt) }\end{array}$ & $\begin{array}{r}\begin{array}{c}\text { Chemi } \\
\text { (effective }\end{array} \\
\text { urea (Mt) }\end{array}$ & $\begin{array}{l}\text { rtilizer } \\
\text { sponent) } \\
\text { subtotal(Mt) }\end{array}$ & $\begin{array}{c}\text { Primary } \\
\text { Polyethylene } \\
\text { (Mt) }\end{array}$ & $\begin{array}{c}\text { Primary } \\
\text { Polypropylene } \\
\text { (Mt) }\end{array}$ \\
\hline 1981 & 3.54 & 53.7 & 57.8 & 12.4 & 51.7 & 204 & 260 & 555 & 012 & 010 \\
\hline 1982 & 3.77 & 110.9 & 169.6 & 108.1 & 66.6 & 247 & 3.26 & $\begin{array}{l}3.53 \\
6.06\end{array}$ & $\begin{array}{l}0.12 \\
0.42\end{array}$ & $\begin{array}{l}0.10 \\
0.20\end{array}$ \\
\hline 1983 & 9.66 & 485.9 & 283.8 & 228.7 & 247.0 & 609 & 4.25 & 8.00 & 0.43 & 0.20 \\
\hline 1984 & 12.32 & 254.0 & 252.7 & 230.2 & 227.4 & 852 & 4.40 & 9.23 & 0.70 & 0.27 \\
\hline 1985 & 20.10 & 355.7 & 487.9 & 268.6 & 224.5 & 1,057 & 3.82 & 7.61 & 0.74 & 0.41 \\
\hline 1986 & 18.47 & 171.1 & 266.2 & 116.9 & 283.2 & 1.221 & 3.01 & 5.10 & 0.68 & 0.35 \\
\hline 1987 & 12.45 & 75.5 & 184.1 & 68.2 & 304.9 & 853 & 5.56 & 10.90 & 0.67 & 0.29 \\
\hline 1988 & 9.15 & 84.4 & 75.4 & 62.0 & 231.9 & 823 & 8.49 & 14.71 & $\begin{array}{l}0.01 \\
1.02\end{array}$ & 0.56 \\
\hline 1989 & 9.52 & 70.1 & 175.5 & 19.2 & 187.9 & 969 & 7.94 & 13.93 & 0.53 & 0.26 \\
\hline 1990 & 4.23 & 40.3 & 71.8 & 4.1 & 40.5 & 211 & 8.13 & 16.27 & 0.36 & 0.22 \\
\hline 1991 & 3.58 & 114.0 & 43.9 & 11.7 & 3.6 & 54.2 & 7.01 & 18.18 & 0.65 & 0.56 \\
\hline 1992 & 7.09 & 379.0 & 229.6 & 42.2 & 10.2 & 59.4 & 7.48 & 18.59 & 1.42 & 0.62 \\
\hline 1993 & 30.22 & 363.5 & 165.7 & 40.1 & 5.8 & 60.8 & 3.61 & 10.21 & 1.04 & 0.58 \\
\hline Year & $\begin{array}{l}\text { Primary } \\
\text { Polystyrene } \\
\text { (Mt) }\end{array}$ & $\begin{array}{l}\text { Primary } \\
\text { Polyvinyl } \\
\text { Chloride } \\
\text { (Mt) }\end{array}$ & $\begin{array}{c}\text { Synthetic } \\
\text { Flber, } \\
\text { Staple } \\
\text { (kt) }\end{array}$ & $\begin{array}{l}\text { Regenerated } \\
\text { Synthetic } \\
\text { Fiber, } \\
\text { Staple } \\
\text { (kt) }\end{array}$ & $\begin{array}{l}\text { Synthetic } \\
\text { Fiber, } \\
\text { Continuous } \\
\text { (kt) }\end{array}$ & $\begin{array}{c}\text { Regenerated } \\
\text { Synthetic } \\
\text { Fiber, } \\
\text { Continuous } \\
\text { (kt) }\end{array}$ & $\begin{array}{l}\text { Paper } \\
\text { Pulp } \\
\text { (kt) }\end{array}$ & $\begin{array}{c}\text { Newsprint } \\
(k t)\end{array}$ & $\begin{array}{l}\text { Sedans } \\
\text { (units) }\end{array}$ & $\begin{array}{l}\text { Trucks } \\
\text { (units) }\end{array}$ \\
\hline 1981 & 0.06 & 0.01 & 497 & 40 & 200 & 21 & 682 & 157 & 1,401 & 20,770 \\
\hline 1982 & 0.04 & 0.02 & 239 & 50 & 98 & 29 & 475 & 69 & 1,101 & 7,730 \\
\hline 1983 & 0.02 & 0.04 & 134 & 41 & 50 & 28 & 731 & 35 & 5,806 & 8,445 \\
\hline 1984 & 0.06 & 0.03 & 270 & 40 & 174 & 17 & 640 & 58 & 21,651 & 28,047 \\
\hline $\begin{array}{l}1984 \\
1985\end{array}$ & 0.13 & 0.06 & 490 & 46 & 300 & 19 & 547 & 269 & 105,775 & $|11,48|$ \\
\hline 1986 & 0.15 & 0.09 & 301 & 80 & 200 & 19 & 523 & 111 & 48,276 & 64,570 \\
\hline 1987 & 0.08 & 0.08 & 241 & 112 & 86 & 22 & 683 & 142 & 30,536 & 19,216 \\
\hline 1988 & 0.23 & 0.10 & 451 & 88 & 112 & 23 & 795 & 102 & 48,276 & 64,570 \\
\hline 1989 & 0.19 & 0.08 . & 392 & 113 & 128 & .11 & 476 & 101 & 30,536 & $\begin{array}{r}-19.216 \\
\end{array}$ \\
\hline 1990 & 0.14 & 0.08 & 376 & 115 & 116 & 2 & 342 & $\frac{16}{16}$ & 34,063 & 15,392 \\
\hline 1991 & 0.27 & 0.14 & 502 & 118 & 118 & i & 1,291 & 21 & 54,409 & 18,578 \\
\hline 1992 & 0.65 & 0.33 & 520 & 65 & 264 & - & 600 & - 60 & 27.558 & 41,521 \\
\hline 1993 & 0.74 & 0.42 & 520 & 29 & 364 & - & 520 & 118 & 71,132 & 72,564 \\
\hline & ad ste & & & & & & & & & \\
\hline Source & na Energy Sta & cal Yearbook & ous years Icu & statistics]; Chi & tatistical Yearb & various years $[c$ & s statistics]. & & & \\
\hline
\end{tabular}


Chapter VIII - Energy and Environment 


\section{Energy and Environment}

$\mathrm{O}$ btaining, processing, transporting, and using energy are the major sources of environmental degradation in any country. In China the problems of energy use are particularly complex, spanning the range from indoor air pollution generated by inefficient combustion of traditional biomass fuels to incipient issues of nuclear waste disposal. ${ }^{1}$ China's efforts at dealing with environmental challenges have been remarkable by the standards of developing countries, but the government must continue to strengthen laws, regulations, and especially implementation if the country is to avoid widespread deterioration in environmental quality.

\section{CARBon DioXIDE}

China is currently the third largest contributor of anthropogenic carbon dioxide emissions. Its 694 Mt of carbon dioxide (carbon weight) accounted for $11 \%$ of worldwide emissions in 1991 (Tables VIII-1 and IX-25). Fossil fuel combustion was the source of $95 \%$ of carbon dioxide emissions, with coal alone accounting for $80 \%$. A growing share of emissions is liberated from limestone in the manufacture of cement, output of which has doubled over the past five years.

The structure of emissions by energy source is similar to that of primary energy consumption, although coal's contribution to total carbon dioxide emissions is relatively larger because its carbon emissions factor is substantially higher than for oil or natural gas. With continued growth of its coaldominated energy system, China will in all likelihood become the world's largest emitter of carbon dioxide early in the next century, contributing the single largest increment to global greenhouse gas emissions.

\section{Sulfur Dioxide ANd Particulate EMISSIONS}

Sulfur dioxide and particulates are considered by many environmental experts in China to be the ambient air pollutants of gravest concern. Most efforts at controlling air pollution have so far been aimed at these two pollutants. China's National Environmental Protection Agency collects data on emissions, focusing on those from industrial enterprises, and estimates national totals. ${ }^{2}$

\section{SULFUR DIOXIDE}

Over the past 20 years a fairly constant fraction of China's coal has been washed, and stack removal of sulfur dioxide has; been virtually unheard of; trends in sulfur dioxide emissions should therefore be expected to follow coal use rather closely. Sulfur dioxide emissions from industry declined between 1980 and 1986 , contrary to the $30 \%$ rise in coal use. Since then, however, reported sulfur dioxide emissions and have climbed, falling briefly only in 1990, a year in which growth in coal use leveled off (Table VIII-2).

Sulfur dioxide emissions densities are highest in the northern half of China, where coal is used to heat homes and other buildings for several months out of the year, and in the industrial centers of northern and eastern China (Table VIII-3). Although it is not the region with the highest sulfur dioxide emissions density, the Southwest suffers more than any other region from acid precipitation (see below). Southern coals are typically high in sulfur, resulting in serious emissions problems where local industry has no access to higher quality coal from the north.

Most coal in developed countries is burned in central power plants, simplifying the task of controlling sulfur emissions. Because of the pervasiveness of direct use of coal in China, however, power plants account for only one-third of sulfur emissions (Table VIII-4). The next largest emitters - the building materials, chemicals, and metals subsectors - all contributed $7 \%$ or less of national emissions each. These and other industrial sources 
tend to be widely scattered, as are residential users, which are responsible for about $20 \%$ of emissions. As long as this situation persists, the effectiveness of reducing sulfur dioxide through stack emissions controls will be limited. More far-reaching solution would include increasing the amount of delivered coal that is sorted and washed, and improving the efficiency of end-use equipment (like boilers) so that less fuel is needed for the same amount of useful energy.

\section{PARTICULATES}

Particulate emissions show a trend similar to that for sulfur dioxide, generally falling until the early 1990s, then rising (Table VIII-2). Since industrial coal consumption increased steadily over this period, the decline could be explained by improvements in and wider penetration of relatively simple emissions controls, especially for particulates from noncombustion processes, such as grinding and sorting. A large share of environmental protection funds are believed to have been used to control particulates, by far the easiest of the airbome pollutant streams to abate. The subsequent rise in emissions may reflect the increasing expense of further degrees of control.

The geographical distribution of particulate emissions generally follows that of sulfur dioxide as well, with densities highest in those regions with both a hard winter (where heating of buildings is permitted) and a high concentration of industry (Table VIII-3). Shanghai tops the list, by virtue of its small area and big industrial base. Beijing and Tianjin follow, both large municipalities in the heating zone (over $40 \%$ of combustion-related particulate emissions come from nonindustrial sources) with a great many factories. Of the provinces, Liaoning and Shandong, also northern centers of industry, have the highest emissions densities, followed by Jiangsu, where three-quarters of combustion-related particulates come from industry.

The single largest contributor of particulate emissions is the building materials industry, which is reportedly responsible for $24 \%$ of total national emissions (Table VIII-4). Cement kilns and mills alone account for $18 \%$. Power plants follow with $21 \%$, then ferrous metals with $8 \%$, and the remaining industrial sectors are all relatively small contributors. Nonindustrial users, mainly households, still account for over one-quarter of estimated emissions. Particulate removal technology is already fairly well developed in China, and although equipment quality remains a significant problem the major barrier to increasing rates of recovery in the industrial sector is weak enforcement of existing emissions regulations, especially in rural areas. In the household sector emissions reductions will depend on fuel switching - from raw coal to coal briquettes, and from coal to gas fuels.

\section{Ambient Pollution in Urban AREAS}

Air pollution in Chinese cities is extremely serious by world standards. Beijing, Shenyang, Xi'an, Shanghai, and Guangzhou are among the world's ten worst cities for air pollution. Along with other damages, this contributes to a very high rate of deaths from acute and chronic respiratory illnesses, which are responsible for $17 \%$ of deaths in urban areas. ${ }^{3}$ By contrast, in the United States less than $7 \%$ of all deaths are attributable to respiratory illnesses. Concern is greatest for particulates and sulfur dioxide, which together are responsible for the worst of China's air pollution-related illnesses. Estimates of annual economic losses these illness in urban areas run into the billions of yuan.

\section{TOTAL SUSPENDED PARTICULATES (TSP)}

To date most efforts at reducing emissions in China have focused on particulates, control of which is relatively inexpensive. The results are evident in steadily declining levels of suspended particulate material and particulate deposition velocities (Tables VIII-5 and VIII-6). Programs to replace raw coal with briquettes in household and other uses have resulted in significant reductions in particulate, sulfur, and carbon monoxide emissions in many residential areas.

Annual average TSP levels of several dozen cities are used to calculate China's national average, which fell from over $700 \mu \mathrm{g} / \mathrm{m}^{3}$ in the early 1980 s to under $400 \mu \mathrm{g} / \mathrm{m}^{3}$ by 1990 (Table VIII-5). Despite some dramatic improvements, however, levels of suspended particulates in many of China's major cities are consistently higher than standards intended to protect human health. Concentrations are generally higher in the northern latitudes, where coal is used to heat building in the winter, but aver- 
ages in some southern cities exceed those in some northern cities. Whereas China's Class $\mathrm{II}^{4}$ daily average standard is $300 \mathrm{\mu g} / \mathrm{m}^{3}$, as late as 1993 some cities registered annual average levels over 500 $\mu \mathrm{g} / \mathrm{m}^{3}$, or even $1,000 \mu \mathrm{g} / \mathrm{m}^{3}$ (i.e., higher than the standard for maximum level of TSP exposure at any time).

Annual variation is considerable, often due to weather; some cities in northwestern Shaanxi Province, for instance, experience year-to-year fluctuations in annual average TSP levels of a factor of two or three. Annual averages tend to hide a great deal of variation in the daily averages that make them up. In Hebei, where city annual averages were between 202 and $517 \mu \mathrm{g} / \mathrm{m}^{3}$, low daily averages were in the tens of $\mu \mathrm{g} / \mathrm{m}^{3}$, while high daily averages were in a few cases over $1,500 \mu \mathrm{g} / \mathrm{m}^{3}$.

\section{PARTICLE DEPOSITION VELOCITY}

While particle deposition velocities cannot easily be related to health effects, it may be related to total emissions of particulates, especially in areas where anthropogenic processes are the dominant sources of particulate matter. For most cities and for the country as a whole the trend has been clearly downward, with averages for both southem and northern cities in the early 1990 s at 11 and $25 \mathrm{t} / \mathrm{km}^{2}$ month respectively, or about half the levels of a decade previously (Tables VIII-5 and VIII-10). Some cities experienced little improvement, and some even a worsening, as in Shaanxi and Gansu Provinces. Cities in coastal areas appear to have enjoyed the greatest reductions in particulate deposition.

\section{SULFUR DIOXIDE}

Improvements in ambient sulfur dioxide have been much less impressive than for particulates, since until recently few efforts have been made to control emissions. By the early 1990s, national annual average levels of sulfur dioxide in Chinese cities had fallen somewhat to between 90 and $100 \mu \mathrm{g} / \mathrm{m}^{3}$, still significantly higher than the relevant Class II standard for annual average levels of $60 \mu \mathrm{g} / \mathrm{m}^{3}$ (Table VIII-5). The worst cities, mainly in the North and Southwest, experience levels four to five times the standard (Table VIII-7). Cities in several provinces, e.g., Heilongjiang, Anhui, and Hainan, experience ambient concentrations well under the standard.

In most cities, sulfur dioxide levels since the mid-1980s have fluctuated, with many cities experiencing sudden rises after several years of continuous declines. As with particulate concentrations, high and low daily averages of sulfur dioxide vary a great deal. While annual averages for Hebei cities ranged from 29 to $186 \mu \mathrm{g} / \mathrm{m}^{3}$ in 1993 , low and high daily averages extended from 3 to $1,435 \mu \mathrm{g} / \mathrm{m}^{3}$ (compared to the Class II standard for daily average levels of $150 \mu \mathrm{g} / \mathrm{m}^{3}$.

China's environmental regulatory system is beginning to carry out some programs that could eventually lead to significant improvements in ambient sulfur dioxide levels. Sulfur dioxide emissions fees, for example, are being tested in nine cities in Guizhou and Sichuan. Under the system all enterprises within these cities are to begin paying fees, at a rate of 0.2 yuan per $\mathrm{kg}$ of sulfur dioxide (or less than $20 \%$ of the cost of emissions control). About a dozen Chinese cities have also begun trial implementation of sulfur dioxide emissions trading schemes.

\section{NITROGEN OXIDES}

Nitrogen oxide levels are usually most closely related to motor vehicle fuel consumption, which has been increasing overall. Effective controls on nitrogen oxide emissions have been almost entirely lacking to date, and this is reflected in the overall rise ${ }^{5}$ in average ambient nitrogen oxide levels over the past decade (Table VIII-5). Episodes of photochemical smog are becoming more widespread, and nitrogen oxide concentrations are likely to continue increasing.

Annual average levels are still about half the daily average standard of $100 \mathrm{\mu g} / \mathrm{m}^{3}$, with only a few cities (e.g., Guangzhou and Dalian) in exceedence (Table VIII-8). Concentrations do not seem to vary a great deal by region; cities with the highest levels are scattered about the country. While the highest daily averages in most cities exceed the standard by a small margin, if at all, some cities experience levels several times the standard. 


\section{CARBON MONOXIDE}

Data on ambient carbon monoxide are available for only a few cities, all but one of which (Guangzhou) are in the North and Northeast (Table VIII-9). No clear trends are apparent. Annual averages in are generally below the Class II daily average standard of $4 \mathrm{mg} / \mathrm{m}^{3}$, although Tianjin, Harbin, and Guangzhou have at various times approached or exceeded it.

Ambient monitoring of carbon monoxide is probably not the most useful way to identify areas in which it is a problem, since most harm typically comes from acute exposures in enclosed spaces. Rapid additions to China's vehicle fleet, most with minimal emissions controls, and increasing congestion of urban streets have meant rising levels of carbon monoxide along streets. Monitoring of levels of these areas, where people spend significant portions of their day, is needed to better assess exposure levels.

\section{ACID Precipitation}

According to the National Environmental Protection Agency, about half of the cities monitored experienced an annual average $\mathrm{pH}$ of below 5.6 , the natural average (Table VIII-5). Most of those cities are in the South. Guizhou is the worst affected province, with cities receiving rain that has on average a $\mathrm{pH}$ value under 4 (Table VIII-11). The Chinese government has officially recognized the seriousness of the problem, and recent efforts to reduce sulfur dioxide emissions are motivated more by the desire to control acid precipitation than anything else.

Formerly confined to southwestern China, acid precipitation can now be found in most locations south of the Yangtze River and in some to the north. There is obvious economic and ecological damage in the most seriously affected areas. Recently a group of experts reported to the Chinese government that between 1985 and 1993 the area affected by acid rain increased from 1.75 to 2.8 million square kilometers, or nearly one-third of total land area. In spite of heavy sulfur emissions, northem China remains relatively less affected by acid precipitation because the airborne dust for which the region is famous is alkaline, neutralizing acidity.

\section{INDOOR AIR QUALITY}

Despite significant improvements in indoor air quality in many urban residences, owing to replacement of solid fuels by gas, electricity, and central heating, and to installation of kitchen fans, indoor air pollution remains one of China's worst environmental problems. The magnitude of the health problem from indoor fuel use in China is roughly comparable that posed by smoking, rates of which are notoriously high. The incidence of disease from indoor air pollution falls mainly on women and children, however, while the main impact of cigarettes is on the men who smoke them.

Levels of particulates, sulfur dioxide, carbon monoxide, and carcinogenic compounds are high because most households still burn solid fuels directly for cooking and heating. Studies of indoor pollution in common household settings suggest that a large portion of China's population is regularly exposed to levels of these pollutants an order of magnitude higher than any standard (Table VIII12). ${ }^{6}$ The continued widespread and inefficient use of biomass fuels and raw coal in residences with poor ventilation contributes to the continuing status of respiratory illness as the leading cause of death. While chronic respiratory problems may be the most widespread of health impacts, acute effects are well known also; every year deaths from carbon monoxide poisoning occur in northern China, where coal is used to heat brick beds in tightly weatherproofed dwellings. Concerns about indoor air pollution in developed countries, by comparison, are relatively mild and focus on pollutants such as nitrogen oxides from gas stove use, formaldehyde, ozone, and radon, as well as cigarette smoke.

1 For a wider ranging discussion of environmental problems in China related to energy use see Sinton and Levine, 1995.

2 Independent estimates of total emissions generally result in figures somewhat higher than those reported by Chinese sources, which cover rural industry and household fuel use incompletely. One recent paper estimate 1990 emissions of sulfur dioxide and particulates from combustion to be $18.6 \mathrm{Mt}$ and $15 \mathrm{Mt}$, compared to the official figures of 14.94 and 13.24 ( $\mathrm{Liu}$ and Spofford, 1994). Nitrogen oxide emissions for that year were estimated to be $6.6 \mathrm{Mt}$.

3 Rates are higher in rural areas (about $27 \%$ of deaths from respiratory illnesses). Most airborne pollutant exposure occurs indoors, where levels are usually higher than outdoors. 
4 Class II standards apply to residential areas and are usually similar to the United States' primary National Ambient Air Quality Standards (Table VII-A).

5 While there is significant variation from year to year, fitting a line to the data shows a mild upward trend.

6 For further information on indoor air pollutant levels in China see Sinton et al., 1995. 
Table VIII-A. Ambient Air Pollution Standards *

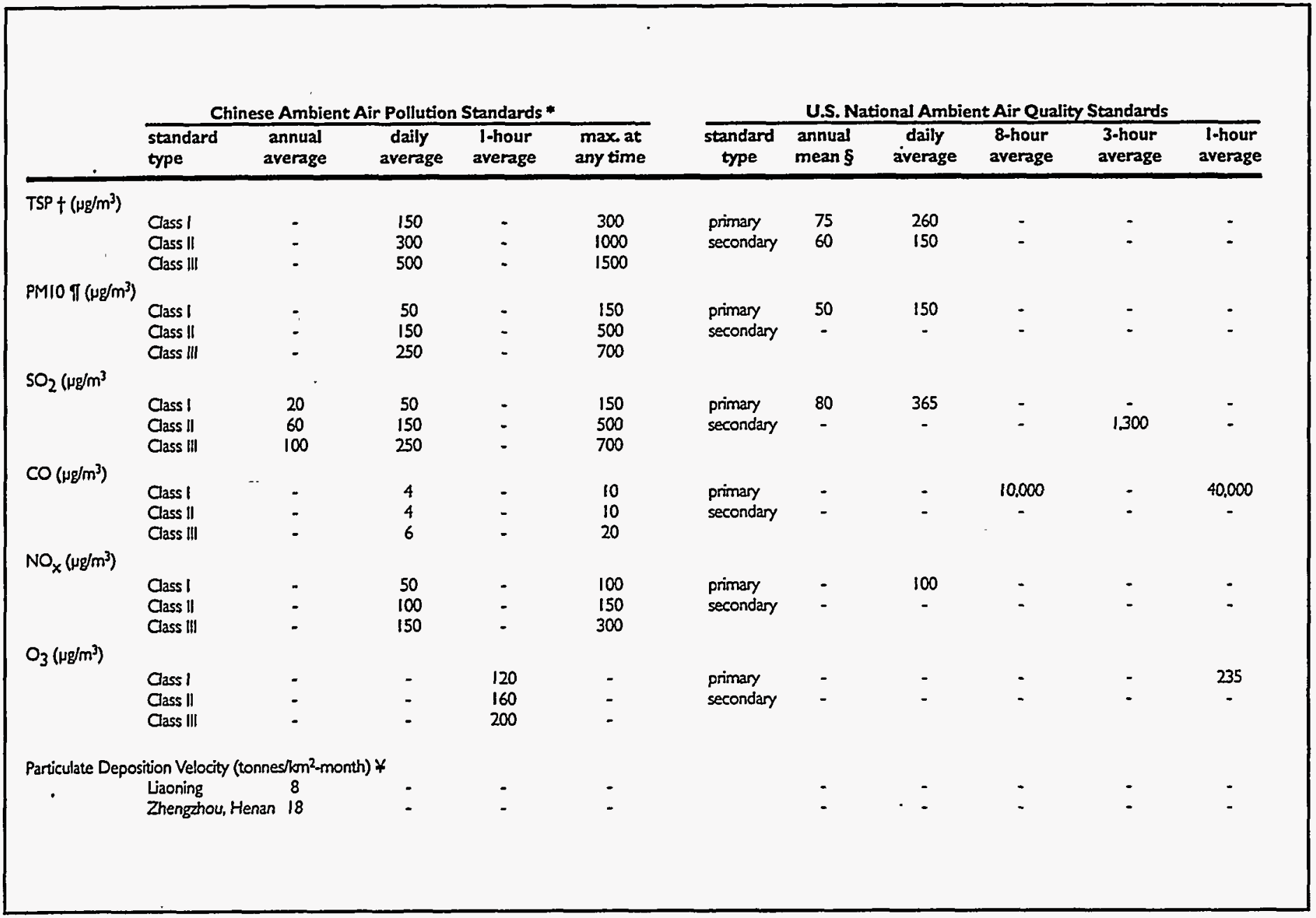

- Class I standards apply to scenic, tourist,and other sensitive areas. Class II air quality standards are intended to protect human health and apply to residential areas. Class III standards are interim targets for heavily polluted areas.

$t$ Total suspended particulate matter.

I Particulates with diameter $\leq 10$ um.

$\S$ US annual standards for TSP and PM1O refer to geometric means and for $\mathrm{SO}_{2}$ to arithmetic means.

P Provincial standards.

Source: State Council Environmental Protection Leadership Group; 1982; China Environmental Science Press, 1986; China Environmental Yearbook, 1991. 
Table VIII-1. Carbon Dioxide Emissions by Source, 1950-1991

\begin{tabular}{|c|c|c|c|c|c|c|c|c|}
\hline \multirow[b]{2}{*}{ Year } & \multicolumn{4}{|c|}{ Fossil Fuels } & \multirow[b]{2}{*}{ Cement } & \multirow{2}{*}{$\begin{array}{c}\text { Gas } \\
\text { Flaring }\end{array}$} & \multirow{2}{*}{$\begin{array}{c}\text { Total } \\
\text { Emissions }\end{array}$} & \multirow{2}{*}{$\begin{array}{c}\text { Per } \\
\text { Capita } \\
\text { Emissions } \\
\text { (t C) }\end{array}$} \\
\hline & Solid & Liquid & Gas & Subtotal & & & & \\
\hline 1950 & 21.4 & 0.2 & 0.0 & 21.6 & 0.1 & 0.0 & 21.7 & 0.04 \\
\hline 1951 & 27.6 & 0.3 & 0.0 & 27.9 & 0.2 & 0.0 & 28.1 & 0.05 \\
\hline 1952 & 34.6 & 0.4 & 0.0 & 35.0 & 0.4 & 0.0 & 35.4 & 0.06 \\
\hline 1953 & 36.0 & 0.5 & 0.0 & 36.5 & 0.5 & 0.0 & 37.0 & 0.06 \\
\hline 1954 & 43.0 & 0.9 & 0.0 & 43.9 & 0.6 & 0.0 & 44.5 & 0.08 \\
\hline 1955 & 50.6 & 1.5 & 0.0 & 52.1 & 0.6 & 0.0 & 52.7 & 0.09 \\
\hline 1956 & 56.6 & 2.2 & 0.0 & 58.8 & 0.9 & 0.0 & 59.7 & 0.10 \\
\hline 1957 & 67.3 & 2.5 & 0.0 & 69.8 & 0.9 & 0.0 & 70.7 & 0.11 \\
\hline 1958 & 140.3 & 3.4 & 0.1 & 143.8 & 1.3 & 0.0 & 145.0 & 0.23 \\
\hline 1959 & 1920 & 5.2 & 0.2 & 197.4 & 1.7 & 0.0 & 199.0 & 0.31 \\
\hline 1960 & 206.6 & 6.3 & 0.5 & 213.4 & 1.8 & 0.0 & 215.3 & 0.33 \\
\hline 1961 & 144.3 & 6.1 & 0.8 & 151.2 & 1.1 & 0.0 & 152.2 & 0.24 \\
\hline 1962 & 113.7 & 5.9 & 0.6 & 120.2 & 1.1 & 0.0 & 121.4 & 0.19 \\
\hline 1963 & 112.1 & 6.4 & 0.5 & 119.0 & 1.4 & 0.0 & 120.4 & 0.18 \\
\hline 1964 & 110.9 & 7.6 & 0.6 & 119.1 & 1.4 & 0.0 . & 120.4 & 0.17 \\
\hline 1965 & 119.6 & 9.6 & 0.6 & 129.8 & 1.5 & 0.0 & 131.2 & 0.18 \\
\hline 1966 & 129.7 & 12.2 & 0.7 & 142.6 & 1.5 & 0.0 & 144.1 & 0.20 \\
\hline 1967 & 105.9 & 11.6 & 0.8 & 118.3 & 1.1 & 0.0 & 119.4 & 0.16 \\
\hline 1968 & 114.0 & 13.3 & 0.7 & 128.0 & 1.2 & 0.0 & 129.2 & 0.17 \\
\hline 1969 & 138.4 & 18.2 & 1.0 & 157.6 & 1.4 & 0.0 & 159.0 & 0.20 \\
\hline 1970 & 183.9 & 24.9 & 1.5 & 210.3 & 1.4 & 0.0 & 211.6 & 0.26 \\
\hline 1971 & 203.3 & 31.8 & 20 & 237.1 & 3.1 & 0.2 & 240.5 & 0.29 \\
\hline 1972 & 2128 & 36.8 & 2.5 & 252.1 & 3.1 & 0.3 & 255.5 & 0.30 \\
\hline 1973 & 216.4 & 42.4 & 3.1 & 261.9 & 3.4 & 0.3 & 265.7 & 0.30 \\
\hline 1974 & 214.3 & 48.9 & 3.9 & 267.1 & 3.4 & 0.4 & 271.0 & 0.30 \\
\hline 1975 & 250.3 & 54.7 & 4.6 & 309.6 & 4.1 & 0.5 & 314.3 & 0.34 \\
\hline 1976 & 251.4 & 64.3 & 5.3 & 321.0 & 6.7 & 0.5 & 328.2 & 0.35 \\
\hline 1977 & 282.3 & 69.4 & 6.3 & 358.0 & 7.6 & 0.6 & 366.2 & 0.39 \\
\hline 1978 & 317.2 & 73.4 & 7.2 & 397.8 & 8.9 & 0.7 & 407.4 & 0.43 \\
\hline 1979 & 325.4 & 72.4 & 7.6 & 405.4 & 10.1 & 0.8 & 416.2 & 0.43 \\
\hline 1980 & 316.6 & 70.7 & 7.5 & 394.8 & 10.9 & 0.8 & 406.4 & 0.42 \\
\hline 1981 & 317.5 & 66.3 & 6.7 & 390.5 & 11.4 & 0.7 & 402.6 & 0.41 \\
\hline 1982 & 345.1 & 66.8 & 6.3 & 418.2 & 12.8 & 0.7 & 431.5 & 0.43 \\
\hline 1983 & 365.0 & 68.4 & 6.4 & 439.8 & 14.7 & 0.7 & 455.2 & 0.45 \\
\hline 1984 & 400.9 & 70.0 & 6.6 & 477.5 & 16.5 & 0.9 & 494.9 & 0.48 \\
\hline 1985 & 437.0 & 73.5 & 6.8 & 517.3 & 19.4 & 0.0 & 536.7 & 0.52 \\
\hline 1986 & 456.8 & 78.4 & 7.2 & 542.4 & 22.0 & 0.0 & 564.4 & 0.54 \\
\hline 1987 & 487.3 & 83.5 & 7.3 & 578.1 & 24.4 & 0.0 & 602.5 & 0.56 \\
\hline 1988 & 520.8 & 89.3 & 7.5 & 617.6 & 28.5 & 0.0 & 646.1 & 0.59 \\
\hline 1989 & 528.0 & 93.1 & 7.9 & 629.0 & 28.1 & 0.0 . & 657.1 & 0.59 \\
\hline 1990 & 533.0 & 92.1 & 8.0 & 633.1 & 27.6 & 0.0 & 660.7 & $\overline{0.58}$ \\
\hline 1991 & 5524 & 99.7 & 8.4 & 660.5 & 33.7 & 0.0 & 694.2 & 0.60 \\
\hline
\end{tabular}

Source: Marland, Andres, and Boden, 1994. 
Table VIII-1. Carbon Dioxide Emissions by Source, 1950-1991(continued)

\begin{tabular}{|c|c|c|c|c|c|c|c|}
\hline \multirow[b]{2}{*}{ Year } & \multicolumn{4}{|c|}{ Fossil Fuels } & \multirow{2}{*}{ Cement } & \multirow{2}{*}{$\begin{array}{l}\text { Gas } \\
\text { Flaring }\end{array}$} & \multirow{2}{*}{$\begin{array}{l}\text { Total } \\
\text { Emissions }\end{array}$} \\
\hline & Solid & Liquid & Gas & Subtotal & & & \\
\hline 1950 & $99 \%$ & $1 \%$ & $0 \%$ & $100 \%$ & $0.5 \%$ & $0 \%$ & $100 \%$ \\
\hline 1951 & $98 \%$ & $1 \%$ & $0 \%$ & $99 \%$ & $1 \%$ & $0 \%$ & $100 \%$ \\
\hline 1952 & $98 \%$ & $1 \%$ & $0 \%$ & $99 \%$ & $1 \%$ & $0 \%$ & $100 \%$ \\
\hline 1953 & $97 \%$ & $1 \%$ & $0 \%$ & $99 \%$ & $1 \%$ & $0 \%$ & $100 \%$ \\
\hline 1954 & $97 \%$ & $2 \%$ & $0 \%$ & $99 \%$ & $1 \%$ & $0 \%$ & $100 \%$ \\
\hline 1955 & $96 \%$ & $3 \%$ & $0 \%$ & $99 \%$ & $1 \%$ & $0 \%$ & $100 \%$ \\
\hline 1956 & $95 \%$ & $4 \%$ & $0 \%$ & $98 \%$ & $2 \%$ & $0 \%$ & $100 \%$ \\
\hline 1957 & $95 \%$ & $4 \%$ & $0 \%$ & $99 \%$ & $1 \%$ & $0 \%$ & $100 \%$ \\
\hline 1958 & $97 \%$ & $2 \%$ & $0 \%$ & $99 \%$ & $1 \%$ & $0 \%$ & $100 \%$ \\
\hline 1959 & $96 \%$ & $3 \%$ & $0 \%$ & $99 \%$ & $1 \%$ & $0 \%$ & $100 \%$ \\
\hline 1960 & $96 \%$ & $3 \%$ & $0 \%$ & $99 \%$ & $1 \%$ & $0 \%$ & $100 \%$ \\
\hline 1961 & $.95 \%$ & $4 \%$ & $1 \%$ & $99 \%$ & $1 \%$ & $0 \%$ & $100 \%$ \\
\hline 1962 & $94 \%$ & $5 \%$ & $0 \%$ & $99 \%$ & $1 \%$ & $0 \%$ & $100 \%$ \\
\hline 1963 & $93 \%$ & $5 \%$ & $0 \%$ & $99 \%$ & $1 \%$ & $0 \%$ & $100 \%$ \\
\hline 1964 & $92 \%$ & $6 \%$ & $0 \%$ & $99 \%$ & $1 \%$ & $0 \%$ & $100 \%$ \\
\hline 1965 & $91 \%$ & $7 \%$ & $0 \%$ & $99 \%$ & $1 \%$ & $0 \%$ & $100 \%$ \\
\hline 1966 & $90 \%$ & $.8 \%$ & $0 \%$ & $99 \%$ & $1 \%$ & $0 \%$ & $100 \%$ \\
\hline 1967 & $89 \%$ & $10 \%$ & $1 \%$ & $99 \%$ & $1 \%$ & $0 \%$ & $100 \%$ \\
\hline 1968 & $88 \%$ & $10 \%$ & $1 \%$ & $99 \%$ & $1 \%$ & $0 \%$ & $100 \%$ \\
\hline 1969 & $87 \%$ & $11 \%$ & $1 \%$ & $99 \%$ & $1 \%$ & $0 \%$ & $100 \%$ \\
\hline 1970 & $87 \%$ & $12 \%$ & $1 \%$ & $99 \%$ & $1 \%$ & $0 \%$ & $100 \%$ \\
\hline 1971 & $85 \%$ & $13 \%$ & $1 \%$ & $99 \%$ & $1 \%$ & $0.1 \%$ & $100 \%$ \\
\hline 1972 & $83 \%$ & $14 \%$ & $1 \%$ & $99 \%$ & $1 \%$ & $0.1 \%$ & $100 \%$ \\
\hline 1973 & $81 \%$ & $16 \%$ & $1 \%$ & $99 \%$ & $1 \%$ & $0.2 \%$ & $100 \%$ \\
\hline 1974 & $79 \%$ & $18 \%$ & $1 \%$ & $99 \%$ & $1 \%$ & $0.2 \%$ & $100 \%$ \\
\hline 1975 & $80 \%$ & $17 \%$ & $1 \%$ & $99 \%$ & $1 \%$ & $0.2 \%$ & $100 \%$ \\
\hline 1976 & $77 \%$ & $20 \%$ & $2 \%$ & $98 \%$ & $2 \%$ & $0.2 \%$ & $100 \%$ \\
\hline 1977 & $77 \%$ & $19 \%$ & $2 \%$ & $98 \%$ & $2 \%$ & $0.2 \%$ & $100 \%$ \\
\hline 1978 & $78 \%$ & $18 \%$ & $2 \%$ & $98 \%$ & $2 \%$ & $0.2 \%$ & $100 \%$ \\
\hline 1979 & $78 \%$ & $17 \%$ & $2 \%$ & $97 \%$ & $2 \%$ & $0.2 \%$ & $100 \%$ \\
\hline 1980 & $78 \%$ & $17 \%$ & $2 \%$ & $97 \%$ & $3 \%$ & $0.2 \%$ & $100 \%$ \\
\hline 1981 & $79 \%$ & $16 \%$ & $2 \%$ & $97 \%$ & $3 \%$ & $0.2 \%$ & $100 \%$ \\
\hline 1982 & $80 \%$ & $15 \%$ & $1 \%$ & $97 \%$ & $3 \%$ & $0.2 \%$ & $100 \%$ \\
\hline 1983 & $80 \%$ & $15 \%$ & $1 \%$ & $97 \%$ & $3 \%$ & $0.2 \%$ & $100 \%$ \\
\hline 1984 & $81 \%$ & $14 \%$ & $1 \%$ & $96 \%$ & $3 \%$ & $0.2 \%$ & $100 \%$ \\
\hline 1985 & $81 \%$ & $14 \%$ & $1 \%$ & $96 \%$ & $4 \%$ & $0 \%$ & $100 \%$ \\
\hline 1986 & $81 \%$ & $14 \%$ & $1 \%$ & $96 \%$ & $4 \%$ & $0 \%$ & $100 \%$ \\
\hline 1987 & $81 \%$ & $14 \%$ & $1 \%$ & $96 \%$ & $4 \%$ & $0 \%$ & $100 \%$ \\
\hline 1988 & $81 \%$ & $14 \%$ & $1 \%$ & $96 \%$ & $4 \%$ & $0 \%$ & $100 \%$ \\
\hline 1989 & $80 \%$ & $14 \%$ & $1 \%$ & $96 \%$ & $4 \%$ & $0 \%$ & $100 \%$ \\
\hline 1990 & $81 \%$ & $14 \%$ & $1 \%$ & $96 \%$ & $4 \%$ & $0 \%$ & $100 \%$ \\
\hline 1991 & $80 \%$ & $14 \%$ & $1 \%$ & $95 \%$ & $5 \%$ & $0 \%$ & $100 \%$ \\
\hline
\end{tabular}

Source: Marland, Andres, and Boden, 1994. 
Figure VIII-1 Carbon Dioxide Emissions

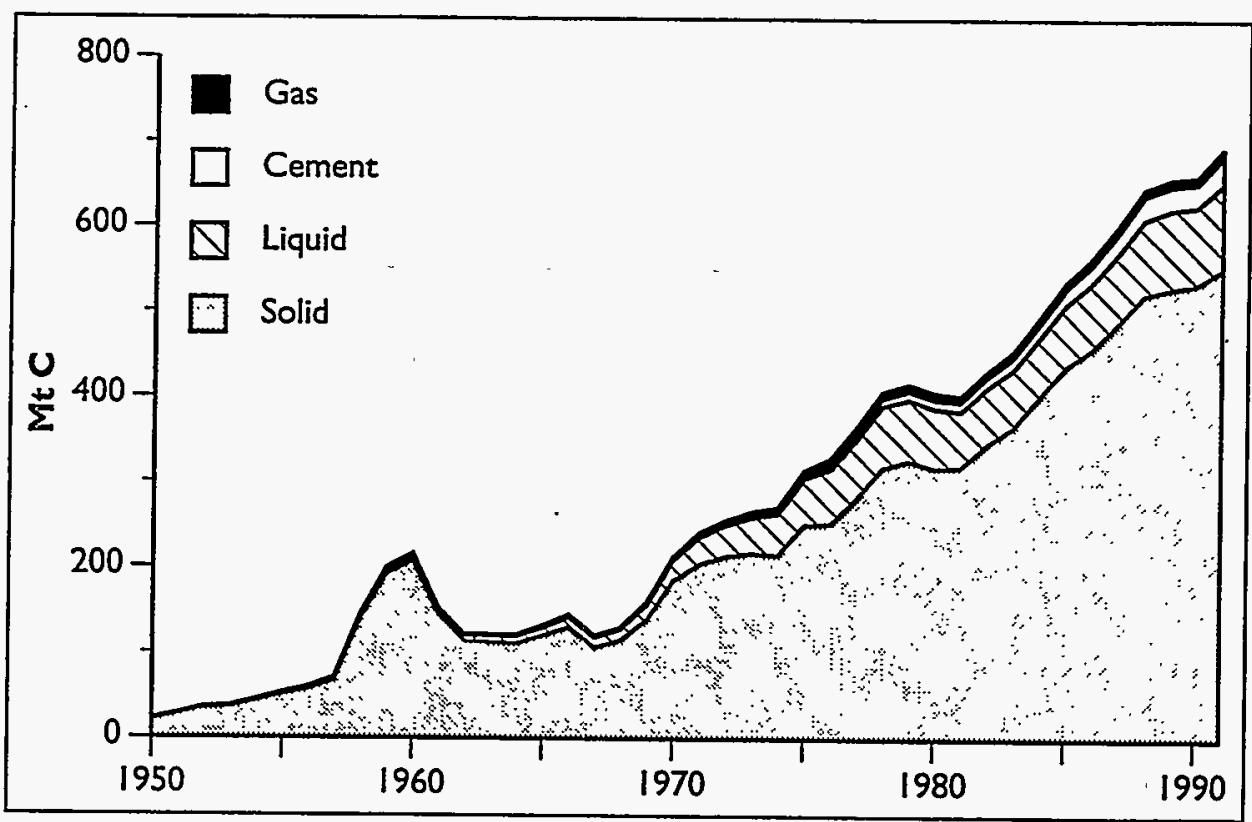


Table VIII-2. National Total Sulfur Dioxide and Particulate

Emissions, 1980 and 1985-1993 *

\begin{tabular}{|c|c|c|c|c|c|c|}
\hline \multirow[b]{2}{*}{ Year } & \multicolumn{2}{|r|}{ Sulfur Dioxide } & \multirow{2}{*}{$\frac{\text { non- }}{\text { combustiont }}$} & \multicolumn{2}{|c|}{ Particulates from Combustion } & \multirow{2}{*}{$\begin{array}{l}\text { Particulates from } \\
\text { Indust. Processes } \$ \\
\text { (noncombustion) }\end{array}$} \\
\hline & total & $\begin{array}{l}\text { portion from } \\
\text { industry * }\end{array}$ & & total & $\begin{array}{l}\text { portion from } \\
\text { industry }\end{array}$ & \\
\hline 1980 & 16.00 & - & - & 14.85 & - & - \\
\hline 1985 & 13.24 & - & - & 12.95 & - & 13.05 \\
\hline 1986 & 12.50 & - & - & 13.84 & - & 11.70 \\
\hline 1987 & 14.12 & - & - & 14.45 & - & 10.04 \\
\hline 1988 & 15.23 & - & - & 14.36 & - & 11.26 \\
\hline 1989 & 15.64 & - & - & 13.98 & - & 8.40 \\
\hline 1990 & 14.95 & - & - & 13.24 & - & 7.81 \\
\hline 1991 & 16.22 & 11.65 & - & 13.14 & 8.45 & 5.79 \\
\hline 1992 & 16.85 & 13.23 & 1.98 & 14.14 & 8.70 & 5.76 \\
\hline 1993 & 17.95 & 12.92 & 2.18 & 14.16 & 8.80 & 6.17 \\
\hline
\end{tabular}

* From all emissions sources on industrial enterprise premises. Includes electric utilities.

$\dagger$ Obtained from direct measurements, mass balances, or empirical equations.

I Literally "smoke dust" (yanchen).

$\S$ Solid particulate matter (fenchen) released in the course of production processes (e.g., grinding and sorting). Calculated as emissions gas volume times particulate density at outlet times duration of operation. Enterprises are required to report emissions regardless of whether they meet emissions standards.

Source: China Environmental Yearbook, various years. 
Figure VIII-2. Sulfur Dioxide and Particulate Emissions

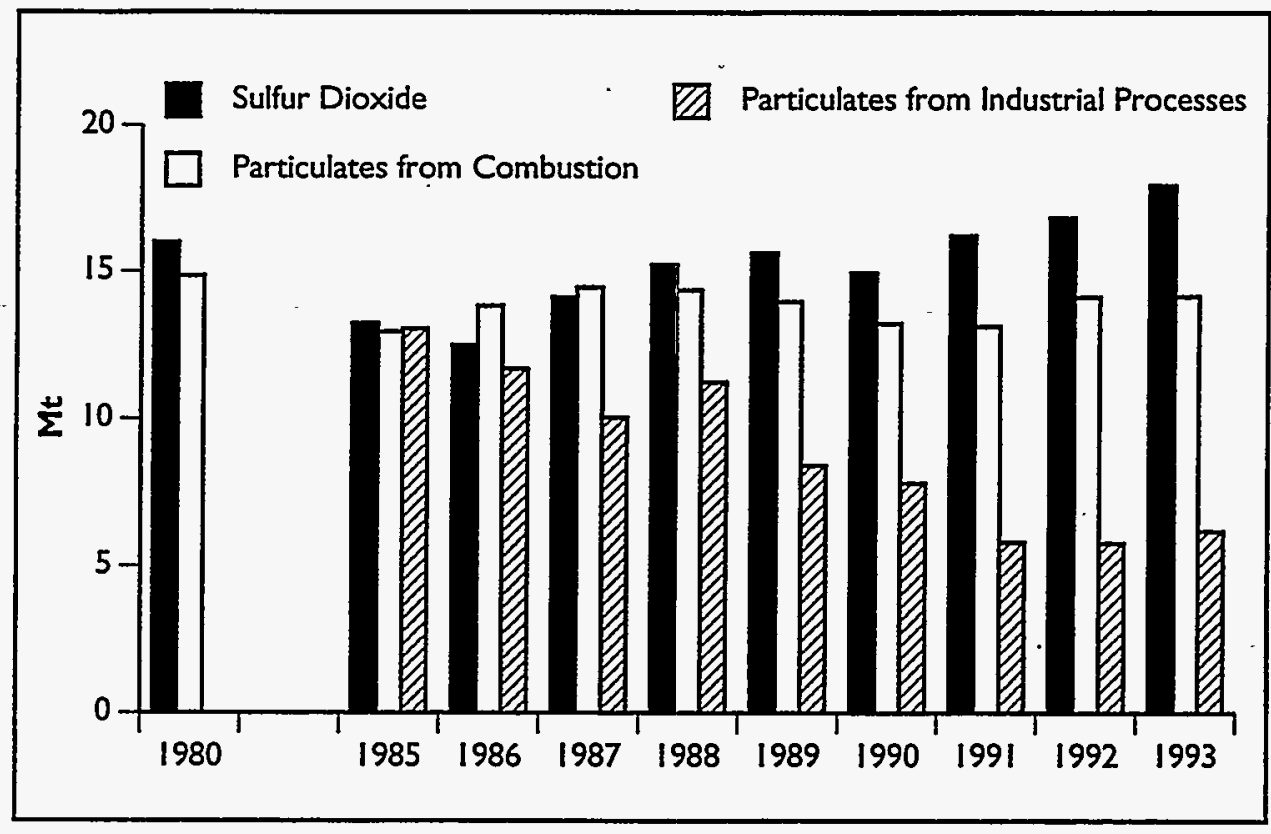


Table VIII-3. Sulfur Dioxide and Particulate Emissions by Region, * 1993

\begin{tabular}{|c|c|c|c|c|c|c|c|c|c|c|}
\hline \multirow[b]{2}{*}{$\begin{array}{l}\text { Planning } \\
\text { Region }\end{array}$} & \multirow[b]{2}{*}{ Province } & \multicolumn{3}{|c|}{ Sulfur Dioxide } & \multicolumn{2}{|c|}{$\begin{array}{c}\text { Particulates } \\
\text { from Combustion }\end{array}$} & \multirow{2}{*}{$\begin{array}{c}\text { Particulates from } \\
\text { Industrial } \\
\text { Processes } \S \\
\text { (noncombustion) } \\
\text { (kt) }\end{array}$} & \multirow{2}{*}{$\begin{array}{c}\text { Provincial } \\
\text { Area } \\
\text { (thousand } \\
\text { km2) }\end{array}$} & \multirow{2}{*}{$\begin{array}{c}\text { Sulfur } \\
\text { Dioxide } \\
\text { Emissions } \\
\text { Density } \\
\text { (t/km2-yr) }\end{array}$} & \multirow{2}{*}{$\begin{array}{c}\text { Particulate } \\
\text { Emissions } \\
\text { Density } \\
\text { (t/km2-yr) }\end{array}$} \\
\hline & & $\begin{array}{c}\text { total } \\
(k t)\end{array}$ & $\begin{array}{c}\text { from } \\
\text { industry* } \\
(k t)\end{array}$ & $\begin{array}{l}\text { non- } \\
\text { combustion } \dagger \\
\text { (kt) }\end{array}$ & $\begin{array}{l}\text { total } \\
(k t)\end{array}$ & $\begin{array}{l}\text { portion from } \\
\text { industry } \\
(k t)\end{array}$ & & & & \\
\hline \multirow[t]{5}{*}{ North } & Beijing & 366 & 204 & 18 & 261 & 109 & 64 & 17 & 21.80 & 19.40 \\
\hline & Tianjin & 238 & 176 & 6 & 173 & 73 & 37 & 11 & 21.03 & 18.61 \\
\hline & Hebei & 1,021 & 860 & 131 & 693 & 460 & 407 & 188 & 5.43 & 5.85 \\
\hline & Shanxi & 1,329 & 615 & 102 & 837 & 332 & 219 & 156 & 8.51 & 6.76 \\
\hline & ner Mongolia & 658 & 434 & 105 & 736 & 387 & 174 & 1,200 & 0.55 & 0.76 \\
\hline \multirow[t]{3}{*}{ Northeast } & Liaoning & 1,081 & 823 & 199 & 1,069 & 653 & 597 & 146 & 7.42 & 11.43 \\
\hline & Jilin & 286 & 188 & 42 & 686 & 642 & 112 & 138 & 2.07 & 5.78 \\
\hline & Heilongjiang & 322 & 219 & 16 & 1,279 & 467 & 186 & 473 & 0.68 & 3.09 \\
\hline \multirow[t]{7}{*}{ East } & Shanghai & 441 & 357 & 22 & 189 & 148 & 66 & 6 & 71.16 & 41.14 \\
\hline & Jiangsu & 1,200 & 914 & 127 & 757 & 581 & 284 & 103 & 11.70 & 10.15 \\
\hline & Zhejiang & 536 & 417 & 50 & 289 & 184 & 219 & 102 & 5.27 & 4.99 \\
\hline & Anhui & 444 & 341 & 87 & 641 & 243 & 198 & 140 & 3.18 & 6.01 \\
\hline & Fujian & 184 & 154 & 14 & 80 & 72 & $|5|$ & 122 & 1.51 & 1.90 \\
\hline & Jiangxi & 343 & 247 & 35 & 338 & 282 & 271 & 167 & 2.05 & 3.65 \\
\hline & Shandong & 2,280 & 1,376 & 160 & 1,348 & 525 & 336 & 153 & 14.89 & 11.00 \\
\hline \multirow[t]{6}{*}{ South-Central } & Henan & 519 & 409 & 45 & 613 & 439 & 290 & 167 & 3.11 & 5.41 \\
\hline & Hubei & 488 & 383 & 117 & 439 & 230 & 260 & 188 & 2.60 & 3.72 \\
\hline & Hunan & 528 & 515 & 112 & 275 & 270 & 305 & 210 & 2.51 & 2.76 \\
\hline & Guangdong & 543 & 508 & 86 & 264 & 243 & 532 & 178 & 3.05 & 4.47 \\
\hline & Guangxi & 655 & 522 & 58 & 337 & 249 & 188 & 231 & 2.84 & 2.28 \\
\hline & Hainan & 25 & 24 & 3 & 17 & 12 & 12 & 34 & 0.72 & 0.85 \\
\hline \multirow[t]{4}{*}{ Southwest } & Sichuan & 1,784 & 1,194 & 198 & 1,015 & 1,238 & 512 & 567 & 3.15 & 2.69 \\
\hline & Guizhou & 737 & 585 & 108 & 347 & 236 & 156 & 176 & 4.18 & 2.85 \\
\hline & Yunnan & 316 & 259 & 68 & 257 & 181 & 127 & 392 & 0.80 & 0.98 \\
\hline & Xizang & 1,9 & 1.7 & 0.0 & 0.1 & 0.1 & 15. & 1.183 & 0.002 & 0.012 \\
\hline \multirow[t]{5}{*}{ Northwest } & Shaanxi & 668 & 560 & 43 & 523 & 383 & 136 & 205 & 3.26 & 3.22 \\
\hline & Gansu & 389 & 338 & 187 & 207 & 149 & 141 & 455 & 0.86 & 0.76 \\
\hline & Qinghai & 24 & 17 & 21 & 90 & 42 & 27 & 779 & 0.03 & 0.15 \\
\hline & Ningxia & 238 & 164 & 7 & 136 & 109 & 59 & 66 & 3.61 & 2.95 \\
\hline & Xinjiang & 305 & 135 & 26 & 267 & 164 & 86 & 1,635 & 0.19 & 0.22 \\
\hline \multirow{2}{*}{\multicolumn{2}{|c|}{$\begin{array}{l}\text { Notional TotallAverage } \\
\text { Balance }\end{array}$}} & 17,948 & 12,925 & 2,179 & 14,163 & 8,804 & 6,166 & 9,586 & 1.87 & 2.12 \\
\hline & & 305 & 125 & 7 & 267 & -136 & 86 & 1,635 & - & - \\
\hline
\end{tabular}

- From all emlssions sources.

Obtained from direct measurements, mass balances, or empirical equations.

Literally "smoke dust" (yanchen).

Solid particulate matter (fenchen) released in the course of productlon proces ource: China Environmental Yearbook, 1994. 


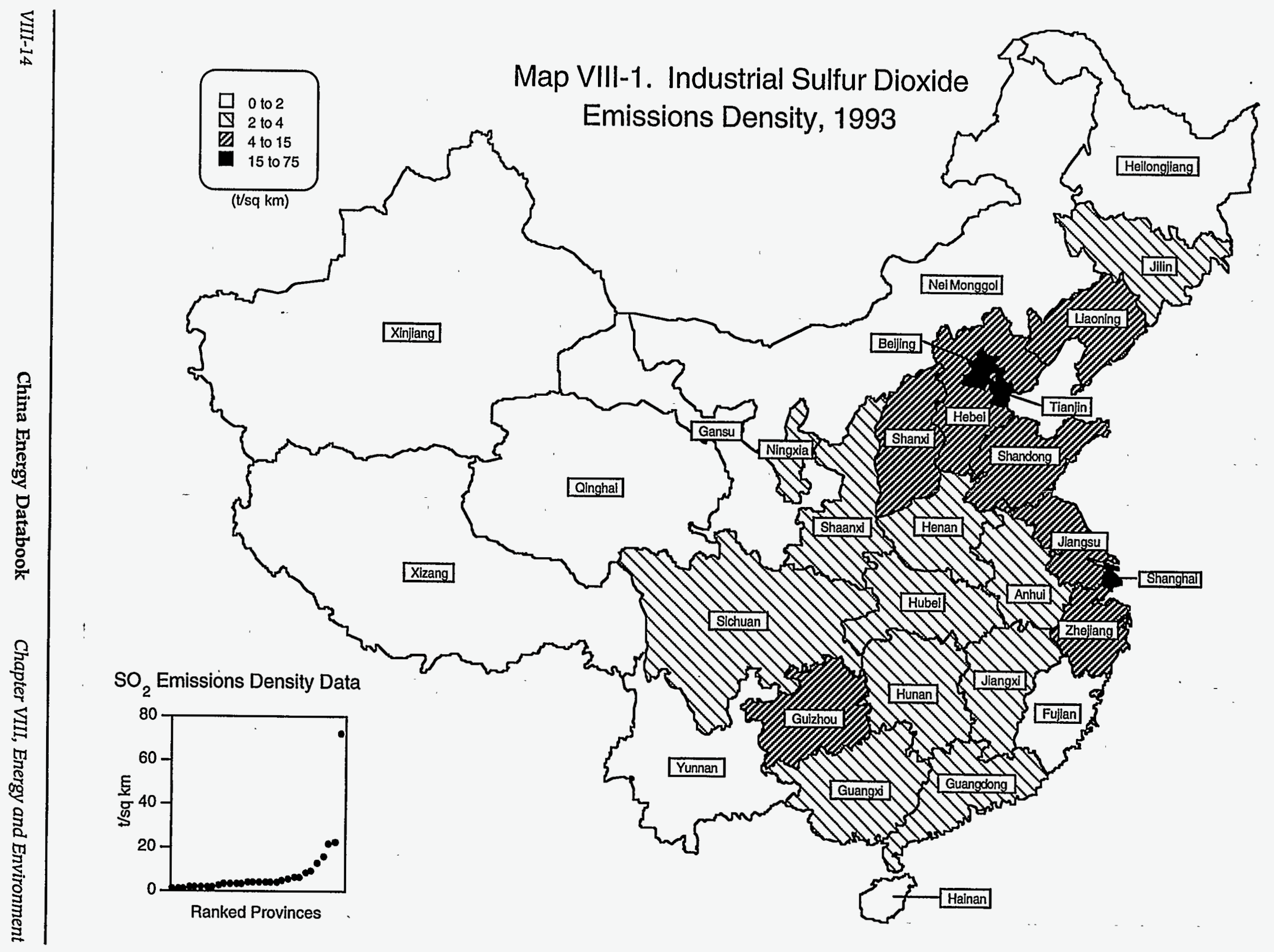




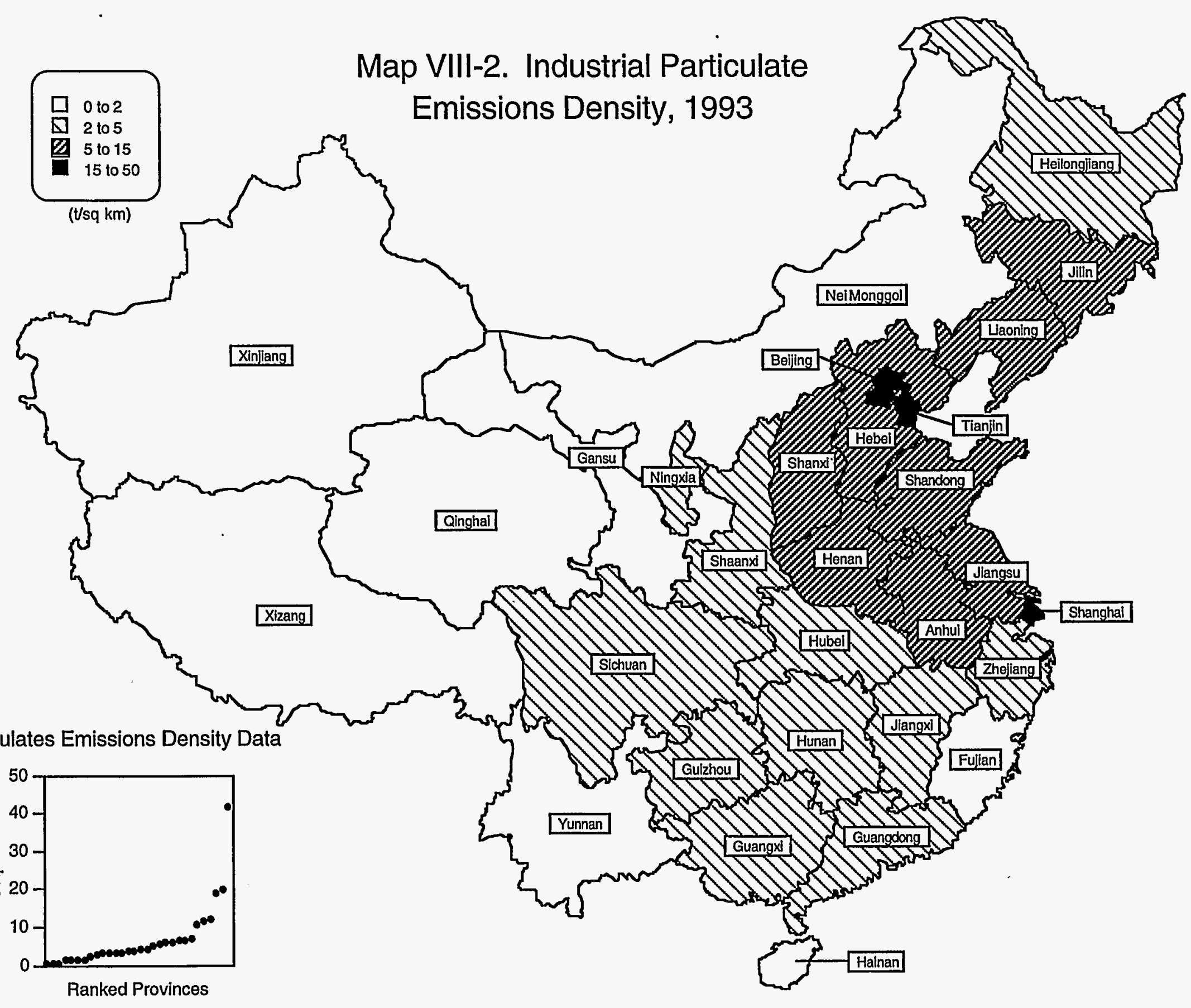


Table VIII-4. Sulfur Dioxide and Particulate Emissions by Industrial Sector, 1991-1993

\begin{tabular}{|c|c|c|c|c|c|c|c|c|c|}
\hline \multirow[b]{2}{*}{ Sector } & \multicolumn{3}{|c|}{1991} & \multicolumn{3}{|c|}{1992} & \multicolumn{3}{|c|}{1993} \\
\hline & total & combustion & $\begin{array}{l}\text { non- } \\
\text { combustion }\end{array}$ & total & combustion & $\begin{array}{c}\text { non- } \\
\text { combustion }\end{array}$ & total & combustion & $\begin{array}{c}\text { non- } \\
\text { combustion }\end{array}$ \\
\hline Mining & 460 & - & - & 1,262 & 1,182 & 80 & 464 & 365 & 98 \\
\hline Food \& beverage & 640 & - & - & 568 & 560 & 8 & 561 & 555 & 7 \\
\hline Textiles & 420 & - & - & 416 & 412 & 3 & 401 & 396 & 5 \\
\hline Leather goods & 20 & - & - & 19 & 19 & 0 & 20 & 20 & 0 \\
\hline Paper & 270 & - & - & 282 & 268 & 14 & 282 & 268 & 14 \\
\hline Printing & 10 & - & - & 12 & 11 & 1 & 9 & 9 & 0 \\
\hline Electric utilities & 5,280 & - & - & 5,758 & 5,598 & 160 & 6,283 & 6,029 & 254 \\
\hline Oil refining & 70 & - & - & 77 & 61 & 16 & 74 & 62 & 11 \\
\hline $\begin{array}{l}\text { Coking \& coal } \\
\text { products }\end{array}$ & 80 & - & - & 98 & 45 & 53 & 102 & 55 & 47 \\
\hline Chemicals & 1,080 & - & - & 1,096 & 830 & 265 & 1,090 & 837 & 253 \\
\hline Pharmaceuticals & 110 & - & - & 137 & 124 & 13 & .122 & 113 & 9 \\
\hline Chemical fibers & 90 & - & - & 116 & 115 & 2 & 113 & 112 & 2 \\
\hline $\begin{array}{l}\text { Building materials } \\
\text { of which: }\end{array}$ & 1,080 & - & - & 1,274 & 714 & 560 & 1,275 & 676 & 599 \\
\hline cement & 560 & - & - & 428 & 116 & 312 & 667 & 181 & 486 \\
\hline Ferrous metals & 70 & - & - & 731 & 409 & 322 & 790 & 415 & 375 \\
\hline Nonferrous metals & 540 & - & - & 527 & 109 & 418 & 580 & 105 & 475 \\
\hline $\begin{array}{l}\text { Metals fabrication } \\
\text { Machinery }\end{array}$ & 50 & - & - & 50 & 42 & 8 & 40 & 38 & 2 \\
\hline \& electronics & 400 & - & - & 443 & 429 & 15 & 411 & 388 & 22 \\
\hline Other & 240 & - & - & 254 & 209 & 45 & 197 & 193 & 4 \\
\hline Total & 11,650 & - & - & 13,226 & 11,242 & 1,984 & 12,925 & 10,746 & 2,179 \\
\hline Balance & 650 & - & - & 0 & 0 & 0 & 0 & 0 & 0 \\
\hline
\end{tabular}




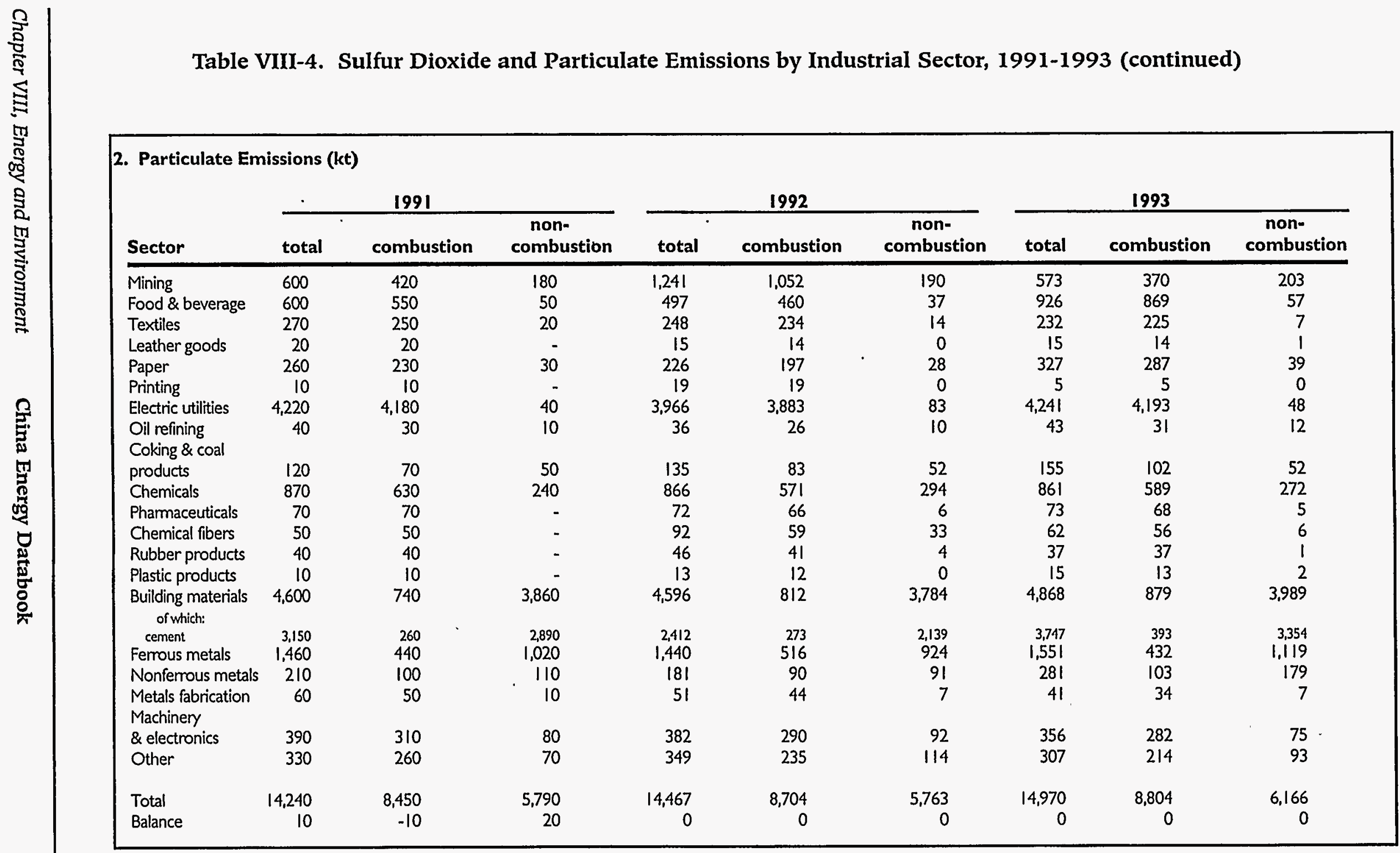

Source: China Environmental Yearbook, various years. 
Figure VIII-3. Pollutant Emissions by Sector

Sulfur Dioxide Emissions, kt

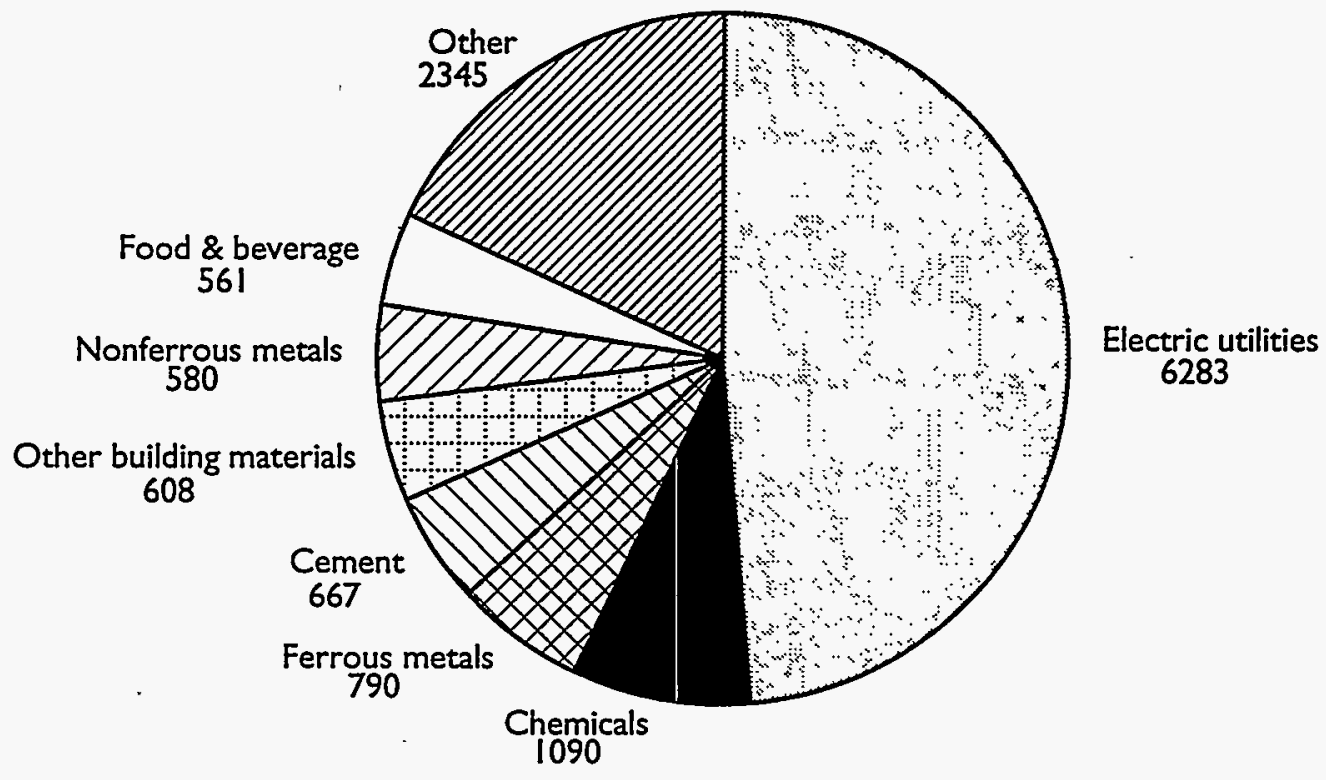

Particulate Emissions, kt

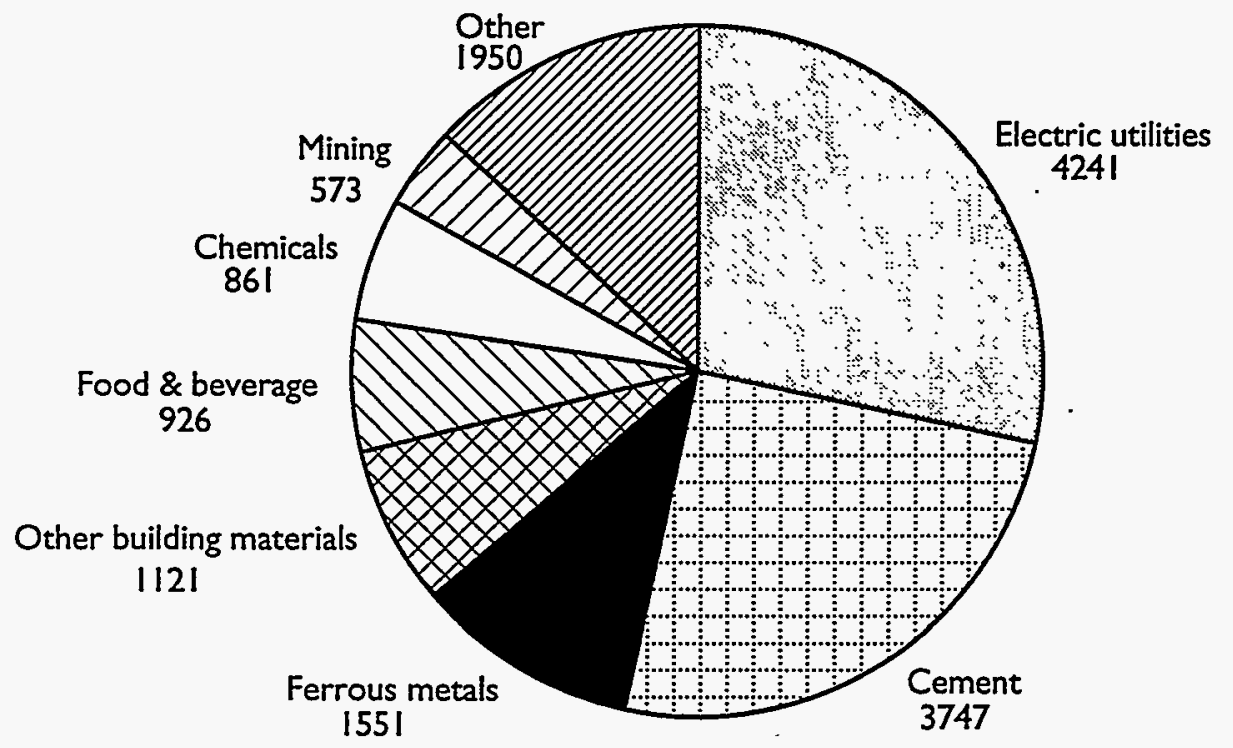


Table VII-5. Ambient Air Quality in Chinese Cities, 1980-1993 (Annual Averages)

\begin{tabular}{|c|c|c|c|c|c|c|c|}
\hline \multicolumn{8}{|c|}{ I. Total Suspended Particulates ( $\mu \mathrm{g} / \mathrm{m} 3$ ) } \\
\hline year & $\begin{array}{l}\text { major cities } \\
\text { average }\end{array}$ & $\begin{array}{l}\text { lowest } \\
\text { city }\end{array}$ & $\begin{array}{l}\text { highest } \\
\text { city }\end{array}$ & $\begin{array}{l}\text { southern } \\
\text { cities } \\
\text { average }\end{array}$ & $\begin{array}{l}\text { northern } \\
\text { cities } \\
\text { average }\end{array}$ & $\begin{array}{l}\text { number } \\
\text { of cities }\end{array}$ & remarks \\
\hline 1980 & 610 & - & - & 340 & 875 & - & \\
\hline 1981 & 703 & 160 & 2,770 & 410 & 930 & - & \\
\hline 1982 & 729 & 220 & 1,910 & 470 & 950 & - & \\
\hline 1983 & 600 & 164 & 1,358 & 330 & 870 & - & \\
\hline 1984 & 660 & 190 & 2,158 & 450 & 870 & - & \\
\hline 1985 & 590 & 224 & 1,767 & 444 & 740 & - & \\
\hline 1986 & 570 & 196 & 1,575 & 391 & 715 & - & \\
\hline 1987 & 590 & 154 & 1,357 & 370 & 805 & - & \\
\hline 1988 & 580 & 220 & 1,597 & 440 & 674 & - & \\
\hline 1989 & 432 & 117 & 1,043 & 318 & 526 & - & \\
\hline 1990 & 379 & 64 & 844 & 268 & 475 & - & \\
\hline 1991 & - & 80 & 1,433 & 225 & 425 & 65 & \\
\hline 1992 & - & 90 & 663 & 243 & 403 & 67 & 51 exceeded Class II sta \\
\hline 1993 & - & 108 & 815 & 251 & 407 & 74 & exceeded Class II \\
\hline
\end{tabular}

2. Sulfur Dioxide ( $(\mu \mathrm{g} / \mathrm{m} 3)$

\begin{tabular}{|c|c|c|c|c|c|c|c|}
\hline & $\begin{array}{c}\text { major cities } \\
\text { average }\end{array}$ & $\begin{array}{l}\text { lowest } \\
\text { city }\end{array}$ & $\begin{array}{l}\text { highest } \\
\text { city }\end{array}$ & $\begin{array}{l}\text { southern } \\
\text { cities } \\
\text { average }\end{array}$ & $\begin{array}{l}\text { northern } \\
\text { cities } \\
\text { average }\end{array}$ & $\begin{array}{l}\text { number } \\
\text { of cities }\end{array}$ & remarks \\
\hline 1980 & 110 & - & - & 100 & 130 & - & \\
\hline 1981 & 115 & 20 & 450 & 110 & 120 & - & \\
\hline 1982 & 115 & 20 & 520 & 110 & 120 & - & \\
\hline 1983 & 94 & 25 & 324 & 80 & 110 & - & \\
\hline 1984 & 92 & 7 & 363 & 93 & 90 & - & \\
\hline 1985 & 105 & 8 & 504 & 100 & 110 & - & \\
\hline 1986 & 106 & 16 & 434 & 108 & 105 & - & \\
\hline 1987 & 117 & 35 & 434 & 104 & 130 & - & \\
\hline 1988 & 94 & 12 & 435 & 99 & 89 & - & \\
\hline 1989 & 105 & 2 & 394 & 120 & 93 & - & \\
\hline 1990 & - & 3 & 422 & 115 & 81 & - & \\
\hline 1991 & - & 4 & 351 & 88 & 92 & 70 & \\
\hline 1992 & - & 7 & 463 & 90 & 97 & 72 & 12 exceeded Class II standard \\
\hline 1993 & - & 8 & 415 & 96 & 100 & 77 & 15 exceeded Class II standard \\
\hline
\end{tabular}

Source: China Environmental Yearbook, various years. 
Table VII-5. Ambient Air Quality in Chinese Cities, 1980-1993 (Annual Averages) (continued)

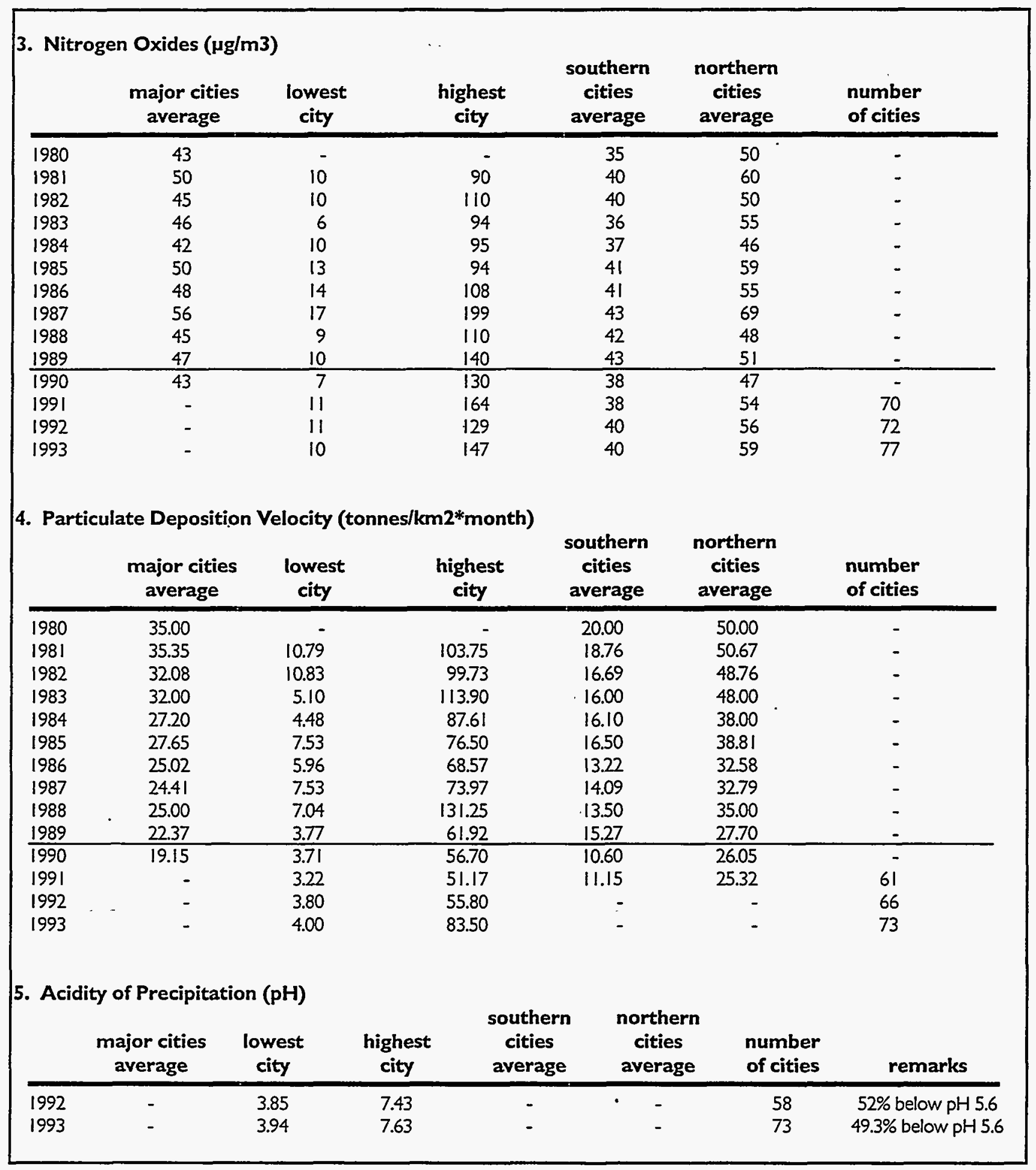

Source: China Environmental Yearbook, various years. 
"sa!!! asau!

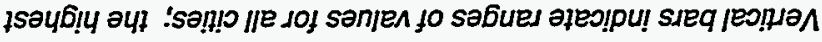

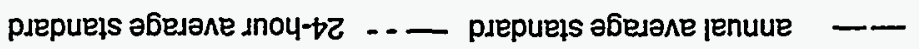

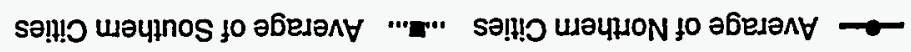
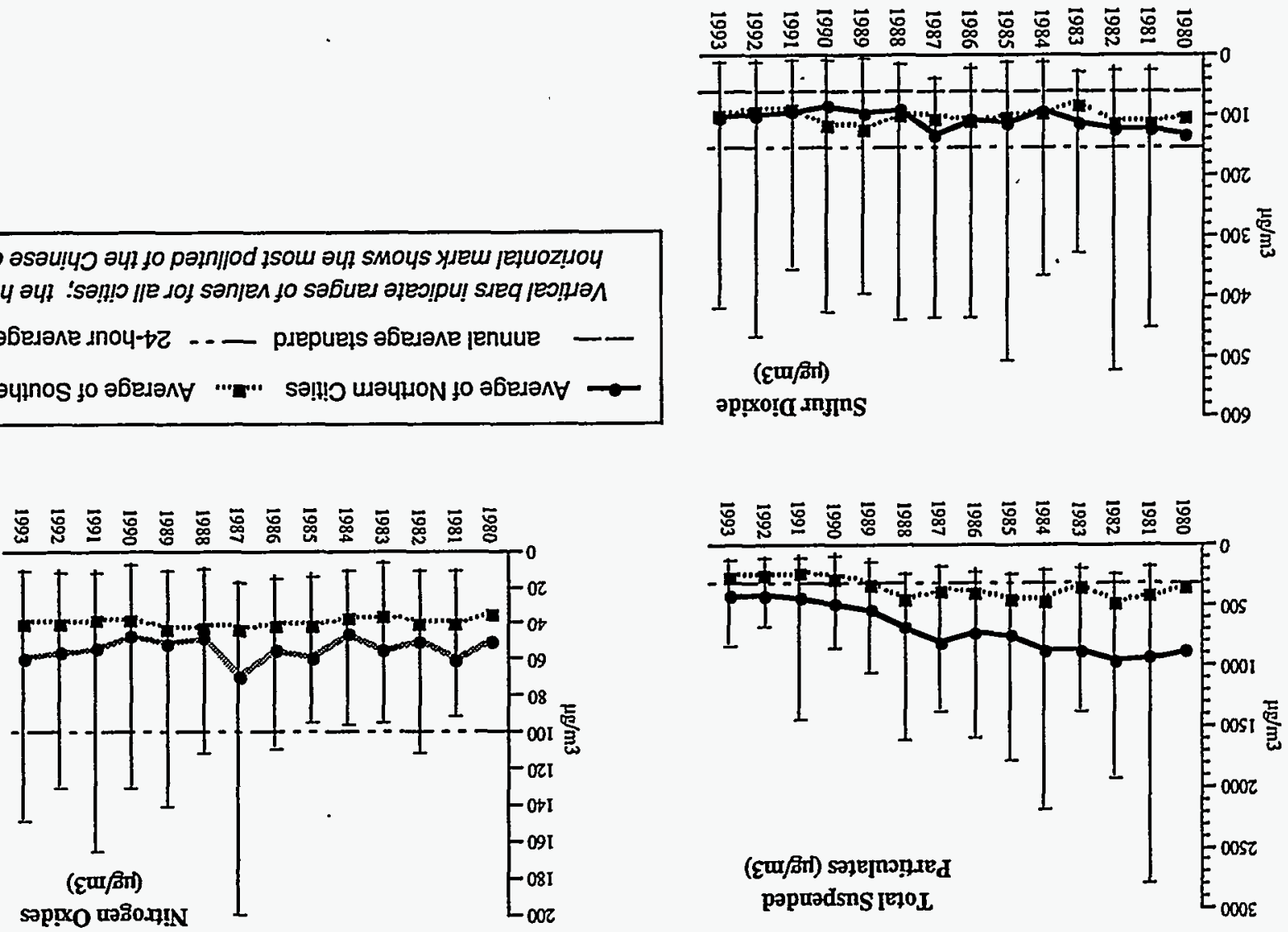

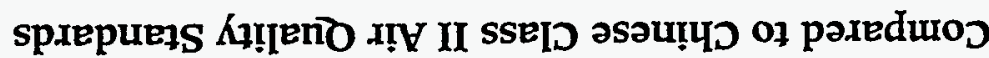

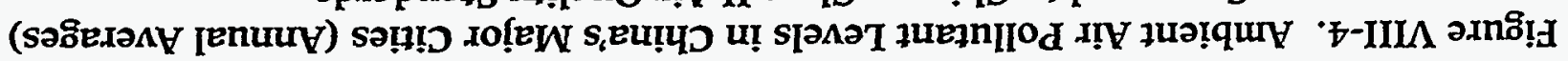


Table VIII-6. Ambient Air Quality in Selected Chinese Cities: Total Suspended Particulates, 1986-1993

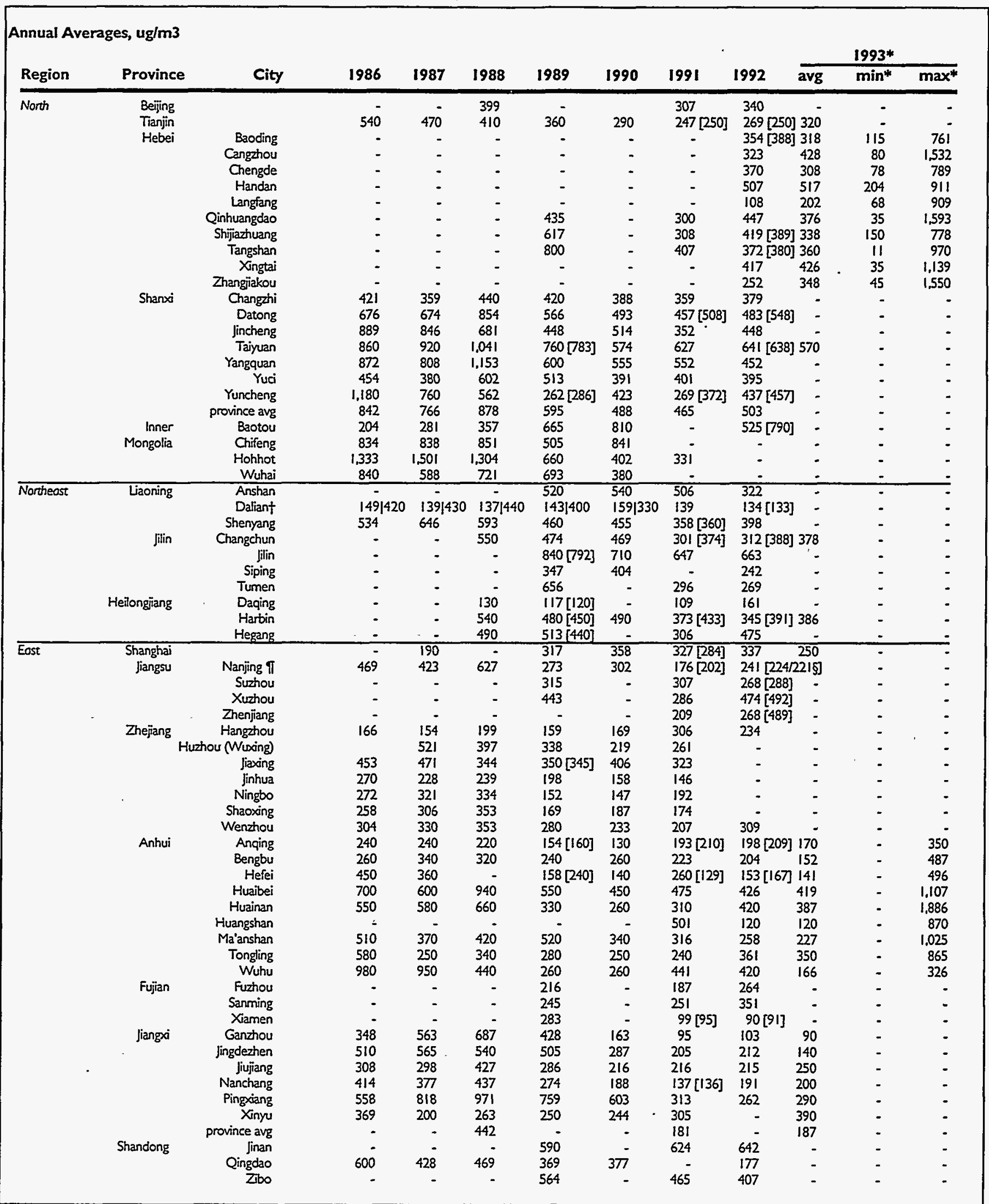

N.B. Province averages are averages of major urban areas. On occasion conflicting data are presented for a single year. In such cases, the data from the more recent source and from tables comparing several cities are preferred. In some cases figures reported by national and local authoritles differ. In such cases the flgures from local government reports appear in square brackets. All 1993 data are from local reports. Minima and maxima are dally averages.

$\dagger$ Between 1986 and 1990 results of air quality monitoring In Dalian were reported for both automatic and chemical analysis. For those years the data are reported as automatic $I$ ehemical. I Nanjing 1981-1984 figures are for "floating dust" (plaochenzhl).

\$ Annual averages for urban/suburban areas.

Source: China Environmental Yearbook, various years. 
Table VIII-6. Ambient Air Quality in Selected Chinese Cities: Total Suspended Particulates, 1986-1993 (continued)

\begin{tabular}{|c|c|c|c|c|c|c|c|c|c|c|c|c|}
\hline \multicolumn{13}{|c|}{ Annual Averages, ug/m3 } \\
\hline Region & Province & City & 1986 & 1987 & 1988 & 1989 & 1990 & 1991 & 1992 & $\overline{\operatorname{avg}}$ & $\min ^{*}$ & $\max { }^{*}$ \\
\hline \multirow{23}{*}{$\begin{array}{l}\text { Sourh- } \\
\text { Centrol }\end{array}$} & Henan & Anyang & - & - & - & 360 & - & 528 & 447 & - & - & - \\
\hline & & Loyang & - & - & - & 686 & - & - & - & - & - & - \\
\hline & & Pingdingshan & - & - & - & 537 & - & 411 & 433 & - & - & - \\
\hline & & Zhengzhous & 640 & 688 & 680 & 608 [680] & 515 & 440 & 421 & - & - & - \\
\hline & & province avg & 792 & 671 & 765 & - & - & - & - & - & - & - \\
\hline & Hubei & Wuhan & 349 & 333 & 358 & 320 & 212 [280] & ] $217[280]$ & 264 & - & - & - \\
\hline & & Xiangfan & - & - & 686 & 407 & 358 & $250[336]$ & 272 & - & - & - \\
\hline & & Yichang & - & - & 410 & 141 & 130 & 274 [263] & 307 & - & - & - \\
\hline & Hunan & Changsha & - & - & - & 449 & - & $206^{\circ}$ & 222 & - & - & - \\
\hline & & Hengyang & - & - & - & 292 & - & 189 & 202 & - & - & - \\
\hline & Guangdong & Guangzhou & 230 & 230 & 290 & $2 \pi$ & 270 & 260 & $297[277]$ & 280 & - & - \\
\hline & & Shantou & - & - & - & 230 & 170 & 220 & $210^{\circ}$ & - & - & - \\
\hline & & Shenzhen & - & - & 200 & 198 & 119 & 161 & $206[147]$ & 153 & - & - \\
\hline & & Zhuhai & - & - & 390 & 190 & 100 & 185 & $109^{\circ}$ & - & - & - \\
\hline & & province avg & - & - & - & - & - & 214 & 243 & 205 & - & - \\
\hline & Guangxi & Beihai & - & - & - & - & - & 94 & 198 & 254 & - & - \\
\hline & & Bose & - & - & - & - & - & $104[125]$ & 141 [149] & 124 & - & - \\
\hline & & Guilin & 441 & 450 & 260 & $170[190]$ & 210 & $184[200]$ & $159[157]$ & 210 & - & - \\
\hline & & Nanning & - & - & - & $182[276]$ & 198 & $181[191]$ & $188[192] 2$ & 210 & - & - \\
\hline & & Liuzhou & - & - & 314 & 219 & 203 & $237^{\circ}$ & 238 & 230 & - & - \\
\hline & & Wuzhou & 290 & 240 & 370 & 340 & 160 & 192 & 104 & 253 & - & - \\
\hline & Hainan & Haikou & - & - & - & - & - & 80 & 99 & 115 & 33 & 211 \\
\hline & & Sanya & - & - & $\because$ & - & - & 100 & - & 113 & 10 & 445 \\
\hline \multirow[t]{15}{*}{ Soustwert } & Sichuan & Chengdus & 360 & 330 & 420 & 320 & 320 & $341[350]$ & $372[398]$ & $\overline{290}$ & - & $\longrightarrow$ \\
\hline & & Chongging & 660 & 620 & 600 & 428 [430] & 490 & $376[400]$ & $351[380]$ & $260 / 300 \S$ & - & - \\
\hline & & huan (Daxian) & & - & - & - & - & 1.080 & 1,480 & 1.014 & - & - \\
\hline & & Nanchong & - & - & - & 916 & - & $362[440]$ & $284[310]$ & 250 & - & - \\
\hline & & Xichang & - & - & - & - & - & 350 & $240^{\circ}$ & 279 & - & - \\
\hline & & Yibin & - & - & - & 412 & - & $248[270]$ & $272[295]$ & 260 & - & - \\
\hline & & province avg & - & - & - & - & - & $400^{\circ}$ & 400 & 330 & - & - \\
\hline & Guizhou & Guiyang & 574 & 465 & 470 & 418 [385] & 407 & 331 [333] & $392[516]$ & - & - & - \\
\hline & & Zunyi & - & - & - & 1,228 & 586 & 569 & 1,382 & - & - & - \\
\hline & & Duyun & - & - & - & 370 & 160 & 236 & 263 & - & - & - \\
\hline & & Anshun & - & - & - & 244 & 178 & 167 & 184 & - & - & - \\
\hline & & Liupanshui & - & - & - & 280 & 352 & $324[321]$ & $415[422]$ & - & - & - \\
\hline & & province avg & 799 & 745 & 539 & 552 & 365 & 284 & 453 & - & - & - \\
\hline & Yunnan & Gejiu & - & 1 & - & 144 & 150 & 106 & 134 & - & - & - \\
\hline & & Kunming & - & - & $=$ & 438 & 420 & 337 & 331 & - & - & $=$ \\
\hline \multirow[t]{11}{*}{ Nontwest } & Shaanxi & Baoji & - & - & - & 482 & - & 721 & 428 & - & - & $=$ \\
\hline & & Hanzhong & - & - & - & 588 & - & 374 & 345 & - & - & - \\
\hline & & Xi'an & - & - & - & 300 & - & 523 & 504 & 131 & - & - \\
\hline & & Yan'an & - & - & - & 1.043 & - & 1,433 & 509 & - & - & - \\
\hline & Gansu & Jiayuguan & - & - & - & $280[290]$ & 360 & $43 !$ & 368 & - & - & - \\
\hline & & Lanzhou & - & - & - & $670[710]$ & 950 & - & 539 & - & - & - \\
\hline & Qinghai & Xning & - & - & 866 & 570 [685] & 598 & 335 [336] & $415[414]$ & - & - & - \\
\hline & Ningxia & Guyuan & - & - & - & & 809 & 428 & 423 & - & - & - \\
\hline & & Shizuishan & - & - & - & $168[185]$ & 177 & $130[135]$ & $188[219]$ & - & - & - \\
\hline & & Yinchuan & - & - & - & 390 [392] & 581 & 461 & $481[470]$ & - & - & - \\
\hline & Xinjiang & Urumqi & 615 & 457 & 530 & $507[518]$ & 707 & 433 & 424 & - & - & - \\
\hline
\end{tabular}

N.B. Province averages are averages of major urban areas. On occasion conflicting data are presented for a single year. In such eases, the data from the more recent source and from tables comparing several cities are preferred. In some cases figures reported by national and local authorities differ. In such cases the figures from local government reports appear in square brackets.

- All 1993 data are from local reports. Minima and maxima are daily averages.

$\dagger$ Between 1986 and 1990 results of air quality monitoring in Dalian were reported for both automatic and chemical analysis. For those years the data are reported as automatic I chemical.

1 Nanjing 1981-1984 figures are for "floating dust" (plaochenzhi).

$\$$ Annual averages for urban/suburban areas.

Source: China Environmental Yearbook, various years. • 
Table VIII-7. Ambient Air Quality in Selected Chinese Cities: Sulfur Dioxide, 1986-1993

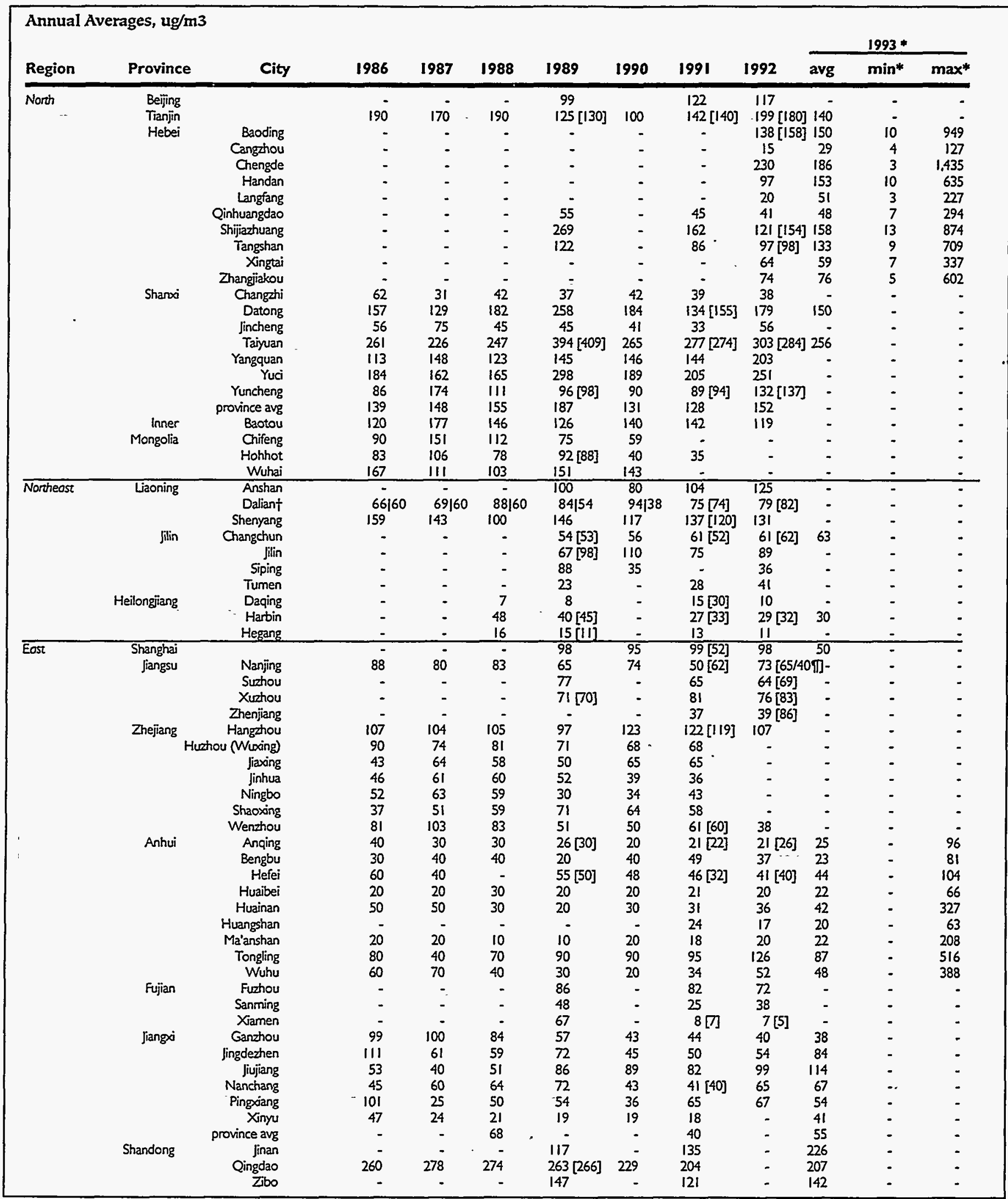

N.B. Province averages are averages of major urban areas. On occasion conflicting data are presented for a single year. In such cases, the data from the more recent source and from tables comparing several cities are preferred. In some cases figures reported by national and local authoritles differ. In such cases the figures from local government reports appear in square brackets.

- All 1993 data are from local reports. Minima and maxima are daily averages.

† Between 1986 and 1990 results of air quality monitoring in Dalian were reported for both automatic and chemical analysis. For those years the data are reported as automatic I chemical

i Annual averages for urban/suburban areas

Source: China Environmental Yearbook, various years. 
Table VIII-7. Ambient Air Quality in Selected Chinese Cities: Sulfur Dioxide, 1986-1993

(continued)

\begin{tabular}{|c|c|c|c|c|c|c|c|c|c|c|c|c|}
\hline \multirow[b]{2}{*}{ Region } & \multirow[b]{2}{*}{ Province } & \multirow[b]{2}{*}{ City } & \multirow[b]{2}{*}{1986} & \multirow[b]{2}{*}{1987} & \multirow[b]{2}{*}{1988} & \multirow[b]{2}{*}{1989} & \multirow[b]{2}{*}{1990} & \multirow[b]{2}{*}{1991} & \multirow[b]{2}{*}{1992} & \multicolumn{3}{|c|}{$1993 *$} \\
\hline & & & & & & & & & & avg & $\min *$ & $\max *$ \\
\hline \multirow{22}{*}{$\begin{array}{l}\text { South- } \\
\text { Centrol }\end{array}$} & Henan & Anyang & - & - & - & 50 & - & 79 & 94 & - & - & - \\
\hline & & Luoyang & - & - & - & 105 & - & & 110 & - & - & - \\
\hline & & Pingdingshan & - & - & - & 38 & - & 43 & 34 & - & - & - \\
\hline & & Zhengdhou & 74 & 79 & 86 & $65[80]$ & 67 & 86 & 90 & - & - & - \\
\hline & & province avg & 57 & 57 & 59 & - & - & - & - & - & - & - \\
\hline & Hubei & Wuhan & 54 & 48 & 43 & 48 & 44 & $40[44]$ & $40[44]$ & - & - & - \\
\hline & & Xiangfan & - & - & 44 & 37 & 42 & $40[41]$ & 38 & - & - & - \\
\hline & & Yichang & - & - & 192 & 177 & 246 & $165[22 \pi]$ & 128 & - & - & - \\
\hline & Hunan & Changsha & - & - & - & 186 & - & 173 & 180 & - & - & - \\
\hline & & Hengyang & - & - & - & 88 & - & 62 & 68 & - & - & - \\
\hline & Guangdong & Guangthou & 90 & 80 & 90 & 100 & 91 & $70[1]$ & 60 [59] & 47 & - & - \\
\hline & & Shantou & - & - & - & 10 & 12 & 36 & $35^{\circ}$ & - & - & - \\
\hline & & Shenzhen & - & - & 20 & $10[16]$ & 9 & $16[15]$ & $16[15]$ & 7 & - & - \\
\hline & & Zhuhai & $<10$ & 10 & 10 & 20 & 10 & 12 & $17^{\circ}$ & - & - & - \\
\hline & Guangxi & Beihai & - & - & - & - & - & 14 & 34 & 18 & - & - \\
\hline & & Bose & - & - & - & - & - & $45[55]$ & $46[86]$ & 28 & - & - \\
\hline & & Guilin & 93 & 106 & 124 & $138[144]$ & 107 & $85[100]$ & $70[72]$ & 76 & - & - \\
\hline & & Nanning & 114 & 68 & 60 & 62 & 56 & $50[54]$ & $86[85]$ & 78 & - & - \\
\hline & & Liuzhou & 263 & 226 & 291 & 211 & 204 & 172 & 216 & 212 & - & - \\
\hline & & Wuzhou & 84 & 116 & 53 & 190 & 130 & 109 & 134 & 142 & - & - \\
\hline & Hainan & Haikou & - & - & - & 2 & - & 4 & - & 6 & 2 & 24 \\
\hline & & Sanye & - & - & - & - & - & 10 & - & 10 & 10 & 10 \\
\hline \multirow[t]{16}{*}{ Sourhwest } & Sichuan & Chengdu & 70 & 80 & 70 & 82 & 70 & $66[70]$ & $75[82]$ & 60 & - & - \\
\hline & & Chongging & 460 & 430 & 360 & $338[340]$ & 340 & 351 [380] & $351[380]$ & $270 / 140$ ? & - & - \\
\hline & & huan (Daxian) & - & - & - & - & - & 80 & 100 & 67 & - & - \\
\hline & & Nanchong & - & - & - & 346 & - & 239 [290] & $242[300]$ & 200 & - & - \\
\hline & & Xichang & - & - & - & - & - & $40^{\circ}$ & 30 & 33 & - & - \\
\hline & & Yibin & - & - & - & 348 & - & 305 [420] & 287 [380] & 290 & - & - \\
\hline & & province avg & - & - & - & - & - & 170 & 170 & 140 & - & - \\
\hline & Guizhou & Guiyang & 465 & 439 & 374 & 372 [330] & 353 & 341 & 463 [475] & ] - & - & - \\
\hline & & Zunyi & - & - & - & 231 & 131 & 183 & 304 & & & \\
\hline & & Duyun & - & - & - & 147 & 220 & 230 & 456 & & & \\
\hline & & Anshun & - & - & - & 371 & 228 & 290 & 402 & & & \\
\hline & & Liupanshui & • & - & - & 60 [59] & 67 & 46 & $55[54]$ & - & - & - \\
\hline & & province avg & 219 & 236 & 214 & 204 & 206 & 188 & 272 & - & - & - \\
\hline & Yunnan & Gejiu & - & - & - & 145 & 114 & 41 & 31 & - & - & - \\
\hline & & Kunming & - & - & - & 55 & 520 & 45 & 50 & - & - & - \\
\hline & Xizang & Lhasa & - & - & - & - & - & - & 2 & $=$ & $\therefore$ & $=$ \\
\hline \multirow[t]{11}{*}{ Nontwest } & Shaanxi & Baoji & - & - & - & 29 & - & 54 & 39 & - & - & $=$ \\
\hline & & Hanzthong & - & - & - & 58 & - & 50 & 61 & - & - & - \\
\hline & & $X X^{\prime} a n$ & - & - & - & 51 & - & 68 & 58 & - & - & - \\
\hline & & Yan'an & - & - & - & 41 & - & 60 & 44 & - & - & - \\
\hline & Gansu & Lanzhou & - & - & - & 62 & 84 & 102 & 79 & - & - & - \\
\hline & & Tianshui & - & - & - & 59 & 46 & 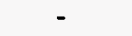 & - & - & - & - \\
\hline & Qinghai & Xining & - & - & 47 & $46[47]$ & 66 & 51 & 46 & - & - & - \\
\hline & Ningxia & Gryuan & - & - & - & 40 & 32 & - & 28 & - & - & - \\
\hline & & Shizuishan & - & - & - & 75 [192] & 106 & 104 & 209 [165] & - & - & - \\
\hline & & Yinchuan & - & - & - & 19 & 53 & 56 & $68[70]$ & - & - & - \\
\hline & Xinjiang & Urumqi & 120 & 128 & 158 & $201[207]$ & 222 & 207 & 301 & - & - & - \\
\hline
\end{tabular}

N.B. Province averages are averages of major urban areas. On occasion conflicting data are presented for a single year. In such cases, the data from the more recent source and from tables comparing several cities are preferred. In some cases figures reported by national and local authorities differ. In such cases the figures from local government reports appear in square brackets.

- All 1993 data are from local reports. Minima and maxima are daily averages.

$\dagger \quad$ Between 1986 and 1990 results of air quality monitoring in Dalian were reported for both automatic and chemical analysis. For those years the data are reported as automatic I chemical

I Annual averages for urban/suburban areas.

Source: China Environmental Yearbook, various years. 
Table VIII-8. Ambient Air Quality in Selected Chinese Cities: Nitrogen Oxides, 1986-1993

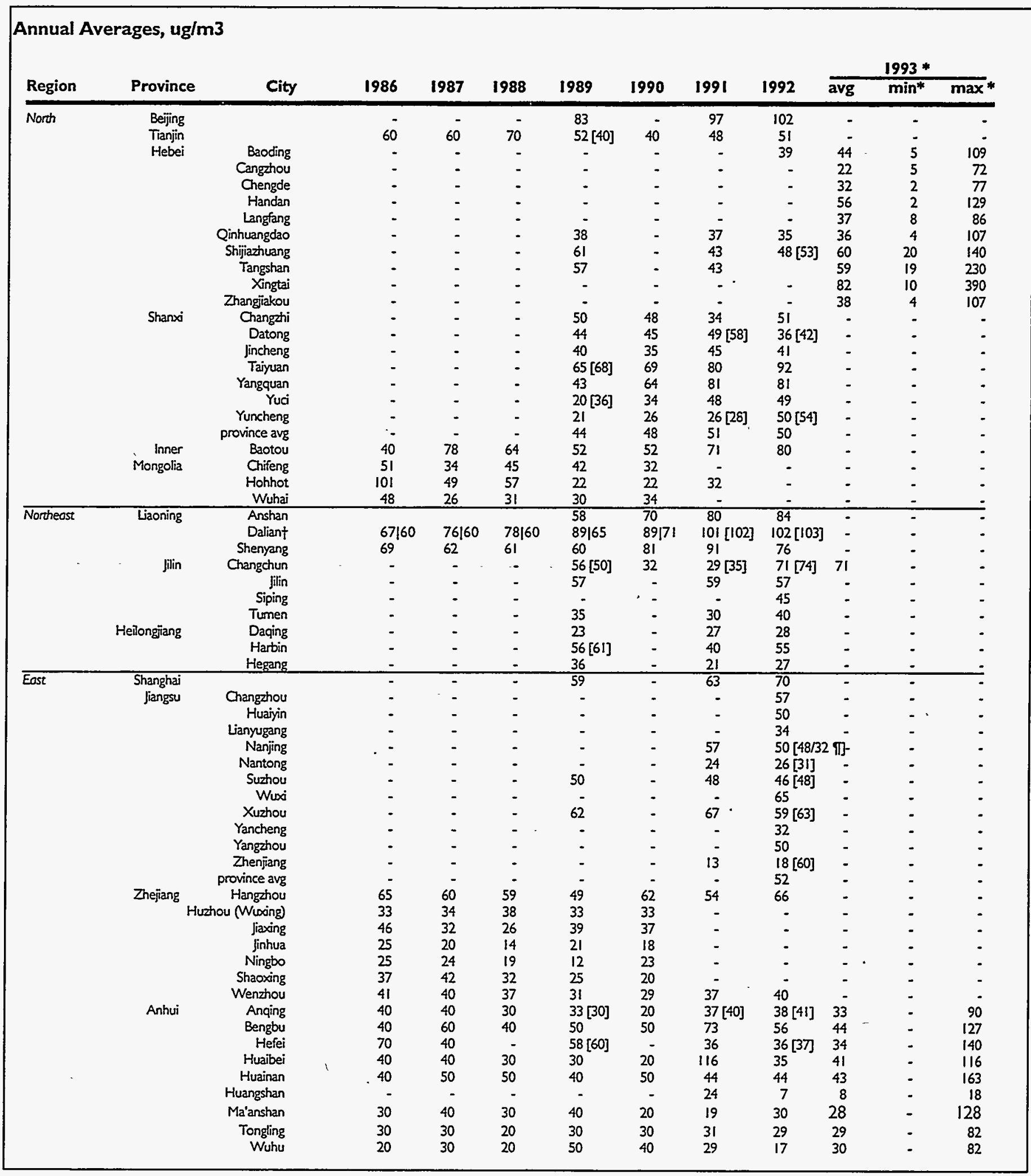

N.B. Province averages are averages of major urban areas. On occasion conflicting data are presented for a single year. In such cases, the data from the more recent source and from tables comparing several cities are preferred. In some cases figures reported by national and local authorities differ. In such cases the figures from local government reports appear in square brackets.

* All 1993 data are from local reports. Minima and maxima are daily averages.

$\dagger$ Between 1986 and 1990 results of air quality monitoring in Dalian were reported for both automatic and chemical analysis. For those years the data are reported as automatic I chemical.

I Annual averages for urban/suburban areas.

Source: China Environmental Yearbook, various years. 
Table VIII-8. Ambient Air Quality in Selected Chinese Cities: Nitrogen Oxides, 1986-1993 (continued)

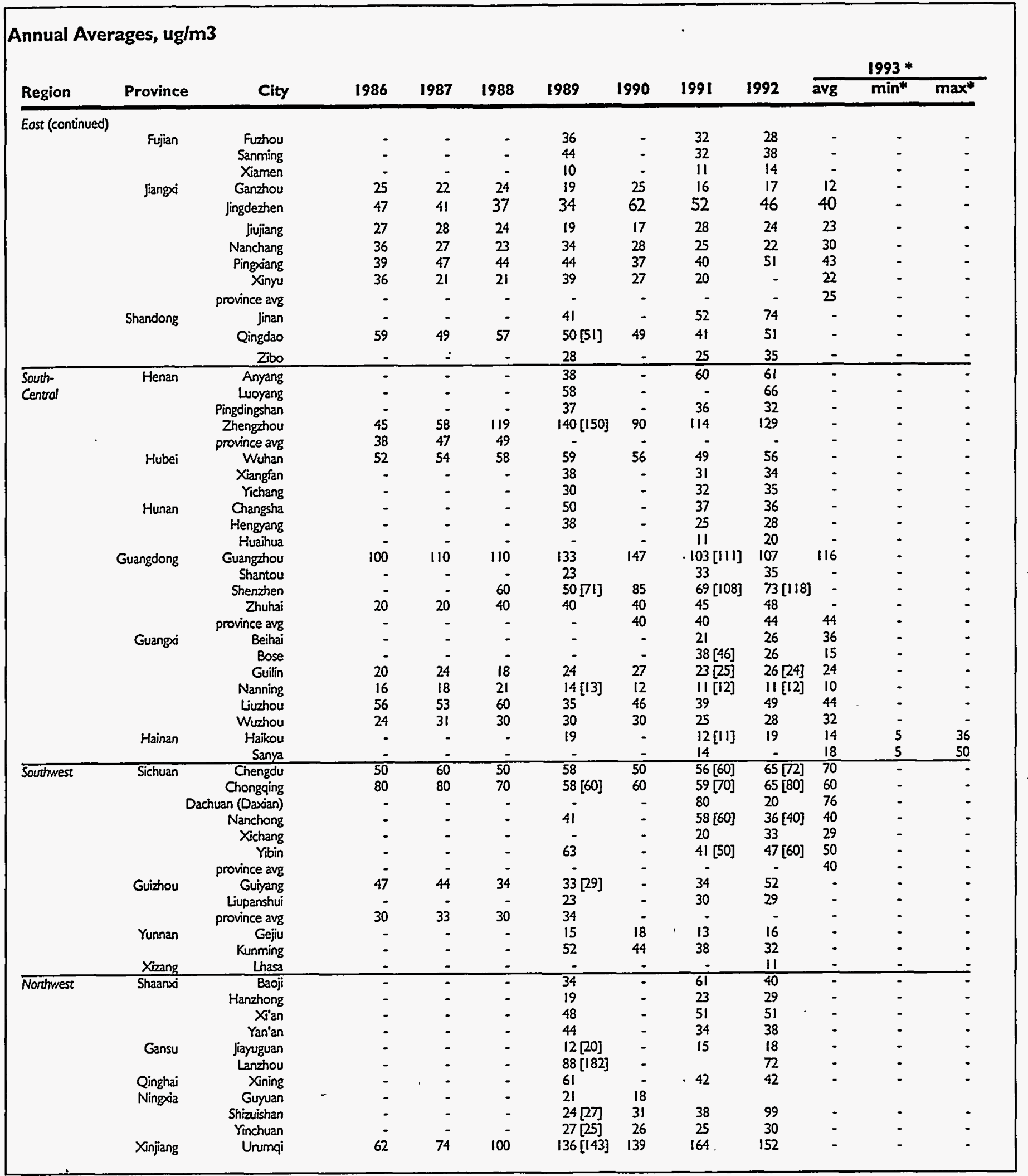

N.B. Province averages are averages of major urban areas. On occasion conflicting data are presented for a single year. In such cases, the data from the more recent source and from tables comparing several cities are preferred. In some cases figures reported by national and local authorities differ. In such cases the figures from local govemment reports appear in square brackets.

- All 1993 data are from local reports. Minima and maxima are daily averages.

$\dagger$ Between 1986 and 1990 results of air quality monitoring in Dalian were reported for both automatic and chemical analysis. For those years the data are reported as automatic / chemical.

8 Annual averages for urban/suburban areas.

Source: China Environmental Yearbook, various years. 
Table VIII-9. Ambient Air Quality in Selected Chinese Cities: Carbon Monoxide, 1981-1993.

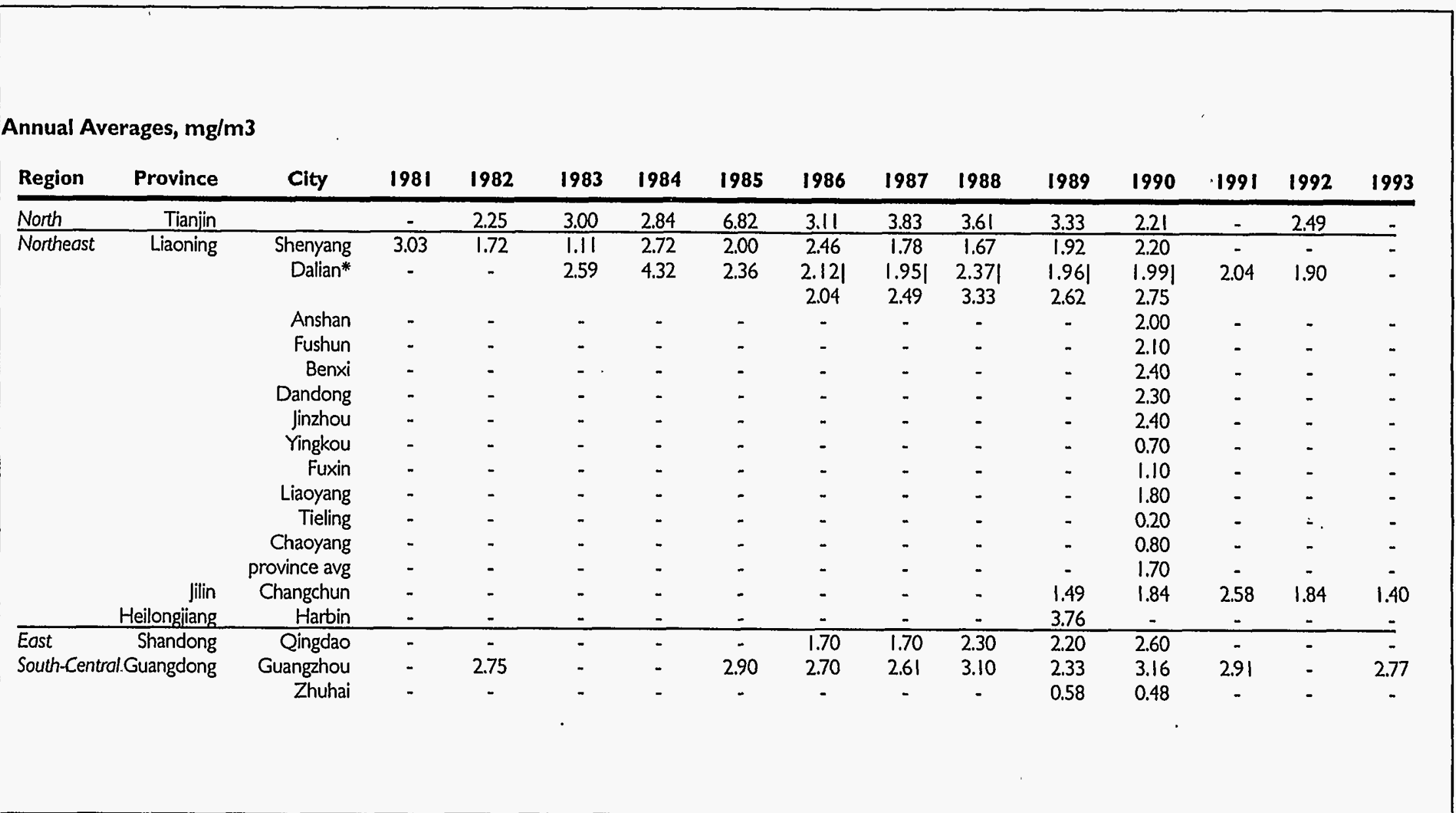

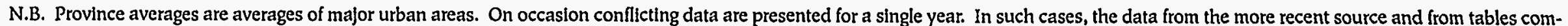
parlng several cities are preferred.

* Between 1986 and 1990 results of alr quality monitoring in Dallan were reported for both automatic and chemical analysis. For those years the data are reported as automatic 1 chemical. Source: China Environmental Yearbook, various years. 
Annual Averages, tonnes per square $\mathrm{km}$ per month

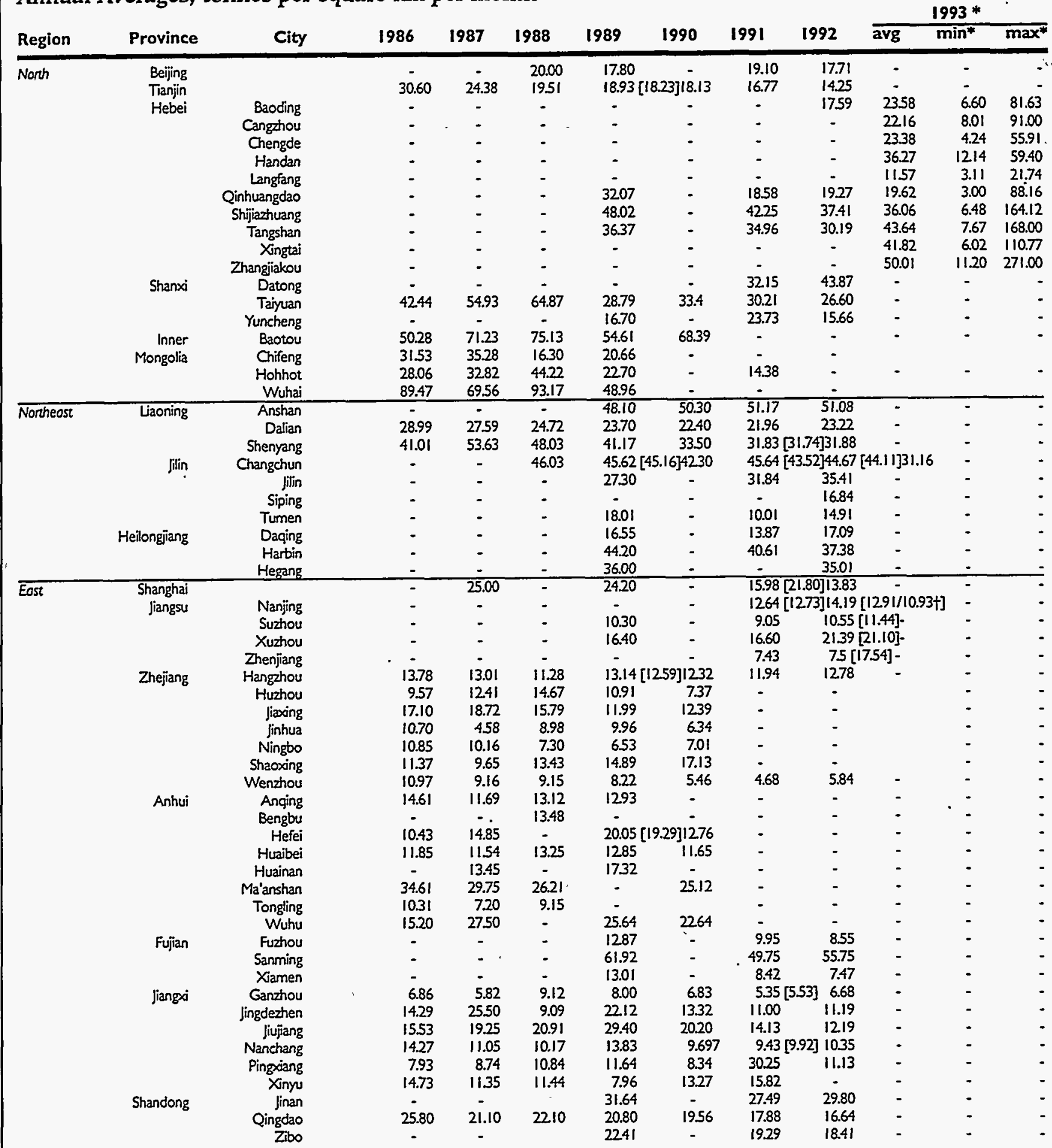

N.B. Province averages are averages of major urban areas. On occasion conflicting data are presented for a single year. In such cases, the data from the more recent source and from tables companing several cities are preferred. In some cases figures reported by national and local authorities differ. In such cases the figures from local government reports appear in square brackets.

- All 1993 data are from local reports. Minima and maxima are daily averages.

Source: China Environmental Yearbook, various years. 
Table VIII-10. Particulate Deposition for Selected Cities, 1986-1993 (continued)

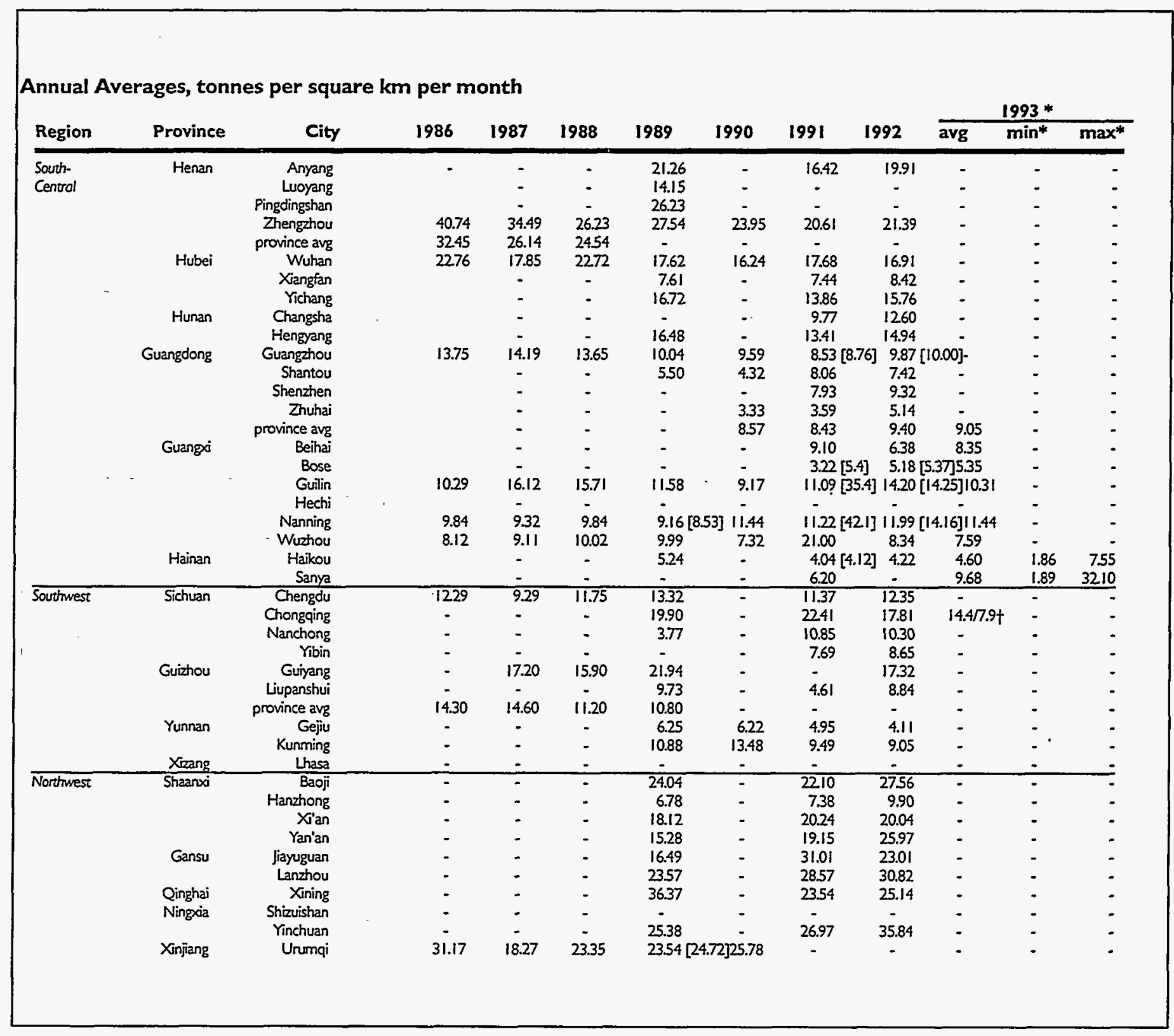

N.B. Province averages are averages of major urban areas. On occasion conflicting data are presented for a single year. In such cases, the data from the more recent source and from tables comparing several cities are preferred. In some cases figures reported by national and local authorities differ. In such cases the figures from local government reports appear in square brackets.

* All 1993 data are from local reports. Minima and maxima are daily averages.

$\dagger$ Between 1986 and 1990 results of air quality monitoring in Dalian were reported for both automatic and chemical analysis. For those years the data are reported as automatic I chemical.

Source: China Environmental Yearbook, various years. 


\section{Table VIII-11. Acidity of Precipitation - Annual Average pH}

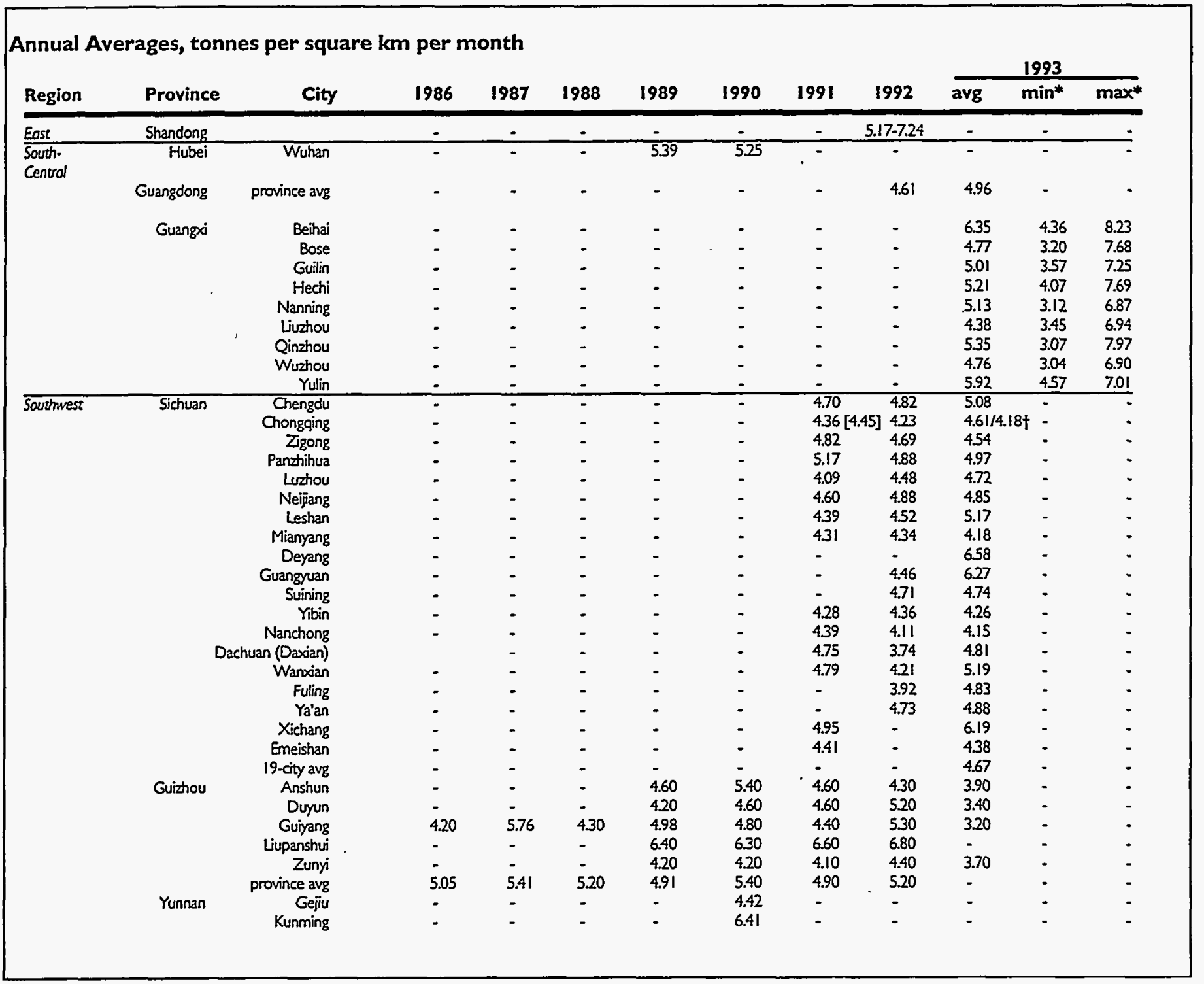

N.B. Province averages are averages of major urban areas. On occasion conflicting data are presented for a single year. In such cases, the data from the more recent source and from tables comparing several cities are preferred. The normal $\mathrm{pH}$ value of precipitation is about 5.6.

* All 1993 data are from local reports. Minima and maxima are daily averages.

$\dagger$ Annual averages for urban/suburban areas.

Source: China Environmental Yearbook, various years. 


\section{Table VIII-12. Indoor Air Pollution in Chinese Residences: Range of Pollutant Levels * Reported in Research Articles}

\begin{tabular}{|c|c|c|c|c|}
\hline Pollutant & Unit & $\begin{array}{c}\text { Urban } \\
\text { Fuel Type }\end{array}$ & $\begin{array}{c}\text { Rural } \\
\text { Households }\end{array}$ & Households \\
\hline Total Suspended Particulates & $\left(\mathrm{mg} / \mathrm{m}^{3}\right)$ & $\begin{array}{c}\text { coal } \\
\text { gas } \\
\text { biomass }\end{array}$ & $\begin{array}{c}0.21-2.8 \\
0.15-0.51 \\
-\end{array}$ & $\begin{array}{c}0.01-20 \\
0.19 \\
0.17-26\end{array}$ \\
\hline PMIO† & $\left(\mathrm{mg} / \mathrm{m}^{3}\right)$ & $\begin{array}{l}\text { coal } \\
\text { gas } \\
\text { biomass }\end{array}$ & $\begin{array}{c}0.16-2.7 \\
0.14-0.45 \\
-\end{array}$ & $\begin{array}{c}0.12-26 \\
- \\
0.83-22\end{array}$ \\
\hline Carbon Monoxide & $\left(\mathrm{mg} / \mathrm{m}^{3}\right)$ & $\begin{array}{c}\text { coal } \\
\text { gas } \\
\text { biomass }\end{array}$ & $\begin{array}{c}0.58-97 \\
0.22-36 \\
-\end{array}$ & $\begin{array}{c}0.70-87 \\
2.4 \\
0.5-16\end{array}$ \\
\hline Sulfur Dioxide & $\left(\mathrm{mg} / \mathrm{m}^{3}\right)$ & $\begin{array}{c}\text { coal } \\
\text { gas } \\
\text { biomass }\end{array}$ & $\begin{array}{c}0.01-5.8 \\
0.01-1.3 \\
-\end{array}$ & $\begin{array}{c}0.01-23 \\
0.02-0.07 \\
0.01-9.1\end{array}$ \\
\hline Nitrogen Oxides & $\left(\mathrm{mg} / \mathrm{m}^{3}\right)$ & $\begin{array}{c}\text { coal } \\
\text { gas } \\
\text { biomass }\end{array}$ & $\begin{array}{c}0.01-1.8 \\
0.01-0.88 \\
-\end{array}$ & $\begin{array}{c}0.01-1.7 \\
0.03-0.05 \\
0.01-.32\end{array}$ \\
\hline Benzo(a)pyrene T & $\left(\mathrm{ng} / \mathrm{m}^{3}\right)$ & $\begin{array}{c}\text { coal } \\
\text { gas } \\
\text { biomass }\end{array}$ & $\begin{array}{c}0.3-190 \\
4.7-93 \\
-\end{array}$ & $\begin{array}{c}5.3-19,000 \\
- \\
3.7-3,100\end{array}$ \\
\hline
\end{tabular}

* Arithmetic means for individual households over single monitoring periods.

$\dagger$ Suspended particulate matter (PM) with diameter $\leq 10 \mu \mathrm{m}$, i.e., the fraction of total suspended particulates most closely associated with serious health impacts.

I Benzo(a)pyrene is a proxy for a class of combustion products, polycyclic aromatic hydrocarbons (PAHs), many of which are known carcinogens.

Source: Sinton et al., 1995. 
Chapter IX-International Comparisons 


\section{International Comparisons}

$\square$ hina is the second largest consumer of commercial energy and produces large shares of the world's output of industrial products. (By 1994 China had surpassed the Russian Federation as the second largest energy user (BP, 1995). In the 1992 data presented here China is rated third.) In the magnitude of its activity, therefore, China resembles already developed countries. In terms of per capita consumption and in terms of patterns of energy use and other activities, however, China more closely resembles other developing nations and formerly centrally planned economies.

Most of the comparisons in this section include China, India, Japan, the United States, and the former Soviet Union. India was chosen because it is a large developing country, with a population second only to China's but with a smaller resource base. Japan and the United States were chosen as representative developed countries. Japan has an economy that has grown rapidly until very recently, is energy-efficient by world standards, and is almost completely reliant on imported energy. The United States is more self-sufficient in energy, since it has a total resource base on par with China, but has the highest total and per capita rates of energy consumption in the world. The former Soviet Union was chosen as the only other country of similar size with a formerly centrally planned economy. Moreover, in its early stages of development, the economy of the People's Republic of China was consciously modeled after that of the Soviet Union, with its characteristic emphasis on the development of heavy industry at the expense of other sectors.

\section{PRIMARY ENERGY PRODUCTION}

China produced 1,037 Mtce, or $9 \%$ of the world's primary energy in 1992 (Table IX-1). ${ }^{2}$ This was significantly less than that produced in the United States and the Russian Federation ${ }^{3}$, with about 2,292 and 1,604 Mtce respectively, and several times that in India and Japan, with 270 Mtce and 107 Mtce respectively. In terms of structure of primary energy production China is closest to India; about threequarters of primary commercial energy in both countries is from coal, but China has a slightly larger share of oil, and correspondingly smaller shares of natural gas and primary electricity. The United States and the Russian Federation differ from China in their much larger shares of primary production from oil and natural gas. About one-third of energy production in the Unites States is coal. Because Japan's fossil fuel resources are insignificant, its primary energy production structure is the farthest from China's; $90 \%$ comes from primary electricity, and about two-thirds of that from nuclear power plants.

\section{PRIMARY ENERGY CONSUMPTION}

China's share of the world's primary commercial energy consumption in 1992 was $9 \%$ also (Table IX-2). This is a much larger share than two decades previously ( $4 \%$ in 1970). India's share has risen as well, approaching $3 \%$. Statistics from the former Soviet Union are difficult to interpret, but energy use is thought to have dropped since its breakup. In 1992 the Russian Federation accounted for $10 \%$ of world energy use. Japan's share has been growing, reaching $5.4 \%$ in 1992 . Energy use in the United States has leveled off, as has its share, now $25 \%$. Per capita consumption has increased recently in the three entirely Asian countries, and apparently started to drop slightly in the United States, where per capita consumption is 13 times that in China.

Absolute amounts of coal consumed increased between 1970 and 1992 in all the countries examined here, but it has become relatively more important for the developing countries (Table IX-3). China and India's shares of world coal consumption more than doubled over the period, to $26 \%$ and $5 \%$ respectively. Japan and the United States still consume the same shares as in 1970, but that of the former Soviet Union dropped from $19 \%$ to $12 \%$. 


\section{PRIMARY ENERGY INTENSITY}

While direct comparisons of the energy intensities (primary energy consumption per unit of gross domestic product) of different national economies are problematic, intensity trends can highlight the relative directions of structural and technological change. 4 Energy intensities in developed countries, represented by Japan and the United States, have declined fairly steadily since 1970 , although very slowly since the mid-1980s (Table IX-4). Intensities in developing countries typically rise until a fairly advanced stage of industrialization is reached, but after the mid1970 s China became an exception to this trend. A combination of improvements in the physical energy intensity of production, growth in the contributions of less energy-intensive sectors to GDP, improvements in the quality and variety of products, changes in output pricing structures resulting from economic reform (i.e., hidden inflation), monetization of previously hidden economic activity, and other factors have led to the dramatic decline observed in energy intensity. Energy intensity in India is still rising, which is more typical of developing countries.

\section{END-USE CONSUMPTION}

Sectoral data on energy end-use consumption from different countries are difficult to compare. Data collection conventions and completeness of coverage vary between countries, so that categories are not necessarily compatible. Data come from many different sources, including research papers that estimate sectoral consumption on the basis of surveys. The data and comparisons in this section, therefore, are not meant to be very accurate, but are intended to provide a rough picture of end-use structures.

\section{SECTORAL END USE}

China stands out in that industry's share of end-use commercial energy consumption ( $67 \%$ in 1992) is larger by far than that in any other country, including the former Soviet Union (47\%; Table IX5). China's transportation sector also takes a smaller share than in any of the other countries, $9 \%$ as opposed to $19 \%$ in the former Soviet Union, which has the next smallest transportation share, and 36\% in the United States, which has the largest. At 20\% the share of China's residential sector share is smaller than that of any other country.but India (14\%). Adding biomass to the picture changes it in one significant respect - the combined household and commercial sector energy use share rises to $35 \%$ for China, higher than in all other countries but India, where these sectors have a $53 \%$ share.

The economic structure of the various countries bears some similarities to their sectoral energy consumption patterns, but there are notable exceptions. In Japan, the United States, and the former Soviet Union the industrial sector accounts for between one-third and $45 \%$ of both energy use (including biomass) and GDP (Table IX-25). In China, industry's share of both energy use and GDP is significantly higher, $55 \%$ and $48 \%$ respectively. India seems to be an exception to the pattern, with industry accounting for one-third of energy consumption, but providing just over one-quarter of output. This is probably due to the fact that agriculture is much more important in India (with 31\% of output) than in any of the other countries, and may also result partly from high energy intensities in industry (from which China also suffers).

China's industrial sector is similar to India's in the dominance of solid fuels (65\% and $73 \%$ in 1992 respectively; Table $\mathrm{IX}-6)$. The developed countries rely much more heavily on oil and gas. The contribution of electricity to Japan's industrial end-use consumption is particularly high at $24 \%$. Delivered heat is particularly important in the former Soviet Union, accounting for over one-third of industrial end use.

Coal makes significant contributions to the transportation sectors in China and India as well ( $18 \%$ and $17 \%$ respectively) since steam locomotives are still common, though they are being phased out in both countries (Table IX-7). Oil products dominate in all countries, though the former Soviet Union exhibits a high rate of natural gas use because of its extensive pipelines.

China's residential and commercial sector again reflects the importance of coal in China's energy system. Among the countries examined only the former Soviet Union obtains a similarly high share (over 20\% in 1992) of sectoral end use from coal 
(Table IX-8). Biomass energy is most important in India ( $86 \%$ of end use) and China (66\%), while it accounts for only a small portion of residential end use in the only developed country for which the information was available (the United States, with $4 \%)$. In the former Soviet Union, delivered heat accounted for a large portion of end use in this sector (37\%) just as in industry.

\section{ENERGY SOURCE END USE}

Coal is more important in China's commercial energy end-use structure than in any other country (Table IX-9). Only India, with $43 \%$ of end use from direct use of coal in 1992, comes close to China's $62 \%$. Oil products and natural gas together account for the largest shares in other countries. China is the only nation of the five in which electricity a has a share of end use smaller than $10 \%$.

For all the countries included in the comparison, end-use energy consumption data show that a large amount of primary energy is used in electricity generation. Electric utilities typically account for the largest share of coal use (up to $87 \%$ in the United States), and they take over $20 \%$ of all oil used in Japan and the former Soviet Union (Tables [X-10 and IX-11). Of the five countries, Japan converts the smallest share of its coal into electricity, $28 \%$ in 1992 compared to China's $35 \%$, the next lowest. The former Soviet Union's residential and commercial sector takes a larger share (24\%) than in any other country. China's is next with $14 \%$ of coal used in the residential and commercial sector; all other countries have shares under $2 \%$. Japan has the highest portion of coal used in industry $(72 \%$, mainly used in steel making). China is next with $46 \%$ of coal used in industry, and the United States last with $12 \%$. If coal inputs to utilities are allocated among sectors according to their shares of electricity consumption, then in all cases industry accounts for over half of coal use. The only exception is the United States; industry would account for $43 \%$ of coal use, compared to $54 \%$ in the residential and commercial sector.

China's petroleum end-use structure is most similar to that of Japan, with the industry and transportation sectors taking about one third each, and utilities and buildings (residential and commercial sectors) taking the next largest shares in order (Table IX-11). The consumption structure in China also resembles that in the former Soviet Union, except in the latter slightly less is used in industry and correspondingly more by utilities. In the United States and India only very small portions of oil are used to generate electricity, and transportation accounts for about two-thirds and one-half respectively.

The dominance of the industrial sector in China relative to other countries is again evident in the pattern of electricity consumption; the sector uses $72 \%$ of all electricity (Table IX-12). The industrial sector also takes the single largest share of electricity consumption in the other four countries, ranging from $35 \%$ in the United States to $55 \%$ in the former Soviet Union. In Japan and the United States the residential and commercial shares are the next most significant, and are several times larger than in China. Agricultural use is most important in India, where the sector takes $28 \%$ of electricity use. In the former Soviet Union and China agriculture only accounts for $10 \%$ and $9 \%$ respectively.

\section{ENERGY-INTENSIVE INDUSTRIAL PRODUCTS}

Statistics on production of various energy-intensive industrial products (including crude steel, cement, primary aluminum, ethylene, ammonia production, caustic soda, soda ash, sulfuric acid, and wood pulp) show that production of all of these in both China and India increased between 1979 and 1992 (Tables IX-13 to IX-21). China's share of worldwide production also clearly increased for each product, and the country now turns out more than a quarter of the world's cement and ammonia, and over one-tenth of its steel, caustic soda, soda ash, and sulfuric acid.

Production of some of these products in Japan, the United States, and the former Soviet Union has declined in absolute terms, and for most of the products shares of world production have stagnated or fallen. These statistics confirm in a general way the impression that the centers of production of energyintensive products are increasingly moving from developed to developing countries. 


\section{TRANSPORTATION STRUCTURE}

China has the smallest total and per capita rates of travel among the countries compared, about one-half and one-third of the figures for India in the two categories respectively (Table IX-22). Another feature that distinguishes passenger travel in China is that rail and water transport are more important than in any of the other countries (although water transport only accounts for $3 \%$ of passenger traffic in China, it is not even $1 \%$ in the other countries). In China $45 \%$ of passenger $-\mathrm{km}$ traveled were by rail in 1992, and the former Soviet Union and Japan were next at about one-third. The share of road transportation in China is relatively small and the same as in the former Soviet Union, $46 \%$ compared to a range of $65 \%$ to $82 \%$ for the other countries.

In terms of freight traffic, water and rail are most important in China; $45 \%$ of freight turnover is by water, and $40 \%$ by rail (Table IX-23). Water transport is similarly important only in Japan, where $45 \%$ of freight turnover is by water, but $51 \%$ by road. Rail transport is almost as important in the United States as in China, but, as with Japan, most of the balance goes by road. The country with the largest share of freight carriage going by rail is the former Soviet Union, at $57 \%$. India is next with $46 \%$. Only the United States and the former Soviet Union move large shares of freight by pipeline. China's per capita freight traffic is again small (about half that in Japan and less than one-tenth that in the United States), though not as small as India's in this case.

\section{CARBON DIOXIDE EMISSIONS}

The world's three largest emitters of anthropogenic carbon dioxide are the United States, the former Soviet Union, and China (Table IX-24). Respectively they contributed $22 \%, 16 \%$, and $11 \%$ of total global emissions of $6.2 \mathrm{Gt}$ carbon in 1991 . The United States and the former Soviet Union have been the major contributors for the past 40 years, together accounting for over $40 \%$ until 1990 . China's emissions, on the other hand, were similar to those from Japan until the mid-1970s (except for a spike in the late 1950s during the Great Leap Forward). Since 1970 China has been a larger contributor than Japan, with its share doubling in 15 years.

In terms of per capita emissions the picture is somewhat different. Per capita emissions from the United States are by far the highest, fluctuating between 4.2 and $6.0 \mathrm{t}$ carbon per person between 1950 and 1991. The former Soviet Union ranks next among the five countries, with per capita emission rising steadily to $3.9 \mathrm{t}$ per person in 1988 before beginning to slide. Japan's per capita emissions leveled off in the early 1970 s near $2.2 \mathrm{t}$ per person, but have recently been edging upwards again. The fact that per capita emissions in China are $0.6 \mathrm{t}$, while China's total emissions are twice Japan's (since China has nearly ten times Japan's populations; Table IX-26) underscores the importance of population in analyzing greenhouse gas issues, and the difficulty of agreeing on a basis for putting in place international controls on greenhouse gas emissions.

\footnotetext{
1 Per capita consumption is actually higher in one country, the United Arab Emirates, the value for which is nearly twice that of the United States. Per capita energy consumption in Canada is marginally lower than in the US.

2 Unlike other Chapters in this volume, in this Chapter electricity is converted at its energy value, i.e., $3.6 \mathrm{MJ} / \mathrm{kWh}$, rather than at the amount of energy needed to replace it in an average thermal power plant (11.8 MJ/kWh for China). The aggregate energy figures for China are therefore somewhat lower than in other chapters. We chose 1992 as the year for comparison in this chapter because it is the most recent year for which relatively complete sets of data exist in all categories for the various countries.

3 The Russian Federation accounts for the majority of energy production, consumption, and economic activity in the former Soviet Union.

${ }^{4}$ Energy intensity indices for the various countries are based on deflated (constant price) GDP series.
} 
Table IX-1. Total Primary Energy Production by Energy Source for Selected Countries, 1989-1992

\begin{tabular}{|c|c|c|c|c|c|c|c|c|c|}
\hline $\begin{array}{l}\text { 1. Mtce } \\
\text { Country }\end{array}$ & Year & Solid* & Liquids $†$ & $\begin{array}{c}\text { Natural } \\
\text { Gas }\end{array}$ & $\begin{array}{l}\text { Primary } \\
\text { Electricity II }\end{array}$ & $\begin{array}{c}\text { Total } \\
\text { Production }\end{array}$ & $\begin{array}{l}\text { Stock } \\
\text { Changes }\end{array}$ & Imports & Exports \\
\hline China $\S$ & $\begin{array}{l}1989 \\
1990 \\
1991 \\
1992 \\
\end{array}$ & $\begin{array}{l}752.2 \\
770.6 \\
775.9 \\
796.6 \\
\end{array}$ & $\begin{array}{l}196.6 \\
197.5 \\
201.4 \\
203.0 \\
\end{array}$ & $\begin{array}{l}20.0 \\
20.3 \\
21.3 \\
20.0 \\
\end{array}$ & $\begin{array}{l}14.5 \\
15.6 \\
15.4 \\
16.3 \\
\end{array}$ & $\begin{array}{r}983.3 \\
1,004.0 \\
1,014.0 \\
1,036.8 \\
\end{array}$ & $\begin{array}{r}23.2 \\
32.0 \\
8.6 \\
0.4 \\
\end{array}$ & $\begin{array}{l}16.8 \\
12.8 \\
19.5 \\
32.4\end{array}$ & $\begin{array}{l}54.8 \\
56.0 \\
55.5 \\
58.5 \\
\end{array}$ \\
\hline India & $\begin{array}{l}1989 \\
1990 \\
1991 \\
1992\end{array}$ & $\begin{array}{l}168.8 \\
172.2 \\
193.0 \\
202.8\end{array}$ & $\begin{array}{l}49.0 \\
48.8 \\
45.7 \\
40.7 \\
\end{array}$ & $\begin{array}{l}10.8 \\
13.2 \\
15.0 \\
15.6\end{array}$ & $\begin{array}{r}10.3 \\
9.4 \\
11.1 \\
11.0\end{array}$ & $\begin{array}{l}237.8 \\
245.4 \\
264.7 \\
270.1\end{array}$ & $\begin{array}{l}1.1 \\
1.2 \\
7.1 \\
4.2\end{array}$ & $\begin{array}{l}40.4 \\
44.6 \\
50.6 \\
58.2\end{array}$ & $\begin{array}{l}0.3 \\
0.6 \\
0.6 \\
0.6\end{array}$ \\
\hline Japan & $\begin{array}{l}1989 \\
1990 \\
1991 \\
1992 \\
\end{array}$ & $\begin{array}{l}9.0 \\
7.3 \\
7.1 \\
6.7 \\
\end{array}$ & $\begin{array}{l}1.0 \\
0.8 \\
1.1 \\
1.2 \\
\end{array}$ & $\begin{array}{l}2.8 \\
2.9 \\
3.0 \\
3.0 \\
\end{array}$ & $\begin{array}{l}81.6 \\
89.1 \\
94.4 \\
96.1 \\
\end{array}$ & $\begin{array}{r}94.4 \\
100.0 \\
105.6 \\
107.1 \\
\end{array}$ & $\begin{array}{r}10.2 \\
2.1 \\
1.6 \\
-0.5 \\
\end{array}$ & $\begin{array}{l}485.0 \\
507.0 \\
520.6 \\
529.9 \\
\end{array}$ & $\begin{array}{r}10.0 \\
11.4 \\
7.4 \\
9.5 \\
\end{array}$ \\
\hline USA & $\begin{array}{l}1989 \\
1990 \\
1991 \\
1992 \\
\end{array}$ & $\begin{array}{l}734.8 \\
771.9 \\
746.6 \\
746.7 \\
\end{array}$ & $\begin{array}{l}623.7 \\
607.7 \\
616.8 \\
602.9 \\
\end{array}$ & $\begin{array}{l}642.5 \\
661.0 \\
656.0 \\
661.2 \\
\end{array}$ & $\begin{array}{l}247.5 \\
268.3 \\
281.4 \\
280.6 \\
\end{array}$ & $\begin{array}{l}2,248.6 \\
2,308.9 \\
2,300.8 \\
2,291.5 \\
\end{array}$ & $\begin{array}{r}-25.4 \\
50.0 \\
-1.7 \\
-5.7 \\
\end{array}$ & $\begin{array}{l}610.0 \\
608.7 \\
597.2 \\
631.9 \\
\end{array}$ & $\begin{array}{l}125.7 \\
129.7 \\
143.4 \\
139.0 \\
\end{array}$ \\
\hline $\begin{array}{l}\text { Russian } \\
\text { Federation }\end{array}$ & 1992 & 225.0 & 570.4 & 742.5 & 65.7 & $1,603.5$ & - & 60.6 & 480.7 \\
\hline Worid & $\begin{array}{l}1989 \\
1990 \\
1991 \\
1992\end{array}$ & $\begin{array}{l}3,340.3 \\
3,260.9 \\
3,167.0 \\
3,199.8\end{array}$ & $\begin{array}{l}4,465.2 \\
4,561.1 \\
4,530.3 \\
4,540.2\end{array}$ & $\begin{array}{l}2,495.2 \\
2,562.2 \\
2,611.3 \\
2,655.0\end{array}$ & $\begin{array}{l}1,004.6 \\
1,049.4 \\
1,086.5 \\
1,089.7\end{array}$ & $\begin{array}{l}11,305.4 \\
11,433.6 \\
11,395.0 \\
11,486.7\end{array}$ & $\begin{array}{r}42.8 \\
143.7 \\
33.2 \\
40.5\end{array}$ & $\begin{array}{l}3,467.1 \\
3,555.8 \\
3,572.2 \\
4,098.7\end{array}$ & $\begin{array}{l}3,390.3 \\
3,533.5 \\
3,521.7 \\
3,999.7\end{array}$ \\
\hline
\end{tabular}

* Hard coal, lignite, peat, and oil shale.

$\dagger \quad$ Crude oil and natural gas liquids.

I Conversion factors for hydro-, nuclear, and geothermal electricity are $0.123,0.372$, and $1.228 \mathrm{kgce} / \mathrm{kwh}$ respectively.

$\S$ Because of the different conversion factors used for primary electricity, the energy production figures for China in this table are lower than those found elsewhere in this volume.

Source: United Nations, 1994. 
Table IX-1. Total Primary Energy Production by Energy Source for Selected Countries, 1989-1992 (continued)

\begin{tabular}{|c|c|c|c|c|c|c|}
\hline \multicolumn{7}{|c|}{ 2. Energy Source Shares of Country Energy Production } \\
\hline Country & Year & Solid * & Liquids $t$ & $\begin{array}{c}\text { Natural } \\
\text { Gas }\end{array}$ & $\begin{array}{c}\text { Primary } \\
\text { Electricity II }\end{array}$ & Total \\
\hline \multirow{4}{*}{ China § } & 1989 & $76.5 \%$ & $20.0 \%$ & $20 \%$ & $1.5 \%$ & $100.0 \%$ \\
\hline & 1990 & $76.8 \%$ & $19.7 \%$ & $2.0 \%$ & $1.6 \%$ & $100.0 \%$ \\
\hline & 1991 & $76.5 \%$ & $19.9 \%$ & $2.1 \%$ & $1.5 \%$ & $100.0 \%$ \\
\hline & 1992 & $76.8 \%$ & $19.6 \%$ & $1.9 \%$ & $1.6 \%$ & $100.0 \%$ \\
\hline \multirow[t]{4}{*}{ India } & 1989 & $71.0 \%$ & $20.6 \%$ & $4.5 \%$ & $4.3 \%$ & $100.0 \%$ \\
\hline & 1990 & $70.2 \%$ & $19.9 \%$ & $5.4 \%$ & $3.8 \%$ & $100.0 \%$ \\
\hline & 1991 & $72.9 \%$ & $17.3 \%$ & $5.7 \%$ & $4.2 \%$ & $100.0 \%$ \\
\hline & 1992 & $75.1 \%$ & $15.1 \%$ & $5.8 \%$ & $4.1 \%$ & $100.0 \%$ \\
\hline \multirow[t]{4}{*}{ Japan } & 1989 & $9.5 \%$ & $1.1 \%$ & $3.0 \%$ & $86.4 \%$ & $100.0 \%$ \\
\hline & 1990 & $7.3 \%$ & $0.8 \%$ & $2.9 \%$ & $89.1 \%$ & $100.0 \%$ \\
\hline & 1991 & $6.7 \%$ & $1.0 \%$ & $28 \%$ & $89.4 \%$ & $100.0 \%$ \\
\hline & 1992 & $6.3 \%$ & $1.1 \%$ & $28 \%$ & $89.7 \%$ & $100.0 \%$ \\
\hline \multirow[t]{4}{*}{$\overline{U S A}$} & 1989 & $32.7 \%$ & $27.7 \%$ & $28.6 \%$ & $11.0 \%$ & $100.0 \%$ \\
\hline & 1990 & $33.4 \%$ & $26.3 \%$ & $28.6 \%$ & $11.6 \%$ & $100.0 \%$ \\
\hline & 1991 & $32.4 \%$ & $26.8 \%$ & $28.5 \%$ & $12.2 \%$ & $100.0 \%$ \\
\hline & 1992 & $32.6 \%$ & $26.3 \%$ & $28.9 \%$ & $12.2 \%$ & $100.0 \%$ \\
\hline \multicolumn{7}{|l|}{ Russian } \\
\hline Federation & 1992 & $14.0 \%$ & $35.6 \%$ & $46.3 \%$ & $4.1 \%$ & $100.0 \%$ \\
\hline \multirow[t]{4}{*}{ World } & 1989 & $29.5 \%$ & $39.5 \%$ & $22.1 \%$ & $8.9 \%$ & $100.0 \%$ \\
\hline & 1990 & $28.5 \%$ & $39.9 \%$ & $22.4 \%$ & $9.2 \%$ & $100.0 \%$ \\
\hline & 1991 & $27.8 \%$ & $39.8 \%$ & $22.9 \%$ & $9.5 \%$ & $100.0 \%$ \\
\hline & 1992 & $27.9 \%$ & $39.5 \%$ & $23.1 \%$ & $9.5 \%$ & $100.0 \%$ \\
\hline
\end{tabular}

\begin{tabular}{|lcccccc|}
\hline 3. Country Shares of World Energy Source Production & & & \\
Country & Year & Solid* & Liquidst & $\begin{array}{c}\text { Natural } \\
\text { Gas }\end{array}$ & $\begin{array}{c}\text { Primary } \\
\text { Electricity }\end{array}$ & Total \\
\hline China§ & 1989 & $22.5 \%$ & $4.4 \%$ & $0.8 \%$ & $1.4 \%$ & $8.7 \%$ \\
& 1990 & $23.6 \%$ & $4.3 \%$ & $0.8 \%$ & $1.5 \%$ & $8.8 \%$ \\
& 1991 & $24.5 \%$ & $4.4 \%$ & $0.8 \%$ & $1.4 \%$ & $8.9 \%$ \\
& 1992 & $24.9 \%$ & $4.5 \%$ & $0.8 \%$ & $1.5 \%$ & $9.0 \%$ \\
\hline India & 1989 & $5.1 \%$ & $1.1 \%$ & $0.4 \%$ & $1.0 \%$ & $2.1 \%$ \\
& 1990 & $5.3 \%$ & $1.1 \%$ & $0.5 \%$ & $0.9 \%$ & $2.1 \%$ \\
& 1991 & $6.1 \%$ & $1.0 \%$ & $0.6 \%$ & $1.0 \%$ & $2.3 \%$ \\
& 1992 & $6.3 \%$ & $0.9 \%$ & $0.6 \%$ & $1.0 \%$ & $2.4 \%$ \\
Japan & 1989 & $0.3 \%$ & $0.0 \%$ & $0.1 \%$ & $8.1 \%$ & $0.8 \%$ \\
& 1990 & $0.2 \%$ & $0.0 \%$ & $0.1 \%$ & $8.5 \%$ & $0.9 \%$ \\
& 1991 & $0.2 \%$ & $0.0 \%$ & $0.1 \%$ & $8.7 \%$ & $0.9 \%$ \\
& 1992 & $0.2 \%$ & $0.0 \%$ & $0.1 \%$ & $8.8 \%$ & $0.9 \%$ \\
\hline USA & 1989 & $22.0 \%$ & $14.0 \%$ & $25.7 \%$ & $24.6 \%$ & $19.9 \%$ \\
& 1990 & $23.7 \%$ & $13.3 \%$ & $25.8 \%$ & $25.6 \%$ & $20.2 \%$ \\
& 1991 & $23.6 \%$ & $13.6 \%$ & $25.1 \%$ & $25.9 \%$ & $20.2 \%$ \\
& 1992 & $23.3 \%$ & $13.3 \%$ & $24.9 \%$ & $25.8 \%$ & $19.9 \%$ \\
\hline Russian & & & & & & \\
Federation & 1992 & $7.0 \%$ & $12.6 \%$ & $28.0 \%$ & $6.0 \%$ & $14.0 \%$ \\
\hline World & 1989 & $100.0 \%$ & $100.0 \%$ & $100.0 \%$ & $10.0 \%$ & $100.0 \%$ \\
& 1990 & $100.0 \%$ & $100.0 \%$ & $100.0 \%$ & $100.0 \%$ & $100.0 \%$ \\
& 1991 & $100.0 \%$ & $100.0 \%$ & $100.0 \%$ & $100.0 \%$ & $100.0 \%$ \\
& 1992 & $100.0 \%$ & $100.0 \%$ & $100.0 \%$ & $100.0 \%$ & $100.0 \%$ \\
\hline
\end{tabular}

* Hard coal, lignite, peat, and oil shale.

$\dagger$ Crude oil and natural gas liquids.

1 Conversion factors for hydro-, nuclear, and geothermal electricity are $0.123,0.372$, and $1.228 \mathrm{kgce} / \mathrm{kwh}$ respectively.

§ Because of the different conversion factors used for primary electricity, the energy production figures for China in this table are lower than those found elsewhere in this volume.

Source: United Nations, 1994. 
Figure IX-1. Shares of Primary Energy Production

by Energy Source, Selected Countries, 1992

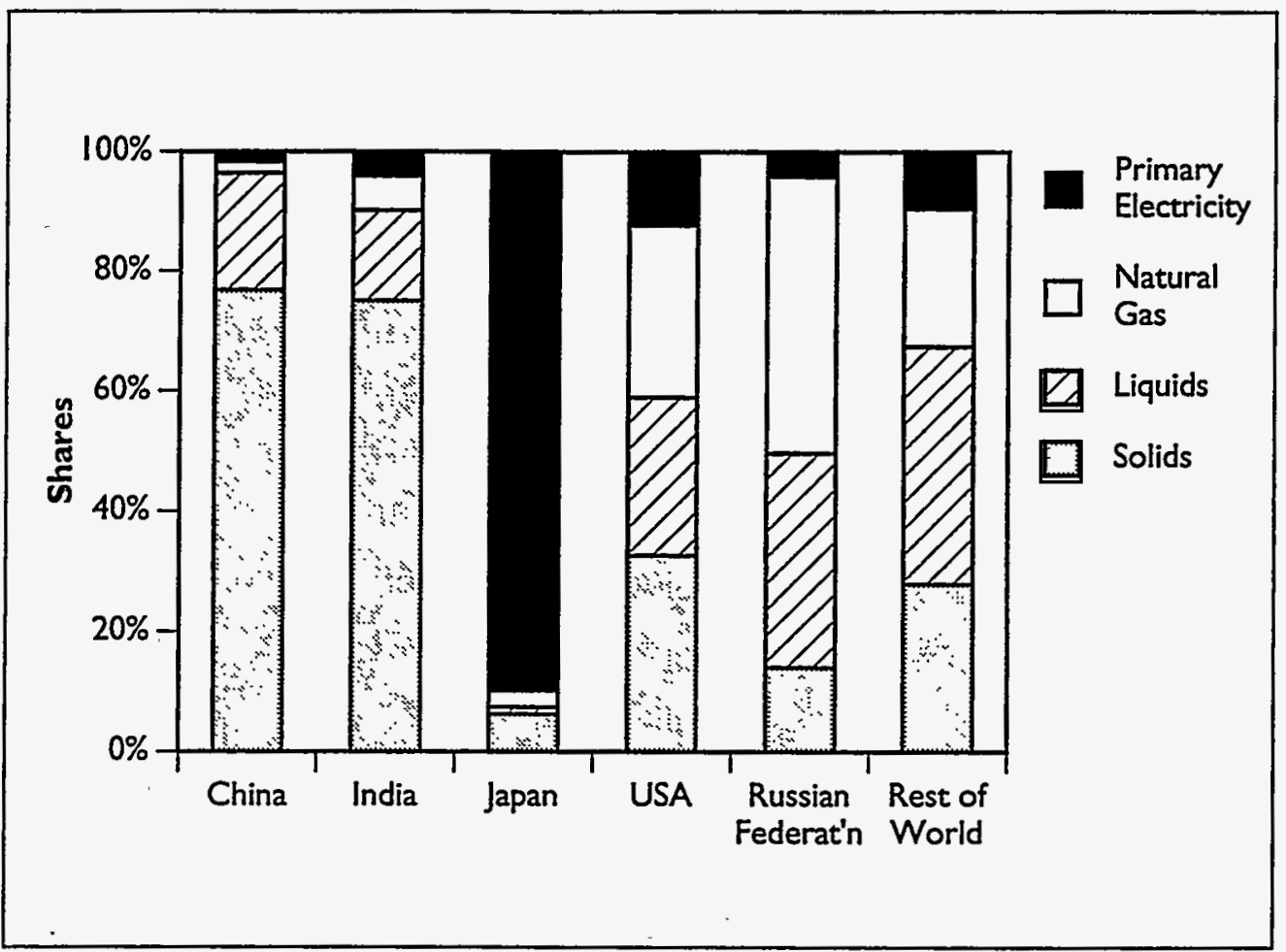

Figure IX-2. Shares of World Primary

Energy Source Production by Country, 1992

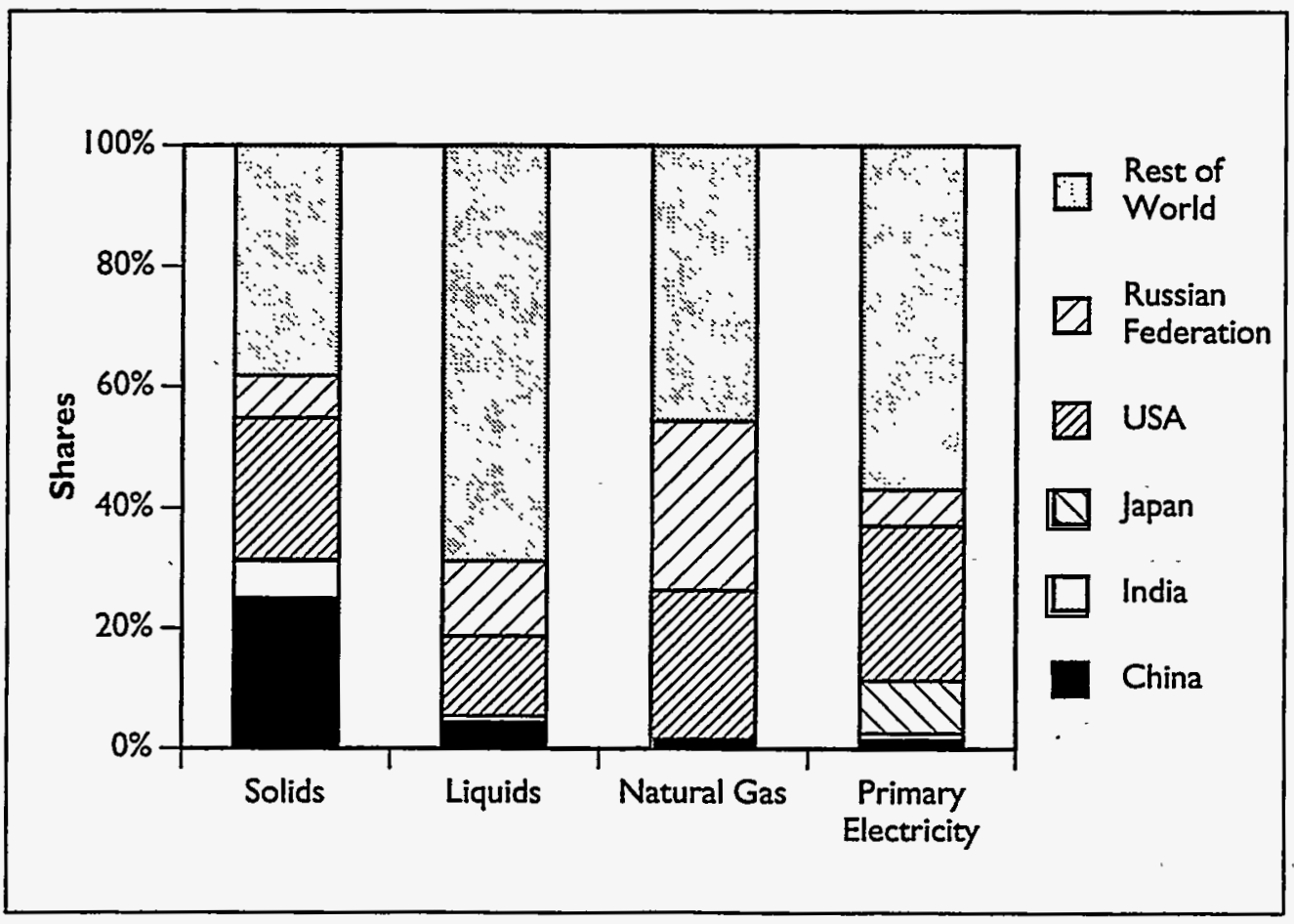




\section{Table IX-2. World Primary Commercial Energy Consumption}

by Region or Nation, 1989-1992

\begin{tabular}{|c|c|c|c|c|c|c|c|}
\hline 1. Mtce & Year & Solid * & Liquid $\uparrow$ & $\begin{array}{c}\text { Natural } \\
\text { Gas }\end{array}$ & $\begin{array}{l}\text { Primary } \\
\text { Electricity II }\end{array}$ & Total & $\begin{array}{c}\text { per capita } \\
\text { consumption } \\
\text { (kgce/person) }\end{array}$ \\
\hline China & $\begin{array}{l}1989 \\
1990 \\
1991 \\
1992 \\
\end{array}$ & $\begin{array}{l}720.8 \\
727.6 \\
754.1 \\
777.9 \\
\end{array}$ & $\begin{array}{l}131.5 \\
129.7 \\
141.8 \\
156.9 \\
\end{array}$ & $\begin{array}{l}20.0 \\
20.3 \\
21.3 \\
21.0 \\
\end{array}$ & $\begin{array}{l}14.8 \\
15.8 \\
15.7 \\
16.9 \\
\end{array}$ & $\begin{array}{l}887.0 \\
893.4 \\
933.0 \\
972.7 \\
\end{array}$ & $\begin{array}{l}795 \\
788 \\
811 \\
833 \\
\end{array}$ \\
\hline India & $\begin{array}{l}1989 \\
1990 \\
1991 \\
1992 \\
\end{array}$ & $\begin{array}{l}172.9 \\
179.4 \\
193.5 \\
205.6 \\
\end{array}$ & $\begin{array}{l}64.9 \\
65.3 \\
69.9 \\
75.4 \\
\end{array}$ & $\begin{array}{l}10.8 \\
13.2 \\
15.0 \\
15.6 \\
\end{array}$ & $\begin{array}{r}9.5 \\
11.3 \\
11.2 \\
11.3 \\
\end{array}$ & $\begin{array}{l}258.2 \\
269.2 \\
289.6 \\
307.8 \\
\end{array}$ & $\begin{array}{l}311 \\
318 \\
336 \\
350 \\
\end{array}$ \\
\hline Japan & $\begin{array}{l}1989 \\
1990 \\
1991 \\
1992 \\
\end{array}$ & $\begin{array}{l}113.3 \\
114.8 \\
119.7 \\
118.4 \\
\end{array}$ & $\begin{array}{l}276.6 \\
291.6 \\
296.7 \\
299.8 \\
\end{array}$ & $\begin{array}{l}64.3 \\
68.7 \\
73.8 \\
75.0 \\
\end{array}$ & $\begin{array}{l}81.6 \\
89.1 \\
94.4 \\
96.1 \\
\end{array}$ & $\begin{array}{l}535.8 \\
564.2 \\
584.6 \\
589.4 \\
\end{array}$ & $\begin{array}{l}4,354 \\
4,567 \\
4,714 \\
4,735 \\
\end{array}$ \\
\hline USA & $\begin{array}{l}1989 \\
1990 \\
1991 \\
1992 \\
\end{array}$ & $\begin{array}{l}671.2 \\
668.1 \\
662.0 \\
665.5 \\
\end{array}$ & $\begin{array}{l}1,080.9 \\
1,054.5 \\
1,038.7 \\
1,051.2\end{array}$ & $\begin{array}{l}701.9 \\
695.7 \\
719.9 \\
738.9 \\
\end{array}$ & $\begin{array}{l}248.9 \\
268.6 \\
284.1 \\
284.1 \\
\end{array}$ & $\begin{array}{l}2,702.9 \\
2,686.9 \\
2,704.7 \\
2,739.6\end{array}$ & $\begin{array}{l}10,920 \\
10,749 \\
10,711 \\
10,737\end{array}$ \\
\hline Russian & & & & & & & \\
\hline$\frac{\text { Federation }}{\text { World }}$ & $\begin{array}{l}\frac{1992}{1989} \\
1990 \\
1991 \\
1992\end{array}$ & $\begin{array}{r}226.2 \\
3,361.2 \\
3,238.4 \\
3,184.3 \\
3,212.6\end{array}$ & $\begin{array}{r}280.8 \\
3,998.0 \\
4,000.4 \\
4,039.9 \\
3,982.1\end{array}$ & $\begin{array}{r}525.5 \\
2,491.7 \\
2,538.9 \\
2,613.6 \\
2,664.3\end{array}$ & $\begin{array}{r}63.7 \\
1,003.9 \\
1,048.8 \\
1,086.5 \\
1,088.6\end{array}$ & $\begin{array}{r}1.096 .2 \\
10,854.9 \\
10,826.5 \\
10,924.2 \\
10,947.7\end{array}$ & $\begin{array}{l}\frac{7,357}{2,044} \\
2,044 \\
2,022 \\
1,993\end{array}$ \\
\hline
\end{tabular}

- Hard coal, lignite, peat, and oil shale.

$\dagger$ Crude oil and natural gas liquids.

I Conversion factor for electricity is $0.123 \mathrm{kgce} / \mathrm{kwh}$.

$\S$ Because of the different conversion factor used for primary electricity, the energy consumption figures for China in this table are lower than those found elsewhere in this volume.

Source: United Nations, 1994. 
Table DX-2. World Primary Commercial Energy Consumption by Region or Nation, 1989-1992 (continued)

\begin{tabular}{|c|c|c|c|c|c|c|}
\hline \multicolumn{7}{|c|}{ 2. Energy Source Shares of Country Primary Consumption } \\
\hline Country & Year & Solid * & Liquids $t$ & $\begin{array}{c}\text { Natural } \\
\text { Gas }\end{array}$ & $\begin{array}{c}\text { Primary } \\
\text { Electricity } \pi\end{array}$ & Total \\
\hline \multirow[t]{4}{*}{ China } & 1989 & $81.3 \%$ & $14.8 \%$ & $2.3 \%$ & $1.7 \%$ & $100.0 \%$ \\
\hline & 1990 & $81.4 \%$ & $14.5 \%$ & $23 \%$ & $1.8 \%$ & $100.0 \%$ \\
\hline & 1991 & $80.8 \%$ & $15.2 \%$ & $23 \%$ & $1.7 \%$ & $100.0 \%$ \\
\hline & 1992 & $80.0 \%$ & $16.1 \%$ & $22 \%$ & $1.7 \%$ & $100.0 \%$ \\
\hline \multirow[t]{4}{*}{ India } & 1989 & $67.0 \%$ & $25.1 \%$ & $4.2 \%$ & $3.7 \%$ & $100.0 \%$ \\
\hline & 1990 & $66.6 \%$ & $24.3 \%$ & $4.9 \%$ & $4.2 \%$ & $100.0 \%$ \\
\hline & 1991 & $66.8 \%$ & $24.1 \%$ & $5.2 \%$ & $3.9 \%$ & $100.0 \%$ \\
\hline & 1992 & $66.8 \%$ & $24.5 \%$ & $5.1 \%$ & $3.7 \%$ & $100.0 \%$ \\
\hline \multirow[t]{4}{*}{ Japan } & 1989 & $21.1 \%$ & $51.6 \%$ & $120 \%$ & $15.2 \%$ & $100.0 \%$ \\
\hline & 1990 & $20.3 \%$ & $51.7 \%$ & $12.2 \%$ & $15.8 \%$ & $100.0 \%$ \\
\hline & 1991 & $20.5 \%$ & $50.8 \%$ & $12.6 \%$ & $16.1 \%$ & $100.0 \%$ \\
\hline & 1992 & $20.1 \%$ & $50.9 \%$ & $12.7 \%$ & $16.3 \%$ & $100.0 \%$ \\
\hline \multirow[t]{4}{*}{ USA } & 1989 & $24.8 \%$ & $40.0 \%$ & $26.0 \%$ & $9.2 \%$ & $100.0 \%$ \\
\hline & 1990 & $24.9 \%$ & $39.2 \%$ & $25.9 \%$ & $10.0 \%$ & $100.0 \%$ \\
\hline & 1991 & $24.5 \%$ & $38.4 \%$ & $26.6 \%$ & $10.5 \%$ & $100.0 \%$ \\
\hline & 1992 & $24.3 \%$ & $38.4 \%$ & $27.0 \%$ & $10.4 \%$ & $100.0 \%$ \\
\hline \multicolumn{7}{|l|}{ Russian } \\
\hline Federation & 1992 & $20.6 \%$ & $25.6 \%$ & $47.9 \%$ & $5.8 \%$ & $100.0 \%$ \\
\hline \multirow[t]{4}{*}{ World } & 1989 & $31.0 \%$ & $36.8 \%$ & $23.0 \%$ & $9.2 \%$ & $100.0 \%$ \\
\hline & 1990 & $29.9 \%$ & $37.0 \%$ & $23.5 \%$ & $9.7 \%$ & $100.0 \%$ \\
\hline & 1991 & $29.1 \%$ & $37.0 \%$ & $23.9 \%$ & $9.9 \%$ & $100.0 \%$ \\
\hline & 1992 & $29.3 \%$ & $36.4 \%$ & $24.3 \%$ & $9.9 \%$ & $100.0 \%$ \\
\hline
\end{tabular}

\section{Country Shares of World Primary Consumption}

\begin{tabular}{lcccccc} 
Country & Year & Solid * & Liquids $†$ & $\begin{array}{c}\text { Natural } \\
\text { Gas }\end{array}$ & $\begin{array}{c}\text { Primary } \\
\text { Electricity I }\end{array}$ & Total \\
\hline China & 1989 & $21.4 \%$ & $3.3 \%$ & $0.8 \%$ & $1.5 \%$ & $8.2 \%$ \\
& 1990 & $22.5 \%$ & $3.2 \%$ & $0.8 \%$ & $1.5 \%$ & $8.3 \%$ \\
& 1991 & $23.7 \%$ & $3.5 \%$ & $0.8 \%$ & $1.4 \%$ & $8.5 \%$ \\
& 1992 & $24.2 \%$ & $3.9 \%$ & $0.8 \%$ & $1.6 \%$ & $8.9 \%$ \\
\hline India & 1989 & $5.1 \%$ & $1.6 \%$ & $0.4 \%$ & $0.9 \%$ & $2.4 \%$ \\
& 1990 & $5.5 \%$ & $1.6 \%$ & $0.5 \%$ & $1.1 \%$ & $2.5 \%$ \\
& 1991 & $6.1 \%$ & $1.7 \%$ & $0.6 \%$ & $1.0 \%$ & $2.7 \%$ \\
& 1992 & $6.4 \%$ & $1.9 \%$ & $0.6 \%$ & $1.0 \%$ & $2.8 \%$ \\
\hline Japan & 1989 & $3.4 \%$ & $6.9 \%$ & $2.6 \%$ & $8.1 \%$ & $4.9 \%$ \\
& 1990 & $3.5 \%$ & $7.3 \%$ & $2.7 \%$ & $8.5 \%$ & $5.2 \%$ \\
& 1991 & $3.8 \%$ & $7.3 \%$ & $28 \%$ & $8.7 \%$ & $5.4 \%$ \\
& 1992 & $3.7 \%$ & $7.5 \%$ & $2.8 \%$ & $8.8 \%$ & $5.4 \%$ \\
\hline USA & 1989 & $20.0 \%$ & $27.0 \%$ & $28.2 \%$ & $24 \%$ & $24.9 \%$ \\
& 1990 & $20.6 \%$ & $26.4 \%$ & $27.4 \%$ & $25.6 \%$ & $24.8 \%$ \\
& 1991 & $20.8 \%$ & $25.7 \%$ & $27.5 \%$ & $26.1 \%$ & $24.8 \%$ \\
& 1992 & $20.7 \%$ & $26.4 \%$ & $27.7 \%$ & $26.1 \%$ & $25.0 \%$ \\
\hline Russian & 1992 & $198 \%$ & & & & $10.1 \%$ \\
Federation & $19.7 \%$ & $7.0 \%$ & $21.1 \%$ & $6.3 \%$ & $100.0 \%$ \\
\hline Word & 1989 & $100.0 \%$ & $100.0 \%$ & $100.0 \%$ & $100.0 \%$ & $100.0 \%$ \\
& 1990 & $100.0 \%$ & $100.0 \%$ & $100.0 \%$ & $100.0 \%$ & $100.0 \%$ \\
& 1991 & $100.0 \%$ & $100.0 \%$ & $100.0 \%$ & $100.0 \%$ & $100.0 \%$ \\
\hline
\end{tabular}

* Hard coal, lignite, peat, and oil shale.

+ Crude oil and natural gas liquids.

I Conversion factor for electricity is $0.123 \mathrm{kgce} / \mathrm{kwh}$.

$\S$ Because of the different conversion factor used for primary electricity, the energy consumption figures for China in this table are lower than those found elsewhere in this volume. 
Figure IX-3. Shares of Primary Commercial Energy Consumption by Energy Source, 1992
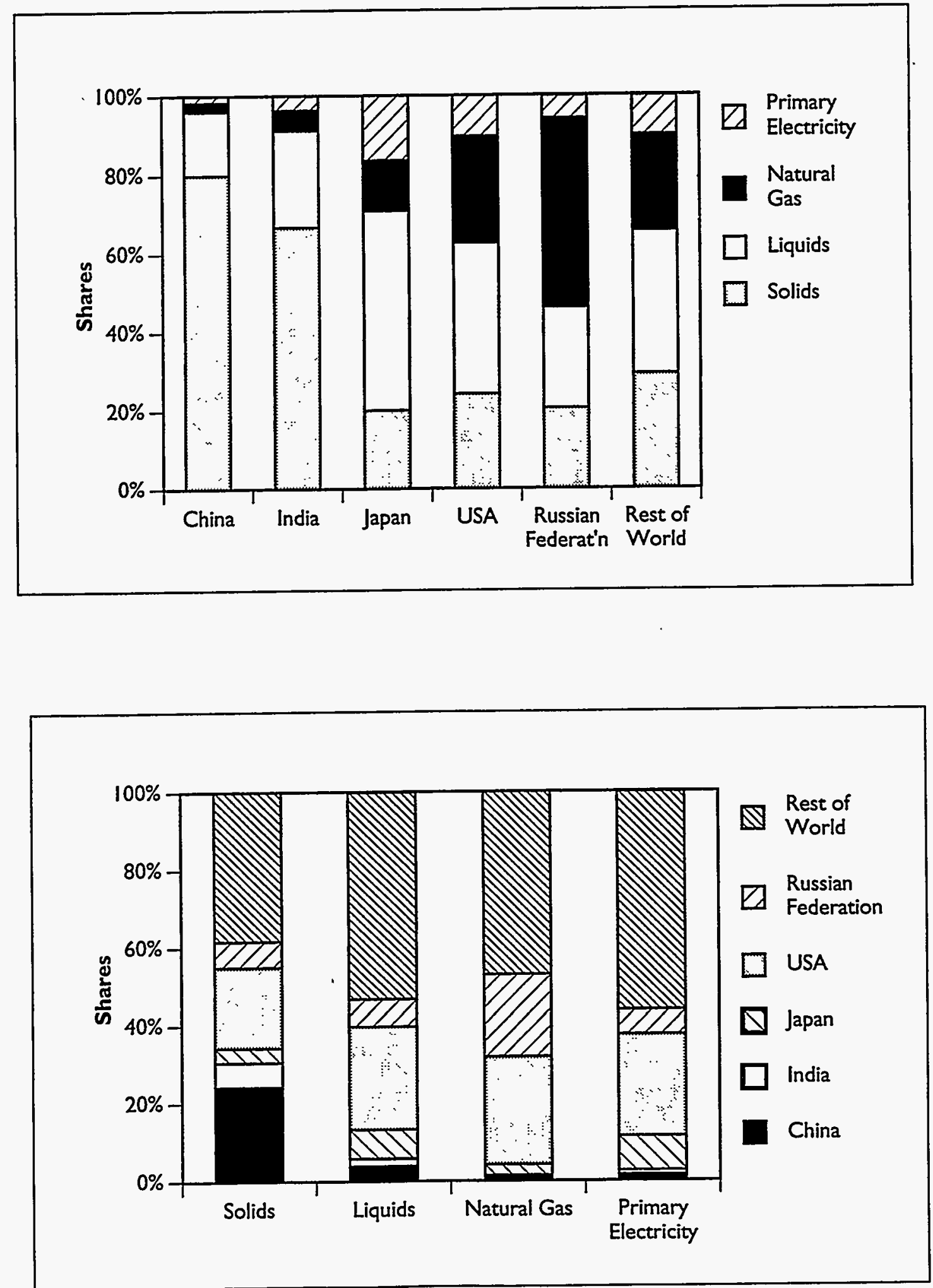
Figure IX-4. Per Capita Primary Commercial Energy Consumption

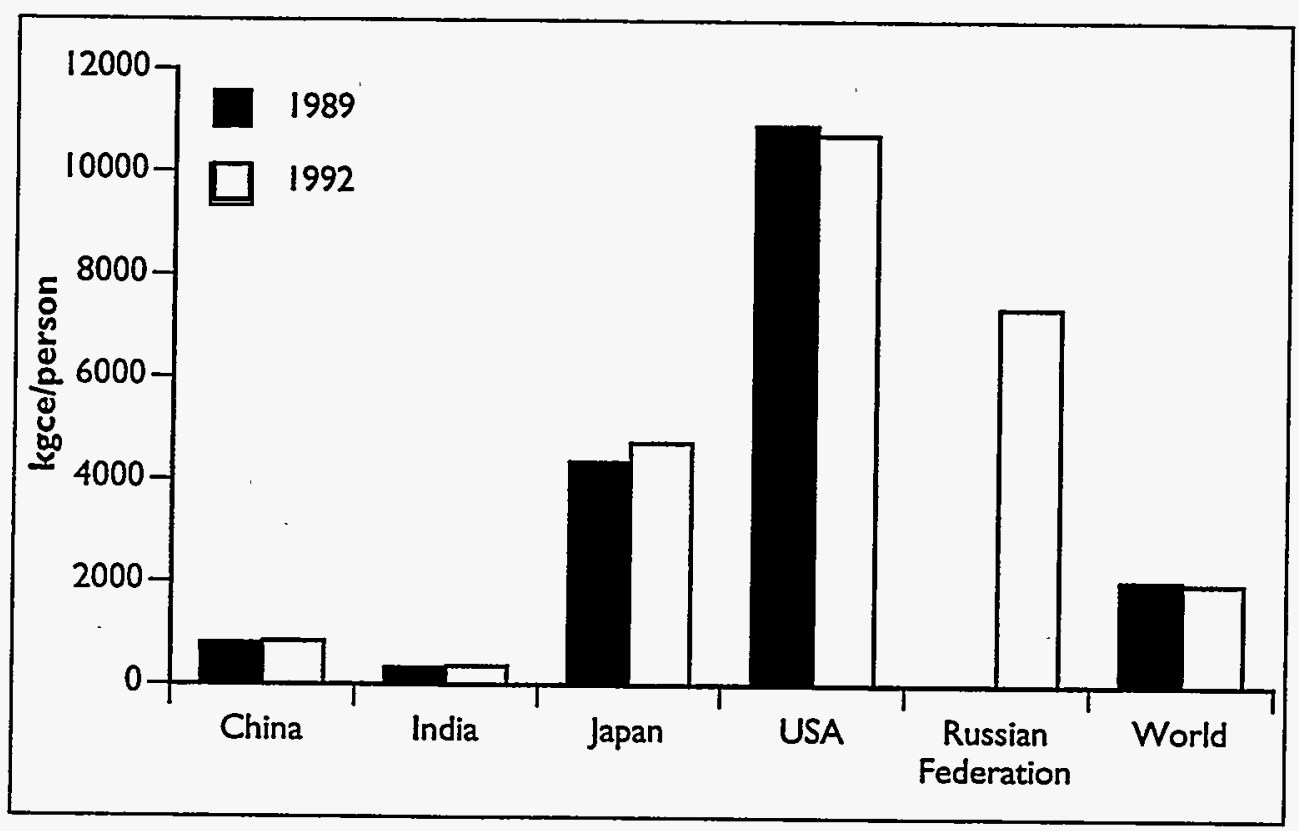


Table IX-3. World Primary Coal Consumption, Selected Years

\begin{tabular}{|lrrrr|}
\hline I. Mtce & & & & \\
& \multicolumn{1}{c}{} & & & \\
Country & 1970 & 1985 & 1990 & 1992 \\
\hline China & 237 & 583 & 752 & 826 \\
India* & 53 & 109 & 146 & 160 \\
Japan & 86 & 105 & 109 & 111 \\
USA & 471 & 629 & 688 & 679 \\
FSU & 420 & 461 & 440 & 379 \\
Rest of World & 887 & 1,073 & 1,065 & 993 \\
Totalt & 2,154 & 2,961 & 3,199 & 3,150 \\
& & & & \\
\hline
\end{tabular}

\begin{tabular}{|lrrrr|}
\hline 2. Shares & & & & \\
Country & 1970 & 1985 & 1990 & 1992 \\
\hline China & $11 \%$ & $20 \%$ & $24 \%$ & $26 \%$ \\
India* & $2 \%$ & $4 \%$ & $5 \%$ & $5 \%$ \\
Japain & $4 \%$ & $4 \%$ & $3 \%$ & $4 \%$ \\
USA & $22 \%$ & $21 \%$ & $21 \%$ & $22 \%$ \\
FSU & $19 \%$ & $16 \%$ & $14 \%$ & $12 \%$ \\
Rest of World & $41 \%$ & $36 \%$ & $33 \%$ & $32 \%$ \\
Totalt & $100 \%$ & $100 \%$ & $100 \%$ & $100 \%$ \\
& & & & \\
\hline
\end{tabular}

* The figure in the 1992 column represents actual 1991 consumption.

$\dagger$ World total is adjusted to reflect difference between British Petroleum and State Statistical Bureau figures for China's primary coal consumption.

Source: China — other tables in this volume; Others - British Petroleum, 1994. 
Figure IX-5. Coal Consumption Shares, Selected Countries

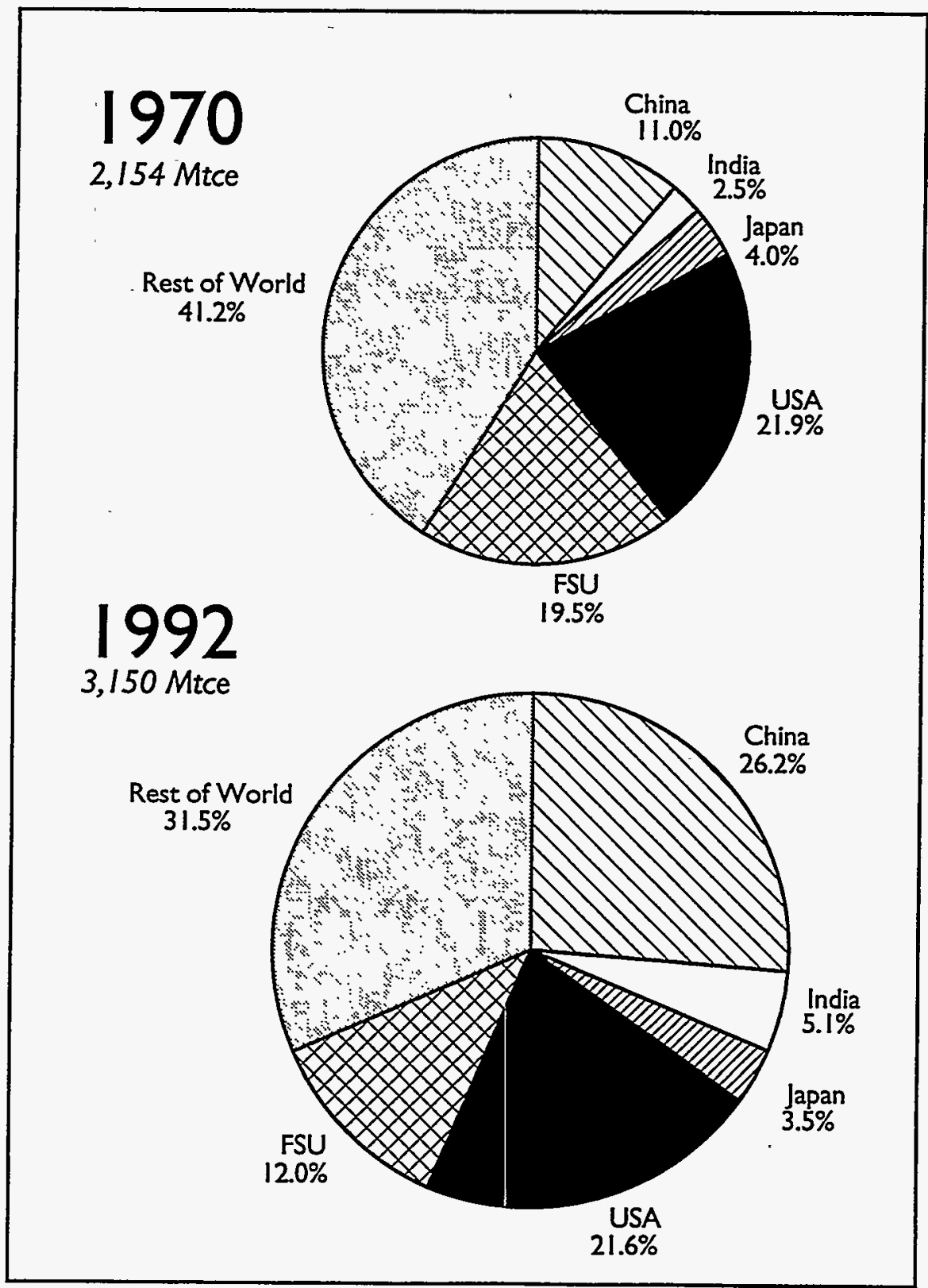


Table IX-4. Intensity Trends:

Primary Commercial Energy Consumption per Unit GDP, 1970-1993 *

\begin{tabular}{|c|c|c|c|c|c|}
\hline \multirow[t]{2}{*}{ 1. China } & \multirow{2}{*}{$\begin{array}{c}\text { Primary } \\
\text { Energy } \\
\text { Consumption } \\
\text { (million tce) }\end{array}$} & \multirow{2}{*}{$\begin{array}{c}\text { GDP } \\
\text { (billion } \\
1980 \text { yuan) }\end{array}$} & \multirow{2}{*}{$\begin{array}{l}\text { Intensity } \\
\text { (tce per } \\
\text { thousand } \\
1980 \text { yuan) }\end{array}$} & \multicolumn{2}{|c|}{ Intensity Indices } \\
\hline & & & & $1970=1$ & $1977=1$ \\
\hline 1970 & 291 & 262 & 1.11 & 1.00 & 0.74 \\
\hline 1971 & 344 & 280 & 1.23 & 1.10 & 0.82 \\
\hline 1972 & 371 & 289 & 1.29 & 1.16 & 0.86 \\
\hline 1973 & 389 & 313 & 1.24 & 1.12 & 0.83 \\
\hline 1974 & 399 & 316 & 1.26 & 1.14 & 0.85 \\
\hline 1975 & 453 & 342 & 1.32 & 1.19 & 0.89 \\
\hline 1976 & 476 & 324 & 1.47 & 1.33 & 0.99 \\
\hline 1977 & 522 & 349 & 1.49 & 1.35 & 1.00 \\
\hline 1978 & 570 & 393 & 1.45 & 1.31 & 0.97 \\
\hline 1979 & 585 & 420 & 1.39 & 1.25 & 0.93 \\
\hline 1980 & 603 & 447 & 1.35 & 1.21 & 0.90 \\
\hline 1981 & 594 & 469 & 1.27 & 1.14 & 0.85 \\
\hline 1982 & 621 & 508 & 1.22 & 1.10 & 0.82 \\
\hline 1983 & 662 & 558 & 1.19 & 1.07 & 0.79 \\
\hline 1984 & 711 & 640 & 1.11 & 1.00 & 0.74 \\
\hline 1985 & 768 & 722 & 1.06 & 0.96 & 0.71 \\
\hline 1986 & 810 & 783 & 1.03 & 0.93 & 0.69 \\
\hline 1987 & 869 & 870 & 1.00 & 0.90 & 0.67 \\
\hline 1988 & 931 & 968 & 0.96 & 0.87 & 0.64 \\
\hline 1989 & 971 & 1.010 & 0.96 & 0.87 & 0.64 \\
\hline 1990 & 986 & 1,050 & 0.94 & 0.85 & 0.63 \\
\hline 1991 & 1,036 & 1,134 & 0.91 & 0.82 & 0.61 \\
\hline 1992 & 1,088 & 1,288 & 0.85 & 0.76 & 0.57 \\
\hline 1993 & 1,113 & 1,460 & 0.76 & 0.69 & 0.51 \\
\hline
\end{tabular}

* No comparable series of data for the Former Soviet Union was available, which is therefore not included.

Source: China - China Statistical Yearbook, various years; China Energy Annual Review, 1994; India - LDC Energy Database, Intemational Energy Studies Group, EAP, LBNL, 1995; Japan - Energy Economics Institute of Japan, 1995; USA - Energy Information Administration, 1994; US Department of Commerce, 1994 
Table IX-4. Intensity Trends:

Primary Commercial Energy Consumption per Unit GDP, 1970-1993 * (continued)

\begin{tabular}{|c|c|c|c|c|c|}
\hline \multicolumn{6}{|c|}{ 2. India } \\
\hline \multirow[b]{2}{*}{ Year } & \multirow{2}{*}{$\begin{array}{c}\text { Primary } \\
\text { Energy } \\
\text { Consumption } \\
\text { (million tce) }\end{array}$} & \multirow{2}{*}{$\begin{array}{c}\text { GDP } \\
\text { (billion } \\
1980 \text { rupees) }\end{array}$} & \multirow{2}{*}{$\begin{array}{l}\text { Intensity } \\
\text { (tce per } \\
\text { thousand } \\
1980 \text { rupees) }\end{array}$} & \multicolumn{2}{|c|}{ Intensity Indices } \\
\hline & & & & $1970=1$ & $1977=1$ \\
\hline 1970 & 92 & 904 & 0.101 & 1.00 & 0.88 \\
\hline 1971 & 96 & 913 & 0.105 & 1.03 & 0.91 \\
\hline 1972 & 99 & 911 & 0.109 & 1.07 & 0.95 \\
\hline 1973 & 104 & 952 & 0.109 & 1.08 & 0.95 \\
\hline 1974 & III & 963 & 0.115 & 1.13 & 1.00 \\
\hline 1975 & 118 & 1,050 & 0.113 & 1.11 & 0.98 \\
\hline 1976 & 127 & 1,063 & 0.119 & 1.18 & 1.04 \\
\hline 1977 & 131 & 1,142 & 0.115 & 1.13 & 1.00 \\
\hline 1978 & 137 & 1,205 & 0.114 & 1.12 & 0.99 \\
\hline 1979 & 142 & 1.142 & 0.124 & 1.22 & 1.08 \\
\hline 1980 & 148 & 1,222 & 0.121 & 1.19 & 1.05 \\
\hline 1981 & 163 & 1.298 & 0.125 & 1.24 & 1.09 \\
\hline 1982 & 169 & 1,338 & 0.126 & 1.24 & 1.10 \\
\hline 1983 & 180 & 1,448 & 0.124 & 1.23 & 1.08 \\
\hline 1984 & 189 & 1,505 & 0.126 & 1.24 & 1.09 \\
\hline 1985 & 206 & 1,582 & 0.130 & 1.28 & 1.13 \\
\hline 1986 & 219 & 1,644 & 0.133 & 1.31 & 1.16 \\
\hline 1987 & 232 & 1,704 & 0.136 & 1.34 & 1.19 \\
\hline 1988 & 257 & 1,874 & 0.137 & 1.35 & 1.19 \\
\hline 1989 & 272 & 1.986 & 0.137 & 1.35 & 1.19 \\
\hline 1990 & 284 & 2,090 & 0.136 & 1.34 & 1.18 \\
\hline 1991 & 296 & 2,119 & 0.140 & 1.38 & 1.22 \\
\hline 1992 & - & - & - & - & - \\
\hline 1993 & - & - & - & - & - \\
\hline
\end{tabular}

- No comparable series of data for the Former Soviet Union was available, which is therefore not included.

Source: China - China Statistical Yearbook, various years; China Energy Annual Review, 1994; India —LDC Energy Database, International Energy Studies Group, EAP, LBNL, 1995; Japan - Energy Economics Institute of Japan, 1995; USA — Energy Information Administration, 1994; US Department of Commerce, 1994 
Table IX-4. Intensity Trends:

Primary Commercial Energy Consumption per Unit GDP, 1970-1993 * (continued)

\begin{tabular}{|c|c|c|c|c|c|}
\hline \multicolumn{6}{|c|}{ 3. Japan } \\
\hline \multirow[b]{2}{*}{ Year } & \multirow{2}{*}{$\begin{array}{c}\text { Primary } \\
\text { Energy } \\
\text { Consumption } \\
\text { (million tce) }\end{array}$} & \multirow{2}{*}{$\begin{array}{c}\text { GDP } \\
\text { (billion } \\
\text { I985 yen) }\end{array}$} & \multirow{2}{*}{$\begin{array}{l}\text { Intensity } \\
\text { (tce per } \\
\text { million } \\
1985 \text { yen) }\end{array}$} & Inten & y Indices \\
\hline & & & & $1970=1$ & $1977=I$ \\
\hline 1970 & 424 & 173,500 & 2.44 & 1.00 & 1.10 \\
\hline 1971 & 431 & 182,196 & 2.36 & 0.97 & 1.07 \\
\hline 1972 & 463 & 198,123 & 2.34 & 0.96 & 1.05 \\
\hline 1973 & 512 & 207,678 & 2.47 & 1.01 & 1.11 \\
\hline 1974 & 506 & 207,884 & 2.43 & 1.00 & 1.10 \\
\hline 1975 & 489 & 215,810 & 2.27 & 0.93 & 1.02 \\
\hline 1976 & 518 & 224,499 & 2.31 & 0.94 & 1.04 \\
\hline 1977 & 521 & 234,975 & 2.22 & 0.91 & 1.00 \\
\hline 1978 & 533 & 246,866 & 2.16 & 0.88 & 0.97 \\
\hline 1979 & 552 & 260,390 & 2.12 & 0.87 & 0.96 \\
\hline 1980 & 543 & 268,945 & 202 & 0.83 & 0.91 \\
\hline 1981 & 526 & 277.743 & 1.89 & 0.77 & 0.85 \\
\hline 1982 & 515 & 287,103 & 1.79 & 0.73 & 0.81 \\
\hline 1983 & 538 & 295,339 & 1.82 & 0.75 & 0.82 \\
\hline 1984 & 551 & 308,538 & 1.79 & 0.73 & 0.81 \\
\hline 1985 & 562 & 322,868 & 1.74 & 0.71 & 0.78 \\
\hline 1986 & 557 & 332,044 & 1.68 & 0.69 & 0.76 \\
\hline 1987 & 585 & 347,389 & 1.68 & 0.69 & 0.76 \\
\hline 1988 & 617 & 368,415 & 1.67 & 0.69 & 0.76 \\
\hline 1989 & 639 & 384,251 & 1.66 & 0.68 & 0.75 \\
\hline 1990 & 666 & 404,667 & 1.65 & 0.67 & $\overline{0.74}$ \\
\hline 1991 & 685 & 418,991 & 1.63 & 0.67 & 0.74 \\
\hline 1992 & 691 & 420,824 & 1.64 & 0.67 & 0.74 \\
\hline 1993 & 693 & 420,866 & 1.65 & 0.67 & 0.74 \\
\hline
\end{tabular}

- No comparable series of data for the Former Soviet Union was available, which is therefore not included.

Source: China - China Statistical Yearbook, various years; China Energy Annual Review, 1994; India - IDC Energy Database, International Energy Studies Group, EAP, LBNL, 1995; Japan - Energy Economics Institute of Japan, 1995; USA — Energy Information Administration, 1994; US Department of Commerce, 1994 
Table IX-4. Intensity Trends:

Primary Commercial Energy Consumption per Unit GDP, 1970-1993 * (continued)

\begin{tabular}{|c|c|c|c|c|c|}
\hline \multicolumn{6}{|c|}{ 4. United States } \\
\hline \multirow[b]{2}{*}{ Year } & \multirow{2}{*}{$\begin{array}{c}\text { Primary } \\
\text { Energy } \\
\text { Consumption } \\
\text { (million tce) }\end{array}$} & \multirow{2}{*}{$\begin{array}{c}\text { GDP } \\
\text { (billion } \\
1980 \text { dollars) }\end{array}$} & \multirow{2}{*}{$\begin{array}{l}\text { Intensity } \\
\text { (tce per } \\
\text { thousand } \\
\text { 1980 dollars) }\end{array}$} & Inten & y Indices \\
\hline & & & & $1970=1$ & $1977=1$ \\
\hline 1970 & 2393 & 1,865 & 1.28 & 1.00 & 1.07 \\
\hline 1971 & 2445 & 1,911 & 1.28 & 1.00 & 1.07 \\
\hline 1972 & 2567 & 2,011 & 1.28 & 0.99 & 1.06 \\
\hline 1973 & 2676 & 2,114 & 1.27 & 0.99 & 1.06 \\
\hline 1974 & 2613 & 2,102 & 1.24 & 0.97 & 1.04 \\
\hline 1975 & 2541 & 2,082 & 1.22 & 0.95 & 1.02 \\
\hline 1976 & 2678 & 2,184 & 1.23 & 0.96 & 1.02 \\
\hline 1977 & 2748 & 2,292 & 1.20 & 0.93 & 1.00 \\
\hline 1978 & 2813 & 2,423 & 1.16 & 0.90 & 0.97 \\
\hline 1979 & 2842 & 2,483 & 1.14 & 0.89 & 0.95 \\
\hline 1980 & 2736 & 2,477 & 1.10 & 0.86 & 0.92 \\
\hline 1981 & 2665 & 2,513 & 1.06 & 0.83 & 0.88 \\
\hline 1982 & 2552 & 2,454 & 1.04 & 0.81 & 0.87 \\
\hline 1983 & 2540 & 2,545 & 1.00 & 0.78 & 0.83 \\
\hline 1984 & 2671 & 2,718 & 0.98 & 0.77 & 0.82 \\
\hline 1985 & 2665 & 2,814 & 0.95 & 0.74 & 0.79 \\
\hline 1986 & 2676 & 2,903 & 0.92 & 0.72 & 0.77 \\
\hline 1987 & 2770 & 3,022 & 0.92 & 0.71 & 0.76 \\
\hline 1988 & 2890 & 3,158 & 0.91 & 0.71 & 0.76 \\
\hline 1989 & 2930 & 3,238 & 0.90 & 0.71 & 0.75 \\
\hline 1990 & 2927 & 3,278 & 0.89 & 0.70 & 0.74 \\
\hline 1991 & 2922 & 3,254 & 0.90 & 0.70 & 0.75 \\
\hline 1992 & 2959 & 3,337 & 0.89 & 0.69 & 0.74 \\
\hline 1993 & 3024 & 3,437 & 0.88 & 0.69 & 0.73 \\
\hline
\end{tabular}

* No comparable series of data for the Former Soviet Union was available, which is therefore not included.

Source: China - China Statistical Yearbook, various years; China Energy Annual Review, 1994; India -LDC Energy Database, Intemational Energy Studies Group, EAP, LBNL, 1995; Japan - Energy Economics Institute of Japan, 1995; USA — Energy Information Administration, 1994; US Department of Commerce, 1994 
Figure IX-6. Energy Intensity Trends, Selected Countries
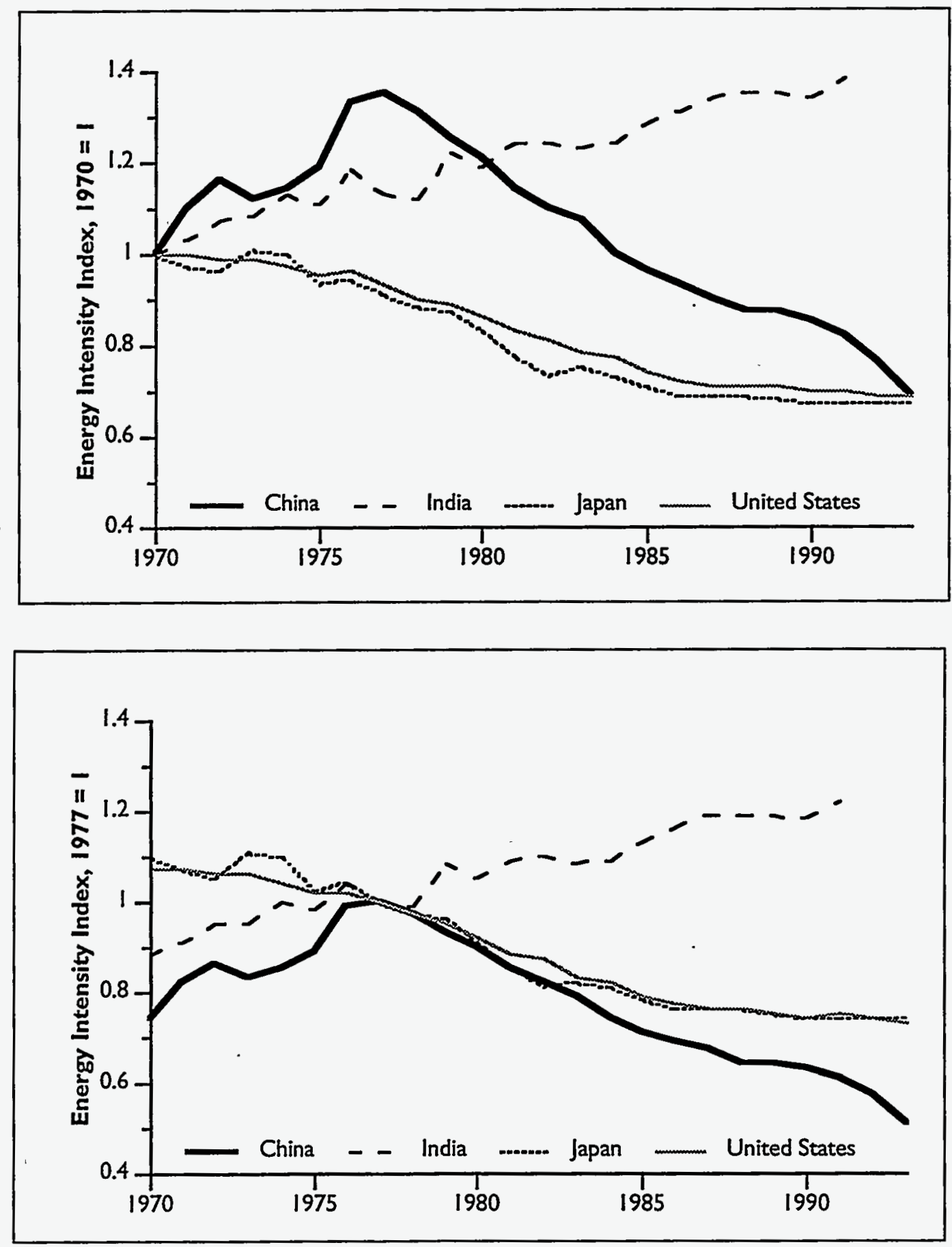
Table IX-5. Total Energy Consumption by Sector for Selected Countries, 1992

\begin{tabular}{|lcccccc|}
\hline I. Commercial Energy Only, Mtce & & & \\
Country & Industry & Agriculture & Transportation & $\begin{array}{c}\text { Residential \& } \\
\text { Commercial }\end{array}$ & Total \\
\hline China & 545 & 30 & 75 & 165 & 815 \\
India & 96 & 8 & 43 & 25 & 172 \\
Japan & 210 & 17 & 114 & 123 & 464 \\
USA & 844 & - & 809 & 580 & 2,233 \\
FSU * & 648 & 80 & 269 & 416 & 1,414 \\
\hline
\end{tabular}

\begin{tabular}{|lcccccc|}
\hline 2. Commercial Energy Only, Shares & & & \\
Country & Industry & Agriculture & Transportation & $\begin{array}{c}\text { Residential \& } \\
\text { Commercial }\end{array}$ & Total \\
\hline China & $67 \%$ & $4 \%$ & $9 \%$ & $20 \%$ & $100 \%$ \\
India & $56 \%$ & $-5 \%$ & $25 \%$ & $14 \%$ & $100 \%$ \\
Japan & $45 \%$ & $4 \%$ & $24 \%$ & $27 \%$ & $100 \%$ \\
USA & $38 \%$ & - & $36 \%$ & $26 \%$ & $100 \%$ \\
FSU * & $46 \%$ & $6 \%$ & $19 \%$ & $29 \%$ & $100 \%$ \\
\hline
\end{tabular}

\begin{tabular}{|lcccccc|}
\hline 3. Commercial and Biomass Energy, Mtce $\dagger$ \\
Country & Industry & Agriculture & Transportation & $\begin{array}{c}\text { Residential \& } \\
\text { Commercial }\end{array}$ & Total \\
\hline China & 664 & 45 & 79 & 422 & 1,210 \\
India & 109 & 9 & 45 & 180 & 342 \\
Japan & 210 & 17 & 114 & 123 & 464 \\
USA & 844 & - & 809 & 684 & 2,338 \\
FSU * & 608 & 81 & 269 & 348 & 1,305 \\
\hline
\end{tabular}

\begin{tabular}{|lcccccc|}
\hline 4. Commercial and Biomass Energy, Shares $\dagger$ & & & \\
Country & Industry & Agriculture & Transportation & $\begin{array}{r}\text { Residential \& } \\
\text { Commercial }\end{array}$ & Total \\
\hline China & $54.9 \%$ & $3.7 \%$ & $6.5 \%$ & $34.9 \%$ & $100.0 \%$ \\
India & $31.7 \%$ & $2.5 \%$ & $13.1 \%$ & $52.7 \%$ & $100.0 \%$ \\
Japan & $45.3 \%$ & $3.7 \%$ & $24.5 \%$ & $26.6 \%$ & $100.0 \%$ \\
USA & $36.1 \%$ & - & $34.6 \%$ & $29.3 \%$ & $100.0 \%$ \\
FSU * & $46.6 \%$ & $6.2 \%$ & $20.6 \%$ & $26.6 \%$ & $100.0 \%$ \\
\hline
\end{tabular}

N.B. Electricity is converted at its end-use value $(1 \mathrm{kWh}=0.123 \mathrm{kgce})$.

* Residential sector use includes municipal sector use for the Former Soviet Union.

$\dagger$ Biomass figures for India and the USA are for 1988. No biomass data available for Japan and the FSU.

Source: China - other tables in this volume; India - Tata Energy Research Institute, 1994; LDC Energy Database, Intemational Energy Studies Group, EAP, LBNL, 1995; Japan — Energy Economics Institute of Japan, 1994; USA — Energy Information Administration, 1994; FSU —-Intemational Energy Studies Group, EAP, LBNL, 1995. 
Figure IX-7. Sectoral Shares of Energy End Use, Commercial Energy Only, 1992

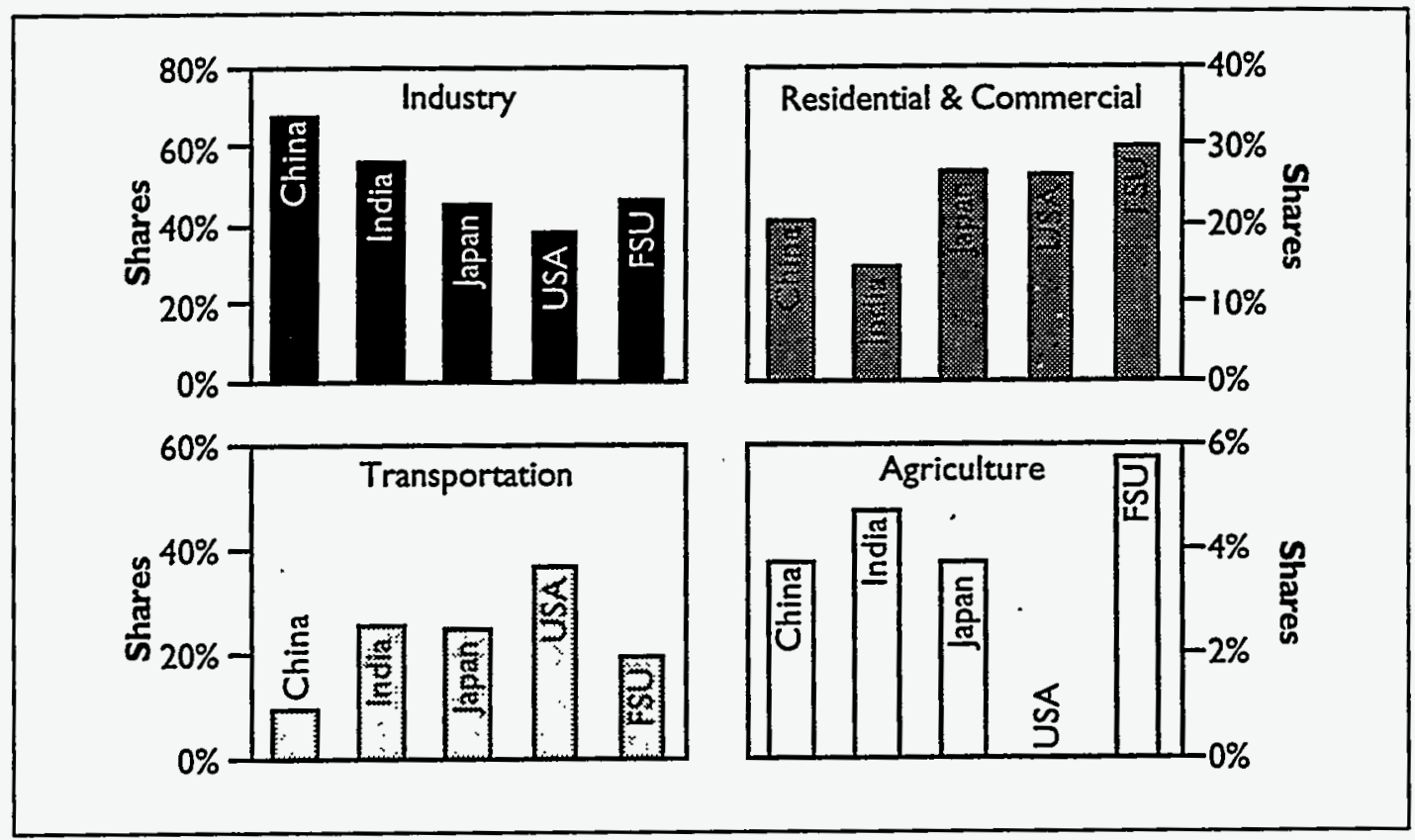

Figure IX-8. Sectoral Shares of Energy End Use, Commercial and Biomass Energy *

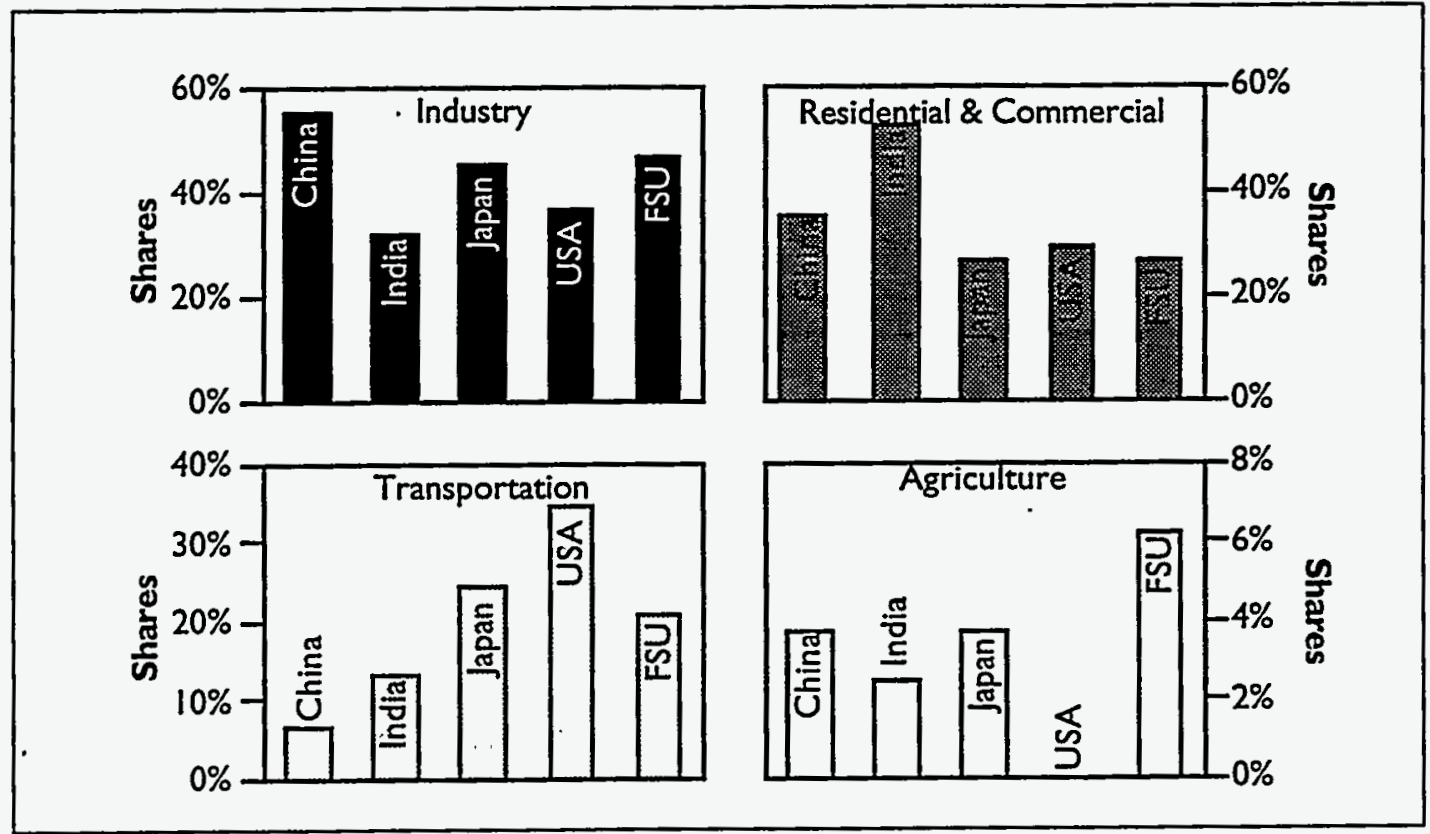

* Biomass consumption figures for India and the USA are for 1988. 
Table IX-6. Industrial * Energy Consumption by Source, 1992

\begin{tabular}{|lrrrrrrr|}
\hline I. Mtce & & & & & & \\
Country & Solid & Liquid & Gas & Electricity & Heat $\mathbb{T}$ & Total \\
\hline China & 354.8 & 75.8 & 18.0 & 52.0 & 44.5 & 545.0 \\
India & 71.0 & 14.4 & 0.9 & 10.8 & - & 97.0 \\
Japan & 55.1 & 96.6 & 8.1 & 50.7 & 0.4 & 210.9 \\
USA & 90.4 & 311.2 & 323.1 & 119.6 & - & 844.3 \\
FSU† & 122.0 & 83.4 & 114.0 & 101.0 & 228.1 & 648.5 \\
& & & & & & & \\
\hline
\end{tabular}

\begin{tabular}{|lrlrrrrr|}
\hline 2. Shares & & & & & & \\
Country & Solid & Liquid & Gas & Electricity & . & Heat T & Total \\
\hline China & $65.1 \%$ & $13.9 \%$ & $3.3 \%$ & $9.5 \%$ & $8.2 \%$ & $100.0 \%$ \\
India & $73.1 \%$ & $14.9 \%$ & $0.9 \%$ & $11.1 \%$ & - & $100.0 \%$ \\
Japan & $26.1 \%$ & $45.8 \%$ & $3.9 \%$ & $24.0 \%$ & $<0.1 \%$ & $100.0 \%$ \\
USA & $10.7 \%$ & $36.9 \%$ & $38.3 \%$ & $14.2 \%$ & & - \\
FSU广 & $18.8 \%$ & $12.9 \%$ & $17.6 \%$ & $15.6 \%$ & $35.2 \%$ & $100.0 \%$ \\
& & & & & & & \\
\hline
\end{tabular}

* Industrial sector includes construction for the China and the FSU.

1990 data.

I Heat includes the energy value in end use of process steam and other heat sources. Figure for China includes about $12 \mathrm{Mtce}$ of coal gas and other miscellaneous fuels.

Source: China - other tables in this volume; India - Tata Energy Research Institute, 1994; LDC Energy Database, Intemational Energy Studies Group, EAP, LBNL, 1995; Japan - Energy Economics Institute of Japan, 1994; USA — Energy Information Administration, 1994; FSU - Intemational Energy Studies Group, EAP, LBNL 1995. 
Figure IX-9. Shares of Total Industrial Sector

Energy End Use by Energy Source, 1992

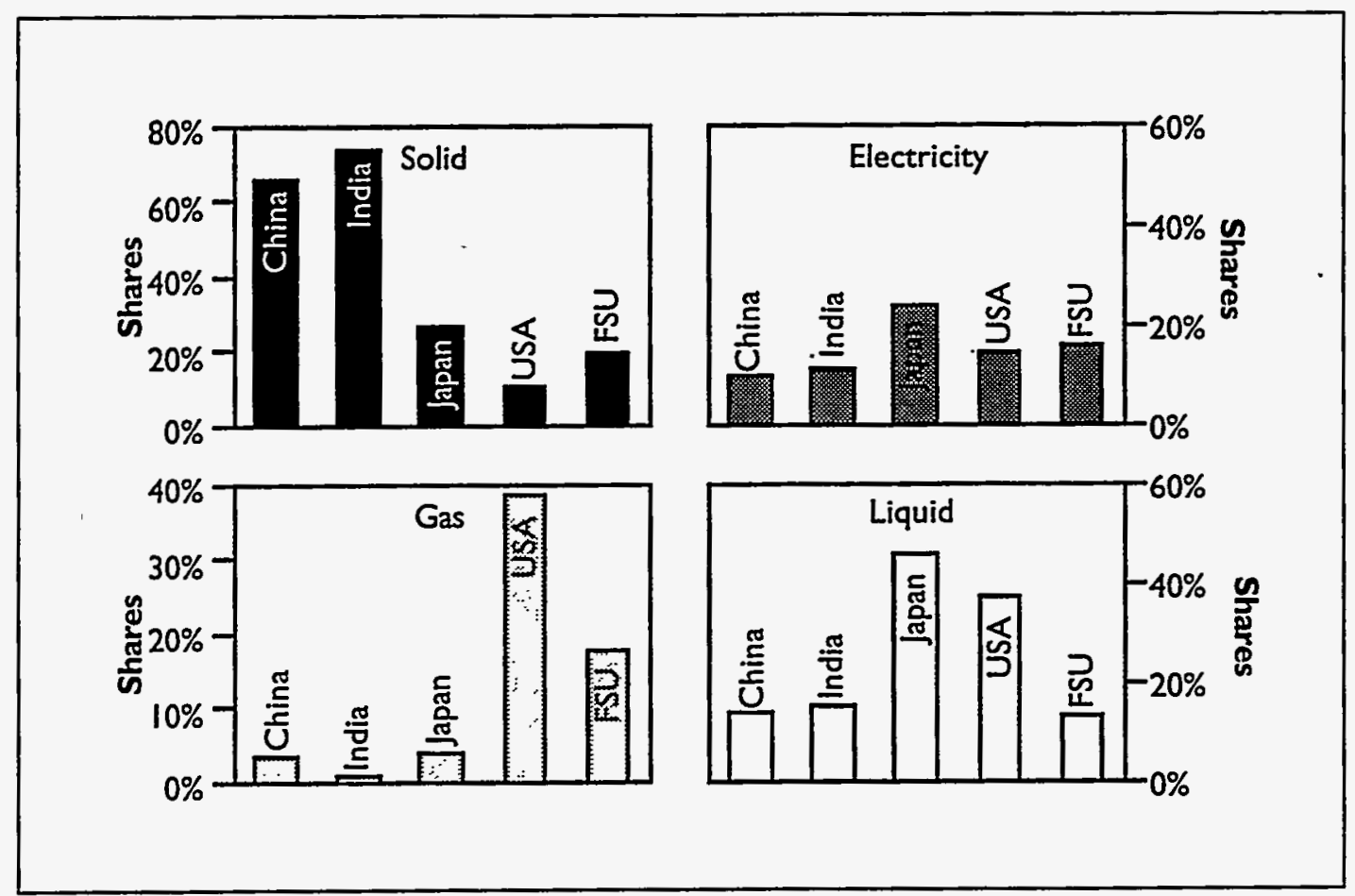


Table IX-7. Transportation Energy Consumption by Source, 1992

\begin{tabular}{|lcccccc|}
\hline I. Mtce & & & & & \\
& & & & & \\
Country & Solid & Liquid & Gas * & Electricity & Total \\
\hline China & 13.4 & 60.2 & 0.2 & 1.7 & 75.4 \\
India & 2.9 & 39.2 & - & 0.6 & 42.7 \\
Japan & - & 111.0 & - & 2.5 & 113.5 \\
USA & -5 & 785.6 & 21.3 & 1.4 & 809.0 \\
FSU & 7.3 & 170.9 & 73.9 & 16.5 & 268.6 \\
& & & & & & \\
\hline
\end{tabular}

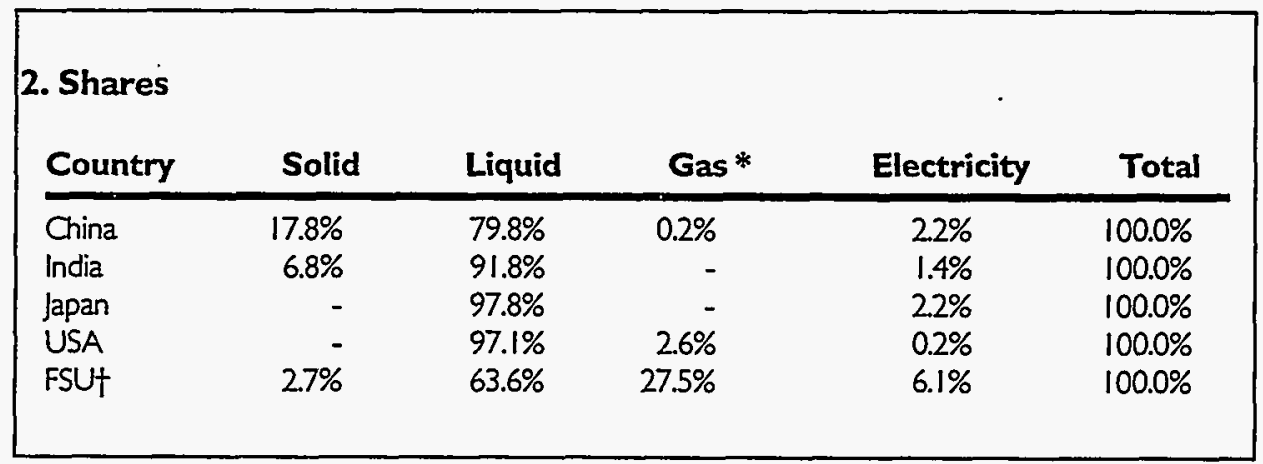

* Mainly pipeline use.

$\dagger 1990$ data. Coal figure includes heat consumption

Source: China - other tables in this volume; India - Tata Energy Research Institute, 1994; Japan -Energy Economics Institute of Japan, 1994; USA — Energy Information Administration, 1994; FSU -International Energy Studies Group, EAP, LBNL, 1995 
Figure DX-10. Energy Use in Transportation, Selected Countries, 1992

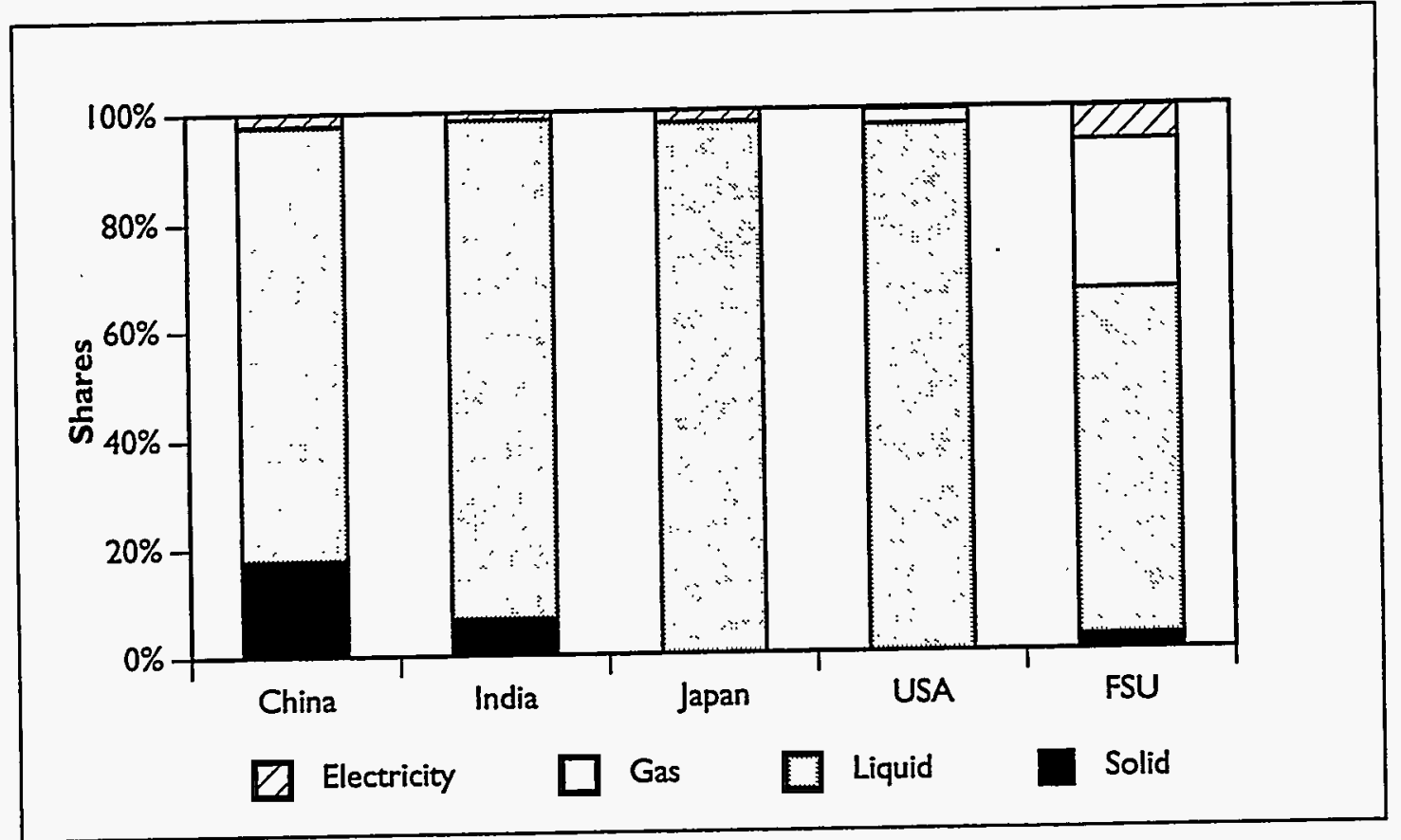


Table IX-8. Residential and Commercial End Use Energy Consumption by Source, 1992

\begin{tabular}{|c|c|c|c|c|c|c|c|}
\hline $\begin{array}{l}\text { I. Mtce } \\
\text { Country }\end{array}$ & Coal & Liquid & Gas & Heat II & Electricity & Biomass & Total \\
\hline $\begin{array}{l}\text { China } \\
\text { India* } \\
\text { Japan } \\
\text { USA } \\
\text { FSUY }\end{array}$ & $\begin{array}{r}105.6 \\
2.2 \\
1.0 \\
5.0 \\
93.7\end{array}$ & $\begin{array}{r}5.4 \\
17.2 \\
54.9 \\
76.7 \\
44.0\end{array}$ & $\begin{array}{r}6.0 \\
0.1 \\
17.6 \\
278.4 \\
78.4\end{array}$ & $\begin{array}{r}3.9 \\
- \\
- \\
- \\
154.6\end{array}$ & $\begin{array}{r}7.9 \\
7.0 \\
49.5 \\
219.7 \\
45.8\end{array}$ & $\begin{array}{r}245.8 \\
161.0 \\
- \\
23.2 \\
-\end{array}$ & $\begin{array}{l}374.5 \\
187.6 \\
123.1 \\
603.2 \\
416.4\end{array}$ \\
\hline
\end{tabular}

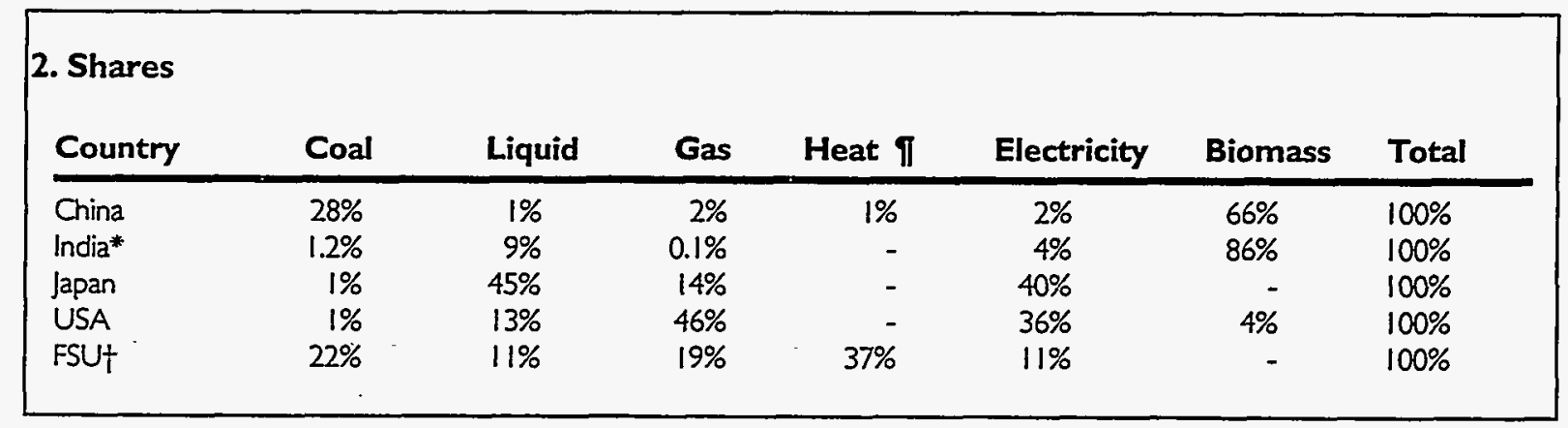

* India's coal consumption figure is for 1989.

$\dagger 1990$ data.

I Heat includes the energy value in end use of process steam and other heat sources.

Source: China - other tables in this volume; India - Tata Energy Research Institute, 1994; LDC Energy Database, Intemational Energy Studies Group, EAP, LBNL, 1995; Japan - Energy Economics Institute of Japan, 1994; USA - Energy Information Administration, 1994; FSU - International Energy Studies Group, EAP, IBNL, 1995. 
Figure IX-11. Residential and Commercial Energy Use Selected Countries, 1992

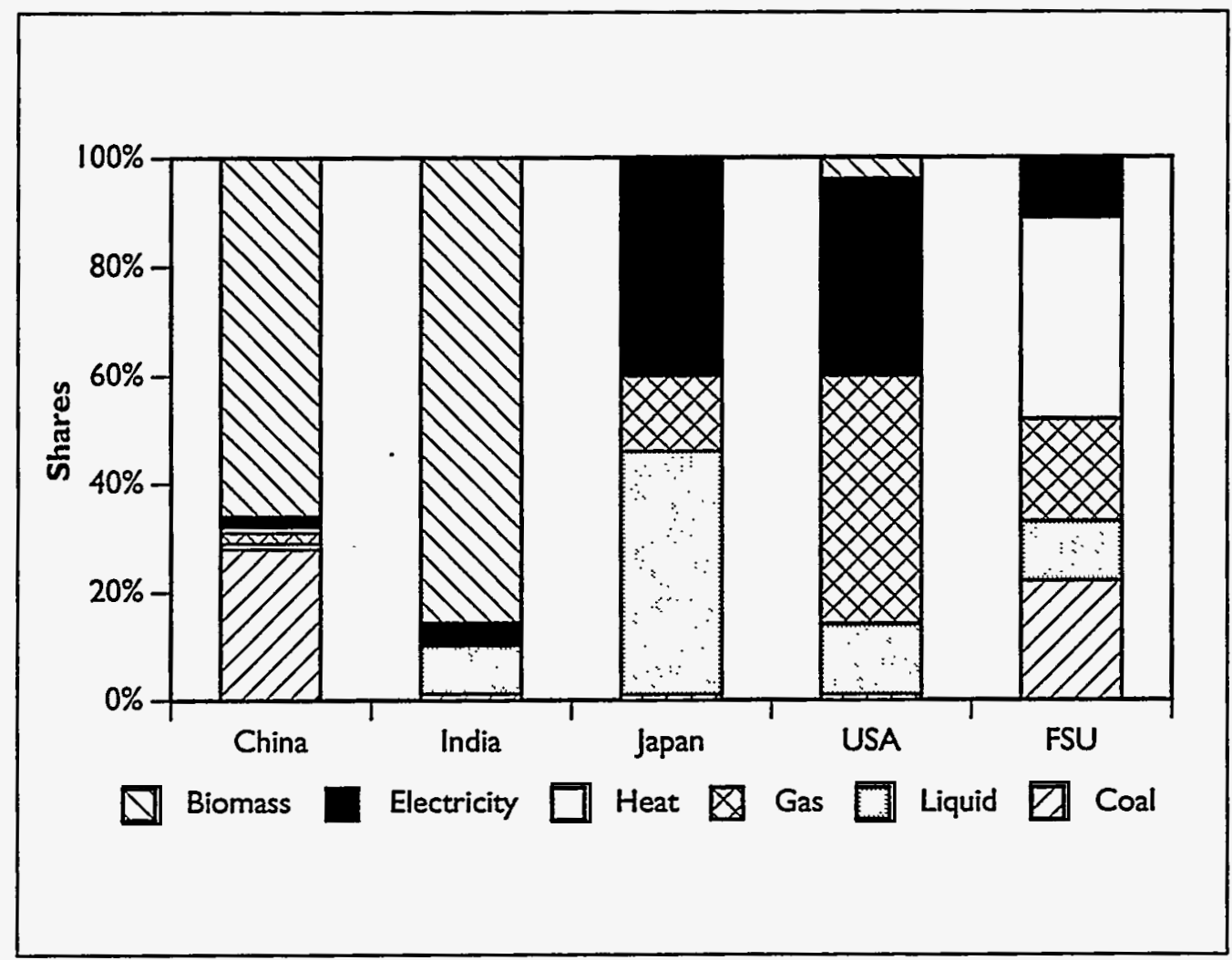


Table IX-9. End Use Energy Consumption by Source, 1992

\begin{tabular}{|c|c|c|c|c|c|c|}
\hline \multicolumn{7}{|l|}{ I. Mtce } \\
\hline Country & Solid & Liquid & Gas & $\begin{array}{l}\text { Delivered } \\
\text { Electricity }\end{array}$ & Heat II & Total \\
\hline China & 508 & 158 & 34 & 73 & 52 & 825 \\
\hline India & 74 & 71 & 1 & 25 & - & 171 \\
\hline Japan & 56 & 279 & 26 & 103 & 0 & 464 \\
\hline USA* & 95 & 1,174 & 602 & 339 & - & 2,233 \\
\hline FSU & 219 & 341 & 269 & 182 & 403 & 1,414 \\
\hline
\end{tabular}

\begin{tabular}{|c|c|c|c|c|c|c|}
\hline \multicolumn{7}{|l|}{ 2. Shares } \\
\hline Country & Solid & Liquid & Gas & $\begin{array}{l}\text { Delivered } \\
\text { Electricity }\end{array}$ & Heat ๆ & Tota \\
\hline China & $61.6 \%$ & $19.2 \%$ & $4.1 \%$ & $8.8 \%$ & $6.3 \%$ & $100.0 \%$ \\
\hline India & $43.1 \%$ & $41.4 \%$ & $0.7 \%$ & $14.9 \%$ & - & $100.0 \%$ \\
\hline Japan & $12.1 \%$ & $60.1 \%$ & $5.6 \%$ & $222 \%$ & $<0.1 \%$ & $100.0 \%$ \\
\hline USA & $4.3 \%$ & $52.5 \%$ & $26.9 \%$ & $15.2 \%$ & - & $100.0 \%$ \\
\hline FSUt & $15.5 \%$ & $24.1 \%$ & $19.0 \%$ & $12.9 \%$ & $28.5 \%$ & $100.0 \%$ \\
\hline
\end{tabular}

* Total is slightly larger than sum of categories because of a small amount of unallocated energy use in the transport sector. † 1990 data.

I Heat includes the energy value in end use of process and other steam, mainly from cogenerators and district heating providers. Figure for China includes about $30 \mathrm{Mtce}$ of coal gas and other fuels.

Source: China - other tables in this volume; India - Tata Energy Research Institute, 1994; LDC Energy Database, International Energy Studies Group, EAP, LBNL, 1995; Japan - Energy Economics Institute of Japan, 1994; USA - Energy Information Administration, 1994; FSU — International Energy Studies Group, EAP, LBNL, 1995; British Petroleum, 1994. 
Figure IX-12. Shares of End Use Energy Consumption

by Energy Source, Selected Countries, 1992

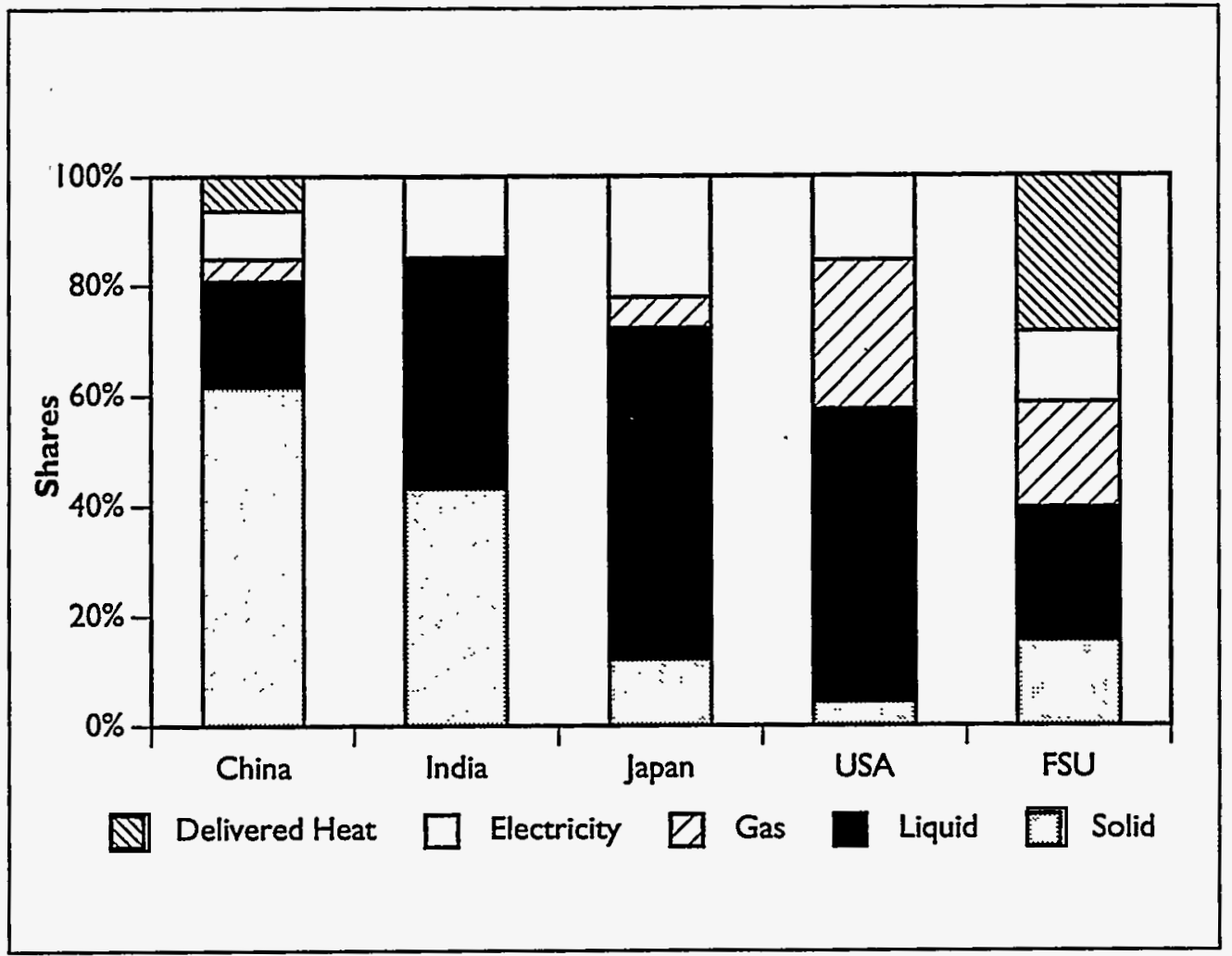


Table LX-10. Solid Fuel Consumption by Sector, 1992

\begin{tabular}{|lcccccc|}
\hline I. Mtce & \multicolumn{7}{c|}{$\begin{array}{c}\text { Residential \& } \\
\text { Country }\end{array}$} & Utilities & Industry $\pi$ & Commercial & Other § & Total \\
\hline China & 272.5 & 358.3 & 112.4 & 40.2 & 783.4 \\
India * & 88.9 & 71.0 & 2.2 & 3.2 & 165.2 \\
Japan & 32.4 & 84.8 & 0.1 & - & 117.2 \\
USA & 545.9 & 74.5 & 4.3 & - & 624.8 \\
FSU + & 156.3 & 122.0 & 88.5 & 8.7 & 375.6 \\
\hline
\end{tabular}

\begin{tabular}{|lllllll|}
\hline 2. Shares & \multicolumn{7}{c|}{ Residential \& } \\
Country & Utilities & Industry I & $\begin{array}{c}\text { Commercial } \\
\text { Comer } \$\end{array}$ & Total \\
\hline China & $34.8 \%$ & $45.7 \%$ & $14.3 \%$ & $5.1 \%$ & $100.0 \%$ \\
India* & $53.8 \%$ & $42.9 \%$ & $1.3 \%$ & $1.9 \%$ & $100.0 \%$ \\
Japan & $27.6 \%$ & $72.3 \%$ & $0.0 \%$ &.- & $100.0 \%$ \\
USA & $87.4 \%$ & $11.9 \%$ & $0.7 \%$ & - & $100.0 \%$ \\
FSU† & $41.6 \%$ & $32.5 \%$ & $23.6 \%$ & $2.3 \%$ & $100.0 \%$ \\
\hline
\end{tabular}

\begin{tabular}{|lcccc|}
\hline 3. Utility coal consumption allocated to end-use sectors $¥$, Mtce \\
Country & Industry T & Commercial & $\begin{array}{c}\text { Residential \& } \\
\text { Other § }\end{array}$ & Total \\
\hline China & 553.5 & 159.4 & 70.6 & 783.4 \\
India* & 108.5 & 26.6 & 30.1 & 165.2 \\
Japan & 100.4 & 15.9 & 1.0 & 117.2 \\
USA & 266.7 & 339.6 & 18.4 & 624.8 \\
FSU† & 208.7 & 127.8 & 39.1 & 375.6 \\
\hline
\end{tabular}

\begin{tabular}{|lcccc|}
\hline 4. Utility coal consumption allocated to end-use sectors, \\
₹ Shares \\
Country & Industry I & $\begin{array}{c}\text { Residential \& } \\
\text { Commercial }\end{array}$ & Other $\$$ & Total \\
\hline China & $70.6 \%$ & $20.3 \%$ & $9.0 \%$ & $100.0 \%$ \\
India* & $65.7 \%$ & $16.1 \%$ & $18.2 \%$ & $100.0 \%$ \\
Japan & $85.6 \%$ & $13.6 \%$ & $0.8 \%$ & $100.0 \%$ \\
USA - & $42.7 \%$ & $54.4 \%$ & $2.9 \%$ & $100.0 \%$ \\
FSUt & $55.6 \%$ & $34.0 \%$ & $10.4 \%$ & $100.0 \%$ \\
\hline
\end{tabular}

* India's residential coal use is for 1989.

† 1990 data.

I Industrial coal includes coal used for making coke, or coke. China's industrial coal use includes feedstock. All washing losses excluded.

$\S$ "Other" includes transportation and agricultural use.

Utility sector coal use is allocated among end use sectors according to electricity end use shares.

Source: China - other tables in this volume; India - Tata Energy Research Institute, 1994; LDC Energy Database, International Energy Studies Group, EAP, LBNL, 1995; Japan — Energy Economics Institute of Japan, 1994; USA - Energy Information Administration, 1994; FSU — International Energy Studies Group, EAP, LBNL, 1995; British Petroleum, 1994. 
Figure IX-13. Sectoral Shares of Coal Consumption, * 1992

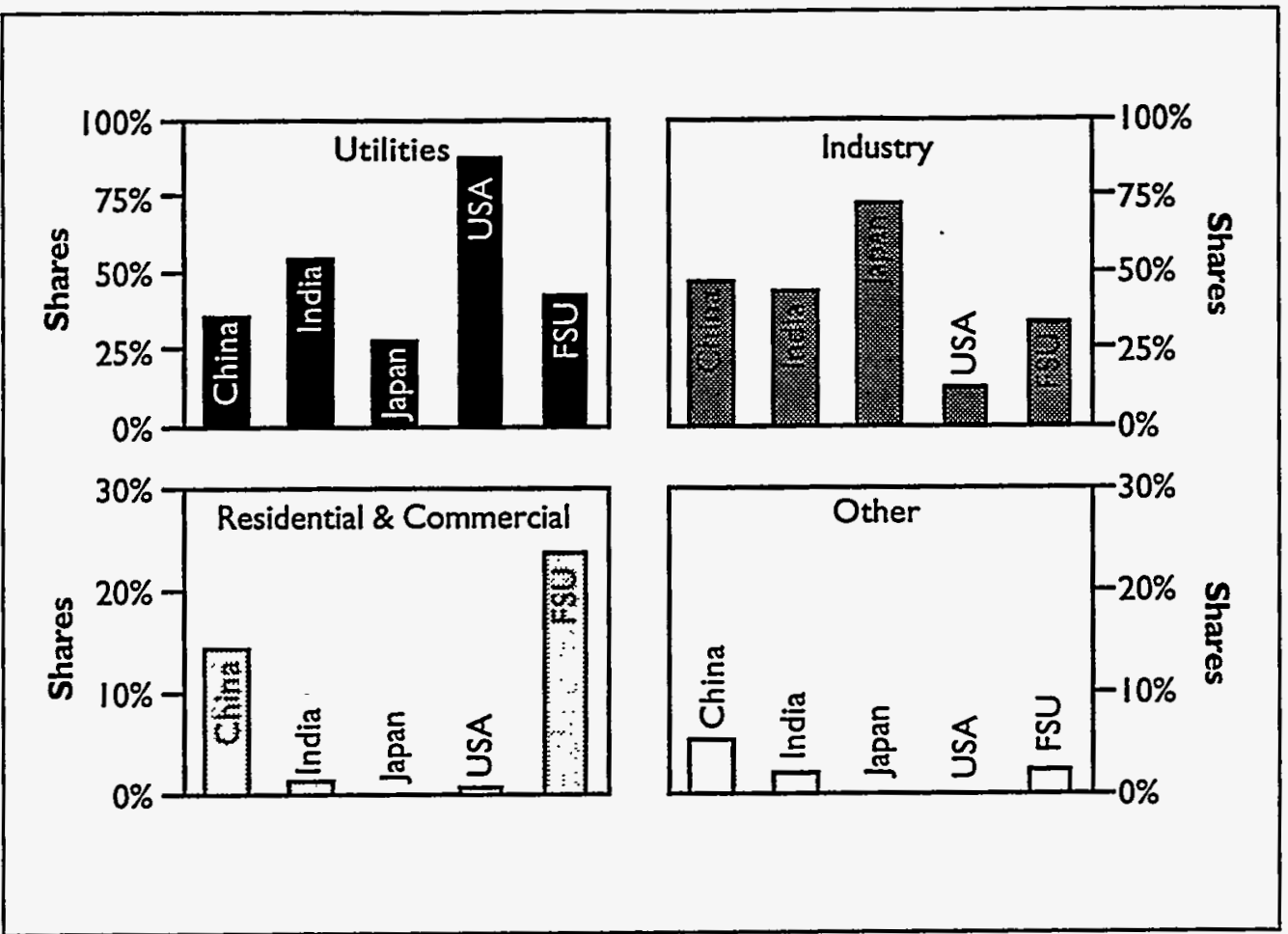

* Coal consumed in other sectors (transportation and agriculture) is not shown here. See Table IX-10.

Figure IX-14. Sectoral Shares of Coal Consumption, 1992: Power Generation Coal Consumption Allocated to End-Use Sectors*

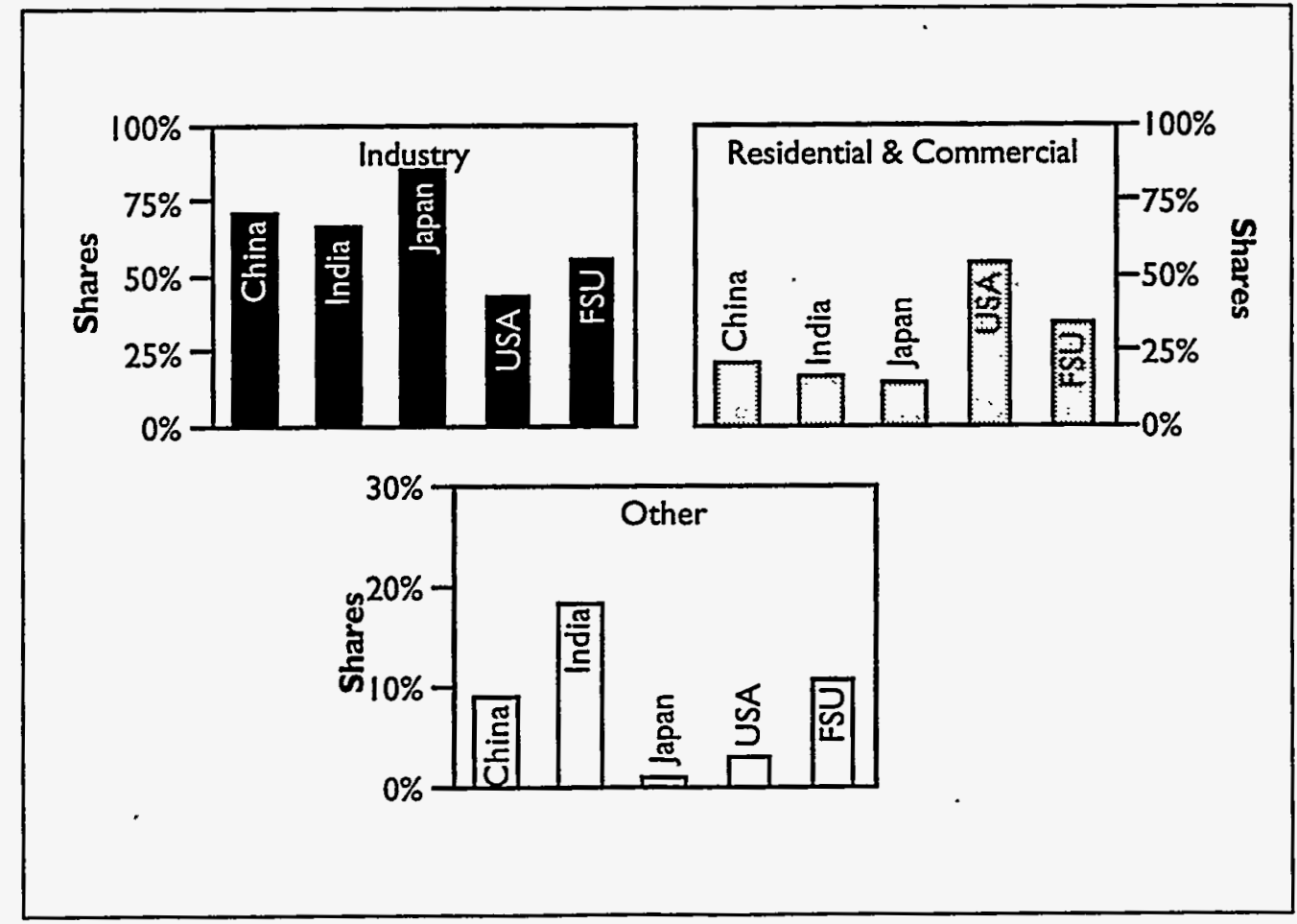

*See Table IX-10 for details. 
Table IX-11. Petroleum Products Consumption by Sector, 1992

\begin{tabular}{|lccccccr|}
\hline I. Mtce & & & & & $\ldots$ & \\
Country & Utilities & Industry & Transportation & $\begin{array}{c}\text { Residential \& } \\
\text { Commercial }\end{array}$ & Agriculture & Total \\
\hline China & 23.5 & 46.4 & 58.8 & 14.0 & 10.5 & 153.3 \\
India & 3.7 & 14.1 & 38.4 & 16.0 & 0.9 & 73.1 \\
Japan & 77.4 & 96.6 & 111.0 & 54.9 & 16.5 & 356.4 \\
USA & 34.2 & 311.2 & 785.6 & 76.7 & - & $1,207.8$ \\
FSU* & 99.4 & 83.1 & 170.9 & 44.0 & 42.6 & 440.0 \\
& & & & & & & \\
\hline
\end{tabular}

\begin{tabular}{|lccccccc|}
\hline 2. Shares & & & & & & \\
Country & Utilities & Industry t & Transportation & $\begin{array}{c}\text { Residential \& } \\
\text { Commercial }\end{array}$ & Agriculture & Total \\
\hline China & $15.4 \%$ & $30.3 \%$ & $38.4 \%$ & $9.2 \%$ & $6.8 \%$ & $100.0 \%$ \\
India & $5.1 \%$ & $19.3 \%$ & $52.5 \%$ & $21.9 \%$ & $1.2 \%$ & $100.0 \%$ \\
Japan & $21.7 \%$ & $27.1 \%$ & $31.1 \%$ & $15.4 \%$ &. & $4.6 \%$ & $100.0 \%$ \\
USA & $2.8 \%$ & $25.8 \%$ & $65.0 \%$ & $6.4 \%$ & - & $100.0 \%$ \\
FSU* & $22.6 \%$ & $18.9 \%$ & $38.8 \%$ & $10.0 \%$ & $9.7 \%$ & $100.0 \%$ \\
\hline
\end{tabular}

* 1990 data. The FSU's residential and commercial sector includes unallocated other energy use.

$\dagger$ Excludes feedstocks. Data for China and FSU include construction.

Source: China - other tables in this volume; India - Tata Energy Research Institute, 1994; LDC Energy Database, International Energy Studies Group, EAP, LBNL, 1995; Japan - Energy Economics Institute of Japan, 1994; USA - Energy Information Administration, 1994; FSU - International Energy Studies Group, EAP, LBNL, 1995 
Figure IX-15. Sectoral Shares of Petroleum Consumption Selected Countries, 1992

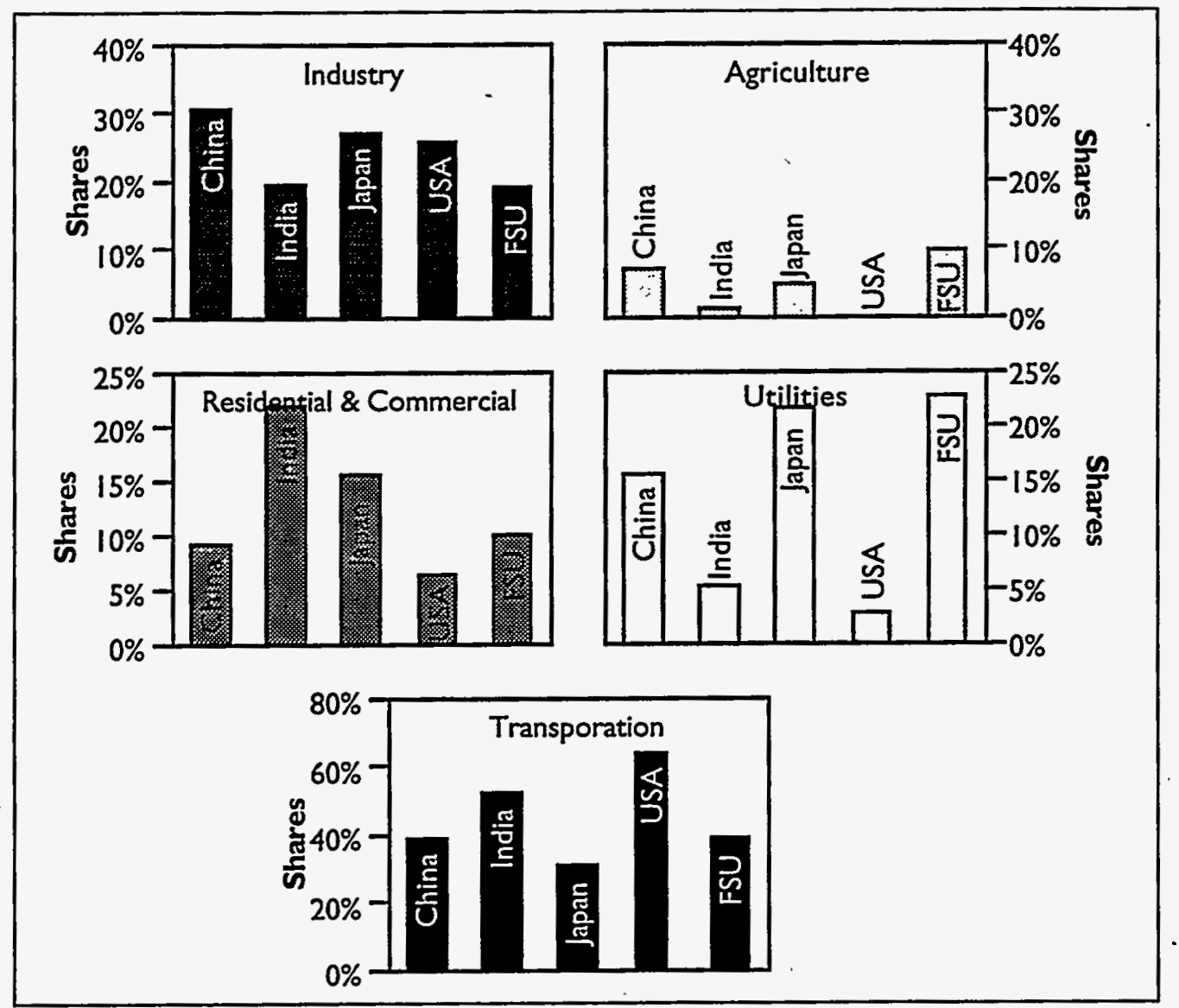


Table IX-12. End Use Electricity Consumption by Sector, 1992

\begin{tabular}{|lccccccc|}
\hline 1. TWh & \multicolumn{7}{c|}{} \\
Country & Industry $t$ & Residential & $\begin{array}{c}\text { Commercial } \\
\text { \& Other }\end{array}$ & Transportation & Agriculture & Total \\
\hline China & 422.73 & 64.00 & 37.78 & 13.61 & 52.24 & 590.36 \\
India & 87.77 & 35.58 & 21.35 & 4.74 & 58.12 & 207.57 \\
Japan & 378.01 & 204.67 & 180.81 & 20.70 & 3.30 & 787.49 \\
USA & 973.00 & 936.00 & 761.00 & 93.00 & - & $2,763.00$ \\
FSU* & 821.94 & 110.28 & 262.50 & 134.17 & 153.61 & $1,482.50$ \\
& & & & & & \\
\hline
\end{tabular}

\section{Shares}

\footnotetext{
* 1990 data.

$\uparrow$ China and FSu include construction.
}

Source: China - other tables in this volume; India - Tata Energy Research Institute, 1994; IDC Energy Database International Energy Studies Group, EAP, LBNL, 1995; Japan - Energy Economics Institute of Japan, 1994; USA — Energy Information Administration, 1994; FSU - International Energy Studies Group, EAP, LBNL, 1995. 
Figure IX-16. Sectoral Shares of Electricity Consumption Selected Countries, 1992

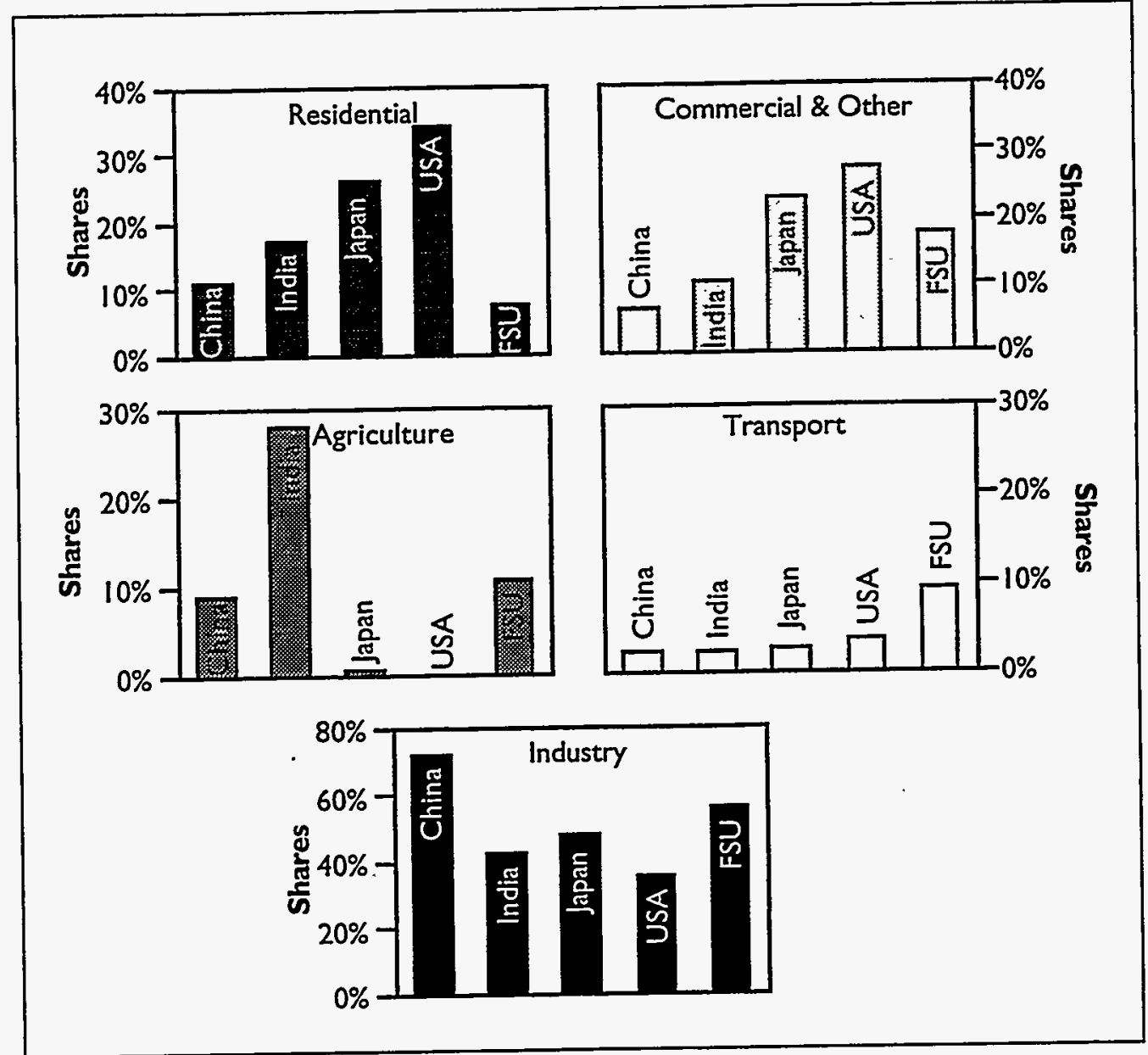


Table IX-13. Crude Steel Production, Selected Countries, 1979-1992

\begin{tabular}{|c|c|c|c|c|c|c|c|}
\hline $\begin{array}{l}\text { I. Mt } \\
\text { Year }\end{array}$ & China & India & Japan & USA & FSU & Subtotal & World Total * \\
\hline 1979 & 34.48 & 9.93 & 110.62 & 123.69 & 127.25 & 405.97 & 702.51 \\
\hline 1980 & 37.12 & 9.36 & 110.17 & 101.46 & 147.94 & 406.04 & 695.89 \\
\hline 1981 & 35.60 & 10.62 & 100.54 & 109.61 & 148.45 & 404.82 & 683.84 \\
\hline 1982 & 37.16 & 10.83 & 98.52 & 67.66 & 147.17 & 361.34 & 618.96 \\
\hline 1983 & 40.02 & 10.05 & 96.30 & 76.76 & 15251 & 375.65 & 650.84 \\
\hline 1984 & 43.47 & 10.26 & 104.68 & 83.94 & 154.24 & 396.59 & 695.23 \\
\hline 1985 & 46.79 & 10.96 & 104.39 & 80.07 & 154.67 & 396.88 & 702.98 \\
\hline 1986 & 52.20 & 11.33 & 97.56 & 74.03 & 160.55 & 395.67 & 697.01 \\
\hline 1987 & 56.28 & 11.98 & 97.87 & 80.88 & 161.89 & 408.90 & 717.07 \\
\hline 1988 & 59.43 & 12.68 & 104.96 & 90.63 & 163.04 & 430.74 & 757.12 \\
\hline 1989 & 61.59 & 12.54 & 107.16 & 87.72 & 160.10 & 429.11 & 759.76 \\
\hline 1990 & 66.35 & 12.66 & 109.55 & 89.73 & 154.44 & 432.73 & 745.04 \\
\hline 1991 & 71.00 & - & 108.91 & 79.74 & 7277 & 332.42 & 687.28 \\
\hline 1992 & 80.94 & - & 97.52 & 84.32 & - & 262.78 & 699.83 \\
\hline
\end{tabular}

\begin{tabular}{|lcccccc|}
\hline 2. Shares & & & & & & \\
Year & China & India & Japan & USA & FSU & Subtotal \\
\hline 1979 & $4.9 \%$ & $1.4 \%$ & $15.7 \%$ & $17.6 \%$ & $18.1 \%$ & $57.8 \%$ \\
1980 & $5.3 \%$ & $1.3 \%$ & $15.8 \%$ & $14.6 \%$ & $21.3 \%$ & $58.3 \%$ \\
1981 & $5.2 \%$ & $1.6 \%$ & $14.7 \%$ & $16.0 \%$ & $21.7 \%$ & $59.2 \%$ \\
1982 & $6.0 \%$ & $1.8 \%$ & $15.9 \%$ & $10.9 \%$ & $23.8 \%$ & $58.4 \%$ \\
1983 & $6.1 \%$ & $1.5 \%$ & $14.8 \%$ & $11.8 \%$ & $23.4 \%$ & $57.7 \%$ \\
1984 & $6.3 \%$ & $1.5 \%$ & $15.1 \%$ & $12.1 \%$ & $22.2 \%$ & $57.0 \%$ \\
1985 & $6.7 \%$ & $1.6 \%$ & $14.8 \%$ & $11.4 \%$ & $22.0 \%$ & $56.5 \%$ \\
1986 & $7.5 \%$ & $1.6 \%$ & $14.0 \%$ & $10.6 \%$ & $23.0 \%$ & $56.8 \%$ \\
1987 & $7.8 \%$ & $1.7 \%$ & $13.6 \%$ & $11.3 \%$ & $22.6 \%$ & $57.0 \%$ \\
1988 & $7.8 \%$ & $1.7 \%$ & $13.9 \%$ & $12.0 \%$ & $21.5 \%$ & $56.9 \%$ \\
1989 & $8.1 \%$ & $1.7 \%$ & $14.1 \%$ & $11.5 \%$ & $21.1 \%$ & $56.5 \%$ \\
1990 & $8.9 \%$ & $1.7 \%$ & $14.7 \%$ & $12.0 \%$ & $20.7 \%$ & $58.1 \%$ \\
1991 & $10.3 \%$ & - & $15.8 \%$ & $11.6 \%$ & $10.6 \%$ & $48.4 \%$ \\
1992 & $11.6 \%$ & - & $13.9 \%$ & $12.0 \%$ & & - \\
& & & & & & $37.5 \%$ \\
\hline
\end{tabular}

* In most cases "world total" is the sum of available country data only and so may be less than the actual world total. Since the major producing countries have been covered, however, this category should be a good approximation of the actual total.

Source: United Nations, $1994 \mathrm{~b}$. 
Table IX-14. Cement Production, Selected Countries, 1979-1992

\begin{tabular}{|c|c|c|c|c|c|c|c|}
\hline \multicolumn{8}{|l|}{ 1. Mt } \\
\hline Year & China & India & Japan & USA & $\mathbf{F S U}$ & Subtotal & Worid Total * \\
\hline 1979 & 73.90 & 18.27 & 87.80 & 76.65 & 123.02 & 379.64 & 865.09 \\
\hline 1980 & 79.86 & 17.80 & 87.96 & 68.24 & 125.05 & 378.91 & 872.06 \\
\hline 1981 & 82.90 & 20.91 & 84.83 & 65.05 & 127.17 & 380.86 & 878.70 \\
\hline 1982 & 95.20 & 22.65 & 80.69 & 57.48 & 123.68 & 379.69 & 880.01 \\
\hline 1983 & 108.25 & 25.26 & 80.89 & 63.93 & 128.16 & 406.48 & 906.95 \\
\hline 1984 & 123.02 & 29.54 & 78.86 & 70.45 & 129.87 & 431.74 & 933.90 \\
\hline 1985 & 145.95 & 31.97 & 72.85 & 70.28 & 130.77 & 451.82 & 949.97 \\
\hline 1986 & 166.06 & 34.98 & 71.26 & 71.11 & 135.12 & 478.54 & 995.88 \\
\hline 1987 & 186.25 & 37.14 & 71.55 & 67.38 & 137.40 & 499.72 & 1043.52 \\
\hline 1988 & 210.14 & 41.14 & 77.55 & 71.54 & 139.50 & 539.87 & 1110.41 \\
\hline 1989 & 210.30 & 44.20 & 79.72 & 71.31 & 140.44 & 545.97 & 1146.18 \\
\hline 1990 & 209.71 & 46.17 & 84.45 & 70.94 & 137.32 & 548.59 & 1153.85 \\
\hline 1991 & 244.66 & 51.66 & 89.56 & 65.05 & 77.46 & 528.39 & 1109.59 \\
\hline 1992 & 308.22 & 51.66 & 88.25 & 70.85 & - & 518.98 & 1189.18 \\
\hline
\end{tabular}

\begin{tabular}{|ccccccc} 
2. Shares & \multicolumn{7}{c}{ USA } & FSU & Subtotal \\
Year & China & India & Japan & USA & $14.2 \%$ & $43.9 \%$ \\
1979 & $8.5 \%$ & $2.1 \%$ & $10.1 \%$ & $8.9 \%$ & $14.3 \%$ & $43.4 \%$ \\
1980 & $9.2 \%$ & $2.0 \%$ & $10.1 \%$ & $7.8 \%$ & $14.5 \%$ & $43.3 \%$ \\
1981 & $9.4 \%$ & $2.4 \%$ & $9.7 \%$ & $7.4 \%$ & $14.1 \%$ & $43.1 \%$ \\
1982 & $10.8 \%$ & $2.6 \%$ & $9.2 \%$ & $6.5 \%$ & $14.1 \%$ & $44.8 \%$ \\
1983 & $11.9 \%$ & $2.8 \%$ & $8.9 \%$ & $7.0 \%$ & $13.9 \%$ & $46.2 \%$ \\
1984 & $13.2 \%$ & $3.2 \%$ & $8.4 \%$ & $7.5 \%$ & $13.8 \%$ & $47.6 \%$ \\
1985 & $15.4 \%$ & $3.4 \%$ & $7.7 \%$ & $7.4 \%$ & $13.6 \%$ & $48.1 \%$ \\
1986 & $16.7 \%$ & $3.5 \%$ & $7.2 \%$ & $7.1 \%$ & $13.2 \%$ & $47.9 \%$ \\
1987 & $17.8 \%$ & $3.6 \%$ & $6.9 \%$ & $6.5 \%$ & $12.6 \%$ & $48.6 \%$ \\
1988 & $18.9 \%$ & $3.7 \%$ & $7.0 \%$ & $6.4 \%$ & $12.3 \%$ & $47.6 \%$ \\
1989 & $18.3 \%$ & $3.9 \%$ & $7.0 \%$ & $6.2 \%$ & $11.9 \%$ & $47.5 \%$ \\
1990 & $18.2 \%$ & $4.0 \%$ & $7.3 \%$ & $6.1 \%$ & $7.0 \%$ & $47.6 \%$ \\
1991 & $22.0 \%$ & $4.7 \%$ & $8.1 \%$ & $5.9 \%$ & & $43.6 \%$ \\
1992 & $25.9 \%$ & $4.3 \%$ & $7.4 \%$ & $6.0 \%$ & & \\
\hline
\end{tabular}

* In most cases "world total" is the sum of available country data only and so may be less than the actual world total. Since the major producing countries have been covered, however, this category should be a good approximation of the actual total.

Source: United Nations, 1994b. 
Table IX-15. Primary Aluminum Production, Selected Countries, 1979-1992

\begin{tabular}{|cccccccc|}
\hline I. Mt & & & & & & & \\
Year & China & India & Japan & USA & FSU & Subtotal & World Total * \\
\hline 1979 & 0.36 & 0.21 & 1.01 & 4.56 & 1.75 & 7.89 & 14.58 \\
1980 & 0.35 & 0.18 & 1.10 & 4.65 & 1.76 & 8.04 & 15.32 \\
1981 & 0.35 & 0.21 & 0.78 & 4.49 & 1.80 & 7.63 & 14.92 \\
1982 & 0.40 & 0.22 & 0.36 & 3.27 & 1.85 & 6.10 & 13.26 \\
1983 & 0.43 & 0.20 & 0.26 & 3.35 & 2.00 & 6.24 & 13.73 \\
1984 & 0.40 & 0.27 & 0.29 & 4.10 & 2.10 & 7.16 & 15.56 \\
1985 & 0.41 & 0.26 & 0.23 & 3.50 & 2.20 & 6.60 & 15.28 \\
1986 & 0.41 & 0.23 & 0.15 & 3.04 & 2.30 & 6.13 & 15.26 \\
1987 & 0.62 & 0.25 & 0.05 & .3 .34 & 2.40 & 6.66 & 16.36 \\
1988 & 0.72 & 0.29 & 0.05 & 3.94 & 2.40 & 7.40 & 17.27 \\
1989 & 0.76 & 0.43 & 0.05 & 4.03 & 2.40 & 7.67 & 18.03 \\
1990 & 0.85 & 0.43 & 0.05 & 4.05 & 2.20 & 7.58 & 17.87 \\
1991 & 0.86 & 0.51 & 0.05 & 4.12 & - & 5.54 & 16.09 \\
1992 & 1.08 & 0.50 & 0.04 & 4.04 & - & 5.66 & 16.37 \\
\hline
\end{tabular}

\begin{tabular}{|lcccccc|}
\hline 2. Shares & & & & & & \\
Year & China & India & Japan & USA & FSU & Subtotal \\
\hline 1979 & $2.5 \%$ & $1.5 \%$ & $7.0 \%$ & $31.3 \%$ & $12.0 \%$ & $54.1 \%$ \\
1980 & $2.3 \%$ & $1.2 \%$ & $7.2 \%$ & $30.4 \%$ & $11.5 \%$ & $52.5 \%$ \\
1981 & $2.3 \%$ & $1.4 \%$ & $5.2 \%$ & $30.1 \%$ & $12.1 \%$ & $51.1 \%$ \\
1982 & $3.0 \%$ & $1.6 \%$ & $2.7 \%$ & $24.7 \%$ & $14.0 \%$ & $46.0 \%$ \\
1983 & $3.1 \%$ & $1.5 \%$ & $1.9 \%$ & $24.4 \%$ & $14.6 \%$ & $45.5 \%$ \\
1984 & $26 \%$ & $1.7 \%$ & $1.9 \%$ & $26.3 \%$ & $13.5 \%$ & $46.0 \%$ \\
1985 & $2.7 \%$ & $1.7 \%$ & $1.5 \%$ & $22.9 \%$ & $14.4 \%$ & $43.2 \%$ \\
1986 & $27 \%$ & $1.5 \%$ & $1.0 \%$ & $19.9 \%$ & $15.1 \%$ & $40.2 \%$ \\
1987 & $3.8 \%$ & $1.5 \%$ & $0.3 \%$ & $20.4 \%$ & $14.7 \%$ & $40.7 \%$ \\
1988 & $4.2 \%$ & $1.7 \%$ & $0.3 \%$ & $22.8 \%$ & $13.9 \%$ & $42.9 \%$ \\
1989 & $4.2 \%$ & $2.4 \%$ & $0.3 \%$ & $22.4 \%$ & $13.3 \%$ & $42.5 \%$ \\
1990 & $4.8 \%$ & $2.4 \%$ & $0.3 \%$ & $22.7 \%$ & $12.3 \%$ & $42.4 \%$ \\
1991 & $5.3 \%$ & $3.2 \%$ & $0.3 \%$ & $25.6 \%$ & - & $34.4 \%$ \\
1992 & $6.6 \%$ & $3.1 \%$ & $0.2 \%$ & $24.7 \%$ & - & $34.6 \%$ \\
& & & & & & \\
\hline
\end{tabular}

* In most cases "world total" is the sum of available country data only and so may be less than the actual world total. Since the major producing countries have been covered, however, this category should be a good approximation of the actual total.

Source: United Nations, 1994b. 
Table IX-16. Ethylene Production, Selected Countries, 1979-1992

\begin{tabular}{|c|c|c|c|c|c|c|c|}
\hline \multicolumn{8}{|l|}{ 1. Mt } \\
\hline Year & China & India & Japan & USA & FSU & Subtotal & World Total * \\
\hline 1979 & 0.43 & 0.10 & 4.78 & 13.24 & - & 18.56 & 35.32 \\
\hline 1980 & 0.49 & - & 4.18 & 13.00 & 1.77 & 19.44 & 34.20 \\
\hline 1981 & 0.50 & - & 3.65 & 13.34 & 209 & 19.60 & 34.14 \\
\hline 1982 & 0.57 & - & 3.59 & 11.11 & 2.13 & 17.40 & 31.90 \\
\hline 1983 & 0.65 & 0.08 & 3.69 & 13.01 & 2.27 & 19.70 & 34.58 \\
\hline 1984 & 0.65 & 0.09 & 4.39 & 14.24 & 2.54 & 21.90 & 37.54 \\
\hline 1985 & 0.65 & 0.09 & 4.23 & 13.54 & 2.67 & 21.17 & 37.15 \\
\hline 1986 & 0.70 & 0.18 & 4.29 & 14.90 & 280 & 22.87 & 39.37 \\
\hline 1987 & 0.94 & 0.15 & 4.58 & 15.85 & 298 & 24.51 & 42.46 \\
\hline 1988 & 1.23 & 0.19 & 5.06 & 16.88 & 3.17 & 26.53 & 45.70 \\
\hline 1989 & 1.40 & 0.20 & 5.60 & 15.87 & 3.14 & 26.21 & 44.90 \\
\hline 1990 & 1.57 & 0.19 & 5.81 & 16.54 & 3.07 & 27.18 & 46.15 \\
\hline 1991 & 1.76 & 0.19 & 6.14 & 18.12 & - & 26.21 & 46.01 \\
\hline 1992 & 2.00 & - & 6.10 & 18.56 & - & 26.66 & 49.53 \\
\hline
\end{tabular}

\begin{tabular}{|lrrrrrr|}
\hline 2. Shares & \multicolumn{7}{c}{} & & & & \\
Year & China & India & Japan & USA & FSU & Subtotal \\
\hline 1979 & $1.2 \%$ & $0.3 \%$ & $13.5 \%$ & $37.5 \%$ & & $52.6 \%$ \\
1980 & $1.4 \%$ & - & $12.2 \%$ & $38.0 \%$ & $5.2 \%$ & $56.8 \%$ \\
1981 & $1.5 \%$ & - & $10.7 \%$ & $39.1 \%$ & $6.1 \%$ & $57.4 \%$ \\
1982 & $1.8 \%$ & - & $11.3 \%$ & $34.8 \%$ & $6.7 \%$ & $54.6 \%$ \\
1983 & $1.9 \%$ & $0.2 \%$ & $10.7 \%$ & $37.6 \%$ & $6.6 \%$ & $57.0 \%$ \\
1984 & $1.7 \%$ & $0.2 \%$ & $11.7 \%$ & $37.9 \%$ & $6.8 \%$ & $58.3 \%$ \\
1985 & $1.8 \%$ & $0.2 \%$ & $11.4 \%$ & $36.4 \%$ & $7.2 \%$ & $57.0 \%$ \\
1986 & $1.8 \%$ & $0.5 \%$ & $10.9 \%$ & $37.9 \%$ & $7.1 \%$ & $58.1 \%$ \\
1987 & $2.2 \%$ & $0.4 \%$ & $10.8 \%$ & $37.3 \%$ & $7.0 \%$ & $57.7 \%$ \\
1988 & $2.7 \%$ & $0.4 \%$ & $11.1 \%$ & $36.9 \%$ & $6.9 \%$ & $58.1 \%$ \\
1989 & $3.1 \%$ & $0.4 \%$ & $125 \%$ & $35.3 \%$ & $7.0 \%$ & $58.4 \%$ \\
1990 & $3.4 \%$ & $0.4 \%$ & $12.6 \%$ & $35.8 \%$ & $6.7 \%$ & $58.9 \%$ \\
1991 & $3.8 \%$ & $0.4 \%$ & $13.3 \%$ & $39.4 \%$ & - & $57.0 \%$ \\
1992 & $4.0 \%$ & - & $12.3 \%$ & $37.5 \%$ & - & $53.8 \%$ \\
& & & & & & \\
\hline
\end{tabular}

* In most cases"world total" is the sum of available country data only and so may be less than the actual world total. Since the major producing countries have been covered, however, this category should be a good approximation of the actual total.

Source: United Nations, 1994b. 
Table IX-17. Ammonia Production, Selected Countries, 1979-1992

\begin{tabular}{|c|c|c|c|c|c|c|c|}
\hline \multicolumn{8}{|l|}{ I. $M t$} \\
\hline Year & China & India & Japan & USA & FSU & Subtotal & World Total \\
\hline 1979 & 13.48 & - & 0.12 & 13.99 & - & 27.59 & 71.76 \\
\hline 1980 & 14.97 & - & 0.13 & 14.74 & - & 29.84 & 75.05 \\
\hline 1981 & 14.83 & - & - & 11.76 & 17.89 & 44.49 & 73.14 \\
\hline 1982 & 15.46 & - & - & 10.22 & 17.76 & 43.44 & 70.70 \\
\hline 1983 & 16.77 & - & - & 12.44 & 20.55 & 49.76 & 80.04 \\
\hline 1984 & 18.37 & - & - & 12.09 & 21.49 & 51.96 & 84.96 \\
\hline 1985 & 17.19 & - & - & 14.26 & 22.17 & 53.62 & 86.87 \\
\hline 1986 & 16.73 & - & 1.80 & 13.14 & 23.82 & 55.49 & 86.47 \\
\hline 1987 & 19.41 & - & 1.79 & 14.60 & 24.23 & 60.04 & 92.97 \\
\hline 1988 & 19.86 & - & 1.82 & 15.26 & 24.43 & 6.1 .36 & 95.34 \\
\hline 1989 & 20.68 & - & 1.83 & 14.94 & 23.62 & 61.07 & 95.51 \\
\hline 1990 & 21.29 & - & 1.83 & 15.42 & - & 38.54 & 81.58 \\
\hline 1991 & 22.02 & - & 1.86 & 15.57 & - & 39.45 & 71.37 \\
\hline 1992 & 22.98 & - & $1.79^{\circ}$ & 16.60 & - & 41.37 & 74.70 \\
\hline
\end{tabular}

\begin{tabular}{|c|c|c|c|c|c|c|}
\hline \multicolumn{7}{|c|}{ 2. Shares } \\
\hline Year & China & India & Japan & USA & USSR & Subtotal \\
\hline 1979 & $18.8 \%$ & - & $0.2 \%$ & $19.5 \%$ & - & $38.4 \%$ \\
\hline 1980 & $20.0 \%$ & - & $0.2 \%$ & $19.6 \%$ & - & $39.8 \%$ \\
\hline 1981 & $20.3 \%$ & - & - & $16.1 \%$ & $24.5 \%$ & $60.8 \%$ \\
\hline 1982 & $21.9 \%$ & - & - & $14.5 \%$ & $25.1 \%$ & $61.4 \%$ \\
\hline 1983 & $21.0 \%$ & - & - & $15.5 \%$ & $25.7 \%$ & $62.2 \%$ \\
\hline 1984 & $21.6 \%$ & - & - & $14.2 \%$ & $25.3 \%$ & $61.2 \%$ \\
\hline 1985 & $19.8 \%$ & - & - & $16.4 \%$ & $25.5 \%$ & $61.7 \%$ \\
\hline 1986 & $19.3 \%$ & - & $2.1 \%$ & $15.2 \%$ & $27.5 \%$ & $64.2 \%$ \\
\hline 1987 & $20.9 \%$ & - & $1.9 \%$ & $15.7 \%$ & $26.1 \%$ & $64.6 \%$ \\
\hline 1988 & $20.8 \%$ & - & $1.9 \%$ & $16.0 \%$ & $25.6 \%$ & $64.4 \%$ \\
\hline 1989 & $21.7 \%$ & - & $1.9 \%$ & $15.6 \%$ & $24.7 \%$ & $63.9 \%$ \\
\hline 1990 & $26.1 \%$ & - & $2.2 \%$ & $18.9 \%$ & - & $47.2 \%$ \\
\hline 1991 & $30.9 \%$ & - & $26 \%$ & $21.8 \%$ & - & $55.3 \%$ \\
\hline 1992 & $30.8 \%$ & - & $2.4 \%$ & $22.2 \%$ & - & $55.4 \%$ \\
\hline
\end{tabular}

* In most cases "world total" is the sum of available country data only and so may be less than the actual world total. Since the major producing countries have been covered, however, this category should be a good approximation of the actual total.

Source: United Nations, 1994b. 
Table IX-18. Caustic Soda Production, Selected Countries, 1979-1992

\begin{tabular}{|ccccccccc|}
\hline I. Mt & & & & & & & & \\
& & & & & & & \\
Year & China & India & Japan & USA & FSU & Subtotal & World Total * \\
\hline 1979 & 1.83 & 0.57 & 2.93 & 11.57 & 2.68 & 19.57 & 31.95 \\
1980 & 1.92 & 0.55 & 3.06 & 10.54 & 2.76 & 18.83 & 31.41 \\
1981 & 1.92 & 0.61 & 279 & 9.63 & 276 & 17.71 & 30.45 \\
1982 & 2.07 & 0.60 & 271 & 8.51 & 2.78 & 16.67 & 29.17 \\
1983 & 2.12 & 0.61 & 2.78 & 9.11 & 285 & 17.47 & 30.83 \\
1984 & 2.22 & 0.70 & 299 & 9.90 & 2.97 & 18.78 & 32.95 \\
1985 & 2.35 & 0.72 & 2.98 & 9.81 & 3.06 & 18.91 & 33.20 \\
1986 & 2.52 & 0.73 & 298 & 9.64 & 3.23 & 19.11 & 33.71 \\
1987 & 2.74 & 0.95 & 3.13 & 10.48 & 3.28 & 20.58 & 35.21 \\
1988 & 3.01 & 0.91 & 3.40 & 9.56 & 3.32 & 20.20 & 35.39 \\
1989 & 3.21 & 0.91 & 3.56 & 10.60 & 3.19 & 21.47 & 36.27 \\
1990 & 3.35 & 0.96 & 3.80 & 11.12 & 297 & 22.20 & 36.40 \\
1991 & 3.54 & 1.02 & 3.79 & 11.11 & 2.04 & 21.50 & 32.99 \\
1992 & 3.80 & - & 3.75 & 11.29 & - & 18.84 & 35.90 \\
& & & & & & & \\
\hline
\end{tabular}

\begin{tabular}{|cccccccc|}
\hline 2. Shares & & & & & & \\
Year & China & India & Japan & USA & FSU & Subtotal \\
\hline 1979 & $5.7 \%$ & $1.8 \%$ & $9.2 \%$ & $36.2 \%$ & $8.4 \%$ & $61.3 \%$ \\
1980 & $6.1 \%$ & $1.7 \%$ & $9.8 \%$ & $33.6 \%$ & $8.8 \%$ & $60.0 \%$ \\
1981 & $6.3 \%$ & $2.0 \%$ & $9.1 \%$ & $31.6 \%$ & $9.1 \%$ & $58.2 \%$ \\
1982 & $7.1 \%$ & $2.0 \%$ & $9.3 \%$ & $29.2 \%$ & $9.5 \%$ & $57.1 \%$ \\
1983 & $6.9 \%$ & $2.0 \%$ & $9.0 \%$ & $29.5 \%$ & $9.3 \%$ & $56.7 \%$ \\
1984 & $6.7 \%$ & $2.1 \%$ & $9.1 \%$ & $30.0 \%$ & $9.0 \%$ & $57.0 \%$ \\
1985 & $7.1 \%$ & $2.2 \%$ & $9.0 \%$ & $29.5 \%$ & $9.2 \%$ & $57.0 \%$ \\
1986 & $7.5 \%$ & $2.2 \%$ & $8.9 \%$ & $28.6 \%$ & $9.6 \%$ & $56.7 \%$ \\
1987 & $7.8 \%$ & $2.7 \%$ & $8.9 \%$ & $29.8 \%$ & $9.3 \%$ & $58.5 \%$ \\
1988 & $8.5 \%$ & $2.6 \%$ & $9.6 \%$ & $27.0 \%$ & $9.4 \%$ & $57.1 \%$ \\
1989 & $8.9 \%$ & $2.5 \%$ & $9.8 \%$ & $29.2 \%$ & $8.8 \%$ & $59.2 \%$ \\
1990 & $9.2 \%$ & $2.6 \%$ & $10.4 \%$ & $30.5 \%$ & $8.2 \%$ & $61.0 \%$ \\
1991 & $10.7 \%$ & $3.1 \%$ & $11.5 \%$ & $33.7 \%$ & $6.2 \%$ & $65.2 \%$ \\
1992 & $10.6 \%$ & - & $10.4 \%$ & $31.4 \%$ & - & $52.5 \%$ \\
& & & & & & \\
\hline
\end{tabular}

* In most cases "world total" is the sum of available country data only and so may be less than the actual world total. Since the major producing countries have been covered, however, this category should be a good approximation of the actual total.

Source: United Nations, 1994b. 
Table IX-19. Soda Ash Production, Selected Countries, 1979-1992

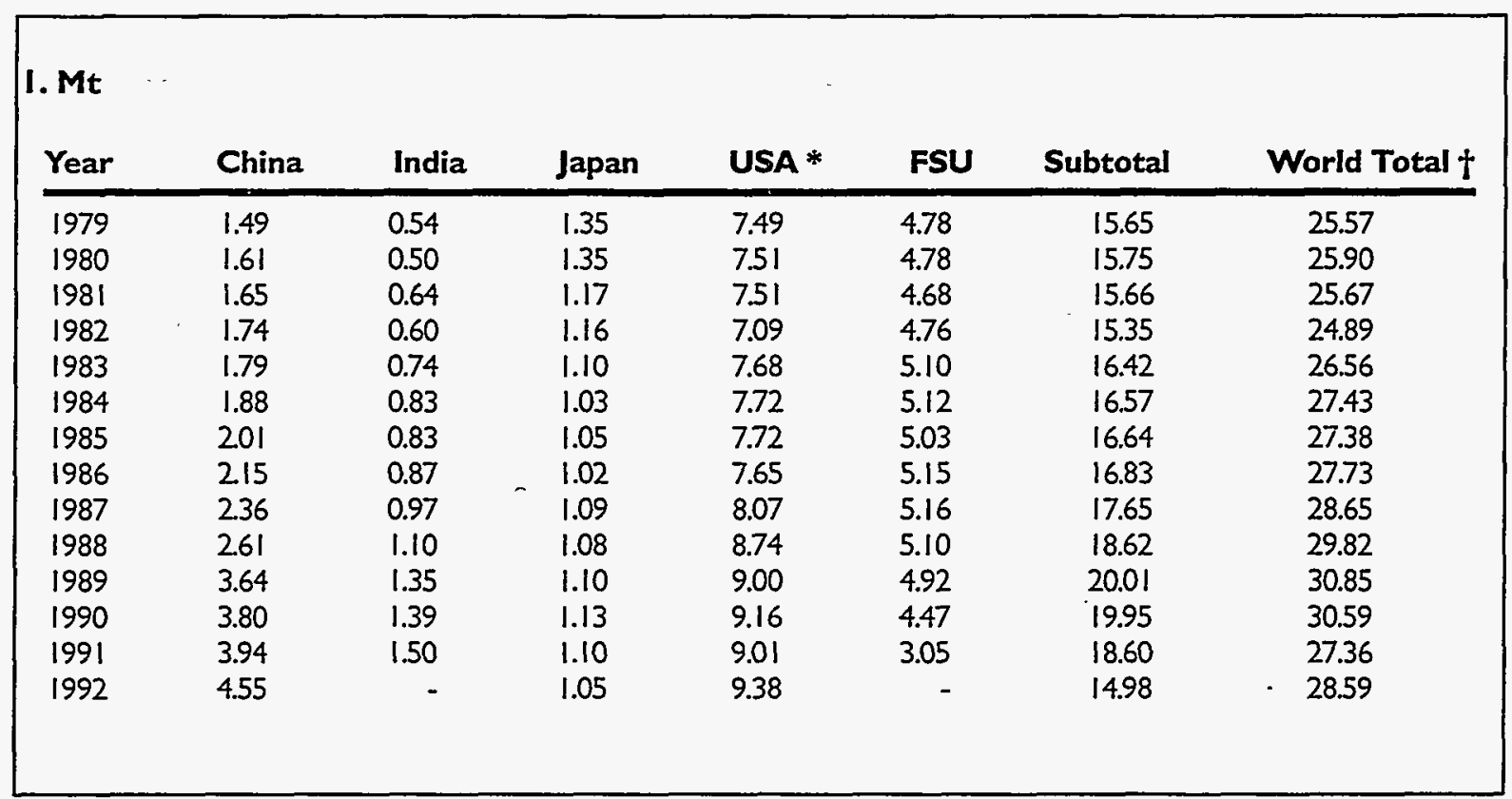

\begin{tabular}{|lccccccc|}
\hline 2. Shares & & & & & & \\
Year & China & India & Japan & USA & FSU & Subtotal \\
\hline 1979 & $5.8 \%$ & $2.1 \%$ & $5.3 \%$ & $29.3 \%$ & $18.7 \%$ & $61.2 \%$ \\
1980 & $6.2 \%$ & $1.9 \%$ & $5.2 \%$ & $29.0 \%$ & $18.5 \%$ & $60.8 \%$ \\
1981 & $6.4 \%$ & $2.5 \%$ & $4.6 \%$ & $29.3 \%$ & $18.2 \%$ & $61.0 \%$ \\
1982 & $7.0 \%$ & $2.4 \%$ & $4.6 \%$ & $28.5 \%$ & $19.1 \%$ & $61.7 \%$ \\
1983 & $6.8 \%$ & $2.8 \%$ & $4.1 \%$ & $28.9 \%$ & $19.2 \%$ & $61.8 \%$ \\
1984 & $7.1 \%$ & $3.1 \%$ & $3.9 \%$ & $29.1 \%$ & $19.3 \%$ & $62.4 \%$ \\
1985 & $7.3 \%$ & $3.0 \%$ & $3.8 \%$ & $28.1 \%$ & $18.3 \%$ & $60.6 \%$ \\
1986 & $7.8 \%$ & $3.2 \%$ & $3.7 \%$ & $28.0 \%$ & $18.8 \%$ & $61.5 \%$ \\
1987 & $8.5 \%$ & $3.5 \%$ & $3.9 \%$ & $29.1 \%$ & $18.6 \%$ & $63.7 \%$ \\
1988 & $8.7 \%$ & $3.7 \%$ & $3.6 \%$ & $29.3 \%$ & $17.1 \%$ & $62.5 \%$ \\
1989 & $11.8 \%$ & $4.4 \%$ & $3.6 \%$ & $29.2 \%$ & $15.9 \%$ & $64.9 \%$ \\
1990 & $12.4 \%$ & $4.5 \%$ & $3.7 \%$ & $29.9 \%$ & $14.6 \%$ & $65.2 \%$ \\
1991 & $14.4 \%$ & $5.5 \%$ & $4.0 \%$ & $32.9 \%$ & $11.1 \%$ & $68.0 \%$ \\
1992 & $15.9 \%$ & - & $3.7 \%$ & $32.8 \%$ & & $52.4 \%$ \\
& & & & & & \\
\hline
\end{tabular}

* Includes natural sodium carbonate.

$\dagger$ In most cases "world total" is the sum of available country data only and so may be less than the actual world total. Since the major producing countries have been covered, however, this category should be a good approximation of the actual total.

Source: United Nations, 1994b. 
Table IX-20. Sulphuric Acid Production, Selected Countries, 1979-1992

\begin{tabular}{|lllllllll|}
\hline 1. Mt & & & & & & & \\
Year & China & India & Japan & USA & FSU & Subtotal & World Total * \\
\hline 1979 & 7.00 & 2.23 & 6.58 & 39.19 & 22.36 & 77.36 & 130.77 \\
1980 & 7.64 & 2.22 & 6.78 & 40.05 & 23.03 & 79.72 & 133.81 \\
1981 & 7.81 & 2.28 & 6.57 & 36.95 & 24.10 & 77.71 & 130.49 \\
1982 & 8.18 & 2.39 & 6.53 & 30.14 & 23.80 & 71.04 & 121.97 \\
1983 & 8.70 & 2.24 & 6.66 & 33.98 & 24.71 & 76.29 & 129.47 \\
1984 & 8.17 & 2.68 & 6.46 & 37.91 & 25.34 & 80.57 & 137.23 \\
1985 & 6.76 & 2.63 & 6.58 & 35.96 & 26.04 & 77.97 & 132.56 \\
1986 & 7.63 & 2.88 & 6.56 & 32.65 & 27.85 & 77.57 & 131.42 \\
1987 & 9.83 & 3.16 & 6.54 & 35.61 & 28.53 & 83.68 & 134.94 \\
1988 & 11.11 & 3.42 & 6.77 & 38.62 & 29.37 & 89.29 & 142.97 \\
1989 & 11.53 & 3.29 & 6.89 & 39.28 & 28.28 & 89.27 & 141.18 \\
1990 & 11.97 & 3.27 & 6.89 & 40.22 & 27.27 & 89.62 & 135.92 \\
1991 & 13.33 & 3.89 & 7.06 & 39.43 & 11.60 & 75.31 & 124.85 \\
1992 & 14.09 & - & 7.10 & 40.70 & & - & 61.89 & 126.80 \\
& & & & & & & & \\
\hline
\end{tabular}

\begin{tabular}{|ccccccc}
\hline 2. Shares & & & & & & \\
& & & & & & \\
Year & China & India & Japan & USA & FSU & Subtotal \\
\hline 1979 & $5.4 \%$ & $1.7 \%$ & $5.0 \%$ & $30.0 \%$ & $17.1 \%$ & $59.2 \%$ \\
1980 & $5.7 \%$ & $1.7 \%$ & $5.1 \%$ & $29.9 \%$ & $17.2 \%$ & $59.6 \%$ \\
1981 & $6.0 \%$ & $1.7 \%$ & $5.0 \%$ & $28.3 \%$ & $18.5 \%$ & $59.5 \%$ \\
1982 & $6.7 \%$ & $2.0 \%$ & $5.4 \%$ & $24.7 \%$ & $19.5 \%$ & $58.2 \%$ \\
1983 & $6.7 \%$ & $1.7 \%$ & $5.1 \%$ & $26.2 \%$ & $19.1 \%$ & $58.9 \%$ \\
1984 & $6.0 \%$ & $2.0 \%$ & $4.7 \%$ & $27.6 \%$ & $18.5 \%$ & $58.7 \%$ \\
1985 & $5.1 \%$ & $2.0 \%$ & $5.0 \%$ & $27.1 \%$ & $19.6 \%$ & $58.8 \%$ \\
1986 & $5.8 \%$ & $2.2 \%$ & $5.0 \%$ & $24.8 \%$ & $21.2 \%$ & $59.0 \%$ \\
1987 & $7.3 \%$ & $2.3 \%$ & $4.8 \%$ & $26.4 \%$ & $21.1 \%$ & $62.0 \%$ \\
1988 & $7.8 \%$ & $2.4 \%$ & $4.7 \%$ & $27.0 \%$ & $20.5 \%$ & $62.5 \%$ \\
1989 & $8.2 \%$ & $2.3 \%$ & $4.9 \%$ & $27.8 \%$ & $20.0 \%$ & $63.2 \%$ \\
1990 & $8.8 \%$ & $2.4 \%$ & $5.1 \%$ & $29.6 \%$ & $20.1 \%$ & $65.9 \%$ \\
1991 & $10.7 \%$ & $3.1 \%$ & $5.7 \%$ & $31.6 \%$ & $9.3 \%$ & $60.3 \%$ \\
1992 & $11.1 \%$ & - & $5.6 \%$ & $32.1 \%$ & & $48.8 \%$ \\
& & & & & & \\
\hline
\end{tabular}

- In most cases "world total" is the sum of available country data only and so may be less than the actual world total. Since the major producing countries have been covered, however, this category should be a good approximation of the actual total.

Source: United Nations, $1994 b$. 
Table IX-21. Wood Pulp Production, * Selected Countries 1979-1992

\begin{tabular}{|ccccccccc|}
\hline I. Mt & & & & & & & \\
& & & & & & & \\
Year & China & India & Japan & USA & FSU & Subtotal & World Total t \\
\hline 1979 & 3.63 & 1.26 & 9.99 & 45.92 & 9.09 & 69.89 & 129.30 \\
1980 & 3.81 & 1.53 & 9.59 & 46.94 & 9.18 & 71.04 & 132.17 \\
1981 & 3.81 & 2.04 & 8.61 & 47.87 & 9.42 & 71.75 & 132.20 \\
1982 & 3.81 & 2.11 & 8.63 & 45.29 & 9.58 & 69.41 & 126.16 \\
1983 & 4.27 & 2.41 & 8.86 & 47.96 & 10.16 & 73.66 & 134.44 \\
1984 & 4.76 & 1.40 & 9.14 & 50.70 & 10.46 & 76.47 & 142.87 \\
1985 & 8.71 & 1.47 & 9.29 & 49.36 & 10.73 & 79.56 & 144.65 \\
1986 & 9.57 & 1.49 & 9.25 & 52.20 & 10.84 & 83.35 & 151.00 \\
1987 & 12.38 & 1.60 & 9.74 & 54.37 & 10.85 & 88.94 & 160.11 \\
1988 & 13.58 & 1.60 & 10.42 & 55.83 & 10.95 & 92.38 & 166.38 \\
1989 & 13.07 & 1.64 & 10.99 & 56.58 & 11.68 & 93.96 & 170.10 \\
1990 & 13.18 & 1.64 & 11.34 & 57.57 & 10.75 & 94.47 & 168.57 \\
1991 & 13.97 & 1.64 & 11.73 & 59.14 & - & 86.48 & 158.63 \\
1992 & 14.44 & 1.87 & 11.20 & 59.47 & - & 86.97 & 158.75 \\
& & & & & & & \\
\hline
\end{tabular}

\begin{tabular}{|lccccccc|}
\hline 2. Shares & & & & & & & \\
Year & China & India & Japan & USA & FSU & Subtotal \\
\hline 1979 & $2.8 \%$ & $1.0 \%$ & $7.7 \%$ & $35.5 \%$ & $7.0 \%$ & $54.1 \%$ \\
1980 & $2.9 \%$ & $1.2 \%$ & $7.3 \%$ & $35.5 \%$ & $6.9 \%$ & $53.8 \%$ \\
1981 & $2.9 \%$ & $1.5 \%$ & $6.5 \%$ & $36.2 \%$ & $7.1 \%$ & $54.3 \%$ \\
1982 & $3.0 \%$ & $1.7 \%$ & $6.8 \%$ & $35.9 \%$ & $7.6 \%$ & $55.0 \%$ \\
1983 & $3.2 \%$ & $1.8 \%$ & $6.6 \%$ & $35.7 \%$ & $7.6 \%$ & $54.8 \%$ \\
1984 & $3.3 \%$ & $1.0 \%$ & $6.4 \%$ & $35.5 \%$ & $7.3 \%$ & $53.5 \%$ \\
1985 & $6.0 \%$ & $1.0 \%$ & $6.4 \%$ & $34.1 \%$ & $7.4 \%$ & $55.0 \%$ \\
1986 & $6.3 \%$ & $1.0 \%$ & $6.1 \%$ & $34.6 \%$ & $7.2 \%$ & $55.2 \%$ \\
1987 & $7.7 \%$ & $1.0 \%$ & $6.1 \%$ & $34.0 \%$ & $6.8 \%$ & $55.5 \%$ \\
1988 & $8.2 \%$ & $1.0 \%$ & $6.3 \%$ & $33.6 \%$ & $6.6 \%$ & $55.5 \%$ \\
1989 & $7.7 \%$ & $1.0 \%$ & $6.5 \%$ & $33.3 \%$ & $6.9 \%$ & $55.2 \%$ \\
1990 & $7.8 \%$ & $1.0 \%$ & $6.7 \%$ & $34.2 \%$ & $6.4 \%$ & $56.0 \%$ \\
1991 & $8.8 \%$ & $1.0 \%$ & $7.4 \%$ & $37.3 \%$ & - & $54.5 \%$ \\
1992 & $9.1 \%$ & $1.2 \%$ & $7.1 \%$ & $37.5 \%$ & - & $54.8 \%$ \\
& & & & & & \\
\hline
\end{tabular}

* Includes wood pulp from all pulping processes and pulp of fibers other than wood.

$\dagger$ In most cases "world total" is the sum of available country data only and so may be less than the actual world total. Since the major producing countries have been covered, however, this category should be a good approximation of the actual total. Some figures include FAO production estimates.

Source: United Nations, $1994 \mathrm{~b}$. 
Table IX-22. Structure of Passenger Travel for Selected Countries, 1992

\begin{tabular}{|lrrrrr|}
\hline \multicolumn{7}{l}{ l. Billion passenger-km } & & & & \\
Country & Rail & Road & Water & Air & Total \\
\hline China & 315.2 & 319.3 & 19.8 & 40.6 & 694.9 \\
India* & 268.9 & 900.1 & - & 8.6. & 1.177 .6 \\
Japan & 402.3 & 869.3 & 6.1 & 56.7 & $1,334.3$ \\
USA & 22.5 & 27.714 .4 & - & 590.5 & $3,327.4$ \\
FSU & 254.4 & 345.7 & 4.2 & 150.4 & 755.0 \\
\hline
\end{tabular}

\begin{tabular}{|lrrrrr|}
\hline 2. Shares & & & & & \\
Country & Rail & Road & Water & Air & Total \\
\hline China & $45.4 \%$ & $45.9 \%$ & $2.8 \%$ & $5.8 \%$ & $100.0 \%$ \\
India* & $22.8 \%$ & $76.4 \%$ & - & $0.7 \%$ & $100.0 \%$ \\
Japan & $30.1 \%$ & $65.2 \%$ & $0.5 \%$ & $4.2 \%$ & $100.0 \%$ \\
USA & $0.7 \%$ & $81.6 \%$ & - & $17.7 \%$ & $100.0 \%$ \\
FSU & $33.7 \%$ & $45.8 \%$ & $0.6 \%$ & $19.9 \%$ & $100.0 \%$ \\
\hline
\end{tabular}

\begin{tabular}{|lrrrrrr|}
\hline 3. Passenger-km per capita & & & & \\
Country & Rail & Road & Water & Air & Total \\
\hline China & 269 & 272 & 17 & 35 & 593 \\
India* & 331 & 1,109 & - & 11 & 1,450 \\
Japan & 3,232 & 6,985 & 49 & 455 & 10,722 \\
USA & 88 & 10,645 & - & 2,316 & 13,049 \\
FSU & 1,707 & 2,320 & 28 & 1,009 & 5,067 \\
\hline
\end{tabular}

* 1989 data. Air travel figure is estimated

Source: China - Transportation Statistical Yearbook of China 1994; India - LDC Energy Database, International Energy Studies Group, EAP, LBL, 1995; Japan - Energy Economics Institute of Japan, 1994; USA - US Department of Commerce, 1994. 
Figure IX-17. Passenger Traffic, Selected Countries, 1992

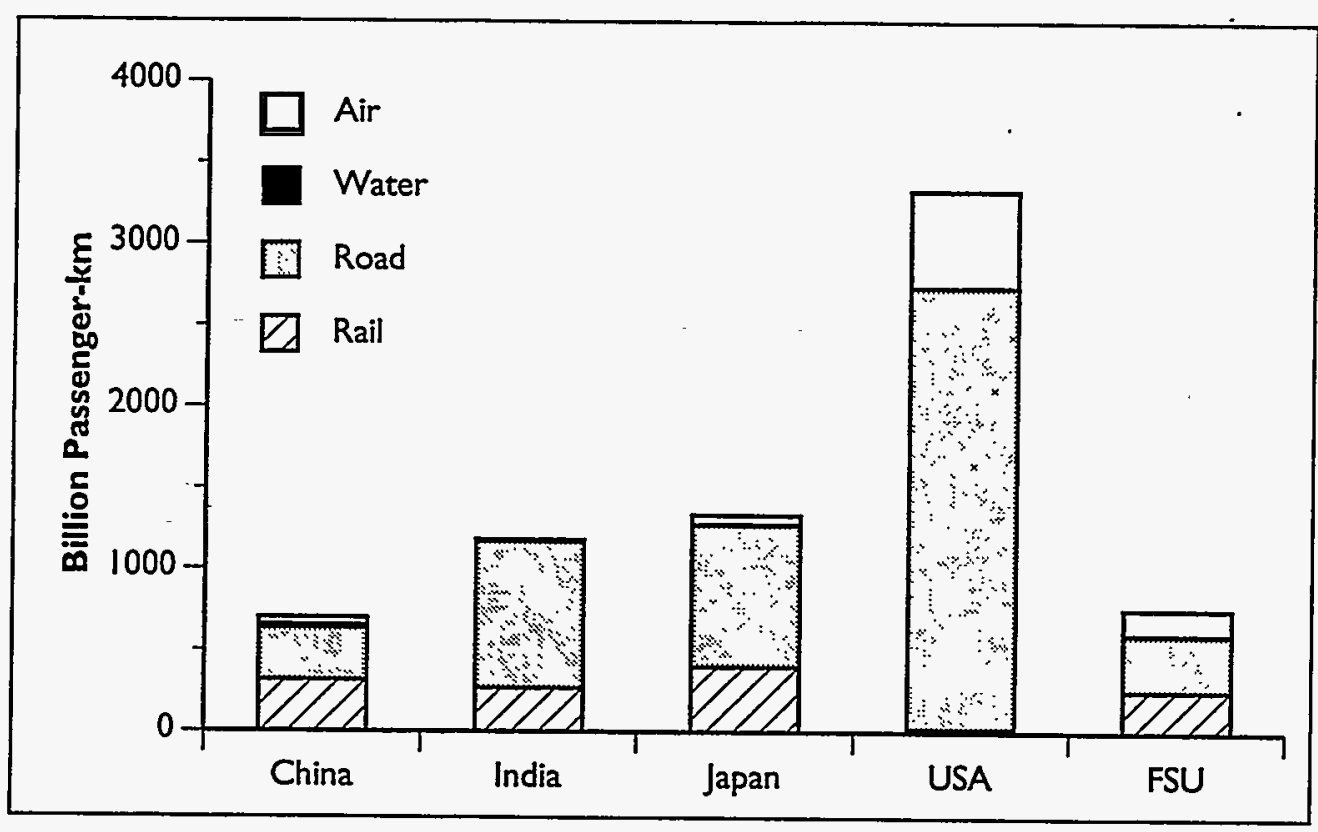

Figure IX-18. Per Capita Passenger Travel by Mode, 1992

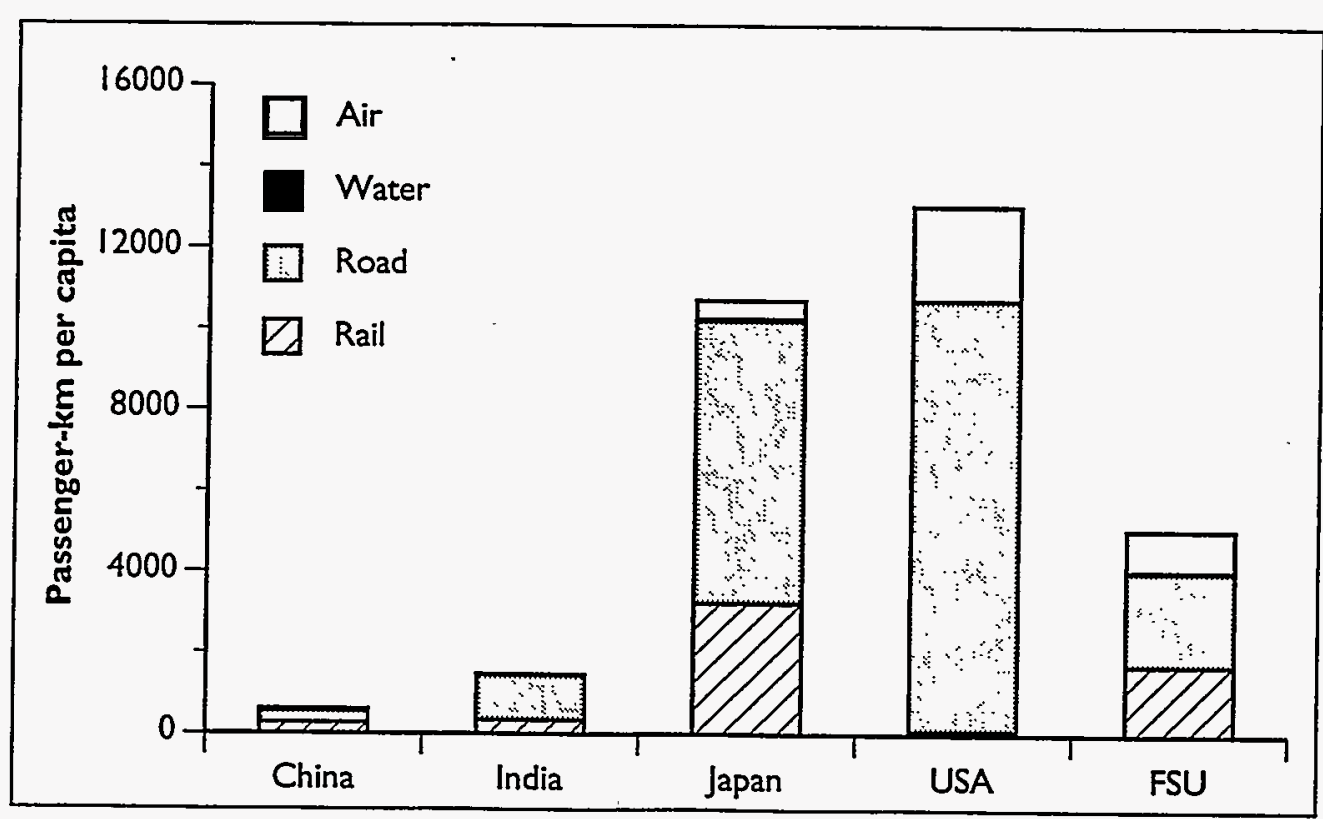


Table IX-23. Structure of Freight Transportation, Selected Countries, 1992

\begin{tabular}{|c|c|c|c|c|c|c|}
\hline \multicolumn{7}{|c|}{ 1. Billion tonne-km } \\
\hline Country & Rail & Road & Water & Air & Pipeline & Total \\
\hline China & $1,157.5$ & 375.5 & $1,325.6$ & 1.3 & 61.7 & $2,921.6$ \\
\hline India* & 232.3 & 2727 & - & & - & 505.0 \\
\hline Japan & 26.7 & 281.6 & 248.0 & 0.8 & - & 557.1 \\
\hline USA & $1,781.2$ & $1,311.3$ & 730.5 & 17.7 & 918.7 & $4,759.4$ \\
\hline FSU & $2,326.0$ & 64.8 & 660.0 & 25 & $1,051.1$ & $4,104.4$ \\
\hline
\end{tabular}

\begin{tabular}{|lrrrrrr|}
\hline 2. Shares & & & & & & \\
Country & Rail & Road & Water & Air & Pipeline & Total \\
\hline China & $39.6 \%$ & $12.9 \%$ & $45.4 \%$ & $0.05 \%$ & $2.1 \%$ & $100.0 \%$ \\
India* & $46.0 \%$ & $54.0 \%$ & - & - & - & $100.0 \%$ \\
Japan & $4.8 \%$ & $50.5 \%$ & $44.5 \%$ & $0.1 \%$ & - & $100.0 \%$ \\
USA & $37.4 \%$ & $27.6 \%$ & $15.3 \%$ & $0.4 \%$ & $19.3 \%$ & $100.0 \%$ \\
FSU & $56.7 \%$ & $1.6 \%$ & $16.1 \%$ & $0.06 \%$ & $25.6 \%$ & $100.0 \%$ \\
\hline
\end{tabular}

\begin{tabular}{|lrrrrrr|}
\hline 3. Tonne-km per capita & & & & & \\
Country & Rail & Road & Water & Air & Pipeline & Total \\
\hline China & 988 & 320 & 1131 & 1 & 53 & 2,493 \\
India* & 286 & 336 & - & - & - & 622 \\
Japan & 215 & 2,271 & 2,000 & 7 & - & 4,493 \\
USA & 6,985 & 5,142 & 2,865 & 69 & 3,603 & 18,664 \\
FSU & 15,610 & 435 & 4,429 & 17 & 7,055 & 27,546 \\
\hline
\end{tabular}

* 1989 data

Source: China - Transportation Statistical Yearbook of China 1994; India - LDC Energy Database, International Energy Studies Group, EAP, LBL, 1995; Japan - Energy Economics Institute of Japan, 1994; USA — US Department of Commerce, 1994. 
Figure IX-19. Freight Traffic, Selected Countries, 1992

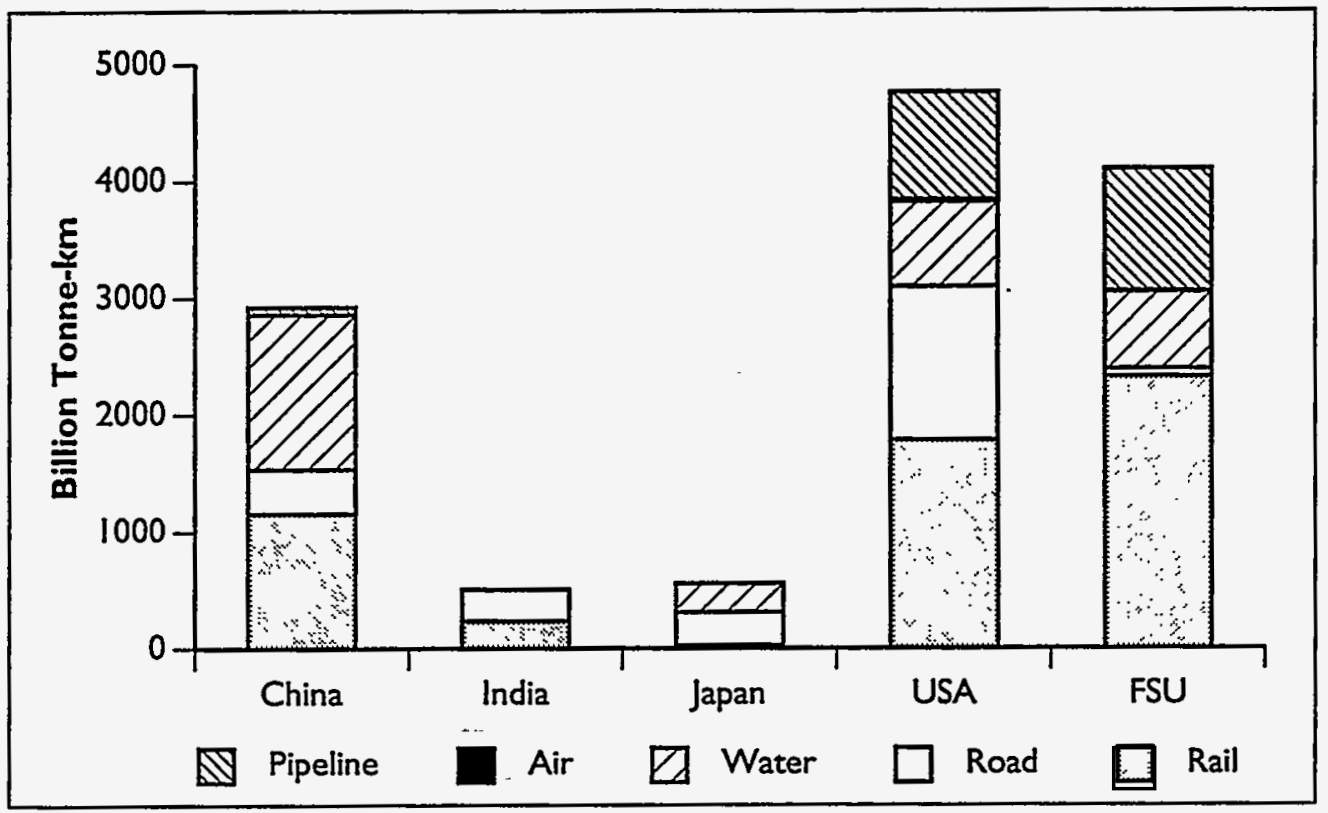

Figure IX-20. Per Capita Freight Traffic by Mode, 1992

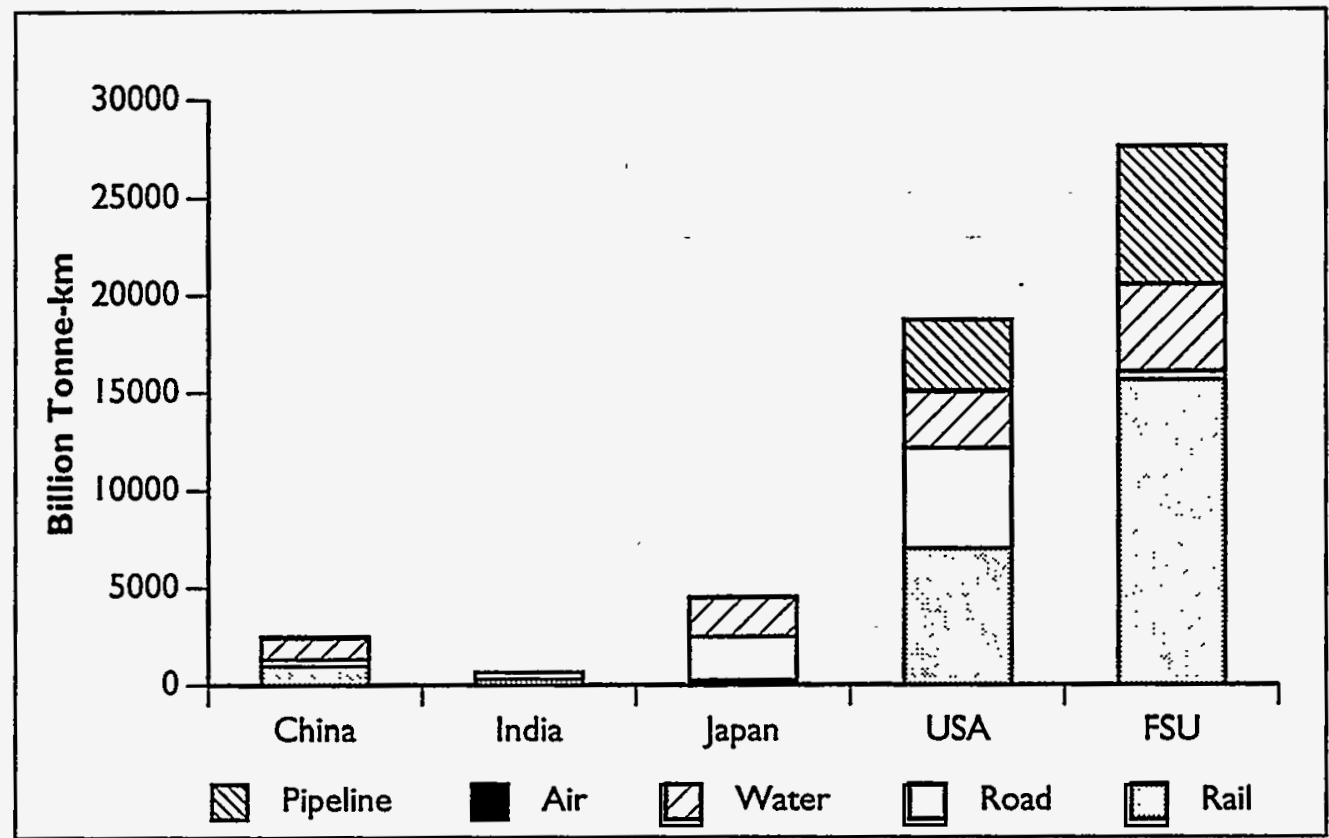


Table IX-24. Carbon Dioxide Emissions from Fossil Fuel Combustion, Cement Production, and Gas Flaring, 1950-1991

\begin{tabular}{|c|c|c|c|c|c|c|}
\hline \multicolumn{7}{|c|}{ 1. Mt of Carbon } \\
\hline Year & China & India & Japan & USA & FSU & $\begin{array}{l}\text { Global } \\
\text { Total }\end{array}$ \\
\hline 1950 & 22 & 18 & 28 & 696 & 186 & 1,638 \\
\hline 1951 & 28 & 19 & 34 & 717 & 201 & 1,775 \\
\hline 1952 & 35 & 20 & 36 & 698 & 216 & 1,803 \\
\hline 1953 & 37 & 21 & 40 & 715 & 228 & 1,848 \\
\hline 1954 & 45 & 22 & 39 & 681 & 249 & 1,871 \\
\hline 1955 & 53 & 24 & 39 & 746 & 283 & 2,050 \\
\hline 1956 & 60 & 24 & 44 & 782 & 310 & 2,185 \\
\hline 1957 & 71 & 27 & 52 & 775 & 339 & 2,278 \\
\hline 1958 & 145 & 29 & 50 & 751 & 362 & 2,338 \\
\hline 1959 & 199 & 30 & 53 & 781 & 380 & 2.471 \\
\hline 1960 & 215 & 33 & 64 & 800 & 396 & 2,586 \\
\hline 1961 & 152 & 36 & 78 & 802 & 409 & 2,602 \\
\hline 1962 & 121 & 40 & 80 & 832 & 429 & 2,708 \\
\hline 1963 & 120 & 42 & 89 & 876 & 460 & 2,855 \\
\hline 1964 & 120 & 41 & 99 & 913 & 489 & 3.016 \\
\hline 1965 & $|3|$ & 46 & 106 & 948 & 519 & 3,154 \\
\hline 1966 & 144 & 47 & 115 & 1,000 & 548 & 3.314 \\
\hline 1967 & 119 & 47 & 134 & 1,039 & 573 & 3,420 \\
\hline 1968 & 129 & 52 & 154 & 1,082 & 589 & 3.596 \\
\hline 1969 & 159 & 52 & 179 & 1,132 & 613 & 3,809 \\
\hline 1970 & 212 & 53 & 203 & 1,166 & 628 & 4,091 \\
\hline 1971 & 241 & 56 & 210 & 1,173 & 667 & 4,242 \\
\hline 1972 & 256 & 59 & 225 & 1,227 & 701 & 4,409 \\
\hline 1973 & 266 & 61 & 251 & 1,275 & 731 & 4,648 \\
\hline 1974 & 271 & 64 & 244 & 1,231 & 758 & 4,656 \\
\hline 1975 & 314 & 69 & 234 & 1,179 & 796 & 4,629 \\
\hline 1976 & 328 & 72 & 239 & 1,262 & 828 & 4,895 \\
\hline 1977 & 366 & 87 & 252 & 1,270 & 857 & 5,034 \\
\hline 1978 & 407 & 87 & 251 & 1,293 & 883 & 5,082 \\
\hline 1979 & 416 & 91 & 260 & 1,301 & 891 & 5,366 \\
\hline 1980 & 406 & 96 & 255 & 1,262 & 923 & 5,292 \\
\hline 1981 & 403 & 103 & 250 & 1,213 & 908 & 5.121 \\
\hline 1982 & 432 & 109 & 245 & 1,152 & 929 & 5,081 \\
\hline 1983 & 455 & 119 & 240 & 1,158 & 944 & 5,072 \\
\hline 1984 & 495 & 123 & 264 & 1,194 & 952 & 5,237 \\
\hline 1985 & 537 & 134 & 254 & 1,218 & 1,033 & 5,413 \\
\hline 1986 & 564 & 144 & 249 & 1,237 & 1,034 & 5,601 \\
\hline 1987 & 603 & 152 & 247 & 1,283 & 1,077 & 5,727 \\
\hline 1988 & 646 & 164 & 270 & 1,357 & 1,109 & 5,953 \\
\hline 1989 & 657 & 179 & 281 & 1,370 & 1,082 & 6.068 \\
\hline 1990 & 661 & 184 & 295 & 1,347 & 1.013 & 6.098 \\
\hline 1991 & 694 & 192 & 298 & 1,346 & 977 & 6,188 \\
\hline
\end{tabular}

Source: The Carbon Dioxide Information Analysis Center, ORNL, 1994. 
Figure IX-21. Carbon Dioxide Emissions

USA, USSR, China, India, Japan

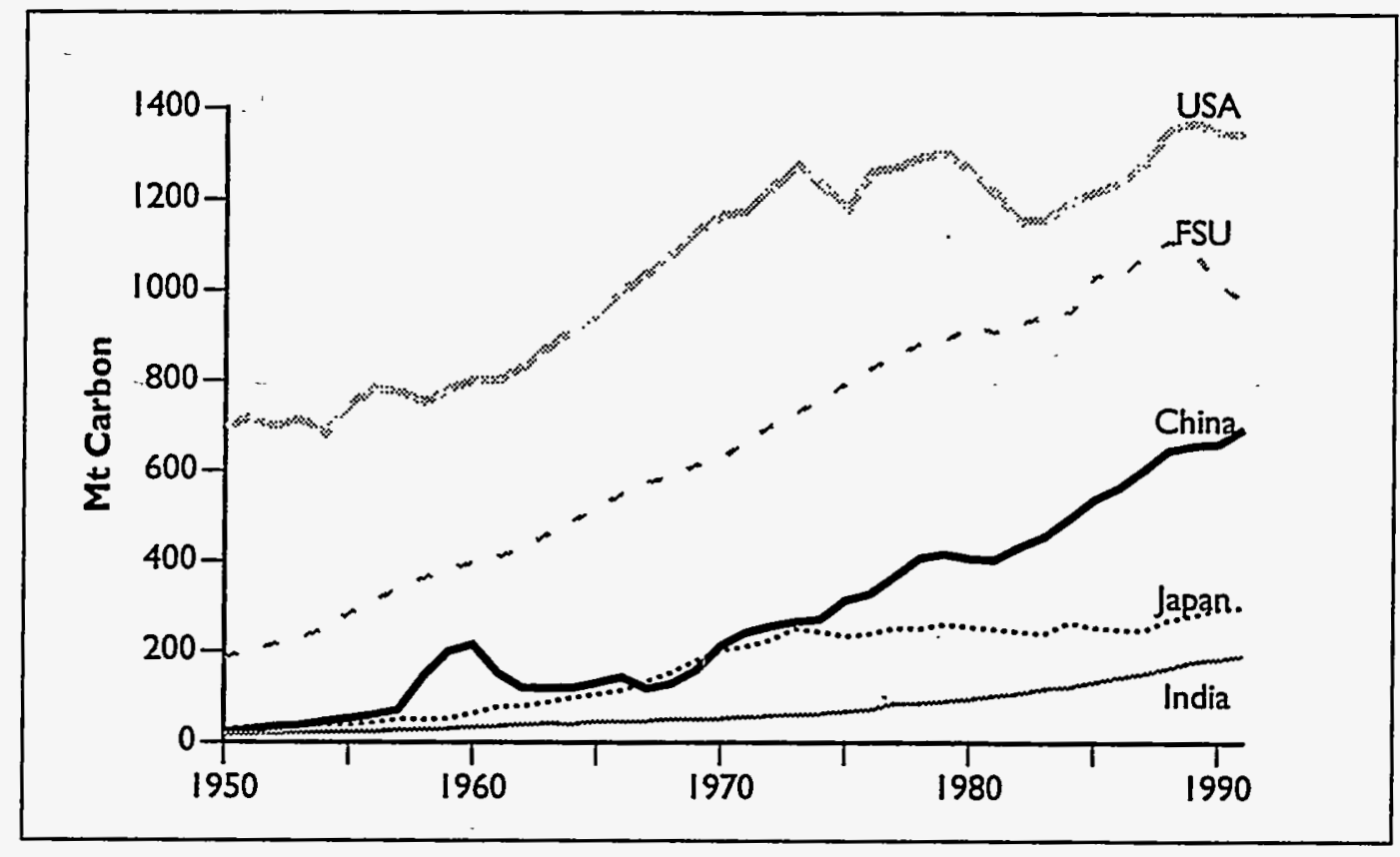


Table IX-24. Carbon Dioxide Emissions from Fossil Fuel Combustion, Cement Production, and Gas Flaring, 1950-1991 (continued)

\begin{tabular}{|c|c|c|c|c|c|c|}
\hline \multicolumn{7}{|c|}{ 2. Shares } \\
\hline Year & China & India & Japan & USA & FSU & $\begin{array}{l}\text { Global } \\
\text { Total }\end{array}$ \\
\hline 1950 & $1 \%$ & $1 \%$ & $2 \%$ & $42 \%$ & $11 \%$ & $100 \%$ \\
\hline 1951 & $2 \%$ & $1 \%$ & $2 \%$ & $40 \%$ & $11 \%$ & $100 \%$ \\
\hline 1952 & $2 \%$ & $1 \%$ & $2 \%$ & $39 \%$ & $12 \%$ & $100 \%$ \\
\hline 1953 & $2 \%$ & $1 \%$ & $2 \%$ & $39 \%$ & $12 \%$ & $100 \%$ \\
\hline 1954 & $2 \%$ & $1 \%$ & $2 \%$ & $36 \%$ & $13 \%$ & $100 \%$ \\
\hline 1955 & $3 \%$ & $1 \%$ & $2 \%$ & $36 \%$ & $14 \%$ & $100 \%$ \\
\hline 1956 & $3 \%$ & $1 \%$ & $2 \%$ & $36 \%$ & $14 \%$ & $100 \%$ \\
\hline 1957 & $3 \%$ & $1 \%$ & $2 \%$ & $34 \%$ & $15 \%$ & $100 \%$ \\
\hline 1958 & $6 \%$ & $1 \%$ & $2 \%$ & $32 \%$ & $15 \%$ & $100 \%$ \\
\hline 1959 & $8 \%$ & $1 \%$ & $2 \%$ & $32 \%$ & $15 \%$ & $100 \%$ \\
\hline 1960 & $8 \%$ & $1 \%$ & $2 \%$ & $31 \%$ & $15 \%$ & $100 \%$ \\
\hline 1961 & $6 \%$ & $1 \%$ & $3 \%$ & $31 \%$ & $16 \%$ & $100 \%$ \\
\hline 1962 & $4 \%$ & $1 \%$ & $3 \%$ & $31 \%$ & $16 \%$ & $100 \%$ \\
\hline 1963 & $4 \%$ & $1 \%$ & $3 \%$ & $31 \%$ & $16 \%$ & $100 \%$ \\
\hline 1964 & $4 \%$ & $1 \%$ & $3 \%$ & $30 \%$ & $16 \%$ & $100 \%$ \\
\hline 1965 & $4 \%$ & $1 \%$ & $3 \%$ & $30 \%$ & $16 \%$ & $100 \%$ \\
\hline 1966 & $4 \%$ & $1 \%$ & $3 \%$ & $30 \%$ & $17 \%$ & $100 \%$ \\
\hline 1967 & $3 \%$ & $1 \%$ & $4 \%$ & $30 \%$ & $17 \%$ & $100 \%$ \\
\hline 1968 & $4 \%$ & $1 \%$ & $4 \%$ & $30 \%$ & $16 \%$ & $100 \%$ \\
\hline 1969 & $4 \%$ & $1 \%$ & $5 \%$ & $30 \%$ & $16 \%$ & $100 \%$ \\
\hline 1970 & $5 \%$ & $1 \%$ & $5 \%$ & $28 \%$ & $15 \%$ & $100 \%$ \\
\hline 1971 & $6 \%$ & $1 \%$ & $5 \%$ & $28 \%$ & $16 \%$ & $100 \%$ \\
\hline 1972 & $6 \%$ & $1 \%$ & $5 \%$ & $28 \%$ & $16 \%$ & $100 \%$ \\
\hline 1973 & $6 \%$ & $1 \%$ & $5 \%$ & $27 \%$ & $16 \%$ & $100 \%$ \\
\hline 1974 & $6 \%$ & $1 \%$ & $5 \%$ & $26 \%$ & $16 \%$ & $100 \%$ \\
\hline 1975 & $7 \%$ & $1 \%$ & $5 \%$ & $25 \%$ & $17 \%$ & $100 \%$ \\
\hline 1976 & $7 \%$ & $1 \%$ & $5 \%$ & $26 \%$ & $17 \%$ & $100 \%$ \\
\hline 1977 & $7 \%$ & $2 \%$ & $5 \%$ & $25 \%$ & $17 \%$ & $100 \%$ \\
\hline 1978 & $8 \%$ & $2 \%$ & $5 \%$ & $25 \%$ & $17 \%$ & $100 \%$ \\
\hline 1979 & $8 \%$ & $2 \%$ & $5 \%$ & $24 \%$ & $17 \%$ & $100 \%$ \\
\hline 1980 & $8 \%$ & $2 \%$ & $5 \%$ & $24 \%$ & $17 \%$ & $100 \%$ \\
\hline $198 \mid$ & $8 \%$ & $2 \%$ & $5 \%$ & $24 \%$ & $18 \%$ & $100 \%$ \\
\hline 1982 & $8 \%$ & $2 \%$ & $5 \%$ & $23 \%$ & $18 \%$ & $100 \%$ \\
\hline 1983 & $9 \%$ & $2 \%$ & $5 \%$ & $23 \%$ & $19 \%$ & $100 \%$ \\
\hline 1984 & $9 \%$ & $2 \%$ & $5 \%$ & $23 \%$ & $18 \%$ & $100 \%$ \\
\hline 1985 & $10 \%$ & $2 \%$ & $5 \%$ & $22 \%$ & $19 \%$ & $100 \%$ \\
\hline 1986 & $10 \%$ & $3 \%$ & $4 \%$ & $22 \%$ & $18 \%$ & $100 \%$ \\
\hline 1987 & $11 \%$ & $3 \%$ & $4 \%$ & $22 \%$ & $19 \%$ & $100 \%$ \\
\hline 1988 & $11 \%$ & $3 \%$ & $5 \%$ & $23 \%$ & $19 \%$ & $100 \%$ \\
\hline 1989 & $11 \%$ & $3 \%$ & $5 \%$ & $23 \%$ & $18 \%$ & $100 \%$ \\
\hline 1990 & $11 \%$ & $3 \%$ & $5 \%$ & $22 \%$ & $17 \%$ & $100 \%$ \\
\hline 1991 & $11 \%$ & $3 \%$ & $5 \%$ & $22 \%$ & $16 \%$ & $100 \%$ \\
\hline
\end{tabular}

Source: The Carbon Dioxide Information Analysis Center, ORNL, 1994. 
Figure IX-22. Shares of Global CO2 Emissions, USA, USSR, China, Japan and India,

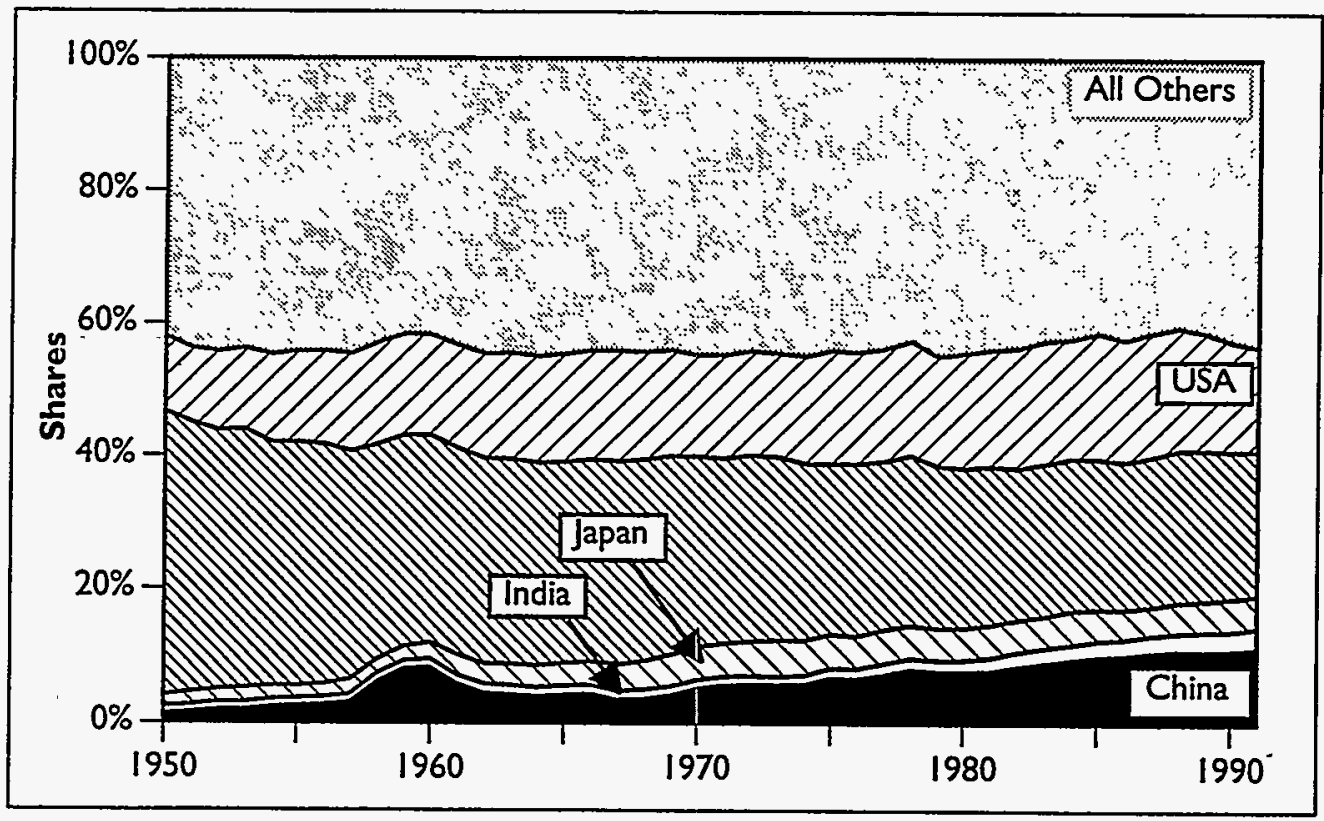


Table IX-24. Carbon Dioxide Emissions from Fossil Fuel Combustion, Cement Production, and Gas Flaring, 1950-1991 (continued)

\begin{tabular}{|c|c|c|c|c|c|c|}
\hline \multicolumn{7}{|c|}{ 3. Per Capita Emissions, tonnes of carbon } \\
\hline Year & China & India & Japan & USA & FSU & $\begin{array}{l}\text { Global } \\
\text { Total }\end{array}$ \\
\hline 1950 & 0.04 & 0.05 & 0.3 & 4.6 & 1.0 & 0.65 \\
\hline $195 \mid$ & 0.05 & 0.05 & 0.4 & 4.4 & 1.1 & 0.69 \\
\hline 1952 & 0.06 & 0.05 & 0.4 & 4.4 & 1.2 & 0.69 \\
\hline 1953 & 0.06 & 0.05 & 0.5 & 4.5 & 1.2 & 0.70 \\
\hline 1954 & 0.08 & 0.06 & 0.4 & 4.2 & 1.3 & 0.69 \\
\hline 1955 & 0.09 & 0.06 & $0.4^{\circ}$ & 4.5 & 1.4 & 0.74 \\
\hline 1956 & 0.10 & 0.06 & 0.5 & 4.6 & 1.6 & 0.78 \\
\hline 1957 & 0.11 & 0.07 & 0.6 & 4.5 & 1.7 & 0.80 \\
\hline 1958 & 0.23 & 0.07 & 0.5 & 4.3 & 1.7 & 0.80 \\
\hline 1959 & 0.31 & 0.07 & 0.6 & 4.4 & 1.8 & 0.83 \\
\hline 1960 & 0.33 & 0.08 & 0.7 & 4.4 & 1.8 & 0.86 \\
\hline 1961 & 0.24 & 0.08 & 0.8 & 4.4 & 1.9 & 0.85 \\
\hline 1962 & 0.19 & 0.09 & 0.8 & 4.5 & 1.9 & 0.86 \\
\hline 1963 & 0.18 & 0.09 & 0.9 & 4.6 & 20 & 0.89 \\
\hline 1964 & 0.17 & 0.09 & 1.0 & 4.8 & 2.1 & 0.92 \\
\hline 1965 & 0.18 & 0.09 & 1.1 & 4.9 & 22 & 0.95 \\
\hline 1966 & 0.20 & 0.09 & 1.2 & 5.1 & 2.3 & 0.97 \\
\hline 1967 & 0.16 & 0.09 & 1.4 & 5.2 & 24 & 0.98 \\
\hline 1968 & 0.17 & 0.10 & 1.5 & 5.4 & 25 & 1.01 \\
\hline 1969 & 0.20 & 0.10 & 1.8 & 5.6 & 2.5 & 1.05 \\
\hline 1970 & 0.26 & 0.10 & 2.0 & 5.7 & 26 & 1.11 \\
\hline 1971 & 0.29 & 0.10 & 2.0 & 5.7 & 2.7 & 1.12 \\
\hline 1972 & 0.30 & 0.10 & 2.1 & 5.9 & 28 & 1.15 \\
\hline 1973 & 0.30 & $0.10^{\prime}$ & 2.3 & 6.0 & 2.9 & 1.18 \\
\hline 1974 & 0.30 & 0.10 & 22 & 5.8 & 3.0 & 1.16 \\
\hline 1975 & 0.34 & 0.11 & 2.1 & 5.5 & 3.1 & 1.13 \\
\hline 1976 & 0.35 & 0.11 & 2.1 & 5.8 & 3.2 & 1.18 \\
\hline 1977 & 0.39 & 0.13 & 22 & 5.8 & 3.3 & 1.19 \\
\hline 1978 & 0.43 & 0.13 & 2.2 & 5.8 & 3.4 & 1.18 \\
\hline 1979 & 0.43 & 0.13 & 2.2 & 5.8 & 3.4 & 1.23 \\
\hline 1980 & 0.42 & 0.14 & 2.2 & 5.5 & 3.5 & 1.19 \\
\hline 1981 & 0.41 & 0.15 & 2.1 & 5.3 & 3.4 & 1.13 \\
\hline 1982 & 0.43 & 0.15 & 2.1 & 5.0 & 3.4 & 1.10 \\
\hline 1983 & 0.45 & 0.16 & 20 & 4.9 & 3.5 & 1.08 \\
\hline 1984 & 0.48 & 0.16 & 2.2 & 5.1 & 3.5 & 1.10 \\
\hline 1985 & 0.51 & 0.18 & 2.1 & 5.1 & 3.7 & 1.12 \\
\hline 1986 & 0.53 & 0.18 & 2.1 & 5.1 & 3.7 & 1.13 \\
\hline 1987 & 0.56 & 0.19 & 2.0 & 5.3 & 3.8 & 1.14 \\
\hline 1988 & 0.59 & 0.20 & 2.2 & 5.5 & 3.9 & 1.16 \\
\hline 1989 & 0.59 & 0.22 & 2.3 & 5.5 & 3.8 & 1.17 \\
\hline 1990 & 0.58 & 0.22 & 2.4 & 5.4 & 3.5 & 1.15 \\
\hline 1991 & 0.60 & 0.22 & 2.4 & 5.3 & 3.4 & 1.15 \\
\hline
\end{tabular}

Source:The Carbon Dioxide Information Analysis Center, ORNL, 1994. 
Figure IX-23. Per Capita CO2 Emissions, USA, USSR, China, Japan and India, 1950-1988

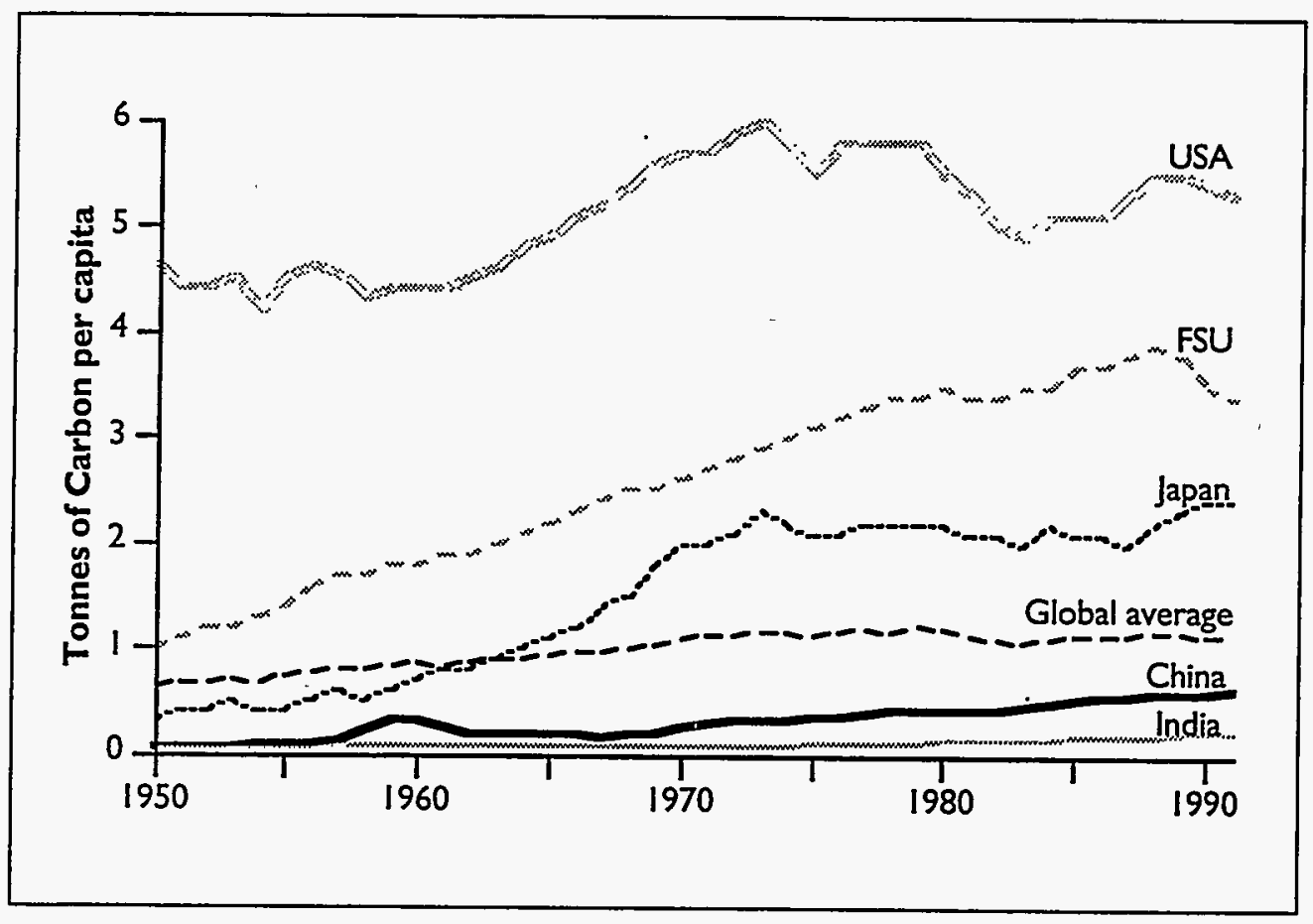


Table IX-25. GDP Structure * for Selected Countries for Selected Years

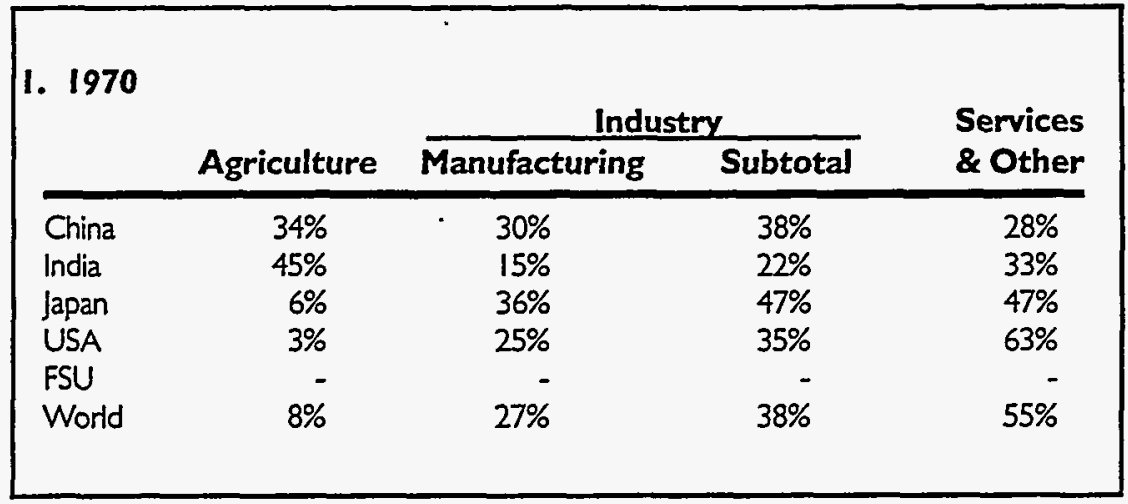

\begin{tabular}{|lrrrrr}
\hline 2. 1980 & & \multicolumn{2}{c|}{ Industry } & Services \\
\cline { 3 - 6 } & Agriculture & Manufacturing & Subtotal & \& Other \\
\hline China & $36 \%$ & - & - & $49 \%$ & $15 \%$ \\
India & $38 \%$ & - & $26 \%$ & $36 \%$ \\
Japan & $4 \%$ & - & $42 \%$ & $54 \%$ \\
USA & $3 \%$ & - & $34 \%$ & $64 \%$ \\
FSU & $14 \%$ & - & $37 \%$ & $49 \%$ \\
World & - & - & - & - \\
\hline
\end{tabular}

\begin{tabular}{|lccccc|}
\hline \multirow{2}{*}{ 3. 1987} & & \multicolumn{2}{c}{ Industry } & & $\begin{array}{c}\text { Services } \\
\text { \& Other }\end{array}$ \\
\cline { 3 - 5 } & Agriculture & Manufacturing & Subtotal & \\
\hline China & $30 \%$ & - & $52 \%$ & $17 \%$ \\
India & $30 \%$ & - & $31 \%$ & $39 \%$ \\
Japan & $3 \%$ & - & $45 \%$ & $52 \%$ \\
USA & $3 \%$ & - & $33 \%$ & $65 \%$ \\
FSU & $18 \%$ & - & $34 \%$ & $48 \%$ \\
Worid & - & - & - & - \\
\hline
\end{tabular}

\begin{tabular}{|lrrrrr|}
\hline \multirow{2}{*}{ 4. 1993} & \multicolumn{4}{c}{ Industry } & Services \\
\cline { 3 - 5 } & Agriculture & Manufacturing & Subtotal & \& Other \\
\hline China & $19 \%$ & $38 \%$ & $48 \%$ & $33 \%$ \\
India & $31 \%$ & $17 \%$ & $27 \%$ & $41 \%$ \\
Japan & $2 \%$ & $24 \%$ & $41 \%$ & $57 \%$ \\
USA & - & - & - & - \\
Russian Fed. & $9 \%$ & - & $51 \%$ & $39 \%$ \\
World & - & - & - & - \\
\hline
\end{tabular}

- Based on current price series. Data for China are different from those that appear in Chapter X of this volume because sources are different. Source: World Bank, 1990 and 1995; United Nations, 1992; International Energy Studies Group, EAP, LBNL. 
Figure IX-24. GDP Structure, Selected Countries, 1980

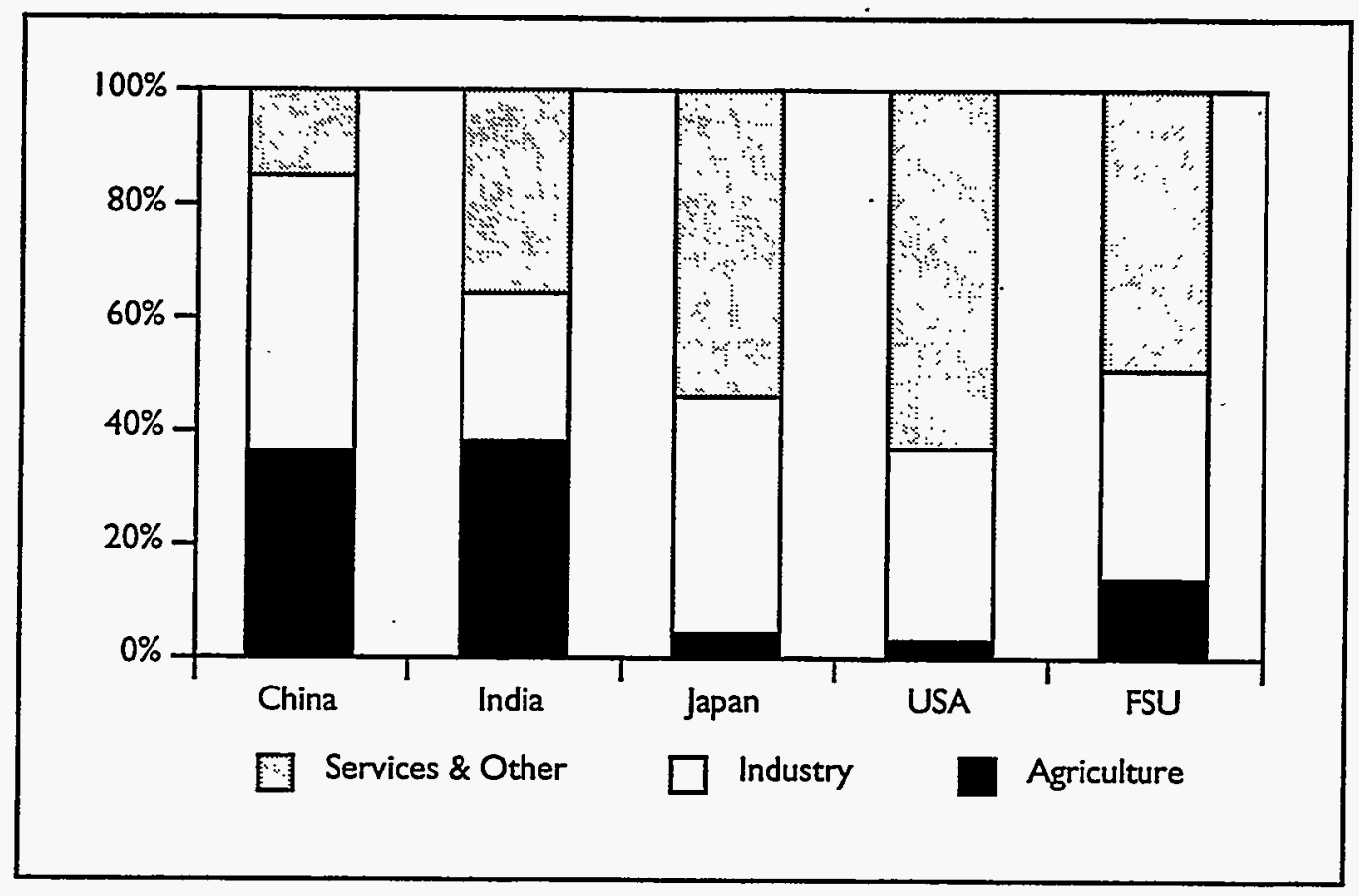

Figure IX-25. GDP Structure, Selected Countries, 1993

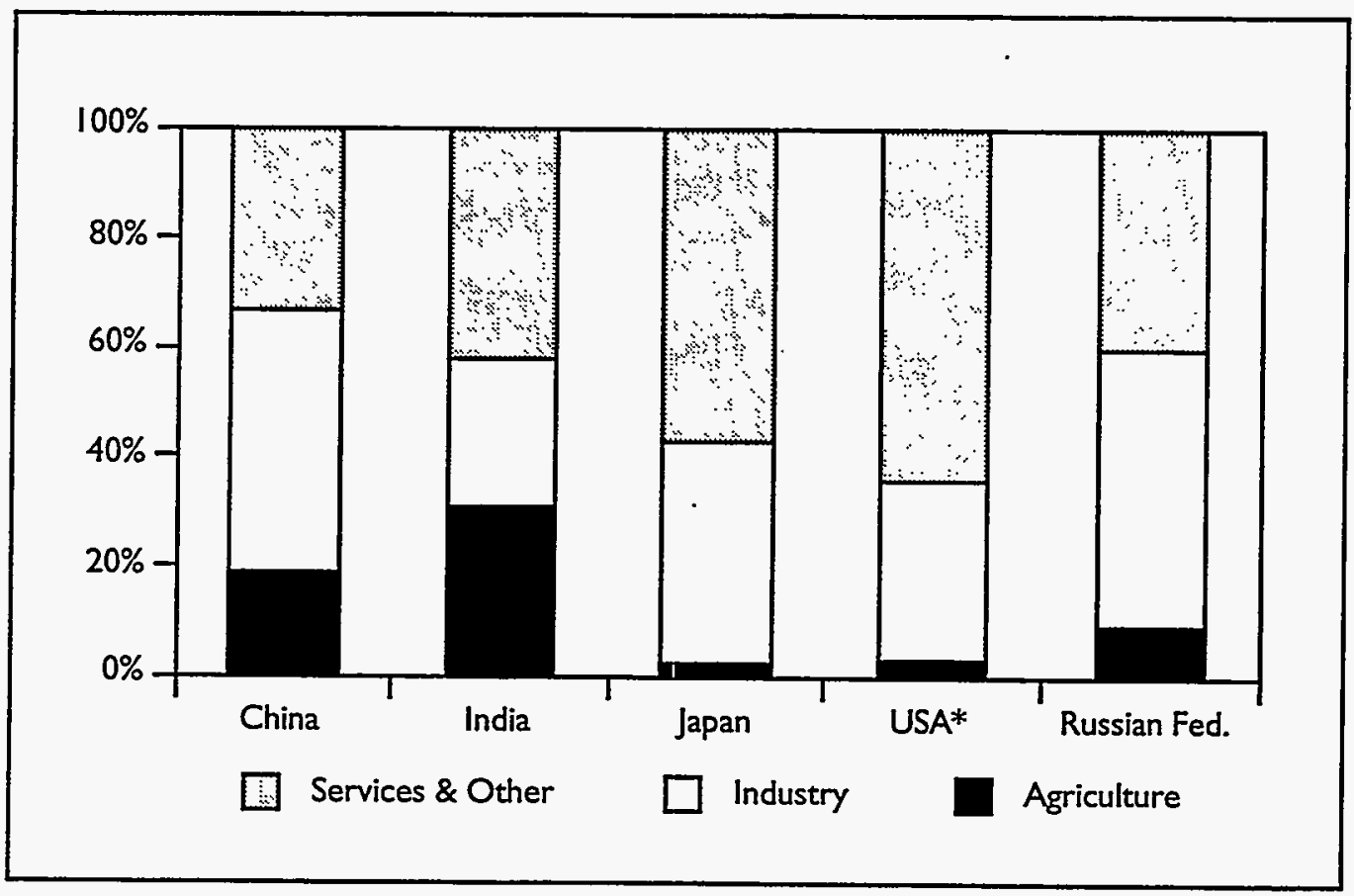


Table IX-26. Population for Selected Countries-Millions

\begin{tabular}{|ccccccc|}
\hline Year & China & India & Japan & USA & FSU* & World Total \\
\hline 1968 & 775 & 523 & 101 & 201 & - & - \\
1969 & 796 & 535 & 103 & 203 & - & - \\
\hline 1970 & 818 & 548 & 104 & 205 & 242 & - \\
1971 & 841 & 560 & 106 & 208 & - & - \\
1972 & 862 & 573 & 107 & 210 & - & - \\
1973 & 882 & 586 & 108 & 212 & - & - \\
1974 & 900 & 600 & 110 & 214 & - & - \\
1975 & 916 & 613 & 112 & 216 & 253 & - \\
1976 & 931 & 628 & 113 & 218 & - & - \\
1977 & 944 & 643 & 114 & 220 & - & - \\
1978 & 956 & 657 & 115 & 223 & - & - \\
1979 & 969 & 672 & 116 & 225 & - & - \\
\hline 1980 & 981 & 687 & 117 & 228 & & 4,453 \\
1981 & 1,008 & 690 & 118 & 230 & 268 & - \\
1982 & 1,021 & 705 & 118 & 232 & 270 & - \\
1983 & 1,033 & 720 & 119 & 234 & 272 & - \\
1984 & 1,046 & 736 & 120 & 236 & 275 & - \\
1985 & 1,060 & 751 & 121 & 238 & 277 & 4,837 \\
1986 & 1,074 & 766 & 121 & 241 & 280 & 4,917 \\
1987 & 1,090 & 781 & 122 & 243 & 283 & 5,024 \\
1988 & 1,106 & 797 & 123 & 245 & 285 & 5,115 \\
1989 & 1,112 & 812 & 123 & 247 & 288 & 5,201 \\
\hline 1990 & 1,139 & 827 & 124 & 250 & 289 & 5,284 \\
1991 & 1,150 & 867 & 124 & 253 & 149 & 5,351 \\
1992 & 1,162 & 884 & 125 & 255 & 149 & 5,438 \\
& & & & & & \\
& & & & & & \\
\hline
\end{tabular}

* 1970 and 1975 Soviet Union data from Intemational Energy Studies Group, EAP, LBNL. 1991-1992 data for Russian Federation only.

Source: World Bank, 1990 and 1994; Intemational Energy Studies Group, EAP, LBNL. 


\section{Chapter X-Economic Indicators and Population}




\section{Economic / Population}

$\mathrm{S}$ ince the late 1970s China's gross national product has risen quickly, at an average annual rate of $9.3 \%$, nearly quadrupling in the 15 years from 1978 to 1993 (Table X-1). ${ }^{1}$ Growth was fastest in the mid-1980s and in the years since 1990. Most growth came from the industrial sector, ${ }^{2}$ the share in gross domestic product of which grew from $46 \%$ in 1978 to $60 \%$ in 1993 . Growth rates in the services sector were also high, although its share peaked at $25 \%$ in 1989 and is now down to $21 \%$, the same level as 15 years ago. Agriculture's contribution to gross domestic product has shrunk by more than half to under $17 \%$.

\section{Gross National Product}

Because of population growth, per capita gross national product rose more slowly than the total, averaging $8.3 \%$ per year between 1978 and 1993 (and over 10\% after 1990), to 2,645 yuan in 1993, or US $\$ 459$ (Table X-2). ${ }^{3}$ Growth rates were depressed to under $3 \%$ in 1989 and 1990 during a recessionary slowdown resulting in part from government deflationary monetary policies.

Regional distribution of gross domestic product roughly follows that of per capita energy use (Table $\mathrm{X}-3$ ). Shanghai, Beijing, Tianjin, and the coastal provinces generally enjoy the highest gross domestic product per capita (over 4,500 yuan - or US $\$ 780$ - per person in 1993), while inland provinces tend to be poorer. The gap between rich and poor areas is widening very quickly; per capita output in Shanghai was seven times that in the poorest province, Guizhou, in 1990, and more than nine times larger in 1993.

\section{Gross Output Value}

In some ways gross output value is a less desirable measure of economic activity than gross national product. Unlike gross national product, gross output value double counts by including the value of intermediate goods and services and is conse- quently about twice as large as gross national product. In some cases, however, gross output value data may be more useful in constructing energy intensity indicators than value-added indicators like gross national product or national income. ${ }^{4}$ Unfortunately, China no longer publishes gross output value for all economic sectors; beginning with 1993 only agricultural and industrial sector statistics are available.

Trends in gross output value since 1952 have been similar to those in energy production and consumption (Table X-4). The structure of gross output value has changed considerably over the past 40 years. In 1952 agriculture accounted for nearly twothirds of the total and industry only one-fifth. In 1992 the situation was the reverse, with industry taking $76 \%$ and agriculture $12 \%$.

Gross output value statistics for the industrial sector make clear how deeply the economic system reforms of the past decade and a half have affected ownership structure. In 1980 state-owned enterprises accounted for three quarters of industrial output, and collectives of various sorts for nearly all the rest (Table X-5). By 1993 the picture was very different; state-owned enterprises accounted for only $43 \%$ of output, a share that was dropping at five percentage points a year. Rural industry including units run by local governments, collectives, and private individuals - was responsible for by far the largest share of growth in output. Foreign and domestic joint ventures have become a significant economic force as well, with a share that grew from less than $1 \%$ in the early 1980 s to over $10 \%$ in 1993. Foreign joint ventures have been a major factor in the rapid growth of China's exports over this period.

\section{NATIONAL INCOME}

National income is probably the indicator closest in accounting terms to gross national product. 5 The structure of national income and trends since 1978 are very similar to those of gross national product, 
and data are available for years beginning in 1952 (Table X-6). Assuming that this relationship has always held true, national income is probably the best replacement for gross national product in conducting historical comparisons. In this volume we have used deflators derived from national income data in converting current yuan to constant yuan. Regional and sectoral patterns of national income distribution are similar to those of gross national product and gross domestic product (Table X-7).

\section{Population}

By 1993 China's population had reached at least 1.185 billion. ${ }^{6}$ The population remains mainly rural, with only about $23 \%$ living in urban areas (Table X-8). ${ }^{7}$ The urban population, however, has been increasing much faster than the rural population, due in part to migration and in part to expansion and reclassification of rural towns; there were 570 cities in China at the end of 1993, compared to fewer than 300 in the early 1980s. Population is overwhelmingly concentrated in the eastern and southern coastal provinces and inland in the Yangtze and Yellow River valleys, for some provinces exceeding 500 persons per $\mathrm{km}^{2}$. (Table X-9). Population in the Northeast and Southwest is somewhat less dense, and in the Northwest and West it is quite sparse.

Statistics on urban households show that rates of employment have been relatively steady, while average household size has decreased steadily, from 4.06 persons in 1983 to 3.31 persons in 1993 (Table $\mathrm{X}-10)$. Most household income is spent on commodities, with food and clothing together accounting for nearly $60 \%$. Because housing and utilities are still subsidized for the vast majority of urban residents, rent requires less than $2 \%$ of disposable income, as does energy (including fuel and electricity).

\section{Technical Note: China's System of NATIONAL ACCOUNTS}

The main sources of Chinese national accounts data are the China Statistical Yearbooks (Zhongguo Tongii Nianjian) and Almanacs of China's Economy (Zhongguo Jingji Nianjian) compiled by China's
State Statistical Bureau, and the World Tables which contain information from the data files of the World Bank. China's national accounts data differ from other countries' in statistical coverage and practice, although efforts have been under way for some time to bring accounts in line with international norms. Their primary measure of national wealth, national income, is comparable to the Material Product System concept of net material product. In order to facilitate intemational comparison, national income must be converted to the western System of National Accounts concept of gross domestic product. Using a methodology developed by the World Bank, China has begun to publish data on gross national product. China's State Statistical Bureau divides gross national product into primary, secondary, and tertiary industries, which are roughly comparable to the more conventional categories of agriculture, industry, and service sectors. The lack of coverage of the service sector, along with uneven coverage of rural industry in the Chinese data complicates the conversion of national income to gross national product. A further difficulty is the use of sectoral classifications which are different from the UN International Standard Industrial Classification.

\section{NET MATERIAL PRODUCT AND NATIONAL INCOME}

The Chinese definition of national income is approximately the same as the United Nations' net material product, i.e., the net output from five "material sectors" of the economy which intentionally excludes the service sector. As defined by the State Statistical Bureau, the difference between material and nonmaterial production is that all activities contributing to the production of goods are material; all other services are nonmaterial. Material production is divided into five sectors: agriculture, including animal husbandry, fishery, forestry, and water conservation; industry; construction; transportation; and commerce, including food service, and materials supply, marketing, and storage. The nonmaterial sector essentially includes all personal and most public services, for example health care, education, scientific research, government, and financial services.

The State Statistical Bureau has two different 
methods for calculating national income: the production approach ("national income produced"), and the distribution approach ("national income used"). The distribution approach identifies two stages, primary distribution and redistribution. Primary distribution, or national income distributed, is comprised of personal income from activities in material sectors and the net revenue of enterprises and undertakings in these sectors. Redistribution is the sum of consumption and accumulation (investment). In practice, the State Statistical Bureau supplements data on national income produced with data on national income distributed, resulting in a hybrid approach. Theoretically, the methods should yield the same aggregate figure after adjustment for the balance of foreign transactions. Problems with the quantity and quality of the data, however, lead to statistical discrepancies.

The State Statistical Bureau also calculates the "gross output value of society", which is the sum of the gross outputs of the five material sectors. This figure, of course, cannot be used as an indicator of national wealth since it double counts the value of the inputs, a problem particularly serious in the industrial sector.

\section{NATIONAL INCOME PRODUCED}

"National income produced" is the sum of the net output value of the five material sectors of the economy. Conceptually, to anive at the net output value of a sector the gross output value of the sector is first determined by multiplying the list price of goods by the quantity produced. Next deductions are made for depreciation and intermediate products and inputs to arrive at the value added or net output value. Finally the net output values from all five material sectors are summed to anive at national income produced.

\section{Industry}

For industrial output, the State Statistical Bureau estimates the gross output value by valuing the volume of output at list prices. Township (formerly commune) industry output is included while village (formerly brigade) level is excluded. To arrive at value added, the value of the inputs and depreciation should be deducted from the gross output value. Since detailed information is generally unavailable for production costs, however, the State Statistical Bureau uses an income approach by adding wages, fringe benefits, profits and other charges to estimate the value added.

\section{Agriculture}

Agriculture consists of three principal activities: crop growing, animal husbandry and sideline production (until 1985 village-level industry was included in the agricultural sector rather than the industrial sector). Gross output is valued at prices prevailing in the locality. Output procured by the state is valued at procurement prices as is output consumed. Net output value is calculating by deducting seed, fertilizer, insecticide, animal feed and equipment inputs as well as depreciation.

\section{Construction}

The gross output value of the construction sector covers the total cost of building "productive" and "nonproductive" (e.g., housing and hospitals) structures. As in the industrial sector, the State Statistical Bureau calculates the net output value by estimating depreciation and using the income approach to estimate the value added by labor.

\section{Transport and Communications}

This sector covers all modes of freight transportation - water, air, road and rail - as well as the postal and telecommunications services provided to the material sectors. Passenger transportation and outlays on private postal and telecommunications services are excluded. Again, the State Statistical Bureau uses an income approach to estimate value added.

\section{Commerce}

Commerce covers all wholesaling and retail- 
ing activities, including restaurants, which are viewed as an extension of material production. Value added is estimated either by taking the difference between purchases and sales, then deducting outlays on transportation, storage and packaging, office expenses and depreciation, or by the income approach.

\section{NATIONAL INCOME USED}

"National income used" is simply defined by the State Statistical Bureau as consumption plus accumulation (investment) and is theoretically equivalent to national income produced if exports are deducted and imports are added. This method attempts to track the distribution of income within the economy. Income is confined to the personal income and the net revenue of enterprises and undertakings from the five material sectors. Personal income consists of: wages and welfare benefits paid to workers; expenses incurred by enterprises for meeting health, education and welfare payments; and income in cash and in kind of agricultural workers and commune members, including income from sideline activities. Net revenue of enterprises includes profits, taxes and payments of interest, and for training workers.

The use of the income is subdivided into social and individual consumption and accumulation. Social consumption is comprised of government and communal consumption (including the expenditures by the state and enterprises on cultural, educational, public health and welfare services). Depreciation and minor repairs on private buildings, assets of government agencies, the armed forces and all nonproductive enterprises are included in consumption. Accumulation is further disaggregated into fixed accumulation and circulating assets. The former represents the part of the national product that leads to increases in fixed capital assets, while the latter comprises increases in inventories.

\section{GROWTH RATES}

The State Statistical Bureau publishes indices of economic indicators which are intended to reflect the ratio of the real value of the indicator in a given year to the real value in the base year. The indica- tor is assigned a value of 100 in the base year which is often 1952 (as is the case for national income). These indices can be used to construct deflators to a given base year. Tables of the indicator in current yuan can then be converted to constant yuan in the chosen base year. The implicit deflators are obtained by dividing the index number for the year of interest by the index number for the base year. For example, we calculated national income in constant yuan by the following formula:

national income in constant yuan =

base year national income in current yuan $x$ (current year index $\div$ base year index)

Because of problems with overreporting of production in the past, especially in the 1950s and 1960s, basing constant prices on 1980 indices, as we do here, gives an upward bias to older indicator values.

In some cases (e.g., for gross output value) values for indicators are given in terms of constant yuan by subperiods of about 10 years, with one year overlapping between subperiods so that comparisons between subperiods are possible.

\section{CHOICE OF INDICATOR FOR GROWTH RATES}

National income is about $20 \%$ lower than gross national product or gross domestic product figures due to two main differences: national income does not include the service sector, and national income subtracts depreciation. Because the State Statistical Bureau did not concentrate on collecting data on the service sector in the past, the figures for gross national product begin with 1978, whereas the State Statistical Bureau publishes figures for national income start at 1952, making the latter more attractive for describing long-term growth trends.

For descriptions of overall growth and the change in the structure of the economy, gross national product and gross domestic product give a truer picture because they include consumption of fixed assets and attempt to capture the service sector. The growth rate of national income, however, may be taken as approximately the same as the growth rates of gross national product and gross domestic product because, by the World Bank's estimates, the ratios of gross national product and gross domes- 
tic product to national income were the same in both 1957 and 1979.8 In terms of general quality of data, it is generally agreed that the statistics do reflect the trends in the economy. However, it is also recognized that statistical reporting was exaggerated during the Great Leap Forward and hence less confidence can be placed in these figures.

When determining growth trends in sectoral energy intensities for China, another macroeconomic indicator is used, i.e., gross output value. Despite the fact that gross output intensities will be quantitatively different from the "true" sector intensities calculated from the net output values, they are more likely to accurately reflect trends in energy intensities than those calculated from the net output value, since the ratio of the latter indicator to physical output probably fluctuates more over time. The State Statistical Bureau calculates net output by calculating the value added by the labor input minus wages, salaries, and social insurance. Even when properly deflated, however, the labor value input may not properly reflect physical net output because of changing productivity and deliberate underuse of labor inputs. Finally, the ratio of net output to physical output may change if production practices change. For instance a factory may begin to purchase from outside sources inputs that it had previously produced itself. The gross output to physical output ratio, on the other hand, is more likely to be constant and therefore is generally a better indicator to use for analyzing trends in energy intensity within subsectors. Aggregate energy intensities are calculated by weighting the sector intensities by energy shares rather than by gross output shares. If instead energy intensities were aggregated by gross output shares, the industrial sector trend would tend to be overweighted since that is where most of the double counting of output occurs

\footnotetext{
1 China only recently began to issue figures on gross national product. Gross national product data are available for years beginning in 1978, unlike data on some other economic indicators, which go back to the early 1950 s. See Technical Note.

2 In gross domestic product accounts the "secondary" sector includes mining, manufacturing, utilities, and construction.

3 Converted at the average 1993 official exchange rate of 5.76 yuan per US dollar. The yuan has since fallen against the dollar (as the Chinese government has taken steps towards making
}

the yuan fully convertible, including unifying the official and "swap" market exchange rates (January 1 1994) and abolishing Foreign Exchange Certificates, a convertible currency paralleling the nonconvertible Renminbi). As of August 1995 the exchange rate was about 8.31 yuan to the dollar.

The World Bank has published an adjusted per capita gross national product of China of US $\$ 490$ (also based on exchange rates) in $1993,11 \%$ of the world average, and $2 \%$ of that in the United States (World Bank, 1995). Using purchasing power parity estimates of gross national product, the same source shows that China's per capita output is much higher, equivalent to about 9\% of that in the United States in 1990.

${ }^{4}$ Gross output value may be the indicator most useful in tracking time trends within subsectors. The most reliable measures of energy intensity generally are based on units of physical output, but this is not possible for most industrial and other subsectors, and not easy to incorporate into aggregate indicators. One advantage of gross output value over value added in comparing energy intensities between years is that the former more directly measures production activity. Another advantage of gross output is that the calculation of value added, which is based on the deflated prices of inputs and outputs, introduces more error than the calculation of gross output value, which is based only on the prices of outputs. In studies of U.S. industries for which data on physical output were available, it was found that trends in energy intensity based on gross output value followed trends in physical energy intensity more closely than did those based on value added (Ross, 1992).

All aggregate indicators of energy intensity within sectors or whole economies are problematic, largely because of structural changes within sectors. Comparing time series of output statistics is possible so long as the degree of vertical integration among enterprises - and therefore transactions counted in output statistics - remains relatively constant, a troublesome assumption for China's changing economic system. This point should be kept in mind when using any of the aggregate data in this chapter in constructing energy intensity indices (or for any other purpose).

${ }^{5}$ Chinese national accounts define national income as the net output value (or value added) of the five "material production" sectors: agriculture, industry, transportation, construction, and commerce. It does not include value added in the "nonmaterial production" sectors, e.g., financial services, education, scientific research, etc. Gross national product is the sum of national income, value added in the "nonmaterial production" sectors, and depreciation of fixed assets. See the Technical Note at the end of this section.

6 Some analysts believe that China's official population statistics understate actual population by up to 100 million.

${ }^{7}$ Many of those classified as residents of urban areas actually inhabit rural counties under the administration of cities. According to this scheme $28 \%$ of China's populations lives in urban areas (before these figures were adjusted in 1991 official statistics reported that over half of China's population lived in urban areas). A more realistic figure for nural population is that based on household classification as "agricultural" and "nonagricultural" 8 World Bank, 1983. 
Table X-1. Gross National Product and Gross Domestic Product

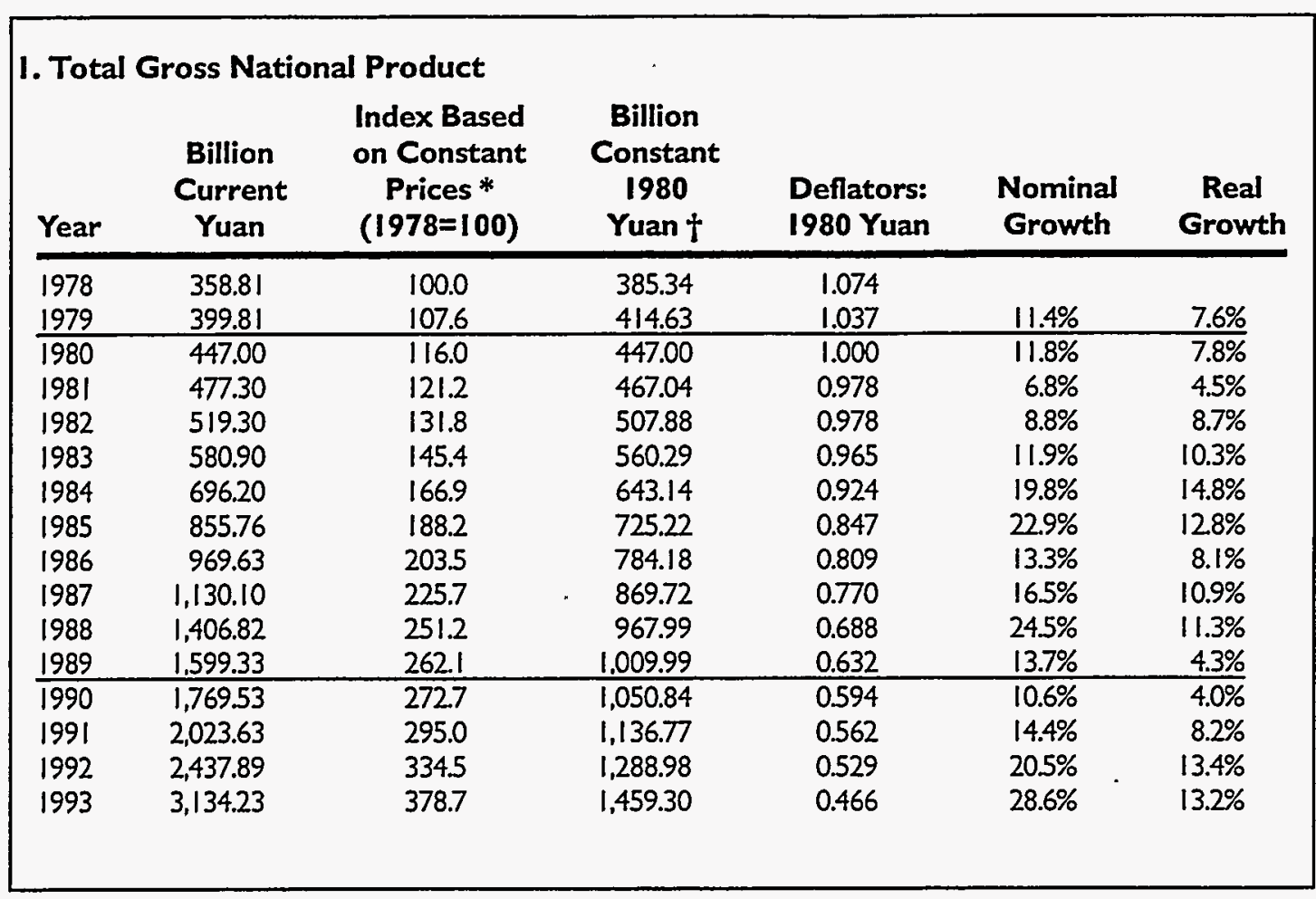

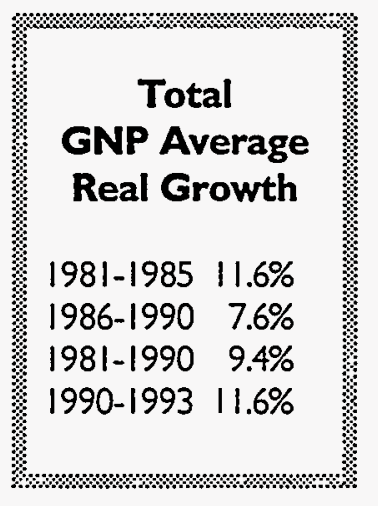

\begin{tabular}{|c|c|c|c|c|c|c|}
\hline \multicolumn{7}{|c|}{ 2. Total Gross Domestic Product } \\
\hline Year & $\begin{array}{l}\text { Billion } \\
\text { Current } \\
\text { Yuan }\end{array}$ & $\begin{array}{c}\text { Index Based } \\
\text { on Constant } \\
\text { Prices * } \\
(1978=100)\end{array}$ & $\begin{array}{c}\text { Billion } \\
\text { Constant } \\
1980 \\
\text { Yuant }\end{array}$ & $\begin{array}{l}\text { Sectoral } \\
\text { Share } \\
\text { (\% of } 1980 \\
\text { yuan total) }\end{array}$ & $\begin{array}{l}\text { Nominal } \\
\text { Growth }\end{array}$ & $\begin{array}{c}\text { Real } \\
\text { Growth }\end{array}$ \\
\hline 1978 & 358.81 & 100.0 & 385.34 & 1.074 & - & - \\
\hline 1979 & 399.81 & 107.6 & 414.63 & 1.037 & $11.4 \%$ & $7.6 \%$ \\
\hline 1980 & 447.00 & 116.0 & 447.00 & 1.000 & $11.8 \%$ & $7.8 \%$ \\
\hline 1981 & 477.51 & 121.2 & 467.04 & 0.978 & $6.8 \%$ & $4.5 \%$ \\
\hline 1982 & 518.23 & 131.5 & 506.73 & 0.978 & $8.5 \%$ & $8.5 \%$ \\
\hline 1983 & 578.70 & 144.9 & 558.36 & 0.965 & $11.7 \%$ & $10.2 \%$ \\
\hline 1984 & 692.82 & 166.0 & 639.67 & 0.923 & $19.7 \%$ & $14.6 \%$ \\
\hline 1985 & 852.74 & 187.4 & 72214 & 0.847 & $23.1 \%$ & $12.9 \%$ \\
\hline 1986 & 968.76 & 203.3 & 783.41 & 0.809 & $13.6 \%$ & $8.5 \%$ \\
\hline 1987 & $1,130.71$ & 225.9 & 870.49 & 0.770 & $16.7 \%$ & $11.1 \%$ \\
\hline 1988 & $1,407.42$ & 251.3 & 968.37 & 0.688 & $24.5 \%$ & $11.2 \%$ \\
\hline 1989 & $1,599.76$ & 262.2 & $1,010.37$ & 0.632 & $13.7 \%$ & $4.3 \%$ \\
\hline 1990 & $1,768.13$ & 272.4 & $1,049.68$ & 0.594 & $10.5 \%$ & $3.9 \%$ \\
\hline 1991 & $2,018.83$ & 294.2 & $1,133.68$ & 0.562 & $14.2 \%$ & $8.0 \%$ \\
\hline 1992 & $2,436.29$ & 334.2 & $1,287.82$ & 0.529 & $20.7 \%$ & $13.6 \%$ \\
\hline 1993 & $3,138.03$ & 379.0 & $1,460.46$ & 0.465 & $28.8 \%$ & $13.4 \%$ \\
\hline $1994 \pi$ & $4,380.00$ & 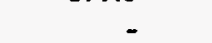 & $1,632.79$ & - & $39.6 \%$ & $11.8 \%$ \\
\hline
\end{tabular}

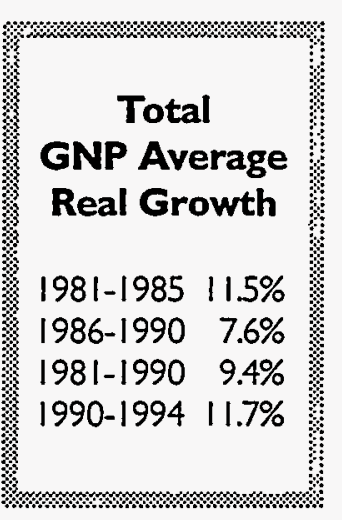

- These index numbers can be thought of as percentages, e.g., at constant prices, GNP in 1993 was $379 \%$ of GNP in 1978. Total GNP in current yuan is slightly different from sum of GNP for sectors due to rounding.

$\dagger$ GNP in constant yuan = base year GNP in current yuan * (index for current year $\div$ index for base year). Total GNP in real yuan is slightly different from sum of GNP for sectors due to rounding and differences in deflators.

I Constant yuan figures based on reported real growth rates.

Source: China Statistical Yearbook, various years; China Daily (overseas edition), 2 March, 1995. 


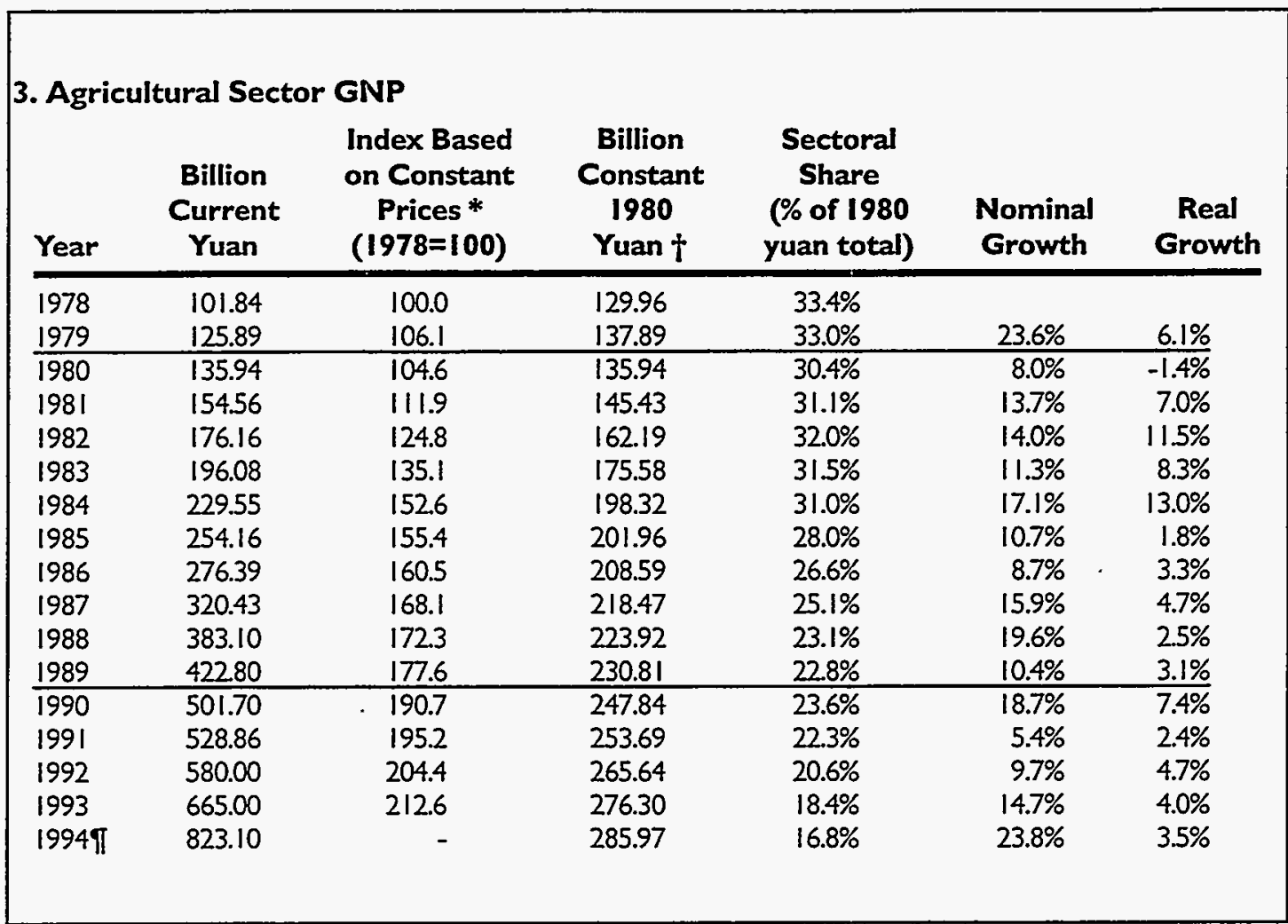

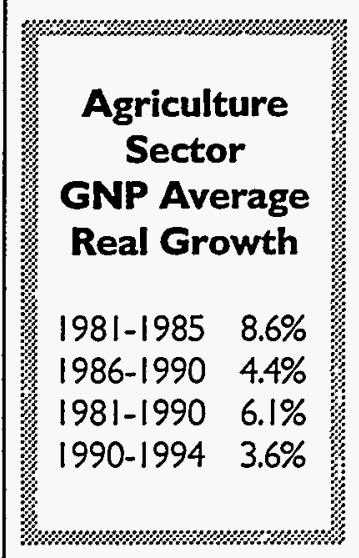

\begin{tabular}{|c|c|c|c|c|c|c|}
\hline Year & $\begin{array}{c}\text { Billion } \\
\text { Current } \\
\text { Yuan }\end{array}$ & $\begin{array}{c}\text { Index Based } \\
\text { on Constant } \\
\text { Prices* } \\
(1978=100)\end{array}$ & $\begin{array}{c}\text { Billion } \\
\text { Constant } \\
1980 \\
\text { Yuan } \dagger\end{array}$ & $\begin{array}{c}\text { Sectoral } \\
\text { Share } \\
\text { (\% of } 1980 \\
\text { yuan total) }\end{array}$ & $\begin{array}{l}\text { Nominal } \\
\text { Growth }\end{array}$ & $\begin{array}{c}\text { Real } \\
\text { Growth }\end{array}$ \\
\hline 1978 & 174.52 & 100.0 & 178.36 & $45.9 \%$ & - & - \\
\hline 1979 & 191.35 & 108.2 & 192.98 & $46.2 \%$ & $9.6 \%$ & $\cdot 8.2 \%$ \\
\hline 1980 & 219.20 & 1229 & 219.20 & $49.0 \%$ & $14.6 \%$ & $13.6 \%$ \\
\hline 1981 & 225.55 & 125.2 & 223.30 & $47.8 \%$ & $2.9 \%$ & $1.9 \%$ \\
\hline 1982 & 238.30 & 132.1 & 235.61 & $46.5 \%$ & $5.7 \%$ & $5.5 \%$ \\
\hline 1983 & 264.62 & 145.8 & 260.04 & $46.6 \%$ & $11.0 \%$ & $10.4 \%$ \\
\hline 1984 & 310.57 & 166.9 & 297.68 & $46.6 \%$ & $17.4 \%$ & $14.5 \%$ \\
\hline 1985 & 386.66 & 197.9 & 352.97 & $48.9 \%$ & $24.5 \%$ & $18.6 \%$ \\
\hline 1986 & 449.27 & 218.2 & 389.17 & $49.7 \%$ & $16.2 \%$ & $10.3 \%$ \\
\hline 1987 & 525.16 & 248.1 & 442.50 & $50.8 \%$ & $16.9 \%$ & $13.7 \%$ \\
\hline 1988 & 658.72 & 284.1 & 506.71 & $52.3 \%$ & $25.4 \%$ & $14.5 \%$ \\
\hline 1989 & 727.80 & 294.8 & 525.79 & $52.0 \%$ & $10.5 \%$ & $3.8 \%$ \\
\hline 1990 & 771.74 & 304.1 & 542.38 & $51.7 \%$ & $6.0 \%$ & $3.2 \%$ \\
\hline 1991 & 910.22 & 344.7 & 614.79 & $54.1 \%$ & $17.9 \%$ & $13.4 \%$ \\
\hline 1992 & $1,169.95^{\circ}$ & 419.8 & 748.74 & $58.1 \%$ & $28.5 \%$ & $21.8 \%$ \\
\hline 1993 & $1,624.49$ & 505.4 & 901.41 & $59.9 \%$ & $38.9 \%$ & $20.4 \%$ \\
\hline $1994 \S$ & $2,125.90$ & - & $1,058.26$ & $62.3 \%$ & $30.9 \%$ & $17.4 \%$ \\
\hline
\end{tabular}

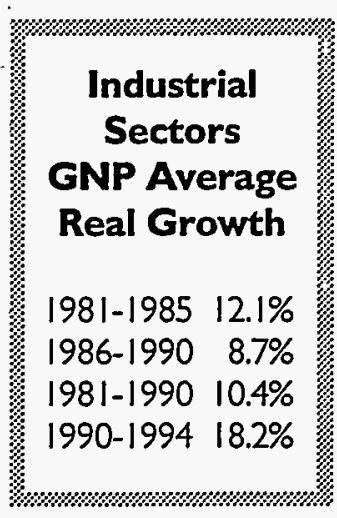

* These index numbers can be thought of as percentages, e.g., at constant prices, GNP in 1993 was 379\% of GNP in 1978. Total GNP in current yuan is slightly different from sum of GNP for sectors due to rounding.

$\dagger$ GNP in constant yuan = base year GNP in current yuan * (index for current year $\div$ index for base year). Total GNP in real yuan is slightly different from sum of GNP for sectors due to rounding and differences in deflators.

i Based on sum of real sectoral GDP.

$\S$ Constant yuan figures based on reported real growth rates.

Source: China Statistical Yearbook, various years; China Daily (overseas edition), 2 March, 1995. 
Table X-1. Gross National Product and Gross Domestic Product (continued)

5. Manufacturing Sector GDP (contained within Industrial Sectors above)

\begin{tabular}{|c|c|c|c|c|c|c|}
\hline Year & $\begin{array}{c}\text { Billion } \\
\text { Current } \\
\text { Yuan }\end{array}$ & $\begin{array}{c}\text { Index Based } \\
\text { on Constant } \\
\text { Prices* } \\
(1978=100)\end{array}$ & $\begin{array}{c}\text { Billion } \\
\text { Constant } \\
1980 \\
\text { Yuan t }\end{array}$ & $\begin{array}{c}\text { Sectoral } \\
\text { Share } \\
\text { (\% of } 1980 \\
\text { yuan total) }\end{array}$ & $\begin{array}{c}\text { Nominal } \\
\text { Growth }\end{array}$ & $\begin{array}{c}\text { Real } \\
\text { Growth }\end{array}$ \\
\hline 1978 & 160.70 & 100.0 & 163.11 & $42.0 \%$ & & \\
\hline 1979 & 176.97 & 108.7 & 177.30 & $42.5 \%$ & $10.1 \%$ & $8.7 \%$ \\
\hline 1980 & 199.65 & 122.4 & 199.65 & $44.7 \%$ & $12.8 \%$ & $12.6 \%$ \\
\hline 1981 & 204.84 & 124.5 & 203.08 & $43.5 \%$ & $2.6 \%$ & $1.7 \%$ \\
\hline 1982 & 216.23 & 131.7 & 214.82 & $42.4 \%$ & $5.6 \%$ & $5.8 \%$ \\
\hline 1983 & 237.56 & 144.5 & 235.70 & $42.2 \%$ & $9.9 \%$ & $9.7 \%$ \\
\hline 1984 & 278.90 & 166.0 & 270.77 & $42.4 \%$ & $17.4 \%$ & $14.9 \%$ \\
\hline 1985 & 344.87 & 196.2 & 320.03 & $44.3 \%$ & $23.7 \%$ & $18.2 \%$ \\
\hline 1986 & 396.70 & 215.2 & 351.02 & $44.8 \%$ & $15.0 \%$ & $9.7 \%$ \\
\hline 1987 & 458.58 & 243.6 & 397.34 & $45.6 \%$ & $15.6 \%$ & $13.2 \%$ \\
\hline 1988 & 577.72 & 280.8 & 458.02 & $47.3 \%$ & $26.0 \%$ & $15.3 \%$ \\
\hline 1989 & 648.40 & 295.0 & 481.18 & $47.6 \%$ & $12.2 \%$ & $5.1 \%$ \\
\hline 1990 & 685.50 & 304.9 & 497.33 & $47.4 \%$ & $5.7 \%$ & $3.4 \%$ \\
\hline 1991 & 808.71 & 346.9 & 565.84 & $49.8 \%$ & $18.0 \%$ & $13.8 \%$ \\
\hline 1992 & $1,028.45$ & 422.9 & 689.80 & $53.5 \%$ & $27.2 \%$ & $21.9 \%$ \\
\hline 1993 & $1,414.00$ & 512.1 & 835.30 & $55.6 \%$ & $37.5 \%$ & $21.1 \%$ \\
\hline
\end{tabular}

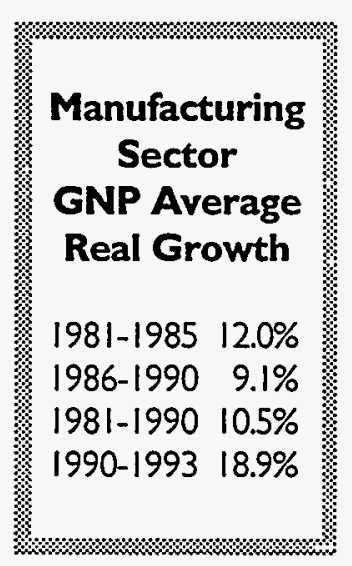

\section{Services Sector GDP}

\begin{tabular}{lcccccc} 
Year & $\begin{array}{c}\text { Billion } \\
\text { Current } \\
\text { Yuan }\end{array}$ & $\begin{array}{c}\text { Index Based } \\
\text { on Constant } \\
\text { Prices } \\
\text { (1978=100) }\end{array}$ & $\begin{array}{c}\text { Billion } \\
\text { Constant } \\
1980 \\
\text { Yuan }\end{array}$ & $\begin{array}{c}\text { Sectoral } \\
\text { Share } \\
\text { (\% of I980 } \\
\text { Yuan total) }\end{array}$ & $\begin{array}{c}\text { Nominal } \\
\text { Growth }\end{array}$ & $\begin{array}{c}\text { Real } \\
\text { Growth }\end{array}$ \\
\hline 1978 & 82.45 & 100.0 & 80.37 & $20.7 \%$ & & \\
1979 & 82.57 & 107.8 & 86.64 & $20.8 \%$ & $0.1 \%$ & $7.8 \%$ \\
\hline 1980 & 91.86 & 114.3 & 91.86 & $20.6 \%$ & $11.3 \%$ & $6.0 \%$ \\
1981 & 97.40 & 122.2 & 98.21 & $21.0 \%$ & $6.0 \%$ & $6.9 \%$ \\
1982 & 103.77 & 135.2 & 108.66 & $21.5 \%$ & $6.5 \%$ & $10.6 \%$ \\
1983 & 118.00 & 1523 & 122.40 & $21.9 \%$ & $13.7 \%$ & $12.6 \%$ \\
1984 & 152.70 & 178.3 & 143.30 & $22.4 \%$ & $29.4 \%$ & $17.1 \%$ \\
1985 & 212.92 & 207.9 & 167.08 & $23.1 \%$ & $39.4 \%$ & $16.6 \%$ \\
1986 & 243.10 & 231.0 & 185.65 & $23.7 \%$ & $14.2 \%$ & $11.1 \%$ \\
1987 & 285.12 & 260.8 & 209.60 & $24.1 \%$ & $17.3 \%$ & $12.9 \%$ \\
1988 & 365.60 & 296.2 & 238.05 & $24.6 \%$ & $28.2 \%$ & $13.6 \%$ \\
1989 & 449.16 & 316.2 & 254.12 & $25.1 \%$ & $22.9 \%$ & $6.8 \%$ \\
\hline 1990 & 494.69 & 323.0 & 259.59 & $24.7 \%$ & $10.1 \%$ & $2.2 \%$ \\
1991 & 579.75 & 340.8 & 273.89 & $24.0 \%$ & $17.2 \%$ & $5.5 \%$ \\
1992 & 686.34 & 371.1 & 298.24 & $22.7 \%$ & $18.4 \%$ &. \\
1993 & 848.54 & 405.6 & 325.97 & $21.7 \%$ & $23.6 \%$ & $9.3 \%$ \\
19948 & 1.431 .00 & & -354.33 & $20.9 \%$ & $68.6 \%$ & $8.7 \%$ \\
& & & & & & \\
\hline
\end{tabular}

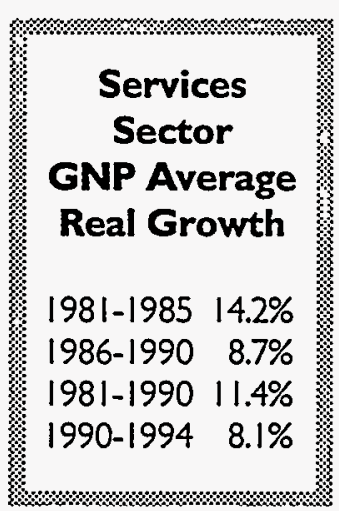

- These index numbers can be thought of as percentages, e.g., at constant prices, GNP in 1993 was $379 \%$ of GNP in 1978 . Total GNP in current yuan is slightly different from sum of GNP for sectors due to rounding.

$\dagger$ GNP in constant yuan = base year GNP in current yuan * (index for current year $\div$ index for base year). Total GNP in real yuan is slightly different from sum of GNP for sectors due to rounding and differences in deflators.

I Based on sum of real sectoral GDP.

$\S$ Constant yuan figures based on reported real growth rates.

Source: China Statistical Yearbook, various years; China Daily (overseas edition), 2 March, 1995. 
Figure X-1. Gross Domestic Product by Sector

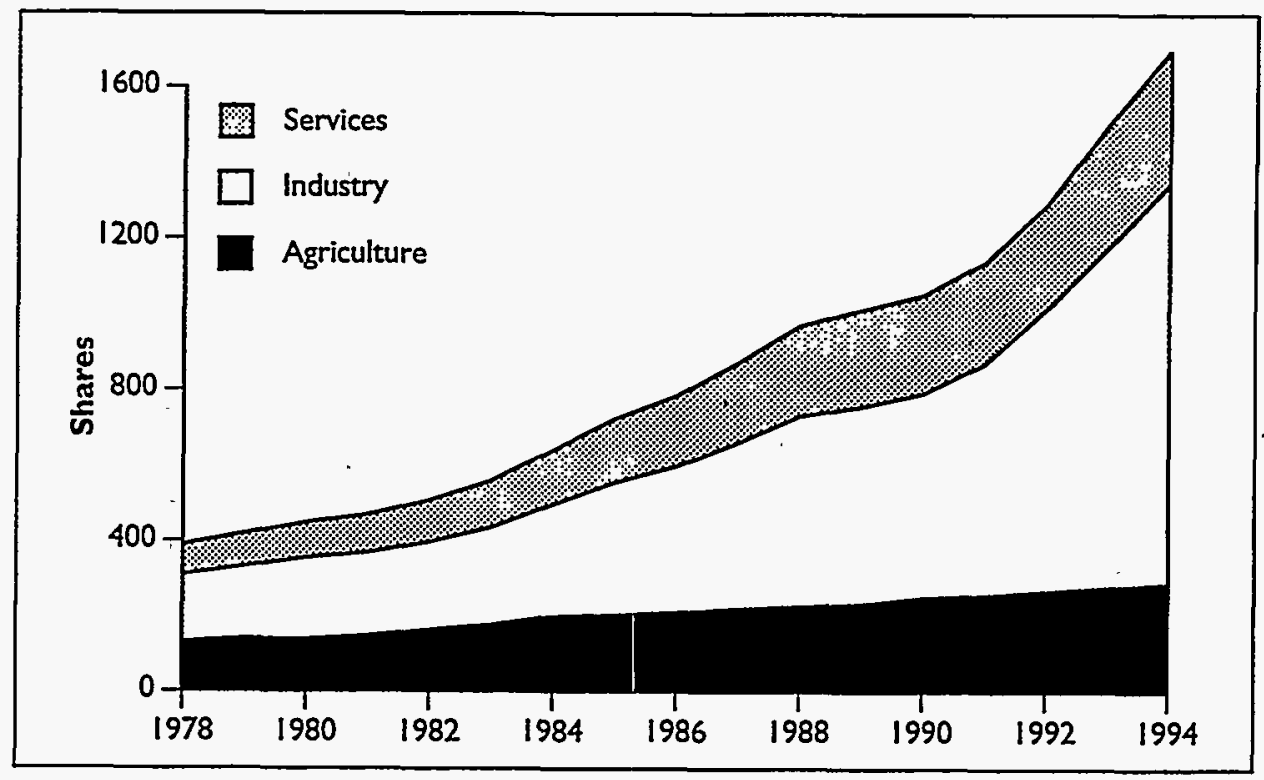

Figure X-2. Sectoral Shares of GDP

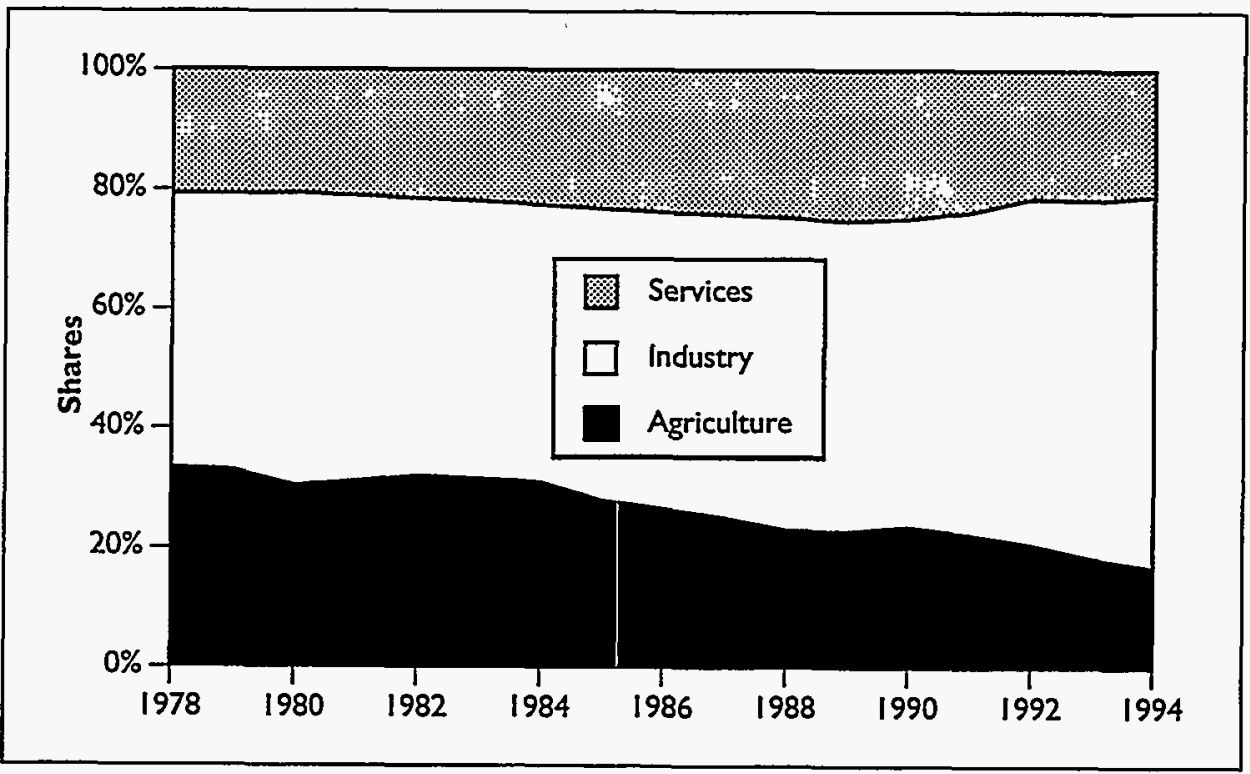


Table X-2. Per Capita Gross National Product, 1978-1993

\begin{tabular}{|c|c|c|c|c|c|c|c|}
\hline Year & $\begin{array}{c}\text { Total } \\
\text { Population } \\
\text { (millions) }\end{array}$ & $\begin{array}{c}\text { GNP } \\
\text { (Billion } \\
\text { Current } \\
\text { Yuan) }\end{array}$ & $\begin{array}{c}\text { GNP } \\
\text { (Billion } \\
\text { Constant } \\
\text { (980 Yuan) }\end{array}$ & $\begin{array}{c}\text { Per Capita } \\
\text { GNP } \\
\text { (Current } \\
\text { Yuan) }\end{array}$ & $\begin{array}{l}\text { Per Capita } \\
\text { GNP } \\
\text { (Constant } \\
\text { 1980 Yuan) }\end{array}$ & $\begin{array}{l}\text { Nominal } \\
\text { Growth Rate } \\
\text { (percent) }\end{array}$ & $\begin{array}{c}\text { Real } \\
\text { Growth Rate } \\
\text { (percent) }\end{array}$ \\
\hline $\begin{array}{l}1978 \\
1979\end{array}$ & $\begin{array}{l}962.59 \\
975.42\end{array}$ & $\begin{array}{l}358.81 \\
399.81\end{array}$ & $\begin{array}{l}385.34 \\
414.63\end{array}$ & $\begin{array}{l}373 \\
410\end{array}$ & $\begin{array}{l}400 \\
425\end{array}$ & $\overline{10.0 \%}$ & - \\
\hline 1980 & 987.05 & 447.00 & 447.00 & 453 & 453 & $10.5 \%$ & $6.5 \%$ \\
\hline 1981 & $1,000.72$ & 477.30 & 467.04 & 477 & 467 & $5.3 \%$ & $3.1 \%$ \\
\hline 1982 & $1,016.54$ & 519.30 & 507.88 & 511 & 500 & $7.1 \%$ & $7.1 \%$ \\
\hline 1983 & $1,030.08$ & 580.90 & 560.29 & 564 & 544 & $10.4 \%$ & $8.9 \%$ \\
\hline 1984 & $1,043.57$ & 696.20 & 641.98 & 667 & 615 & $18.3 \%$ & $13.1 \%$ \\
\hline 1985 & $\mid, 058.51$ & 855.76 & 723.68 & 808 & 684 & $21.2 \%$ & $11.1 \%$ \\
\hline 1986 & $1,075.07$ & 969.63 & 783.79 & 902 & 729 & $11.6 \%$ & $6.6 \%$ \\
\hline 1987 & $1,093.00$ & $1,130.10$ & 870.11 & 1,034 & 796 & $14.6 \%$ & $9.2 \%$ \\
\hline 1988 & $1,110.26$ & $1,401.82$ & 965.67 & 1,263 & 870 & $22.1 \%$ & $9.3 \%$ \\
\hline 1989 & $1,127.04$ & $1,591.63$ & $1,003.82$ & 1,412 & 891 & $11.8 \%$ & $24 \%$ \\
\hline 1990 & $1,143.33$ & $1,768.61$ & $1,056.23$ & 1,547 & 924 & $9.5 \%$ & $3.7 \%$ \\
\hline 1991 & I. I 158.23 & $2,023.63$ & $1,136.77$ & 1,747 & 981 & $12.9 \%$ & $6.8 \%$ \\
\hline 1992 & $1,171.71$ & $2,437.89$ & $1,288.98$ & 2,081 & 1,100 & $19.1 \%$ & $12.1 \%$ \\
\hline 1993 & 1.185 .17 & $3,134.23$ & $1,459.30$ & 2,645 & 1,231 & $27.1 \%$ & $11.9 \%$ \\
\hline
\end{tabular}

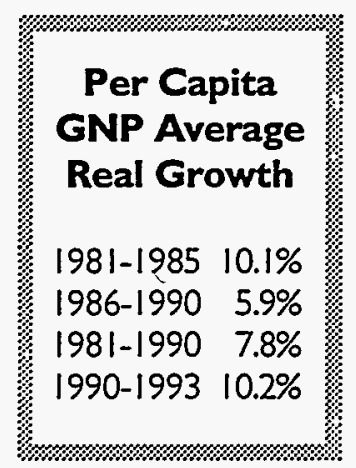

Sources: China Statistical Yearbook, various years. 
Table X-3. Gross National Product by Province, 1990-1993

\begin{tabular}{|c|c|c|c|c|c|c|c|c|c|c|c|}
\hline \multirow{3}{*}{$\begin{array}{c}\text { Planning } \\
\text { Region }\end{array}$} & \multirow[b]{3}{*}{ Province } & \multicolumn{5}{|c|}{ GDP (billion 1990 Yuan) } & \multicolumn{5}{|c|}{ Per Capita GDP (1990 Yuan) } \\
\hline & & \multirow[b]{2}{*}{1990} & \multirow[b]{2}{*}{1991} & \multirow[b]{2}{*}{1992} & \multicolumn{2}{|r|}{ avg annua } & \multirow[b]{2}{*}{1990} & \multirow[b]{2}{*}{ I99| } & \multirow[b]{2}{*}{1992} & \multicolumn{2}{|c|}{ avg annual } \\
\hline & & & & & 1993 & growth & & & & 1993 & growth \\
\hline \multirow[t]{5}{*}{$\overline{\text { North }}$} & Beijing & 50.08 & 56.65 & 63.14 & 67.69 & $10.6 \%$ & 4,611 & 5,178 & 5,729 & 6,088 & $9.7 \%$ \\
\hline & Tianjin & 31.10 & 32.42 & 36.61 & 42.03 & $10.6 \%$ & 3,518 & 3,567 & 3,980 & 4,529 & $8.8 \%$ \\
\hline & Hebei & 83.61 & 90.77 & 102.85 & 122.81 & $13.7 \%$ & 1,358 & 1,459 & 1,639 & 1,939 & $126 \%$ \\
\hline & Shanxi & 39.99 & 40.82 & 46.28 & 50.63 & $8.2 \%$ & 1,379 & 1,388 & 1,554 & 1,681 & $6.8 \%$ \\
\hline & Inner Mongolia & 28.67 & 30.36 & 33.71 & 38.15 & $10.0 \%$ & 1,325 & 1,390 & 1.527 & 1,709 & $8.8 \%$ \\
\hline \multirow[t]{3}{*}{ Northeast } & Liaoning & 96.57 & 101.52 & 115.55 & 141.75 & $13.6 \%$ & 2,434 & 2,544 & 2,877 & 3,507 & $12.9 \%$ \\
\hline & Jilin & 39.40 & 40.11 & 45.82 & 52.68 & $10.2 \%$ & 1,587 & 1,598 & 1,810 & 2,062 & $9.1 \%$ \\
\hline & Heilongilang & 65.90 & 69.50 & 76.21 & 84.42 & $8.6 \%$ & 1.860 & 1.944 & 2.112 & 2,319 & $7.6 \%$ \\
\hline \multirow[t]{7}{*}{ Eost } & Shanghai & 74.47 & 81.13 & 99.22 & 118.50 & $16.7 \%$ & 5,570 & 6,055 & 7,377 & 8,785 & $16.4 \%$ \\
\hline & Jiangsu & 131.58 & 139.15 & 175.55 & 215.94 & $18.0 \%$ & 1,944 & 2,033 & 2,540 & 3.100 & $16.8 \%$ \\
\hline & Zhejiang & 83.69 & 93.03 & 108.69 & 133.11 & $16.7 \%$ & 2,008 & 2,214 & 2,566 & 3,121 & $15.8 \%$ \\
\hline & Anhui & 60.65 & 56.77 & 65.02 & 76.80 & $8.2 \%$ & 1,069 & 985 & 1,114 & 1,302 & $6.8 \%$ \\
\hline & Fujian & 45.95 & 51.78 & 61.86 & 80.60 & $20.6 \%$ & 1,513 & 1,682 & 1,985 & 2,559 & $19.1 \%$ \\
\hline & Jiangxi & 41.95 & 43.99 & 49.82 & 55.03 & $9.5 \%$ & 1,101 & 1,138 & 1,273 & 1,388 & $8.0 \%$ \\
\hline & Shandong & 133.34 & 151.05 & 176.48 & 211.86 & $16.7 \%$ & 1,570 & 1,763 & 2,050 & $2,4 \dot{5} 2$ & $16.0 \%$ \\
\hline \multirow[t]{6}{*}{ South-Central } & Henan & 89.57 & 93.94 & 108.02 & 124.11 & $11.5 \%$ & 1,036 & 1,072 & 1,219 & 1,387 & $10.2 \%$ \\
\hline & Hubei & 79.11 & 81.05 & 89.16 & 101.79 & $8.8 \%$ & 1,454 & 1,470 & 1,598 & 1,801 & $7.4 \%$ \\
\hline & Hunan & 70.26 & 74.33 & 81.93 & 93.48 & $10.0 \%$ & 1,147 & 1.197 & 1,307 & 1,481 & $8.9 \%$ \\
\hline & Guangdong & 147.18 & 168.43 & 204.21 & 252.85 & $19.8 \%$ & 2,319 & 2,616 & 3.130 & 3,827 & $18.2 \%$ \\
\hline & Guangxi & 39.28 & 42.85 & 50.96 & 61.78 & $16.3 \%$ & 922 & 991 & 1,163 & 1,392 & $14.7 \%$ \\
\hline & Hainan & 9.50 & 10.21 & 1262 & 17.65 & $22.9 \%$ & 1,433 & 1.515 & 1.839 & 2.518 & $20.7 \%$ \\
\hline \multirow[t]{4}{*}{ Southwest } & Sichuan & 114.49 & 121.18 & 131.89 & 153.55 & $10.3 \%$ & 1,060 & 1,112 & 1,199 & 1,383 & $9.3 \%$ \\
\hline & Guizhou & 25.49 & 27.41 & 29.53 & 32.02 & $7.9 \%$ & 780 & 827 & 879 & 939 & $6.4 \%$ \\
\hline & Yunnan & 39.60 & 40.94 & 45.41 & 51.91 & $9.4 \%$ & 1,061 & 1,083 & 1.185 & 1,336 & $8.0 \%$ \\
\hline & Tibet & 2.45 & 2.89 & 2.97 & 2.92 & $6.1 \%$ & 1.101 & 1.278 & 1,300 & 1,260 & $4.6 \%$ \\
\hline \multirow[t]{5}{*}{ Northwest } & Shaanxi & 37.41 & 40.48 & 43.86 & 48.17 & $8.8 \%$ & 1.128 & 1,204 & 1.288 & 1.399 & $7.4 \%$ \\
\hline & Gansu & 23.40 & 24.16 & 26.85 & 28.09 & $6.3 \%$ & 1,038 & 1,057 & 1.161 & 1,198 & $4.9 \%$ \\
\hline & Qinghai & 6.63 & 6.87 & 7.51 & 8.29 & $7.7 \%$ & 1,481 & 1,512 & 1,628 & 1,774 & $6.2 \%$ \\
\hline & Ningxia & 6.11 & 6.48 & 7.00 & 7.71 & $8.1 \%$ & 1,300 & 1,350 & 1,437 & 1,558 & $6.2 \%$ \\
\hline & Xinjiang & 25.19 & 29.48 & 34.04 & 37.78 & $14.5 \%$ & 1.647 & 1.896 & 2.153 & 2,354 & $12.6 \%$ \\
\hline National Total & & $1,768.13$ & $1,909.632$ & $2,169.27$ & $2,460.06$ & $11.6 \%$ & 1,546 & 1,649 & 1,851 & 2,076 & $10.3 \%$ \\
\hline Balance* $^{*}$ & & 45.52 & 59.89 & 36.52 & -54.05 & - & - & - & - & - & - \\
\hline
\end{tabular}

* Totals differ from the sum of regional GDP because regions calculate GDP with their own methods, which may differ from those used by the State Statistical Bureau.

Source: China Statistical Yearbook, various years. 
Table X-4. Gross Output Value by Sectors, * 1952-1993

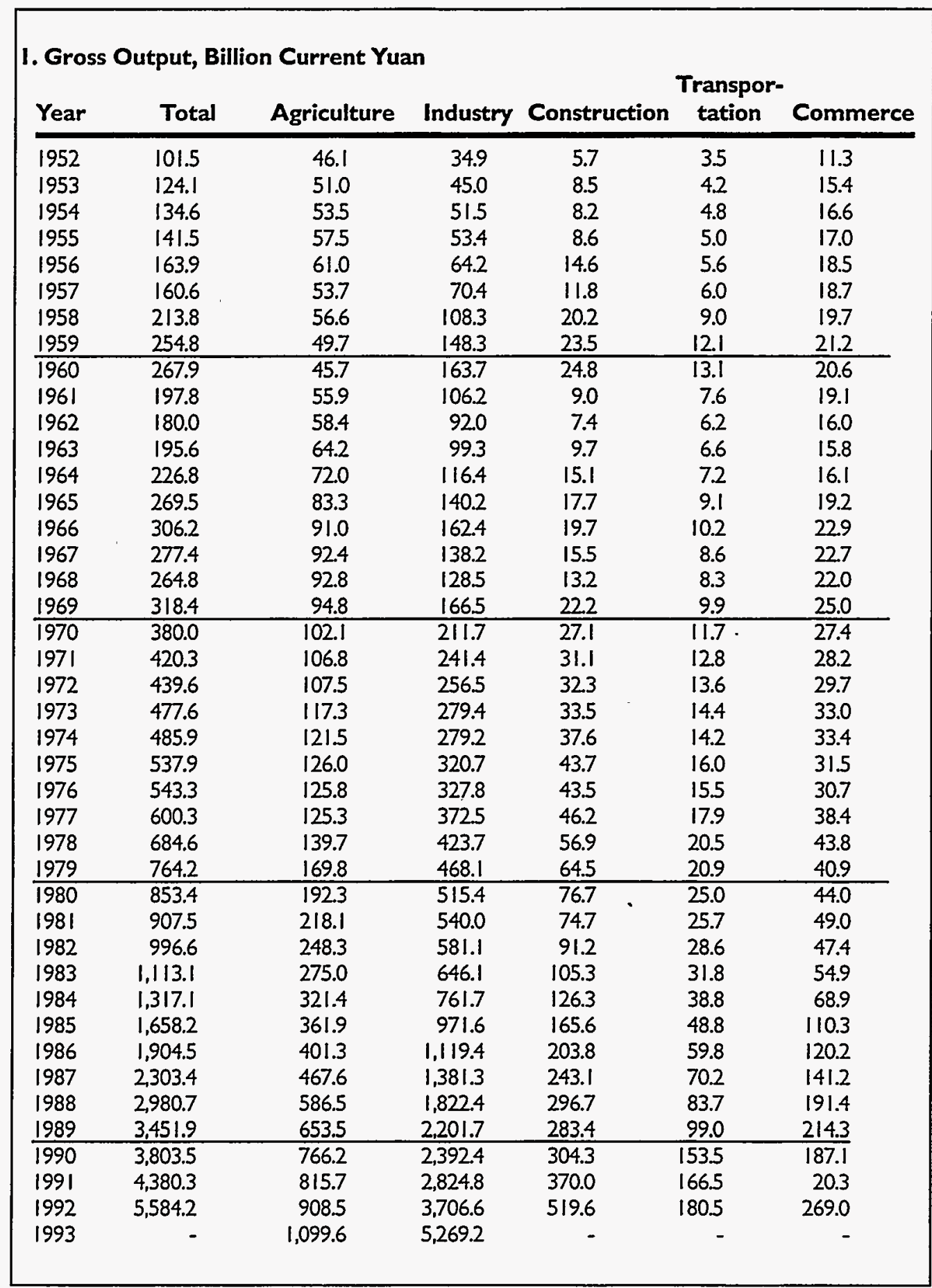

- 1992 is the last year for which total gross output value statistics are available. Only industrial andagricultural gross output value data are published for subsequent years.

Source: China Statistical Yearbook, various years. 
Table X-4. Gross Output Value by Sectors, $1952-1993$ * (continued)

\begin{tabular}{|c|c|c|c|c|c|c|}
\hline \multicolumn{7}{|c|}{ 2. Gross Output, Index Based on Constant Prices $(1952=100) \dagger$} \\
\hline Year & Total & Agriculture & Industry & Construction & $\begin{array}{c}\text { Transpor- } \\
n \text { tation }\end{array}$ & Commerce \\
\hline 1952 & 100.0 & 100.0 & 100.0 & 100.0 & 100.0 & 100.0 \\
\hline 1953 & 118.7 & 103.1 & 130.3 & 154.4 & 125.7 & 130.1 \\
\hline 1954 & 128.8 & 106.6 & 151.6 & 152.6 & 145.7 & 137.2 \\
\hline 1955 & 136.6 & 114.7 & 160.1 & 163.2 & 154.3 & 140.7 \\
\hline 1956 & 161.1 & 120.5 & 205.0 & 249.1 & 177.1 & $\mid 53.1$ \\
\hline 1957 & 170.9 & 124.8 & 228.6 & 236.8 & 200.0 & 151.3 \\
\hline 1958 & 226.6 & 127.8 & 353.9 & 403.4 & 303.3 & 159.4 \\
\hline 1959 & 267.4 & 110.4 & 481.8 & 439.6 & 406.7 & 171.6 \\
\hline 1960 & 279.8 & 96.4 & 535.7 & 453.6 & 443.3 & 165.9 \\
\hline 1961 & 186.2 & 94.1 & 330.8 & 162.6 & 256.7 & 135.1 \\
\hline 1962 & 167.5 & 99.9 & 276.0 & 138.5 & 206.7 & 131.9 \\
\hline 1963 & 184.6 & 111.5 & 299.4 & 184.7 & 220.0 & 140.8 \\
\hline 1964 & 216.9 & 126.7 & 358.1 & 285.0 & 240.0 & 142.4 \\
\hline 1965 & 258.2 & 137.1 & 452.6 & 351.2 & 303.3 & 142.4 \\
\hline 1966 & 301.9 & 149.0 & 547.4 & 395.4 & 340.0 & 170.7 \\
\hline 1967 & 272.0 & 151.3 & 471.8 & 311.1 & 290.0 & 169.9 \\
\hline 1968 & 259.2 & 147.6 & 448.1 & 264.9 & 283.3 & 164.3 \\
\hline 1969. & 324.7 & 149.2 & 601.6 & 445.6 & 336.7 & 188.6 \\
\hline 1970 & 403.2 & 157.8 & 798.1 & 543.9 & 400.0 & 210.4 \\
\hline 1971 & 445.4 & 162.9 & 915.3 & 614.2 & 437.6 & 216.5 \\
\hline 1972 & 465.3 & 161.2 & 978.2 & 630.2 & 465.0 & 228.1 \\
\hline 1973 & 505.5 & 174.5 & $1,071.3$ & 640.3 & 492.3 & 253.4 \\
\hline 1974 & 515.1 & 180.7 & $1,077.7$ & 702.5 & 485.5 & 256.5 \\
\hline 1975 & 574.4 & 186.3 & $1,244.7$ & 800.8 & 547.0 & 266.5 \\
\hline 1976 & 582.3 & 185.5 & $1,274.9$ & 784.8 & 529.9 & 275.7 \\
\hline 1977 & 642.5 & 184.8 & $1,461.1$ & 820.9 & 612.0 & 303.3 \\
\hline 1978 & 726.3 & 199.8 & $1,659.0$ & 995.5 & 700.9 & 344.8 \\
\hline 1979 & 788.2 & 214.8 & $1,805.3$ & $1,101.9$ & 714.5 & 376.3 \\
\hline 1980 & 854.2 & 217.9 & $1,972.3$ & $1,282.6$ & 844.4 & 400.1 \\
\hline 1981 & 891.7 & 230.5 & $2,057.1$ & $1,212.3$ & 868.1 & 469.2 \\
\hline 1982 & 976.4 & 256.5 & $2,217.7$ & $1,438.1$ & 966.0 & 499.2 \\
\hline 1983 & $1,076.2$ & 276.5 & $2,465.8$ & $1,588.6$ & $1,053.9$ & 551.9 \\
\hline 1984 & $1,234.6$ & 310.4 & $2,867.3$ & $1,800.9$ & $1,172.1$ & 617.4 \\
\hline 1985 & $1,446.3$ & 321.0 & $3,480.7$ & $2,167.1$ & $1,405.2$ & 741.0 \\
\hline 1986 & $1,593.1$ & 331.8 & $3,886.8$ & $2,469.8$ & $1,553.8$ & 822.0 \\
\hline 1987 & $1,818.2$ & 351.0 & $4,574.5$ & $2,717.3$ & $1,726.0$ & 899.2 \\
\hline 1988 & $2,106.0$ & 364.9 & $5,525.4$ & $2,914.6$ & $1,945.6$ & 981.1 \\
\hline 1989 & 2.219 .9 & 376.2 & 5.997 .3 & $2,576.5$ & 2.158 .4 & 926.5 \\
\hline 1990 & $2,367.5$ & 404.9 & $6,462.9$ & $2,588.5$ & $2,266.5$ & 892.9 \\
\hline 1991 & $2,640.0$ & 419.9 & $7,419.4$ & $2,848.0$ & 2,4127 & 964.0 \\
\hline 1992 & $3,212.6$ & 446.6 & $9,459.7$ & $3,561.6$ & $2,609.1$ & $1,043.2$ \\
\hline 1993 & - & 481.4 & $12,110.3$ & - & - & - \\
\hline
\end{tabular}

* 1992 is the last year for which total gross output value statistics are available. Only industrial and agricultural gross output value data are published for subsequent years.

$\dagger$ These index figures can be thought of as percentages, e.g., at constant prices, total gross output in 1992 was $3,213 \%$ of gross output in 1952.

Source: China Statistical Yearbook, various years. 
Table X-4. Gross Output Value by Sectors, 1952-1990* (continued)

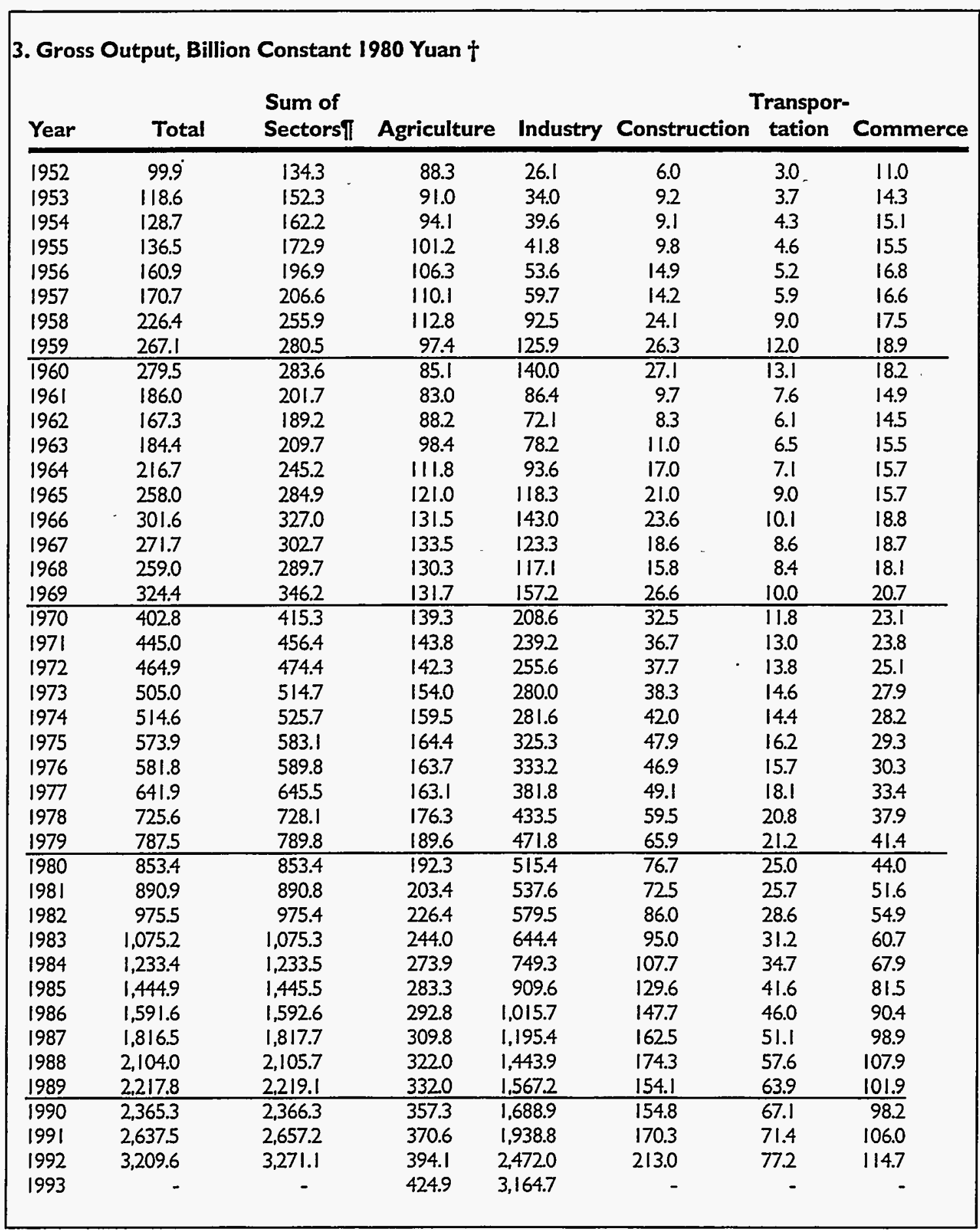

* 1992 is the last year for which total gross output value statistics are available. Only industrial and agricultural gross output value data are published for subsequent years.

$\dagger$ Gross output in constant yuan = base year gross output in current yuan * (index for current year $\div$ index for base year).

Total gross output in 1980 yuan is not equal to the sum of sectoral gross outputs because the sectoral deflators are different from the deflators for total gross output.

Source: China Statistical Yearbook, various years. 
Figure X-3. Gross Output Value

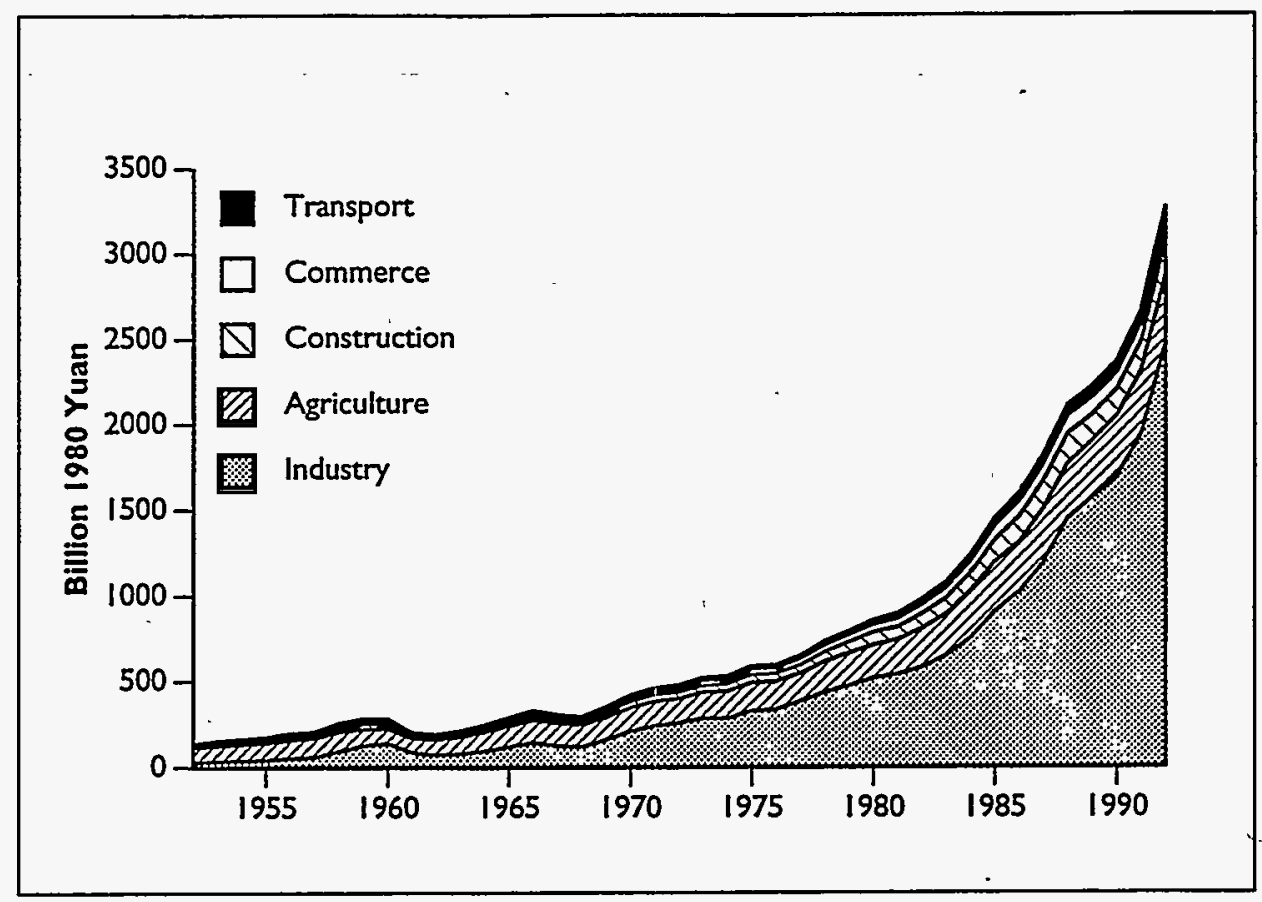

Figure X-4. Sectoral Shares of GOV

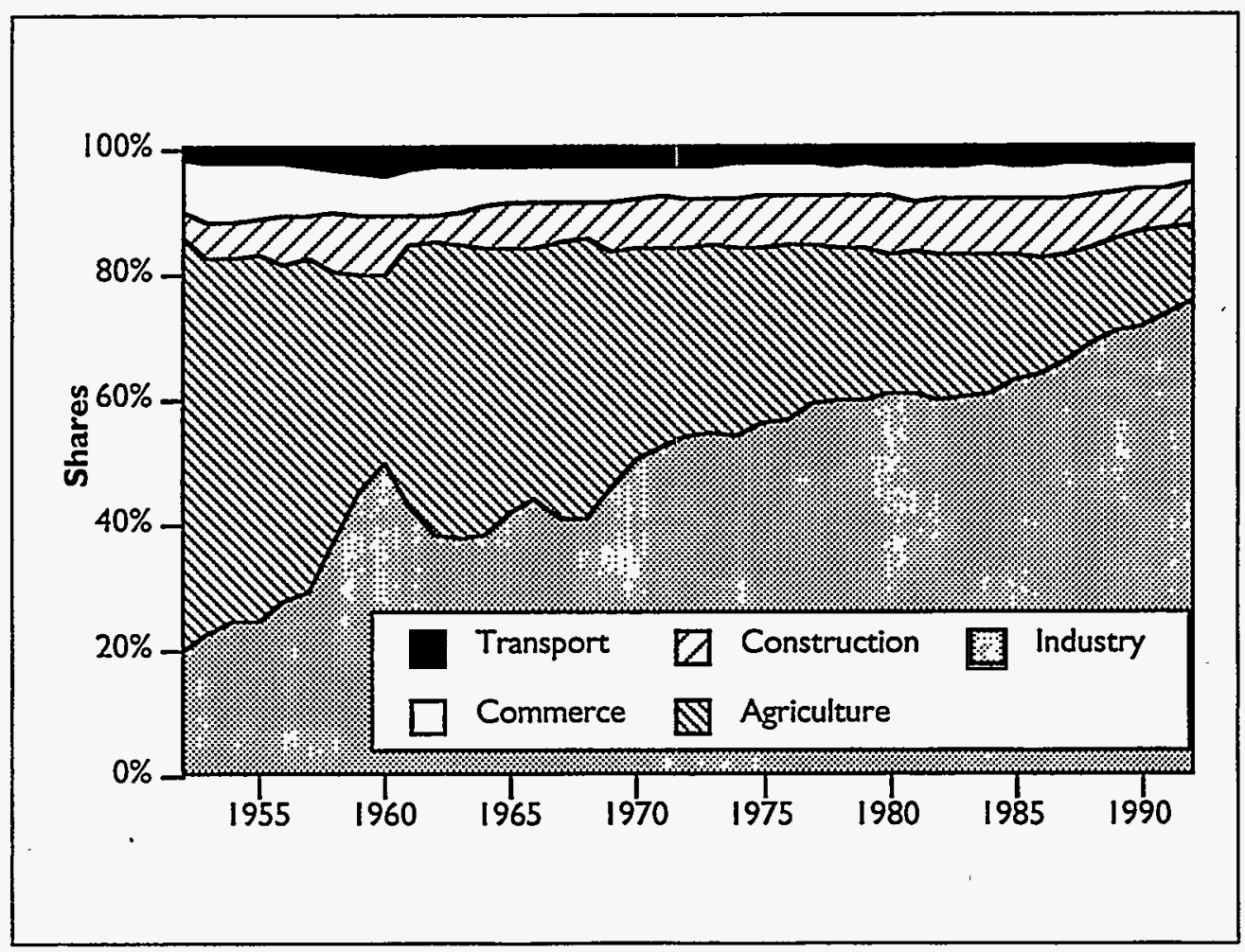


Table X-4. Gross Output Value by Sectors, 1952-1990 * (continued)

\begin{tabular}{|c|c|c|c|c|c|}
\hline \multicolumn{6}{|c|}{ 4. Sectoral Shares of Gross Output, Percent $¥$} \\
\hline Year & Agriculture & Industry & Construction & Transport & Commerce \\
\hline 1952 & $65.7 \%$ & $19.5 \%$ & $4.5 \%$ & $2.2 \%$ & $8.2 \%$ \\
\hline 1953 & $59.7 \%$ & $224 \%$ & $6.1 \%$ & $24 \%$ & $9.4 \%$ \\
\hline 1954 & $58.0 \%$ & $24.4 \%$ & $5.6 \%$ & $27 \%$ & $9.3 \%$ \\
\hline 1955 & $58.6 \%$ & $24.2 \%$ & $5.6 \%$ & $26 \%$ & $9.0 \%$ \\
\hline 1956 & $54.0 \%$ & $27.2 \%$ & $7.6 \%$ & $2.7 \%$ & $8.6 \%$ \\
\hline 1957 & $53.3 \%$ & $28.9 \%$ & $6.9 \%$ & $29 \%$ & $8.1 \%$ \\
\hline 1958 & $44.1 \%$ & $36.1 \%$ & $9.4 \%$ & $3.5 \%$ & $6.9 \%$ \\
\hline 1959 & $34.7 \%$ & $44.9 \%$ & $9.4 \%$ & $4.3 \%$ & $6.7 \%$ \\
\hline 1960 & $30.0 \%$ & $49.4 \%$ & $9.6 \%$ & $4.6 \%$ & $6.4 \%$ \\
\hline 1961 & $41.2 \%$ & $42.9 \%$ & $4.8 \%$ & $3.8 \%$ & $7.4 \%$ \\
\hline 1962 & $46.6 \%$ & $38.1 \%$ & $4.4 \%$ & $3.2 \%$ & $7.7 \%$ \\
\hline 1963 & $46.9 \%$ & $37.3 \%$ & $5.3 \%$ & $3.1 \%$ & $7.4 \%$ \\
\hline 1964 & $45.6 \%$ & $38.2 \%$ & $7.0 \%$ & $29 \%$ & $6.4 \%$ \\
\hline 1965 & $42.5 \%$ & $41.5 \%$ & $7.4 \%$ & $3.2 \%$ & $5.5 \%$ \\
\hline 1966 & $40.2 \%$ & $43.7 \%$ & $7.2 \%$ & $3.1 \%$ & $5.7 \%$ \\
\hline 1967 & $44.1 \%$ & $40.7 \%$ & $6.1 \%$ & $28 \%$ & $6.2 \%$ \\
\hline 1968 & $45.0 \%$ & $40.4 \%$ & $5.5 \%$ & $2.9 \%$ & $6.2 \%$ \\
\hline 1969 & $38.0 \%$ & $45.4 \%$ & $7.7 \%$ & $29 \%$ & $6.0 \%$ \\
\hline 1970 & $33.5 \%$ & $50.2 \%$ & $7.8 \%$ & $2.9 \%$ & $5.6 \%$ \\
\hline 1971 & $31.5 \%$ & $52.4 \%$ & $8.0 \%$ & $28 \%$ & $5.2 \%$ \\
\hline 1972 & $30.0 \%$ & $53.9 \%$ & $7.9 \%$ & $29 \%$ & $5.3 \%$ \\
\hline 1973 & $29.9 \%$ & $54.4 \%$ & $7.4 \%$ & $28 \%$ & $5.4 \%$ \\
\hline 1974 & $30.3 \%$ & $53.6 \%$ & $8.0 \%$ & $27 \%$ & $5.4 \%$ \\
\hline 1975 & $28.2 \%$ & $55.8 \%$ & $8.2 \%$ & $28 \%$ & $5.0 \%$ \\
\hline 1976 & $27.8 \%$ & $56.5 \%$ & $8.0 \%$ & $27 \%$ & $5.1 \%$ \\
\hline 1977 & $25.3 \%$ & $59.2 \%$ & $7.6 \%$ & $28 \%$ & $5.2 \%$ \\
\hline 1978 & $24.2 \%$ & $59.5 \%$ & $8.2 \%$ & $29 \%$ & $5.2 \%$ \\
\hline 1979 & $24.0 \%$ & $59.7 \%$ & $8.3 \%$ & $2.7 \%$ & $5.2 \%$ \\
\hline 1980 & $22.5 \%$ & $60.4 \%$ & $9.0 \%$ & $29 \%$ & $5.2 \%$ \\
\hline 1981 & $22.8 \%$ & $60.3 \%$ & $8.1 \%$ & $29 \%$ & $5.8 \%$ \\
\hline 1982 & $23.2 \%$ & $59.4 \%$ & $8.8 \%$ & $29 \%$ & $5.6 \%$ \\
\hline 1983 & $22.7 \%$ & $59.9 \%$ & $8.8 \%$ & $2.9 \%$ & $5.6 \%$ \\
\hline 1984 & $22.2 \%$ & $60.7 \%$ & $8.7 \%$ & $2.8 \%$ & $5.5 \%$ \\
\hline 1985 & $19.6 \%$ & $62.9 \%$ & $9.0 \%$ & $2.9 \%$ & $5.6 \%$ \\
\hline 1986 & $18.4 \%$ & $63.8 \%$ & 9.3\% & $29 \%$ & $5.7 \%$ \\
\hline 1987 & $17.0 \%$ & $65.8 \%$ & $8.9 \%$ & $28 \%$ & $5.4 \%$ \\
\hline 1988 & $15.3 \%$ & $68.6 \%$ & $8.3 \%$ & $27 \%$ & $5.1 \%$ \\
\hline 1989 & $15.0 \%$ & $70.6 \%$ & $6.9 \%$ & $2.9 \%$ & $4.6 \%$ \\
\hline 1990 & $15.1 \%$ & $71.4 \%$ & $6.5 \%$ & $28 \%$ & $4.1 \%$ \\
\hline 1991 & $13.9 \%$ & $73.0 \%$ & $6.4 \%$ & $27 \%$ & $4.0 \%$ \\
\hline 1992 & $12.0 \%$ & $75.6 \%$ & $6.5 \%$ & $2.4 \%$ & $3.5 \%$ \\
\hline 1992 & - & 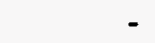 & - & - & - \\
\hline
\end{tabular}

* 1992 is the last year for which total gross output value statistics are available. Only industrial and agricultural gross output value data are published for subsequent years.

$¥$ Relative to the sum of real sectoral gross output (second column of data on previous page), not the total calculated from a single deflator.

Source: China Statistical Yearbook, various years. 


\begin{tabular}{|c|c|c|c|c|c|c|c|c|c|c|c|c|}
\hline \multicolumn{13}{|c|}{ 1. Billion Current Yuan } \\
\hline \multirow[b]{3}{*}{ Year } & \multirow{3}{*}{$\begin{array}{l}\text { State- } \\
\text { Owned } \\
\text { Enterprises }\end{array}$} & \multicolumn{6}{|c|}{ Non-State Enterprises } & \multirow{2}{*}{\multicolumn{3}{|c|}{ Private }} & \multirow[b]{3}{*}{ Other* } & \multirow[b]{3}{*}{ Total } \\
\hline & & Township- & Village- & Rural & Urban & Uncate- & & & & & & \\
\hline & & Owned & Owned & Collective & Collective & gorized & Subtotal & Rural & Urban & Subtotal & & \\
\hline 1980 & 391.560 & - & - & - & - & - & 121.336 & - & - & 0.081 & 2.449 & 515.426 \\
\hline 1981 & 403.710 & - & - & - & - & - & 132.938 & - & - & 0.190 & 3.140 & 539.978 \\
\hline 1982 & 432.600 & - & - & - & - & - & 144.242 & - & - & 0.340 & 3.940 & 581.122 \\
\hline 1983 & 473.940 & - & - & - & - & - & 166.314 & - & - & 0.750 & 5.040 & 646.044 \\
\hline 1984 & 526.270 & - & - & - & - & '- & 226.309 & - & - & 1.480 & 7.670 & 761.729 \\
\hline 1985 & 630.212 & 76.055 & 66.272 & 15.175 & - & 154.217 & 311.719 & 14.636 & 3.339 & 17.975 & 11.741 & 971.647 \\
\hline 1986 & 697.112 & 98.108 & 83.849 & 22.723 & 2.056 & 168.418 & 375.154 & 27.941 & 2.913 & 30.854 & 16.306 & $1,119.426$ \\
\hline 1987 & 825.009 & 128.419 & 116.535 & 28.615 & 3.031 & 201.574 & 478.174 & 45.212 & 5.027 & 50.239 & 27.877 & $1,381.299$ \\
\hline 1988 & $1,035.128$ & 184.669 & 170.363 & 40.011 & 3.927 & 259.779 & 658.749 & 72.200 & 6.848 & 79.048 & 49.532 & $1,822.458$ \\
\hline 1989 & 1.234 .291 & 219.384 & 211.768 & 44.627 & .5 .003 & 305.023 & 785.805 & 96.796 & 8.970 & 105.766 & 75.844 & $2,201.706$ \\
\hline 1990 & $1,306.375$ & 244.141 & 239.402 & 48.447 & 5.453 & 314.830 & 852.273 & 118.306 & 10.724 & 129.030 & 104.756 & $2,392.436$ \\
\hline 1991 & $1,495.458$ & 300.131 & 293.408 & 50.026 & 6.901 & 358.009 & $1,008.475$ & 147.982 & 12.928 & 160.910 & 159.958 & $2,824.801$ \\
\hline 1992 & $1,782,412$ & 441.724 & 453.983 & 76.794 & 10.188 & 427.432 & $1,410.121$ & 231.142 & 19.538 & 250.680 & 263.358 & $3,706.571$ \\
\hline 1993 & $2,272.467$ & 749.520 & 645.429 & 116.644 & 15.552 & 494.176 & $2,021.321$ & 400.587 & 39.618 & 440.205 & 535.206 & $5,269.199$ \\
\hline \multicolumn{13}{|c|}{ 2. Shares } \\
\hline \multirow[b]{3}{*}{ Year } & \multirow{3}{*}{$\begin{array}{c}\text { State- } \\
\text { Owned } \\
\text { Enterprises }\end{array}$} & \multicolumn{6}{|c|}{ Non-State Enterprises } & \multirow{3}{*}{\multicolumn{3}{|c|}{$\frac{\text { Private }}{\text { Urban Subtotal }}$}} & & \\
\hline & & Township- & Village- & Rural & Urban & Uncate- & & & & & & \\
\hline & & Owned & Owned & Collective & Collective & gorized & Subtotal & & & & Other* & Total \\
\hline 1980 & $76.0 \%$ & - & - & - & - & - & $23.5 \%$ & - & - & $0.0 \%$ & $0.5 \%$ & $100.0 \%$ \\
\hline 1981 & $74.8 \%$ & - & - & - & - & - & $24.6 \%$ & - & - & $0.0 \%$ & $0.6 \%$ & $100.0 \%$ \\
\hline 1982 & $74.4 \%$ & - & - & - & - & '- & $24.8 \%$ & - & - & $0.1 \%$ & $0.7 \%$ & $100.0 \%$ \\
\hline 1983 & $73.4 \%$ & - & - & - & - & - & $25.7 \%$ & - & - & $0.1 \%$ & $0.8 \%$ & $100.0 \%$ \\
\hline 1984 & $69.1 \%$ & - & - & - & - & - & $29.7 \%$ & - & - & $0.2 \%$ & $1.0 \%$ & $100.0 \%$ \\
\hline 1985 & $64.9 \%$ & $7.8 \%$ & $6.8 \%$ & $1.6 \%$ & - & $15.9 \%$ & $32.1 \%$ & $i .5 \%$ & $0.3 \%$ & $1.8 \%$ & $1.2 \%$ & $100.0 \%$ \\
\hline 1986 & $62.3 \%$ & $8.8 \%$ & $7.5 \%$ & $2.0 \%$ & $0.2 \%$ & $15.0 \%$ & $33.5 \%$ & $2.5 \%$ & $0.3 \%$ & $2.8 \%$ & $1.5 \%$ & $100.0 \%$ \\
\hline 1987 & $59.7 \%$ & $9.3 \%$ & $8.4 \%$ & $2.1 \%$ & $0.2 \%$ & $14.6 \%$ & $34.6 \%$ & $3.3 \%$ & $0.4 \%$ & $3.6 \%$ & $2.0 \%$ & $100.0 \%$ \\
\hline 1988 & $56.8 \%$ & $10.1 \%$ & $9.3 \%$ & $2.2 \%$ & $0.2 \%$ & $14.3 \%$ & $36.1 \%$ & $4.0 \%$ & $0.4 \%$ & $4.3 \%$ & $2.7 \%$ & $100.0 \%$ \\
\hline 1989 & $56.1 \%$ & $10.0 \%$ & $9.6 \%$ & $2.0 \%$ & $0.2 \%$ & $13.9 \%$ & $35.7 \%$ & $4.4 \%$ & $0.4 \%$ & $4.8 \%$ & $3.4 \%$ & $100.0 \%$ \\
\hline 1990 & $54.6 \%$ & $10.2 \%$ & $10.0 \%$ & $2.0 \%$ & $0.2 \%$ & $13.2 \%$ & $35.6 \%$ & $4.9 \%$ & $0.4 \%$ & $5.4 \%$ & $4.4 \%$ & $100.0 \%$ \\
\hline 1991 & $52.9 \%$ & $10.6 \%$ & $10.4 \%$ & $1.8 \%$ & $0.2 \%$ & $12.7 \%$ & $35.7 \%$ & $5.2 \%$ & $0.5 \%$ & $5.7 \%$ & $5.7 \%$ & $100.0 \%$ \\
\hline 1992 & $48.1 \%$ & $11.9 \%$ & $12.2 \%$ & $2.1 \%$ & $0.3 \%$ & $11.5 \%$ & $38.0 \%$ & $6.2 \%$ & $0.5 \%$ & $6.8 \%$ & $7.1 \%$ & $100.0 \%$ \\
\hline 1993 & $43.1 \%$ & $14.2 \%$ & $12.2 \%$ & $2.2 \%$ & $0.3 \%$ & $9.4 \%$ & $38.4 \%$ & $7.6 \%$ & $0.8 \%$ & $8.4 \%$ & $10.2 \%$ & $100.0 \%$ \\
\hline
\end{tabular}

* Joint ventures, including foreign and domestlc joint ventures.

Source: China Statistical Yearbook, varlous years. 
Table X-6. National Income, 1952-1993

\begin{tabular}{|c|c|c|c|c|c|c|}
\hline \multicolumn{7}{|c|}{ I. National Income, Billion Current Yuan } \\
\hline Year & Total & $\begin{array}{l}\text { Agri- } \\
\text { culture }\end{array}$ & Industry & $\begin{array}{c}\text { Con- } \\
\text { struction }\end{array}$ & $\begin{array}{l}\text { Trans- } \\
\text { portation }\end{array}$ & Commerce \\
\hline 1952 & 58.9 & 34.0 & 11.5 & 21 & 25 & 8.8 \\
\hline 1953 & 70.9 & 37.4 & 15.6 & 28 & 29 & 122 \\
\hline 1954 & 74.8 & 38.8 & 17.4 & 26 & 3.2 & 128 \\
\hline 1955 & 78.8 & 41.7 & 17.9 & 3.0 & 3.3 & 12.9 \\
\hline 1956 & 88.2 & 43.9 & 21.2 & 5.5 & 3.7 & 13.9 \\
\hline 1957 & 90.8 & 42.5 & 25.7 & 4.5 & 3.9 & 14.2 \\
\hline 1958 & 111.8 & 44.0 & 40.1 & 6.8 & 5.9 & 15.0 \\
\hline 1959 & 122.2 & 37.6 & 52.7 & 7.6 & 7.8 & 16.5 \\
\hline$\overline{1960}$ & 122.0 & 33.2 & 56.5 & 7.9 & 8.4 & 16.0 \\
\hline 1961 & 99.6 & 43.2 & 34.5 & 25 & 4.8 & 14.6 \\
\hline 1962 & 92.4 & 44.4 & 30.3 & 3.2 & 3.8 & 10.7 \\
\hline 1963 & 100.0 & 48.8 & 33.7 & 4.0 & 3.9 & 9.6 \\
\hline 1964 & 116.6 & 54.9 & 42.2 & 5.0 & 4.4 & 10.1 \\
\hline 1965 & 138.7 & 64.1 & 50.5 & 5.3 & 5.8 & 13.0 \\
\hline 1966 & 158.6 & 69.2 & 60.6 & 5.8 & 6.6 & 16.4 \\
\hline 1967 & 148.7 & 70.3 & 50.5 & 5.5 & 5.2 & 17.2 \\
\hline 1968 & 141.5 & 71.4 & 44.9 & 4.4 & 4.9 & 15.9 \\
\hline 1969 & $\cdot 161.7$ & 72.2 & 58.7 & 6.0 & 6.2 & 18.6 \\
\hline 1970 & 192.6 & 77.8 & 78.9 & 8.0 & 7.4 & 20.5 \\
\hline 1971 & 207.7 & 80.8 & 89.1 & 9.1 & 8.0 & 20.7 \\
\hline 1972 & 213.6 & 80.8 & 94.2 & 8.8 & 8.4 & 21.4 \\
\hline $1973^{\circ}$ & 231.8 & 88.6 & 1020 & 9.2 & 8.9 & 23.1 \\
\hline 1974 & 234.8 & 92.2 & 101.5 & 9.9 & 8.5 & 227 \\
\hline 1975 & 250.3 & 94.6 & 115.2 & 11.3 & 9.6 & 19.6 \\
\hline 1976 & 242.7 & 94.0 & 110.6 & 120 & 9.2 & 16.9 \\
\hline 1977 & 264.4 & 91.3 & 126.3 & 12.4 & 10.6 & 23.8 \\
\hline 1978 & 301.0 & 98.6 & 148.7 & 12.5 & 11.8 & 29.4 \\
\hline 1979 & 335.0 & 122.6 & 1628 & 13.0 & 121 & 24.5 \\
\hline 1980 & 368.8 & 132.6 & 180.4 & 18.5 & 126 & 24.7 \\
\hline 1981 & 394.1 & 150.9 & 184.0 & 19.3 & 13.1 & 26.8 \\
\hline 1982 & 425.8 & 172.3 & 194.8 & 20.9 & 14.7 & 23.1 \\
\hline 1983 & 473.6 & 192.1 & 213.6 & 25.9 & 16.6 & 25.4 \\
\hline 1984 & 565.2 & 225.1 & 251.6 & 30.3 & 20.5 & 37.7 \\
\hline 1985 & 702.0 & 249.2 & 316.3 & 40.9 & 25.9 & 69.7 \\
\hline 1986 & 785.9 & 272.0 & 357.3 & 51.4 & 32.0 & 73.2 \\
\hline 1987 & 931.3 & 315.4 & 426.2 & 63.7 & 38.4 & 87.6 \\
\hline 1988 & $1,173.8$ & 381.8 & 541.6 & 78.3 & 46.0 & 126.1 \\
\hline 1989 & $1,317.6$ & 420.9 & 624.1 & 77.4 & 54.7 & 140.5 \\
\hline 1990 & $1,438.4$ & 500.0 & 661.0 & 83.9 & 78.7 & 114.8 \\
\hline 1991 & 1,655.7 & 526.9 & 770.3 & 100.9 & 88.7 & 168.9 \\
\hline 1992 & $2,022.3$ & 579.5 & 788.5 & 141.1 & 96.8 & 216.4 \\
\hline 1993 & $2,488.2$ & 631.7 & 1286.2 & 205.4 & 111.3 & 253.6 \\
\hline
\end{tabular}

Source: China Statistical Yearbook, various years. 
Table X-6. National Income, 1952-1993 (continued)

\begin{tabular}{|c|c|c|c|c|c|c|}
\hline \multicolumn{7}{|c|}{ 2. National Income Constant Price Index, $1952=100 *$} \\
\hline Year & Total & $\begin{array}{l}\text { Agri- } \\
\text { culture }\end{array}$ & Industry & $\begin{array}{c}\text { Con: } \\
\text { struction }\end{array}$ & $\begin{array}{c}\text { Trans- } \\
\text { portation }\end{array}$ & Commerce \\
\hline 1952 & 100.0 & 100.0 & 100.0 & 100.0 & 100.0 & 100.0 \\
\hline 1953 & 114.0 & 101.6 & 133.6 & 138.1 & 120.0 & 133.0 \\
\hline 1954 & 120.6 & 103.3 & 159.1 & 133.3 & 136.0 & 136.4 \\
\hline 1955 & 128.3 & 111.5 & 169.1 & 152.4 & 140.0 & 137.5 \\
\hline 1956 & 146.4 & 116.5 & 219.1 & 261.9 & 164.0 & 146.6 \\
\hline 1957 & 153.0 & 120.1 & 244.5 & 242.9 & 176.0 & 146.6 \\
\hline 1958 & 186.7 & 120.3 & 383.5 & 367.0 & 270.8 & 155.9 \\
\hline 1959 & 202.0 & 100.6 & 501.5 & 388.6 & 356.5 & 170.3 \\
\hline 1960 & 199.1 & 83.6 & 541.4 & 394.0 & 383.6 & 164.1 \\
\hline 1961 & 140.0 & 84.7 & 315.9 & 129.5 & 221.1 & 130.1 \\
\hline 1962 & 130.9 & 88.7 & 267.4 & 161.9 & 171.5 & 117.7 \\
\hline 1963 & 144.9 & 98.9 & 300.7 & 205.1 & 176.0 & 120.8 \\
\hline 1964 & 168.8 & 111.9 & 374.9 & 259.0 & 198.6 & 123.9 \\
\hline 1965 & 197.4 & 122.9 & 477.7 & 286.0 & 261.7 & 128.0 \\
\hline 1966 & 231.0 & 131.9 & 598.5 & 313.0 & 297.8 & 155.9 \\
\hline 1967 & 214.3 & 134.2 & 504.3 & 296.8 & 239.2 & 164.1 \\
\hline 1968 & 200.3 & 131.6 & 458.6 & 237.5 & 225.6 & 151.8 \\
\hline 1969 & 239.0 & 1322 & 6223 & 323.8 & 284.3 & 179.6 \\
\hline 1970 & 294.6 & 139.8 & 863.0 & 421.0 & 343.0 & 199.2 \\
\hline 1971 & 315.3 & 142.0 & 979.0 & 468.3 & 370.8 & 201.2 \\
\hline 1972 & 324.3 & 140.5 & $1,043.5$ & 452.5 & 389.3 & 208.0 \\
\hline 1973 & 351.2 & 153.1 & $1,134.3$ & 457.8 & 412.5 & 224.5 \\
\hline 1974 & 355.2 & 159.2 & $1,128.9$ & 484.1 & 394.0 & 220.6 \\
\hline 1975 & 384.7 & 162.3 & $1,297.3$ & 5420 & 444.9 & 220.6 \\
\hline 1976 & 374.5 & 159.1 & $1,249.2$ & 568.3 & 426.4 & 214.8 \\
\hline 1977 & 403.7 & 155.1 & $1,434.0$ & 578.8 & 491.3 & 242.0 \\
\hline 1978 & 453.4 & 161.2 & $1,679.1$ & 573.5 & 546.9 & 296.4 \\
\hline 1979 & 485.1 & 171.5 & $1,814.7$ & 584.1 & 560.8 . & 316.8 \\
\hline 1980 & 516.3 & 168.4 & $2,012.7$ & 757.7 & 584.0 & 318.8 \\
\hline 1981 & 541.5 & 180.4 & $2,046.8$ & 770.0 & 607.2 & 379.4 \\
\hline 1982 & 585.8 & 201.6 & $2,170.1$ & 806.9 & 681.3 & 397.5 \\
\hline 1983 & 644.2 & 218.7 & $2,383.7$ & 954.3 & 755.5 & 449.1 \\
\hline 1984 & 731.9 & 247.0 & $2,738.8$ & $1,056.7$ & 852.8 & 499.5 \\
\hline 1985 & 830.6 & 253.7 & $3,275.2$ & $1,310.6$ & $1,024.3$ & 593.7 \\
\hline 1986 & 894.5 & 261.4 & $3,590.6$ & $1,540.0$ & $1,140.2$ & 636.3 \\
\hline 1987 & 985.7 & 273.2 & $4,058.8$ & $1,744.8$ & $1,269.9$ & 715.0 \\
\hline 1988 & $1,097.2$ & 279.4 & $4,765.0$ & $1,884.0$ & $1,413.6$ & 779.5 \\
\hline 1989 & $1,137.2$ & 288.3 & 5.0526 & $1,724.3$ & $1,557.3$ & 734.4 \\
\hline 1990 & $1,195.3$ & 309.9 & $5,328.0$ & $1,732.8$ & $1,631.2$ & 706.9 \\
\hline 1991 & $1,287.4$ & 317.0 & $6,011.2$ & 1,9226 & $1,743.3$ & 711.1 \\
\hline 1992 & $1,485.4$ & 3328 & $7,297.1$ & $2,347.7$ & $1,895.3$ & 864.6 \\
\hline 1993 & $1,709.8$ & 346.1 & $8,895.2$ & $2,643.6$ & $2,045.1$ & 904.3 \\
\hline
\end{tabular}

* These can be thought of as percentages; e.g. at constant prices, total national income in 1993 was 1,710\% of total national income in $\mathbf{1 9 5 2 .}$

Source: China Statistical Yearbook, various years. 
Table X-6. National Income, 1952-1993 (continued)

\begin{tabular}{|c|c|c|c|c|c|c|}
\hline \multicolumn{7}{|c|}{ 3. National Income Billion Constant 1980 Yuan * } \\
\hline Year & Total II & $\begin{array}{l}\text { Agri- } \\
\text { culture }\end{array}$ & Industry & $\begin{array}{c}\text { Con- } \\
\text { struction }\end{array}$ & $\begin{array}{l}\text { Trans- } \\
\text { portation }\end{array}$ & Commerce \\
\hline 1952 & 100.1 & 78.7 & 9.0 & 24 & 2.2 & 7.7 \\
\hline 1953 & 108.2 & 80.0 & 120 & 3.4 & 2.6 & 10.3 \\
\hline 1954 & 112.4 & 81.3 & 14.3 & 3.3 & 2.9 & 10.6 \\
\hline 1955 & 120.3 & 87.8 & 15.2 & 3.7 & 3.0 & 10.7 \\
\hline 1956 & 132.7 & 91.7 & 19.6 & 6.4 & 3.5 & 11.4 \\
\hline 1957 & 137.6 & 94.6 & 21.9 & 5.9 & 3.8 & 11.4 \\
\hline 1958 & 156.0 & 94.7 & 34.4 & 9.0 & 5.8 & 12.1 \\
\hline 1959 & 154.5 & 79.2 & 44.9 & 9.5 & 7.7 & 13.2 \\
\hline 1960 & 145.0 & 65.8 & 48.5 & 9.6 & 8.3 & 12.7 \\
\hline 1961 & 113.0 & 66.7 & 28.3 & 3.2 & 4.8 & 10.1 \\
\hline 1962 & 110.6 & 69.8 & 24.0 & 4.0 & 3.7 & 9.1 \\
\hline 1963 & 123.0 & 77.9 & 27.0 & 5.0 & 3.8 & 9.4 \\
\hline 1964 & 141.9 & 88.1 & 33.6 & 6.3 & 4.3 & 9.6 \\
\hline 1965 & 162.1 & 96.8 & 428 & 7.0 & 5.6 & 9.9 \\
\hline 1966 & 183.6 & 103.9 & 53.6 & 7.6 & 6.4 & 12.1 \\
\hline 1967 & 176.0 & 105.7 & 45.2 & 7.2 & 5.2 & 12.7 \\
\hline 1968 & 167.2 & 103.6 & 41.1 & 5.8 & 4.9 & 11.8 \\
\hline 1969 & 187.8 & 104.1 & 55.8 & 7.9 & 6.1 & 13.9 \\
\hline 1970 & 220.5 & 110.1 & 77.4 & 10.3 & 7.4 & 15.4 \\
\hline 1971 & 234.6 & 111.8 & 87.7 & 11.4 & 8.0 & 15.6 \\
\hline 1972 & 239.7 & 110.6 & 93.5 & 11.0 & 8.4 & 16.1 \\
\hline 1973 & 259.7 & 120.6 & 101.7 & 11.2 & 8.9 & 17.4 \\
\hline 1974 & 264.0 & 125.4 & 101.2 & 11.8 & 8.5 & 17.1 \\
\hline 1975 & 284.0 & 127.8 & 116.3 & 13.2 & 9.6 & 17.1 \\
\hline 1976 & 277.0 & 125.3 & 112.0 & 13.9 & 9.2 & 16.6 \\
\hline 1977 & 294.1 & 122.1 & 128.5 & 14.1 & 10.6 & 18.7 \\
\hline 1978 & 326.2 & 126.9 & 150.5 & 14.0 & 11.8 & 23.0 \\
\hline 1979 & 348.6 & 135.0 & 1627 & 14.3 & 12.1 & 24.5 \\
\hline 1980 & 368.8 & 1326 & 180.4 & 18.5 & 12.6 & 24.7 \\
\hline 1981 & 386.8 & 142.0 & 183.5 & 18.8 & 13.1 & 29.4 \\
\hline 1982 & 418.4 & 158.7 & 194.5 & 19.7 & 14.7 & 30.8 \\
\hline 1983 & 460.3 & 172.2 & 213.7 & 23.3 & 16.3 & 34.8 \\
\hline 1984 & 522.9 & 194.5 & 245.5 & 25.8 & 18.4 & 38.7 \\
\hline 1985 & 593.4 & 199.8 & 293.6 & 320 & 22.1 & 46.0 \\
\hline 1986 & 639.2 & 205.8 & 321.8 & 37.6 & 24.6 & 49.3 \\
\hline 1987 & 704.3 & 215.1 & 363.8 & 426 & 27.4 & 55.4 \\
\hline 1988 & 784.0 & 220.0 & 427.1 & 46.0 & 30.5 & 60.4 \\
\hline 1989 & 812.5 & 227.0 & 452.9 & 42.1 & 33.6 & 56.9 \\
\hline 1990 & 853.8 & 244.0 & 477.6 & 423 & 35.2 & 54.8 \\
\hline 1991 & 928.0 & 249.6 & 538.8 & 46.9 & 37.6 & 55.1 \\
\hline 1992 & 1081.3 & 262.0 & 654.0 & 57.3 & 40.9 & 67.0 \\
\hline 1993 & 1248.6 & 272.6 & 797.3 & 64.5 & 44.1 & 70.1 \\
\hline
\end{tabular}

$\dagger$ National income in constant yuan = base year national income in current yuan * (index for current year $\div$ index for base year).

i Sum of real sectoral national incomes, not calculated from indices.

Source: China Statistical Yearbook, various years. 
Figure X-5. National Income

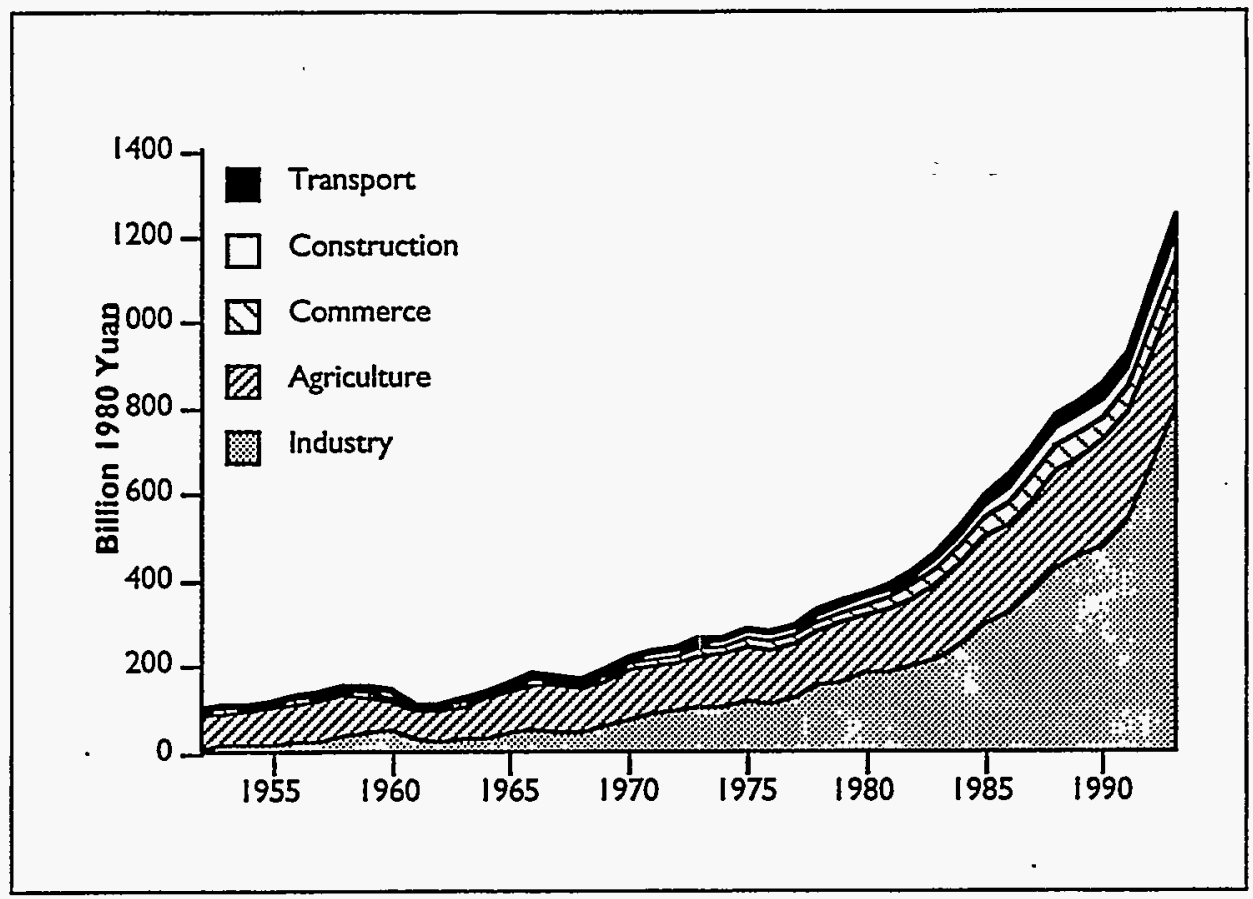

Figure X-6. Sectoral Shares of National Income

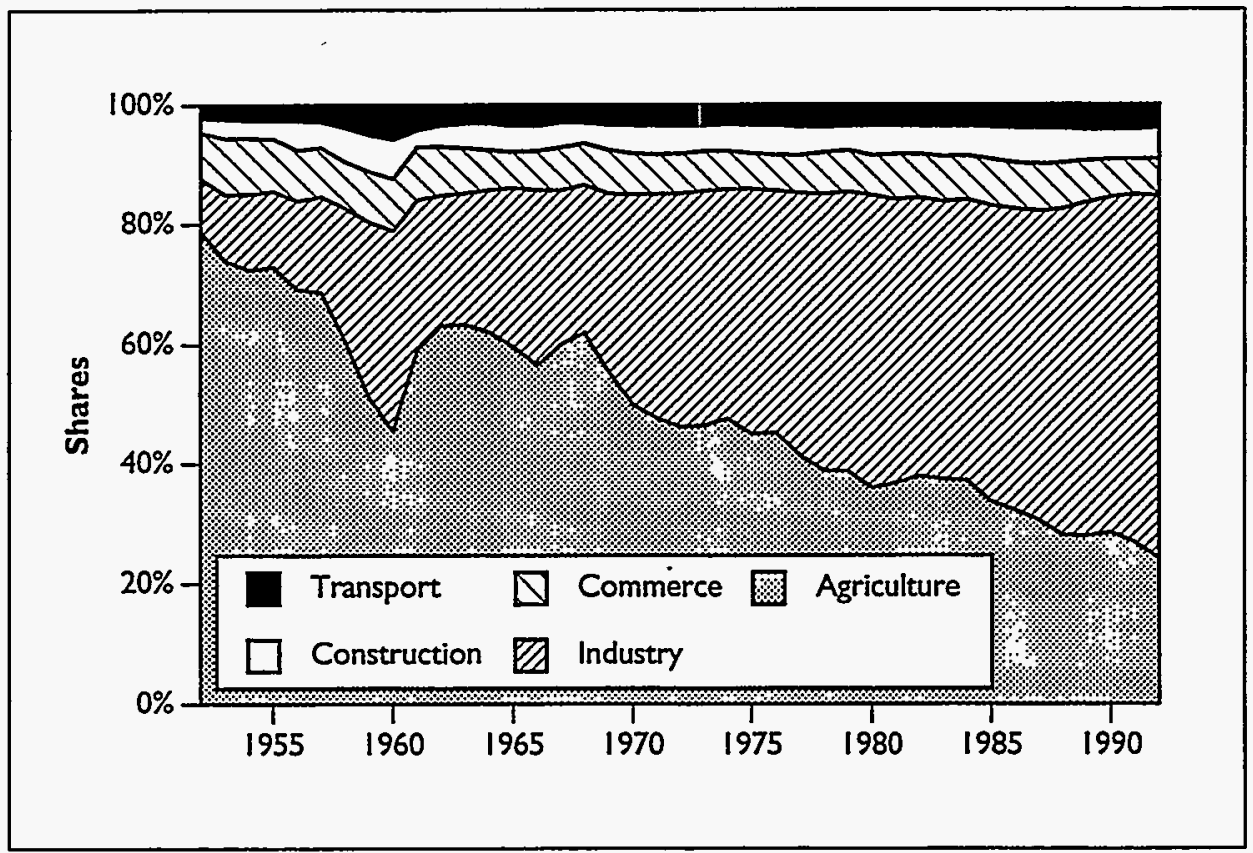


Table X-6. National Income, 1952-1993 (continued)

\begin{tabular}{|c|c|c|c|c|c|c|}
\hline \multicolumn{7}{|c|}{ 4. Sectoral Shares of Real National Income, Percent } \\
\hline Year & Total & $\begin{array}{l}\text { Agri- } \\
\text { culture }\end{array}$ & Industry & $\begin{array}{c}\text { Con- } \\
\text { struction }\end{array}$ & $\begin{array}{c}\text { Trans- } \\
\text { portation }\end{array}$ & Commerce \\
\hline 1952 & $100.0 \%$ & $78.7 \%$ & $9.0 \%$ & $24 \%$ & $22 \%$ & $7.7 \%$ \\
\hline 1953 & $100.0 \%$ & $73.9 \%$ & $11.1 \%$ & $3.1 \%$ & $2.4 \%$ & $9.5 \%$ \\
\hline 1954 & $100.0 \%$ & $724 \%$ & $12.7 \%$ & $2.9 \%$ & $26 \%$ & $9.4 \%$ \\
\hline 1955 & $100.0 \%$ & $73.0 \%$ & $126 \%$ & $3.1 \%$ & $2.5 \%$ & $8.9 \%$ \\
\hline 1956 & $100.0 \%$ & $69.1 \%$ & $14.8 \%$ & $4.8 \%$ & $27 \%$ & $8.6 \%$ \\
\hline 1957 & $100.0 \%$ & $68.7 \%$ & $15.9 \%$ & $4.3 \%$ & $2.8 \%$ & $8.3 \%$ \\
\hline 1958 & $100.0 \%$ & $60.7 \%$ & $22.0 \%$ & $5.7 \%$ & $3.7 \%$ & $7.7 \%$ \\
\hline 1959 & $100.0 \%$ & $51.3 \%$ & $29.1 \%$ & $6.1 \%$ & $5.0 \%$ & $8.5 \%$ \\
\hline 1960 & $100.0 \%$ & $45.4 \%$ & $33.5 \%$ & $6.6 \%$ & $5.7 \%$ & $8.8 \%$ \\
\hline 1961 & $100.0 \%$ & $59.0 \%$ & $25.1 \%$ & $2.8 \%$ & $4.2 \%$ & $8.9 \%$ \\
\hline 1962 & $100.0 \%$ & $63.2 \%$ & $21.7 \%$ & $3.6 \%$ & $3.3 \%$ & $8.2 \%$ \\
\hline 1963 & $100.0 \%$ & $63.3 \%$ & $21.9 \%$ & $4.1 \%$ & $3.1 \%$ & $7.6 \%$ \\
\hline 1964 & $100.0 \%$ & $62.1 \%$ & $23.7 \%$ & $4.5 \%$ & $3.0 \%$ & $6.8 \%$ \\
\hline 1965 & $100.0 \%$ & $59.7 \%$ & $26.4 \%$ & $4.3 \%$ & $3.5 \%$ & $6.1 \%$ \\
\hline 1966 & $100.0 \%$ & $56.6 \%$ & $29.2 \%$ & $4.2 \%$ & $3.5 \%$ & $6.6 \%$ \\
\hline 1967 & $100.0 \%$ & $60.0 \%$ & $25.7 \%$ & $4.1 \%$ & $29 \%$ & $7.2 \%$ \\
\hline 1968 & $100.0 \%$ & $62.0 \%$ & $24.6 \%$ & $3.5 \%$ & $2.9 \%$ & $7.0 \%$ \\
\hline 1969 & $100.0 \%$ & $55.4 \%$ & $29.7 \%$ & $4.2 \%$ & $3.3 \%$ & $7.4 \%$ \\
\hline 1970 & $100.0 \%$ & $49.9 \%$ & $35.1 \%$ & $4.7 \%$ & $3.4 \%$ & $7.0 \%$ \\
\hline 1971 & $100.0 \%$ & $47.7 \%$ & $37.4 \%$ & $4.9 \%$ & $3.4 \%$ & $6.6 \%$ \\
\hline 1972 & $100.0 \%$ & $46.1 \%$ & $39.0 \%$ & $4.6 \%$ & $3.5 \%$ & $6.7 \%$ \\
\hline 1973 & $100.0 \%$ & $46.4 \%$ & $39.1 \%$ & $4.3 \%$ & $3.4 \%$ & $6.7 \%$ \\
\hline 1974 & $100.0 \%$ & $47.5 \%$ & $38.3 \%$ & $4.5 \%$ & $3.2 \%$ & $6.5 \%$ \\
\hline 1975 & $100.0 \%$ & $45.0 \%$ & $40.9 \%$ & $4.7 \%$ & $3.4 \%$ & $6.0 \%$ \\
\hline 1976 & $100.0 \%$ & $45.2 \%$ & $40.4 \%$ & $5.0 \%$ & $3.3 \%$ & $6.0 \%$ \\
\hline 1977 & $100.0 \%$ & $41.5 \%$ & $43.7 \%$ & $4.8 \%$ & $3.6 \%$ & $6.4 \%$ \\
\hline 1978 & $100.0 \%$ & $38.9 \%$ & $46.1 \%$ & $4.3 \%$ & $3.6 \%$ & $7.0 \%$ \\
\hline 1979 & $100.0 \%$ & $38.7 \%$ & $46.7 \%$ & $4.1 \%$ & $3.5 \%$ & $7.0 \%$ \\
\hline 1980 & $100.0 \%$ & $36.0 \%$ & $48.9 \%$ & $5.0 \%$ & $3.4 \%$ & $6.7 \%$ \\
\hline 1981 & $100.0 \%$ & $36.7 \%$ & $47.4 \%$ & $4.9 \%$ & $3.4 \%$ & $7.6 \%$ \\
\hline 1982 & $100.0 \%$ & $37.9 \%$ & $46.5 \%$ & $4.7 \%$ & $3.5 \%$ & $7.4 \%$ \\
\hline 1983 & $100.0 \%$ & $37.4 \%$ & $46.4 \%$ & $5.1 \%$ & $3.5 \%$ & $7.6 \%$ \\
\hline 1984 & $100.0 \%$ & $37.2 \%$ & $46.9 \%$ & $4.9 \%$ & $3.5 \%$ & $7.4 \%$ \\
\hline 1985 & $100.0 \%$ & $33.7 \%$ & $49.5 \%$ & $5.4 \%$ & $3.7 \%$ & $7.8 \%$ \\
\hline 1986 & $100.0 \%$ & $32.2 \%$ & $50.4 \%$ & $5.9 \%$ & $3.8 \%$ & $7.7 \%$ \\
\hline 1987 & $100.0 \%$ & $30.5 \%$ & $51.7 \%$ & $6.0 \%$ & $3.9 \%$ & $7.9 \%$ \\
\hline 1988 & $100.0 \%$ & $28.1 \%$ & $54.5 \%$ & $5.9 \%$ & $3.9 \%$ & $7.7 \%$ \\
\hline 1989 & $100.0 \%$ & $27.9 \%$ & $55.7 \%$ & $5.2 \%$ & $4.1 \%$ & $7.0 \%$ \\
\hline 1990 & $100.0 \%$ & $28.6 \%$ & $55.9 \%$ & $5.0 \%$ & $4.1 \%$ & $6.4 \%$ \\
\hline 1991 & $100.0 \%$ & $26.9 \%$ & $58.1 \%$ & $5.1 \%$ & $4.1 \%$ & $5.9 \%$ \\
\hline 1992 & $100.0 \%$ & $24.2 \%$ & $60.5 \%$ & $5.3 \%$ & $3.8 \%$ & $6.2 \%$ \\
\hline 1993 & $100.0 \%$ & $21.8 \%$ & $63.9 \%$ & $5.2 \%$ & $3.5 \%$ & $5.6 \%$ \\
\hline
\end{tabular}

Source: China Statistical Yearbook, various years. 
Table X-6. National Income, 1952-1993 (continued)

\begin{tabular}{|c|c|c|c|c|c|c|}
\hline \multicolumn{7}{|c|}{ 5. Real Growth Rates by Sector of National Income, Percent, 1953-1993 } \\
\hline Year & Total & $\begin{array}{l}\text { Agri- } \\
\text { culture }\end{array}$ & Industry & $\begin{array}{l}\text { Con- } \\
\text { struction }\end{array}$ & $\begin{array}{c}\text { Trans- } \\
\text { portation }\end{array}$ & Commerce \\
\hline 1953 & $8.2 \%$ & $1.6 \%$ & $33.6 \%$ & $38.1 \%$ & $20.0 \%$ & $33.0 \%$ \\
\hline 1954 & $3.8 \%$ & $1.7 \%$ & $19.1 \%$ & $-3.5 \%$ & $13.3 \%$ & $2.6 \%$ \\
\hline 1955 & $7.1 \%$ & $7.9 \%$ & $6.3 \%$ & $14.3 \%$ & $2.9 \%$ & $0.8 \%$ \\
\hline 1956 & $10.2 \%$ & $4.5 \%$ & $29.6 \%$ & $71.9 \%$ & $17.1 \%$ & $6.6 \%$ \\
\hline 1957 & $3.7 \%$ & $3.1 \%$ & $11.6 \%$ & $-7.3 \%$ & $7.3 \%$ & $0.0 \%$ \\
\hline 1958 & $13.4 \%$ & $0.2 \%$ & $56.9 \%$ & $51.1 \%$ & $53.9 \%$ & $6.3 \%$ \\
\hline 1959 & $-0.9 \%$ & $-16.4 \%$ & $30.8 \%$ & $5.9 \%$ & $31.6 \%$ & $9.2 \%$ \\
\hline 1960 & $-6.2 \%$ & $-16.9 \%$ & $8.0 \%$ & $1.4 \%$ & $7.6 \%$ & $-3.6 \%$ \\
\hline 1961 & $-22.0 \%$ & $1.3 \%$ & $-41.7 \%$ & $-67.1 \%$ & $-42.4 \%$ & $-20.7 \%$ \\
\hline 1962 & $-2.2 \%$ & $4.7 \%$ & $-15.4 \%$ & $25.0 \%$ & $-22.4 \%$ & $-9.5 \%$ \\
\hline 1963 & $11.2 \%$ & $11.5 \%$ & $12.5 \%$ & $26.7 \%$ & $2.6 \%$ & $2.6 \%$ \\
\hline 1964 & $15.4 \%$ & $13.1 \%$ & $24.7 \%$ & $26.3 \%$ & $128 \%$ & $2.6 \%$ \\
\hline 1965 & $14.2 \%$ & $9.8 \%$ & $27.4 \%$ & $10.4 \%$ & $31.8 \%$ & $3.3 \%$ \\
\hline 1966 & $13.3 \%$ & $7.3 \%$ & $25.3 \%$ & $9.4 \%$ & $13.8 \%$ & $21.8 \%$ \\
\hline 1967 & $-4.2 \%$ & $1.7 \%$ & $-15.7 \%$ & $-5.2 \%$ & $-19.7 \%$ & $5.3 \%$ \\
\hline 1968 & $-5.0 \%$ & $-1.9 \%$ & $-9.1 \%$ & $-20.0 \%$ & $-5.7 \%$ & $-7.5 \%$ \\
\hline 1969 & $12.4 \%$ & $0.5 \%$ & $35.7 \%$ & $36.3 \%$ & $26.0 \%$ & $18.3 \%$ \\
\hline 1970 & $17.4 \%$ & $5.7 \%$ & $38.7 \%$ & $30.0 \%$ & $20.6 \%$ & $10.9 \%$ \\
\hline 1971 & $6.4 \%$ & $1.6 \%$ & $13.4 \%$ & $11.2 \%$ & $8.1 \%$ & $1.0 \%$ \\
\hline 1972 & $2.2 \%$ & $-1.1 \%$ & $6.6 \%$ & $-3.4 \%$ & $5.0 \%$ & $3.4 \%$ \\
\hline 1973 & $8.3 \%$ & $9.0 \%$ & $8.7 \%$ & $1.2 \%$ & $6.0 \%$ & $7.9 \%$ \\
\hline 1974 & $1.6 \%$ & $4.0 \%$ & $-0.5 \%$ & $5.7 \%$ & $-4.5 \%$ & $-1.7 \%$ \\
\hline 1975 & $7.6 \%$ & $1.9 \%$ & $14.9 \%$ & $12.0 \%$ & $12.9 \%$ & $0.0 \%$ \\
\hline 1976 & $-2.5 \%$ & $-2.0 \%$ & $-3.7 \%$ & $4.9 \%$ & $-4.2 \%$ & $-2.6 \%$ \\
\hline 1977 & $6.2 \%$ & $-2.5 \%$ & $14.8 \%$ & $1.8 \%$ & $15.2 \%$ & $12.7 \%$ \\
\hline 1978 & $10.9 \%$ & $3.9 \%$ & $17.1 \%$ & $-0.9 \%$ & $11.3 \%$ & $22.5 \%$ \\
\hline 1979 & $6.9 \%$ & $6.4 \%$ & $8.1 \%$ & $1.8 \%$ & $25 \%$ & $6.9 \%$ \\
\hline 1980 & $5.8 \%$ & $-1.8 \%$ & $10.9 \%$ & $29.7 \%$ & $4.1 \%$ & $0.6 \%$ \\
\hline 1981 & $4.9 \%$ & $7.1 \%$ & $1.7 \%$ & $1.6 \%$ & $4.0 \%$ & $19.0 \%$ \\
\hline 1982 & $8.2 \%$ & $11.8 \%$ & $6.0 \%$ & $4.8 \%$ & $12.2 \%$ & $4.8 \%$ \\
\hline 1983 & $10.0 \%$ & $8.5 \%$ & $9.8 \%$ & $18.3 \%$ & $10.9 \%$ & $13.0 \%$ \\
\hline 1984 & $13.6 \%$ & $12.9 \%$ & $14.9 \%$ & $10.7 \%$ & $12.9 \%$ & $11.2 \%$ \\
\hline 1985 & $13.5 \%$ & $2.7 \%$ & $19.6 \%$ & $24.0 \%$ & $20.1 \%$ & $18.9 \%$ \\
\hline 1986 & $7.7 \%$ & $3.0 \%$ & $9.6 \%$ & $17.5 \%$ & $11.3 \%$ & $7.2 \%$ \\
\hline 1987 & $10.2 \%$ & $4.5 \%$ & $13.0 \%$ & $13.3 \%$ & $11.4 \%$ & $12.4 \%$ \\
\hline 1988 & $11.3 \%$ & $2.3 \%$ & $17.4 \%$ & $8.0 \%$ & $11.3 \%$ & $9.0 \%$ \\
\hline 1989 & $3.6 \%$ & $3.2 \%$ & $6.0 \%$ & $-8.5 \%$ & $10.2 \%$ & $-5.8 \%$ \\
\hline 1990 & $5.1 \%$ & $7.5 \%$ & $5.5 \%$ & $0.5 \%$ & $4.7 \%$ & $-3.7 \%$ \\
\hline 1991 & $8.7 \%$ & $2.3 \%$ & $12.8 \%$ & $11.0 \%$ & $6.9 \%$ & $0.6 \%$ \\
\hline 1992 & $16.5 \%$ & $5.0 \%$ & $21.4 \%$ & $22.1 \%$ & $8.7 \%$ & $21.6 \%$ \\
\hline 1993 & $15.5 \%$ & $4.0 \%$ & $21.9 \%$ & $12.6 \%$ & $7.9 \%$ & $4.6 \%$ \\
\hline
\end{tabular}

Source: China Statistical Yearbook, various years. 
Table X-6. National Income, 1952-1993 (continued)

\begin{tabular}{|c|c|c|c|c|c|c|}
\hline \multicolumn{7}{|c|}{ 6. National Income Implicit Deflators to Constant 1980 Yuan $\S$} \\
\hline Year & Total & $\begin{array}{l}\text { Agri- } \\
\text { culture }\end{array}$ & Industry & $\begin{array}{c}\text { Con- } \\
\text { struction }\end{array}$ & $\begin{array}{l}\text { Trans- } \\
\text { portation }\end{array}$ & Commerce \\
\hline 1952 & 58.9 & 43.2 & 128.3 & 86.0 & 115.9 & 113.6 \\
\hline 1953 & 65.5 & 46.7 & 130.3 & 83.0 & 112.0 & 118.4 \\
\hline 1954 & 66.6 & 47.7 & 122.0 & 79.9 & 109.1 & 121.1 \\
\hline 1955 & 65.5 & 47.5 & 118.1 & 80.6 & 109.3 & 121.1 \\
\hline 1956 & 66.5 & 47.9 & 108.0 & 86.0 & 104.6 & 122.4 \\
\hline 1957 & 66.0 & 44.9 & 117.3 & 75.9 & 102.7 & 125.0 \\
\hline 1958 & 71.7 & 46.4 & 116.7 & 75.9 & $10 i .0$ & 124.2 \\
\hline 1959 & 79.1 & 47.5 & 117.2 & 80.1 & 101.4 & 125.1 \\
\hline 1960 & 84.2 & 50.4 & 116.4 & 82.1 & 101.5 & 125.8 \\
\hline 1961 & 88.1 & 64.8 & 121.8 & 79.1 & 100.6 & 144.8 \\
\hline 1962 & 83.6 & 63.6 & 126.4 & 81.0 & 102.7 & 117.3 \\
\hline 1963 & 81.3 & 627 & 125.0 & 79.9 & 102.7 & 102.6 \\
\hline 1964 & 82.2 & 62.3 & 125.6 & 79.1 & 102.7 & 105.2 \\
\hline 1965 & 85.5 & 66.2 & 117.9 & 75.9 & 102.7 & 131.1 \\
\hline 1966 & 86.4 & 66.6 & 113.0 & 75.9 & 102.7 & 135.8 \\
\hline 1967 & 84.5 & 66.5 & 111.7 & 75.9 & 100.8 & 135.3 \\
\hline 1968 & 84.7 & 68.9 & 109.2 & 75.9 & 100.7 & 135.2 \\
\hline 1969 & 86.1 & 69.4 & 105.2 & 75.9 & 101.1 & 133.7 \\
\hline 1970 & 87.3 & 70.7 & 1020 & 77.8 & 100.0 & 1328 \\
\hline 1971 & 88.5 & 72.3 & 101.5 & 79.6 & 100.0 & 132.8 \\
\hline 1972 & 89.1 & 73.0 & 100.7 & 79.7 & 100.0 & 132.8 \\
\hline 1973 & 89.3 & 73.5 & 100.3 & 82.3 & 100.0 & 1328 \\
\hline 1974 & 89.0 & 73.6 & 100.3 & 83.8 & 100.0 & 132.8 \\
\hline 1975 & 88.1 & 74.0 & 99.1 & 85.4 & 100.0 & 114.7 \\
\hline 1976 & 87.6 & 75.0 & 98.8 & 86.5 & 100.0 & 101.5 \\
\hline 1977 & 89.9 & 74.8 & 98.3 & 87.7 & 100.0 & 126.9 \\
\hline 1978 & 92.3 & 77.7 & 98.8 & 89.3 & 100.0 & 128.0 \\
\hline 1979 & 96.1 & 90.8 & 100.1 & 91.2 & 100.0 & 99.8 \\
\hline 1980 & 100.0 & 100.0 & 100.0 & 100.0 & 100.0 & 100.0 \\
\hline 1981 & 101.9 & 106.2 & 100.3 & 102.7 & 100.0 & 91.2 \\
\hline 1982 & 101.8 & 108.5 & 100.2 & 106.1 & 100.0 & 75.0 \\
\hline 1983 & 102.9 & 111.6 & 100.0 & 111.2 & 101.8 & 73.0 \\
\hline 1984 & 108.1 & 115.7 & 102.5 & 117.4 & 111.4 & 97.4 \\
\hline 1985 & 118.3 & 124.7 & 107.7 & 127.8 & 117.2 & 151.5 \\
\hline 1986 & 123.0 & 1321 & 111.0 & 136.7 & 130.1 & 148.5 \\
\hline 1987 & 132.2 & 146.6 & 117.2 & 149.5 & 140.2 & 158.1 \\
\hline 1988 & 149.7 & 173.5 & 126.8 & 170.2 & 150.8 & 208.8 \\
\hline 1989 & 162.2 & 185.4 & 137.8 & 183.8 & 1628 & 246.9 \\
\hline 1990 & 168.5 & 204.9 & 138.4 & 198.3 & 223.6 & 209.6 \\
\hline 1991 & 178.4 & 211.1 & 143.0 & 214.9 & 235.8 & 306.6 \\
\hline 1992 & 187.0 & 221.2 & 151.1 & 246.2 & 236.7 & 323.1 \\
\hline 1993 & 199.3 & 231.8 & 161.3 & 318.2 & 252.2 & 3620 \\
\hline
\end{tabular}

§ Used in converting investment data (elsewhere in this volume) to constant yuan.

Source: China Statistical Yearbook, various years. 
Table X-7. National Income by Sector and Province, 1992

\begin{tabular}{|c|c|c|c|c|c|c|c|c|c|c|}
\hline \multirow[b]{2}{*}{ Region } & \multirow[b]{2}{*}{ Province } & \multicolumn{5}{|c|}{$\begin{array}{l}\text { Sectoral National Income } \\
\text { (billion current yuan) }\end{array}$} & \multirow[b]{2}{*}{$\begin{array}{l}\text { Popu- } \\
\text { lation }\end{array}$} & \multirow{2}{*}{$\begin{array}{l}\text { Total } \\
\text { National } \\
\text { Income }\end{array}$} & \multirow{2}{*}{$\begin{array}{l}\text { Per Capita } \\
\text { National } \\
\text { Income } \\
\text { (yuan) }\end{array}$} & \multirow[b]{2}{*}{ Rank } \\
\hline & & Agriculture & Industry & Construction & $\begin{array}{c}\text { Trans- } \\
\text { portation }\end{array}$ & Commerce & & & & \\
\hline \multirow[t]{5}{*}{ North } & Beijing & 4.63 & 31.24 & 5.12 & 2.56 & 7.18 & 50.73 & 11.02 & 4,603 & 2 \\
\hline & Tianjin & 3.14 & 20.52 & 2.12 & 2.90 & 5.77 & 34.45 & 9.20 & 3,744 & 3 \\
\hline & Hebei & 25.61 & 51.35 & 5.57 & 4.26 & 8.19 & 94.98 & 62.75 & 1.514 & 14 \\
\hline & Shanxi & 8.35 & 22.78 & 2.96 & 2.38 & 4.14 & 40.61 & 29.79 & 1,363 & 17 \\
\hline & Inner Mongolia & lia 12.14 & 11.16 & 3.24 & 2.44 & 1.66 & 30.64 & 22.07 & 1,388 & 16 \\
\hline \multirow[t]{3}{*}{ Northeast } & Liaoning & 20.11 & 65.17 & 7.75 & 5.35 & 7.69 & 106.07 & 40.16 & 2,641 & 5 \\
\hline & Jilin & 13.23 & 22.47 & 2.77 & 1.76 & 3.23 & 43.46 & 25.32 & 1.716 & 12 \\
\hline & Heilongiiang & 18.11 & 39.06 & 5.56 & 2.63 & 4.90 & 70.26 & 36.08 & 1.947 & 9 \\
\hline \multirow[t]{7}{*}{ East } & Shanghai & 3.60 & 62.37 & 4.15 & 5.89 & 12.08 & 88.09 & 13.45 & 6,550 & 1 \\
\hline & Jiangsu & 39.57 & 102.50 & 10.02 & 6.19 & 11.42 & 169.70 & 69.11 & 2,456 & 7 \\
\hline & Zhejiang & 25.67 & 59.49 & 7.15 & 3.75 & 11.06 & 107.12 & 42.36 & 2,529 & 6 \\
\hline & Anhui & 24.41 & 30.17 & 5.15 & 2.07 & 4.74 & 66.54 & 58.34 & 1.141 & 28 \\
\hline & Fujian & 19.74 & 24.82 & 4.98 & 3.24 & 6.22 & 59.00 & 31.16 & 1,893 & 10 \\
\hline & Jiangxi & 20.19 & 17.64 & 2.66 & 2.03 & 4.07 & 46.59 & 39.13 & 1,191 & 22 \\
\hline & Shandong & 52.34 & 88.13 & 10.62 & 6.14 & 11.33 & 168.56 & 86.10 & 1,958 & 8 \\
\hline South- & Henan & 35.03 & 46.24 & 6.87 & 4.03 & 9.56 & 101.73 & 88.61 & 1,148 & 27 \\
\hline \multirow[t]{5}{*}{ Central } & Hubei & 30.27 & 37.90 & 4.54 & 2.71 & 6.91 & 82.33 & 55.80 & 1,475 & 15 \\
\hline & Hunan & 32.40 & 28.48 & 5.32 & 3.88 & 6.66 & 76.74 & 62.67 & 1,225 & 21 \\
\hline & Guangdong & 46.43 & 87.87 & 17.28 & 8.05 & 19.73 & 179.36 & 65.25 & 2,749 & 4 \\
\hline & Guangxi & 23.25 & 16.87 & 2.71 & 1.65 & 3.91 & 48.39 & 43.80 & 1,105 & 29 \\
\hline & Hainan & 5.77 & 2.01 & 1.77 & 0.51 & 1.05 & 11.11 & 6.86 & 1,620 & 13 \\
\hline \multirow[t]{4}{*}{ Southwest } & Sichuan & 48.85 & 50.01 & 10.50 & 3.76 & 13.20 & 126.32 & 109.98 & 1,149 & 25 \\
\hline & Guizhou & 11.80 & 10.20 & 1.62 & 0.87 & 2.57 & 27.06 & 33.61 & 805 & 30 \\
\hline & Yunnan & 18.25 & 18.51 & 2.54 & 0.79 & 4.58 & 44.67 & 38.32 & 1,166 & 24 \\
\hline & Xizang & 1.78 & 0.22 & 0.34 & 0.12 & 0.36 & 2.82 & 2.28 & 1,237 & 20 \\
\hline \multirow[t]{5}{*}{ Northwest } & Shaan $x i$ & 12.69 & 18.71 & 3.54 & 2.71 & 2.25 & 39.90 & 34.05 & 1.172 & 23 \\
\hline & Gansu & 7.45 & 11.08 & 1.81 & 1.42 & 4.81 & 26.57 & 23.14 & 1,148 & 26 \\
\hline & Qinghai & 1.92 & 2.30 & 0.89 & 0.19 & 0.95 & 6.25 & 4.61 & 1,355 & 18 \\
\hline & Ningxia & 1.81 & 2.64 & 0.66 & 0.33 & 0.61 & 6.05 & 4.87 & 1,242 & 19 \\
\hline & Xinjiang & 11.26 & 9.58 & 3.98 & 1.43 & 2.95 & 29.20 & 15.81 & 1,847 & 11 \\
\hline National Total & & 579.50 & 988.50 & 141.10 & 96.80 & 216.40 & $2,022.30$ & $1,171.71$ & 1,726 & $(11-12)$ \\
\hline Balance* & & -0.28 & -2.99 & -3.09 & 10.76 & 32.62 & 37.02 & 6.01 & - & - \\
\hline
\end{tabular}

National income totals differ from the sum of regional national income because each region calculates national income by its own methods, which may differ from that used by the State Statistical Bureau.

Source: China Statistical Yearbook, various years. 


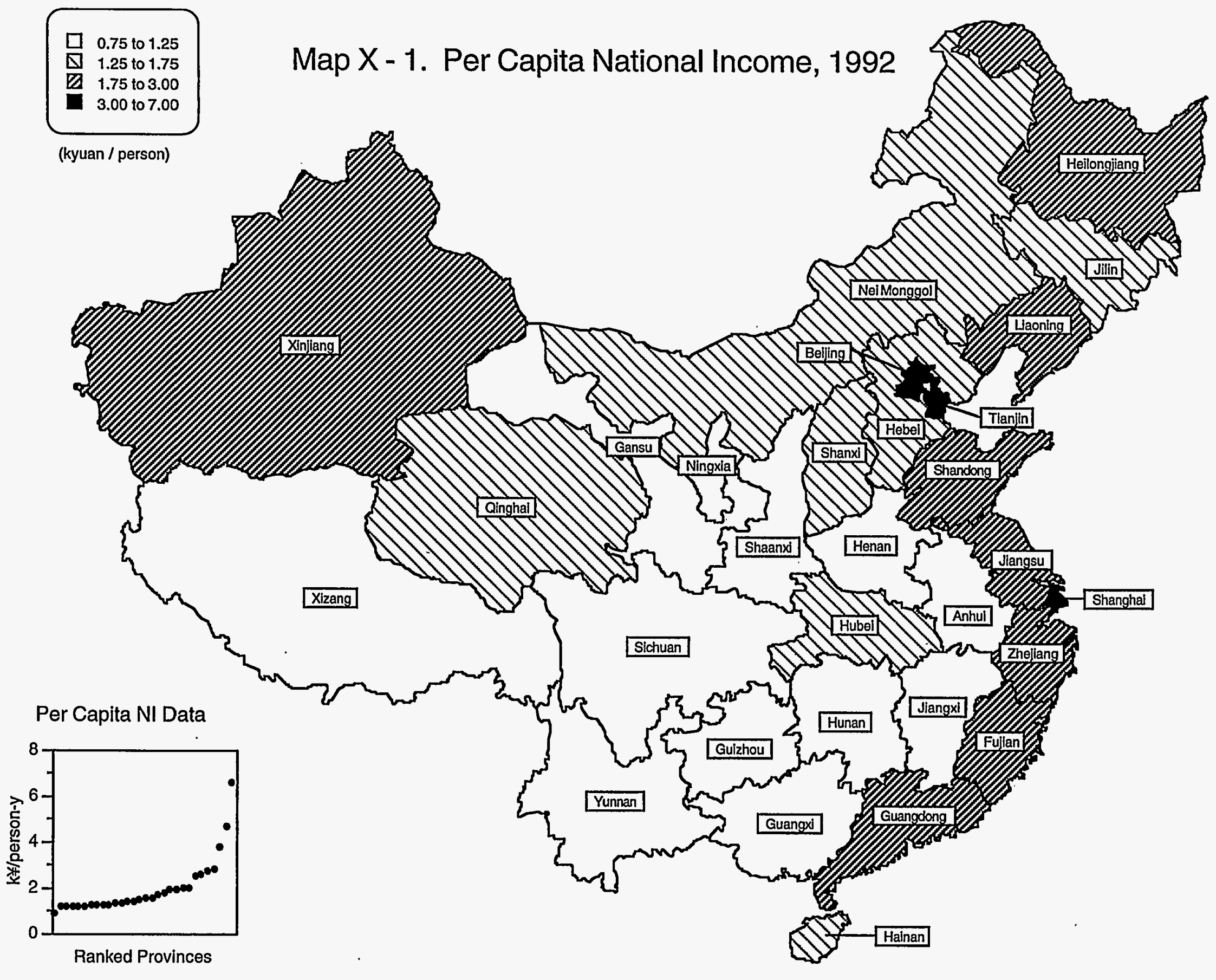


Table X-8. Population, * 1950-1993

\begin{tabular}{|c|c|c|c|c|c|}
\hline \multicolumn{6}{|c|}{ 1. Millions } \\
\hline Year & $\begin{array}{c}\text { Total } \\
\text { Population }\end{array}$ & $\begin{array}{c}\text { City } \\
\text { \& Town }\end{array}$ & Rural & $\begin{array}{c}\text { Non- } \\
\text { Agricultural }\end{array}$ & Agricultural \\
\hline 1950 & 551.96 & 61.69 & 490.27 & 91.37 & 460.59 \\
\hline 1955 & 614.65 & 82.85 & 531.80 & 93.35 & 521.30 \\
\hline 1960 & 662.07 & 130.73 & 531.34 & 137.31 & 524.76 \\
\hline 1965 & 725.38 & 130.45 & 594.93 & 121.22 & 604.16 \\
\hline 1970 & 829.92 & 144.24 & 685.68 & 126.60 & 703.32 \\
\hline 1971 & 852.29 & 147.11 & 705.18 & 133.50 & 718.79 \\
\hline 1972 & 871.77 & 149.35 & 722.42 & 136.32 & 735.45 \\
\hline 1973 & 892.11 & 153.45 & 738.66 & 139.92 & 752.19 \\
\hline 1974 & 908.59 & 155.95 & 752.64 & 140.79 & 767.80 \\
\hline 1975 & 924.20 & 160.30 & 763.90 & 14278 & 781.42 \\
\hline 1976 & 937.17 & 163.41 & 773.76 & 145.17 & 792.00 \\
\hline 1977 & 949.74 & 166.69 & 783.05 & 146.74 & 802.80 \\
\hline 1978 & 962.59 & 172.45 & 790.14 & 152.30 & 810.29 \\
\hline 1979 & 975.42 & 184.95 & 790.47 & 161.86 & 813.56 \\
\hline 1980 & 987.05 & 191.40 & 795.65 & 168.00 & 819.05 \\
\hline 1981 & $1,000.72$ & 201.71 & 799.01 & 174.13 & 826.59 \\
\hline 1982 & $1,016.54$ & 214.80 & 801.74 & 179.10 & 836.31 \\
\hline 1983 & $1,030.08$ & 222.74 & 807.34 & 183.78 & 841.17 \\
\hline 1984 & $1,043.57$ & 240.17 & 803.40 & 196.86 & 837.89 \\
\hline 1985 & $1,058.51$ & 250.94 & 807.57 & 210.54 & 834.78 \\
\hline 1986 & $1,075.07$ & 263.66 & 811.41 & 209.03 & 848.18 \\
\hline 1987 & $1,093.00$ & 276.74 & 816.26 & 215.92 & 856.48 \\
\hline 1988 & $1,110.26$ & 286.61 & 823.65 & 225.51 & 864.27 \\
\hline 1989 & 1.127 .04 & 295.40 & 831.64 & 233.71 & 873.05 \\
\hline 1990 & $1,143.33$ & 301.91 & 841.42 & 238.87 & 904.46 \\
\hline 1991 & $1,158.23$ & 305.43 & 852.80 & 246.93 & 905.25 \\
\hline 1992 & $1,171.71$ & 323.72 & 847.99 & 260.17 & 911.54 \\
\hline 1993 & $1,185.17$ & 333.51 & 851.66 & 271.84 & 913.34 \\
\hline
\end{tabular}

* Here we present two different types of population divisions in China. One type divides the population into city $\&$ town and rural categories (referred to above as Type I). A change in the definition of urban areas in 1984 increased the reported urban population, though 1991 and later editions of the China Statistical Yearbook have corrected for this. Another type of division cuts the population into nonagricultural and agricultural categories (Type II). We consider the latter to reflect more closely the division of population between urban and rural areas.

$\dagger$ The sum of these two categories as reported is not always equal to total population.

Source: Almanac of China's Population, various years; China Statistical Yearbook, various years; China Rural Statistical Yearbook, various years. 
Table X-8. Population, * 1950-1993 (continued)

\begin{tabular}{|c|c|c|c|c|c|}
\hline \multicolumn{6}{|c|}{ 2. Shares of Total } \\
\hline \multirow[b]{2}{*}{ Year } & \multirow[b]{2}{*}{$\begin{array}{c}\text { Total } \\
\text { Population }\end{array}$} & \multicolumn{2}{|c|}{ Type I Categories } & \multicolumn{2}{|c|}{ Type II Categoriest } \\
\hline & & $\begin{array}{c}\text { City } \\
\text { \& Town }\end{array}$ & Rural & $\begin{array}{c}\text { Non- } \\
\text { Agricultural }\end{array}$ & Agricultural \\
\hline 1950 & $100 \%$ & $11 \%$ & $89 \%$ & $17 \%$ & $83 \%$ \\
\hline 1955 & $100 \%$ & $13 \%$ & $87 \%$ & $15 \%$ & $85 \%$ \\
\hline 1960 & $100 \%$ & $20 \%$ & $80 \%$ & $21 \%$ & $79 \%$ \\
\hline 1965 & $100 \%$ & $18 \%$ & $82 \%$ & $17 \%$ & $83 \%$ \\
\hline 1970 & $100 \%$ & $17 \%$ & $83 \%$ & $15 \%$ & $85 \%$ \\
\hline 1971 & $100 \%$ & $17 \%$ & $83 \%$ & $16 \%$ & $84 \%$ \\
\hline 1972 & $100 \%$ & $17 \%$ & $83 \%$ & $16 \%$ & $84 \%$ \\
\hline 1973 & $100 \%$ & $17 \%$ & $83 \%$ & $16 \%$ & $84 \%$ \\
\hline 1974 & $100 \%$ & $17 \%$ & $83 \%$ & $15 \%$ & $85 \%$ \\
\hline 1975 & $100 \%$ & $17 \%$ & $83 \%$ & $15 \%$ & $85 \%$ \\
\hline 1976 & $100 \%$ & $17 \%$ & $83 \%$ & $15 \%$ & $85 \%$ \\
\hline 1977 & $100 \%$ & $18 \%$ & $82 \%$ & $15 \%$ & $85 \%$ \\
\hline 1978 & $100 \%$ & $18 \%$ & $82 \%$ & $16 \%$ & $84 \%$ \\
\hline 1979 & $100 \%$ & $19 \%$ & $81 \%$ & $17 \%$ & $83 \%$ \\
\hline 1980 & $100 \%$ & $19 \%$ & $81 \%$ & $17 \%$ & $83 \%$ \\
\hline 1981 & $100 \%$ & $20 \%$ & $80 \%$ & $17 \%$ & $83 \%$ \\
\hline 1982 & $100 \%$ & $21 \%$ & $79 \%$ & $18 \%$ & $82 \%$ \\
\hline 1983 & $100 \%$ & $22 \%$ & $78 \%$ & $18 \%$ & $82 \%$ \\
\hline 1984 & $100 \%$ & $23 \%$ & $77 \%$ & $19 \%$ & $80 \%$ \\
\hline 1985 & $100 \%$ & $24 \%$ & $76 \%$ & $20 \%$ & $79 \%$ \\
\hline 1986 & $100 \%$ & $25 \%$ & $75 \%$ & $19 \%$ & $79 \%$ \\
\hline 1987 & $100 \%$ & $25 \%$ & $75 \%$ & $20 \%$ & $78 \%$ \\
\hline 1988 & $100 \%$ & $26 \%$ & $74 \%$ & $20 \%$ & $78 \%$ \\
\hline 1989 & $100 \%$ & $26 \%$ & $74 \%$ & $21 \%$ & $77 \%$ \\
\hline 1990 & $100 \%$ & $26 \%$ & $74 \%$ & $21 \%$ & $79 \%$ \\
\hline 1991 & $100 \%$ & $26 \%$ & $74 \%$ & $21 \%$ & $78 \%$ \\
\hline 1992 & $100 \%$ & $28 \%$ & $72 \%$ & $22 \%$ & $78 \%$ \\
\hline 1993 & $100 \%$ & $28 \%$ & $72 \%$ & $23 \%$ & $77 \%$ \\
\hline
\end{tabular}

- Here we present two different types of population divisions in China. One type divides the population into city $\&$ town and rural categories (referred to above as Type I). A change in the definition of urban areas in 1984 increased the reported urban population, though 1991 and later editions of the China Statistical Yearbook have corrected for this. Another type of division cuts the population into nonagricultural and agricultural categories (Type II). We consider the latter to reflect more closely the division of population between urban and rural areas.

$\dagger$ The sum of these two categories as reported is not always equal to total population.

Source: Almanac of China's Population, various years; China Statistical Yearbook, various years; China Rural Statistical Yearbook, various years. 
Figure X-7. Population

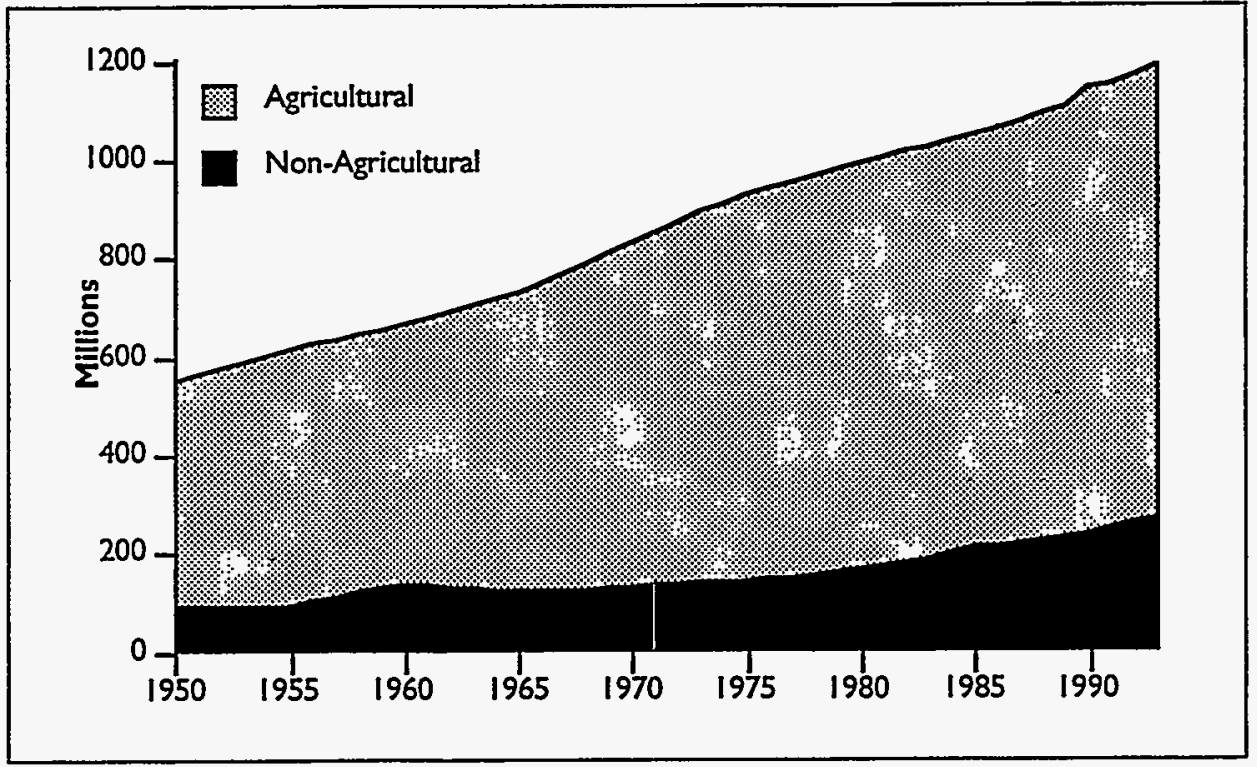

Figure X-8. Nonagricultural Fraction of Total Population

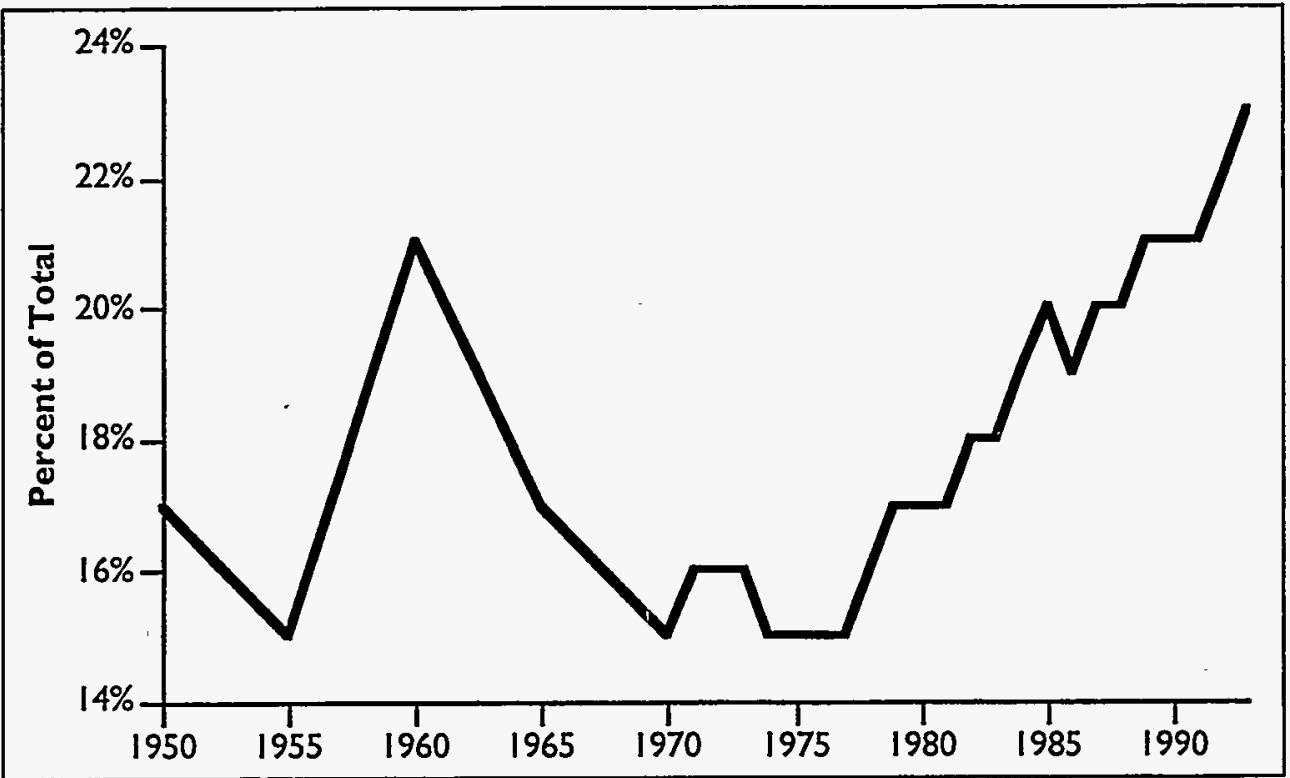


Table X-9. Population and Area by Province, 1992 and 1993

\begin{tabular}{|c|c|c|c|c|c|}
\hline $\begin{array}{l}\text { Planning } \\
\text { Region }\end{array}$ & Province & $\begin{array}{c}1992 \\
\text { Population } \\
\text { (Millions) }\end{array}$ & $\begin{array}{c}1993 \\
\text { Population } \\
\text { (Millions) }\end{array}$ & $\begin{array}{c}\text { Provincial } \\
\text { Area } \\
\text { (1000 sq km) }\end{array}$ & $\begin{array}{c}1993 \\
\text { Population } \\
\text { Density } \\
\text { (persons/sq km) }\end{array}$ \\
\hline \multirow[t]{5}{*}{ North } & Beijing & 11.02 & 11.12 & 16.8 & 662 \\
\hline & Tianjin & 9.20 & 9.28 & 11.3 & 821 \\
\hline & Hebei & 62.75 & 63.34 & 188.0 & 337 \\
\hline & Shanxi & 29.79 & 30.12 & 156.1 & 193 \\
\hline & Inner Mongolia & 22.07 & 22.32 & $1,200.0$ & 19 \\
\hline \multirow[t]{3}{*}{ Northeast } & Liaoning & 40.16 & 40.42 & 145.8 & 277 \\
\hline & & 25.32 & 25.55 & 138.0 & 185 \\
\hline & Heilongiang & 36.08 & 36.40 & 473.4 & $\pi$ \\
\hline \multirow[t]{7}{*}{ Eost } & Shanghai & 13.45 & 13.49 & 6.2 & 2,176 \\
\hline & Jiangsu & 69.11 & 69.67 & 1026 & 679 \\
\hline & Zhejiang & 42.36 & 42.66 & 101.8 & 419 \\
\hline & Anhui & 58.34 & 58.97 & 139.5 & 423 \\
\hline & Fujian & 31.16 & 31.50 & 121.5 & 259 \\
\hline & Jianxi & 39.13 & 39.66 & 166.8 & 238 \\
\hline & Shandong & 86.10 & 86.42 & 153.1 & 564 \\
\hline \multirow[t]{6}{*}{ South-Centrol } & Henan & 88.61 & 89.49 & 166.9 & 536 \\
\hline & Hubei & 55.80 & 56.53 & 187.5 & 301 \\
\hline & Hunan & 62.67 & 63.11 & 210.1 & 300 \\
\hline & Guangdong & 65.25 & 66.07 & 178.0 & 371 \\
\hline & Guangxi & 43.80 & 44.38 & 230.5 & 193 \\
\hline & Hainan & 6.86 & 7.01 & 34.0 & 206 \\
\hline \multirow[t]{4}{*}{ Southwest } & Sichuan & 109.98 & 111.04 & 566.6 & 196 \\
\hline & Guizhou & 33.61 & 34.09 & 176.3 & 193 \\
\hline & Yunnan & 38.32 & 38.85 & 392.2 & 99 \\
\hline & Xizang & 2.28 & 2.32 & 1,1827 & 2 \\
\hline \multirow[t]{5}{*}{ Northwest } & Shaanxi & 34.05 & 34.43 & 205.0 & 168 \\
\hline & Gansu & 23.14 & 23.45 & 455.0 & 52 \\
\hline & Qinghai & 4.61 & 4.67 & 779.1 & 6 \\
\hline & Ningxia & 4.87 & 4.95 & 66.0 & 75 \\
\hline & Xiniliang & 15.81 & $16.05^{\circ}$ & $1,635.2$ & 10 \\
\hline \multicolumn{6}{|l|}{ National } \\
\hline Totall Averoge & & $1,171.71$ & $1,185.17$ & $9,586.0$ & 124 \\
\hline Balance* & & 6.01 & 7.81 & $=$ & - \\
\hline
\end{tabular}

* Because of differences in the coverage and collection of local and national statistics the sum of local statistics may not equal the national total.

Source: China Statistical Yearbook, various years. 
Table X-10. Socioeconomic Indicators of Urban Households *

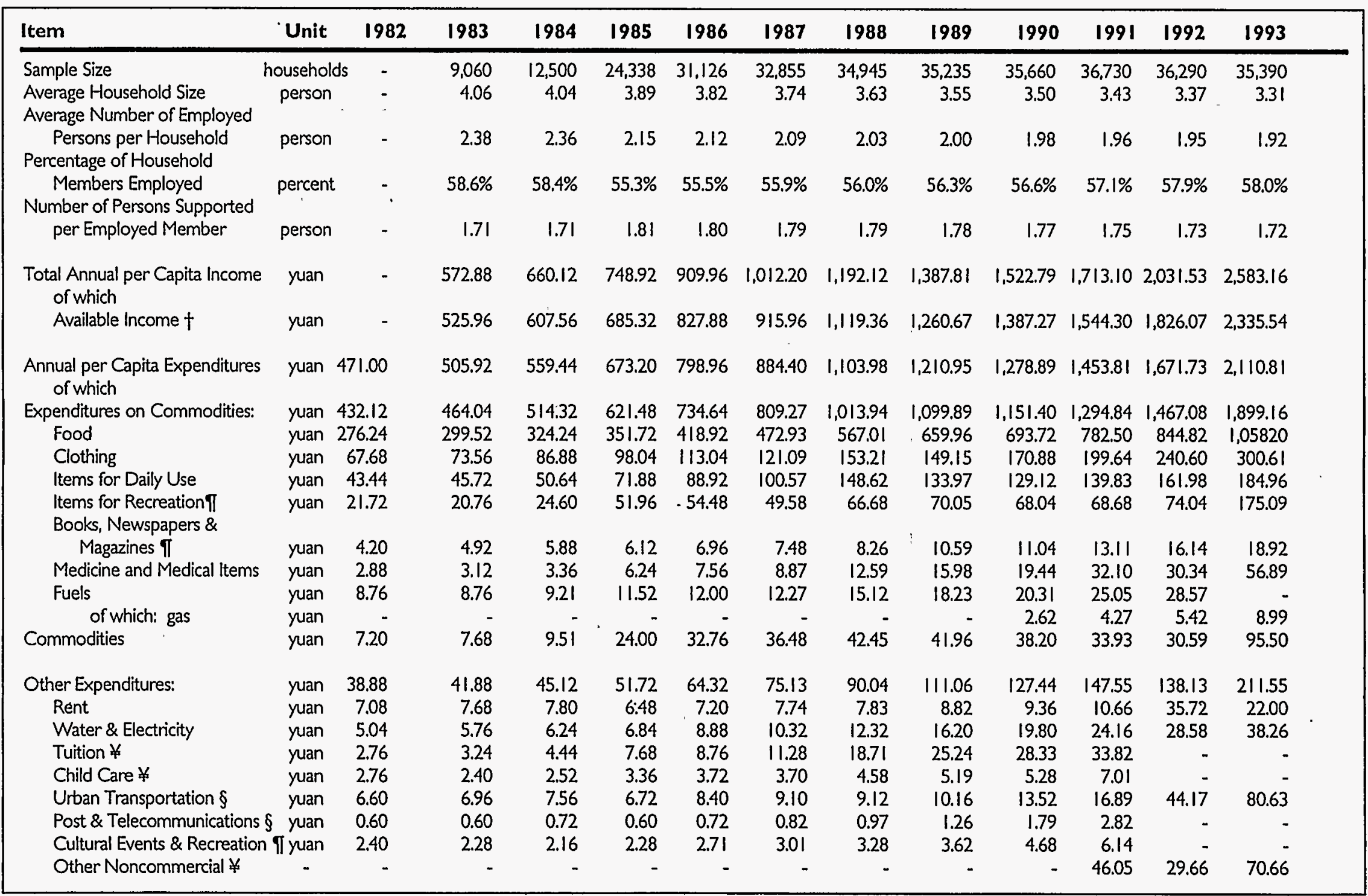

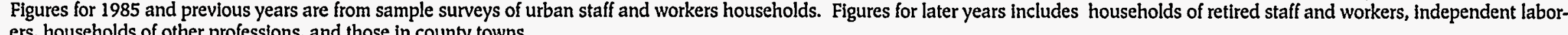
ers, households of other professions, and those in county towns.

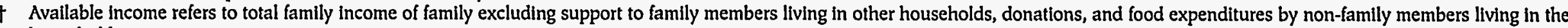
household.

After 1992, recreation includes expenditures on cultural events.

Beginning in 1992, urban transportation and post and telecommunications are combined in one category.

Beginning in 1992, other noncommercial expenditures include tuition and child care.

Source: Yearbook of China's Economy, 1990; China Statistical Yearbook, various years; China Social Statistics Yearbook, 1993. 
Figure X-9. Urban Household Expenditures on Fuels as a Percentage of Total Expenditures

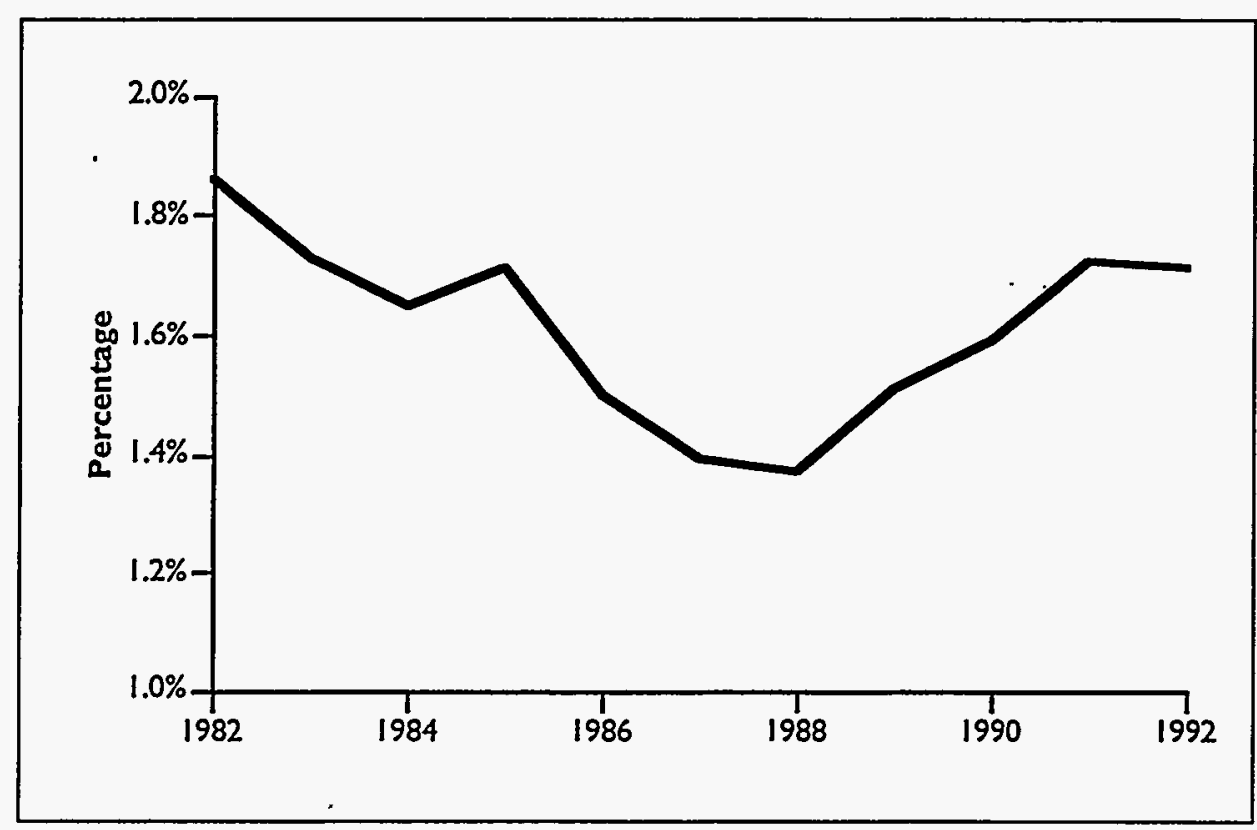




\section{Appendix 1. \\ Sectoral Divisions in Official Chinese Statistics}

Productive: This refers to sectors primarily involved in the production and distribution of physical goods.

\section{AGRICULTURE}

Includes agriculture, forestry (excludes harvesting of timber and other forest products, which is included under industry, usually in the mining subsector), animal husbandry, fishery, and water conservancy.

\section{INDUSTRY}

Often divided into light and heavy. Subsectoral divisions vary. In official statistics industrial subsectors for 1984 and previous years are not strictly comparable to 1985 and later years because of a change in definition.

\section{GEOLOGY}

Includes prospecting and surveying.

\section{CONSTRUCTION}

In this book the construction sector is often added to the industrial sector.

\section{TRANSPORTATION}

Includes post and telecommunications as well as units devoted exclusively to transportation. Many units in other sectors, especially industry and agriculture, perform transportation functions, so the official figures for this sector tend to undercount actual transportation sector statistics.

\section{COMMERCE}

Includes the sale of goods, public food preparation (e.g. restaurants), and the supply, distribution and storage of materials.
NONPRODUCTIVE: This refers to sectors primaily engaged in activities which do not contribute directly to the production or distribution of physical goods.

\section{PUBLIC SERVICES}

Includes the management of buildings and land, residential services, and public services such as public transportation and street lighting.

\section{PUBLIC HEALTH}

Sanitation, sports, and social services.

\section{EDUCATION}

Includes also cultural and artistic activities, and broadcasting.

\section{RESEARCH}

Scientific research and "comprehensive technical services".

\section{FINANCIAL}

Banking, other financial services, and insurance.

\section{GOVERNMENT}

Government, Party, and social organizations.

\section{OTHER SECTORS}




\section{Appendix 2. Abbreviations}

$\begin{array}{ll}\text { BP } & \text { British Petroleum } \\ \text { CERS } & \text { China Energy Research Society } \\ \text { CSY } & \text { China Statistical Yearbook } \\ \text { DOE } & \text { U.S. Department of Energy } \\ \text { EAP } & \text { Energy Analysis Program, Energy Environment Division, LBNL } \\ \text { ERI } & \text { Energy Research Institute of the Chinese State Planning } \\ \text { CESY } & \text { Commission } \\ \text { IEA } & \text { China Energy Statistical Yearbook } \\ \text { IES } & \text { International Energy Agency } \\ \text { LBNL } & \text { International Energy Studies Group, EAP, LBNL } \\ \text { MOE } & \text { Lawrence Berkeley National Laboratory } \\ & \text { Chinese Ministry of Energy, formed in 1988 through the merger of } \\ \text { the Ministries of Coal, Petroleum, and Water Resources and }\end{array}$




\section{Appendix 3. Bibliographic References for Selected Sources in the Data Tables}

Simplified Reference

China Energy Annual Review

China Energy Statistical Yearbook

China Statistical Yearbook

China Transportation Yearbook

Energy in China

Energy Conservation in China

Handbook of Comprehensive

Sinopec Yearbook

Statistical Yearbook of China's

\section{Full Reference}

State Economic and Trade Commission, Department of Resources Conservation and Comprehensive Utilization. 1994. China Energy Annual Review, 1994. Beijing, State Economic and Trade Commission.

State Statistical Bureau (1986, 1989, and 1991). Zhongguo Nengyuan Tongii Nianjian (China Energy Statistical Yearbook), 1986, 1989, and 1991 editions. Beijing, Zhongguo Tongji Chubanshe.

State Statistical Bureau (1982-1994). Zhongguo Tongji Nianjian (China Statistical Yearbook), 1982-1994 edi tions. Beijing, Zhongguo Tongi Chubanshe.

China Transportation Association (1994). Zhongguo Jiaotong Nianjian (China Transportation Yearbook), 1994. Beijing, Zhongguo Jiaotong Nianjian She.

Ministry of Energy (1989-1992). Zhongguo Nengyuan (Energy in China), 1989-1992 editions. Beijing, Ministry of Energy.

State Planning Commission, Department of Resources Conservation and Comprehensive Utilization (1993). Energy Conservation in China, 1993. Beijing, State Planning Commission.

State Planning Commission, Department of Resources Conservation and Resources Utilization Comprehensive Utilization (1991). Ziyuan Heli Liyong Shouce (Handbook of Comprehensive Resource Utilization). Beijing, Zhongguo Kexue Jishu Chubanshe.

Editorial Board of the Sinopec Yearbook (1991). Zhongguo Shiyou Huagong Zonggongsi Nianjian (Sinopec

Yearbook), 1991. Beijing, Zhongguo Shihua Chubanshe.

State Statistical Bureau (1988-1993). Zhongguo Gongye Jingji Tongji Nianjian Industrial Economy (Statistical Yearbook of China's Industrial Economy), 1988-1993 editions. Beijing, Zhongguo Tongji Chubanshe. 
Azimi, Sayed A., and Howard E. Lowitt (1988). The U.S. Steel Industry: An Energy Perspective. Report no. DOE/RI/01830-T55 (DE88005313), Springfield, VA, National Technical Information Service.

British Petroleum Company (1995). British Petroleum Statistical Review of World Energy. London, Economics Unit, British Petroleum Company. June.

The Carbon Dioxide Information Analysis Center (1994). Trends '93: A Compendium of Data on Global Change. Oak Ridge, Tennesee, Oak Ridge National Laboratory.

CHEN, Yingrong (1991). Renewables in China, in Energy Policy 19(9): 892-896. September.

China Energy Research Society (1995). Miscellaneous statistical materials. January.

China OGP and PetroMin \& Hydrocarbon Asia (1994). China Petroleum Investment Guide. Beijing, China OGP, China Features; and Singapore, AP Energy Business Publications.

China Transportation Association (1994). Zhongguo Jiaotong Nianjian (China Transportation Yearbook), 1994. Beijing, Zhongguo Jiaotong Nianjian She.

CHOW, Larry Chuen-ho (1991). The rise and fall of Chinese oil production in the 1980s, in Energy Policy 19(9). September.

Cooper, R. Caron, and Lee Schipper, (1991). The Soviet energy conservation dilemma, in Energy, the International Journal. May.

Editorial Board of National Rural Energy Planning (1990). Quanguo Nongcun Nengyuan Guihua (National Rural Energy Planning). Beijing, Zhongguo Biaozhun Chubanshe.

Editorial Board of the Almanac of China's Foreign Economic Relations and Trade (1984-1991). Almanac of China's Foreign Economic Relations and Trade, 1985-1990/91 editions. Hong Kong, China Resources Advertising Co.

China Automotive Industry Corporation and the China Automotive Technology Research Center (1994). 1993 Zhongguo Qiche Gongye Nianjian (China Automotive Industry Yearbook). Beijing, Editorial Board of the China Automotive Industry Yearbook.

Editorial Board of the China Coal Industry Yearbook (1982-1993). Zhongguo Meitan Gongye Nianjian (China Coal Industry Yearbook), 1982-1993 editions. Beijing, Meitan Gongye Chubanshe.

Editorial Board of the China Environmental Yearbook (1990-1994). Zhongguo Huanjing Nianjian (China Environmental Yearbook), 1990 - 1994 editions. Beijing, Zhongguo Huanjing Kexue Chubanshe.

Editorial Board of the China Iron and Steel Industry Yearbook (1994). Zhongguo Gangtie Gongye Nianjian (China Ferrous Metals Industry Yearbook), 1994. Beijing, Zhongguo Jianzhu Gongye Chubanshe.

Editorial Board of the China Nonferrous Metals Industry Yearbook (1994). Zhongguo Youse Jinshu Gongye Nianjian (China Nonferrous Metals Industry Yearbook), 1994. Beijing, Editorial Board of the China Nonferrous Metals Industry Yearbook.

Editorial Board of the China Rural Statistical Yearbook (1994). Zhongguo Nongcun Tongii Nianjian (China Rural Statistical Yearbook) 1994. Beijing, Zhongguo Tongji Chubanshe.

Editorial Board of the Sinopec Yearbook (1991). Zhongguo Shiyou Huagong Zonggongsi Nianjian (Sinopec Yearbook), 1991. Beijing, Zhongguo Shihua Chubanshe.

Editorial Board of the China Urban Economic and Social Yearbook (1986-1993). Zhongguo Chengshi Jingii Shehui Nianjian (China Urban Economic and Social Yearbook), 1986-1993 editions. Beijing: Zhongguo Chengshi Jingji Shehui Chubanshe.

Editorial Board of China Social Statistical Materials (1987, 1990, and 1993). Zhongguo Shehui Tongii Ziliao (China Social Statistical Materials), 1987, 1990, and 1993 editions. Beijing: Zhongguo Tongji Chubanshe.

Energy Data and Modelling Center, Energy Economics Research Institute of Japan (1995). Enerugi Keizai Tokei Yöran (Energy Statistics Summary), 1995 edition. Tokyo, Energy Conservation Center.

Energy Information Administration (1987). The Petroleum Resources of China. Washington D.C., U.S. Department of Energy.

Energy Information Administration (1991a). Estimates of U.S. Biofuels Consumption, 1989. Washington, D.C., U.S. Department of Energy. 
Energy Information Administration (1991b). Manufacturing Energy Consumption Survey: Consumption of Energy, 1988. DOE/EIA-0512(88). Washington, D.C., U.S. Department of Energy. May.

Energy Information Administration (1994). Annual Energy Review 1993. Report no. DOE/EIA-0384(93). Washington, D.C., U.S. Government Printing Office. July.

Energy Research Institute (1991). Collected data. Beijing.

Federation of Japanese Aluminum Industry, personal communication to Prof. Marc Ross, Dept. of Physics, University of Michegan, Ann Arbor, August 1990.

GU Shuhua, HUANG Kun, QIU Daxiong, and Kirk R. Smith (1991). 100 Million Improved Biomass Stoves in China: How Was It Done? EWC/ESMAP/UNDP Evaluation of Improved Cookstove Programs. Honolulu, Environment and Policy Institute, East-West Center. November.

HUANG, J. P. (1991). Fueling the economy, in The China Business Review 18(2): 22-29 March-April.

Information Research Institute of Water Resources and Electric Power, Ministry of Energy, et al. (1989). China's Construction in Four Decades (1949-1989), Volume X: Electric Power Industry in China. Hong Kong, Coastal International Investment Consultant Co.

International Energy Studies Group, Energy Analysis Program, Lawrence Berkeley National Laboratory (1995). LDC Energy Database.

JIA Yunzhen (1991). A review of China's coal mining business, in Coal in Asia-Pacific: Third Coal in AsiaPacific Workshop, 1991, Quarterly Report, vol. 3, no. 3. Tokyo, New Energy and Industrial Tachnology Development Organization.

JIANG Zhenping, head, Systems Analysis Division, Energy Research Institute, State Planning Commission (1995). Personal communication. March.

Joint Survey Group, Ministry of Energy (1991). Survey of Network Power Losses in China. Beijing, Ministry of Energy.

Kahane, Adam (1986). Industrial Electrification: Case Studies of Four Industries, Steel, Paper, Cement, and Motor Vehicles Production in the United States, Japan, and France. Research performed for EPRI under contract RP-2345-42-00. Palo Alto, Electrical Power Research Institute. March.

Levine, Mark D., and'LIU Xueyi (1990). Energy Conservation Programs in the People's Republic of China. Report no. LBL-29211. Berkeley, Lawrence Berkeley Laboratory . August.

LI Qiuhui, WANG Bangcheng, and QU Shiyuan, eds. (1991). Zhongguo Gaohaoneng Wuxiao Gongye (China's Five Energy-Intensive Small-Scale Industries). Beijing, Beijing Kexue Jishu Chubanshe.

LIU Feng and Walter O. Spofford (1994). Air Pollution Control in China: Current Status, Policy Issues, and Prospects. Washington, D.C., Quality of the Environment Division, Resources for the Future. August.

LIU Zhiping, Jonathan E. Sinton, Fuqiang YANG, Mark D. Levine, and Michael Ting (1994). Industrial Sector Energy Conservation Programs in the People's Republic of China during the Seventh Five-Year Plan (19861990). Report no. LBL-36395. Berkeley, Lawrence Berkeley Laboratory.

LU Yingzhong. 1988. Energy prospects in the nineties, presented at the seminar on China and the World in the Nineties, Beijing, 30 May-2 June 1988.

LU Yingzhong (1993). Fueling One Billion: An Insider's Story of Chinese Energy Policy Development. Washington, D.C., The Washington Institute.

Masters, C. D., D. H. Root, et al. (1991). Resource constraints in petroleum production potential, in Science 253:146-152.

Meunier, Maurice Y., and Oscar de Bruyn Kops (1984). Energy Efficiency in the Steel Industry with Emphasis on Developing Countries. World Bank Technical Paper no. 22, Washington, D.C., The International Bank for Reconstruction and Development.

Ministry of Energy (1989-1992). Zhongguo Nengyuan (Energy in China), 1989-1992 editions. Beijing, Ministry of Energy. [bilingual]

Ministry of Metallurgy, Department of Planning (1993). Zhongguo Gangtie Tongji (China Iron and Steel Statistics) 1993. Beijing, Yejin Bu. August. 
Overseas Economic Cooperation Fund (OECF) (1991). Japanese Contribution to Economic Development of China Through OECF Loans. Tokyo, OECF, December.

Population Research Institute and Chinese Academy of Sciences (1991). Zhongguo Renkou Nianjian (Almanac of China's Population), 1990. Beijing, Jingji Guanli Chubanshe.

Marc Ross, University of Michigan, Ann Arbor (1992). Personal communication, 19 June.

Sathaye, Jayant A. Economics of Improving Efficiency of China's Electricity Supply and Use: Are Efficiency Investments Cost-effective? Berkeley, Lawrence Berkeley Laboratory. May 1992.

Sinton, Jonathan E. and Mark D. Levine (1994). Changing energy intensity in Chinese industry, in Energy Policy 22(3):239-258. March.

Sinton, Jonathan E. and Mark D. Levine (1995). Environmental impacts of energy use in China. Discussion paper. Berkeley, Energy Analysis Program, Lawrence Berkeley National Laboratory. February.

Sinton, Jonathan E , Kirk R. Smith, HU Hansheng, and LIU Junzhuo (1995). Indoor Air Pollution Database for China. Environmental and Occupational Epidemiology Series. Geneva, Global Environmental Epidemiology Network, World Health Organization.

Smil, Vaclav (1988). Energy in China's Modernization. New York, M.E. Sharpe.

State Economic and Trade Commission, Department of Resources Conservation and Comprehensive Utilization. 1994. China Energy Annual Review, 1994. Beijing, State Economic and Trade Commission. [bilingual]

State Planning Commission, Department of Resources Conservation and Comprehensive Utilization (1991). Ziyuan Heli Liyong Shouce (Handbook of Comprehensive Resource Utilization). Beijing, Zhongguo Kexue Jishu Chubanshe.

State Planning Commission, Department of Resources Conservation and Comprehensive Utilization (1993). Energy Conservation in China, 1993. Beijing, State Planning Commission.

State Statistical Bureau (1982-1994). Zhongguo Tongji Nianjian (China Statistical Yearbook), 1982-1994 editions. Beijing, Zhongguo Tongji Chubanshe. [English editions also available; 1994 edition bilingual.]

State Statistical Bureau (1986, 1989, and 1991). Zhongguo Nengyuan Tongji Nianjian (China Energy Statistical Yearbook), 1986, 1989, and 1991 editions. Beijing, Zhongguo Tongji Chubanshe.

State Statistical Bureau (1988-1993). Zhongguo Gongye Jingii Tongii Nianjian (Statistical Yearbook of China's Industrial Economy), 1988-1993 editions. Beijing, Zhongguo Tongii Chubanshe.

State Statistical Bureau (1989). China Rural Statistics 1988. New York, Praeger.

State Statistical Bureau (1990). China: The Forty Years of Urban Development. Beijing and Hong Kong, China Statistical Information and Consultancy Service Center and International Center for the Advancement of Science and Technology.

State Statistical Bureau (1987). Nengyuan Tongji Gongzuo Shouce (Handbook of Energy Statistical Work). Tianjin, Nengyuan Chubanshe.

Tata Energy Research Institute (1994). TERI Energy Data Directory and Yeärbook 1994/95. New Delhi, Tata Energy Research Insitute.

Taylor, Robert P. (1981). Rural Energy Development in China. Washington, D.C., Resources for the Future. United Nations (1994a). Energy Statistics Yearbook 1992. Sales no. E/F.94.XVII.9. New, York, United Nations.

United Nations (1994b). Industrial Statistics Yearbook 1992, vol.II, Commodity Production Statistics. New York, United Nations.

U.S. Congress, Office of Technology Assessment [RIP] (1993). Industrial Energy Efficiency. Report no. OTA-E-560. Washington, D.C., U.S. government Printing Office. August.

U.S. Department of Commerce, Bureau of the Census (1994). Statistical Abstract of the United States: the National Data Book, 1994, 114th edition. Washington, D.C., U.S. Government Printing Office.

Venkateswaren, S.R. and H.E. Lowitt (1988). The U.S. Cement Industry: An Energy Perspective. Report no. DOE/RU/01830-T58. Washington, D.C., U.S. Department of Energy, Office of Industrial Programs. May. 
WANG Qingyi. (1988). Zhongguo Nengyuan (Energy in China). Beijing, Yejin Gongye Chubanshe.

WANG Qingyi, Jonathan E. Sinton, and Mark D. Levine (1995). China's Energy Conservation Policies and Their Implementation, 1980 to the Present, and Beyond. Berkeley, Energy Analysis Program, Lawrence Berkeley National Laboratory. forthcoming.

Weil, Martin (1991). The Rise-and fall-of Antaibao, in The China Business Review 18(2): 38-39 March-April. Wind Energy Weekly (1995). China Plans 33\% Increase in Wind Power by 2000. 26 June, p.4.

The World Bank (1983). China: Socialist Economic Development. Volume I: The Economy, Statistical System, and Basic Data. Washington, D.C., The World Bank.

World Bank (1991). China: Efficiency and Environmental Impact of Coal Use, 2 volumes. Report no. 8915CHA Washington D.C., The World Bank. March.

The World Bank (1990 and 1994). World Tables, 1988-1989 and 1993-1994 editions. Baltimore, MD, Johns Hopkins University Press.

The World Bank (1995). World Development Report 1995: Workers in an Integrating World. New York, Oxford University Press.

World Energy Council (1992). 1992 Survey of Energy Resources, 16th edition. Oxford, Holywell Press.

YANG Hongnian (1991). Zhongguo yunshu xitong huanjing yingxiang pingjia (Assessment of environmental impacts of China's transportation system), in Beijing Meitan yu Huanjing Guoji Huiyi Lunwenji (Proceedings of the Beijing International Conference on Coal and the Environment). Beijing. December.

Zhongguo Nengyuan (Energy of China). [journal containing monthly energy production statistics] 
